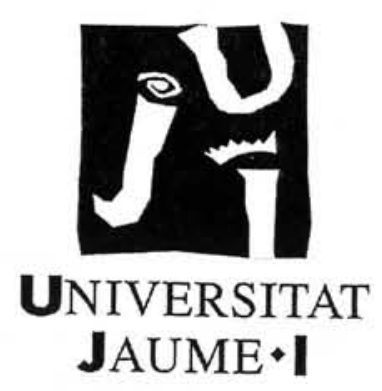

Facultat de ciències jurídiques $\mathrm{i}$ econòmiques

Departament de dret privat

\title{
La impugnació dels acords socials a la cooperativa
}

Tesi doctoral de María José Senent Vidal Dirigida pel prof. dr. José Miguel Embid Irujo 


\title{
ÍNDEX D'ABREVIACIONS
}

\author{
AA. DD.: autors diversos \\ ACI: Aliança cooperativa internacional \\ ADC: Anuario de derecho civil \\ AktG: Aktiengesetz (Llei de societats per accions d'Alemanya) \\ $B G B$ : Bürgerliches Gesetzbuch (Codi civil alemany) \\ BOE: Boletín Oficial del Estado \\ CC: Codi civil \\ $\mathrm{CCi}$ : Códice civile italià; Code civil francès \\ CCo: Codi de comerç \\ CCJC: Cuadernos civitas de jurisprudencia civil \\ CCP: Código cooperativo portugués \\ CDC: Cuadernos de derecho y comercio \\ $\mathrm{CE}$ : Constitució espanyola \\ Cfr.: confronteu \\ CNMV: Comissió Nacional del Mercat de Valors \\ Coop: cooperativa \\ corr. ee.: correcció d'errades \\ CRP: Constitució de la República de Portugal \\ CSC: Código das sociedades comerciais \\ DGRN: Direcció General dels Registres i del Notariat \\ DN: Derecho de los negocios \\ epíg.: epígraf \\ Giur. comm.: Giurisprudenza commerciale \\ $\mathrm{GmbHG:}$ \\ HGB: Handelsgesetzbuch (Codi de comerç alemany) \\ IPSA: Industrial and Provident Societies Act \\ LA: Llei d'arbitratge \\ LAC: Llei d'auditoria de comptes \\ LCA: Llei 9/1998, de 22.12, de cooperatives d'Aragó
}

LCC: Decret legislatiu 1/1992, de 10 de febrer, pel qual s'aprova el Text refós de la llei de cooperatives de Catalunya

LCC: Llei 13/1989, de 26.5, de cooperatives de crèdit

LCCM: Llei 4/1999, de 30.3, de cooperatives de la Comunidad de Madrid

LCCV: Decret legislatiu 1/1998, de 23 de juny, pel qual s'aprova el Text refós de la llei de cooperatives de la Comunitat Valenciana

LCE: Llei 2/1998, de 26.3, de societats cooperatives d'Extremadura

LCG: Llei 5/1998, de 18.12, de cooperatives de Galícia

LCoop: Llei 27/1999, de 16 de juliol, de cooperatives

LCPV: Llei 4/1993, de 24 de juny, de cooperatives del País Basc

LEC: Llei 1/2000, de 7 de gener, d'enjudiciament civil

LFCN: Llei foral 12/1996, de 2 de juliol, de cooperatives de Navarra

LGC: Llei 3/1987, de 2 d'abril, general de cooperatives

LMV: Llei del mercat de valors

LO: Llei orgànica

LOSAP: Llei 30/1995, de 8.11, d'ordenació i supervisió de les assegurances privades

LOTC: Llei orgànica del Tribunal Constitucional

LRJAPPAC: Llei de règim jurídic de les administracions públices i del procediment administratiu comú

LSA: Llei de societats anònimes

LSCA: Llei 2/1999, de societats cooperatives andaluses

LSRL: Llei de societats de responsabilitat limitada

op. cit.: obra citada (opus citatu)

p. e.: per exemple

QGC: Quaderni di giurisprudenza commerciale 
RCC: Reial Decret 84/1993, de 22.1, pel qual s'aprova el Reglament de la llei de cooperatives de crèdit

RCDI: Revista crítica de derecho inmobiliario

RD: Reial decret

RDBB: Revista de derecho bancario y bursátil

RDGRN: Resolució de la Direcció General dels Registres i del Notariat

RDM: Revista de derecho mercantil

RDNot: Revista de derecho notarial

RDPri: Revista de derecho privado

RDPro: Revista de derecho procesal

RdS: Revista de sociedades

RECMA: Revue d'études coopératives, mutualistiques et associatives.

Rev. des soc.: Revue des sociétés

REVESCO: Revista de estudios cooperativos

RGD: Revista general del derecho

Riv. coop.: Rivista della cooperazione

Riv. dir. comm.: Rivista di diritto commerciale

Riv. dir. proc. civ: Rivista di diritto e procedura civile

Riv. soc.: Rivista delle società

RJA: Repertori de jurisprudència Aranzadi

RJC: Revista jurídica de Cataluña

RJN: Revista jurídica del notariado

RRI: Reglament de règim intern, o interior

RRM: Reglament del Registre Mercantil

RTDCDE: Revue trimestrielle de droit commercial et de droit économique.

S. 1a: Sala primera

S.p.A: societat per accions

SA: Societat anònima

SAP: Sentència de l'Audiència provincial

SJPI: Sentència del Jutjat de primera instància

SRL: Societat de responsabilitat limitada

STC: Sentència del Tribunal Constitucional

STS: Sentència del Tribunal Suprem

TC: Tribunal constitucional

TRLSA: Text refòs de la llei de societats anònimes

TS: Tribunal Suprem 


\section{CAPÍTOL PRIMER}

\section{LA IMPUGNACIÓ DELS ACORDS SOCIALS A LA COOPERATIVA}

\section{Introducció}

El règim d'impugnació dels acords socials es va incloure per primera vegada en la legislació cooperativa de l'Estat espanyol en la Llei general de cooperatives 52/1974, sota l'epígraf "revisió d'acords socials" (article 27), junt amb altres institucions originàries del dret de les societats de capital ${ }^{1}$. L'abundant producció normativa posterior en matèria de regulació de l'estructura cooperativa ha assumit, amb millor o pitjor fortuna, però amb naturalitat, la necessitat de preveure un procediment que permeta dissoldre els acords (i, si escau, altres manifestacions de voluntat o de ciència) que patisquen de vicis greus.

Al llarg del treball que ara s'inicia intentarem demostrar com, encara que les normes legals que regulen la impugnació dels acords a la cooperativa són gairebé exclusivament una translació literal dels textos normatius de les

\footnotetext{
'VICENT CHULIÁ, Francisco, "La asamblea general de la cooperativa», RJC, núm. 2, 1978, pàg. 199: "Aquesta incorporació es va realitzar no sense "profund dolor" d'algun procurador membre de la comissió de treball de les Corts, per "això de demanar prestades les categories a la Llei de societats anònimes (nota 132: [...] el senyor MADRID DEL CACHO apuntava un doble criteri en la regulació d'aquesta matèria [...]. En primer lloc, el que "la roba bruta es llava a casa", en al-lusió a la necessitat d'establir una conciliació prèvia o arbitratge sindical o cooperatiu, abans de la via judicial. En segon lloc, el que es prenga de la LSA tan sols allò que convinga a la LGC. En el fons, aquests postulats creiem que eren defensables i s'haurien d'haver tingut més en compte)». SÁNCHEZ CALERO, Fernando, "Los conceptos de sociedad y de empresa en la Ley de cooperativas", en Libro-homenaje a Ramón M. Roca Sastre, tom III, Madrid, 1976, en pàg. 509, nota 42, també recull el debat de les Corts i dóna compte que ues va transigir a recórrer al procediment de la Llei de societats anònimes, sempre que s'admetera la possibilitat d'acudir a l'arbitratge previ».
} 
societats de capital (fonamentalment, de la $\operatorname{LSA}^{2}$ ), i sense perjudici que aquesta siga la intenció indissimulada del legislador, l'especial identitat cooperativa ${ }^{3}$ impregna la institució i la dota de trets específics ${ }^{4}$.

D'una banda, la mutualitat que caracteritza la fórmula cooperativa, amb l'obligatorietat consegüent per als socis de participar en l'activitat cooperativitzada, sumada al principi cooperatiu de gestió democràtica, es tradueixen estructuralment en una multiplicitat d'òrgans socials, que no es produeix en altres fórmules juridicosocietàries, i en la necessitat de preveure els instruments que en garantisquen la participació o representació igualitària en els òrgans esmentats. Al seu torn, aquesta efervescència participativa comporta un risc més elevat de conflictivitat interna, cosa per la qual adquireixen més

${ }^{2}$ SÁNCHEZ CALERO, F., «Los conceptos...», op. cit., pàg. 508 i 509; MORILlas JARILlO, M. José, i FELIU REY, Manuel Ignacio, Curso de cooperativas, Tecnos, Madrid, 2000, pàg. 252; VICENT CHULIÁ, Francisco, "Análisis crítico del nuevo Reglamento de cooperación», RDM, 1972, núm. 125-126, juliol-desembre, pàg. 457.

${ }^{3}$ Vergez SÁNCHEZ, Mercedes, El derecho de las cooperativas y su reforma, Madrid, Civitas, 1973, pàg. 17 a 19: «La societat cooperativa, fruit del fenomen cooperatiu, no és una forma més de gestió d'empresa al mateix nivell econòmic i social que puga ser-ho la societat anònima [...], si bé ha de considerar-se com a empresa econòmica amb les tècniques pròpies d'aquest tipus d'activitat, té també característiques peculiars que determinen la seua naturalesa antiespeculativa i acapitalista. [...] Si la societat cooperativa és una forma d'exercici d'empresa i l'empresa cooperativa no es diferencia des del punt de vista tecnicoeconòmic d'una empresa capitalista, és des d'un punt de vista jurídic, una forma especial d'estructurar el subjecte empresari»; $i$ en pàg. 67: "Les funcions pròpies que la societat cooperativa compleix exigeixen una configuració especial d'aquesta institució d'acord amb uns principis que condicionen de manera fonamental l'estructura de les seues relacions jurídiques».

${ }^{4}$ MONTOLf́ HERNÁNDEZ, José M., Legislación cooperativa en la comunidad europea, Madrid, Institut Nacional de Foment de l'Economia Social, 1993, pàg. 34: "Així com en el comú de les societats prevaldran els aspectes patrimonials, la essència mateixa de la societat cooperativa n'elevarà a drets de primer ordre altres que hi pogueren ser considerats subordinats. Així, en especial, els relacionats amb la participació en la presa de decisions». SÁNCHEZ CALERO, F., «Los conceptos..., op. cit., pàg. 513: "La influència de la normativa de la societat anònima en la nova Llei de cooperatives és, doncs, palmària. Però constatar aquest fet no ens hauria de portar a la conclusió equivocada que la societat cooperativa ha perdut la seua individualitat, sinó que ens sembla més cert que - mantenint el respecte als seus principis- aquesta societat ha sofert una tecnificació més gran i s'ha aprofitat l'experiència de la regulació de l'organització societària anònima». En dret francès, MESTRE, Jacques, "Sur l'originalité du droit coopératif», RECMA, núm. 261, 3r trimestre 1996, pàg. 83-86, on assenyala que l'originalitat del dret cooperatiu s'expressa, entre altres aspectes, «en el funcionament de la persona jurídica, on la personalitat dels cooperadors resulta [...] molt present», i apunta com alguns dels trets característics d'aquesta originalitat el principi d'igualtat de vot, el control de la transmissió de les participacions socials i el poder d'exclusió del soci. A Itàlia, GROsso, P., «I controlli interni nelle società cooperative», QGC, núm. 117, Giuffrè, Milà, 1990, pàg. VII. 
transcendència els procediments de resolució dels conflictes ${ }^{5}$. En aquest sentit, no és casual que en la cooperativa, juntament amb el procediment d'impugnació ordinari, se'n prevegen uns altres d'alternatius, com l'arbitratge, o de previs, com el procediment de revisió interna davant dels òrgans socials.

D'una altra banda, la proliferació de normes cooperatives al llarg de tot el procés de reconversió de l'Estat espanyol en un sistema democràtic origina un problema competencial que no es dóna en relació amb altres persones jurídiques. Hi ha en l'actualitat deu lleis reguladores de l'estructura cooperativa vigents als diferents territoris de $1^{\prime} E s t a t^{6} i$, encara que no aporten grans diferències en el contingut, són, majoritàriament, d'aplicació exclusiva i, per

${ }^{5}$ Com indica SÁNCHEZ RUIZ, Mercedes, Conflictos de intereses entre socios en sociedades de capital. Artículo 52 de la Ley 2/1995, de 23 de marzo, RdS Monografías, núm. 15, Aranzadi, Elcano (Navarra), 2000, pàg. 32, els conflictes intrasocietaris o intracorporatius que poden plantejar-se són d'una gran varietat. L'autora distingeix entre els anomenats conflictes estructurals ("aquells conflictes intrasocietaris de tal entitat que la seua solució passa necessàriament per l'extinció de la relació conflictiva, a través de la dissolució de la societat, o de l'exclusió o la separació del soci». Cfr. AlFARO ÁGUILA-REAL, "Conflictos intrasocietarios (Los justos motivos como causa legal no escrita de exclusión y separación de un socio en la sociedad de responsabilidad limitada)", RDM, 1996, pàg. 1079 a 1141], i els "conflictes conjunturals», entre els quals s'inclouen els que donen lloc a la impugnació d'acords lesius de l'interès social.

${ }^{6}$ La Llei 27/1999, de 16 de juliol, de cooperatives (d'ara endavant LCoop), BOE núm. 170, de 17.9, que substitueix la Llei 3/1987, de 2 d'abril, general de cooperatives; la Llei 4/1993, de 24 de juny, de cooperatives del País Basc, BOPV 135, de 19.7.93, que substitueix l'anterior 1/1982, d'11.2, parcialment modificada per la Llei 1/2000, de 29 de juny, BOPV 146, 1.8.00; el Decret Legislatiu 1/1992, de 10 de febrer, pel qual s'aprova el Text refós de la Llei de cooperatives de Catalunya, DOGC 1563, de 2.3.92, amb correcció d'errades al DOGC 1494, refon la Llei 4/1983, de 9.3, i la Llei 13/1991, d'1.7; la Llei 2/1999, de societats cooperatives andaluses, BOE núm. 107, de 5.5, que substitueix l'anterior, 2/1985, de 2.5; el Decret legislatiu 1/1998, de 23 de juny, pel qual s'aprova el Text refós de la Llei de cooperatives de la Comunitat Valenciana, DOGV 3275, de 30.6.98, que refon la Llei 11/1985, de 25.10, i la Llei 3/1995, de 2.3; la Llei foral 12/1996, de 2 de juliol, de cooperatives de Navarra, BON 87, de 19.7.96, que substitueix l'anterior, 12/1989, de 3.7; Llei 2/1998, de 26.3, de societats cooperatives d'Extremadura, DOE 49, de 2.5.98; la Llei 5/1998, de 18.12, de cooperatives de Galícia, DOG núm. 251, de 30.12; la Llei 9/1998, de 22.12, de cooperatives d'Aragó, BOE núm. 23, de 27.1.99; la Llei 4/1999, de 30.3, de cooperatives de la Comunitat de Madrid, BOE núm. 131, de 2.6.99. També afecten, encara que en menor mesura, l'estructura i el funcionament orgànic de les cooperatives la Llei 13/1989, de 26.5 , de cooperatives de crèdit, BOE 129 , de 31.5.89, desplegada pel Reial decret $84 / 1993$, de 22.1, pel qual se n'aprova el Reglament, BOE 43, de 19.2; correcció d'errades en el BOE 65, 17.3, i la Llei 30/1995, de 8.11, d'ordenació i supervisió de les assegurances privades, BOE 268, de 9.11. En l'àmbit autonòmic hi ha altres normes que regulen l'activitat sectorial de les cooperatives $\mathrm{i}$ que també n'afecten l'estructura orgànica, com ara la Llei 8/1985 de la Generalitat Valenciana, de 31.5 , de regulació de l'actuació financera de les cooperatives amb secció de crèdit a la Comunitat Valenciana (DOGV 259, de 10.6.85; correcció d'errades al DOGV 279, 12.8), i la Llei 
tant, excloent. Això fa inevitable tenir en compte les més divergències significatives que es donen entre aquestes, si bé nosaltres ens centrarem fonamentalment en la Llei 27/1999, de 16 de juliol, de cooperatives (LCoop) i en el Decret legislatiu 1/1998, de 23 de juny, pel qual s'aprova el Text refós de la Llei de cooperatives de la Comunitat Valenciana (LCCV).

Pel que fa als aspectes processals de la impugnació, no seran objecte d'estudi, tret dels aspectes en què siga necessària una referència, perquè afecte el contingut juridicomaterial de les normes analitzades. L'extensió de la matèria que abordem ens ha portat a centrar-nos en l'objecte de la impugnació $i$ en els subjectes legitimats per exercir-la, deixant als estudiosos del dret processal la tasca d'analitzar les importants reformes introduides en el procediment judicial per a la impugnació d'acords socials amb l'entrada en vigor de la Llei 1/2000, de 7 de gener, d'enjudiciament civil ${ }^{7}$.

\section{Concepte i naturalesa jurídica de la impugnació dels acords socials}

Les normes legals substantives no aporten una definició directa de què haja d'entendre's per "impugnació d'acords socials", per la qual cosa s'ha d'acudir a la seua exegesi i a les aportacions doctrinals sobre la matèria. De partida, a un terreny purament intuïtiu, pot convenir-se que, quan es parla d'impugnar

6/1998 del Parlament de Catalunya, de 13 de maig, de regulació del funcionament de les seccions de crèdit de les cooperatives.

${ }^{7}$ BOE núm. 7, de 8.1.2000. Comentaris de les modificacions introduïdes per la LEC en el procés d'impugnació poden veure's en CABALLOL i ANGELATS, L., "Comentario al artículo 122», en AA. DD., Comentarios a la Ley de sociedades anónimas (coords. I. Arroyo i J. M. Embid), vol. II, Tecnos, Madrid, 2001; DAMIÁN MORENO, Juan, «Aspectos generales en torno al proceso de impugnación de acuerdos sociales de las sociedades anónimas", RDPro, 2000, núm. 1, pàg. 49-76; DE LA VEGA GARCIA, Fernando L., "Aspectos mercantiles de la nueva Ley de enjuiciamiento civil», La Ley, núm. 5103, 24.7.2000, pàg. 1-10; Pérez DAUDf, V., CACHÓN CADENAS, M. i FRANCO ARIAS, J., "Comentario al artículo 118», en AA. DD., Comentarios a la Ley de sociedades anónimas (coords. I. Arroyo i J. M. Embid), vol. II, Tecnos, Madrid, 2001, pàg. 1174-1269; i en SÁNCHEZ ÁlVAREZ, 
acords socials, s'està fent referència a la realització d'una sèrie d'actuacions normades que pretenen arribar, si més no, a evitar les conseqüències danyoses que poden anar unides a l'execució d'aquests acords ${ }^{8}$.

Pot fer-se referència, per tant, a la impugnació com a instrument ${ }^{9}$ juridicosocietari o curs procedimental ${ }^{10}$ que permeta constatar, si escau, que els acords $i$ altres declaracions de voluntat o de ciència ${ }^{11}$ amb transcendència per $a$ la persona jurídica han estat realitzats indegudament, i que és tan greu la incorrecció que l'ordenament jurídic considera que no s'han de produir els efectes perseguits ${ }^{12}$. L'adopció de l'esmentada perspectiva fa necessari analitzarne alguns aspectes. Així, en primer lloc, quin pot ser l'objecte sobre el qual recaiga la impugnació, però també quin tipus de vicis es consideren prou greus per invalidar els acords, $\mathrm{i}$ quins efectes han de desaparèixer ${ }^{13} \mathrm{i}$ amb quina radicalitat. A tot això dedicarem els epígrafs i capítols següents.

Una qüestió prèvia serà, però, determinar el fonament jurídic de la institució: per què l'ordenament jurídic regula un curs processal que permet evitar els efectes no desitjats de decisions incorrectes de les persones jurídiques? Es tracta

Manuel M., «Aspectos societarios de la nueva Ley de enjuiciamiento civil: la impugnación de acuerdos sociales, en particular», RdS, núm. 15, pàg. 383-387.

'SAlelles Climent, José Ramón, El funcionamiento del consejo de administración, Civitas, Madrid, 1995, pàg. 374.

${ }^{9}$ DUQUE DOMf́nguez, Justino F., Tutela de la minoria. Impugnación de acuerdos lesivos (art. 67 L.S.A.), Universidad de Valladolid. Tesi doctoral, Valladolid, 1957, pàg. 8.

"AlCALÁ Díaz, M. Ángeles, La impugnación de acuerdos del consejo de administración de sociedades anónimas, Madrid, Civitas, 1998, pàg. 78, nota 1.

"Galgano, Francesco, El negocio jurídico (trad. per F. Blasco i L. Prats), Tirant lo Blanch, València, 1992, pàg. 25: "L'efecte de les declaracions de ciència no és, com per a les declaracions de voluntat, constituir o modificar o extingir relacions jurídiques, sinó provar l'existència de fets jurídics, constitutius o modificatius o extintius de relacions, per ells mateixos».

${ }^{12}$ AlcalÁ díaz, M. Á., La impugnación...., op. cit., pàg. 191.

${ }^{13}$ Duque Domínguez, J. F., Tutela..., op. cit., pàg. 11; SORIA FerRando, José Vicente, La impugnación de los acuerdos sociales en la Ley de sociedades anónimas, tesi doctoral inèdita, València, 1978, pàg. 18. 
de resoldre la qüestió dels interessos protegits mitjançant la norma ${ }^{14}$. Després de determinar els esmentats interessos que es consideren dignes de tutela podrem, a més, validar, si escau, la legitimació reconeguda als subjectes portadors d'aquests interessos. Llavors podrà parlar-se, utilitzant una perspectiva subjectiva, de la impugnació com de dret, o, com s'ha proposat, $d^{\prime}$ un poder ${ }^{15}$, o d'una potestat, i del seu exercici.

\subsection{La impugnació com a eina d'invalidació de negocis jurídics}

Encara que, com veurem, l'objecte de la impugnació pot ser diferent a l'acord $\operatorname{social}^{16}$, sens dubte és aquest, amb diferència, el supòsit més comú i el que dóna origen a la institució que ara estudiem. Pot prendre's, doncs, com a punt de partida per a la seua anàlisi.

Sobre la naturalesa jurídica dels acords socials, es dóna l'opinió doctrinal generalitzada del seu caràcter de negocis jurídics unilaterals ${ }^{17}$. Estem davant de

${ }^{14}$ URÍA, R., MENÉNDEZ, A. i MUÑOZ, J. M., «La junta general de accionistas (arts. 93 a 122 de la Ley de sociedades anónimas)", en Comentario al régimen legal de las sociedades mercantiles, (dirs. R. Uría, A. Menéndez i M. Olivencia), tom V, Civitas, Madrid, 1992, pàg. 304.

${ }^{15}$ DUQUE DOMf́NGUEZ, J. F., Tutela..., op. cit. pàg. 154.

${ }^{16}$ La nostra intenció és demostrar que amb la impugnació regulada en el dret de societats poden sotmetre's a revisió altres declaracions de voluntat o de ciència no adoptades mitjançant el procediment col-legial que conclou amb un acord.

${ }^{17}$ CABALlol I ANGElATS, Lluís, "Comentario al artículo 115", en AA. DD., Comentarios a la Ley de sociedades anónimas (coords. I. Arroyo i J. M. Embid), vol. II, Tecnos, Madrid, 2001, pàg. 1106 i 1107: "Quan entra a formar part de l'ens col-lectiu, el soci canvia, en allò que constitueix l'objecte de la societat i la seua aportació, la facultat d'obligar-se individualment pel dret de participar, en proporció a l'aportació realitzada, en la formació de la voluntat de la societat i en els resultats de l'activitat social»; GARRIGUES, Joaquín, "Nulidad e impugnabilidad de los acuerdos de la Junta general», RDM, núm. 3, vol. I, 1946, pàg. 418 i 419; GIMENO SENDRA, Vicente, El proceso de impugnación de acuerdos de las sociedades anónimas y cooperativas, 2a ed., Madrid, Civitas, 1985, pàg. 13; RUBIO, Jesús, Curso de derecho de sociedades anónimas, 3a ed., Editorial de Derecho Financiero, Madrid, 1974, pàg. 240: «caràcter unilateral de la declaració que l'acord significa: No és la concurrència de diverses voluntats [...] el que concedeix a una declaració la seua naturalesa bilateral o plurilateral, sinó la contraposició de voluntats que concorren des de diverses parts. L'acord de la Junta general és un negoci unilateral, perquè és la declaració d'una sola part, la societat»; SORIA FERRANDO, J. V., La impugnación..., op. cit., pàg. 39; TATO PLAZA, Anxo, Sustitución y anulación por la sociedad de acuerdos sociales impugnables (contribución al estudio del art. 115.3 LSA), McGraw-Hill, Madrid, 1997, pàg. 75; URf́, Rodrigo, 
negocis jurídics, en la mesura que aquests es defineixen com un instrument per a l'autoregulació dels propis interessos, per a la creació per la persona, en el seu àmbit privat, de regles de conducta per a si i en relació amb els altres ${ }^{18}$. Si el negoci jurídic és una manifestació o declaració de voluntat dirigida a produir efectes jurídics ${ }^{19}$, l'acord és un negoci jurídic unilateral, en la mesura que hi ha una única part, la persona jurídica, en l'interès de la qual es produeix la deliberació dels socis: hi ha "unicitat d'interessos" 20.

Derecho mercantil , 27a ed., Madrid, Marcial Pons, 2000, pàg. 321; URfA, R., MENÉNDEZ, A. i MUÑ̄Z, J. M., La junta..., op. cit., pàg. 50.

GIRÓN TENA, José, Derecho de sociedades, Madrid, 1976, tom I, pàg. 310; això no obstant, en Derecho de sociedades anónimas, Valladolid, 1952, pàg. 278 i 279, reflecteix el debat doctrinal sobre el concepte de negoci jurídic i s'ocupa d'especificar: «Atenent la rellevància de la voluntat que s'hi continga, podrà aparèixer com una declaració de voluntat que serà pressupòsitt perquè es produïsquen efectes jurídics que són posats pel dret positiu -acte jurídic-o que produirà els efectes jurídics posats per la voluntat mateixa, perquè l'ordenació l'autoritze - negoci jurídic-; 0 com una declaració de ciència o de veritat o de desig o d'opinió; en aquest cas la voluntarietat continuarà sent pressupòsit de l'acte, com a acte, però no la dada jurídicament rellevant per a la producció dels efectes, de manera que continuarà sent subclasse dels actes jurídics en sentit estricte, però, com a subclasse amb tractament particular [...] l'acord ja format pot portar-se a la doctrina general dels fets, actes i negocis jurídics en forma semblant a la seguida per a l'estudi dels actes individuals de les persones físiques. Per tant, la caracterització dels acords des d'aquest punt de vista com a negocis jurídics, com a actes jurídics, etc., no té solució unitària; un s'ha d'atenir a l'índole de cada acord concret».

SAlelles ClIMENT, J. R., El funcionamiento..., op. cit., pàg. 374 els considera com a "categoria especial de negocis jurídics".

En contra de l'aplicació de les normes del negoci jurídic als acords socials, SCORDINO, F., $\mathrm{La}$ società cooperativa, Casa Editrice Dott. Eugenio Jovene, Nàpols, 1970, pàg. 286, en considerar diferent la "voluntat negocial» de la «voluntat assembleària» de l'òrgan col-legial.

\section{${ }^{18}$ De Castro y Bravo, Federico, El negocio jurídico, Civitas, Madrid, 1985, pàg. 11 i 12.}

${ }^{19}$ Aquesta és, segons Galgano, F., El negocio jurídico, pàg. 26-37, la definició més difosa, deguda a la ciència del dret civil alemany del segle XIX. Aquest autor, tanmateix, explica com en ordenaments jurídics com l'italià (i també pot afirmar-se respecte de l'espanyol) el "superconcepte de negoci jurídic, transcendent al contracte $\mathrm{i}$ a l'acte unilateral" es manté en l'actualitat "més per costum lingüístic que per convicció conceptual», i s'utilitza en realitat aquell com a sinònim d'aquests. Certament, vistes les nostres ordenacions positives, seria més correcte distingir entre fets jurídics, en tant que fets humans que produeixen els efectes previstos per l'ordenament jurídic sempre que es tracte d'un fet conscient $i$ voluntari (però sent irrellevant que l'autor del fet haja volgut a més els efectes jurídics), i actes jurídics entesos com a fets jurídics que no produeixen efectes si es constata que el subjecte no els havia volguts. Els fets jurídics seran, doncs, el gènere $i$ els actes jurídics l'espècie, en la qual s'inclouran tant declaracions de voluntat com declaracions de ciència (amb les quals el subjecte declara tenir coneixement d'un fet jurídic) i participacions i comunicacions (declaracions permissives, prohibitives, determinatives, notificacions, denúncies, intimacions, etc.).

${ }^{20}$ GALGANO, F., El negocio jurídico, op. cit., pàg. 29; GIRÓN TENA, J., Derecho de sociedades, op. cit., tom I, pàg. 310; SORIA FERRANDO, J. V., La impugnación..., op. cit., pàg. 39, 41 i 42. 
És el principi d'autonomia privada el que permet que la persona jurídica s'autoorganitze mitjançant la utilització de diversos negocis jurídics ${ }^{21}$, entre els quals, les declaracions de voluntat $\mathrm{o}$ de ciència en què consisteixen els acords dels òrgans socials ${ }^{22}$. I és la qualificació de l'acord com a negoci jurídic el que va portar, abans de la construcció explícita de la seua impugnació, a aplicar-li el règim comú de les accions de nul-litat i anul-labilitat regulades en el Codi civil ${ }^{23}$.

Però aquesta aplicació produïa situacions poc satisfactòries: la tòpica necessitat de l'àmbit juridicomercantil de combinar agilitat i seguretat no cohonestava fàcilment amb un règim general civil, sobre alguns dels aspectes essencials dels quals encara en l'actualitat planen dubtes i debats doctrinals, i que sotmetia en tot cas els acords socials al tràmit lent, complex $\mathrm{i}$ car d'un judici declaratiu ordinari. Això va portar a establir, en la LSA del 1951, un sistema de menor complexitat, en el qual els acords socials invàlids s'unificaven en dues úniques categories: nul.litat i impugnabilitat ${ }^{24}$; $1^{\prime}$ esmentada diferenciació transcendia a la legitimació i al tipus de procés aplicable.

La necessitat de reduir al màxim els supòsits en què l'acord quedara sotmès a la incertesa de la anul-lació possible ${ }^{25}$, va portar ja llavors la nostra doctrina a considerar la impugnació d'acords socials com a disciplina especial davant la general dels vicis del negoci jurídic, ja que en aquella se subverteix el principi

\footnotetext{
${ }^{21}$ DE CASTRO Y BRAvo, F., El negocio jurídico, op. cit., pàg. 11.

${ }^{22}$ Vegeu supra, en nota 17, la distinció de GIRÓN TENA, J., Derecho de sociedades, op. cit., tom I, pàg. 312, en la configuració de l'acord com a declaració de voluntat o com una declaració de ciència o de veritat, o de desig o d'opinió, o de sentiment. "Aquests efectes diferents es donen en el dret de societats (acords sobre comptes i balanços, opinions de la junta imposats als administradors preceptivament per a supòsits determinats, vots de gràcies)».
}

${ }^{23}$ AlcalÁ Díaz, M. Á., la impugnación..., op. cit., pàg. 171; CABAllol I ANGelats, L., "Comentario al artículo 115...», op. cit., pág. 1106; VICENT CHULIÁ, F., La asamblea..., op. cit., pàg. 201.

${ }^{24}$ GIRÓN TENA, J., Derecho de sociedades anónimas, op. cit., pàg. 315 a 317; AlCALÁ DIAZ, M. Á., La impugnación..., op. cit., pàg. 78 i 171-173, on es recullen també les diferents opcions de dret comparat; SALELLES CLIMENT, J. R., El funcionamiento ..., op. cit., pàg. 376.

${ }^{25}$ GIRÓN TENA, J., Derecho de sociedades anónimas, op. cit., pàg. 318. 
general de nul-litat i se'n fa, de l'anul-labilitat, la regla, evitant tant com es puga els casos de nul.litat ${ }^{26}$. Com s'ha assenyalat, "al marge de l'encert dogmàtic que aquesta separació estricta pot contenir, el cert és que el legislador espanyol ha intentat resoldre el problema difícil de distingir nul-litat d'anul-labilitat en termes extremadament simples, sense que per això hi hagen faltat crítiques doctrinals" ${ }^{27}$.

A més, la doctrina aviat va advertir que la necessitat d'un grau més alt d'agilitat, de simplicitat dels procediments i de seguretat del tràfic es compadia poc amb la imprescriptibilitat de l'acció de nul-litat ${ }^{28}$. Aquest va ser un dels motius que van conduir a abordar, en la reforma de la legislació societària del 1989, la unificació de les accions d'impugnació en un sol "tràmit judicial senzill, ràpid i d'instància única" que, encara que manté la distinció entre acords nuls i acords anul-lables, preveu un termini de caducitat, també per a la impugnació dels acords nuls ${ }^{29}$. Aquesta evolució en el tractament dels efectes jurídics dels

${ }^{26}$ DUQUE DOMf́NGUEZ, J. F., Tutela..., op. cit. pàg. 58, nota 55.

${ }^{2}$ EMBID IRUJO, José Miguel, "Notas sobre la impugnación de acuerdos sociales en la Ley española de Sociedades Anónimas», Noticias de la Unión Europea-CISS, núm. 121, 1995, pàg. 52. En el mateix sentit, URÍA, R., MENÉNDEZ, A. i MUÑOZ, J. M., La junta, pàg. 316 i 317. POLO SÁNCHEZ, Eduardo, "Los administradores y el consejo de administración de la S.A»., en Comentario al régimen legal de las sociedades mercantiles (dirs. R. Uría, A. Menéndez i M. Olivencia, tom VI, Civitas, Madrid, 1992., pàg. 531-532, es refereix a aquestes crítiques doctrinals.

28 AlCAlÁ DÍAZ, M. Á., La impugnación..., op. cit., pàg. 223; GARrigUES, J., «Nulidad e impugnabilidad...», op. cit., pàg. 429 i 430; ESTEBAN VELASCO, Gaudencio, "La estructura de las sociedades anónimas en el Derecho comunitario (El Proyecto modificado de Quinta Directiva)", CDC, núm. 5, juny, 1989, pàg. 340; URf́A, R., MENÉNDEZ, A. i MuNNoz, J. M., La junta..., pàg. 318 i

${ }^{29}$ SAlelles Climent, J. R., El funcionamiento..., op. cit., pàg. 376-377. POlO SÁNCHEZ, E., Los administradores..., .op. cit., pàg. 533-534: «la norma (present ja en la Llei de cooperatives [articles 52.4 i 66.4]) sembla inspirada en l'article 44 de la proposta modificada de cinquena directiva i atén les crítiques que el projecte del govern havia suscitat entre la nostra doctrina en mantenir la imprescriptibilitat dels acords nuls [...]. D'altra banda, i encara que l'arrelament entre els nostres juristes de la posició anterior farà que es desperten certes crítiques a la reforma, la norma respon a una evolució certa produïda en el dret comparat respecte de la institució de la nul.litat, a raó de la inseguretat jurídica que es deriva de la permanència indefinida dels seus efectes, evolució singularment manifestada en les directives de la CEE en el tractament de la nul-litat i l'anul-labilitat tant en la constitució de la societat, com en les operacions de fusió i escissió».

En la mateixa línia, ALCALÁ DíAz, M. Á., La impugnación..., op. cit., pàg. 173-174, que, tot i coincidir a identificar la notable influència del projecte de cinquena directiva en proposar l'agudització dels mecanismes de protecció de la seguretat jurídica i del tràfic, constata que 
acords impugnables, descrits i analitzats per la doctrina per a les societats de capital, ha tingut, com veurem més endavant, el parangó en les modificacions successives de la legislació cooperativa.

Amb això s'ha anat aprofundint en el tractament diferenciat de la invalidesa dels acords socials respecte del règim general del negoci jurídic, en nom de la preservació de l'estabilitat societària, "encara que per a això calga sacrificar o subvertir els principis que governen aquesta matèria en les lleis civils" ${ }^{\prime 30}$.

I encara que en la dècada llarga de vigència de la reforma no s'han acabat de resoldre satisfactòriament alguns dels seus aspectes essencials, com ara el de l'«encaix» de la nul-litat radical dels acords contraris a l'ordre públic, i no obstant les crítiques reiterades a la subversió produïda en la distinció clàssica entre nul-litat $\mathrm{i}$ anul-labilitat, sembla que és ja moment de passar pàgina, assumint que la institució de la impugnació dels acords socials, encara que deutora de la teoria general, ha esdevingut en un sistema d'invalidesa diferent,

aquest projecte de directiva no suposa en realitat una harmonització de les legislacions nacionals en matèria d'impugnació d'acords socials, ja que no es delimiten les diferents sancions jurídiques aplicables (nul-litat, anul-labilitat $o$, en el seu cas, inexistència) i es refereix únicament als vicis de procediment en l'adopció d'acords, sense establir un règim específic per als vicis de contingut, respecte dels quals es manté l'aplicació de les legislacions nacionals.

3n URíA, R., MENÉnDEZ, A. i MuÑoz, J. M., La junta..., pàg. 309; GALGANO, Francesco, Diritto commerciale. Le società, ed. 1997/1998, Bolonya, Zanichelli, 1997, pàg. 244: "L'interès protegit és l'interès de la majoria assembleària en l'estabilitat de les pròpies deliberacions: l'interès que les deliberacions assembleàries - fins $i$ tot les contràries a normes imperatives- no estiguen perpètuament exposades a les accions de nul-litat de qualsevol interessat i queden, doncs, en una condició d'incertesa perenne. I, si es consideren les relacions economicosocials subjacents, l'interès de la classe empresarial: el Codice civile no dubta, en aquest com en tants altres casos, a derogar les normes de dret comú, quan l'aplicació d'aquestes normes es pogueren traduir en un destorb a l'activitat empresarial, en un obstacle a l'eficiència de la gestió".

SORIA FERRANDO, J. V., La impugnación..., op. cit., pàg. 19: «la regulació de la impugnació $\mathrm{d}$ 'acords de la junta general d'accionistes es debat entre dues exigències contraposades. D'una banda, l'interès dels socis en la legalitat de l'activitat social i, d'una altra, l'exigència de més rapidesa, seguretat i estabilitat en el tràfic jurídic de la societat. Tanmateix, ateses les exigències del tràfic modern, la regulació de la impugnació dels acords socials no sol reflectir un equilibri entre aquestes dues exigències contraposades. Així, amb diverses mesures es pretén donar més estabilitat a les relacions jurídiques nascudes d'acords socials, encara que hagen estat irregularment adoptats. Aquesta tendència és tan forta que amb diverses mesures els diferents ordenaments jurídics estan sostraient la impugnació dels acords socials a la disciplina del negoci jurídic». 
a raó de l'especialitat de l'objecte sobre el qual recauen: les declaracions de voluntat o de ciència dels òrgans de les persones jurídiques ${ }^{31}$.

Fora d'això, aquesta afirmació no ha d'obstar a l'aplicació supletòria de la disciplina de la invalidesa del negoci jurídic, quan siga necessari cobrir les llacunes que es produïsquen ${ }^{32}$. Com veurem, són múltiples les propostes doctrinals en aquest sentit.

\subsection{La impugnació i la capacitat autonormativa de la persona jurídica}

En configurar, doncs, la impugnació com a instrument processal per eliminar acords i altres actes i negocis jurídics d'autoorganització de la persona jurídica, es desvetla el seu caràcter de límit o, si es prefereix, de mesura de control, contra l'exercici abusiu de l'autonomia privada. Alhora, però, com que la capacitat autonormativa en què consisteixen els acords socials troba el seu fonament en el principi constitucional de llibertat associativa, consagrat en l'article $22 \mathrm{CE}^{33}$, la invalidació d'aquests acords només podrà realitzar-se quan aquestes suposen un exercici il·legítim, excessiu, del dret d'associació.

Anteriorment a la CE de 1978, el constitucionalisme liberal de la fi del segle XVIII i el començament del XIX no reconeixia les associacions ni el dret a fundar-les, perquè trencava l'equilibri individualista de l'oferta i la demanda en el mercat, que havia de regir-se de manera natural a través de les relacions econòmiques en el mode de producció capitalista. En aquest context, l'aparició d'associacions obreres (sindicats, partits) que reivindicaven drets polítics (sufragi) suposava

\footnotetext{
${ }^{31}$ AlCALÁ DÍAZ, M. Á., La impugnación..., op. cit., pàg. 166; ASCARELLI, Tullio, «L'interesse sociale dell'art. 2441 c.c. La teoria dei diritti individuali e il sistema dei vizi delle deliberazioni assambleare», en Riv. Soc., 1956, pàg. 108, 114 i 115: "s'entén l'oportunitat d'una disciplina especial [...] per als actes col-legials, atesos precisament els diversos problemes sorgits en la disciplina general dels vicis del negoci jurídic».
}

${ }^{32}$ Salelles Climent, J. R., El funcionamiento..., op. cit., pàg. 374. 
atemptar, no solament contra el fonament econòmic, sinó també contra el fonament polític, en buscar una legitimitat democràtica diferent a l'establerta.

Segle i mig després, en un context social radicalment diferent, la Constitució espanyola del 1978 proclama l'estat social i democràtic de dret i el reconeixement del pluralisme com a valor superior de l'ordenament jurídic (article 1.1); conseqüentment, també reconeix el dret fonamental a fundar i pertànyer a una associació (article 22.1 CE). El dret d'associació comporta, al seu torn, el dret a establir la pròpia organització "dins del marc de la Constitució $\mathrm{i}$ de les lleis que, respectant el contingut essencial d'aquest dret, el desenvolupen o el regulen" (SSTC 218/1988 i 96/1994 $4^{35}$ ). Una de les manifestacions bàsiques d'aquest dret són els estatuts socials, com a normes de compliment obligat per als qui vulguen pertànyer a l'entitat; una altra és la capacitat o el poder de decisió, la facultat d'adoptar acords conformes a la llei i els estatuts.

Com que la capacitat de dotar-se de normes pròpies i de prendre acords té uns límits (els establerts en la Constitució i en les lleis) no està exempta de control, però aquest control, després de l'aprovació de la Constitució, ha de ser sempre posterior, atès el caràcter fonamental del dret. Ha de ser una resolució judicial la que, després d'inscriure l'associació, entenga sobre la il·legalitat possible de les seues normes o dels seus actes. I el control judicial no és il-limitat, "continua existint, però el seu abast no consisteix en el fet que el jutge puga entrar a valorar, amb independència del judici que ja han realitzat els òrgans de l'associació, la conducta del soci, sinó a comprovar si hi hagué una base raonable

${ }^{33}$ PAZ CANALEjO, Narciso, «Ante la nueva Ley estatal de cooperativas: algunos puntos críticos», Anuario de estudios cooperativos 1998, Instituto de Estudios Cooperativos, Universidad de Deusto, Bilbao, 1999, pàg. 82-83.

${ }^{34}$ Sentència del Tribunal Constitucional (S. 2a) de 22.11.1988, núm. 218/1988, BOE núm. 22.12.1988.

${ }^{35}$ Sentència del Tribunal Constitucional (S. 2a) de 21.3.1994, núm. 96/1994, BOE núm. 26.4.1994. 
perquè els òrgans de les associacions prengueren la decisió corresponent ${ }^{36}$. "El respecte al dret d'associació exigeix que l'apreciació judicial es limite en aquest punt a verificar si s'han donat circumstàncies que puguen servir de base a la decisió dels socis, (...), deixant el judici sobre aquestes circumstàncies als òrgans directius de l'associació, tal com prescriuen els seus estatuts"' (STC 218/1988).

Això no obstant, el tribunal modula aquesta interpretació del tipus d'associacions. Així, en la STC 96/1994 assenyala que "el dret d'associació sols podrà invocar-se en aquells casos en què realment apareguera vulnerat el contingut d'aquest dret, ja que en les societats mercantils $i$, en particular, en les societats de capitals, predominen davant les relacions derivades de la unió de persones, les nascudes de la unió de capitals, la qual cosa, sense excloure la possibilitat que en certs casos puga produir-se una lesió del dret d'associació respecte a aquest tipus de societats, cal plantejar en cada supòsit si el dret que es tracta i que s'entén lesionat és efectivament de naturalesa associativa (...) l'abast del control judicial haurà de modular-se, en cada cas, segons el que es preveu en la legislació específica que regule cada modalitat associativa, sempre que aquesta legislació salvaguarde, com s'ha dit, les exigències que deriven de l'article $22 \mathrm{CE}^{\prime \prime}$.

D'aquesta última sentència es deriva doncs una conseqüència curiosa: les associacions en què només es dóna una unió de persones gaudirien de més capacitat d'autoregulació i, per tant, de més limitació de la intervenció judicial, mentre que en les associacions que comporten associació de capital hi ha un

\footnotetext{
${ }^{36}$ La teoria de la base raonable s'ha convertit en l'element que permet al tribunal valorar les decisions dels òrgans directius de les associacions en aquells aspectes que, encara que pertanyen a l'àmbit del seu poder d'autoregulació o poder de decisió, no tinguen una justificació suficient des del punt de vista de la raonabilitat; es possibilita, en definitiva, la intervenció del TC en els supòsits en què la decisió resultara arbitrària per la falta d'arguments. La dificultat es produeix a l'hora de determinar el que "és o no raonable» [SALVADOR CODERCH, P. (coord.), VON MŸNCH, I. i FERRER I RIBA, J., Asociaciones, derechos fundamentales y autonomía privada, Cuadernos Civitas, Madrid, 1997, pàg. 59-63], encara que segons es desprèn de les seues sentències, sembla que el TC identifica raonable amb raonat, en contraposició al que entén per una decisió arbitrària o mancada d'arguments; és a dir, que el TC es conforma amb l'existència d'arguments que justifiquen la decisió.
} 
menor grau d'autonomia ${ }^{37} \mathrm{i}$ una possibilitat més gran d'intervenció judicial, tenint en compte que el poder de decisió de l'associació pot tenir unes conseqüències que comporten un perjudici econòmic significatiu per al soci. Sembla, doncs, que la conseqüència econòmica possible de la decisió, el perjudici per al soci, rebaixarà la teoria de la base raonable per a les persones jurídiques amb aportació de capital.

En tot cas, i amb major o menor grau de control jurisdiccional, del dret a l'autoorganització es deriva el principi de manteniment de la voluntat de l'associació/persona jurídica: mentre no es vulneren els límits constitucionals, s'ha de considerar vàlid l'acord mitjançant el qual es manifesta la voluntat social. Com s'ha dit, ha d'aplicar-se una interpretació restrictiva de les causes d'impugnació i mantenir-se la presumpció de validesa dels acords mentre no hagen estat declarats nuls ${ }^{38}$.

Aquest respecte bàsic al dret d'autoorganització de la persona jurídica i a les seues decisions implica que el control judicial, la impugnació dels acords socials, només prosperarà quan l'activitat social haja vulnerat els límits de la seua capacitat autoorganitzativa. I en l'exercici d'aquest control, els tribunals no poden entrar en judicis de valor sobre l'oportunitat de les decisions ${ }^{39}$, sinó que

\footnotetext{
${ }^{37}$ SALVADOR CODERCh, P. (coord.), VON MŸNCH, I. i FERRER I RIBA, J., Asociaciones, derechos..., op. cit., pàg. 70-73; pàg. 71: «Una cooperativa no té un àmbit tan ampli d'autonomia decisòria, ja que compta amb una configuració legal, prèvia als estatuts, sobre l'extensió de la revisió judicial».

${ }^{3 *}$ BERCOVITZ, Alberto, "Los acuerdos impugnables en la Sociedad Anónima», en AA. DD., Estudios de derecho mercantil en homenaje al profesor Manuel Broseta Pont, València, Tirant lo Blanch, 1995, pàg. 381: «Aquest principi constitucional, favorable al manteniment dels acords socials, es manifesta clarament en la Llei de societats anònimes a través de diversos preceptes: es reconeix la possibilitat de reparar els acords impugnables (article 115.3); s'estableix la caducitat de l'acció per impugnar els acords nuls que no siguen contraris a l'ordre públic (article 116)...».
}

${ }^{34}$ SAlelles Climent, J. R., El funcionamiento..., op. cit., pàg. 383-384: «encara que hi poguera intervenir, el jutge no estaria normalment en situació de poder valorar l'oportunitat de la decisió presa. [...] Quan en el moment de prendre una decisió són diferents les alternatives raonables, l'opció per una d'aquestes no pot comportar-ne l'anul-lació pels tribunals, ni tan sols en els supòsits en què es recórrega a informes pericials, atenent criteris de mèrit (nota 435 in fine: «En el Dret nord-americà se segueix aquest mateix criteri a través del principi jurisprudencial business-judgement rule. Un acord del Consell adoptat de bona $\mathrm{fe}$, amb la diligència deguda i una 
han de cenyir-se a comprovar que no hi haja una decisió contrària a la Constitució o a les lleis que despleguen el dret d'associació; en el cas que ens ocupa, com veurem, les normes legals cooperatives bàsiques estableixen com paràmetres de l'autoorganització la llei, els estatuts i la no lesió de l'interès social.

La impugnació és, doncs, un instrument per al control de constitucionalitat del principi d'autonomia organitzativa: quan la cooperativa excedisca els límits del seu dret d'autoorganització, les seues decisions podran ser impugnades. Però l'autonomia privada de la voluntat cooperativa, al seu torn, limita el dret del soci a impugnar els acords.

Després d'establir el paper que la Constitució, com a norma jurídica bàsica, atribueix a la impugnació, es requereix aprofundir en la seua configuració actual en l'ordenament jurídic. Correspon, en primer lloc, determinar el fonament jurídic de la institució, els interessos que el legislador ha pres en consideració per regular la impugnació; en definitiva, els interessos que es consideren dignes de tutela davant del dret a l'autonomia organitzativa.

\section{Fonament jurídic de la impugnació dels acords socials}

Davant de l'escassetat d'aportacions doctrinals en l'àmbit cooperatiu i atès l'indubtable origen tecnicojurídic de la institució, l'elaboració de la fonamentació jurídica de la impugnació d'acords socials a la cooperativa fa aconsellable recórrer (com, en general, succeeix en l'estudi dels òrgans socials) als treballs desenvolupats per a les societats mercantils, i intentar aplicar-los, amb les modificacions necessàries, a les característiques especials del model cooperatiu. 
Són diverses les propostes que s'han elaborat per fonamentar jurídicament la impugnació dels acords ${ }^{40}$. Això no obstant, la majoria semblen tenir un element comú: la consideració que la impugnació dels acords socials gira al voltant de la defensa de l'interès social, siga de manera directa o indirecta ${ }^{41}$. En la mesura que la impugnació s'institueix per a la defensa de la manera més correcta d'actuar de la societat en la consecució dels seus objectius, es converteix en garantia dels seus interessos.

En efecte, la major part de les teories elaborades sobre quins són els interessos que el legislador pretén protegir mitjançant la impugnació dels acords socials coincideixen a assenyalar la protecció de l'interès social com, almenys, un dels seus objectius. La fonamentació jurídica de la impugnació requereix, doncs, prendre en consideració el concepte $d^{\prime}$ «interès social», i també les peculiaritats

\footnotetext{
${ }^{40}$ Poden veure-se'n resums en la major part de les obres que analitzen la institució; destaquen, per la seua minuciositat, SORIA FERRANDO, J. V., La impugnación..., op. cit., pàg. 55; i per la seua capacitat de síntesi, URtA, R., MENÉNDEZ, A. i MUÑ̃Z, J. M., La junta..., pàg. 315.
}

${ }^{41}$ BASSI, Amedeo, Le società cooperative, UTET, Torí, 1995, pàg. 26: «En la cooperativa, com en tots els tipus de societat, hi ha, abans que res, regles de tutela objectiva dels interessos dels socis: cada soci, fent-se portador d'interessos comuns, i independentment dels actes de la societat que lesionen directament les seues expectatives, pot pretendre la conformitat de les operacions de la societat amb la finalitat $i$ a l'objecte social. Tots els socis [...] poden oposar-se a les decisions dels òrgans socials o de la societat que no siguen, directament o indirecta, conformes a la finalitat $i$ a l'objecte de la societat, encara que, en el cas concret, el soci no rep un perjudici personal i directe». Així, se sosté el caràcter de la impugnació com a instrument de defensa de l'interès social, fins $i$ tot en els casos en què es manté que el soci que impugna exercita un dret subjectiu, "perquè al fons de tota impugnació hi ha sempre un interès del soci que és propulsor constant de la seua acció independentment que satisfaça al mateix temps l'interès dels altres socis o el de la societat» (URíA, R., MENÉNDEZ, A. i MUÑOZ, J. M., La junta..., pàg. 315). En la mateixa línia, DUQUE DOMÍNGUEZ, J. F., Tutela..., op. cit. pàg. 156-158; BuSTILlo SAIZ, M. del Mar, La subsanación de acuerdos sociales por la junta general de la sociedad anónima, Aranzadi, Elcano (Navarra), 1999, pàg. 205; RUBIO, J., Curso..., op. cit., pàg. 261.

Això no obstant, alguns autors han plantejat un dubte raonable sobre l'interès social com a fonament últim de la impugnació d'acords, ja que, almenys en els acords lesius, es requereix per la norma un plus: no sols han de lesionar interessos socials sinó que, a més, es requereix la producció d'un benefici extrasocial; cfr. DUQUE, Tutela..., op. cit., pàg. 154 i DfAZ DE LEZCANO SEVILLANO, Nicolás, Los acuerdos del consejo de administración. Especial referencia a su régimen de impugnación, J. M. Bosch Editor, Barcelona, 1999, pàg. 20; contràriament, SÁNCHEZ RUIZ, M., Conflictos de intereses..., op. cit., pàg. 173, nota 78: «En la nostra opinió, el fet que no totes les lesions possibles a l'interès social permeten la impugnació de l'acord lesiu, sinó només aquelles que deriven d'una hipòtesi de conflicte amb un interès extrasocial [...] no impedeix considerar l'interès social o comú com l'interès tutelat per aquestes normes, [...] Els socis (a diferència dels administradors) no estan obligats a perseguir amb el seu vot l'interès de la societat, però (igual com aquests), sí que, en virtut del seu deure de lleialtat cap la societat, han d'ometre lesionar-lo en benefici d'un o més socis o de tercers". 
que presenta en la cooperativa. En definitiva, la concreció de l'interès (o els interessos) jurídicament rellevant(s) per a la cooperativa ens donarà(an) les pautes per concloure'n quins són els interessos protegits mitjançant la regulació de la impugnació dels seus acords. Es fa necessari, per tant, un repàs sumari a l'evolució doctrinal en el desenvolupament de la noció general d'interès social.

\subsection{La impugnació $\mathrm{i}$ el concepte d'interès social}

És àmpliament coneguda la divisió tradicional d'opinions doctrinals ${ }^{42}$, entre els partidaris de teories institucionalistes i les contractualistes. Institucionalisme i contractualisme tenen el seu origen en dues concepcions oposades de la societat anònima en el seu conjunt ${ }^{43}$ : la que posa l'accent en la seua qualitat de

42 Per a una exposició extensa dels trets fonamentals del debat doctrinal sobre el concepte d'interès social i de les dues grans teories, institucionalista i contractualista, són cita obligada ALBORCH BATALLER, Carmen, El derecho de voto del accionista (supuestos especiales), Madrid, Tecnos, 1977, pàg. 79-125, que segueix JAEGER, Pier Giusto, L'interesse sociale, Milà, 1964; DUQUE DOMíNGUEZ, J. F., Tutela..., op. cit. pàg. 68 i següents; ESTEBAN VELASCO, Gaudencio, El poder de decisión en las sociedades anónimas, Civitas, Madrid, 1982, pàg. 561 i següents; i SORIA FERRANDO, J. V., La impugnación..., op. cit., pàg. 249-315. JAEGER ha posat al dia les seues argumentacions en "L'interesse sociale rivisitato (quarant'anni dopo)», Giur. Comm., núm. 27/6, nov.-des. 2000, pàg. 795/I-812/I.

La noció d'interès social també ha estat revisitada quan els autors han abordat les normes concretes que en la LSA i en la LSRL l'inclouen en el seu supòsit de fet: 115 LSA, però també el 159 LSA (interès social com a pressupòsit per a l'exclusió lícita del dret de subscripció preferent), i el 52 LSRL (conflicte d'interessos entre el soci i la societat). Poden veure's resums actualitzats del debat en ALFARO AGUILA-REAL, Jesús, Interés social y derecho de subscripción preferente (Una aproximación económica), Civitas, Madrid, 1995; ALONSO LEDESMA, Carmen, "Algunas consideraciones sobre el juego de la cláusula del interés social en la supresión o limitación del derecho de suscripción preferente», en AA. DD., Derecho mercantil de la Comunidad Económica Europea. Estudios en homenaje a José Girón Tena, Civitas, Madrid, 1991, i en La exclusión del derecho de suscripción preferente en las sociedades anónimas, Madrid, 1995; COSTAS COMESAN̄A, Julio, El deber de abstención del socio en las votaciones, Tirant lo Blanch, València, 1999, pàg. 67-68 i 74-84; LARGO GIL, Rita, "La exclusión del derecho de suscripción preferente», en AA. DD., Derecho de sociedades anónimas, tom III, vol. 1, Civitas, Madrid, 1994, pàg. 603-700; PolO SÁNCHEZ, Eduardo, "Abuso o tiranía. Reflexiones sobre la dialéctica entre mayoría y minoría en la sociedad anónima", en AA. DD., Estudios jurídicos en homenaje al profesor Aurelio Menéndez, coord. Juan Luis Iglesias Prada, Madrid, Civitas, 1996, tom II, pàg. 2269-2293; SÁNCHEZ RUIZ, M., Conflictos de intereses..., op. cit., pàg. 57-78; VÁZQUEZ ALBERT, Daniel, «El conflicto entre mayoría y minoría en la exclusión del derecho de suscripción preferente», CDC, núm. 26, set. 1998, pàg. 159-202.

${ }^{43}$ SÁNCHEz RUIZ, M., Conflictos de intereses..., op. cit., pàg. 58; VÁZQUEZ ALBERT, D., «El conflicto entre mayoría...», op. cit., pàg. 178-180: "Aquesta dualitat [...] té l'origen en el canvi de paradigma de societat anònima. El paradigma liberal [...] s'assenta en un model de societat estrictament privada [...] accentuava clarament la consideració de la societat com un contracte [...]. Ara com ara, el paradigma liberal no respon a la realitat. [...] La crisi del liberalisme 
contracte $^{44}$ i la que remarca l'essència de l'organització que es desenvolupa a partir del pacte contractual ${ }^{45}$.

\section{a) Noció d'interès social}

\section{Després de reconduir el debat a la noció de l'interès social, les teories} institucionalistes es decanten per considerar que l'interès social és el que tendeix al manteniment de l'empresa, de la institució ${ }^{46}$, i que s'hi han d'integrar els interessos dels diversos subjectes que es relacionen amb l'empresa social:

econòmic clàssic i l'increment de la intervenció de l'Estat en l'economia fan que les societats obertes es convertisquen en el marc de realització no sols dels interessos dels socis, sinó també d'altres grups implicats en l'empresa, fet que desemboca en la denominada publicitació $\mathrm{d}$ 'interessos [...]. Aquest context estimula una concepció institucionalista de l'interès social».

En aquesta contextualització del debat s'entén millor la queixa de RUBIO, defensor de la tesi institucionalista, davant dels qui la criticaven des de posicions contractualistes: «Hi ha una cosa que no pot deixar de sorprendre: la mateixa direcció individualista establerta en l'aspecte privat del Dret, que no va vacil-lar a reconèixer, cada vegada amb caràcter més absolut, la personalitat jurídica de les societats de comerç contraposada a la de les persones dels seus socis com a expedient, en gran part, per excusar la responsabilitat en l'exercici dels negocis, és la que sent avui aquestes repugnàncies cap al que enfoca com a personificació de l'empresa».

${ }^{44}$ ALFARO ÁGUILA-REAL, J., Interés social y..., op. cit., pàg. 22: «El contracte de societat regula [...] les relacions entre accionistes $\mathrm{i}$ entre accionistes i administradors. Alhora, l'atribució de personalitat jurídica a aquest contracte per part de l'ordenació, unifica les relacions entre accionistes $\mathrm{i}$ li permet d'actuar com a nexe dels contractes que els accionistes acorden amb els altres subjectes que intervenen en la vida de l'empresa: proveïdors, clients, treballadors $i$, en un cert sentit, l'Estat. Concebuda així la societat, el problema de l'interès social és un problema referit al contracte de societat. Al contrari, els interessos dels treballadors, creditors, clients i del públic en general, constitueixen el contingut (i els problemes) dels seus contractes respectius amb la societat».

${ }^{45}$ EMBID IRUJO, José Miguel i MARTÍNEZ SANZ, Fernando, "Libertad de configuración estatutaria en el derecho español de sociedades de capital», RdS, núm. 7, 1996, pàg. 16: «No ha de pensarse que amb la caracterització de la societat com a contracte té lloc una aplicació indiscriminada de la disciplina pròpia del Dret d'obligacions i contractes. Com s'ha dit, les societats serien negocis destinats a produir efectes, no sols entre les parts contractants, sinó també davant tercers; d'altra banda, només l'aspecte juridicosocietari intern tindria, pròpiament, naturalesa negocial». TRICOT, Daniel, "Abus de droits dans les sociétés. Abus de majorité et abus de minorité», RTDCDE, núm. 4 oct.-des. 1994, pàg. 618 i 627 : «Les societats no són ni universalitats, ni copropietats, ni indivisions. La personalitat jurídica, que els és reconeguda per la llei, no s'acomoda a la seua submissió als sols interessos dels socis. [...] La sanció de l'abús de drets reposa així sobre la distinció entre l'interès social i els interessos dels associats: el primer, que no és la suma dels segons, justifica una protecció particular».

th RUBIO, J., Curso..., op. cit., pàg. 252: «Per separar l'interès comú del majoritari no hi haurà més remei, en la major part dels casos, que atendre les finalitats i l'activitat que la societat té com a objecte, la naturalesa de la seua empresa, el desenvolupament, la productivitat i la conservació de l'organització mercantil o industrial que constitueix el contingut i la finalitat de la companyia». 
socis, però també treballadors, creditors, consumidors, administracions... ${ }^{47} . \mathrm{La}$ teoria de la Unternehmen an sich, elaborada principalment en el dret alemany, va quedar molt desprestigiada per la utilització sota el règim nazi com a argument per fonamentar el Führerprinzip, que atribuïa als administradors poders gairebé absoluts. Això no obstant, va ser actualitzada després de la caiguda d'aquell règim per ressaltar el caràcter d'empresa de la societat i la coexistència $\mathrm{d}$ 'interessos diferents als dels socis, però també integrables en les relacions socials. Com a manifestacions específiques d'aquestes tesis, que les confirmarien, han estat vistes, per exemple, la incorporació a Alemanya de la cogestió $i$, amb aquesta, la rellevància social dels interessos dels treballadors ${ }^{48}, 0$ l'«administrativització» progressiva de les grans societats, sobretot les cotitzades, amb l'adopció de mesures de control per garantir els.interessos de tercers i de la seguretat del tràfic mercantil ${ }^{49}$.

Les teories contractualistes, que són les més esteses entre la doctrina mercantilista $i$ en la jurisprudència ${ }^{50}$, tendeixen a identificar interès social amb

\footnotetext{
“" Bustillo SAIZ, M. M., La subsanación de acuerdos..., op. cit., pàg. 202.

"Esteban Velasco, G., El poder de decisión..., op. cit., pàg. 585; SÁnChez RUIz, M., Conflictos de intereses..., op. cit., pàg. 60, nota 10 .
}

"En relació amb això, JAEGER, L'interesse sociale rivisitato..., op. cit., pàg. 798-799/I apunta com els canvis que es produeixen en les últimes dècades en les societats anònimes actualitzen teories que "semblaven superades, però que són represes en el marc de les perspectives més modernes», en la línia "d'afermar-se una relació estreta entre dret de societats $i$ dret del mercat financer" $\mathrm{i}$ de diferenciar cada vegada més entre societats cotitzades $\mathrm{i}$ no cotitzades ("es distingeixen dos models de societat: l'angloamericà, que reflecteix una shareholder society; $\mathrm{i}$ l'alemany, que correspon a una stakeholder society'). Aquest autor, com veurem, finalitza per advocar per la superació tant de les tesis contractualistes com de les institucionalistes, en virtut
de la notable transformació dels models societaris.

${ }^{50} \mathrm{~A}$ més, és generalment admès (fins $\mathrm{i}$ tot pels partidaris de tesis institucionalistes; cfr. ESTEBAN VELASCO, G., El poder de decisión..., op. cit., pàg. 583) que la teoria contractual és la consagrada en els textos legals vigents de les societats de capital. Vegeu, per tots, GARRIGUES, J., Curso de derecho mercantil, tom I, 7a edició revisada amb la collaboració d'A. BERCovITZ, Imprenta Aguirre, Madrid, 1982, pàg. 512, que identifica interès social amb «interès comú dels socis». En la doctrina italiana, on la qüestió s'ha debatut intensament, vegeu ASCARELLI, T., L'interesse sociale..., op. cit., pàg. 95; i FERRI, G., recensió a la monografia de JAEGER (L'interesse sociale, Milà, 1963), a Riv. dir. comm., 1965, I, pàg. 244-245.

SÁNCHEZ RUIZ, M., Conflictos de intereses..., op. cit., pàg. 68-69, aporta abundants referències bibliogràfiques $i$ jurisprudencials en notes 35 i 36; i més endavant, en pàg. 176, nota 89; també 
l'interès comú dels socis, això és, aquell que els ha portat a la seua participació en el contracte social. Els autors partidaris de les tesis contractualistes solen identificar, a més, interès dels socis, amb interès de lucre ${ }^{51}$.

Així doncs, l'interès social considerat com la suma dels interessos particulars dels socis en l'obtenció del màxim benefici repartible ha estat, des dels seus inicis, el nucli de les tesis contractualistes sobre l'interès social, encara que també s'hi apuntaven ja biaixos cap la distinció entre interès social i interès particular del soci ${ }^{52}$. A més, com s'ha indicat, les diverses teories contractualistes

aporta referències jurisprudencials DIAZ DE LEZCANO SEVILLANO, N., Los acuerdos del consejo..., op. cit., pàg. 272.

51 Així, Alfaro ÁGuILA-REAL, J., Interés social y..., op. cit., pàg. 34 i 39; ARROYo, Ignacio, "Comentario al art. 56», en AA. DD., Comentarios a la Ley de sociedades de responsabilidad limitada, (coords. I. Arroyo i J. M. Embid), Tecnos, Madrid, 1997., pàg. 612; CosTAS COMESAÑA, J., El deber de abstención..., op. cit., pàg. 81, nota 119; GIMENO SENDRA, Vicente, La reforma procesal mercantil. Los nuevos procesos de impugnación de acuerdos y de la propiedad industrial (Estudios sobre la L.S.A. 19/1989 y las Leyes 11/1989 y 32/1988), València, Tirant lo Blanch, 1990, pàg. 20.

En la doctrina italiana, JAEGER, P. G., L'interesse sociale rivisitato... , op. cit., pàg. 803/I: «Els interessos que han de ser presos en consideració en aquesta seu són exclusivament de caràcter econòmic; hi queden exclosos els interessos el contingut econòmic dels quals no pot ser valorat i determinat [...], els interessos en qüestió es poden dividir en dues categories: $a$ ) [...] interès en la renda que es deriva de la distribució de beneficis [...] o dels avançaments sobre dividends [...]. $b$ ) La segona categoria destaca el valor real de les accions [...] la noció de Shareholder Value és particularment rellevant, en l'evolució del dret societari i dels mercats financers, en les finalitats de la individuació de l'interès social. Respon a l'objectiu de maximitzar el valor actual de les accions que componen el paquet accionari de la societat». Aquest autor recorda a més com a les elaboracions de la Corporate Governance es fa una crida a la maximització del valor de les accions. Això no obstant, SÁNCHEZ RUIZ, M., Conflictos de intereses..., op. cit., pàg. 77, nota 55, recull en aquest punt els debats doctrinals sobre si el lucre ha de considerar-se com un element essencial de les societats de capital, i la seua transcendència en la noció d'interès social: «L'acceptació d'aquesta configuració de l'interès comú en connexió amb la finalitat lucrativa dependrà, en definitiva, de si es considera l'ànim de lucre com un element essencial inherent a les societats de capital (cas en què s'identifica amb la finalitat comuna, i aquest amb la causa lucrativa) o bé s'admet la possibilitat de societats anònimes o limitades no lucratives, cas en el qual l'interès social s'identificaria amb la finalitat comuna, qualsevol que siga la seua naturalesa (lucrativa, consorcial, mutualista, etc.)».

${ }^{52}$ Així, DuQue DOMfNGuEZ, J. F., Tutela..., op. cit., pàg. 74: «Només és correcte dir que "l'interès de l'ens no és més que la suma d'aquests interessos típics" a condició que aquests s'entenguen socials. El soci es troba així sol-licitat per diversos interessos i l'interès social no és més que un entre aquests interessos egoistes i individuals que, en coincidir amb el dels altres, adquireix la categoria de comú. [...] La identificació d'interessos de l'ens i interessos comuns dels accionistes és, per tant, certa, però la de l'interès social amb els interessos dels accionistes pot no ser-ho, quan hi ha en els últims interessos que no són directament propis de la societat»; i GARRIGUES, Joaquín, «La protección de las minorías en el derecho español», en Temas de derecho vivo, Madrid, Tecnos, 1978, pàg. 110: "Certament, els socis ingressen en societat perseguint un interès particular, que és el seu propi. Però en crear una persona jurídica diferent han creat també un interès social que se superposa a aquell altre. Certament, l'interès comú és la suma dels 
presenten divergències a l'hora de formular els criteris per a la concreció de quins són els interessos dels socis susceptibles d'integrar l'"interès comú": mentre unes centren l'interès social en el dels socis actuals, altres l'amplien per incloure els dels futurs socis, altres recorren al concepte d'interès del soci mitjà i altres identifiquen interès social amb el que en cada moment es reconega per l'assemblea de socis ${ }^{53}$.

\section{b) Interès social i impugnació}

Si es trasllada el desenvolupament doctrinal de la noció d'interès social a la fonamentació de la impugnació d'acords, alguns autors, des de perspectives institucionalistes i identificant l'interès social amb l'existència d'un interès superior de l'ens que transcendeix els interessos dels socis, consideren la impugnació com instrument de salvaguarda d'aquell, davant les decisions que en contra seu adopte la majoria ${ }^{54}$. A aquest corrent se sumen les tesis que mantenen que amb la impugnació es protegeixen també interessos diferents als dels socis, com ara els dels treballadors, els dels creditors o el de l'ordre econòmic i social mateix ${ }^{55}$.

interessos particulars dels socis, però també és cert que per compondre aquest interès comú el soci ha fet desistiment d'una part del seu interès egoista, i l'ha sacrificat, en certa manera, a l'interès social. L'interès particular del soci serà respectable mentre es realitze a través de l'interès de la societat. La consecució de l'interès comú s'eleva així a finalitat social». Per la seua banda, COZIAN, M., VIANDIER, A. i DEBoISSY, F., Droit des sociétés, 12a ed., Litec, París, 1999, pàg. 186 , distingeixen entre interès comú dels socis i interès social: "Aquest ha de guiar el govern general de la societat; aquell ha de regir les atribucions particulars de guanys o d'avantatges als socis; un està més dirigit cap a allò col-lectiu, l'altre més cap a allò individual".

${ }^{53}$ SÁNCHEZ RUIZ, M., Conflictos de intereses..., op. cit., pàg. 61-62. JAEGER, P. G., L'interesse sociale rivisitato..., op. cit., pàg. 796/I, 801/I, 805/I i 806/I ha plantejat recentment que en el concepte mateix d'interès social s'han d'incloure els interessos dels anomenats futurs socis.

${ }^{54}$ RUBIO, J., Curso..., op. cit., pàg. 250: "Quan la llei declara impugnables els acords contraris a l'interès social, pensa que el vot de la majoria decisori de l'acord representa l'interès d'aquesta majoria, però no l'interès de la societat».

${ }^{55}$ Vegeu en COZIAN, M., VIANDIER, A. i DEBOISSY, F., Droit des sociétés, op. cit., pàg. 178 i 179, el comentari a la sentència Fruehauf-France (París, 22.5.1965, JCP 1965, 14274 bis), àmpliament comentada en el seu moment, per considerar que "consagrava una nova visió de l'interès social, en endavant confosa amb l'interès de l'empresa, que pren en compte l'interès dels assalariats, el dels creditors, i fins i tot l'interès general». La societat Fruehauf-France, filial del grup americà Fruehauf International, va rebre un encàrrec de transportar mercaderia a la República Popular de la Xina; poc temps després, Fruehauf-France va rebre del president de Fruehauf 
Des de posicions contractualistes, que afirmen que l'interès social no és més que la suma dels interessos particulars que han portat els socis al contracte social, es considera que amb l'exercici de la impugnació es tutela l'interès personal del soci impugnant, i posen l'accent en el seu caràcter de dret individual del soci. En aquest grup poden situar-se també les tesis que mantenen que la impugnació és un mitjà de tutela de la minoria davant d'un exercici abusiu del dret de vot per la majoria: quan la manifestació de la voluntat formada per la majoria deixa de representar l'interès social, es permet a la minoria d'actuar.

Altres autors consideren que la impugnació d'acords constitueix un instrument per a la protecció de diferents interessos confluents, encara que les propostes destaquen elements diversos. Entre aquestes, un corrent ja tradicional és el que agrupa els qui mantenen que allò que el legislador pretén mitjançant la regulació de la impugnació no és altra cosa que salvaguardar la legalitat vigent ${ }^{56}$, si bé se serveix dels interessos particulars en joc ${ }^{57}$.

Una altra proposta distingeix finalitats diferents segons el tipus d'acords que es vulga impugnar. Així, en els acords contraris a l'ordre públic, la impugnació perseguirà la protecció d'interessos col-lectius que no tenen l'origen en les relacions juridicoprivades, sinó en principis generals de l'ordenament jurídic, cosa que n'explica la nul-litat radical; en la resta d'acords impugnables, la

Internacional l'ordre de no executar el contracte, en compliment de l'embargament decretat per l'administració americana. Els representants dels accionistes minoritaris francesos van demandar dels tribunals l'execució d'una sèrie de mesures que garantiren l'execució de l'encàrrec, en nom de la protecció de l'interès social. El Tribunal d'Apel-lació de París no va dubtar a reconèixer «l'interès evident que presenta per a la societat Fruehauf-France la bona execució del contracte realitzat amb el seu principal client [...], sinó sobretot les incidències catastròfiques que hauria comportat [...] la rescissió d'aquest contracte».

${ }^{56}$ SORIA FERRANDO, J. V., La impugnación...., op. cit., pàg. 42-43.

${ }^{57}$ DUQUE DOMÍNGUEZ, J. F., Tutela..., op. cit. pàg. 155: «Per determinar l'interès que es protegeix mitjançant el poder d'impugnació, cal partir de les normes que disciplinen l'acció [...] en cada ordenació positiva (DONATI, La invalidesa..., pàg. 106: "el problema es resol no ja determinant la finalitat que el soci persegueix en obrar, sinó la finalitat perseguida pel legislador en concedir-li l'acció i l'aspecte fonamental d'aquesta") i, més específicament, de la manera com el legislador ha reglat la matèria de la legitimació». 
impugnació sí que respon a la protecció d'interessos juridicoprivats nascuts del negoci societari, però que seran diferents segons la funció de l'òrgan en què es produïsca l'acord. Es considera en aquesta tesi que la impugnació d'acords de la junta general constitueix un instrument vinculat essencialment a la protecció dels socis individuals o de minoria, mentre que la impugnació d'acords del consell d'administració està connectada als deures de diligència i lleialtat dels administradors $i$ té com a finalitat la protecció de l'interès social ${ }^{58}$.

\section{c) L'interès social a les cooperatives}

Amb independència del major o menor grau d'aprofitament que puguen tenir en l'actualitat els diferents elements aportats per les teories apuntades, pot afirmar-se ja des d'ara que el debat no és reproduible en l'àmbit cooperatiu, almenys en els termes fins ara exposats, ja que haurien de desestimar-se, de partida, les teories contractualistes més radicals. L'afirmació que efectuem se sosté en la constatació que la finalitat social de la cooperativa no és l'ànim de lucre propi de les societats, entès aquest com la intenció d'obtenir un benefici repartible entre els socis ${ }^{59}$, sinó l'atenció a una doble finalitat: la satisfacció de

\footnotetext{
${ }^{58}$ ALCALÁ DIAZ, M. Á., La impugnación..., op. cit., pàg. 166-195.
}

59 GRAZIANI, Alessandro, "Società cooperativa e scopo mutualistico», Riv. dir. com., 1950, pàg. 283: «La cooperativa no persegueix per se (entesa com a subjecte diferent de les persones dels socis) una finalitat de lucre; [...] es pot, tanmateix, mantenir que els socis persegueixen una finalitat de lucre; finalitat de lucre que en les cooperatives de consumidors es realitza en l'estalvi de la despesa, en la cooperativa de productors en el major guany; lucre que tanmateix s'actua i s'aconsegueix [...] no en relació i en proporció amb el capital conferit, sinó en relació i proporció a les prestacions rebudes o realitzades».

ASCARELLI, Tullio, "Cooperativa e società. Concettualismo giuridico e magia delle parole», Riv. Soc., 1957, pàg. 420-423: "Es nega amb aquestes afirmacions una finalitat lucrativa o egoista [...] del cooperador? No. L'individu, òbviament, persegueix un benefici i un benefici patrimonial; adquirir a preu més baix (cooperativa de consum), vendre més car (cooperativa de vendes), obtenir una remuneració més alta pel propi treball (cooperativa de treball). [...] Egoista perquè la finalitat de l'individu és [...] lucrativa. [...]. Certament, si amb lucratiu es vol entendre "participació en la divisió dels beneficis aconseguits per l'entitat en una activitat amb tercers" el terme 'lucratiu' no podrà usar-se per a un avantatge que no tinga aquest origen. [...] El que importa no és la possibilitat d'usar o no usar en aquests dos casos el mateix terme lèxic i la preferència per un ús més lat del terme lucratiu [...] o, al contrari, per un ús més restringit [...]. El que en qualsevol cas es manté (a part de l'ús d'una o una altra paraula) és precisament la diferència entre el benefici perseguit pel soci i el perseguit pel cooperador: participar en la distribució d'un benefici aconseguit per l'ens en una activitat amb tercers; realitzar directament en la pròpia economia un avantatge patrimonial atesos els serveis de l'ens. [...] la doctrina 
necessitats i interessos comuns dels qui en cada moment en siguen socis, mitjançant l'ajuda mútua, i la creació d'un patrimoni comú irrepartible que garantisca el manteniment de l'entitat ${ }^{60}$.

En efecte, és lloc comú de la doctrina juridicocooperativa que la finalitat de la cooperativa és satisfer els interessos i les necessitats de tota una categoria social $^{61}$, entre la qual, els socis són els actuals beneficiaris de l'activitat cooperativitzada $^{62}$. Sobre aquesta finalitat es construeix, precisament, el principi

sembla tanmateix sotmetre's [...] a la màgia de la paraula lucratiu»; més endavant, en pàg. 422 i 423, nota 18: "La disputa aparent, al meu entendre, naix del fet que la qualificació d'altruista, egoista, lucratiu atén sempre la finalitat de l'individu (i no hi ha dubte de l'egoisme de la finalitat del cooperador, encara que no es vulga usar l'adjectiu lucratiu), mentre que no pot aplicar-se, conservant el mateix abast, a la finalitat de l'ens, que, fins i tot quan és egoista és altruista des de la perspectiva dels propis membres (i viceversa). Fins i tot la societat és altruista per als socis".

" GIRÓN TENA, J., Derecho de sociedades, tom I, pàg. 96; VICENT CHULIÁ, Francisco, "Mercado, principios cooperativos y reforma de la legislación cooperativa (estudio introductorio y de síntesis)», Ciriec-España, núm. 29, agost 1998, pàg. 19: "La finalitat que ha d'orientar l'estratègia d'objectius: si en aquelles (les societats cotitzades) és la creació o maximització del valor de les accions, en interès dels accionistes [...], a la cooperativa ha de ser forçosament la maximització de la utilitat dels serveis subministrats per la cooperativa i, en el seu cas, si s'ha de mantenir, el principi d'un patrimoni cooperatiu irrepartible per a les futures generacions».

61 O, més correctament, els d'aquells membres de la categoria social que es manifesten interessats a resoldre aquests interessos i necessitats a través de l'organització cooperativa, mitjançant l'ajuda mútua (ESPAGNE, François, «Les coopératives à but social et le multisociétariat", RECMA, núm. 274, pàg. 71). Sobre el significat $i$ les diverses posicions doctrinals entorn del concepte de 'categoria social' a la cooperativa, vegeu SERRANO Y SOLDEVILlA, Alfonso Diego, La cooperativa como sociedad abierta, Ministerio de Trabajo y Seguridad Social. Col-lecció "Tesis Doctorales", Sevilla, 1982, pàg. 30-36.

${ }^{12}$ ASCARELLI, T., Cooperativa e società, op. cit., pàg. 419-420: «La cooperativa es presenta així com un organisme de categoria; com una organització d'una comunió d'interessos preexistents, mentre que en la societat la comunió d'interessos pot nàixer també només en virtut del contracte. La qualificació de la cooperativa com a organització de categoria es fa des d'ENRICO FINZI(Studi in onore diu Della Volta, Florència, 1936, vol. II, pàg. 111); [...] distinció entre un contracte que es limita a organitzar una comunitat d'interessos que ja existeix (mútua) i un contracte que en canvi pot constituir una comunitat d'interessos anteriorment inexistent (societat)». En el mateix sentit, SÁNCHEZ CALERO, F. i OLIVENCIA RUIZ, M., "Relaciones del régimen jurídico de las sociedades mercantiles y de las sociedades cooperativas", en El cooperativismo en la coyuntura española actual, pàg. 135-176, Anales de Moral Social y Económica, Madrid, 1964, pàg. 136 i següents; SERRANO Y SOLDEVILLA, A. D., La cooperativa como..., op. cit., pàg. 51-52 i nota 22; VERRUCOLI, Piero, La società cooperativa..., pàg. 122.

VICENT CHULIÁ, Francisco, Compendio crítico de derecho mercantil, toms I, vol. $1 \mathrm{r}$ i 2n, i II], 3a ed., Barcelona, J. M. Bosch Editor, 1991 i 1992, pàg. 1014, referint-se a les que ell denomina "agrupacions o empreses mutualistes», entre les quals està la cooperativa: "Aquest doble caràcter, intern $\mathrm{i}$ extern, d'interès privat i públic, del mutualisme, està present sobretot en el cooperativisme». També es refereixen a la vocació de la cooperativa per estendre la seua actuació en favor de tots aquells que es troben davant de la mateixa necessitat economicosocial LEÓN SANZ, Francisco José, "Fusión, transformación y otras modificaciones estructurales de 
cooperatiu de porta oberta ${ }^{63}$, que garanteix que qualsevol persona que complisca els requisits objectius que defineixen la pertinença a la categoria, tinga accés a la cooperativa ${ }^{64}$.

sociedades cooperativas. Distribución de competencias entre el Estado y las Comunidades Autónomas", RdS núm. 9, 1997, pàg. 31; i OfICINA INTERNACIONAL DEL TRABAJO, Conferencia internacional del trabajo, $89^{a}$ reunión, 2001. Informe V. Promoción de las cooperativas, Ginebra, 2001, pàg. 69: «En defensar els interessos dels seus socis, les cooperatives defensen alhora els interessos de certs grups de ciutadans (petits agricultors, consumidors, titulars de comptes d'estalvi, etc.) i demostren al públic en general que les activitats econòmiques no han d'estar necessàriament dirigides a obtenir el màxim benefici $i$ incrementar tant com es puga el valor de les accions, sinó que també poden estar orientades a donar resposta a les necessitats, a millorar la qualitat o a reduir el preu dels béns i serveis».

Això no obstant, adverteix DUQUE, "Principios cooperativos y experiencia cooperativa», en Congreso de cooperativismo, Instituto de Estudios Cooperativos, Universidad de Deusto/Gobierno Vasco, Bilbao, 1988, pàg. 105, sobre l'evolució que s'observa en l'homogeneïtat originària del col-lectiu de socis, pertanyents a una mateixa categoria sociològica, amb les mateixes necessitats; així, s'estaria produint un desenvolupament de les cooperatives que introdueix desigualtats, quantitatives i qualitatives, en la base personal, el que produeix, per exemple, la desviació en el principi de l'exercici estrictament igualitari del vot. En relació amb això, MÜNKNER, Hans, "Nueva Ley cooperativa de 1973 y evolución de la legislación cooperativa en la República Federal de Alemania», Institut für Kooperation in legislació partia del principi que l'organització demo/Lahn, 1976, pàg. 12-13: «L'antiga l'absoluta igualtat dels drets i obligacions democràtica d'una cooperativa comportava (igualtat relativa) dels socis, justificat eventualmentes, fet que impedia tot tracte diferencial [...]. Aqueixes regles s'havien concebut eventualment per les condicions econòmiques o socials iguals en el pla humà, sinó que constituiens la idea que no sols tots els cooperadores eren d'obrers o de propietaris d'empreses privades ona una ació més o menys homogènia moderna, aquesta homogeneïtat reses privades o d'explotacions agrícoles. En una economia econòmic de cada membreitat relativa ja no existeix. Cada vegada es remarca més el potencial considerables».

S'ha de tenir en compte, tanmateix, que la «tendència cap la diversificació de la base social» de la cooperativa no necessàriament ha de ser vista negativament, ja que pot ser manifestació de realitats socials la cooperativització de les quals és recomanable: aquest és el cas, per exemple, de les anomenades cooperatives de finalitat social, que els últims anys han estat expressament regulades per les legislacions europees a fi de recollir, entre altres especificitats, la integració de diferents col-lectius: usuaris, els seus representants legals, assalariats, beneficiaris d'ajuts, voluntaris, col-lectivitats públiques, associacions amb finalitats idèntiques o complementàries, simples col-laboradors, etc. (ESPAGNE, F., «Les coopératives à but social..., op. cit.).

${ }^{63}$ GIRÓN TENA, J., Derecho de sociedades, tom I, pàg. 96: «En aquest servei al grup se situa un ideal de la cooperació: el principi de porta oberta. Que no se substantive una finalitat de la persona tractant que tota persona que tinga aquella sempre estranya a l'empresa, fer el màxim bé, en la cooperativa, puga veure-la satisfella necessitat, definitòria del grup social que s'agrupa dimensió empresarial no aconsellable per entrant a l'empresa. I això, fins i tot si origina una preu a què s'obtindria el bé o el servei raons econòmiques, mentre hi haja un marge entre el l'organització cooperativa”; ó el servei en el mercat capitalista i el que s'obté mitjançant seua finalitat, sinó que va més enllà dels seus pàg. 105: "No sols és aliena a la cooperativa la que el benefici cooperatiu arribe a totes les persones: la regla de porta oberta tracta d'obtenir economicosocial que tracta de remeiar l'org persones que es troben en la mateixa situació socis actuals, sinó que arribe a les persones que es trió cooperativa. Que no aprofite només als Primer principi cooperatiu (segons la que es troben en la mateixa condició que aquells». Manchester, setembre de 1995): 
tracta de garantir així el compliment dels principis cooperatius i, amb això, d'una finalitat social que va més enllà de la satisfacció dels interessos particulars dels socis actuals.

Així doncs, amb la constitució de la cooperativa es pretén no sols adoptar la forma jurídica més adequada per al desenvolupament de l'objecte social, sinó que l'estructura creada en garantisca la disponibilitat per a tota la categoria social a la satisfacció dels interessos de la qual es dirigeix; que la realització de l'objecte social es desenvolupe, bàsicament, mitjançant la necessària participació directa dels socis, i que els efectes econòmics positius revertisquen no sols en els socis, sinó en l'entorn en què la cooperativa es desenvolupa. La finalitat mutualista fa que en la noció d'interès social cooperatiu hagen d'incloure's, sens dubte, al costat de la satisfacció de les necessitats dels socis, la consolidació progressiva d'un patrimoni comú i irrepartible que, davant la consubstancial variabilitat del col-lectiu de socis cooperatius, romanga. En la cooperativa hi ha, doncs, interessos socials diversos a la suma d'interessos individuals dels socis, dirigits aquests a la satisfacció de les seues necessitats mitjançant l'ajuda mútua.

I si hem d'entendre que quan es possibilita la impugnació de les manifestacions de voluntat de la cooperativa s'està intentant la defensa de tots els diversos interessos socials que hi ha presents, les teories tradicionals sobre l'interès social exposades abans no són suficients per explicar la institució. Tanmateix, l'evolució en el debat doctrinal general apunta en les últimes dècades cap a la consideració que hi ha, no un únic interès social, sinó una pluralitat $d^{\prime}$ interessos, que seran socials en la mesura que siguen reconduibles al contracte de societat ${ }^{68}$.

\footnotetext{
"A* Amb aquesta posició doctrinal adquireix ple sentit l'afirmació que «quan en virtut del vot s'obté un acord lesiu per a l'interès social i beneficiós per a l'interès particular, s'infringeix el contracte de societat» (GARCtA LUENGO, Ramón i SOTO VÁZQUEZ, Rodolfo, El nuevo régimen jurídico de la sociedad anónima. Comentarios y jurisprudencia, Editorial Comares, Granada, 1991,
pàg. 541).
} 
d) L'interès social com a conjunt d'interessos derivats del contracte social

Efectivament, fins i tot en les teories contractualistes de l'interès social s'observa la necessitat de tenir en compte la confluència, mitjançant el contracte social, de diversos interessos; $i$, encara que es manté per la majoria que aquesta pluralitat $d^{\prime}$ interessos socials continua sent de titularitat exclusiva dels socis ${ }^{69}$, no deixen de reconèixer-se "trets institucionalistes" control que s'adopten davant les grans societats, fonamentalment les que intervenen en el mercat de valors ${ }^{71}$.

"GALGANO, Francesco, La società per azioni. Li altre società diu capitale. Li cooperative. 3a ed. Zanichelli Editore, Bolonya, 1978, pàg. 157 i següents: «Partint del contracte de societat establert en els articles 1665 Cc. i 116 Cco., es pot afirmar [...] que en tota societat hi ha una pluralitat $d^{\prime}$ interessos dels socis coordinats entre si que poden qualificar-se com a interessos socials, i es pot distingir un interès social preliminar: l'interès que el patrimoni social siga utilitzat per exercitar l'activitat productiva que constitueix l'objecte de la societat; un interès social intermedi: l'interès que l'activitat productiva estiga dirigida a l'obtenció de guanys; i un interès social final: l'interès que els guanys siguen repartits entre els socis.[...] En definitiva, no hi ha un únic interès social, sinó una pluralitat d'interessos socials dels socis, que són tots aquells que es poden reconduir al contracte de societat». Segueix aquesta posició COSTAS COMESAÑA, J., El deber de
abstención ..., op. cit., pàg. 67-68.

SÁNCHEZ RUIZ, M., Conflictos de intereses..., op. cit., sota la denominació genèrica d'interessos societaris ("els titulars últims dels quals són sempre els socis en la seua pròpia condició») inclou l'interès social, l'interès del soci individual i l'interès de la minoria. Interès social és, per a aquesta autora «una clàusula general que fa referència, de manera abstracta, a un conjunt considerats dels socis d'una societat determinada que, de manera apriorística, poden ser comuna que es troba en l'origen del contracte de societat».

Interés social..., op. cit., cap. II, «l'interès dents interessos en la societat ALFARO AGUILA-REAL, J., i VÁzQUEZ ALBERT, D., «El conflicto entre mayoría...», op. cit., gàg. 180-181 peracte de societat», l'interès social s'integra exclusivament per l'interès comú dels socis, sense mantenen que reconèixer la necessitat de protecció, per altres branques de l'ordenació, dels interessos d'altres subjectes vinculats a la societat.

${ }^{70}$ JAEGER, P. G., L'interesse sociale rivisitato..., op. cit., pàg. 796/I, 801/I, 805/I i 806/I, estima que, fins i tot des de la consideració que l'interès del soci se situa en l'augment del valor de les pròpies accions, aquest no pot desvincular-se de l'interès al creixement econòmic de l'empresa. GROSsO, P., I controlli interni..., op. cit., pàg. 6: "Quan s'ofereixen els instruments als accionistes de minoria per tutelar els seus drets davant la direcció de la societat, no es tutela només el seu interès egoista, es persegueix també l'objectiu d'ordre general de tutelar i animar la inversió de

ALONSO LEDESMA, C., "Algunas consideraciones...", op. cit., pàg. 41-42: "A mesura que penetren en l'estructura de la societat anònima, per una o una altra via, elements de clar signe institucional, es fa difícilment sostenible una concepció tancadament contractualista de l'interès mocial [...]. Concepció que, potser, només seria possible sostenir en aquelles societats de tipus exclusión del derecho de suscripción preferente», en AA. DD., Derecho de sociedades anónimas, 
No és una novetat, sens dubte, que en la societat de capital confluïsquen interessos diversos. Precisament, aquest fet s'afirma com a premissa per a l'elaboració de propostes en la superació dels seus problemes principals. Per això mateix, no pot servir ja un concepte en què l'interès social siga simplement la suma dels interessos individuals dels socis ${ }^{2}$; però tampoc que l'interès social s'haja de limitar a la recerca del valor més alt dels títols de participació.

En efecte, ni l'interès de la societat ni el dels socis té cap motiu per ser sempre, ni exclusivament, un interès en la maximització del benefici, ja que es pot pretendre, per exemple, assegurar de manera prioritària l'estabilitat de l'empresa; però a més, com queda quotidianament patent, la recerca de la maximització de beneficis tampoc té una única fórmula infal-lible: pot buscar-se a mitjà o llarg termini, pot intentar-se sobre la base de menys beneficis immediats o de requerir fins i tot nous esforços inversors dels socis ${ }^{73}$.

D'altra banda, des de les tesis que incideixen en l'interès social com a interès de l'empresa, també s'ha advertit que l'eficàcia pràctica de considerar la inclusió d'interessos diferents als dels socis serà molt limitada, si no hi ha mecanismes

tom III, vol. 1, Civitas, Madrid, 1994, pàg. 627-629, i SÁNCHEZ RUIZ, M., Conflictos de intereses..., op. cit., pàg. 63, nota 18: «En les grans societats anònimes obertes, sobretot en les cotitzades, s'ha considerat com un tret institucionalista, per exemple, l'existència d'òrgans externs de control (com la CNMV), la funció dels quals excedeix el marc estricte dels interessos dels accionistes».

7 POLO SÁNCHEZ, E., Abuso o tiranía..., op. cit., pàg. 2276: «Només en absència de conflicte, la voluntat social es forma mitjançant la coincidència - la suma- de totes les voluntats individuals que componen l'òrgan".

${ }^{73}$ En aquest sentit, ESTEBAN VELASCO, G., El poder de decisión..., op. cit., pàg. 586-590, assenyala com «des de l'economia i la política de l'empresa s'han posat de manifest les diferents maneres d'entendre la conservació de l'empresa (conservació de la independència econòmica, conservació de la substància: capacitat productiva en un període determinat, etc.) i la impossibilitat pràctica de determinar a priori si una mesurada determinada contribueix o no $a$ l'objectiu de la conservació de l'empresa. Mesures que a curt termini ocasionen pèrdues, a llarg termini poden ajudar a mantenir l'empresa, i determinades inversions socials en favor dels treballadors o dels interessos públics a llarg termini poden redundar en benefici de la conservació i la prosperitat de l'empresa». 
institucionals que ho garantisquen ${ }^{74}$. Tanmateix, s'ha de recordar que en l'àmbit cooperatiu sí que hi ha en les normes legals mateixes mecanismes d'expressió $i$ defensa dels interessos de tercers: així, per exemple, la representació de treballadors no socis als òrgans socials, o les mesures de garantia del compliment de l'aplicació dels recursos del fons de formació i promoció cooperativa. I tampoc pot oblidar-se, en la matèria que ens ocupa, la legitimació per a la impugnació atribuïda en favor de tercers amb interès legítim.

Una altra qüestió que s'ha plantejat en relació amb la defensa de l'interès social com a "composició d'interessos plurals" és la relativa al denominat "interès del grup". La doctrina es qüestiona quina ha de ser la solució correcta al conflicte d'interessos que pot produir-se al si dels grups de societats (en el nostre cas, als grups cooperatius), entre l'interès comú del grup i els interessos dels seus membres. Tot i que aquest tema es desenvolupa més endavant ${ }^{75}$, es pot indicar ara l'existència de corrents doctrinals i jurisprudencials que accepten la prioritat de l'interès del grup en conjunt davant de l'interès social d'un dels membres ${ }^{76}$. $\mathrm{Si}$ es confirma aquesta prevalença, el significat mateix de l'interès social de cada membre haurà de veure's modificat per acollir, entre els seus interessos socials, els que es deriven de la seua pertinença al grup.

\footnotetext{
${ }^{74}$ ESTEBAN VelasCO, G., El poder de decisión..., op. cit., pàg. 585; i AlONSO LeDESMA, C., "Algunas consideraciones...", op. cit., pàg. 42. En relació amb això, des de posicions contractualistes s'estima, precisament, que la tutela d'interessos d'altres subjectes diferents als socis no ha de pretendre's a través de les normes del dret de societats, sinó mitjançant altres instruments jurídics, com ara les relacions contractuals mateixes i les normes d'altres sectors de l'ordenament jurídic, com el dret del treball, el dret de la competència, o les normes de protecció M., Consumidors (ALFARO AGUILA-REAL, J., Interés social..., op. cit., pàg. 63-67; SÁNCHEZ RUIZ, M., Conflictos de intereses..., op. cit., pàg. 71; VAZQUEZ ALBERT, D, El conflicto entre mayoría..., op.
cit., pàg. 180-181).
}

${ }^{75}$ Vegeu el capítol tercer, epígraf 3.5.

7" Alfaro Águila-Real, J., Interés social...,op. cit., pàg. 42-43; Cozian, M., Viandier, A. i DEBOISSY, F., Droit des sociétés, op. cit., pàg. 608-609. EMBID IRUJO, José Miguel, «Derecho europeo de sociedades anónimas. Estudio preliminar y traducción de las normas sobre la sociedad anónima de la República Federal de Alemania, Francia e Italia», en Documentación Jurídica, núm. 55, tom XIV, juliol-setembre 1987, pàg. 13-14, recull l'acceptació per l'AktG de "l'existència d'unions de societats en què una en domina - per la via de la participació en el capital, generalment- una altra o altres, i sotmet el seu interès social al del grup en el seu conjunt [...] establint, això sí, mesures de protecció dels socis i creditors de les societats dominades, així com l'obligació de presentar una documentació comptable relativa al grup en el seu conjunt». 
Totes aquestes qüestions, que semblen tendir cap la confluència de les dues teories tradicionals sobre la noció d'interès social, han portat alguns autors a proposar-ne la superació definitiva ${ }^{\pi}$. Així, sobre la base que en la persona jurídica coexisteixen diversos interessos, entre els quals són socials tots aquells que s'integren en el contracte social, i es consideren "extrasocials" els altres ${ }^{78}$, quan es plantege un conflicte d'interessos ${ }^{79}$, no hi haurà cap dubte si algun d'aquests és dels extrasocials: haurà de cedir davant dels socials; és el que succeeix quan la majoria adopta un acord lesiu per a un interès social a favor

"JAEGER, P. G., L'interesse sociale rivisitato... , op. cit., pàg. 811 i 812/I sosté que la teoria mateixa de la shareholder value, que representa, aparentment, la més radical de les concepcions contractualistes, en la qual l'interès social és identificat amb l'interès dels socis en l'augment del valor de les pròpies accions, pot utilitzar-se com a argument, no sols d'aproximació a les tesis institucionalistes, sinó de superació d'unes i altres: «És hora de preguntar-se quines diferències es donen entre l'interès en creixement econòmic de l'empresa i la shareholder value, ja que s'assumeix que el valor de les accions tendeix a dependre del valor de l'empresa; [...] en aquest punt es podria sostenir que la shareholder value, més que ser contractualista, és la versió moderna de la institucionalista de la Unternehmen an sich, entesa tanmateix la Unternehmen no com una comunitat de persones, sinó com un sac de diners que ha de ser omplert cada vegada més. És més senzill $\mathrm{i}$ acceptable, tanmateix, alçar acta de la superació d'ambdues teories». SÁNCHEZ RuIz, M., Conflictos de intereses..., op. cit., pàg. 62: "La importància actual de la tradicional polèmica doctrinal entre concepcions contractualistes $i$ institucionalistes [...] ha de ser relativitzada", $i$ assenyala que el seu estudi troba sentit en l'actualitat només en la mesura que determinades normes positives inclouen l'interès social en els seus supòsits de fet.

Tampoc falten opinions que plantegen la inutilitat de recórrer a un concepte que estimen excessivament indeterminat; així, POLO SÁNCHEZ, E., Abuso o tiranía..., op. cit., pàg. 2276-2280.

${ }^{7 \pi}$ GARRIGUES, J., Curso..., op. cit., pàg. 329-330. Així doncs, per parlar amb propietat, serà interès comú dels socis l'interès en la consecució de la finalitat social, però aquest coexistirà amb altres interessos, socials i extrasocials dels socis. També distingeixen entre una pluralitat d'interessos socials i extrasocials COSTAS COMESAN̄A, J., El deber de abstención..., op. cit., pàg. 67-68; POLO SÁNCHEZ, E., Abuso o tiranía..., op. cit., pàg. 2276-2280; SÁNCHEZ RUIZ, M., Conflictos de intereses..., op. cit., pàg. 67, recollint les tesis de PREITE, D., "L'abuso" della regola diu maggioranza nelle deliberazioni assembleari delle società per azioni, Giuffrè, Milà, 1992.

7y Per a una anàlisi dels diferents conflictes intrasocietaris, vegeu ALFARO ÁGUILA-REAL, J., "Conflictos intrasocietarios...", op. cit., pàg. 1080-1081; i SÁNCHEZ RUIZ, M., Conflictos de intereses..., op. cit., pàg. 145-237, els quals distingeixen entre conflictes la solució dels quals exigeix l'extinció total o parcial de la relació en què sorgeixen (conflictes estructurals o permanents) i aquells que encara poden ser resolts mitjançant altres tècniques (conflictes conjunturals o eventuals); la impugnació d'acords socials se situa entre les tècniques disposades per l'ordenament jurídic per a la resolució de conflictes conjunturals. 
d'un d'extrasocial, però també quan el soci que ha d'intervenir en una votació és portador d'un interès extrasocial contradictori amb interessos socials ${ }^{80}$.

En canvi, quan el conflicte es plantege entre interessos que poden qualificar-se tots de socials, el principi majoritari serà el que decidirà regularment quin $\mathrm{d}^{\prime}$ aquests ha de prevaler ${ }^{{ }^{81}}$, llevat que l'interès contraposat al de la majoria siga un dels reconeguts per l'ordenament jurídic com a dret subjectiu, individual o corporatiu, inderogable ${ }^{82}$.

" POLO SÁNCHEZ, E., Abuso o tiranía..., op. cit., pàg. 2277. Sobre la caracterització tant del conflicte d'interessos en sentit tècnic com de la impugnació d'acords lesius com a "mecanismes de tutela directa i preferent de l'interès social» i de "postergació o subordinació dels interessos extrasocials", SÁNCHEZ RUIZ, M., Conflictos de intereses..., op. cit., pàg. 158-159.

" COSTAS COMESAÑA, J., El deber de abstención ..., op. cit., p. 67; GIRÓN TENA, J., Derecho de sociedades..., op. cit., pàg. 274: «El fonament del principi majoritari rau en la consideració que els altres reflectiran l'interès social - maior pars, melior pars-, prenent com a explicació de la seua eficàcia l'esperança que a més risc en l'empresa, més interès per aquesta»; POLO SÁNCHEZ, E., Abuso o tirania..., op. cit., pàg. 2276-2277; SÁNCHEZ RUIZ, M., Conflictos de intereses..., op. cit., pàg. 182-183; i VÁZQUEZ ALBERT, D., «El conflicto entre mayoría...», op. cit., pàg. 177-178.

${ }^{82}$ RUBIO, J., Curso..., op. cit., pàg. 184-185: «Drets d'un soci o d'un grup de socis que, encara que nascuts del contracte de societat i relacionats amb la seua posició en la companyia, suposen un compromís particular i tenen un contingut privilegiat al marge de l'estatus corporatiu. [...]. Aquests drets no poden ser disminuïts, modificats ni negats per la voluntat social. Només poden ser-ho amb la del soci o els socis titulars. Però, per al cas que es tracte d'un grup o categoria d'aquests, si bé la llei impedeix que puguen ser alterats sense el seu consentiment, facilita la consecució d'això últim, arbitrant un sistema mitjançant que puga formar-se corporativament». SÁNCHEZ RUIZ, M., Conflictos de intereses..., op. cit., pàg. 84-86: «La terminologia emprada per al-ludir a aquest conjunt de drets del soci difereix notablement segons els autors i els països [...] (nota 17: "Aquests drets no poden ser perjudicats per una decisió majoritària sense el consentiment del seu titular. Per a SCHMIDT, aquest principi regeix per a les societats anònimes, cooperatives, societats limitades i per a les societats de persones les decisions de les quals s'adopten per majoria [...]). [...] Alhora, no tota situació prevista pel legislador com a inderogable haurà de qualificar-se com a dret, ja que cal que es tracte d'una situació subjectiva activa del soci davant la societat, reconeguda a aquest per a la tutela del seu propi interès uti individu sed soci. Tampoc pot identificar-se [...] amb el conjunt dels drets individuals reconeguts al soci en la seua condició de tal». Sobre la disponibilitat dels drets individuals tornarem en epígrafs següents (2.3 La impugnació com a dret subjectiu o potestat; 3.3.1 Els estatuts socials: contingut obligatori i possibilitats d'autoregulació).

HANNOUN, Charley, "L'action en nullité et le droit des sociétés (Réflexions sur les sources procédurales du droit de critique et leurs fonctions)», RTDCDE núm. 2, abril-juny 1993, pàg. 237, citant JAPIOT (Des nullités en matière d'actes juridiques. Essai d'une théorie nouvelle, tesi, Dijon, 1909, pàg. 176): «Hi ha interessos en lluita entre els quals no se sabria decidir justament sense inspirar-se en aquesta directiva que es coneix amb el nom de principi de l'equilibri dels interessos en presència. Davant interessos de la persona especialment protegida per la nul.litat, hi ha interessos respectables d'alguna altra persona, els interessos generals de tercers, els interessos de la societat; hi ha necessitats de crèdit, l'atenció deguda a la confiança pactada [...]" 
En definitiva, l'interès social rellevant respecte de la impugnació hauria d'identificar-se, més que $a m b$ un únic contingut immutable, amb un procediment per a la determinació de quin haja de ser en cada moment, en cada supòsit concret, l'interès social predominant ${ }^{83}$. Per això, quan s'estime que el conflicte d'interessos en la persona jurídica s'ha resolt amb lesió "de l'interès social" rellevant, la impugnació servirà com a instrument de salvaguarda.

En aquest nou context, es poden incloure perfectament els trets propis que hem apuntat per a la noció d'interès social en la cooperativa. Així, al feix d'interessos socials diversos susceptibles de tutela, l'interès del soci capitalista perquè "l'activitat productiva estiga dirigida a l'obtenció de guanys" i perquè "els guanys siguen repartits entre els socis" se substitueix, en la cooperativa, pel del soci cooperador, que té interès perquè siguen satisfetes, de la manera més adequada, les seues necessitats que el porten a integrar-se en la cooperativa. En

\footnotetext{
${ }^{* 3}$ ESTEBAN VelasCO, G., El poder de decisión..., op. cit., pàg. 585 i 591-593: «L'interès de l'empresa "no és un factor permanent davant del qual s'hagen de valorar la resta dels interessos", sinó el resultat de la confrontació dels diferents interessos parcials establert en el marc d'un procediment determinat per a la seua obtenció i realització. L'interès de l'empresa és una "magnitud complexa, multidimensional i variable, els nombrosos components de la qual no es poden reduir sense més ni més a denominador comú", que "no s'ha d'entendre com una pauta per a l'acció dels membres dels òrgans sinó com un contingut a determinar en un procés de discussió dialèctica". [...] L'interès pluralista de l'empresa en el sentit indicat pressuposa que cada membre dels òrgans defensa en l'execució de la política empresarial la seua pròpia valoració d'interessos que, naturalment, estarà connectada amb la del grup de procedència. [...] $\mathrm{El}$ que el legislador vol (i ha previst) no és una pauta unitària de conducta dels membres, sinó una política d'empresa que resulte de la composició d'interessos i que, una vegada fixada, s'accepte i s'execute responsablement".

ALONSO LEDESMA, C., "Algunas consideraciones...»., op. cit., pàg. 42-43: «Alguns dels greus problemes que planteja una noció substantiva de la clàusula concebuda com a criteri (o paràmetre) material d'adequació (o de control) del contingut dels actes societaris, poden superar-se a través d'una noció formal que, en lloc d'identificar l'interès social amb un objectiu material concret, l'identifique simplement amb el procediment per a la seua determinació [...]. El contingut de l'interès social o de l'interès de l'empresa no seria així una fórmula de què es parteix, sinó un resultat a què s'arriba, $i$ la preservació de l'interès social es correspondria amb l'existència (o el deure d'existència) o d'un complex de regles estructurals que garantirien la participació de la pluralitat d'interessos que pot haver-hi en la societat en els mecanismes d'adopció de les decisions encaminades a definir, en cada cas, quin haja de ser (prevalent sobre els interessos diversificats) el comú interès de la societat com un tot [...]. El contingut de l'interès social només podrà concretar-se cas per cas, i a través dels procediments que la norma preveja». També podria entendre's connectada a aquesta interpretació la proposta d'ALFARO ÁGUILAREAL, J., Interés social ..., op. cit., cap. II, en concebre «l'interès social com a regla d'integració del contracte de societat» (pàg. 21-49), com a clàusula que actue de «sistema de control» de la eficiència de la decisió adoptada per la majoria o pels administradors.
} 
un cas i en l'altre, ens trobem davant d'un interès social típic, ja que forma part essencial del respectiu contracte de societat ${ }^{84}$.

Però, a més, en la cooperativa hi ha almenys un altre interès social típic: el de l'entitat mateixa a subsistir i a la continuació de la seua activitat, més enllà de la durada de la relació concreta amb el soci actual, a fi de garantir la finalitat mutualista de tota la categoria social.

Així doncs, en conclusió, la impugnació d'acords pot considerar-se un instrument de protecció dels diversos interessos socials que conflueixen en el contracte de la persona jurídica. I com que l'interès social adquireix trets propis en la cooperativa, aquest concepte és el que ha de ser considerat per determinar quins interessos es tracten de protegir mitjançant la impugnació dels acords socials.

Per tot això, quan es produïsca un conflicte intern d'interessos s'haurà d'atendre la seua naturalesa: quan s'enfronten interessos socials a extrasocials, no hi haurà dubte de la preeminència dels primers. Però quan els interessos en conflicte siguen tots integrants del contracte social cooperatiu, s'haurà de tenir en consideració que, davant la decisió de la majoria no només podran defensarse drets subjectius inderogables dels socis, sinó també l'interès social enl manteniment de la cooperativa i del seu patrimoni.

${ }^{M}$ BASSI, A., Le società cooperative, op. cit., pàg. 27: «En la cooperativa es pot afirmar a més l'existència de drets a les prestacions mutualistes com a expressió d'una relació obligatòria directa entre societat i socis, que no hi ha en altres tipus de societat; relació que té un règim de tutela que s'afegirà als de caràcter objectiu i que permet al soci oposar-se a tots els actes de la societat que, d'una manera o una altra, causen una lesió específica dels drets d'aquell, com a beneficiari de la gestió de servei (nota 16: «La Cass., 24-1-1990, n. 420, en Le società, 1990, 750, amb nota de CARNEVALI ha considerat nul per il-licitud de l'objecte, i per tant no subjecte a prescripció l'acord del consell d'una cooperativa d'habitatges -assembleari o del consell- que, en perjudici dels adjudicataris, transferisca habitatges a altres socis que no hi tinguen dret. La Cass., 27-1-1989, n. 493, en Società, 1989, 572, amb nota de PROTETT, ha establert que la impugnació d'acords assemblearis de cooperativa, que comporten la modificació d'un altre acord precedent conforme als interessos del soci i no impugnat per altres interessats, queda circumscrita al fet que amb l'acord precedent s'haja produït un dret en favor del soci que es presente com definitivament adquirit»); més endavant, en pàg. 28: "En la cooperativa se subratlla justament l'existència d'una duplicitat de relacions: contracte de societat i relació
mutualista». 


\section{e) Defensa de l'interès social i obligació d'impugnar}

Un dels supòsits en què s'observa amb la major claredat que és intenció del legislador protegir els interessos socials és el de la legitimació específica que s'estableix per als administradors ${ }^{85}$, així com l'obligació d'impugnar que en alguns casos se'ls atribueix. A més, en la legislació cooperativa s'amplia la legitimació específica a altres membres d'òrgans socials i, al nostre entendre, es fa amb la mateixa finalitat essencial: reforçar la defensa de l'interès social. Així, la LCoop legitima els interventors per a la impugnació dels acords nuls i anul-lables de l'assemblea i per a la dels acords anul-lables del consell rector; a més, "el comitè de recursos" està legitimat per impugnar els acords nuls de l'assemblea. Per la seua part, la LCCV reconeix legitimació per impugnar tots els acords de l'assemblea general als membres de la comissió de control.

Si es té en compte que els administradors que siguen socis ja disposen de la legitimació general que a tots els cooperativistes se'ls reconeix, l'atribució expressa d'una legitimació específica ${ }^{86}$ (i més àmplia que la general ${ }^{87}$ ) per als administradors (siguen socis o no) es justifica en el deure de diligència que assumeixen en relació amb el compliment de les seues funcions, deure de diligència en què s'haurà d'incloure el deure de defensar l'interès social.

\footnotetext{
${ }^{* 5}$ RUBIO, J., Curso..., op. cit., pàg. 261: «La llei encomana als administradors, com a òrgans de la societat i fins i tot contra la voluntat dels socis mateixos, la defensa d'interessos generals emparats per l'ordenació, quan la seua infracció ha de repercutir necessàriament en perjudici d'interessos socials legalment protegits". BUSTILLO SAIZ, M. M., La subsanación de acuerdos..., op. cit., pàg. 208, nota 138: «Si les normes infringides per l'acord tutelen l'interès social, el legislador vol que la seua tutela s'assegure no sols indirectament a través de l'acció de qui és portador d'un interès individual connex, també directament a través de qui és portador de l'interès social, els administradors".

${ }^{86}$ RUBIO, J., Curso..., op. cit., pàg. 261.

${ }^{87}$ Els administradors estan legitimats sempre per a la impugnació tant dels acords nuls com dels anul-lables de l'assemblea general (articles 31.4 LCoop i 36.4 i 36.5 LCCV), amb independència de quina haja estat la seua posició en l'adopció de l'acord; respecte dels acords del consell rector, la LCCV manté la seua legitimació en tot cas (article 41.6), mentre que la LCoop (article 37.2), en els supòsits d'acords anul-lables, la restringeix.
} 
Una part de la doctrina ha plantejat que en l'administrador hi ha un interès propi a la impugnació ${ }^{88}$, ja siga com a expressió del deure de diligència que adquireix amb el càrrec, ja com a mecanisme eventual d'exoneració de responsabilitat. En efecte, encara que en la LSA no hi ha una norma concreta que impose expressament als administradors l'obligació d'impugnar els acords que consideren invàlids, la doctrina debat si hi ha aquesta obligació quan es pretenga evitar una reclamació eventual per la responsabilitat que poguera derivar-se de l'execució d'un acord contrari a la llei o als estatuts, o fóra lesiu dels interessos socials ${ }^{89}$.

En aquest sentit, s'ha de recordar que l'article 133.2 de la LSA estableix que "respondran solidàriament tots els membres de l'òrgan d'administració que va realitzar l'acte o va adoptar l'acord lesiu, llevat dels que proven que, no havent intervingut en la seua adopció i execució, en desconeixien l'existència o, coneixent-la, van fer tot el convenient per evitar el dany o, almenys, s'hi van oposar expressament". El que ha qüestionat un sector doctrinal és, en definitiva, si en "tot allò convenient per evitar el dany" s'ha d'incloure necessàriament,

${ }^{80}$ En contra, RUBIO, J., Curso..., op. cit., pàg. 262: «Aquesta preocupació peremptòria de fugir de
qualsevol contagi institucionalista ha portat a buscar, tan afanyosament com inútil, la proporció
d'aquesta legitimació, [...] en el propi interès dels administradors [...], sense percebre potser que
tampoc aquestes consideracions deixen d'oferir un matís clarament transpersonalista»; ALCALÁ
DIAZ, M. Á., La impugnación..., op. cit., en pàg. $190 \mathrm{i} 405:$ «El fet que l'exercici de les accions
esmentades puga constituir un mecanisme d'exoneració de la responsabilitat no és sinó la
conseqüència de la protecció de l'interès social i no la finalitat pretesa amb l'atribució de
legitimació als administradors»; i SALELLES CLIMENT, J. R., El funcionamiento...op. cit., pàg. $401-$
$402:$ "Que els membres del consell no defensen en la seua actuació un interès propi, fa que no
tinga transcendència la posició que van adoptar en relació amb l'acord que s'impugna». "És ja clàssica la citació de MINERVINI, G., "Sulla legittimazione degli amministratori a l'impugnativa delle deliberazioni assembleari di società perazioni», Riv. dir. comm., 1955, pàg. 215, (SAlelles CLIMENT, J. R., El funcionamiento..., op. cit., pàg. 378; SORIA FERRANDO, J. V., La impugnación...., op. cit., pàg. 66; SILVETT, C., i CAVALLI, G., Le società per azioni, op. cit., pàg. 199) en relació amb l'«alternativa penosa» a què es veurien sotmesos els administradors "en presència d'un acord anul-lable per part dels socis no conformes, i respecte del qual ells hagen impugnació, esecució abans de la decadència del termini prefixat per la llei per a l'exercici de la executen l'acord robaran en una alternativa penosa: si ells, en previsió de la impugnació no dels socis o per una a a d'exercici de la impugnació per part després exercitada altra causa, seran responsables; si ells executen l'acord, i la impugnació és de l'anul-lació [. per un o més socis, i acollida pel magistrat, en virtut de l'eficàcia retroactiva conseqüències ".. 
obligatòriament, la impugnació perquè l'administrador puga exonerar-se d'una responsabilitat eventual ${ }^{90}$.

La doctrina italiana ha elaborat àmpliament la matèria, i s'hi han establert diferents posicions en virtut de les diverses teories sobre quins són els interessos jurídics defensats pel sistema d'impugnació dels acords de la Junta ${ }^{91}$. Així, els qui entenen que el fonament de la legitimació per a la impugnació és l'interès propi dels administradors afirmen que, a aquests, els és atribuït per l'ordenament jurídic un dret-mitjà per a la protecció d'aquest interès ${ }^{92}$; no existirà, doncs, per a ells una obligació, sinó un instrument per a la millor defensa dels seus interessos. En canvi, els qui consideren que el fonament de la legitimació és l'interès social afirmen, bé l'existència d'un deure incondicionat $\mathrm{d}^{\prime}$ impugnació ${ }^{93}$, bé la d'un poder i d'un deure d'impugnació ${ }^{94}$.

Les tesis que consideren que la impugnació és un deure per als administradors estableixen que el caràcter definitiu de l'acord pel transcurs de temps, no impedit mitjançant la falta d'impugnació, fa que siguen responsables dels danys que es cause a la societat com a conseqüència de l'execució de l'acord irregular.

\footnotetext{
${ }^{90}$ Així, VICENT CHULIÁ, F., Compendio crítico..., op. cit., pág. 655: «La mera oposició expressa és un mínim de diligència, en el cas que no siga possible una altra mesura. En els altres casos, coneixent l'acte o acord lesiu, hauran de demostrar que no han intervingut en l'adopció $i$ l'execució $i$ que van fer tot el possible per evitar el dany. Aquesta exigència converteix la facultat d'impugnar els acords socials de l'article 143 en un deure (així ho expressa la Llei de cooperatives valenciana)». Com veurem, la menció a la llei valenciana de cooperatives es refereix a l'article 41 de la Llei 11/1985 que requeria explícitament, per a l'exoneració de responsabilitat dels membres del consell rector, la interposició per la seua part d'acció d'impugnació. Posteriorment, aquesta norma ha estat modificada en aquest aspecte per la Llei 3/1995.
}

${ }^{11}$ Les diferents postures doctrinals poden veure's en SILVETTI, C., i CAVALLI, G., Le società per azioni, op. cit., pàg. 199 i 206-209; i en SORIA FERRANDO, J. V., La impugnación..., op. cit., pàg. 66, 67,69 i $71-73$.

${ }^{2}$ MINERVINI, "Sulla legittimazione degli amministratori all'impugnativa delle deliberazioni assembleari di società per azioni», Riv. dir. comm., 1955, pàg. 215.

${ }^{43}$ GalGanO, F., Diritto commerciale. Le società, op. cit., pàg. 168 i següents; AlLEGRI, V., Contributo allo studio della responsabilità civile degli amministratori, Milà, 1979, pàg. 218.

${ }^{44}$ TRIMARCHI, P., «Titolarità del diritto di impugnare le deliberazioni annullabili», Riv. soc., 1957, pàg. 68 i següents; SCORZA, B., «Gli amministratore di società per azioni di fronte alle delibere invalide dell'assemblea», Riv. soc., 1963, pàg. 510 i següents. 
Contràriament, si es manté que la impugnació constitueix un dret, o es configura simultàniament com a poder i deure, la impugnació com a expressió del deure de diligència no és ja exigible en tot cas com a criteri d'exoneració de responsabilitat; només si, en el cas concret, la falta d'exercici de la impugnació pot considerar-se com a absència de la diligència deguda, es converteix en criteri d'imputació de responsabilitat. S'argumenta que de l'execució d'un acord impugnable no sempre es derivarà un dany a la societat i, quan així siga, els administradors podran provar en alguns casos, en justificació de l'absència d'impugnació, que el risc, les despeses i la durada del procediment haurien causat un dany més gran que el benefici de l'eliminació de l'acord.

En l'àmbit del nostre ordenament la major part de la doctrina manté que no és possible acollir la tesi de l'obligatorietat d'impugnar: d'una bansa, el tenor mateix de l'article 115 TRLSA estableix que els acords irregulars de la junta "podran" ser impugnats; d'una altra, el ja esmentat article 133 TRLSA no imposa en tot cas l'obligació d'impugnar l'acord per exonerar-se de responsabilitat ${ }^{95}$.

En la legislació cooperativa trobem que la LCoop estableix expressament, per a administradors i altres membres d'òrgans socials, l'obligació d'impugnar els acords contraris a la llei o als estatuts que siguen adoptats per l'assemblea general $^{96}$. La LCCV es limita a reconèixer la possibilitat d'impugnar dels

95 AlCALÁ DIAZ, M. Á., La impugnación..., op. cit., pàg. 406-412; BERCOVITZ, A., "Los acuerdos impugnables...", op. cit., pàg. 396; DIAZ DE LEZCANO SEVILLANO, N., Los acuerdos del consejo..., op. cit., pàg. 293; PÉREZ CARRILlO, E. F., «El deber de diligencia de los administradores de sociedades", RdS, núm. 14, 2000, pàg. 283; SALELLES CLIMENT, J. R., El funcionamiento..., op. cit., pàg. 390-392; SÁNCHEZ CALERO, Fernando, Administradores. Artículos 123 a 143 , en Comentarios a 268: "La impey de Sociedades Anónimas (dir. F. Sánchez Calero), tom IV, EDERSA, Madrid, 1994, pàg. 267l'execució impugnació de l'acord [...] és en molts supòsits la manera més vigorosa d'evitar op. cit., pàg. 300 (11a ed. 1998) En contrag. 300 (11a ed., 1998).

anónima, Valladolido GONZÁLEZ, Jesús, La responsabilidad civil de los administradores de la sociedad del dany és, com *

" L'article correlatiu 66 de la LGC es referia a "acords socials» en general, la qual cosa podria l'òrgan d'administractar l'obligatorietat també en els acords d'altres òrgans, especialment els de organ d'administració, per al qual s'ometia (i es continua ometent) la menció a l'obligatorietat. 
administradors, sense recollir-ne expressament l'obligatorietat, però això no és obstacle, al nostre parer, perquè també en relació amb les cooperatives valencianes puga qüestionar-se, com s'ha fet respecte de les societats de capital, si és possible deduir aquesta obligatorietat en virtut del deure de diligència.

Pel que fa a la llei estatal, la concreció mateixa de l'obligació per a determinats supòsits indica que no ho és amb caràcter general, i tampoc ho és, necessàriament, com a mitjà que puga evitar la responsabilitat: en aquesta matèria, la LCoop (article 43) remet expressament a "allò que es disposa per als administradors de les societats anònimes" que, com hem vist, no exigeix la impugnació per a l'exoneració. Quant a la legislació cooperativa valenciana, l'anterior Llei 11/1985 sí que establia l'obligació d'interposar una acció d'impugnació si es volia evitar una responsabilitat eventual ${ }^{97}$. Tanmateix, la nova redacció donada a aquesta norma per la Llei 3/1995 substitueix la impugnació com a instrument d'exoneració de responsabilitat pel vot en contra de l'acord, fent constar l'oposició bé en l'acta, bé mitjançant un document fefaent posterior ${ }^{98}$.

Sembla, doncs, que el deure d'impugnar haurà de valorar-se per a cada cas ${ }^{99}$ : serà obligatori impugnar, bé en compliment del mandat legal davant acords assemblearis contraris a la llei o als estatuts en supòsits sotmesos a la LCoop, bé perquè el deure de diligència exigible als administradors en el supòsit de fet concret reclame la impugnació a fi de fer tot el convenient per evitar el dany. Però no pot afirmar-se l'existència d'una obligatorietat general d'impugnar per als

L'actual text de l'article 31.4 LCoop substitueix tal expressió per la d'«acords contraris a la llei i als estatuts" $i$, atès que està ubicat en l'article titulat "Impugnació d'acords de l'assemblea general», sembla que impedeix tal generalització.

${ }^{97}$ Article 41. L 11/1985: «[...] Quedaran exempts de responsabilitat els qui no hagen participat o hagen votat en contra de l'acord i hi interposen en contra acció d'impugnació».

${ }^{90}$ Article 42.1 LCCV: "[...] Quedaran exempts de responsabilitat, els qui no hagen participat o hagen votat en contra de l'acord, i en facen constar l'oposició a l'acta, o mitjançant document fefaent que es comunique al consell en els 10 dies següents a l'acord».

"9 SÁNCHEZ CALERO, F., Administradores...., op. cit., pàg. 267. 
administradors, sinó només quan la impugnació siga allò convenient ${ }^{100}$. Ni serà, doncs, imprescindible impugnar en tot cas a fi d'eludir una responsabilitat eventual $^{101}$, ni la interposició d'una acció d'impugnació, per si sola, exoneraria d'aquesta responsabilitat l'administrador ${ }^{102}$. La fonamentació de l'obligatorietat s'ha de buscar, per tant, en altres motius: al nostre parer, una vegada més, en el deure de diligència inherent al càrrec en virtut del qual es té legitimació.

\subsection{La impugnació com a instrument de tutela de la minoria}

${ }^{100}$ EMBID IRUjo, José Miguel, "Comentario al art. 70", en AA. DD., Comentarios a la Ley de sociedades de responsabilidad limitada (coords. I. Arroyo i J. M. Embid), Tecnos, Madrid, 1997, pàg. 738-746, pàg. 743; SAlELlES CLIMENT, J. R., El funcionamiento..., op. cit., pàg. 401, 393 i 394: «Hi haurà únicament falta de diligència en l'acompliment del càrrec quan l'expectativa del cost que comporta l'execució de l'acord o de la seua regularització siga més gran que el cost implícit en la seua impugnació. Cal tenir en compte que els recursos emprats en un procés judicial no podran estats utilitzats per a la consecució d'objectius alternatius que poden ser més eficients per a l'interès social».

GADEA, Enrique, Derecho de las cooperativas. Análisis de la Ley 4/1993, de 24 de junio, de cooperativas del País Vasco, Universidad de Deusto, Bilbao, 1999, pàg. 188: «Les causes d'exoneració [...] se centren en tres supòsits: a) Que l'administrador desconega l'existència de l'acord. L'absència [...], ni tan sols justificada, no serà per si suficient [...] a més, caldrà que en desconega l'existència. Tal desconeixement ha de referir-se tant al moment anterior a la reunió, com al posterior. b) Que si la coneix, fera tot el possible per evitar el dany. Es tracta d'una fórmula general que haurà d'aplicar-se al cas concret per conèixer si l'actuació del membre del consell és suficient o no per exonerar-lo de responsabilitat. La manera més vigorosa d'evitar l'execució de l'acord lesiu és la impugnació, encara que no ha d'estimar-se l'única. [...]. c) Que almenys s'haja oposat expressament a l'acord lesiu".

${ }^{101}$ LLEBOT MAJó, José Oriol, Los deberes de los administradores de la sociedad anónima, Madrid, Civitas, 1996, pàg. 83: «La imputació de la responsabilitat i el consegüent haver d'indemnitzar la societat pel detriment del patrimoni social només tindrà lloc quan, a més, es determine l'existència d'una relació de causalitat entre la infracció del deure de diligència i el dany".

${ }^{102} \mathrm{P}$

PÉREZ CARRILLO, E. F., «El deber de diligencia...», op. cit., pàg. 283-284, on, davant de la complexitat inherent a l'execució dels acords socials, estima que el deure de diligència, al que obliga és a "actuar tal com ho faria un empresari ordenat i un representant lleial», i reflexiona sobre quina entre les diverses opcions és la més adequada: pot optar-se per impugnar; per "reconsiderar els termes de l'acord"; en alguns casos, "podran executar els acords anul.lables o nuls sense incórrer en responsabilitat quan el vici no siga evident o no resulte evident per a un "empresari ordenat i representant lleial" que haguera pres les mesures oportunes d'investigar i i possorar-se (llevat si l'execució d'acords viciats de nul-litat o anul-labilitat és intencionada...)"; i poden no executar o executar parcialment l'acord o esperar que transcórrega el termini per a la impugnació. «Però, en qualsevol cas, la seua actuació respecte dels acords socials haurà de tenir com a referent la conducta d'un empresari ordenat i representant lleial.» 
L'exposició de motius de la Llei de societats anònimes del 1951, en referir-se a la introducció de la regulació de la impugnació dels acords socials la qualificava com a "mitjà de garantir els drets de les minories". Posteriorment, un sector doctrinal reputat ha desenvolupat l'estudi de la institució des de la perspectiva d'instrument de "tutela de la minoria", per als supòsits en què la voluntat majoritària ja no personifica $l^{\prime}$ interès social ${ }^{103}$. Des d'aquesta perspectiva, tutela de la minoria significa "l'activitat realitzada pels òrgans judicials per determinar, en l'interès de l'existència de la societat, si els acords de la junta s'adeqüen a les normes de legalitat que, per al seu funcionament, s'han dictat, quan la valoració minoritària dissenteix de la realitzada per la majoria sobre l'interès social" ${ }^{104}$. Es diu llavors que l'acció d'impugnació suposa una atenuació del principi de la submissió dels socis al vot de la majoria ${ }^{105}$, i es parla de defensa de la minoria, o de "tutela de la minoria en sentit ampli"106.

Es fonamenta aquesta defensa en l'existència d'un deure de fidelitat del soci, com a translació del principi de bona fe que regeix les relacions

${ }^{113}$ DUQUE DOMfNGUEZ, J. F., Tutela..., op. cit., pàg. 4-5: «Es tracta de la solució del "conflicte entre l'interès de la societat i l'interès egoista de la majoria", expressat sia directament, sia a través d'una administració que és instrument d'aquella. En aquests supòsits, com que ja no és cert el dogma de la personificació de la voluntat social per la majoria, és interès social que la voluntat majoritària no prevalga sobre la minoritària o, més encara, que aquesta s'impose a aquella, per la qual cosa el principi de la sobirania de la junta general que, normalment coincideix amb la sobirania de la majoria, s'atenua".

${ }^{104}$ DUQUE DOMf́NGUEZ, J. F., Tutela..., op. cit., pàg. 10-11.

${ }^{105}$ DUQue DOMíNGUEZ, J. F., Tutela..., op. cit., pàg. 4-5. També JUSTE MENCfA, Javier, Los derechos de minoría en la sociedad anónima, Aranzadi, Pamplona, 1995, pàg. 50, nota 55; SALELLES CLIMENT, J. R., El funcionamiento..., op. cit., pàg. 374-375; i URfA, R., MENÉNDEZ, A. i MUÑOZ, J. M., La junta..., op. cit., pàg. 304-306.

GENCO, R, «Il volto cooperativo...», op. cit., pàg. 17: «Les societats estan governades per la regla majoritària, però les minories que sofreixen la voluntat majoritària tenen dret a controlar les actuacions a fi de maximitzar l'eficiència de gestió de l'empresa (i per tant, de passada, la conveniència de la seua inversió financera)"».

${ }^{106}$ POLO SÁNCHEZ, E., "Abuso o tiranía...", op. cit., pàg. 2275-2276; SÁNCHEZ RUIZ, M., Conflictos de intereses..., op. cit., pàg. 132-135, que, això no obstant, manté «dubtes seriosos sobre la utilitat o l'eficàcia per delimitar d'una expressió tan àmplia", el que justifica intentar definir l'àmbit propi d'una "tutela de la minoria en sentit estricte»; aquesta autora rebutja la teoria que identifica "tutela de la minoria" i "tutela de l'interès social", perquè "sembla excloure la possibilitat de conflictes entre diversos interessos societaris, tots susceptibles de tutela pel dret 
juridicocontractuals ${ }^{107}$. Partint d'aquest deure de fidelitat es justifica la impugnació dels acords per l'incompliment, per part de la majoria, dels seus deures fiduciaris, en afectar les seues decisions no sols els seus interessos, sinó els dels socis minoritaris ${ }^{108}$.

Però només "en un sentit ampli o impropi" pot parlar-se de protecció de la minoria, perquè, realment, "en concedir una acció d'impugnació contra la decisió de l'assemblea, el que es vol defensar d'una manera directa són la llei, l'estatut o l'interès de la societat", encara que també es protegisca la minoria ${ }^{109}$. D'aquesta manera, la tutela d'interessos generals es realitza a través de l'atribució d'instruments de garantia en favor de socis que, defensant interessos legítims, han quedat en minoria ${ }^{110}$ davant l'adopció per la majoria d'una manifestació de voluntat social que és contrària a la llei o als estatuts, o lesiva de l'interès social.

de societats i entre els quals no es pot establir, a priori i de manera general, una relació jeràrquica».

107 Ulmer, Peter, Principios fundamentales del Derecho alemán de sociedades de responsabilidad limitada, Civitas, Madrid, 1998, pàg. 79-81 i 155-158. Sobre el "qualificat deure de fidelitat» del cooperativista, que no té «només - com en les societats de capitals, per exemple- un contingut negatiu, en virtut del qual ha d'abstenir-se de realitzar actes o activitats que, a costa de l'interès de la cooperativa, promoguen els interessos particulars que el cooperativista tinga fora", sinó també un contingut positiu que l'obliga a "promocionar els interessos cooperatius, participant en el desenvolupament de l'activitat cooperativa», vegeu DUQUE DOMfNGUEZ, Justino F., «La baja obligatoria del socio", REVESCO, núms. 56-57, 1988-89, pàg. 19. ALCALÁ DIAZ, M. Á., La impugnación..., op. cit., pàg. 183-184; ALFARO ÁGUILA-REAL, J., Interés
social..., op. cit., pàg. 40 .

GARRIGUES, J., «La protección de las minorías...», op. cit., pàg. 98: "Quan la minoria ha d'invocar la contradicció amb la llei, amb els estatuts o amb l'interès de la societat, en realitat el que directament s'està protegint és la llei, l'estatut o la societat mateixa. No és la defensa de la minoria el que hi ha en joc, sinó el respecte a la llei, a l'estatut o a un interès superior, i és aquest respecte el que s'imposa a la voluntat de la majoria per raons evidents. El que ocorre és que si la víctima de la violació ha estat un accionista minoritari, aquest accionista, en impugnar l'acord de la majoria, s'ha situat ipso facto al costat de la llei, de l'estatut o de l'interès social». CABALLOL I ANGELATS, L., "Comentario al artículo 115...", op. cit., pàg. 1114: «El que és cert és que les minories d'accionistes, pel sol fet de ser-ho, no necessiten cap protecció [...]. Allò que sí que necessita ser defès són l'interès comú dels accionistes [...] i el principi de no-discriminació dels accionistes de la mateixa classe, perquè ambdós aspectes constitueixen el fonament $i$ el límit de la vinculació de l'accionista al criteri de la majoria».

En l'àmbit cooperatiu, Morillas JARILLO, M. J., i Feliú REY, M.I., Curso..., op. cit., p. 253.

"'t' DUQUE, J. F., Tutela..., pàg. 155-160. En el context de la impugnació dels acords del consell d'administració, SAlelles CLIMENT, J. R., El funcionamiento..., op. cit., pàg. 82-83. 
En realitat, quan es qualifica la impugnació com a mitjà de tutela de la minoria s'incorre en una certa confusió terminològica ${ }^{111}$. Estrictament parlant, són únicament mitjans de tutela de la minoria aquells en què aquesta (definida normativament mitjançant la fixació de la seua composició mínima: normalment mitjançant un percentatge sobre el total de socis o, com veurem, sobre el capital social ${ }^{112}$ ) no necessita acudir a una instància externa a la societat (jurisdiccional o administrativa) ni invocar cap transgressió de la llei, dels estatuts o de l'interès social. En aquest sentit, "a falta d'un criteri de raó, la llei

"' GIRÓN TENA, J., Dret de societats anònimes, op. cit., pàg. 188: "Certament, els socis que componen, en cada cas, una minoria determinada, estan protegits pel conjunt de preceptes que atribueixen drets a cada un individualment $\mathrm{i}$ per totes les normes que ordenen interessos [...]; però no és convenient parlar llavors de dret de minoria, si es vol conservar la utilitat sistemàtica d'aquest concepte». RUBIO, J., Curso..., op. cit., pàg. 180: «Encara que aquesta expressió sol emprar-se més sovint en sentit ampli per designar tot límit als acords de la Junta general, [...] sembla preferible reservar-la per a aquelles normes destinades a emparar-ne una minoria determinada. [...] Sia que traduïsquen un poder d'iniciativa concedit a un percentatge minoritari, encara que en definitiva la resolució corresponga a la majoria [...] sia que es tracte de vertaders
drets de la minoria». En aquest sentit, entenem que han de rebutjar-se, per confuses, afirmacions com ara la següent: "La LSA atribueix legitimació per a la impugnació específicament a socis minoritaris, és a dir, a aquells que no han contribuït a la formació de la majoria, per no haver assistit a la junta, per haver votat en contra i haver fet constar la seua oposició a l'acord o per haver estats privats il-legítimament del seu dret de vot» (ALCALÁ DIAZ, M. Á., La impugnación..., op. cit., pàg. 178). Això no obstant, s'ha de reconèixer que «el terme sol estar emprat amb una pluralitat de concepte unívoc de minoria" (Cfr. SÁNCHEZ RUIZ, M. Conflictos de 142; i JUSTE MENCAA, J., Los derechos de minoria..., op. cit., pàg. 46-49). A l'efecte del nostre treball, la noció de minoria que es pren en consideració és aquella que fa referència al col-lectiu de socis que gaudeixen d'un mitjà de tutela dels seus drets com a tal "valor merament fàctic i puntual», referit al resultat d'una votació concreta.

${ }^{112}$ El principi d'«un vot per persona» imposa a la cooperativa que els còmputs de majories $i$ minories s'establisquen, com a norma general, sobre el total dels socis i no del capital social, com ocorre en les societats capitalistes (BONFANTE, Guido, «Imprese cooperative», en AA. DD., Commentario del Codice Civile Scialoja-Branca, a cura di Francesco Galgano, llibre cinquè: Lavoro art. 2511-2545, Zanichelli Editore, Bolonya, 1999, pàg. 607: «En un pla formal, sent el vot per cap, no hi ha una minoria en els mateixos termes que en la S.p.A». Com a excepció, l'article $41.6 \mathrm{LCCV}$ estableix que la legitimació dels socis per a la impugnació dels acords del consell rector requerirà que representen, almenys, un $5 \%$ del capital social (vegeu infra, cap. 4). Sobre el diferent còmput de majories i minories en les societats de capital, vegeu SÁNCHEZ RUIZ, M., Conflictos de intereses..., op. cit., pàg. 35-37; aquesta autora també es refereix a la possibilitat de tractar, en l'àmbit de les societats de capital, conjuntament $i$ indistintament els drets individuals $i$ els de la minoria, ja que la minoria pot estar constituïda per un únic soci i, per tant «l'única peculiaritat que [...] caracteritza [els drets de minoria] és l'exigència d'un percentatge de capital determinat». Com és evident, això no és traslladable a les cooperatives, en les quals regeix el
principi de vot per cap. 
atén un criteri de quantitat", quan el grup minoritari representa un percentatge important del capital social, la llei, sense més ni més, deroga el principi de submissió a la majoria" ${ }^{113}$.

Així doncs, són vertaders mitjans de defensa de la minoria ${ }^{14}$, per exemple, les normes relatives a la intervenció de la minoria en la convocatòria (articles $23.3 \mathrm{i}$ 24.2 LCoop, i 29.1 i 30.3 LCCV) i en l'aprovació de l'acta (article 34.2 LCCV) de l'assemblea general; les relatives a la representació estable dels socis de treball en el consell rector (article $38.4 \mathrm{LCCV}$ ); les relatives al dret d'oposició a la transacció o renuncia a l'exercici de l'acció de responsabilitat contra administradors o interventors (article 43 LCoop) o, si escau, el dret a iniciar l'acció en nom de la cooperativa (article $42.3 \mathrm{LCCV}$ ), i les relacionades amb el nomenament d'intervenció de la liquidació (article 72 LCoop). Però no pot considerar-se, stricto sensu, instrument de tutela de la minoria a la impugnació dels acords socials, perquè la protecció en aquest cas s'opera mitjançant la intervenció dels tribunals i només en la mesura que es comprove que hi ha vulneració de la llei, dels estatuts o de l'interès social.

A més, la impugnació pot ser exercida per socis que, en solitari, pretenguen tutelar un interès legítim ${ }^{115}$. hi ha, sens dubte, un interès personal del soci

${ }^{113}$ GARRIGUES, J., «La protección de las minorías...», op. cit., pàg. 98-99; POLO SÁNCHEZ, E., "Abuso o tiranía...», op. cit., pàg. 2285. SÁNCHEZ RUIZ, M., Conflictos de intereses..., op. cit., pàg.
140-141, tampoc no considera suficient aquesta concepció de la tutela de la minoria perquè, al seu entendre, «no esgota totes les hipòtesis de conflicte majoria-minoria [...] resulten únicament protegits aquells interessos específics del soci i de la minoria que han assolit el rang de dret subjectiu $i$ han estat reconeguts com ara en el règim jurídic de les societats de capital»; en la de la minoria» 0 "abús de la regla de la majoria».

${ }^{114}$ POLO SÁNCHEZ, E., "Abuso o tiranía...", op. cit., pàg. 2275, els denomina "drets corporatius del soci", "atribuïts precisament a les minories que posseeixen uns percentatges determinats en los dels "apital de la societat com a mitjà de defensa davant el poder de la majoria", per diferenciarminoria..., op. individuals», i els classifica en pàg. 2283-2285; JUSTE MENCfA, J., Los derechos de refereixen com cit. pàg. 47 i SÁNCHEZ RUIZ, M., Conflictos de intereses..., op. cit., pàg. 119 s'hi un

pretenguen impugnar acords com el supòsit de la legitimació als socis no administradors que quart. 
(individualment considerat, o eventualment agrupat en una minoria no exigida legalment) que resulta protegit, però només en la mesura que resulte confluent $a m b$ el manteniment de l'ordenament jurídic vigent $i$ amb el funcionament regular de la societat. El que succeeix és que s'aprofita i es protegeix també l'interès particular que normalment indueix el soci a prendre sobre si la càrrega d'un procés per a, simultàniament, aconseguir la tutela de l'interès general o social $^{116}$.

Una excepció sembla plantejar-se respecte al que s'ha exposat: la legitimació dels socis no administradors per a la impugnació d'acords de l'òrgan d'administració, que es reconeix únicament en favor, no ja de cada soci individual, sinó d'un col-lectiu de socis que el legislador considera rellevant ${ }^{117}$. Però en aquest cas tampoc pot parlar-se estrictament d'instrument de tutela de la minoria, ja que aquesta necessitarà recórrer a un àmbit extern, judicial, perquè es determine si l'acord vulnera la llei, els estatuts socials o l'interès social. En aquest supòsit es compleix, efectivament, que els anomenats drets de minoria no signifiquen un augment del poder de la minoria, sinó un "debilitament dels drets del soci individual" ${ }^{118}$.

"16 DUQUE, J F., Tutela..., pàg. 158, que, tanmateix, insisteix que «la relació entre protecció de l'interès social i protecció de l'interès del soci no s'esdevé en un pla de subordinació, sinó en un pla de coordinació»; URf́A, R., MENÉNDEZ, A., i MUÑOZ, J. M., La junta..., op. cit., pàg. 305: «La funció de la minoria en l'ordre intern de la societat anònima és senzillament de control. [...] En definitiva, la tutela de la minoria no és més que la tutela de la societat mateixa mitjançant l'acció de l'accionista aillat». En la doctrina italiana, SILVETTI, C., i CAVALLI, G., Le società per azioni, op. cit., pàg. 199.

${ }^{117}$ SÁNCHEZ CALERO, F., Administradores...., op. cit., pàg. 544.

${ }^{11 *}$ DUQUE DOMfNGUEZ, Justino F., "Introducción a la protección de los derechos del accionista frente a los acuerdos de la mayoría", RdS, núm. 1, 1993; i en AA. DD., Derecho de sociedades anónimas, II, Capital y acciones, vol. 1, Civitas, Madrid, 1994, pàg. 80-81: «La concessió d'aquests drets pretén evitar que un accionista aillat puga exercir un influx desmesurat en la vida social $i$ que no manté cap proporció amb la seua participació en la societat. La majoria és així protegida de l'arbitrarietat d'un soci aillat. [...] Drets de minoria i drets individuals no es distingeixen en el fons substancialment, sinó tan sols gradualment. Els drets de grup són formalment drets de l'exercici individual debilitats (WIEDEMANN, Gesellshaftrecht, p. 363)"; SÁNCHEZ RUIZ, M., Conflictos de intereses..., op. cit., pàg. 123.

L'expressió, atribuïda a BRODMAN, també es recull en JUSTE MENCfA, J., Los derechos de minoría..., op. cit., pàg. 102, nota 91. 


\subsection{La impugnació com a dret subjectiu o potestat}

Des d'una perspectiva diferent, es parla molt habitualment de la impugnació dels acords socials com un dret del soci ${ }^{119}$. Les normes jurídiques mateixes solen recollir aquesta qualificació (article 48.2, c) LSA, entre els drets de l'accionista; article 24.2 LCCV, entre els drets que, en el seu cas, tindrà l'associat, en equiparació als del soci). Això no obstant, com ja s'ha advertit, en el llenguatge jurídic s'empra la locució dret amb freqüència extraordinària, i s'utilitza, de vegades, sense excessiu rigor tècnic ${ }^{120}$, com a denominació genèrica $d^{\prime} u n$ conjunt de situacions que atribueixen poder jurídic.

A l'efecte de la caracterització de la impugnació d'acords, la diferenciació que convé tenir present és la que distingeix entre dret subjectiu i potestat: mentre que aquell es reconeix per l'ordenament jurídic a la persona titular perquè actue lliurement en satisfacció dels seus interessos legítims ${ }^{121}$, aquesta se li atribueix

11 ESTEBAN Velasco, G., El poder de decisión..., op. cit., pàg. 563; GIMENO SENDRA, J. V., El proceso..., op. cit., pàg. 19-25 i 70; GÓMEZ ORBANEJA, Emilio, «El proceso de impugnación de la Ley de sociedades anónimas", RDPri, 1955, pàg. 125; JUSTE MENCtA, J., Los derechos de minoría..., op. cit., pàg. 91; POLO SÁNCHEZ, E., Los administradores..., op. cit., pàg. 540; RUBIO, J., Curso..., op. cit., pàg. 180; SÁNCHEZ CALERO, F., Administradores...., op. cit., pàg. 544; SÁNCHEZ RUIZ, M.,
Conflictos de intereses..., op. cit., pàg. 134 .

${ }^{120}$ DfeZ-PICAZO, L. i GULlÓN, A., Instituciones..., op. cit., vol. I, pàg. 284; DUQUE DOMf́NGUEZ, J. F. "Introducción a la protección...", op. cit., pàg. 76-77. Per a les crítiques a l'article 48 LSA, perquè considera un sector doctrinal que, entre altres "efectes pertorbadors", que l'enumeració que intereses..., or de qualificar-se com de vertaders drets, vegeu SÁNCHEZ RUIZ, M., Conflictos de

121

DfEZ-PiCAzO, L., i Gullón, A., Instituciones..., op. cit., vol. I, pàg. 285, 286 i 296: «És una situació que permet a la persona adoptar una sèrie de possibilitats d'obrar [...] està compost per un conjunt o feix de facultats agrupades unitàriament $\mathrm{i}$ harmònica». Per a una anàlisi de les intereses..., op teories sobre els drets individuals del soci, vegeu SÁNCHEZ RUIZ, M., Conflictos de dret subjectiu cit., pàg. 82-115; en pàg. 91, nota 36: «De manera simplificada, pot definir-se el (cfr. LOPEZ LO com el poder atribuit a un subjecte per a la consecució o conservació dels seus interessos "Un "concepte realista . MONTÉS PENADÉs: Derecho civil, cit., pàg. 483)"; en pàg. 92-93, nota 39: jurídic), que pressuposa dret subjectiu" [...] haurà de tenir en compte la seua naturalesa (poder constitueixen la proporció un ofici i una funció (la protecció de l'interès del subjecte) que poder jurídic en el doble sentita tutela que li atorga el dret objectiu. Es tracta així mateix, d'un fixen, abstractament, l'estructur de no estar fora de l'ordenament $i$ d'estar limitat per les normes, que en C.: "Observaciones crítictura, la funció, el contingut $i$ els efectes típics (cfr. VATTIER FUENZALIDA, 
(individualment considerat, o eventualment agrupat en una minoria no exigida legalment) que resulta protegit, però només en la mesura que resulte confluent $\mathrm{amb}$ el manteniment de l'ordenament jurídic vigent $\mathrm{i}$ amb el funcionament regular de la societat. El que succeeix és que s'aprofita i es protegeix també l'interès particular que normalment indueix el soci a prendre sobre si la càrrega d'un procés per a, simultàniament, aconseguir la tutela de l'interès general o social $^{116}$.

Una excepció sembla plantejar-se respecte al que s'ha exposat: la legitimació dels socis no administradors per a la impugnació d'acords de l'òrgan d'administració, que es reconeix únicament en favor, no ja de cada soci individual, sinó d'un colllectiu de socis que el legislador considera rellevant ${ }^{117}$. Però en aquest cas tampoc pot parlar-se estrictament $d$ 'instrument de tutela de la minoria, ja que aquesta necessitarà recórrer a un àmbit extern, judicial, perquè es determine si l'acord vulnera la llei, els estatuts socials o l'interès social. En aquest supòsit es compleix, efectivament, que els anomenats drets de minoria no signifiquen un augment del poder de la minoria, sinó un "debilitament dels drets del soci individual" ${ }^{118}$.

${ }^{116}$ DUQUE, J F., Tutela..., pàg. 158, que, tanmateix, insisteix que «la relació entre protecció de l'interès social i protecció de l'interès del soci no s'esdevé en un pla de subordinació, sinó en un pla de coordinació»; URfA, R., MENÉNDEZ, A., i MUÑOZ, J. M., La junta..., op. cit., pàg. 305: «La funció de la minoria en l'ordre intern de la societat anònima és senzillament de control. [...] En definitiva, la tutela de la minoria no és més que la tutela de la societat mateixa mitjançant l'acció de l'accionista aillat». En la doctrina italiana, SILVETTI, C., i CAVALLI, G., Le società per azioni, op. cit., pàg. 199.

${ }^{117}$ SÁNCHEZ CALERO, F., Administradores...., op. cit., pàg. 544.

${ }^{11}$ DUQUE DOMf́NGUEZ, Justino F., "Introducción a la protección de los derechos del accionista frente a los acuerdos de la mayoría", RdS, núm. 1, 1993; i en AA. DD., Derecho de sociedades anónimas, II, Capital y acciones, vol. 1, Civitas, Madrid, 1994, pàg. 80-81: «La concessió d'aquests drets pretén evitar que un accionista aillat puga exercir un influx desmesurat en la vida social $i$ que no manté cap proporció amb la seua participació en la societat. La majoria és així protegida de l'arbitrarietat d'un soci aillat. [...] Drets de minoria i drets individuals no es distingeixen en el fons substancialment, sinó tan sols gradualment. Els drets de grup són formalment drets de l'exercici individual debilitats (WIEDEMANN, Gesellshaftrecht, p. 363)»; SÁNCHEZ RUIZ, M., Conflictos de intereses..., op. cit., pàg. 123.

L'expressió, atribuïda a BRODMAN, també es recull en JUSTE MENCIA, J., Los derechos de minoría..., op. cit., pàg. 102, nota 91 . 


\subsection{La impugnació com a dret subjectiu o potestat}

Des d'una perspectiva diferent, es parla molt habitualment de la impugnació dels acords socials com un dret del soci ${ }^{119}$. Les normes jurídiques mateixes solen recollir aquesta qualificació (article 48.2, c) LSA, entre els drets de l'accionista; article $24.2 \mathrm{LCCV}$, entre els drets que, en el seu cas, tindrà l'associat, en equiparació als del soci). Això no obstant, com ja s'ha advertit, en el llenguatge jurídic s'empra la locució dret amb freqüència extraordinària, i s'utilitza, de vegades, sense excessiu rigor tècnic ${ }^{120}$, com a denominació genèrica $d^{\prime}$ un conjunt de situacions que atribueixen poder jurídic.

A l'efecte de la caracterització de la impugnació d'acords, la diferenciació que convé tenir present és la que distingeix entre dret subjectiu i potestat: mentre que aquell es reconeix per l'ordenament jurídic a la persona titular perquè actue lliurement en satisfacció dels seus interessos legítims ${ }^{121}$, aquesta se li atribueix

119 ESTEBAn Velasco, G., El poder de decisión..., op. cit., pàg. 563; GIMENO SENDRA, J. V., El proceso..., op. cit., pàg. 19-25 i 70; GOMEZ ORBANEJA, Emilio, «El proceso de impugnación de la Ley de sociedades anónimas", RDPri, 1955, pàg. 125; JUSTE MENCiA, J., Los derechos de minoría..., op. cit., pàg. 91; POLO SÁNCHEZ, E., Los administradores..., op. cit., pàg. 540; RUBIO, J., Curso..., op. cit., pàg. 180; SÁNCHEZ CALERO, F., Administradores...., op. cit., pàg. 544; SÁNCHEZ RUIZ, M., Conflictos de intereses..., op. cit., pàg. 134.

${ }^{120}$ DíEZ-PICAZO, L. i GULlÓN, A., Instituciones..., op. cit., vol. I, pàg. 284; DUQUE DOMÍNGUEZ, J. F., "Introducción a la protección...", op. cit., pàg. 76-77. Per a les crítiques a l'article 48 LSA, perquè considera un sector doctrinal que, entre altres «efectes pertorbadors», que l'enumeració que conté no ha de qualificar-se com de vertaders drets, vegeu SÁNCHEZ RUIZ, M., Conflictos de intereses..., op. cit., pàg. 100-101.

${ }^{121}$ Dífz-PICAZO, L., i GUllóN, A., Instituciones..., op. cit., vol. I, pàg. 285, 286 i 296: «És una situació que permet a la persona adoptar una sèrie de possibilitats d'obrar [...] està compost per un conjunt o feix de facultats agrupades unitàriament $i$ harmònica». Per a una anàlisi de les diferents teories sobre els drets individuals del soci, vegeu SÁNCHEZ RUIZ, M., Conflictos de intereses..., op. cit., pàg. 82-115; en pàg. 91 , nota 36: «De manera simplificada, pot definir-se el dret subjectiu com el poder atribuït a un subjecte per a la consecució o conservació dels seus interessos (cfr. LOPEZ LOPEZ, A. i V. MONTÉS PENADÉS: Derecho civil, cit., pàg. 483)"; en pàg. 92-93, nota 39: "Un "concepte realista de dret subjectiu" [...] haurà de tenir en compte la seua naturalesa (poder jurídic), que pressuposa un ofici i una funció (la protecció de l'interès del subjecte) que constitueixen la proporció de la tutela que li atorga el dret objectiu. Es tracta així mateix, d'un poder jurídic en el doble sentit de no estar fora de l'ordenament $i$ d'estar limitat per les normes, que en fixen, abstractament, l'estructura, la funció, el contingut $i$ els efectes típics (cfr. VATTIER FUENZALIDA, C.: "Observaciones críticas", cit., pàg. 38 in fine i 39) [...] Juna situació de poder concedida per 
"per a la defensa dels interessos d'una altra persona, de manera que el seu

exercici i la seua defensa no són lliures i arbitraris, sinó que són imposats en consideració als interessos en el servei dels quals es donen" ${ }^{122}$; com a conseqüència d'això, la potestat "produeix efectes jurídics en l'esfera jurídica de persona distinta d'aquella que l'exercita, això és, directament a l'esfera jurídica de la societat $i$, indirectament, a l'esfera dels altres socis". ${ }^{123}$

Així plantejats els termes de la qüestió, no hi ha cap dubte que la impugnació d'acords socials és una potestat, un poder que s'atorga al seu titular per l'ordenament jurídic per a la defensa dels interessos de persona diferent, la

l'ordenament a una persona, institucionalitzat i tipificat per aquest, que es concreta en certes possibilitats d'actuació específica (facultats), i constitueix el costat actiu de la relació jurídica (encara que amb entitat independent i vida autònoma), i n'és el tret essencial (el que fa que una situació de poder adquirisca la categoria de dret subjectiu) el fet que el seu maneig i exercici queda a discreció del titular [...] Cfr. LACRUZ BERDEJO, José Luis i altres, Elementos de derecho civil I, Parte general, volum 3r, Derecho subjetivo. Negocio jurídico (edició revisada per J. Delgado Echeverría), Dykinson, Madrid, 1999, en pàg. 99: "«Serem en presència d'un dret individual quan es reconega al soci una prerrogativa o un poder jurídic atribuït a aquest per a la tutela del seu interès en la societat, i per això de caràcter inderogable sense el seu consentiment».

${ }^{122}$ DízZ-PICAZO, L. i GUllón, A., Instituciones..., op. cit., vol. I, pàg. 285, que distingeixen així mateix les "facultats", com a "possibilitats d'actuació que s'atribueixen a la persona com a contingut d'un dret subjectiu més ampli o, ailladament»; i l'«acció», com a "possibilitat que l'individu té d'acudir als tribunals de justícia i reclamar-ne el pronunciament d'una decisió». Encara es refereix DUQUE DOMÍNGUEZ, J. F., «Introducción a la protección...», op. cit., pàg. 77, a un altre tipus de situacions amb transcendència jurídica, les anomenades "posicions favorables del soci», "que no poden qualificar-se de drets subjectius: són normes que imposen als administradors deures que no poden exigir-se pels accionistes, però que, en cas d'incompliment, desfermen accions de responsabilitat. Constitueixen deures dels òrgans de la societat que, reflexament, protegeixen l'accionista».

Assenyalen les dificultats d'optar entre la caracterització com a dret subjectiu o com a potestat, quan es refereixen al vot, GIRÓN TENA, J., Derecho de sociedades, op. cit., tom I, pàg. 314; i AlBORCH BATALLER, C., El derecho de voto..., op. cit., pàg. 126-127, qui estima que «la potestat comporta una obligació determinada d'exercir-la i, a més, de fer-ho en un sentit determinat», el que derivaria en un vertader deure d'exercir-lo de conformitat amb l'interès social, lligat a un eventual deure de fidelitat, que l'autora nega en relació amb el vot, perquè el seu incompliment generaria la responsabilitat del soci. També entén que l'exercici d'una potestat comporta l'obligació de fer-lo en un sentit determinat GIMENO SENDRA, J. V., El proceso..., op. cit., pàg. 19. RECALDE CASTELLS, Andrés, Limitación estatutaria del derecho de voto en las sociedades de capital, Civitas, Madrid, 1996, pàg. 29, es decanta explícitament per la configuració del vot com a dret subjectiu, en el marc de la concepció contractual predominant en la societat de capital: «La possibilitat de contemplar la clàusula de $\mathrm{l}^{\prime \prime}$ "interès social" com a límit al lliure exercici del dret de vot no sembla que siga capaç de justificar la substitució d'un plantejament essencialment privat de la societat anònima per consideracions transpersonalistes que serviren per fonamentar la vinculació de la voluntat dels socis a interessos diferents dels seus propis».

${ }^{123}$ DUQUe DOMÍNGUEZ, J. F., Tutela..., op. cit. pàg. 56. 
persona jurídica en substitució de la qual actua ${ }^{124}$. Però ja hem vist que l'ordenament aprofita l'existència d'un interès propi ${ }^{125}$ del substitut com a motor de l'acció, interès que es considera legítim i per tant creditor de protecció, cosa per la qual es pot parlar també de dret subjectiu a la impugnació ${ }^{126}$.

${ }^{124}$ A favor de la qualificació de potestat, SORIA FERRANDO, J. V., La impugnación..., op. cit., pàg. 44 , si bé adverteix que en la LSA hi ha arguments que permetrien sostenir la tesi contrària; en contra, GIMENO SENDRA, J. V., El proceso..., op. cit., pàg. 19, perquè considera que, si la LSA no consagra en matèria $d^{\prime}$ 'interès social la tesi institucionalista, «l'actor no pot perseguir dins del procés un interès diferent al seu propi». En contra de la qualificació del soci com a substitut processal, FAIRÉN, El proceso en la Ley de sociedades anónimas (estudio sobre los artículos 67 a 70), Barcelona, 1954, pàg. 46, que considera que el soci actua únicament «en interès propi, que té com a soci", encara que posteriorment afirma que "sols menys directament, com que la resolució que es dicte afecta necessàriament tota l'entitat - "acord social" -, resulta tutelat també l'interès dels altres socis".

JUSTE MENCIA, J., Los derechos de minoría..., op. cit., pàg. 88-90, afirma que «la major part dels drets administratius - $\mathrm{i}$ assenyaladament els de minoria- mereixen el qualificatiu de poder", encara que adverteix que «la utilització exclusiva del terme poder pot conduir a equívocs sobre l'interès que aquestes figures pretenen satisfer. En l'exercici dels concedits a l'accionista, sembla exagerat assenyalar que serveixen de manera exclusiva a un interès aliè al dels qui els exerciten [...]. Resulta indubtable que a través del seu exercici es pot buscar també la satisfacció d'un interès particular, ja que parlem de corporacions de dret privat, creades per l'autonomia reglada- de la voluntat. [...] A causa d'aquesta especialitat del dret de societats, no sembla absurd parlar del dret de [...] impugnació o de qualsevol altra figura que poguera entendre's més pròxima a la de poder o una altra categoria, ja que el seu exercici també s'entén que serveix a l'interès de la persona que el posa en acte».

${ }^{125}$ GÓMEZ ORBANEjA, E., «El proceso de impugnación...», op. cit., pág. 126, nota 1: «No es tracta, per tant, d'un interès personal a l'exclusió de l'acord, sinó de l'interès comú a tots els accionistes i a la pròpia societat, que la Junta general procedisca conforme a la llei i als estatuts».

${ }^{126}$ AlCALÁ DÍAZ, M. Á., La impugnación...., op. cit., pàg. 178, tanmateix, sosté que «l'ordenament jurídic configura els anomenats drets de caràcter auxiliar, que no suposen el reconeixement d'un dret subjectiu en sentit estricte sinó l'atribució d'un poder el contingut del qual es vincula a la protecció dels drets subjectius inclosos dins de la relació jurídica que configura la condició jurídica de soci»; entre aquests "drets auxiliars» inclou el d'impugnar els acords de la junta general contraris a la llei o lesius a l'interès social; això no obstant, posteriorment, indica que la legitimació judicial en favor del soci té, en tot cas, caràcter ordinari, "és a dir, l'exercici de les accions s'efectua en interès propi».

DUQUE DOMf́NGUEZ, J. F., en "Introducción a la protección...", op. cit., pàg. 76-77, encara que inclou la impugnació entre els "drets del soci», manté que «l'article 48 TRLSA [...] utilitza el terme "drets» d'una manera àmplia. Dret, designa en aquesta norma no sols autèntics drets subjectius - com el dret d'informació o el dret d'assistir a les juntes generals- sinó també poders, en virtut dels quals l'accionista no podrà exigir una conducta a la societat, llevat que observe el deure general d'abstenir-se d'actes que obstaculitzen l'exercici d'aquests drets - per exemple el dret de vot o el d'impugnació dels acords socials viciats». En tot cas, aquest autor mateix es manifesta contrari a la subsidiarietat de la impugnació, en Tutela..., op. cit. pàg. 160161: «De l'agrupació del poder d'impugnació amb altres poders alguns autors han deduït que aquell és un poder accessori del de vot — que realment és, en el quadre dels poders de gestió de l'accionista, el més important-, sostenint, per tant, que el seu titular serà el titular del poder de vot. Però aquesta conclusió extreta de la instrumentalitat que el poder d'impugnació té per fer valer la voluntat de l'accionista en relació amb la voluntat social no és certa, ja que hi ha socis com els morosos- que estan desproveïts del poder de vot $i$, tanmateix, poden impugnar els 
En realitat, entenem que, encara que es presenten com a contraposades, ambdues tesis "tenen una part de veritat" ${ }^{\prime \prime 27}$ : la primera, això és, la consideració de la impugnació com a potestat, en abstracte, compleix la finalitat principal perseguida pel legislador i fa innecessari que l'actor prove que ha sofert un dany personal; la segona, la seua qualificació com a dret subjectiu, és més realista i atén el moment en què s'exercita el dret, en el qual no s'exigeix al legitimat la prova que persegueix l'interès social ${ }^{128}$. Es concilien, doncs, interessos diversos en la mateixa acció, cosa que no deixa de ser allò que, d'una manera o d'una altra, donant més èmfasi a un interès o a un altre, proposa la major part de la doctrina ${ }^{129}$.

No trobem, a més, una altra argumentació que puga justificar les diverses legitimacions que l'ordenació concedeix. D'una banda, com s'ha dit, considerar que hi ha únicament una legitimació indirecta, de substitució de la societat pel soci, no explicaria que aquest veja exclòs l'exercici de la impugnació en alguns supòsits; si exercitara únicament "un poder que la llei li confereix per a la tutela d'un interès aliè", no hi hauria raó perquè el seu comportament a l'assemblea

acords il-legítims [...]. En realitat, la relació entre ambdós poders és de complementarietat, ja que el soci, mitjançant l'exercici del poder impugnatori, fa valer el seu interès amb relació a la marxa dels negocis socials, quan aquest no ha estat satisfet amb l'exercici del poder de vot».

${ }^{127}$ GIRÓN TENA, J., Derecho de sociedades anónimas, op. cit., pàg. 190, si bé utilitza aquesta expressió per explicar la finalitat perseguida pel legislador en atribuir els drets de minoria. Es tracta, en definitiva, d'entendre la impugnació des de dues perspectives diferents: "L'aspecte objectiu contemplat des del punt de vista de l'ordenació» i «l'aspecte subjectiu contemplat des del punt de vista de l'accionista" (RUBIO, J., Curso..., op. cit., pàg. 181-182, amb referència a les "bases essencials de la societat», que "es tradueixen en projectar-se sobre un subjecte que té interès en el seu compliment en els anomenats drets individuals d'aquest legitimant-lo per al seu compliment».

${ }^{128}$ SÁNCHEZ RUIZ, M., Conflictos de intereses..., op. cit., pàg. 123-124, en relació amb els drets de minoria en general, i particularment respecte de la impugnació per la minoria dels acords del consell d'administració.

129 DuQue DomíngueZ, J. F., Tutela..., op. cit. pàg. 156-158; SORIA FERRANDO, J. V., La impugnación..., op. cit., pàg. 60-61; SÁNCHEZ RUIZ, M., Conflictos de intereses..., op. cit., pàg. 123124; BUSTILlO SAIZ, M. M., La subsanación de acuerdos..., op. cit., pàg. 207. 
fóra rellevant: sempre gaudiria de legitimació ${ }^{130}$. D'altra banda, l'àmplia atribució de legitimació uti singuli a persones diferents dels socis ${ }^{131}$ no fa sinó recordar que, al costat de l'interès de la societat i del soci, coexisteixen interessos diversos de terceres persones, igualment legítims, i que troben la seua tutela mitjançant el reconeixement d'un dret subjectiu a impugnar els acords que els siguen perjudicials.

En tot cas, la consideració de la impugnació com a dret del soci ha portat la major part dels autors que estudien la matèria a incloure-la en les diferents classificacions que es proposen. Així, quan es distingeix bàsicament entre drets polítics o administratius i drets econòmics o patrimonials ${ }^{132}$, indubtablement la impugnació s'integra entre els primers ${ }^{133}$; altres vegades, però, passa a formar part d'una categoria diferent, la dels anomenats drets de control ${ }^{134}$.

130 Alborch BATAlleR, C., El derecho de voto..., op. cit., pàg. 127; Bustillo SAIZ, M. M., La subsanación de acuerdos..., op. cit., pàg. 212-213; DUQUE DOMf́NGUEZ, J. F., Tutela..., op. cit. pàg. 157; SORIA FERRANDO, J. V., La impugnación..., op. cit., pàg. 43, 44 i 58.

${ }^{131}$ Vegeu en el capítol quart, dedicat a la legitimació, l'extensa gamma de persones no sòcies a les quals, en la cooperativa, se'ls reconeix legitimació per a la impugnació: administradors no socis, però també interventors no socis (LCoop), els liquidadors no socis (LCoop) i, en general, qualsevol tercer amb interès legítim, entre els quals poden comptar-se els exsocis; els socis $i$ associats de les cooperatives sòcies $\mathrm{i}$ altres persones jurídiques sòcies; els treballadors; la direcció i altres càrrecs similars; els creditors; els obligacionistes; el comissari del sindicat d'obligacionistes; i les entitats associatives a què pertanya la cooperativa.

${ }^{132}$ GIRÓN TENA, J., Derecho de sociedades anónimas, op. cit., pàg. 178: «S'hi tracta de portar el contingut de la posició de soci a la part general del dret civil, que s'ocupa de caracteritzar els tipus de drets subjectius; allà es distingeixen entre drets de caràcter personal i de caràcter patrimonial; a aquells s'assignen, per regla general, les notes d'intransmissibilitat, no susceptibles d'estimació econòmica ni d'adquisició o pèrdua per usucapió o prescripció; els d'índole patrimonial tenen les notes contràries». RUBIO, J., Curso..., op. cit., pàg. 330-331, també recull aquesta classificació doctrinal bàsica, si bé s'estima més "parlar de drets materials i de drets instrumentals».

${ }^{13}$ SCHRIEVER, Olav, "Membership in a registered cooperative society and the of this resulting legal relationship between the registered cooperative society and its members", Boletin de la Asociación Internacional de Derecho Cooperativo, núm. 29, 1995, pàg. 245; ULMER, P., Principios fundamentales..., op. cit., pàg. 75.

${ }^{134}$ DUQUE DOMf́NGUEZ, J. F., «Introducción a la protección...», op. cit., pàg. 75-81; GROSSO, P., I controlli interni..., op. cit., pàg. 6-7, nota 8 , inclou la impugnació d'acords socials entre els controls interns "successius» (aquells que es donen quan l'acte és jurídicament perfecte i eficaç), davant els controls interns "preventius». 
Respecte dels drets del soci, la doctrina ha analitzat una qüestió que presenta un interès indubtable en relació amb la impugnació: la possibilitat o no del seu desplegament estatutari. Penseu, per exemple, en la possibilitat de regular estatutàriament la impugnació d'acords i declaracions de voluntat d'òrgans socials respecte dels quals l'ordenament jurídic no es manifesta. Sense perjudici del seu desenvolupament posterior (vegeu l'epígraf 3.3. d'aquest capítol), poden avançar-se'n ara alguns trets, incidint en la perspectiva subjectiva que ofereix la impugnació com a dret/potestat.

D'entrada, tant la LCoop (article 16.1) com la LCCV (article 20, i) preveuen que els estatuts puguen establir drets en favor dels socis; qüestió diferent serà la possibilitat de modificar aquells que se'ls hagen atribuït legalment. És indubtable que les clàusules estatutàries no podran suprimir o disminuir el contingut d'aquests drets, o agreujar-ne l'exercici exigint condicions o requisits no posats en la norma legal ${ }^{135}$, però suscita dubtes la possibilitat d'ampliar el seu "contingut mínim legal".

En aquests supòsits, s'ha manifestat que caldrà atendre la compatibilitat de la millora estatutària que es pretenga amb els principis que configuren el tipus social, així com amb el respecte al nucli essencial del dret ${ }^{136}$. En efecte, s'ha de tenir present, a l'hora del seu desenvolupament estatutari eventual, que estem davant del que s'ha qualificat com a "drets individuals irrenunciables que no poden ser eliminats per la via d'un acord majoritari, però que, a més, no entren en l'esfera de disposició de l'accionista, en la mesura que no es donen en el seu

\footnotetext{
${ }^{135}$ GOMEZ ORBANEJA, E., «El proceso de impugnación...», op. cit., pàg. 127: «El dret d'impugnació és irrenunciable $i$ indisponible. [...] Els estatuts no poden ni suprimir ni limitar el dret d'impugnar. Tampoc sotmetre'l a uns terminis de caducitat diferents dels assenyalats per la llei. Sobre seu no és possible ni transacció ni compromís».

${ }^{136}$ DUQUE DOMÍNGUEZ, J. F., «Introducción a la protección...», op. cit., pàg. 78 i 88. EMBID IRUJO, J. M. i MARTíNEZ SANZ, F., "Libertad de configuración...», op. cit., pàg. 15; RUBIO, J., Curso..., op.
cit., pàg. $175-185$ i en pàg. 246.
} 
interès exclusiu, sinó per protegir, simultàniament, un interès propi i l'interès social $^{1.37}$.

Un desenvolupament estatutari eventual del dret d'impugnació de declaracions de voluntat de la cooperativa hauria de tenir presents, doncs, el respecte al contingut actual del dret en l'ordenament jurídic, als principis que configuren la cooperativa i al caràcter simultani de dret irrenunciable i de potestat.

\subsection{La impugnació com a instrument de tutela d'interessos generals}

Com hem vist, en ampliar-se la noció d'interès social alguns autors han proposat la inclusió, entre els diversos interessos que integren el contracte social, d'alguns diferents als dels socis. Aquestes propostes poden servir per sostenir que la impugnació d'acords socials tendeix a la protecció d'interessos que poden estar qualificats de generals, en la mesura que transcendeixen l'àmbit mateix de la persona jurídica. D'una banda, s'ha apuntat l'interès en el "manteniment de la legalitat vigent"; d'una altra, s'indica la defensa dels interessos de persones legítimament interessades que, si no foren protegits, deixarien aquestes persones en una situació $\mathrm{d}^{\prime}$ indefensió ${ }^{138}$.

${ }^{137}$ DUQUE DOMf́NGUEZ, J. F., «Introducción a la protección...», op. cit., pàg. 80: "Són drets funció -com el vot- per la qual cosa no són renunciables, encara que, naturalment l'accionista pot deixar d'exercitar-los». La categoria de drets irrenunciables, ja s'esmenta, entre els drets individuals inderogables, per GIRÓN TENA, J., Derecho de sociedades anónimas, op. cit., pàg. 181-185, que qualifica expressament el dret a la impugnació d'acords com a tal dret irrenunciable: "Serien d'aquest gènere els que es concedeixen per la llei a virtut d'una norma donada en interès general de la societat, o és essencial en l'arquitectura legislativa del tipus social creat per la Llei». També qualifiquen la impugnació de dret subjectiu indisponible, GIMENO SENDRA, J. V., El proceso..., op. cit., pàg. 22; o de dret mínim i inderogable, URfA, R., MENÉNDEZ, A. i MUÑOZ, J. M., La junta..., pàg. 313. SÁNCHEZ RUIZ, M., Conflictos de intereses..., op. cit., pàg. 91-92, distingeix entre els drets
inderogables per decisió exclusiva de la majoria (límit al principi majoritari) i els drets
irrenunciables irrenunciables, indisponibles fins $\mathrm{i}$ tot pel seu titular, sense perjudici d'una eventual renúncia concreta al seu exercici (límit al principi d'autonomia de la voluntat). Aquests últims han d'estar establerts pel legislador amb caràcter imperatiu.

138

ALONSO LEDESMA, C., "Algunas consideraciones sobre...», op. cit., pàg. 41: «Es dóna una penetració d'interessos que no són exclusivament els dels socis (nota 29: "[...] existència, al costat de l'interès individual dels socis, d'altres interessos de naturalesa heterogènia com són els 
No hi ha dubte que el legislador instaura el procediment d'impugnació en favor del respecte a la vigència de l'ordenament jurídic ${ }^{139}$. Són manifestació de la seua defensa les normes que declaren la nul-litat dels acords contraris a la llei en general i a l'ordre públic en particular. Però també ho és la impugnabilitat de la vulneració de normes estatutàries, com a expressió del principi jurídic d'autoorganització de la persona jurídica privada.

D'altra banda, la protecció d'interessos públics o particulars diferents als dels socis (creditors, treballadors, "inversors", usuaris/consumidors...) també són assenyalats per la doctrina com a part del fonament de la impugnació ${ }^{140}, \mathrm{i}$

dels treballadors, consumidors, proveïdors, creditors $i$ inversors $i$, fins i tot els de la col-lectivitat total, atesa la transcendència de l'esmentada activitat empresarial per al desenvolupament de l'economia nacional. Interessos que, òbviament, no poden quedar ignorats perquè són, igual com el dels socis, dignes de tutela; i que, en definitiva, posen en relleu, com encertadament ha estat assenyalat "en quina mesura la gran empresa ha deixat de ser un assumpte privat i per què el seu manteniment o eventual desaparició transcendeixen de l'esfera purament individual dels socis". FERNÁNDEZ DE LA GÁNDARA, Luis, La atipicidad en derecho de sociedades, Pórtico, Saragossa, 1977, pàg. 41)».

En contra, ALFARO ÁGUILA-REAL, J., Interés social y..., op. cit., pàg. 53: «Sent obvi que els interessos de treballadors, consumidors i tercers en general han de ser protegits i sent igualment obvi que l'Estat ha d'establir els instruments jurídics que permeten la defensa d'aquests interessos i el control de l'activitat econòmica dels particulars [...] no hi ha bones raons ni de política jurídica ni de lege lata per afirmar que la tasca corresponga al dret de societats. Correspon [...] a altres sectors del dret».

${ }^{139}$ ARROYO, I., "Comentario al art. 56...», op. cit., pàg. 606; BUSTILlO SAIZ, M. M., La subsanación de acuerdos..., op. cit., pàg. 204, nota 130; DIAZ DE LEZCANO SEVILLANO, N., Los acuerdos del consejo..., op. cit., pàg. 201; SALELLES ClIMENT, J. R., El funcionamiento..., op. cit., pàg. 374-375; SÁNCHEZ RUIZ, M., "Capítulo Sexto...», op. cit., pág. 222; i SORIA FERRANDO, J. V., La impugnación..., op. cit., pàg. 65 .

${ }^{140}$ EMBID IRUJO, J. M., «Notas sobre la impugnación...», op. cit., pàg. 51-52. ALCALÁ DíAZ, M. Á., "El conflicto de interés socio-sociedad en las sociedades de capital», RdS, núm. 9, 1997, pàg. 123, nega que la lesió de determinats interessos, «com el dels treballadors protegits a través de normes que afecten l'estructura societària imposant determinades formes de participació en els òrgans com la cogestió o la vulneració de preceptes dictats en protecció dels inversors", puguen integrar-se en el concepte d'interès social utilitzat, concretament, en la causa d'anul-labilitat per conflicte d'interessos, que entén vinculada a la protecció de la minoria de socis i al sistema de relacions majories-minories. Estima que «la protecció d'aquests interessos i la seua transcendència en el marc del poder de decisió de la majoria ha de situar-se en les causes de nul-litat dels acords dels òrgans socials per contravenció de l'ordre públic, en funció de la seua vinculació a aspectes reguladors del mercat $i$, per tant, a aspectes imperatius $i$ inderogables per voluntat privada".

En contra de la inclusió en la noció d'interès social de la tutela dels interessos de treballadors o creditors, JAEGER, P. G., L'interesse sociale rivisitato... , op. cit., pàg. 799/I, per considerar-los subjectes en conflicte d'interessos amb els accionistes; i ALFARO AGUILA-REAL, J., Interés social y..., op. cit., pàg. 66-67. 
arriben a materialitzar-se en la norma legal. En efecte, es protegeixen els interessos de tercers quan se'ls atribueix legitimació per a la impugnació, i quan s'expressa la inefectivitat de la sentència que estime la impugnació davant dels drets adquirits per tercers de bona $\mathrm{fe}^{141}$. La protecció dels interessos legítims de tercers és ací també protecció a la seguretat jurídica i del tràfic empresarial ${ }^{142} \mathrm{i} a$ la bona fe. En tot cas, entenem que la defensa de la seguretat del tràfic mercantil no ha d'identificar-se unívocament amb la tendència al manteniment dels acords adoptats per garantir l'estabilitat; en realitat, la defensa dels interessos i de les expectatives dels socis minoritaris i dels tercers també contribueix a generar seguretat, sobretot en persones jurídiques que, com les cooperatives, basen el compliment de la seua finalitat social en la participació directa dels socis i en la incorporació massiva de persones interessades. Una via per oferir als candidats a socis seguretat i estabilitat de l'activitat empresarial és simplificar i agilitar els procediments, alhora que dotar-los d'instruments que permeten la publicitat, la transparència i la garantia dels drets de les parts.

En relació amb la defensa d'interessos públics ja s'ha referit com, en l'àmbit de les societats mercantils, precisament en aquelles que representen més bé la gran societat capitalista, s'observen elements institucionals ${ }^{143}$. Així es poden qualificar, per exemple, la legitimació en favor del Banc d'Espanya o de la Comissió Nacional del Mercat de Valors per a la impugnació de determinats acords de les societats anònimes de crèdit $o$ de les societats cotitzades ${ }^{144}$. I també pot

${ }^{111}$ URIA, R., MENÉNDEZ, A, i MUÑOZ, J. M., La junta..., pàg. 343-347.

${ }^{112}$ ALCALÁ DIAZZ, M. Á., La impugnación..., op. cit., pàg. 174-177. També incideixen a considerar la Seguretat jurídica i del tràfic mercantil com a finalitat de la impugnació d'acords socials crítico..., op. cit., pàg. 606-607.

${ }^{113}$ ALCALÁ DÍAZ, M. Á., «El conflicto...», op. cit., pàg. 123; AlONSO LEDESMA, C., «Algunas consideraciones sobre ...», op. cit., pàg. 41.

${ }^{14}$ SALELLES CLIMENT, J. R., El funcionamiento..., op. cit., pàg. 378-379, esmenta aquests supòsits: legitimació del Banc d'Espanya per impugnar els acords socials de les societats anònimes de crèdit (disp. ad. 2a de la Llei sobre disciplina i intervenció de les entitats de crèdit de 29 de juliol de 1988) i de la CNMV per impugnar els acords adoptats amb accions que representen una participació significativa en el capital i les adquirides sense l'oferta pública preceptiva (article 
considerar-se ampliat el concepte d'interès social mitjançant la introducció $d^{\prime}$ instruments com l'OPA, que atenen els interessos dels futurs socis ${ }^{145}$. Com s'ha dit, hi ha en el dret mercantil un interès general públic més intens que en altres sectors del dret privat, ja que els efectes de l'actuació de les seues institucions transcendeix habitualment l'interès privat dels seus membres ${ }^{146}$.

En les cooperatives, la coexistència de la defensa d'interessos públics i socials que transcendeixen l'estricta defensa dels interessos juridicoprivats dels socis $\mathrm{i}$ de la persona jurídica mateixa sempre ha estat patent ${ }^{147}$. Precisament, el que ha estat rectament criticable i criticat en el passat ha estat l'establiment de pretesos mecanismes de control del compliment d'aquests interessos, que en realitat suposaven una ingerència del poder polític, una via de control ideològic sobre les cooperatives. Afortunadament, com veurem més endavant, amb la instauració a l'Estat espanyol de la Constitució del 1978, mentre s'eleva a rang constitucional la declaració de l'existència d'un interès general en el foment de les cooperatives (article 129.2 CE), en la reforma subsegüent de la legislació cooperativa es tendeix a reduir als termes justos els mecanismes d'intervenció pública $^{148}$.

60.3 de la Llei del mercat de valors de 28 de juliol de 1988), considerant-los com una manifestació particular de la legitimació a favor de qualsevol tercer que tinga un interès legítim. ${ }^{145}$ JAEGER, P. G., L'interesse sociale rivisitato... , op. cit., pàg. 796, 801, 805 i 806.

${ }^{146}$ GADEA, Enrique, Evolución de la legislación cooperativa en España, Consejo Superior de Cooperativas de Euskadi, Vitòria, 1999, pàg. 161-162: «L'Estat va influint, cada vegada més penetrantment, sobre el curs dels esdeveniments econòmics, a fi de corregir, amb la seua acció,
les consequències injustes a què conduüa el funcionament autònom del mercat».

${ }^{147}$ OFICINA INTERNACIONAL DEL TREBALL, Conferència internacional del treball, 89ena reunió..., op. cit., pàg. 69: «Malgrat que, per la seua orientació especial, les cooperatives es dirigeixen a promoure els interessos dels seus socis, també tenen repercussions indirectes i positives en el públic en general. Per exemple, les cooperatives de consumidors fixen normes per a la protecció del consumidor (Migros i Coop a Suissa) i per a la protecció del medi ambient (les cooperatives de consumidors del Japó, pioneres en el reciclatge de residus, la utilització de furgonetes per a subministrament elèctric en ciutats congestionades i cooperatives agrícoles especialitzades en l'agricultura biològica). Les cooperatives de l'habitatge fixen també normes de caràcter general per als habitatges socials, les cooperatives de treballadors creen ocupació $i$ els bancs cooperatius faciliten l'accés de les persones de pocs recursos als serveis bancaris de la localitat».

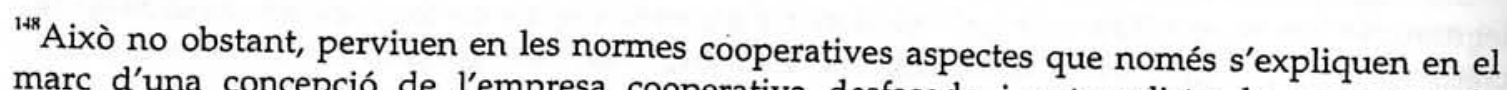
marc d'una concepció de l'empresa cooperativa desfasada i paternalista: la necessitat de qualificació prèvia de la constitució de la cooperativa, així com de les modificacions estatutàries 
En tot cas, els interessos públics presents en l'activitat de les cooperatives també poden ser defensats mitjançant la impugnació dels seus acords: penseu, per exemple, en les situacions en què les cooperatives siguen receptores d'ajuts públics o beneficis fiscals, o siguen objecte de polítiques de foment, com ara les que es deriven, en alguns casos, de la seua qualitat d'entitats aplicadores de la política agrària comuna de la Unió Europea, de promotores d'habitatges de protecció oficial o d'adjudicatàries de contractes d'obres o serveis de les administracions públiques.

Concloent $\mathrm{amb}$ aquest recorregut per la diversitat de propostes que sobre el fonament jurídic de la impugnació d'acords socials ha plantejat la doctrina, hem d'intentar una síntesi dels seus aspectes que poden tenir sentit en l'àmbit de les cooperatives.

En primer lloc, sembla que s'ha d'acceptar, si més no, que amb la impugnació el legislador intenta tutelar diversos interessos ${ }^{149}$ que considera mereixedors de protecció. Entre aquests, és bàsic el respecte al principi de legalitat, com a límit

i estructurals de la cooperativa, per part del Registre de Cooperatives, que continua depenent del Ministeri o de l'òrgan autonòmic competent en matèria de treball, n'és una de les mostres més evidents, però no l'única. La intervenció pública en el funcionament intern de la cooperativa té altres manifestacions en els textos legals que no es justifiquen amb l'estricta defensa dels interessos públics de foment del cooperativisme i d'utilització d'aquesta forma empresarial com a instrument d'aplicació de polítiques socials: així, l'establiment d'un sistema d'inspecció i sanció especial per a les cooperatives, que pot acabar amb la seua desqualificació (articles 113-116 LCoop i 106-108 LCCV); les figures de la intervenció temporal (article 109 LCCV), o de la intervenció de la liquidació (article 72 LCoop).

149 ALCALÁ DIAZ, M. Á., La impugnación..., op. cit., pàg. 167: «La impugnació dels acords constitueix un instrument al servei de la protecció de diferents interessos que s'emmarquen, en uns casos, en el conjunt de relacions jurídiques derivat del contracte de societat i en altres, en les relacions externes creades com a conseqüència del funcionament en el tràfic econòmic de l'organització societària»; RODRÍGUEZ RUIZ DE VILLA, Daniel, Impugnación de acuerdos de las juntas de accionistas. Legislación, doctrina y jurisprudencia según el nuevo texto refundido de la Ley de sociedades anónimas, Pamplona, Aranzadi, 1992, pàg. 20: «Cal, per tant, establir, com assenyalen Fernando RoDrígUEZ ARTIGUESi Jesús QUIJANO GONZÁLEZ (Vid. [...],«El nuevo derecho de las sociedades de capital», sota la direcció d'Ignacio QUINTANA CARLO, pàg. 164, Editorial Trivium, SA, 1990), una coordinació entre l'estabilitat dels acords de la junta, adoptats a través d'un procediment llarg, complicat i costós i el manteniment del qual pot ser imprescindible per a la bona marxa de la societat, amb la necessària protecció dels diversos interessos afectats per aquests acords quan no es respecten les normes sobre la seua validesa, establertes, precisament per protegir aquests interessos». 
al d'autonomia privada de la voluntat: els acords socials mitjançant els quals la persona jurídica s'autoorganitza en la seua esfera de lliure determinació no poden contradir l'ordenament jurídic vigent. Si això es produeix, la impugnació facilitarà el procediment per al restabliment de la legalitat. La defensa de l'ordenació constitucional és la que fonamenta la impugnació dels acords que vulneren la legalitat vigent $\mathrm{i}$ els interessos públics.

D'altra banda, també es tutela l'interès social o, més ben dit, els interessos que, integrats en el contracte social, poden ser considerats socials. Ja hem vist com l'interès que porta el soci a ingressar en la cooperativa no és un ànim de lucre directe, sinó la satisfacció de necessitats mitjançant l'ajuda mútua ${ }^{150}$. Però també $s^{\prime}$ han de considerar altres interessos socials: l'interès a la realització de l'objecte social de manera mutualista, i l'interès al manteniment de la cooperativa mitjançant la creació d'un patrimoni comú.

Finalment, es protegeixen interessos legítims de terceres persones: treballadors, creditors, consumidors i usuaris, inversors... El fonament de la seua protecció es pot reconduir, tant a la defensa d'interessos generals presents en l'ordenament jurídic, com a la de l'interès social: d'una banda, s'observa la tendència legislativa general a la restricció de l'autonomia contractual en favor de la protecció necessària dels qui quedarien, en cas contrari, en situació $d^{\prime}$ indefensió ${ }^{151}$; d'una altra, la garantia de la seguretat jurídica en general i la del tràfic empresarial en particular, que ja no pot entendre's protegida exclusivament mitjançant una defensa a ultrança del principi de manteniment de les decisions socials, sinó amb l'establiment de procediments de revisió àgils, segurs i transparents.

\footnotetext{
${ }^{150} \mathrm{Amb}$ el seu ingrés en l'estructura cooperativa, el soci assoleix una economia d'escala a la qual no tindria accés d'una altra manera, i ho fa, no solament mitjançant l'aportació d'un capital del qual moltes vegades no disposarà en quantitats importants, sinó també mitjançant l'aportació de la seua participació directa. El soci cooperador no persegueix (almenys, no directament) invertir un capital per obtenir la rendibilitat òptima, sinó resoldre les seues necessitats (de d'accés al de serveis, de subministrament de productes, d'obtenció d'un lloc de treball estable, d'accés al crèdit o a l'habitatge... etc.) en canvi de la seua col-laboració personal.
} 


\section{Normes reguladores de la impugnació d'acords de la cooperativa}

Com hem assenyalat en la Introducció, la diversitat de normes reguladores del fenomen cooperatiu i, per tant, de la impugnació de les seues declaracions de voluntat o de coneixement, en condiciona inevitablement la configuració i l'aplicació. S'ha d'atendre, doncs, amb caràcter previ a l'anàlisi de la institució, el seu marc normatiu regulador.

Les societats cooperatives apareixen a Europa entre les últimes dècades del segle $X V I^{152}$ i la primera meitat del segle XIX, com a resposta de les classes treballadores davant de la crítica situació econòmica i social. Intenten amb aquestes accedir directament a la propietat dels mitjans de producció $\mathrm{i}$ als béns $\mathrm{i}$ serveis de consum, mitjançant l'ajuda mútua ${ }^{153}$. Es tracta d'un moviment social que no pot ubicar-se en un moment i un lloc concrets, sinó que s'estén per tot Europa, amb diferents especificitats i tipus ${ }^{154}$. Com és natural, només posteriorment se'n planteja des dels poders legislatius la regulació jurídica ${ }^{155}$.

${ }^{151}$ DUQUE DOMÍNGUEZ, J. F., «Introducción a la protección...», op. cit., pàg. 85.

${ }^{152}$ MONTOLfo HERNÁNDEZ, J. M., Legislación cooperativa en la Comunidad europea, op. cit., pàg. 443.

${ }^{150}$ ARANZADI TELLERIA, D., "Orígenes históricos y asentamientos ideológicos del asociacionismo socioeconómico», en AA. DD., Congreso de cooperativismo, Departamento de publicaciones de la Universidad de Deusto, Bilbao, 1988, pàg. 94-97.

${ }^{154}$ Vegeu ALONSO PÉREZ, Matilde, «El cooperativismo valenciano: desde sus inicios hasta la Ley de 1974», CIRIEC-España, núm. 11, octubre, 1991, pàg. 53-68, on s'analitza la clàssica divisió del moviment cooperatiu en dos corrents importants: «l'un afecta els partits i sindicats d'esquerres, amb base en les cooperatives de producció $i$ consum, una altre patrocinat per grups catòlics amb orientació cap al camp». També poden veure's desenvolupaments històrics del moviment General en AA. DD., Manual de derecho cooperativo. Adaptado a la Ley 3/1987 de 2 de abril, redactal de Cooperativas, (dir. B. Pendás Díaz), Editorial Praxis, Barcelona, 1987, pàg. 3-23, cap. 1, Valenciò, Eer PRIETO GUTIÉRREZ, G.; ÁlVAREZ RUBIO, Amparo, Història del cooperativisme al País cooperativo itorial Lavinia, Barcelona, 1968; BORJABAD GONZALO, Primitiu J., Manual de derecho extensa relació y catalán, 2a ed., J. M. Bosch Editor, Barcelona, 1993, pàg. 15-20, amb una 
La legislació cooperativa en dret comparat europeu ${ }^{156}$ presenta, històricament i en l'actualitat, una varietat que $s^{\prime}$ ha justificat amb les diverses bases jurídiques en què a cada estat es funda l'ordenament jurídic en general (dret codificat o common law $w^{157}$ ) i el dret de societats en particular, bases a les quals s'ha remès, en tot o en part, la disciplina de les cooperatives ${ }^{158}$.

Una classificació bàsica de les diferents opcions legislatives pot fer-se distingint entre les que es decanten per una regulació sui generis de la cooperativa (és el cas d'Alemanya, Espanya i Portugal) i les que consideren que els seus trets definitoris poden organitzar-se sense necessitat d'elaborar normes especials completes, reconduint el seu procés de formació i el seu funcionament en

Derecho de sociedades, tom I, pàg. 97-101; KELLNER, Herbert, "La specifité et la realité socioéconomique du secteur cooperatif dans la Communauté Éuropéene», Congreso de Cooperativismo, Universidad de Deusto, 1988, pàg. 302-303; LlobreGAT HURTADO, M. L., Mutualidad y..., op. cit., pàg. 1-20; MONTOLf́O HERNÁNDEZ, J. M., Legislación cooperativa en la Comunidad europea, op. cit.; REVENTÓS CARNER, Joan, El movimiento cooperativo en España, Ariel, Barcelona, 1960.

155 VICENT CHULIÁ, Francisco, «El accidentado desarrollo de nuestra legislación cooperativa», RJC, 1979 (4), pàg. 869 i següents; i en Estudios de derecho mercantil en homenaje al profesor Antonio
Polo, Madrid, 1981, pàg. 1222.

${ }^{156}$ Per motius d'acotació de l'objecte d'estudi, ens centrem en l'àmbit europeu. Per a una anàlisi recent de la legislació cooperativa a escala internacional vegeu OFICINA INTERNACIONAL DEL TREBALL, Conferència internacional del treball, 89a reunió, 2001. Informe V. Promoció de les cooperatives, Ginebra 2001, així com l'adreça electrònica de l'Aliança Cooperativa Internacional:

17 SALAZAR LeITE, João, "Sobre o Código cooperativo e da necessidade da sua revisão», Anuario de estudios cooperativos 1992, Instituto de Estudios Cooperativos, Universidad de Deusto, Bilbao,
1993, pàg. 164 i 165.

${ }^{15}$ BONFANTE, G., Imprese cooperative..., op. cit., pàg. 562-563; DARBÓMIDA, Renato, «Derecho cooperativo europeo y ordenamiento comunitario: ¿Hacia la armonización o la uniformación de las legislaciones en el seno de la C.E.E.?», Revista Ciriec-España núm. 7, junio-septiembre 1989 DíVAR, Javier, "El derecho comparado cooperativo en Europa», Anuario de estudios cooperativos 1988, Instituto de Estudios Cooperativos, Universidad de Deusto, Bilbao, 1988, pàg. 111; GIRÓN TENA, J., Derecho de sociedades, tom I, pàg. 97-98; SUSO VIDAL, José M., "Algunas notas sobre la armonización del derecho de sociedades cooperativas en la Comunidad Económica Europea", Congreso de Cooperativismo, Universidad de Deusto, 1988, pàg. 319-324, que, això no obstant, reconeix que «també seria faltar a la veritat no destacar que, al costat de la lògica existència traquests punts de desconnexió, s'adverteixen solucions en les quals només matisos de detall quen unes tendències normatives que guarden un cert paral-lelisme». 
l'adopció de les formes tradicionals de les persones jurídiques, en la majoria dels casos a les de les societats mercantils (França, Itàlia) ${ }^{159}$.

Aquestes opcions responen, amb matisos, a dues concepcions diferents de la legislació cooperativa: una concepció minimalista i una maximalista. Segons la que alguns autors qualifiquen com a minimalista, la llei, que no necessàriament ha de ser específicament cooperativa, ha de limitar-se a fixar regles d'organització clares i pràctiques, preferiblement amb l'assentiment de les persones interessades, ja que constitueix "una caixa d'eines de la qual cada cooperativa en pot traure les que s'adapten més a les exigències particulars de la seua gestióm ${ }^{160}$. Al contrari, la concepció maximalista de la legislació cooperativa reclama que aquesta traduïsca a dret positiu els valors i principis cooperatius en resposta a una doble exigència, la del moviment cooperatiu que reclama l'especificitat legislativa, i la demanda de control per part de l'Estat per garantir que el reconeixement d'aquesta especificitat (i els avantatges aparellats: beneficis fiscals, mesures de foment...) no siga indegudament utilitzat ${ }^{161}$.

Utilitzant altres paràmetres, s'han distingit quatre models juridicocooperatius en l'àmbit europeu: el mutualista (França, Itàlia, Bèlgica), en el qual s'exalta la gestió mutualista de l'activitat amb els socis i per als socis, i es destaca el principi de la doble qualitat del soci i consumidor/destinatari de l'activitat; el model economicista (Alemanya, Holanda, Dinamarca, Suïssa, Àustria, Finlàndia,

${ }^{159}$ GIRÓN TENA, J., Derecho de sociedades, tom I, pàg. 101-102: «La susceptibilitat d'independència
de les cooperatives com a tipus, planteja el problema de si han de subsistir només quan
serveixen a la cooperació o independentment d'això, cas en què seria el tracte de favor de l'Estat
(fiscal, administratiu, social) l'únic que dependria d'aquell ligament».

${ }^{1611}$ WORMS, esmentat per LÉVESQUE, Benoît i CÔTÉ, Daniel, «La renovación de las legislaciones metodología” la cooperación en el momento de la mundialización: la búsqueda de una ZEVI, A. ogía", en AA. DD., Cooperativas, mercado, principios cooperativos (dirs. MONZÓN, J. L., i ZEVI, A.), Ciriec-España, València, 1994, pàg. 10-11. conseqüèneratives tenen una estructura particular, que no està disponible a voluntat. $\mathrm{Si}$, en que una llei la llibertat de redactar els estatuts inclou la d'eixir del concepte de base, jo diria allemande de trim. 1992 de 1973 et la question des sociétaires non coopérateurs», RECMA, núms. 44-45, 4t 12). 
Suècia), en les ordenacions del qual es fixa que la finalitat de les cooperatives consisteix a afavorir i promoure les economies individuals dels socis ${ }^{162}$; el sociològic (Espanya, Portugal), basat en la caracterització de les cooperatives com a expressió d'una categoria de persones que tenen les mateixes necessitats econòmiques, a la satisfacció de les quals es dirigeix l'activitat empresarial cooperativa, i el neutre o anglosaxó (Gran Bretanya, Irlanda) que, encara que presenta, en abstracte, semblances amb tots els models anteriors, no pot si més no de qualificar-se com a peculiar, tant per la seua formulació com per la seua aplicació $^{163}$.

Els trets peculiars $i$ les afinitats que presenten les normes cooperatives europees són elements que ajuden a entendre millor les característiques de la legislació cooperativa vigent a l'Estat espanyol. Farem per això un breu resum del que, al nostre parer, representen millor els diferents models normatius $i$ les diverses tradicions cooperatives, sempre des de la perspectiva de l'organització estructural de la cooperativa, en general, i de la regulació, si escau, de la impugnació d'acords.

\subsection{El dret cooperatiu europeu}

${ }_{1 / 2}^{1 / 2}$ MÜNKNER, Hans-H, «Panorama d'une économie sociale qui ne se reconnaît pas comme telle: le cas de l'Allemagne", RECMA, núms. 44-45, 4t trim. 1992/1r trim. 1993, pàg. 112-115.

${ }^{163}$ DARBÓMIDA, R., "Derecho cooperativo europeo...», op. cit., pàg. 11-41, seguint VERRUCOLI, P. "Società cooperative. Diritto straniero i comparato», en Enciclopèdia Giuridica, Treccani, XXXIX, Roma, 1993; també en DARBÓMIDA, Renato, «Evoluzione dei principi e dei diritto cooperativo: dall'utopia ad imprenditoria del futuro", en Anuario de estudios cooperativos 1988, Instituto de Estudios Cooperativos, Universidad de Deusto, Bilbao, 1988, pàg. 97-99, on apunta dos models més, ja a escala internacional: el de les aleshores "economies planificades" $\mathrm{i}$ el dels "països en via de desenvolupament africans i asiàtics». PANIAGUA ZURERA, Manuel, Mutualidad y lucro en la sociedad cooperativa , McGraw Hill, Madrid, 1997, pàg. 95-102, parteix de la classificació de Dabórmida per sotmetre-la a crítica i manifestar la seua preferència per una classificació bàsica entre la "cooperació funcional o economicista» i la "concepció classista» de la cooperació.

Altres classificacions dels diferents tipus de lleis cooperatives poden veure's en NAMORADO, Rui, Introdução ao direito cooperativo, Livraria Almedina, Coimbra, 2000, pàg. 26-33. 
Un dels moviments cooperatius europeus amb més tradició i consolidació és l'alemany, les notables peculiaritats del qual s'han vist reflectides en les opcions legislatives corresponents ${ }^{164}$. En efecte, el dret cooperatiu alemany es caracteritza per dotar les cooperatives d'una regulació pròpia, sobre la base de la seua identitat peculiar, sense que això signifique la desvinculació del sistema institucional de les persones jurídiques en conjunt sinó, ben al contrari, el seu encastament en aquell des del reconeixement de la seua especificitat ${ }^{165}$. La llei de cooperatives de 1889 (Gesetz betreffend die Erwerbs und Wirtschaftsgenossenschaften) que, després d'actualitzacions successives, es manté en vigor ${ }^{166}$, defineix les cooperatives com a "societats que no estan subjectes a un nombre fix de socis i tenen per objecte facilitar-los la producció o el consum per mitjà d'una activitat econòmica desenvolupada en comú" ${ }^{167}$. El seu règim jurídic és, bàsicament, el contingut en l'esmentada $l \mathrm{li}^{168}$, que en alguns dels

${ }^{16}$ BOTTERI, Tullio, «La normativa delle cooperative nella legislazione della Repubblica Federale Tedesca", Riv. coop., abril-junio 1980, pàg. 87.

${ }^{115}$ DfVAR, J., "El derecho comparado...», op. cit., pàg. 117: «Partint del reconeixement que el Codi de comerç fa de les cooperatives com a comerciants (article 17-2), és a dir com a entitats mercantils, la legislació especial dota les cooperatives de la naturalesa jurídica de "societats mercantils especials"». MÜNKNER, Hans-H., "Ley de cooperativas en la República Federal Alemana", Revista CIRIEC-España, núm. 7, juny-setembre 1989, pàg. 99 arriba a afirmar que "el model legal de societat cooperativa pot ser definit com una barreja d'associació i societat»; i en "Panorama d'une économie sociale...", op. cit., pàg. 114, que "a Alemanya, les cooperatives hi són segons la seua tradició, segons la seua estructura i segons el dret cooperatiu un tipus
particular d'associació amb finalitat econòmica (Wirtschaftsverein)».

${ }^{166}$ MONTOLIO HERNÁNDEZ, J. M., Legislación cooperativa en la Comunidad europea..., op. cit., pàg. 1153 i 507-549, recull el text actualitzat de la llei, i les referències a les modificacions més rellevants de què ha estat objecte la llei, entre les quals es pot destacar, en la matèria que ens ocupa, la produïda el 1889, per la qual es va establir un òrgan intern de fiscalització com a tercer òrgan social obligatori i la intervenció externa, i el reconeixement de la possibilitat d'integració en entitats de grau superior; la del 1922, en què es va produir l'admissió d'assemblees de delegats; i la del 1973, dirigida, entre altres aspectes, a incrementar les facultats de la direcció aproximantles a la legislació mercantil, i a admetre el vot plural amb subjecció a certes referències.

$$
\text { co }
$$


seus aspectes deixa traslluir una clara influència, tant de l'ordenació genèrica de les persones jurídiques, com de les concretes d'altres tipus societaris de dret privat, a les quals remet sovint. A més, s'ha indicat que algunes de les normes genèriques que, per a les associacions, estableix el Codi civil alemany $(B G B)$ són directament aplicables a les cooperatives ${ }^{169}$, així com les que el Codi de comerç alemany $(H G B)$ disposa per a qualsevol tipus societari ${ }^{170}$.

La llei té la consideració de text únic en els aspectes estrictament cooperatius, sense que haja estat desenvolupada per disposicions reglamentàries ni postergada per una eventual aplicació prioritària de la normativa sectorial ${ }^{171}$. En els altres aspectes s'aplicaran les normes de caràcter general ${ }^{172}$. D'altra banda, la llei dóna una importància essencial a l'autonomia de la voluntat, en remetre a la

persona jurídica. Quant a les cooperatives de segon grau, la majoria operen com a companyies $i$ societats de responsabilitat limitada $(\mathrm{GmbH})$. Només unes poques organitzacions d'aquest grup usen un model legal de societat cooperativa registrada $(e G)$, i en el supòsit d'alguna activitat especial, com el de les mutualitats d'assegurances, com a "associacions de mutualitats d'assegurances (VvaG)». Sobre la pluralitat de formes jurídiques utilitzades pel moviment cooperatiu alemany torna el mateix autor en «Panorama d'une économie sociale...», op. cit., pàg. 112; també es refereix a això MONTOLIO, J. M., Legislación cooperativa en la Comunidad europea..., op. cit., pàg. 26.

${ }^{169}$ Montolio, J. M., Legislación cooperativa en la Comunidad europea..., op. cit., pàg. 18, per exemple, l'obligatorietat de l'existència d'una directiva, el règim de majories per a la modificació d'estatuts, i la normativa per la qual ha de regir-se el contracte de societat.

${ }^{170}$ Montolio, J. M., Legislación cooperativa en la Comunidad europea..., op. cit., pàg. 18, per exemple, la regulació en relació amb la documentació, llibres, estats comptables, publicitat, i dotació de reserves.

${ }^{171}$ Les referències de les principals normes sectorials aplicables als bancs cooperatius, a les cooperatives d'habitatges d'interès públic $i$ a les cooperatives agrícoles que funcionen com a organitzacions de productors agraris poden veure's en MÜNKNER, H., "Ley de cooperativas...», op. cit., pàg. 94-96. Això no obstant, MoNTOLIO, J. M., Legislación cooperativa en la Comunidad europea..., op. cit., pàg. 25-26, indica que la llei no estableix classes de cooperatives en el sentit tradicional, ni règims especials: «Si fóra imposada alguna especialitat jurídica es derivarà de la regulació sectorial de l'activitat que es tracte (v.gr.: crèdit) que no de l'específicament cooperativa». En el mateix sentit, VON SPIES, F., "La legislació sobre cooperatives a Alemanya", en INSTITUT PER A LA PROMOCIÓ I LA FORMACIÓ COOPERATIVES, Legislació sobre cooperatives als Estats membres de la C.E.E, Generalitat de Catalunya, Departament de Treball, Barcelona, 1987, pàg. 9.

${ }^{172}$ PANIAGUA ZURERA, M., Mutualidad y lucro..., op. cit., pàg. 108. 
regulació estatutària la major part de les relacions societàries; en aquest sentit són mínims els continguts imperatius que seran exigits ${ }^{173}$.

L'estructura orgànica de les cooperatives alemanyes segueix l'esquema tripartit derivat del model dualista de l'administració social, propi del dret de societats germànic: a l'òrgan d'administració bàsic se n'afegeix un altre que el controla i al qual, en determinats supòsits, poden correspondre facultats que superen el mer control; tot això, sense perjudici de la revisió externa, a càrrec de l'associació d'auditoria a la qual amb caràcter obligatori ha d'estar afiliada tota cooperativa $^{174}$. Així doncs, les cooperatives han de dotar-se de tres òrgans necessaris: assemblea general (generalversammlumg) ${ }^{175}$, direcció (Vorstand) ${ }^{176} \mathrm{i}$ consell de vigilància (Aufsichtsrat) ${ }^{177}$.

${ }^{173}$ LLOBREGAT HURTADO, M. L., Mutualidad y..., op. cit., pàg. 79; BOTTERI, T., «La normativa delle cooperative...", op. cit., pàg. 99. Un exemple assenyalat, entre altres matèries confiades a l'autoregulació, és l'aspecte relatiu a l'establiment d'un règim sancionador intern, que no s'esmenta en la Llei, però que és d'incorporació usual a la regulació estatutària (MONTOLIO, J. M., Legislación cooperativa en la Comunidad europea..., op. cit., pàg. 36).

Això no obstant, també s'ha assenyalat que els principis del dret consuetudinari (igualtat de tracte als socis, deure de lleialtat dels socis cap la cooperativa i de la cooperativa als socis, i el deure de tolerància), desenvolupats per la jurisprudència i la doctrina també han de ser respectats per les normes estatutàries (SCHRIEVER, O., "Membership in a registered cooperative society...", op. cit., pàg. 244).

${ }^{174}$ BOTTERI, T., «La normativa delle cooperative...», op. cit., pàg. 91, i 97-99; MÜNKNER, H.H., "Nueva Ley cooperativa de $1973 . . . »$, op. cit., pàg. 5, i en "Panorama d'une économie sociale...», op. cit., pàg. 114. El debat sobre els avantatges i inconvenients dels dos models europeus de l'estructura de l'òrgan d'administració també s'ha estès a l'àmbit cooperatiu; així GENCO, R., "Il volto cooperativo...», op. cit., pàg. 20-21, es manifesta clarament partidari del model dualista, per considerar-lo més eficaç per al control propietari en les societats de base fraccionada, partint de la situació dels drets dels propietaris en seu d'assemblea, de la funció de representació d'aquests drets, confiada a un òrgan restringit que pot controlar millor la gestió de l'empresa, en elegir al seu torn els membres de l'òrgan de gestió.

175 DOLDE, Tobías, "The organs of the German registrated co-operative society and their functions", Boletín de la Asociación internacional de Derecho cooperativo, núm. 29, 1995, pàg. 296-
303 .

${ }^{176}$ DOLDE, T., «The organs of the German registrated co-operative society...», op. cit., pàg. 282-
291.

DOLDE, T., "The organs of the German registrated co-operative society...", op. cit., pàg. 291296; MÜNKNER, H.-H., "Ley de cooperativas...», op. cit., pàg. 106: «D'acord amb la Llei sobre la coparticipació dels treballadors d'11 d'octubre de 1952 i la Llei de cogestió de 4 de maig de 1976, d'ad societats cooperatives amb més de 500 o 2.000 empleats permanents, respectivament, han d'admetre representants, elegits entre els empleats, perquè participen en el consell de vigilància». També el mateix autor, en Co-operative principles and the national co-operative 
La llei de cooperatives alemanya regula expressament la impugnació dels acords de l'assemblea general en el $\S 51$. En virtut d'això, els socis (tant els presents en l'assemblea que feren constar en acta la seua oposició a l'acord, com els absents que no hi hagueren estat admesos sense causa justificada o la impugnació de la qual se sostinguera en el fet que l'assemblea general no haguera estat degudament convocada o que l'objecte de l'acord no haguera estat anunciat en la forma deguda) podran impugnar els acords de l'assemblea general contraris a la llei o als estatuts. També hi estan legitimats la direcció, el consell de vigilància, o qualsevol dels seus membres, si de l'execució de l'acord poguera derivar-se'n sanció o responsabilitat davant els creditors de la societat, així com, si escau, els liquidadors ${ }^{178}$. La legitimació passiva recau en la cooperativa, representada per la seua direcció, llevat que aquesta figurara com a demandant, i pel seu consell de vigilància.

Correspon el coneixement del litigi a la jurisdicció ordinària, i s'ha de donar publicitat, tant a la interposició com al resultat de la impugnació. Quan l'acord que, si escau, es declare nul, haguera estat inscrit en el Registre de Cooperatives, la decisió judicial, després d'adquirir fermesa, serà objecte d'inscripció en el Registre de Cooperatives. El § 52 estableix, a més, que "els qui sostingueren maliciosament una pretensió infundada respondran dels danys $\mathrm{i}$ perjudicis causats a l'entitat".

legislation in Germany, op. cit., pàg. 27; BONFANTE, G., Imprese cooperative..., op. cit., pàg. 562; i VON SPIES, F., "La legislació sobre cooperatives a Alemanya», op. cit., pàg. 12. Tanmateix, BOTTERI, T., "La normativa delle cooperative...", op. cit., pàg. 102, nota 12 , recull opinions doctrinals que dubten de l'aplicabilitat de la Llei de cogestió a les cooperatives. Sobre la cogestió (Mitbestimmung), com a tema especialment desenvolupat en el dret alemany de societats i la seua concreció a la integració dels representants dels treballadors al consell de vigilància, EMBID IRUJO, J. M., «Derecho europeo...», op. cit., pàg. 13-14.

DOLDE, T., "The organs of the German registrated co-operative society...», op. cit., pàg. 281, indica que, a més dels tres òrgans esmentats, és possible introduir-hi altres òrgans (\$27 II), "com per exemple un consell assessor, comitès especials, apoderats generals o particulars, etc».

${ }^{178} \S 89$ Drets i obligacions dels liquidadors. «Els liquidadors tenen els drets i obligacions que els paràgrafs $26,27,33$ apartat 3 incís $1,34,44$ a 47,48 apartat $3,51,57$ a 59 , disposen per a la
direcció...». 
Quant als acords dels òrgans d'administració, la llei de cooperatives alemanya no preveu expressament la possibilitat de la seua impugnació, per la qual cosa pot repetir-se, amb matisacions, el debat doctrinal que es desenvolupa en $l^{\prime}$ àmbit de les societats anònimes ${ }^{179}$. En efecte, en $l^{\prime} A k t G$ de 1965 es conté un règim de nul·litat $i$ anul-labilitat d'acords de la junta general ( $\S \S 241$ a 257), però no per als acords viciats de l'Aufsichtsrat i del Vorstand ${ }^{180}$. Partint d'aquesta llacuna legal, doctrina $i$ jurisprudència han defensat dues posicions ben diferenciades: d'una banda, un sector manté l'aplicació del règim sobre acords de les associacions $(\S \S 32,134 \text { i } 138 B G B)^{181}$, mentre que un altre sector proposa, en canvi, l'aplicació del règim d'impugnació d'acords de la junta general de societats anònimes ${ }^{182}$.

17\% Vegeu ALCALÁ DIAZ, M. Á, La impugnación..., op. cit., pàg. 35-43 i 176-177 (en nota 160); DÍAZ
DE LEZCANO SEVILLANO, N., Los acuerdos del consejo..., op. cit., pàg. 63-65; i SCHRIEVER, O,
"Membership in a registered cooperative society...», op. cit., pàg. 248, en relació amb la
vulneració del principi d'igualtat de tracte.

${ }^{180}$ DIAZ DE LEZCANO SEVILLANO, N., Los acuerdos del consejo..., op. cit., pàg. 62-64; en nota 127: «El silenci, en relació amb el Vorstand, es justifica perquè l'òrgan de gestió social no és un òrgan col-legiat, el legislador germànic imposa de manera general que la seua actuació siga per unanimitat»; a més, (pàg. 63), es "preveu que els estatuts socials establisquen criteris que permeten sostenir l'eficàcia de l'acord de la direcció, encara que no tinga alguna formalitat
necessària".

${ }^{181}$ Aquesta posició, que és la que pot considerar-se majoritària en la doctrina i la jurisprudència alemanyes, suposa l'aplicació de la normativa general civil sobre associacions als acords dels òrgans de gestió i vigilància i implica la nul-litat dels acords que contravinguen una norma prohibitiva ( $\$ 134 B G B)$, o que infringisquen els bons costums ( $\$ 138$ BGB), o la normativa sobre convocatòria i majories de l'assemblea general de les associacions ( $\$ 32 B G B$ ); la impugnació haurà d'efectuar-se mitjançant l'exercici d'accions declaratives ordinàries, que no estan sotmeses a prescripció o caducitat $\mathrm{i}$ poden ser exercitades per qualsevol persona amb interès
legítim.

La negativa a l'aplicació analògica del règim d'impugnació dels acords viciats de la junta general s'ha sustentat no solament sobre la base del sistema d'integració de les normes del dret impugsiacions i de societats anònimes, sinó també per les diferències en la proporció de la l'aplicació d'acords de la junta general i dels òrgans d'administració i control. Tanmateix, plantejat duls acords de l'Aufsichtsrat i Vorstand del règim sobre acords de les associacions ha en els casos d'es relatius a l'adequació de la sanció de nul-litat que seria excessivament rigorosa autors han propracció o inobservança de les normes de procediment, per la qual cosa alguns finalitats de prosat la limitació dels efectes de la nul-litat en aquests casos, en consideració a les impugnación..., op. cit., pàg. 37-39).

in

AlCALÁ Díaz, M. Á, La impugnación..., op. cit. pàg. 40: «Els arguments que serveixen per són ulicar la previsió normativa d'un règim específic d'impugnació d'acords de la junta general de gestió gestió i vigilància. Aquesta conclusió és defensada per un sector minoritari de la doctrina 
Si s'adoptara aquesta última posició, hauria de tenir-se present, en tot cas, que el règim establert en el $\S 51$ de la llei de cooperatives alemanyes per a la impugnació difereix en alguns punts essencials de l'establert per l'AktG. En efecte, com hem vist, la norma cooperativa alemanya no distingeix entre acords nuls i anul-lables, sinó entre acords contraris a la llei o als estatuts socials que són sotmesos, tots, al mateix règim d'impugnació, en un termini d'un mes; la legitimació està, a més, limitada a determinats subjectes. En definitiva, la llei de cooperatives alemanya segueix, en el paràgraf 51, el "patró» dels acords anul-lables ${ }^{183}$, cosa que podria confirmar la tesi segons la qual, tant els acords nuls $^{184}$ de l'assemblea, com tots els acords viciats dels òrgans d'administració se sotmetrien al règim del dret civil ${ }^{185}$.

alemanya per considerar que la seguretat jurídica i el tràfic estaran més ben protegits pel règim previst en el dret de societats anònimes que mitjançant l'aplicació de la normativa civil sobre associacions».

${ }^{183}$ «El §243 de l'AktG estableix com a causes d'anul-labilitat (Anfechtbarkeit), la infracció de la llei o dels estatuts i l'adopció d'acords en què el dret de vot s'exercite amb la intenció d'obtenir avantatges especials en favor del votant o d'un tercer, amb perjudici a l'interès social o d'altres accionistes. L'anul-lació [...] només serà procedent com a conseqüència de l'exercici de les accions previstes en la Llei ( $\$ 246 A k t G)$ per les persones legitimades per a això ( $\$ 245 A k t G)$ i dins del termini d'un mes, transcorregut el qual es produirà el guariment dels vicis» (ALCALÁ DIAZ, M. Á, La impugnación..., op. cit., pàg. 42).

${ }^{184}$ DÍAZ DE LeZCANO SEVILLANO, N., Los acuerdos del consejo..., op. cit., pàg. 64, nota 130: «El §241 de la Aktiengesetz recull que els acords de la Junta general només seran nuls si han estat adoptats en una Junta general que no haguera estat convocada conforme al que disposa el $\$ 121$, paràgrafs 2 i 3 , llevat que hi hagueren comparegut o estigueren representats tots els accionistes; no estan protocolitzats, segons el que disposa el $\$ 130$, paràgrafs 1,2 i 4; resulten incompatibles amb la naturalesa de la societat anònima, o pel seu contingut lesionen normes dictades, exclusivament o majoritària, per a la protecció dels creditors de la societat, o d'una altra manera, de l'interès públic; el seu contingut és contrari als bons costums; han estat declarats nuls per sentència resolutòria d'una acció d'impugnació; han estat anul-lats amb una decisió judicial definitiva segons el que disposa el \$144, paràgraf 2, de la Llei relativa a assumptes de la jurisdicció voluntària».

${ }^{125}$ En dret civil alemany, el caràcter originari de la nul-litat porta a la possibilitat d'instar-la no solament judicialment, sinó també per mitjà d'una oposició extrajudicial al negoci jurídic, mitjançant la simple comunicació d'una de les parts dirigida a l'altra part invocant-ne la nul-litat. Així mateix, és possible estimar la nul-litat no solament per acció sinó també per excepció i fins i tot pot ser declarada d'ofici pel jutge encara que cap de les parts l'haja invocada. ALCALÁ DÍAZ, M. Á, La impugnación..., op. cit., pàg. 42, nota 9: "Ambdós instituts jurídics, accions judicials declaratives i oposició són els mitjans admesos en Dret no només per a la impugnació dels negocis jurídics en general, sinó també per a la impugnació d'acords de les associacions de dret civil i en l'àmbit mercantil, per a les societats personalistes, cosa que és discutida per a les societats de responsabilitat limitada». "[...] La possibilitat [...] implica l'extensió de legitimació activa a qualsevol persona titular d'un interès legítim i la inexistència 
Itàlia és un dels tres països europeus (juntament amb Espanya i Portugal) la Constitució dels quals reconeix expressament la funció social del cooperativisme i la necessitat de fomentar-lo ${ }^{186}$; a més, compta amb un règim de descentralització regional que suposa l'existència de normes regionals en la matèria, si bé amb diferent abast, perquè no totes les regions tenen assumit el mateix sostre competencial ${ }^{187}$. Però els caràcters principals de la institució cooperativa italiana estan expressats en els articles 2511, 2516 i 2517 del seu Codice civile.

Així, l'article 2511 CC italià estableix que "les empreses que tinguen finalitat mutualista podran constituir-se com a societat cooperativa...", cosa que ha portat autors significats a considerar que, en virtut d'aquesta regulació, la cooperativa es converteix en un nou tipus de societat propi, i deixa de ser una subespècie de les societats mercantils ${ }^{188} \mathrm{o}$, almenys, se situa a mig camí entre les societats de persones $i$ les de capital ${ }^{189}$. En tot cas, no es qüestiona que el tipus social cooperatiu, des del punt de vista estructural, s'ha modelat prenent clarament com a referent el de les societats de capital i, més específicament, el

de terminis per al seu exercici»; i en pàg. 43, nota 11: «[...] Per als tercers aquest serà l'únic mitjà de protecció davant acords nuls de la junta general que pogueren afectar els seus interessos, per la qual cosa el $\$ 247$ de l'AktG no els atribueix legitimació per a l'exercici de les accions juridicosocietàries».

${ }^{186}$ Anàlisis crítiques de l'article 45 de la Costituzione italiana, fonamentalment al voltant del concepte de mutualitat que haja de prendre's en consideració, poden veure's en BONFANTE, G., Imprese cooperative..., op. cit., pàg. 37-46; i en GRAZIANI, A., "Società cooperativa e...», op. cit., pàg. 278-280.

${ }^{1 k 7}$ MONTOLf́o HERNÁNDEZ, J. M., Legislación cooperativa en la Comunidad europea, op.cit., pàg. 308, 309,315 i 316, que assenyala que totes les regions han adoptat mesures, ja siga de foment, ja de promulgació de legislació pròpia o d'adaptació de la legislació general, fonamentalment en relació amb la intervenció administrativa. BASSI, A., Le società cooperative, op. cit., pàg. 11. Una ressenya de les diverses lleis regionals pot consultar-se en BONFANTE, G., Imprese cooperative..., op. cit., pàg. 215-218.

\footnotetext{
${ }^{189}$ BASSI, Amedeo, El derecho cooperativo en Italia, Cuadernos de Trabajo núm. 9, Ciriec-España, València, pàg. 8; PANIAGUA ZURERA, M., Mutualidad y lucro..., op. cit., pàg. 119 i 121. ASCARELLI, T., "Cooperativa e società...», op. cit., pàg. 415-418, va més enllà i distingeix entre cooperativa $i$ societat, partint de la característica de la mutualitat.
}

${ }^{1 \times 5}$ BUONOCORE, Vincenzo, Diritto della cooperazione, Il Mulino, Bologna, 1997, pàg. 94. 
de la societat per accions ${ }^{190}$. Així es reconeix explícitament en l'article 2516, quan disposa que, a les societats cooperatives, els seran d'aplicació (entre altres matèries), "en tot cas", les disposicions de la societat per accions relatives a les assemblees, els administradors, els síndics, els llibres socials, el balanç i la liquidació de la societat, quan siguen compatibles amb les disposicions especials cooperatives del Codice mateix i amb les contingudes en lleis especials.

La menció a les lleis especials es refereix fonamentalment a la regulació sectorial de les cooperatives, segons l'activitat. Efectivament, bancs populars, caixes rurals i artesanes, cooperatives agràries, de producció, de consum, d'habitatges, etc., compten amb normes pròpies ${ }^{191}$ que, en virtut del que preveu l'article 2517 del Codice civile, han de ser aplicades preferentment, seguides de les disposicions sobre cooperatives del Codice; i, si manquen aquestes dues, són aplicables les disposicions de les societats per accions ${ }^{192}$.

\footnotetext{
${ }^{190}$ BASSI, Amedeo, "Delle imprese cooperative e delle mutue assicuratrici, art. 2511-2548", en Codice civile. Commentario (dir. P. Schlesinger), Giuffrè, Milano, 1995, pàg. 291; BONFANTE, G., Imprese cooperative..., op. cit., pàg. 563; BUONOCORE, V., Diritto della cooperazione, pàg. 94-95; GROSSO, P., I controlli interni..., op. cit., pàg. 13; PALMA, R., «Il fenómeno cooperativo...», op. cit., pàg. 30. ASCARELLI, T., "Cooperativa e società", op. cit., pàg. 421-422, tanmateix, matisa: "Certament la retramesa de l'article 2516 es coordina no només amb la problemàtica comuna a totes les corporacions i per a la qual la disciplina de les societats per accions ha desenvolupat una funció de pionera [...]. Però la comparació entre l'abast de la retramesa que troba una explicació en aquesta consideració (i que concerneix essencialment a les normes sobre constitució, balanç i liquidació) i la normativa privatística mateixa dictada després per a la cooperativa és freqüentment no sol contrastant amb la de la societat per accions, sinó que disminueix l'abast de la retramesa a aquelles entre les normes reclamades que més directament es connecten amb la finalitat econòmica».
}

${ }^{191}$ Poden veure's referències de les principals «lleis especials de sectors» en BASSI, A., Le società cooperative, op. cit., pàg. 9-10; i en BONFANTE, G., Imprese cooperative..., op. cit., pàg. 209-215.

${ }^{192}$ BASSI, A., Delle imprese cooperative..., pàg. 290; BONFANTE, G., Imprese cooperative..., op. cit., pàg. 199-220; BUONOCORE, V., Diritto della cooperazione, pàg. 91; PALMA, R., Il fenomeno cooperativo..., op. cit., pàg. 30: «En presència de lleis especials [...] les disposicions del Codi s'apliquen només en tant que siguen compatibles amb l'especialitat de la disciplina específica. Aquesta compatibilitat ha d'estar valorada mitjançant l'aplicació de la "no-contrarietat o funcionalitat" de les normes esmentades respecte al compliment de la finalitat no lucrativa». En MONTOLfo HERNÁNDEZ, J. M., Legislación cooperativa en la Comunidad europea, op.cit., pàg. 993-1025, pot consultar-se un extracte de les normes del Codice civile relatives a les cooperatives, així com altres normes especials. 
Però la producció normativa en matèria de cooperatives també inclou altres disposicions no sectorials ${ }^{193}$, com la Llei 59/1992 que va suposar una reforma parcial de la disciplina cooperativa ${ }^{194}$, les disposicions que donen lloc a la regulació de les anomenades cooperatives socials ${ }^{195}$, la introducció de la piccola società cooperativa, que intenta donar forma a un tipus simplificat de societat cooperativa de responsabilitat limitada, aplicable a activitats econòmiques de petites i mitjanes dimensions ${ }^{196}$; així com el desenvolupament normatiu de la

${ }^{130}$ BASSI, A., Le società cooperative, op. cit., pàg. 8: "Quan es parla de lleis "especials" s'està referint, en la pràctica, a tota la normativa que està col-locada fora del codi civil. Presa aquesta accepció, l'expressió llavors comprèn tant lleis, o singulars normes especials que atenen sectors 0 aspectes específics d'activitat cooperativa [...]; com a lleis que, sent especials perquè queden situades fora del codi, pel seu contingut, tenen caràcter general [...] a les quals els ha de ser reconegut un abast general, en el sentit que una part de les seues disposicions atén les cooperatives en general, i no a aquest o a aquell tipus particular d'empresa mutualista». Entre les lleis especials d'aplicació general es refereix especialment a les normes tributàries BONFANTE, G., Imprese cooperative..., op. cit., pàg. 205-209.

${ }^{144}$ Vegeu una extensa referència bibliogràfica a l'abundant producció doctrinal en relació amb aquesta Llei en BASSI, A., Le società cooperative, op. cit., pàg. 10, nota. 2. Un resum comentat del seu contingut pot veure's en DARBÓMIDA, Renato, "Recientes reformas en el derecho cooperativo italiano, (trad. G. Fajardo), Revista de legislación y jurisprudencia, CIRIEC-España, núm. 4, pàg. 165-170; en relació amb la matèria que ens ocupa, una de les principals novetats que aporta la Llei 59/1992 és la introducció dels socis inversors (sovventori), els vots totals dels quals no han de superar un terç dels vots totals dels socis, les aportacions dels quals seran nominatives i podran estar sotmeses a límits en la seua transmissibilitat, i que poden estar afavorits estatutàriament amb condicions particulars en relació amb el repartiment de beneficis $i$ la liquidació de les accions. Vegeu, per la seua relació amb la nova figura en dret espanyol del "soci financer" de la cooperativa mixta, cap. quart, epíg. 1.1.1, A, b).

${ }^{195}$ BASSI, A., Le società cooperative, op. cit., pàg. 71: «Les cooperatives socials, ex article 1 de la L. N. 381 del 1991 [8-11-1991], tenen la finalitat de perseguir "l'interès general de la comunitat a la promoció humana i a la integració social dels ciutadans", a través de: a) la gestió de serveis sociosanitaris i educatius; b) el desenvolupament d'activitats agrícoles, industrials, comercials o de serveis dirigides a la inserció laboral de persones discapacitades». En nota 25 recull l'autor les referències a diverses aportacions doctrinals sobre les cooperatives socials. DARBÓMIDA, R., "Recientes reformas...", op. cit., en pàg. 164-165, resumeix els principals trets jurídics d'aquestes cooperatives $\mathrm{i}$ indica que la Llei mateixa confia a les regions la potestat d'emanar normes d'execució de la Llei i de promoció, manteniment i desenvolupament d'aquestes cooperatives.

${ }^{196}$ Vegeu BONFANTE, G., Imprese cooperative..., op. cit., pàg. 564-566, amb abundant ressenya de doctrina; PALMA, R., Il fenomeno cooperativo..., op. cit., pàg. 44. Entre els treballs monogràfics, poden veure's CAPO, G., Piccole società cooperative e grandi illusioni: riflettendo sull'art. 21, $l .7$ agosto 1997, n. 266, Giur. comm., núm. 25.3, maig-juny 1998, pàg. 444/I a 470/I; MoscoNI, Romano, La piccola società cooperativa. Costitucione. Adempimenti contabili e fiscali. Statuto, Pirola Società, Milà, 1995; PASTOR SEMPERE, Carmen, "La nueva "piccola cooperativa" del derecho italiano: una manifestación de la tendencia a la simplificación del derecho de sociedades", RdS, núm. 8, 1997, pàg. 496-505; SARALE, M., "Un nuovo tipo di società mutualistica: la piccola in tetà cooperativa», Giur. comm., núm. 25.5, set.-oct. 1998, pàg. 735/I-763/I; i SERRA, A., "Note vol. primer piccola società cooperativa", en AA. DD., Scritti in onore di ANTONIO PAVONE LA ROSA, vol. primer, tom III, Giuffrè Editore, Milà, 1999, pàg. 1281-1297. 
figura del consorci de cooperatives, com a forma associativa típica entre ens mutualistes ${ }^{197}$.

En relació amb la matèria de la impugnació d'acords socials, les lleis especials no conformen règims diferenciats ${ }^{198}$, per la qual cosa, en relació amb la retramesa que efectua l'article $2516 C C i$, es discuteix si s'haurà d'atendre el que es preceptua per a les societats per accions o si l'ampli control administratiu al qual es veuen sotmeses les cooperatives italianes serà suficient per tutelar no sols els "interessos generals" sinó també els dels socis ${ }^{199}$.

Si s'entén aplicable la remissió, amb les especificitats necessàries, al control judicial establert per a les societats anònimes, seran nuls els acords de l'assemblea que tinguen un objecte il-lícit o impossible (article 2379), i se'ls aplicarà les disposicions relatives a la nul-litat dels contractes ${ }^{200}$. Seran anul-lables els acords adoptats per l'assemblea en contra del que preveuen les

${ }^{197}$ PALMA, R., Il fenomeno cooperativo..., op. cit., pàg. 44-45; MONTOLfo HERNÁNDEZ, J. M., Legislación cooperativa en la Comunidad europea, op.cit., pàg. 344-347. Es preveuen tres models de consorcis: els consorcis de societats cooperatives, els consorcis de cooperatives «admissibles en concursos públics», i els consorcis entre cooperatives "per a la coordinació de la producció i dels intercanvis». També es refereixen als tres models de consorcis de cooperatives ALFONSO SÁNCHEZ, Rosalía, La integración cooperativa y sus técnicas de realización: la cooperativa de segundo grado, Tirant lo Blanch, València, 2000, pàg. 183, i CAMPOBASSO, G. F., Diritto Commerciale, 2, Diritto delle società, 2a ed., UTET, Torí, 1992, pàg. 540-541.

${ }^{198}$ BASSI, A., Le società cooperative, op. cit., pàg. 9.

199 Paz Canalejo, N., en Paz Canalejo, N. i Vicent Chuliá, F., "Ley general de cooperativas», en Comentarios al Código de comercio y legislación mercantil especial, tom $X X$, Ley general de cooperativas, Edersa, Madrid, vol. II, pàg. 569. Sobre la discussió doctrinal respecte del caràcter de la retramesa de l'article 2516 CCi en general i en relació amb l'aplicació del control judicial en particular, vegeu les diferents posicions i arguments en BASSI, A., Le società cooperative, op. cit., pàg. 262-265; BONFANTE, G., Imprese cooperative..., op. cit., pàg. 197-198; i SERRANO Y SOLDEVILLA, A. D., La cooperativa como..., op. cit., pàg. 207-208, nota 117.

${ }^{2(x)}$ Articles 1421: legitimació, qualsevol que tinga interès; 1422: imprescriptibilitat de l'acció; i 1423: impossibilitat de convalidació.

SilvetTI, C. i CAVAlli, G., Le società per azioni..., op. cit., pàg. 198: «En virtut de la retramesa operada per l'article 2379 a l'article 1421, la legitimació no sofreix limitacions de cap tipus i pot ser apreciada d'ofici [...] no valen per a ella [...] ni els terminis prescrits per a l'acció d'anul-lació, ni l'obligació de dipòsit d'almenys una acció [...] l'oposició respecte a l'acord impugnat, ni la circumstància de no haver estat soci en el moment de l'acord». 
lleis o l'acte constitutiu ${ }^{201}$ (article 2377); estaran legitimats per a això els socis absents o dissidents, els administradors i els síndics, en el termini de tres mesos des de l'adopció de l'acord o de la seua inscripció al registre, tot i que l'acord anul-lable pot ser substituït ${ }^{202}$. L'anul-lació de l'acord, si escau, afectarà tots els socis, però no perjudicarà els interessos de tercers de bona fe. En tot cas, per a ambdues accions, la de nul-litat i la d'anul-labilitat, es requereix interès per actuar, en el sentit de "necessitat de recórrer al jutge per evitar una lesió actual al dret mateix i el dany consegüent a la pròpia esfera jurídica" ${ }^{203}$.

Quant a la impugnabilitat dels acords dels administradors, en virtut de l'esmentada remissió de l'article 2516 CCi a les disposicions de la societat per accions, seran impugnables els supòsits en què es viole el que es preveu en els articles 2388 (quòrum i majoria per a l'adopció dels acords), 2391 (conflicte d'interessos $^{204}$ ), 2421.3 (gestió i custòdia dels llibres socials) i 2527 (expulsió de socis). A més, doctrina i jurisprudència debaten si pot fer-se una interpretació extensiva en favor de la impugnació dels altres acords de l'òrgan $\mathrm{d}^{\prime}$ administració ${ }^{205}$. En relació $\mathrm{amb}$ això, la jurisprudència, que en una primera ${ }^{201}$ ASCARELLI, T., L'interesse sociale..., op. cit., pàg. 114: «Interpretarem acte constitutiu com a
equivalent d'estatut».

${ }^{202}$ Entre les normes procedimentals de l'anul-lació destaquen la possibilitat d'exigir als impugnadors la prestació de fiança, l'acumulació de totes les accions d'impugnació davant l'acord mateix, la possibilitat d'acordar judicialment la suspensió de l'execució de l'acord, i la inscripció registral de la suspensió i de la sentència.

20 Silvetri, C. i CAVALLI, G., Le società per azioni..., op. cit., pàg. 198.

${ }^{214}$ EMBID IRUJO, J. M., «Derecho europeo...», op. cit., pàg. 18, destaca, en aquest supòsit, la legitimació atribuïda, no sols als administradors absents, sinó també als síndics del collegio sindacale, per impugnar els acords del consell lesius de l'interès social.

${ }^{201}$ DiAZ DE LEZCANO SEVILLANO, N., Los acuerdos del consejo..., op. cit., pàg. 80-87, on sintetitza la doctrina i la jurisprudència contrària. Es tracta d'evitar la paralització possible de l'activitat de la societatria resultar d'una utilització inadequada de la impugnació, i de protegir l'interès com la revol conflicte d'interessos, els acords viciats només donaran lloc a sancions alternatives, reconeixement dels administradors o l'exercici de l'acció de responsabilitat) i la favorable al que regulen la -dividida al seu torn, entre els partidaris d'aplicar analògicament les normes per als acords impugnació dels acords de l'assemblea; els que defensen que el règim aplicable atribueixen del consell és el previst a l'article 2.391 CC (conflicte d'interessos); i els que atribueixen la resolució de la impugnació a l'assemblea; ALCALÁ DíAZ, M. Á, La impugnación..., 
època va ser contrària a l'admissió, ha produït un canvi en la seua orientació, declarant que l'absència d'una normativa especial no pot ser causa justificada per excloure el dret del soci a la seua tutela judicial ${ }^{206}, \mathrm{i}$ estimant aplicable analògicament la disciplina general de la impugnació dels acords de l'assemblea $^{207}$. En matèria de legitimació, la jurisprudència ha admès, no solament la dels components de l'òrgan d'administració, sinó també la del soci que haja estat lesionat en els seus drets.

A França, la regulació de les cooperatives es basa en un sistema normatiu
múltiple en el qual, al costat d'una llei bàsica, l'Estatut general de la cooperació $^{208}$, hi ha una pluralitat de normes especials d'aplicació a cada un dels sectors cooperatius particulars ${ }^{209}$; a més, són d'aplicació a les cooperatives el títol III de la Llei de 24 de juliol de 1867 (disposicions relatives a la variabilitat del capital social, no derogades per la Llei de 24 de juliol de 1966 de les societats

op. cit. pàg. 66-68; VICENT CHULIA, F., PAZ CANALEJo, N. i VICENT CHULIÁ, F., Ley general..., op.
cit., vol. II, pàg. 850-852.

${ }^{206}$ DÍAZ DE LEZCANO SEVILLANO, N., Los acuerdos del consejo..., op. cit., pàg. 87.

${ }^{2107}$ Vegeu Cass. 28 agost 1995, n. 9040, en Società, 1996, pàg. 162, amb nota de F. ZUCCONI, i en Giur. It., 1996, I, I, 308. BONFANTE, G., Imprese cooperative..., op. cit., pàg. 605, nota 12, cita, a més,
altra jurisprudència, favorable i desfavorable a l'ampliació.

${ }^{208}$ Aprovat per Llei 47-1775, de 10 de setembre de 1947, modificat per la Llei 92-643, de 13 de juliol de 1992. Aquesta última norma, que introdueix reformes importants, fonamentalment en matèria de finançament de la cooperativa, ha estat objecte de diverses anàlisis doctrinals, entre les quals poden esmentar-se, PIOT, B., "Une réforme en profondeur...», op. cit.; i SAINTOURENS, Bernard, "Sociétés coopératives et sociétés de droit commun», Reo. des soc., gener-març, 1996,
pàg. 1-15.

A Espanya ha estat comentada FAJARDO GARCtA, Isabel-Gemma, «Ley francesa $n^{\circ} 92$ de 13 de julio 1992 relativa a la modernización de las empresas cooperativas», Revista de legislación y jurisprudencia, CIRIEC-España, núm. 4, pàg. 171-180.

${ }^{209}$ En MONTOLfo HERNÁNDEZ, J. M., Legislación cooperativa en la Comunidad europea..., op. cit., pàg. 197-239, i 877-942, poden consultar-se els textos tant de l'Estatut general de la cooperació com de les leis particulars: Codi rural, aprovat per Decret 81-276, de 18.3.1981; Llei 83-657, de 20.7.1983, relativa al desenvolupament de determinades activitats d'economia social; Llei 82409, de 17.5.1982, per la qual es promulga l'Estatut de les societats cooperatives de banca; Llei de 7.5.1917, sobre organització del crèdit a les cooperatives de consum; Llei 72-652, de 11.7.1972, relativa a les societats cooperatives de comerciants detallistes; Llei 78-763, de 19.7.1978, reguladora de les cooperatives obreres de producció; Codi de la construcció i de l'habitatge. Les esmentades normes han estat parcialment modificades i actualitzades per la Llei 92-643, de 13.7. Un examen somer dels principals tipus de cooperatives franceses pot veure's en COZIAN, M., VIANDIER, A. i DEBOISSY, F., Droit des sociétés, op. cit., pàg. 523-525; i en RIPERT, G. i ROBLOT, R., Traité de droit commercial, tom 1, 16a ed. (M. Germain), L.G.D.J., 1996, pàg. 1211-1214. 
mercantils) i el "Dret comú de les societats, que s'aplica en la mesura que no hi haja disposicions especials que regulen la matèria" (Llei 66-537, de 24 de juliol de 1966 , de societats mercantils) ${ }^{210}$.

Però no es pot atribuir a l'estatut, pròpiament, el caràcter de generalitat que sembla indicar la seua denominació, ja que no conforma un conjunt normatiu coherent i complet, aplicable preferentment a totes les cooperatives ${ }^{211}$. D'entrada, es parteix del principi que, si falta previsió normativa expressa, les cooperatives poden adoptar qualsevol de les "formes clàssiques de societat", cosa que condueix a obviar en l'estatut la regulació sistemàtica i organitzada dels aspectes estructurals, $\mathrm{i}$ es dóna per descomptat que seran aplicables els continguts en la legislació del tipus social concret que s'haja adoptat ${ }^{212}$.

${ }^{210}$ AA. DD. (Nordine Aïci, Claire Autran, Iannis Ait-Ali, Arnaud Dupin, Olivier Dartois, Michel Palos Pinto), «La coopérative française. Le statut général de la coopération: Statut 10 septembre 1947 modifiée par la Loi du 13 juillet 1992», Boletín de la Asociación Internacional de Derecho Cooperativo, pàg. 55; MESTRE, Jacques, "Sur l'originalité du droit coopératif, RECMA, núm. 261, 3r. trim. 1996, pàg. 82-83, citant també la Llei de 24.7.1966, "quan la cooperativa haja adoptat una forma que la convertisca automàticament en mercantil (SARL, SA) o almenys tinga un objecte que la faça adoptar la mercantilitat», així com "altres cossos de normes, exteriors al dret de societats pròpiament dit, però susceptibles d'abastar tota empresa de dret privat - pense, per exemple, en el dret de la competència o en el dret d'empreses en crisi». PANIAGUA ZURERA, M., Mutualidad y lucro..., op. cit., pàg. 110-111. SAINTOURENS, B., "Sociétés coopératives...», op. cit., pàg. 2-3, on apunta que l'aplicació del dret comú s'accentua en les normes cooperatives franceses i europees de les últimes dècades, on s'assisteix una "profunda reducció del particularisme de les societats cooperatives».

${ }^{211}$ LLOBREGAT HURTADO, M. L., Mutualidad y empresas cooperativas..., op. cit., pàg. 50: «El propòsit del legislador era que, en una fase ulterior, l'Estatut de la cooperació passara a integrar-se dins del Codi general de la cooperació concebut com un cos orgànic de normes, la segona part del qual contindria els textos legals especials». Aquest propòsit no ha estat dut a terme.

FAJARDO GARCIA, I. -G., "Ley francesa...», op. cit., pàg. 172: "Quant a la resolució dels conflictes de lleis, la Llei 47-1775 establia en l'article 2 que "les cooperatives es regeixen per la present llei i per les lleis particulars per a cada categoria, en la mesura que aquestes lleis no la contradiguen" l'Estatut de la Cooperació, sobre les lleis especials. Aquesta prelació que -com diu GoURLAY [GoURLAY, G., «La modernisation des entreprises coopératives par la Loi du 13 juillet 1992», en Droit des sociétés, núm. 11, nov. 1992, pàg. 1-4] - no sempre va ser respectada, s'altera amb la nova Llei. L'article 2 d'aquesta assenyala: "Les cooperatives es regeixen per la present llei, llevat de reserva de les lleis particulars a cada categoria d'aquestes"».

${ }^{212}$ LLOBREGAT HURTADO, M. L., Mutualidad y empresas cooperativas..., op. cit., pàg. 51: «La llei de

${ }^{212}$ LLOBREGAT HURTADO, M. L., Mutualidad y empresas cooperativas..., op. cit., pàg. 51: «La llei de pràctica, ha proposat entre els seus objectius crear un nou tipus societari, sinó tan sols posar en comú, una el pla jurídic a partir d'un estatut bàsic que és propi de les cooperatives de dret cooperativa sèrie de principis especials de caràcter cooperatiu [...]. No existeix, doncs, la autònoma $\mathrm{i}$ independentia jurídica pròpia i uniforme, amb una disciplina organitzativa 
A això s'afegeix que aquest principi es veu severament exceptuat, tant per les normes sectorials cooperatives ${ }^{213}$, com per la interpretació de la doctrina i de la jurisprudència: una cooperativa, segons la seua classe i activitat, pot veure's obligada per la legislació específica a adoptar una forma mercantil determinada (anònima o de responsabilitat limitada, fonamentalment, per exemple en la cooperativa de producció), o civil (de "vocació genèrica, articles 1832 i ss. CC, o subjecta a estatut particular, com és el cas de determinades cooperatives regulades pel Code rural o les de professionals") ${ }^{214}$.

En matèria d'òrgans socials es fa particularment evident que falta una disciplina juridicocooperativa pròpia ${ }^{215}$ : si bé l'estatut general de la cooperació dedica els seus articles 6 a 19 a "l'organització i administració de les cooperatives", dista molt d'oferir un sistema coherent de la seua estructura orgànica, i el mateix succeeix amb les normes cooperatives sectorials. Vist el seu contingut, no hi ha dubte que caldrà acudir a les regles corresponents a la forma jurídica que s'haja

${ }^{213}$ PIOT, B., Une réforme en profondeur..., op. cit., pàg. 37, on recorda que el conflicte possible de lleis es resol mitjançant l'aplicació del principi que estableix que els textos particulars tenen aplicació preferent respecte de les lleis de caràcter general. RIPERT, G., i ROBLOT, R., Droit commercial, op. cit., tom 1, pàg. 1209: «Els textos generals sobre societats no s'apliquen més que en la mesura que no estiguen derogats pels textos especials de les cooperatives; entre aquests últims, la Llei de 10 de setembre de 1947 cedeix davant dels estatuts particulars».

${ }^{214}$ MONTOLfo HERNÁNDEZ, J. M., Legislación cooperativa en la Comunidad europea..., op. cit., pàg. 202. En AA. DD., La coopérative française..., op. cit., pàg. 56-58, s'afirma, a més que són mercantils les cooperatives d'assegurances o bancàries, ja que duen a terme habitualment actes de comerç, en el sentit de l'article 632 del CCo ("compra de béns mobles o immobles per revendre'ls, activitats industrials i financeres com les operacions de banca, de canvi, etc.»), però que "en cas contrari, en general, són societats civils. Aquest és el cas d'una cooperativa de consum que no ven més que als seus socis i sense ànim de lucre; quan la cooperativa presta els seus serveis a tercers de manera habitual, esdevé mercantil».

A tot això s'ha d'afegir, com indica Llobregat HURTADo, M. L., Mutualidad y empresas cooperativas..., op. cit. , pàg. 51, que «hi ha altres figures, com les societats de crèdit agrícola mutu, les societats de crèdit mutu immobiliari, les societats de caució mútua, els bancs populars, etc. que, malgrat no anomenar-se cooperatives, utilitzen tècniques pròpies d'aquestes últimes i se subsumeixen dins del concepte ampli - i imprecís- de cooperativa, consagrat en l'article 1 de la llei de 1947»". 
adoptat en cada cas, per determinar el règim aplicable a la revisió dels seus acords socials ${ }^{216}$.

La Llei de 24 de juliol de 1966 sobre les societats comercials, en l'article 360 (capítol VI, Disposicions comunes a les diverses societats comercials dotades de personalitat jurídica, del títol I) estableix un règim comú per a la nul-litat de la societat i per a la dels actes i les deliberacions posteriors a l'acte constitutiu, que haurà de derivar-se d'una disposició expressa de la Llei mateixa ${ }^{217} \mathrm{o}$ de les que regeixen la nul-litat dels contractes ${ }^{218}$. Entre els actes i les deliberacions posteriors a la constitució de la societat susceptibles de nul-litat, es distingeix en el mateix article 360 , paràgraf 2 , els que suposen una modificació estatutària $i$ els que no constituïsquen tal modificació; per a aquests últims la Llei no exigeix que la nul-litat es derive d'una disposició expressa i s'acontenta amb l'incompliment d'una disposició imperativa. En ambdós casos, doctrina i

${ }^{216}$ AA. DD., La coopérative française..., op. cit., pàg. 91; PANIAGUA ZURERA, M., Mutualidad y lucro..., op. cit., pàg. 113; PAZ CANALEJO, N., en PAZ CANALEJO, N. i VICENT CHULIÁ, F., Ley general..., op. cit., vol. II, pàg. 569-570.

${ }^{217}$ COZIAN, M., VIANDIER, A. i DEBOISSY, F., Droit des sociétés, op. cit., pàg. 189: «Aquests casos són rars; alguns exemples: -per a les SARL, no respecte de les formes i els terminis de convocatòria de les assemblees (L., article 57 , paràgraf 2 ), incompliment de les regles relatives a la transformació (L. Article 69, paràgraf 4); -per a les societats per accions, incompliment de les formes i els terminis de convocatòria (L., article 159, paràgraf 2 ), condicions de quòrum i de majoria de les assemblees extraordinàries (L., article 154, 173), falta d'informe del comissari de comptes en cas de supressió del dret de subscripció preferent (L., article 186), [...]. Fora d'aquests casos, a falta de text enunciant la nul-litat, aquesta no pot afectar la decisió». LEGROS, Jean-Pierre, "La nullité des décisions de sociétés», Rev. des soc., 1991, pàg. 280-284, sistematitza els diferents supòsits en que la llei preveu expressament la sanció de nul.litat, i es refereix a aquells altres que denomina supòsits de "nul-litat descartada", en què la norma mateixa rebutja l'aplicació de la nul-litat o estableix una sanció diferent (p. e., els acords adoptats amb la participació d'un administrador anomenat irregularment).

LEGROS, J.-P., «La nullité des décisions...», op. cit., pàg. 276: «És a dir, segons la jurisprudència, el dret comú dels contractes (article 1108 i ss. Cciv) i el dret específic del contracte de societat (article 1832 i ss. Cciv)». COZIAN, M., VIANDIER, A., i DEBOISSY, F., Droit des sociétés, op. cit., pàg. 190: "La deliberació serà, doncs, nul-la per il-licitud de l'objecte o de la causa, o per vici del consentiment. Si es tracta d'aquesta última circumstància, és el frau allò que s'esdevé més sovint». 
jurisprudència plantegen així mateix la nul-litat dels acords adoptats en frau de llei o de drets de tercers, o amb abús de majoria ${ }^{219}$.

Les principals dificultats que assenyala la doctrina respecte de l'aplicació de l'esmentat règim de nul-litat són, d'una banda, la determinació de què s'haja $\mathrm{d}^{\prime}$ entendre per disposició imperativa ${ }^{220} \mathrm{i}$, d'una altra, la restricció que s'estableix quan es refereix la violació a les disposicions contingudes en la llei mateixa. Aquesta última qüestió té una relació estreta amb la impugnació dels acords en les cooperatives franceses, ja que la vulneració pot estar en relació amb les normes especials que regulen el tipus concret de cooperativa, o amb el contingut de l'estatut de la cooperació; en relació amb això, hi ha una tendència jurisprudencial "a l'extensió del perímetre de textos la violació dels quals pot comportar la nul-litat", sancionant amb aquesta acords que vulneren regles

${ }^{219}$ COZIAN, M., VIANDIER, A. i DEBOISSY, F., Droit des sociétés, op. cit., pàg. 171-176 i 190-191; DIAZ DE LezCANO SEvillano, N., Los acuerdos del consejo..., op. cit., pàg. 67; JEANTIN, Michel, Droit des sociétés, 2a ed., Montchrestien, París, 1992, p. 285; LEGROS, J. P., "La nullité des décisions...», op. cit., pàg. 276 i 296-300; RIPERT, G., i ROBLOT, R., Traité de droit commercial, op. cit., pàg. 886; TRICOT, D., «Abus de droits...», op. cit.

220 COZIAN, M., VIANDIER, A. i DEBOISSY, F., Droit des sociétés, op. cit., pàg. 190-191; RIPERT, G. i ROBLOT, R., Traité de droit commercial, op. cit., pàg. 885: «No sols les que es dicten sota sanció expressa de nul-litat, sinó totes aquelles que estan inspirades pel desig d'assegurar la supremacia de l'interès general sobre els interessos particulars». LEGROS, J. P., "La nullité des décisions...», op. cit., pàg. 287-288: "És imperativa, en una primera accepció, la disposició que s'imposa en tota circumstància, aquella que la voluntat no pot descartar»; això no obstant, "tota regla de dret és obligatòria, siga imperativa, "supletiva", dispositiva. La llei "supletiva" s'aplica en defecte de precisió de les parts, la llei dispositiva s'aplica en defecte que les parts hagen escollit una altra solució diferent a la del legislador»; i en pàg. 291: «S'ha de vigilar l'ambivalència de la fórmula que permet les clàusules contràries dels estatuts. Dues hipòtesis poden donar-se: una regla supletiva en la qual els socis són lliures, una regla mínima d'ordre públic en què els socis no són enterament lliures (derogació in melius)". ALCALÁ DIAZ, M.A. La impugnación..., op. cit. pàg. 51, recollint diverses posicions doctrinals, cita BÉZARD[La société anonyme, París, 1986, pàg. 326 i ss.]: «Tota norma que no admet disposició o actuació de fet en contrari, completant el concepte amb aquelles normes les disposicions de les quals són qualificades com d'ordre públic»; i altres autors partidaris de deduir la imperativitat de la norma dels interessos protegits [MERCADAL, M. B., i JANIN, M. P., Sociétés commerciales, en "Memento Practique Francis Lefevre», 20a ed., París, 1990, pàg. 1108 i ss.], i fins i tot de connectar la nul-litat de la norma imperativa amb la nul-litat radical o absoluta, derivada de violació de norma dictada en protecció d'interessos públics, davant la nul-litat relativa com a sanció aplicable als casos d'infracció de normes dictades en protecció dels interessos d'una persona o grup de persones [GouRLAY, P. G., Le Conseil d'administration de la société anonyme, París, 1971, pàg. 225]. 
imperatives diferents a la llei de societats comercials ${ }^{221}$ o disposicions estatutàries ${ }^{222}$.

La llei preveu també la possibilitat de regularització dels acords nuls, llevat que la nul-litat estiga fundada en la il-licitud de l'objecte ${ }^{223}$. Pel que fa a l'acció de nul-litat prevista en els articles 360 i ss., exigeix que el demandant compte amb

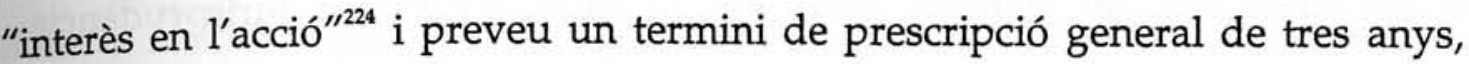
que es redueix a sis mesos en els casos de fusió o d'escissión ${ }^{225}$. En alguns casos, la nul-litat és completada o reemplaçada per la condemna a danys i perjudicis o

${ }^{21}$ AA. DD., La coopérative française.., op. cit., pàg. 70; COZIAN, M., VIANDIER, A., i DEBOISSY, F., Droit des sociétés, op. cit., pàg. 191; DIAZ DE LEZCANO SEVILLANO, N., Los acuerdos del consejo..., op. cit., pàg. 67; JEANTIN, M., Droit des sociétés, op. cit., pàg. 285, nota 266; LEGROS, J. P., «La nullité des décisions...", op. cit., pàg. 301 a 306; RIPERT, G., i ROBLOT, R., Traité de droit commercial, op. cit., pàg. 885 , nota 1 ; SAINTOURENS, Bernard, "La nullité d'une délibération du conseil d'administration d'une coopérative agricole pour violation de dispositions impératives relatives à la composition du conseil», Rev. des soc., núm. 3, jul.-sept. 2000, pàg. 545 i 546.

22 LEGROS, J. P., "La nullité des décisions...", op. cit., pàg. 306: "Una sentència de 20 de desembre de 1990 sembla admetre clarament, respecte d'una societat civil cooperativa, que l'acord adoptat en incompliment d'una disposició estatutària és nul. M. Guyon subratlla, d'altra banda, que l'article 360, com l'article 1833-1r, inclouen igualment les nul-litats que afecten els contractes, i conseqüentment l'article 1134 del Codi civil segons el qual el contracte té entre les parts la mateixa força que la llei. La nul-litat es deriva del dret comú de les obligacions". També recull jurisprudència sobre la nul.litat de la violació estatutària SAINTOURENS, B., "La nullité d'une délibération...», op. cit., pàg. 546.

RIPERT, G., i ROBLOT, R., Traité de droit commercial, op. cit., pàg. 887 i 888 . Poden veure's estudis del sistema francès d'esmena dels acords socials en BUSTILLO SAIZ, M. M., La subsanación de acuerdos..., op. cit., pàg. 92 a 100; i en LEGROS, J.-P., "La nullité des décisions», op. cit., pàg. 307 a 329.

${ }^{24}$ RIPERT, G., i ROBLOT, R., Traité de droit commercial, op. cit., pàg. 887: “La jurisprudència aplica a les irregularitats de les deliberacions d'assemblees la distinció de dret comú entre nul.litat absoluta i nul-litat relativa [...]. Si la nul.litat és la sanció d'una regla protectora d'interessos propis d'un accionista determinat [...] l'acció de nul-litat ha d'estar reservada a l'accionista interessat. (..) En els altres casos, la jurisprudència considera que la nul-litat per ignorància de les prescripcions legals és d'ordre públic, de manera que l'acció de nul-litat correspon a tota persona que justifique un interès legítim [...], fins $\mathrm{i}$ tot un accionista que haguera votat la resolució criticada". En el mateix sentit, ALCALÁ DÍAZ, M.A. La impugnación..., op. cit. pàg. 53; DiAz DE LeZCano SEVIllano, N., Los acuerdos del consejo..., op. cit., pàg. 67 i 68; JEANTIN, M., Droit des sociétés, op. cit., pàg. 285.

${ }^{23}$

Això no obstant, CozIAN, M., VIANDIER, A., i DEboIssY, F., Droit des sociétés, op. cit., pàg. 192, assenyalen que encara que l'acció de nul-litat s'extingisca, de conformitat amb el dret comú, qualsevol intereșsat podrà oposar l'excepció de nul-litat, pel seu caràcter de perpètua. 
amb la designació d'un administrador provisional la missió del qual consisteix a conduir la societat al seu funcionament normal ${ }^{226}$.

En tot cas, el règim de nul-litat previst, com hem indicat, en el capítol VI de la Llei 66-537, titulat Disposicions comunes a les diverses societats comercials dotades de personalitat jurídica, es refereix a la nul-litat dels "actes o deliberacions" de la societat comercial, en general, cosa per la qual doctrina i jurisprudència interpreten que serà d'aplicació, no solament als acords de l'assemblea general, sinó també a les decisions d'altres òrgans, com el d'administració, amb les adaptacions necessàries ${ }^{227}$.

Però també s'ha de tenir present que el règim previst en la Llei 66-537 no és aplicable a totes les cooperatives. Així, per exemple, a les cooperatives agrícoles, que són considerades com un tipus sui generis de persona jurídica, se'ls aplica el règim de nul-litat dels actes i deliberacions previst en el Code civil (article 184410), a falta de previsió específica en el Code rural, en l'Estatut de la cooperació o en el títol III de la Llei de 24 de juliol de 1867 relatiu a les societats de capital variable $^{228}$. En virtut d'això, la nul-litat "no pot resultar més que de la violació d'una disposició imperativa d'aquest títol [articles 1832 a 1844-17 CC] o d'una de les causes de nul-litat dels contractes en general", encara que també per a les societats civils es planteja l'ampliació de les causes de nul-litat a la violació de normes reglamentàries, $\mathrm{i}$ fins $\mathrm{i}$ tot de normes directament aplicables a la

${ }^{226}$ RIPERT, G., i ROBLOT, R., Traité de droit commercial, op. cit., pàg. 885 i 886.

${ }^{227}$ ALCALÁ DÍAZ, M. A. La impugnación..., op. cit. pàg. 51 a 53; DÍAZ DE LEZCANO SEVILlANO, N., Los acuerdos del consejo..., op. cit., pàg. 66 a 68; RIPERT, G., i ROBLOT, R., Droit commercial, op. cit., tom 1, pàg. 951 i 952, que assenyala la dificultat especial que planteja el fet que "moltes regles sobre la reunió del consell d'administració són enunciades al Decret de 1967 i no per la Llei"; TRICOT, D., "Abus de droits...», op. cit., pàg. 624 i 625, on ressenya també, per als supòsits d'abús de majoria o minoria, altres sancions possibles, com la multa o l'exclusió dels socis minoritaris.

${ }^{22 \pi}$ SAINTOURENS, B., «La nullité d'une délibération...», op. cit., pàg. 544. 
cooperativa, com les normes de composició dels òrgans socials previstes en el Code rural ${ }^{229}$.

Al Regne Unit, el primer text legislatiu en matèria de cooperatives és la Industrial and Provident Societies Act (IPSA), que continua vigent ${ }^{230}$, i que constitueix el més pròxim a una "llei comuna" per a totes les cooperatives que dóna la realitat anglesa, encara que "no pot estar considerada tanmateix com una llei cooperativa, des del moment que, partint d'aquesta, poden ser registrades també altres organitzacions sense finalitat de lucre que operen en benefici de la comunitat ${ }^{\prime 231}$. També s'hi aplica la Friendly and Industrial and Provident Act, del 1968, principalment en els aspectes registrals. Hi ha, a més, diverses normes sectorials, com ara la Credit Unions Act (CUA) 1979, reguladora de les cooperatives d'estalvi i crèdit, la Housing Act de 1976, i altres normes especials per al sector agrari (fonamentalment, l'Horticultural Act, del 1960, i l'Horticultural Association Act, del 1962).

Això no obstant, les cooperatives han de constituir-se adoptant una de les formes jurídiques de les societats mercantils, en la major part dels casos, com a societats de responsabilitat limitada, encara que també poden optar per altres fórmules $^{232}$. Es parteix del principi que el marc juridicoformal ha de ser flexible i

${ }^{20}$ SAINTOURENS, B., «La nullité d'une délibération...», op. cit., pàg. 546.

${ }^{20}$ La promulgació de l'IPSA es va produir el 1852, però el text actualment vigent és del 1965. Pot consultar-se en MONTOLfo HERNÁNDEZ, J. M., Legislación cooperativa en la Comunidad europea, op. cit., pàg. 1114 i ss.

${ }^{211}$ DARBOMIDA, R., «Evoluzione dei principi...», op. cit., pàg. 94; PANIAGUA ZURERA, M., Mutualidad y lucro..., op. cit., pàg. 103.

${ }^{22}$ MONTOLfo HERNÁNDEZ, J. M., Legislación cooperativa en la Comunidad europea, op. cit., pàg. $447 \mathrm{i}$ 448: "vg.: societats «de capitals» (companies) o «de persones» (partnership) [...] a les quals, a més, es veuran necessitades d'acudir si no reuneixen els requisits de Dret necessaris d'acord amb la legislació IPSA o la particular que corresponguera". En el mateix sentit, SNAITH, Ian «U. K. cooperative legislation in the 1980's: a decade of Neglect», Yearbook of co-ooperative entreprise 1988, pàg. 158; TURNER, J., "La regulació legal de les cooperatives al Regne Unit», en INSTITUT PER A LA PROMOCIÓ I LA FORMACIÓ COOPERATIVES, Legislació sobre cooperatives als Estats membres de la C.E.E, pàg. 13; i DfvAR, J., «El derecho comparado cooperativo...», op. cit. , pàg. 115, que assenyala que "s'admet també el seu funcionament com a associacions (voluntary associations), en el cas que no tingueren objectius econòmics". 
que la naturalesa cooperativa resultarà substancialment, no del tipus societari adoptat, sinó de la configuració estatutària que adopte la persona jurídica ${ }^{233}$. Per això, resulta fonamental en el règim juridicocooperatiu anglès el procés d'inscripció registral, ja que només podrà estar qualificada com a cooperativa aquella entitat que demostre al registrador que és una societat cooperativa de bona fe, o que l'activitat a realitzar és en benefici de la comunitat ${ }^{234}$.

La legislació esmentada no conté previsions respecte a quin haja de ser el dret supletòriament aplicable, la qual cosa no deixa de ser una de les característiques pròpies del sistema del common law: s'haurà d'estar fonamentalment a les resolucions i criteris registrals i jurisprudencials. I també s'haurà d'atendre el contingut dels estatuts socials que, entre altres matèries, regularan

\footnotetext{
${ }^{223}$ MONTOLfO HERNÁNDEZ, J. M., Legislación cooperativa en la Comunidad europea, op. cit., pàg. 448 i 449: "Com ja s'ha assenyalat (ThOMAS, A.; KendALL, J.; KNAPP, M. i PATON, R.: The "Social Economy" in the United Kingdom, pàg. 113) el terme cooperativa no implica ací "una entitat jurídica d'un tipus determinat». La cooperativa és una empresa "que pertany als seus membres, que és controlada per ells de manera democràtica i desenvolupada en benefici mutu» i que, generalment respondrà als principis ACI". MÜNKNER, Hans-H, "Los principios cooperativos y el progreso social", 1990, Revista CIRIEC-España, núm 9, pàg. 150: “els principis cooperatius exerceixen a Anglaterra un paper especial, ja que, sent una figura legal, no estan subjectes a cap llei especial d'organitzacions. El caràcter cooperatiu d'una organització està garantit principalment pel respecte de determinats fonaments fixats en els principis cooperatius".
}

${ }^{234}$ MONTOLf́ HERNÁNDEZ, J. M., Legislación cooperativa en la Comunidad europea, op. cit., pàg. 452 : "A l'objecte d'assentar les bases sobre les quals poder qualificar l'entitat com de «bona fide" cooperativa, s'entén que una societat ho serà quan resulte que: -l'activitat es realitza en benefici mutu dels socis; -el control corresponga als socis de manera igualitària i no segons la participació financera de cada un; - $l$ 'interès a pagar sobre les aportacions a capital i els préstecs no passarà del tipus necessari per obtenir i mantenir el capital necessari per assolir els objectius societaris; -els guanys, una vegada pagats els interessos pel capital aportat i si la seua distribució estiguera prevista en els Estatuts, es farà en proporció amb el volum d'operacions efectuades per cada soci; -no podrà existir restricció artificiosa a l'admissió de socis. La segona via per tenir accés al Registre serà la demostració que l'activitat projectada puga qualificar-se entre les que es duen a terme "en benefici de la comunitat" $i$ això requereix que hi concórreguen les condicions següents: -que l'activitat es duga a terme en benefici de la comunitat i que per tant resultaran beneficiats (sic) persones que no són sòcies; -que hi haja raons d'entitat suficient perquè aquesta societat puga registrar-se a l'empara d'aquesta Llei, més que com a societat mercantil segons la "Companies Act». Tot això té com a conseqüència necessària una àmplia discrecionalitat administrativa que deixa a les mans del registrador la decisió d'inscriure o no una societat, segons si en el moment de la qualificació dels seus Estatuts troba que aquests acompleixen o no els principis cooperatius". També es refereixen a la importància de la qualificació registral Df́VAR, J., "El derecho comparado cooperativo...», op. cit., pàg. 115; $i$ PANIAGUA ZURERA, M., Mutualidad y lucro..., op. cit., pàg. 105 i 106.

Un comentari sobre les diferències entre el règim legal aplicable a les societats inscrites al registre IPSA $i$ les altres companyies que actuen com a cooperatives pot veure's en SNAITH, I., "U. K. co-operative legislation...», op. cit. 
necessàriament el funcionament intern de la societat i, en particular, les condicions d'admissió i baixa de socis, la convocatòria de les assemblees, l'exercici en aquestes del dret de vot i la manera d'acordar, modificar o derogar les regles estatutàries, el nomenament i la revocació del consell d'administració, dels gerents o altres executius, i la seua remuneració.

Els òrgans socials de la cooperativa són l'assemblea general, el consell d'administració i els comissaris de comptes. A més, la cooperativa ha de sotmetre els seus comptes a auditoria externa.

L'IPSA no conté un procediment d'impugnació d'acords socials a l'ús del dret continental, sinó que preveu, en la secció 60, una norma general per a la resolució de tots els conflictes "entre una societat registrada o un executiu d'aquesta i, (a) un soci de la societat; o (b) qualsevol perjudicat que haguera deixat de ser soci de la societat amb antelació no superior a sis mesos; o (c) qualsevol persona que reclame segons els estatuts de la societat".

En virtut d'això, el conflicte es resoldrà segons el procediment que s'haja previst en els estatuts de la societat. En aquest sentit, si els estatuts no ho prohibeixen expressament, les parts en conflicte podran, de comú acord, sotmetre la controvèrsia al registrador competent, en funcions d'arbitratge $\mathrm{e}^{235}$. També està expressament previst en la secció 60 que els estatuts puguen disposar, o les parts mateixes acordar, que el conflicte es resolga davant de la jurisdicció ordinària $^{236}$. Així mateix, es remet al procediment judicial en els supòsits en què els estatuts no continguen cap disposició quant a conflictes, o quan no s'haja adoptat cap decisió sobre la controvèrsia dins del termini de quaranta dies des que s'haguera cursat la sol-licitud.

\footnotetext{
${ }^{225}$ SNAITH, I., «U. K. co-operative legislation...», op. cit., pág. 166. SNAITH, I., «U. K. co-operative legislation...», op. cit., pág. 166.
} 
La decisió que recaiga, ja siga mitjançant el procediment previst estatutàriament, ja siga mitjançant la resolució del registrador, serà obligatòria $\mathrm{i}$ concloent per a totes les parts, sense que siga possible un recurs davant de cap tribunal de justícia; ben al contrari, se'n pot sol-licitar l'execució judicial.

En tot cas, el principi general que regeix en el dret anglès és el formulat pel cas Foss vs. Harbottle $e^{237}$, que consagra la sobirania dels acords adoptats per cada òrgan social, sobre la base del dret de la majoria a dirigir la societat ${ }^{238}$ segons la seua apreciació del que haja d'entendre's en cada moment per interès social ${ }^{239}$. El soci, llevat de supòsits extraordinaris, no té legitimació per reclamar el dany ocasionat a la societat, ja que són els administradors els legitimats per actuar en nom seu ${ }^{240}$.

${ }^{27}$ HOLLINGTON, R., Minority shareholders 'rights , op. cit., pàg. 15 a 18; SNAITH, I., «U. K. cooperative legislation...», op. cit., pág. 165.

${ }^{228}$ CHARLESWORTH \& MORSE, Company Law, 16a ed., Sweet \& Maxwell, Londres, 1999, pàg. 302 i 306 a 308; HOLLINGTON, Robin, Minority shareholders'rights, 3a ed., Sweet \& Maxwell, Londres, 1999, pàg. 16: "La major part de les formulacions clàssiques de "la regla Foss vs. Harbottle" i les seues excepcions emfasitzen la qüestió òbvia que una acció derivativa no hauria d'estar permesa si la majoria pot ratificar o substituir l'acord objecte de l'acció derivativa. Aquestes formulacions poden ser útils en casos en què és clar que la majoria pot, o bé que no pot, ratificar l'acord: per exemple en casos en què els directors han actuat trencant els requisits processals en els quals la ratificació és permesa, i casos en què els directors han actuat ultra vires, en què la ratificació no és possible almenys per majoria simple", però "hi ha una diferència nítida entre la ratificació d'una transacció injusta, que pot no ser permissible, i una decisió de no iniciar una acció respecte d'aquella transacció, cosa que pot ser permissible si és acceptada per accionistes independents: vegeu Knox J. en Smith vs. Croft (no. 2). Les formulacions clàssiques poden, per tant, ser errònies. [...] Una formulació moderna de la regla i de les seues excepcions [...] pot trobar-se en la sentència del Tribunal d'apel-lació en Prudential Assurance vs. Newman Industries (no. 2) [...] [1982] Ch. 204 en 210 F-211B".

${ }^{239}$ CHARLeSWORTH \& MORSE, Company Law, op. cit., pàg. 305, Re Swindon Town Football Club Ltd, [1990], B.C.L.C. 467: "La companyia està legitimada per deliberar sobre acords conformes amb la llei, però imprudents, i si ho considera oportú, aprovar-los, i el Tribunal no està facultat per manifestar a la companyia que aquells no haurien de ser erronis". HollingTON, R., Minority shareholders 'rights, op. cit., pàg. 8 i 9: "(i) Clarament, l'equitat no justifica la intervenció pel Tribunal merament perquè la minoria al-legue que la valoració comercial de la majoria és errònia o fins $i$ tot manifestament errònia: els tribunals no estan autoritzats a intervenir com assessors comercials. (ii) Els tribunals no han d'intervenir merament perquè s'al-legue que la majoria té un interès personal en la matèria de l'acord", i cita a més l'opinió de Sir Richard Baggallay en North-West Transportation Co. Ltd. vs. Beatty [1887] 12 Ap. Cas. 589, aplicat en altres assumptes més recents [1990, 1994, 1998].

${ }^{240}$ Díaz De LezCANo SeVILlano, N, Los acuerdos del consejo..., op. cit., pàg. 76 i 77; Hollington, R., Minority shareholders 'rights , op. cit., pàg. 15. 
Excepcionalment, el principi no s'aplica quan no s'han observat les normes específiques per a l'adopció de l'acord ${ }^{241}$, quan es vulneren drets subjectius de l'accionista $^{242}$ i quan es produeix frau a la minoria ${ }^{243}$, és a dir, els casos d'expropiació de la propietat social (la majoria s'apropia dels avantatges d'un bé social) $)^{244}$ o aquells en què la majoria no adopta els acords pensant en el benefici de la societat ${ }^{245}$. En aquests casos, el soci, mitjançant una acció derivativa ${ }^{246}$ o representativa $a^{247}$, pot sol-licitar una declaration o injunction i, si escau, l'adopció pel tribunal d'altres mesures, com ara la regulació del funcionament de l'òrgan, l'adquisició per la societat o per la majoria de les accions dels perjudicats $^{248} \mathrm{o}$, fins i tot, la liquidació de la societat ${ }^{249}$.

${ }^{241}$ CHARLESWORTH \& MORSE, Company Law, op. cit., pàg. 311 i 312.

${ }^{212}$ CHARLESWORTH \& MORSE, Company Law, op. cit., pàg. 314 i 315.

${ }^{203}$ CHARLESWORTH \& MORSE, Company Law, op. cit., pàg. 309 a 311.

${ }^{24}$ CHARLESWORTH \& MORSE, Company Law, op. cit., pàg. 303, Menier vs. Hooper 's Telegraph Works; HolLINGTON, R., Minority shareholders' rights , op. cit., pàg. 11 i 12, Dafen Tinplate Co. Ltd. vs. Llanelly Steel Co. Ltd. [1920] 2 Ch. 124, i cita altres casos més recents, com Gambotto vs. WCP [1995] 13 A.C.L.C. 342.

${ }^{2.5}$ CHARLESWORTH \& MORSE, Company Law, op. cit., pàg. 304 i 305.

${ }^{246}$ HollingtON, R., Minority shareholders 'rights , op. cit., pàg. 15.

${ }^{207}$ CHARLESWORTH \& MORSE, Company Law, op. cit., pàg. 308 i 309: "és a dir, el dret a demandar deriva del de la companyia. Els accionistes com a tals no hi tenen dret. Si els seus drets personals estan sent infringits, han d'entaular una acció representativa, post. La naturalesa de l'acció derivativa és que és un «artifici processal que permet al Tribunal fer justícia en una companyia controlada per directors o accionistes deshonestos» [...] També porta la seua causa de la naturalesa de l'acció derivativa el fet que, si la companyia, mitjançant els seus directors o els seus accionistes majoritaris, no té dret a entaular una acció, cap acció pot ser permesa. Una minoria d'accionistes no pot tenir més dret que la companyia si aquesta fóra la demandant".

24a CHARLESWORTH \& MORSE, Company Law, op. cit., pàg. 330 a 332.

2.6. Díaz de LezCANO SeVILlano, N., Los acuerdos del consejo..., op. cit., pàg. 77; CHARLESWORTH \& MORSE, Company Lazv, op. cit., pàg. 306, on s'indiquen altres mesures previstes en les normes legals per a situacions específiques; en pàg. 315 a 320, desenvolupa el procediment per a la liquidació de la societat; en pàg. 320 a 333, s'exposen altres "remeis alternatius".

SNAITH, I., "U. K. co-operative legislation...", op. cit., pàg. 165 i 166, estima, però, que serà difícil aplicar aquestes accions a les cooperatives $\mathrm{i}$ que aquesta és una de les raons que fa altament recomanable reformar la legislació aplicable a les cooperatives al Regne Unit. 
A la República de Portugal, com ja s'ha esmentat, la Constitució mateixa recull expressament la voluntat de foment del cooperativisme, i ho fa reconeixent el sector cooperatiu com un dels tres sectors de propietat dels mitjans de producció, al mateix nivell, per tant, que el sector públic i el sector privat ${ }^{250}$. Com a expressió d'aquest principi constitucional i de les propostes històriques del cooperativisme portuguès, es va promulgar el 1980 el Código cooperativo, substituït per un nou text mitjançant la Llei 51/1996, que va entrar en vigor al gener del 1997.

Aquest text legislatiu general es veu complementat per diverses normes reguladores dels diferents "rams del sector cooperatiu"251; a més, l'article 9 estableix que, com a dret subsidiari "per aclarir les llacunes (...) que no es puguen resoldre pel recurs a la legislació complementària (...), es pot recórrer, en la mesura que no siga contrària als principis cooperatius, al Código das sociedades comerciais, en particular als preceptes aplicables a les societats anònimes".

${ }^{250}$ En realitat, després de les reformes constitucionals del 1989 i del 1997, l'actual "sector cooperatiu i social" previst en l'article 82 de la Constitució de la República Portuguesa comprèn quatre subsectors: el cooperatiu, que inclou "els mitjans de producció tinguts i gestionats per cooperatives en compliment dels principis cooperatius" (article 82.4, a), i els subsectors comunitari, autogestionari i solidari.

La importància $\mathrm{i}$ amplitud del reconeixement constitucional portuguès del cooperativisme ha estat destacat per diversos autors. Poden veure's, entre altres, els comentaris de MONTOLfo HERNÁNDEZ, J. M., Legislación cooperativa en la Comunidad europea, op. cit., pàg. 401 a 404; i de NAMORADO, R., Introdução ao direito cooperativo, op. cit. L'extens estudi d'aquest últim adopta una perspectiva especial, ja que és un dels principals responsables de l'actual redacció del text constitucional en matèria cooperativa, així com coordinador del grup de treball que va elaborar el projecte del Código cooperativo vigent.

${ }^{251}$ Vegeu l'article 4 del CCP. En la traducció anotada elaborada per FAJARDO GARCtA, I. G., publicada en el núm. 10 de la Revista Jurídica d'Economia Social $i$ Cooperativa de CIRIEC-Espanya, pàg. 455 a 477, poden trobar-se, en pàg. 456, nota 2 , les referències d'aquestes disposicions complementàries.

Els textos poden veure's en MONTOLf́O HERNÁNDEZ, J. M., Legislación cooperativa en la Comunidad europea, op. cit., pàg. 1058 a 1111; en pàg. 405: "Per [...] raons [...] d'especialitat, rang normatiu i posterioritat, resulta incontestable que la regulació d'aquestes normes específiques prevaldrà sobre el Código. Ara bé, d'ordinari, aquesta normativa de "ram" o classe es veurà limitada a aspectes del tot concrets, amb la qual cosa en els altres aspectes cobraran plena efectivitat les determinacions d'aquell". 
Així doncs, encara que la doctrina dominant considera que el Codi cooperatiu portuguès consagra implícitament la cooperativa com un "tipus legal autònom de persona col-lectiva" ${ }^{\prime 252}$, s'ha d'acudir a les normes del Codi de societats comercials per als aspectes no regulats per aquell. I això és precisament el que succeeix en matèria d'impugnació d'acords socials.

Efectivament, encara que el Código cooperativo destina tot el capítol V a la regulació dels òrgans de la cooperativa, les úniques referències a la revisió dels acords que s'hi pot trobar són, d'una banda, la que amb caràcter general es refereix al fet que "contra les decisions de l'assemblea general es pot interposar recurs davant dels tribunals" (article 43.8, secció primera, destinada als principis generals rectors. de tots els òrgans socials); i, d'una altra, la que s'inclou en l'apartat 8 de l'article 37 dedicat a l'exclusió dels socis, que estableix que "sempre es pot recórrer davant dels tribunals contra la decisió de l'assemblea general que en determine l'exclusió".

Es fa necessari doncs recórrer al Código das sociedades comerciais, que en els articles 56 a 62 regula la nul-litat i l'anul-labilitat de les deliberacions dels socis a l'assemblea general, i en els articles 411 i 412 regula la invalidesa de les deliberacions del consell d'administració de la societat anònima.

Es consideren nuls els acords adoptats en assemblea general no convocada, llevat que tots els socis hi estigueren presents o representats ${ }^{253}$; els adoptats per escrit sense que tots els socis amb dret de vot hagueren participat o hagueren

\footnotetext{
${ }^{252}$ NAMORADO, R., Introdução ao direito cooperativo, op. cit., pàg. 313. També GoUvEIA E CÁsSIO, M., "Legislació sobre cooperatives a Portugal», en INSTITUT PER A LA PROMOCIÓ I LA FORMACIÓ COOPERATTVES, Legislació sobre cooperatives als Estats membres de la C.E.E, pàg. 51; MONTOLíO HERNÁNDEZ, J. M., Legislación cooperativa en la Comunidad europea, op. cit., pàg. 398 a $401 ; \mathrm{i}$ SALAZAR LEITE, J. «Sobre o Código cooperativo...», op. cit., pàg. 158 i 166. total de convocatòria, a la qual s'equipara la convocatòria per qui no té competència, la falta la convocatòria".
} 
estat convidats a fer-ho ${ }^{254}$; els acords el contingut dels quals no siga competència de l'assemblea, $\mathrm{i}$ aquells el contingut dels quals siga contrari als bons costums o a preceptes legals imperatius ${ }^{255}$. Seran anul-lables els acords que violen normes legals no imperatives o preceptes estatutaris; els que "siguen apropiats per satisfer el propòsit" de socis que hagen exercitat el seu dret de vot per aconseguir avantatges especials per a si o per a tercers en perjudici de la societat o d'altres socis, o simplement per perjudicar-los, llevat que es prove que els seus vots no han estat determinants per a l'adopció de l'acord ${ }^{256}$, i els acords "no precedits del subministrament al soci d'elements mínims d'informació"; a més, l'article 69 també estableix l'anul-labilitat d'acords que violen preceptes legals relatius a l'elaboració dels comptes socials. Així doncs, el règim general d'invalidesa serà el de l'anul-labilitat, i només en els casos més greus, taxativament previstos, els acords seran nuls ${ }^{257}$.

L'acció de nul-litat pot ser promoguda en tot moment, per qualsevol interessat o per l'òrgan de control, a qui el CSC (article 57) atribueix deures especials de diligència en relació amb la nul-litat ${ }^{258}$. L'acció d'anul-lació pot estar proposada

\footnotetext{
${ }^{254}$ PEREIRA DE AlmeIdA, A., Sociedades comerciais, op. cit., pàg. 86 i 87 , qualifica aquests dos primers supòsits de "vicis de formació", i no els considera "nul-litats pures", ja que, segons el que preveu l'apartat 3 de l'article 56 CSC, admeten confirmació d'esmena del vici.

${ }^{255}$ PEREIRA DE ALMEIDA, A., Sociedades comerciais, op. cit., pàg. 88 , indica que no n'hi ha prou que l'acord viole una disposició legal imperativa, ja que cal que es tracte d'una disposició “d'ordre públic i que no puga ser obviada, ni tan sols, per voluntat unànime dels socis. Estan en aquest últim cas les normes que intenten protegir interessos de tercers, creditors i del públic en general".
}

${ }^{256}$ PeREIRA DE AlmEIDA, A., Sociedades comerciais, op. cit., pàg. 90: "la llei no exigeix la prova de l'element subjectiu intencional per a l'anul-labilitat de l'acord abusiu; $n$ 'hi ha prou que aquest "siga adequat per satisfer el propòsit". A més, l'article 58.3 estableix la responsabilitat solidària dels socis majoritaris pels perjudicis causats davant la societat i a la resta de socis.

257 PEREIRA DE ALMEIDA, A., Societats comerciais, op. cit., pàg. 85; en nota 95, recull, a més jurisprudència i doctrina sobre acords considerats inexistents quan "no es verifiquen els requisits necessaris mínims perquè puga ser jurídicament eficaç de manera que vincule la societat, o quan no siga adequat, ni tan sols en l'aparença material, per responsabilitzar la societat".

${ }^{25 \times}$ L'òrgan de control (o si no n'hi ha, qualsevol gerent) ha de donar a conèixer a l'assemblea general la nul-litat; en defecte d'actuació dels socis o de la societat, ha de promoure la declaració de nul-litat, i proposar al tribunal el nomenament de representant de la societat en l'acció judicial. 
per qualsevol soci que no haguera votat en el sentit de l'acord ni ho haguera aprovat posteriorment, expressament o tàcita (article 59.1), o per l'òrgan de control. Ambdues accions es dirigeixen contra la societat, i no depenen de l'aprovació de l'acta de la sessió; a més el soci pot invocar la impossibilitat d'obtenir-la i requerir-ne la presentació al tribunal. El CSC regula també, entre altres aspectes, la possibilitat de sol-licitar la suspensió de l'acord, i la de renovar els acords socials invàlids, amb efectes retroactius ${ }^{259}$.

Pel que fa als acords del consell d'administració, també la regla general és la de l'anul-labilitat dels que violen la llei o els estatuts socials, de manera que són nuls únicament aquells supòsits expressament previstos en l'apartat 1 de l'article 411 CSC: acords adoptats en consell no convocat, llevat que tots els administradors hi estigueren presents o representats o que, quan els estatuts ho permeten, que hagueren votat per correspondència; acords el contingut dels quals no siga competència del consell, $\mathrm{i}$ acords el contingut dels quals vulnere els bons costums o preceptes legals imperatius.

Els acords nuls poden ser substituïts per acords de l'assemblea, llevat que es referisquen a matèries de competència exclusiva del consell; els acords anul-lables poden ser ratificats per l'assemblea general. També per als acords del consell estableix el CSC un deure especial de diligència, aquesta vegada sobre els administradors, en exigir-los que no executen o consenten que siguen executats els acords nuls; en canvi, poden executar acords anul.lables mentre no se'n declare l'anul-lació o siguen suspesos ${ }^{260}$.

\footnotetext{
${ }^{259}$ PEREIRA DE ALMEIDA, A., Sociedades comerciais, op. cit., pàg. 94: "Naturalment que en els acords nuls per vici de contingut la renovació no és possible, ja que, en tractar-se de preceptes d'ordre i interessos públics, la nova deliberació de contingut idèntic patiria sempre dels mateixos vicis. D'altra banda, els acords anul-lables també poden ser substituïts per noves deliberacions, no viciades amb efectes retroactius (article 62, núm. 2) [...]. Això no obstant, el soci que tinguera un interès atendible, pot, així mateix, obtenir l'anul-lació del primer acord en relació amb el període anterior a l'acord renovador".
}

\footnotetext{
${ }^{260}$ Difaz DE Lezcano Sevillano, N., Los acuerdos del consejo..., op. cit., pàg. 70: "Tanmateix, l'administrador, des que conega la causa d'anul-labilitat, haurà de promoure'n la declaració d'ineficàcia sense arribar a executar-la per evitar els perjudicis que la declaració puga ocasionar"; PEREIRA DE AlMEIDA, A., Sociedades comerciais, op. cit., pàg. 251.
} 
La diferència essencial entre la invalidesa dels acords del consell i els de l'assemblea rau en el procediment especial establert per a aquell, que suposa una novetat absoluta en l'àmbit de les societats mercantils, però que, com veurem, té l'equivalent en l'àmbit cooperatiu espanyol. En efecte, la competència, en primera instància, per declarar la nul-litat o l'anul-lació $\mathrm{d}^{\prime}$ acords del consell recau en el consell mateix o en $\mathrm{l}^{\prime}$ assemblea general ${ }^{261}$ i no en els tribunals de justícia. Estan legitimats per sol-licitar-les qualsevol administrador, el consell fiscal o qualsevol accionista amb dret de vot.

Sobre l'establiment de l'esmentat règim d'impugnació intern, extrajudicial, s'hi han elaborat diverses fonamentacions. D'una banda, s'ha justificat al caràcter essencialment executiu de l'òrgan d'administració, cosa que porta alguns autors a concloure que els seus acords tenen "transcendència merament intrasocietària" ${ }^{\prime 262}$. D'altres, davant de l'indubtable risc per al principi constitucional del dret a la tutela judicial ${ }^{263}$, estimen que "serà possible, això no obstant, sempre acció judicial davant l'acord de l'assemblea general que substituïsca o ratifique un acord del consell amb vicis de contingut" ${ }^{264}$; però aquesta proposta deixa sense resoldre els supòsits en què s'haja instat la impugnació davant del consell mateix. A parer nostre, el règim intern d'impugnació d'acords socials no ha d'impedir la possibilitat alternativa que el soci recórrega als tribunals de justícia, ja siga davant la resolució orgànica

${ }^{261}$ DíAZ DE LEZCANO SEVILLANO, N., Los acuerdos del consejo..., op. cit., pàg. 69, assenyala que no hi ha una prioritat competencial entre ambdós òrgans, "la persona legitimada per impugnar l'acord pot dirigir-se a un o un altre òrgan social". També es refereix al règim d'impugnació intern dels acords del consell d'administració portuguès, SÁNCHEZ CALERO, F., Administradores ..., op. cit., pàg. 534.

${ }^{2 \kappa 2}$ AlCALÁ DÍAZ, M. A. La impugnación..., op. cit., pàg. 59.

${ }^{263}$ DíAZ DE LEZCANO SEVILlANO, N., Los acuerdos del consejo..., op. cit., pàg. 70, en nota 157, recull l'opinió de VENTURA (Estudos vários sobre sociedades anónimas, Coïmbra, 1992, pàg. 558 i 559), en el sentit que l'absoluta falta de menció als tribunals de justícia, no pot interpretar-se com incompetència d'aquests, ja que això podria atemptar principis constitucionals, per la qual cosa "és preferible entendre que l'Assemblea i el Consell d'Administració tenen aquesta competència per raons pràctiques, però sense exclusió de les competències dels tribunals". 
desfavorable, ja siga constant el termini per al recurs intern. Hi tornarem quan analitzem els recursos interns en la cooperativa ${ }^{265}$

\subsection{Legislació cooperativa de $1^{\prime}$ Estat espanyol}

La legislació cooperativa a l'Estat espanyol reflecteix, com poques, les vicissituds socials i polítiques del segle $\mathrm{i}$ mig en què s'ha desplegat ${ }^{266}$. Són precisament els grans canvis polítics els que sol utilitzar la doctrina per establir les diferents etapes en l'evolució de la regulació de les cooperatives ${ }^{267}$. A l'efecte de la matèria concreta que ens ocupa, les modificacions més importants en la legislació cooperativa es poden reconduir a tres grans períodes.

En una primera etapa, els textos legislatius comencen a esmentar les cooperatives $i$ es fan intents successius d'ubicar-les normativament, intents que culminen amb la promulgació, el 1931, de la primera Llei de cooperatives de l'Estat espanyol.

La segona etapa comprèn tot el període franquista de l'organització de l'Estat espanyol, i s'hi poden observar dues fases clarament diferenciades: en la primera, la preocupació fonamental rau a sotmetre el fenomen cooperatiu a la jerarquia nacionalsindicalista; en la segona, ja en les últimes dècades del règim,

${ }^{2 \times 5}$ Vegeu el capítol tercer, epígraf 2.2.1.

${ }^{2 \star s}$ VICENT CHULIÁ, F., «El accidentado desarrollo...», op. cit., pàg. 1226 i 1227, i en «La Ley 27/1999 de 16 de julio de Cooperativas Estatal», RGD, núm. 663, 1999, pàg. 14561.

\footnotetext{
${ }^{2 \pi}$ Poden veure's comentaris comparats de les diferents normes reguladores de les cooperatives a l'Estat espanyol en ALFONSO SÁNCHEZ, R., La integración cooperativa..., op. cit., pàg. 327 a 349 ; FAJARDO GARCfA, Isabel-Gemma, «El derecho cooperativo en España: incidencia de la Constitución de 1978» , CIRIEC-España, núm. 11, octubre 1991, en pàg. 12 a 15; GADEA, E., Evolución de la legislación cooperativa..., op. cit.; LLOBREGAT HURTADO, M. L., Mutualidad y empresas cooperativas, op. cit., pàg. 93 a 138; LLUIS Y NAVAS, Jaime, "La evolución de las directrices fundamentales de la legislación cooperativa española (1931-1975)", en Estudios Cooperativos, núms. 36-37-38, maig 1975/abril 1976, pàg. 3 a 39; PANIAGUA ZURERA, M., Mutualidad y lucro..., op. cit., pàg. 135 a 192; SÁNCHEZ CALERO, F., «Los conceptos...», op. cit., pàg. 493 a 523, especialment en pàg. 496 a 500; VICENT CHULIÁ, F., "Análisis crítico...»,op. cit.,
pàg. 465 i 466 .
} 
es produeixen diverses reformes que tendeixen a adaptar la legislació cooperativa a una realitat marcada pel desenvolupament econòmic i l'obertura política.

La tercera etapa, que s'obri amb la promulgació de la Constitució del 1978, comprèn dos períodes ${ }^{268}$, marcats ambdós pel debat doctrinal i jurisprudencial al voltant de la independència possible de la legislació cooperativa respecte de la mercantil, i a l'atribució d'aquesta competència a l'Estat o a les comunitats autònomes.

\subsubsection{Evolució històrica. L'estat de les autonomies i les cooperatives. Conflicte de competències}

En l'etapa inicial del desenvolupament de la regulació jurídica de les cooperatives a l'Estat espanyol, els primers textos que les esmenten es limiten a reconèixer-ne l'existència, sense atribuir-los un règim jurídic propi, o bé a regular determinats tipus de cooperatives i altres "ens de dubtós perfil jurídic amb vocació cooperativista" ${ }^{269}:$ sindicats agrícoles, pòsits, sindicats industrials i mercantils, cases barates, etc.

El ben cert és que en aquest moment inicial s'opta, amb caràcter general, per sotmetre les cooperatives a la Llei d'associacions de 30 de juny de 1887 (Gaseta de 12.7), amb una regulació clarament insuficient. Així, en matèria orgànica,

${ }^{26 *}$ LLOBREGAT HURTADO, M. Luisa, "La reforma de la legislación cooperativa», RdS, 1994, núm. 2, pàg. 146 i 147: "El que s'ha anomenat "segona reforma de les cooperatives» s'havia produit tant en l'àmbit estatal, amb la Llei general de Cooperatives de 2 d'abril de 1987, com en l'àmbit de les comunitats autònomes", però "les transformacions econòmiques dels últims anys, la crisi econòmica i l'agosarat esforç dut a terme en aquest sector per conciliar l'estructura jurídica i funcional de les cooperatives amb l'absència de capital-risc suficient, la major dificultat d'accés d'aquestes societats a la informació, així com la necessitat d'adaptar-se a la legislació comunitària, a un mercat cada vegada més competitiu i a les innovacions tecnològiques $i$ financeres que els temps exigeixen, han obert un nou procés de reforma promogut aquesta vegada pels mitjans cooperatius mateixos". 
s'exigeix únicament l'expressió estatutària de "la forma de la seua administració o govern", i en punt a l'"adquisició, possessió i disposició dels seus béns, per al cas de dissolució" les subjecta "a allò que disposen les lleis civils respecte a la propietat col-lectiva ${ }^{270}$.

D'altra banda, el Codi de comerç de 1885 conté dues úniques mencions explícites a les cooperatives, ambdues en el sentit d'excloure-les amb caràcter general del seu àmbit. Així, l'exposició de motius manifesta que el Codi comprèn totes les societats que es consideren mercantils, $i$ no ha atribuït aquest caràcter a les mútues ni a les cooperatives ${ }^{271}$. L'altra menció és la de l'article 124, en el qual s'estableix que "Les companyies mútues d'assegurances d'incendis, de combinacions tontines sobre la vida per a ajuts a la vellesa i de qualsevol altra classe, i les cooperatives de producció, de crèdit o de consum, només es consideraran mercantils i quedaran subjectes a les disposicions d'aquest Codi quan es dedicaren a actes de comerç estranys a la mutualitat o es convertiren en societats a prima fixa". Es manifesta, doncs, una clara voluntat del codificador de 1885 d'excloure les cooperatives de l'àmbit de la mercantilitat ${ }^{272}$, partint del

${ }^{200}$ VICENT CHULIÁ, F., "Análisis crítico...»,op. cit., pàg. 459, assenyala com ni tan sols en aquest
moment inicial era satisfactòria la qualificació de les cooperatives com a associacions, "ja que el
que es feia era estendre'ls el règim general del dret d'associació i no encaixar-les dins d'una
institució hipotètica denominada "associació" que encara no havia rebut regulació legal". En el
mateix sentit, SÁNCHEZ CALERO, F., "Los conceptos...», op. cit., pàg. 497: "la Llei d'Associacions
de 1887 [...] s'ocupa de l'aspecte polític de l'exercici del dret d'associació i estableix controls
governatius [...]. Però no regula, perquè no era la seua missió, el règim jurídic que exigeix la
realitat econòmica del fenomen cooperativista". 2

d'No ha atribuït aquest caràcter a les associacions mútues perquè hi falta l'esperit d'especulació, que és incompatible amb aquestes societats, ni les cooperatives, perquè obeeixen, abans que res, la tendència manifestada a les poblacions fabrils del nostre país, i principalment a les d'Alemanya, Anglaterra i França, d'associar-se els obrers amb l'única finalitat de millorar la condició de cada un, facilitant-los els mitjans per a treballar, de donar eixida als seus productes o d'obtenir barats els articles necessaris per a la seua subsistència. I com que no és l'afany de lucre el que impulsa el que s'anomena moviment cooperatiu, no poden reputar-se com a mercantils aquestes societats mentre no resulte clarament dels seus estatuts o de l'exercici habitual d'alguns actes de comerç que mereixen aquella denominació. Per això no s'ha ocupat el Projecte de l'ordenació d'aquestes manifestacions de l'associació, perquè considera que en tot cas quedaran emparades per la legislació general de societats, que no pot ser més àmplia, ja que dins caben i són possibles totes les formes que exigisca el progrés comercial dels temps

Lla I això, en contradicció oberta amb el que preveu l'exposició de motius i la base cinquena de la
Llei de bases del codi, que requerien l'ampliació de la regulació dels contractes de companyies 
si de l'article 124 del Cco podia encara deduir-se que era possible l'existència de cooperatives mercantils ("quan es dedicaren a actes de comerç estranys a la mutualitat"), l'article 45 de la LCoop de 1931 establia la desqualificació d'aquelles que, encara que compliren externament els requisits corresponents a les de la seua classe, encaminaren "el seu funcionament a servir o realitzar qualsevol combinació lucrativa" ${ }^{280}$.

Això no obstant, el seu acceptable nivell general de tècnica jurídica, la Llei de 1931 conté escasses referències al funcionament orgànic ${ }^{281}$ llevat de la necessitat de fixar estatutàriament el "règim d'administració i govern", l'existència, sempre, d'assemblea general i de junta directiva, i en algunes cooperatives d'una comissió d'inspecció de comptes. No s'hi fa referència en absolut a possibles procediments d'impugnació d'acords, però sí que hi ha un antecedent del que més tard es denominarà "recurs intern", o "segona instància cooperativa $^{\prime 282}$.

279 ALFONSO SÁNCHEZ, R., La integración cooperativa..., op. cit., pàg. 329, nota 3; LLOBREGAT HURTADO, M. L., Mutualidad y empresas cooperativas, op. cit., pàg. 98 i 99.

${ }^{2 \times 0}$ En definitiva, "aquelles condicions que segons l'article 124 del Codi de Comerç porten a la qualificació de mercantil de la cooperació, són les que, d'acord amb la Llei especial, donen lloc que els siga retirada la qualificació de cooperatives" (POLO DíEZ, Antonio, Misión y sentido de la nueva Ley de cooperación, RDPri, núms. 302 i 303, abril i maig 1942). En contra, PANIAGUA ZURERA, M., Mutualidad y lucro..., op. cit., pàg. 138 a 141, que nega l'existència d'una relació "dialèctica" entre mutualitat i absència d'ànim de lucre, i estima que l'article 124 Cco es limita a establir un "criteri de mercantilitat desafortunat" de les cooperatives: que realitzen actes de comerç estranys a la mutualitat, això és, operacions cooperativitzades amb tercers, per la qual cosa "només quan les cooperatives desenvolupen de manera habitual actes de comerç amb tercers no socis, es considera legalment que les societats són mercantils".

${ }^{281}$ GADEA, E., Evolución de la legislación..., op. cit., pàg. 50, i Derecho de las cooperativas..., op. cit., pàg. 156; LlOBREGAT HURTADO, M. L., Mutualidad y empresas cooperativas , op. cit., pàg. 100: "[...] caràcter boirós amb què es delimiten les competències funcionals dels diferents òrgans $\mathrm{i}$ l'atribució, amb caràcter residual, d'un poder gairebé absolut a l'Assemblea de socis"...; PANIAGUA ZURERA, M., Mutualidad y lucro..., op. cit., pàg. 146.

2\$2 Article 15: "Les designacions per a les Juntes o Consells directius i Comissions especials i tota mena d'autoritzacions i mandats per actuar en nom de la societat seran revocables per acord de l'Assemblea general, sense que puga prevaler-hi pacte en contrari". Sobre la "segona instància cooperativa", vegeu infra, epígraf 2.2.1 del capítol tercer. 
L'etapa "autoritària" ${ }^{223}$ de la legislació cooperativa comença, com és sabut, amb la instauració del règim nacionalsindicalista. En l'àmbit de la legislació cooperativa això es tradueix en la promulgació de diverses normes que tenen com a finalitat la integració del moviment cooperatiu en l'estructura jeràrquica de l'organització sindical ${ }^{284}$. La primera d'aquestes, la Llei de cooperació del $1938^{225}$, dictada en plena Guerra Civil, es va promulgar amb l'objectiu explícit $\mathrm{d}^{\prime \prime \prime}$ esborrar l'empremta liberal, democràtica i socialitzant que caracteritzava la Llei del 1931, per substituir-la per una concepció totalitària i jeràrquica de la cooperació, més concorde amb les directrius polítiques del nou Estat ${ }^{\prime 286}$. En matèria d'òrgans socials s'introdueixen canvis radicals: les cooperatives passen a regir-se per una Direcció integrada pel cap i la junta rectora, elegits un i una altra per l'assemblea general. Les vertaderes facultats executives rauen únicament en el cap, mentre que en la Junta recauen les facultats merament assessores. A més, l'intervencionisme estatal es porta a la seua màxima expressió, en disposar que el ministre d'Organització i Acció Sindical podrà destituir o vetar qualsevol nomenament de cap de l'entitat ${ }^{287}$.

${ }^{20}$ PANIAGUA ZURERA, M., Mutualidad y lucro..., op. cit.

${ }^{24}$ AA. DD., La legislación cooperativa en España. Análisis comparado, (dir., J. A. GALINDO BUENO), Universitat Politècnica de València, València, 1991, pàg. 132: "El nou règim promulgarà la Llei de cooperació de 27 d'octubre de 1938 inspirada en la ideologia nacionalsocialista, l'objectiu de la qual era enquadrar i integrar tots els moviments socials en una organització vertical. Amb la Llei d'unitat sindical de 26 de gener de 1940 i la Llei de 2 de setembre de 1940 es dóna el colp definitiu i es consigna la plasmació de l'objectiu integrador. Fruit de la consolidació de la concepció nacionalsindicalista és la Llei de cooperatives de 2 de gener de 1942 i el seu Reglament d'11 de novembre de 1943".

${ }^{20}$ Llei de 27 d'octubre de 1938 (BOE núm. 132, de 9.9).

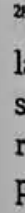

${ }^{204}$ Polo DfEZ, A., Misión y sentido..., op. cit., pàg. 217 i 218. LLUIS Y NAVAS, J., «La evolución de las directrices...”, op. cit., pàg. 4: "Obeïa a un problema polític: en sancionar-se el sistema de sindicats únics corporatius, es va témer amb raó que les cooperatives foren un vehicle per restaurar sindicats privats de fet que el sistema corporatiu del nou estat repudiava. D'ací a títol preventiu la idea de la vinculació col-laboradora de les cooperatives al Sindicalisme oficial".

${ }^{20}$ AA. DD., Manual de derecho cooperativo..., op. cit., pàg. 36. 
En tot cas, es tractava d'una llei de transició cap a una regulació més estable que es va concretar en la Llei de cooperació del $1942^{288} \mathrm{i}$ en el primer Reglamen de desenvolupament ${ }^{289}$. No es dedica molta atenció en aquestes normes l'estructura orgànica: es manté l'obligació de fixar estatutàriament el "règim de gestió i representació"; al costat dels òrgans necessaris en tot cas (junta general junta rectora) s'incorpora el consell de vigilància; $i$ continua sense fer-se referència a possibles procediments d'impugnació d'acords; desapareix è "recurs intern" o "segona instància cooperativa", que preveia la Llei de 1931 per a alguns acords. Això no obstant, el Reglament inicia un cert desenvolupament normatiu del funcionament dels òrgans en el capítol III del títol primer.

La major part dels autors coincideixen a constatar, a partir dels últims anys de la dècada dels seixanta, intents progressius d'adequació del règim jurídic cooperatiu als canvis econòmics i socials que havien de portar l'Estat espanyol a un règim polític de democràcia formal i a una economia de mercat homologables amb els estats de l'Europa occidental. Una de les primeres manifestacions d'aquests impulsos se situa en la promulgació d'un nou Reglament de cooperació el $1971^{290}$, però hi inclou també la del primer Estatut

${ }^{2 \times 8}$ La Llei de cooperació, de 2 de gener de 1942, ha estat diversament comentada. Vegeu AA.
DD., Manual de derecho cooperativo..., op. cit., pàg. 36 a 44 ; ALFONSO SÁNCHEZ, R., La integración
cooperativa..., op. cit., pàg. 330 a 332 ; GADEA, E., Evolución de la legislación..., op. cit., pàg. 67 a 80 i
Derecho de las cooperativas..., op. cit. ; LLOBREGAT HURTADO, M. L., Mutualidad y empresas
cooperativas, op. cit., pàg. 100 a 102; PANIAGUA ZURERA, M., Mutualidad y lucro..., op. cit., pàg. 149
a 153 , amb una àmplia ressenya bibliogràfica, en nota 187 ; POLO DfEZ, A., Misión y sentido..., op.
cit.; VERGEZ SANCHEZ, M., El derecho de las cooperativas..., op. cit., pàg. 27 a 32 , que es refereix a la
despreocupació, tant en la Llei com en el Reglament, per la "vida orgànica" de la cooperativa;
VICENT CHULIÁ, F., "Análisis crítico...", op. cit., pàg. $467 \mathrm{i} 468$.

${ }^{289}$ Decret d'11 de novembre de 1943 (BOE núm. 55, de 24.2.1944), modificat per "una extensa $i$ atípica" correcció d'errades (BOE núm. 76, de 16.13.1944) (PANIAGUA ZURERA, M., Mutualidad y
lucro..., op. cit., pàg. 152).

${ }^{200}$ Decret 2396/1971, de 13 d'agost. AA. DD., La legislación cooperativa en España..., op. cit., pàg. 132 i 133: "Amb l'arribada dels tecnòcrates del Govern i la iniciació dels plans de desenvolupament, comença una nova època. [...] Per decret 888/1969, de 9 de maig, es publica l'Estatut fiscal de les cooperatives i, com a norma pont fins a la promulgació d'una nova llei, 1943". Aquesta última norma intenta, efectivacret 2396/1971, de 13 d'agost, que deroga el del cooperatives, adaptant-les a la importància econòmica ina nova etapa en la regulació de les dotant-les d'unes regles tècnicament més depurades i atenuant la ses anaven adquirint, 
fiscal de les cooperatives ${ }^{291}$, la Llei general de cooperatives de $1974^{292}$ i el seu Reglament d'aplicació ${ }^{293}$.

La Llei general de cooperatives del 1974 és la primera norma cooperativa de l'Estat espanyol que, sota el títol de "revisió d'acords socials", estableix un procediment per a la impugnació dels acords socials (article 27), seguint el model de la LSA de 1951, si bé amb la introducció d'innovacions, (alguna de les quals no eximeix de crítica, com la que considera nuls, tant els acords contraris a la llei, com els contraris als estatuts socials). També destaca en aquesta Llei la regulació de la figura de la direcció d'una manera extensa (articles 32 a 37) ${ }^{294}$.

l'organització sindical (AA. DD., Manual de derecho cooperativo..., op. cit., pàg. 46). LLUIS Y NAVAS, J., "La evolución de las directrices...", op. cit., pàg. 5.

Una anàlisi extensa del Reglament del 1971 pot veure's en VICENT CHULIÁ, F., "Análisis crítico...", op. cit.; també es comenta el Reglament en VERGEZ SÁNCHEZ, M., El derecho de las cooperativas..., op. cit., pàg. 33 a 58. Ambdós autors troben a faltar una regulació de la impugnació dels acords socials, en la línia del que ja es preveia en la LSA de 1951 (VICENT CHULIA, F., "Análisis crítico...», op. cit., en pàg. 489 i 490; VERGEZ SÁNCHEZ, M., El derecho de las cooperativas..., op. cit., pàg. 41, nota 50, ), si bé VICENT CHULIÁ, F., (op. cit., pàg. 474) interpreta la menció de l'article 44.3 ("És obligació de la Junta Rectora facilitar als socis la informació a què es refereixen els dos apartats del número anterior. Davant de l'incompliment total o parcial d'aquesta, qualsevol dels socis que haguera sol-licitat aquesta informació pot reclamar davant de la jurisdicció competent") com una al-lusió al dret del soci a impugnar els acords socials. Altres aspectes del Reglament de 1971 es comenten en ALFONSO SÁNCHEZ, R., La integración cooperativa..., op. cit., pàg. 331 i 331; GADEA, E., Evolución de la legislación..., op. cit., pàg. 83 a 98 i Derecho de las cooperativas..., op. cit., pàg. 157 i 158; LlOBREGAT HURTADO, M. L., Mutualidad y empresas cooperativas..., op. cit., pàg. 103 i 104; PANIAGUA ZURERA, M., Mutualidad y lucro..., op.
cit., pàg. 155 a 157.

També es va promulgar en aquesta etapa una normativa específica per a les cooperatives de crèdit, el Reial decret de 3 de novembre de 1978.

Decret 888/1969, de 19 de maig (BOE núm. 114, de 13.5; corr. ee., en BOE de 12.6 i 1.7).

Llei 52/1974, de 19 de desembre, general de cooperatives (BOE núm. 305, de 21.12.1974). cooperativase's comentaris de la Llei en LLOBREGAT HURTADO, M. L., Mutualidad y empresas 157 a 15..., op. cit., pàg. 104 a 112; PANIAGUA ZURERA, M., Mutualidad y lucro..., op. cit., pàg. 197, i PAZ CANALEJO, Narciso, El nuevo derecho cooperativo español, Madrid, 1979.

Reial decret 2710/1978, de 16 de novembre, pel qual s'aprova el Reglament d'aplicació a les de 17 ats cooperatives regulades per la Llei 52/1974, de 19 de desembre (BOE núms. 275 a 277 , de 17 a 20.11.1978).

${ }^{24}$ Una tan detallada regulació porta GADEA, E., Evolución de la legislación..., op. cit., pàg. 110 a el model germàn si la Llei de 1974 no hauria adoptat, a diferència de l'opció de la LSA del 1951, que hi ha ramànic d'òrgan administratiu doble. Això no obstant, l'autor arriba a la conclusió aufsichtsrat ions en la normativa espanyola que impedeixen l'assimilació del consell rector en 
Per la seua banda, el Reglament d'aplicació, com s'ha dit, "en rigor, no és només un desenvolupament normatiu de la Llei de 1974, sinó que recull —de vegades, probablement superant la capacitat pròpia d'una norma d'aquest rang segons la jerarquia de les fonts jurídiques- elements nous, i recull ja els nous principis polítics que es plasmen en la Constitució del $1978^{\prime 295}$. L'excés de capacitat normativa es reflecteix clarament en la matèria de la impugnació d'acords socials, ja que l'article 54, que hauria d'haver-se limitat a desenvolupar el contingut de l'article 27 de la Llei del 1974, regula de manera detalladíssima tot un procés especial, fins llavors inexistent ${ }^{296}$.

En l'etapa constitucional també es donen dos períodes diferenciats. En l'inicial, a l'empara del procés constituent es promulguen cinc lleis cooperatives autonòmiques (les corresponents al País Basc, Catalunya, Andalusia, Comunitat Valenciana i Navarra), la Llei general de cooperatives del $1987^{297}$, la Llei de cooperatives de crèdit del 1988 i el seu Reglament de desenvolupament, i la Llei sobre règim fiscal de les cooperatives.

Posteriorment, en la dècada dels noranta es produeix un procés de reforma generalitzat en la legislació cooperativa, tant autonòmica com estatal, que ha suposat la promulgació de noves lleis de cooperatives en les cinc comunitats autònomes que ja disposaven de norma pròpia, d'una nova llei estatal i, fins a la

${ }^{295}$ AA. DD., Manual de derecho cooperativo, op. cit., pàg. 49. LORCA NAVARRETE, Antonio, "Algunas observaciones procesales sobre la Ley de cooperativas de la comunidad autónoma de Euskadi", RDPri, oct. 1983, pàg. 900, nota 3: "la desincrustació de la cooperació de l'antiga organització sindical es normalitzaria en el nou context democràtic mitjançant el Decret 2710/78, de 16 de novembre, que aprova el Reglament de cooperatives".

${ }^{296}$ LORCA NAVARRETE, A., "Algunas observaciones...», op. cit., pàg. 911.

${ }^{297}$ PANIAGUA ZURERA, M., Mutualidad y lucro..., op. cit., pàg. 179: “abans de la publicació el 1987 de la LGC quatre de les cinc (en aquell moment) comunitats autònomes amb competència exclusiva sobre cooperatives emanen les seues pròpies lleis". Es tractava del País Basc, Catalunya, Andalusia i la Comunitat Valenciana; Navarra, que també tenia competència normativa exclusiva, la va exercir posteriorment a la LGC, el juliol de 1989.

VICENT CHULIÁ, Francisco, en «La Ley General de Cooperativas de 2 de abril de 1987 y las leyes de cooperativas autonómicas", REVESCO, núms. 54-55, 1986-87, pàg. 286, i en «Notas en torno a la Ley General de Cooperativas de 2 de abril de 1987», La Ley, 1987-3, pàg. 6: "s'inverteix l'ordre 
data, de quatre noves lleis autonòmiques a les comunitats d'Extremadura, Galícia, Aragó i Comunitat de Madrid; el canvi es veu propiciat per l'ampliació de l'àmbit competencial de les comunitats autònomes que inicialment no tenien competència normativa en matèria de cooperatives, i pel diferent criteri del Tribunal Constitucional en relació amb l'aplicació supletòria de la legislació estatal.

En la major part d'aquests textos legislatius recents s'observa una tendència cap a la concepció minimalista ${ }^{298}$, amb una aproximació cada vegada més gran a la legislació de les societats de capital ${ }^{299}$ i una preocupació fonamental per l'eficàcia empresarial de la cooperativa que porta, en el terreny normatiu, a la recerca de vies alternatives de finançament ${ }^{300} \mathrm{i}$ a la concentració de poder de decisió en els òrgans d'administració ${ }^{301} 302$.

lògic del procés, que hauria d'haver començat per la Llei estatal o general, per, a partir d'aquesta, els parlaments autònoms haver fet les seues opcions particulars en la matèria".

"MARIN LOPEZ, Juan José, «Notas sobre la Ley 27/1999, de 16 de julio, de cooperativas», Diario La Ley, núm. 4930, 18.11.1999, D-284: "s'introdueix una àmplia dosi de flexibilització del règim jurídic de les cooperatives, "on les cooperatives mateixes puguen entrar a autoregular-se, $\mathrm{i}$ estableix els principis que, amb caràcter general, han de ser aplicats a la seua actuació, fugint del caràcter reglamentista que, en molts aspectes, dificulta l'activitat societària”"

"m Exposició de motius de la Llei 27/1999: “[...] Des de 1989, bona part del dret de societats ha estat modificat per adaptar-lo a les directives europees sobre la matèria. Amb això, s'hi han introduït algunes noves regulacions que sembla molt convenient incorporar també a la legislació cooperativa".

3in És aquesta una preocupació comuna en el sector cooperatiu internacional, sobretot en l'àmbit dels països industrialitzats. Vegeu, per tots, OFICINA INTERNACIONAL DEL TREBALL, Conferència internacional del treball, 89a reunió, 2001. Informe V. Promoció de les cooperatives, Ginebra, 2001, pàg. 87,88 i 94 . També en LÉVESQUE, B., i CÓTÉ, EN, La renovació de les legislacions nacionals..., op. cit., pàg. 16; i MONTOLfo HERNÁNDEZ, José M., "Leyes de cooperativas de las comunidades autónomas: determinación de un modelo", REVESCO, núm. 66, 1998, pàg. 244 i 245.

En relació amb la primera part del procés de reforma legislativa a l'Estat espanyol, vegeu LLOBREGAT HURTADO, M. L., La reforma..., op. cit.. VICENT CHULIA, F., en «La Ley 27/1999...», op. cit., pàg. 14563 i 14564 atribueix el procés de reforma de la dècada dels noranta a un impuls de la societat civil en el sentit de sotmetre a crítica un plantejament anterior "tan exigent en el respecte als principis cooperatius", oposant "els imperatius de la propietat privada i de la necessat d'empresa en la configuració de l'organització corporativa i financera de l'empresa, jurídiques perquè la cooperativa poguera competir en igualtat de condicions amb altres formes pàg. 17 ues d'empresa al mercat". MAŔ́N LOPEZ, J. J., "Notas sobre la Ley 27/1999...», op. cit., pàg. 1798 i 1799, es fa ressò del que l'exposició de motius mateixa de la Llei 27/1999 fa explícit.

\footnotetext{
"Llobregat HuRTADo, M. L., La reforma..., op. cit., pàg. 149: “L'aproximació gradual, que en l'actualitat assoleix els nivells màxims, de la normativa cooperativa al modern dret de societats fa que, respectant l'essencial d'aquest principi cooperatiu [el de participació democràtica], es
} 
El procés polític que encara desenvolupa l'Estat espanyol per consolidar una estructura juridicopolítica democràtica s'ha manifestat en l'àmbit cooperatiu en una efervescència normativa que, vistos els resultats, era digna de millor causa ${ }^{303}$. El punt de partida, com no pot ser d'una altra manera, ha de situar-se en la Constitució espanyola del 1978, en la qual, l'article 129.2 imposa als poders públics el deure de fomentar les societats cooperatives mitjançant una legislació adequada $^{304}$. Però també $s^{\prime}$ hi troba el germen del debat doctrinal i jurisprudencial que arriba als nostres dies, ja que el legislador constitucional no hi reserva de manera expressa la matèria legislativa cooperativa en favor de l’Estat ni la inclou en la llista de competències autonòmiques.

\section{A l'empara de l'esmentada situació i del mandat constitucional de foment, diverses comunitats autònomes, fent ús de la clàusula residual de l'article 149.3 (“les matèries no atribuïdes expressament a l’Estat per aquesta Constitució}

duga a terme un organicisme de tercers a través de les atribucions que la legislació atorga al consell rector, reconeixent-se la figura del director que du a terme la gestió i l'administració professionalitzada, condició que pot adquirir un tercer no soci".

302 Es tracta del que PANIAGUA ZURERA, Manuel, «La reforma de la legislación cooperativa andaluza", Revista CIRIEC-España, núm. 29, agost 1998, pàg. 51, qualifica de "tòpics encunyats per la legislació autonòmica de la segona generació, com ara el perfeccionament tècnic de les normes cooperatives, la recepció del dret mercantil" en general i societari en particular, $i$ assumpció del repte de la integració del cooperativisme al mercat.

${ }^{313}$ VICENT CHULIÁ, F., «Mercado, principios cooperativos...», op. cit., pàg. 9: "Destapat el flascó del geni regulatori hispà, la imaginació al poder no troba fronteres".

314 Poden veure's comentaris a aquesta norma constitucional en VICENT CHULIÁ, F., «El accidentado desarrollo...", op. cit., pàg. 1231 a 1236; "Mercado, principios cooperativos...», op. cit., pàg. 13 i 14: "l'exercici en forma cooperativa de la llibertat d'empresa que l'article 38 de la Constitució reconeix a tot ciutadà ofereix avantatges d'eficiència social, fet que justifica el mandat de l'article 129.2 de la Constitució", però "si el legislador actual aproxima tant la cooperativa a la societat lucrativa que la confon amb aquesta, el mandat constitucional no té sentit"; i en "Situación actual de las cooperativas en el marco constitucional español: legalidad autonómica, estatal y fiscal», Revista Ciriec-España, núm. extraordinari, pàg. 32 a 47; en GADEA, E., Evolución de la legislación..., op. cit., pàg. 145 a 160; MONTOLIO, J. M., Legislación cooperativa en la Comunidad europea..., op. cit.; i en PANIAGUA ZURERA, M., Mutualidad y lucro..., op. cit., pàg. 160 a 163 .

Comentant els preceptes de la Constitució de la República de Portugal, NAMORADO, R., Introdução ao direito cooperativo, op. cit., cap. 5 , pàg. 131 i ss., extreu conclusions traslladables al context espanyol, de rellevància especial, com ara que el principi de protecció i foment de les cooperatives ha de traduir-se en mesures de discriminació positiva i, per contra, serà una 
podran correspondre a les comunitats autònomes en virtut dels respectius estatuts") van incloure la potestat normativa en matèria de cooperatives en els seus estatuts d'autonomia, unes vegades en concepte de competència exclusiva i unes altres com a facultat de desenvolupament i d'execució de la legislació estatal. En els casos en què s'assumia la competència exclusiva s'expressava que el seu exercici es realitzaria "conforme a la legislació general en matèria mercantil ${ }^{\prime \prime 305}$. En virtut d'això, les comunitats autònomes del País Basc, Catalunya, Andalusia, Comunitat Valenciana i Navarra es van dotar de lleis de cooperatives.

Tanmateix, l'exercici de la competència autonòmica va suscitar molt aviat el conflicte competencial entre l'Estat $i$ les comunitats autònomes, tant en l'aspecte material com territorial. Com hem avançat, malgrat l'expressa exclusió de les cooperatives de l'àmbit d'aplicació del Codi de comerç, mai no ha estat pacífica la qüestió sobre la seua possible mercantilitat, partint del seu caràcter empresarial innegable $e^{306}$, motiu pel qual es va plantejar davant del Tribunal

violació de la CRP que "les cooperatives siguen tractades com si foren organitzacions pertanyents al sector privat".

Segons la redacció donada per l'Estatut basc d'autonomia; el català, l'andalús i el valencià utilitzen l'expressió "respectant la legislació mercantil"; l'Estatut navarrès, "conforme a la legislació general en la matèria.

FAJARDO GARCfA, I-G, «El derecho cooperativo...», op. cit., pàg. 13 i 14, traça un resum dels diferents corrents doctrinals, on situa en un primer grup els autors que consideren que l'ànim de lucre no és essencial en el concepte de societat, per la qual cosa les cooperatives serien societats, ja siga civils (postura inicialment mantinguda per POLO) o mercantils (en aquest grup poden situar-se ARROYO, DíVAR, GADEA, GIRÓN, LEÓN SANZ, PANIAGUA ZURERA, SÁNCHEZ CALERO, VERGEZ SÁNCHEZ, URIA). Un altre grup, centrat en la mutualitat com a element definidor de les cooperatives, les exclouria del caràcter mercantil en virtut de l'article 124 Cco (GARRIGUES i SERRANO Y SOLDEVILLA). Vegeu relació una extensa i recent de les diferents postures doctrinals en ALFONSO SÁNCHEZ, Rosalía, «Aspectos básicos de la nueva regulación de la sociedad cooperativa (Ley 27/1999, de 16 de julio)», CDC, núm. 31, abril del 2000, pàg.163 i 164 , notes 4,5 i 6.

En qualsevol cas, com assenyalen FAJARDO GARCtA, op. cit., i SERRANO Y SOLDEVILLA, La cooperativa como..., op. cit., pàg. 21 i 22 , nota 1 , siga quina siga la posició adoptada, hi ha un consens generalitzat de qualificar la cooperativa d'empresari en la mesura que du a terme una activitat econòmica de manera professional i organitzada. I és la configuració de la cooperativa com a empresari el que justifica l'aplicació a aquesta de moltes de les institucions que conformen l'estatut de l'empresari, regulades en la legislació mercantil. En la mateixa línia, legislación ÁNCHEZ, R., La integración cooperativa..., op. cit., pàg. 335 , nota $25, \mathrm{i}$ «La reforma de la sin lación estatal sobre sociedades cooperativas: su incidencia en las comunidades autónomas sin ley reguladora», La Ley, núm. 4750, 9.3.1999, nota 14; LlOBREGAT HURTADO, M. L., 
Constitucional la invasió possible de la competència estatal en legislació mercantil ${ }^{307}$. A més, la delimitació de l'àmbit territorial de les normes autonòmiques va suscitar la qüestió de l'aplicabilitat davant la llei estatal, això és, quan ha de considerar-se aplicable, en una cooperativa concreta, la llei autonòmica i quan l'estatal. El recurs d'inconstitucionalitat núm. 201/1982

Mutualidad y empresas..., op. cit.; i MONGE GIL, A. L., "Algunas reflexiones...», op. cit., pàg. 727 a 735. De la seua banda, BORJABAD GONZALO, P. J., "Capítulo Primero...», pàg. 2 i 3 , nota 3 , considera que, des de la publicació de la Llei de 1974 i del Reglament de 1978, la discusió doctrinal "en els termes en què s'havia fet ja no tenia sentit pràctic", ja que quedaven resoltes les dues qüestions que se'n derivaven: si hi eren d'aplicació les normes generals del CCo en matèria de societats $i$ altres normes dictades per a les societats mercantils.

Un dels autors que més ha analitzat la polèmica qüestió ha estat VICENT CHULIÁ, F., (Compendio crítico..., op. cit., pàg. 1014 i 1015; «Las empresas mutualisticas..., op. cit., pàg. 69 a 89; «El accidentado desarrollo...», op. cit., pàg. ; «La Llei de cooperatives catalana...», op. cit., pàg. 581 i 582). El professor VICENT advoca per l'existència d'un tertium genus en la classificació de les agrupacions de persones del nostre ordenament jurídic. Entre les associacions d'interès públic $i$ les societats hi hauria les "agrupacions o empreses mutualístiques", en les quals inclou les cooperatives: "La seua característica fonamental és ser "mutualístiques», és a dir, que, en la seua activitat empresarial a la condició de soci se superposa la d'usuari dels seus serveis [...]. La comunitat d'interès entre els seus socis naix abans de constituir el fons comú, perquè pertanyen a una categoria social, amb la necessitat comuna dels serveis que prestarà l'entitat. Per això mateix, la finalitat o causa del contracte pot consistir en el mer desenvolupament de l'objecte o activitat social al servei de les necessitats dels socis, mitjançant l'«autogestió» o «autoajuda»; sense necessitat d'obtenir beneficis repartibles. Alhora, la seua vocació latent a estendre els serveis a altres membres de la categoria, siga adquirint prèviament la condició de socis siga com a "tercers», dóna al caràcter mutualista una generositat que transcendeix l'interès immediat del grup de socis (ASCARELLI). Aquest doble caràcter, intern i extern, d'interès privat i públic, del mutualisme, és present sobretot en el cooperativisme" (VICENT CHULIÁ, F., Compendio crítico..., op. cit., pàg. 1040).

En la doctrina italiana, ASCARELLI, T., "Cooperativa e società...», op. cit., pàg. 424: "la comunitat d'interessos preexistent organitzada a través de la mútua constitueix precisament l'expressió més precisa de [...] el perfil social de la cooperació $i$, consegüentment, la peculiaritat rellevant respecte de l'avantatge econòmic perseguit pel cooperador. Això justifica, al meu entendre, la classificació de la cooperativa entre les associacions, si bé subdistingint entre les associacions (com les altres mútues, els sindicats obrers o patronals, els consorcis) en què els membres persegueixen un avantatge patrimonial, i aquelles els membres de les quals persegueixen una finalitat ideal. [...] És per això que les associacions (i per això també les mútues) atenen el que podríem dir l'estructuració social del país i que per això plantegen tradicionalment problemes de caràcter públic que no es plantegen en les societats".

MONTOLÍO HERNÁNDEZ, J. M., "Leyes de cooperativas de las comunidades autónomas...», op. cit., pàg. 236 a 238, efectua una anàlisi comparativa de diferents lleis autonòmiques, en què conclou que "predomina la categorització "societària»", sense perjudici que s'observa un cert grau d'indefinició en els textos legals de la Comunitat Valenciana i d'Extremadura.

307 Això no obstant, com s'ha assenyalat, l'exercici de la potestat normativa també podria plantejar l'afectació d'altres competències estatals, com la relativa a la legislació civil; la relacionada amb les bases de l'exercici de la llibertat d'associació; la legislació laboral, l'ordenació dels registres i els instruments públics, les bases de les obligacions contractuals, i les bases de l'ordenació del crèdit, la banca i les assegurances (LEÓN SANZ, F. J., "Fusión, transformación...», op. cit., pàg. 28; PANIAGUA ZURERA, M., Mutualidad y lucro..., op. cit., pàg. 164; VICENT CHULIÁ, F., «El accidentado desarrollo...., op. cit., pàg. 1239, i «La Llei de cooperatives catalana...", op. cit., pàg. 576). 
promogut pel president del Govern contra els articles 3, 8.1 i la disposició final primera de la Llei 1/1982 de cooperatives del País Basc va donar lloc a la Sentència 72/1983, de 29 de juliol, en la qual el Tribunal Constitucional va tenir ocasió de manifestar-se sobre ambdues qüestions.

En relació amb la competència material, l'alt tribunal recorda que la interpretació ha de fer-se observant la seua conformitat o disconformitat respecte de l'anomenat «bloc de constitucionalitat», això és, "a més dels preceptes constitucionals, les lleis que, dins del marc constitucional, s'han dictat per delimitar les competències de $l^{\prime} E s t a t ~ i$ les diferents comunitats autònomes 0 per regular i harmonitzar l'exercici de les competències d'aquestes" (article 28 LOTC). Per a això ha d'atendre's, doncs, no sols que la Constitució no reserva de manera directa i expressa competència a l'Estat en matèria de cooperatives, sinó que la comunitat autònoma, en aplicació de l'article 149.3 CE sí que l'ha assumida en el seu estatut d'autonomia ${ }^{308}$. Es fixa, per tant, el principi que la competència en matèria de cooperatives és atribuïda a la comunitat autònoma que l'haja assumida estatutàriament, en virtut de la interpretació del bloc de constitucionalitat.

En relació amb la qüestió plantejada sobre si la legislació autonòmica cooperativa envairia la competència exclusiva estatal sobre la legislació mercantil, el Tribunal Constitucional evita el debat espinós sobre la mercantilitat de les cooperatives. Partint del fet que la competència exclusiva en matèria de cooperatives està establerta en l'article 10 de l'Estatut d'autonomia, i que si la regulació de les cooperatives haguera de qualificar-se de mercantil

\footnotetext{
"LEÓN SANZ, F. J., «Fusión, transformación...", op. cit., pàg. 32: "En el bloc de constitucionalitat la competència exclusiva sobre legislació de cooperatives és atribuïda a les comunitats autònomes (nota 27: “[...] El model d'Estat autonòmic no s'articula en la Constitució d'una manera tancada, probablement per la situació sociopolítica en què se'n va produir l'aprovació. La Constitució predetermina [D'OTTO: Derecho Constitucional, cit., 1995, pàg. 249 i ss.] un marc i disposa els instruments per a la seua concreció: els estatuts d'autonomia i, també, les lleis de transferència i delegació $i$ les lleis marc [...]. El paràmetre de constitucionalitat sobre la titularitat de les competències i el seu exercici va referit a aquest conjunt normatiu que integra el bloc de Homenacionalitat [article 28.1 LOTC; RUBIO LLORENTE: «El bloque de constitucionalidad» en menatge al Professor Eduardo García de Enterría, cit., tom I, pàg. 3 i ss.])
} 
aquella atribució competencial quedaria buida de contingut i que la seua inclusió en l'Estatut no seria correcta, es conclou que la interpretació dels preceptes de la Constitució i de l'Estatut d'autonomia ha de fer-se des del mateix contingut de l'ordenació vigent, i fonamentalment en relació amb el bloc de constitucionalitat i no des de qualsevol posició doctrinal sobre si les cooperatives han de qualificar-se o no com a societats mercantils ${ }^{309}$. Tot això sense perjudici que la conformitat de la legislació autonòmica cooperativa respecte de la legislació general mercantil haja d'entendre's, segons el Tribunal, en el sentit que "haurà de respectar tal legislació quan siga aplicable a les cooperatives, com succeeix en aquells aspectes en què la legislació general de cooperatives remet a la legislació mercantil o també quan conté preceptes mercantils".

\section{La sentència ha estat diversament criticada en relació amb la conclusió relativa} a la competència material autonòmica. D'una banda, continua subjacent el dubte sobre la constitucionalitat que les comunitats autònomes, quan regulen el funcionament i l'estructura cooperatives, estiguen legislant en matèries que poden considerar-se incloses en altres títols competencials estatals ${ }^{310}$. D'una

3ry LEÓN SANZ, F. J., "Fusión, transformación...", op. cit., pàg. 33: "respecte als títols competencials en què la Constitució utilitza termes emprats per determinar sectors en què es divideix tradicionalment l'ordenament jurídic, el TC (entre altres, SSTC 37/1981, 40/1982, $71 / 1982,88 / 1986$ i $37 / 1987$ ) ha assenyalat encertadament que la interpretació d'aquests conceptes ha de ser d'acord amb el que disposa la Constitució sense subjectar-se a una opinió doctrinal determinada". Això no obstant, més endavant i en relació amb el principi de nobuidament adverteix que "la competència en matèria de cooperatives està continguda en els estatuts d'autonomia. En conseqüència, es requereix una interpretació del precepte estatutari que siga conforme amb el que disposa el text constitucional. L'aplicació del principi de nobuidament a aquest supòsit és discutible ja que la Constitució estableix que les comunitats autònomes podran assumir la competència sobre aquelles matèries no atribuïdes expressament pel text constitucional a l'Estat (article 149.3). És a dir, en aquest cas el principi de no-buidament té com a pressupòsit que la regulació de la societat cooperativa no estiga integrada en cap títol constitucional de l'Estat. Per tant, el fet rellevant consisteix a determinar el seu caràcter específic i diferent dels títols estatals".

311" VICENT CHULIÁ, Francisco, "La legislación cooperativa como desafío para el jurista», en Primeros encuentros cooperativos de la Universidad del País Vasco, Departamento de Trabajo, Sanidad y Seguridad Social. Administración de la Comunidad Autónoma Vasca, Bilbao, 1986, pàg. 43: "S'ha produït així una situació en la qual es reconeix a les comunitats autònomes competència legislativa en matèries de dret privat [...] i en especial en matèria de "registres públics» (el Registre de Cooperatives, de publicitat jurídicoprivada), malgrat el fet que segons l'article 149-1-8 de la Constitució aquestes matèries semblen ser de competència exclusiva 
altra, des de les posicions doctrinals que mantenen la mercantilitat de la
cooperativa o, almenys, "la caracterització de la societat cooperativa com a tipus associatiu especificat segons les exigències de l'empresa cooperativa" ${ }^{\prime 311}$, se sosté que, si bé la competència autonòmica pot afavorir el principi constitucional de promoció del cooperativisme $e^{312}$, també pot comprometre altres principis constitucionals, com ara el d'unitat de mercat, de llibertat d'establiment, de lliure circulació de béns i prestació de serveis i de no-discriminació per raó del territori (article $139.1 \mathrm{CE})^{313}$.

estatal: «legislació civil», no foral, i «legislació sobre bases de la contractació» i sobre «instruments i registres públics». És evident que hi subjau un dubte immens: si és constitucional que les comunitats autònomes hagen legislat en matèria de constitució, publicitat registral, drets i obligacions dels socis, caràcter inembargable dels béns afectes a la reserva de formació i promoció cooperativa, representació de l'entitat, organització econòmica, normativa comptable i d'auditoria, impugnació d'acords socials (llei basca i andalusa) arbitratge cooperatiu (llei basca i valenciana), etc.".

En aquest sentit, s'ha de recordar, per les seues implicacions en la matèria de la impugnació d'acords socials, que l'article 149.1-6 CE també reserva a l'Estat la competència exclusiva en legislació processal, "sense perjudici de les especialitats necessàries que en aquest ordre es deriven necessàriament de les particularitats del dret substantiu de les comunitats autònomes". En relació amb això, VICENT CHULIÁ, Francisco, «Consideraciones sobre la futura ley valenciana de cooperativas. La sentencia del Tribunal constitucional sobre la Ley de cooperativas vascas (I)", Revista UTECO, núm. 7, oct. 1983, pàg. 18, assenyala que tal competència estatal va ser la que va portar el primer legislador autonòmic català a substituir l'arbitratge cooperatiu per una simple mediació prèvia a l'acció davant dels tribunals, i a fer remissió a la legislació de l'estat en matèria d'impugnació d'acords socials.

En la mateixa línia, LEÓN SANZ, F. J., «Fusión, transformación...», op. cit., pàg. 37 adverteix que "la configuració del tipus societari cooperatiu no és l'única matèria que requereix regulació en relació amb les cooperatives. $\mathrm{D}^{\prime}$ altra banda, el règim jurídic privat de la societat cooperativa es pot considerar inclòs també en altres competències segons el que s'estableix en el bloc de constitucionalitat".

"1 LEÓN SANZ, F. J., «Fusión, transformación...», op. cit., pàg. 38 i 39; PANIAGUA ZURERA, M., Mutualidad y lucro..., op. cit., pàg. 164 i 167.

${ }^{312}$ BORJABAD GONZALO, P. J., "Capítulo Primero... ", op. cit., pàg. 4 i 5, ho posa, però, en dubte: " $L$ 'interés legislatiu autonòmic en la pràctica totalitat està abocat en regular la Cooperativa com a Societat, donant-li voltes una i altra vegada, a la regulació de la seua constitució, de la seua organització, el seu règim econòmic, les seues modificacions [...] , les seues classes i la seua desaparició. [...] però regular una i altra vegada la societat cooperativa no s'està manifestant en la pràctica com un vertader foment".

${ }^{313}$ A més dels autors citats en la nota anterior, GADEA, E., Evolución de la legislación..., op. cit., pàg. 162 i 163, citant la STC de 28.1.1982: "La unicitat de l'ordre econòmic nacional és un pressupost necessari perquè el repartiment de competències entre l'Estat $\mathrm{i}$ les diferents comunitats autònomes en matèries econòmiques no conduïsca a resultats disfuncionals 0 desintegradors"; i ALFONSO SÁNCHEZ, R., La integración cooperativa..., op. cit., pàg. 343 i 344, encara que aquesta autora no es refereix en concret a la Sentència 72/1983, sinó a "la pluralitat de lleis cooperatives, que estima incompatibles amb els principis constitucionals esmentats, $\mathrm{i}$ que considera que pot provocar l'anomenat «efecte Delaware», en el sentit que en constituir una 
Això enllaça amb una altra qüestió plantejada en l'esmentat recurs d'inconstitucionalitat, la delimitació de la competència territorial. La disposició final primera de la Llei basca 1/82 establia: “Aquesta Llei s'aplicarà a totes les cooperatives amb domicili a la comunitat autònoma del País Basc, amb independència del seu àmbit territorial d'actuació". La sentència ara analitzada declara la inconstitucionalitat d'aquesta norma, en considerar que la competència legislativa de la comunitat autònoma del País Basc abasta "les cooperatives que duen a terme la seua activitat societària típica en els termes ja exposats, dins del territori de la comunitat autònoma, encara que establisquen relacions jurídiques o realitzen activitats de caràcter instrumental fora del seu territori". L'extensió territorial de $1^{\prime \prime}$ activitat societària típica", que és la que es du a terme internament entre la cooperativa i els seus socis ${ }^{314}$, és, per tant, la que determina l'aplicació de la legislació autonòmica o estatal, i no el domicili social $^{315}$.

Per arribar a aquesta conclusió, el Tribunal va atendre, una vegada més, el bloc de constitucionalitat, on es troba l'article 20.6 de l'Estatut d'autonomia del País Basc, que estableix (com fan tots els altres estatuts d'autonomia) que, "si no hi ha disposició expressa en contrari totes les competències esmentades en els articles anteriors $\mathrm{i}$ altres en aquest Estatut s'entenen referides a l'àmbit territorial del País Basc". Hauria estat, doncs, necessària una disposició expressa

cooperativa es busque la submissió a la llei que resulte més favorable. Aquest mateix temor és manifestat per LEÓNSANZ, F. J., "Fusión, transformación...», op. cit., pàg. 37.

314 "Així com les que en virtut de la legislació aplicable hagen d'assimilar-s'hi, com succeeix en el cas previst a l'article 57.2 de la Llei impugnada, relatiu al supòsit en què les cooperatives de consum podrien subministrar als no socis".

${ }^{315}$ ALFONSO SÁNCHEZ, R., La integración cooperativa..., op. cit., pàg. 337, nota 34: "És fonamental la distinció entre domicili $i$ àmbit pròpia del dret cooperatiu. El domicili es determina conforme a criteris anàlegs als utilitzats per a la resta de les formes socials, però per contra no determina ni la llei aplicable a la cooperativa ni el registre competent per a la seua inscripció. Aquests paràmetres es concreten entorn de l'àmbit de la cooperativa". 
en contrari que estiguera continguda en el bloc de constitucionalitat per poder superar la limitació al territori del País Basc ${ }^{316}$.

Aquest criteri va ser seguit pel Tribunal en sentències posteriors (44/1984, de 27.3, i 165/1985, de 5.12), i va ser recollit en les successives lleis autonòmiques $i$ en la Llei general de cooperatives del $1987^{317}$, que va establir expressament l'esmentat criteri en la disposició final 1a 1r paràgraf. ${ }^{318}$. Com s'ha dit, en cap moment es va qüestionar la constitucionalitat de la norma estatal, en atenció a la "clàusula residual" de l'article 149.4 de CE, en virtut de la qual "la

${ }^{316}$ FAJARDO GARCIA, I. G., "El derecho cooperativo...", op. cit., pàg. 26: "I posa com a exemple l'article 10.13 de l'EAPV que atribueix competència exclusiva al País Basc en matèria de "fundacions i associacions de caràcter docent, cultural, artístic, benèfic, assistencial i similars, en tant que desenvolupen principalment les seues funcions al País Basc. En aquest cas hi ha una norma expressa i pertanyent al "bloc de la constitucionalitat" que atribueix "la competència al País Basc, encara que les fundacions $i$ associacions no desenvolupen totes les seues funcions al territori autonòmic".

Això no obstant, una via interessant de reflexió sobre la matèria s'obri amb el vot particular a la Sentència dels magistrats DíEZ PICAZO i RUBIO LLORENTE, que consideren que: $a$ ) les normes per resoldre els conflictes de lleis són competència de $\left.l^{\prime} E s t a t ; b\right)$ que aquestes normes no són només les relatives al dret internacional privat, sinó que també s'inclouen les normes de "dret interregional" que el CC inclou; i c) que, entre aquestes normes, l'article $9.11 \mathrm{CC}$ diu que la llei personal de la persona jurídica és la determinada per la seua nacionalitat i que "regirà en tot allò relatiu a capacitat, constitució, representació, funcionament, transformació, dissolució i extinció". A això afegeix LEÓN SANZ, F. J., "Fusión, transformación...", op. cit., pàg. 42, que "La nacionalitat de les persones jurídiques, en aquest cas, el veïnatge, es determina, amb caràcter general, pel seu domicili (article $28 \mathrm{CC}$ )".

${ }^{317}$ La Llei 3/1987, de 2 d'abril, general de cooperatives (BOE núm. 84, de 8.4) és una de les normes cooperatives que la doctrina ha estudiat més. El més comentari extens i complet és el realitzat per PAZ CANALEJO, N. i VICENT CHULIÁ, F., Ley general..., op. cit.. També es comenta àmpliament la Llei en AA. DD., Comunidades de bienes, cooperativas y otras formas de empresa, Consejo General del Notariado, Madrid, 1996; AA. DD., Manual de derecho cooperativo..., op. cit.; i BorJaBAD GonZALO, P. J., Manual de derecho cooperativo..., op. cit.

\footnotetext{
आı "Aquesta Llei és d'aplicació a totes les societats cooperatives amb domicili social al territori de l'Estat, excepte aquelles en què les relacions de caràcter cooperatiu intern que resulten definitòries de l'objecte social cooperativitzat, entenent-se per aquestes relacions les de la cooperativa amb els seus socis, es duguen a terme dins del territori d'una comunitat autònoma que, en ús de la seua competència legislativa exclusiva, haja regulat aquestes societats sense perjudici que establisquen relacions jurídiques amb tercers o que realitzen activitats de caràcter instrumental o personals accessòries a l'esmentat objecte social fora del territori de la comunitat autònoma esmentada".
} 
competència sobre les matèries que no hagen estat assumides pels estatuts d'autonomia correspondrà a l'Estat" ${ }^{319}$.

Quant al valor supletori de la Llei estatal a les comunitats autònomes amb legislació pròpia, l'article 149.3 CE estableix que "el dret estatal serà en tot cas supletori del dret de les comunitats autònomes", cosa que s'interpretava pacíficament en el sentit que l'ordenació estatal era aplicable no sols a les comunitats autònomes que no hagueren assumit competència en la matèria, 0 que no l'hagueren exercida encara, sinó també per "suplir les llacunes (...) dels territoris autonòmics en què hi haja la competència corresponent i se n'haja fet ús $^{\prime \prime 20}$.

Tanmateix, aquesta ordenació competencial s'ha vist profundament modificada per la conjunció de dues circumstàncies: d'una banda, l'ampliació del sostre competencial de les comunitats autònomes, que en l'actualitat tenen totes la competència exclusiva en matèria de cooperatives; d'una altra, els canvis produïts en la interpretació del Tribunal Constitucional sobre els conflictes competencials entre l’Estat i les comunitats autònomes.

En relació amb la primera qüestió, les lleis orgàniques 9/1992, de 23 de desembre, 16/1995, de 27 de desembre, i 4/1996, de 30.12, transfereixen

${ }^{319}$ ALFONSO SÁNCHEZ, R., "La reforma de la legislación estatal...», op. cit., pàg. 2, i La integración cooperativa..., op. cit., pàg. 338.

${ }^{320}$ FAJARDO GARCIA, I. G., «El derecho cooperativo...», op. cit., pàg. 30 a 33: "El dret supletori compleix una funció integradora de l'ordenament jurídic, i només té aplicació quan hi ha una llacuna en el dret. Per "llacuna legal" podem entendre, com diu Lacruz Berdejo (LACRUZ BERDEJO, J. L., Derecho Civil. Parte general, vol I. Introducción, Llibreria Bosch, Barcelona, 1988, pàg. 288), "un estat incomplet de la norma o del conjunt normatiu, en el qual la falta de regulació no està d'acord amb el sentit, les idees fonamentals i l'ordenació de mitjans afins de la normativa total [...]. Les llacunes es produeixen, segons veiem, quan la llei no pot resoldre un problema plantejat per la llei. No es tracta, doncs, d'una matèria que estiga sense regular quan el clamor públic exigeix una normativa [...]. Les disposicions la promulgació de les quals es reclama enriquiran l'ordenació si apareixen, però no "tapen un buit" en el teixit legal, buit que només existeix quan la matèria hauria d'estar expressament regulada segons la lògica interna de l'ordenació mateixa, no perquè la gent anhele una nova llei. [...] El Dret supletori a què es refereix l'article 149.3 CE és el dret estatal que regula la mateixa matèria sobre la qual la comunitat autònoma ha assumit competències". 
competències a les comunitats autònomes que van accedir a l'autonomia per la via de l'article 143 de la Constitució (Astúries, Cantàbria, La Rioja, Regió de Múrcia, Aragó, Castella-la Manxa, Extremadura, Illes Balears, Madrid i Castella i Lleó), Galícia i Canàries. En aquestes, entre altres matèries, es transfereix la competència exclusiva en matèria de cooperatives, "respectant la legislació mercantil ${ }^{\prime \prime 321}$. En l'aplicació, s'han promulgat les corresponents lleis orgàniques de reforma dels estatuts d'autonomia, a fi d'incorporar les competències transferides ${ }^{322}$. Com a conseqüència $d^{\prime}$ 'això, totes les comunitats autònomes han assumit competència exclusiva en matèria de cooperatives (queden al marge les ciutats autònomes de Ceuta i Melilla), competència que ha estat exercida ja per quatre comunitats: Extremadura, Galícia, Aragó i la Comunitat de Madrid.

L'atribució de la competència sobre legislació de cooperatives a totes les comunitats autònomes ha plantejat, a la llum dels pronunciaments del Tribunal Constitucional els últims anys, un interrogant sobre quin ha de ser l'abast de la competència legislativa estatal en aquesta matèria. Si totes les comunitats autònomes tenen expressament reconeguda en els seus estatuts d'autonomia la potestat legislativa en matèria de cooperatives, de manera exclusiva, $s^{\prime}$ haurà de concloure que no la té l'Estat, ja que el TC considera que, d'acord amb la Constitució, en el sistema espanyol no hi ha competències legislatives plenes atribuïdes simultàniament a l'Estat i a les comunitats autònomes, excepte en el

\footnotetext{
${ }^{\text {nal }}$ ALFONSO SANCHEZ, R., "La reforma de la legislación estatal...", op. cit., nota 31, i La integración cooperativa..., op. cit., pàg. 339 , nota 41 : "Pel que fa al respecte a la legislació mercantil a què al-ludeixen la LO 9/1992, i la LO 16/1995, segons l'annex I dels acords autonòmics adoptats el 28 de febrer de 1992, per delimitar i donar contingut a aquesta competència exclusiva hauran de «tenir-se en compte no sols els límits derivats de la legislació mercantil, sinó la legislació sectorial especifica $i$ les limitacions a la competència exclusiva de les activitats que poden exercir aquestes entitats. Aquestes limitacions a la competència exclusiva han estat clarament determinades per la Sentència del Tribunal Constitucional de 28 de maig de 1987».

SANTOS DomínGUEZ, Miguel Ángel, «Notas sobre la Ley 2/1998, de 26 de marzo, de Sociedades Cooperativas de Extremadura", Revista CIRIEC-España, núm. 29, agost 1998, pàg. 105, estima que la LCE ha respectat la legislació mercantil de l'Estat "des de dos punts de vista: un, en tots aquells aspectes puntuals del text en què hi ha connexió amb matèries que són competència de l'Estat (v. g., auditoria de comptes o dipòsit de comptes); i, dos, amb caràcter general, en l'article 110.3 segons el qual "en tot cas, les societats cooperatives quedaran subjectes a la legislació específica aplicable segons l'activitat empresarial que desenvolupen".
} 
cas de la cultura ${ }^{323}$. I si l'Estat no té títol competencial propi, les SSTC 118/1996i 61/1997 han rebutjat l'aprovació de normes estatals que tinguen per objecte únicament establir un règim supletori, sense suport en un títol específici ${ }^{324}$; qüestió diferent serà que la llei autonòmica mateixa declare l'aplicació supletòria de l'estatal, com han fet algunes ${ }^{325}$. Aquesta interpretació, aplicada rigorosament, porta a mantenir, com s'ha fet, que a les comunitats autònomes que encara no s'haja exercit la competència legislativa en cooperatives, continua vigent la LGC del $1987^{326}$.

Això no obstant, és ben cert que la matèria de cooperatives té peculiaritats que excedeixen dels supòsits sotmesos a revisió en les sentències esmentades del Tribunal Constitucional. L'activitat cooperativitzada d'algunes cooperatives no es pot o no es vol considerar circumscrita a una sola comunitat autònoma, i hi ha altres aspectes del funcionament empresarial i social que difícilment poden

${ }^{322}$ Les referències legislatives poden veure's en PANIAGUA ZURERA, M., Mutualidad y lucro..., op.
cit., pàg. 165. ${ }^{323}$ LEÓN SANZ, F. J., «Fusión, transformación...», op. cit., pàg. 35, nota 39: "(article 149.2 CE; STC
49/1984)".

${ }^{324}$ Fonament 6è STC 118/1996: "La clàusula de supletorietat és, segons la doctrina exposada, una previsió constitucional emanada de la CE que es dirigeix a l'aplicador del dret, indicant-li la manera com han de superar-se les llacunes de l'ordenació autonòmica quan n'hi haja. D'acord amb aquesta, una vegada que l'aplicador del dret, utilitzant els mitjans usuals d'interpretació, haja identificat una llacuna en l'ordenació autonòmica, haurà d'omplir-la acudint a les normes pertinents, dictades per l'Estat en l'exercici de les competències que la Constitució li atribueix: en això consisteix la supletorietat del dret estatal que, per la seua naturalesa mateixa, no comporta cap atribució competencial. [...] Per dictar qualssevol normes l'Estat necessita un títol competencial específic que les justifique, i la supletorietat no ho és".

A més de LEÓN SANZ, admet aquesta interpretació ALFONSO SÁNCHEZ, R., en "La reforma de la legislación estatal...», op. cit., notes 49 i 51.

${ }^{325}$ LFCN (disposició addicional segona), LCA (disposició final primera), LCE (disposició final segona), i LCCM (disposició final quarta). Això no obstant, s'ha de tenir present, com recorda MORILLAS JARILLO, M. José, "La nueva regulación estatal de las sociedades cooperativas", DN, núm. 111, desembre 1999, nota 42, que, mentre que la LFCN i la LCA assenyalen com supletòria a la LGC de 1987, la LCCM i la LCE es refereixen, més genèricament, a la legislació de cooperatives estatal, per la qual cosa és possible entendre la remissió a la LCoop actualment vigent. Com indica ALFONSO SÁNCHEZ, R., "La reforma de la legislació estatal..», op. cit., nota 25 , in fine, en el primer cas, la remissió a la llei estatal es fa amb una finalitat estàtica, és a dir, al contingut exacte i concret de la Llei general de cooperatives; en el segon, la tramesa és dinàmica, és a dir, a qualsevol que siga la legislació estatal vigent en cada moment".

${ }^{326}$ LEON SANZ, F. J., «Fusión, transformación...», op. cit., pàg. 40. 
quedar regulats únicament per normes autonòmiques: penseu en els canvis de domicili social, o en el trasllat de l'establiment principal, o en l'obertura de sucursals, o en l'extensió de la prestació de serveis, tot això en comunitats autònomes diferents, així com les modificacions estructurals i les associacions entre cooperatives de diferents comunitats autònomes, o entre cooperatives $i$ altres persones jurídiques ${ }^{327}$. Tanmateix, l'opció d'admetre la possibilitat que coexistisca una legislació cooperativa autonòmica i una d'estatal per a les cooperatives que desenvolupen la seua activitat en tot el territori de l'Estat s'enfronta amb la falta de reconeixement constitucional: la Constitució recull un sistema d'assignació competencial basat en l'exclusivitat, excepte en la matèria de cultura, $\mathrm{i}$ no hi ha un reconeixement general del territori com a criteri d'atribució de competència.

S'ha proposat, sobre la base que la disparitat de les normes autonòmiques podria afectar la unitat de mercat i el principi d'igualtat, la conveniència de la promulgació d'una "llei marc" o "llei d'harmonització estatal", en exercici del títol competencial de l'Estat en matèria de regulació de les condicions bàsiques que garantisquen la igualtat en l'exercici de drets fonamentals (article 149.1.1

\footnotetext{
3 LEÓN SANZ, F. J., "Fusión, transformación...», op. cit., pàg. 40 i 44 . En relació amb les dues últimes matèries, això és, les modificacions estructurals entre cooperatives o entre aquestes i altres persones jurídiques, $\mathrm{i}$ les associacions de cooperatives de diferents comunitats autònomes l'autor assenyala en les pàgines següents els problemes especials que plantegen: així, mentre que les modificacions estructurals mixtes requeriran una doble regulació, tant en les normes estatals com en les autonòmiques, les modificacions estructurals i les associacions entre cooperatives de diferents comunitats presenten l'inconvenient que la seua regulació autonòmica passaria de l'àmbit competencial, per la qual cosa no és possible més que l'aplicació de l'article $9.11,2 n$ paràgraf $C C$, que estableix que "a la fusió de societats de diferent nacionalitat s'han de tenir en compte les lleis personals respectives".

També es refereix a les modificacions estructurals VICENT CHULIÁ, F., «Mercado, principios cooperativos...", op. cit., pàg. 11 i 12, que estima que la solució adequada "només pot provenir de la promulgació d'una llei transversal, similar a la llei alemanya de 28 d'octubre de 1994, i donant com a resultat entitats que queden inscrites en el Registre mercantil".

Per la seua part, ALFONSO SÁNCHEZ, R., «La reforma de la legislación estatal...», op. cit., nota 54, manifesta els seus dubtes sobre la validesa de la regulació i sobre l'àmbit d'aplicació de les normes que inclouen tant la LCoop com les lleis autonòmiques sobre l'associacionisme cooperatiu.
} 
$(\mathrm{CE})^{328}$. Però tan estimable proposta de lege ferenda no ha estat atesa, i s'ha optat per una solució que "desconeix", almenys parcialment, la interpretació del TC.

En efecte, la Llei 27/1999, de 16 de juliol, de cooperatives ${ }^{329}$ (de la denominació de la qual desapareix, significativament, el qualificatiu de "general" que incorporaven les lleis estatals anteriors) refereix el seu àmbit d'aplicació (article 2) a les cooperatives "que desenvolupen la seua activitat cooperativitzada ${ }^{330 /}$ en

${ }^{328}$ VICENT CHULIÁ, F., en "La Ley 27/1999...», op. cit., pàg. 14563 i 14564, on recorda que ja ho proposava des del 1979; i en "Mercado, principios cooperativos...», op. cit., pàg. 10. En la mateixa línia, ARROYO, Ignacio, «Prólogo a la primera edición» en Legislación cooperativa, 5a ed., Tecnos, Madrid, 1995, pàg. 16; EMBID IRUJO, José Miguel, «Problemas actuales de la integración cooperativa», RDM, núm. 227, gener-març 1998, pàg. 35; LEÓN SANZ, F. J., "Fusión, transformación...", op. cit., pàg. 35, nota 39, i pàg. 40, encara que, tanmateix, adverteix que "en la delimitació del que es considera com a bàsic en aquesta matèria i sobre si ha de tenir caràcter bàsic i amb quin abast [...] s'obri un ampli camp d'incertesa (per tots, D'OTTO: Estudios sobre derecho estatal y autonómico, cit., pàg. 143 i ss.)"; MORILAS JARILLO, M. J., "La nueva regulación estatal...», op. cit., pàg. 6; i PANIAGUA ZURERA, M., "La reforma de la legislación...», op. cit., pàg. 56: "s'imposa una crida a la mesura. Mesura que no significa negar les lleis cooperatives autonòmiques, però sí demanar (com aviat faran els operadors econòmics) un mínim comú en la regulació dels aspectes substantius de la societat cooperativa. Per la seua part, els aspectes procedimentals, accessoris, adjectius i, especialment, el foment de la cooperació, pot articular-se en la forma i manera que cada legislador competent estime més oportuna o encertada a la seua realitat territorial o nacional".

ALFONSO SÁNCHEZ, R., "La reforma de la legislación estatal...», op. cit., pàg. 3 i 4, estima que una llei d'harmonització seria insuficient per abordar "els diversos plans que, al nostre judici ha de cobrir el legislador estatal en matèria de cooperatives", ja que una llei d'harmonització "no pot ordenar de manera exhaustiva i directa supòsits de fet", tasca que correspon a les lleis autonòmiques; BORJABAD GONZALO, P. J., "Capítulo Primero...", op. cit., també s'hi mostra escéptic: "N'hi ha que indiquen la conveniència de reduir o, almenys, paralitzar aquest devessall legislatiu, altres asenyalen la necesitat d'una llei d'harmonització d'àmbit estatal $i$ també tenim els qui parlen d'una llei europea sobre la base dels principis de l'Aliança Cooperativa Internacional. Açò són més lleis, que si no deroguen les anteriors, l'única cosa que produeixen és un volum més grande l'ordenament jurídic".

${ }^{329}$ L'Exposició de motius de la Llei, publicada en el BOE núm. 170, de 17.7, refereix com a fonaments de la seua promulgació els següents: "assumir les comunitats autònomes la competència exclusiva en aquesta matèria significa, en la pràctica, que l'àmbit d'aplicació de la nova llei ha estat àmpliament reformulat, per la qual cosa en fa necessària una definició. Així s'ha establert en l'article 2, seguint la doctrina del Tribunal Constitucional". A més, "la llei ofereix un marc de flexibilitat, on les cooperatives mateixes puguen entrar a autoregular-se, $\mathrm{i}$ estableix els principis que, amb caràcter general, han de ser aplicats a la seua actuació, fugint del caràcter reglamentista que, en molts aspectes, dificulta l'activitat societària". D'altra banda, no s'oculta que "un objectiu prioritari és reforçar la consolidació empresarial de la cooperativa, per a la qual cosa ha estat necessari flexibilitzar el seu règim econòmic $i$ societari $i$ acollir novetats en matèria de finançament empresarial. Així, el reforçament de l'òrgan de govern i administració o l'habilitació d'accés a noves modalitats de captació de recursos permanents mitjançant l'emissió de participacions especials, o de títols participatius".

${ }^{330}$ En relació amb la delimitació del concepte d'activitat cooperativitzada en la Llei 27/1999, així com de $\mathrm{l}^{\prime \prime \prime}$ extraterritorialitat" de les relacions jurídiques amb tercers $\mathrm{i}$ de les activitats de 
el territori de diverses comunitats autònomes, excepte quan en una d'aquestes es desenvolupe amb caràcter principal, així com a les que realitzen "principalment" la seua activitat cooperativitzada a les ciutats de Ceuta i Melilla. Dues qüestions bàsiques es deriven d'aquesta definició competencial i de la recent doctrina constitucional: què ha d'entendre's per "desenvolupament amb caràcter principal de l'activitat cooperativitzada" ${ }^{\prime 31}$, i quina legislació serà l'aplicable a les cooperatives l'activitat cooperativitzada de les quals es desenvolupe "principalment" en l'àmbit d'una comunitat autònoma que no haja exercit encara la seua competència legislativa.

El primer interrogant, relatiu a la manera de determinar quan ens trobem davant d'una cooperativa que desenvolupa principalment la seua activitat cooperativitzada en l'àmbit territorial d'una comunitat autònoma, introdueix de manera innegable un element d'inseguretat en el ja per si confús sistema de repartiment competencial, pel marge d'indeterminació que suposa ${ }^{332}$. Amb l'actual redacció de l'article 2 LCoop s'estableix un doble criteri per determinar la llei aplicable: “a) l'espai territorial en què es desenvolupe l'activitat cooperativitzada i b) el caràcter amb què aquesta es realitze ${ }^{\prime \prime 333}$. És aquest segon element el que fa més inestable el criteri.

caràcter instrumental o accessori, vegeu PAZ CANALEJO, Narciso, «Ante la nueva Ley estatal de cooperativas: algunos puntos críticos", Anuario de estudios cooperativos 1998, Instituto de Estudios Cooperativos, Universidad de Deusto, Bilbao, 1999, pàg. 95 i 96.

${ }^{301}$ MARÍN LÓPEZ, J. J., «Notas sobre la Ley 27/1999...», op. cit., pàg. 1798.

32 URfA, R., MENÉNDEZ, A. i VERGEZ, M., "Sociedades cooperativas», en AA. DD., Curso de derecho mercantil (dirs. R. Uría i A. Menéndez), tom I, Civitas, Madrid, 1999, cap. 53, pàg. 1280 i 1281: "En introduir-se en el debat la Llei al Senat [sic] com a requisit necessari per a la seua aplicació que l'activitat cooperativitzada de la societat no es desenvolupe amb caràcter principal en una comunitat autònoma, no sols s'ha consagrat un criteri difícil de justificar des de la mera tècnica jurídica i des de la funcionalitat mateixa de la figura, sinó que la seua aplicació pràctica pot originar constants problemes". 
Entesa la qualitat de principal en la seua accepció de més gran en importància, haurà de determinar-se el paràmetre que mesure la importància ${ }^{334}$; la doctrina es decanta per considerar que ha de tractar-se d'una estimació quantitativa, per ser la més fàcilment objectivable $e^{335}$. També es proposa, per les dificultats que la indeterminació i l'aplicació del criteri comporten, concretar-lo estatutàriament $\mathrm{t}^{336}$. Si aquesta concreció no es produeix, com que falta jurisprudència en la matèria, l'anàlisi del debat parlamentari previ a l'aprovació permet concloure que la principalitat de l'activitat pot establir-se quan el volum d'operacions cooperativitzades en la comunitat autònoma principal siga del 50\% o fins i tot davant de percentatges inferiors, "sempre que el «sentit comú» així ho considerara" ${ }^{\prime 337}$. Sens dubte la norma persegueix l'ampliació dels supòsits en els quals les cooperatives quedaran adscrites a l'aplicació de lleis autonòmiques, però a aquelles que es troben en situacions "limítrofes" podria conduir-los a situacions bastant peculiars: la seua submissió a la norma autonòmica o a l'estatal pot variar d'un exercici a un altre, en un sentit o en un altre, segons el volum d'operacions cooperativitzades dins i fora del territori de la comunitat

${ }^{334}$ BORJABAD GonZALO, Primitivo J., "Capítulo Primero...», op. cit., pàg. 10 i 11, nota 15, apunta com a posibles "instruments de mesura de la principalitat" el nombre de socis, el volum de producció, consum o facturació, "segons la classe de cooperativa de què parlem".

335 ALFONSO SÁNCHEZ, R., "Aspectos básicos...», op. cit., pàg. 168; FAJARDO GARCIA, IsabelGemma, «La reforma de la legislación cooperativa estatal», Revista jurídica de economía social y cooperativa, Ciriec-España, núm. 10, octubre 1999, pàg. 48; MORILlAS JARILlO, M. J., «La nueva regulación estatal...», op. cit., pàg. 5 .

${ }^{336}$ ALFONSO SÁNCHEZ, R., "Aspectos básicos...», op. cit., pàg. 168.

${ }^{337}$ FAJARDO GARCIA, I.G., "La reforma de la legislación...», op. cit., pàg. 48. ALFONSO SÁNCHEZ, R., "La reforma de la legislación...», op. cit. , nota 3, i MORILLAS JARILLO, M. J., "La nueva regulación estatal...", op. cit., nota 34 , es fan ressò d'una esmena al Projecte de Llei que proposava que s'especificara que l'activitat fora de la "comunitat principal" no havia de superar el $20 \%$ del total (esmena núm. 46, del Grup Mixt-Bloque Nacionalista Galego), que no va prosperar. BORJABAD GONZALO, Primitivo J., "Capítulo Primero...», op. cit., pág. 11, nota, 15: "ha $\mathrm{d}^{\prime}$ observarse que sempre hi haurà una comunitat on el volum serà més gran que en altres, però no té motiu per ser sempre més gran que entre totes les altres, cosa per la qual haurà de delimitar-se bé si per ser qualificat el desenvolupament com a principal ha d'efectuar-se més del cinquanta per cent de l'activitat en una comunitat autònoma determinada (el major desenvolupament està dins i no fora) o sols cal que siga en aqueixa comunitat on més activitats realitze la cooperativa (el desenvolupament en aquesta comunitat és el més gran en comparació amb els altres)". 
autònoma principal, el qual, en virtut del principi de porta oberta no sempre podrà estar previst ${ }^{338}$.

Pel que fa a la qüestió relativa a la llei aplicable a les comunitats autònomes que encara no han exercit la seua competència legislativa en matèria de cooperatives, ja hem manifestat la nostra opinió en el sentit d'estimar que no podria aplicar-s'hi la LCoop de 1999, perquè, segons el criteri del Tribunal Constitucional, $\mathrm{l}^{\prime}$ Estat no té títol competencial propi ${ }^{339}$. En tot cas, ja que tampoc la LCoop s'ha atrevit a explicitar la seua aplicació en les esmentades comunitats autònomes, correspon adoptar el règim previst, en general, per als supòsits en què transitòriament una comunitat autònoma no ha exercit encara una competència exclusiva: és aqueixa comunitat autònoma la que ha de manifestar la seua opció de política legislativa en la matèria. A falta de l'esmentada especificació, els estatuts d'autonomia contenen, majoritàriament, clàusules que resolen els buits legals que puguen sorgir; però mentre que "alguns opten per mantenir en vigor les actuals lleis de l'Estat, és a dir, les vigents en el moment de l'assumpció competencial; altres s'inclinen per la genèrica aplicació de les lleis de $l^{\prime}$ Estat relatives a una matèria de competència autonòmica. En el primer cas, es podria entendre transitòriament aplicable la $\mathrm{LGC}^{340}$; en el segon, podria defensar-se l'aplicació de la LCoop". Però a més s'ha de tenir en compte que alguns estatuts no es manifesten sobre aquesta matèria, per la qual cosa en les

\footnotetext{
Això no obstant, també és possible que, com indica ALFONSO SÁNCHEZ, R., "Aspectos básicos...", op. cit., pàg. 170, els problemes possibles derivats del confús àmbit competencial "siguen només «hipòtesi de laboratori" i que la pràctica dels registres de cooperatives responguen a criteris flexibles que eviten el "conflicte de lleis» i el recurs constant als tribunals manté reldre aquestes qüestions". El ben cert és que, la mera possibilitat que es done el conflicte manté un marge d'inestabilitat indesitjable per a la competitivitat mateixa de les empreses

${ }^{305}$ Vegeu la nota 321 anterior.

${ }^{340}$ També URtA, R., MENÉNDEZ, A. i VERGEZ, M., "Sociedades cooperativas», op. cit. pàg. 1280 i
1281".
} 
comunitats autònomes respectives és especialment urgent un pronunciament exprés sobre la norma aplicable ${ }^{341}$.

Una qüestió competencial ulterior ha estat advertida pel legislador basc, que ha intentat resoldre-la en la Llei 1/2000 de la Presidència del Govern Basc, que modifica parcialment la Llei 4/1993 de cooperatives del País Basc, de manera bastant qüestionable. En efecte, sent conscient que la comunitat autònoma ha de respectar "la legislació general de caràcter mercantil, i també aquells àmbits competencials diferents al de cooperatives quan el contingut de la regulació que s'aborda afecte de manera rellevant aquests àmbits", així com que el bloc de constitucionalitat no li atribueix competència normativa en matèria laboral, "s'hi fa una reproducció integral de l'article 86.2 de la Llei estatal 27/1999", que equipara els socis treballadors als treballadors per compte aliè en les situacions de subrogació empresarial ${ }^{342}$. La norma és, si més no, de dubtosa constitucionalitat, ja que si la comunitat autònoma no té competència en legislació laboral, com es reconeix expressament, no pot declarar aplicable a les cooperatives sotmeses a la llei autonòmica una norma que (també es reconeix) és de caràcter laboral.

${ }^{341}$ ALFONSO SÁNCHEZ, R., La integración cooperativa..., op. cit., pàg. 340 a 342 ; en nota $54:$ "[...] Si
s'opta per l'assumpció de la LGC, això no significa que la norma estatal revisca malgrat la seua
derogació per la LCoop, sinó que els seus continguts materials es converteixen, per voluntat
explícita del legislador autonòmic, en norma legal pròpia de la comunitat autònoma". L'autora,
a més, explicita en "La reforma de la legislación estatal...», op. cit., nota 47 , que, en aplicació de
la línia actual d'interpretació del TC, la LGC haurà de considerar-se congelada, "ja que l'Estat,
ara sense competència per haver-la transferida, ja no podria [...] modificar-la ni derogar-la"; així
com que (pàg. 3) la falta total de pronunciament dels estatuts sobre l'aplicació supletòria de llei
estatal no pot sinó interpretar-se com "una opció legislativa particular tendent a desplaçar la
vigència de la llei estatal d'àmbit competencial autonòmic", cosa que fa més urgent en aquests
casos el pronunciament explícit, en un sentit o un altre.

${ }^{342} \mathrm{~L}$ 'esmentat article, efectivament reproduït en l'article 99.9 LCPV estableix que "d'acord amb el que estableix l'article 86.2 de la Llei estatal 27/1999, de 16 de juliol, de cooperatives, quan una cooperativa de treball associat cesse, per causes no imputables a aquesta, en una contracta de serveis o concessió administrativa i un nou empresari se'n fera càrrec, els socis treballadors que hi desenvolupen la seua activitat tindran els mateixos drets i deures que els hagueren correspost, d'acord amb la normativa vigent, si hagueren prestat el seu treball en la cooperativa en la condició de treballadors per compte aliè". El legislador basc afegeix un segon paràgraf a l'article 99.9 que diu que "els treballadors que es trobaren en la situació del paràgraf anterior 
Si la legislació laboral és atribuïda a l’Estat per l'article 149.1.7a ("sense perjudici de l'execució pels òrgans de les comunitats autònomes"), només una norma estatal pot regular la matèria relativa, en aquest cas, a la subrogació empresarial. Podria considerar-se directament aplicable a les cooperatives basques la previsió de l'article 86.2 LCoop, però ha de salvar-se per a això l'escull paradoxal que suposa l'article 2.A), segons el qual la LCoop només és aplicable a "las societats cooperatives que desenvolupen la seua activitat cooperativitzada en el territori de diverses comunitats autònomes, excepte quan en una es desenvolupe amb caràcter principal ${ }^{\prime 343}$. El mateix podria dir-se de la nova redacció de l'article 103 LCPV, amb l'expressada intenció d'introduir "en matèria de suspensió i extinció de contractes de socis treballadors (...), en coherència amb la regulació laboral vigent, els nous termes (causes tècniques, organitzatives o de producció) encunyats posteriorment a l'entrada en vigor" de la LCPV.

A parer nostre, en virtut de tot el que s'ha exposat fins ara, correspondria al legislador estatal prendre la iniciativa, ja de modificar la LCoop, ja de promulgar una nova norma, que regulara les matèries relatives a "la legislació general de caràcter mercantil", i a altres àmbits competencials diferents a l'específic de cooperatives que afecten de manera rellevant el seu funcionament (laboral, processal, registral...), i que es declarara aplicable a totes les comunitats autònomes. Mentrestant, només l'aplicació analògica, i no un exercici indegut de competències no atribuïdes, pot pal-liar l'evident perjudici que per a les cooperatives autonòmiques suposa no poder accedir a un tractament favorable en matèries de competència estatal. En tot cas, s'haurà d'atendre futures interpretacions jurisprudencials.

tindran, durant un termini de cinc anys, dret preferent de reingrés a la seua cooperativa d'origen si en aquesta es crearen nous llocs de treball de contingut similar al que ocupaven". Curiosament, l'art. 23 de la mateixa Llei $1 / 2000$, de la Presidència del Govern Basc, a l'hora
de redefinir l'àmbit d'aplicació de la LCPV, i estendre'l a totes les cooperatives que
desenvolupen amb caràcter principal la seua activitat cooperativitzada al País Basc, ho fa
"d'acord amb el que preveu l'article 2.a de la Llei $27 / 1999$ ". O s'entén que la comunitat
autònoma hi té competència suficient, amb la qual cosa no és necessària tal submissió a la llei 


\subsubsection{Situació actual}

Siga quina siga l'opinió que ens meresca l'esforç legislatiu i interpretador dut a terme ${ }^{344}$, és ben cert que, en l'actualitat, a l'Estat espanyol es disposa de deu textos (una llei estatal i, fins al moment, nou lleis de cooperatives autonòmiques) que regulen, amb caràcter general, les cooperatives, als quals han de sumar-se les normes estatals que regulen tipus concrets de cooperatives (la Llei de cooperatives de crèdit, el seu Reglament de desenvolupament, la Llei d'ordenació de les assegurances privades i el RD 2028/1995, que regula les condicions d'accés al finançament qualificat estatal dels habitatges promoguts per cooperatives); els seus autors han considerat necessari, en tots els casos, abordar, des del seu àmbit, la regulació de l'estructura orgànica de la $\operatorname{cooperativa}^{345}$. Vegem quins en són els trets principals i les previsions que, si escau, inclouen en relació amb la impugnació dels acords socials.

estatal, o l'ampliació excedeix de l'àmbit competencial autonòmic actual i hauria de recollir-se en una norma del bloc de constitucionalitat.

${ }^{344}$ VICENT CHULIÁ, F., «La llei de cooperatives catalana...», op. cit., pàg. 577: "El segon problema, si ha pagat la pena aquest esforç legislatiu, pot tenir avui respostes molt diverses. Hom no podia saber quina legislació cooperativa aprovarien les distintes assemblees legislatives. $\mathrm{Si}$ ara descobríem que el contingut de les cinc lleis és molt diversificat, seria una prova que la competència legislativa pròpia estava ben justificada. Per contra, si les cinc lleis s'assemblen notablement, com és la valoració més generalitzada, aquesta dispersió de les fonts de producció hauria acreditat la seua inutilitat (nota 4: "Amb vehemència ho diu el prof. Ignacio ARROYO: "[...] crida poderosament l'atenció [...] que el mosaic legislatiu amb prou feines revesteix coloració. La simple lectura comparada entre els preceptes cooperatius de bascs, catalans, andalusos, valencians i diguem estatals, quasi no ofereix sorpreses. Jo els convide a sortejar el trànsit, després d'estudiar el gairebé miler d'articles que integren les cinc lleis promulgades de moment» [pròleg a la primera edició, op. cit., $4 \mathrm{t}$ par.])".

PANIAGUA ZURERA, M., "La reforma de la legislación...", op. cit., pàg. 55: "no podem deixar de constatar una sèrie de circumstàncies summament greus des de l'òptica del foment del cooperativisme, de la llibertat d'empresa, de la unitat de mercat, de les competències exclusives de l'Estat, etc. Ens referim a aquesta espècie de competició atleticonormativa en què estan sumides diferents comunitats autònomes amb aparences de reformes periòdiques de les seues lleis de cooperatives. Competició a què se suma l'Estat [...]. A aquesta circumstància, ja greu, s'afegeix la irrupció d'altres comunitats autònomes - que estrenen competències sobre cooperatives en virtut de les transferències estatals- a l'espai normatiu col-lapsat que avui constitueix la legislació cooperativa espanyola".

${ }^{3.5} \mathrm{Hi}$ ha altres normes, estatals (per exemple, la Llei d'ordenació dels transports terrestres, i el seu Reglament de desenvolupament) i autonòmiques (per exemple, la Llei 8/1985 de la 
a) L'estructura dels òrgans

Els òrgans que amb caràcter necessari ${ }^{346} \mathrm{~s}^{\prime}$ estableixen en totes les lleis cooperatives actualment vigents a l'Estat espanyol són l'assemblea general, l'òrgan d'administració i els liquidadors quan la cooperativa es dissolga. Quant a l'òrgan de control, com hem vist, a l'Estat espanyol s'ha adoptat tradicionalment una estructura orgànica que segueix essencialment el model "llatí o francès", si bé denota una tendència a enfortir la creació i les competències dels òrgans de control, cosa que les apropa al model "germànic" ${ }^{347}$.

Així, la major part dels textos legals mantenen la intervenció com a òrgan de control típic, de caràcter obligatori, al qual progressivament $s$ 'incorporen noves competències que van més enllà de les de la supervisió dels comptes anuals (LCoop, LCC, LSCA, LFCN, LCE, LCG, LCA, LCCM, RCCred. facultativament). Però també es creen noves figures alternatives que, amb caràcter potestatiu 0 obligatori, assumeixen la funció de control de manera permanent (articles 48

Generalitat Valenciana, de 31.5, de regulació de l'actuació financera de les cooperatives amb secció de crèdit a la Comunitat Valenciana; el Decret 2/1997, de 7.1, de cooperatives de crèdit de la Comunitat Valenciana; i la Llei 6/1998 del Parlament de Catalunya, de 13 de maig, de regulació del funcionament de les seccions de crèdit de les cooperatives), que regulen el funcionament de la cooperativa, però la seua incidència en l'estructura orgànica no és tan rellevant.

346 TATO PLAZA, Anxo, "Os órganos sociais», en Estudios sobre a Lei de cooperativas de Galicia, (dir. D. Bello Janeiro), Escola Galega de Administración Pública, Santiago de Compostel-la, 1999, pàg. 70, distingeix tres classes d'òrgans a la cooperativa: necessaris (que haurà d'haver-hi en tota cooperativa), facultatius (que podran ser adoptats, en el seu cas, voluntàriament), i eventuals (que seran obligatoris només per a algunes cooperatives).

${ }^{30}$ GADEA, E., Evolución de la legislación..., op. cit., pàg. 110 a 112, i Derecho de las cooperativas..., op. cit., pàg. 161 a 164, estima que el model d'administració adoptat per la LCPV imposa una estructura dualista a les cooperatives que reunisquen determinats requisits i deixa llibertat d'elecció entre la dualista i la monista en els altres casos. LlOBREGAT HURTADO, M. L., La reforma..., op. cit., pàg. 161: "La Llei basca ha consagrat el sistema dualista de la Llei alemanya de societats anònimes atorgant al Consell de Vigilància (Comissió de Vigilància) les funcions de vigilància i control de l'òrgan d'administració, opera com una "minijunta»"; TATO PLAZA, A., "Os órganos sociais...", op. cit., pàg. 86 , considera que la comissió de vigilància basca i la comissió de control de la gestió valenciana són expressions del model dualista germànic. 
LCCV; 50 a 53 LCPV) ${ }^{348}$. Tot això sense perjudici que les cooperatives poden estar sotmeses, per mandat legal, per previsió estatutària o per decisió dels seus òrgans competents, al control extern d'una auditoria de comptes.

Atès el caràcter essencialment democràtic i participatiu de la cooperativa, l'assemblea s'ha configurat realment com el seu òrgan sobirà. Tanmateix, en les últimes reformes legislatives s'observa una certa tendència a establir límits a la seua amplíssima competència d'altres temps ${ }^{349}$. Així, la LCoop i la LCCM expliciten que l'assemblea "podrà prendre únicament acords obligatoris en matèries que aquesta Llei no considere competència exclusiva $d^{\prime} u n$ altre òrgan social" (articles 21.1 LCoop; 29.4, 2n paràgraf LCCM), mentre que atribueix al consell rector "les facultats que no estiguen reservades a altres òrgans socials", sense cap limitació (articles 32.1, 3r paràgraf LCoop; 39.1, 2n paràgraf LCCM); això no obstant, llevat d'una disposició estatutària, l'assemblea podrà impartir instruccions al consell rector o sotmetre a la seua autorització les decisions o els acords de l'òrgan d'administració en determinats assumptes (articles 21.1, 2n paràgraf LCoop; 29.4 LCCM $)^{350}$.

\footnotetext{
${ }^{348}$ Un comentari sobre la comissió de vigilància pot veure's en RODRíGUEZ, M. P. i SUSO, J. M., capítol V "Los órganos de la cooperativa», en AA. DD., Glosa a la Ley de cooperativas de Euskadi, (dir. N. Paz Canalejo), Consejo Superior de Cooperativas de Euskadi, Vitòria, 1999, pàg. 204 a 209.
}

${ }^{349}$ En la LGC de 1987 s'establia (article 43.1) que "tots els assumptes propis de la cooperativa, encara que siguen de la competència d'altres òrgans socials, podran ser objecte de debat $i$ acord de l'assemblea general", encara que s'atribuïen al consell rector (article 53.1, 2n par.) "totes les facultats que no estiguen reservades per la llei o pels estatuts a altres òrgans socials", però "sense perjudici del que estableix el número 1 de l'article 43". Ara, en la LCoop, "s'exclou la posibilitat que l'assemblea prenga decisions vinculants en matèries que la llei ha considerat com a competència exclusiva del consell rector o de qualsevol altre òrgan (cfr. art. 21.1)", i s'assenyala, a més a més, que ara la competència residual s'atribueix al consell rector (SÁNCHEZ RUIZ, M., "Capítulo Sexto...", op. cit., pàg. 202 i 203).

Se segueix, així, la tendència observada durant dècades en l'àmbit de les societats de capital (ESTEBAN VELASCO, Gaudencio, "Algunas reflexiones sobre la estructura orgánica de la sociedad de responsabilidad limitada en la nueva Ley", en AA. DD., Derecho de sociedades de responsabilidad limitada. Estudio sistemático de la Ley 2/1995, tom II, McGraw Hill, Madrid, 1996, pàg. 549 a 585; RODRíGUEZ ARTIGAS, Fernando, "La junta general de socios", en AA. DD., Derecho de sociedades de responsabilidad limitada. Estudio sistemático de la Ley 2/1995, tom II, McGraw Hill, Madrid, 1996, pàg. 591).

35" ALFONSO SÁNCHEZ, R., "Aspectos básicos...", op. cit., pàg. 176, ho considera "una clara ingerència" de l'assemblea en les funcions de l'òrgan d'administració, i que entorpeix la tasca de gestió i representació que la llei atribueix als administradors. SÁNCHEZ RUIZ, M., «Capítulo 
En la resta de lleis autonòmiques poden traçar-se diversos models, segons a quin òrgan atribuïsquen la competència residual: en favor de l'assemblea (LCC, LCCV, LCE ${ }^{351}$ ), o a l'òrgan d'administraciós ${ }^{352}$ (LCPV, LSCA, LCA ${ }^{353}$ ); per

Sexto...", op. cit., pàg. 205 i 206: "La dificultat més gran continua sent la determinació dels límits de l'actuació de l'assemblea en aquest context", citant la nombrosa doctrina que comenta el règim equivalent a la LSRL; a més a més, estima que "és important destacar que aquest sistema [...] té caràcter dispositiu [...]. Serà possible, en conseqüència, que en els estatuts d'una cooperativa concreta s'impedisca fer ús d'aquestes vies d'intervenció assembleària en assumptes de gestió. Així mateix, serà possible, $\mathrm{i}$ fins i tot convenient, que en els estatuts es concreten els sectors o les matèries sobre els quals l'assemblea podrà impartir instruccions 0 exigir autoritzacions, o bé aquells en què s'exclou aquesta possibilitat".

${ }^{351}$ LCC: article 28: "L'assemblea pot debatre i decidir qualsevol matèria de la cooperativa que no haja estat expressament atribuïda a un altre òrgan social"; article 39, "el consell rector [...] té competència per establir les directrius generals d'actuació, amb subordinació a la política fixada per l'assemblea general, i per realitzar els altres actes que li siguen atribuïts per aquesta Llei, els reglaments i els estatuts socials". En la mateixa línia, LCCV (articles 27.2 i 37.1, 2n par.), si bé "qualsevol limitació de les facultats representatives dels administradors serà ineficaç davant tercers". La LCE, tanmateix, va més enllà i estableix que "l'assemblea general té la doble missió de deliberar i decidir mitjançant votació, com a òrgan suprem de la voluntat social, tots els assumptes propis de la societat cooperativa, encara que siguen competència d'altres òrgans" (article 30.1, 2n pár.), mentre que "corresponen al consell rector totes les facultats que no estiguen reservades per la llei o pels estatuts a altres òrgans socials, sense perjudici del que estableix l'apartat segon del número 1 de l'article 30" (article 36.2).

${ }^{352}$ SÁNCHEZ RUIZ, M., «Capítulo Sexto...», op. cit., pág. 203: "Havent-hi assignat [...] al consell rector la competència residual per a decidir sobre matèries no atribuïdes per la llei o els estatuts a altres órgans, pareix que serà necessària una iniciativa expressa de l'assemblea per virtut de la qual atraga per a aquesta en concret la facultat decisòria sobre alguna d'aqueixes matèries. Sembla que l'assemblea [...] hauria d'anticipar-se a l'actuació del consell [...] ja que, a falta d'aqueixa iniciativa de l'assemblea, funcionaria la competència residual reconeguda al consell rector."

${ }^{30}$ LCPV: article 31.1: "L'assemblea general de la cooperativa és la reunió dels socis, constituïda per deliberar i prendre acords en les matèries de la seua competència"; article 40.1: "Els administradors són l'òrgan a què correspon en exclusiva la gestió i la representació de la cooperativa, i exerceixen a més totes les facultats que no estiguen expressament reservades per la llei o els estatuts a altres òrgans socials". GADEA, E., Derecho de las cooperativas..., op. cit., pàg. 165: "com que la normativa basca atribueix als administradors un protagonisme de primer ordre i els assigna, a més de les seues funcions pròpies, competència residual sobre totes aquelles facultats que no estiguen expressament reservades a altres òrgans per la llei o pels estatuts, caldrà que aquests prevegen que aquesta atribució, en principi no encomanada per llei a cap òrgan social, correspon a l'assemblea. En cas contrari, partint de que s'assenyala en l'últim incís de l'article 40 , serà competent l'òrgan d'administració". En la mateixa línia, la LSCA (articles 46 i 57). La LCA estableix que l'assemblea només podrà decidir en matèries que no siguen de competència exclusiva d'un altre òrgan social (article 27.1) i permet que es determinen estatutàriament les competències que corresponguen amb caràcter exclusiu al consell (article 37). Un comentari d'aquestes normes pot veure's en GUTIÉRREZ DíEZ, Ángel, «El 87.

Això no obstant, com assenyala PANIAGUA ZURERA, M., "La reforma de la legislación...», op. cit., pàg. 69, "per un arrossegament històric que es deixa sentir en la major part de la nostra 
excepció, la LCG reconeix a l'assemblea general la possibilitat d'adoptar acords en matèries no atribuïdes exclusivament a altres òrgans (article 31.2), i al consell rector exercitar "totes les facultats que no estiguen reservades per aquesta llei o pels estatuts a un altre òrgan social" (article 41.1)

Una altra via de "fugida" de competències de l'assemblea que s'apunta és en els casos en què la cooperativa pertany a un grup empresarial, en què tindrà competències delegades en aquesta entitat (articles 21 en relació amb el 78 LCoop; 135bis LCPV; 79 LFCN $^{355}$; 129 LCCM $^{356}$ ).

Finalment, s'observa una tendència a afavorir la realització de l'assemblea de delegats, fórmula ja tradicional en l'àmbit cooperatiu. Aquesta peculiar assemblea en dues fases té com a objectiu declarat facilitar la participació de col-lectius de socis amb dificultats per reunir-se per raons com ara el gran nombre o la dispersió geogràfica; però comporta un risc de manipulació pels grups interns més influents, ja que la delegació del vot personal es converteix en necessària ${ }^{357}$. Aquest risc s'aguditza amb la possibilitat incorporada a una

legislació cooperativa, quan el PLCA enumera les competències exclusives i indelegables de l'assemblea general insereix, a manera d'afegit, aquest incís qualsevol altra que, amb tal caràcter, siga prevista legalment o estatutàriament"; encara que el comentari es fa respecte del llavors Projecte de llei, la redacció de l'article 48.1 roman idèntica en la Llei.

${ }^{354}$ És aquesta només una de les diverses contradiccions en què incorre el text autonòmic gallec en matèria de delimitació de competències entre l'assemblea $i$ el consell, com analitza detalladament TATO PLAZA, A., "Os órganos sociais...», op. cit., pàg. 71 a 75 i 90 a 93.

${ }^{355}$ La LFCN regula, entre "altres formes de col-laboració entre cooperatives (article 79)", els "concerts per a [...] formació de fons de compensació, establiment de direcció única a les operacions concertades, "[...] cosa que pot interpretar-se com una via de fet per constituir vertaders grups cooperatius amb "unitat de direcció" i consolidació de resultats (ALFONSO SÁNCHEZ, R., "Aspectos básicos...», op. cit., pàg. 192: "grup cooperatiu [...] es defineix com un conjunt, format per diverses societats cooperatives qualsevol que siga la seua classe, i l'entitat cap de grup que exercita facultats o emet instruccions de compliment obligat per a les cooperatives agrupades de manera que es produeix una unitat de decisió en l'àmbit de les esmentades facultats").

${ }^{356}$ La LCA reconeix la possibilitat que les cooperatives constituïsquen grups cooperatius (article 91), però no es refereix a la delegació en aquests de facultats de l'assemblea.

${ }^{357}$ CUÑAT EDO, Vicente, «Consideraciones generales sobre la reforma del régimen de los órganos sociales de la Ley de cooperativas de la Comunidad Valenciana», Revista Jurídica de Economía Social y Cooperativa, CIRIEC-España, núm. 9, pàg. 138: "Especialment greu ens sembla aquest règim quan no es preveuen en la Llei causes d'aturada en la condició de delegat, ni tampoc 
bona part de les normes cooperatives (articles 30 LCoop; 35.4 LCCV; 38.2 LCPV; 55.10 LSCA; 37.2 LCCM; 19.3 RCCred.) que la delegació es produïsca amb caràcter permanent per un període de fins tres anys (o sense limitació temporal, en la LCPV i en el RCCred. ${ }^{358}$ ).

L'òrgan d'administració, que anteriorment podia adoptar únicament la forma pluripersonal col-legiada, el denominat "consell rector", pot ara, en diverses de les normes vigents, adoptar la forma unipersonal (articles 32.1, 2n paràgraf LCoop; article 37.2 LCCV; 41.1 LCPV; 63 LSCA; 37.2, 4t paràgraf LFCN; 41.1, 2n paràgraf LCG; 38.9 LCA; 39.1, 2n paràgraf LCCM) i, en algun cas, la pluripersonal no col-legiada (LCCV; LCA; LCCM); en altres, es preveu la possibilitat de reducció de la composició del consell (article 58.1, 2n paràgraf LSCA; 37.1 LCE). Amb això es pretén, fonamentalment, agilitar la gestió empresarial a les cooperatives amb un col-lectiu reduït de socis, en les quals el legislador suposa més immediatesa en la participació i, per tant, menys necessitat d'intervenció directa i permanent al control ${ }^{359}$.

D'altra banda, s'incorporen fórmules que preveuen, en circumstàncies determinades, la participació dels treballadors no socis, o la representació directa de determinats col-lectius de socis, o dels associats (articles 33 LCoop; 38.4 LCCV; 41.3 i 45.4 LCPV $^{360}$; 11 LCC; 58.4 i 6 LSCA; 37.3 LFCN; 37.2 i . 3 LCE; 43.3 i .4 LCG; 38.5 LCA; 41.1, 1r i 3r paràgrafs LCCM; 23.2 RCCred.).

s'exigeix, per a la validesa del pacte estatutari, que s'establisca un règim que atenga els problemes que aquesta "subsistència» de la «delegació» pot suscitar, en especial en cas de mal ús de la delegació".

${ }^{350}$ La LCA no esmenta si el mandat dels delegats és per a una sola assemblea, i remet a la regulació estatutària el tipus de mandat (article 35.2).

\footnotetext{
"MARÍN LOPEZ, J. J., «Notas sobre la Ley 27/1999...», op. cit., pàg. 1800, assenyala també com a objectiu la reducció dels costos "no sols econòmics, que suposaria l'existència d'un consell rector col-legiat que per prescripció legal hauria de tenir com a mínim tres socis".

de reseA, E., Derecho de las cooperativas..., op. cit. , pàg. 183, assenyala que "d'aquesta norma ha consell casos no ex és explificativa o oberta, per la qual cosa podrà utilitzar-se l'habilitació legal en convenient (nessament contemplats per aquesta, però en els quals també puga resultar en el régimenta 261: "Suso Vidal, J. M., «La confluencia del Derecho de sociedades mercantiles
} 
La tendència cap la professionalització de l'activitat de gestió es denota en diverses mesures. D'una banda, s'obri la possibilitat que persones no sòcies s'incorporen com a part minoritària, però significativa, de l'òrgan col-legiat $\mathrm{d}^{\prime}$ administració ${ }^{361}$ (articles 34.2 LCoop $^{362} ; 41.2$ LCPV $^{363} ; 60.2$ LSCA, únicament per al secretari; $44.1 \mathrm{LCG}^{364} ; 38.2 \mathrm{LCA} ; 41.1$, 2n paràgraf $\mathrm{LCCM}^{365}$ ), de la intervenció (articles 38.3, 2n paràgraf LCoop; 65.2, 3r paràgraf LSCA; article 53.1, 2n paràgraf LCG; 46.1 LCCM) i dels liquidadors (articles 71.1, 2n paràgraf i . 2 LCoop; 71.3 LCCV; 90.2 LCPV; 74.2 LCC; 113.2 LSCA; 98.1 LCE; 89.3 LCG; 68.3 LCA; 98.2 LCCM); d'una altra, s'observa més obertura i simplicitat en la

361 CUÑAT EDO, V., "Consideraciones generales...», op. cit., pàg. 147; VICENT CHULIA, F "Mercado, principios cooperativos...", op. cit., pàg. 18 i 19: "El càrrec d'administrador es professionalitza, es fa retribuït [...] i admet la incorporació de fins una quarta part de consellers no socis", però adverteix que "aquesta circumstància, tanmateix, per si mateixa no garanteix que aquests consellers reunisquen els requisits dels denominats "consellers independents" en els codis de bon govern de les societats cotitzades, és a dir, la no-pertinença a la direcció o staff de l'empresa, requisit indispensable per poder aportar una visió independent i crítica sobre la marxa de l'empresa".

${ }^{362}$ ALFONSO SÁNCHEZ, R., "Aspectos básicos...", op. cit., pàg. 180: "S'exigeix per a això previsió estatutària i que aquests tercers siguen "persones qualificades $\mathrm{i}$ expertes» - se suposa que en tasques de gestió i representació de la cooperativa en consideració al gir o tràfic d'aquesta (nota 72: "[...] TUSQUETS TRIAS DE BES, F., «La profesionalización de los cargos directivos en la nueva Ley de Cooperativas", RGD, núms. 664-665, 2000, pàg. 48-60)".

${ }^{363}$ RODRÍGUEZ, M. P. i SUSO, J. M., «Los órganos de la cooperativa...», op. cit., pàg. 168 i 173 ressalten, també com a mesura en nom d'una major professionalització de l'òrgan d'administració, que en la LCPV (article 131. 2) es preveu la possibilitat que a les cooperatives de segon o ulterior grau una part dels administradors siguen elegits "internament", això és, pels mateixos "rectors electes, entre persones capacitades que podran ser o no membres d'alguna cooperativa del grup".

${ }^{364}$ TATO PLAZA, A., "Os órganos sociais...", op. cit., pàg. 87: "les raons que justificaven l'existència d'un director desapareixen en gran manera amb la LCG [...] aquest text legal preveu la possibilitat de nomenar com administradors persones que no tenen la condició de socis [...]. D'aquesta manera, s'obri la possibilitat de nomenar com a administradors persones que tinguen els coneixements necessaris per a la gestió adequada del tràfic ordinari de l'empresa. I, quan això succeeix, desapareix en gran manera la necessitat de contractar un director o gerent".

${ }^{365} \mathrm{La}$ LFCN no esmenta la necessitat que els membres del consell rector siguen socis (article 37), a diferència de la previsió expressa per als interventors (article 40.1). El Reglament de la Llei reguladora de les cooperatives de crèdit (RD 84/1993) establia, al seu article 2.1.f, entre els requisits necessaris per obtenir i conservar l'autorització com a cooperativa de crèdit "comptar amb un consell rector format, almenys, per cinc membres, dos dels quals podran ser no socis"; tanmateix, la STC núm. 275/2000, de 16.11 (RJC 2000/275) ha declarat que aquesta norma no té el caràcter bàsic que li atribueix la disposició final quarta del Reglament mateix, en la mesura 
possibilitat que l'òrgan d'administració delegue part de les seues funcions, ja siga en una única persona, en qualitat de conseller delegat, o de diverses que funcionen col-legiadament, reunides en comissió executiva (articles 36.1 LCoop; 43.1, 2 i .3 LCCV; 43 LCC; 61 LSCA; 41 LCG, només per a un o diversos consellers delegats; 40.1 LCA; 42.5 LCCM, els consellers delegats del qual hauran de ser, si escau, dos de mancomunats; 25 RCCred, amb restriccions importants a la modalitat de consellers delegats); i l'apoderament, siga general o particular, s'incorpora com a opció explícita d'auxili a l'activitat empresarial (articles 32.3 LCoop; 41.6 LCPV; 61.4 LSCA; 36.5 LCE; 42.3 LCG; 40.1, 2n paràgraf LCA; 1 RD 2028/95).

La direcció adopta diferents configuracions: en la LCoop i en algunes normes autonòmiques va perdent els trets orgànics, en favor d'una clara caracterització com a apoderat general (article 32.3 LCoop; $41.6 \mathrm{LCPV}$, que permet que siguen diversos); al contrari, en altres normes autonòmiques, la seua regulació explícita i separada (articles 43.4 LCCV; 44 LCC; 64 LSCA $^{366}$; 39 LFCN; 39 LCE; 41 LCA; 45 LCCM; 27 RCCred) i, en algun cas, el reconeixement de la possibilitat d'una direcció pluripersonal (LCC; LSCA; LFCN; LCA; LCCred $^{367}$ ), permeten establir hipòtesis sobre el seu caràcter orgànic i sobre la possibilitat d'impugnació de les seues declaracions de voluntat ${ }^{368}$.

El caràcter participatiu de la cooperativa mateix i la peculiar activitat dirigida als propis socis fomenten l'existència d'altres òrgans. Així, la possibilitat d'organització de l'activitat en seccions fa que apareguen en aquests casos les assemblees de la secció (articles 5.3 LCoop; 7.4 LCCV; 6.2 LCPV; 6 LSCA; 112.2

que resulta incompatible amb les facultats de desenvolupament normatiu que en aquesta matèria tenen atribuïdes les comunitats autònomes.

\footnotetext{
34s PANIAGUA ZURERA, M., "La reforma de la legislación...», op. cit., pàg. 70 i 71, es planteja dubtes sobre si la direcció que regula la LCA és un òrgan o un apoderat voluntari.

${ }^{307}$ El RCCred (article 27) arriba a especificar que "quan els directors siguen dos o més, l'estatut haurà de determinar si han d'actuar de manera individual, conjunta o amb caràcter col-legiat"
} 
LCE; 9.2 LCG; 6.5 LCA; 6.2 LCCM ${ }^{369}$ ), i que es plantege la possibilitat d'òrgans d'administració o de direcció d'aquestes (articles 6.2, 2n paràgraf LCPV; 7.2 LCCV; 10.2 LCG; 6.3 LCCM; 4 LSSCred.C.). D'altra banda, la obligatorietat de participació del soci mateixa en l'activitat cooperativitzada genera una conflictivitat potencial en les relacions sociocooperatives, cosa que porta a preveure la possibilitat d'establir un òrgan especialitzat en la resolució dels conflictes interns: el comitè o comissió de recursos ${ }^{370}$ (articles 44 LCoop; 47 LCCV; 55 LCPV; 49 LCC; 75 LSCA; 41 LFCN; 46 LCE; 56 LCG; 45 LCA; 47 LCCM; 26.2 RCCred). A més, la majoria dels textos normatius preveuen la possibilitat d'altres òrgans socials (article 76 LSCA; article 26.2 RCCred), com el consell social (articles 54 LCPV; 46 LCA).

En relació amb els liquidadors, la LCoop sembla introduir una certa novetat, en indicar (article 71.1, 2n paràgraf) que "si els estatuts no hagueren previst a qui correspon executar les tasques de liquidació, l'assemblea general designarà, entre els socis (...), els liquidadors". S'obri així la possibilitat que puga regularse estatutàriament un altre procés de nomenament (per un altre òrgan, a persones no sòcies, etc.), o que, fins $i$ tot, es fixe per endavant qui, o quins càrrecs, efectuaran les funcions liquidadores, que podran, per exemple, recaure en membres de l'òrgan d'administració. De manera similar, la LFCN (article 61) remet als estatuts o, si escau, a l'assemblea, la determinació del procediment per a la liquidació, amb inclusió de nomenament dels liquidadors.

${ }^{368}$ La LCE (article 43.1, 2n par.) estableix explícitament que "els actes i les decisions adoptats pel gerent, a l'efecte de la possibilitat de la impugnació a la qual es refereix aquest article, es consideren acords adoptats pel consell rector".

${ }^{369}$ La LFCN, si bé preveu la possibilitat que les cooperatives constituïsquen seccions, mitjançant regulació estatutària, no es refereix al seu funcionament (article 9).

37" TATO PlAZA, A., "Os órganos sociais...", op. cit., pàg. 102: "l'existència del comitè de recursos pot semblar aconsellable en aquelles cooperatives amb un nombre elevat de socis en què la convocatòria d'una assemblea per a la resolució del recurs interposat per un soci puga generar problemes organitzatius i significatius costos econòmics". RoDRíGUEZ, M. P. i SUSO, J. M., "Los órganos de la cooperativa...", op. cit., pàg. 210, recullen la indicació que efectua l'exposició de motius de la LCPV en el sentit de recordar que el comitè no té l'obligació de limitar-se a resoldre reclamacions sobre resolucions de caràcter disciplinari, $\mathrm{i}$ els estatuts poden sotmetre altres qüestions a la seua revisió. 
b) La regulació de la impugnació dels acords

Una primera lectura dels articles destinats a la regulació de la impugnació dels acords en les diferents lleis cooperatives permet concloure, sense grans esforços, que la influència de la regulació de la matèria en les societats de capital ${ }^{371}$, i més concretament en la LSA, arriba fins al punt de transcriure literalment els textos legals originaris ${ }^{372}$. És sorprenent, precisament, la varietat que resulta d'aquesta tasca de mimetisme. Sense perjudici d'una anàlisi posterior en profunditat en els capítols següents (sobretot pel que fa a la LCoop i a la LCCV), pot efectuarse un apunt dels principals trets comuns i de les innovacions més significatives.

El règim bàsic de la impugnació s'estableix, de manera implícita, en relació amb l'assemblea general $^{373}$. Potser perquè històricament aquest ha estat el primer a establir-se, la seua regulació més detallada serveix de referència per a l'aplicació a la impugnació de les manifestacions de voluntat d'altres òrgans socials, ja siga per remissió expressa ${ }^{374}$, ja per aplicació analògica.

Les causes d'impugnació són, en general, tres: a) la contrarietat a la llei, b) l'oposició als estatuts socials, o c) la lesió als interessos de la cooperativa en

"n SÁNCHEZ RUIZ, M., «Capítulo Sexto...», op. cit., pág. 223.

${ }^{3 n}$ RoDRf́GUEZ, M. P. i SUSO, J. M., «Los órganos de la cooperativa...”, op. cit., pàg. 164: “Aquesta incorporació dels criteris legals aplicables a la impugnació d'acords de societats de capital a les cooperatives es justifica perquè la problemàtica subjacent a aquests articles és més semblant del que l'índole diferent de les persones jurídiques podria fer pensar [...]. Per contra, presenta l'avantatge afegit de permetre incorporar tota la riquesa interpretativa que la jurisprudència ha anat aportant al llarg de molts anys en la sempre conflictiva matèria de la impugnació d'acords societaris".

35 Com a excepció, la LCA (article 36, "Impugnació d'acords socials") es refereix expressament i en general a la impugnació "dels acords socials".

\footnotetext{
${ }^{3 / 4}$ Alguns exemples de remissió explícita poden trobar-se, per exemple, en els articles 16.4 LCoop (per a la negativa del consell rector a proporcionar informació obligatòria), 7.4 LCCV (per a la impugnació dels acords de l'assemblea de socis de la secció), 55.4, 2n paràgraf LCPV (per a la impugnació dels acords del comitè de recursos), i 112.2 LCE (per als acords de la junta de socis de la secció).
} 
benefici d'interessos extrasocials ${ }^{375}$. En el primer cas, els acords seran nuls; en els dos restants, es consideraran anul-lables. Les principals conseqüències de la distinció entre la nul-litat i l'anul·labilitat són un règim de legitimació diferent ${ }^{376} \mathrm{i}$ terminis diferents de caducitat per interposar l'acció; en relació amb aquesta última matèria, s'exceptuen els acords contraris a l'ordre públic, l'acció d'impugnació del qual no caduca ${ }^{377}$. En la major part de les normes es preveu la possibilitat d'"eliminar la causa de la impugnació", deixant sense efecte o substituint vàlidament l'acord impugnable per un altre (articles 31.1, 2n paràgraf LCoop, 36.3 LCCV; 39 LCPV; 38.1 LCC; 56.1, 2n paràgraf LSCA; 35.3 LCE; 40.1, 2n paràgraf LCG; 38.3 LCCM).

El procediment que s'estableix per a la impugnació és, en general, de caràcter extern i davant de la jurisdicció ordinària. L'opció legislativa passa, en la majoria dels casos, per remetre als articles que en la LSA regulen la impugnació dels acords socials ${ }^{378}$. En tot cas, això significa la submissió al judici ordinari previst en la LEC, en virtut de la remissió que efectua l'article 118 LSA $^{379}$.

\footnotetext{
${ }^{375}$ Els beneficiats poden ser tant socis com tercers, excepte en la LFCN (article 36), que només preveu la impugnació dels acords lesius de l'interès social quan beneficien socis.

${ }^{376}$ Sobre l'àmplia gamma de subjectes que poden ser titulars de legitimació per impugnar la LCoop i la LCCV, vegeu infra, capítol quart. La LCC (article 38) i la LFCN (article 36) estableixen un règim de legitimació bastant deficient que no inclou els tercers amb interès legítim; la LSCA (article 56) i la LCA (article 36) tampoc legitimen tercers.

La LCG deixa sense legitimació per a la impugnació dels acords lesius de l'interès social els administradors i els interventors no socis (TATO PLAZA, A., "Os órganos sociais...», op. cit., pàg. 85 i 86: "Situació aquesta que, certament, no sembla excessivament raonable, per tal com la impugnació d'un acord lesiu per a la cooperativa bé es podria entendre inclosa en el deure de diligència que l'article 50 exigeix a aquests administradors)".
}

${ }^{377}$ Contràriament, la LCC (article 38.4) estableix un únic termini de caducitat per a acords nuls i anul-lables, sense exceptuar a més els acords contraris a l'ordre públic. La LCA (article 36) no esmenta els acords contraris a l'ordre públic.

${ }^{378}$ La LCoop, la LCPV, i la LCCM, amb una tècnica més depurada en aquesta matèria que altres normes, remeten als articles 118 a 121 LSA, que són els que realment regulaven (fins a l'entrada en vigor de la LEC de 2000) els aspectes processals de la impugnació. La LCCV i la LCG, en canvi, es refereixen als articles 115 a 122 LSA, que inclouen aspectes no processals ja regulats, a més, expressament en les normes cooperatives. La LCE estableix que "les accions d'impugnació s'han d'acomodar a les normes establertes en l'article 118 de la Llei de règim jurídic de les societats anònimes (article 35.7). La LCA diu que els acords socials (en general !) "podran ser impugnats segons el procediment previst per a les societats anònimes". 
La Llei $1 / 2000$, de 8 de gener, d'enjudiciament civil, l'entrada en vigor de la qual es va produir el 8 de gener de 2001, ha reformat el procediment d'impugnació dels acords dels òrgans socials. En l'article 249.1.3r LEC es disposa que es decidiran en judici ordinari "les demandes sobre impugnació d'acords socials adoptats per juntes o assemblees generals o especials de socis o d'obligacionistes o per òrgans col-legiats d'administració en entitats mercantils". Com s'ha assenyalat, la redacció del precepte és confusa en diversos aspectes; en un dels que més directament ens afecten, és a dir, si en la menció a les "entitats mercantils" es pot incloure les cooperatives, sembla que la interpretació ha de ser afirmativa, atès el sentit amb què va ser inclosa, gràcies a l'esmena 289 del Grup Parlamentari Socialista, la motivació del quial assenyalava que "la inclusió de les actuacions relatives a impugnació d'acords socials ha d'incloure's amb la referència expressa a la naturalesa mercantil de les societats o entitats afectades (SA, SL i Cooperatives fonamentalment) $)^{\prime \prime 380}$.

La LSCA (article 56.5) es limita a dir que "el procediment d'impugnació dels acords nuls o anul-lables s'ajustarà a les normes de tramitació previstes en la legislació estatal aplicable [?!]". La LFCN (article 36), en una clara reminiscència de l'antic règim d'impugnació establert en la LSA de 1951 estableix per als acords nuls una presumpta doble via procedimental: la del judici declaratiu ordinari i la del "procediment especial previst en l'apartat següent". Aquest pretès "procediment especial", que és l'únic aplicable per als acords anul-lables, no és sinó el previst en l'"article 119 del Reial decret 1564/1989, de 22 de desembre, pel qual s'aprova el text refós de la Llei de societats anònimes". L'article 119.1 del TRLSA establia que "les accions d'impugnació dels acords socials s'han de tramitar d'acord amb el que disposa la Llei d'enjudiciament civil per al judici de menor quantia" que, com se sap, era el procediment declaratiu ordinari.

Comentari a part mereix la disposició final primera RCCred: "1. Els acords de l'assemblea general de les cooperatives de crèdit seran revisables judicialment d'acord amb les normes sobre impugnació d'acords socials establertes en el Text refós de la Llei de societats anònimes, [...] 2. La remissió que, sobre normes processals aplicables, conté la legislació cooperativa es considerarà realitzada, tractant-se de les entitats regulades pel present Reglament, en la normativa del Text refós a què es refereix el número anterior". Si ja era discutible que una norma de rang reglamentari poguera modificar els criteris continguts en normes legals, en l'actual marc competencial la norma podria ser titlada d'inconstitucional..., si no fóra perquè no té interès, ja que adopta la mateixa solució que les normes a les quals pretén interpretar".

La disposició final 3.1 i 3.2 de la Llei 1/2000, d'enjudiciament civil ha donat una nova redacció als articles 118 i 122 LSA. La disposició derogatòria única 2.2 ha derogat els articles 119 a 121 LSA, oblidant-se del contingut de l'article 31, apartats 5 i 6 LCoop, així com d'alguns dels articles citats en la nota anterior sobre la regulació autonòmica.

\footnotetext{
(3ñ SÁNCHEZ ÁlvAREZ, M. M., "Aspectos societarios de la nueva Ley de enjuiciamiento civil...", op. cit., pàg. 383 i 384.
} 
D'altra banda, l'article 222.3 LEC disposa que "les sentències que es dicten sobre impugnació d'acords societaris afectaran a tots els socis, encara que no hagueren litigat". Malgrat la derogació de l'anterior article 122.1 LSA, no pot entendre's que s'haja modificat la no-afectació als drets adquirits per tercers de bona fe a conseqüència de l'acord, ja que tal efecte s'assoleix per l'aplicació de les regles generals de la bona fe (articles 20.2 in fine i $21 \mathrm{Cco}$, i 7, 8 i 9 del $R R M)^{381}$. Tot això, a més, sense perjudici que l'oblit derogatori de la LEC respecte de l'existència de normes específiques en la legislació cooperativa fa que es mantinga en vigor la previsió de l'article 31.6 LCoop i de les normes autonòmiques equivalents.

La major part dels textos legals cooperatius actuals reconeixen explícitament la possibilitat d'impugnar els acords del consell rector (articles 37 LCoop; 41.6 LCCV; 49 LCPV; 62 LSCA; 43 LCE; 52 LGC; 44 LCCM $^{382}$ ), i estableixen algunes diferències notables respecte de la regulació de la impugnació d'acords de l'assemblea general (fonamentalment, la unificació de la legitimació i del termini per impugnar, tant en cas de nul-litat com d'anul-labilitat ${ }^{383}$ ), a la qual, d'altra banda, es remet per als aspectes processals.

${ }^{3 * 1}$ SÁNCHEZ ÁlVAREZ, M. M., "Aspectos societarios de la nueva Ley de enjuiciamiento civil...", op. cit., pàg. 386 .

${ }^{322}$ No preveuen la impugnació dels acords del consell la LCC i la LFCN. La LCA (article 36), com ja hem apuntat, regula la impugnació "dels acords socials", per la qual cosa és possible interpretar que els acords d'òrgans diferents a l'assemblea poden ser impugnats mitjançant la regulació general (en contra d'aquesta interpretació, BORJABAD GONZALO, P.J., Manual de derecho cooperativo..., op. cit., pàg. 385 i 386); això no obstant, com que remet al procediment previst per a les societats anònimes, l'aplicable per als acords de l'òrgan d'administració serà el regulat en la LSA per al consell d'administració.

${ }^{383}$ Contràriament, la LCPV (article 49) i la LCG (article 52) estableixen règims diferenciats d'impugnació per als acords nuls i per als anul-lables; vegeu, per a la LCPV, RODRfGUEZ, M. P. i SUSO, J. M., "Los órganos de la cooperativa...», op. cit., pàg. 201 a 203, i per a la LCG, TATO PLAZA, A., "Os órganos sociais...", op. cit., pàg. 96. La LSCA (article 62) estableix diferències en la legitimació $i$ remet, per a tota la resta d'aspectes a la impugnació dels acords de l'assemblea. La LCCM (article 44) que, com hem vist, per a la impugnació d'acords de l'assemblea remet expressament "als articles 118 a 121 del Text refós de la Llei de societats anònimes, aprovat per Reial decret legislatiu 1564/1989, de 22 de desembre (RCL 1989/1737 i RCL 1990/206)", en relació amb els acords del consell rector indica que "es tramitaran pel procediment establert en la legislació estatal". La parquedat del text, a més de cridar l'atenció en comparació amb la remissió exhaustiva efectuada per a l'assemblea, no deixa de suscitar dubtes: la menció a la 
Més dificultats planteja, com veurem, l'extensió de la impugnació a les altres formes d'organització de $1^{\prime}$ òrgan d'administració ${ }^{384}$, als òrgans en què aquest puga delegar competències ${ }^{385}$, i a la direcció ${ }^{386}$. Es reconeix en general la possibilitat d'impugnar els acords del comitè o comissió de recursos (articles 44.3 LCoop; 47.2 LCCV; 55.4, 2n paràgraf LCPV; 49.6 LCC; 75.3 LSCA; 41 LFCN; 46.3 , 4t paràgraf LCE; 56.3, 4t paràgraf LCG; 47 LCCM). Al contrari, no es diu res de les decisions de la intervención ${ }^{387}$ o dels liquidadors, ni tan sols quan se'ls reconeix la possibilitat d'actuació col-legiada ${ }^{388}$ (article 69 LSCA), ni, de bon tros, quan es faculta les cooperatives per a la constitució d'altres òrgans socials (article 76 LSCA).

Per a alguns acords, generalment del consell rector i relacionats amb l'alta i la baixa del soci o amb l'aplicació del règim disciplinari, s'estableix el que es podria anomenar una doble instància interna: l'acord de l'òrgan que inicialment resolga pot ser objecte de recurs davant d'un altre òrgan intern, generalment el comitè de recursos, si n'hi ha, o l'assemblea general ${ }^{389}$.

"legislació estatal» es refereix a la LSA o a la LCoop?; s'hi fa referència al procediment aplicable a la impugnació d'acords de la junta o assemblea general, o al de l’òrgan d'administració?.

34. Tanmateix, la LSCA (article 63) declara aplicable a l'administrador únic el règim d'impugnació d'acords previst en l'article 62 per als acords del consell rector.

30 Però l'article 49.1 LCPV i l'article 25.1 RCCred sí que reconeixen explícitament la possibilitat d'impugnar els acords de la comissió executiva pel mateix procediment que s'estableix per als acords del consell rector; i la LCG (article 52.1, 3r par.) equipara "els acords dels consellers delegats" als adoptats pel consell rector, a l'efecte de la impugnació.

346 Amb l'excepció ja esmentada de la LCE (article 43.1, 2n par.), que equipara "els actes i decisions adoptats pel gerent" als acords adoptats pel consell rector, a l'efecte de la possibilitat de la impugnació.

"En algun cas, com el de la LCG (article 53.4) s'estableix, amb caràcter general, que "serà d'aplicació als interventors, quan siga compatible, la regulació establerta per al consell rector".

"Com a excepció, la LCCM (article 98.4) preveu que "als liquidadors, els seran d'aplicació les normes establertes per als administradors que no s'oposen al que disposa aquesta secció".

wor Per al desenvolupament d'aquesta via de recurs intern a la LCoop i en la LCCV, vegeu infra l’epigraf 2.2.1 del capítol tercer. 
Finalment, en bona part dels textos legislatius citats es reconeix la possibilitat alternativa de sotmetre la impugnació a arbitratge privat (disposició addicional desena LCoop; articles 111 LCCV; 145.2, f) LCPV; 107 LCC; 176 LSCA; 166 i 167 LCE; 135.2, f) LCG; 136.3, e) LCCM).

A la vista del que s'ha exposat, poden extraure's dues conclusions bàsiques. La primera, reiterada per la doctrina, que "veritablement, no hi ha una raó objectiva que justifique" la multiplicitat de la regulació de les cooperatives a $l^{\prime}$ Estat espanyol ${ }^{390} \mathrm{i}$ que es fa cada vegada més patent la conveniència d'adoptar un nou model de distribució competencial, en el qual una llei estatal harmonitzadora regule els aspectes bàsics del funcionament i de l'estructura cooperativa $^{391}$ (entre els quals, els relatius a l'estructura orgànica bàsica i al

390

ALFONSO SÁNCHEZ, R., La integración cooperativa..., op. cit., pàg. 339 i 340: "Es tracta de la diversitat per la diversitat, sense atendre la possibilitat que alguna comunitat autònoma puga estar conforme amb la legislació estatal i no pretenga exercir la seua competència exclusiva"; i en "Aspectos básicos...", op. cit., pàg. 194 i 195: "Contrasta així l'extensió i densitat de la regulació estatal de la societat cooperativa amb el seu àmbit reduït d'aplicació; circumstància que es reprodueix en les - fins al moment- nou lleis autonòmiques, atès que en totes s'aborda el tractament dels mateixos aspectes concernents a la societat cooperativa i amb la mateixa intensitat [...] No obstant això, el sistema permet constatar que les lleis de cooperatives s'inspiren unes en altres, que les últimes recullen els aspectes més rellevants de les regulacions que les precedeixen, $i$ que les reformes se succeeixen per aprofitar les millores que s'advertisquen en la resta de les lleis de cooperatives. S'assisteix, doncs, a una mena d'esquizofrènia legislativa només controlable $i$ controlada gràcies a la vigència dels principis cooperatius, punt obligat $i$ comú de referència a l'hora de regular una forma social que meresca el cognom de cooperativa. I és que no hi ha en veritat particularitats territorials que reclamen la promulgació de lleis cooperatives autonòmiques, igual com no n'hi ha per pretendre, per exemple, una regulació autonòmica de la societat anònima". Ja hem vist les opinions coincidents de VICENT CHULIÁ, F., (p. e., en "La Llei de cooperatives catalana...», op. cit., pàg. 577; o en «La Ley 27/1999...», op. cit., pàg. 14567: "Una altra observació s'imposa, vista l'enorme producció normativa en matèria de cooperatives: Mai no s'ha cregut tant en la institucionalització, des dels poders públics, en tant que agències públiques de regulació, malgrat el fet que el cooperativisme històricament s'ha inspirat en el principi d'autoregulació, a partir del reconeixement doctrinal dels "principis cooperatius», fins al punt que alguns països europeus no han tingut legislació sobre cooperatives") i de ARROYO, I. («Prólogo a la primera edición...», op. cit., 4t par.). En el mateix sentit es manifesten GADEA, E., Evolución en la legislación..., op. cit., pàg. 6; i MONGE GIL, A. L., "Algunas reflexiones...», op. cit., pàg. 735.

${ }^{391}$ GADEA, E., Evolución en la legislación..., op. cit., pàg. 163 i 164: "L'existència de diverses lleis reguladores del règim jurídic de les societats cooperatives és perjudicial per a una societat que ha de competir amb institucions capitalistes que tenen una regulació uniforme [...]".Un altre argument bàsic en la mateixa direcció deriva de la lògica jurídica mateixa. Les comunitats autònomes en matèria de cooperatives no necessiten regular ex novo i totalment tot el que hi fa referència. Certament, no es veu cap necessitat que matèries com el concepte legal de societat cooperativa, els principis cooperatius $i$ la seua realització legal, el règim dels òrgans de gestió $i$ control de la cooperativa i de verificació o censura de comptes, el règim del capital, les causes 
procediment d'impugnació de declaracions orgàniques de voluntat) i les comunitats autònomes mantinguen la capacitat de desenvolupament.

La segona conclusió és que la legislació cooperativa actual es debat entre dues tendències: "d'una banda, la fidelitat al model defensor dels principis cooperatius i de la formació d'un patrimoni cooperatiu col-lectiu o irrepartible", i d'una altra, "la relaxació d'aquests objectius, a fi de satisfer les creixents exigències de l'individu, en resposta a la formació i a la disposició del seu patrimoni o propietat individual $i$, sobretot, del mercat ${ }^{392 / .}$. No és de fàcil resolució la tensió entre ambdues tendències: si bé és previsible que l'evolució legislativa vaja aprofundint en la uniformització de la cooperativa en els paràmetres de les formes empresarials col-lectives per excel-lència, les societats de capital, la relaxació dels principis cooperatius comporta la desaparició progressiva dels motius que justifiquen l'existència mateixa de la forma empresarial cooperativa. Per això, amb independència del criteri d'oportunitat que es mantinga, la doctrina continua posant èmfasi en el caràcter de principis configuradors que es pot atribuir als principis cooperatius, cosa que ha portat fins i tot a proposar-los com a regles d'harmonització legislativa, tant a escala estatal com internacional ${ }^{393}$.

de dissolució, el procediment de liquidació i el règim jurídic aplicable en cas d'insolvència, siguen diferents en cadascun dels territoris autònoms".

3n VICENT CHULIA, F., «La Ley 27/1999...», op. cit., pàg. 14567. GROSso, P., I controlli interni..., op. cit., pàg. 190: "allà on la dimensió de la cooperativa creix, [...] comporta inevitablement el recurs a criteris d'eficiència de gestió que, en part, sacrifiquen el principi democràtic que hauria d'animar la societat cooperativa (en el sentit que l'administrador-gerent, per no ser frenat en les seues decisions pel temps tècnic necessari per convocar l'assemblea i obtenir un acord ad hoc, serà investit de més poders que fins ara eren propis de l'assemblea de socis)".

ALFONSO SÁNCHEZ, R., «Aspectos básicos...», op. cit., pàg. 165 i 166: "els principis cooperatius juguen un paper transcendental en l'ordenació de la societat cooperativa a les nostres fronteres ja que actuen [tàcitament] com a regles d'harmonització legislativa, cosa que s'adverteix amb una simple lectura de les diverses lleis cooperatives. La similitud que guarden uns textos amb dels, malgrat que, lògicament, hi haja algunes divergències, no és el resultat d'un acord previ dels diferents poders legislatius en ordre a regular de forma homogènia la societat cooperativa, i tampoc és fruit de la casualitat sinó conseqüència del respecte als principis cooperatius particuts per l'Aliança Cooperativa Internacional [...] principis [i valors] comuns, assumits funcionarment i expressament per cada norma com a criteris als quals sotmetre l'actuació i el FAJARDO GARCi la societat cooperativa".

dels prin GARCIA, I-G, «El derecho cooperativo...», op. cit., pàg. 34: "reconèixer el valor universal principis cooperatius, com a nucli delimitador del concepte de cooperativa, és fer un pas 


\subsection{Els principis cooperatius}

Les cròniques de l'aparició i el desenvolupament del moviment cooperatiu deixen constància de la consolidació d'uns principis generalment admesos com a definidors del model, als quals haurien de subjectar-se les cooperatives que volgueren ser reconegudes com el que són. Aquests principis van ser formulats encara abans que la cooperativa fóra objecte de regulació jurídica; l'expressió més coneguda entre les primeres és la recollida en els estatuts de la cooperativa de consum anglesa dels "Justos Pioners de Rochdale" el $1844^{394}$. Sobre la seua base, l'Aliança Cooperativa Internacional ha efectuat successives versions, per adaptar-los als nous temps i a les noves circumstàncies en què es desenvolupen les cooperatives d'arreu el món ${ }^{395}$.

endavant en el camí, pretès per molts, cap a l'harmonització del dret cooperatiu als països de la
CEE".

MONTOLfO HERNÁNDEZ, J. M., "Leyes de cooperativas de las comunidades autónomas...», op. cit., pàg. 247 i 248: "l'acceptació d'uns principis inspiradors comuns - a través de la tècnica de la llista o enumeració, de remissió a la formulació de l'Aliança Cooperativa Internacional o de la seua invocació genèrica - unifica sense cap dubte la referència institucional. Podria concloure's que totes les regulacions se sostenen en una unitat doctrinal que suporta aquella".

${ }^{394}$ No és, tanmateix, l'única. TRUILlo DfEZ, Iván Jesús, «El valor jurídico de los principios cooperativos. A propósito de la Ley 27/1999, de 16 de julio, de cooperativas», en RCDI, núm. 658, març-abril, 2000, pàg. 1331 i 1331 explica com "a Alemanya, determinades contingències històriques han provocat que les seues cooperatives es regisquen per principis diferents [...]. La raó s'ha de buscar en el prompte desenvolupament de la banca cooperativa alemanya i paral-lelament la ràpida recepció legislativa del fenomen cooperatiu". A més, $s$ 'ha de reconèixer la influència decisiva, en els dos sectors principals de cooperatives a Alemanya, l'agrícola $i$ el de la banca popular, de dos personatges clau per al seu desenvolupament, Hermann SchulzeDelitzch i Friedrich Wilhelm Raiffeisen: "RAIFFEISEN va defensar una cooperació agrícola fundada en valors de solidaritat cristiana; SCHULZE-DELITZCH es va preocupar d'un cooperativisme comercial i aconfessional". Ambdós moviments es van dotar dels seus propis principis, diferents, almenys en part, als acceptats internacionalment (poden veure-se'n referències bibliogràfiques en CRACOGNA, Dante, «Reflexiones sobre los valores y los principios cooperativos en la Alianza Cooperativa Internacional», en Anuario de estudios cooperativos 1991, Instituto de Estudios Cooperativos, Universidad de Deusto, 1991, pàg. 99). Per això, com assenyala MÜNKNER, H., "Ley de cooperativas...", op. cit., pàg. 101 a 103, "explícitament el text legal vigent [la Llei de cooperatives alemanya] no conté cap precepte dedicat sistemàticament als principis que han de respectar les cooperatives. [...] Per aillar els principis que, des de Rochdale, caracteritza la institució cooperativa caldrà acudir a diferents seccions de l'articulat"; en la mateixa línia, PANIAGUA ZURERA, M., Mutualidad y lucro..., op. cit., pàg. 110.

${ }^{345}$ "L'Aliança Cooperativa Internacional (ACI), creada per les cooperatives el 1895, és l'organització coordinadora del moviment cooperatiu. L'ACI reuneix, representa i serveix els 
La redacció actual dels principis cooperatius es recull en la Declaració sobre la identitat cooperativa que l'ACI va adoptar al Congrés de Manchester, al setembre del $1995^{396}$. Aquesta Declaració suposa una ampliació del marc ideològic, en incloure, a més de la nova formulació dels principis cooperatius, una definició de cooperativa ${ }^{397}$ i una relació de valors ${ }^{398}$. La resolució de l'ACI per la qual s'aprova la Declaració dirigeix, a més, un doble missatge a les organitzacions membres $\mathrm{i}$ als òrgans governamentals $\mathrm{i}$ internacionals: a les primeres, els encarrega la missió de transmetre a les cooperatives la conveniència d'incorporar la Declaració a les seues normatives i reglaments, a posar-la en

seus membres, que inclouen les organitzacions cooperatives nacionals $\mathrm{i}$ internacionals en nombrosos sectors econòmics que van des de l'agricultura a la banca, l'energia i la indústria, $i$ des de les assegurances a la pesca, els habitatges, el turisme $i$ les cooperatives de consum. En total, l'ACI té més de 230 organitzacions membres de més de 100 països diferents que representen més de 730 milions d'individus a tot el món. El principal objectiu de l'ACI és promoure i enfortir les cooperatives autònomes a tot el món. Mitjançant les seues activitats internacionals, regionals i nacionals, l'ACI també procura encoratjar i defensar els valors i principis del cooperativisme" (OFICINA INTERNACIONAL DEL TRABAJO, Conferencia internacional del trabajo, $89^{a}$ reunión..., pàg. 122). Sobre la creació i evolució de l'ACI pot veure's DEL ARCO ÁlvAREZ RUBIO, José Luis, "Alianza Cooperativa Internacional», Congreso de cooperativismo, Universidad de Deusto, 1988, pàg. 205 a 230; i DRAPERI, Jean-François, L'ACI a cent ans: regard sur une histoire mémorable, RECMA, núm. 258, 3r trim. 1995, pàg. 73 a 82; i 259, 1r trim. 1996, pàg. 75 a 86; núm. 258, pàg. 76: "la història de l'ACI pot ser entesa com una dialèctica entre un moviment d'idees, la utopia cooperativa, i un moviment d'empreses, les pràctiques cooperatives". Sobre les formulacions successives dels principis cooperatius pels congressos de l'ACI, PANIAGUA ZURERA, M., Mutualidad y lucro..., op. cit., pàg. 80 a 90.

3\% La Declaració de l'Aliança Cooperativa Internacional sobre la identitat cooperativa ha estat editada a Espanya pel Consell Superior de Cooperatives d'Euskadi, i reeditada per la Confederació de Cooperatives de la Comunitat Valenciana. És aquesta edició, la tercera, del 1996, la que utilitzem per al nostre estudi. Un comentari d'aquesta pot veure's en CHOMEL, André i VIENNEY, Claude, «Déclaration de l'ACI: la continuité au risque de l'irrealité», RECMA, núm. 260, 2n trim. 1996, pàg. 64 a 71.

37 "Una cooperativa és una associació autònoma de persones que s'han unit de manera voluntària per satisfer les seues necessitats $i$ aspiracions econòmiques, socials $i$ culturals en comú mitjançant una empresa de propietat conjunta i de gestió democràtica."

33 "Les cooperatives estan basades en els valors de l'autoajuda, l'autoresponsabilitat, la democràcia, la igualtat, l'equitat i la solidaritat. Seguint la tradició dels seus fundadors, els socis cooperatius fan seus els valors ètics de l'honestedat, la transparència, la responsabilitat i la vocació socials". CRACOGNA, D, «Reflexiones sobre los valores...», op. cit., pàg. 98: "el moviment cooperatiu tendeix a la consecució de finalitats que són en si mateixes estats de perfecció inabastables, però que operen com un vertader nord per a la seua activitat (aquests serien els valors). Al seu torn, hi ha pautes o guies per a l'acció, que asseguren a través de la seua observança, estar orientats cap les finalitats perseguides; aquestes pautes serien els principis cooperatius". També pot veure's MARTÍNEZ CHARTERINA, Alejandro, "Los valores y principios cooperativos», REVESCO, núm. 61, 1995, pàg. 35 a 45. 
pràctica en el treball diari i a "animar els seus governs, allà on corresponga, a basar-hi la legislació cooperativa"; als governs, els demanda la conformació $d^{\prime \prime \prime}$ un marc jurídic que permeta les cooperatives funcionar com a organitzacions independents controlades pels socis, i en igualtat de condicions amb altres tipus d'empresa".

Els principis cooperatius actualment vigents, definits per l'ACI com a "pautes mitjançant les quals les cooperatives posen en pràctica els seus valors", són els següents: 1 . Adhesió voluntària i oberta ${ }^{399} ; 2$. Gestió democràtica per part dels socis $^{400}$; 3. Participació econòmica dels socis; 4 . Autonomia i independència; 5 . Educació, formació i informació; 6 . Cooperació entre cooperatives; i 7. Interès per la comunitat ${ }^{401}$. La seua anàlisi, tant des de la perspectiva històrica, com des de la jurídica i l'econòmica, ha donat lloc a una literatura abundant ${ }^{402}$. A l'efecte

\footnotetext{
${ }^{349}$ L'anomenat principi de "porta oberta" ha estat un dels que més interès ha despertat entre la doctrina mercantilista, que ha elaborat notables estudis sobre el tema. Vegeu DUQUE DOMfNGUEZ, Justino F., «La libre adhesión y el principio de puerta abierta en las sociedades cooperativas", en Primeros encuentros cooperativos de la Universidad del País Vasco, Departamento de Trabajo, Sanidad y Seguridad Social. Administración de la Comunidad Autónoma Vasca, Bilbao, 1986, pàg. 183 a 222; i SERRANO Y SOLDEVILLA, A. D., La cooperativa como..., op. cit. DARBÓMIDA, R., «Evoluzione dei principi...», op. cit., pàg. 99 i 100: "És conegut que el principi de l'open membership queda sotmès a contínues tensions i no sols - com s'ha acceptat històricament- de naturalesa religiosa, política o racial. L'aspirant a soci no té un vertader $i$ propi dret a ser admès si té els requisits objectius exigits per l'estatut, ni d'altra banda, la societat està obligada a acollir a qualsevol que sol-licite, en els terminis $\mathrm{i}$ amb les modalitats previstes, entrar-hi. Alguns sostenen que, de fet, en certs sectors de la cooperació «la porta està entretancada» [...] són perfectament legítims, en conjuntures econòmiques particulars, acords del consell d'administració o de l'assemblea que contenen la denegació, provisional, a nous ingressos, quan una dilatació excessiva de l'activitat i del col-lectiu social correria el risc de comprometre l'eficiència de l'empresa".
}

${ }^{400}$ MORILlas JARILLO, M. J., "La nueva regulación estatal...», op. cit., pàg. 4: "Es tracta d'un dels que, malgrat les consideracions crítiques realitzades des del pla teòric o observades en la pràctica de la vida cooperativa, no ha canviat el contingut"; tanmateix, la mateixa autora estima que alguns dels canvis que s'introdueixen en la legislació cooperativa, "com el vot plural ponderat i la possibilitat d'administració unipersonal, suposen "un xoc frontal amb l'esmentat principi, que, això no obstant, continua invocant-se d'una doble manera", directament i per remissió als formulats per l'Aliança Cooperativa internacional".

${ }^{101}$ Sobre aquest nou principi, afegit a Manchester, després de debats interessants al Congrés anterior de l'ACI, a Tòquio (1992), vegeu CHOMEL, A. i VIENNEY, C., "Déclaration de l'ACI...", op. cit., pàg. 69.

${ }^{412}$ Poden veure's, entre altres, diversos números monogràfics de les principals publicacions periòdiques sobre economia social, com ara el Boletín de la Asociación Internacional de Derecho Cooperativo, núms. 23/24, de maig-agost i setembre-desembre 1995, (BONFANTE, G., 
del nostre treball, interessa essencialment determinar quin és el valor dels principis cooperatius com a normes jurídiques aplicables al funcionament de les cooperatives $\mathrm{i}$ les repercussions possibles en el sistema d'impugnació de les declaracions de voluntat de la cooperativa.

L'origen històric prelegislatiu ${ }^{403}$, el seu caràcter marcadament ètic ${ }^{404} \mathrm{i}$ la denominació mateixa dels principis cooperatius poden portar a pensar, en una primera aproximació, que es tracta de normes metajurídiques o, almenys, de principis generals del dret, informadors només de manera implícita del concepte de cooperativa i dels seus trets normatius. Això no és així, almenys en les normes cooperatives de $1^{\prime}$ Estat espanyol, totes les quals assumeixen ${ }^{405}$, de

Cooperativism and large cooperatives; DARBOMIDA, R., EEC LAW, Cooperatives and co-operative principles; MUNKNER, H., Co-operative principles and the national co-operative legislation in Germany; PIOr, B., Les principes coopératifs et la réforme de la legislation cooperative française); Revista CIRIECEspanya, núm. 9, desembre, 1990 (MÜNKNER, H., "Los principios cooperativos...», op. cit., pàg. prácticas societarias de la cooperación», pàg. 15 a 33). També poden consultar-ses y monogràfiques col-lectives, com AA. DD., Congreso de cooperativismo, Universidad de obres 1988 (CARELLO, L. A., "El empresarialismo cooperativo, el cambio de los principios», pàg 203; DEFOURNY, J., "De la cooperation a l'economie sociale», pàg. 71 a 88; SCHUMMAN, 183 a línea ortodoxa cooperativa, el cooperativismo tradicional», pàg. 163 a 182); AA." "La Cooperativas, mercado, principios cooperativos (dir. J. L. Monzón Campos i A. Zevi), Ciriec-España, València, 1994; i altres treballs, com els de CRACOGNA, D, «Reflexiones sobre los valores cit., pàg. 97 a 109; DARBÓMAA, R «Evoluzione dei principi...», op. cit., pàg. 87 a 110; GAR, op. DEPALMA, Víctor M. "La cooperativa en el Derecho español a través de sus principios», RDNOt, núm. 111, gener pàg. 147 a 152. 5 . DízZ, I. J., "El valor jurídico de los principios...», op. cit.; i VERGEZ SÁNCHEZ, M., El derecho de las cooperativas..., op. cit., pàg. 67 a 71 .

"TRUJlllo Df́eZ, I. J., "El valor jurídico de los principios...”, op. cit., pàg. 1333 i 1334: "Quan apareixen les primeres legislacions cooperatives, la identificació del fenomen els imposa assumir una construcció normativa mínima ja elaborada, que es defineix pels principis cooperatius. [...] Molt lliure hauria estat la Llei de configurar al seu gust el règim de les cooperatives, però llavors hauria regulat un fenomen diferent al que hi havia en la vida social $i$, per tant, les cooperatives continuarien sense llei reguladora".

"PAZ Canalejo, N., «Principios cooperativos...», op. cit., pàg. 32 i 33. En la mateixa línia, LLOBREGAT HURTADO, M. L., Mutualidad y empresas cooperativas, op. cit., pàg. 11 i 12.

\footnotetext{
${ }^{40}$ Articles 1.1 LCoop; 1.2 LCPV; 1.3 i .4 LCC; 2.2 i .3 LSCA; 3 LCCV; 2 LFCN; 2 LCE; 1.4 LCG; 2.2 LCA; 1.2 LCCM.

LLUf́s I NAVAS, J., «La evolución de las directrices...», op. cit., pàg. 9 i 10, assenyala com tots els textos legals cooperatius de $1^{\prime}$ Estat espanyol han anat plasmant els principis cooperatius, d'una

0 una altra manera.
} 
manera explícita encara que amb fórmules diferents ${ }^{406}$, que l'estructura i el funcionament de les cooperatives que regulen han d'ajustar-se als principis cooperatius. Són, doncs, vertaderes normes jurídiques, i ho són amb rang legislatiu ${ }^{407}$, no en qualitat de principis generals del dret ${ }^{408}$.

Però a més, el seu caràcter definitori del model cooperatiu, converteix els principis cooperatius en l'equivalent dels anomenats "principis configuradors" dels tipus societaris capitalistes. En efecte, com veurem en tractar la qüestió de l'ordre públic com a límit a la caducitat de la impugnació dels acords nuls, en l'àmbit de les societats mercantils s'ha proposat que els acords contraris als

${ }^{406}$ En l'assumpció dels principis cooperatius, els diversos textos legals adopten diferents nivells de compromís, des d'aquells que es limiten a esmentar-los com a criteris orientadors, "en els termes resultants de la present Llei" (LCoop, LCPV, LCE), fins a aquells altres en què s'adopta expressament la formulació de l'ACI (LCG, LCCV, LCA, LFCN, LCCM) i/o es reprodueix la llista dels principis (LCC, LSCA, LCCV). En relació amb la LCoop., VICENT CHULIA, F., «La Ley $27 / 1999 . . .$, op. cit., pàg. 14569, assenyala el seu caràcter de "normes obligatòries», malgrat l'absència de la seua enumeració legal, i cita, en nota 13, les SSTS de 26.1.1983, 20.3.1986 i 28.1.1991. Com indica TRUJILlO DÍEZ, I. J., «El valor jurídico de los principios...», op. cit., pàg. 1337 i 1338: "La referència de la Llei a l'Aliança Cooperativa Internacional té una importància estètica i una altra real. Des del punt de vista estètic, s'ha de recordar que la de l'ACI no és l'única formulació dels principis cooperatius que ha gaudit de predicament. [...] Des de una perspectiva més pragmàtica [...] una remissió legal expressa als principis de l'Aliança Cooperativa Internacional podrà facilitar que el jutge motive fonamentadament $i$ sobre la base del Dret la seua decisió, acudint a la interpretació de les declaracions de l'ACI referides als principis cooperatius".

${ }^{407}$ MONGE GIL, A. L., "Algunas reflexiones..., op. cit., pàg. 737: "Aquests principis, aprovats per $\mathrm{l}^{\prime} \mathrm{ACI}$, tenen el caràcter de normes de Dret objectiu, al que han de sotmetre's els Estatuts i els acords socials. Així ho ha declarat el T. S. en sentències de 26 de gener de 1983 (RJA 389) i 20 de març de 1986 (RJA 1273) (en aquest sentit, VICENT CHULIÁ, F.: Compendio..., cit., pàg. 1020)". PAZ CANAlejo, PAZ CANAlejo, N. i VICENT CHUliÁ, F., Ley general... op. cit., pàg. 43 a 45, i en AA. DD., Glosa a la Ley de cooperativas de Euskadi, (dir. N. Paz Canalejo), Consejo Superior de Cooperativas de Euskadi, Vitoria, 1999, pàg. 14, on indica, com a concreció de l'aplicació normativa dels principis, que en alguns articles de la LCPV la trasgressió dels principis cooperatius constitueix infracció molt greu i pot arribar, per això, a ser causa legal de desqualificació (articles 139.3, d i 141.1, a LCE).

4lR TRUILLO DIEZ, I. J., «El valor jurídico de los principios...”, op. cit., pàg. 1342 i 1343: "Els principis cooperatius són normes directament aplicables, no perquè l'article 1.1 del Codi civil els constituïsca en font de l'ordenament jurídic, sinó perquè l'article 1.1 de la Llei de cooperatives de 1999 disposa que la cooperativa és una societat «conforme als principis formulats per l'aliança cooperativa internacional». Els principis cooperatius s'apliquen en defecte de regulació de la Llei de cooperatives, no perquè l'article $1.4 \mathrm{del}$ Codi civil mane que s'apliquen, en tant que principis generals del dret, en defecte de llei o de costum, sinó perquè la generalitat de l'article 1.1 de la Llei de cooperatives cedeix davant de la derogació singular de les seues normes particulars. [...] els principis cooperatius són finalitat de la Llei, no perquè es 
principis configuradors són contraris a l'ordre públic i, per tant, nuls amb una nul.litat indefinida, no caducable ${ }^{409}$.

D'una altra banda, s'assigna als principis cooperatius la funció de bases essencials de la cooperativa ${ }^{410}$. Des d'aquesta perspectiva, és gairebé obvi establir l'equivalència: els acords de la cooperativa que siguen contraris als principis cooperatius no sols seran nuls per ser contraris a la norma legal que els converteix en obligatoris jurídicament, sinó que la nul-litat podrà ser actuada

deriven del seu sentit general ni de la voluntat històrica del legislador, sinó perquè la Llei mateixa s'hi remet i els assumeix com a normes"

* Vegeu infra, capítol segon, epígraf 2.1.2 "Els contractes ordinaris requereixen per a la seua modificació el consentiment de tots els contractants [...]. En canvi, el contracte de societat permet [...] modificar els convenis fundacionals d'acord amb el principi de formació d'una voluntat corporativa. [...] La doctrina i la jurisprudència [...] partia del concepte que en l'escriptura s'havia establert el dret de la majoria a la modificació. És a dir, els contractants havien consentit prèviament en les reformes que s'acordaren per majoria. [...] es passava així de l'afirmació absoluta de la voluntat de cada soci a la seua negació absoluta en tant que no formava part de cada majoria, cosa que permetia a aquesta desconèixer tot dret a la minoria. Per evitar-ho es van elaborar: per la jurisprudència francesa, la doctrina de les bases essencials de la societat; per la doctrina alemanya, la dels drets irrevocables de l'accionista. Ambdues persegueixen una mateixa finalitat: [...]. Fixar una zona autònoma per a l'interès i la voluntat del soci davant la competència de l'interès i de la voluntat social". (RUBIO, J., Curso..., op. cit. pàg. 175 a 177).

"10 ALFONSO SÁNCHEZ, R., "Aspectos básicos...", op. cit., pàg. 165 i 166: "La LCoop incorpora així les previsions de la LSA i de la LSRL, assumides també per algunes lleis autonòmiques quant a la consideració dels [respectius] principis configuradors com a límits a la llibertat de pactes"; BASSI, A., Le società cooperative, op. cit., pàg. 14: "els "principis» serveixen per individualitzar el model minim d'organització mutualista per als legisladors dels estats adherents i per als diferents moviments cooperatius nacionals"; EMBID IRUJO, José Miguel, "El voto plural en la sociedad anónima. Comentario a la STS (Sala 1a) de 5 de noviembre de 1990", La Ley, 1991-1, pàg. 691 i 692: "el que la vigent llei (article 10) denomina "principis configuradors de la societat anònima" [...] No queda clar [...] el que l'expressió al-ludida significa, atesa l'absència d'un referent segur sobre això —com succeeix amb els "principis cooperatius» esmentats per la llei espanyola de cooperatives"; FAJARDO GARCfA, I. G., "El derecho cooperativo...», op. cit., pàg. 34: "què té d'especial que ens permeta reivindicar-ne el foment, una legislació adequada o un tracte més adequat a les seues peculiaritats? La resposta rau possiblement en el reconeixement dels principis cooperatius com a caràcters tipològics que defineixen més bé el que és la cooperativa, i en la seua incorporació a les diferents legislacions LLOBREGAT HURTADO, M. L., "La reforma...", op. cit., pàg. 147, s'hi refereix com els "principis ordenadors bàsics" de la cooperativa; Es refereixen concretament a la inclusió en el concepte d'ordre públic dels principis cooperatius, en tant que principis configuradors de la cooperativa, MORILLAS JARILLO, M. J. i FELIÚ REY, M. I., Curso..., op. cit., pàg. 255. VICENT CHULIÁ, F., «Mercado, principios cooperativos...», op. cit., pàg. 12: "Si en el dret de societats en sentit estricte o lucratives tant el Codi civil com el Codi de comerç $\mathrm{i}$ les lleis mercantils especials [...] imposen límits indubtables a l'autonomia de la voluntat [...], això és més comprensible encara en dret de cooperatives. Sobretot quan, seguint una pura tradició històrica, aquest pretén regular una forma d'agrupació de persones/empresa lucratives". 

cooperatiu", als elements essencials de la cooperativa. No hi ha, doncs, caf dubte sobre la impugnabilitat dels acords contraris als principis cooperatius ${ }^{411}$.

\subsection{Normes derivades de l'autonomia de la voluntat}

Vist el marc juridicolegal en què ha de desenvolupar-se la impugnació dels acords en la cooperativa, queden per veure la resta de normes que poden afectar aquest procés. Com ja s'ha indicat, l'autonomia de la voluntat de la persona jurídica li permet autoregular-se, dotar-se de l'estructura i de les normes de funcionament que considere convenients, amb els únics límits que es deriven del respecte a les lleis, a la moral i a l'ordre públic.

\section{La capacitat autocompositiva de les persones jurídiques es manifesta} fonamentalment en els estatuts socials ${ }^{412}$, en els reglaments de règim intern i en els acords dels òrgans socials amb competències per decidir sobre l'organització. L'interrogant bàsic que es produeix és l'abast d'aquesta autonomia: fins on pot arribar la voluntat de la persona jurídica en la configuració del procés d'impugnació?

Com s'ha dit, el paper de l'autonomia privada en la determinació del règim de la persona jurídica, en general, pot considerar-se des d'una doble perspectiva:

A11 MORILLAS JARILLO, M. J., «La nueva regulación estatal...», op. cit., pàg. 9, tanmateix, en dubta. Al contrari, DARBÓMIDA, R., "Evoluzione dei principi...", pàg. 100 i 101, reclama "la impugnació dels acords del consell d'administració que rebutge la sol-licitud de l'aspirant a soci, siguen
davant d'un òrgan col-legiat intern (com el col-legi arbitral o dels probiviri o el consell de
vigilància) o davant de l'asser possibilitat de reaccionar a les eventual'aquesta manera es donaria a l'aspirant a soci la satisfacció als propis interessos que s'assumeitren cetats dels administradors i trobar pacífica d'altra banda es permetria als socis verificar l'ex comuns als dels components de la societat $i$ administradors".

"12 Sobre la rellevància especial que en l'autoorganització de les cooperatives de segon grau pàg. $367 \mathrm{i} 368$. 
l'estructural i la tecnicolegislativa ${ }^{413}$. En el primer sentit, s'ha d'observar que els elements configuradors del tipus social que es tracte actuen com a límit a la libertat d'individualització de l'entitat particular; en el cas que ens ocupa, són els principis cooperatius els que hauran de ser respectats, en tot cas, per les normes juridicoprivades amb què es dote la cooperativa. El segon aspecte atén l'abundància o la mancança de normes legals dispositives i imperatives que regulen la matèria. Com més normes obligatòries o prohibitives continguen els textos legals aplicables el marge a l'autoregulació serà menor ${ }^{414}$; contràriament, si la norma legal conté fonamentalment normes dispositives (derogables o que ofereixen alternatives, o un contingut mínim ampliable ${ }^{415}$ ), la flexibilitat del tipus serà més gran.

Posats així els termes de la qüestió, poden observar-se tendències contradictòries en el marc de l'autoregulació cooperativa. Al nostre entendre, es pot afirmar que els principis cooperatius atribueixen, en principi, més grau de "rigidesa" al tipus cooperatiu, ja que inclouen trets metajurídics: l'entitat que pretenga ser qualificada com a cooperativa, no sols ha d'establir mecanismes que permeten l'adhesió voluntària i oberta dels qui vulguen ser-ne socis o deixar de ser-ho, així com la seua participació democràtica en la gestió i en l'activitat econòmica dels socis, sinó que ha de garantir l'autonomia i la independència de la cooperativa, ha de procurar l'educació, la formació i la informació dels seus socis i treballadors, $\mathrm{i}$ ha de tendir cap a la intercooperació entre cooperatives i el desenvolupament sostenible de la seua comunitat.

Tanmateix, com manifesta la doctrina, en les últimes dècades s'està produint una clara tendència cap a la "hibridació" de la cooperativa, mitjançant l'"atenuació" del rigor en l'exigència del compliment dels principis

\footnotetext{
MASSAGUER FUENTES, José, "La autonomía privada y la configuración del régimen jurídico de la sociedad de responsabilidad limitada», RGD, núm. 603, 1994, pàg. 12961.

"EMBID IRUJo, J. M. i MARTÍNEZ SANZ, F., "Libertad de configuración...", op. cit., pàg. 26.

${ }^{115}$ EMBID IRUJO, J. M. i MARTÍNEZ SANZ, F., "Libertad de configuración...», op. cit., pàg. 14.
} 
cooperatius $^{416}$. La necessitat constatada per les cooperatives d'adaptar-se a un mercat competitiu les porta a demandar canvis legislatius en aquest sentit i a adoptar fórmules organitzatives cada vegada més pròximes a les de les societats de capital ${ }^{417}$ : davant del principi d'adhesió lliure i voluntària, l'establiment de llargs períodes (fins a cinc anys) de permanència obligatòria mínima 0 els vincles societaris de durada determinada; davant la gestió democràtica, la regulació cada vegada més generosa del vot plural i la "professionalització" dels òrgans de gestió i de control; davant la consolidació d'un patrimoni comú irrepartible, la possibilitat de repartiment no solament d'excedent, sinó també de part dels beneficis...

Quant a l'aspecte relacionat amb el grau de flexibilitat del marc legal, el punt de partida no és gens encoratjador: en el ja comentat elenc de normes legals

\footnotetext{
416 CHOMEL, A. i VIENNEY, C., "Déclaration de l'ACI...», op. cit., pàg. 70; LLOBREGAT HuRTADO, M. L., «La reforma...», op. cit., pàg. 158: "En el fons d'aquest debat subjau la vella qüestió politicojurídica de com assegurar a les cooperatives un punt d'equilibri entre la inequívoca dimensió social atribuïda a aquesta figura $i$ les exigències inherents al seu vessant economicoempresarial. Aquesta polaritat implica necessàriament una certa dosi de flexibilitat en la posada en pràctica dels principis cooperatius, $i$ de vegades $n$ 'ha de quedar subordinada l'aplicació a les exigències de la realitat econòmica"; i en "Algunas reflexiones en torno a la nueva Ley de cooperativas valenciana", en Legislación y jurisprudencia, CIRIEC-España, núm. 6 , octubre, 1995, pàg. 269: "A aquestes alçaces no hi ha dubte sobre el fet que en sentit tecnicojurídic s'ha produït un procés legislatiu que va evolucionant cap a uns trets comuns característics de la cooperativa del futur, orientat cap a un model de cooperativa mixta on concórreguen socis cooperativistes $\mathrm{i}$ socis no usuaris, amb una doble causa mutualística $\mathrm{i}$ lucrativa". En la mateixa línia, MORILLAS JARILLO, M. J., «La nueva regulación estatal...», op. cit., pàg. 7.
}

${ }^{417}$ LLOBREGAT HURTADO, M. L., Mutualidad y empresas cooperativas, op. cit., pàg. 82 i 83: "comença a estendre's la preocupació per la pèrdua d'identitat de la cooperativa com a forma jurídica $i$ econòmica autònoma, davant les societats de capitals d'una banda $i$ les organitzacions d'interès col-lectiu, d'una altra. [...] s'introdueixen dins de l'ordenació cooperativa fórmules típicament capitalistes, com la figura del vot plural. Aquesta tendència es reforça encara més, com ja ha estat apuntat, per la creixent significació adquirida pel capital en el si de la pràctica empresarial $i$, en particular, per la posició que les noves fonts de finançament extern assumeixen en la direcció d'aquesta última. El resultat, com no podia ser d'una altra manera, ha estat el debilitament del paper actiu assignat als socis i l'ampliació de les relacions amb tercers. En les empreses cooperatives de grans dimensions, nascudes del procés de fusió i concentració d'altres unitats productives més menudes, la distància entre la cooperativa i el soci s'ha fet cada vegada més gran. De manera anàloga al que succeeix en altres grans empreses en forma de societat anònima, en la cooperativa comencen a advertir-se, a partir de la dècada dels setanta, símptomes creixents de burocratització $\mathrm{i}$ independència de la seua tecnoestructura". En la mateixa línia, DARBÓMIDA, R., "Evoluzione dei principi...», op. cit., pàg. 103, qui, davant el "risc inevitable de la desnaturalització de la idea cooperativa" aporta una recepta bàsica: "La resposta a aquests problemes és una sola: la circulació més àmplia i efectiva de la informació". 
cooperatives de l'Estat espanyol s'observa una general resistència a abandonar el tradicional i marcat caràcter "reglamentista" ${ }^{\text {"418 }}$. Tanmateix, en els textos legals aprovats en el procés de reforma de la dècada dels noranta s'apunta una tendència cap a la simplificació i la confiança en els mecanismes d'autocomposició societària, tant per la influència del dret de societats mercantils, al qual expressament s'aproximen, com per les demandes de flexibilitat legal efectuades pel moviment cooperatiu mateix. En aquest sentit, la LCoop és una de les normes que recullen més bé aquest esperit desregulador, expressant amb més amplitud l'admissibilitat d'autoorganitzaciós ${ }^{419}$, remetent aspectes importants al desenvolupament estatutari ${ }^{420}$ i renunciant a normar-ne d'altres ${ }^{421}$ o simplificant els seus requisits imperatius.

\subsubsection{Els estatuts socials: contingut obligatori i possibilitats d'autoregulació.} El procediment intern d'impugnació

" ${ }^{\text {st }}$ La reiteració en l'extensió i el detall normatiu cooperatiu sembla ser reflex condicionat de velles concepcions administratives paternalistes $\mathrm{i}$ intervencionistes heretades del règim autoritari anterior, així com de l'intent d'evitar que la fórmula cooperativa puga ser utilitzada amb interessos espuris.

"Així, per exemple, en l'article 10.1, 2n par. s'incorpora la norma societària que preveu que "en l'escriptura es podran incloure tots els pactes $\mathrm{i}$ les condicions que els promotors jutgen convenient establir, sempre que no s'oposen a les leis ni contradiguen els principis configuradors de la societat cooperativa". La inexpressió anterior no podia, evidentment, interpretar-se com a impossibilitat de la llibertat de pactes; el que es produeix ara és un canvi de tendència en la concepció legislativa, que comença a veure realment a la cooperativa com una modalitat específica d'empresa.

\footnotetext{
Les remissions a la previsió estatutària són abundantíssimes. A títol d'exemple, entre les més significatives, per la seua transcendència, poden esmentar-se l'atribució del vot plural o fraccionat (article 26) i la possibilitat que l'òrgan d'administració no adopte la forma de consell rector, sinó la d'administrador únic (article 32.1, $2 n$ par.). També es refereix a la notable flexibilitat i foment de l'autoregulació de la LCoop MORILLAS JARILLO, M. J., "La nueva regulación estatal...", op. cit., pàg. 8 i 9 , amb exemples abundants.

"Per exemple, la modificació dels estatuts socials, a la qual la LGC de 1987 dedicava els articles 92 i 93 , es redueix ara a la menció següent: "Qualsevol modificació dels estatuts es farà constar LCoscriptura pública, que s'inscriurà en el Registre de Societats Cooperatives" (article 11.3
} 
Els estatuts socials són, en l'àmbit de les persones jurídiques, la màxima expressió del principi de l'autonomia de la voluntat ${ }^{422}$. En aquests, els socis estableixen les principals normes de funcionament amb vocació de permanència amb què volen dotar-se, en el marc del respecte a "les lleis, la moral o l'ordre públic ${ }^{\prime \prime 23}$. Els estatuts socials són, a més, juntament amb la llei, fonts creadores de drets per als socis ${ }^{424}$. El reconeixement de la seua importància com a norma d'autoorganització es fa patent en establir la llei que l'acord que vulnere el que es preveu en els estatuts socials serà anul-lable. A falta de norma legal, doncs, o en el seu desplegament, s'haurà d'acudir als estatuts de la cooperativa, també per determinar el règim jurídic aplicable a la impugnació dels seus acords socials.

Efectivament, sens dubte els estatuts socials, en la seua qualitat de norma jurídica cooperativa, poden, $\mathrm{i}$ en alguns casos han de regular aspectes de la impugnació. Una de les qüestions que requerirà, necessàriament, un desenvolupament estatutari és la denominada "via interna d'impugnació judicial diferida ${ }^{\prime 425}$. En els supòsits ${ }^{426}$ en què l'acord d'un òrgan social pot estar

${ }^{422}$ Sobre el debat doctrinal respecte de la naturalesa negocial o normativa dels estatuts socials, vegeu SORIA FERRANDO, J. V., La impugnación..., op. cit., pàg. 230 a 233, on l'autor conclou que en l'àmbit del dret de societats espanyol "els Estatuts socials tenen naturalesa negocial i que els criteris que han de presidir-ne la interpretació són els de la interpretació dels contractes".

${ }^{423}$ Això no obstant, VICENT CHULIÁ, F., «Mercado, principios cooperativos...», op. cit. , pàg. 13, coneixent la realitat cooperativa, insisteix "en la necessitat d'estimular l'autonomia de la voluntat dels socis cooperativistes, i lamenta que, per exemple, l'opció de la nostra legislació exigint que en els Estatuts socials conste detalladament tot el règim de la cooperativa no haja estimulat l'«enginyeria contractual societària», sinó que la pràctica s'haja limitat a transcriure els models preredactats per l'administració pública".

${ }^{424}$ Tant la LCoop (article 16.1) com la LCCV (article 20, i) assenyalen la llei i els estatuts com a fonts dels drets dels socis. Qüestió diferent és, com indica ELEJABARRIETA GOIENETXE, A., "De los socios...», op. cit., pàg. 92, que "la manera concreta d'exercici dels drets" també puga precisar-se i desenvolupar-se mitjançant els acords vàlidament adoptats pels òrgans de les cooperatives.

${ }^{425}$ Vegeu el capítol tercer, epígraf 2.2.1.

${ }^{426}$ Per exemple, l'admissió o la inadmissió de la sol-licitud d'ingrés (articles 13.2 i 3 LCoop i 15.2 LCCV); la denegació d'informació als socis (article 16.4 LCoop); la imposició de sanció, inclosa la sanció màxima, l'expulsió (articles 18.3.c) LCoop, i 18.2 LCCV); la baixa obligatòria (17.5, 3r LCoop); la qualificació i els efectes de la baixa (17.6 LCoop); i la liquidació de les aportacions al capital en cas de baixa (51.2 LCoop). 
impugnat internament davant d'un altre òrgan, és de vegades la llei mateixa la que remet determinats aspectes a la seua regulació estatutària ${ }^{427}$, però en altres la norma legal, sense fer una crida expressa, en requerirà 0 aconsellarà un desenvolupament. La qualitat de la matèria, en la qual habitualment es veuen implicats drets dels socis $\mathrm{i}$ de tercers, reclamarà de vegades una regulació de rang estatutari, que el dote de transparència i de garanties jurídiques ${ }^{428}$.

D'altra banda, l'opció de la cooperativa per tenir un comitè o comissió de recursos implicarà necessàriament una previsió estatutària, que haurà de contenir el seu règim de funcionament, i en la qual podran també ampliar-se les competències de l'òrgan, més enllà de les que amb caràcter mínim li atribueixen l'article 44 LCoop o el 47 LCCV.

Un altre aspecte, que veurem més endavant i que presenta interès especial, és la possibilitat d'estendre la impugnació a acords i declaracions de voluntat d'òrgans socials per als quals l'ordenament jurídic no ha esmentat mecanismes de revisió: òrgans d'administració no colllegiats, òrgans de control, direcció, liquidadors, etc.

Però a més es pot plantejar la possibilitat o conveniència de desenvolupar aspectes continguts en la norma legal que en cada cas regule la impugnació, sempre que amb això no es vulneren mandats imperatius ni es lesionen interessos individuals ${ }^{429}$. Així, per exemple, no trobem raons que impedisquen que els estatuts qualifiquen concrets tipus d'acords com lesius per a l'interès de

\footnotetext{
"Per exemple, l'article 13.3 LCoop, per a la impugnació de l'acord d'admissió d'un nou soci, o els articles 18.2, 2n paràgraf i 47.2 LCCV, per a la submissió de la revisió de l'expulsió al comitè de recursos.

Aixi, per exemple, ELEJABARRIETA GOIENETXE, A., "De los socios...", op. cit., pàg. 122,
suggereix que "els estatuts de les cooperatives poden preveure que el silenci dels òrgans socials
en la resolució dels recursos per expedients de disciplina social es pot considerar com
denegatori dels recursos, amb el requisit que els Estatuts mateixos establisquen el termini a
partir del qual el silenci s'entendrà com a denegatori del recurs". EMBid IRUJo, J. M. i MARTínez SANZ, F., «Libertad de configuración...», op. cit., pàg. 15.
} 
la cooperativa, o que desenvolupen el procediment per eliminar la causa d'impugnació, o que establisquen mesures que garantisquen l'accés dels legitimats a la informació necessària per a una impugnació eventual o, com s'ha proposat, que tipifiquen sancions per la interposició d'impugnacions obstruccionistes i temeràries ${ }^{430}$. Altres aspectes de la impugnació, en canvi, per la seua formulació legal imperativa, no poden veure's modificats: els supòsits de nul-litat i d'anul-labilitat, la legitimació, la caducitat ${ }^{431}$, els aspectes processals i els efectes de la impugnació no són assumptes disponibles estatutàriament ${ }^{32}$.

\subsubsection{Altres normes: el reglament de règim intern; altres reglaments; els acords vàlidament adoptats pels òrgans competents}

És una pràctica societària bastant estesa, sobretot en persones jurídiques de dimensions importants o de funcionament complex, l'adopció de reglaments de règim intern que regulen aspectes de l'estructura i el funcionament social no previstos o que requerisquen més desenvolupament que el contingut en els estatuts socials. Poden, per tant, trobar-se en les cooperatives, com en altres persones jurídiques ${ }^{433}$, els anomenats usualment reglaments de règim intern o

${ }^{430}$ Elejabarrieta GoIENETXE, A., «De los socios...», op. cit., pàg. 79 i 80.

"31 GOMEZ ORBANEJA, E., "El proceso de impugnación...», op. cit., pàg. 127: "Els estatuts no poden ni suprimir ni limitar el dret d'impugnar. Tampoc sotmetre'l a uns terminis de caducitat diferents dels assenyalats per la llei. Sobre aquest no és possible ni transacció ni compromís".

${ }^{432}$ En relació amb això, ja s'ha fet referència supra, en l'epígraf 2.3 "La impugnació com a dret subjectiu o potestat" d'aquest capítol al caràcter de dret irrenunciable de la impugnació dels
acords.

${ }^{433}$ Es refereix a la freqüència relativa en les societats de capital d'aquests reglaments SÁNCHEZ CALERO, Fernando, Administradores..., op. cit., pàg. 453, distingeix entre els d'organització i els d'activitats, i n'assenyala l'abast estrictament intern. En el context del debat sobre la corporate governance, en els codis de conducta o codis de bon govern dirigits als consells d'administració de les societats cotitzades, es planteja, entre altres qüestions, la conveniència de dotar les societats cotitzades de reglaments reguladors del funcionament dels seus consells d'administració. Per a una anàlisi de les propostes espanyoles i de dret comparat sobre aquests codis de bon govern, vegeu AA. DD. El gobierno de las sociedades cotizadas, (coord. G. Esteban Velasco), Marcial Pons, Barcelona, 1999. Per a l'Estat espanyol, pot consultar-se el text del anomenat "Informe Olivencia", elaborat per la Comissió especial per a l'estudi d'un codi ètic 
interior, que unes vegades es dirigeixen a regular el funcionament de tots els òrgans socials, i unes altres atenen només determinades parts de l'estructura cooperativa $^{434}$. S'hi pretén, en general, agilitar i dotar de seguretat jurídica els processos de presa de decisions ${ }^{435}$, d'execució d'acords o de participació en la gestió. Aquesta normativa és aprovada normalment mitjançant l'acord majoritari de l'assemblea general ${ }^{436}$.

Com veurem més endavant, es qüestiona seriosament que puga impugnar-se un acord adoptat en contradicció amb les normes previstes en un reglament de règim intern ${ }^{437}$, ja que el tenor literal de la regulació de la impugnació es refereix sempre únicament a la infracció de normes legals o estatutàries. Però també s'haurà d'atendre, en cada cas, l'òrgan que haja aprovat el reglament (normalment, l'assemblea) i a qui tinga, legalment o estatutàriament, la competència per adoptar les corresponents normes de funcionament. En aquest

dels consells d'administració de les societats, a l'adreça electrònica de la Comissió Nacional del Mercat de Valors (http://www.cnmv.es).

Això no obstant, i a diferència del que s'ha apuntat en relació amb el reglament de funcionament del consell d'administració de les societats de capital, no és habitual trobar en les cooperatives una regulació específica del funcionament de determinats òrgans, almenys de l'òrgan d'administració; aquest reglament de règim intern tendeix a ser text regulador del funcionament de tots els òrgans socials. En les cooperatives, el funcionament del consell rector se sol detallar en els estatuts de l'entitat, i la LCCV (article 10.i) arriba a exigir-ne la inclusió com a contingut mínim estatutari; tanmateix, la LCoop deixa la porta oberta a una regulació extraestatutària possible, en assenyalar (article 36.1) que "els estatuts o, si no n'hi ha, l'assemblea general, regularan el funcionament del consell rector".

Sí que és més corrent trobar, en determinats tipus de cooperatives, reglaments de les seues seccions o fases. Així se sol donar, encara que no siga normalment obligatòria més que la regulació estatutària, en les cooperatives amb secció de crèdit, les cooperatives d'habitatges que desenvolupen diverses fases o promocions, o les cooperatives agràries organitzades en diverses seccions o que compten amb la qualificació d'organització de productors agraris.

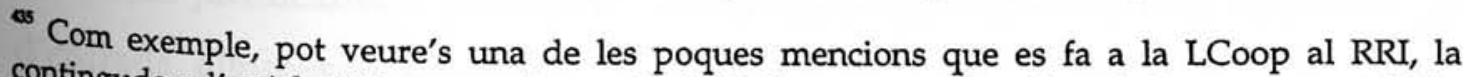
continguda a l'article 82.1 que, en la regulació de les cooperatives de treball associat, estableix que "els estatuts o el reglament de règim intern, establiran el règim disciplinari dels socis treballadors".

\footnotetext{
"L'article 11.4 LCoop preveu únicament que "els estatuts podran ser desenvolupats mitjançant un reglament de règim intern". L'article 10, in fine LCCV, en canvi, arriba a esmentar que "els estatuts podran ser desenvolupats mitjançant un reglament de règim intern aprovat per l'assemblea, la inscripció del qual en el Registre no serà obligatòria". Vegeu, en capítol segon, epígraf 1.2 in fine, les opinions d'AlCALÁ DÍAZ, M. A., La
impugnación..., op. cit., pàg. 308 a $310 \mathrm{i} 411$; DíAZ DE LEZCANO SEVILLANO, N., Los acuerdos del
} 
sentit, s'ha de recordar que, per exemple, la LCoop (article 36) legitima l'assemblea per regular el funcionament del consell rector, si no hi ha norma estatutària; en un altre supòsit (article 82.1), la LCoop reclama directament que els estatuts o el reglament de règim intern establisquen el règim disciplinari dels socis de les cooperatives de treball associat. Si el consell (o un altre òrgan) ignora voluntàriament alguna de les normes incorporades per l'assemblea al reglament, podria estar vulnerant aquelles normes legals.

En tot cas, amb independència de la possibilitat o no d'impugnar un acord lesiu de les normes reglamentàries, no hi ha dubte que aquestes poden contenir, d'altra banda, un desenvolupament detallat dels processos d'impugnació, sempre que no vulneren les disposicions legals i estatutàries, de caràcter més general, ni posen en perill els drets de les persones legitimades ${ }^{438}$.

I els mateixos arguments permeten sostenir el caràcter de normes reguladores d'altres reglaments o normatives interns que decidisquen adoptar els òrgans de la cooperativa facultats per desenvolupar el principi d'autonomia organitzativa.

consejo..., op. cit., pàg. 261 a 268; i SALELLES CLIMENT, J. R., El funcionamiento..., op. cit., pàg. 72 i 73.

${ }^{438}$ En contra, RODRfGUEZ, P. i SUSO, J. M., «Los órganos de la cooperativa...», op. cit., pàg. 166, que ni tan sols consideren que els estatuts socials puguen "entrar a regular aquestes matèries", encara que no ho argumenten. Crida l'atenció aquesta oposició, en el context d'una obra i d'una Llei que admeten àmpliament la possibilitat de regulació estatutària i reglamentària de molts altres aspectes (vegeu, per exemple, en pàg. 23, per a "la relació entre la junta de socis d'una secció i els administradors de la cooperativa"). 
CAPITOL SEGON

L'OBJECTE DE LA IMPUGNACIÓ (I): SEGONS LA CAUSA DE LA INVALIDESA I SEGONS LA NATURALESA DE LA CAUSA D'INVALIDESA

\section{Introducció}

Ja hem vist en el capítol primer que la impugnació en l'àmbit cooperatiu i del dret de societats és un procediment previst en l'ordenament jurídic per limitar la llibertat d'autoorganització de les persones jurídiques quan aquestes, mitjançant els seus acords (o, com veurem, altres declaracions de voluntat o de ciència) s'excedisquen en el seu àmbit d'autonomia. Es pretén amb això salvaguardar els diversos interessos que podrien quedar lesionats per l'actuació abusiva de la majoria social: l'interès al manteniment de la legalitat vigent, els interessos integrats al contracte social cooperatiu, els interessos legítims de terceres persones relacionades amb la cooperativa i els interessos socials $\mathrm{i}$ públics derivats de les finalitats i de l'activitat de la cooperativa. Hem vist també, a grans trets, el marc jurídic cooperatiu de referència. Correspon ara analitzar l'objecte sobre el qual recau la impugnació en la cooperativa.

De manera general s'admet que l'objecte de la impugnació en l'àmbit de les persones jurídiques són els acords dels seus òrgans collegiats que lesionen interessos jurídicament protegits ${ }^{439}$. Tanmateix, aquesta afirmació requereix, ja d'entrada, algunes matisacions.

D'una banda, s'ha de tenir en consideració que per a les cooperatives és encara més qüestionable que per a les societats de capital la restricció del procediment d'impugnació als acords d'òrgans col-legiats. En aquest sentit, veurem en el 
capítol tercer com pot interpretar-se que la legislació cooperativa permet d'impugnar-ne també els actes i les decisions d'òrgans unipersonals o pluripersonals no collegiats ${ }^{440}$.

D'altra banda, s'ha plantejat la possibilitat d'impugnar altres defectes, com ara els vicis de la convocatòria o de la constitució dels òrgans que han de prendre els acords, els documents relacionats amb els acords adoptats (acta de la sessió, balanç de la societat...), o els pronunciaments declaratius de drets relacionats amb la validesa d'acords (incompatibilitat o incapacitat d'administradors, condició de soci i el seu manteniment, realitat i quantia d'aportacions in natura, capacitat per a la seua realització.... ${ }^{441}$. Això no obstant, pel que fa a aquest segon bloc de "qüestions impugnables", hem d'avançar que al nostre entendre sempre hi haurà en relació amb els vicis, documents o pronunciaments, un 0 diversos acords o decisions de l'òrgan cooperatiu facultat per a això, que, o bé sancionen la seua validesa ${ }^{42}$ o bé seran fruit de deliberacions en les quals el vici ha estat determinant del resultat ${ }^{43}$; aquests acords o decisions són el vertader objecte de la impugnació.

A més s'ha de tenir present que no tots els actes d'un òrgan social són impugnables, sinó que cal que es tracte pròpiament de declaracions (de voluntat o de ciència) amb transcendència jurídica de l'òrgan com a tal. Així, no poden impugnar-se els actes que siguen simple execució dels acords de l’òrgan

\footnotetext{
${ }^{400}$ Vegeu el capítol tercer, epígraf 2.3. "Actes i decisions dels administradors".

${ }^{441}$ RODRÍGUEZ RUIZ DE VILLA, D., Impugnación..., op. cit., pàg. 25 i 26.

${ }^{4}$ Per exemple, l'article 74.2 LCoop estableix que el balanç final i el projecte de distribució de l'actiu sobrant de la liquidació "podran ser impugnats"; entenem que en aquest cas l'objecte de la impugnació serà, en realitat, l'acord corresponent d'aprovació de l'assemblea general, encara que el motiu de la impugnació faça referència a la incorrecció de les dades contingudes en aquells. En relació amb la no-nul-litat per se dels acords sobre els quals es nega l'emissió de certificació, vegeu RODŔ́GUEZ RUIZ DE VILLA, D., Impugnación... op. cit., pàg. 87, que cita en suport seu la STS RJA 1986/4407, i ROJO FERNÁNDEZ-Río, Ángel, «El derecho a obtener la certificación de acuerdos sociales», La Ley 1984 - 2, pàg. 1.131 a 1.143.
}

${ }^{43}$ Per exemple, els vicis de la convocatoria o de la constitució de l'órgan invaliden tots els acords adoptats en la reunió. Vegeu el capítol tercer, epígraf 1.2.3, "Impugnació de la realització de l'assemblea i, per tant, de tots els seus acords". 
mateix o d'un altre ${ }^{44}$. D'això es deriva, doncs, que no seran impugnables els actes d'un o diversos membres aillats, o del president de l'òrgan col-legiat (encara que, com veurem infra en relació amb aquest segon cas, les seues actuacions puguen viciar els acords que en conseqüència s'adopten). I això és predicable, al nostre entendre, de la major part dels òrgans de la cooperativa, no sols del d'administració, ni sols de les formes col-legiades.

En tot cas, la varietat dels supòsits que poden sorgir a l'efecte de la impugnabilitat dels acords ens han conduït a l'esbós de diverses classificacions de l'objecte de la impugnació, en consideració a diferents criteris.

Així, si atenem la causa d'invalidesa de l'acord ${ }^{45}$, l'ordenament jurídic mateix distingeix entre acords contraris a la llei, acords que s'oposen als estatuts i acords que lesionen els interessos de la cooperativa en benefici de socis o tercers. Si el que es pren en consideració és la naturalesa de l'esmentada causa $\mathrm{d}^{\prime}$ invalidesa ${ }^{446}$, parlarem d'acords nuls i d'acords anul-lables ${ }^{47}$. També podem

\footnotetext{
"' SÁNCHEZ CALERO, F., Administradores..., op. cit., pàg. 537. En aquest sentit, DIAZZ DE LEZCANO SEVILLANO, N., Los acuerdos del consejo..., op. cit., pàg. 239 i 240: "cal distingir entre les persones que formen l'òrgan i l'òrgan en si mateix. (...) Hi ha, per tant, una voluntat pròpia de la col-lectivitat davant la individual de cada membre", i cita molta jurisprudència.
}

${ }^{43}$ GOMEZ ORBANEJA, E., «El proceso de impugnación...», op. cit., pàg. 124; assumeixen aquesta posició GARCIA LUENGO, R., i SOTO VAZQUEZ, R., El nuevo régimen jurídico..., op. cit., pàg. $535 \mathrm{i}$ 536: "Ara bé, conforme a la teoria general, el negoci jurídic nul es caracteritza per la manca d'alguns requisits essencials, o per la infracció d'una norma legal de dret necessari, és a dir, d'una prohibició de la llei, de la moral o de l'ordre públic. (...) la distinció entre acords nuls i anul.lables (...) es basa, no en l'indole de l'acord, sinó en l'índole de la causa que l'invalida (...). No s'ha elegit el criteri de distinció entre nul-litat i anul-labilitat basat en la manca d'un element essencial, ni en el criteri basat en l'interès públic o privat tutelat per la norma infringida"; i SORIA FERRANDO, José Vicente, "Consideraciones sobre la eficacia de los acuerdos sociales declarados nulos (art. 67, párrafo $2^{\circ}$, de la Ley de sociedades anónimas)", RDM, 1982, núms. 165-166, pàg. 540. RODRíGUEZ ARTIGAS, Fernando i ESTEBAN VELASCO, Gaudencio, «Los órganos de la sociedad anónima", en AA. DD., El nuevo régimen jurídico de la sociedad anónima, Centro de estudios judiciales, Ministerio de Justicia, Centro de Publicaciones, Madrid, 1991, pàg. 113, es refereixen a aquesta classificació de les categories d'acords impugnables com a realitzada "des del punt de vista de l'objecte o dels interessos lesionats ".

"todríguez ArTigas, F. i Esteban Velasco, G., "Los órganos...”, op. cit., pàg. 113: "Des del punt de vista de la sanció...". anul-labilitat tenen un doble significat: com a concepte jurídic amb què es qualifica l'acte o 
classificar els acords i les decisions impugnables segons l'òrgan del qua emanen; en aquest cas, com veurem, pot plantejar-se la possibilitat d'impugnal els acords o les decisions de la major part dels seus òrgans col-legiate (assemblea general, altres assemblees i juntes, consell rector, comitè de recursos...) i d'alguns que són o poden ser unipersonals (òrgan d'administració unipersonal o pluripersonal solidari, direcció...); a més, per a alguns supòsits concrets d'acords impugnables (alta, sanció, baixa o expulsió de socis, denegació d'informació...) la Llei estableix la possibilitat de la impugnació interna, prèvia a la judicial, davant d'òrgans diferents al que va formular l'acord.

\section{L'objecte de la impugnació segons la causa d'invalidesa}

Tant l'article 31.1 LCoop com l'article 35.1 LCCV enumeren les causes que produeixen la invalidesa dels acords, en considerar impugnables els "que siguen contraris a la Llei, que s'oposen als Estatuts o lesionen, en benefici d'un o diversos socis o tercers, els interessos de la cooperativa". Tanmateix, la doctrina s'ha plantejat la qüestió de si hi ha únicament aquests motius d'impugnació o si podria ampliar-se l'elenc de supòsits impugnables.

Així, s'ha assenyalat l'absència d'esment sobre la impugnació possible dels acords presos amb abús de dret, la qual cosa ha plantejat un debat doctrinal sobre la seua admissibilitat ${ }^{448}$. Altres autors consideren nuls els acords "que siguen contraris a la moral, a l'ordre públic o als bons costums" ${ }^{\prime 449}$. I també $s^{\prime}$ han indicat com causes possibles de nul-litat dels acords "els vicis del consentiment o la voluntat (violència, error, frau causant) o d'incapacitat (minoria d'edat 0

negoci afectat d'un vici del qual es deriva l'ineficàcia, i com a règim jurídic, en tant que la qualificació del negoci jurídic viciat suposa l'aplicació d'un determinat i diferent règim jurídic".

${ }^{448}$ Vegeu infra, l'epígraf 1.3 d'aquest mateix capítol, en analitzar els supòsit d'acords impugnables per lesió de l'interès social i la referència, in fine, als acords adoptats amb abús de dret, com a categoria més general. 
decisiu per a la formació de la majoria necessària per a l'adopció de l'acord", o aquells altres que infringisquen la causa de la cooperativa ${ }^{450}$.

Davant d'aquests supòsits alguns autors consideren que la impugnació serà reconduible, en la majoria dels casos, a la infracció de norma legal, mentre que uns altres afirmen que, a falta de previsió normativa expressa, "no poden ser impugnats per causes diverses a les legals", ja que "la relació de vicis als quals s'aplica l'esmentat sistema ha de considerar-se exhaustiva", sense que es puga plantejar la seua impugnabilitat mitjançant l'aplicació de la disciplina pròpia del negoci jurídic ${ }^{451}$.

\subsection{Acords contraris a la Llei}

Respecte a què ha d'entendre's per "acords contraris a la Llei", GIMENO SENDRA i PAZ CANALEJO ${ }^{452}$ han traslladat a l'àmbit cooperatiu, sintetitzant-la, la polèmica doctrinal desenvolupada al seu dia per a les societats de capital. El debat s'ha centrat en dues qüestions bàsiques: la primera, relativa a si s'ha de considerar l'al-lusió exclusivament referida a la Llei concreta reguladora (LCoop, LCCV...) o si s'ha d'entendre l'accepció com referida a la «llei en sentit material», això és,

\footnotetext{
Vegeu infra, l'epígraf 2.1.2. d'aquest capítol, en analitzar els supòsit d'acords contraris a l'ordre públic.

"Vegeu la introducció a l'epígraf 2.1. "Acords nuls".

"Vegeu la introducció a l'epígraf 2.1. "Acords nuls". CABALlol I ANGELATS, L., "Comentario al artículo 115...», op. cit., p. 1109; SALELLES CLIMENT, J. R., El funcionamiento... op. cit., pàg. 383 a

En el dret italià, mantenen la no-aplicabilitat del règim dels vicis del negoci jurídic al dels acords socials, ASCARELI, Tullio, «L'interesse sociale dell'art. 2441 c.c. La teoria dei diritti individuali e il sistema dei vizi delle deliberazioni assambleare», en Riv. soc., 1956, pàg. 104; i SCARDINO, F., La società cooperativa, op. cit., pàg. 286.

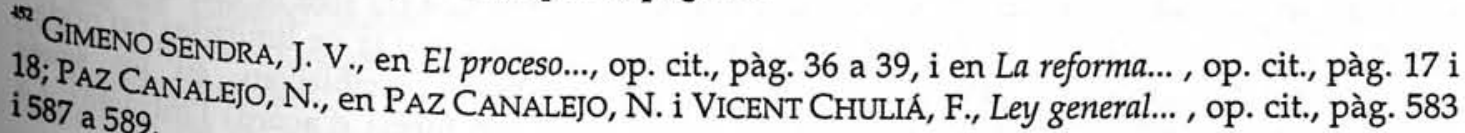


a qualsevol norma jurídica de rang legal en general; la segona qüestió es dedica a dilucidar si l'esment a la llei s'ha de considerar referit exclusivament a les normes de caràcter imperatiu o si s'hi ha d'incloure també les normes de caràcter dispositiu.

Pel que fa a la primera qüestió, una part de la doctrina manifesta els seus dubtes $^{453}$ o fins i tot es decanta clarament per considerar que la llei contrariada per $l^{\prime}$ acord ha de ser exclusivament la que regule el tipus social ${ }^{454}$. En síntesi, es

${ }^{453}$ Paz Canalejo, N., en .Paz CANAlejo, N. i Vicent Chullå, F., Ley general... ,op. cit., pàg. 583, 587 i 588: "principalment, sembla que es tracta d'al-ludir no només a la Llei general de cooperatives mateixa, sinó a qualsevol altra norma legal que resulte d'aplicació a aquestes societats i tinga relació amb l'acord assembleari...", però, tanmateix, adverteix que la tesi jurisprudencial aleshores dominant era aquella "segons la qual el fonament (de nul-litat) de l'acció d'impugnació ha de consistir, precisament, en la infracció d'una norma de la Llei de societats anònimes (i en el nostre cas, per tant, de la Llei de cooperatives)", per la qual cosa "potser s'hauria d'arribar a una altra conclusió diferent, a saber: que el legislador cooperatiu, quan al-ludeix als "acords contraris a la Llei" qualificant-los com a nuls, no pretén reiterar una cosa que, amb caràcter general, ja està afirmada en el Codi civil (article 6.3), sinó que relaciona l'acció (especial) impugnativa de nul-litat (que regula l'article 52 mateix) amb les transgressions a la (sola) Llei general de cooperatives (...) Amb tot, aquesta tesi no em sembla incontrovertible, davant la posició partidària d'interpretar àmpliament la fórmula legal".

L'opinió de VICENT CHULIÁ, F., en aquesta matèria sembla haver evolucionat; així, mentre que en "El derecho de los órganos sociales desde la perspectiva de la legislación cooperativa», RDM, núms. 153-154, juliol-desembre, 1979, pàg. 526, manté sobre les cooperatives que "la infracció de Llei, que implica nul-litat, no es refereix només a la Llei general de cooperatives (com estableix l'article 67-1r LSA vigent i el 83 de l'avantprojecte de LSA), sinó a qualsevol "llei"; i, d'altra banda, (...) ha de tractar-se de llei imperativa o prohibitiva, que no preveja, a més, expressament, un altre tipus de sanció diferent a la nul-litat (tot això si es té en compte l'article 6-3r del Codi civil); aquesta interpretació apareix com a doctrinalment pacífica en relació amb la Llei de societats anònimes, però hauria hagut de quedar fixada per la llei"; en canvi, en el Compendio crítico..., op. cit., Pàg. 607, respecte a la LSA considera que "...son nuls els contraris a la Llei (observeu, sempre en majúscula, referida a la Llei de societats anònimes, i no qualsevol altra norma de rang legal i menys reglamentari: per exemple, del RRM)". Finalment, en PAZ CANALEJO, N. i VICENT CHULIÁ, F., Ley general..., op. cit., pàg. 858, si bé manté la tesi restrictiva ("Violació de la Llei, és a dir, de la LGC mateixa, excloent-se que pel procediment de l'article 70 de la LSA puga exercitar-se acció de nul-litat en cas d'infracció d'altres lleis imperatives: tributàries, administratives, successòries, relatives als títols o contractes d'adquisició de la condició de soci quan no siguen regulats per la LGC"), acaba per concloure que "en realitat, després de la reforma del judici regulat en l'article 70 de la LSA per la disposició addicional cinquena de la Llei orgànica del poder judicial, substituint el procediment d'una instància pel de dos, ha perdut sentit la limitació legal de la contingència de la causa d'aquest judici especial".

${ }^{454}$ ARANGUREN URRIZA, Francisco José, "Los órganos de la sociedad limitada", en AA. DD., La sociedad de responsabilidad limitada, tom I, Madrid, Trivium, 1996, pàg. 1172 a 1177: "no es diu que no siguen impugnables els acords contraris a una altra norma que no siga la Llei de societats anònimes ni la de limitades, sinó que la Llei de societats anònimes o la de limitadas no poden regular qualsevol nul-litat diferent de la que elles mateixes estableixen, en les seues conseqüències materials, per més que siga un òrgan social (en forma d'acord) l'infractor. La 
tractaria, segons aquests autors, de distingir els acords que vulneren preceptes
concrets de la llei reguladora del tipus social i que no poden considerar-se inclosos en les causes de nul-litat absoluta previstes en el Codi civil. Els primers serien els únics sotmesos al procediment impugnador que ara s'analitza, mentre que els segons seguirien, si escau, el procediment declaratiu ordinari aplicable als supòsits de nul-litat radical dels negocis jurídics ${ }^{455}$.

Contràriament, l'opinió majoritària interpreta l'accepció "acords socials contraris a la Llei" com a referència a tots aquells que contravinguen qualssevol normes legals de caràcter imperatiu ${ }^{456}$. En efecte, la inclusió de tota classe de

unificació processal és una cosa, i s'admet que ha desaparegut el procediment especial, com a instància única, però hi ha un procediment amb especialitats per a determinats supòsits d'antijuridicitat $i$ aquestes especialitats, entre les quals hi ha fonamentalment la caducitat en

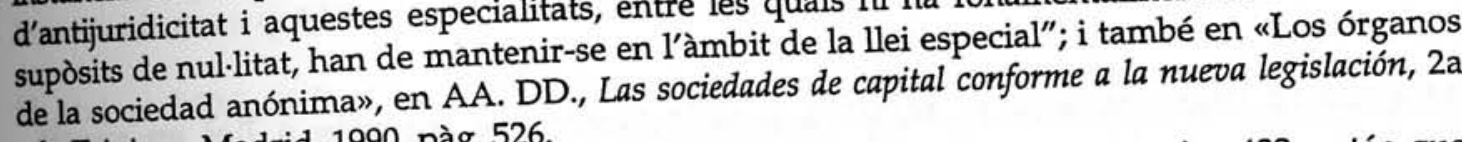
ed., Trivium, Madrid, 1990, pàg. 526.

Ávila NAVARro, Pedro, La sociedad limitada , vol. I, Barcelona, Bosch, 1996, pàg. 422, entén que l'article 115 LSA, quan parla d'acords contraris a la Llei ho fa "amb majúscula", per la qual cosa es "a una llei concreta, la mateixa de què està parlant; perquè per declarar nuls els acords contraris a la llei en general n'hi havia prou amb l'article $6 \mathrm{CC}$, que no pot entendre's tàcitament derogat per l'article 115 LSA". Això no obstant, d'altra banda, aquest autor entén que en virtut de l'article $6 \mathrm{CC}$, han de continuar entenent-se nuls de ple dret, en un règim de "nul-litat absoluta, no susceptible de convalidació expressa ni tàcita, ni tan sols per caducitat de l'acció (...) els actes contraris a la llei en general i també als principis de la Llei de societats anònimes mateixa diferents dels que regulen estrictament els requisits de convocatòria, funcionament $i$ competència de la junta", que serien els únics sotmesos al que denomina "nul-litat especial" de la LSA, i com a suport d'aquesta interpretació cita la regulació dels acords contraris a l'ordre

"Diaz de lezcano Sevillano, N., Los acuerdos del consejo..., op. cit., pàg. 244 i 245 diu que aquesta postura era la mantinguda per la major part de la doctrina $\mathrm{i}$ de la jurisprudència anterior a la Llei de reforma i adaptació del 1989, "per tal com a l'emparament de la LSA de 1951 coexistien dos procediments, un d'especial previst a l'article 70 de la Llei, i un altre, el procediment declaratiu ordinari aplicable als supòsits d'ineficàcia no previstos en la Llei de societats anònimes".

" EMBID IRUJO, J. M., i MARTINEZ SANZ, F., "Libertad de configuración...", op. cit., pàg. 17; GIRON TENA, J., Derecho de sociedades anónimas, op. cit., pàg. 319; GIMENO SENDRA, J. V., «El proceso... op. cit., pàg. 37 i 38; GOMEZ ORBANEJA, E., «El proceso de impugnación...», op. cit. pàg. 124; LASSALETA GARCíA, Pedro, "Impugnación de acuerdos del consejo rector en las sociedades cooperativas", RDPri, abril, 1994, pàg. 335, nota 7: "no s'ha d'entendre el terme Llei exclusivament a la Llei general de cooperatives: quan (...) es parla d' «acords contraris a la Llei», pel caràcter general que li confereix l'article la; altrament, en comptes de la Llei hauria d'expressar aquesta Llei"; i MORILlAS JARILLO, M. J., i Feliú REY, M. I., Curso..., op. cit., pàg. 254. La tesi de GIMENO també la subscriuen de manera expressa MARÍN LOPEZ, Juan José, "Novedades de la Ley general de cooperativas de 2 de abril de 1987 en materia de impugnación de acuerdos sociales", La Ley, 1988 - 2, pàg. 1.126 i 1.127 (especificant, això no obstant, que "la vulneració de la norma ha de ser directa i terminant, i la norma vulnerada ha de ser 
normes esdevé imprescindible si es pensa en determinats supòsits en els quals l'acord adoptat per la cooperativa vulnera, no ja la Llei cooperativa aplicable mateixa, sinó una altra norma legal d'obligat compliment relacionada amb l'activitat de la cooperativa (per exemple: acord de l'assemblea general, que compleix tots els requisits formals, suprimint les vacances dels treballadors per compte d'altri). Sotmetre aquests acords al procediment declaratiu ordinari, sense les especificitats pròpies de la impugnació de les declaracions de voluntat de les persones jurídiques, introduiria un greu risc d'inseguretat jurídica a l'hora de determinar les condicions aplicables, i no creiem que haja estat aquesta la intenció del legislador, sinó la d'establir un procediment àgil i específic, apte per resoldre totes les nul-litats que es puguen produir en un tipus de negoci jurídic molt concret: el que es perfecciona mitjançant' l'acord de voluntats dels membres d'un òrgan social.

Una qüestió diferent serà la relativa a si la norma es refereix a llei en sentit formal, com a norma emanada del poder legislatiu, o al-ludeix a llei material; llavors s'hi podran considerar incloses les normes de rang inferior, com ara els reglaments ${ }^{457}$. Al nostre entendre, si bé l'enunciat del text legal no donaria lloc a

qualitativament important") i UCELAY URECH, Inés, "El abuso del derecho por socios de cooperativas", La Ley, 1997 (2.9.97), D-228, pàg. 1349 a 1359, i ha estat citada per nombrosos autors, entre altres, N. PAZ CANALEjo mateix en PAZ CANAlejo, N., Vicent CHULIÁ, F., Ley general..., op. cit., pàg. 588.

${ }^{457}$ A favor, DIAZ DE LEZCANO SEVILlanO, N., Los acuerdos del consejo..., op. cit., pàg. 24, que estima que el concepte de llei material s'ha d'entendre com "tot acte dels poders públics que incloga autèntiques normes jurídiques amb independència que emanen del poder legislatiu 0 no" i que s'hi han d'incloure "una disposició normativa governamental Decret-Llei o Decret Legislatiu, així com "els Reglaments de les entitats locals", i "quan es tracte de normes reglamentàries si hi ha una habilitació legal expressa per regular matèries no organitzatives de l'administració pública; FERRÁNDIZ, J. R., i GIMENO-BAYÓN, R., Praxis mercantil. Sociedades mercantiles. Sociedades anónimas: junta general y administradores, vol. II., pàg. 328/11 i 12: "considerar la Llei, a aquests efectes, en el seu sentit material, per comprendre, a més de la Constitució, les ordinàries en sentit estricte, emanades de les Corts generals i de les Comunitats Autònomes, els tractats internacionals integrats a l'Ordenació, els decrets-lleis i Legislatius i, fins i tot, els reglaments. Quant a aquests, això no obstant, el judici de l'antijuridicitat exigirà prendre en consideració, a més de la jerarquia normativa (articles 97 i 106, Const. I 6, L. org. P. $\mathrm{J}$.), la qual cosa és pròpia matèria reglamentària i límit substancial de la potestat de reglamentar, com assenyala García de Enterría: l'organització de l'administració, àmbit natural del Reglament, o qualsevol altra matèria sempre que hi haja una habilitació legal concreta que haja obert la possibilitat de la seua regulació per aquest tipus de norma jurídica"; MORILLAS JARILLO, M. J. i FELIÚ REY, M. I., Curso..., op. cit., pàg 254; i RODRfGUEZ RUIZ DE VILLA,D., Impugnación..., op. cit., pàg. 30: "si es manté la concepció formalista d'aquesta, resultaria que no hi hauria la 
ua ampliació tan important, la interpretació literal no deixa de plantejar dubtes, ja que, en aquest cas, els acords vulnerants de normes reglamentàries aplicables a les cooperatives ${ }^{458}$ quedarien fora de l'àmbit dels acords nuls per contraris a la Llei. D'altra banda, no trobem motius per considerar fora del concepte les lleis promulgades per les comunitats autònomes ni els tractats internacionals ${ }^{459}$.

Pel que fa a la necessitat que les normes vulnerades siguen de caràcter imperatiu $^{460}, \mathrm{~s}^{\prime}$ ha fonamentat en tres tipus d'arguments ${ }^{461}$ : en primer lloc, partint impugnació dels acords socials per la infracció dels preceptes mateixos del text refós de la Llei d'anònimes".

LASSALETA GARCIA, P., Impugnación...., op. cit., pàg. 335, nota. 7: "es limita a aquelles disposicions legislatives emanades de les Corts generals, amb exclusió de les disposicions normatives governamentals (decrets-lleis, decrets legislatius - texts articulats i texts refosos-, ordres ministerials...), les emanades de les Comunitats Autònomes i Entitats Locals i els Tractats Internacionals en què l'Estat espanyol forme part".

- Així, el RRM, el Reglament de desenvolupament de la Llei 13/1989, de 26 de maig, de cooperatives de crèdit, o altres normes reglamentàries que hem citat supra, al capítol primer, epígraf 3.2.3..

- Diez-Picazo, Luis, i Gullón, Antonio, Instituciones de derecho civil, 2 vols., Tecnos, Madrid, 1995, pàg. 76: "la paraula «llei» s'ha utilitzat per designar les normes jurídiques nascudes de la potestas normandi de l'Estat, és a dir, les normes d'origen estatal decretades per l'organització política constituïda en forma d'Estat. Encara que, vista la Constitució del 1978, aquesta manera de concebre la paraula «llei» ha d'ampliar-se, ja que les Comunitats Autònomes dins de l'Estat tenen facultat de dictar normes dins de les seues competències".

"Diaz De LezCANO SeVILlano, N., Los acuerdos del consejo..., op. cit., pàg. 247 i 248; EMBID IRUJO, J.M., «Notas sobre la impugnación... op. cit., pàg. 51; GIMENO SENDRA, J. V., en «La reforma...», op. cit., pàg. 17, i en "El proceso...», op. cit., pàg. 37 i 38; LASSALETA GARCAA, P., Impugnación..., op. cit., pàg. 335; LOJENDIO OSBORNE, Ignacio, «La junta general de accionistas», en AA. DD., Derecho mercantil, (Coord. G. J. Jiménez Sánchez), 4a ed., Ariel, 1997, pàg. 272; MARín LOPEZ, J. J., "Novedades..., op. cit., pàg. 1126; PEMÁN MELERO, M., en AA. DD., Comunidades de bienes, cooperativas y otras formas de empresa, Consejo General del Notariado, Madrid, 1996, tom II, pàg. 748; RODRfGUEZ RUIZ DE VILLA, D., Impugnación..., op. cit., pàg. 28 a 32; SÁNCHEZ CALERO, Fernando, Instituciones de derecho mercantil , tom I, 24a ed., McGraw Hill, Madrid, 2001; URÍA, R., MENÉNDEZ, A., i MUÑOZ PLANAS, J. M., La junta general..., op. cit., pàg. 333 i 334, que advoquen per una interpretació integradora dels articles 115 LSA i 6.3 CC, ja qee, encara que "...no distingisca l'article 115 entre unes $i$ altres lleis, no sembla que pot seguir-se un criteri diferent en un cas i en un altre (...) potser aquesta interpretació siga massa rígida. Pot observar-se, en contra, que en realitat la valoració que l'ordenament jurídic expressa en les normes dispositives difereix molt poc de la que presta a les disposicions estatutàries, des del moment en què la norma dispositiva es dicta únicament per al cas que els estatuts no previnguen res de diferent"; i VICENT CHULIA, F., "La asamblea...», op. cit., pàg. 203. ARANGUREN URRIZA, F. J., "Los órganos de la sociedad limitada... op. cit., pàg. 1179 i 1180, observa, tanmateix, que la mera derogació d'una norma dispositiva sense l'autoregulació correlativa sí que és un acord contrari a la Llei, ja que deroga el règim supletori de la LSA sense tampoc exercir la llibertat estatutària legalment establerta. Tanmateix, és difícil imaginar com pot derogar-se una norma dispositiva si no és mitjançant la norma estatutària corresponent que, al seu torn, no tindrà sentit si no ofereix una regulació alternativa. 
de l'article 6.3 CC, que circumscriu la nul-litat de ple dret als "actes contraris a les normes imperatives", llevat que la llei imperativa mateixa declare un efecte diferent (la qual cosa no ocorre en aquest cas); en segon lloc, perquè si l'autonomia de la voluntat pot anteposar-se a la norma dispositiva, res no impedeix que, posteriorment a la contravenció d'aquesta, les parts mateixes puguen, mitjançant la seua voluntat, validar l'acte, i, finalment, perquè la interpretació dels actes nuls ha de ser sempre restrictiva, si s'atén la major gravetat dels efectes que porta.

Tanmateix, la determinació que la llei vulnerada siga una norma imperativa planteja no sols la necessitat de distingir quan ens trobem davant d'una norma $\mathrm{d}^{\prime}$ aquest caràcter ${ }^{462}$, sinó també el dubte de quina serà llavors la sanció ạplicable

En contra de la interpretació majoritària, són autors favorables a la inclusió de les normes dispositives GOMEZ ORBANEJA, E., "El proceso de impugnación...», op. cit., pàg. 124 i 125, sobre la base que el precepte legal no distingeix entre normes imperatives i dispositives; JIMÉNEZ DE PARGA, Rafael, La impugnación de los acuerdos sociales en la ley reguladora de las sociedades anónimas, en AA. DD., Estudios jurídicos sobre la sociedad anónima, Madrid, Civitas, 1995, i en AA. DD., Estudios de derecho mercantil en homenaje al profesor Manuel Broseta Pont, tom II, Tirant lo Blanch, València, 1995, pàg. 1805; i SORIA FERRANDO, J. V., La impugnación..., op. cit., pàg. 153 a 159.

${ }^{461}$ L'argumentació, ja clàssica perquè se cita habitualment, és de GIMENO SENDRA, J. V., en «La reforma...», op. cit., pàg.. 17, i en «El proceso...», op. cit., pàg. 37 i 38.

4² CASTÁn TOBEÑAS, José, Derecho civil español, común y foral, Reus S. A., Madrid, 1986, 12a ed. (rev. J. L. De los Mozos), tom I, vol. 1, pàg. 403 i 404: "Encara que tot el dret té caràcter imperatiu, això no obsta perquè la seua aplicació $i$ eficàcia obligatòria puga estar més o menys condicionada per la voluntat de les parts. Hi ha normes d'eficàcia incondicionada que exclouen o suprimeixen la voluntat privada, de manera que la regulació que estableixen s'imposa als interessats, els quals no poden modificar-la ni sostraure's a les seues conseqüències. N'hi ha d'altres, d'eficàcia condicionada, que respecten la iniciativa i la voluntat dels particulars, i es limiten a reconèixer els efectes d'aquesta voluntat o a establir una regulació supletòria per al cas que l'esmentada voluntat no s'haja exterioritzat. Les primeres són les normes imperatives, que integren l'anomenat Dret absolut, necessari o impositiu (ius cogens). Les segones, les normes permissives o, el que és igual, les de Dret voluntari, facultatiu, supletori o dispositiu (ius dispositivum)"; en les pàg. 405 i 406 subdivideix les normes imperatives en prohibitives (normes forçoses negatives) i preceptives (normes forçoses positives), i les dispositives en interpretatives $\mathrm{i}$ integradores: les primeres tendeixen a determinar la voluntat de les parts quan aquesta s'ha expressat, encara que de manera dubtosa i incompleta; les segones tenen per finalitat suplir la falta o manca d'una declaració de voluntat de les parts. Aquesta classificació la recull SORIA FERRANDO, J. V., La impugnación..., op. cit., pàg. 157 i 158, i hi afegeix que “Díez-Picazo adverteix que la distinció entre norma imperativa i norma dispositiva rau en un problema senzill de jerarquia, ja que la classificació de les normes en imperatives i dispositives només pot imaginarse des del punt de vista de les seues relacions amb l'autonomia privada. La norma és dispositiva quan l'ordenament jurídic permet que s'hi antepose el precepte creat per l'autonomia privada. És imperativa, pel contrari, quan l'ordenament jurídic li concedeix un rang jeràrquic superior, (...) l'ordre de prelació és, doncs: 1r. Norma imperativa. $2 \mathrm{n}$. Precepte privat. 3r. Norma dispositiva [vegeu «La autonomia privada y el derecho necesario en la Ley de 
a la infracció de llei dispositiva. En aquest sentit, s'ha afirmat que "la valoració que l'ordenament jurídic fa de les normes dispositives no difereix substancialment de la que deixa a les disposicions estatutàries ${ }^{\prime 463}$, ja que aquelles només són aplicables quan els socis no decidisquen dotar-se d'una norma estatutària específica; "per això pot afirmar-se que la remissió per arrendamientos urbanos", ADC, 1956, II, pàg. 1162 i ss....]". LACRUZ BERDEJO, José Luis i altres, Elementos de derecho civil I, Parte general, vol. 3r, Derecho subjetivo. Negocio jurídico (edició revisada per J. Delgado Echeverría), Dykinson, Madrid, 1999, pàg. 110 i 111: "En altres paraules: no tota norma obliga d'igual manera. Unes imperen una conducta determinada activa o passiva (mandats o prohibicions) sense deixar lloc a l'autoregulació del subjecte i s'anomenen imperatives (...); mentre que unes altres regeixen a falta d'aquesta autoregulació i s'anomenen de Dret dispositiu o voluntari, perquè poden ser substituïdes o eliminades per l'arbitri individual".

ALCALÁ DIAZ, M. A., La impugnación..., op. cit., pàg. 215 a 218: "tindrà aquesta qualificació tota norma no incluible dins del principi d'autonomia de la voluntat per ser vinculant en les relacions juridicoprivades. Així, es consideren com a normes de naturalesa imperativa totes aquelles dictades en protecció d'interessos generals i ordre públic (així article 6.3, articles 1255, 1271 i 1275 del CC), així com les que determinen els requisits mínims per a la formació d'un negoci jurídic. En l'àmbit del Dret de societats es consideren normes imperatives aquelles que són no derogables per voluntat dels socis o dels òrgans socials (...) en alguns supòsits s'admet la llibertat estatutària, però limitada a oferir als socis la possibilitat d'optar entre diferents alternatives, les quals, tanmateix, no poden ser alterades (...) aquest conjunt de normes no són de naturalesa dispositiva pel fet que el legislador admeta un marge reduit d'elecció dels socis dins d'uns límits estrictes, sinó que amb elles es pretén adaptar el model legal als diferents models reals de societat anònima sense alterar el caràcter imperatiu de la norma". En relació amb aquesta última qüestió, LEGROS, J-P., "La nullité des décisions...», op. cit., pàg. 291: "S'ha de vigilar l'ambivalència de la fórmula que permet les clàusules contràries dels estatuts. Dues hipotesis poden donar-se: una regla supletiva en la qual els socis són lliures, una regla mínima d'ordre públic en el qual els socis no són enterament lliures (derogació in melius)", i en pàg. 287 i 288: "És imperativa, en una primera accepció, la disposició que s'imposa en tota circumstància, aquella que la voluntat no pot descartar"; això no obstant, "tota regla de dret és obligatòria, siga imperativa, "supletiva» o dispositiva. La llei "supletiva" s'aplica en defecte de precisió de les parts, la llei dispositiva s'aplica en defecte que les parts hagen escollit una altra solució diferent a la del legislador".

EMBID IRUJO, J. M. i MARTíNEZ SANZ, F., «Libertad de configuración...», op. cit., pàg. 15: "sempre hi haurà un mínim normatiu no disponible per les parts. (...) On s'establisquen normes prohibitives (...), o estiguen involucrats interessos o drets de tercers, o drets individuals dels socis, ha de cedir l'autonomia de la voluntat, llevat que expressament s'admeta el contrari en la norma mateixa. Passa el mateix amb aquelles normes que s'encarreguen d'establir el funcionament essencial de la societat".

GALGANO, F., El negocio jurídico, op. cit., pàg. 253 i 254: "El grau d'imperativitat de la norma violada, exigit a les finalitats de la nul-litat del contracte és més elevat del que resulta de la constatació de la no-derogabilitat per voluntat de les parts (...) la violació d'una norma imperativa no porta la nul.litat quan «la llei disposa de manera diversa», (...) aquesta disposició legislativa diversa no ha de consistir necessàriament en l'expressa exclusió de la nul.litat, ja que pot ser "deduible de la raó de la prohibició»". En relació amb això, en el nostre ordenament, l'article 6.3 CC: "Els actes contraris a les normes imperatives $\mathrm{i}$ a les prohibitives són nuls de ple dret, llevat que en aquestes s'establisca un efecte diferent per al cas de contravenció".

\footnotetext{
URtA, R., MENÉNDEZ, A. i MUÑoz PlANAS, J. M., La junta general..., op. cit., pàg. 333. En la mateixa línia, CABALLOL I ANGELATS, L., «Comentario al artículo 115...», op. cit., pàg. 1113; i Morillas Jarillo, M. J., i Feliú ReY, M. I., Curso..., op. cit., pàg. 254.
} 
voluntat dels socis a un precepte legal dispositiu té naturalesa contractual i, per tant, la norma dispositiva es converteix en norma estatutària" ${ }^{\prime 464}$.

\subsection{Acords que s'oposen als Estatuts}

Es tracta, en aquest cas, $\mathrm{d}^{\prime \prime \prime}$ acords que, bé pel seu contingut, bé per la manera com hagen estat presos, vulneren qualsevol requisit o mandat imposat pels estatuts i no exigit també per la llei ${ }^{\prime \prime 465}$. Ara bé, la doctrina atribueix diferents efectes als acords segons quina siga la relació entre les normes estatutàries vulnerades i la llei; així, es distingeix entre normes estatutàries secundum legem, contra legem i praeter legem ${ }^{466}$.

En el primer cas, ço és, acords contraris a estatuts que reprodueixen la llei, no estarem davant d'un cas d'anul-labilitat sinó de nul-litat ${ }^{467}$. En el segon, la

${ }^{464}$ ALCALÁ DfAZ, M. A., La impugnación..., op. cit., pàg. 216 i 217. RUBIO, J., Curso..., op. cit., pàg. 246: "Seria totalment inadequada en aquest punt una interpretació literal que reputara els acords de "radicalment nuls», (...). Com ja va assenyalar GOMEZ ORBANEJA, ha d'atribuir-se's una mateixa naturalesa respecte dels que vulneren disposicions estatutàries". En el mateix sentit d'optar per l'anul-labilitat de les normes legals dispositives es manifesten la majoria dels autors partidaris de la restricció de la nul-litat als supòsits de contravenció de norma imperativa, en subscriure els arguments de GIMENO SENDRA, J. V., («La reforma...», op. cit., pàg. 17 , i en «El proceso...», op. cit., pàg. 37 i 38 ) apuntats supra.

465 URf́A, R., MENÉNDEZ, A., i MUÑOZ PlANAS, J. M., La junta general..., op. cit., pàg. 334 . VICENT CHULIÁ, F., "La asamblea...", op. cit., pàg. 203: "els acords contraris als Estatuts (...) no constitueixen sinó la infracció o l'incompliment d'un contracte plurilateral (que només es pot modificar, dins d'alguns límits...; però no incomplir-lo)".

46h GIMENO SENDRA, J. V., en «El proceso...», op. cit., pàg. 42 i 43, i en «La reforma...», op. cit., pàg. 19; RODRfGUEZ RUIZ DE VILLA, D, Impugnación... op. cit., pàg. 32 a 39, seguint, entre altres, GIMENO, classifica els acords contraris als estatuts segons que es tracte de normes estatutàries que reprodueixen la Llei, que l'agreugen, i que la contrarien. SORIA FERRANDO, J. V., La impugnación..., op. cit., pàg. 234 a 236, atribueix la classificació a DízZ PICAZO («La autonomía privada y el derecho necesario en la Ley de Arrendamientos Urbanos», ADC, 1956, II, pàg. 1149 a 1181), i s'estima més distingir entre clàusules estatutàries ineficaces (contràries a la llei o que traspassen els límits de l'autonomia de la voluntat), eficaces (que regulen un supòsit de fet no previst per la llei) $\mathrm{i}$ innecessàries (que reprodueixen normes imperatives).

477 GIMENO SENDRA, J. V., en «El proceso...», op. cit., pàg. 43, i en «La reforma...», op. cit., pàg. 19; RODRÍGUEZ RUIZ DE VILLA, D., Impugnación... op. cit., pàg. 32 a 34, el qual, quan cita FERRANDIZ, J. R., i GIMENO-BAYÓN, R., especifica que "si hi ha reproducció estatutària de dictats legals ens trobem davant de l'existència d'antijuridicitats duplicades, que han de ser tractades com a 
vulneració de preceptes estatutaris que siguen contraris a un text legal és perfectament vàlida i els acords socials en aquest sentit, no impugnables, si s'ha respectat la llei en la convocatòria, constitució i celebració de la Junta ${ }^{468}$. És, doncs, la tercera categoria de normes estatutàries, que inclou aquelles que regulen supòsits no previstos imperativament per la llei, la qual, en ser contravinguda per un acord social, donarà lloc a la seua anul-labilitat. Entre aquests supòsits s'ha de considerar aquells assumptes per als quals el text legal estableix "un règim legal supletori, i confereix directament la regulació de la matèria, dins de certs límits, als estatuts ${ }^{\prime 469}$.

contravencions legals, segons el principi que exigeix sancionar el vici de major gravetat". Aquest autor també apunta que, això no obstant, en el passat s'han donat opinions doctrinals i jurisprudencials que consideraven idèntiques sempre les violacions estatutàries $i$ les legals, per jurisprudencials que consider
considerar que els estatuts tenen força de llei tant per a l'entitat com per als seus socis; RUBIO, J.,
Curso..., op. cit., pàg. 247; SORIA FERRANDO, J. V., La impugnación..., op. cit., pàg. 241; URIA, R., MENÉNDEZ, A., i MUÑOZ PLANAS, J. M., La junta general..., op. cit., pàg. 334.

En l'àmbit específicament cooperatiu, VICENT CHULIÁ, F., «La asamblea...», op. cit., pàg. 203; N. Paz Canalejo, en PAZ CANAlejo, N. i Vicent ChuliÁ, F., Ley general..., op. cit., pàg. 589 i 590; i MARIN LOPEZ, J. J., «Novedades... op. cit., pàg. 1127.

DIAZ DE LEZCANO SEVILLANO, N., Los acuerdos del consejo..., op. cit., pàg. 241, 258 i 259, citant les sentències del TS de 3.2.1966 (RJA 1966/308) i de 28.9.1979 (RJA 1970/3774) en les quals es considera la possibilitat que un mateix acord puga ser alhora contrari a la Llei, als Estatuts i lesionar l'interès social; això no obstant, aquest autor assenyala que "si la norma legal reproduida pels Estatuts és un precepte dispositiu susceptible de ser modificat per voluntat social, no és admissible concebre que l'acord contrari supose la infracció d'una norma legal coactiva, sinó que estarem davant d'un autèntic supòsit d'infracció merament estatutària, sancionable (...) amb anul-labilitat". En el mateix sentit, per a les cooperatives, LASSALETA GARCIA, P., «Impugnación...», op. cit., pàg. 336.

" GIMENO SENDRA, J. V., «El proceso... op. cit., pàg. 43; SORIA FERRANDO, J. V., La impugnación..., op. cit., pàg. 236 a 239: "Respecte a les clàusules contràries a una norma legal imperativa o que traspassen els límits de l'autonomia de la voluntat, cal distingir dos supòsits (...). En primer lloc, pot ocórrer que la Junta general adopte un acord social seguint el mandat contingut en una clàusula estatutària nul-la. (...) així doncs, l'acord adoptat serà nul (...); en segon lloc, pot succeir, que la Junta general adopte un acord vulnerant una clàusula estatutària nul-la. En aquest cas, per esbrinar la validesa o invalidesa de l'acord social adoptat, s'haurà de determinar, cas per cas, si en la convocatòria, constitució i celebració de la Junta general s'ha vulnerat o respectat la Llei"; URtA, R., MENÉNDEZ, A., i MUNNOZ PLANAS, J. M., La junta general..., op. cit., citant sentències del TS que "van reputar nuls els acords adoptats partint de preceptes estatutaris que estaven en oposició a normes d'autèntic dret imperatiu o necessari".

RODRIGUEZ RUIZ DE VILLA, D., Impugnación..., op. cit., pàg. 37 a 39, adverteix que, a sensu contrari, seran nuls els acords socials conformes als estatuts que contrarien la Llei, i cita, entre altres, la STS de 15.10.56 (RJ 1956, 3194), en relació amb una clàusula estatutària de submissió dels conflictes sobre acords socials a l'arbitratge; LASSALETA GARCÍA, P., «Impugnación...», op. cit., pàg. 337 , indica que el supòsit dels acords socials conformes als estatuts que infringisquen la Llei no és més que una manifestació de la vulneració del principi general de l'autonomia de la voluntat, citant la STS de 27 de gener de 1968 (RJA 1968/550). ARROYO, Ignacio, "Comentario al art. 56», en AA. DD., Comentarios a la Ley de sociedades de
responsabilidad limitada, (coords. I. Arroyo i J. M. Embid), Tecnos, Madrid, 1997, pàg. 611, el qual 
Però, a més, hi ha la possibilitat que els estatuts socials, en virtut del principi de l'autonomia de la voluntat, "agreugen" requisits establerts en la Llei. Davant d'aquest supòsit la doctrina és dispar: mentre alguns autors consideren que els acords que lesionen les normes estatutàries esmentades seran nuls ${ }^{470}$, una altres els estimen anul·lables ${ }^{471}$; una tercera opinió, que ens sembla més encertada distingeix: "l'acord serà nul quan contradiga la llei (norma imperativa, sens

afegeix que "el silenci estatutari, en una matèria no imperativa, posa en marxa la previsió legislativa i si l'acord s'aparta del que estableix la llei, la contravenció és nul-la relativament perquè, si s'infringeix la llei, la matèria no és d'ordre públic". En el mateix sentit de considerar la vulneració de norma dispositiva com a acord anul-lable, DIAZ DE LEZCANO SEVILLANO, N., Los
acuerdos del consejo..., op. cit., pàg. 259 .

Per la seua part, CABANAS TREJO, Ricardo, "Comentario al artículo 56 LSRL", en AA. DD., Lo sociedad de responsabilidad limitada , tom I, Colegios Notariales de España, Madrid, 1995, pàg. 315 i 316, indica que "la LSRL, en moltes qüestions, no fixa un mínim no derogable, sinó un règim legal supletori, i confereix directament la regulació de la matèria, dins de certs límits, als estatuts", i cita l'exemple de la forma de la convocatòria de la Junta general, per al qual es declara que els estatuts podran establir un altre sistema: "és clar que si els estatuts imposen una convocatòria pública mitjançant anunci en un diari determinat, però els administradors després convoquen la Junta a través d'un anunci insert en un altre diari o mitjançant una comunicací́ privada, s'ha d'entendre que la convocatòria vulnera allò disposat en aquests, però no el que estableix la llei, ja que el règim legal supletori de l'article 46.1 no és aplicable, ni com a contingut mínim, des del moment que hi ha una previsió estatutària específica". Això no obstant, "vista aquesta situació" apunta "com a mera hipòtesi de treball que potser seria possible sostenir que en els casos de substitució en bloc del règim legal per l'estatutari, l'acord també s'ha de reputar nul, almenys en relació als requisits mínims imposats als estatuts".

477) ARANGUREN URRIZA, F. J., "Los órganos de la sociedad anónima...», op. cit., pàg. 527, per a "l'acord que s'opose a una norma estatutària que, en ús de la delegació legal, agreuge quòrum o majories, en aquest cas, (...) el que hi ha és una tramesa legal quant a la manera com es constitueix l'òrgan o per quina majoria decideix"; posteriorment, en "Los órganos de la sociedad limitada..., op. cit., pàg. 1180, generalitza el criteri en afirmar que "no és causa d'anul-labilitat sinó de nul.litat la contravenció de normes estatutàries (...) si agreugen els requisits legals". En la mateixa línia, GARCtA LUENGO, R., i SOTO VÁZQUEZ, R., El nuevo régimen jurídico..., op. cit., pàg. 539; i RUBIO, J., Curso..., op. cit., pàg. 247.

${ }^{471}$ URÍA, R., MENÉNDEZ, A. i MUÑoz, J. M., La junta general..., op. cit., pàg. 334 i 335, en relací6 amb l'agreujament de "requisits essencials de la llei per a la constitució vàlida l'òrgan (així, per exemple, els quòrums)", justifica aquest criteri a partir de "la diferent naturalesa de la disposició legal i estatutària", i sobre la base de "la doctrina establerta en matèria de recurs de cassació sobre la inviabilitat del recurs quan les disposicions invocades no tenen el caràcter de lleis del Regne" ; GIMENO SENDRA, J. V., en "El proceso...», op. cit., pàg. 43, i en "La reforma...", op. cit., pàg. 19, especifica que es tracta de supòsits en els quals la norma estatutària suposa un reforçament de la imperativa; RODRf́GUEZ RUIZ DE VILLA, D., Impugnación..., op. cit., pàg. 34 a 37, considera que "el contrari significaria dotar de rang de Llei imperativa alguna cosa (l'estatut societari) que no deixa de ser un acord pres al si de la societat anònima pels seus integrants". En aquest sentit, DIAAZ DE LEZCANO SEVILLANO, N., Los acuerdos del consejo..., op. cit., pàg. 260, tret que "el precepte estatutari reculla un principi moral o d'ordre públic". 
dubte) i anul-lable quan viole la clàusula estatutària que reforça el mínim legall $^{1472}$.

Finalment, s'han d'esmentar els acords que constituïsquen, precisament, modificació dels estatuts. S'ha de recordar, encara que puga semblar obvi, que aquests acords no són impugnables per vulnerar els estatuts; en cas contrari seria inviable la modificació estatutària, que està reconeguda en la llei mateixa ${ }^{43}$. Altres casos seran, per exemple, aquells en què l'acord de modificació estatutària s'impugne per incompliment dels requisits formals especials que per a això establisca la $\operatorname{Llei}^{\mathrm{i} 74}$, o que s'utilitze la via de l'adaptació estatutària a un nou text legal per introduir modificacions estatutàries que van més enllà de l'exigit per la Llei, intentant evitar l'obligatorietat de majoria reforçada que s'exigeix per a la modificació ${ }^{475}$; en aquests supòsits, $1^{\prime}$ acord serà nul per vulneració de precepte legal.

D'altra banda, s'han plantejat per a les societats de capital dos supòsits concrets d'acords anul-lables que presenten diferents implicacions en l'àmbit cooperatiu. El primer és el d'acords de la junta universal sobre matèries que estatutàriament hagen estat atribuïdes a l'òrgan d'administració, cas en què no

" CABANAS TREjO, Ricardo, "Comentario al artículo 56 LSRL...", op. cit., pàg. 315, on cita la STS 24 setembre 1987; DIAZ DE LEZCANO SEVILLANO, N., Los acuerdos del consejo..., op. cit., pàg. 260, on cita les SSTS de 28 de setembre de 1970 (RJA 1970/3774), de 15 d'octubre de 1964 (RJA 1964/4450), i de 30 de novembre de 1971 (RJA 1971/5019); LASSALETA GARCíA, P., "Impugnación...", op. cit., pàg. 336 i 337, on cita, a més, la STS de 28 d'abril de 1967 (RJA 1967/2208); i SORIA FERRANDO, J. V., La impugnación..., op. cit., pàg. 240.

"s ARROYO, I., "Comentario al art. 56...", op. cit., pàg. 612; CABAllol I ANGELATS, L., "Comentario al artículo $115 . . . "$, op. cit., pàg. 1114.

${ }^{04}$ L'article 30.5 LCCV, exigeix que la convocatòria de l'assemblea incloga indicació expressa que el nou text que es proposa i l'informe de justificació corresponent es troben a disposició dels socis; en relació amb això, vegeu la STS, Sala del Civil, de 3.5.1994, núm. 416/1994, RJA 1994/3559, que exigeix els mateixos requisits legals per a l'adaptació a un nou text legal (en aquest cas la LCCV 11/1985) com per a la modificació estatutària.

\footnotetext{
En relació amb això, vegeu les SSTS, Sala del Civil, de 20.10.1998, núm. 944/1998, RJA $1998 / 8229$, i de 18.3.1998, en la qual es conclou que "si hi ha un acord que no és de vertadera s'ha adació, sinó que és modificació dels estatuts que necessita una majoria reforçada i aquesta no resta aconseguit, la nul-litat arribarà a aquest acord concret que serà anul-lat, sense afectar la resta dels acords assolits legítimament, és a dir, s'accepta el concepte de nul-litat parcial",
} 
hi ha infracció de llei, ja que la LSA (article 99) i la LSRL (article 48) atribueixen a les juntes universals competència per conèixer de qualsevol assumpte, però que suposaria una infracció dels estatuts i, per tant, l'anul-labilitat de l'acord" Aquest supòsit no és traslladable a l'àmbit cooperatiu perquè, contràriament a allò disposat per a les societats de capital, en la legislació cooperativa no es preveu una ampliació de la competència de l'assemblea universal respecte a la de les legalment convocades $i$, contràriament, el règim competencial general de l'assemblea li permet adoptar acords en totes les matèries que la llei mateixa no considere competència exclusiva d'un altre òrgan social ${ }^{47}$. Així doncs, una eventual atribució competencial estatutària en favor de l'òrgan d'administració més allà del que expressament li reconeix el text legal no impediria que l'assemblea prenguera acords en l'esmentada matèria.

El segon supòsit és el de la possibilitat d'anul-lar aquells acords que vulneren allò que preveu el reglament de règim intern del consell d'administració ${ }^{47}$. La "sense que puga estendre's l'anul-lació de tots els altres acords d'adaptació d'articles a la nova
LSA".

476 ARANGUREN URRIZA, F. J., "Los órganos de la sociedad anónima...», op. cit., pàg. 528; RODRIGUEZ RUIZ DE VILLA, D., Impugnación..., op. cit., pàg. 38 i 39.

${ }^{477}$ Articles 23.5 i 21.1 LCoop, i 28.4 i 27.2 LCCV. Vegeu, això no obstant, supra, en l'epígraf 3.2.3. a), del capítol primer, les tendències cap a la limitació de competències de l'assemblea en favor de l'òrgan d'administració.

${ }^{478}$ AlCALÁ DÍAZ, M. A., La impugnación..., op. cit., pàg. 308 a 310 i 411; CABALlOl I ANGELATs, L., "Comentario al artículo 115...", op. cit., pàg. 1114, referint-se a qualsevol de les "normes de règim interior de la societat, si n'hi ha", que, al seu parer, "han de rebre el mateix tracte que les infraccions estatutàries"; DIAZ DE LEZCANO SEVILLANO, N., Los acuerdos del consejo..., op. cit., pàg.
261 a 268.

En l'àmbit cooperatiu, MORILLAS JARILLO, M. J. i FeLIÚ REY, M. I., Curso..., op. cit., pàg. 255 consideren que "la sanció d'anulabilitat hauria d'estendre's també a la vulneració d'aquelles normes reglamentàries de caràcter intern: concretament el reglament de règim intern, ja que, en definitiva, no és més que el desenvolupament del que estableixen els estatuts $i$, encara que des d'un punt de vista purament formal no tenen la mateixa consideració, està fora de tot dubte la seua importància pràctica. A més a més, estatuts i reglament de règim intern tenen o participen almenys de dues notes comunes: d'una banda, plasmen i són fruit de la voluntat social; d'altra, articulen la vida mateixa de la societat cooperativa".

SALELLES CLIMENT, J. R., El funcionamiento..., op. cit., pàg. 72 i 73, estima que la vulneració de les disposicions reglamentàries no afecta la validesa dels acords del consell, però pot donar lloc a exigència de responsabilitat.

En contra de l'oposabilitat davant la societat de les normes previstes al reglament de règim intern, per considerar-ho inclòs en el concepte de "pactes parasocials" de l'article 7.1 LSA, GARRIDO DE PALMA, Víctor M., "Autonomía de la voluntad y principios configuradores. Su 
qüestió té una rellevància indubtable en l'àmbit de les societats de capital, ja que la seua estructura i organització reclamen amb freqüència una regulació extraestatutària detallada ${ }^{479}$. Al sector cooperatiu és més usual trobar la regulació del règim intern del consell rector en els estatuts de l'entitat. Arriba a ser una exigència de la LCCV (article 10, i) la seua inclusió com part del contingut mínim estatutari. La LCoop, en canvi, deixa la porta oberta a una regulació extraestatutària possible, en assenyalar (article 36.1) que "els estatuts 0 , quan aquests no ho facen, $l^{\prime}$ assemblea general, regularan el funcionament del consell rector".

En tot cas, no és habitual trobar a les cooperatives una regulació específica del funcionament de l'òrgan d'administració, sinó, si escau, un text regulador, entre altres matèries, del funcionament de tots els òrgans socials: l'anomenat reglament de règim intern. En efecte, algunes cooperatives mitjanes o grans o amb una estructura geogràficament dispersa, s'han dotat d'una normativa interna de desenvolupament $\mathrm{d}$ 'aspectes no previstos o insuficientment regulats en els estatuts, amb la finalitat usual d'agilitar i dotar de seguretat jurídica els processos de presa de decisions, d'execució d'acords o de participació en la gestió. Els reglaments esmentats, sancionats en general mitjançant l'acord majoritari de l'assemblea general, només fa poc s'han anat incorporant als textos legals, i únicament per fer esment de la seua existència possible ${ }^{480}$. Es planteja, doncs, la qüestió de si els acords adoptats en contradicció amb allò previst en un reglament de règim intern d'una cooperativa seran impugnables.

problemática en las sociedades anónimas y de responsabilidad limitada», en AA. DD., Estudios jurídicos en homenaje al profesor Aurelio Menéndez (coord. J. L. Iglesias Prada), Madrid, Civitas, 1996, tom II, pàg. 1873 i 1874.

\footnotetext{
"Una bona prova d'això és la proliferació els últims anys dels codis de conducta o codis de bon govern dirigits als consells d'administració de les societats cotitzades, que han generat un conegut i extens debat doctrinal, encara obert, en què es planteja, entre altres qüestions, la conveniència de dotar les societats cotitzades de reglaments reguladors del funcionament dels seus consells d'administració. Per a una anàlisi de les propostes espanyoles i de dret comparat sobre aquests codis de bon govern, vegeu AA. DD. El gobierno de las sociedades cotizadas, op. cit..

- Article 11.4 LCoop : "Els estatuts podran ser desenvolupats mitjançant un reglament de règim intern". Article 10, in fine: LCCV : "Els estatuts podran ser desenvolupats mitjançant un reglament de règim intern aprovat per l'assemblea, la inscripció de la qual al Registre no serà
} 
Considerem que, des d'un punt de vista formal, el tenor literal de la norma implica que no seran impugnables els acords que infringisquen el reglament de règim interior ${ }^{481}$, ja que aquesta norma únicament fa referència a la infracció de la llei o dels estatuts. I tanmateix, des d'un punt de vista material, no hi ha diferència en la finalitat de les prescripcions estatutàries i les reglamentàries: "en ambdós casos, l'origen de la normativa es funda en l'autonomia privada i en ambdós casos es regulen aspectes organitzatius que tendeixen a garantir més eficiència en el funcionament (...). De fet, l'elecció d'un sistema de regulació estatutari o reglamentari depèn, en molts casos, de les característiques de la societat (...) segons la mida i l'activitat de l'empresa" ${ }^{\prime 482}$.

És per això que seria desitjable un pronunciament legal exprés en aquesta matèria. Mentrestant, no sembla que hi haja la possibilitat d'establir la impugnació amb caràcter general, excepte si prospera una interpretació del reglament com a "extensió", "desenvolupament" o "aclariment" del text estatutari, a la manera en què, com hem vist, els estatuts socials poden contenir normes secundum legem que "agreugen" o "milloren" els preceptes legals que desenvolupen. En aquest sentit, podria dotar-se el reglament de més eficàcia si l'acord d'aprovació incloguera una modificació estatutària que incorporara al text dels Estatuts una referència explícita a la naturalesa supletòria d'aquell.

En tot cas, s'haurà d'atendre també les circumstàncies de cada cas, ja que si el reglament de règim intern ha estat aprovat per l'assemblea general, per a la regulació del funcionament també d'altres òrgans socials, si aquests

obligatòria". La LCPV dóna més importància al RRI, i remet al seu contingut en nombrosos preceptes; vegeu, per exemple, els articles 6.2 , 3r; $13.2 ; 24.2$, a); 29.1; 31.3, j); 53.2; i 102 LCPV.

4*1 VICENT CHULIÁ, F., "Análisis crítico...", op. cit., pàg. 514: "el Reglament de règim interior (...) jurídicament no constitueix més que un acord de Junta general".

${ }^{482}$ ALCALÁ DÍAZ, M.A., La impugnación..., op. cit., pàg. 309. 
incompleixen el que es preveu en el reglament, poden estar vulnerant la norma legal o estatutària que permeta a l'assemblea adoptar el reglament ${ }^{483}$.

1.3 Acords que lesionen els interessos de la cooperativa en benefici d'un o diversos socis, associats o tercers

En l'actualitat, tant la LCoop (article 31.1) com la LCCV (article 36.1) estableixen la impugnabilitat dels acords que "lesionen, en benefici d'un o diversos socis o tercers, els interessos de la cooperativa". Encara que s'ha indicat que el fenomen de control de l'entitat per la concentració de.la propietat de la majoria del capital en poques persones no seria molt freqüent en l'àmbit cooperatiu, a causa del principi de vot per cap, les severes restriccions a la representació del soci i altres mecanismes democràtics ${ }^{484}$, també s'han facilitat exemples (tristament reals) que encaixen plenament en el tipus legal: els supòsits de control "ideològic" de la cooperativa o aquells de "falses cooperatives", en què existeix un patró ocult o, almenys, un proveïdor o client dominant ${ }^{485}$.

La doctrina situa l'antecedent normatiu d'aquest supòsit en la legislació alemanya de les societats de capital ${ }^{486}$, que intenta pal-liar amb açò l'aparició

\footnotetext{
${ }^{4}$ En concret i per exemple, recordeu que l'article 36.1 LCoop estableix que "Els estatuts o, si aquests no ho fan, l'assemblea general, regularan el funcionament del consell rector"; i més endavant, l'article 82.1 LCoop, que "els estatuts o el reglament de règim intern establiran el règim disciplinari dels socis" a les cooperatives de treball associat. A més, TATO PLAZA, A., "Os órganos sociais...", op. cit., pàg. 94: "una vegada ratificades les normes de funcionament intern [del consell] per l'Assemblea, aquestes no podrien ser modificades pel Consell mateix, ja que aquesta modificació implicaria una clara vulneració del principi de jerarquia entre ambdós organs socials".
}

"VICENT CHULIÁ, F., «La asamblea...”, op. cit., pàg. 209.

Paz Canalejo, N. en Paz Canalejo, N. i Vicent Chuliá, F., Ley general... op. cit., pàg. 585; VICENT CHULIA, F., «La asamblea...», op. cit., pàg. 209.

Paz Canalejo, N. en PAZ CANalejo, N. i Vicent Chuliá, F., Ley general..., op. cit., pàg. 584. EMBID IRUJO, J. M., "Derecho europeo...», op. cit., pàg. 144, article 243.2 AktG: "La impugnació també podrà basar-se en el fet que un accionista ha tractat, amb l'exercici del dret de vot, d'aconseguir, per a si o per a un tercer, avantatges especials en perjudici de la societat o dels altres accionistes, i l'acord és adequat per servir a aquesta finalitat. L'anterior disposició no s'aplicarà si l'acord concedeix als altres accionistes una compensació adequada pel dany 
d'aquests casos, cada vegada més freqüents en el tràfic mercantil concurrencial, i especialment en l'àmbit dels grups de societats ${ }^{487}$. L'específic fonament jurídic d'aquesta causa d'anul-labilitat s'ha situat en "el deure de fidelitat del soci com a expressió, en l'àmbit juridicosocietari, del principi de bona fe que regeix en les relacions juridicoprivades ${ }^{\prime 488}$.

El supòsit de fet que origina l'anul-labilitat de l'acord requereix la conjunció de dos elements: lesió de l'interès social i benefici aliè (benefici "extrasocial", ja siga el particular d'alguns socis, ja siga el de terceres persones), lligats ambdós per un nexe de causalitat; del perjudici a la cooperativa es deriva l'afavoriment $d^{\prime}$ interessos aliens.

Pel que fa al primer element de la relació causal, s'han de determinar dues qüestions: què s'ha d'entendre per "interès social" i quan s'entén que aquest ha estat "lesionat". En relació amb el concepte d'interès social, ens remetem a tot

experimentat". Com assenyala VICENT CHULIÅ, F., en "El derecho de los órganos...», op. cit., pàg. $527 \mathrm{i}$ en Compendio crítico..., op. cit., pàg. 611, l'Aktiengesetz va més enllà, en permetre la impugnació d'acords lesius, no sol d'interessos socials, sinó també dels interessos d'accionistes aillats; RODRíGUEZ RUIZ DE VILLA, D., Impugnación..., op. cit., pàg. 50 també cita la llei alemanya. L'antecedent en la legislació cooperativa estatal el situa VICENT CHULIÁ en la LGC de 1974 ( «Los órganos sociales...», op. cit., pàg. 491).

${ }^{487}$ EMBID IRUJO, J. M., "Notas sobre la impugnación...», op. cit., pàg. 51: "amb aquesta modificació s'amplia sensiblement l'àmbit d'aplicació de la norma que comprén situacions freqüents en els grups de societats on el benefici pot referir-se a una societat del mateix no accionista de la que adopta l'acord"; també esmenten supòsits subsumibles en aquesta causa d'impugnació DfEZ-PICAZO GIMÉNEZ, Ignacio, i DE LA OLIVA SANTOS, Andrés, «Especialidades procesales en la Ley de Sociedades Anónimas", RDPro, 1990, núm. 3, pàg. 1053; VICENT CHULIA, F., Compendio crítico..., op. cit., pàg. 610. Per la seua part, GARRIGUES, J. i URIA, R., en 1976, en Comentario..., op. cit., pàg. 764 , no veuen amb bons ulls la inclusió, i consideren que "aquella ampliació de la protecció dispensada fins a incloure l'acord en benefici de tercer pot comprometre, potser en forma inacceptable, el funcionament de la junta general $i$ el respecte al principi majoritari".

${ }^{488}$ ALCALÁ DIAZ, M. A., "El conflicto...», pàg. 115; VICENT CHULIÁ, F., Compendio crítico..., op. cit,, pàg. 611. DIAZ DE LEZCANO SEVILLANO, N., Los acuerdos del consejo..., op. cit., pàg. 201, situa el fonament últim de la impugnació d'aquests acords en "la protecció de la legalitat, figura pròxima a l'interès social", ja que perquè un acord puga ser impugnat per ser contrari a l'interès social ha de comportar un plus: produir benefici a un o diversos accionistes o tercers; i perjudici a la societat; en conseqüència, l'acord contrari a l'interès social no és impugnable in genere, excepte quan comporte un benefici per als accionistes o tercers i perjudici social". SORIA FERRANDO, J. V., La impugnación..., pàg. 357 a 366, també descarta, per les mateixes raons, que el bé jurídic tutelat per aquesta causa d'impugnació siga exclusivament l'interès social, i ho identifica, en canvi, amb el "principi o deure de col-laboració". 
allò exposat a l'epígraf 2, "fonament jurídic de la impugnació dels acords socials" del capítol primer.

Fora d'això, s'ha assenyalat que no és necessària la presència de cap element intencional $^{499}$ en la lesió dels interessos cooperatius, encara que aquest s'haja produit ja ${ }^{400}$; per contra, el tenor literal de la norma no deixa dubtes respecte al

- GIRÓN TENA, J., Derecho de sociedades anónimas, op. cit., pàg. 328: "S’elimina d'aquesta manera la inseguretat en la investigació dels mòbils dels votants en l'acord que es tracte. Però s'estén la possibilitat d'impugnacions, ja que, fins i tot sense l'aparença de votants en conflicte d'interessos, es podria sotmetre a revisió acords que prima facie tingueren aquest contingut lesiu"; DIAZ DE LEZCANO SEVILLANO, N., Los acuerdos del consejo..., op. cit., pàg. 275, cita BACIGALUPO, Los delitos societarios en el nuevo Código penal, Curs de Dret penal econòmic (Madrid-Barcelona, 1998), pàg. 129 i ss., per establir les diferències amb el tipus penal de l'article $291 \mathrm{CP}$, en el qual sí que es requereix a l'actor l'ànim de lucre; RODRfGUEZ RUIZ DE VILLA, D., Impugnación..., op. cit., pàg. 47; SORIA FERRANDO, J. V., La impugnación..., pàg. 331 a 334; URtA, R., MENÉNDEZ, A., i MUÑOZ J. M., La junta general..., op. cit., pàg. 337. En aquest sentit vegeu, entre altres, la STS, Sala del Civil, de 17.4.1997, núm. 298/1997, RJA 915. DUQUE DOMfNGUEZ, J. F., Tutela..., op. cit. pàg. 98 a 100, considera que "no es requereix la intenció de produir un dany als interessos socials, que, de vegades, pot faltar, sinó la de beneficiar-se els votants a expenses de l'acord social".

Sobre el delicte societari d'acord abusiu i l'exigència típica d'ànim de lucre, així com el delicte afi d"'acord lesiu mitjançant majoria fictícia", vegeu GARCtA DE ENTERRfA, Javier, Los delitos societarios. Un enfoque mercantil, Civitas, Madrid, 1996, pàg. 64 a 85, on diu que "la seua referència exclusiva a la Junta d'accionistes (...) ha d'impedir la condemna de conductes equivalents que puguen verificar-se en tipus socials diferents de la societat anònima", a més de qüestionar la conveniència d'uns tipus delictius que s'encobrisquen obertament amb la impugnació d'acords socials. En la mateixa línia, FARALDO CABANA, Patricia, Los delitos societarios. Aspectos dogmáticos y jurisprudenciales, Tirant lo Blanch, València, 2000, pàg. 419 a 476; i MATA Y MARTÍN, Ricardo, "Delitos societarios: administración desleal y demás figuras 354 a 380 .

" Garcia luengo, R., i Soto VÁzquez, R., El nuevo régimen jurídico..., op. cit., pàg. 541 i 542; GIMENO SENDRA, V., «La reforma... ", op. cit., pàg. 20; RODRf́GUEZ RUIZ DE VILLA, D., Impugnación..., op. cit., pàg. 47; SÁNCHEZ CALERO, F., Administradores..., op. cit., pàg. 542: "Sentències de 2 de juliol de 1963, Rep. A. 3.514; 11 de maig de 1968, cit. [Rep. A. 4.538]., 11 de novembre de 1980, cit. [Rep. A. 4.132], i la també citada de 19 de febrer de 1991"; SORIA FERRANDO, J. V., La impugnación..., pàg. 324 a 327, on admet tant els danys presents com els futurs, amb la condició que siguen certs: "la mera possibilitat en la producció del dany, els simptomes, els danys hipotètics, eventuals o potencials, és a dir, tots aquells danys la realitat intels quals no puga determinar-se amb certesa en el moment de jutjar-se la seua existència, no integren el supòsit de fet"; VICENT CHULIÁ, F., Compendio crítico..., op. cit., pàg. 610; URíA, R., ARROYNEZ, A., i MUÑOZ J. M., La junta general..., op. cit., pàg. 338.

exigeix, I., "Comentario al art. 56...", op. cit., pàg. 613, considera que "la infracció per danys estar sote el dany siga real i efectiu, no presumpte o probable. Una qüestió diferent és que, en maniobres la impugnació per aquesta causa a un breu termini, es corre el risc de facilitar tanmateix, es cusives, amb tendència a desvirtuar la finalitat de la Llei (STS 11 maig 1968), que produït. (...) corregeixen i s'entén que el terme de decadència no s'inicia fins que el dany s'haja (SSTS 2 juli.) tanmateix, (...) és suficient que hi haja un perill potencial que es produirà el dany Conflictos juliol 1963; 11 maig 1968; 11 novembre 1980 i 19 febrer 1991)"; i SÁNCHEZ RUIZ, M., nflictos de intereses..., op. cit., pàg. 155 (en nota 27) i 159, la qual considera que, a diferència del 
fet que la lesió pot recaure únicament sobre interessos de la cooperativa i no sobre els particulars d'altres socis ${ }^{491}$. D'altra banda, el perjudici, la lesió ha de ser d'una entitat tal que no puga suposar-se fonamentadament que es dega a l'error en la valoració de l'interès social, ${ }^{492}$ i pot consistir, tant en una pèrdua per al patrimoni social, com en un guany deixat d'obtenir, ${ }^{493}$ i també hi hauria la possibilitat d'una lesió extrapatrimonial en la persona jurídica. ${ }^{494}$

Quant al benefici extrasocial, compartim la tesi doctrinal que manté que "no ha d'entendre's en sentit exclusivament econòmic, ja que pot consistir en qualsevol

que succeeix en els supòsits de conflicte d'interessos en sentit tècnic, que és una mesura de tipus preventiu en què "no existeix encara un dany o lesió", "en el supòsit previst a l'article 115 LSA (...) la lesió de l'interès social ja s'ha verificat, ja que cal que concórrega un dany cert i no simplement possible, encara que es tracte d'un "dany futur" (...) conforme a la regla de l'experiència comuna"; més endavant, en la pàg. 176 i 177, intenta definir el "dany futur".

La STS, Sala del Civil, de 10.7.1997, núm. 641/1997, RJA 1997/5823, insisteix en el fet que "és suficient que hi haja perill potencial que s'ocasione" la lesió social, però adverteix que "no n'hi ha prou que subjectivament se sospite que es causarà el dany, ja que és necessari que s'aporten proves objectives suficients de les quals es puga presumir o deduir, en un procés lògic, normal i amb racionalitat mitjana, que s'ocasionarà el resultat negatiu advertit i denunciat, amb la major càrrega de probabilitat".

${ }^{491}$ VICENT CHULIÁ, F., «El derecho de los órganos...», op. cit., pàg. 527: "La definició del supòsit de lesió dels interessos socials (...) incorpora una concepció restrictiva de l'exercici abusiu del dret de vot, acollida per la Llei de societats anònimes davant la concepció més àmplia representada per l'article 243-2n de la Llei d'accions alemanya, que permet impugnar els acords socials "quan el dret de vot siga exercitat en benefici especial propi o d'un tercer, i cause danys danys a la societat o a altres accionistes". DIAAZ DE LEZCANO SEVILLANO, N., Los acuerdos del consejo..., op. cit., pàg. 202, també parla de com en el dret italià "es concedeix acció al soci per impugnar l'acord del Consell que siga lesiu únicament per a ell, encara que no ho siga per a la societat". SÁNCHEZ RUIZ, M., Conflictos de intereses..., op. cit., pàg. 175, cita així mateix l'article 58.1 b) del Codigo das sociedades comerciais portuguès com a receptor de la causa d'impugnació d'acords que, sense suposar una lesió per a l'interès social, sí que determinen un perjudici directe dels interessos dels socis.

ALCALÁ DÍAZ, M. A., «El conflicto...», op. cit., pàg. 137 i 138, proposa, tanmateix, "la reforma de l'article 115.1 in fine de manera que el supòsit d'anul-labilitat per conflicte d'interessos es configure com la lesió de l'interès social o dels altres socis".

${ }^{442}$ DuQue DOMf́NGUEZ, J. F., Tutela..., op. cit. pàg. 60.

${ }^{403}$ DUQUe DOMINGUEZ, J. F., Tutela..., op. cit. pàg. 62; SORIA FERRANDO, J. V., La impugnación...”, pàg. 318 i 319: "La doctrina civilista espanyola discuteix si els termes danys i perjudicis són equivalents, o si, pel contrari, tenen diferent significat. (...) Aquesta dificultat $s$ 'ha evitat en la Llei de societats anònimes (...) en utilitzar el terme lesió. En efecte, el significat del terme lesió és prou ampli per comprendre tant el dany emergent com el lucre cessant.

${ }^{494}$ SORIA FERRANDO, J. V., La impugnación..., pàg. 322 i 323. 
avantatge de caràcter politicosocial o professional. ${ }^{\prime 495} \mathrm{I}$, en relació amb el benefici, tampoc es requereix que s'haja produit ja. ${ }^{496}$ Pel que fa als subjectes receptors del benefici extrasocial, la LGC de 1987 va aclarir l'anterior imprecisió de la Llei de 1974 (que utilitzava l'expressió "membres" de la cooperativa), fent esment exprés de socis i associats ${ }^{497}$ com a beneficiaris de la lesió social i incloent-hi, com més tard farien la LSA i la LCCV, el supòsit del benefici de tercers.

“ URIA, R., MENÉNDEZ, A., i MUÑ̃Z J. M., La junta general..., op. cit., pàg. 337. En la mateixa línia, ALBORCH BATALLER, C., El derecho de voto..., op. cit., pàg. 265, per a qui el benefici pot consistir en avantatges de caràcter politicosocial, com ara el nomenament per a un càrrec social; ARROYO, I., "Comentario al art. 56...", op. cit., pàg. 613: "Per exemple, el dret de representació de les minories al Consell és un benefici polític, sens dubte no econòmic (STS 19 febrer 1991)"; DIAZ DE LEZCANO SEVILLANO, N., Los acuerdos del consejo..., op. cit., pàg. 274, cita jurisprudència que confirma la tesi que el benefici que resulte de l'acord lesiu no ha de limitar-se al contingut patrimonial estricte: STS de 19 de febrer de 1991 (RJA 1991/1512), així com sentències de les audiències provincials de Madrid de 30 de març de 1993 i de València de 21 d'octubre de 1997; GARCIA LUENGO, R., i SOTO VÁZQUEZ, R., El nuevo régimen jurídico..., op. cit., pàg. 540; GIMENO SENDRA, V., "El proceso...», op. cit., pàg. 47; LASSALETA GARCfA, P., «Impugnación...», op. cit., pàg. 339; SÁNCHEZ CALERO, F., Administradores..., op. cit., pàg. 542: "qualsevol avantatge de caràcter politicosocial o professional"; SORIA FERRANDO, J. V., La impugnación..., pàg. 335 i 336; VICENT CHULIÁ, F., «La asamblea...», op. cit. pàg. 479 i 480.

Es manifesten en contra, DUQUE DOMÍNGUEZ, J. F., Tutela..., op. cit., pàg. 132 i 133: "Aquesta interpretació pot, a més, recolzar-se en el text legal mateix, on es parla de benefici -i no de l'avantatge-"; i RODRÍGUEZ RUIZ DE VILLA, D., Impugnación..., op. cit., pàg. 49, el qual considera que "a causa de l'índole eminentment econòmica de l'activitat mercantil de les anònimes, aquests beneficis hauran de ser-ho de contingut econòmic".

Ávila Navarro, P., La sociedad..., op. cit., pàg. 423, que cita la STS de 12.5.68; DíAZ DE Lezcano Sevillano, N., Los acuerdos del consejo..., op. cit., pàg. 275 i 276: "n'hi ha prou que racionalment siga possible, al temps de presentar la demanda [vegeu la STS de 10 de juliol de 1997 (RJ 1997, 5823) (...). També les SSTS de 19 de febrer de 1991 (RJ 1991, 1512) i de 4 de març de 1967 (RJ 1967, 1349)]"; DUQUE DOMf́nGUEZ, J., Tutela..., op. cit., pàg. 98 i 226; RUBIO, J., Curso..., op. cit., pàg. 254, de l'expressió "en benefici d'un o diversos accionistes" dedueix que no és necessària la realitat del benefici extrasocial, sinó que $n^{\prime}$ hi ha prou amb la intenció d'aconseguir-lo.

El legislador autonòmic valencià no ha considerat necessària la referència als associats, probablement per la seua subsumpció en la categoria de "tercers", i la LCoop l'ha suprimit, en coherència amb el canvi de denominació d'aquesta figura en l'àmbit estatal, que passa a denominar-se "soci col-laborador".

"Gimeno Sendra, V., «La reforma...», op. cit., pàg. 20 i 21; PAZ CANAlejo, N., en PAZ CANalejo, N. i ViCent Chuliß, F., Ley general..., op. cit., pàg. 584 i 585. Tanmateix, sorprenentment, aquest tercer supòsit no era aplicable als acords del Consell Rector (ni, per tant, als actes i decisions de la Direcció) en l'àmbit de la LGC, a causa de la inexplicable supressió de la menció als tercers en l'article 66.1. Amb diferent criteri, la LCoop adopta en aquesta matèria, com veurem, una redacció, essencialment idèntica a la de la LSA, reiteradament criticada per obviar, precisament, què s'ha d'entendre per acords nuls i anul-lables; això fa que s'haja de recórrer a l'aplicació analògica d'allò previst per a l'assemblea 
Fora d'això, i per a qualsevol dels supòsits de lesió dels interessos societaris en benefici aliè, la doctrina és unànime en destacar la necessitat que hi haja un nexe causal entre els dos elements del supòsit, ço és, entre l'acord contrari als interessos socials i el benefici particular o extrasocial ${ }^{499}$, que es configura com "l'element decisiu" concórreguen ambdós elements connectats causalment fa que res no impedisca "que el soci pretenga, mitjançant la seua participació en la formació de la

general, per la qual cosa s'ha d'entendre ara inclòs el benefici de tercer en el supòsit
d'anul-labilitat. En relació amb les novetats introduïdes en el seu moment en la matèria per la LGC del 1987, vegeu MARÍN LOPEZ, J. J., "Novedades...», op. cit., pàg. 1127; i VICENT CHULIÁ, F., en PAZ CANALEJO, N. i VICENT CHULIÁ, F., Ley general... op. cit., pàg. 856. En tot cas, com indica Polo SÁNCHEZ, E., Los administradores... op. cit., pàg. 530 i 531, "aquesta ampliació en la protecció dels interessos de la societat resulta particularment oportuna en l'àmbit dels acords de l'organ d'administració, ja que la major part de les decisions de contingut econòmic perjudicials per als interessos socials en benefici de tercers és al si del consell d'administració en què solen adoptarse, en tractar-se de competències de gestió empresarial que permeten desviar en benefici de tercers - $\mathrm{i}$ de vegades dels administradors mateixos, siguen o no accionistes- operacions i
contractes conclosos en clar perjudici dels interessos de la societat".

499 AlCALA DIAZ, M. A., "El conflicto...», op. cit., pàg. 115; ARANGUREN URRIZA, F. J., "Los órganos de la sociedad anónima...», op. cit., pàg. 528; ARROYO, I., "Comentario al art. 56...», op. cit., pàg. 613, on cita jurisprudència: SSTS 11 novembre 1980, RJA 4.132 i 17 juny 1991, RAJ 4.469; DIAAZ DE LEZCANO SEVILLANO, N., Los acuerdos del consejo..., op. cit., pàg. 274; DUQUE DOMÍNGUEZ, J., Tutela..., pàg. 90 i 91 , assenyala que, com que la LSA no indica quin criteri ha de seguir-se per establir la causalitat, s'ha d'acudir a les normes que en l'ordenació civil disciplinen la matèria amb caràcter general (article $1107 \mathrm{CC}$ ); GIMENO SENDRA, J. V., «El proceso...», op. cit., pàg. 49; PAZ CANALEJO, N., en PAZ CANALEJO, N. i ViCENT CHULIÁ, F., Ley general..., op. cit., pàg. 585; SÁNCHEZ CALERO, F., Administradores..., op. cit., pàg. 542: "Sentències de 23 de juny de 1962, Rep. A. 3.021; 4 de març de 1967, Rep. A. 1.349; 11 de maig de 1968, Rep. A. 4.538; 23 de novembre de 1970, Rep. A. 4885, i de 19 de febrer de 1991, Rep. A. 1512"; SÁNCHEZ RUIZ, M., Conflictos de intereses..., op. cit., p". 177 i 178; SORIA FERRANDO, J. V., La impugnación..., pàg. 327 a 331: "és necessària l'existència d'un nexe de causalitat, d'una banda, entre l'acord $i$ la lesió $i$, d'altra banda, entre l'acord lesiu per als interessos socials i el benefici d'un o diversos accionistes"; VICENT CHULIÁ, F., "La asamblea...», op. cit., pàg. 204: "doble relació de causalitat, acord social-lesió als interessos socials i lesió d'interessos socials-benefici directe o indirecte, actual o previsible d'un o més socis", i en Compendio crítico..., op. cit., pàg. 610; URfA, R, MENÉNDEZ, A., i MUÑOZ J. M., La junta general..., op. cit., pág. 337". Les SSTS, Sala del Civil, de 18.9.1998, núm. 825/1998, RJA 1998/6545, i de 27.10.1997, núm. 928/1997, RJA 1997/7617, expliciten la necessitat que concórreguen els tres elements: lesió a l'interès social, benefici de socis o tercers i nexe causal entre la lesió i el benefici, així com que aquests pressuposts han de ser provats". En la mateixa línia hi ha la STS, Sala del Civil, de 17.4.1997, núm. 298/1997, RJA
$1997 / 2915$.

50x) Això no obstant, es discuteix sobre l'ordre de causalitat: SORIA FERRANDO, J. V., La impugnación..., pàg. 330, defén la tesi que "el benefici no és la causa de la lesió de l'interès social, sinó el seu resultat, és a dir, el seu efecte", i critica DUQUE DOMf́NGUEZ, J., Tutela..., pàg. 96, per mantenir la tesi contrària. RODRfGUEZ RUIZ DE VILLA, D., Impugnación de..., op. cit., pàg. 47: "allo 
voluntat social, l'obtenció d'avantatges o beneficis de caràcter personal i, fins i tot, de naturalesa extrasocial, sempre que la consecució d'aquests beneficis no provoque una lesió dels interessos socials ${ }^{\prime 2501}$.

Encara que subscrivim plenament l'afirmació, també sustentable en l'àmbit cooperatiu, que no importa quina siga la motivació que oriente la participació del soci, sempre que no siga lesiva als interessos socials, no podem acceptar l'asseveració que "l'acord no serà anul-lable si poden derivar-se danys a l'interès de la societat, però aquests no són producte de l'exercici del dret de vot motivat per un interès personal i privat dels socis majoritaris ${ }^{\prime 502}$. Perquè la llei no exigeix aquest element subjectiu d'intencionalitat ${ }^{503}$. L'acord ha de lesionar interessos de l'entitat "en benefici de" socis o tercers, però no s'hi diu res d'una motivació concreta dels qui intervenen en la formació de la voluntat social, la concurrència de la qual no sols seria de prova difícil ${ }^{504}$, sinó que n'exclouria d'impugnació supòsits com aquells en què els socis no siguen conscients dels efectes que l'acord haja de causar, o en què la proposta partisca dels qui no són socis (direcció, grup empresarial, etc.).

En definitiva, "és irrellevant la intencionalitat que mou el soci" en l'emissió del vot, "no són elements integrants del supòsit ni la intenció de danyar l'interès

que és beneficiós per a accionistes o tercers és perjudicial per a la societat, perjudici que constitueix l'efecte d'aquell benefici".

sor ALCALA DfAZ, M. A., "El conflicto...», op. cit., pàg. 115 i 116. Com assenyala GARRIGUES, J., "La protección de las minorías...", op. cit., pàg. 101 i 102, la llei mateixa arriba a establir preceptes en què es protegeix el soci, no ja com a integrant d'un grup minoritari, sinó com a individu, i no perquè en aquests casos es convertisca en intèrpret de l'interès de la societat, sinó simplement com a representant del seu propi interès; l'exemple típic n'és el dret de separació que es reconeix al soci en determinats supòsits en els quals aquest considere que l'execució de l'acord majoritari perjudica els seus interessos".

STl ALCALÁ DIAZ, M. A., «El conflicto...», op. cit., pàg. 115 i 116.

${ }^{500}$ MORILlas Jarillo, M. J. i Feliú REY, M. I., Curso..., op. cit., pàg. 256. En aquest sentit, vegeu supra la nota 51 on es recullen les opinions doctrinals contràries al fet de requerir intencionalitat
en la lesió.

jut En relació amb això, SÁNCHEZ CALERO, F., Administradors..., op. cit., pàg. 542, cita jurisprudència que requereix que les circumstàncies del tipus legal han de provar-se per qui 
social" ni la finalitat d'assolir amb l'acord beneficis extrasocietaris: "el vici es predica del contingut de l'acord (no dels vots emesos), i deriva del resultat que produeix (dany a l'interès social i benefici exclusiu per a determinats socis o tercers), amb independència de quina haja estat la intenció o la finalitat perseguida pels votants" ${ }^{205}$

Dos dels supòsits possibles d'acords lesius de l'interès social mereixen un estudi més detallat: els acords en benefici de tercers, l'anul-lació dels quals puga, al seu torn, perjudicar interessos de tercers de bona fe, $\mathrm{i}$ els adoptats pels socis en abús del seu dret de participar, mitjançant el seu vot, en la conformació de la voluntat social.

En el primer supòsit, s'ha advertit sobre la necessitat de fer compatible la impugnació de l'acord lesiu en benefici de tercers amb el mandat legal exprés que "la sentència estimatòria de l'acció d'impugnació (...) no afectarà els drets adquirits per tercers de bona fe a conseqüència de l'acord impugnat" ${ }^{\prime \prime 506}$. Amb això s'ha volgut significar, especialment, la casuística variada que pot donar-se en relació amb els acords invàlids relacionats amb el nomenament i l'actuació extrasocial dels administradors $^{507}$; però també hauria de plantejar-se la hipòtesi

demana l'anul-lació de l'acord, i no n'hi ha prou amb la seua simple al-legació "així, entre altres, SSTS de 10.12.1973, RJA 1974/3; 11.11.1980, RJA. 1980/4132; i 17.6.1991, RJA 1991/4469".

${ }^{505}$ SÁNCHEZ RUIZ, M., Conflictos de intereses..., op. cit., pàg. 178 a 181, que destaca que el supòsit de fet es construeix d'acord amb un criteri objectiu, no subjectiu; en cas admetre's un element intencional en el soci, en els supòsits de benefici de tercers seria necessari provar, a més del dany produït a la societat, la relació existent entre els socis que van votar a favor i el tercer directament beneficiat, així com el caràcter determinant dels vots. Però com que el supòsit de fet es descriu pel legislador en termes objectius, no és necessària la prova de resistència.

${ }^{506}$ JUSTE MENCIAA, J., Los derechos de minoría..., op. cit., pàg. 405 i 406: "la inclusió, entre els acords anul.lables, d'aquells que beneficien en perjudici de la societat a un tercer ha de ser ponderat a l'aplicació estricta de les normes sobre protecció del tràfic, almenys respecte dels actes exclosos de l'objecte social".

${ }^{507}$ SÁNCHEZ CALERO, F., Administradores..., op. cit., pàg. 554 i 555; JUSTE MENCIAA, J., Los derechos de minoría..., op. cit., pàg. 405 i 406: "aquest article [122.1 LSA] (...) presenta especialitats en el cas que l'acord ho siga del Consell d'Administració. La raó d'això està en la protecció de la funció de representació amb que la llei dispensa els administradors (article 129 LSA ). En relació amb aquesta matèria, s'ha assenyalat que si l'acte de representació «dins de l'objecte social» és conseqüència de l'acord la nul-litat o l'anul-labilitat del qual es reconeix en la sentència, el tercer no queda afectat per aquesta (129.1); si l'acord es refereix al nomenament d'administradors (v. 
que amb qualsevol tipus d'acord lesiu de l'interès cooperatiu s'afavorisca un tercer de bona fe: en aquest cas l'eventual anul-lació judicial de l'acord no haurà d'arribar als drets del tercer.

Quant a la segona qüestió indicada, la doctrina s'ha plantejat reiteradament l'admissibilitat o no de la impugnació de l'acord adoptat mitjançant abús de $\operatorname{dret}^{508}$ per part de la majoria social ${ }^{509}$, proposant-ne en alguns casos la g. cooptació), per aplicació del que disposa l'article 8 de la Primera directiva de 1968, els seus efectes no s'estenen als actes realitzats com a conseqüència del vot del conseller o consellers afectats; finalment, si l'acte no està comprès a l'objecte social, haurà d'exigir-se del tercer, per a l'article 122 LSA".

- El concepte d'abús de dret ha estat llargament debatut per la doctrina francesa, que assenyala dos vessants: l'abús de majoria i l'abús de minoria. Així, COZIAN, M., VIANDIER, A., i DEBOISSY, F. L., Droit des sociétés, op. cit., pàg. 171 a 173: “...què és un abús de majoria? És la transposició al dret de societats (encara que amb matisos) de la teoria civilista de l'abús de dret (es pot usar el propi dret, però no abusar amb la sola intenció de perjudicar-ne un altre). No cal dir que la seua aplicació ha de ser excepcional (...) sota pena de paràlisi social"; LEGROS, J-P., "La nullité des décisions...", pàg. 296 a 300; TRICOT, D., "Abus de droits...", op. cit., pàg. 618: "L'abús no resulta mai del fet que l'exercici del dret cause un dany a un altre. Però pot haver-hi abús de drets en dos casos (...): - - si el dret no és utilitzat més que amb la intenció de perjudicar, i sense cap utilitat per al seu titular (...); - si, independentment de tota intenció de perjudicar, l'acte realitzat en virtut del dret en causa presenta un caràcter anormal".

DUQUE DOMfNGUEZ, J. F., Tutela..., op. cit. pàg. 22 i 23, refereix l'opció d'una part de la doctrina italiana (encapçalada per CARNELUTTI i seguida per ASCARELLI i FERRI) pel rebuig de la noció d'abús de dret a favor de la d'excés de poder, "partint de la idea que el vot és una potestat que ha de ser exercitada per a la tutela d'un interès aliè —el de la societat en aquest cas-. (...) es trasllada al dret mercantil una noció del dret administratiu que, en diferenciar interès del titular del poder i interès del subjecte per a la protecció del qual aquell s'atorga per l'ordenació, permet parlar d'una desviació de poder". També esmenta DUQUE (op. cit., pàg. 49 a 51) la recepció per una part de la doctrina i de la jurisprudència (fonamentalment, la belga) de la noció de frau de llei, que comprén l'abús i la desviació de poder, però rebutja aquest concepte com a fonamentació de l'anul-lació d'acords per dos motius: d'una banda, en l'abús o la desviació de poder hi ha una vulneració directa de la llei, que en el fraus legis es dóna només per mitjans indirectes; d'una altra, el frau de llei permetria únicament l'anul-lació quan s'hagueren emprat maniobres i artificis deslleials. Assenyalen la dificultat d'aplicar en el Dret privat la "teoria de l'abús o desviació de poder", "en estar elaborada en el camp del Dret administratiu", a causa de les diferències entre l'estructura $\mathrm{i}$ el funcionament $d^{\prime}$ 'òrgans administratius i societaris, entre interès general $i$ interès social, $i$ entre el control judicial sobre l'oportunitat de les decisions administratives i les societàries, SALELLES CLIMENT, J. R., El funcionamiento..., op. cit., pàg. 385; i URIA, R., MENÉNDEZ, A., i MUÑOZ, J. M., La junta..., op. cit., pàg. 340 i 341, encara que reconeixen que "la jurisprudència del nostre Tribunal Suprem no ha deixat d'invocar, de vegades, la noció de l'abús o frau i de mala fe en l'exercici del dret en la matèria", i cita molta jurisprudència.

Vegeu també una extensa cita a les posicions doctrinals relatives a l'abús o desviació de poder en ALCALÁ DIAZ, M. A., La impugnación..., op. cit., pàg. 184 i 185, nota 172.

\$m Propugnen la impugnabilitat dels acords adoptats amb abús de dret ÁvILA NAVARRO, P., La
sociedad..., op. cit., pàg. 423; GARCIA LUENGO, R., i SOTO VÁZQUEZ, R., El nuevo régimen..., op. cit.,
pàg. 543 i 544, que cita les SSTS de 30.1.1970, $22.12 .1970,16.3 .1987$ i $19.10 .1987 ;$ GARRGUES, J, i
URtA, R., Comentario a..., op. cit., pàg. 762, “si hi ha intenció de danyar l'interès social estem 
impugnació en la mesura que supòsit específic d'acord lesiu de l'interès $\operatorname{social}^{510}$.

davant del supòsit referit fins i tot quan no s'haja produït el benefici"; també GARRIGUES, J., en "La protección de las minorías...", op. cit., pàg. 112: "En entrar en la societat, el soci se sotmet voluntàriament a les decisions de la majoria (...). Però aquesta submissió no es fa d'una manera incondicionada, sinó d'una manera condicional, és a dir, només en el cas que, efectivament, la majoria represente i defense l'interès de la societat. Quan la majoria s'aparta d'aquest interès i, tanmateix, continua exercint els seus poders, indubtablement n'abusa o es desvia en la seua actuació"; GIRÓN TENA, J., Derecho de sociedades anónimas, op. cit., pàg. 325; PEMÁN MELERO, M., op. cit., tom II, pàg. 748; POLO SÁNCHEZ, E., "Abuso o tiranía...», op. cit., pàg. 2279 a 2283, es mostra partidari d'incloure l'abús de dret de la majoria com a causa d'impugnació per lesió de l'interès social, encara que reconeix que s'ha de fer "amb caràcter excepcional", aplicant-se "amb una prudència exquisida", i només en els casos on "la finalitat il-legítima o la intenció de perjudicar siguen patents i manifestes"; SALELLES CLIMENT, J. R., El funcionamiento..., op. cit.,
pàg. 385 i 386, cita en la nota 444 , juó de pàg. 385 i 386, cita en la nota 444, jurisprudència que admet la impugnació en supòsits d'abús (R. 4980), 30 de gener i 22 de altres, SSTS de 4 de març de 1967 (R. 1349), 25 d'octubre de 1969 de març de 1987 (R. 1483)"; VIesembre de 1970 (R. 525 i 5632), 25 de maig de 1979 (R. 1892) o 16 i 2 de juliol de 1963, 4 de març 1967, ., Compendio..., també cita jurisprudència: SSTS d'1 SORIA FERRANDO, J. V., La impugnación..., p. 334.

DIAAZ DE LEZCANO SEVILLANO, N., Los acuerdos del consejo..., op. cit., pàg. 248 i 272, considera els supòsits d'abús de dret com acords contraris a la llei i, per tant, nuls; DUQUE DOMÍNGUEZ, J., Tutela..., op. cit., pàg. 102, planteja l'anul-labilitat d'un tipus concret d'acords: "quan, sense cap avantatge, ni tan sols potencial per a aquest interès, el vot siga exercitat amb la finalitat de perjudicar $i$, efectivament, perjudicant els altres socis en un interès privat extrasocial, el vot serà nul i, per tant, anul-lable l'acord, encara que d'aquest no s'obtinga cap avantatge - ni social ni la majoria requerida perquè tinga existència legal".

Estimen que la incorporació de l'article 159 LSA (exclusió del dret de subscripció preferent) provoca l'ampliació de l'àmbit d'aplicació de la impugnació dels acords lesius, que ara no només inclouria la lesió a l'interès social, sinó també als interessos dels socis minoritaris, ALFARO AGUILA-REAL, J., Interés social..., op. cit., pàg. 36 i 37, i SÁNCHEZ RUIZ, M., Conflictos de
intereses..., op. cit., pàg. 189.

Dubta de la impugnabilitat dels acords abusius N. PAZ CANALEjO, en PAZ CANALejO, N. i VICENT CHULIA, F., Ley general..., op. cit., pàg. 584 i 585 . VICENT CHULIÁ, F., també cita jurisprudència que admet la seua impugnabilitat en l'àmbit societari ("La asamblea...", op. cit., pàg. 210 i 211, i Compendio..., op. cit.); tanmateix, en relació amb la LGC de 1974, encara que adverteix la seua absència al text legal ("El derecho de los órganos...», op. cit., pàg. 526 a 529) i apunta la sanció possible de l'abús de dret mitjançant allò que preveu l'article 7 del CC, entén que "això no originaria la nul-litat de l'acord (...) encara que sí que podria justificar la suspensió de la seua execució $i$, per això, la seua ineficàcia".

URÍA, R., MENÉNDEZ, A., i MUÑOZ, J. M., La junta..., op. cit., pàg. 340 i 341, es mostren contraris a l'aplicació de la noció d'abús de dret en l'àmbit societari, encara que, com ja hem apuntat, adverteixen de la jurisprudència reiterada del Tribunal Suprem en què s'invoca "la noció de l'abús o frau i de mala fe en l'exercici del dret en matèria societària".

st" SAlelles Climent, J. R., El funcionamiento..., op. cit., pàg. 384 i 385: "...els acords de la Junta en casos de desviació de poder o d'abús de dret, o quan, adoptats de bona fe, tinguen un caràcter irracional. La impugnació d'aquests acords és una tècnica correctora del funcionament de la societat per permetre la tutela de la minoria i de l'interès social al marge de les infraccions legals o estatutàries". 
Tanmateix, s'ha de recordar que, perquè es done aquest tipus d'acord impugnable concret, l'exercici abusiu del propi dret no només ha de lesionar l'interès social, sinó que ha de produir un benefici aliè, lligats ambdós per una relació causal ${ }^{511}$.

L'abús de dret és, al nostre entendre, una institució més àmplia ${ }^{512}$, en la qual poden enquadrar-se, entre altres, els supòsits d'exercici abusiu del seu dret per la majoria social que produiran perjudici a la cooperativa $i$ benefici a altres persones: és en aquests casos que podrà impugnar-se l'acord ${ }^{513}$. Però també se n'inclouen d'altres, en els quals l'abús de dret per la majoria no té per objecte beneficiar a ningú: la finalitat pot ser, exclusivament, el perjudici a determinats socis o tercers ${ }^{514}$ o a la cooperativa mateixa, o no haver-hi una finalitat, com és el

" GARRIGUES, J., «La protección de las minorías...», op. cit., pàg. 112 i 113: “El (...) problema que se suscita és el de la conveniència de concedir a l'òrgan judicial una intervenció en la gestió de les societats anònimes per decidir si la majoria s'ha desviat efectivament de les seues facultats de manera que es lesiona l'interès de la societat que hauria hagut de defensar. Molts autors consideren nociva aquesta intervenció (...). Segons el nostre parer, la llei espanyola ha salvat aquest inconvenient en exigir no només la violació de l'interès social, sinó que aquesta violació $s$ 'haja traduït en benefici d'un o de diversos accionistes. D'aquesta manera, el jutge no està obligat a decidir sobre l'interès social per damunt de la majoria (...). Està només obligat a decidir si hi ha conflicte entre l'interès social comú i l'interès extrasocial egoista d'un accionista aillat o d'un grup d'accionistes".

La STS, Sala del Civil, de 10.7.1997, núm. 641/1997, RJA 1997/5823 considera que pot haver-hi acords lesius dels interessos socials, en benefici d'altres, amb concurrència de les circumstàncies que tipifiquen l'abús de dret, i cita al seu torn la STS de 10.2.1992, RJA 1992/1204.

${ }^{512}$ SÁNCHEZ RUIZ, M., Conflictos de intereses..., op. cit., pàg. 175: "malgrat el fet que la tècnica de resolució de conflictes intrasocietaris prevista en l'article 115.1 in fine constitueix «el límit més enèrgic que la nostra Llei de societats oposa a l'abús del poder majoritari, ja que no es tracta de sancionar l'ús legal o antiestatutari del seu poder, sinó el seu ús en benefici d'un o de diversos accionistes o de tercers» [nota 87: Cfr. POLO SÁNCHEZ, E.: "Abuso o tirania», op. cit., pg. 2275], no esgota tots els supòsits d' «abús de la majoria»".

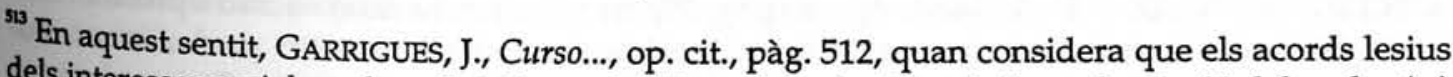
dels interessos socials en benefici d'un o de diversos accionistes és "una desviació del poder (...) un abús de facultats", la qual cosa indica que no és l'únic supòsit possible.

S4 SALELLES CLIMENT, J. R., El funcionamiento..., op. cit., pàg. 385: "Per exemple, quan s'acorda
l'augment del capital contra tot criteri d'administració raonable amb la finalitat que alguns socis
no puguen subscriure l'ampliació, o quan s'oculten diverses activitats en el balanç i l'informe
dels administradors amb la finalitat dolosa de crear una aparença de precarietat i la situació de
l'empresa és correcta, en relació directa amb un acord d'augment del capital i amb una clara
finalitat fraudulenta".
En relació amb els supòsits en què el perjudici no recau en la societat, sinó en els altres socis,
s'ha de recordar que, com hem comentat supra, el Codi penal vigent (LO 10/1995, de 23.11)
introdueix una nova figura delictiva, la dels qui "prevalent-se de la seua situació majoritària en 
cas dels anomenats "acords irracionals" indicat, la doctrina i la jurisprudència debaten la idoneïtat d'acceptar la impugnació de l'acord.

En la nostra opinió, a l'efecte d'evitar les conseqüències perjudicials de l'abús de dret, han de distingir-se ambdues modalitats. L'abús realitzat amb perjudici social i en benefici extrasocial serà plenament anul-lable quan s'exercisca mitjançant l'adopció d'un acord per la majoria. En canvi, l'arbitrarietat en l'exercici del propi dret quan no es donen els elements de l'acord impugnable per lesiu a l'interès social (acord que lesiona interessos de la cooperativa i que produeix beneficis extrasocials), només podrà donar lloc a la reclamació de "la indemnització corresponent i l'adopció de les mesures judicials administratives que impedisquen la persistència en l'abús" en la mesura que es donen les circumstàncies previstes en l'article 7.2 del Codi civil ${ }^{516}$.

Així doncs, en el segon cas, perquè puga ser sancionable l'abús de dret, es requerirà un ús del dret de vot "manifestament anormal o extralimitat". La anormalitat podrà tenir l'origen en causes subjectives (quan puga provar-se una intenció de lesionar) o objectives (quan l'acord, pel seu contingut, supose un sacrifici desproporcionat dels interessos dels socis minoritaris sense resultar

la Junta d'accionistes o l'òrgan d'administració de qualsevol societat constituïda o en formació, imposaren acords abusius, amb ànim de lucre propi o aliè, en perjudici dels altres socis, i sense que reporten beneficis a aquesta". La doctrina critica l'esmentada tipificació penal, per la seua falta de coordinació amb les normes societàries i per la no-aplicació d'intervenció mínima del Dret penal. Vegeu, per tots, ALCALÁ DÍAZ, M. A., La impugnación..., op. cit., pàg. 189, nota 179.

515 DUQUE DOMfNGUEZ, J. F., Tutela..., op. cit. pàg. 35, esmenta l'anomenat «acord opressiu» del dret anglès que "es manifesta per la mala fe consistent en que el «motiu predominant» és danyar uns altres o "dominar pel fet de dominar i no per protegir-se a si mateix»".

${ }^{516}$ DUQUE DOMÍNGUEZ, J. F., Tutela..., op. cit. pàg. 101; RODRfGUEZ RUIZ DE VILLA, Impugnación..., op. cit., pàg. 93 i 94; SALELlES CLIMENT, J. R., El funcionamiento..., op. cit., pàg. 385 i 386, que cita en el seu suport LANGLE (Manual de derecho mercantil español, Bosch, Barcelona, 1950); SÁNCHEZ RUIZ, M., Conflictos de intereses..., op. cit., pàg. 228 a 233; VICENT CHULIÁ, F., en Compendio..., op. cit., tom I, 1, pàg. 611, i en "El derecho de los órganos...", pàg. 528 i 529.

Article 7.2 CC: "La Llei no empara l'abús del dret o l'exercici antisocial d'aquest. Qualsevol acte o omissió que per la intenció del seu autor sobrepasse manifestament els límits normals de l'exercici d'un dret pel seu objecte o per les circumstàncies en què es duga a terme, amb dany per a tercer, donarà lloc a la indemnització corresponent i a l'adopció de les mesures judicials 0 administratives que impedisquen la persistència a l'abús". 
particularment avantatjós per a la societat) ${ }^{517}$; i el caràcter manifest de l'exercici abusiu del dret de vot significa que l'extralimitació ha de ser patent, és a dir, provada $^{518}$, i d'una certa entitat ${ }^{519}$. Quant a la sanció corresponent, la doctrina es divideix entre els qui entenen que, una vegada provada la situació d'abús, l'acord serà en tot cas nul, ja que s'infringeix un precepte legal (l'article 7.2 $(C)^{520} \mathrm{i}$ els qui, atenent el tenor del $\mathrm{CC}$, consideren que s'haurà de conèixer les circumstàncies del cas per determinar la sanció aplicable ${ }^{521}$.

"s" SANCHEZ RUIZ, M., Conflictos de intereses..., op. cit., pàg. 228 a 230. Es tracta del que qualifica de concepció eclèctica de l'abús de dret GeTE-ALONSO Y CALERA, M. del C., "Comentario al art. 7n, en AA. DD., Comentarios al Código Civil y Compilaciones forales (dirs. M. Albaladejo i S. Díaz Alabart), tom I, vol. 1, 2a ed., EDERSA, 1992, pàg. 906.

s" SÁNCHEZ RUIZ, M., Conflictos de intereses..., op. cit., pàg. 230. GETE-ALONSO Y CALERA, M. del C., "Comentario al artículo 7...", op. cit., pàg. 918: "L'abús de dret ha de provar-se en cada cas concret, no se suposa la seua existència perquè la presumpció - conforme a la regla de qui sui iure utitur neminem laedit- és, precisament, la contrària".

"s GETE-ALONSO Y CALERA, M. del C., "Comentario al artículo 7...", op. cit., pàg. 918: "És copiosa la jurisprudència del Tribunal Suprem (...) en la qual s'al-ludeix repetidament al seu caràcter excepcional (...), i s'afirma que ha d'aplicar-se «amb una cura especial i sempre pressuposada l'existència real de l'abús». (...) El caràcter excepcional que se li atorga, derivat de l'exigència que siga manifest, comporta una conseqüència ulterior: la subsidiarietat d'aquest. $\mathrm{Si}$ hi ha un altre remei legal particular, aquest té aplicació preferent respecte de la regla de l'article 7, 2n, del Codi civil".

Diaz de LeZCANO SeVILlano, N., Los acuerdos del consejo..., op. cit., pàg. 248; GARCfA LUENGO, R, i SOTO VÁZQUEZ, R., El nuevo régimen..., op. cit., pàg. 543 i 544; RODRíGUEZ RUIZ DE VILLA, D., Impugnación..., op. cit., pàg. 93 i 94; SÁNCHEZ RUIZ, M., Conflictos de intereses..., op. cit., pàg. 231 i 232. Contràriament, DUQUE DOMíNGUEZ, J. F., Tutela..., op. cit. pàg. 101, considera anul-lable l'acord "quan, sense cap avantatge, ni tan sols potencial per a aquest interès, el vot siga exercitat amb la finalitat de perjudicar i, efectivament, perjudicant els altres socis en un interès privat extrasocial", en la mesura que el vot singular del soci serà nul i, per tant, puga aplicar-se la prova de resistència.

21 GETE-Alonso y CALERA, M. del C., «Comentario al artículo 7...», op. cit., pàg. 926: "Quan el dany prové de la conclusió d'un negoci, la ineficàcia es tradueix en l'admissió de la legitimació activa per sol-licitar, el perjudicat per aquest, la declaració de nul-litat del negoci. És coneguda la sentència del T. S. de 14 de febrer 1959, en la qual s'afirma que la doctrina de l'abús de dret "porta 0 a la nul-litat de l'acte d'extralimitació de facultats jurídiques o a la seua limitació dins dels cursos del normal exercici del dret o, en últim terme, a la indemnització del perjudici indegudament causat»"; VICENT CHULIÁ, F., «El derecho de los órganos...», pàg. 528 i 529: "la sanció prevista per aquest precepte (...) no originaria la nul-litat de l'acord (interpretació congruent amb l'article 6-3r del Codi civil mateix), encara que sí que podria justificar la suspensió de la seua execució $i$, per això, de la seua ineficàcia". 
Finalment, s'ha plantejat la possibilitat d'impugnar els acords irracionals encara que la irracionalitat no siga manifestació d'un abús de dret ${ }^{52}$. Considerem que aquesta hipòtesi no sols manca de suport normatiu, sinó que obriria la perillosa via del control judicial sobre l'oportunitat de les decisions socials ${ }^{523}$.

\section{L'objecte de la impugnació segons la naturalesa de la causa d'invalidesa}

Tant l'article 31.2 LCoop com el 36.2 LCCV estableixen que "seran nuls els acords contraris a la Llei. Els altres acords a què es refereix el número anterior [que s'oposen als estatuts o que lesionen, en benefici d'un o de diversos socis, associats o tercers els interessos de la cooperativa] seran anul-lables". Atenent, doncs, la naturalesa diferent de la causa d'invalidesa ${ }^{524}$, la impugnació determinarà, bé la nul-litat, bé l'anul-labilitat dels acords

${ }^{522}$ SAlelles CLIMENT, J. R., El funcionamiento..., op. cit., pàg. 386: "L'argument no és diferent a l'utilitzat per justificar la impugnació dels acords adoptats en exercici abusiu del poder de la majoria. Es tracta així d'evitar el perjudici de l'interès típic de la societat ocasionat per la presa de decisions que, encara que de bona fe, passen dels criteris d'administració raonable de l'empresa [en el Dret americà es reconeix la possibilitat de revisió judicial dels acords irracionals (...), i, en el mateix sentit, en el Dret anglès]".

${ }^{523}$ Aquest control judicial ha estat reiteradament criticat per la doctrina en general i per l'autor partidari d'aquesta impugnació en particular: "El jutge no ha d'immiscir-se en les decisions adoptades per la majoria i substituir-la en la seua esfera de competències. Aixi, els tribunals han de procedir amb cautela i han de procurar no envair amb la seua intervenció l'àmbit de competències reservat per la Llei o els estatuts als òrgans de la societat. Únicament quan en el procés d'adopció d'acords d'aquests òrgans hi haja indicis raonables que l'òrgan social s'ha extralimitat en l'exercici de les seues facultats legals o estatutàries o ha causat lesió a l'entitat en benefici d'algun soci o d'un tercer, el jutge pot $\mathrm{i}$ ha de revisar l'acord adoptat" (SALELLS CLIMENT, J. R., El funcionamiento..., op. cit., pàg. 383 i 384, cita en la nota 435 referèricies doctrinals i jurisprudencials). En el mateix sentit, DÍAZ DE LEZCANO SEVILLANO, N., Los acuerdos del consejo..., op. cit., pàg. 203: "La autoritat judicial o extrajudicial només pot valorar criteris de legalitat, mai d'oportunitat, per la qual cosa no es pot requerir la seua intervenció per examinar la gestió social per una altra causa que no siga la de verificar la seua licitud, i és per això que per impugnar l'acord contrari a l'interès social aquest haja d'anar acompanyat d'una dada objectiva [,] la relació perjudici-benefici". AlCALÁ DíAZ, M. A., "El conflicto...», op. cit., pàg. 122: "Si (...) es produïren danys a la societat sense que foren conseqüència de la consecució de beneficis per part d'un grup de socis o de tercers, l'acord no seria anul-lable i quedaria inclòs dins de la discrecionalitat atribuïda a la junta general en la interpretació de l'interès social, com igualment succeiria si l'obtenció d'avantatges particulars no estiguera associada a la lesió de l'interès social". 
La distinció entre acords socials nuls i anul-lables va ser incorporada al dret de societats espanyol per la LSA del 1951 i "porta la seua causa de la distinció en el Dret comú entre les categories de nul-litat i anul-labilitat" del negoci jurídic ${ }^{525}$. Com s'ha assenyalat, "al marge de l'encert dogmàtic que aquesta separació estricta pot contenir, allò cert és que el legislador espanyol ha intentat resoldre el no gens fàcil problema de distingir nul-litat d'anul-labilitat en termes extremadament simples, sense que per això hagen faltat crítiques doctrinals" ${ }^{\prime 256}$.

En efecte, aviat la doctrina va advertir que la major necessitat d'agilitat, de simplicitat dels procediments i de seguretat del tràfic en l'àmbit empresarial es compadia poc amb la complexitat i lentitud del procés d'impugnació indefinida dels acords nuls ${ }^{527}$; aquest va ser un dels motius que van conduir ă abordar, en la reforma de la legislació societària del 1989, la unificació de les accions

${ }_{25}$ GIRÓN TENA, J., Derecho de sociedades anónimas, op. cit., pàg. 316 i 317; AlCALÁ DíAZ, M. A., Impugnación..., op. cit., pàg. 78; SALELLES CLIMENT, J. R., El funcionamiento..., pàg. 376.

52^ EMBID IRUJO, J. M., «Notas sobre la impugnación...», op. cit., pàg. 52; en el mateix sentit RUBIO, J., Curso..., op. cit., pàg. 243 a 245; URÍA, R., MENÉNDEZ, A., i MUÑOZ, J. M., La junta..., pàg. 316 i 317. POLO SÁNCHEZ, E., Los administradores..., op. cit., pàg. 531 i 532, es refereix a aquestes crítiques doctrinals: "No es pot $\operatorname{dir}(. .$.$) que la distinció entre nul-litat i anul-labilitat, segons que$ l'acord siga contrari a la Llei o bé contrari als estatuts o lesiu per a l'interès social, sense atendre la naturalesa intrínseca o el contingut de l'acord, culmine totes les aspiracions de la nostra doctrina (sobre això, vegeu GIRÓN, 317-320; RUBIO, 245-246; SORIA, "Consideraciones sobre la eficacia de los acuerdos sociales declarados nulos», RDM, 1982, 544; després de 1'aprovació de la Llei SÁNCHEZ CALERO [Instituciones..., op. cit., pàg. 373]; és més, l'aplicació indiscriminada d'aquest criteri pot conduir a resultats certament paradoxals $i$ poc equitatius que la jurisprudència mateixa ha tractat de vegades d'evitar amb posicions vacil-lants $i$ fins $i$ tot contradictòries".

"URtA, R., MENÉNDEZ, A., i MUÑOZ, J. M., La junta..., pàg. 318 i 319: "la imprescriptibilitat de l'acció de nul-litat no deixava de ser criticable per l'amenaça constant que suposa la possibilitat d'exercitar indefinidament les accions. Els acords socials, que exigeixen certesa i estabilitat, es troben, d'aquesta manera sotmesos al risc permanent d'una acció eventual de nul-litat; la qual cosa constitueix una font d'inseguretat per al tràfic jurídic"; ALCALÁ DÍAZ, M. A., La impugnación..., op. cit., pàg. 223.

GALGANO, F., Diritto commerciale. Le società , p. 244: "L'interès protegit és l'interès de la majoria assembleària en l'estabilitat de les pròpies deliberacions: l'interès que les deliberacions assembleàries - fins $i$ tot les contràries a normes imperatives- no estiguen perpètuament exposades a les accions de nul-litat de qualsevol interessat i queden, doncs, en una condició de incertesa perenne. I, si es consideren les relacions economicosocials subjacents, l'interès de la classe empresarial: el Codice civile no dubta, en aquest com en tants altres casos, a derogar les normes de dret comú, quan l'aplicació d'aquestes normes es pogueren traduir en un destorb a l'activitat empresarial, en un obstacle a l'eficiència de la gestió". 
d'impugnació en un sol "tràmit judicial senzill, ràpid i d'instància única" "encara mantenint la distinció entre acords nuls i acords anul-lables (...) preveu un termini de caducitat, també per a la impugnació dels acords nuls ${ }^{\prime 2528}$.

Aquesta evolució en el tractament dels efectes jurídics dels acords impugnables ha tingut el seu parangó en les modificacions successives de la legislació cooperativa. Així, mentre que la LGC de 1974 distingia entre els acords nuls, que podien ser revisats indefinidament pel procediment declaratiu ordinari, i els anul-lables, sotmesos a un breu termini de caducitat i revisables únicament

${ }^{528}$ SALELlES ClIMENT, J. R., El funcionamiento..., op. cit., pàg. 376 i 377. CABALLOL I ANGELATS, L "Comentario al artículo 115...", op. cit., pàg. 1116 explica com la LSA vigent ja no fa una utilització estricta de les categories d'ineficàcia pròpies de la teoria general del negoci jurídic: "Més aviat se serveix de la terminologia tradicional i la trasllada a l'ambit societari per dotar-la d'una significació ad hoc" que només té rellevància per fixar els terminis de caducitat i la pretensió d'impuge que siga possible "diferenciar una versió declarativa o constitutiva de la estableix un únic règim j...) perquè la LSA mateixa, en regular els efectes de la sentència (...) "la Llei ha portat, fim jurídic"; POLO SÁNCHEZ, E., Los administradores..., op. cit., pàg. 533 i 534 : tractament unitari ment, a les seues últimes conseqüències en materia $\mathrm{d}^{\prime}$ acords del consell $\mathrm{el}$ l'article 116, in de junta establert en Novament, la imprescriptibilitat dels acords nuls en l'article 44 de (articles 52.4 i 66.4)] sembla inspirada acords nuls (vegeu en mantenir la imprescriptibilitat dels l'arrelamenta a la rastes els nostres juristes de la posició anterior farà que es desperten certes crítiques institorma, la norma respon a una evolució certa produïda en el Dret comparat respecte de la institució de la nul-litat, en raó de la inseguretat jurídica que es deriva de la permanència indefinida dels seus efectes, evolució singularment manifestada en les Directives de la CEE en el tractament de la nul-litat i l'anul-labilitat tant en la constitució de la societat, com en les operacions de fusió i escissió (vegeu POLO SÁNCHEZ, RJC, 1991, 72-73 i 92 i bibliografia citada en
aquesta obra)".

URÍA, R., MENÉNDEZ, A., i MUÑOZ, J. M., La junta..., p. 309: “Del que es tracta, en definitiva, (...) és de preservar fins on siga possible l'estabilitat dels acords socials $i$ encara que per a això siga necessari sacrificar o subvertir els principis que governen aquesta matèria en les lleis civils". Sobre la unificació del termini de caducitat per a acords nuls i anul-lables en la fusió de societats anònimes que ja estiga inscrita en el Registre, la diferent durada, així com la falta de referència a l'excepció relativa als acords contraris a l'ordre públic, GOMEZ PORRÚA, Juan Manuel, La fusión de sociedades anónimas en el derecho español y comunitario, La Ley, Madrid, 1991, pàg. 259 i 260; en la mateixa línia, DUQUE DOMf́NGUEZ, Justino F., "La fusión en el Proyecto de reforma del Derecho de las Sociedades de Capital y su comparación con el Derecho comunitario de la Tercera Directiva», RDBB, núm. 32, octubre-desembre 1988, pàg. 725 a 781, quan esmenta els considerants $\mathrm{i}$ els articles corresponents de la Tercera directiva en matèria de dret de societats (78/855/CEE); EMBID IRUJO, José Miguel, «En torno a la nulidad de la fusión y de la escisión en la nueva Ley de Sociedades Anónimas», RGD, núms. 550-551, juliol-agost 1990, pàg. 5613 a 5617 , trasllada, en gran part, el règim de la nul-litat de la fusió al de l'escissió, i en "En torno a las modificaciones estructurales de las sociedades mercantiles (fusión, escisión y otros procedimientos similares)", CDC, núm. 9, setembre 1991, pàg. 25 i 26; i MARTínEZ SANZ, Fernando, "La nulidad de la fusión en la Ley de sociedades anónimas», RDM, núm. 195, gener- 
pel procediment establert per la LSA de $1951^{529}$, la LGC de 1987, avançant-se parcialment a la reforma del dret de societats de capital del $1989^{530}$, ja va introduir la unificació del procediment d'impugnació dels acords socials i la submissió a un termini de caducitat dels acords nuls.

Tanmateix, les solucions legislatives vigents continuen sense donar satisfacció plena a la realitat societària. D'una banda, la invalidesa radical d'alguns acords, que reclamava el manteniment de la seua impugnabilitat indefinida, ha impedit una unificació total del procediment, $\mathrm{i}$ ha portat a l'exclusió de la caducitat dels anomenats "acords contraris a l'ordre públic", concepte, com veurem, de contorns vagues i imprecisos i que no contribueix, precisament, a la seguretat jurídica.

D'altra banda, s'ha dubtat que "la distinció entre nul-litat i anul-labilitat, segons si l'acord és contrari a la Llei o bé contrari als estatuts o lesiu per a l'interès social, sense atendre la naturalesa intrínseca o el contingut de l'acord, satisfaça totes les aspiracions d'equitat manifestades per un sector autoritzat de la nostra doctrina" ${ }^{2531}$. En efecte, com també veurem, mentre alguns acords contraris a la llei vulneren únicament requisits formals no essencials, per a la salvaguarda dels quals sembla excessiva la sanció de nul-litat, altres acords poden resultar no impugnables quan, per exemple, encara que siguen lesius per a l'interès social no es demostre el benefici en favor de socis o tercers.

març 1990, pàg. 76 a 78.

Sha de tenir present, això no obstant, que el Reial Decret 2710/1978, de 16.11, pel qual s'aprova el Reglament de la LGC de 1974, mantenia la possibilitat indefinida d'acció de nul.litat mitjançant el judici declaratiu ordinari però, contra la més elemental norma de tècnica de desplegament legislatiu, ignorava el mandat legal previst a l'apartat Dos de l'article 27 de la LGC 1974, pel qual s'establia que per al procediment d'impugnació especial s'havien d'observar "les normes processals contingudes en l'article 70 de la Llei de 17 de juliol de 1951", i establia una regulació completa del procediment.

\footnotetext{
VICENT CHULIÁ, Francisco, "Los órganos sociales de la cooperativa», RJC, núm. 1/1978, gener-març, pàg. 488

POLO SÁNCHEZ, E., Los administradores..., op. cit., pàg. 531. GIRÓN TENA, Derecho de sociedades anónimas, op. cit., pàg. 317 a 320; RUBIO, J., Curso..., op. cit., pàg. 245 i 246; SÁNCHEZ CALERO, F.,
Instituciones..., op. cit., pàg. 373; SORIA FERRANDO, J. V., La impugnación..., op. cit., pàg. 139 i 140, i
en uConsideraciòn en "Consideraciones sobre la eficacia...", op. cit., pàg. 544
} 
Respecte a la qüestió àmpliament debatuda en el passat per la nostra doctrina sobre els acords "inexistents", sembla que actualment es descarta el seu manteniment com a categoria independent ${ }^{532}$, contràriament al que succeeix en dret italià, on es manté viva la polèmica sobre la seua admissibilitat $t^{533}$.

La qüestió no és fútil, ja que, si s'admet que l'aplicació del règim d'impugnació d'acords socials requereix dues condicions, una de negativa, la no-conformitat amb la llei, els estatuts o els interessos socials, i una altra de positiva, l'existència mateixa de l'acord, la conseqüència que es derivaria seria la no-

${ }^{532}$ Com a exponent paradigmàtic del contingut de la posició doctrinal, GIRÓN TENA, J. Derecho de sociedades anónimas, op. cit., pàg. 319 i 320: "la utilització per a la nul-litat de la referència a la Llei (...) permet portar al nostre cas la doctrina, molt generalitzada per al nostre dret, $\mathrm{d}$ 'indiferenciació entre inexistència i nul-litat, que es recullen sota l'expressió genèrica de nul.litat radical, i fan caure sota aquest concepte els casos en què no es donen en absolut els elements pressuposats mínims de configuració del negoci jurídic (...). Aquesta interpretació és abonada pel fet que la doctrina d'efectes de les nul-litats està generalitzada en els casos d'inexistència"; això no obstant, ha de tenir-se en compte que l'esmentada tesi s'elaborava en el context d'un règim d'impugnabilitat que mantenia la impossibilitat de reparació dels acords nuls. En el mateix sentit, ALCALÁ DIAZ, M. A., Impugnación..., op. cit., pàg. 80; GARRIGUES, J., Curso..., op. cit., pàg. 511; SORIA FERRANDO, J. V., La impugnación..., op. cit., pàg. 132 i 133: "com assenyala Díez Picazo, no pot admetre's la distinció entre inexistència $i$ ineficàcia en mancar d'utilitat i de necessitat el concepte $d^{\prime}$ inexistència. D'utilitat, perquè la inexistència no produeix unes conseqüències jurídiques més grans que la nul-litat radical i absoluta (...) i de necessitat, perquè no cal que la ineficàcia estiga taxativament imposada per la Llei, sinó que $n^{\prime}$ hi ha prou que l'exigisca el significat i la finalitat de la Llei mateixa" [Vegeu «Eficàcia i ineficàcia del negoci jurídic», ADC, 1961, pàg. 824 i ss.]; aquest mateix autor, en "Consideraciones sobre la eficacia...", op. cit., pàg. 538; i VICENT CHULIÁ, F., Compendio crítico..., op. cit., pàg. 609.

Amb diferent criteri, ARANGUREN URRIZA, F. J., "Los órganos de la sociedad limitada...", op. cit., pàg. 1179: "VICENT CHULIÁ, entén que no és possible configurar com a categoria independent de l'«acord contrari a llei» la de l'«acord inexistent», ja que sempre recondueix a l'omissió de requisits legals de convocatòria, constitució o adopció d'acords. (...) th́nmateix, entenem que quan la nul-litat derive de la suposició de la Junta (per exemple, certificació d'una falsa reunió inexistent) (...), els supòsits queden fora de l'article $115 \mathrm{i}$, —com diu VICENT CHULIA - han de quedar fora del règim de prescripció $i$ caducitat de la Llei de societats anònimes. (...) no hi ha termini d'impugnació".

${ }^{533}$ ZANARONE, Giuseppe, "L'invalidità delle deliberazioni assembleari», en Tratato delle societd per azioni, vol. $3^{* *}$, (dirs. G. E., Colombo i G. B. Portale), UTET, Tori, 1993, pàg. 188 i 189, nota 4: "Presentar un quadre exhaustiu de les intervencions en la matèria és pràcticament impossible, ja que no hi ha gairebé autors que, en el terreny monogràfic o manualístic, no hagen intervingut sobre la matèria, gairebé com no hi ha sentència, dictada en matèria d'impugnació d'un acord assembleari, que no haja deliberat, encara que siga en un obiter dictum, sobre la qüestió relativa a l'existència o la inexistència d'aquesta"; aquest autor fa, això no obstant, un resum de les principals intervencions doctrinals i jurisprudencials. En l'àmbit específic de les cooperatives, BUONOCORE, V., Diritto della cooperazione, pàg. 271, fa constar que la categoria de la inexistència tampoc està disciplinada en la legislació italiana, però se suma a la tesi de GRAZIANI (Diritto delle società, pàg. 356 ) en el sentit de considerar que no pot aplicar-se la normativa prevista per als acords nuls i anul-lables (articles 2377 i 2379 Codice Civile), sinó la disciplina dels contractes 
aplicabilitat als supòsits d'inexistència, que haurien de sotmetre's al règim general dels negocis jurídics, amb la consegüent ineficàcia indefinida.

La dificultat d'establir quan ens trobem veritablement davant de supòsits $\mathrm{d}^{\prime}$ acords inexistents ${ }^{534}$, així com la tendència al manteniment de la voluntat social majoritàriament expressada en nom de la seguretat jurídica del tràfic ${ }^{535}$, semblen ser les raons implícites de l'abandonament del debat per part de la doctrina $\mathrm{i}$ la jurisprudència espanyoles. És per això que, en els supòsits de clara inexistència, però amb una aparença que ha produït efectes, l'opció majoritària es decanta per considerar-los inclosos en el concepte d'acords nuls ${ }^{536}$.

\subsection{Acords nuls}

nuls, "quan siga compatible amb la naturalesa d'actes unilaterals pròpia dels acords socials"; en la mateixa línia, SCARDINO, F., La società cooperativa, op. cit., pàg. 292.

${ }^{34}$ GIRÓN TENA, J., Derecho de sociedades anónimas, op. cit., pàg. 319: "sembla que no pot donar-se cap acord que puga ser inexistent $i$, alhora, no haja trencat algun precepte legislatiu, que n'assegure la subsumpció sota el concepte de nul-litat en la interpretació literal de la Llei"; BUONOCORE, V., Diritto della cooperazione, p. 271: "És difícil delimitar la línia de demarcació entre invalidesa $\mathrm{i}$ inexistència, excepte en els casos en què la inexistència jurídica corresponga a la inexistència de fet" entre els quals l'autor cita com a exemples els acords documentats de reunions assembleàries no realitzades mai o els adoptats sense cap tipus de convocatòria.

"2s ZANARONE, G., "L'invalidità...”, op. cit., pàg. 190: "la categoria esmentada es converteix en un multiplicador de les causes d'invalidesa absoluta, imprescriptible i irreparable, amb greu atemptat a les exigències de certesa que han portat el legislador a sacrificar, en la nostra matèria, la nul-litat en favor de l'anul-labilitat".

stu Aixi, Delgado ECheVerrfta, J., Comentarios al Código civil y compilaciones forales, tom XVII, vol. 2, Madrid, 1992, pàg. 306 a 310, que considera el concepte d'inexistència com un simple instrument dialèctic però no com una categoria dogmàtica: “La introducció de la categoria de la inexistència de l'acte o contracte es va deure a una necessitat pràctica conjuntural a França. En l'antiga doctrina francesa s'havia consolidat la regla pas de nullité sans texte. Quan es va promulgar el Codi, es va advertir que el legislador havia deixat d'assenyalar la nul-litat d'actes la falta de protecció pel Dret dels quals era evident (...) i si no s'accepta el principi d'expressió legal necessària de totes les causes de nul-litat, el"concepte d'inexistència ens és innecessari". En contra, ALCALÁ DÍAZ, M. A., Impugnación..., op. cit., pàg. 80: "La absència d'un règim jurídic s'aplicarà el règim propi de la nul-litat o de l'anul-labilitat". 
La legislació cooperativa postconstitucional ha circumscrit la nul-litat dels acords cooperatius als supòsits que siguen "contraris a la Llei" ${ }^{\prime 237}$, i ha esmenat, amb això, la criticada normativa preconstitucional que considerava també nuls els acords contraris als estatuts socials ${ }^{538}$.

Però la simplicitat aparent del criteri ha estat qüestionada, com veurem, per diversos motius. Així, ja ha quedat apuntada (vegeu supra, epígraf 1.1. d'aquest mateix capítol) la polèmica sobre quins textos legals poden entendre's inclosos en la referència a "la llei". D'altra banda, diversos autors plantegen supòsits d'acords socials d'índole variada que contravenen de tal manera l'ordenament jurídic que reclamen la seua declaració de nul.litat i que, tanmateix, no estarien previstos explícitament per cap norma de rang legal imperativa o prohibitiva. Tampoc falten opinions autoritzades que propugnen la mera anul-labilitat d'acords que vulneren normes legals imperatives quan aquestes imposen "meres formalitats accessòries". I, finalment, la legislació mateixa reguladora del tipus social es refereix específicament a determinats acords qualificant-los directament o indirectament com a nuls, amb la qual cosa sembla donar-se a entendre que la clàusula general no és suficient.

${ }^{537}$ Amb l'única excepció de la Llei 2/1985 de 2 de maig, de societats cooperatives andaluses, que adoptava (article 35.1) la tesi majoritàriament criticada de la nul-litat dels acords contraris als estatuts socials (PANIAGUA ZURERA, M., "La reforma de la legislación...», op. cit. , pàg. 57, ho qualifica com "la atècnica solució de la LCA"). Posteriorment, la nova Llei de cooperatives andaluses, (Llei 2/1999, de 31 de maig, BOE 5-5-1999, núm. 107), ha modificat aquest aspecte en l'article 56.2, i declara la nul.litat únicament dels acords contraris a la llei.

${ }^{53 *}$ GIMENO SENDRA, J. V., «El proceso...», op. cit., pàg. 36, 40 i 41; MARÍN LOPEZ, J. J., «Novedades...», op. cit., pàg. 1125; MUÑOZ VIDAL, Antonio B., El proceso de impugnación de acuerdos sociales en las cooperativas : comentarios al art. 54 del Reglamento de aplicación de la Ley general de cooperativas, separata de REVESCO, núm. 46, 1978, pàg. 53 i ss; VICENT CHULIA, F., «El derecho de los órganos...», op. cit., pàg. 501 i 525, i «La asamblea...», op. cit., pàg. 201 a 204. PAZ CANAlejo, en PAZ CANALEJo, N. i VICENT CHULIÁ, F., Ley general..., op. cit., pàg. 587, recorda que "aquesta última tesi legislativa (instaurada pel legislador cooperatiu anterior) havia estat criticada, tant des d'una perspectiva pràctica (ja que el règim de la nul-litat constitueix una font d'inseguretat per al tràfic jurídic) com des d'un punt de vista dogmàtic (els Estatuts són, en principi, mers pactes negocials, de naturalesa privada). Com s'ha dit, amb raó, tan sols des d'una concepció normativista del negoci jurídic "abandonada des de fa temps per la doctrina» podia sostenir-se la solució legislativa del 1974; però des de fa anys el Tribunal Suprem ha aclarit que les simples vulneracions de les normes estatutàries no poden servir de fonament un recurs de cassació per infracció de la Llei". 
Pel que fa a la possibilitat d'ampliació dels supòsits en els quals s'ha de considerar un acord nul, són diverses les propostes doctrinals. Així, s'esmenten els acords contraris als principis cooperatius ${ }^{539}$, els acords contraris a la Constitució, vulnerant garanties constitucionals o drets fonamentals ${ }^{540}$, els acords contraris a la moral, a l'ordre públic o als bons costums ${ }^{541}$, els acords contraris a la causa de la cooperativa ${ }^{542} \mathrm{i}$ els acords afectats pel vot "viciat" $\mathrm{d}^{\prime}$ un o diversos accionistes ${ }^{543}$. Contràriament, no falta qui argumenta la impossibilitat

" MARIN LOPEZ, J. J., «Novedades...», op. cit., pàg. 1126 i 1127, cita jurisprudència del TS $(21 / 10 / 82 ; 26 / 1 / 83)$ que declara la nul-litat d'acords contraris al principi cooperatiu d'igualtat dels socis, i exemples presos de PAZ CANALEjO, N. respecte d'altres principis cooperatius, equiparant-los als principis configuradors de l'article 10 LSA; UCELAY URECH, I., «El abuso del derecho...", op. cit., pàg. 1349 a 1359.

s. MARÍN LOPEZ, J. J., «Novedades...», op. cit., pàg. 1126 i 1127; UCELAY URECH, I., «El abuso del derecho...», op. cit., pàg. 1349 a 1359.

sn Vegeu infra, l'epígraf 2.1.2. d'aquest capítol, en analitzar els supòsit d'acords contraris a l'ordre públic.

se VICENT CHULIÁ, F., «El derecho de los órganos...», op. cit., pàg. 529. En l'àmbit de les societats de capital, CABALLOL I ANGELATS, L., "Comentario al artículo 115...», op. cit., pàg. 1119: "un acord viciat en la causa és aquell que revesteix una aparença de legalitat en la forma i en el contingut però que entra en contradicció amb els límits teleològics de la voluntat societària"; aquest autor considera que "serien vicis que afecten a la causa els anomenats "acords lesius"".

${ }^{30}$ GIRÓN TENA, J., Derecho de sociedades anónimas, op. cit., pàg. 322: "El defecte de voluntat ha de donar lloc a la nul-litat (...) en tot cas, naturalment, després de dur a terme l'anomenada prova de resistència: deducció dels vots per esbrinar si, després de restar-los, queda o no majoria, ja que en el primer cas no es produeix repercussió sobre l'acord"; URtA, R., MENÉNDEZ, A., i MUÑOZ, J. M., La junta general..., op. cit., pàg. 331; EMBID IRUJO, J. M., «Notas sobre la impugnación...», op. cit., pàg. 53.

ALBORCH BATALLER, C., El derecho de voto..., op. cit., pàg. 157 a 160, en una extensa anàlisi de les diverses teories sobre les conseqüències de l'emissió del vot viciat, considera que "la concurrència d'un vici en l'emissió del vot té com a conseqüència la nul-litat o l'anul-labilitat del vot i la possibilitat d'impugnar l'acord adoptat si el vot viciat haguera estat decisiu per a la formació de la majoria".

VICENT CHULIA, F., en «El derecho de los órganos... «», op. cit., pàg. 527 i 528, considera que aquests acords se sotmetrien a l'acció d'anul-labilitat, encara que ho argumenta en el context de la LGC de 1974: "podem destacar, com altres fonaments possibles nous per a l'acció d'anul-labilitat, els vicis del consentiment o la voluntat (violència, error, frau causant) o d'incapacitat (minoria d'edat o malaltia) que afecten un o diversos socis o associats el vot dels quals haja estat decisiu per a la formació de la majoria necessària per a l'adopció de l'acord". També opinen que es tracta d'acords anul-lables RUBIO, J., Curso..., op. cit., pàg. 245 i 246; i GIMENO SENDRA, J. V., "El proceso...», op. cit., pàg. 38: "no tota la infracció d'una norma ha de comportar la nul-litat radical i automàtica de l'acord, sinó que, de vegades, la infracció de determinades normes imperatives origina, això no obstant, l'aparició d'un acte o negoci anul-lable. Això és el que succeiria davant de la infracció de meres formalitats accessòries o en el de volsit que un acord social fóra adoptat mitjançant l'emissió de declaracions de vot amb vicis (article 1265 ) aquests casos, i encara que el CC repute ara inexistent (article 1261, 1r), ara nul (article 1265) al negoci prestat amb vicis del consentiment, allò cert és que n'admet la 
La legislació cooperativa postconstitucional ha circumscrit la nul-litat dels acords cooperatius als supòsits que siguen "contraris a la Llei" ${ }^{\prime 237}$, i ha esmenat, amb això, la criticada normativa preconstitucional que considerava també nuls els acords contraris als estatuts socials ${ }^{538}$.

Però la simplicitat aparent del criteri ha estat qüestionada, com veurem, per diversos motius. Així, ja ha quedat apuntada (vegeu supra, epígraf 1.1. d'aquest mateix capítol) la polèmica sobre quins textos legals poden entendre's inclosos en la referència a "la llei". D'altra banda, diversos autors plantegen supòsits d'acords socials d'índole variada que contravenen de tal manera l'ordenament jurídic que reclamen la seua declaració de nul-litat i que, tanmateix, no estarien previstos explícitament per cap norma de rang legal imperativa o prohibitiva. Tampoc falten opinions autoritzades que propugnen la mera anul-labilitat $\mathrm{d}^{\prime}$ acords que vulneren normes legals imperatives quan aquestes imposen "meres formalitats accessòries". I, finalment, la legislació mateixa reguladora del tipus social es refereix específicament a determinats acords qualificant-los directament o indirectament com a nuls, amb la qual cosa sembla donar-se a entendre que la clàusula general no és suficient.

${ }^{537}$ Amb l'única excepció de la Llei 2/1985 de 2 de maig, de societats cooperatives andaluses, que adoptava (article 35.1) la tesi majoritàriament criticada de la nul-litat dels acords contraris als estatuts socials (PANIAGUA ZURERA, M., «La reforma de la legislación...», op. cit. , pàg. 57, ho qualifica com "la atècnica solució de la LCA"). Posteriorment, la nova Llei de cooperatives andaluses, (Llei 2/1999, de 31 de maig, BOE 5-5-1999, núm. 107), ha modificat aquest aspecte en l'article 56.2, i declara la nul-litat únicament dels acords contraris a la llei.

${ }^{538}$ GIMENO SENDRA, J. V., «El proceso...», op. cit., pàg. 36, 40 i 41; MARÍN LOPEZ, J. J., «Novedades...», op. cit., pàg. 1125; MUNNOZ VIDAL, Antonio B., El proceso de impugnación de acuerdos sociales en las cooperativas : comentarios al art. 54 del Reglamento de aplicación de la Ley general de cooperativas, separata de REVESCO, núm. 46, 1978, pàg. 53 i ss; VICENT CHULIA, F., «El derecho de los órganos...», op. cit., pàg. 501 i 525, i «La asamblea...», op. cit., pàg. 201 a 204. PAZ CANALejo, en PAZ CANALejo, N. i ViCENT CHULIÁ, F., Ley general..., op. cit., pàg. 587, recorda que "aquesta última tesi legislativa (instaurada pel legislador cooperatiu anterior) havia estat criticada, tant des d'una perspectiva pràctica (ja que el règim de la nul-litat constitueix una font d'inseguretat per al tràfic jurídic) com des d'un punt de vista dogmàtic (els Estatuts són, en principi, mers pactes negocials, de naturalesa privada). Com s'ha dit, amb raó, tan sols des d'una concepció normativista del negoci jurídic "abandonada des de fa temps per la doctrina" podia sostenir-se la solució legislativa del 1974; però des de fa anys el Tribunal Suprem ha aclarit que les simples vulneracions de les normes estatutàries no poden servir de fonament a un recurs de cassació per infracció de la Llei". 
Pel que fa a la possibilitat d'ampliació dels supòsits en els quals s'ha de considerar un acord nul, són diverses les propostes doctrinals. Així, s'esmenten els acords contraris als principis cooperatius ${ }^{539}$, els acords contraris a la Constitució, vulnerant garanties constitucionals o drets fonamentals ${ }^{540}$, els acords contraris a la moral, a l'ordre públic o als bons costums ${ }^{541}$, els acords contraris a la causa de la cooperativa ${ }^{542} \mathrm{i}$ els acords afectats pel vot "viciat" $\mathrm{d}^{\prime} \mathrm{un}$ o diversos accionistes ${ }^{543}$. Contràriament, no falta qui argumenta la impossibilitat

MARIN LOPEZ, J. J., "Novedades...», op. cit., pàg. 1126 i 1127, cita jurisprudència del TS $(21 / 10 / 82 ; 26 / 1 / 83)$ que declara la nul-litat d'acords contraris al principi cooperatiu d'igualtat dels socis, i exemples presos de PAZ CANALEjO, N. respecte d'altres principis cooperatius, equiparant-los als principis configuradors de l'article 10 LSA; UCELAY URECH, I., «El abuso del derecho...», op. cit., pàg. 1349 a 1359.

s\$ MARÍN LOPEZ, J. J., «Novedades...», op. cit., pàg. 1126 i 1127; UCELAY URECH, I., «El abuso del derecho...", op. cit., pàg. 1349 a 1359.

sı Vegeu infra, l'epígraf 2.1.2. d'aquest capítol, en analitzar els supòsit d'acords contraris a l'ordre públic.

"VICENT CHULIA, F., "El derecho de los órganos...», op. cit., pàg. 529. En l'àmbit de les societats de capital, CABALLOL I ANGELATS, L., "Comentario al artículo 115...", op. cit., pàg. 1119: "un acord viciat en la causa és aquell que revesteix una aparença de legalitat en la forma i en el contingut però que entra en contradicció amb els límits teleològics de la voluntat societària"; aquest autor considera que "serien vicis que afecten a la causa els anomenats "acords lesius»".

\$o GIRÓN TENA, J., Derecho de sociedades anónimas, op. cit., pàg. 322: "El defecte de voluntat ha de donar lloc a la nul-litat (...) en tot cas, naturalment, després de dur a terme l'anomenada prova de resistència: deducció dels vots per esbrinar si, després de restar-los, queda o no majoria, ja que en el primer cas no es produeix repercussió sobre l'acord"; URÍA, R., MENÉNDEZ, A., i MUN̄OZ, J. M., La junta general..., op. cit., pàg. 331; EMBID IRUJO, J. M., «Notas sobre la impugnación...», op. cit., pàg. 53.

ALBORCH BATALLER, C., El derecho de voto..., op. cit., pàg. 157 a 160, en una extensa anàlisi de les diverses teories sobre les conseqüències de l'emissió del vot viciat, considera que "la concurrència d'un vici en l'emissió del vot té com a conseqüència la nul-litat o l'anul-labilitat del vot i la possibilitat d'impugnar l'acord adoptat si el vot viciat haguera estat decisiu per a la formació de la majoria".

VICENT CHULIÁ, F., en «El derecho de los órganos... «», op. cit., pàg. 527 i 528, considera que aquests acords se sotmetrien a l'acció d'anul-labilitat, encara que ho argumenta en el context de la LGC de 1974: "podem destacar, com altres fonaments possibles nous per a l'acció d'anul-labilitat, els vicis del consentiment o la voluntat (violència, error, frau causant) o d'incapacitat (minoria d'edat o malaltia) que afecten un o diversos socis o associats el vot dels quals haja estat decisiu per a la formació de la majoria necessària per a l'adopció de l'acord". També opinen que es tracta d'acords anul-lables RUBIO, J., Curso..., op. cit., pàg. 245 i 246 ; i GIMENO SENDRA, J. V., «El proceso...», op. cit., pàg. 38: "no tota la infracció d'una norma ha de comportar la nul-litat radical i automàtica de l'acord, sinó que, de vegades, la infracció de determinades normes imperatives origina, això no obstant, l'aparició d'un acte o negoci anul.lable. Això és el que succeiria davant de la infracció de meres formalitats accessòries o en el supòsit que un acord social fóra adoptat mitjançant l'emissió de declaracions de vot amb vicis (articluntat. En aquests casos, i encara que el CC repute ara inexistent (article 1261, 1r), ara nul (article 1265) al negoci prestat amb vicis del consentiment, allò cert és que n'admet la 
d'ampliar els supòsits d'acords nuls legalment previstos, sobre la base de dos motius: d'una banda, perquè l'excepcionalitat de la nul-litat n'impedeix la interpretació extensiva ${ }^{544}$; d'una altra, perquè a falta de previsió normativ expressa no poden impugnar-se acords socials mitjançant l'aplicació de la disciplina general del negoci jurídic ${ }^{545}$.

En tot cas, això no obsta perquè puga proposar-se la qualificació de la major part dels supòsits plantejats per la doctrina com "acords contraris a la llei", entesa aquesta en la seua accepció àmplia, ço és, qualsevol norma legal imperativa. Així, els principis cooperatius són avui, a l’Estat espanyol, normes de rang legal, en virtut de la seua incorporació explícita a la legislació substantiva cooperativa ${ }^{546}$; la vulneració de garanties constitucionals o de drets

possibilitat de confirmació (articles 1309-1313) i que, tant la doctrina [DE CASTRO, DíEz PICAZO] com la jurisprudència [STS 20.12.1977] estimen que els negocis no són nuls, sinó merament
anul-lables".

GARRIGUES, J., Curso..., op. cit., pàg. 344 i 345, en el context de la nul.litat de la societat.

SCARDINO, F., La società cooperativa, op. cit., pàg. 286: "la figura de l'error (...) - -segons la doctrina general- és causa d'anul-labilitat dels acords només quan és substancial, és a dir, que sense
això, l'acord no s'hauria pres".

${ }^{544}$ DUQUE DOMfNGUEZ, J. F., Tutela..., op. cit. pàg. 58, nota 55.

${ }^{545}$ SAlELlEs CLIMENT, J. R., El funcionamiento..., op. cit., pàg. 383 a 385, que cita la STS de 27 de desembre de 1973 (RJA 4982) i a DE CASTRO, F., El negocio jurídico, op. cit. pàg. 500, en suport de la tesi que considera exhaustiva la relació legal de vicis. Fonamenta també aquesta interpretació partint de "la inconveniència i la dificultat de dur a terme un control judicial d'oportunitat de les actuacions socials", encara que acaba acceptant que aquesta posició ha de matisar-se, almenys "pel que fa als acords de la Junta en casos de desviació de poder o d'abús de dret, o quan, havent-se adoptat de bona fe, tinguen un caràcter irracional. La impugnació d'aquests acords és una tècnica correctora del funcionament de la societat per permetre la tutela de la minoria i de l'interès social al marge de les infraccions legals o estatutàries".

D'altra banda, la referència a l'obra de DE CASTRO, F., El negocio jurídico, ha de matisar-se, ja que l'autor citat, indica, efectivament, que l'enumeració feta en l'article 1301 de les classes de defectes o vicis als quals s'aplica el sistema d'anul-labilitat pot considerar-se exhaustiva" ja que "d'això convenç, deixant a part la valoració dels antecedents del precepte, el caràcter restringit que li imposa l'abast general propi de la sanció de nul-litat absoluta", però en nota 8 al peu salva "els casos en els quals lleis especials utilitzen el sistema per a altres supòsits".

DíAZ DE LEZCANO SEvillanO, N., Los acuerdos del consejo..., op. cit., pàg. 241, cita doctrina italiana i francesa; també considera que "les regles que regulen la nul.litat dels acords socials són derogatòries de les disposicions del dret comú, per una equiparació que es produeix per la via de la generalització en l'àmbit mercantil de l'anul-labilitat, en lloc de la nul.litat radical". En el dret italià mantenen la no-aplicabilitat del règim dels vicis del negoci jurídic al dels acords socials, ASCARELLI, T., "L'interesse sociale dell'art. 2441 c.c...», op. cit., pàg. 104; i SCARDINO, F., La società cooperativa, op. cit., pàg. 286.

${ }^{5+6}$ Totes les lleis de cooperatives de l'Estat espanyol inclouen, com a part del text legal, els principis cooperatius, bé siga assumint la redacció que en fa l'Aliança Cooperativa 
fonamentals és, evidentment, contrària a la Constitució espanyola; els acords contraris a la causa de la cooperativa ${ }^{547}$ són, amb tota probabilitat, contraris a l'ordre públic cooperatiu (vegeu infra, en l'epígraf 2.1.2. l'aproximació al concepte d'acords contraris a l'ordre públic i la seua relació amb els anomenats "principis configuradors" de la persona jurídica ${ }^{548}$; els acords contraris a l'ordre públic s'inclouen de manera explícita per la llei entre els acords nuls; i la declaració de voluntat en què consisteix el vot del soci, quan està viciada, suposa la vulneració dels preceptes corresponents del Codi civil (articles del 1261 a 1270) ${ }^{549}$. Finalment, els acords contraris "a la moral o als bons costums",

Internacional, bé desplegant-los amb una redacció pròpia. Així: LCoop, article 1.1; LCC, article 1.3, b), LCPV, article 1.1 i 2; LFCN, article 2; LCE, article 2, 3 r. Párr.; LCCV, article 3 i disp. ad. 2"; LCG, article 1.4 ; LCA, article 1.2; LCCM, article 1.1; LSCA, article 2.2. Vegeu, supra, epígraf 3.2.4. del capítol primer.

"LlOBREGAT HURTADO, M. L., "La reforma...», op. cit., pàg. 154: "la mutualitat continua sent la causa de les societats cooperatives. Aquesta afirmació es fonamenta en dos tipus de mesures legislatives que es mantenen (...) en les últimes reformes. En primer lloc, la necessitat d'establir en el contingut mínim dels Estatuts la quantificació de la participació mínima obligatòria del soci en l'activitat empresarial (...). La segona mesura legislativa (...) es refereix a l'establiment d'uns límits, legalment establerts en relació amb la ruptura de la mutualitat".

" VICENT CHULIA, F., "La asamblea...", op. cit., pàg. 211: "Encara podrien invocar-se, com a nocions que permeten protegir el membre de la Cooperativa contra els acords de l'Assemblea general, la "violació de les bases essencials de la societat» o, millor encara, la «violació de la causa o finalitat de la cooperativa". Si bé és cert que aquestes nocions apareixen absorbides totalment o parcialment per la de violació de Llei. Així, la doctrina opina respecte a les «bases essencials de la Societat Anònima», que GARRIGUES [ «La protección de las minorías...», pàg. 260] entén absorbides pel reconeixement legal dels drets del soci (...) en relació amb la causa, no hi ha dubte que els acords socials en la Societat anònima han d'ajustar-se a la causa del contracte de societat (la finalitat lucrativa). La seua violació constitueix un supòsit de nul-litat de l'acord social, que igual com ocorre amb altres supòsits de nul-litat per vicis en els elements essencials del negoci han de ser reconduïts a la infracció de Llei. En el cas de la Cooperativa, la causa s'identifica amb la finalitat mutualística $i$ el servei als socis i a tota la comunitat (...), i, en general, amb el conjunt dels Principis Cooperatius que determinen l'essència del cooperativisme i que avui recull també la Llei. La violació de la causa o finalitat de la Cooperativa en un concret acord social és, doncs, violació de la Llei, i supòsit de nul.litat plena de l'acord". En la mateixa línia, SERRANO I SOLDEVILLA, A. D., La cooperativa..., op. cit., pàg.

AlBORCH BATALLER, C., El derecho de voto..., op. cit., pàg. 150 i 151: "La declaració de voluntat, en què consisteix el vot, és el resultat final i extern del procés formatiu de la voluntat, configurada amb la concurrència de diferents elements. Com a tal, està subjecte als principis generals de la declaració de voluntat de les persones físiques per a la perfecció de negocis juridics, que no perd la seua autonomia en confluir amb altres a la formació d'un acte col-legiat, i està subjecte a la impugnació per vicis provinents de frau, error o violència. (...) el vot és nul o Recordle per incapacitat, error, frau, intimidació i violència".

(com (com es veurà infra per als supòsits de vot en conflicte d'interessos), en primer lloc de si el vot anul-lat era determinant de l'adopció d'aquell (prova de resistència) i, si ho era, del caràcter de 
malgrat la seua difícil concreció, poden estimar-se vulnerants de l'article 1271 CC $\mathrm{i}$ inclosos, com veurem, en el concepte d'acords contraris a l'ordre públic.

D'altra banda, molts dels autors que analitzen la impugnació dels acords socials, sense deixar de reconèixer la virtut de claredat en el criteri diferenciador establert, no deixen d'advertir sobre l'excessiva simplicitat de la norma, entenent que "la seua aplicació literal pot conduir a conclusions pràctiques difícilment justificables ${ }^{\prime 550} \mathrm{i}$ no falten els qui estimen que "no tota infracció d'una norma ha de comportar la nul-litat radical i automàtica de l'acord, sinó que, devegades, la infracció de determinades normes imperatives origina, això no obstant, l'aparició d'un acte o negoci anul-lable ${ }^{\prime 251}$. Tot això ha

la norma vulnerada.

${ }^{550}$ GIRÓN TENA, J., Derecho de sociedades..., op. cit., pàg. 317 a 329; RUBIO, J., Curso..., op. cit., pàg. 243; SORIA FERRANDO, "Consideraciones sobre...», op. cit., pàg. 537 a 554; POLO, E., Los administradores..., op. cit., pàg. 531; RODRf́GUEZ RUIZ DE VILLA, D., Impugnación...op. cit., pàg. 57: "La LSA, avui el seu Text Refós, ha d'integrar-se dins del nostre Dret general -Civil i Mercantil- en matèria d'eficàcia dels negocis jurídics (...). Aquesta conclusió es defensa també en la nostra Jurisprudència per desestimar la nul-litat per infraccions de caràcter lleu $i$ intrascendents a l'efecte de l'eficàcia dels acords adoptats", però afegeix que "l'apreciací́ judicial de la transcendència o no introdueix inseguretat jurídica", i cita a l'efecte dues sentències contradictòries del TS, que consideren o no alternativament, la no-presència del Secretari a la Junta com a causa de nul-litat; URtA, R., MENÉNDEZ, A., i MUÑOZ, J. M., La junta general..., op. cit., pàg. 316 a 318, citen també la Sentència del TS de 7.2.1984 en la qual es reitera el criteri jurisprudencial d'evitar un "rigor exagerat", "sense que s'haja de pensar que tota disconformitat amb la llei o tota omissió de formalitats legals, que puguen ser merament accidentals, amb relació a l'acte que es tracte, hagen de comportar la sanció extrema de la nul-litat, que només és procedent quan hi haja raons transcendents".

${ }^{551}$ GIMENO SENDRA, J. V., «El proceso...», op. cit., pàg. 38, que cita les STS de 20.11.1959, 19.10.1944, i 8.4.1958 en suport de la tesi que l'incompliment de meres formalitats no dóna lloc a la nul-litat de l'acord. També SÁNCHEZ CALERO, F., Administradores..., op. cit., pàg. 540; i, URtA, R., MENÉNDEZ, A., i MUÑOZ, J. M., La junta general..., op. cit., pàg. 317: "no pot deixar de valorarse - $\mathrm{i}$ el Tribunal Suprem mateix ho ha recordat per evitar un "rigor exagerat" en la interpretació de la llei de 1951 (vegeu STS 7/2/1984)- el conegut criteri jurisprudencial que el principi sancionat per l'article $6.3 \mathrm{del}$ Codi civil ha de ser interpretat amb criteri flexible ino rígid, sense que s'haja de pensar que tota disconformitat amb la llei o tota omissió de formalitats legals, que puguen ser merament accidentals, amb relació a l'acte de què es tracte, hagen de comportar la sanció extrema de la nul.litat".

Això no obstant, POLO SÁNCHEZ, E., Los administradores..., op. cit., pàg. 532, en relació amb la impugnació dels acords de l'òrgan d'administració adverteix que "la informalitat mateixa del funcionament del consell d'administració - amb poques normes legals $i$ algunes de les quals són de caràcter dispositiu - restringirà certament l'existència d'aquells supòsits de nul-litat per incompliment de meres formalitats legals de caràcter nimi denunciats per la nostra doctrina (vegeu GIRÓN, 318) i causants de les freqüents vacil-lacions jurisprudencials a l'hora de qualificar la nul-litat o anul-labilitat dels acords de les juntes generals". ALCALÁ DÍAZ, M. A., La impugnación..., op. cit., pàg. 288, en la mateixa línia, i partint que "l'absència d'una normativa legal imperativa relativa al procediment d'adopció d'acords del consell d'administració implica 
portat una part de la doctrina a mantenir l'oportunitat, de lege ferenda, d'introduir en els textos normatius la distinció entre els diferents supòsits d'acords contraris a la llei que sí que serien nuls, d'aquells altres en què la contravenció d'aspectes formals accessoris produiria únicament l'anul-labilitat ${ }^{52}$, o la distinció entre grans corporacions, $a m b$ un règim de funcionament més rígid dels seus òrgans socials, i un altre de més flexible per a les societats menudes ${ }^{553}$.

Però el tenor literal de la norma no estableix cap excepció a la nul.litat dels acords contraris a la llei, a diferència d'altres ordenaments jurídics en els quals s'opta per efectuar una llista de supòsits de causes d'impugnación ${ }^{54}$ i es discriminen "determinats actes contraris a la llei com nuls i d'altres com anul-lables, reservant la primera categoria per als supòsits d'infraccions més greus, bé siga perquè s'infringeix clarament l'interès públic o bé perquè es posa en perill la seguretat del tràfic jurídic. ${ }^{555}$ Per això, no sembla possible que en l'actualitat, a l'Estat espanyol, puga efectuar-se aquesta diferenciació: tots els acords contraris a la llei són nuls, amb independència de la transcendència de la vulneració legal en què incorren.

que si es preveu estatutàriament un règim sobre aquesta matèria, la seua infracció o noobservança se sancionarà amb l'anul-labilitat i no afectarà la validesa dels acords adoptats si el procediment d'adopció d'acords s'haguera regulat en un reglament de règim interior".

RODRígUEZ ARTIGAS, F., i ESTEBAN VELASCO, G., "Los órganos...», op. cit., pàg. 114; ESTEBAN VELASCO, G., «La estructura...», op. cit., pàg. 343; RODRf́GUEZ RUIZ DE VILLA, D., Impugnación..., op. cit., pàg. 58.

ALCALA DÍAZ, M. A., La impugnación..., op. cit., pàg. 291, en la línia de la reforma de la Aktiengesetz alemanya de 1966 mitjançant la promulgació de la Gesetz für kleine Aktiengesellschaften und zur Deregulierung des Aktienrechts de 2.8.1994.

Així, la Llei de societats per accions alemanya (article 241) ja citada, el Codi civil italià (article 2379), o el Codi de societats portuguès (article 56), i en la Proposta de Cinquena directiva referent a l'estructura de les societats anònimes (ALCALÁ DÍAZ, M. A., La impugnación..., op. cit., pàg. 288; ESTEBAN VELASCO, G., "La estructura...», op. cit., pàg. 341 a 343; GIRÓN TENA, J., Derecho de sociedades..., op. cit., pàg. 315 i 316; SORIA FERRANDO, J. V., La impugnación..., op. cit., pàg. 138 i 139; VICENT CHULIÁ, F., Compendio crítico..., op. cit., pàg. 607).

${ }^{35}$ GIMENO SENDRA, J. V., El proceso..., op. cit., pàg. 39, que estima que l'opció de l'ordenació espanyola per una redacció genèrica, evitant una enumeració dels supòsits en què l'acord social haja d'estat estimat com a nul, fa que la frase «acord social contrari a la Llei» constituisca una 
Finalment, pel que fa a l'anàlisi sobre què ha d'entendre's per "acords nuls", $\mathrm{s}^{\prime}$ ha de fer referència a aquells tipus concrets d'acords respecte dels quals e] legislador ha considerat convenient explicitar-ne la nul-litat ${ }^{556}$. En alguns casos, res no sembla indicar que es tracte d'una cosa més que una referència a la conseqüència normal d'adoptar un acord que vulnera una norma legal: és el cas de l'article 28.4 LCoop quan assenyala que "seran nuls els acords sobre assumptes que no consten en l'ordre del dia..." ${ }^{\prime 57}$ o dels articles 41.4 LCoop i 39.3 LCCV, que adverteixen de la nul-litat de la segona designació en casos $\mathrm{d}^{\prime}$ incompatibilitat entre càrrecs, si el nomenat no opta per un d'aquests ${ }^{558}$. Altres casos, tanmateix, com els supòsits d'acords adoptats amb la participació del soci que està en conflicte d'interessos, o els d'acords contraris a l'ordre públic, requereixen una anàlisi.

\subsubsection{Supòsits de conflicte d'interessos}

L'ordenament jurídic estableix, essencialment, dues vies per a la superació de les situacions en què, amb caràcter general, puga plantejar-se un conflicte d'interessos entre el soci i la persona jurídica de què forma part ${ }^{55}$. D'una banda,

clàusula general oberta que diàriament ha de ser integrada per la jurisprudència.

556 Contràriament, com veurem més endavant (epígraf 3.2 d'aquest mateix capítol), la norma eludeix explicitar què s'ha d'entendre per acords nuls de l'òrgan d'administració.

${ }^{557}$ La LCCV en canvi, (article 32.1) no explicita la nul.litat d'aquests acords, sense que per això hi haja cap dubte respecte de la seua nul-litat: "Per deliberar i prendre acords sobre un assumpte, serà indispensable que conste en l'ordre del dia de la convocatòria o en l'aprovat a l'inici de l'assemblea general universal, excepte en els casos següents:...".

${ }^{558}$ Vegeu, això no obstant, en els epígrafs 1.2.5. i 2.2.2. del capítol tercer, algunes especificitats d'aquest tipus d'acords nuls.

${ }^{559}$ ALCALÁ DÍAZ, M. A., «El conflicto...», op. cit., pàg. 94. EMBID IRUJO, José Miguel, «Comentario al art. 52", en AA. DD., Comentarios a la Ley de sociedades de responsabilidad limitada, (coord. I Arroyo i J. M. Embid), Tecnos, Madrid, 1997, pàg. 561, en analitzar la novetat que en el seu moment suposava la introducció de l'article 52 LSRL vigent: "Si bé es mira, això no obstant, la realitat del conflicte $d^{\prime}$ interessos (...) no constitueix pròpiament una novetat (...). Trobem empremtes de l'esmentat conflicte, abans que res, en seu d'impugnació d'acords socials, en admetre, com a causa d'impugnació la lesió dels interessos socials en benefici de socis o tercers (...) altres referències al conflicte d'interessos (...) al voltant de la posició de l'administrador social, en regular modalitats concretes del règim de separació (article 132 LSA) o quan es preveu 
om ja hem vist, quan la majoria de socis adopta un acord que lesiona l'interès ;ocial en benefici propi o de tercers, la llei sanciona tal infracció del deure de fidelitat $^{560}$ amb l'anul-labilitat de l'acord. Però també preveu la possibilitat de prevenir $i$, per tant, d'evitar l'incompliment prohibint al soci en situació de conflicte l'exercici del seu dret de $\operatorname{vot}^{561}$. Són aquests últims casos els que són denominats correntment situacions de "conflicte d'interessos per l'ordenament jurídic i per la doctrina". ${ }^{562}$

la prohibició de competència". Sobre la impugnació d'acords lesius com a remei a posteriori, HERNÁNDEZ SAINZ, Esther, "El deber de abstención en el voto como solución legal ante determinados supuestos de conflicto de intereses en la sociedad de responsabilidad limitada", RdS, núm. 6, 1996, pàg. 106. Per a un estudi detallat dels diferents conflictes d'interessos intrasocietaris, així com de l'anomenat "conflicte d'interessos en sentit tècnic", o "estricte", vegeu SÁNCHEZ RUIZ, M., Conflictos de intereses..., op. cit.

ALONSO ESPINOSA, Francisco José, "Capítulo VII. Órgano de administración», en AA. DD., La sociedad cooperativa en la Ley 27/1999, de 16 de julio, de cooperativas, (coord., F. J. Alonso Espinosa), Editorial Comares, Granada, 2001, pág. 240: "La lleialtat suposa la proscripció de conductes que suposen benefici propi a expenses del perjudici de la cooperativa ja siga en forma de lucre cessant o de dany emergent".

3a ALCALA DIAZ, M. A., «El conflicto...», op. cit., pàg. 93; DUQUE DOMÍNGUEZ, J. F., Tutela..., op. cit. pàg. 9 i 10 , es refereix a dos tipus de mitjans, interns i externs, de tutela de la minoria: els primers es produeixen en via preventiva i prescindeixen de la intervenció judicial; els segons exigeixen l'esmentada intervenció jurisdiccional. Aquests mitjans interns integren el que denomina "sistema de cauteles preventives mitjançant les quals s'impedisca al soci usar els seus poders en la junta en què s'adopten acords en què està interessat personalment" (pàg. 37); les línies generals del sistema són les següents: 1 . Obligació d'abstenció per part del soci en conflicte; 2 . Nul-litat del vot que es done incomplint el deure anterior; 3. Anul-labilitat dels acords socials en què haja concorregut el vot en conflicte, si la seua emissió haguera estat decisiva per a l'adopció d'aquells (pàg. 114). En la mateixa línia, SÁNCHEZ RUIZ, M., Conflictos de intereses..., op. cit., pàg. 157, 158 i 162, nota 45: “... subjau una presumpció absoluta que el soci anteposarà els seus interessos extrasocials a l'interès social, la qual cosa es valora com un risc 0 perill de lesió per a aquest últim. (...) Sí que hi ha ja un conflicte d'interessos, i també un judici previ del legislador (...). El que encara no hi ha és un dany a l'interès social, la qual cosa justifica el caràcter preventiu de la tècnica que ens ocupa, que tendeix a prevenir no el conflicte, sinó el dany".

GIRÓN TENA, J., Derecho de sociedades anónimas, op. cit., pàg. 327 i 328, ja esmentava la necessitat d'atendre un punt de vista preventiu del conflicte d'interessos, "generalitzant un deure d'abstenció".

SÁNCHEZ RUIZ, M., Conflictos de intereses..., op. cit., quan els anomena "conflictes d'interessos en sentit estricte o tècnic», segueix VICENT CHULIA, F., Introducción al derecho mercantil, Tirant lo Blanch, 12e ed., València, 1999, que els qualifica com "la tècnica del "conflicte d'interessos per antonomàsia» (pàg. 211), o el "conflicte d'interessos en sentit tècnic»" (pàg. 483).

La relació del conflicte d'interessos i del deure d'abstenció consegüent amb el deure de fidelitat del soci com a "translació, a l'àmbit de funcionament de l'organització societària, del principi de bona fe en el compliment de les obligacions contractuals" (ALCALÁ DíAZ, M. A., "El conflicto...», op. cit., pàg. 91) s'ha recollit per un sector ampli de la doctrina espanyola, entre la qual s'ha de destacar BOQUERA MATARREDONA, Josefina, "La regulación del conflicto de intereses en la ley 1019; Duades de responsabilidad limitada", RDM, 1995, núm. 217, juliol-setembre, pàg. 1016 a 1019; DUQUE DOMf́NGUEZ, J. F., Tutela..., op. cit.; EMBID IRUJO, J. M., «Comentario al art. 52...», op. 
El conflicte d'interessos ha estat definit com una situació objectiva de col-lisió, de "divergència incompatible", entre l'interès social i l'interès individual d'un soci o d'un grup de socis, de manera que, com que les posicions són antitètiques en relació amb l'objecte de l'acord, resulta impossible la satisfacció simultània d'ambdós interessos, perquè la consecució d'un representa el sacrifici de l'altre i viceversa ${ }^{563}$.

cit., pàg. 561 a 571, i en «Notas sobre...», op. cit., pàg. 53 FERNÁNDEZ DE LA GÁNDARA, Luis, «La sociedad de responsabilidad limitada: acto final», RdS, núm. 5, 1995, pàg. 3 a 37; GIRÓN TENA, J., Derecho de sociedades anónimas, op. cit., pàg. 198 a 200, i pàg. 328; RECALDE CASTELLS, Andrés, «Deberes de fidelidad y exclusión del socio incumplidor en la sociedad civil. Comentario a la STS (Sala 1ade 6 de marzo de 1992", La Ley 1993 - 1, pàg. 304 i ss; SÁNCHEZ ANDRÉs, A., Las acciones, en Comentario al régimen legal de las sociedades mercantiles, (dirs. R. Uría, A. Menéndez i M. Olivencia), tom IV, vol. 1r, Civitas, Madrid, 1994, pàg. 99 i 100.

Per a l'estudi de la institució del conflicte d'interessos a partir de la promulgació de la LSRL de 1995, vegeu ALCALÁ DÍAZ, M. A., en «El conflicto...», i en La impugnación..., op. cit.; BOQUERA MATARREDONA, J., "La regulación del conflicto...», op. cit.; COSTAS COMESAÑA, J., El deber de abstención..., op. cit.; EMBID IRUJO, J. M., ., "Comentario al art. 52...», op. cit.; GALAN CORONA, Eduardo, "La Junta general», en AA.DD., La reforma de la sociedad de responsabilidad limitada, (coords. R. Bonardell Lenzano, J. Mejías Gómez, U. Nieto Carol), Civitas, Madrid, 1994, pàg. 515 a 520; HERNÁNDEZ SAINZ, E., «El deber de abstención...», op. cit.; MARTÍNEZ MACHUCA, Pablo, La protección de los socios externos en los grupos de sociedades, Publicaciones del Real Colegio de España, Bolonia, 1999, pàg. 227 a 262; RODRf́GUEZ ARTIGAS, F., «La junta general de socios...», op. cit., pàg. 624-627; SALELles ClimENT, J. R., El funcionamiento..., op. cit., pàg. 187 a 195; SÁNCHEZ RUIZ, M., Conflictos de intereses..., op. cit.; i SÁNCHEZ CALERO GUILARTE, J., «El conflicto de intereses en la sociedad limitada", en AA. DD., Derecho de sociedades de responsabilidad limitada. Estudio sistemático de la Ley 2/1995, tom I, McGraw Hill, Madrid, 1996, pàg. 677 a 701, i «Principio mayoritario y conflicto de intereses en la Ley de sociedades de responsabilidad limitada de 1995», en AA. DD., Jornadas de Derecho de sociedades (Málaga 14, 15 y 16 de Mayo de 1997), (coords. A. Aurioles Martín i J. C. Martín Romero), Ilustre Colegio Notarial de Granada, Granada, 1998, pàg. 7 a 30.

En l'àmbit cooperatiu tracten la qüestió PAZ CANALejo, N. en PAZ CANALEjo, N. i Vicent CHULIÁ, F., Ley general..., op. cit., pàg. 446 a 449, i PEMÁN MELERO, M., en AA. DD., Comunidades de bienes..., op. cit., pàg. 734 i 735 .

${ }^{5 / 3}$ DUQUE DOMÍNGUEZ, J. F., Tutela..., op. cit. pàg. 124 i 125, cita abundant doctrina italiana. GALGANO, F. (La società per azioni, op. cit., citada també per PAZ CANALEJO, N. en PAZ CANALEJO, N. i VICENT CHULIÁ, F., Ley general..., op. cit., pàg. 447 i 448) considera que aquesta situació no pressuposa un contrast entre l'interès del soci i l'interès (superior) de la societat, sinó una oposició entre dos interessos que afecten, ambdós, el mateix soci. Per això, considera que "hi ha conflicte d'interessos quan el soci és portador «davant d'una votació determinada " d'un doble interès: el seu com a soci i, a més, un interès aliè a la societat; la naturalesa d'aquesta duplicitar $\mathrm{d}^{\prime}$ interessos fa que no se'n puga dur a terme un si no és sacrificant l'altre". Tot això es por relacionar amb allò que ja s'ha vist al capítol primer sobre els diversos interessos que conflueixen en el concepte $\mathrm{d}^{\prime \prime}$ interès social". 
La LGC de 1987 (article 47.4) ja exigia ${ }^{564}$ que els estatuts de la cooperativa indicaren els supòsits en què els socis $i$ els associats en general havien de ser considerats en situació de conflicte d'interessos amb la cooperativa, amb la conseqüència $\mathrm{d}^{\prime}$ abstenir-se de participar en la votació corresponent ${ }^{565}$. A aquest efecte, s'esmentaven alguns supòsits en què els membres del consell rector, de la intervenció o de la direcció es consideraven explícitament afectats per conflicte $d^{\prime}$ interessos (article $63^{566}$ ). Per a la validesa d'aquestes últimes operacions de «conflicte d'interessos legal» es requeria no sols l'abstenció del soci que ocupara el càrrec afectat a la corresponent votació, sinó que foren ratificades prèviament per l'assemblea; en cas contrari, la LGC declarava la nul-litat "de ple dret dels actes, contractes i operacions" realitzats en virtut de l'acord adoptat amb la parțicipaçió del soci en conflicte o sense l'esmentada autorització assembleària.

su BOQUERA MATARREDONA, J., «La regulación del conflicto...», op. cit., pàg. 1013; EMBID IRUJO, J. M., "Comentario al artículo 52...», op. cit., pàg. 562; GALAN CORONA, E., "La Junta general...», op. cit., pàg. 512; HERNÁNDEZ SAINZ, E., El deber de abstención..., op. cit., pàg. 106 i 107; SALELLES CLIMENT, J. R., El funcionamiento..., op. cit., pàg. 187. ALCALÁ DIAZ, M. A., "El conflicto...», op. cit., pàg. 99 , nota 20 , assenyala que també en el dret cooperatiu alemany es preveu ( $\$ 43.6 \mathrm{GenG})$ "la prohibició de vot del soci d'una cooperativa quan l'acord es referisca a l'exigència o l'alliberament d'una obligació o a l'exercici per part de la cooperativa de qualsevol tipus de reclamació contra el soci".

* Com assenyala COSTAS COMESAÑA (El deber de abstención..., op. cit., pàg. 55 i 56) "és necessari (sic) una formulació [estatutària] que no prive el soci de votar davant de "qualsevol" conflicte d'interessos, sinó només en situacions d'oposició absoluta efectiva entre l'interès extracooperatiu i l'interès de la cooperativa". En aquest sentit es manifesten també PAZ CANAlejo, N. en PAZ CANALejo, N. i ViCEnT CHULIÁ, F., Ley general..., op. cit., pàg. 446; PEMÁN MELERO, M., en AA. DD., Comunidades de bienes..., op. cit., pàg. 734; i RODRíGUEZ, M. P., i SUSO, J. M., capítol V «Los órganos...», op. cit., pàg. 151: "els supòsits en què hi ha un deure d'abstenció (...) és inexcusable que (...) constituïsquen vertaders casos de conflicte d'interessos, la interpretació dels quals, quan deroguen el dret bàsic del soci al vot, ha de ser restrictiva".

"* En relació amb els supòsits regulats en l'article $63 \mathrm{~s}$ 'ha especificat que es tracta $\mathrm{d}^{\prime \prime}$ alguns supòsits especials de col-lisió" (PEMÁN MELERO, M., en AA. DD., Comunidades de bienes..., op. cit., pàg. 734), no pot "reconduir el número 4 de l'article 47 únicament als casos previstos en l'article 63 de la Llei mateixa (...). Afirmar l'equivalència absoluta entre ambdós preceptes legals faria ociós tot l'article 47.4, que, tanmateix, conté un mandat imperatiu dirigit als redactors de l'estatut de qualsevol Cooperativa i, a més, es refereix a la posició d'associat o soci de base (i no a la de membres del Consell Rector" (PAZ CANALEjo, N. en PAZ CANALEjo, N. i Vicent ChULí́, F., Ley general..., op. cit., pàg. 449; COSTAS COMESANNA, J., El deber de abstención..., op. cit., pàg. 56). PAZ CANALEjO, Narciso, "Visión general de la legislación cooperativa estatal: situación actual y perspectiva de reforma", Revesco, núm. 66, 1998, pàg. 34, també considera que "resulta incoherent haver oblidat els interventors $\mathrm{i}$ els membres del Comitè de Recursos en l'article 63, 
La LCCV, en canvi, no esmenta amb caràcter general i en relació amb els socis el conflicte d'interessos, però sí que recull, en l'article 44, allò referit als membres de l'òrgan d'administració o de la direcció, declarant el seu deure d'abstenció, i que "no serà vàlida" l'estipulació dels corresponents contractes ni l'assumpció de les obligacions per part de la cooperativa "si no recau autorització prèvia o ratificació posterior de l'assemblea general".

De la seua banda, la LCoop ha introduït algunes novetats rellevants en la regulació cooperativa estatal del conflicte d'interessos: d'una banda, respecte al mandat general d'indicació estatutària dels supòsits en què el soci haja d'abstenir-se de votar per trobar-se en conflicte d'interessos (article 26.8), la pròpia norma determina que s'inclouran, en tot cas, els "previstos en la Llei de societats de responsabilitat limitada" ${ }^{\prime 567}$ i per a les cooperatives de treball

núm. 2".

${ }^{567}$ ALFONSO SÁNCHEZ, R., "Aspectos básicos...», op. cit., pàg. 179: "Això no obstant, no tots els supòsits previstos en l'article 52 LSRL són traslladables a la cooperativa [nota 64: "Així per exemple, no resulta aplicable el deure d'abstenció del soci quan es tracte d'un acord que l'autoritze a transmetre participacions de les quals siga titular, ja que aquest sistema no regeix en la societat cooperativa; o de l'acord que l'excloga de la societat, ja que aquesta decisió és competència del Consell rector". En la mateixa línia, SÁNCHEZ RUIZ, Mercedes, "Capítulo VI. Asamblea general", en AA. DD., La sociedad cooperativa en la Ley 27/1999, de 16 de julio, de cooperativas, (coord., F. J. Alonso Espinosa), Editorial Comares, Granada, 2001, pàg. 218 i 219.

Per a l'anàlisi dels supòsits de conflicte d'interessos de la LSRL, vegeu les obres que es ressenyen en la nota 124. RODRíGUEZ ARTIGAS, F., «La junta general...», op. cit., pàg. 626, apunta les mancances que al seu parer es produeixen en la regulació legal respecte a la prevista inicialment en el Projecte de LSRL: "a diferència del que succeïa en el P-LSRL i com a conseqüència de la supressió de la clàusula general, l'enumeració de l'article 52.1 LSRL és una enumeració tancada (...) ja no hi ha la possibilitat que en els estatuts, a l'emparament de la clàusula general, es consideren altres situacions (...) que no estan clarament contemplades com aquest conflicte en la LSRL, com, per exemple, el supòsit on es produeix aquest conflicte a través de persona interposada o d'una societat sobre la qual el soci té el control (...) si bé els estatuts, quan desapareix la clàusula general, no poden ampliar l'elenc de supòsits de conflicte d'interessos (...) tampoc poden eliminar o modificar els supòsits contemplats en l'article 52 de la LSRL, a causa del caràcter imperatiu d'aquest precepte i dels concordants. Sens dubte, la nova redacció de l'article 52 impedeix que la Junta General o el seu president puguen considerar, en relació amb un acord determinat, l'existència d'un conflicte d'interessos $i$, en conseqüència, privar el soci afectat de l'exercici del dret de vot corresponent a les seues participacions". EMBID IRUJO, J. M., "Comentario al artículo 52...", op. cit., pàg. 562 i 563: "es tracta, en realitat, d'una enumeració tancada, sense possibilitat aparent d'ampliació ni de reducció, ja siga per la via estatutària o per mera interpretació (...). Militen a favor d'aquest criteri no només el tenor literal de la norma, sinó, sobretot, raons de certesa i seguretat jurídiques que han de posar-se en primer pla davant de la conclusió que el legislador extrau del conflicte d'interessos tipificat l'exclusió del dret de vot. (...) Tot i estar clares les raons favorables al criteri legislatiu vigent, no és del tot segur, però, que, des d'una perspectiva realista i de futur, siga la millor opció de política legislativa. La freqüència amb què cal observar en la pràctica supòsits de conflictes 
associat estableix un supòsit específic relacionat amb els socis en període probatori (article $\left.81.3, c^{568}\right)$. Però, a més, en relació amb el conflicte d'interessos relacionat amb consellers o interventors (article 42.2), canvia el criteri mantingut anteriorment $\mathrm{i}$ declara que els actes, els contractes o les operacions realitzats sense l'autorització de l'assemblea seran ara anul-lables.

d'interessos de caràcter indirecte dóna seriosos dubtes sobre l'adequació al tràfic contemporani de la regulació establerta". També consideren que es tracta d'una enumeració taxativa, ALCALÁ DtAZ, M. A., "El conflicto...», op. cit., pàg. 98, 102 i 103, amb abundants cites relatives al debat doctrinal; BOQUERA MATARREDONA, J., «La regulación del conflicto...», op. cit., pàg. 1022 a 1025: "pel que fa a la possibilitat que els estatuts establisquen nous supòsits (...) s'ha d'insistir en el fet que l'enumeració de l'article 52 no és ad exemplum i que la seua inclusió suposaria una derogació del dret al vot. (...) Però, d'altra banda, la llista (...) deixa fora moltes situacions de conflicte d'interessos directes $i$ indirectes (...). Encara que també podria pensar-se que en aquests casos es pot recórrer a la impugnació de l'acord social per lesió de l'interès social"; i HERNÁNDEZ SAINZ, E., El deber de abstención..., op. cit., pàg. 110 a 112: "a la vista de les dues possibilitats exposades, clàusula general o llista tancada, considerem que l'opció legislativa adoptada resulta en conjunt més encertada. (...) En primer lloc, ha de tenir-se en compte que la restricció del deure d'abstenció (...) no implica que no puga reaccionar-se contra els acords en què el benefici d'un o de diversos socis i fins $\mathrm{i}$ tot de tercers haja prevalgut sobre l'interès social. Per a això (...) qualsevol soci podrà impugnar l'acord (...). A més, (...) la configuració d'un deure d'abstenció es fonamenta en una presumpció iuris et de iure que el soci en conflicte es decantarà per satisfer els seus interessos particulars. (...) La gravetat d'aquesta presumpció i de les seues conseqüències fan aconsellable que es limite a uns supòsits taxats (...). Finalment, el sistema de la clàusula general suposava un greu perill, a saber, l'abús de la minoria". Aquesta última autora considera que "un dels postulats en què es fonamenta la regulació de la Societat de Responsabilitat Limitada és el de flexibilitzar la configuració del seu règim jurídic (...). El caràcter dispositiu de la majoria dels preceptes de la Llei arriba fins i tot al dret de vot. L'article 53.4 disposa que «llevat de disposició contrària dels estatuts, cada participació social concedeix al seu titular el dret a emetre un vot». (...) Ja no és un dret inderogable i s'ha d'admetre la possibilitat de participacions sense vot. Tanmateix, la jurisprudència i la DGRN hauran de concretar l'abast d'aquesta possibilitat. (...) Els estatuts no podran establir un deure general d'abstenció per a qualsevol cas de conflicte d'interessos entre el soci i la societat, perquè amb això es vulneren les intencions del legislador".

En contra de l'opinió sobre la limitació legal d'ampliar estatutàriament l'elenc de causes, GARRIDO DE PALMA, V. M., "Autonomía de la voluntad...», op. cit., pàg. 1878 a 1881: "hi ha principis configuradors de la institució que són incontrovertibles: (...) C) El principi de fidelitat entre els socis i amb la societat, del qual la Llei obté aplicacions concretes, no exemptes de dificultats en la seua expressió pràctica (a les quals es refereix, sobretot, l'article 52, sense perjudici que davant de la societat concreta estatutàriament es prevegen altres causes possibles, a més de les enumerades en el precepte)".

En tot cas, aquestes limitacions no es donen en la LCoop, que remet expressament als estatuts socials la tasca de completar l'elenc de supòsits de conflicte d'interessos.

sa

Article 81.3, c) LCoop: "1. A les cooperatives de treball associat (...) 3. Els nous socis, durant el periode en què es troben en situació de prova, tindran els mateixos drets $\mathrm{i}$ obligacions que els socis treballadors, amb les particularitats següents: (...) c) No podran votar, en l'assemblea general, cap punt que els afecte personalment i directa".

La LCCV, en canvi, ha optat per una regulació totalment oposada del règim del soci en període provatori: li reconeix únicament els drets de veu, informació i partició en retorns, així com l'obligació de participar en les pèrdues, per la qual cosa en aquest cas no cal una aplicació específica del conflicte d'interessos. 
El principal problema que ha plantejat per a la doctrina cooperativa la regulació del conflicte d'interessos no ha estat, doncs (com succeïa en l'àmbit mercantil fins a la promulgació de la vigent LSRL), el de la validesa eventual d'una clàusula estatutària que establira el deure d'abstenció del soci, ja que això s'exigeix expressament $\mathrm{i}$ amb caràcter imperatiu per la norma legal, sinó els supòsits que poden estar regulats estatutàriament com a conflicte. Sembla que l'element determinant ha de ser que els interessos contraposats (socials i extrasocials) siguen efectivament antitètics i impossibles de conciliar ${ }^{569}$, la qual cosa ha portat la doctrina a admetre la participació del soci, per exemple, en la votació en què se'l propose per a un càrrec social ${ }^{570}$, o de l'administrador en l'aprovació de la gestió i del balanç sociall ${ }^{571}$, o a l'exercici de l'acció de responsabilitat que l'afecte ${ }^{5 / 2}$, quan es considera que en aquests casos els interessos coexistents són compatibles ${ }^{573}$.

D'altra banda, amb la finalitat de determinar els efectes del conflicte d'interessos entre el soci i la cooperativa, estimem que s'han de separar els "actes, contractes i operacions" en què el soci puga tenir interessos contraposats als de la cooperativa, de l'acord en què l'òrgan cooperatiu facultat per a això

569 BOQUERA MATARREDONA, J., «La regulación del conflicto...», op. cit., pàg. 1008.

570 GALÁN CORONA, E., "La Junta general...", op. cit., pàg. 519: "doctrina assentada pel TS en sentència de 18 d'octubre de 1985, segons la qual el nomenament com a conseller d'una SA d'un soci majoritari fet per ell mateix «és un dret que la Llei concedeix en harmonia i en defensa dels interessos que té en la societat i no un exercici abusiu del mateix»"; HERNÁNDEZ SAINZ, E., "El deber de abstención...», op. cit., pàg. 115 i 116; SALELLES CLIMENT, J. R., El funcionamiento..., op. cit., pàg. 190.

${ }^{571}$ ALCALÁ DfAZ, M. A., «El conflicto...», op. cit., pàg. 110

${ }^{572}$ HeRnÁNDEZ SAINZ, E., «El deber de abstención...», op. cit., pàg. 116: "L'exclusió del dret de vot en aquests casos és una qüestió molt polèmica. En favor d'aquesta cal al-legar que l'administrador (...) està participant a la formació d'un judici sobre la seua pròpia conducta. (...) Aquest és un argument fal-laç, ja que la falta d'acord per part de la Junta General i, fins i tot, l'acord denegatori de l'exercici de l'acció no impedeix la minoria (...) exercitar l'acció per si mateixa". ALCALÁ DIAZ, M. A., "El conflicto...», op. cit., pàg. 111, "fins i tot si s'admet que la legitimació subsidiària d'accionistes i tercers (...) podran afavorir, d'alguna manera, l'efectivitat del règim de responsabilitat previst en la llei, seria convenient, de lege ferenda, incloure aquest supòsit dins de la norma legal que preveu la prohibició de vot". 
prenga la decisió corresponent o els autoritze. La validesa dels primers
dependrà bé del que preceptua la norma cooperativa mateixa (com és el cas de l'article 42.2 LCoop), bé de l'aplicació de les regles generals del negoci jurídic ${ }^{574}$.

Però la validesa de l'acord que ha donat origen o ha autoritzat les obligacions afectades pel conflicte d'interessos, dependrà de l'anomenada "prova de resistència ${ }^{1575}$ : la nul-litat o l'anul-labilitat del vot ${ }^{576} \mathrm{~d}^{\prime}$ un soci afectarà únicament

"DUQUE DOMfNGUEZ, J. F., Tutela..., op. cit. pàg. 132, que defensa així mateix l'exigència que l'interès extrasocial perseguit pel soci siga de caràcter patrimonial; PAZ CANALEJO, N. en PAZ CANALEJO, N. i VICENT CHULIÁ, F., Ley general..., op. cit., pàg. 447 i 448.

s4 ALCALÁ DIAZ, M. A., La impugnación..., op. cit., pàg. 234, propugna la submissió per als negocis d'execució dels acords del consell d'administració de la societat anònima, en tot cas, a la normativa general sobre nul-litat dels actes i negocis jurídics, "i queda la seua substanciació al marge de les accions de nul.litat de l'ordenament juridicosocietari". Fonamenta la seua opinió en el tenor literal de l'article 143 LSA, que circumscriu el seu àmbit d'aplicació només als acords de l'òrgan d'administració, a diferència d'allò que preveu el dret francès, que fa extensiu el règim societari de nul-litats tant als acords com als actes $i$ a les decisions, interns i externs, dels organs socials.

ALCALA DIAZ, M. A., «El conflicto...», op. cit., pàg. 96; EMBID IRUJO, J. M., "Comentario al artículo 52...», op. cit., pàg. 565 i 566, i en «Notas sobre...», op. cit., pàg. 53; GALÁN CORONA, E., «La junta gēneral...», op. cit., pàg. 518; GIRÓN TENA, J., Derecho de sociedades anónimas, op. cit., pàg. 322; RODRf́GUEZ ARTIGAS, F., «La junta general...», op. cit., pàg. 627: "La infracció del deure d'abstenció dóna lloc a la nul-litat de vot emès que, al seu torn, pot suposar la nul-litat de l'acord una vegada s'ha sotmès a la denominada "prova de resistència", és a dir, quan el vot en qüestió haja estat determinant per a l'adopció de l'acord"; SÁNCHEZ RUIZ, M., Conflictos de intereses..., op. cit., pàg. 169.

FLORES DOÑA, M. de la Sierra, "La suspensión del ejercicio de los derechos correspondientes a las acciones, sobre las que se debe informar a la sociedad", en AA. DD.., Estudios jurídicos en homenaje al profesor Aurelio Menéndez (coord. J. L. Iglesias Prada), Civitas, Madrid, 1996, tom II, pàg. 1763 i 1764, en relació amb la violació de la suspensió del dret de vot en general: "pel que fa a l'exercici dels drets de vots en suspens es defensa la impugnabilitat de l'acord de la Junta General pres amb el seu concurs, sempre que aquest últim haja estat decisiu per obtenir-ne la majoria exigida legalment. Aquesta solució és la continguda en l'article 4.2 de la Proposta modificada d'IX Directiva (així com en l'article 5 , paràgraf cinquè i 5 bis, paràgraf quart italià) i la defensada per la doctrina germànica per entendre que l'exercici dels drets de vots en suspens constitueix un supòsit d'infracció de llei (...). La nul-litat de l'acte d'emissió dels drets de vots en suspens troba suport en l'article $6.3 \mathrm{del} \mathrm{CC}$, que diu: «Els actes contraris a les normes imperatives i a les prohibitives són nuls de ple dret, llevat que s'hi establisca un efecte diferent per al cas de contravención. L'aplicació d'aquest precepte al cas que ens ocupa és justificada. D'una banda, l'emissió del dret de vot és un acte contrari a una norma imperativa (...). D'altra banda, el legislador no ha previst una sanció específica per als supòsits d'exercici dels drets en suspens, que pogueren tallar l'aplicació de l'article 6.3 del CC".

Contràriament, són partidaris de la nul-litat de l'acord en tots els casos, i no només quan el vot en conflicte haja estat determinant, SÁNCHEZ CALERO GUILARTE, J., «El conflicto de intereses...», op. cit., pàg. 701, i BOQUERA MATARREDONA, J., «La regulación del conflicto... , op. cit., pàg. 1044; i, per a les cooperatives, Vicent CHULIÁ, F., en PAZ CANALejo, N. i Vicent CHULIÁ, F., Ley general..., op. cit., pàg. 583 i 806: “63, sobre conflicte d'interessos, l'apartat 2 n del qual estableix la nul-litat dels actes (i també lògicament dels acords previs del CR) que en aquest supòsit no 
la validesa de l'acord al qual haja concorregut si aquell fóra necessari per a ]
seua adopció, en virtut del joc de les majories i dels quòrums de l'òrgan i de l
matèria corresponents ${ }^{57}$.

En aquest cas, s'obri l'interrogant sobre l'entitat de la sanció corresponent : l'acord adoptat amb la participació del soci que va haver d'abstenir-se: lé majoria dels autors que tracten la matèria opten per la nul-litat, encara que sense argumentar $1^{\prime}$ opció ${ }^{578}$; recentment s'ha proposat la nul.litat,

vengen precedits d'autorització de l'AG". dels acords, el vot té la independència conceptual necessària perquè s'hi puga distingir els 97, on considera que el conflicte d'interess . ASCARELLI, T., "L'interesse sociale...", op. cit., pàg. $95 \mathrm{i}$ valorat per la majoria ha de prevaler sobre l' pressuposa el principi general que l'interès social això del vot de l'accionista que (...) està en conflicte"; $l^{\prime}$ esmentat principi "troba, i es preocupa per en la neutralització del poder quan qui l'haja d'exercitar estiga típicipi "troba el seu origen (...) finalitat per a la qual el poder és reconegut".

${ }^{57}$ En relació amb el còmput de la majoria i quòrum corresponents, encara que la legislació N. i VICENT CHULIÁ, F., Ley general..., op. cit., sumem a PAZ CANALEJO, N. en PAZ CANALEjo, Comunidades de bienes..., op. cit., pàg. 735, quan consideren que, a semblanca en AA. DD., preveu en l'article 52.2 LRSL, s'hauran d'excloure els vots corresponents als şa d'allò que es conflicte d'interessos. Això es justifica, a més, en el fet que, si no es fa així, socis incursos en seria impossible assolir els quòrums o les majories previstes, precisament per la no-participací́ de qui genera el conflicte (DUQUE DOMf́NGUEZ, J. F., Tutela..., op. cit. pàg. 133 a 135).

En la LCoop, afavoreix aquesta interpretació el fet que els articles 28.1 i 36.4 prenguen en consideració per al còmput de la majoria, tant de l'assemblea com del consell rector, "els vots vàlidament expressats", amb la qual cosa, a més d'excloure's les abstencions, els vots en blanc i els vots nuls, s'exclouen els vots dels qui no poden exercir-ho per estar incursos en alguna causa d'abstenció (TATO PLAZA, A«Os órganos sociais...», op. cit., pàg. 84).

BOQUERA MATARREDONA, J., "La regulación del conflicto...", op. cit., pàg. 1040 i 1041: "les participacions del soci en conflicte d'interessos s'han tingut en compte per al còmput dels socis (...) Quan es comprova que exa la Junta General i el seu titular apareixerà a la llista d'assistents. còmput dels vots exigits en cada cax el conflicte, s'exclouen per a l'adopció de l'acord i per al 作

"E7x EMBID IRUJO, J. M., "Comentario al artículo 52...», op. cit., pàg. 565 i 566; GALÁN CORONA, E., "Là Junta general...", op. cit., pàg. 518; RODRf́GUEZ ARTIGAS, F., "La junta general...», op. cit,

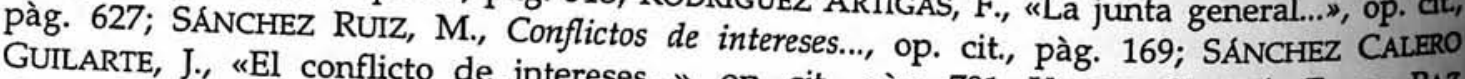
CANALEJO, N. i VICENT CHULIÁ, F., Ley general, op. cit., pàg. 701; VICENT CHULIÁ, F., en PAZ expliquen la seua opció BOQUERA MAT general..., op. cit., pàg. 583 i 806. Com a excepció, sí que 1044: "L'acord contravé una norma legal pronA, J., «La regulación del conflicto... , op. cit., pàg. podrà ser impugnat. El vot emès pel sol prohibitiva (article $6.3 \mathrm{del} \mathrm{CC}$ ) $\mathrm{i}$, per tant, serà nul $\mathrm{i}$ il-legal, ja que contravé una norma legal impenflicte d'interessos serà un vot il-lícit, més aines FLORES DOÑA, M. S., "La suspensión.... imperativa. L'acord adoptat serà nul de ple dret"; i sanció específica per als supòsits d'ex...", op. cit., pàg. 1764, "el legislador no ha previst una de l'article 6.3 del CC". 
contrarietat a la norma legal que requereix l'adopció dels acords per majoria ${ }^{579}$, i tampoc falten autors partidaris de l'anul-labilitat ${ }^{580}$; finalment, segons una opinió doctrinal autoritzada, "s'haurà de discriminar el caràcter del vici del vot, a fi que només els que donen lloc a un vot radicalment nul puguen donar lloc a un acord "del mateix caràcter, i la discriminació entre vots nuls i anul·lables" ha de fer-se per aplicació de la doctrina general sobre actes i negocis jurídics" ${ }^{\prime 281}$.

" ALCALÁ DíAZ, M. A., El conflicto..., op. cit., pàg. 96: "la sanció legal sobre l'acord, és a dir, la nul-litat, no es produeix com a conseqüència de la infracció del deure de fidelitat, sinó com a conseqüència de l'absència de la majoria legalment exigida, ja que en el còmput de la majoria es va comptabilitzar el vot d'un soci que no estava legitimat per al seu exercici"; en el mateix sentit, COSTAS COMESAÑA, J., El deber..., op. cit., pàg. 98.

"DUQUE DOMf́nGUEZ, J. F., Tutela..., op. cit., pàg. 150 i 151: "la desaparició de la majoria per la impugnació amb èxit de vots anul-lables o de vots nuls per causes que no es refereixen al seu contingut, fa l'acord merament impugnable, sense que s'hi opose l'essencialitat que indubtablement posseeix la regla majoritària en la societat anònima. En efecte, si s'admetera la nul-litat de l'acord derivada de l'anul-labilitat de vots per alguna d'aquestes causes, (...) llavors no solament els socis la voluntat dels quals no ha concorregut a la formació de l'acord, sinó també un soci que haguera votat a favor - i per tant, també el soci que va votar en conflictepodrà demanar la nul-litat, si l'acord produeix un dany imprevist al votant que va infringir la prohibició, amb la qual cosa es permetrà al que va intentar violar la llei per obtenir un benefici, acudir posteriorment a la mateixa llei la prohibició de la qual ha vulnerat per evitar les conseqüències danyoses d'aquella vulneració"; SALELLES CLIMENT, J. R., Funcionamiento del consejo..., op. cit., pàg. 195: "En el pla de l'eficàcia de l'acord s'ha entès que si el vot del vocal en situació de conflicte va ser determinant a la seua adopció podria arribar-se a la conclusió que l'acord adoptat en aquest cas és absolutament nul. Atesa la presumpció de frau que inspira la prohibició d'autocontractació i l'abús de dret comès pel vocal (...), la sanció podria ser la nul-litat del contracte estipulat (article $6.3 \mathrm{CC}$ ). Al meu parer, tanmateix, aquesta conseqüència sembla excessiva. En efecte, de la interpretació restrictiva que ha de prevaler en matèria de nul-litat dels acords socials i de l'exteriorització d'una voluntat que afecta l'esfera jurídica de la societat, se'n segueix que haja de reconèixer-se alguna eficàcia a l'acord adoptat. (...) l'acord així adoptat és eficaç, però $\mathrm{amb}$ una eficàcia claudicant que desapareix si s'exercita l'acció d'impugnació i es demostra el perjudici causat".

"TII GÓN TENA, J., Derecho de sociedades anónimas, op. cit., pàg. 322 i 323: “A primera vista sembla que la solució ha de donar-se d'acord amb la indiferenciació de nul-litat o anul-labilitat dels vots; i la raó rau en el fet que la regla majoritària ha d'entendre's en ordre públic, de manera que predomine aquest criteri sobre qualsevol altre d'índole purament dogmàtica. Però aquesta estimació és enganyosa: la voluntat de l'òrgan no és voluntat diferent de la dels membres de la majoria; la diferent entitat dels vicis que afecten cada vot com a manifestació de voluntat només podria conservar-se i ser operant si es manté una diferent manera de repercussió". En la mateixa línia, ASCARELLI, T., L'interesse sociale..., op. cit., pàg. 104 i 105; i HERNÁNDEZ SAINZ, E., El deber de abstención..., op. cit., pàg. 124: "La nul.litat de la declaració de voluntat en què consisteix el vot comportarà la nul.litat de l'acord adoptat si aquest no supera la prova de resistència. (...) en canvi, si el vot simplement va contravenir previsions estatutàries, serà nerament anul-lable i en conseqüència, la mateixa qualificació mereixerà l'acord resultant que no supere la prova de resistència".

il.licitud delNGUEZ, J. F., Tutela..., op. cit. pàg. 147 i 148, també sosté que la sanció aplicable a la actes i negol vot ha de determinar-se d'acord amb les normes del dret comú per als vicis dels com hem vist jurídics, atès que "el vot no és més que un negoci jurídic unilateral"; tanmateix, vist supra, aquest autor acull una tesi diferent per a la sanció aplicable, no al vot 
Al nostre parer, després d'establir la transcendència del vot viciat per a l'adopció de l'acord mitjançant la "prova de resistència", s'haurà d'atendre, no el vici que invalida el vot, sinó a la naturalesa de la norma que establia el deure $d^{\prime}$ 'abstenció $i$ que ha estat vulnerada amb el vot ${ }^{582}$ : si el conflicte d'interessos es recull en una norma legal imperativa ${ }^{583}, l^{\prime}$ acord que la incompleix serà nul; si el conflicte és dels concretats estatutàriament, en ampliació dels exigits legalment, l'acord haurà de considerar-se anul·lable ${ }^{584}$.

Fora d'això, la nul-litat o anul-labilitat serà predicable respecte de l'acord en què haja participat el soci "en conflicte", siga el de l'òrgan que en virtut de les seues competències haja decidit la realització de l'operació o el d'autorització prèvia o ratificació posterior per l'assemblea ${ }^{585}$.

invàlid, sinó a l'acord adoptat amb la concurrència d'aquell: l'anul-labilitat.

${ }^{5 * 2}$ COSTAS COMESAÑA, J., El deber de abstención..., op. cit., pàg. 295; SÁNCHEZ RUIZ, M., Conflictos de intereses..., op. cit., pàg. 163: "La modalitat concreta d'ineficàcia de l'acord (nul-litat o anul-labilitat) resultarà de l'aplicació de les regles generals en matèria d'impugnació d'acords socials. (...) l'acord que infringisca una prohibició legal de vot serà nul per contrari a llei (...), quan la prohibició de vot infringida es continga en els estatuts socials, l'acord social adoptat haurà de ser considerat contrari a aquells, i per tant anul-lable"; més endavant, tanmateix, (pàg. 368) considera que seria més aconsellable, de lege ferenda, que l'acord fóra considerat en tot cas anul-lable, ja que resulta paradoxal que en situacions de mer risc de dany per a l'interès social l'acord puga ser nul, mentre que en els supòsits d'impugnació per acord que ja ha produit un
dany la sanció siga d'anul-labilitat.

${ }^{583}$ Com, per exemple, els supòsits previstos a l'article 52.1 LSRL (vegeu nota supra), als quals, com ha quedat ressenyat, remet expressament i imperativament l'article 26.8 LCoop, o els
recollits en l'article $44 \mathrm{LCCV}$.

${ }^{584}$ DUQUE DOMíNGUEZ, J. F., Tutela..., op. cit. pàg. 148 proposa també discriminar segons la norma vulnerada per l'emissió del vot il-lícit, però per a aquest autor la norma que s'ha de considerar és la que establisca la majoria corresponent.

${ }^{5 \times 5}$ VICENT CHULIÁ, F., "La asamblea...», op. cit., pàg. 159: "hem de distingir dues categories de supòsits: els d'autorització de negocis, sobre la decisió i l'execució de la qual és competent l'òrgan d'administració de la cooperativa; i els de vertadera decisió de l'Assemblea general, per tractar-se de matèries de la seua competència pròpia, i que l'òrgan d'administració s'ha de limitar a executar, estipulant, si escau, els necessaris negocis jurídics amb tercers, quan no el facen apoderats nomenats expressament per l'Assemblea".

DUQUE DOMÍNGUEZ, J. F., Tutela..., op. cit., pàg. 127: "L'efectivitat del conflicte subsisteix encara que el contingut de l'acord adoptat no siga la conclusió del contracte amb el soci $\longrightarrow$ amb el tercer per compte de qui actua aquell-, sinó autoritzar únicament l'administració perquè execute posteriorment l'acord, atès que la societat, en concedir aquest poder, ja disposa d'interès social (...). Les mateixes consideracions (...) permeten afirmar l'efectivitat del conflicte 
Finalment, la doctrina apunta dues llacunes normatives sobre el conflicte d'interessos: els supòsits en què el soci exerceix el seu vot mitjançant representació ${ }^{586} \mathrm{i}$ els anomenats "conflictes indirectes d'interessos".

En relació amb el conflicte d'interessos quan el dret de vot s'exerceix mitjançant representant, s'ha assenyalat que, si bé del tenor literal de la norma corresponent es podria concloure que la prohibició d'exercir el vot afecta només la persona del soci $^{587}$; aquesta interpretació literal permetria fàcilment l'elusió de la prohibició legal. És per això que hem de concloure admetent que el soci està exclòs en tots els casos de la votació en què incorre en conflicte d'interessos ${ }^{588}$, tant si pretén exercir el vot mitjançant representant, com si és ell qui representa un altre soci, ${ }^{589}$ llevat, en aquest últim cas, si el soci representat (que no

en el cas que la junta es reunisca per acordar l'aprovació d'un negoci ja conclòs entre el soci i l'òrgan administratiu".

" COSTAS COMESAÑA, J., El deber de abstención..., op. cit., pàg. 252 a 254, apunta altres supòsits en què el dret de vot en la societat de capital pot exercir-se per persona diferent, com ara el copropietari o el titular d'un dret real sobre la participació social. Aquests supòsits no són, òbviament, traslladables a la cooperativa. També es refereixen a aquesta llacuna legislativa GALAN CORONA, E., «La Junta general...», op. cit., pàg. 520; i RODRíGUEZ ARTIGAS, F., «La junta general...", op. cit., pàg. 627.

COSTAS COMESAÑA, J., El deber de abstención..., op. cit., pàg. 248 i 249, referint-se a les SRL, si bé l'argumentació és plenament aplicable a les cooperatives; així, l'article 26.8 LCoop: "Els estatuts establiran els supòsits en què el soci haja d'abstenir-se de votar per estar en conflicte d'interessos...", l'article 42.1 LCoop: "[...] el soci sotmès aquesta situació de conflicte no podrà prendre part en la votació corresponent", i l'article 44.1 in fine: "Els socis afectats no podran prendre part en la votació corresponent de l'assemblea". També són partidaris de la interpretació restrictiva GALÁN CORONA, E., «La Junta general...», op. cit., pàg. 520; i RODRíGUEZ ARTIGAS, F., "La junta general...», op. cit., pàg. 627.

Com a excepció, l'article 21.1 del RCC estableix que "l'estatut haurà de concretar necessàriament en quines situacions un soci no podrà representar-ne uns altres, incloent en aquest cas els socis que estigueren sancionats o en conflicte d'interessos per votar..."

COSTAS COMESAÑA, J., El deber de abstención..., op. cit., pàg. 249 a 252. DUQUE DOMíNGUEZ, J. F., Tutela..., op. cit., pàg. 129 a 131 fa dependre la rellevància del conflicte entre el representant del soci i la societat de circumstàncies diferents, com ara el tipus social de la persona jurídica sòcia.

SÁNChez Calero Gullarte, J., «El conflicto de intereses...», op. cit., pàg. 698 i 699: "el representant podrà votar en la Junta sota les mateixes circumstàncies en què ho faria el entre ambdós (..), d'altra banda, la representació d'un soci per un altre no suposa per se que hi ha en l'assumpte en participacions del qüestió el representant no pot exercitar el dret de vot provinent de les 

incórrega, al seu torn, en conflicte) haja fixat el sentit en què el representant ha
de manifestar el seu vot. ${ }^{500}$

Quant als conflictes indirectes d'interessos, han estat identificats amb aquelles situacions en què "el soci és (o raonablement es pot creure que és) portador d'un interès personal, oposat al social, però que no li és propi, sinó d'una tercera persona amb la qual l'uneix algun tipus de vinculació jurídica, econòmica, de parentiu o d'amistat i que resulta estar directament afectada per l'acord sotmès a votació ${ }^{\prime \prime 591}$. En relació a açò s'ha assenyalat, en l'anàlisi de la SL,

Contràriament, GALÁN CORONA, E., "La Junta general...», op. cit., pàg. 520: "no seria d'excloure corresponents a les participacions interessos amb la societat utilitze en interès propi els vots

haurà problema si pot succeir que la representánt actua conforme a la representació que se li ha conferit. Perd podrà votar". HERNÁNDEZ SAó s'haja atorgat en blanc (...). En aquest supòsit el representant no que "el soci ha pogut ser instituït detalle quin ha de ser el sentit del vot. En representant mitjançant un poder especial en què es aquest el cas més freqüent. El més comú és quest cas no s'hi haurà d'objectar res (...). Però no és especial per a la representació en comú és que hi haga un apoderament general o bé un poder haurà d'adoptar-s'hi. També en aquest cas coninada, però sense especificar la postura que prescripció estatutària en contrari. $\mathrm{Si}$ en votar no es compo podrà votar, excepte si hi ha els seus propis interessos i no els del seu rar no es comporta com un representant lleial $i$ atén cosa suposaria la nul-litat del vot $i$, en conseqüètnat, hi hauria una desviació de poder, la qual l'acord, la nul-litat d'aquest".

${ }^{591}$ COSTAS COMESAÑA, J., El deber de abstención..., op. cit., pàg. 255. BOQUERA MATARREDONA, J., "La regulación del conflicto...», op. cit., pàg. 1011; EMBID IRUJO, J. M., "Comentario al artículo 52...", op. cit., pàg. 563: "A més del que es donaria en casos de parentiu i vinculació familiar, no poden menysprear-se els nombrosos conflictes d'aquesta naturalesa susceptibles de concórrer en situacions de grup de societats"; GALÁN CORONA, E., "La Junta general...», op. cit., pàg. 518: "El conflicte d'interessos pot plantejar-se respecte d'un soci, no directament, sinó indirectament, com a titular, per exemple, d'una participació de control en una altra societat els interessos de la qual col-lisionen amb els de la SRL. Considere que en aquest supòsit, $\mathrm{i}$ amb suport en la doctrina jurisprudencial consolidada de l'«alçament del vel», té aplicació també la norma de l'article 55.1"; HERNÁNDEZ SAINZ, E., «El deber de abstención...», op. cit., pàg. 117 i 118: "...si partim del text del Projecte de Llei, era possible argumentar en favor de l'existència d'un deure d'abstenció en els supòsits de conflicte indirecte. (...) Aquesta interpretació ja no és possible si ens atenem a la dicció literal del precepte vigent; el soci no podrà exercir el dret de vot quan es tracte d'adoptar l'acord que $l$ 'autoritze..., $l$ 'excloga..., $l$ 'allibere... o $l i$ concedisca, etc."; SÁNCHEZ CALERO GUILARTE, J., "El conflicte d'interessos...», op. cit., pàg. 695: "els interessos d'un soci no estan en contraposició directa amb els de la societat, però hi ha una vinculació estreta entre els primers i els d'un altre soci que, en l'assumpte plantejat, sí que entren en conflicte obert amb la societat. (...) La nota comuna consisteix en (...) relacions de parentiu, de dependència societària, comercials o obligacionals". No ha de considerar-se, en canvi, conflicte indirecte, sinó directe, el supòsit a què es refereix SÁNCHEZ CALERO GUILARTE, J., «El conflicte d'interessos...», op. cit., en pàg. 690: "l'article $52 \mathrm{LSRL}$ afecta el vot d'altres socis que puguen resultar indirectament 
la inseguretat jurídica que introduiria la seua acceptació com a causa del deure d'abstencio $^{592}$, com a conseqüència de l'àmplia casuística que es pot plantejar, així com la dificultat objectiva de provar-ne $a$ priori l'existència, per la qual cosa $s$ 'ha proposat, per a l'admissió, l'existència d'un vincle jurídic i una comunitat $d$ 'interessos entre el soci i la tercera persona directament afectada ${ }^{593}$.

En aquesta matèria, $s^{\prime}$ ha de recordar que, a diferència de la LSRL, tant la LCoop (article 42.1) com la LCCV (article 44.1) estenen expressament les situacions de conflicte d'interessos entre la cooperativa $i$ els membres del consell o altres càrrecs $^{54}$ a aquelles operacions que afecten els seus parents en diversos graus de

beneficiats per l'alliberament del principal obligat. L'exemple més senzill és el del soci fiador, que pot tenir interès per votar a favor de l'alliberament del deutor principal —soci o no-"; el benefici pot ser indirecte, el conflicte és directe entre l'interès extrasocial del soci fiador i l'interès social.

DUQUE DOMINGUEZ, J. F., Tutela..., op. cit., pàg. 120, dóna a l'expressió "conflicte indirecte" una accepció diferent. Parteix de la configuració del conflicte d'interessos com una forma particular de la relació representant-representat; en aquest context, el conflicte indirecte es dóna quan "el representant" obté els avantatges en perjudici del "representat" no directament i immediatament del "negoci representatiu" sinó posteriorment i segons certes circumstàncies eventuals. Aquests supòsits no estan previstos, per regla general, per la llei.

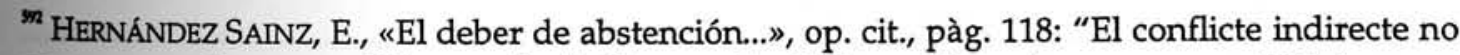
es preveu en la norma. S'ha seguit així l'exemple d'altres ordenacions que no estableixen un deure d'abstenció si hi ha conflicte indirecte, atesa la inseguretat jurídica que genera. [nota 44: "Així el Dret alemany ( $§ 136 \mathrm{AktG}$ i $\S 47.4 \mathrm{GmbHG}$ ) i el portuguès (article 251 del Código das sociedades comerciais)"].

" SÁNCHEZ CALERO GUILARTE, J., «El conflicto de intereses...», op. cit., pàg. 695 a 697: “...com a primera opció proposem la que l'article 52 LSRL estenga el seu abast prohibitiu sobre la base de criteris incorporats a la nostra ordenació societària. Es priva del vot el soci que està en conflicte d'interessos amb els de la societat, així com els altres socis que pertanyen al mateix grup que aquell $o$ que actuen en concert amb aquest (...). Ara bé, no sense raó podrà al-legar-se que si la intenció del legislador fóra la d'estendre la prohibició del dret de vot (...), això s'hauria d'haver traduït en una previsió expressa en aquest sentit. En un altre cas, la restricció del dret de vot haurà d'ajustar-se a l'àmbit estricte que deriva de la literalitat de la redacció actual. (...) Es probable que siguen aquestes consideracions les que fonen la postura que defensa un sector autoritzat de la doctrina $\mathrm{i}$ jurisprudència alemanyes en entendre que el principi de la seguretat jurídica impedeix estendre la prohibició del vot a aquells socis emparentats amb qui col-lisiona amb l'interès social. En aquests casos, la protecció dels interessos socials haurà de canalitzar-se a través de l'acció d'impugnació (...). Per contra, l'article 52 resultarà plenament aplicable en aquells supòsits en què el soci assumeix la defensa d'interessos d'un estrany contraris als de la societat. L'exemple més notori n'és el de la filial (...). L'exercici del vot en aquestes situacions constitueix un frau de llei manifest".

La LCoop aplica aquesta situació de conflicte als interventors, mentre que la LCCV l'estén als
directors. 
consanguinitat o afinitat ${ }^{595}$. Això no obstant, queden per resoldre altres supòsits, com ara aquells en què el soci en conflicte d'interessos siga una persona jurídica.

\subsubsection{Acords contraris a l’ordre públic}

La legislació cooperativa també assenyala com un tipus específic d'acords nuls aquells "que, per la seua causa o contingut, resulten contraris a l'ordre públic" (article 31.3 LCoop; article 36.4 LCCV), i ho fa, a semblança del que estableix en la LSA, per excloure'ls del termini de caducitat a què se sotmet la impugnació de la resta d'acords nuls. Aquesta excepció té el seu origen en l'aplicació que tradicionalment s'ha fet en la impugnació d'acords socials de la teoria general de la nul-litat dels negocis jurídics, considerant que aquells acords "que patiren de nul-litat radical serien, per definició, no esmenables i l'acció declarativa de la seua inexistència no estaria subjecta a caducitat, mentre que aquells que foren merament anul-lables podrien quedar guarits pel mer transcurs del temps, si no s'exercitara l'acció constitutiva d'anul-labilitat".

Davant d'aquest tractament originari de la impugnació d'acords socials, ja ha quedat indicat com l'adaptació del dret de cooperatives al nou marc constitucional del $1978 \mathrm{i}$ a les tendències de reforma que ja s'apuntaven per a les societats de capital, va introduir la caducitat de l'acció d'impugnació dels acords nuls ${ }^{59}$ i la possibilitat de la seua esmena.

\footnotetext{
${ }^{595}$ En relació amb aquesta matèria, a més, la LCE (article 41.1) inclou expressament els supòsits de consanguinitat o afinitat extramatrimonial, això és, la que es deriva d'una "relació afectiva anàloga a la matrimonial".

${ }^{5 \% 6}$ GIMENO SENDRA, J. V. "La reforma... op. cit., pàg. 21 i 22, comentant la incorporació del termini de caducitat en la LSA, explica que "la ratio legis d'aquesta innovació (fora d'això no absoluta, ja que ja existia en l'àmbit de la legislació cooperativa) se l'ha de trobar en la crisi de la teoria de la nul-litat del negoci jurídic davant de les exigències de la celeritat $i$ seguretat del tràfic mercantil (...) ni la societat mercantil, ni els tercers poden veure's exposats a l'eterna possibilitat d'una sentència declarativa que, amb efectes ex tunc, sancione la nul-litat d'un acord social".

URÍA, R., MENÉNDEZ, A., i MUÑoz, J. M., La junta general..., op. cit., pàg. 318 i 319 recorden que
} 
Això no obstant, la LGC de 1987 encara no feia una menció expressa relativa als acords nuls contraris a l'ordre públic. Serà amb les reformes de la LCCV primer (1995) i de la Llei estatal de cooperatives després (1999) quan, seguint l'exemple de la Llei 19/1989 de reforma del dret de societats, s'assumisca, també per a les cooperatives, que no "s'ha volgut portar a les últimes conseqüències el tractament conjunt de la nul-litat i de l'anul-labilitat dels acords socials de la junta general, salvant la no-prescripció d'aquells acords que per la seua causa o contingut resultaren contraris a l'ordre públic ${ }^{\prime \prime 57}$.

En efecte, la tesi majoritària sobre la conveniència d'unificar el procediment per obtenir la nul-litat o l'anul-labilitat dels acords socials no ha pogut mantenir la universalitat de la justificació de la millora dels acords nuls pel mer transcurs del temps; la seguretat jurídica i l'agilitat en el tràfic empresarial esdevenen insuficients davant la nul-litat radical d'alguns acords. Això ha conduït el legislador a exceptuar de caducitat els acords contraris a l'ordre públic, encara que l'única opinió unànime sobre el concepte siga, precisament, la seua concreció difícil ${ }^{598}$.

\begin{abstract}
"aquest tractament de la nul-litat com a anul-labilitat, des del pla de la impugnació dels acords socials (...) ja va ser assumida per l'Avantprojecte LSA de 1979 i per la Llei general de cooperatives (article 52.4)", i que ja l'any 1947, el President de la Comissió Redactora de l'Avantprojecte de Llei de societats anònimes de l'Institut d'Estudis Polítics, el professor GARRIGUES "aconsellava unificar totes les accions de nul-litat dels acords socials sota el nom d'acció d'impugnació i de sotmetre aquella acció a un termini de caducitat breu", així com que GOMEZ ORBANEJA deia poc després de la promulgació de la Llei de 1951 que "l'ideal seria fer de tota invalidesa d'un acord social causa de simple impugnació per excloure d'aquesta manera la possibilitat de situacions divergents i apartar l'amenaça indefinida de l'acció de nul-litat".
\end{abstract}

"POLOSÁNCHEZ, E., Los administradores..., op. cit., pàg. 535.

5IF DICAZO, Ignacio, i DE LA Oliva SANTOS, Andrés, «Los procedimientos judiciales en la nueva legislación societaria», La Ley, 1990 - 1, pàg. 1059; EMBID IRUJO, José Miguel, «Notas sobre el régimen de la junta general y el estatuto jurídico de los administradores en la nueva ley de sociedades anónimas», en Anales de Derecho, Universidad de Murcia, núm. 10, 1987-1990, pàg. 167; JUSTE MENCIA, J., Los derechos..., op. cit., pàg. 403, que considera que es tracta d'una "categoria, d'altra banda, de contorns discutibles"; POLO SÁNCHEZ, E., Los administradores..., op. cit, pàg. 535, que es refereix al "vaporós i imprecís concepte d'ordre públic"; RODRf́GUEZ ARTIGAS, F., i ESTEBAN VELASCO, G., "Los órganos...", op. cit., pàg. 114: "la disposició no té perfils clars i no és fàcil determinar el seu contingut"; VICENT CHULIÁ, F., Compendio crítico..., op. not, pàg. 612; URíA, R., MENÉNDEZ, A., i MUÑOZ, J. M., La junta general..., op. cit., pàg. 325, "la noció d'ordre públic (...) com a límit de l'autonomia privada, ofereix serioses dificultats de concreció. La jurisprudència mateixa en té un concepte lat. (...) davant de la seua no-concreció hi 
En tot cas, el tenor de la norma planteja la necessitat de l'anàlisi i la determinació, la qual cosa ha portat alguns autors a distingir entre acords afectats d'una nul-litat "radical" o "absoluta", no compensable pel mer transcurs del temps, i la resta d'acords nuls, la nul-litat dels quals serà "relativa" o "ordinària" ${ }^{1599}$. Tanmateix, encara que tots coincideixen a qualificar als acords contraris a l'ordre públic de viciats per aquesta nul-litat absoluta, divergeixen en dues qüestions: sobre la possibilitat que en aquesta categoria s'incloguen altres acords diferents als contraris a l'ordre públic ${ }^{600}$ i sobre

ha el risc greu, en l'aplicació de la llei, que la imprescriptibilitat de l'acció de nul-litat (...) entre en la societat "per la finestra» de presumptes infraccions de l'ordre públic".

599 SÁNCHEZ CALERO, F., Instituciones..., op. cit., pàg. 373: "dins dels acords nuls cal distingir, al seu torn, entre acords la nul-litat dels quals és absoluta i que el pas del temps no pot guarir, i altres la nul·litat dels quals és relativa, ja que l'acció d'impugnació contra aquests caduca en el termini d'un any, de tal manera que han de considerar-se aquests acords vàlids una vegada transcorregut aquell termini. Si el criteri de distinció entre acords nuls i anul-lables era discutit per la doctrina majoritària sota l'imperi de la LSA del 1951, les matisacions que ha sofert per la Llei vigent no poden considerar-se afortunades. (...) Dins d'aquests acords nuls es troben els que "per la seua causa o contingut resultaren contraris a l'ordre públic" (article 116.1), la nul-litat dels quals ha de considerar-se com absoluta i no reparable amb el transcurs del temps". També estableixen aquesta distinció EMBID IRUJO, J. M., "Notas sobre la impugnación...», op. cit., pàg. 52, ARROYO, I., "Comentario al art. 56..., op. cit., pàg. 609 a 611; ÁVILA NAVARRO, P., La sociedad limitada, op. cit., pàg. 422; BERCOVITZ RODRfGUEZ-CANO, A., "Los acuerdos impugnables..., op. cit., pàg. 383; i TATO PLAZA, A., Substitución y anulación..., op. cit., pàg. 76 i 77: "els diferents supòsits de nul-litat i d'anul-labilitat d'acords socials previstos en l'article 115 LSA són, sota la perspectiva de la teoria general del negoci jurídic, supòsits de nul-litat relativa o, si es prefereix, d'anul-labilitat [nota. 18:...els únics acords que serien radicalment nuls en el sentit de la teoria general del negoci jurídic serien aquells que, per la seua causa o contingut, resulten contraris a l'ordre públic]".

Això no obstant, s'ha de tenir en compte que encara en l'actualitat, en algunes ocasions s'utilitzen les expressions "nul-litat absoluta" o "radical" davant "nul-litat relativa" per referirse a la nul-litat i anul-labilitat dels acords. Així, la STS, Sala del civil, de 21-10-1994, núm. 929/1994 RJ 1994\7678: "existència de dues classes o tipus de nul-litats: la radical que sorgeix quan es tracta d'acords contraris a la llei, i la relativa o anul-labilitat referida als que s'oposen als Estatuts o lesionen, en benefici d'un o diversos accionistes o de tercers, els interessos de la societat".

${ }^{6 \times(x)}$ Ja hem vist com SÁNCHEZ CALERO, F., Instituciones..., op. cit., pàg. 373 considera que "dins d'aquests acords nuls [acords nuls la nul-litat dels quals és absoluta] es troben els que, per la seua causa o contingut resultaren "contraris a l'ordre públic, encara que no en cita altres que considere afectats per la nul-litat radical. ÁvILA NAVARRO, P., La sociedad limitada, op. cit., pàg. 422 , es refereix a la regulació dels acords contraris a l'ordre públic de l'article $116 \mathrm{com}$ un dels supòsits de nul-litat absoluta, categoria en què inclou tots els actes contraris a la llei en general [tota norma legal diferent a la LSA] i també als principis de la Llei de Societats Anònimes mateixa diferents dels que regulen estrictament els requisits de convocatòria, funcionament $i$ competència de la junta.

EMBID IRUJO, J. M., «Notas sobre la impugnación...», op. cit., pàg. 52, sembla decantar-se per considerar que els acords contraris a l'ordre públic integrarien per si sols la categoria dels 
l'adequació del procediment d'impugnació societari per a l'obtenció de la declaració de la nul-litat absoluta 0 , alternativament, la reconducció al règim general de nul-litat dels negocis jurídics ${ }^{601}$.

En la línia d'aquesta última proposta, ha estat formulada recentment la tesi que manté que "l'establiment d'un règim particular per a la impugnació d'acords nuls de la junta general respecte del que preveu la normativa civil sobre actes $\mathrm{i}$ negocis jurídics ha obligat al legislador a establir com a excepció el tractament jurídic dels acords contraris a l'ordre públic encara que el contingut de la norma siga, precisament, la tramesa al règim general sobre nul-litat dels actes i negocis jurídics $^{\prime \prime 62}$. Segons aquesta línia interpretativa, els acords contraris a l'ordre públic no se sotmetran al procediment d'impugnació previst per als acords socials, sinó al més general aplicable a la remoció dels actes i negocis jurídics ${ }^{603}$.

absolutament nuls: "d'una banda, són els acords nuls, ordinaris, que utilitzen una terminologia aliena a la llei, la impugnació dels qual es veu circumscrita per un termini concret de caducitat (un any, article 116.1). D'altra banda, els acords nuls, que per la seua causa o contingut resultaren contraris a l'ordre públic (article 116.1r), per als quals no regiria aparentment l'esmentat termini de caducitat". En la mateixa línia, ARROYO, I., "Comentario al art. 56...", op. cit., pàg. 609 a 611; BERCOVITZ RODRíGUEZ-CANO, A., «Los acuerdos impugnables...», op. cit., pàg. 383; i TATO PLAZA, A., Substitución y anulación..., op. cit., pàg. 77.

"ARROYO, I., "Comentario al art. 56...», op. cit., pàg. 609 a 611, sembla referir-se implícitament a l'aplicació del procediment "especial» de la llei societària quan indica que "els nuls no caduquen absolutament, sempre podran ser objecte d'impugnació. Els nuls, relativament, estan sotmesos al termini anual d'impugnació, transcorregut l'any sense accionar la impugnació esdevenen vàlids o no impugnables".

És Ávilla NAVARro, P., La sociedad limitada, op. cit., tom I, pàg. 422, qui, en canvi, es decanta clarament per l'aplicació de l'article $6 \mathrm{CC}$, "que no pot entendre's tàcitament derogat per l'article 115 LSA", i entén que els acords contraris a les normes de la LSA que regulen els requisits de convocatòria, funcionament $\mathrm{i}$ competència de la junta serien únicament els sotmesos al que denomina «nul-litat especial» de la LSA.

ALCALÁ DIAZ, M. A., La impugnación..., op. cit., pàg. 225: "en cas d'haver-se utilitzat la tècnica legislativa inversa, és a dir, partir dels principis generals per ressenyar només aquells supòsits que reben un tractament particular respecte dels principis esmentats, la menció relativa als acords contraris a l'ordre públic hauria estat innecessària".

ALCALÁ DIAZ, M. A., La impugnación..., op. cit., pàg. 224: "la distinció entre acords nuls per infracció de llei, en sentit general i per contravenció de l'ordre públic es produeix en la previsió de terminis diferents per a l'exercici de les accions i no en la delimitació de les causes en què n'estaria la seu conceptual. D'això es deriva que el legislador haja creat tres nivells diferents d'invalidesa dels acords socials en consideració a aspectes accessoris de naturalesa procedimental i no en relació amb elements juridicosubstantius, i així no aplica els principis essencials de la invalidesa dels actes i negocis jurídics i configura un sistema especial en consideració a la finalitat de política jurídica de protecció de la seguretat del tràfic. (...) El legislador, en consideració a les finalitats esmentades (...) ha establert particularitats de règim 
En tot cas, la importància de l'excepció legal establerta fa necessari intentar una major aproximació al concepte "d'acords que, per la seua causa o contingut, resulten contraris a l'ordre públic", en relació amb el qual la doctrina ha ressaltat tres aspectes: la necessitat que la contrarietat a l'ordre públic supose la vulneració d'una norma de caràcter imperatiu; la limitació als supòsits en què la vulneració de l'ordre públic es produïsca en virtut de la causa o contingut de l'acord, i finalment el significat que s'haja de donar a l'expressió ordre públic.

En primer lloc, efectivament, en la mesura que es tracta d'un tipus concret d'acords nuls, haurà de tractar-se d'acords que contradiguen qualsevol norma imperativa. En aquest sentit, no falten autors que opinen que acords contraris a $l^{\prime}$ ordre públic seran tots els que vulneren normes legals imperatives ${ }^{64}$, ni altres que opinen que es donen acords contraris a l'ordre públic "la formulació del qual freqüentment no està recollida per la llei" ${ }^{605}$.

(...) No obstant això, en relació amb els acords contraris a l'ordre públic, la menció del legislador és per reiterar que, pel que fa als acords esmentats, no seran d'aplicació les particularitats de règim previstes per als acords nuls per infracció de llei de manera que aquests se sotmetran al règim de nul-litat dels actes i negocis jurídics $i$, per tant, es manté la legitimació general i l'exercici de les accions no estaran sotmeses a cap termini d'impugnació".

${ }^{614}$ ARROYO, I., "Comentario al art. 56...», op. cit., pàg. 610 i 611: "s'han d'incloure en la nul.litat absoluta, com a contraris a l'ordre públic, tots els acords que disposen contràriament a allo establert expressament amb caràcter imperatiu en la LSL. (...) Tanmateix, (...) el fet de tenir una redacció imperativa no significa que necessàriament el seu contingut siga d'ordre públic. (...) L'ordre públic no entra en joc quan el supòsit de fet està tipificat o regulat per la llei, però bé admet pacte en contrari (...) o bé ho fa de manera dispositiva. (...) El silenci estatutari, en una matèria no imperativa, posa en marxa la previsió legislativa i si l'acord s'aparta del que estableix la llei, la contravenció és nul-la relativament perquè, si s'infringeix la llei, la matèria no és d'ordre públic". En el mateix sentit, afirma posteriorment: "siguen absoluts, contra l'ordre públic, o relatius, només contra la llei (norma dispositiva quan els contractants no han disposat una altra cosa en els estatuts socials), tots estan sotmesos al mateix règim de legitimació". En canvi, LEGROS, J-P., "La nullité des décisions...», op. cit., pàg. 289: “de vegades imperatiu es considera com sinònim d'ordre públic. En realitat, aquestes dues nocions no s'identifiquen. Les disposicions d'ordre públic comporten efectes que no produeixen les disposicions imperatives. Aquests efectes afecten l'aplicació de la llei en el temps el procediment i les condicions de confirmació [nota. 72: "L'ordre públic justifica l'aplicació de la llei nova als efectes dels contractes en curs, justifica la intervenció del ministeri públic...."]. En resum, tota disposicí d'ordre públic és imperativa, però tota disposició imperativa no és necessàriament d'ordre públic".

${ }^{615}$ SÁNCHEZ CALERO, F., Instituciones..., op. cit., pàg. 374 (tanmateix, vegeu nota infra, on, posteriorment, considera que la nul-litat absoluta només es donarà quan l'acord, a més d'infringir una norma imperativa, siga contrari per la seua causa o contingut a l'ordre públic); 
Per la nostra part, considerem que ha de prevaler la tesi que han de concórrer dos trets: vulneració de norma legal imperativa ${ }^{606} \mathrm{i}$, a més, que la transgressió de la norma siga d'una entitat que puga qualificar-se de "contrària a l'ordre públic $^{\prime \prime 60}$ siga quin siga el significat que, com veurem, haja d'atribuir-se a aquesta expressió; en un altre cas, no tindria sentit l'esment explícit als acords contraris a l'ordre públic com a subgrup específic dins de la categoria dels acords nuls.

A més, la vulneració de la norma d'ordre públic ha de produir-se en relació amb la causa o el contingut de l'acord. Això significa que quedaran únicament fora de la caducitat els acords la "motivació, el fonament o la finalitat (és a dir, la causa)" dels quals o la "matèria (és a dir, el contingut)" del qual vagen en

recull $i$ assumeix la tesi de contravencions a l'ordre públic no previstes en la llei; POLOSÁNCHEZ, E., Los administradores..., op. cit., pàg. 535 i 536. També RODRtGUEZ RUIZ DE VILLA, D., Impugnación..., op. cit., pàg. 90: "amb independència que aquest ordre públic haja tingut la seua plasmació legislativa en una norma jurídica expressa", i en pàg. 91: "actualment, el legislador permet la sol-licitud de nul-litat de tots aquells acords socials contraris a l'ordre públic, amb independència que estiga formulat o no en una disposició concreta, la qual cosa podrà plantejar problemes de determinació pràctica, a causa de la inseguretat que en tot cas comporten les clàusules generals del tipus de les de l'ordre públic, per a la delimitació del qual s'haurà d'esperar a l'actuació de la Jurisprudència". No se'ns ocorren, tanmateix, ni els autors esmentats en citen, exemples d'acords que vulneren l'ordre públic i no puguen entendre's afectats per una disposició legal. En aquest sentit, DÍAZ DE LEZCANO SEVILLANO, N., Los acuerdos del consejo..., op. cit., pàg. 252 considera que "el legislador s'ha preocupat de recollir en els texts positius els principis d'ordre públic, però encara que hi haja supòsits no plasmats en una norma imperativa, la seua violació tindrà la mateixa conseqüència que la infracció d'una norma imperativa per aplicació de l'article 1255 del Codi civil en el que s'estableix, com a límit a l'autonomia de la voluntat, l'ordre públic; per tant, l'acord que atempte contra aquest infringeix el precepte civil"

\footnotetext{
* RUBIO, J., Curso de derecho de..., op. cit., pàg. 244: "la infracció de l’ordre públic i dels bons costums queda compresa en la de la llei, la qual, a més, ens indicarà en cada cas l'abast i la conseqüència de la infracció".

ALCALA DÍAZ, M. A., La impugnación..., op. cit., pàg. 227, seguint una interpretació restrictiva de l'article $6.3 \mathrm{CC}$, considera que encara "cal distingir entre normes imperatives el contingut de les quals és precisament una prohibició i la infracció del qual, per tant, és sancionada amb la nul-litat radical segons els termes de l'article 6.3 CC i normes imperatives que constitueixen un límit a l'autonomia de la voluntat sense que la seua no-observança haja de donar lloc, necessàriament, a la nul-litat radical (...). Segons aquesta interpretació, l'article 6.3 seria la formulació concreta de la sanció de nul-litat per contravenció de l'ordre públic".
}

$$
\text { cis }
$$


contra de l'ordre públic, per la qual cosa han de descartar-se els acords que vulneren aspectes formals ${ }^{608}$.

Però l'aspecte que sens dubte, més inseguretat suscita és el concepte d'ordre públic. La doctrina ha apuntat diverses orientacions sobre la interpretació que s'ha de donar a la menció a l'ordre públic en seu d'acords societaris impugnables $^{609}$. Si, com sembla, la pretensió legislativa ha estat conciliar la

${ }^{608}$ ARROYO, I., «Comentario al art. 56...», op. cit., pàg. 610. En aquest sentit, POLO SÁNCHEZ, E., Los administradores..., op. cit., pàg. 535, es planteja el dubte sobre "si la referència a la causa 0 al contingut suposa una limitació o, pel contrari, una ampliació del concepte mateix d'ordre públic"; i RODRíGUEZ RUIZ DE VILLA, D., Impugnación..., op. cit., pàg. 91, nota 95 bis.

SORIA FERRANDO, J. V., La impugnación..., op. cit., pàg. 197 i 198, considera que la causa de l'acord s'identifica amb la pròpia del contracte de societat, això és, "l'exercici en comú de l'activitat que forma l'objecte social", si bé en la cooperativa la finalitat de repartiment del lucre $s^{\prime}$ haurà de substituir per la de satisfacció dels interessos o les necessitats comunes dels socis.

${ }_{\text {GNO }}$ ALCALÁ DÍAZ, M. A., La impugnació..., op. cit., pàg. 228: “el concepte d'ordre públic té un contingut proper als principis generals del Dret, considerats com a idees fonamentals $i$ informadores de les institucions $\mathrm{i}$ organització jurídica d'una comunitat entre les quals cal esmentar els bons costums, la moral o l'ordre economicojurídic"; ARANGUREN URRIZA, F. J., «Los órganos de la sociedad anónima...», op. cit., pàg. 527: "El concepte d'ordre públic és un concepte que remet als principis generals que configuren la societat anònima. (...) No es pot, tanmateix, descartar un acord contrari a l'ordre públic econòmic general..."; ARROYO, I, "Comentario al art. 56...", op. cit., pàg. 609 a 611: "la noció d'ordre públic és oberta, són els principis configuradors de l'ordenació que depenen de les circumstàncies d'un poble $\mathrm{i}$ d'una època determinada (STS 31 desembre 1979)"; CABALLOL I ANGELATS, L., "Comentario al artículo $115 . . . "$, op. cit., pàg. 1110 a 1113, inclou en el "contingut positiu de l'ordre públic" la violació de drets fonamentals i els delictes públics i semipúblics, i manifesta el seu dubte sobre la necessitat $\mathrm{d}$ 'incloure en el concepte els principis configuradors del tipus social; CABANILLAS SANCHEZ, Antonio, "Comentario al artículo 6.2", en AA. DD., Comentarios al Código Civil y Compilaciones forales, tom I, vol. 1, 2a ed., Edersa, Madrid, 1992, pàg. 760, recull les tesis de DE CASTRO i de DíEZ-PICAZO i GULLÓN: "es refereix als principis o les directives que en cada moment informen les institucions. (...) El concepte d'ordre públic és molt proper al dels principis generals del dret, ja que aquests no són una altra cosa que les idees fonamentals i informadores de l'organització jurídica de la comunitat. L'ordre públic no seria més que l'expressió que es dóna a aquells principis en l'àmbit de l'autonomia privada, consistent a limitar-ne el desenvolupament en allo que els vulnere"; Dízz PICAZO, I., i DE LA OLIVA, A., "Especialidades procesales...», op. cit., dubten entre equiparar-ho a "la violació de les normes legals imperatives" o identificar-ho amb "els principis generals o fonamentals del tràfic mercantil"; EMBID IRUJO, J. M., "Notas sobre la impugnación...", op. cit., pàg. 52: "l'expressió esmentada apareix en la nostra legislació bàsica de Dret privat en diferents apartats (articles 1.3, 12.3, 1255 del Codi civil, entre daltres), i expressa els principis essencials de l'ordenació que no poden ser desconeguts de cap manera (...). Al nostre parer, la ubicació sistemàtica de l'ordre públic en l'àmbit ara examinat justifica la seua hermenèutica en relació directa al conjunt de principis i normes reguladores de la societat anònima. Pensem en concret en els "principis configuradors" de l'esmentat tipus social que, amb caràcter de límit a l'autonomia de la voluntat dels socis, estableix l'article 10 LSA (...). Encara que l'expressió, certament, no resulta clara a primera vista, ofereix un camp més delimitat i precís on inserir també el significat de l'uordre públic»"; GIRÓN TENA, J., Derecho de sociedades anónimas..., op. cit., pàg. 319, considera que el concepte de norma d'ordre públic "ha d'esbrinar-se mitjançant una interpretació adequada", i s'ha de distingir entre les disposicions que estiguen fora de la LSA $i$ les que es troben en el text legal regulador del tipus social; 
seguretat jurídica i del tràfic mercantil amb el respecte als "principis essencials de l'ordenament que no poden ser desconeguts de cap manera" ${ }^{\prime 10}$, s'haurà d'intentar concretar quins dels esmentats principis poden veure's afectats per la causa o pel contingut d'un acord social.

En primer lloc, s'ha d'establir el principi d'interpretació restrictiva dels supòsits afectats de "nul-litat radical": a l'afirmació que "la regla general ha de ser la nul-litat relativa, perquè el principi general del dret societari és que les normes són dispositives (...) per això, el dubte ha d'interpretar-se a favor de la nul.litat relativa $^{\prime 611}$, ha de sumar-se la que la fluïdesa del tràfic mercantil demanda la

aquest últim cas "hauran de tenir-se en compte les circumstàncies particulars d'aquesta figura jurídica i de la seua regulació legislativa, d'on em sembla que ha de deduir-se que els acords incompatibles amb l'estructura d'aquesta (vegeu, sobre capital, trencant amb el principi d'estabilitat), o que trenquen les disposicions sobre protecció dels creditors (que en definitiva, atenen la perillositat de la figura social en el tràfic), donaran lloc a la nul-litat radical de l'acord"; POLOSÁNCHEZ, E., Los administradores..., op. cit., pàg. 535: "No ens correspon entrar en aquesta seu ni en el vaporós i imprecís concepte d'ordre públic -corporatiu, econòmic, social?"; RODRfGUEZ ARTIGAS, F., i ESTEBAN VELASCO, G., «Los órganos...”, op. cit., pàg. 114: "sembla que amb la categoria d'uacords contraris a l'ordre públic» s'està pensant en acords incompatibles amb l'essència de la societat anònima per atemptar als principis del capital, o a regles fonamentals del funcionament de la societat, o a la protecció dels interessos dels creditors"; VICENT CHULIÁ, F., Compendio crítico..., op. cit., pàg. 612: "pensem que els efectes de la caducitat han de ser plens; i l'ordre públic interpretat restrictivament (limitant-lo als principis i drets protegits per la Constitució)"; URÍA, R., MENÉNDEZ, A., i MUNNOZ, J. M., La junta general..., op. cit., pàg. 324 a 327, consideren que els acords contraris a l'ordre públic tenen el seu fonament en els principis generals del dret $\mathrm{i}$ els identifiquen amb els "principis o les directives que en cada moment informen les institucions jurídiques" i, si es trasllada aquesta noció a la disciplina legal de la SA, la identifiquen amb els " "principis configuradors" de la societat que l'article 10 de la llei posa com a última instància normativa, superior a les lleis mateixes, que no pot sobrepassar l'autonomia de la voluntat. (...) Aquests principis constituirien l'ordre públic de la vida corporativa; (...) d'altra banda, és evident que al costat d'aquest ordre públic que es fonamenta en els principis configuradors de la societat, hi ha el que dimana d'altres principis generals extracorporatius. En aquest sentit, és obvi el respecte a la moral i als bons costums i, a més, als postulats bàsics de l'ordre públic econòmic."

"EMBID IRUJO, J. M., «Notas sobre la impugnación...», op. cit., pàg. 52; SÁNCHEZ CALERO, F., Instituciones..., op. cit., pàg. 350, URf́, MENÉNDEZ, i MUÑOZ, La junta..., p. 324.

"ARROYO, I., Comentario..., op. cit., pàg. 611. En aquest sentit, vegeu la Resolució de la DGRN de 27.4.1989 en què es considera invàlida una clàusula estatutària que pretenia resoldre els empats en l'adopció d'acords pel consell d'administració d'una SA mitjançant l'aplicació de la Llei d'arbitratge. La DGRN entén que "pretendre aplicar aquesta institució en bloc, vulnera principis bàsics de l'ordre públic, ja que no correspon a l'autonomia privada definir el paper dels jutges i tribunals ampliant les funcions que constitucionalment o legalment li siguen dels manades", mentre que l'aplicació de la Llei d'arbitratge "podria donar lloc a la introducció dels òrgans judicials en comeses alienes a la seua funció de jutjar i fer executar el que s'ha jutjat". 
mínima intervenció juridicopública en l'àmbit de la llibertat de pactes juridicoprivats ${ }^{612}$.

D'altra banda, s'ha fet notar que les normes d'ordre públic han de caracteritzarse per estar promulgades en protecció d'interessos col-lectius, per damunt d'interessos particulars i privats i, per tant, sostretes a l'àmbit d'autonomia de la voluntat ${ }^{613}$; això fa que hagen de descartar-se les normes de caràcter imperatiu la finalitat exclusiva de les quals siga la protecció d'interessos particulars.

També s'ha apuntat la distinció entre normes d'ordre públic corporatiu i extracorporatiu ${ }^{614}$. Les primeres s'identifiquen amb els anomenats "principis configuradors" del tipus societari que es tracte; per a la integració de les segones s'han proposat "els postulats bàsics de l'ordre públic econòmic", les normes imperatives de sectors del dret diferents al societari (dret laboral, fiscal, penal, etc. $)^{615} \mathrm{i}$ "el respecte a la moral $\mathrm{i}$ als bons costums" "616. $^{\text {. }}$

Pel que fa als principis configuradors del tipus social, la majoria d'autors que aborden la qüestió es manifesten a favor de considerar-los inclosos o fins i tot

${ }^{612}$ La STS, Sala del civil, de 3-10-1995, RJA 1995/6982, en relació amb les causes de nul-litat de la societat, refereix el seu caràcter restrictiu, així com "la interpretació rigorosa i cenyida que ha de fer-se d'aquestes fora de temptacions expansionistes, per evitar que el tràfic civil $i$ comercial es veja obstaculitzat en el desenvolupament normal amb imposicions que es traduisquen en l'accentuació de l'intervencionisme administratiu o corporatiu, sobre la llibertat de contractació i sobre el dret a fundar societats de naturalesa civil o mercantil, siguen o no de responsabilitat limitada".

${ }^{613}$ AlCALÁ DíAZ, M. A., La impugnación..., op. cit., pàg. 231.

${ }^{614}$ URÍA, R., MENÉNDEZ, A., i MUÑOZ, J. M., La junta general..., op. cit., pàg. 326 i 327. En aquest sentit, ja hem vist com GIRÓN TENA, J. Derecho de sociedades anónimas, op. cit., pàg. 319 assenyalava com a exemples d'acords contraris a l'ordre públic, al costat d'acords incompatibles amb l'estructura de la societat, uns altres que trenquen les disposicions sobre protecció dels creditors; RUBIO, J., Curso..., op. cit., pàg. 245 també inclou entre els preceptes legals en defensa els acords contraris a l'estructura essencial de la societat anònima, a les normes en defensa del capital o als drets essencials dels socis".

615 ALCALÁ DíAZ, M. A., La impugnación..., op. cit., pàg. 236. La STS, Sala del Social, de 14.7.1989, RJA 1989/5471 recorda que "la nul-litat dels acomiadaments (...) és matèria d'ordre públic", per la qual cosa la junta general d'una societat anònima no pot entrar a determinar-la. 
d'identificar-los amb el concepte d'ordre públic ${ }^{617}$. La noció de principis configuradors s'ha elaborat fonamentalment a l'entorn de la societat anònima, la llei de la qual els esmenta (encara que no els explicita), en l'article 10, com a "última instància normativa, superior a les lleis mateixes, que no pot sobrepassar l'autonomia de la voluntat" ${ }^{\prime \prime 18}$.

MORILLAS JARILLO, M. J., i FELIÚ REY, M. I., Curso..., op. cit., pàg. 255.

En contra, ALCALÁ DíAZ, M. A., La impugnación..., op. cit., pàg. 264 i 265: " Considerar que els principis configuradors de la societat anònima constitueixen l'ordre públic de la corporació suposa traslladar a una entitat juridicoprivada el sentit d'aquest concepte en l'ordenament jurídic en general, i es força així una noció jurídica per explicar un tipus societari concret l'estructura del qual no pot connectar-se a conceptes generals de l'ordenament jurídic. (...) Les normes que es manifesten com expressió d'elements configuradors de la societat anònima constitueixen límits no derogables a l'autonomia privada, sense que d'això puga derivar-se que constitueixen l'ordre públic de la corporació perquè aquest concepte té una significació aliena al concepte jurídic de societat anònima com a organització".

"s URfA, R., MENÉNDEZ, A., i MUÑOZ, J. M., La junta general..., op. cit., pàg. 326. Vegeu una extensa exposició de l'evolució de l'anomenada "teoria de les bases essencials" de la societat anònima en tant que "instrumentació tècnica dels límits dels poders de la junta extraordinària en DUQUE DOMÍNGUEZ, J. F., "Introducción a la protección...», op. cit., pàg. 66 i ss. GARRIGUES, J., "La protección de las minorías...", op. cit., pàg. 106, considera que "la doctrina de les bases essencials s'identifica amb la dels drets individuals de l'accionista, que constitueixen així un límit infranquejable de la competència de l'assemblea", ja que "l'accionista entra en la societat perquè la configuració legal de la societat anònima respon millor a una motivació econòmica determinada"; mentre que DUQUE DOMínGUEZ, J. F., en Tutela..., op. cit. pàg. 44 destaca que "la vulneració dels drets individuals no és sinó la infracció d'una base essencial". Per la seua part, GARRIDO DE PALMA, V. M., en "Autonomía de la voluntad...», op. cit., pàg. 1878 a 1881, defineix els principis configuradors com aquelles característiques de la societat que es constitueixen en "punt de partida indiscutible, de base i sosteniment de la institució en estudi, de manera que la seua alteració desfigura el tipus social, i intenta una concreció $i$ classificació d'aquests en l'àmbit de la societat de responsabilitat limitada. També tracten el concepte de principis configuradors de la SA i de la SRL, EMBID IRUJO, J. M., i MARTíNEZ SANZ, F., "Libertad de configuración...», op. cit., pàg. 17 a 23.

La teoria de les bases essencials de la societat anònima en tant que límit als poders de la junta general pot veure's en ARANGUREN URRIZA, F. J., "Los órganos de la sociedad anónima...», op. cit., pàg. 527; EMBID IRUJO, J. M., en «El voto plural...», op. cit., pàg. 691 i en "Notas sobre la impugnación... op. cit., pàg. 52; GARRIGUES, J., Curso..., op. cit., pàg. 497; GIRÓN TENA, J., Derecho de sociedades anónimas, op. cit., pàg. 319; RUBIO, J., Curso..., pàg. 175 a 177; URfA, R., MENÉNDEZ, A., i MuÑ̄Zz, J. M., La junta general..., op. cit., pàg. 324, 326 i 327.

En contra, ALFARO AGUILA-REAL, J., "Conflictos intrasocietarios...», op. cit., pàg. 1133 a 1135, per considerar la doctrina dels "principis configuradors" del tipus de part "d'una concepció lamentablement molt estesa en la nostra cultura jurídica segons la qual el Dret de societats no és Dret contractual en sentit estricte" que faria que no es predique "el seu caràcter prima facie dispositiu".

ALONSO SOTO, Ricardo, "Consideraciones sobre el ejercicio de la acción social de responsabilidad de los administradores de la sociedad anónima», La Ley, núm. 5090, 5.7.2000, pàg. 2 i 3, comenta la Sentència del Jutjat de 1a Instància núm. 7 de Madrid de 27.7.1999 ("cas $\mathrm{K} \mathrm{O}^{\prime \prime}$ ), que assumeix el concepte d'ordre públic encunyat per GIRÓN ("s'entén aquest com a protecció ilitat amb l'estructura de la societat o com a transgressió de les normes sobre protecció dels creditors socials"), qualifica com a contrari a l'ordre públic l'acord de la junta 
Com s'ha indicat en el capítol primer (vegeu l'epígraf 3.3), en traslladar el concepte dels "principis configuradors" al tipus cooperatiu, s'ha identificant-los amb els principis cooperatius ${ }^{619}$ establerts Cooperativa Internacional, que han estat incorporats a tots els textos legals cooperatius de l’Estat espanyol.

En relació a la menció en «ordre públic econòmic» com a integrant del concepte d'ordre públic extrasocietari, sembla que ha d'entendre's conformada pels "principis generals o fonamentals del tràfic mercantil»" ${ }^{620}$, com ara les normes imperatives i prohibitives sobre competència o sobre regulació del mercat.

general que intentava validar una decisió anterior dels administradors en una matèria (l'acció social de responsabilitat) que és competència de la Junta, "ja que versa $\mathrm{i}$ incideix directament sobre l'atribució legal o el repartiment de competències entre la junta general d'accionistes $i$ l'òrgan d'administració de la societat i, per tant, s'oposa als principis configuradors de l'esmentat tipus social tal com apareixen dissenyats en la Llei de societats anònimes".

VICENT CHULIA, F., «La asamblea...», op. cit., pàg. 148, nota 1, trasllada a l'àmbit cooperatiu la doctrina mercantilista respecte de la societat anònima en el sentit de considerar pertanyent a les anomenades «bases essencials de la societat» la matèria relativa a la seua estructura orgànica, en què s'inclouen assumptes com ara el nombre d'òrgans, les seues competències respectives i les

619 ALFONSO SÁNCHEZ, R., "Aspectos básicos...», op. cit., pàg. 165 i 166; BASSI, A., Le socieț cooperative, op. cit., pàg. 14; EMBID IRUJO, J. M., «El voto plural...», op. cit., pàg. 691; FAJARDO GARCÍA, I-G, «El derecho cooperativo...», op. cit., pàg. 34; VICENT CHULIÁ, F., «Mercado, principios cooperativos...», op. cit., pàg. 12. Es refireixen concretament a la inclusió dels principis cooperatius, en tant que principis configuradors de la cooperativa, en el concepte d'ordre públic MORILLAS JARILlo, M. J. i Feliú REY, M. I., Curso..., op. cit., pàg. 255.

${ }^{620}$ URÍA, R., MENÉNDEZ, A., i MUÑOZ, J. M., La junta general..., op. cit., pàg. 327: "Les societats el camp d'acció de les quals és el món econòmic i financer, poden amb les seues decisions arribar a infringir la disciplina coactiva ordenadora del mercat en què operen. I aquests acords, per infringir unes normes, la majoria de les vegades tenyides pels imperatius que inspiren l'ordre públic de l'economia, serien (...) radicalment nuls i no susceptibles de millora"; ALCALA DfAZ, M. A., La impugnación..., op. cit., pàg. 231 i 239: "Així doncs, seran nuls els acords el contingut dels quals infringisca preceptes reguladors del funcionament del mercat, com les normes sobre competència o les que afecten el mercat financer i de capitals"; així mateix, en "El conflicto...", op. cit., pàg. 123, inclou entre els acords nuls per contravenció de l'ordre públic extracorporatiu "la lesió de determinats interessos, com ara el dels treballadors protegits a través de normes que afecten l'estructura societària perquè imposen determinades formes de participació en els òrgans, com la cogestió o la vulneració de preceptes dictats en protecció dels inversors", ja que la defensa d'aquests interessos "no pot integrar-se en el concepte d'interès social utilitzat en la causa d'anul-labilitat" $i$ a la seua transcendència $i$ la seua vinculació a aspectes reguladors del mercat $i$, per tant, a aspectes imperatius i no derogables per voluntat privada. RODRfGUEZ RUIZ DE VILLA, D., Impugnación..., op. cit., pàg. 91, identifica la noció d'ordre públic en l'àmbit societari com essencialment vinculada al seu aspecte econòmic, adaptat al sistema d'economia de mercat consagrat en la Constitució. 
També $s^{\prime}$ ha proposat la inclusió entre els principis generals extracorporatius que conformarien el concepte d'ordre públic, el respecte a la moral i als bons costums $^{621}$, com a límits a l'autonomia contractual, "en defensa de valors de naturalesa col-lectiva que afecten la convivència dels ciutadans i l'organització social $^{1 / 622}$. Tanmateix, això planteja dos interrogants: la falta de menció expressa per part de la normativa cooperativa o societària i la indeterminació del concepte.

Respecte al primer, $\mathrm{s}^{\prime}$ ha assenyalat ${ }^{623}$ que el Codi civil estableix en diversos articles $(1116,1255,1271$ i 1275 CC) la moral i els bons costums com a límits expressos a l'autonomia de la voluntat, límits que invaliden el contracte o negoci que els excedisca.

"AlCALÁ DIAZ, M. A., «El conflicto...», op. cit., pàg. 237 a 246; DÍAZ DE LEZCANO SEVILLANO, N., Los acuerdos del consejo..., op. cit., pàg. 250 i 253-256; DUQUE DOMÍNGUEZ, J. F., Tutela..., op. cit. pàg. 51 a 53; GARRIGUES, J., «La protección de las minorías...», op. cit., pàg. 107; RODRf́GUEZ RUIZ DE VILLA, D., Impugnación..., op. cit., pàg. 91 i 92; VICENT CHULIÁ, F., «El derecho de los órganos...», op. cit., p. 526; URÍA, R., MENÉNDEZ, A., i MUÑOZ, J. M., La junta general..., op. cit., pàg. 327 i 331 . En relació amb la matèria, ALCALÁ DIAZ, M. A., indica en «El conflicto...», op. cit., pàg. 116, nota 68, que "en Dret alemany, la infracció dels bons costums a través del contingut de l'acord se sanciona amb la nul-litat radical, segons que s'estableix en el \#241.4 AktG, (...), en els ordenaments jurídics d'orientació llatina (...) la infracció dels bons costums se sotmetrà, en tot cas, als supòsits de nul-litat radical i imprescriptible a través de la seua inclusió dins del concepte de contravenció de l'ordre públic (article 115 en relació amb el 116 de la LSA, així, també article 2379 del CC i article 360.2 LSC francesa, article 58 del CSC portuguès del 1986)". DUQUE DOMf́NGUEZ, J. F., Tutela..., op. i loc. cits. explica l'origen i les raons de la diferent infracció en l'ordenament alemany i en els llatins.

DiAZ DE LEZCANO SEVILLANO, N., Los acuerdos del consejo..., op. cit., pàg. 253 a 256, argumenta els motius que, al seu entendre, qualifiquen l'acord contrari a la moral o als bons costums com un dels subtipus d'acords nuls, al mateix nivell que els contraris a l'ordre públic. En la mateixa línia, però en l'àmbit cooperatiu i dels acords del consell rector, LASSALETA GARCíA, P., "Impugnación...», op. cit., pàg. 335 i 336.

En contra de la seua impugnabilitat, si bé en el context de la LSA de 1951, GIRÓN TENA, J., Derecho de sociedades anónimas, per a qui la supressió en l'esmentat text legal de la menció que es feia en l'Avantprojecte de l'Institut d'Estudis Polítics a les infraccions contra els bons costums, era significativa de la intenció del legislador d"'evitar la gravetat de la nul-litat en aquest cas, en la mesura que el perill ve de la indeterminació del concepte com a clàusula general".

Alcalá Díaz, M. A., en la impugnación..., op. cit., pàg. 237; en aquesta pàgina i en les seguients l'autora du a terme una extensa anàlisi de la nul.litat per infracció dels bons costums.

A., en La imín MENÉNDEZ, A., i MUÑoz, J. M., La junta general..., op. cit., pàg. 331; ALCALÁ DíAZ, M. 
Quant a la concreció dels conceptes de moral i bons costums ${ }^{624} s^{\prime}$ apunta cap a la seua identificació amb "una sèrie de regles segons les quals es jutgen les conductes i els comportaments contractuals dels particulars d'acord amb el principis positius o negatius basats en idees o creences comunes als membres d'un grup social"; es tractaria amb això de connectar l'ordenament jurídic amb els valors ètics predominants en una societat en un moment històric determinat ${ }^{625}$, encara que es requereix que aquests valors tinguen un reflex "implícit o explícit" en l'ordenament jurídic positiu ${ }^{626}$.

En tot cas, prenent com a referència les diverses aportacions doctrinals exposades, sembla clar que el concepte d'ordre públic no gaudeix d'un contingut unívoc d'acceptació general, a més a més de caracteritzar-se per la variabilitat a través del temps ${ }^{627}$, raó per la qual resultaria infructuós intentar-ne una elaboració completa, encara que fora mitjançant la tècnica d'exposar

${ }^{624}$ Respecte a les diferències entre ambdós conceptes, s'ha apuntat que el concepte de moral té
connotacions referides a l'àmbit de la personalitat, mentre que el de bon costum es referiria a un
àmbit més ampli, el de les relacions socials (ALCALA DÍAZ, M. A., La impugnación..., op. cit., pàg.
243 ), si bé la doctrina civil majoritària considera que les diferències entre ambdós conceptes són
simples matisacions sense transcendència jurídica (DE CASTRO Y BRAVO, F., El negocio jurídico,
op. cit., pàg. 245 i 246; REVERTE NAVARRO, A., Comentarios al Código civil..., op. cit., pàg. 257 i
258 ).

${ }^{625}$ ReVerte NAVArro, Antonio, Comentarios al Código Civil y Compilaciones forales, Madrid, 1993, tom XVII, vol. 1 A, article 1255, pàg. 257. En relació amb això, CABALLOL I ANGELATs, L., "Comentario al artículo 115", fa una proposta innovadora, en propugnar que en l'actualitat tenen una repercusió especial en la conformació del contingut de l'ordre públic tant l'anomenada "globalització de l'economia" com l'exigència del respete al pluralisme cultural i ideològic; així, "la globalització afavoreix la reducció de la influència de l'ordre públic particular" $\mathrm{i}$ "el pluralisme (...) té com a conseqüència la reducció progressiva dels continguts exclusius del grup majoritari o dominant en la conformació de l'ordre públic general, per a passar a quedar constituït per aquells continguts que el converteixen en una garantia global de l'exercici de llibertat col-lectiva i individual que està implícita en l'accepció de la pluralitat".

${ }^{626}$ AlCAlÁ DíAz, M. A., en La impugnación..., op. cit., pàg. 244: "des d'aquesta perspectiva, l'acord de la junta general que decideix la modificació de l'objecte social en el sentit de realitzar activitats que són considerades immorals donaria lloc a la nul-litat de l'acord per contravenció de la moral o dels bons costums (...). Això al marge que, a més d'immorals puguen qualificar-se com a delictives (...), amb independència que la normativa penal no puga ser aplicada per la simple adopció de l'acord i només puga ser transcendent des del punt de vista d'aquest àmbit jurídic una vegada que l'acord haja estat executat".

${ }^{227}$ Merino Hernández, Santiago, Rodríguez Álvarez, M. Pilar, i SAN José Martinez, Fernando, Manual de arbitraje cooperativo vasco, Consejo Superior de Cooperativas de Euskadi, 
diferents classes de supòsits; s'haurà d'atendre cada cas concret per intentar determinar si estem davant d'un acord que contravinga l'ordre públic ${ }^{628}$.

Finalment, cal esmentar l'absència d'una indicació legal explícita sobre la caducitat o no dels acords contraris a l'ordre públic adoptats per l'òrgan d'administració $^{629}$. Un sector de la doctrina fa una interpretació literal de l'omissió normativa, i nega per a aquests la distinció entre acords nuls en general i acords nuls contraris a l'ordre públic, basant-se en una major necessitat de seguretat jurídica en els acords d'aquest òrgan ${ }^{630}$. Corroboraria aquesta interpretació el fet que, en seu de junta/assemblea general, la distinció entre acords que infringeixen l'ordre públic i la resta d'acords nuls no es fa en relació amb la determinació de les causes d'impugnació, sinó a l'hora d'establir els terminis d'exercici de l'acció; de la seua banda, la regulació de la impugnació dels acords del consell, mentre que per a la distinció entre acords nuls i anul-lables fa una tramesa implícita a la junta/assemblea, no renuncia a regular els seus propis terminis, sense esmentar, tanmateix, explícitament els acords contraris a l'ordre públic.

Tanmateix, altres autors estimen que la inexistència de menció expressa no permet de concloure la caducitat dels acords contraris a l'ordre públic. Es considera que tal referència a la no-caducitat no seria necessària, bé perquè s'atribueix als elements integrants del concepte d'ordre públic el caràcter de

Vitòria, 2001, pàg. 34: "el contingut concret de l'ordre públic haurà de ser fixat en cada cas pels Tribunals, segons quina siga la realitat social del temps i lloc al qual haja d'aplicar-se".

URtA, R., MENÉNDEZ, A., i MUÑOZ, J. M., La junta general..., op. cit., pàg. 325 a 327 . En el mateix sentit, ARROYO, I., «Comentario al art. 56...», op. cit., pàg. 610; i LEGROS, J-P., "La nullité des decisions...», op. cit., pàg. 289.

\footnotetext{
També s'ha fet notar la falta de referència explícita a l'excepció relativa als acords contraris a l'ordre públic en la regulació per la LSA (article 246) de la nul.litat de la fusió ja inscrita: GÓMEZ PORRÚA, J. M., La fusión de sociedades anónimas..., op. cit., pàg. 260; i MARTíNEZ SANZ, F., "La nulidad de la fusión...», op. cit., pàg. 76 a 78.

" Dlaz De Lezcano Sevillano, N., Los acuerdos del consejo..., op. cit., pàg. 253; RODRíGueZ ARTIGAS, F., i ESTEBAN VELASCO, G., «Los órganos...», op. cit., pàg. 140; SÁNCHEZ CALERO, F., Administradores..., op. cit., pàg. 540. POLO SÁNCHEZ, E., Los administradores..., op. cit., pàg. $523 \mathrm{i}$ 535, també interpreta l'omissió com a voluntat de sotmetre al termini de caducitat els acords de l'òrgan d'administració contraris a l'ordre públic, si bé considera poc afortunat el criteri.
} 
principis generals del dret ${ }^{631}$, bé perquè s'interpreta que la impugnació dels acords nuls per infracció de l'ordre públic s'ha de realitzar mitjançant l'aplicació del règim general de nul-litat dels actes i negocis jurídics, en virtut del qual no s'estableix termini per a l'exercici de les accions i està legitimada tota persona titular d'un interès legítim ${ }^{632}$

Per la nostra part, subscrivim la tesi que manté que el mateix raonament que porta a l'aplicació analògica dels conceptes d'acord nul i anul-lable de la junta/assemblea general a l'òrgan d'administració, serveix per estendre aquesta interpretació al concepte d'acord contrari a l'ordre públic ${ }^{633}$. Si com hem vist el legislador no ha pogut sostraure's a la impossibilitat de regularització dels acords de la junta/assemblea contraris a l'ordre públic, no sembla la seguretat del tràfic mercantil argument suficient per permetre que els acords de l'òrgan d'administració puguen vulnerar "principis essencials de l'ordenació que no poden ser desconeguts de cap manera".

\subsection{Acords anul-lables} pàg. 535: "Novament s'ha de considerar ací que estem en presència de la mateixa tramesa estableix la secció 2a per als acords del consell els conceptes substantius que en la matèria que hi haja raons perquè no ho siga), ni tan s analògic. El concepte d'ordre públic, a què tants seria necessari recórrer a l'aplicació del criteri els articles 1.3,6. 12.3, 1255 obligatoris per a la conservació del $\mathrm{CC}$ ) està constituït per principis jurídics absolutament de $5 / 4 / 1966 \mathrm{i} 31 / 12 / 1979$ ) $\mathrm{i}$ la fordre social en un poble $\mathrm{i}$ en una època determinats (SSTS (...). Des d'aquest punt de vista constitueix del qual (s'ha dit) sovint no està recollida per la Llei acords socials del consell, que s'ha de conside límit immanent a la validesa, en aquest cas, dels Llei no ho haja establert expressament". Enderar radicalment nul i imprescriptible encara que la op. cit., pàg. 350 .

JUSTE MENCf́A, J., Los derechos..., op. cit., pàg. 403: "Ara bé, si s'admet aquest raonament, resultarà extraordinàriament important la delimitació correcta dels supòsits de contrarietat a l'ordre públic, ja que la seguretat sobre la validesa dels acords és un valor de més importància en la seua aplicació a l'activitat de l'òrgan administratiu".

${ }^{\wedge 12}$ AlCALÁ DÍAZ, M. A., La impugnación..., op. cit., pàg. 175, 176 (en nota 159), i 221.

${ }^{423}$ POLO SÁNCHEZ, E., Los administradores..., op. cit., pàg. 535. 
Mentre que, com hem vist, per construir una nul-litat dels acords socials que intenta compaginar la seguretat jurídica i l'efectivitat i agilitat del tràfic mercantil, tant la legislació societària, com la cooperativa se separen del model de nul-litat general dels negocis jurídics, el règim de l'anul-labilitat segueix bàsicament el patró del que està previst per als negocis jurídics anul-lables: la convalidació dels acords anul-lables pel transcurs del temps, després d'un breu termini de caducitat, i l'establiment d'una legitimació activa restrictiva per a la seua impugnació ${ }^{634}$.

D'altra banda, la identitat entre les opcions legislatives cooperatives i la societària, com veurem en analitzar la impugnació dels acords de l'òrgan d'administració, ometen definir què ha d'entendre's per acords anul-lables de l'esmentat òrgan (articles 37.1 LCoop, 41.6 LCCV i 143.1 LSA), la qual cosa ha portat algun autor ${ }^{635}$ a qüestionar-se si aquesta omissió respon a l'assumpció implícita de la definició que es fa per a l'assemblea general d'acords nuls i anul-lables o si ha d'entendre's que es renuncia a aquesta definició per intranscendent, ja que hi hauria una unificació del procediment d'impugnació en seu d'acords de l'òrgan administratiu. Aquesta segona interpretació se sustentaria també en l'observació que la tramesa que s'efectua en el mateix article a l'aplicació de les normes reguladores de l'assemblea general, es fa expressament i exclusivament per al "procediment" o la "tramitació" de la impugnació, no per a les causes que la provoquen.

Considerem, tanmateix, que ha de recórrer-se a l'aplicació analògica d'allò previst per als acords de l'assemblea general, encara que la llei no remeta expressament a aixó ${ }^{636}$, ja que la qüestió no és irrellevant, almenys en l'àmbit de

\footnotetext{
"Rodríguez Ruiz de VILLA, D., Impugnación..., op. cit., pàg. 94.

"JUSTE MENCIA, J., Los derechos..., op. cit., pàg. 395. Mis DIAZ DE LEZCANO SEVILLANO, N., Los acuerdos del consejo..., op. cit., pàg. 243, 244 i 256; POLO
SÁNCHEZ, E., Los administradores..., op. cit., pàg. 529 i 530; SÁNCHEZ CALERO, F.,
Administradores..., op. cit. pàn 540. Administradores..., op. cit., pàg. 540 .
} 
la llei cooperativa estatal, en la qual s'estableixen diferents legitimacions i diferents terminis d'impugnació.

Quant al tipus d'acords que es consideren anul-lables, també la legislació cooperativa (articles 31.1 i 2 LCoop i 36.1 i .2 LCCV) incorpora l'opció legislativa societària: es consideren anul-lables els acords que s'oposen als estatuts o que lesionen els interessos de la cooperativa en benefici d'alguns socis o de tercers. En relació amb els tipus assenyalats s'ha de recordar, tanmateix, que, com ha quedat apuntat supra, s'han de considerar inclosos alguns supòsits no expressament esmentats pels textos legals.

Així, la infracció de llei dispositiva s'equipara a la infracció estatutària, en entendre's que l'omissió de regulació estatutària expressa en una matèria prevista dispositivament en un text legal equival a una submissió voluntària a aquesta per part dels socis que, d'altra banda, podran, en qualsevol, moment evitar-la mitjançant la modificació estatutària corresponent ${ }^{637}$. Per tant, l'acord que vulnere un text legal dispositiu serà anul.lable.

També hem vist com els supòsits de conflicte d'interessos entre la cooperativa i els seus socis i administradors pot donar lloc a acords anul-lables. Aquests supòsits de conflicte requereixen, per generar l'anul-labilitat de l'acord, bàsicament, que el soci en conflicte haja participat en la votació corresponent, que el seu vot haja estat determinant per a l'adopció de l'acord i que la norma que establisca la situació de conflicte siga una norma estatutària (o legal dispositiva) ${ }^{638}$.

Finalment, s'ha de tenir present que, de vegades, entre l'anul-labilitat i la validesa dels acords hi ha supòsits en què no es dóna "el compliment absolut de les normes", però que no en comportarien la impugnació; és el que s'ha

${ }^{637}$ Vegeu supra, en l'epígraf 1.1. in fine. 
denominat "infraccions intranscendents" ${ }^{1639}$. Per discriminar en aquests casos si s'ha d'aplicar la sanció d'anul-labilitat o respectar-ne la validesa s'ha proposat atendre els interessos que les normes infringides tracten de protegir per comprovar si aquests interessos han sofert o no perjudici ${ }^{640}$.

" Sobre el conflicte d'interessos com a causa de nul-litat o anul-labilitat de l'acord adoptat amb la participació del soci en conflicte, vegeu supra l'epígraf 2.1.1. d'aquest capítol mateix.

"GIRÓn TENA, J., Derecho de sociedades anónimas, op. cit., pàg. 325: "per exemple, citació per a un lloc dels afores que només difícilment satisfaria l'obligació de fer les Juntes en la localitat de la Societat, però amb concurrència de la immensa majoria dels socis; convocatòria en la qual hi haja alguna expressió de significat equívoc i que s'aclarisca, prèviament a la Junta, però una vegada reunida, etc."

"GIRÓN TENA, J., Derecho de sociedades anónimas, op. cit., pàg. 326. 


\section{CAPÍTOL TERCER}

\section{L'OBJECTE DE LA IMPUGNACIÓ (II): SEGONS L'ÒRGAN DEL QUE EMANEN. ACORDS NO IMPUGNABLES}

\section{Introducció}

Un dels aspectes de la impugnació d'acords socials on pot observar-se clarament la diferència estructural i teleològica entre cooperatives i societats de capital és el relacionat amb l'origen dels acords ${ }^{611}$.

En la cooperativa, la participació del soci no és únicament un dret, sinó una obligació, i el seu vessant polític es realitza segons el principi democràtic d"'una persona, un vot"; a més, és possible la intervenció de persones no sòcies en les decisions socials, en la gestió i, fins i tot, en el control de la gestió. La necessitat de donar curs a la proliferació de les diverses ocasions i modalitats de participació fa que es multipliquen els òrgans socials ${ }^{62}$. D'altra banda, el fet que la participació s'articule normalment segons el principi igualitari $\mathrm{d}^{\prime \prime \prime}$ una persona, un vot" influeix en l'estructura dels òrgans en què es materialitza, que

641 URÍA, R., MENÉNDEZ, A. i VERGEZ, M., «Sociedades cooperativas», op. cit., pàg. 1289, en referir-se a la regulació de l'assemblea general ja assenyalen que es tracta de "normes paral-leles a les que ordenen la convocatòria, la constitució i el funcionament de la junta general de les societats mercantils de capital encara que amb peculiaritats pròpies, algunes de les quals responen al matís personalista de la participació del soci [...] sens dubte amb la finalitat de fer efectiu el principi de màxima democratització personal no capitalista a què respon aquesta societat".

642 GALGANO, F., El negocio jurídico, op. cit., pàg. 403: “El concepte d'òrgan té l'origen en l'antiquada concepció orgànica de la persona jurídica com a entitat social que, a semblança de l'home, forma la seua pròpia voluntat (a l'assemblea) i la realitza (mitjançant els administradors). L'ús d'aquest concepte, que ha entrat també en el llenguatge legislatiu, està actualment deslligat de qualsevol referència a la teoria orgànica [...]: indica simplement a aquells que tenen el poder de realitzar actes jurídics vinculants per a una organització col-lectiva, siguen actes interns, com els acords assemblearis, o actes externs, com els contractes 
adopta amb més freqüència la forma pluripersonal col-legiada i que més habitualment que en les societats de capital estableix representacions de determinats col-lectius, amb la finalitat de garantir la seua participació. Tot açò fa necessari analitzar quan i de quina manera els acords i les decisions d'aquesta multiplicitat d'òrgans poden ser objecte d'oposició.

Una de les principals novetats que, en el seu moment, va aportar la legislació cooperativa en aquesta matèria va ser la regulació explícita de la impugnabilitat dels acords de l'òrgan d'administració, que la LSA de 1951 no regulava i que havia donat lloc a una interpretació jurisprudencial discordant i a la divisió d'opinions doctrinals. Però, a més, com veurem, tant la legislació cooperativa com la de societats de capital han anat incorporant la possibilitat d'impugnar també els acords d'altres òrgans col-legiats i, fins i tot en algun cas, les decisions d'òrgans unipersonals.

En relació amb la LGC, MARÍN LÓPEZ establia quatre grups d'acords impugnables en la cooperativa, segons l'òrgan emissor de l'acord ${ }^{63}$ :

a) Acords de l'assemblea general, incloent-hi tots els obtinguts en qualsevol classe d'assemblea general: ordinària, extraordinària, de delegats o de segon grau, i fins i tot de liquidació (i encara que aquest autor no l'esmenta, també s'ha d'entendre inclosa la universal).

b) Acords del consell rector, on la seua impugnació judicial directa constitueix una novetat legislativa en $l^{\prime}$ àmbit cooperatiu estata $1^{\text {sto }}$.

fets pels administradors".

643 MARín LÓPEZ, Juan José, «Novedades de la Ley general de cooperativas de 2 de abril de 1987 en materia de impugnación de acuerdos sociales», La Ley, 1988-2, pàg. 1117 a 1124 .

644 estanmateix, matisa MARfN aquesta novetat en un doble sentit: d'una banda, la regulació ja ja regu recollida en tres de les quatre lleis autonòmiques llavors en vigor i, d'altra banda, la LGC regulava la possibilitat d'impugnació "intracooperativa" per a davant de l'assemblea, l'acord 
c) Acords del comitè de recursos.

d) Actes i decisions de la direcció, els quals, en virtut de l'article $66,1,2 \pi$ paràgraf de la LGC, es consideraven com a acords adoptats pel consell rector a l'efecte de la seua impugnació possible (la desaparició d'aquesta menció a la LCoop i el canvi de la concepció de la direcció com a òrgan per la direcció com a apoderament general s'analitzen infra en l'epígraf 2.5).

A més, MARÍN LÓPEZ assenyalava la falta de pronunciament de la LGC respecte de la possibilitat d'impugnació dels acords de les seccions de la cooperativa i els de les juntes preparatòries de les assemblees generals mitjançant delegats ${ }^{\text {ats }}$. Pel que fa als acords de les assemblees de socis de les seccions, com veurem més endavant (epígraf 1.4), davant el silenci assenyalat de la LGC ${ }^{64}$, la LCCV (article 7.4) no sols en preveu expressament la impugnació, sinó també la suspensió possible per l'assemblea general, mentre que la LCoop només esmenta la suspensió dels acords de la secció que l'assemblea general "considere contraris a la llei, als estatuts o a l'interès general de la cooperativa".

Quant a la impugnació dels acords de les juntes preparatòries de les assemblees de delegats, la LCCV (article 35.6) primer i la LCoop (article 30.5) després, han explicitat que "només serà impugnable l'acord adoptat per l'assemblea de

ratificador del consell de la qual sí que era impugnable, i es donava una mena d'impugnació judicial "indirecta"; aquesta "doble instància interna", com veurem, es manté en la LCoop.

645 Sobre la possibilitat d'impugnació dels acords de les juntes preparatòries en la normativa anterior a la LCoop, poden veure's MUÑNOZ VIDAL, A. B., El proceso..., op. cit., pàg. 28 i 29; $\mathrm{PAZ}$ CANALEJO, N., en PAZ CANALEJO, N. i VICENT CHULIA, F., Ley general..,. op. cit., pàg. 579; i VICENT CHULIÁ, F., «La asamblea...», op. cit., pàg. 467 i 468, i «El derecho de los órganos...», op. cit., pàg. $520 \mathrm{i} 521$.

646 Sobre el règim jurídic dels òrgans de les seccions d'acord amb la normativa anterior a la LGC, poden veure's MUÑOZ VIDAL, A. B., El proceso..., op. cit., pàg. 30 a 35; SANTOS MARTINEZ, Vicente, "Las secciones de las cooperativas en el derecho español", en AA. DD., Estudios de derecho mercantil en homenaje al profesor Antonio Polo, Madrid, 1981, pàg. 1084 a 1101; i VICENT CHULIÁ, F., «La asamblea...»..., op. cit., pàg. 467 i 468, «El derecho de los órganos...», op. cit, pàg. 521; ja segons la LGC, PAZ CANALEjo, N., en PAZ CANALEjO, N. i ViCENT CHULIÁ, F., Ley 
delegats, encara que per examinar el seu contingut $i$ validesa es tindran en compte les deliberacions $\mathrm{i}$ els acords de les juntes preparatòries" (les especialitats que el procés impugnador presenta en aquestes "assemblees bifàsiques" s'analitzen en l'epígraf 1.3).

Per la nostra part, considerem que també s'ha de reflexionar sobre la possibilitat d'impugnar els acords i les decisions d'altres òrgans que poden ser constituïts en les cooperatives.

Així, s'ha esmentat, en l'àmbit de les societats de capital, la impugnabilitat, tant dels acords de les juntes especials dels titulars de classes d'accions determinades (articles 148.4t i 240.3r LSA), com els acords de l'assemblea d'obligacionistes (article 301.3r LSA). Com veurem (epígraf 1.6), aquests supòsits poden ser traslladables, amb les necessàries adaptacions, a l'àmbit cooperatiu. A la cooperativa hi ha determinats col-lectius de socis $^{647}$, tipus especials de socis $^{648}$ i fins $\mathrm{i}$ tot persones no sòcies ${ }^{699}$, que poden estar facultats per acordar assumptes que incidisquen en el funcionament de la cooperativa. Encara que el règim per a l'adopció d'aquests acords no queda clar, pot donarse, per mandat estatutari o per analogia, l'aplicació del procediment majoritari de l'assemblea general. Cal, en tot cas, plantejar-se la possibilitat d'anul-lar aquests acords amb transcendència jurídica.

general .... op. cit., pàg. 580 i 581, rebutja la impugnabilitat dels acords de les reunions de socis de la secció.

647 Article 107.5 LCoop: "La validesa de qualsevol modificació autoreguladora que afecte els drets i obligacions d'algun dels col-lectius de socis, requerirà el consentiment majoritari del grup corresponent, que podrà obtenir-se mitjançant votació separada a l'assemblea general" (art. 90, 4t paràgraf i 96.6 LCoop).

648 Per exemple, article 40.3 LCCV: "Els consellers representants dels socis de treball, dels treballadors assalariats o de minories qualificades de socis, només podran estats revocats pels seus representats, de conformitat amb el règim específic determinat en estatuts".

649

Article $33,3 \mathrm{r}$ paràgraf LCoop: "Quan la cooperativa tinga més de cinquanta treballadors amb contracte per temps indefinit i estiga constituït el comitè d'empresa, un d'ells formarà part del consell rector com a membre vocal, que serà elegit i revocat pel comitè; si hi ha diversos comitès d'empresa, serà elegit pels treballadors fixos". 
En relació amb els acords de l'assemblea d'obligacionistes, veurem (epígraf 1.5.) quines són les especialitats que planteja el seu règim en l'àmbit cooperatiu, en virtut de l'autorització legal expressa en la cooperativa per emetre obligacions, amb sotmetiment a la legislació general aplicable (articles 54.1 LCoop i 56.3 LCCV).

També s'haurà de reflexionar sobre la possibilitat d'impugnar els acords 0 decisions dels òrgans d'administració diferents al consell rector: administrador únic, administradors mancomunats o col-legiats, comissió executiva i conseller delegat. En relació amb això, s'ha de recordar que la limitació de la impugnació dels acords dels òrgans d'administració que l'article 143 de la LSA estableix respecte a aquells que tinguen caràcter col-legiat, reiteradament criticada per la doctrina, no s'ha recollit en la legislació cooperativa.

A més, en la cooperativa es permet la creació d'altres òrgans, si bé el desenvolupament legislatiu del seu funcionament en general i de la possibilitat d'impugnar les seues decisions en particular és, almenys, desigual (en alguns casos ni tan sols queda clar si funcionen col-legiadament). En efecte, a més del comitè o comissió de recursos, ja esmentat, i en relació amb els acords pels quals se n'estableix expressament la impugnabilitat, la LCoop i la LCCV preveuen la figura dels liquidadors ${ }^{650}$; la LCoop manté $1^{\prime}$ òrgan de la intervenció ${ }^{651}$ (articles 19 i 38 a 43) i la LCCV, en canvi, crea la comissió de control de la gestiós (article $48)$.

650 Article 71.3 LCoop: “Quan els liquidadors siguen tres o més, actuaran de manera col-legiada, i adoptaran els acords per majoria". La LCCV, en canvi, no preveu res respecte del seu funcionament.

651 Encara que no esmenta el règim de funcionament del que qualifica com a "òrgan de fiscalització", el seu funcionament col-legiat sembla poder deduir-se, a sensu contrario, de l'article 38.2, quan estableix que "en cas de disconformitat, els interventors hauran d'emetre informe separadament".

652 Tampoc per a aquesta comissió s'esmenta el règim de funcionament ni, per tant, la possibilitat d'impugnar els seus acords eventuals. 
tenint en compte l'amplitud amb què la legislació cooperativa considera la articipació orgànica i la possibilitat d'impugnar acords d'aquests òrgans, hauria d'afegir, almenys com a hipòtesi que cal analitzar, les possibilitats l'impugnar l'activitat de col-laboradors externs la repercussió intracooperativa tels quals pot ser de gran transcendència. Ens referim a la intervenció dels auditors i del lletrat assessor (epígraf 4). Respecte als auditors de comptes podria entendre's que, entre altres, efectuen una funció substitutòria, almenys en part, de la intervenció interna, com a òrgan de control de la gestió. Quant a la figura del lletrat assessor, si bé ha desaparegut de l'articulat de la LCoop ${ }^{63}$, se'n manté la regulació en la LCCV, com a secció quarta del capítol IV, significativament titulat "Òrgans socials".

Finalment, cal plantejar-se si la cooperativa pot dotar-se, mitjançant regulació estatutària o reglamentària o acord de l'assemblea o del consell, $d$ 'altres òrgans diferents; si els òrgans podran adoptar decisions amb transcendència jurídica per a la cooperativa; i, en definitiva, si les declaracions de voluntat seran impugnables (vegeu introducció a l'epígraf 3 i l'epígraf 3.3.). En l'àmbit cooperatiu, l'article 2 de la LGC semblava poder interpretar-se com a atribució de la més àmplia autonomia organitzativa, si bé l'article 61, en desenvolupar la possibilitat de creació estatutària 0 assembleària de "comissions, comitès 0 consells" adverteix que la denominació d'aquestes "instàncies participatives i intermèdies no haurà d'induir a confusió amb la dels òrgans de la cooperativa $\mathrm{i}$ en cap cas el seu criteri podrà ser vinculant per a aquests, sense perjudici que el seu informe puga establir-se com a preceptiu" ${ }^{\prime 54}$, i ni tan sols preveu la possibilitat que el consell rector delegue competències.

653 La seua supressió en la LCoop planteja, com veurem, davant del seu anterior caràcter obligatori per a les cooperatives de més volum, si en l'actualitat en serà possible la regulació estatutària o per acord, assembleari o de l'òrgan d'administració.

654 Paz Canalejo, N., en PaZ CANALejo, N., i ViCent Chuliá, F., Ley general... op. cit., pàg. 580 i581, que assenyalava una excepció legal (article $48.2,2$ n paràgraf) al caràcter no vinculant de la proposta de tals comitès, però es mostrava obertament contrari a la possibilitat d'impugnar els seus acords. 
La LCoop encara sembla diluir més la capacitat autoorganitzativa de la cooperativa, en esmentar en l'article 19 , com a únics òrgans, l'assemblea, el consell rector i la intervenció, i només afegeix la possibilitat de regulació estatutària $d^{\prime \prime \prime}$ altres instàncies de caràcter consultiu o assessor (...) que, en cap cas, puguen confondre's amb les pròpies dels òrgans socials". Així doncs, les funcions d'aquestes "instàncies" (que s'han de diferenciar respecte dels "òrgans socials"), encara que es concreten estatutàriament, hauran de ser necessàriament de caràcter consultiu o assessor, per la qual cosa pot descartarse'n el caràcter vinculant, $l^{\prime}$ efecte obligatori, amb transcendència jurídica. Una impugnació hipotètica de les seues manifestacions de coneixement o voluntat seria, doncs, en tot cas, innecessària.

La LCCV, en canvi, afirma, en l'article 25, dedicat als òrgans de la cooperativa, que "els estatuts podran regular la creació i el funcionament de comissions delegades de l'assemblea general". Es deixa amb això la porta oberta a l'autoregulació, si bé, com s'ha assenyalat en relació amb les societats de capital $^{\text {sss}}$, aquests òrgans estatutaris haurien de respectar les disposicions imperatives sobre competències dels òrgans legals $i$, en particular, el règim d'actuació a efectes externs. En la mesura, doncs, en què podran adoptar acords en les matèries de la seua competència, aquests altres òrgans poden generar supòsits d'impugnabilitat.

\section{Acords de l'assemblea general i d'altres assemblees de la cooperativa}

La impugnació dels acords socials es va establir inicialment com a instrument de control del funcionament correcte de l'assemblea general, per això no és estrany que la seua regulació siga la més detallada i que funcione com a règim 
supletori per a la impugnació dels acords d'altres òrgans socials, ja siga per mandat explícit, ja siga per aplicació analògica ${ }^{656}$.

En aquest epígraf analitzarem el règim general $\mathrm{i}$ ens referirem a determinats supòsits específics de transcendència significativa; després reflexionarem sobre l'aplicació possible, amb les adaptacions necessàries, als acords que s'adopten en altres assemblees, juntes o reunions de socis de la cooperativa.

El règim d'impugnació dels acords de l'assemblea general universal o el de les assemblees de les entitats representatives de les cooperatives, com ara unions, federacions i confederacions (articles 118.2 i 119.5 LCoop, i 96.5-i 974. LCCV), no requereixen, en canvi, un desenvolupament específic, ja que els hi és plenament aplicable, sense modificacions, el procediment general.

\subsection{Acords de l'assemblea general}

La casuística dels acords impugnables de l'assemblea general pot dividir-se, per al seu estudi, entre els que els seus vicis es refereixen a aspectes formals de la realització de l'assemblea i els que el seu contingut és el que pateix de causa $d^{\prime}$ impugnación ${ }^{65}$.

Els aspectes formals que més habitualment donen lloc a la nul.litat o anul-lació dels acords corresponents són els relatius a defectes en la convocatòria (antelació de la convocatòria, mitjans de publicitat, inclusió i claredat en els punts de l'ordre del dia, posada a disposició de la documentació, etc.), però també pot haver-hi incompliment de requisits formals per a la constitució de l'assemblea (quòrum de constitució, admissió de representacions i de persones

${ }^{656}$ CABALLOL I ANGelATS, L., «Comentario al artículo 115», op. cit., pàg. 116 i 1107.

\footnotetext{
657 GARRIGUES, J., «Nulidad e impugnabilidad...», op. cit., pàg. 421. SORIA FERRANDO, J. V., La impugnación..., op. cit., pàg. 159, s'estima més distingir entre la violació de normes que tutelen el procés de formació de la voluntat i la infracció de normes de caràcter material, i es qüestiona a més si l'acta de la junta, com a forma de l'acord, és requisit necessari per a la validesa dels
} 
no sòcies, etc.), o en el procediment de deliberació (omissió d'informes preceptius, presentació dels comptes anuals per persones diferents als membres de l'òrgan d'administració, etc.) i adopció dels acords (règim de majories, còmput dels vots, procediment de votació, etc. ${ }^{658}$.

Els requisits formals exigits per norma legal imperativa donen lloc a la nul.litat dels acords corresponents, mentre que els defectes de manera que vulneren normes estatutàries (o legals dispositives) generen anul-labilitat. Les crítiques doctrinals que ja s'han exposat poden reproduir-se ací, d'una banda, en relació amb la sanció desproporcionada que suposa la nul-litat per defectes formals quan l'incompliment esdevinga intranscendent, en no afectar els interessos que es pretenen protegir amb l'establiment de la formalitat; i, d'una altra banda, amb la impunitat que es donarà quan s'incomplisquen requisits formals establerts en reglaments interns o en acords anteriors de la assemblea mateixa.

Cal plantejar-se, a més, si l'incompliment dels requisits formals en l'emplenament de l'acta de la sessió (inclosa la llista d'assistents) donen lloc a la impugnació dels acords que hi conté. Tractarem la qüestió en l'epígraf 1.2.4. "Impugnació d'acords en virtut de l'actuació de la presidència o de la secretaria de la sessió", in fine. La doctrina mercantilista, a l'hora de respondre a la qüestió, es divideix en dues postures fonamentals: "la dels que entenen que els documents de la junta (o almenys l'acta) són necessaris, per dependre'n l'eficàcia dels acords"659, i la partidària de considerar que "la documentació no és la decisió del col-legi; no és tampoc la manera com ha d'encarnar-se la decisió o l'acord d'aquell òrgan, no és, finalment, un nou requisit o un element del supòsit de fet la concurrència del qual s'exigisca per a la validesa o per a

acords.

658 Per al desenvolupament de la impugnació d'acords per incompliment de requisits formals, vegeu els epígrafs 1.2.3 "Impugnació de la realització de l'assemblea i, per tant, de tots els seus acords", i 1.2.4 "Impugnació d'acords en virtut de l'actuació de la presidència o de la secretaria de la sessió".

659 PATERNOTTRE SuÁREZ, Aquiles, Las actas de las juntas de accionistas, Civitas, Madrid, 1994, pàg. 323. 
l'eficàcia de l'acord. És simplement una documentació que serveix per acreditar el que ocorre" 660 .

Els supòsits de nul-litat o anul-labilitat que es deriven del contingut mateix de l'acord són més difícilment ordenables, per la seua varietat ${ }^{\text {sil }}$. Entre els assumptes més habituals en la jurisprudència podem trobar tots els relacionats amb la vulneració del dret d'informació del soci (vegeu, per exemple, el desenvolupament infra de la impugnació de la negativa d'informació per part del consell ${ }^{1 \alpha^{12}}$ ), o amb l'aprovació dels comptes anuals (falta o deficiència dels informes previs preceptius, vulneració del principi d'imatge fidel $l^{6 / 3}$, etc.).

\subsection{Supòsits específics}

1.2.1. Acords de l'assemblea en matèries atribuïdes a l'òrgan d'administració

660 PATERNOTTRE SUÁREZ, A., Las actas de las juntas..., op. cit., pàg. 334.

661 SORIA FERRANDO, J. V., La impugnación..., op. cit., pàg. 193 a 204, distingeix entre els acords contraris a l'objecte de l'acord, els contraris a la causa $i$ els que vulneren drets essencials dels socis, seguint l'esquema tradicional del negoci jurídic. En relació amb el concepte d'objecte de l'acord, assenyala que "ha de ser susceptible de determinació [...], ha de ser possible, tant físicament com jurídicament. I [...] ha de ser lícit, és a dir, no contrari a la llei, a l'ordre públic o als bons costums (vide art. 1271 i següents del CC)". La causa de l'acord s'identifica amb la pròpia del contracte de societat, això és, "l'exercici en comú de l'activitat que forma l'objecte social", si bé en la cooperativa la finalitat de repartiment del lucre s'haurà de substituir per la de satisfacció dels interessos o necessitats comunes dels socis; en relació amb els acords contraris a la causa social, aquest autor destaca com els acords lesius de l'interès social només se sancionen amb l'anul-labilitat. Pel que fa als drets essencials dels socis, l'autor els estudia separadament, per la gran importància i el nombre de sentències que en provoca la violació, encara que els considera com a supòsit típic d'acords socials amb objecte il-lícit.

${ }^{662}$ La negativa d'informació pel consell rector als socis s'analitza en l'epígraf 2.2.1 "Acords del consell rector que poden impugnar-se internament", juntament amb altres supòsits especials d'impugnació d'acords del consell, encara que tal denegació pot donar lloc també a la impugnació d'acords de l'assemblea, quan la informació haja de proporcionar-se en el transcurs d'aquesta". L'opció per la seua inclusió en la impugnació d'acords del consell es deu, d'una banda, al fet que, en tot cas, és el consell qui acorda denegar la informació, i d'una altra, que aquesta informació pot ser també sol-licitada en relació amb assumptes diferents als tractats en assemblea. 
En la jurisprudència més reiterada sobre impugnació d'acords socials a la cooperativa hi ha un supòsit paradigmàtic d"invasió" de les competències del consell rector per part de l'assemblea general: l'expulsió de socis ${ }^{64}$, l'atribució competencial de la qual, en primera instància, és unànime en la legislació cooperativa en favor de l'òrgan d'administració. Així doncs, es dóna el fenomen contrari al que sol produir-se en seu de societats capitalistes, on la tendència a "expandir" l'àmbit competencial sol donar-se en l'òrgan administratiu ${ }^{66 s}$.

Aquesta inversió de l'"expansionisme competencial" no sembla, d'altra banda, casual: mentre les societats de capital han estat clarament configurades com a entitats d'inversió, en què els socis es limiten, a tot estirar, a controlar la maximització dels beneficis i el seu repartiment ${ }^{666}$, en les cooperatives, la participació nuclear dels socis en la gestió ha presentat el consell rector com un

664 Poden veure's les SSTS, Sala $1^{\text {a }}$, de 3.11 .1992 , núm. 953/1992, RJA 1992/9188; 14.10.1993, núm. 955/1993, RJA 1993/7517 i 14.5.1994, núm. 436/1994, RJA 1994/4582.

665 Pot veure's una síntesi recent de les anàlisis que incideixen en el desplaçament del poder cap a l'òrgan d'administració en les societats capitalistes (fonamentalment en les de tipus obert i, sobretot, en les cotitzades) en SÁNCHEZ RUIZ, M., Conflictos de intereses..., op. cit., pàg. 46 a 50, on es refereixen també les propostes de control que s'apunten en els Principles of Corporate Governance, $\mathrm{i}$ als informes i recomanacions que, amb caràcter similar, s'han efectuat els últims anys. Com a exemple de la tendència "acaparadora" de competències per part de l'organ d'administració en l'anònima pot veure's el comentari a la SJPI núm. 7 de Madrid, de 27 de juliol de 1999 (dictada en el "cas KIO"), que realitza ALONSO SOTO, R., «Consideraciones...», op. cit., pàg. 1 a 4.

666 SÁNCHEZ RUIZ, M., Conflictos de intereses..., op. cit., pàg. 48: "el soci (tots o bé el soci aliè al grup de control [...]) deixa pas a l'inversor els interessos del qual són la seguretat, la rendibilitat i la liquiditat de la seua inversió, i no té incentius per a l'exercici dels seus drets polítics". SORIA FERRANDO, J. V., La impugnación..., op. cit., pàg. 89, recollia les tesis de GALGANO [Societd per azioni i classi sociali, Riv. soc., 1972, pàg. 965 i ss, i Li instituzione dell 'economia capitalistica. Societi per azioni, Stato $i$ classi sociali, Bolonya, 1974, pàg. 72 i ss.] sobre les diverses formes de concebre la riquesa al si de l'accionariat de la societat anònima: "per a la burgesia industrial i comercial, la finalitat primordial del qual és l'obtenció de cada vegada més plusvàlua, per a la qual cosa cal que l'acumulació siga més gran, és a dir, que el menor nombre de plusvàlua possible siga consumida i la major possible reinvertida en la societat mateixa, cal ampliar, i cada vegada més, la productivitat per obtenir així més plusvàlua. Mentre que, per contra, els rendistes tendeixen a la realització immediata dels beneficis, que els dividends siguen sempre els més elevats. [...] Aquesta contraposició d'interessos roman al centre dels problemes de la societat anònima, això és «el conflicte entre les tendències oposades a la reinversió dels beneficis i a la seua percepcí immediata; entre la política de l'autofinançament de l'empresa perseguida pel capital de comandament i la política d'alts dividends ambicionada pel capital d'estalvi»". 


\section{òrgan veritablement "instrumental" de les decisions assembleàries ${ }^{667}$.} Curiosament, les tendències en les últimes dècades s'orienten a canvis radicals en els models: en les societats de capital, l'aparició de socis inversors "professionals", representants de "minories qualificades", fan que es tendisca a més control i delimitació del poder tradicionalment centrat en l'òrgan $d^{\prime}{ }^{\prime}$ dministracióos ${ }^{6 s}$, mentre que la necessitat de competir en el mercat porta les cooperatives a la professionalització dels seus òrgans administratius i a una cessió de competències a favor seu cada vegada més gran ${ }^{6 * 9}$.

Però la incertesa més gran en aquesta matèria no es produeix en els supòsits de competència legal (com el de l'expulsió de socis), sinó en aquells en què l'atribució es realitza en virtut de clàusula estatutària, de reglament de règim intern o d'acord dels òrgans socials. És el cas que es produeix en les societats de

667 VerGeZ, M., El derecho de las cooperativas..., op. cit., pàg. 48 i 49, ja assenyalava que el progressiu enfortiment de la gestió que s'observa en les societats anònimes amb l'atribució general de competència en favor de l'òrgan d'administració "exigeix la seua reconsideració en el dret de societats cooperatives, en el qual la debilitat i la falta de tecnificació de l'òrgan de gestió constitueix una rèmora important en el funcionament", encara que no puga "desconèixer-se certament la importància decisiva dels principis democràtics $i$, per tant, la sobirania de la junta general".

668 SANCHEZ RUIZ, M., Conflictos de intereses..., op. cit., pàg. 50. SORIA FERRANDO, J. V., La impugnación..., op. cit., pàg. 95 i 96, seguint GALGANO (Le instituzione ...op. cit.): “davant de la dissociació propietat-control en la societat anònima, la doctrina s'ha decantat fonamentalment en dues posicions. Uns pretenen la restauració de la sobirania de la junta general i més participació de la minoria (o majoria desorganitzada) en la gestió de la gran societat anònima. Per contra, uns altres pretenen que s'institucionalitze la distinció dels dos grups d'accionistes en conflicte en la societat anònima, mitjançant, per exemple, institucions com les accions sense vot. "Sembla que la solució més realista és la segona, ja que, en la primera, com diu Galgano, «hi ha una manca d'anàlisi, en termes de classe, del dret privat», ja que "es creu fer opera di democracia instant la tutela de l'accionista minoritari, però s'abstenen de preguntar-se quins grups socials formen la figura abstracta de l'accionista minoritari»".

669

MESTRE, J., «Sur l'originalité...", op. cit., pàg. 88: "les cooperatives es troben avui, en certa manera, en una cruilla: partint d'un marc molt personalitzat, es dirigeixen cada vegada més cap a un estatut d'empreses, d'actors de la vida econòmica, plenament sotmesos al dret dels segocis. Aquest camí seguit és finalment tant més remarcable en tant que és d'alguna manera el financer, rel realitzat per les societats per accions. Partint d'un quadre anònim, essencialment accionariat a testes es personalitzen cada vegada més, assajant formes de controlar el seu derecho de las de fidelitzar-lo, fonamentalment a través de pactes estatutaris". VERGEZ, M., El condiciona caoperativas..., op. cit., pàg. 49 i 50: "no pot oblidar-se que la tecnificació de la gestió loggic que el mantegada més l'eficàcia econòmica mateixa de la societat cooperativa. [...] Sembla perquè ser manteniment a ultrança dels principis democràtics al si d'aquesta societat, no té 
capital $^{60}$ quan s'adopten acords per la junta universal sobre matèries que estatutàriament han estat atribuïdes a l'òrgan d'administració: en aquest cas no hi ha infracció de llei, ja que l'article 99 LSA atribueix a les juntes universals competència per conèixer qualsevol assumpte, però que suposaria una infracció dels estatuts i, per tant, l'anul-labilitat de l'acord.

Aquest últim supòsit, tanmateix, no és traslladable a l'àmbit cooperatiu: d'entrada, en la legislació cooperativa no es preveu una ampliació de la competència de l'assemblea universal respecte a la de les convocades legalment; $i$, per contra, diversament al que s'ha preceptuat per a les societats de capital, el règim competencial general de l'assemblea cooperativa li permet d'adoptar acords en totes les matèries que la llei mateixa no considere competència exclusiva d'un altre òrgan social ${ }^{67}$.

Així doncs, una eventual atribució competencial estatutària en favor de l'òrgan d'administració (o de qualsevol altre òrgan diferent a l'assemblea) més enllà de les que expressament li reconeix el text legal, no impediria que l'assemblea prenguera acords en aquesta matèria. I el mateix s'ha d'indicar en relació amb les competències assignades pel reglament de règim intern o mitjançant acord de l'assemblea mateixa.

Finalment, també pot donar-se el supòsit contrari, és a dir, matèries que, tot $i$ constituir administració ordinària (atribuïda, en principi, a l'òrgan d'administració), siguen declarades estatutàriament com a competència de $1^{\prime}$ assemblea general ${ }^{62}$; un exemple específic d'això s'analitza infra en l'epígraf 2.2.3.: el dels acords del consell rector delegant funcions o nomenant els

controls que sobre aquest han de mantenir-se com a postulats veritablement democràtics".

670 ARANGUREN URRIZA, F. J., «Los órganos de la sociedad anónima», op. cit., pàg. 528; RODRÍGUEZ RUIZ DE VILLA, D., Impugnación... op. cit., pàg. 38 i 39.

671 Art. 21.1 i 23.5 LCoop, i 27.2 i 28.4 LCCV.

672 VICENT CHULIÅ, F., «La asamblea...»..., op. cit., pàg. 161. 
membres de l'òrgan delegat, quan s'hagen establert restriccions estatutàries a favor de l'assemblea.

1.2.2 Acords d'aprovació de comptes

A. Aprovació dels comptes anuals i de l'informe de gestió

L'aprovació dels comptes anuals per part de l'assemblea general és la manifestació bàsica del control del soci sobre la gestió $i$, per tant, competència essencial que ha d'exercir l'assemblea específicament destinada a això, l'obligatòria assemblea general ordinària anual. Però el caràcter cada vegada més complex $\mathrm{i}$ tècnic dels comptes va portar en el seu moment a incorporar en les societats de capital, primer, i en les cooperatives, després, la figura dels socis censors de comptes o interventors, elegits per la junta/assemblea amb la missió específica de revisar per si mateixos o mitjançant el concurs de professionals externs la gestió social realitzada durant l'exercici per l'òrgan d'administració i la correcció dels comptes resultants.

Més recentment, la legislació cooperativa, avançant-se amb això a la legislació mercantil, va incorporar les directrius europees en matèria de submissió directa de la revisió dels comptes anuals a auditors externs, cosa que reconeix en la pràctica la irrellevància, en la major part dels casos, de la participació de socis en aquestes tasques, pel seu desconeixement usual dels aspectes tecnicocomptables, i per la suficient garantia de neutralitat que els professionals poden oferir ${ }^{63}$. Això no obstant, la legislació estatal ha mantingut l'informe

673 ESTEBAN VELASCO, G., «Algunas reflexiones...», op. cit., pàg. 558, descriu el mateix procés per a les societats de capital: "Com és sabut, en el marc de la SA s'ailla la funció del "control comptable", que històricament exerceix la JG mateixa i que després es confia institucionalment a un grup separat d'accionistes (els censors de comptes) i més tard a un grup d'experts professionals $\mathrm{i}$ independents (auditors de comptes)". MARTf LACALLE, Rocío, "El derecho de información del accionista en materia de contabilidad social: contenido y límites (Comentario a la STS de 15 de diciembre de 1998 [Civil]. R.A. 9636/1998)», RDM, núm. 232, abril-juny 1999, 
sobre els comptes per part de la intervenció per a aquells casos en què l'auditoria no siga obligatòria ni s'haja acordat voluntàriament, mentre que la LCCV opta per una regulació més dispositiva: l'auditoria externa sols es realitzarà en els supòsits legalment o estatutàriament previstos, o per acord dels òrgans cooperatius competents, i quedaran els comptes anuals sense informe previ de control per a la resta de casos.

En tot cas, per garantir el compliment d'aquesta mesura de defensa tant dels interessos socials, com els dels socis, la LGC (articles 68.6 i 69.6) establia expressament la impugnabilitat de l'acord d'aprovació dels comptes anuals quan no s'haguera realitzat l'informe previ obligatori, tant si va a càrrec dels interventors interns, com dels auditors externs.

Com que, probablement, era innecessària aquesta menció (l'acord seria, en tot cas, nul), la LCoop ha optat per considerar que "mentre no s'haja emès l'informe o haja transcorregut el termini per fer-ho, no podrà ser convocada l'assemblea general a l'aprovació de la qual hagen de sotmetre's els comptes" (article 39.2). Aquest canvi implica, tanmateix, greus conseqüències: d'una banda, la realització de l'assemblea ordinària dins del termini previst per a la formulació de l'informe, però sense que s'haja emès aquest, suposarà la nul.litat de tot allò acordat en l'esmentada assemblea, sense que es puga interpretar limitada la nul-litat a l'acord d'aprovació dels comptes; d'altra banda, del tenor literal de l'article 39.2 sembla desprendre's que l'assemblea podrà ser convocada després de finalitzar el termini per a l'emissió d'informe, fins i tot sense aquest. En aquest últim cas, almenys l'acord d'aprovació dels comptes sense l'informe preceptiu serà nul, per vulneració d'allò que preveuen els articles 39.1 i 62 .

La LCCV també presenta diferències en aquesta matèria. D'entrada, com ha quedat assenyalat, sols s'exigeix la revisió dels comptes anuals per auditoria externa i sols per als supòsits legalment previstos (article $45.1 \mathrm{LCCV}$ ); en els 
altres casos, els comptes es presentaran directament per ser aprovats per l'assemblea. Paral-lelament, la cooperativa pot dotar-se estatutàriament d'un òrgan de control intern, la comissió de control de la gestió, que, entre altres funcions, haurà d'informar "en tots els casos" l'assemblea general ordinària sobre la conformitat de la gestió dels òrgans d'administració i de la direcció amb la política fixada per l'assemblea (article 48.2); aquesta comissió també té la facultat d'acordar, per si mateixa, la realització de l'auditoria externa.

Està clar, doncs, que quan la cooperativa haja de veure revisats els seus comptes, internament o externament, serà impugnable l'acord d'aprovació dels comptes anuals que no haja comptat amb l'informe preceptiu de l'auditoria o de la intervenció6 ${ }^{64}$; i succeirà el mateix quan, tot i comptar la cooperativa amb comissió de control de la gestió, aquesta no emeta el seu informe. Una qüestió diferent és la dels efectes de l'anul-lació.

Quan el vici de l'acord d'aprovació dels comptes anuals siga la falta de l'informe de l'auditoria o de la intervenció, és evident la vulneració de norma legal (articles 39.1 i 2 i 62.1 LCoop, i 45.1 LCCV) per la qual cosa n'és indubtable la nul-litat. En canvi, la manca d'informe de la comissió de control de la gestió pot suscitar dubtes, ja que la creació d'aquesta és dispositiva, i el seu funcionament és regulat estatutàriament; això no obstant, considerem que

674 La STS, Sala 1a, de 9.7.1998, núm. 680/1998, RJA 1998/5780 resol la nul-litat dels acords adoptats en junta general ordinària sense haver-se procedit $\mathrm{ni}$ tan sols al nomenament dels "censors de comptes"; la STS, Sala 1a, de 11.11.1998, núm. 1027/1998, RJA 1998/8593 equipara un supòsit en què l'informe d'auditoria presentat a la junta general d'una SA contenia omissions importants, amb la situació de falta absoluta d'auditoria, i manifestava a més que "el que l'accionista puga conèixer que no hi ha opinió d'auditoria [...], no allibera la societat de complir amb aquest precepte".

La STS, Sala 1a, de 24.9.1998, núm. 875/1998, RJA 1998/7068 declara anul-lable l'acord social revocatori del nomenament de l'auditoria per lesiu dels interessos socials $\mathrm{i}$ consegüentment nul l'acord d'aprovació de comptes de l'exercici següent, que no havia estat auditat; tanmateix, no fa extensiva la nul-litat a l'aprovació dels comptes de l'exercici anterior, que s'havien aprovat en la mateixa junta general que va revocar el nomenament d'auditor, però en un punt anterior de l'ordre del dia.

La STS, Sala 1a, de 27.10.1997, núm. 928/1997, RJA 1997/7617 va acceptar la substitució pel consell d'administració dels auditors nomenats per la junta general, davant de la renúncia d'aquests, "sense temps per fer compatible l'anàlisi dels comptes amb el manteniment de la convocatòria, la suspensió del qual sí que haguera produït danys a la societat". 
també en aquest cas s'haurà de sancionar l'acord amb la seua nul-litat, ja que, si existeix aquesta comissió, ha d'informar "en tots els casos" a l'assemblea general ordinària, per mandat legal.

Un altre supòsit diferent, en relació amb els acords d'aprovació de comptes, és el que s'ha indicat per al cas que els aquests comptes vulneren el principi comptable d'imatge fidel ${ }^{675}$, que garanteix que el soci puga "imaginar una representació exacta i fidel del concurs dels negocis i beneficis de l'empresa". L'obligatorietat del respecte envers aquest principi es concreta en les normes legals que regulen l'estructura dels comptes socials (articles del 34 al 49 Cco; 290 CP; del 171 al 202 LSA; 61.1 LCoop; 57.1 LCCV), per la qual cosa no hi ha dubte respecte de la nul-litat de la seua vulneració6\%, si bé en aquest cas la dificultat principal es derivarà de la prova de la inexactitud ${ }^{67}$.

675 La STS, Sala 1a, de 7.9.1998, núm. 806/1998, RJA 1998/7547 resumeix la doctrina aplicable, citant les SSTS de 12.5.1982 (RJA 1982/2569) i de 29.11.1983 (RJA 1983/6733); també poden veure's les SSTS de 23.10.1999 (RJA 1999/7341), 15.12.1998 (RJA 1998/9636), i 1.7.1996 (RJA 1996/5545). RODRÍGUEZ RUIZ DE VILLA, D., Impugnación..., op. cit., pàg. 80 i 81, cita abundant jurisprudència anterior al TRLSA. Sobre el principi d" imatge fidel" pot veure's GONDRA ROMERO, José M., "Significado y función del principio de «imagen fiel» (true and fair view) en el sistema del nuevo Derecho de balances», en AA. DD., Derecho mercantil de la CEE, Civitas, Madrid, 1991, pàg. 553 a 599; MARTI LACALLE, R., "El derecho de información...", op. cit.; i SANZ PARAíso, Luis Fernando, "Efectos de la nulidad del acuerdo de aprobación de las cuentas anuales sobre otros acuerdos sociales (SAP Burgos 3 diciembre 1997)", RdS, núm 12, 1999, pàg. 326 a 335, en relació amb la nul.litat de tots els acords que porten causa de la nul-la aprovació dels comptes. Sobre l'exigència del principi d'imatge fidel a la comptabilitat de la cooperativa FAJARDO GARCfA, Isabel-Gemma, La gestión económica de la cooperativa: responsabilidad de los socios, Tecnos i Confederación de Cooperativas de la Comunidad Valenciana, Madrid, 1997, pàg. $119 \mathrm{i}$ 120; i FAJARDO GARCíA, Isabel-Gemma i SENENT VIDAL, M. José, Texto refundido de la Ley de cooperativas de la Comunidad Valenciana. Edición comentada, Confederación de Cooperativas de la Comunidad Valenciana, València, 1999, pàg. 74 i 76.

676 MARTf LACALLE, R., «El derecho de información...», op. cit., pàg. 853. RODRfGUEZ RUIz DE VILLA, D., Impugnación..., op. cit., pàg. 80 i 81 , nota 60 , sembla dubtar sobre l'admissibilitat judicial de la nul-litat, quan planteja que "haurà de demanar-se judicialment, amb caràcter principal la nul-litat dels acords $i$, subsidiàriament l'anul-lació per lesió a l'interès social, encara que considerem que sempre hauria d'estimar-se la primera, per tal com els accionistes, a causa d'aquesta absència o incorrecta imputació de despeses, és evident que no obtenen la "imatge fidel" de la situació econòmica de l'empresa societària".

677 RODRÍGUEZ RUIZ DE VILLA, D., Impugnación..., op. cit., pàg. 81, recorda, a més, que "la càrrega de la prova de la inexactitud recau sobre l'impugnant, i no és, com és lògic suficient amb la seua mera al.legació [(RJA 1968/543) ... (RJA 1983/6733)]". 
Com a supòsits específics d'aprovació de comptes que vulneren el principi d'imatge fidel s'ha plantejat el de gestió de doble comptabilitat $^{778}$ o el $d^{\prime}$ incompliment dels requisits exigits legalment per a la presentació dels comptes ${ }^{67}$, encara que també $s^{\prime}$ ha fet notar que no cal reconduir a aquesta figura el supòsit de mer retard en la presentació dels comptes a la seua aprovació per

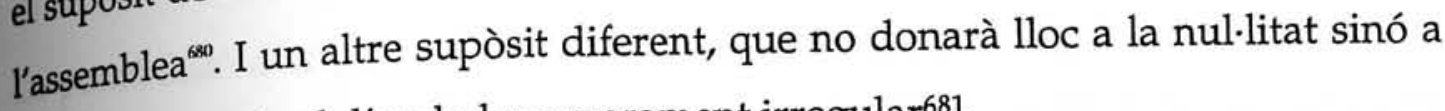
l'anul-labilitat, és el d'un balanç merament irregular ${ }^{681}$.

Ni la LCoop ni la LCCV es refereixen al supòsit en què ni tan sols es pren l'acord de no aprovar els comptes. Pareix que caldrà reconduir aqueixos supòsits a l'acció de responsabilitat.682

678 RODRfGUEZ RUIZ DE VILLA, D., Impugnación..., op. cit., pàg. 81, cita com a jurisprudència de suport la STS RJA 1967/425 i la Sentència de la Secció 3a de l'Audiència Provincial de Pontevedra de 24 de setembre de 1991 (RGD, núm. 574, juny 1992, pàg. 6067-6068), mentre que la Sentència de 12 de maig de 1973 (RJA 1973/2334) no va considerar que la doble comptabilitat consistent en un balanç presentat a la delegació d'hisenda amb pèrdues i un altre a la junta d'accionistes amb beneficis, poguera servir per estimar la nul-litat de l'aprovació d'aquest últim, perquè el balanç presentat a Hisenda "[...] pel seu caràcter administratiu fiscal no pot servir de base a un recurs de cassació, segons la constant i reiterada doctrina jurisprudencial". Aquest autor estima, això no obstant, que "si s'aconseguira acreditar la conformitat de tots els socis en aquesta tenedoria, per exemple per raons fiscals, així com que els socis tenien coneixement integre $i$ exacte de les dues comptabilitats (la real i la que podríem denominar fiscal), això hauria d'impedir l'èxit de l'acció impugnatòria".

679

RODRíGUEZ RUIZ DE VILLA, D., Impugnación..., op. cit., pàg. 81 i 82, RJA 1970/4182.

${ }^{680}$ RODRfGUEZ RUIZ DE VILLA, D., Impugnación... op. cit., pàg. 87 i 88 : "no es considera causa de nul.litat: [...] 3. La formulació pels administradors del balanç fora del termini legal (avui el de tres mesos de l'article 171 TR) sempre que s'acomplisca el requisit d'informació regulat actualment en l'article 212.2 TR, en relació amb l'article 112 TR [RJA 1986/4412]".

681 GalganO, F., El negocio jurídico, op. cit., pàg. 276: “El balanç redactat pels administradors pot ser un balanç fals, en ser redactat violant el principi de veracitat, en el qual hagen estat introduits assentaments ficticis en l'actiu o en el passiu, o en el qual determinats assentaments de l'actiu o del passiu hagen estat omesos; també pot ser un balanç irregular, això és, quan en la seua redacció resulta violat el principi de «claredat i precisió» o els criteris de valoració previstos per a determinats beneficis. [...] La jurisprudència dominant distingeix entre les dues hipòtesis considerades anteriorment: jutjant nul l'acord de l'assemblea que aprove un balanç la redacció del qual viole el principi de veracitat; i només anul.lable aquell en que s'aprove un balanç la redacció del qual viole el principi de claredat i precisió". 
Però, a més, la normativa legal cooperativa continua l'estela de la regulació en les societats de capital, i exigeix la revisió del balanç econòmic de l'entitat no sols una vegada a l'any, una volta tancat l'exercici, sinó en altres moments de transcendència per a l'entitat, com quan es decidisca la modificació estructural de la cooperativa, o la seua dissolució.

\section{B. Aprovació del balanç en cas de modificació estructural}

La LGC, en esmentar la impugnació del balanç de fusió en l'article $98.2^{\infty}$, semblava indicar la possibilitat que s'impugnara, exclusivament, el balanç, sense qüestionar la resta del contingut de l'acord de fusió ${ }^{684}$, ja que, a més, aquesta impugnació no suspendria el procés de fusió685, a diferència del que podria succeir si s'impugnara l'acord totalment. Corroborava aquesta interpretació, d'una banda, que també es preveiera la impugnació del balanç final de liquidació i del projecte de distribució de l'actiu fins i tot en supòsits en què no havien pogut ser aprovats per l'assemblea ${ }^{686}$, possibilitat que es manté en

683 Article 98 LGC: "1. Podrà considerar-se balanç de fusió l'últim balanç anual aprovat, sempre que no siga anterior en més de vuit mesos a la data de realització de l'assemblea que ha de resoldre sobre la fusió. Si el balanç anual no complira amb aquest requisit, caldrà elaborar un balanç dins del termini esmentat abans, que haurà de ser censurat pels interventors $i$ haurà de ser sotmès a l'aprovació de l'assemblea. 2. La impugnació del balanç de fusió no podrà suspendre per si sola l'execució d'aquesta." Fora d'això, la redacció d'aquest apartat 2 és essencialment idèntica a la de l'article 239.3 LSA

684 En contra d'aquesta interpretació, MARíN LÓPEZ, J. J., «Novedades...», op. cit., pàg. 1118, nota 20: "Noteu la imprecisió terminològica dels tres articles fins ara esmentats [article 68.6, 69.6 i 98.2 LGC]: el que s'impugna no és l'aprovació dels comptes anuals o el balanç de fusió sinó els acords de l'assemblea general amb aquest contingut".

685 S'hi tractaria, a imatge del que passa en la nul-litat de la fusió ja inscrita en l'àmbit de la LSA, de no interrompre l'eficàcia de la fusió, "per tal d'una tutela més intensa i efectiva, no solament dels creditors de les societats intervinents a la fusió, sinó també de l'interès que socis i tercers en general tenen en l'estabilitat de la fusió i els seus efectes" (MARTíNEZ SANZ, F., «La nulidad de la fusión...», op. cit., pàg. 74, que més endavant, en pàg. 80, afirma la impugnabilitat autònoma del balanç de la fusió en la LSA mitjançant el règim general de la impugnació d'acords socials).

686 Article 113.4 LGC: "Si fóra impossible la realització de l'assemblea general, els liquidadors han de publicar el balanç final i el projecte de distribució de l'actiu, una vegada censurats, en el Butlletí Oficial de l'Estat i en un diari dels de més circulació a la província del domicili social de 
la LCoop; d'altra banda, que la impugnabilitat de l'acord de fusió en la seua totalitat, o per qualsevol altre motiu diferent a la disconformitat amb el balanç, no requeria una menció expressa, ja que no tindria especialitats rellevants respecte al règim general ${ }^{687}$.

La possibilitat d'impugnar exclusivament el balanç de la fusió es traslladava, a més, al balanç de l'escissió (102.2 LGC) i a la LCCV (article 65. 2, i), 2n paràgraf), en virtut de remissió expressa dels articles corresponents.

Però la LCoop, en els articles del 63 al 67, dedicats a regular el procés de fusió, ha eliminat tota referència a la impugnació, no ja del balanç de la fusió, sinó de l'acord mateix. Entenem, per tant, que no hi té cabuda ara la. interpretació feta per a la LGC, ja que una impugnació eventual del balanç de la fusió suposa la impugnació de l'acord en la seua totalitat per la via prevista en l'article 31 LCoop i, per tant, amb la possibilitat explícitament regulada a l'article 31.5 de sol-licitar i obtenir la suspensió de l'acord. Tot això és també aplicable al procediment d'escissió (article 68.5 LCoop) i a la LCCV (article 65. 2, e), 2n paràgraf, ja que la remissió a la LGC del qual ha d'entendre's ara en favor de la LCoop).

la cooperativa. Transcorreguts sis mesos des d'aquestes publicacions sense que hagen estat impugnats [...]".

687 S'ha de tenir present que, a diferència del que es preveu per a les societats anònimes en l'article 246 LSA, en l'àmbit cooperatiu no s'ha regulat un procediment específic per a la nul-litat de la fusió ja inscrita. En aquest sentit, cal separar "l'acció de nul.litat de la fusió pròpiament dita i l'acció d'impugnació de l'acord - nul o anul-lable- de fusió [...] ja que la mera impugnació de l'acord d'una societat participant en la fusió permetria invalidar únicament l'acord respectiu"; i també s'han d'entendre separadament l'acció de nul-litat de la fusió "d'altres extrems d'impugnació judicial possibles en el règim vigent de la fusió [...], per exemple, amb el balanç de fusió " (EMBID IRUJO, J. M., "En torno a la nulidad de la fusión...", op. cit., pàg. 5611 i 5612, i en "En torno a las modificaciones estructurales...", op. cit., pàg. 26). En el mateix sentit, GÓMEZ PORRÚA, J. M., La fusión..., op. cit., pàg. 257, en relació amb les societats anònimes, assenyala que la LSA (article 246), seguint el que estableix la Directiva 78/855/CEE "es limita a contemplar la nul-litat de la fusió ja inscrita en el Registre Mercantil; per això, anteriorment a aquest moment, la nul-litat $\mathrm{o}$, si escau, l'anul-labilitat del procediment de fusió queda sotmesa al règim general establert per a la impugnació dels acords socials".

Quiestió diferent serà la qualificació del règim de la nul-litat de la fusió ja inscrita prevista en la LSA, respecte del qual la doctrina debat "si el que es preveu [...] és pròpiament un règim de nul.litat, anàleg [...] en el seu fonament i finalitat al que recullen els articles 34 i 35 de la LSA ("nul-litat de societats")", o si pot plantejar-se "la possibilitat de trobar-nos més aviat davant d'una mera translació del règim de la impugnació dels acords socials" (MARTíNEZ SANZ, F., "La 
D'altra banda, la LCCV (article 65. 2, a) exigeix que el projecte de fusió vaja acompanyat, en la presentació a l'assemblea, per "un informe dels auditors de comptes, que estigueren exercint el seu càrrec, sobre la situació econòmica i financera de les cooperatives que intervenen i la previsible de la cooperativa resultant i dels socis, com a conseqüència de la fusió". Cal, doncs, reproduir aci tot allò apuntat per a l'aprovació de comptes anuals sense l'informe preceptiu dels auditors, si bé s'ha de fer notar que l'informe sobre la fusió sols serà exigible, al nostre parer, si en el moment de la fusió la cooperativa que aprovarà el projecte en l'assemblea té nomenats auditors en exercici ${ }^{68}$.

Es pot arribar a conclusions anàlogues, si bé amb les adaptacions necessàries, amb la regulació d'altres modificacions estructurals que la legislació cooperativa més recent incorpora ${ }^{689}$. En efecte, tant la LCoop (article 69) com la LCCV (articles 68 i 69) regulen la transformació de les cooperatives en altres persones jurídiques, i d'aquestes en cooperatives; a més, la LCCV (article 67) reglamenta explícitament la figura de la cessió global de l'actiu i del passiu. En tots aquests processos es preveu, en un moment o en un altre, la incorporació del balanç de l'entitat; vegem-ne quines són les especificitats.

nulidad de la fusión...", op. cit., pàg. 67).

688 FAJARDO GARCIA, I. G., i SENENT VIDAL, M. J., Texto refundido..., op. cit., pàg. 87: "[...] no obstant això, atès el seu interès, encara que la cooperativa no estiga obligada a auditar els seus comptes, l'assemblea pot acordar el nomenament d'auditors per a la seua realització".

689 EMBID IRUJO, J. M., «En torno a las modificaciones estructurales...», op. cit., pàg. 32: "sota la denominació genèrica de modificacions estructurals de la societat. S'ha d'anotar, inicialment, l'esforç progressiu de tipificació que s'observa en el panorama del dret comparat [...]. D'altra banda, l'evolució de la pràctica comercial en la matèria és molt ràpida, de manera que el procés de tipificació legal, per continu que siga, no arriba a assolir un estat satisfactori. El sector de la atipicitat en el tema que ens ocupa serà, consegüentment, molt ampli, i obligarà a una reflexí́ permanent sobre el règim a aplicar i sobre la possibilitat de dur a terme una extensió analógica [...] Ens enfrontem, per això, amb una categoria dinàmica els perfils externs de la qual són necessàriament delimitats pels trets caracteritzadors de les figures tipificades legalment", i en pàg. 34: "Sembla, en conseqüència, que són dos, bàsicament, els elements la transferència dels quals ens situa davant d'una modificació estructural de la societat: elements del patrimoni i posicions de soci. [...] Tanmateix, qualsevol negoci o transmissió relativa a aquests elements no en constitueix necessàriament una "modificació estructural». [...] Caldrà trobar, per tant, una circumstància específica que singularitze la transmissió [...]. En la nostra opinió, aquest element és de naturalesa teleològica i consisteix en la finalitat de servir, per vies diferents de la fusió, al propòsit de concentració empresarial". 
Pel que fa a la transformació de cooperatives en altres persones jurídiques, la LCoop (article 69.2) opta per sotmetre l'acord corresponent de l'assemblea als termes $\mathrm{i}$ les condicions establerts per a la fusió en la Llei mateixa i en els estatuts, per la qual cosa reproduïm el que s'ha conclòs anteriorment: la impugnació del balanç de la transformació suposa la impugnació de l'acord en la seua totalitat, pel procediment general de l'article 31 LCoop i amb la possibilitat de sol-licitar i d'obtenir la suspensió de l'acord.

La LCCV (article 68. 1), en canvi, no exigeix l'aprovació del balanç com a part del contingut de l'acord assembleari, però sí que requereix, per a la inscripció de l'escriptura pública corresponent en el Registre de Cooperatives, l'acompanyament del "balanç de situació tancat el dia anterior a l'acord de transformació i verificat pels auditors de comptes". Tanmateix, permet que aquet balanç puga ser substituït pel de l'últim exercici, si encara no han transcorregut sis mesos des del seu tancament, per la qual cosa, en aquest cas, el balanç pot no comptar amb la verificació si la cooperativa no estava obligada al tancament de l'exercici.

En relació amb aquesta regulació, s'han d'observar diverses qüestions: en primer lloc, quan el balanç haja de ser auditat, la falta de l'informe corresponent suposa una vulneració del precepte legal; en segon lloc, en el cas que la cooperativa no haja d'auditar els seus comptes, no serà, al nostre parer, preceptiva la verificació externa, per analogia amb allò que s'ha deduït per a la fusió, ni quan es tracte del balanç de situació, ni quan es presente el balanç anual en els sis mesos següents al seu tancament; $i$ en tercer lloc, ens hem de plantejar, en tot cas, si un balanç que no necessàriament ha estat aprovat per l'assemblea pot ser objecte d'impugnació.

En relació amb aquesta última qüestió, plantejaríem, almenys teòricament, la possibilitat d'impugnar l'acord de l'òrgan d'administració que haguera decidit 
la validesa del balanç de situació690 o el de l'assemblea ordinària que aprovara el balanç de l'últim exercici. Però aquesta solució no sembla molt efectiva, si es pensa en els terminis limitats del procediment d'impugnació i en les majors restriccions que presenta la impugnació d'acords del consell rector.

Sembla més eficaç, doncs, plantejar la impugnació de l'acord assembleari de transformació, sobre la base que un balanç incorrecte podria ser element essencial de la formació errònia de la voluntat social. En efecte, encara que la llei no obligue a la presentació a l'assemblea del balanç de situació, pot argumentar-se que aquest serveix de base econòmica a la transformació, per la qual cosa un vici eventual en la seua formalització podria ser de suficient transcendència perquè els socis, si estigueren correctament informats, hagueren pres una decisió diferent ${ }^{691}$.

Finalment, pel que fa a la transformació de les cooperatives en un altre tipus d'entitats, s'ha de dir que la LSRL regula, en els articles 87-93, el supòsit de transformació de cooperativa en societat de responsabilitat limitada, i exigeix, entre altres requisits, que l'acord de transformació incloga l'aprovació del balanç tancat el dia anterior a l'acord; això faria legalment obligatori el requisit també a les cooperatives regulades per la LCCV. Això no obstant, s'ha qüestionat la constitucionalitat de l'aplicació de la LSRL per la superposició amb les normes autonòmiques cooperatives (precisament posant com a exemple la matèria de la transformació social) ja que, en principi, aquestes últimes desenvolupen en aquesta matèria una competència exclusiva ${ }^{69}$.

${ }^{690}$ MARTÍNEZ SANZ, F., «La nulidad de la fusión...», op. cit., pàg. 75 i 76, nota 21.

691 Sobre la necessitat que el soci reba informació suficient per poder exercir un control de la necessitat ("plausibilitat") de la fusió, vegeu EMBID IRUJO, J. M., "En torno a las modificaciones estructurales...", op. cit., pàg. 22 i 23.

692 LEÓN SANZ, F. J., "Fusión, transformación...», op. cit., pàg. 25 a 59, especialment en pàg. 46; i en LEÓN SANZ, Francisco José, «Modificaciones estructurales de sociedades cooperativas. Distribución de competencias entre el Estado y las Comunidades Autónomas", en AA. DD., Estudios de derecho mercantil. Homenaje al profesor Justino F. Duque, tom I, Universidad de Valladolid, Valladolid, 1998, pàg. 465 a 488. ALFONSO SÁNCHEZ, Rosalía, "Ámbito subjetivo de 
En els supòsits de transformació d'un altre tipus de persones jurídiques en cooperatives s'haurà d'atendre, fonamentalment, allò que preveu la legislació que ho regula, encara que tant la LCoop (article 69.3) com la LCCV (article 69.3) també reclamen que, en tot cas, en l'escriptura s'incloga, al costat de l'acord de l'assemblea i altres mencions, "el balanç de l'entitat transformada tancat el dia anterior a l'adopció de l'acord"; la LCCV exigeix, a més, que el balanç siga verificat pels auditors de comptes, per la qual cosa el seu informe serà preceptiu quan la cooperativa estiga obligada a auditar els seus comptes.

Quant a la cessió global de l'actiu i del passiu, la LCCV (article 67) incorpora una regulació explícita ${ }^{693}$ que indica que els socis, per a l'adopció de l'acord corresponent, "hauran de tenir en compte l'informe preceptiu elaborat per un expert independent sobre la valoració del patrimoni cedit", i que autoritza l'assemblea a sol-licitar un segon informe d'un altre expert. S'ha de repetir, doncs, tot allò que s'ha dit anteriorment: la manca d'informe suposarà la nul-litat de l'acord de cessió, que podrà impugnar-se pel procediment general de l'article $36 \mathrm{LCCV}$. Una qüestió diferent serà que l'informe siga vinculant; al nostre parer, l'assemblea, després de conèixer l'informe, pot prendre una decisió diversa a la que, si s'escau, poguera ser recomanada pels experts.

\section{Impugnació del balanç final i del projecte de distribució de l'actiu sobrant}

\footnotetext{
la transformación en la legislación cooperativa (algunos aspectos críticos)», RdS, núm. 8, 1997, pàg. 188 i 189, estima, contràriament, que es tracta "d'una intromissió del legislador autonòmic en altres lleis mercantils, matèria reservada en exclusiva a l'Estat", a més d' "una discriminació per raó del territori [...] l'exprés reconeixement d'un règim jurídic per a les operacions de transformació en què intervinga una societat cooperativa en part del territori nacional i no en la resta". Vegeu sobre això el que s'exposa en l'epígraf 3.2.1 "Evolució històrica. L'estat de les autonomies i les cooperatives. Conflicte de competències", del capítol primer. 
L'article 74 LCoop exigeix, en l'apartat 1, l'aprovació per part de l'assemblea del balanç final de la liquidació i del projecte de distribució de l'actiu ${ }^{64}$; però, a més, en l'apartat 2 explicita que "el balanç final i el projecte de distribució de l'actiu (...) podran ser impugnats en el termini de quaranta dies comptadors des de la publicació i conforme al procediment establert per a la impugnació dels acords de l'assemblea general, per qualsevol soci que se senta ofès i pels creditors els crèdits dels quals no hagueren estat satisfets o garantits. Mentre no haja transcorregut el termini per a la impugnació o s'hagen resolt per sentència ferma les reclamacions interposades, no es podrà repartir l'actiu resultant...".

Aquesta regulació (que, com ha quedat apuntat, té l'origen en una regulació similar adoptada per la LGC, encara que varia alguns aspectes essencials ${ }^{\mathrm{es5}}$ ) obri la possibilitat de dues impugnacions diferents: una, la de l'acord assembleari, pel procediment general d'impugnació per la via de l'article 31 LCoop; i una altra, reservada per a la sola impugnació del balanç i del projecte que, si bé seguirà també el procediment de l'article 31 , té un termini $\mathrm{i}$ una legitimací diferents als generals, i que suspèn almenys una part de l'execució de l'acord, el repartiment de l'actiu. ${ }^{696}$

694 La LCoop exigeix, a més, en el cas que hagen estat nomenats els "interventors de la liquidació" regulats a l'article 72, que el balanç final i el projecte de distribució de l'actiu hagen estat prèviament censurats per aquells.

695 Article 113 LGC: 2 . El balanç final i el projecte de distribució de l'actiu seran censurats [...] i se sotmetran per a la seua aprovació a l'assemblea general. Els esmentats acords es publicaran [...]. "3. Els acords a què es refereix el número anterior podran estats impugnats pel soci 0 associat que se senta ofès, o pels creditors els crèdits dels quals no hagueren estat satisfets 0 consignats, així com pel Consell Superior del Cooperativisme, per disconformitat en la quantia o destinació del sobrant de l'haver líquid, conforme a l'article 112. La impugnació es tramitarà conforme a les normes de l'article 52. “4. Si fóra impossible la realització de l'assemblea general, els liquidadors publicaran el balanç final i el projecte de distribució de l'actiu, una vegada censurats [...]. Transcorreguts sis mesos des d'aquestes publicacions sense que siguen impugnats [...] s'entendran aprovats definitivament".

Noteu com la LGC sí que especifica inicialment, en l'apartat 3, que el que s'impugna són "els acords" d'aprovació per l'assemblea del balanç final i del projecte de distribució de l'actiu, peró amb una legitimació i unes causes d'impugnació diferents a les generals. Tanmateix, posteriorment, en l'apartat 4, admet expressament la impugnació de tals documents encara sense haver estat aprovats per l'assemblea, quan siga impossible la seua realització, com assenyala MARíN LOPEZ, J. J., «Novedades...», op. cit., pàg. 1118.

696 En contra, CORONADO FERNÁNDEZ, F., «Capítulo X...», op. cit., pàg. 350, que considera que 
En efecte, aquesta última modalitat d'impugnació es reserva a socis que se senten ofesos $\mathrm{i}$ a creditors els crèdits dels quals no hagueren estat satisfets o garantits, que tenen un termini de quaranta dies per contradir el balanç de liquidació i el projecte de distribució de l'actiu. Encara que la llei no s'estén en la seua regulació, sembla que aquesta mesura està destinada a aquells supòsits en què determinats socis o creditors, conformes amb la liquidació en termes generals, consideren que el repartiment concret del líquid social que es proposa vulnera els seus drets sobre aquest; aquest seria el sentit que s'hauria d'atribuir a l'expressió sobre el sentiment de greuge que permetrà a un soci o a un tercer creditor impugnar directament uns documents comptables que no li són favorables.

Tanmateix, es planteja el dubte sobre si la impugnació haurà de cenyir-se a les causes previstes en el procediment general, això és, contrarietat amb la Llei o amb els estatuts socials, o lesió a l'interès social en benefici de socis o tercers. Considerem que això no es correspon amb la intenció del legislador; en primer lloc, l'apartat 2 de l'article 74 LCoop es remet, precisament, "al procediment establert per a la impugnació dels acords de l'assemblea general", no a les causes d'aquesta; en segon lloc, aquesta interpretació resultaria excessivament restrictiva i podria arribar a deixar sense efecte la previsió normativa que, si té algun sentit, és, al nostre parer, permetre a socis i creditors defensar els seus interessos particulars fins $\mathrm{i}$ tot quan no siga possible impugnar l'acord d'aprovació de la liquidació697.

\footnotetext{
"encara que textualment s'indica que el balanç i el projecte poden ser impugnats, el cert és que el que s'impugna és l'acord de l'assemblea que decideix sobre aquests".

${ }^{697} \mathrm{D}$ 'altra banda, tampoc ha de pensar-se que les possibilitats d'impugnació per aquesta via estan absolutament obertes. Succeeix, de manera semblant als supòsits d'impugnació de la fusió per disconformitat amb la relació de canvi de les accions (vegeu MARTfNEZ SANZ, F., "La nulidad de la fusión...», op. cit., pàg. 78 i 79), que les actuacions economicopatrimonials de la liquidació, no resolent-se exclusivament amb meres operacions matemàtiques, tampoc deixen un ampli marge a la discrecionalitat.
} 
Tampoc en aquest aspecte coincideix la regulació de la LCCV, que no fa menció expressa a la impugnació ni a l'article 71 ("Liquidació") ni al 72 ("Extinció"). S'estableix, això sí, l'obligació dels liquidadors de realitzar un inventari i un balanç inicials de la liquidació i un balanç final; aquests documents han de ser verificats, si escau, pels auditors "que exerciren el càrrec en el moment de la dissolució". La cancel-lació registral de la cooperativa sols es produirà quan se certifique l'acord de l'assemblea general amb l'aprovació d'"el balanç final de liquidació i les operacions d'aquesta". No es preveu, doncs, en la LCCV, la impugnació separada dels documents comptables de la liquidació. Per tant, les operacions de liquidació podran ser impugnades únicament, en principi, mitjançant l'oposició al total acord de l'assemblea (això no obstant, vegeu infra la possibilitat d'impugnar els acords i actuacions dels liquidadors en l'epígraf 3.4. d'aquest capítol).

1.2.3. Impugnació de la realització de l'assemblea i, per tant, de tots els seus acords

Encara que la institució de la impugnació es construeix legalment sobre la base dels acords adoptats pels òrgans socials, la jurisprudència deixa constància abundant de la impugnació de la realització de tota la sessió, des del principi a la fi, en general en virtut de vicis en la convocatòria o en la constitució de $l^{\prime}$ òrgan ${ }^{698}$. Aquests vicis invaliden tots els acords adoptats en la sessió, per la

698 En l'àmbit cooperatiu, pot veure's la STS, Sala 1a, de 3.5.1994, núm. 416/1994, RJA 1994/3559. Per a les societats de capital, ÁviLA NAVARRO, P., La sociedad ... op. cit., pàg. 424, cita les SSTS de 20.05.83 i de 14.05.86; CARBAJO CASCÓN, Fernando, Los requisitos de convocatoria de junta general de la sociedad anónima, Tecnos, Madrid, 1996, pàg. $10 \mathrm{i} 11$, cita al seu torn les SSTS de 28.4.1967, (RJA 1967/2208), de 22.10.1974 (RJA 1974/3970) i de 13.5.1976 (RJA 1976/2177) i la RDGRN 11.2.1970 (RJA 1970/3009); i RODRfGUEZ RUIZ DE VILLA, D., Impugnación..., op. cit., pàg. 59 a 69, cita abundant jurisprudència, i la RDGRN de 26.2.1953 (RJA 1953/1114) que qualifica els requisits de convocatòria i celebració de normes de dret necessari, així com la STS, Sala 1a, de 3.2.1966 (RJA 1966/30) que assenyala que aquests requisits "s'estableixen com a garantia que els acords socials siguen adoptats amb coneixement $i$ llibertat per part de tots els que hagen d'intervenir en la seua proposta, deliberació i votació".

SORIA FERRANDO, J. V., La impugnación..., op. cit., pàg. 160: "els requisits de publicitat de les convocatòries de les juntes s'estableixen en benefici de tots els accionistes, [...] tenen per finalitat oferir a cada soci la possibilitat $d$ 'intervenir en les juntes, amb coneixement de les matèries a 
qual cosa són aquests els que s'han de considerar l'objecte de la impugnació699. però, a més, com ha assenyalat la doctrina jurisprudencial, la invalidesa afecta acords posteriors i els actes d'execució corresponents ${ }^{700}$.

En tot cas, els supòsits d'impugnació de la totalitat d'acords d'una assemblea per vicis en la convocatòria o constitució presenten una casuística variada ${ }^{701}$. En relació amb la convocatòria, s'ha assenyalat que la seua regulació s'integra per normes de diversa índole: les que atribueixen la realització a l'òrgan d'administració i, si no n'hi ha, a l'autoritat judicial; les que estableixen els requisits formals de l'anunci de la convocatòria, i les relatives a l'ordre del dia i altres extrems relacionats amb el dret d'informació del soci.

Pel que fa als vicis de la convocatòria relatius a la competència per a la seua realització, la legislació cooperativa, de manera idèntica a allò que preveu per a les societats de capital, atribueix aquesta funció, inicialment, a l'òrgan d'administració; únicament si aquest no actua pot sol-licitar-se la convocatòria

tratar-hi. Potser per aquestes raons en la Llei de societats anònimes la vulneració de les normes que regulen el procés de formació de l'anomenada "voluntat social» produeix la nul-litat absoluta de la junta general així celebrada i, per tant, la nul-litat de tots els acords en ella adoptats".

699 En contra, CABALLOL I ANGELATS, L., «Comentario al artículo 115», op. cit., pàg. 1117 i 1119 , considera que en aquests supòsits "l'objecte de la impugnació no és pròpiament l'acord, sinó la junta", per bé que, després, afirma que "l'estimació d'una impugnació basada en un vici d'aquest tipus [...] no afectarà els acords que no siguen efectivament impugnats".

700 La STS, Sala 1a, de 29.7.1998, núm. 768/1988, RJA 1998/6379 manté la nul-litat radical declarada pel tribunal d'instància de tota la junta general "per haver-se faltat a principis de legalitat formal en la convocatòria", derivant-ne la nul-litat de tots els acords basats en aquesta (successius augments del capital) adoptats en juntes i consells d'administració posteriors, així com la falta de valor de les escriptures i inscripcions registrals corresponents, "ja que la nul-litat radical d'uns acords porta la ineficàcia dels que descansen en aquests, fins i tot encara que no foren combatuts". En el mateix sentit, la STS, Sala 1a, de 29.6.1995, núm. 634/1995, RJA 1995/5269.

$701 \mathrm{~S}$ ' trob de tenir present que els requisits de convocatòria i constitució de l'assemblea no sols es con les normes legals, sinó que els estatuts en molts casos poden i han de contenir normes es comentàries, $\mathrm{i}$ fins $\mathrm{i}$ tot normes derogatòries d'algunes de les quals amb caràcter dispositiu contenen en la llei corresponent (RODŔfGUEZ, M. P., i SUSO, J. M., «Los órganos de la cooperativa", op. cit., pàg. 146 i 147). 
judicial $^{702}$. Això no obstant, la DGRN ha admès la possibilitat que la junte general puga ordenar la convocatòria i predeterminar el seu contingut (RRDGRN de 31.3, 29.4 i 30.4.1992). En l'àmbit cooperatiu, la LCoop (article 21.1) permet que l'assemblea general done instruccions al consell rector sotmeta a la seua instrucció l'adopció pel consell de determinats assumptes; en canvi, la LCCV autoritza únicament l'assemblea perquè adopte acords en matèries que la llei no atribueix a un altre òrgan (article 27.2), i atribueix competència expressa per a la convocatòria al consell rector (article 29), per la qual cosa no sembla possible en aquest cas el mandat assembleari.

En tot cas, aquesta atribució competencial determina que la convocatòria, en general, requerisca un acord de l'òrgan d'administració organitzat de manera col-legial ${ }^{703}$. Això planteja una casuística variada, recollida abundantment per la doctrina i la jurisprudència. Així, la inexistència de l'acord o, el que és el mateix la convocatòria realitzada exclusivament pel president o per alguns membres del consell, determina la invalidesa de $1^{\prime}$ assemblea ${ }^{704}$. També pot plantejar-se la invalidesa de la convocatòria quan l'acord del consell siga, per la seua banda,

702 Es refereix a la impugnabilitat de la sessió convocada judicialment de manera indeguda GALÁN CORONA, "La Junta general», op. cit., pàg. 506: "la no admissió de recursos contra la resolució judicial que accedisca a la convocatòria de la JG no exclou la possibilitat que en via d'impugnació d'acords socials puga invocar-se la convocatòria indeguda de la Junta pel jutge com a motiu impugnatori, com admet la STS de 12 de juliol de 1983 i estima encertadament Sacristán Represa comentant-la". En la mateixa línia, RODRÍGUEZ ARTIGAS, F., "La junta general de socios", op. cit., pàg. 600.

Una diferència substancial que s'observa en la convocatòria judicial de l'assemblea general en la LCoop (article 23) respecte a la regulada en la LCCV i en les societats de capital (arts. 29.2 LCCV, 101 LSA i 45 LSRL) és que en aquella no es requereix que el jutge haja de donar audiència prèvia als administradors.

També pot convocar l'assemblea general en determinats supòsits el comissari del sindicat d'obligacionistes (article 304.2 LSA).

703 Les restants modalitats possibles per a l'òrgan d'administració a la cooperativa (art. 321 LCoop i 37.2 LCCV) no semblen plantejar conflictes: la decisió de l'administrador únic o d'un dels administradors solidaris serà suficient per a la validesa de la convocatòria, mentre que es requerirà la unanimitat dels administradors mancomunats per a la seua realització.

704 CARBajo CASCÓN, F., Los requisitos..., op. cit., pàg. 17, cita les SST de 31.5.1983 (RJA 1983/2954), de 8.3.1984 (RJA 1984/1204), de 25.2.1986 (RJA 1986/852), de 23.10.1987 (RJA $1987 / 7466)$, de 27.12.1993 (RJA 1993/10152), i de 24.2.1995 (RJA 1995/1113); RODRfGUEZ RUIZ DE VILLA, D., Intpugnación..., op. cit., pàg. 60 i 61, cita les SSTS, Sala 1a, de 3.2.1966 (RJA 1966/30), de 13.5.1976 (RJA 1976/2177), i de 25.2.1986 (RJA 1986/852); SORIA FERRANDO, J. V., Le 
impugnable ${ }^{705}$. Quant a la convocatòria realitzada per administradors amb mandat caducat, coincidim amb la posició doctrinal i jurisprudencial que $n^{\prime}$ admet la validesa quan es tracte de donar continuïtat al funcionament social mateix ${ }^{706}$.

També s'ha plantejat la possibilitat de delegar la decisió de convocar en un conseller delegat o en un membre del consell; aquest supòsit s'admet en seu de societats de capital, "excepte si es tracta d'incloure en l'ordre del dia l'exercici d'alguna de les facultats no delegables" i sempre que conste inscrita la delegació en el Registre Mercantil (RDGRN 8.5.1987, RJA 1987223) ${ }^{707}$. En l'àmbit cooperatiu, no s'exclou explícitament aquesta possibilitat: la LCoop (article 36.1) remet als estatuts la fixació de les competències dels consellers delegats, sense

impugnación..., op. cit., pàg. 170 a 173.

705 RODRfGUEZ RUIZ DE VIILA, D., Impugnación..., op. cit., pàg. 61, cita la STS, Sala 1a, de 28.1.1986 (RJA 1986/442); SORIA FERRANDO, J. V., La impugnación..., op. cit., pàg. 170 a 173.

706 ALONSO ESPINOSA, F. J., "Capítulo VII», op. cit., pàg. 263: "El venciment del termini per al qual foren nomenats determina la caducitat automàtica del nomenament, cosa que no implica el cessament automàtic com a administrador. L'administrador amb càrrec caducat cessa en efecte quan, a més de vençut el termini per al qual va ser nomenat, s'haja produït l'acceptació de qui el substituïsca". POLO SÁNCHEZ, E., Los administradores..., op. cit., pàg. 129: "s'hauria d'estimar per això que la competència de l'òrgan d'administració amb administradors decaiguts als seus càrrecs ha de mantenir-se, però limitada únicament, bé a la convocatòria de la junta que acorde sobre la seua renovació, bé —en el supòsit que els administradors no foren accionistes- a la sol-licitud al jutge de la convocatòria de l'esmentada junta". Recull aquesta mateixa opinió CARbajo CASCÓN, F., Los requisitos..., op. cit., pàg. 22. RodRíGUEZ RUIZ DE VILLA, D., Impugnación..., op. cit., pàg. 61, cita la STS, Sala 1a, de 22.10.1974 (RJA 1974/3970), diferencia aquest supòsit del de la junta convocada per administradors que hagueren estat cessats, encara que el cessament no s'haguera inscrit encara en el Registre (RDGRN de 26.2.1953, RJA 1953/1114) o no hagueren estat encara substituïts (SAP de Madrid de 3.12.1991, RGD núm. 572, maig 1992, pàg. 4524 a 4533), cas en què les úniques alternatives que es proposen són la convocatòria judicial o la junta universal.

Més recentment, la STS, Sala 1a, de 27.10.1997, núm. 928/1997, RJA 1997/7617 es refereix a aquesta qüestió: "el recurrent diu que les convocatòries de junta general fetes pel president del consell d'administració, això no obstant la caducitat del seu càrrec, són nul-les (vegeu S. 22 octubre 1974 [RJA 1974/3970]). El motiu no prospera perquè és molt reiterada i constant la jurisprudència que admet la convocatòria de juntes per consells d'administració que han depassat el seu període de direcció, entre altres raons per la necessitat social de regularitzar els Organs de les societats i acomodar-los a la legalitat estricta".

cit. considerar-se semblant el supòsit esmentat per SORIA FERRANDO, J. V., La impugnación..., op. cit., pàg. 171, de la STS de 10.6.1970, que estima la validesa de la convocatòria d'una junta general efectuada per uns administradors l'acord de nomenament dels quals estava sotmès a impugnació, ja que "no pot tenir-se per nul-la l'esmentada junta, ni en conseqüència els acords que s'hi van prendre, fins que aquesta nul-litat no siga declarada per sentència ferma". 
cap restricció; per la seua part, la LCCV (article 43.2) no inclou entre les facultats no delegables la de convocar l'assemblea, si bé adverteix que "les facultats delegades sols poden comprendre el tràfic empresarial ordinari de la cooperativa". Sembla, doncs, que els consells rectors de les cooperatives sotmeses a la LCoop podran, excepte en cas de restricció estatutària, delegar la convocatòria en algun dels seus membres; més discutible es presenta aquesta possibilitat en les cooperatives regulades per la LCCV, ja que és difícil enquadrar la convocatòria $\mathrm{d}^{\prime}$ assemblea entre les competències necessàries per al "tràfic empresarial ordinari".

Quant als requisits formals, legals o estatutaris de la convocatòria, l'incompliment dels quals pot donar lloc a la impugnació de l'assemblea, podem distingir els relacionats amb les mencions que ha de contenir, amb el termini d'antelació i amb la difusió que se li ha de donar. Pel que fa a les indicacions de la convocatòria, la Llei s'encarrega d'establir un contingut mínim (data, lloc i hora de la reunió, en primera i segona convocatòria ${ }^{708}$, ordre del dia, i informació o documentació que s'acompanye o que quede dipositada al domicili social), però no ha d'oblidar-se que els estatuts en poden afegir d'altres, i que algunes mencions són òbviament necessàries (com ara, per exemple, la denominació social ${ }^{709}$ ) encara que no estiguen expressament exigides.

707 CARBajo CASCón, F., Los requisitos..., op. cit., pàg. 17 a 19.

708 TATo PlAZA, A., «Os órganos sociais», op. cit., pàg. 79, comentat la LCG: "davant el que succeeix - per exemple-en la legislació en matèria de societats anònimes, on la previsió d'una segona convocatòria té caràcter facultatiu (article 98 LSA), en matèria de cooperatives la data, el lloc i l'hora de la segona convocatòria constitueixen una menció obligatòria de l'anunci. La seua omissió, doncs, podria implicar la nul-litat de la convocatòria i, per tant, dels acords adoptats a l'Assemblea". Tanmateix, s'ha de tenir present que la redacció de l'article 24.2 LCoop permet la convocatòria separada: "La convocatòria indicarà, almenys, la data, hora i lloc de la reunió, si és en primera o segona convocatòria", amb la qual cosa l'obligatorietat serà d'indicar, almenys, quina és la convocatòria que s'està comunicant.

709 CARBAJO CASCÓN, F., Los requisitos..., op. cit., pàg. 29 i 30: "poden sorgir casos en què la vertadera denominació de la societat, que necessàriament consta en estatuts (...), i la que efectivament figura a l'anunci no coincideixen, fet aquest que podria induir a error els accionistes. La DGRN s'ha ocupat d'aquesta situació en sengles resolucions de 2 i 3 d'agost de
1993 (RJA. 7114 i 7115), ambdues amb contingut idèntic. [...] "suposa un defecte de manera que 
Els terminis mínim i màxim d'antelació de la convocatòria estan establerts legalment, però l'interval pot ser delimitat pels estatuts socials; a més, tant la LCoop com la LCCV preveuen la possibilitat d'afegir nous punts a l'ordre del dia, a petició d'una minoria de socis, amb la qual cosa el consell rector haurà de remetre el nou ordre del dia, amb una antelació mínima determinada i seguint la mateixa forma que per a la convocatòria inicial. En canvi, l'incompliment del termini de sis mesos des del tancament de l'exercici no dóna lloc a la impugnabilitat de l'assemblea general ordinària, tal com es recull explícitament en la LCCV (article 28.5), amb independència que el retard puga suposar l'exigència de responsabilitat als membres dèl consell.

En tot cas, la conflictivitat que ha generat la interpretació sobre quina ha de ser la manera de comptabilitzar els terminis ${ }^{70}$ ha portat a la LCoop (article 24.1) a aclarir que "el termini quinzenal es comptarà excloent del còmput tant el dia de l'exposició com el de la celebració de l'assemblea. Ignorem per què es refereix la norma legal exclusivament al termini mínim de quinze dies, però considerem que pot aplicar-se anàlogament al termini màxim: el dia de realització de la junta s'exclou per la dicció mateixa de la norma reguladora de la convocatòria, que es refereix al termini d'antelació; el dia d'emissió de la convocatòria s'exclou per aplicació de l'article $5.1 \mathrm{CC}^{711}$.

podria portar la nul-litat de la convocatòria i, per tant, dels acords adoptats en aquesta" però en el cas analitzat per la DGRN tal discrepància «manca clarament d'identitat suficient per induir a error els convocats»". A això afegeix altres fonaments jurídics relacionats amb la conservació del negoci. Tot quedaria, en suma, sotmès a l'apreciació de si efectivament es va produir error o no en els convocats, la qual cosa apareix indissolublement unida, a efectes de prova, al principi general de bona fe de l'article 7.1 del Codi civil".

${ }^{710}$ Veure en CARBAjO CASCÓN, F., Los requisitos..., op. cit., pàg. 26 a 28, una síntesi excel.lent de la "peculiar contradicció interpretativa entre TS i DGRN". També en SORIA FERRANDO, J. V., La impugnación...., op. cit., pàg. 183. SÁNCHEZ CALERO, Fernando, Principios de derecho mercantil, McGraw Hill, Madrid, 2000, pàg. 171, recull jurisprudència i RRDGRN recents en què s'inclou el dia de l'anunci en el còmput del termini.

711

CARBajo CASCÓN, F., Los requisitos..., op. cit., pàg. 27. 
Quant als mitjans de publicitat, la legislació cooperativa estableix la necessitat de difondre la convocatòria mitjançant anunci al domicili social i, si escau, a la resta dels centres de treball, sense perjudici que puguen establir-se estatutàriament altres mitjans de comunicació. A més, la LCCV exigeix la remissió de la convocatòria al domicili del soci ${ }^{712} \mathrm{i}$ la LCoop preveu la publicació en un diari, quan la cooperativa tinga més de 500 socis o ho exigisquen els estatuts.

Tanmateix, en la legislació cooperativa no s'exigeix amb caràcter general ${ }^{73}$ la publicació de la convocatòria en mitjans de difusió pública, a diferència d'allo que preveu la legislació de societats de capital (articles 97 LSA i 46 LSRL). Sha plantejat $^{714}$, per a aquestes últimes, la justificació possible de la necessitat de convocatòria pública, si s'entén que la realització de la sessió i l'adopció de determinats assumptes poden afectar interessos de terceres persones, amb la finalitat de garantir que els tercers puguen impugnar els acords per defectes de convocatòria. Això no obstant, s'ha conclòs que per als tercers la lesió no es derivarà de la infracció possible de normes de convocatòria, sinó de les decisions adoptades; prova d'això seria la regulació de l'assemblea general universal, en la qual es requereix únicament el coneixement de l'ordre del dia per tots els socis, i és irrellevant el de tercers potencialment afectats.

712 TATO PLAZA, A., "Os órganos sociais», op. cit., pàg. 80, analitza els problemes que pot plantejar la determinació del dies a quo quan la convocatòria requereix no només la publicació d'anunci en el domicili social, sinó també (com en el cas de la LCG, però també en el de la LCCV) mitjançant carta dirigida als socis. L'autor conclou en que el termini ha de computar-se a partir de la publicació en el domicili social i en els centres de la cooperativa, amb independència de les dates de remissió i recepció de les cartes. S'ha de tenir present, això no obstant, que la redacció de la LCCV no és idèntica a la LCG (que comenta TATO) i pot donar lloc a altres interpretacions, però que en tot cas, tampoc en la Llei valenciana s'exigeix l'adopció de mesures que n'asseguren la recepció $i$ en deixen constància.

713 Només per a l'adopció de determinats acords d'especial transcendència social i que puguen afectar interessos de terceres persones, com ara les modificacions estatutàries, estructurals o la dissolució, es preveu en la legislació cooperativa la publicació, no ja de la convocatòria de l'assemblea, sinó de l'acord ja adoptat (arts. 64.2, 70.4 i 74.2 LCoop; arts. 63.3, 64.1, 65.2, b, 67.2, 68.1, c, 70.3 LCCV), en mitjans de comunicació públics. 
Considerem, això no obstant, que aquesta interpretació requereix alguna matisació. En les cooperatives pot haver-hi col-lectius de persones no sòcies amb una implicació directa en el seu funcionament: és el cas dels associats (article $24 \mathrm{LCCV}$ ), que tenen dret d'assistència a l'assemblea i poden tenir-lo de vot, d'impugnació i de representació en el consell rector; o el dels treballadors no socis, que poden arribar a comptar amb una representació en el consell rector (articles 33 LCoop i 38.4 LCCV) i als quals l'assemblea pot assignar una participació en els excedents (articles 58.5 LCoop i 59.3, B LCCV). D’altra banda, les diferents fórmules de finançament extern (participacions especials: article 53 LCoop; obligacions: articles 54.1 LCoop i 56.3 LCCV; títols participatius: articles 54.2 LCoop ${ }^{715}$ i 56.4 LCCV $^{716}$; comptes en participació: article 54.3 LCoop) que es preveuen en fan necessària la informació correcta als seus titulars, amb la finalitat que puguen defensar els seus interessos.

En tot cas, entenem que qui tinga dret a assistir a l'assemblea general encara que no siga soci té, evidentment, dret a ser convocat individualment $\mathrm{i}$ de manera deguda, per la qual cosa una convocatòria incorrecta eventual o la noconvocatòria ha de permetre'ls impugnar l'assemblea corresponent. Quant a les terceres persones a les quals ni la llei, ni els estatuts, ni l'acord que els atribuïsca interessos en el funcionament de la cooperativa, els reconeguen dret a participar en l'assemblea, siga directament, siga mitjançant representació, s'ha de preveure i garantir el seu dret a obtenir la informació necessària; per això, considerem recomanable que les cooperatives que compten amb col-lectius de tercers amb interessos legítims en el funcionament normal, establisquen algun procediment de difusió pública de la convocatòria, com a mitjà, juntament amb altres, de facilitar aquesta informació.

715 Article 54.2 LCoop: "L'assemblea general podrà acordar l'emissió de títols participatius [...]. L'acord d'emissió [...] podrà establir el dret d'assistència dels seus titulars a l'assemblea general, amb veu i sense vot" interessos dels subscriptors a l'assemblea general i al consell rector, sense reconèixer-los dret de 
El contingut principal de la convocatòria és l'ordre del dia, que ha de recollir tots els assumptes que es tractaran a la reunió, amb precisió, claredat i suficiència, per garantir el dret d'informació dels socis i la possibilitat que exerciten, en les millors condicions possibles, el seu dret a ser representats ${ }^{77}$. Un dels supòsits més comuns en què s'exigeix aquesta claredat és el de la proposta de modificació estatutària, per a la qual es demanda que la convocatòria expresse " 1 'essència i abast de la reforma, la qual cosa ordinàriament resultarà en la mera referència dels articles dels estatuts que han de ser modificats" ${ }^{\prime \prime 78}$; en relació amb això, la LCCV (article 30.5) exigeix que, en la convocatòria s'indique, de manera expressa, que el nou text que es proposa $\mathrm{i}$ un informe de justificació de la reforma estan a disposició dels socis durant el període que va entre la convocatòria i la realització de l'assemblea.

vot".

717 La STS, Sala del Civil, de 17.5.1995, núm. 451/1995, RJA 1995/3924 recorda que "l'anunci de la junta ha d'expressar tots els assumptes que s'hi han de tractar i ha de ser prou informatiu per consentir als socis la intervenció en les discussions i votacions amb una preparació suficient i que no siguen sorpresos amb deliberacions sobre punts que no hi havia motiu de pensar que

se'n tractaria".
RODRÍGUEZ RUIZ DE VILLA, D., Impugnación..., op. cit., pàg. 61, esmenta les SSTS, Sala 1a, de 16.4.1970 (RJA 1970/2017), de 10.7.1970 (RJA 1970/2917), de 25.1.1977 (RJA 1977/117), 31.10.1984 (La Ley, 1985-1, 4917), 22.10.1974 (RJA 1974/3970). També s'esmenta jurisprudència anterior en SORIA FERRANDO, J. V., La impugnación..., op. cit., pàg. 176 a 182, entre la qual es recull la STS de 16.3.1970 en la qual es rebutja que per tractar de la dissolució i liquidació haja d'expressar-se la causa legal de la pretesa dissolució, per entendre que cap precepte exigeix tal minuciositat.

718 STS, Sala 1a, de 29.6.1995, núm. 634/1995, RJA 1995/5269, que cita al seu torn la STS, Sala 1a, de 17.12.1966, (RJA 1966/5825), "si no es diu res sobre les prescripcions estatutàries que concretament ha d'afectar la reforma, ni el sentit d'aquesta, i es limita a una referència general que no permeta a l'accionista conèixer per anticipat l'extensió i abast de la modificació projectada, haurà d'entendre's la convocatòria defectuosa i il-legalment formulada, encara que el vici només afecte part de la reforma projectada [...], ha de transcendir necessàriament a tots els acords adoptats en la junta a què aquella va servir d'avís".

CARBAJO CASCÓN, F., Los requisitos..., op. cit., pàg. 32 cita abundant jurisprudència en relació amb la convocatòria per a la modificació estatutària: "no cal concretar la modificació projectada a cada clàusula estatutària, sinó que només $n^{\prime}$ hi ha prou a indicar els articles dels estatuts que es volen modificar (SSTS 17-12-1966, RJA 5825; 25-3-1988, RJA 2473; 30-4-1988, RJA 3329; i 15-71988, RJA 5723) o, si es tracta d'una adaptació global dels estatuts, adoptar una fórmula general clara i precisa (RRDGRN 29-3-1993, RJA 2366; 16-9-1993, RJA 6920; i 1-2-1995, RJA 1327). [...] [il TS ha rebutjat repetidament fórmules ambigües (SSTS 9-7-1966, RJA 3939; 17-12-1966, RJA 5825; 22-10-1970, RJA 3970; i 15-7-1988, RJA 5723) i insuficients (SSTS 28-6-1962, RJA 3179; 20-10-1962, RJA 3670; i RDGRN 29-3-1993, RJA 2366) pel que a ordre del dia es refereix". Per la seua part, RODRÍGUEZ RUIZ DE VILLA, D., Impugnación..., op. cit., pàg. 61, esmenta la STS, Sala 1a, de RODRIGUEZ RUIZ DE VILLA, D., Impugnación..., op. cit., pàg. 61, esmenta la STS, Sala la STS de
25.3.1988 (RJA 1988/2473), i SORIA FERRANDO, J. V., La impugnación..., op. cit., pàg. 178, la
17.12.1966. 
També s'han assenyalat com a impugnables "per defecte de convocatòria" els acords el contingut material dels quals no es corresponga amb el dels assumptes inclosos en l'ordre del dia ${ }^{719}$, però s'ha de recordar, així mateix, que la norma legal mateixa estableix una relació d'acords que poden adoptar-se encara que no consten en l'ordre del dia de l'assemblea (articles 28.4 LCoop i $32.1 \mathrm{LCCV}$ ). Al contrari, no es considera necessari per a la validesa de la sessió que $s^{\prime}$ hagen de tractar tots els assumptes de l'ordre del dia ${ }^{720}$.

La convocatòria també pot requerir el compliment d'altres normes relacionades amb el dret d'informació del soci. La legislació cooperativa (articles 16.3, $d$ i e LCoop ; 21.2, b, 30.2 i $30.4 \mathrm{LCCV}^{721}$ ) exigeix la posada a disposició dels socis en el domicili social, de la documentació relacionada amb els assumptes a tractar en l'assemblea, i la LCCV (article 21.2, b); a més, demanda que la convocatòria faça referència al dret que assisteix als socis a l'obtenció gratuïta d'exemplars d'aquesta documentació o consultar-la, així com la manera d'exercitar-ho ${ }^{72}$. La LCoop, en canvi, que restringeix notablement les garanties en favor del dret d'informació que anteriorment establia la LGC ${ }^{723}$ i les que ara s'exigeixen en les

719 CARBAjo CASCóN, F., Los requisitos..., op. cit., pàg. 31.

720 CARBAJO CASCÓN, F., Los requisitos..., op. cit., pàg. 33, cita la RDGRN 11-2-1993, RJA 1408, Fonament de dret $3 r$.

721 En relació amb l'exigència de l'article $30.5 \mathrm{LCCV}$ que la convocatòria per a la modificació estatutària indique la posada a disposició dels socis del nou text que es proposa $\mathrm{i}$ informe justificatiu de la reforma, pot veure's l'esmentada STS, Sala 1a, de 3.5.1994, núm. 416/1994, RJA $1994 / 3559$.

${ }^{722}$ A més d'això i del ja apuntat supra per a les modificacions estatutàries, la LCCV preveu, en relació amb les modificacions estructurals, el lliurament directe, juntament amb la convocatòria, de la documentació relacionada amb la proposta d'acord, sense necessitat que el soci haja de sol-licitar-la. Així, l'article 65.2, a.

${ }^{723}$ L'article 36.5 LGC establia l'obligació de posar de manifest en el domicili social, des de la convocatòria fins a la realització de l'assemblea ordinària, els comptes anuals, la proposta de distribució dels resultats i l'informe de la intervenció, perquè els socis pogueren examinar-ho; aquests, a més podien sol-licitar explicacions o aclariments sobre la documentació. L'obligació s'estenia a qualsevol assemblea en la qual es tractaren assumptes "de naturalesa econòmica [...], si bé referit a la documentació bàsica". L'article 92.1 exigia per a la modificació estatutària, a semblança del previst encara en la LCCV, el dipòsit social de la proposta de modificació i 
societats de capital (articles 212 LSA i 86 LSRL; 173 CCo), ni tan sols obliga al lliurament dels comptes anuals que han de ser aprovats per l'assemblea general ordinària, ni tampoc de la documentació relacionada amb un projecte de modificació estatutària o estructural o amb la dissolució, ni fa cap referència al fet que la convocatòria haja d'advertir sobre el dret de consulta de la documentació en el domicili social.

Els casos en què s'anul-la una assemblea per defectes en la constitució (regulada en els articles 25 LCoop i 31 LCCV) són menys freqüents. El Tribunal Suprem ha considerat nul-la la junta d'accionistes duta a terme en segona convocatòria quan podia haver-se constituit en primera convocatòria, en reunir-se el quòrum suficient; la nul-litat s'ha fonamentat en la consideració com a norma imperativa de la regulació de la constitució en primera convocatòria ${ }^{74}$.

En relació al quòrum que es requereix, en primera i segona convocatòria, la LCoop (article 25.1, 1r paràgraf) els refereix "als vots socials", mentre que la LCCV (article 31.1) els computa sobre el nombre de socis ${ }^{725}$. Sembla, en principi, més correcta tècnicament l'opció de la LCoop, que no obvia la possibilitat que a la cooperativa hi haja titulars de dret de vot diferents als socis, encara que trasllada a l'àmbit del quòrum constitutiu l'admissió del vot plural, que suposa, com tothom sap, una excepció al principi cooperatiu de participació democràtica $^{726}$. La LCCV, per la seua part, es decanta per una opció més

l'informe justificatiu, així com que constara en la convocatòria el dret que els socis tenien a l'examen.

724 RodrígUEZ RUIZ DE VILLA, D., Impugnación..., op. cit., pàg. 61, cita la STS, Sala 1a, de 17.11.1972 (RJA 1972/4567).

$725 \mathrm{Ha}$ de tenir-se en compte, a més, que els estatuts no poden derogar les normes legals reguladores dels quòrums, però sí poden "endurir-los", això és, elevar el percentatge necessari que cal assolir (RODRíGUEZ, M. P., i SUSO, J. M., "Los órganos de la cooperativa», op. cit., pàg. 143; GADEA, E., Derecho de las cooperativas..., op. cit., pàg. 170).

726 ALFONSO SÁNCHEZ, R., "Aspectos básicos...», op. cit., pàg. 177, nota 55, que s'estima més utilitzar l'expressió «vot ponderat» i no la de "vot plural», tanmateix, matisa: el vot plural "implica concedir a socis amb idèntica posició davant la cooperativa, diferent dret de vot, cosa que no ocorre en les previsions de la LCoop, i que, entre altres circumstàncies, alteraria
principi d'igualtat, ja que el vot plural és, sempre, un vot de qualitat. Per contra, el vot 
justada als principis cooperatius i mutualístics: és la participació dels socis, que amb la seua activitat personal colllaboren en la realització de les finalitats de la cooperativa, que ha de ser garantida ${ }^{727}$, mentre que els associats, que poden tenir dret de vot, no computen en el quòrum de constitució.

Possiblement amb la intenció d'evitar la desvirtuació de la participació dels "socis que desenvolupen activitat cooperativitzada", la LCoop (article 25.1, 2n paràgraf) permet que els estatuts establisquen un quòrum específic d'aquest col-lectiu, amb la finalitat de garantir que les decisions no siguen preses en virtut de la presència majoritària d'altres col-lectius de socis.

També pot considerar-se nul-litat per defecte de constitució la que invalida la reunió d'una pretesa assemblea general universal sense estar-hi presents o representats tots els socis o quan no haja comptat amb unanimitat en l'acceptació de la sessió i de l’ordre del dia (articles 23.5 LCoop i 28.3 LCCV).

Els quòrums especials que els estatuts puguen exigir per a l'adopció de determinats acords són diferents dels quòrums per a la vàlida constitució de l'assemblea, la falta dels quals provoca la invalidesa de tots els acords que s'hi han adoptat. La no-observança d'aquests quòrums especials no invalida la totalitat de l'assemblea, sinó els acords concrets per als quals es requereixen.

La LCoop no diu res sobre a qui correspon efectuar el còmput dels quòrums ni si han de reflectir-se en la llista d'assistents corresponent, per la qual cosa caldrà atendre allò que es preveu, si escau, en els estatuts o en el reglament de règim

proporcional garanteix la paritat de tracte dels socis: és cert que no tots tenen un vot; és més, pot ser que no tots tinguen el mateix nombre de vots, però aquest és directament proporcional al grau de participació en l'activitat cooperativitzada (a més participació, més dret de vot). No es tracta d'originar privilegis sinó de prevaler la major vinculació del soci amb la cooperativa ja que no sembla ser contrari a l'essència de la cooperació el fet de que el poder de decisió més gran quede a les mans dels socis que més col-laboren perquè la cooperativa resulte viable".

${ }^{727}$ TATO PLAZA, A., "Os órganos sociais», op. cit., pàg. 82: "no es prendran en consideració per a efectes de còmput de quòrum els vots dels socis que foren sancionats amb suspensió d'aquest
dret". 
intern; en tot cas, siga o no preceptiu, és altament recomanable confeccionar la llista d'assistents amb la finalitat de poder constatar l'existència del quòrum ${ }^{\text {tas }}$.

La LCCV, amb millor tècnica en aquesta matèria, assenyala que serà el president el qui ordenarà la confecció de la llista d'assistents a càrrec del secretari, i decidirà sobre les representacions dubtoses, a més de proclamar l'existència de quòrum i la constitució de l'assemblea; també permet que una minoria del $5 \%$ dels socis designe un interventor en la confecció de la llista. Encara que la llei valenciana no ho esmenta expressament, caldrà fer constar el caràcter o la representació dels assistents, així com, si escau, el nombre de vots $a m b$ què compten ${ }^{729}$.

Finalment pel que fa als vicis de la convocatòria o constitució, s'ha d'assenyalar (sense perjudici de la seua anàlisi més detallada en seu de legitimació) que quan els vicis siguen anul-lables, doctrina $i$ jurisprudència exigeixen que el soci que pretenga impugnar l'assemblea faça menció expressa de la seua oposició a la realització de la reunió abans de l'inici.

1.2.4 Impugnació d'acords en virtut de l'actuació de la presidència o de la secretaria de la sessió

728 SORIA FERRANDO, J. V., La impugnación..., op. cit., pàg. 187 a 190: "La llista d'assistents compleix una triple funció: $a$ ) legitimar per a l'exercici de dret de vot, $b$ ) fer possible el càlcul del quòrum, i c) determinar, per exclusió, quins accionistes conserven determinats drets (dret d'impugnació i dret de separació [...])", citant, entre altres, DUQUE DOMf́NGUEZ, Justino F., "La lista de los asistentes en la Junta General de la Sociedad anónima", RDM, 1962, pàg. 7 a 45 i 315 a 363. RODRÍGUEZ RUIZ DE VILLA, D., Impugnación..., op. cit., pàg. 70 i 71 també esmenta la funció de la llista d'assistents com a prova de la no-assistència per a la legitimació dels absents, amb abundant jurisprudència; i cita, en relació amb altres funcions de la llista d'assistents, VாLLA VEGA, Enrique, "Comentario a la sentencia de 25 de mayo de 1984", CCJC núm. 5, abril-agosi 1984, pàg. 1703 a 1705, i AÑOVEROS TRtAS DE BES, X., «Validez de la junta general de la sociedad anónima con convocatoria irregular y falta de quorum. Comentario de la Sentencia del Tribunal Supremo de 7 de abril de 1987», RJC, 1988, núm. 4, pàg. 1040 a 1041.

729 SORIA FERRANDO, J. V., La impugnación..., op. cit., pàg. 188, cita la STS de 28.9.1970. 
Poden donar-se alguns supòsits en què els acords de l'assemblea esdevinguen nuls 0 anul-lables, no per la actuació mateixa de l'òrgan, sinó per les decisions i les actuacions de la presidència, en virtut de les facultats que exerceix ${ }^{730}$. En aquest sentit, s'ha indicat que les facultats de la presidència són fonamentalment tres: l'examen de la legalitat de la constitució de la junta, la direcció de les deliberacions i la constatació dels acords ${ }^{731}$.

Pel que fa a l'examen de la legalitat de la constitució, ja hem vist que la LCoop, a diferència de l'anterior LGC (article 46.1), no diu res sobre a qui correspon realitzar el còmput del quòrum i la declaració de la constitució de l'assemblea, però sembla que, a falta de menció estatutària o reglamentària, s'haurà d'atribuir aquesta funció a la persona que exercirà la presidència ${ }^{732}$. La LCCV, al contrari, no sols és explícita, sinó taxativa en atribuir a la presidència de la reunió, amb caràcter imperatiu, l'ordre de confeccionar la llista d'assistents, la decisió sobre l'admissió de les representacions dubtoses, així com la facultat de decidir, en primera instància, sobre l'assistència de persones no sòcies. No hi ha dubte que la presidència, en l'exercici d'aquestes funcions, pot dur a terme actuacions que convertisquen en impugnables tots o alguns dels acords que

730 VICENT CHULIÁ, F., en «La asamblea...»..., recull les principals funcions del president, $\mathrm{i}$ en "La Ley 27/1999...", op. cit., pàg. 14576 cita com a paradigmàtiques de la rellevància de la seua actuació, en exercici de la representació legal, les SSTS de 17.4.1996 i de 27.9.1995. Per contra, DIAZ DE LEZCANO SEVILLANO, N., Los acuerdos del consejo..., op. cit., pàg. 240 cita jurisprudència del TS en què, contràriament, $s^{\prime}$ ha rebutjat la impugnació de "manifestacions fetes pel president de l'òrgan expressant que la convocatòria patia un requisit de forma" o de "la negativa del president a proporcionar un intèrpret".

En l'àmbit de les societats de capital, es refereix a la transcendència de l'actuació del president en la validesa dels acords adoptats, RECALDE CASTELLS, A., Limitación estatutaria..., op. cit., pàg. $129 \mathrm{i} 130$.

731 RODRfGUEZ ARTIGAS, F., "La junta general de socios», p. 620. La classificació $i$ la seua anàlisi ja eren presents en GIRÓN, J., Derecho de sociedades anónimas, pàg. 299, 300 i 305. RODRíGUEZ, M. P., i Suso, J. M., «Los órganos de la cooperativa», op. cit., pàg. 145 i 146, es refereixen també al manteniment de l'ordre en el desenvolupament de l'assemblea, encara que aquesta facultat sembla que ha d'incloure's en la més general de direcció de les deliberacions.

${ }^{732}$ L'única concreció que la LCoop realitza respecte de la presidència i de les seues funcions és la que s'indica en l'article 25.2: "L'assemblea general estarà presidida pel president $i$, si no n'hi ha, pel vicepresident del consell rector; hi actuarà de secretari qui ho siga del consell rector 0 qui el substituïsca estatutàriament. Si ningú ocupa aquests càrrecs, seran els que elegisca 
s'adopten a l'assemblea irregularment constituïda; penseu, per exemple, que el còmput d'assistències $\mathrm{i}$ de representacions determina l'existència $\mathrm{o}$ no dels quòrums corresponents ${ }^{733}$ o que la inadmissió incorrecta d'una representació pot suposar la privació al soci del dret de $\operatorname{vot}^{734}$.

D'altra banda, com veurem després, la inexistència o la confecció incorrecta de la llista d'assistents, com a part de l'acta de la sessió, no pot produir per si sola la impugnabilitat dels acords que s'hi adopten, ja que el corrent majoritari doctrinal atribueix únicament a l'acta un valor probatori, no constitutiu dels acords ${ }^{735}$. Tanmateix, quan la llista siga determinant per a la constatació de circumstàncies relacionades amb la impugnació (per exemple, els quòrums, l'absència d'un soci, l'acreditació de la representació, etc.), la seua inexistència o la realització incorrecta podria sostenir la invalidació dels acords o, almenys, l'acció de responsabilitat davant de qui correspon garantir-ne la realització.

En matèria de direcció de les deliberacions, també la LCoop ha suprimit l'anterior atribució de la LGC a la presidència de les funcions de "dirigir les deliberacions, mantenir l'ordre en el desenvolupament de l'assemblea i vetlar pel compliment de les formalitats exigides per la llei" (article 46.2 LGC), però sembla que no poden interpretar-se d'una altra manera les funcions mínimes que s'han d'atribuir a qui exercisca la presidència d'un òrgan ${ }^{736}$. La LCCV sí que

733 RODRf́GUEZ RUIZ DE VILLA, D., Impugnación... op. cit., pàg. 83, refereix la STS de 6.7.1963, RJA 1963,3768 , en la qual es declara la nul.litat de la junta general vàlidament constituida en primera convocatòria, però suspesa pel president per continuar-la l'endemà.

734 En relació amb això, GIRÓN, J., Derecho de sociedades anónimas, pàg. 299, arriba a proposar, a efectes pràctics i a fi d'evitar la impugnació, que el president, en cas de dubte, efectue una consulta a la junta mateixa, com a qüestió de procediment.

735 En aquest sentit, la sentència de la SAP-Madrid, de 18.1.2000 (AC 2000/613) considera que si bé l'article 111 LSA exigeix la formació de la llista d'assistents a fi de facilitar el coneixement del quòrum legal de presència, personal o per representació, i legitimar l'exercici del dret al vot i, eventualment, després, el d'impugnació dels acords, qualsevol infracció no ha de comportar automàticament la invalidesa de la constitució de la junta i la nul-litat subsegüent dels acords que s'hi han adoptat, citant la STS anterior de 7.2.1984.

736 GIRÓN, J., Derecho de sociedades anónimas, pàg. 299: "el càrrec [...] no es podria concebre sense aquesta funció; d'ací es dedueix que en aquesta matèria les seues facultats no han d'entendre's 
li adjudica expressament la direcció de les deliberacions "fent respectar l'ordre del dia $\mathrm{i}$ el de les intervencions sol-licitades, d'acord amb els criteris fixats en els estatuts, si n'hi ha", la facultat expressa d'"expulsar de la sessió els assistents que facen obstrucció o falten al respecte a l'assemblea o a algun dels assistents" (article 30.4), i la conclusió del debat i de l'ordenació de les propostes de votació (article 31.2).

En efecte, la presidència, en compliment de la seua funció moderadora pot retirar la paraula als socis que facen impossible la deliberació $i$, fins $i$ tot arribar a excloure'ls de l'assemblea amb la privació consegüent dels drets d'informació, proposta, veu i vot ${ }^{737}$; també "serà competència del president de la junta general determinar, vist el precepte legal, si hi ha o no conflicte d'interessos i, en cas que en considere l'existència, privar del vot el soci en conflicte, sense perjudici del dret que assisteix a aquest d'impugnar, si escau, $1^{\prime}$ acord adoptat"738; a més,

subordinades a la majoria, sinó considerar-se atribuïdes a la presidència amb caràcter originari pel dret positiu".

737 GIRÓN, Derecho de sociedades anónimas, op. cit., pàg. 299; RODRíGUEZ ARTIGAS, F., «La junta general de socios", op. cit., pàg. 626.

738 RoDRfGUEZ ARTIGAS, F., "La junta general de socios», op. cit., p. 626. EMBID IRUJO, J. M., "Comentario al art. 52", op. cit., pàg. 565: "Si el soci d'una societat limitada es troba en qualsevol de les situacions descrites en l'article 52 LSRL [...] L'expressió legal i el sentit mateix del precepte permeten parlar [...] de l'existència d'un deure d'abstenció per al soci en conflicte $d^{\prime}$ interessos [...] conseqüència específica del deure de fidelitat [...]. Sembla lògic, per això, que siga el soci mateix, si obra de bona fe, qui s'abstinga [...]. Però si no obrara de bona fe, o patira un error excusable, també sembla lògic reconèixer, com es fa en la nostra doctrina, la competència del president de la junta per privar el soci en conflicte del seu dret de vot [...] la decisió del president privant el soci del seu vot permetrà a aquest últim, en tot cas, la impugnació de l'acord, si no es considera sotmés a situació de conflicte"; SÁNCHEZ-CALERO GUILARTE, J., "El conflicto de intereses...", op. cit., pàg. 698, entén que, a falta de l'advertiment pel soci mateix, "compet al president de la junta, per pròpia iniciativa o a requeriment de qualsevol altre soci, advertir abans de la votació", però estima que és la junta la que ha de pronunciar-se en els supòsits de conflictes d'interès indirectes: "No sembla que puga mantenirse que en aquest supòsit el president de la junta està facultat per resoldre la qüestió. La seua funció moderadora i rectora del curs de la reunió no l'autoritza per determinar si en alguna situació imprevista per la norma s'està davant d'un conflicte d'interessos i, eventualment, privar d'un dret tan rellevant com és el de vot el soci afectat".

També limiten el poder d'actuació del president BOQUERA MATERREDONA, J., «La regulación del de motu pr, op. cit., pàg. 1032, 1033 i 1043: "el soci no té l'obligació de denunciar el conflicte [...] succeir proprio pot comunicar a la societat que es troba en conflicte d'interessos. [...] Però pot tinguen que el soci no comunique que existeix el conflicte i siguen els administradors els qui en comunicació a ment, [...] en aquest cas, és un deure dels administradors procedir a la seua plantejarà atesa la diligència que ha d'informar totes les seues actuacions. [...] El problema es jarà quan ni el soci ni els administradors fan saber que un o diversos socis es troben en 
"decidirà, lliurement, si el tema o els temes estan prou debatuts; en aquest cas donarà pas a la votació, i es fixarà, si escau, l'ordre d'aquesta si hi ha diverses propostes, així com la manera, si no s'hi ha disposat res en els estatuts ni hi ha propostes dels socis sobre aquesta matèria"739.

No hi ha dubte, doncs, que l'ampli marge d'ordenació atribuït a la presidència podria conduir, en el cas d'actuacions incorrectes per la seua part, a la impugnabilitat d'acords adoptats, per exemple, després de deliberacions en què $\mathrm{s}^{\prime}$ haguera negat injustificadament la intervenció a alguns socis, o mitjançant propostes de votació formulades de manera clarament tendenciosa.

Quant a la funció de constatació dels acords, la doctrina entén que, encara que no li està expressament atribuïda a la presidència, ni en la legislació

situació de conflicte [...]. En aquest cas, si el president de la junta en té coneixement, ho podrà posar de manifest durant la realització de la junta. [...] Ha de realitzar un control formal de la situació de conflicte, com en el cas de falta de legitimació per exercir el vot [...] La comprovació esmentada s'inclourà dins de les tasques de coordinació del president de la junta [...] Correspon a la junta decidir si existeix o no el conflicte d'interessos. El president de la junta general serà el competent per prohibir al soci l'exercici del dret en el supòsit de conflicte"; DUQUE DOMINGUEZ, J. F., Tutela ..., op. cit. pàg. 139 a 147, que considera que "els punts en què el dubte es produïsca han de ser proposats pel president, com a qüestions de procediment, a la junta en funcions, que és l'òrgan de decisió d'aquells punts que, referint-se a l'interès social - del qual és, en principi, l'únic intèrpret-, no estiguen atribuïts per la llei $\longrightarrow$ pels estatuts en el camp del dret voluntari- a la competència de qualsevol altre òrgan. [...] El president, per tant, pot limitar únicament l'exercici d'un poder de l'accionista mitjançant la invocació de l'interès social quan la llei expressament li haja atribuït tal poder".

Tanmateix, HERNÁNDEZ SAINZ, E., «El deber de abstención...», op. cit., pàg. 123 i 124, estima que "amb la regulació actual ja no és menester realitzar una ponderació d'interessos ja que aquesta ja l'ha realitzada el legislador o bé els socis mateixos en els estatuts. [...] Per això ara no hi ha cap inconvenient perquè siga el president de la junta qui, després d'examinar l'ordre del dia, assenyale als socis afectats per l'acord conflictiu que no poden participar amb el seu vot a l'adopció d'aquest. [...] Si el president no impedeix el vot del soci en conflicte d'interessos havent de fer-ho, li podrien ser exigides responsabilitats pels perjudicis que s'hagen ocasionat si hi va haver mala fe o negligència en la seua conducta. Pot succeir que la persona afectada pel conflicte siga precisament el president. En aquest cas haurà d'abstenir-se voluntàriament no solament d'emetre el seu vot sinó també de dirigir les deliberacions, ja que podria tractar d'influir en el sentit del vot [...]. El president, encara que arribe a descobrir que va votar qui no devia, no pot anul-lar el vot. Aquest ha quedat perfeccionat després de l'emissió de la declaració de voluntat i la seua anul-lació correspon en exclusiva als òrgans judicials".

739 RODRÍGUEZ ARTIGAS, F., «La junta general de socios», pàg. 620. Tanmateix, sobre la facultat concreta de "donar forma" $i$ "ordenar" les propostes de votació, $s^{\prime}$ ha de tenir present que queda únicament esmentada en la llei valenciana, mentre que la legislació cooperativa estatal no s'hi ha referit mai; l'esmentada absència de regulació ja era indicada per VICENT CHULIA, F. en «Bi derecho de los órganos...",op. cit., pàg. 513, en relació amb la Llei de 1974, absència que no s'ha modificat ni en la LGC de 1987 ni en la vigent LCoop. 
cooperativa, ni en la de societats de capital, efectivament li correspon "la proclamació dels resultats com a activitat subsegüent al recompte de vots" ${ }^{\prime 740}$; aquesta és una activitat de transcendència si es té en compte que, si bé "es discuteix si aquesta proclamació té o no caràcter constitutiu per a l'acord, (...) el TS ha assenyalat que si hi ha discrepància entre el resultat real de l'acord i el proclamat, preval el primer (STS de 29 de gener de 1962) ${ }^{\prime \prime 44}$; a sensu contrari doncs, excepte en els casos en què es prove un resultat diferent, el resultat proclamat per la presidència serà el que s'haurà de prendre en consideració.

També formen part de les activitats tendents a la constatació dels acords la confecció de l'acta i de la llista d'assistents, la realització de les quals, com tothom sap, correspon a la secretaria de l'assemblea, si bé se sotmet a la supervisió de la presidència ${ }^{742}$. La possibilitat d'impugnar els acords socials per inexistència o realització incorrecta d'aquests documents ha portat la doctrina mercantilista a decantar-se entre dues postures fonamentals: "la dels que entenen que els documents de la junta (o almenys l'acta) són necessaris, per dependre'n l'eficàcia dels acords, $i$ la dels que opinen que aquests documents $i$, per tant, la seua falta o les seues irregularitats, per regla general, no tenen transcendència a l'efecte de la validesa i l'eficàcia de les decisions del col-legi"743.

740 RODRíguez ARTIGAS, F., "La junta general de socios», pàg. 621. GIRÓN, Derecho de sociedades anónimas, op. cit., pàg. 305: "la proclamació no fa sinó culminar un procés d'escrutini, que correspon al president $\mathrm{i}$ que, en definitiva, persegueix la constatació que hi ha majoria legal i vàlida; sense aquesta constatació, que correspon a la presidència, no pot saber-se la voluntat de l'ens i l'atribució de la facultat dóna lloc al fet que, en cas que la presidència no la realitze, només puga ser realitzada pel jutge".

741 RODRIGUEZ ARTIGAS, F., «La junta general de socios», pàg. 621.

742 L'article 29 LCoop estableix que la redacció de l'acta de l'assemblea, que inclourà entre altres aspectes la "relació d'assistents", correspon al secretari, però la seua aprovació, si no l'efectua l'assemblea mateixa, correspondrà al president i a dos socis. La LCCV afegeix a les funcions supervisores del president (l'aprovació de l'acta en defecte de la assemblea mateixa es recull en l'article 34.2) la responsabilitat d'"ordenar" la confecció de la llista d'assistents, i decidir sobre les representacions dubtoses (article 31.4). 
La primera de les posicions doctrinals considera que l'acta no es requereix per a l'existència dels acords (no és forma ad solemnitatem), però és necessària perquè tinga eficàcia ${ }^{744}$. La segona és partidària de considerar que, a falta d'una disposició legal que atribuïsca a l'acta el caràcter d'element essencial, ad substantiam o ad solemnitatem, per a la validesa dels acords, no es pot mantenir la nul-litat dels que no estiguen recollits en aquell document; es considera que la constància formal a l'acta és exigida ad probationem, per la qual cosa la seua falta dificultarà la prova de l'existència o del contingut de l'acord, però que aquesta inseguretat no és raó suficient perquè se'l considere invàlid ${ }^{745}$. És aquesta l'opinió majoritària, la que considera que el valor de l'acta és essencialment probatori "dels fets i dels actes de les assemblees", per la qual cosa "la falta de veracitat és sempre possible $i$, en conseqüència, la prova contrària admissible, de conformitat amb les regles aplicables a la prova legal"746; la impugnació

744 Són partidaris d'aquesta postura GIRón, J., Derecho de sociedades, op. cit., pàg. 306 i 307: "el joc dels art. 68 i 69 resolen la qüestió contra el caràcter ad solemnitatem. Aquell pren com a moment per començar a comptar el còmput per a la caducitat de les accions d'impugnació, el de la data de l'acord, i com pot ocórrer que aquesta precedisca l'aprovació de l'acta, [...] vol dir-se que aquells acords existeixen sense l'acta. D'altra banda, en condicionar-se l'acció de l'article 69 de dissidents a la protesta consignada en acta, podria donar-se que la demora en l'aprovací donara lloc a un ajornament perjudicial a la defensa dels seus interessos [...]. Aquests resultats no semblen haver estat volguts per la Llei"; i RUBIO, J., Curso..., op. cit., pàg. 236 i 237.

745 DUQUE DOMínGUEZ, J. F., "La lista de los asistentes...», pàg. 340 i 347 i ss. ; GALGANO, F., Diritto civile e commerciale, vol. III, Imprese e società, tom 2n, 1990, pàg. 186; GARRIGUES, J., Curso..., op. cit., pàg. 509; PATERNOTTRE SUÁREZ, A., Las actas de las juntas..., op. cit., en un extens estudi, en les pàg. 321 a 351; ROJO FERNÁNDEZ-Rfo, Á., «El derecho a obtener la certificación...”, op. cit., pàg. 1138; RUEDA MARTÍNEZ, José-Alejo, "Comentario al art. 54», en AA. DD., Comentarios a la Ley de sociedades de responsabilidad limitada (coords. I. Arroyo i J. M. Embid), Tecnos, Madrid, 1997, pàg. 594 i 595, cita les RRDGRN de 17.2.1992 i de 5.1.1993; SANCHEZ CALERO, F., Instituciones..., op. cit., pàg. 369 i 370 : "la falta d'aprovació de l'acta no significa que els acords no siguen vàlids sinó que en dificulta la prova i l'eficàcia, $i$ hi ha una inseguretat respecte al contingut", i en Administradores..., op. cit., pàg. 528 i 529: "Doctrina que [...] té una justificació fins i tot més gran respecte a l'òrgan d'administració que amb relació a la junta general, ja que la gestió de la societat pot aconsellar l'adopció d'acords amb una certa rapidesa, que han d'executar-se immediatament, descuidant així la documentació"; SORIA FERRANDO, J. V., La impugnación..., op. cit., pàg. 204 a 206; URf́. R, MENÉNDEZ, A. MuÑoz, J. M., La junta..., op. cit., pàg. 280 i 281.

746 PATERNOTTRE SUÁREZ, A., Las actas de las juntas..., op. cit., pàg. 133; més endavant, en pàg. 324, nota 9: "Probablement siga semblant (...) l'opinió que diu que l'acta no és condició de validesa de la deliberació, $\mathrm{i}$ afegeix que aquesta, a falta del document, serà ineficaç, però que no es pot excloure que l'acta, que és una declaració de ciència referent a la deliberació adoptada puga ser substituïda per una sentència de fixació".

SÁNCHEZ CALERO, F., Administradores..., op. cit., pàg. 529: "serà possible acudir a altres mitjans 
haurà de dirigir-se, si s'escau, a negar l'eficàcia com a prova legal de l'acta: si s'accepta, invalidarà l'acta com a mitjà de prova de l'acord, però no incidirà directament en la validesa $\mathrm{d}^{\prime}$ aquest ${ }^{747}$

Pel que fa a la resta, i en tot cas, per a la determinació de la nul-litat o l'anul-labilitat dels acords que es vegen afectats per una actuació incorrecta de la presidència de l'assemblea s'haurà d'atendre la naturalesa de la norma, legal o estatutària, vulnerada amb aquesta actuació $^{748}$, i no perdre de vista que allò que s'impugna no és l'actuació de la presidència, sinó la validesa de l'acord resultant de l'òrgan presidit ${ }^{79}$.

1.2.5 Acords de nomenament de càrrecs socials

S'han plantejat en seu de societats de capital diverses qüestions en relació amb el nomenament viciat dels administradors que, amb les excepcions i modificacions necessàries, poden servir també per analitzar els vicis en el nomenament d'altres càrrecs socials per l'assemblea general.

La doctrina indica, essencialment, dues qüestions relatives a vicis possibles en la composició de l'òrgan d'administració, que, a més, podrien afectar la validesa dels acords posteriors adoptats per aquest òrgan amb la concurrència del vot de

per acreditar-ne l'existència, com igualment podran provar-se per altres procediments les deliberacions i discussions mantingudes durant la sessió".

${ }^{747}$ L'única excepció sembla plantejar-se en els supòsits sotmesos a l'article 55 LSRL, segons el qual, sol-licitat l'alçament d'acta notarial amb les condicions legalment previstes, aquesta acta adquireix valor ad solemnitatem (SAP-Valladolid, 28.2.2000, AC 2000/648)

748 ALCALÁ DíAz, M. A., La impugnación..., op. cit., pàg. 293, planteja l'anul-labilitat dels acords adoptats amb infracció de normes estatutàries que regulen les facultats de la presidència del consell d'administració. D'altra banda, manifesta l'autora els seus dubtes respecte de la impugnabilitat d'acords que infringeixen normes establertes, en el seu cas, en el reglament de règim intern de l'entitat. La nostra opinió desenvolupada en el capítol segon epígraf 1.2 in fine, és, en principi, contrària a l'admissió de la impugnabilitat, si bé amb certs matisos.

${ }^{749}$ ALONSO ESPINOSA, F. J., «Capítulo VII»,op. cit., pàg. 238, recull la polèmica doctrinal sobre la qualificació hipotètica del president com a òrgan, però considera "més correcte concebre el 
l'administrador "irregular". D'una banda, es refereix a la situació en què el càrrec nomenat incórrega ${ }^{750}$ en alguna de les causes d'incapacitat (menors i impossibilitats), inhabilitació (amb fallida, sotmesos i condemnats a penes d'inhabilitació), prohibicions absolutes per raó del càrrec, o incompatibilitats (funcionaris de les administracions públiques) que es preveuen per a l'exercici del càrrec ${ }^{751}$; d'una altra banda, el nomenament de càrrecs que no reunisquen els requisits estatutaris exigits específicament.

En relació amb la incapacitat, la inhabilitació, la prohibició o la incompatibilitat dels administradors, la doctrina espanyola ha mantingut dos criteris diferenciats respecte a les conseqüències jurídiques del nomenament, encara que coincidents en els seus efectes en el funcionament de l'òrgan de què formen part. Una de les línies interpretatives manté que la normativa sobre societats anònimes estableix una doble via de destrucció dels efectes de l'acord: la seua impugnació per nul-litat i la destitució immediata a proposta de qualsevol accionista prevista per la LSA mateixa (article 132)752; en canvi, altres autors consideren que és únicament aplicable aquesta última mesura, en virtut d'allo que preveu l'article $6.3 \mathrm{del} \mathrm{CC}$, que imagina la possibilitat que l'ordenament jurídic preveja una sanció diferent a la nul·litat per a la infracció de llei prohibitiva $^{753}$.

president com a titular de les facultats d'execució" de la voluntat cooperativa.

750 Es planteja ací, inicialment, el supòsit en què la incapacitat, la inhabilitació la o incompatibilitat es produïsca $a b$ initio, des del mateix moment de l'elecció; els efectes són essencialment els mateixos en els casos en què aquests vicis sobrevinguen posteriorment al nomenament, però en aquests casos no donaran lloc, com és obvi, a la invalidesa de l'acord assembleari de nomenament.

751 POLO SÁNCHEZ, E., Los administradores.., op. cit., pàg. 82, 83 i 249 a 254 . En el mateix sentit SÁNCHEZ CALERO, F., Administradores, op. cit., pàg. 45 i 46, però reduint a tres els supòsits de prohibició: incapacitat, inhabilitació i incompatibilitat. GARRIGUES, J., Curso..., op. cit., pàg. 479: "La llei empra com a fórmula general la fórmula prohibitiva ("no podran ser administradors"). [...] Però [...] sota aquesta fórmula general prohibitiva conté supòsits d'incompatibilitat $i$ altres d'incapacitat per ser administrador. [...] la prohibició suposa la capacitat, mentre que capacitat i incapacitat són estats que s'exclouen mútuament".

752 SÁNCHEZ CALERO, F., Administradores, op. cit., pàg. 217 a 219.

753 Polo SÁNCHEZ, E., Los administradores.., op. cit., pàg. 252 a 254. 
En ambdós casos, tanmateix, es defensa l'eficàcia del nomenament, fins a la destitució i/o declaració de nul-litat, i es manté la validesa dels acords adoptats amb la participació de l'administrador i dels actes que aquest haja dut a terme en nom de l'entitat $^{754}$. A aquesta eficàcia general es planteja una sola excepció: els supòsits d'incapacitat, en què el nomenament no pot considerar-se perfeccionat quan l'acceptació per l'incapaç és invàlida, i les declaracions de voluntat en què consisteixen els seus vots són nul-les, la qual cosa, en aquest últim cas, podria donar lloc a la nul-litat de l'acord adoptat amb la seua participació si el seu vot haguera estat rellevant ${ }^{755}$.

A la mateixa conclusió s'arriba en $1^{\prime}$ àmbit cooperatiu ${ }^{756}$, si bé són diverses les especialitats que planteja la seua regulació en els supòsits esmentats. Una de les més importants és la relativa a l'extensió del règim d'incompatibilitats a altres càrrecs socials, el nomenament (per l'assemblea o per l'òrgan que, si escau, siga el competent) dels quals també podria patir d'aquests vicis i provocar la nul-litat de l'acord de nomenament.

$754 \mathrm{Si}$ es defensa la nul-litat de l'acord de nomenament, l'eficàcia dels seus efectes es fonamentarà en raó de la protecció de la seguretat jurídica i del tràfic econòmic; si s'exclou la nul-litat del nomenament per exprés mandat legal que, d'acord amb el previst a l'article $6.3 \mathrm{CC}$, estableix un efecte diferent, la destitució, els actes realitzats mentrestant pel nomenat són perfectament vàlids.

755 AlCALÁ DÍAZ, M. A., La impugnación..., op. cit., pàg. 302 a 304.

756 VICENT CHULIÁ, F., «El derecho de los órganos...», op. cit., pàg. 494: "Ni la LGC ni el seu Reglament han resolt expressament el problema de la sort que corren els acords del consell rector $\mathrm{i}$ els actes $\mathrm{i}$ contractes estipulats amb tercers en execució d'aquests, amb la concurrència -si es vol, determinant, de la majoria- de consellers sotmesos a causes d'incapacitat o prohibició (...). Hi ha dues solucions possibles: o aplicar-hi la doctrina sobre els acords socials, admetent que si l'acord es va adoptar amb majoria viciada és nul, i nuls els actes en què es va plasmar l'execució. O partir de la diferència essencial entre òrgan i persona que exerceix les seues funcions i del principi de conservació dels negocis jurídics, en protecció de l'aparença i del tràfic. I això sense perjudici de les responsabilitats que s'hagen originat. El sistema de destitució sembla suposar que, en tant aquesta no es produeix i s'inscriu (...), l'actuació de l'òrgan d'administració i les seues facultats de representació són vàlides i plenament eficaces". Contràriament, SCORDINO, F., La società cooperativa, op. cit., pàg. 290, manté que els actes executats pels administradors elegits indegudament mai no tindran efecte davant els tercers de
bona fe. 
La LCoop estableix el règim general $\mathrm{d}^{\prime \prime \prime}$ incompatibilitats, incapacitats prohibicions" per a l'exercici dels càrrecs de conseller o interventor en l'article 41, però aquest règim es fa extensible a l'administrador únic (article 32.1) i als membres del comitè de recursos (article 44.4). Per la seua part, la LCCV refereix les incompatibilitats $i$ inhabilitacions ${ }^{757}$ dels membres del consell rector a l'article 39.2, també aplicables a l'administrador únic o als administradors mancomunats o solidaris (article 37.2) ${ }^{758}$. A més, no s'ha d'oblidar que tenen el seu propi règim d'incompatibilitats els lletrats assessors ${ }^{759} \mathrm{i}$ els auditors $\mathrm{s}^{760}$ de la cooperativa, que són nomenats, respectivament, pel consell rector i per l'assemblea. Finalment, s'ha de tenir present que ambdues normes, LCoop (article 41.2) i LCCV (articles 39.3, 47.1 i 48.1), esmenten expressament les incompatibilitats entre càrrecs, amb conseqüències específiques.

Quant a la possibilitat d'una doble via, impugnadora i destitutòria, per a la privació dels efectes del nomenament invàlid, les diferents solucions adoptades per la legislació cooperativa introdueixen matisacions respecte de la polèmica doctrinal desenvolupada per a les societats de capital.

Així, mentre l'article 132 LSA estableix que, en tot cas, els administradors afectats hauran de ser immediatament destituïts, a petició de qualsevol accionista, sense perjudici d'una responsabilitat eventual per deslleialtat,

757 No s'hi esmenten les incapacitats, probablement per la seua innecessarietat, atesa la seua aplicabilitat general també en l'àmbit de l'exercici de càrrecs socials.

758 És discutible si el règim d'incompatibilitats del consell rector arriba als membres de la comissió de recursos regulada per la LCCV, que en l'article 47.2 estableix que se'ls aplicaran "las normes d'aquesta llei sobre consell rector a l'elecció, acceptació, inscripció en el Registre de Cooperatives, funcionament de la comissió de recursos, i a la revocació, retribució i responsabilitat dels seus membres". La regulació de la comissió de control de la gestió (article 48) no estableix cap altra incompatibilitat per als seus membres més que la relativa a l'exercici simultani de la direcció o del càrrec de membre del consell rector.

759 Article 46.5 LCCV, i la legislació reguladora del càrrec: Llei 39/1975, de 31 d'octubre (BOE núm. 263, de 3.11), modificada per la Llei 19/1989, de 25 de juliol (BOE núm. 178, de 27.7) i desenvolupada pel RD 2288/1977, de 5 d'agost (BOE núm. 212, de 5.9).

760 Llei 19/1988, de 12 de juliol, d'auditoria de comptes (BOE núm. 169, de 15.7). 
I'article 41.4 LCoop estableix una excepció sobre aquest règim: els supòsits d'incompatibilitat entre diferents càrrecs a la cooperativa, en els quals l'afectat ha d'optar per un dels dos en un termini, transcorregut el qual "serà nul-la la segona designació". La LCCV (article 40.1), d'altra banda, es refereix al fet que el consell rector haurà de constatar en acta "la concurrència de la causa de la cessació", però no esmenta la necessitat de destitució immediata de l'administrador afectat ${ }^{761}$, i en canvi regula l'obligatorietat d'opció entre els nomenaments de director i membre del consell rector i la nul-litat, si no n'hi ha, de la segona designació.

Al nostre parer, tampoc en l'àmbit cooperatiu és necessària l'especificació que l'acord de nomenament és, en general, nul, per contravenir una llei prohibitiva (la que establisca la incompatibilitat, inhabilitació o incapacitat ${ }^{762}$ ), amb independència que es determine o no la necessitat de la destitució immediata. La vertadera especialitat del règim cooperatiu rau en la diferenciació que es fa en els supòsits d'incompatibilitats entre càrrecs: $s^{\prime} h i$ ha considerat preferible permetre a l'afectat la possibilitat d'optar per un d'aquests, però es regula, això no obstant, una solució per als supòsits en què no s'exercite l'opció. Aquesta solució no és una altra que la que es produeix en la resta de nomenaments invàlids: la nul.litat de l'acord de nomenament per al segon càrrec.

Un altre supòsit que ha reclamat l'interès de la doctrina és, com ha quedat anotat, el que fa referència al nomenament de càrrecs amb incompliment de requisits personals o professionals fixats estatutàriament. En aquesta matèria s'ha defensat que és perfectament vàlid l'establiment de condicions o requisits

761 L'article 40.1 esmenta la incapacitació i la incompatibilitat com a causes de cessació dels membres del consell rector, però no esmenta qui podran instar-ho. En requerir que els membres del consell rector en actiu hauran de constatar en acta la concurrència de la causa de la cessació, s'afegeix "i donar possessió efectiva del càrrec als suplents, de conformitat amb allò previst en els estatuts", però això no suposa una atribució expressa de la destitució, que podria correspondre, com en el supòsit de la revocació, a l'assemblea.

\footnotetext{
762

I'assemso ESPINOSA, F. J., "Capítulo VII», op. cit., pàg. 234, assenyala, a més a més, que càrremblea no pot adoptar un acord vàlid que supose el manteniment de l'administrador en el rrec, ja que es tracta de normes d'ordre públic societari.
} 
positius (edat, professió, coneixements tècnics, vinculació amb l'empresa, etc.) que els candidats hagen d'acomplir per ser elegits, sempre que això no supose que l'assemblea resulte obligada al nomenament de determinades persones ${ }^{7 / 3}$.

La qüestió que es formula és quina serà l'actuació correctora que s'ha de seguir en els casos de nomenament de càrrecs que no complisquen els requisits establerts estatutàriament ${ }^{764}$. L'única norma cooperativa que preveu la destitució immediata dels càrrecs nomenats indegudament (article 41.4 LCoop) es refereix exclusivament als supòsits en què s'incorre en les prohibicions, incapacitats i incompatibilitats previstes en el mateix article, però el deure de diligència que recau sobre els administradors vàlidament nomenats els hauria de portar a proposar l'esmena; en tot cas, res no impedeix la impugnació de l'acord, que en aquest cas serà anul-lable, quan la norma vulnerada siga estatutària. L'anul-labilitat, a més, implica en aquest cas, sense cap dubte, la validesa dels acords adoptats amb la participació del càrrec elegit indegudament $\mathrm{i}$ dels actes que haja pogut dur a terme en compliment de les seues funcions.

D'altra banda, pot donar-se el supòsit en què es nomene un nombre de càrrecs diferent a allò que es preveu estatutàriament ${ }^{765}$. En aquest cas, s'ha proposat, per

763 SÁNCHEZ CALERO, F., Administradores, op. cit., pàg. 33 i 34 ; ALCALA DIAZ, M. A., La impugnación..., op. cit., pàg. 305. Aquesta solució doctrinal és radicalment oposada a l'elaborada respecte a la possibilitat d'establiment de prohibicions o limitacions estatutàries al poder de la junta general per nomenar $i$, sobretot, separar els administradors, en què el criteri doctrinal predominant és la no-admissibilitat; sembla que la raó de tal disparitat se l'hauria de situar en la diferent finalitat perseguida: mentre les incompatibilitats $i$ les prohibicions intenten evitar els abusos a l'exercici del càrrec, l'exigència de requisits personals o professionals pretén assegurar més idoneïtat en aquest exercici. En aquesta línia, s'ha recordat que els diferents informes i codis per al bon govern de les societats formulats dins $i$ fora de les nostres fronteres estableixen recomanacions per a la composició dels consells i cuiden especialment el procés de nomenament de consellers.

764 En relació amb els supòsits en què els requisits s'establisquen en el reglament de règim intern, ja hem manifestat supra la nostra opinió sobre la impossibilitat actual d'impugnar acords que incomplisquen aquestes normes autoreguladores; això no obstant, també la conveniència $\mathrm{d}^{\prime} u n a$ reforma legislativa que reconeguera aquesta possibilitat.

765 En aquesta matèria, s'ha de recordar que l'article 123 LSA permet que els estatuts establisquen un nombre màxim i mínim de membres del consell d'administració, i que es fixe 
als administradors, la validesa de les seues actuacions fins al moment en què, en compliment del deure de diligència, convoquen l'assemblea general que regularitze la situació, bé nomenant els càrrecs que falten, bé revocant els que sobren $^{766}$. Al nostre parer, això no impedeix la impugnació de l'acord de nomenament, sobretot en els casos en què els administradors no convoquen diligentment l'assemblea. D'altra banda, s'ha de recordar que en l'àmbit cooperatiu altres òrgans socials poden estar regulats en els estatuts, i el nocompliment del nombre de càrrecs que preveuen no podria ser pal-liat pels afectats mateixos més que sol-licitant la convocatòria d'assemblea general segons les vies legals i estatutaris generals; en aquests casos resulta més evident la utilitat de la impugnació de l'acord de nomenament.

Un supòsit específic de nomenament de càrrecs socials és el que es planteja quan la Llei o els estatuts socials indiquen que l'acord siga adoptat, no per l'assemblea (o l'òrgan que es tracte, en conjunt), sinó per un col-lectiu concret (de socis o de tercers), amb la finalitat de dotar-los de més representació. Aquest supòsit, per les característiques especials, s'analitza més endavant, en l'epígraf 1.7.

\subsection{Acords de l'assemblea de delegats i de les juntes preparatòries}

Tradicionalment, la legislació cooperativa ha previst la possibilitat de realitzar les sessions de l'assemblea general mitjançant una fórmula peculiar: l'adscripció dels socis a diverses juntes preparatòries que, amb un únic ordre del dia, es reuneixen separadament per debatre els assumptes i elegir els seus

posteriorment el nombre mitjançant acord de la junta general, fet que diversifica les possibilitats que s'incomplisca el mandat estatutari. En l'àmbit cooperatiu aquesta possibilitat no està prevista expressament, si bé sembla tenir cabuda en el text estatal (article 33 LCoop: "Els estatuts establiran la composició del consell rector. El nombre de consellers no podrà ser inferior a tres ni superior a quinze [...]"), mentre és d'acceptació més difícil segons el text legislatiu valencià (article 38.1 LCCV: "Els estatuts socials han de fixar el nombre de components del consell rector, que no serà inferior a tres $\left.[\ldots]^{\prime \prime}\right)$. 
representants; aquests, posteriorment, es reuniran, al seu torn, per adoptar els acords definitius en l'anomenada assemblea general de delegats ${ }^{767}$.

Es tracta de facilitar la participació, encara que siga mitjançant representants, en les cooperatives amb un nombre elevat de socis, o quan aquests tinguen els domicilis en poblacions disperses i allunyades del domicili social, o quan la cooperativa es dedique a diverses activitats clarament diferenciades 0 , com esmenta la LCCV, "quan altres circumstàncies dificulten greument la presència simultània de tots els socis".

En l'actualitat, qualsevol cooperativa pot optar per aquesta modalitat assembleària, sempre que la tinga prevista en els seus estatuts socials; la LCoop exigeix, això no obstant, que es donen causes "objectives i expresses" que justifiquen l'opció.

En el que ara ens interessa, ço és, la impugnabilitat dels acords de l'assemblea general, tant la LCoop (article 30.4) com la LCCV (article 35. 6) són explícites: "només serà impugnable l'acord adoptat per l'assemblea general de delegats, encara que per examinar el seu contingut i la seua validesa es tindran en compte les deliberacions i els acords de les juntes preparatòries". Ambdues normes, d'altra banda, es preocupen d'aclarir que, en allò que no estiga previst legalment o estatutàriament en relació a la constitució i el funcionament de les

767 SÁNCHEZ RUIZ, M., "Capítulo VI», op. cit., p. 208, situa aquesta fórmula "entre els elements del règim orgànic genuïnament de dret cooperatiu $i$, per això, sense equivalent en el dret de les societats de capital". La Llei general de cooperatives de 1974 (article 26) i el seu Reglament d'aplicació de 1978 (article 53) ja regulaven aquesta fórmula assembleària "en dues fases"; la LGC la incloïa en l'article 51. En l'actualitat, la LCoop recull aquest sistema en l'article 30, i la LCCV en l'article 35. BUONOCORE, V., Diritto della cooperazione, op. cit., pàg. 96 i 272 a 274, qualifica l'institut, que en dret italià es denomina assemblee separate, com a "peculiar de les societats cooperatives, i clarament preordenat a valorar la participació personal del soci en la vida i en les decisions de la cooperativa"; també es refereixen a les assemblees "separades" de. dret italià, com a institut típic de les cooperatives, BASSI, A., Le società cooperative, op. cit., pàg. 254 a 257; BONFANTE, G., Imprese cooperative, op. cit., pàg. 588 a 591; GENCO, R., "Il volto cooperativo...», op. cit.,; GROSSO, P., I controlli interni..., op. cit., pàg. 182 a 187; PALMA, R., «I fenómeno cooperativo...», op. cit., pàg. 41 i 42, i PAOLUCCI, Luigi Filippo, Le società cooperatioe, Giuffrè Editore, Milà, 1999, pàg. 104. 
assemblees de delegats i de les juntes preparatòries, seran d'aplicació les normes reguladores de l'assemblea general ${ }^{768}$.

L'especificació de la limitació de la impugnació només als acords de l'assemblea de delegats i no respecte de les actuacions fetes en les juntes preparatòries era necessària, ja que la legislació cooperativa anterior no deixava clara la qüestió ${ }^{769}$, si bé l'opinió doctrinal majoritària coincidia amb l'opció legislativa actual ${ }^{770}$.

Les raons que justifiquen la limitació de la impugnació continuen sent vàlides en l'actualitat (encara que el règim d'aquestes assemblees "bifàsiques" ha evolucionat notablement, sobretot en la LCoop): en primer lloc, com s'ha dit $^{71}$, es tracta $\mathrm{d}^{\prime \prime \prime}$ un procés unitari, com una única assemblea general descentralitzada i de realització progressiva", "l'ordre del dia serà comú a totes aquestes i la convocatòria" és en realitat única, encara que hi haja un lapse necessari de temps entre la realització de les juntes preparatòries i l'assemblea de delegats; a més, en les juntes preparatòries no s'adopten acords definitius ${ }^{7 / 2}$ sobre els assumptes de l'ordre del dia, sinó que s'elegeixen els representants, el mandat dels quals no té perquè ser imperatiu.

768 Això no obstant, per a les cooperatives de crèdit, l'article 19 del Reglament de desenvolupament de la Llei 13/1989 estableix més detall del funcionament de les juntes.

769 L'article 51 LGC es referia a l'assemblea de delegats com una "assemblea de segon grau, integrada pels delegats designats en juntes preparatòries", amb la qual cosa semblava donar a entendre que aquestes últimes serien una espècie d"'assemblees de primer grau", per a les quals, a més, en allò no previst legalment $\mathrm{i}$ estatutària, s'havien d'observar "quan siguen aplicables, les normes establertes sobre Assemblees generals...".

770 VICENT CHULIÁ, F., «La asamblea...», op. cit., pàg. 193, i «El derecho de los órganos...», op. cit., pàg. 520 a 523. PAZ CANALEjO, N., en PAZ CANALEJO, N. i VICENT CHULIÁ, F., Ley general... op. cit., pàg. 579; defensava la impugnació dels acords de les juntes preparatòries, MUN̄OZ VIDAL, A. B., El proceso..., op. cit., pàg. 29 i 30.

771 El tema ha estat extensament estudiat per la doctrina juridicocooperativa italiana; un resum de la qual, incloent-hi una relació de cites, pot veure's en PAOLUCCI, L. F., Le società cooperative, pàg. 105. També sintetitza les diferents posicions doctrinals italianes VICENT CHULIÁ, F., «La asamblea...», op. cit., pàg. 192.

772 VICENT CHULIÁ, F., "La asamblea...», op. cit., pàg. 195, i «El derecho de los órganos...», op. tot acord 521 a 523: "falta en els «acords» de les juntes preparatòries la característica essencial de tot acord social que la voluntat de la majoria absorbisca la de la minoria". 
Això significa que els acords de l'assemblea de delegats seran sempre l'objecte de la impugnació, encara que els vicis s'hagen produït en una junta preparatòria. En aquests supòsits s'haurà d'atendre també la naturalesa de la norma o l'interès vulnerats per decidir sobre la nul-litat o anul-labilitat de l'acord corresponent. Això no obstant, s'ha de tenir present, a més, que els efectes invalidants d'alguns vicis produïts en les juntes poden afectar només una part dels vots; en aquest cas s'haurà d'efectuar la prova de resistència: en aquests supòsits, l'acord definitiu adoptat per aquesta podrà ser impugnat sols si la invalidesa dels vots de la junta preparatòria destrueix la majoria assolida en l'assemblea de delegats ${ }^{73}$. Però poden donar-se molts altres supòsits en què el defecte de la junta comporte directament la nul-litat o l'anul-labilitat d'alguns o tots els acords de l'assemblea de delegats: penseu, per exemple, en la junta preparatòria que nega la representació vàlida d'un soci, o el seu dret de vot, 0 que es constitueix invàlidament, etc.

D'altra banda, com que el mandat que porten els delegats pot ser imperatiu o subjecte a determinats criteris $^{74}$, pot plantejar-se el dubte sobre la

773 Paz Canalejo, N., en Paz CANAlejo, N. i Vicent ChuliA, F., Ley general... op. cit., pàg. 579, propugna aquesta solució per a tots els vicis de la junta: "els vicis o els defectes de forma apareguts en una junta preparatòria [...] afectaran la validesa de l'acord social definitiu si el nombre de vots anul-lats destrueix la majoria assolida a l'assemblea de delegats". En el mateix sentit, VICENT CHULIA, F., «La asamblea...», op. cit., pàg. 193.

774 La LCoop (article 30.1) indica que els estatuts han de regular, entre altres aspectes de les juntes preparatòries, "el caràcter i la durada del mandat", mentre que la LCCV (article 35.3) es refereix expressament que "el mandat podrà ser facultatiu o contenir instruccions de vot"; l'article 19.3 del RCC també remet a la regulació estatutària "el caràcter i l'abast del mandat dels delegats, que podrà ser diferent segons les matèries a tractar en l'assemblea". VICENT CHULIÁ, F., "La asamblea...", op. cit., pàg. 196, aplicant expressament la doctrina mercantilista per a la comissió, assenyala que "el mandat que detenen els delegats segons l'abast de les instruccions rebudes i incorporades a l'acta, pot ser de tres tipus [...]: a) Mandat imperatiu, en el qual el delegat, en principi, té absolutament vinculat el seu vot. [...] Això no obstant, encara podrien trobar-se els delegats davant de la necessitat de votar en sentit contrari, si les circumstancies hagueren canviat en el sentit que complir les instruccions del mandant aniria contra els interessos d'aquest [...]. b) Mandat indicatiu, en el qual al delegat se li imposen només uns criteris dins dels quals exercitarà ell mateix l'elecció. [...], es fixen un màxim i un mínim [...]. c) Mandat facultatiu, en el qual al delegat se li dóna plena llibertat per defensar en l'assemblea general els criteris o interessos dels seus representats, però decidint per si mateix en quin sentit orientar el vot d'aquells". 
impugnabilitat dels acords adoptats quan es considere que el delegat no ha acomplert les instruccions rebudes. Considerem que, en aquest cas, el que s'ha de dilucidar és si s'han vulnerat les obligacions derivades de la relació de representació; sols en aquest cas els vots exercits pel delegat poden arribar a ser declarats nuls o anul-lables i correspondrà aplicar la prova de resistència al resultat de la votació.

\subsection{Acords de l'assemblea de socis de la secció}

Tant la LCoop (article 5) com la LCCV (article 7) preveuen la possibilitat que els estatuts de la cooperativa regulen "la constitució i el funcionament de seccions que desenvolupen, dins de l'objecte social, activitats economicosocials específiques". La secció de la cooperativa no té personalitat jurídica independent $^{775}$ però sí un ampli marge d'autonomia per a la seua gestió que fa que s'exigisca la gestió de comptabilitat separada i que s'establisca un règim de responsabilitat peculiar: del compliment de les obligacions derivades de l'activitat de la secció responen, en primer lloc, les aportacions i garanties compromeses pels socis integrats en la secció ${ }^{776}$.

Les seccions són fórmules organitzatives tradicionals en alguns tipus de cooperatives, com les d'habitatges o les agràries; aquestes últimes, a més, són les que, en major mesura, s'han dotat d'una modalitat de secció notablement complexa per raó de la seua activitat: la secció de crèdit ${ }^{7 m}$. La seua proliferació i

\footnotetext{
775 Aquesta qüestió, avui pacífica en la doctrina, no sempre ha estat clara. L'escarida regulació que de les seccions feia l'article 6 del Reglament de desenvolupament de la Llei de cooperatives de 1974, l'important volum econòmic que anaven adquirint algunes seccions, especialment les de crèdit, i la confusió pràctica que algunes vegades es va produir en l'àmbit agrari entre aquestes $i$ les caixes rurals, poden ser les causes que MUÑOZ VIDAL, A. B. (El proceso..., op. cit., pàg. 31 a 35) arribara a propugnar la personalitat jurídica independent de les seccions.
}

776 Per a l'anàlisi de la responsabilitat patrimonial de les seccions, vegeu FAJARDO GARCfA, I. G.,
La gestión económica..., op. cit., pàg. 205 a 213 . ${ }^{777}$ Les seccions de crèdit, per la transcendència especial de la seua activitat econòmica, han estat objecte de regulació específica d'índole variada. Així, per exemple, la LGC de 1987 
la seua creixent activitat econòmica diferenciada han motivat que, ja des de la seua regulació expressa inicial en el Reglament d'aplicació de la Llei de cooperatives de 1974, la doctrina s'haja plantejat quin n'és el règim jurídic ${ }^{7^{3}}$ D'aquest debat doctrinal i del tenor literal de l'actual regulació en la LCoop i en la LCCV podem concloure alguns trets definitoris, dels quals ha de dependre la impugnabilitat $d^{\prime}$ acords eventuals al si de les seccions.

La primera qüestió debatuda ha estat precisament la possibilitat que els socis de la secció prengueren acords vàlids en relació amb els assumptes propis de la secció. La evolució irregular en la regulació legislativa sembla ser en l'origen del debat, ja que ni l'esmentat Reglament de 1978 ni la LGC de 1987 (que regulava únicament les seccions de crèdit) es referien a la qüestió ${ }^{79}$. En canvi, la vigent normativa cooperativa soluciona aquesta llacuna en esmentar expressament

regulava únicament aquest tipus de seccions; en l'actualitat, la LCoop li dedica en exclusiva l'apartat 4 de l'article 7, i la LCCV l'article 83. A més, a les comunitats autònomes amb més tradició en la creació $\mathrm{i}$ manteniment de seccions de crèdit s'han promulgat normes específiques, aquest és el cas de la Comunitat Valenciana, que compta amb la Llei 8/1985, de 31 de maig desenvolupada pel Decret 151/1986, de 9 de desembre, i modificada per la Llei 14/1997, de 26 de desembre, de mesures de gestió administrativa i financera de la Generalitat Valenciana; i de Catalunya, que compta amb la Llei 6/1998, de 13 de maig, de regulació del funcionament de les seccions de crèdit de les cooperatives.

778 Sobre el règim jurídic dels òrgans de les seccions d'acord amb la normativa anterior a la LGC, poden veure's MUÑOZ VIDAL, A. B., El proceso..., op. cit., pàg. 30 a 35; SANTOS MARTINBZ, V., «Las secciones...», pàg. 1084 a 1101; i VICENT CHULIÁ, F., «La asamblea...», op. cit., pàg. $197 \mathrm{i}$ $198, \mathrm{i}$ «El derecho de los órganos...», op. cit., pàg. 520 i 521. Ja segons la LGC, PAZ CANALEjo, N., en PAZ CANALEjo, N. i Vicent CHULIÂ, F., Ley general.,,. op. cit., pàg. $580 \mathrm{i} 581$.

779 Això va portar Paz CANalejo, N., en PAZ CANALEjo, N. i Vicent ChuliÁ, F., Ley general... op. cit., pàg. 580 i 581 , a afirmar que, sota la vigència de la LGC, "no es pot parlar d' «assemblees de secció", sinó, com a màxim de "comissions o comitès de secció" el criteri del qual no constituirà un acord, sinó un informe o una proposta no vinculant per als òrgans necessaris. Per tant, de cap manera és vàlid pretendre que davant d'aquestes opinions o criteris suborgànics serà possible accionar a l'emparament de l'article 52 de la Llei"; "La Llei vigent -a diferència de l'article 4.3, de la norma legal de 1974- no reconeix la possibilitat d'organitzar al si d'una societat "juntes, grups o seccions [...] amb autonomia de gestión; d'altra banda, el legislador 1987, certament, proclama la capacitat autoorganitzativa de qualsevol cooperativa [...], però de cap manera admet la possibilitat de crear més d'una assemblea (fins $i$ tot quan funcionen les juntes preparatòries només continua havent-hi un òrgan assembleari; cfr. l'article 51) i tampoc permet articular instàncies subassembleàries amb capacitat per adoptar autèntics acords. El màxim que es pot dur a terme, des de l'estatut o des del reglament de règim intern, en el pla orgànic (una vegada exclòs el comitè de recursos, que la Llei prefigura i no té res a veure amb les seccions), és crear "comissions, comitès o consells" amb funcions no resolutòries (cfr. l'article 61), llevat de previsió legal expressa en contra (per exemple, en l'article 48.2, segon paràgraf)". 
l'assemblea de socis de la secció $0^{780}$ i l'adopció per aquesta d'acords l'eficàcia normal dels quals pot ser suspesa per l'assemblea general.

En tot cas, aquest debat doctrinal va tenir la virtut d'avançar altres qüestions respecte a aquestes reunions de socis de la secció: no poden considerar-se juntes preparatòries de l'assemblea general, de manera semblant a allò vist per a les assemblees de delegats, ja que els acords de les seccions, que se circumscriuen als assumptes propis de la secció ${ }^{781}$, són acords definitius, amb efectes jurídics directes $^{72}$. El contrari, això és, considerar les reunions de la secció com a juntes preparatòries i sotmetre els seus acords a l'acord definitiu de l'assemblea general, constituiria una vulneració directa de la proclamada autonomia de gestió de la secció.

A més, aquests acords també queden sotmesos al principi de majoria ${ }^{783}$ democràtica (majoria del nombre de vots, contràriament al còmput que parteix del percentatge de participació en el capital social), si bé el colllectiu de referència ja no pot ser el total de socis de la cooperativa, sinó el de socis adscrits a la secció.

${ }^{780}$ FAJARDO GARCIÁ, I. G., La gestión económica..., op. cit., pàg. 207: "Els socis integrats a la secció s'organitzen internament en una «assemblea de socis de la secció»-com la defineix la Llei valenciana, per distingir-la de l'assemblea general. Aquesta assemblea és la que decideix com ha de gestionar-se la secció".

${ }^{781}$ SANTOS MARTíNEZ, V., «Las secciones...», op. cit., pàg. 1101.

782 MUÑOZ VIDAL, A. B., El proceso..., op. cit., pàg. 30; SANTOS MARTÍNEZ, V., «Las secciones...», op. cit., pàg. 1089 i 1097; VICENT CHULIÁ, F., «La asamblea...», op. cit., pàg. 197 i 198, i en «El derecho de los órganos...", op. cit., pàg. 520 i 521.

783

SANTOS MARTINEZ, V., «Las secciones...», op. cit., pàg. 1099: "l'acord adoptat per la majoria en una junta particular de la "secció», per resoldre els problemes particulars d'aquesta, [...], haurà de prevaler sobre la minoria. A la secció es pot traslladar, per a l'àmbit d'activitats que li és propi, aquesta configuració corporativa que s'ha de reconèixer en tota la societat cooperativa. L'aplicació del principi de porta oberta, amb la possibilitat de separació del soci, confirma la procedència d'aplicar a les decisions de la secció el principi majoritari". Encara que ni l'autor ni concret àmbit de la secció hauria de tenir com a conseqüència la lliure adhesió i la baixa voluntària de la secció. 
L'eficàcia directa d'aquests acords, sense necessitat d'una ratificació posterior de l'assemblea general $^{784}$, es deriva implícitament del reconeixement legal mateix que aquesta última pot suspendre'ls, amb certes limitacions: sols quan els "considere contraris a la llei, als estatuts o a l'interès general de la cooperativa", segons la LCoop (article 5.3); o, segons la LCCV (article 7.4), "si fa constar els motius pels quals els considera impugnables o contraris a l'interès general de la cooperativa".

Això no obstant, la LCoop no es refereix explícitament a la impugnabilitat dels acords de l'assemblea de socis de la secció, encara que la redacció de la facultat de la seua suspensió per l'assemblea general sembla estar pensada com a pas previ a una impugnació eventual de l'acord que s'ha de suspendre: els motius que fonamenten la suspensió són els mateixos que possibiliten la impugnació dels acords de l'assemblea general, i totes les normes reguladores de processos d'impugnació d'acords socials preveuen la suspensió, en determinats supòsits, amb la finalitat de facilitar el desenvolupament del procediment; en cas contrari, no s'entén quina altra finalitat podria motivar la suspensió, ni quan podria alçar-se aquesta ${ }^{785}$.

És aconsellable, de lege ferenda, la compensació d'aquesta llacuna legislativa que aclarira, a més, si la impugnació ha de seguir les normes previstes per a la dels acords de l'assemblea general, amb les adaptacions necessàries, o es considera preferible optar per un règim propi, que tinguera en compte les especials circumstàncies en aspectes com ara la legitimació; mentrestant, una eventual regulació estatutària de la impugnació dels acords de l'assemblea de socis de la

\footnotetext{
784 SANTOS MARTÍNEZ, V., "Las secciones...", op. cit., pàg. 1101, fent seua l'opinió de VICENT CHULIÁ en «La asamblea...", op. cit., pàg. 197: "l'assemblea general de la cooperativa no hauria de tenir una altra missió, davant les assemblees de grup, que declarar, a instància o denúncia del consell rector, que un acord d'aquestes assemblees s'ha passat de la competència que els correspon".

785 MARÍN LÓPEZ, J. J., «Notas sobre la Ley 27/1999...», op. cit., pàg. 1799, estima que es poden impugnar els acords de la secció "en les condicions en què, amb caràcter general, cap impugnar judicialment els acords de la pròpia cooperativa (Cfr. bàsicament article 31 de la Llei)".
} 
secció en les cooperatives sotmeses a la LCoop es converteix en altament aconsellable.

La LCCV sí que reconeix explícitament la impugnació dels acords de l'assemblea de socis de la secció, "en els termes assenyalats en l'article 36 d'aquesta llei", això és, amb aplicació d'allò que preveu per a la impugnació dels acords de l'assemblea general ${ }^{786}$, la qual cosa tampoc evita l'aparició $d$ 'interrogants, entre els quals el més immediat és el relatiu a l'interès protegit. En efecte, s'ha de tenir en consideració que els interessos dels socis de la secció poden ser diferents $\mathrm{i}$ fins $\mathrm{i}$ tot contradictoris amb els de la cooperativa en $\operatorname{conjunt}^{787}$, o amb els dels socis no adscrits a la sección ${ }^{788}$, la qual cosa afecta, almenys, dos aspectes essencials: l'interès eventualment lesionat amb l'acord com a causa de la impugnació, i la legitimació, activa i passiva, per a la impugnació.

En relació amb l'interès que puga resultar lesionat per l'acord, s'han de distingir diverses qüestions. En primer lloc, no hi ha dubte que l'acord de la secció que lesione l'interès general de la cooperativa en benefici extrasocial (siga a favor dels socis de la secció, siga a favor de tercers) és dretament impugnable. En segon lloc, tampoc obri interrogants especials la legitimitat segons la qual els

${ }^{786}$ En la mateixa línia, els art. 6.2 LCPV, 6 LCA i 6.2 LCCM.

787 DuQue DomínGuez, J. F., Tutela ..., op. cit. pàg. 106: "L'assemblea especial ha de [...] perseguir l'interès de la categoria d'accions, això és, «la protecció dels seus membres» [...]. Això significa que la satisfacció de l'interès social mitjançant l'acord de la junta especial, sols s'aconseguirà mediatament quan l'interès de la categoria coincidisca - coincidència que no es produeix sempre d'una manera necessària- amb l'interès de la societat, per la qual cosa un acord de la junta especial que, en decidir, contemple exclusivament aquest interès, serà impugnable per desviació de poder". En el mateix sentit, SÁNCHEZ RUIZ, M., Conflictos de intereses..., op. cit., pàg. 110, nota 83 , citant MIGNOLI, "en l'assemblea especial d'accionistes d'una categoria determinada, els socis persegueixen l'interès propi del grup, que ha estat considerat mereixedor de tutela pel legislador, interès que no pot identificar-se, ni té perquè coincidir, amb l'interès social".

788

MuÑoz VIDAL, A. B., El proceso..., op. cit., pàg. 31: "Els acords que s'adopten dins de la secció poden tenir una repercussió que es limite dins del cercle de persones integrades a la secció, o per contra també pot ocórrer que afecten la cooperativa mateixa, i per tant els socis d'aquesta no membres de la secció. La nul-litat o lesivitat dels acords que s'adopten tenen una repercussió de molt variada índole". 
socis adscrits a la secció actuen en defensa dels seus interessos mitjançant l'adopció d'acords que no lesionen interessos de la cooperativa en conjunt. El conflicte podria plantejar-se, tanmateix, quan l'assemblea de socis de la secció adoptara un acord, en benefici dels seus socis adscrits i sense lesió de l'interès social, però que perjudicara els interessos d'altres socis de la cooperativa.

Ja ha quedat ressenyat que la legislació espanyola, a diferència d'altres, com l'alemanya, no preveu la impugnació dels acords que lesionen interessos legítims, però extrasocials ${ }^{789}$ dels socis. Però també s'han de tenir ara en consideració altres aspectes derivats de la peculiar estructura cooperativa i de les seues seccions: l'assemblea de socis de la secció, la composició de la qual pot ser minoritària respecte al total col-lectiu de socis de la cooperativa, podria adoptar acords que, si no pateix de cap de les causes d'impugnació assenyalades en l'article 36.1 LCCV, podrien ser perjudicials per als interessos d'altres socis (que poden ser fins i tot la majoria), però no atacables per l'assemblea general.

Ens hem de plantejar, doncs, si la normativa legal o estatutària de la cooperativa hauria de preveure instruments de defensa dels socis afectats, com ara l'articulació d'una segona instància interna, a semblança d'allò preceptuat, com veurem 790 , per a acords del consell rector, com ara les baixes $i$ altes de socis, en què es pot recórrer contra l'acord davant de l'assemblea general o el comitè de recursos, i això sense necessitat que el motiu del recurs siga la vulneració de norma legal o estatutària o de l'interès social. L'opció no és senzilla: permetre que l'assemblea de la secció adopte acords perjudicials als socis no adscrits pot generar greus conflictes interns $i$, fins i tot, produir-se la paradoxa que l'estructura cooperativa done cobertura a la defensa dels interessos minoritaris davant els de la majoria; regular la segona instància l'assemblea general obri la

789 Per interès extrasocial ha d'entendre's ací l'interès particular del soci no coincident amb els interessos socials de la cooperativa, siguen aquests quins siguen (capítol primer).

790 Vegeu infra l'epígraf 2.2.1. "Acords del consell rector que poden impugnar-se internament". 
via del control d'oportunitat de les decisions de la secció, amb greu limitació de la seua pretesa autonomia de gestió. Per això, potser caldrà plantejar, com s'ha defensat, la impugnabilitat d'aquells acords adoptats exclusivament en satisfacció d'interessos extrasocials quan no es perseguisca simultàniament l'interès comú ${ }^{791}$.

Tampoc és menys conflictiva la qüestió de la legitimació per a la impugnació dels acords de l'assemblea de la secció. La LCCV demanda l'aplicació a l'esmentada impugnació d'allò preceptuat en l'article 36, que inclou, en els apartats 4 i 5, les pautes de legitimació; tanmateix, la translació d'aquestes normes a l’àmbit de la secció planteja alguns interrogants.

Quan encara estava vigent la Llei de cooperatives de 1974 es va qüestionar la legitimació dels socis no adscrits per algun autor que estimava que se'ls havia de considerar com a tercers a l'efecte de la impugnació dels acords de la secció $^{7 n}$; amb això es produiria la seua deslegitimació per a la impugnació dels acords anul-lables, opció que ens sembla incorrecta. En efecte, si bé és cert que els socis de la secció són els qui han de decidir el que corresponga millor a la defensa dels seus interessos, no ho és menys que haja de ser amb respecte total a la llei, als estatuts socials i a l'interès general de la cooperativa, i que una vulneració eventual d'aquestes causes ha de legitimar tots els socis per a la seua impugnació, ja que tots es veurien perjudicats per la lesió.

791 DuQUE DOMíNGUEZ, J. F., Tutela ..., op. cit. pàg. 102.

792 MUÑOz VIDAL, A. B., El proceso..., op. cit., pàg. 35: "l'acord nul o lesiu pot afectar els altres socis de la cooperativa no integrats en la secció. En aquest cas s'ha d'ampliar la interpretació i entendre que aquests socis — no de la secció, però sí de la cooperativa- poden igualment estar legitimats de manera activa per interposar la demanda corresponent. Però només en el cas que exercite l'acció de nul.litat, ja que com veurem també correspon fins i tot als tercers. Si el perjudici es produeix per infracció dels estatuts, entenent per tals també el reglament propi de la secció, o per infracció de normes el camí queda expedit. Però si no és així, encara que l'acord siga lesiu, el soci no membre de la secció no podrà accionar, ja que com a màxim podria, al seu esta, haver-se oposat a la constitució de la secció, que ha d'estar legalment prevista en els estatuts generals de l'entitat" (recordeu que l'article 27.1 de la Llei de cooperatives de 1974 considerava nuls tant els acords contraris a la llei com els contraris als estatuts socials). 
Tanmateix, l'aplicació de l'article 36.5 LCCV als acords anul-lables de l'assemblea de la secció tindria efectes similars als criticats, ja que legitima únicament els assistents que hi hagueren fet constar la seua oposició, els absents i els il-legítimament privats de vot, els membres del consell rector, els administradors i els membres de la comissió de control de la gestió. I no escau d'equiparar, a l'efecte de la legitimació, els socis no adscrits amb els socis de la secció absents, ja que aquells no són membres de l'assemblea de la secció.

Quant a la legitimació passiva, la falta de personalitat jurídica independent de la secció condueix inevitablement a l'exercici de la defensa de l'acord de la secció per la representació general de la cooperativa, això és, l’òrgan d'administració. Tanmateix, en aquests casos pot donar-se amb més freqüència que en la impugnació dels acords de l'assemblea general, que siguen els administradors de la cooperativa els que actuen la legitimació activa. En aquests supòsits, com veurem més endavant 793 , s'ha d'aplicar analògicament la solució adoptada pel segon paràgraf de l'article 117.3 LSA, això és, que "quan l'actor tinguera la representació exclusiva de la societat i la junta no tinguera designat ningú a aquest efecte, el jutge nomenarà la persona que ha de representar-la en el procés, entre els accionistes que ha votat a favor de l'acord impugnat". Però aquest nomenament judicial sols procedirà quan qui impugna és "representant exclusiu" i no s'haja designat un altre representant per a l'exercici de la legitimació passiva. En aquest sentit, entenem que és la assemblea mateixa de socis de la secció la que podrà nomenar el representant.

En tot cas, com que el mandat legal mateix (articles 5.1 LCoop i 7.1 LCCV) exigeix la regulació estatutària de les seccions, és altament convenient aprofitar aquest desenvolupament per concretar-ne i detallar-ne l'estructura i el funcionament orgànic en general, i el règim d'impugnació dels acords de la seua assemblea en particular. 
La pràctica i la doctrina ${ }^{794}$ aconsellen dotar de reglament propi les seccions que compten amb un volum d'activitat suficient, cosa que en alguns casos és obligatori en virtut de normatives sectorials ${ }^{795}$. Tanmateix, encara que els reglaments de les seccions són instruments útils per a la seua organització, s'ha de recordar que la seua vulneració no dóna lloc, en principi, a la impugnació de l'acord corresponent ${ }^{796}$.

1.5. Acords de l'assemblea d'obligacionistes

Tant la LCoop (article 54.1) com la LCCV (article 56.3) preveuen la possibilitat que l'assemblea general acorde l'emissió d'obligacions "el règim de les quals s'ajustarà al que dispose la legislació aplicable". La legislació bàsica vigent en la matèria és la Llei 211/1964, de regulació de l'emissió d'obligacions per societats que no hagen adoptat la forma d'anònimes ${ }^{797} \mathrm{i}$, supletòriament, els articles del 282 al 310 LSA, així com la LMV, el RRM i el Reial decret 291/1992, de 27 de març, sobre emissions i ofertes públiques de valors; entre aquestes, les normes fonamentals a l'efecte de la impugnació possible dels acords de l'assemblea del sindicat d'obligacionistes són els articles 10 i 12, 2n paràgraf de la Llei 211/164 i l'article 301.3 LSA.

En efecte, la Llei 211/1964 estableix, entre altres facultats de l'assemblea del sindicat d'obligacionistes, les d'acordar "allò necessari per a la millor defensa dels interessos dels obligacionistes davant l'entitat emissora (...) i exercitar,

794 SANTOS MARTíneZ, V., «Las secciones...», op. cit., pàg. 1101; MUÑoz VIDAL, A. B., El proceso..., op. cit., pàg. 31.

795 Aquest és el cas de les cooperatives agràries que volen obtenir la qualificació d'organització de productors per a alguna de les seues seccions.

${ }^{796}$ Vegeu supra epígraf 1.2 del capítol segon.

${ }^{797}$ Llei 211/1964, de 24 de desembre, de regulació de l'emissió d'obligacions per societats que no hagen adoptat la forma d'anònimes, associacions o altres persones jurídiques i la constitució del sindicat d'obligacionistes (BOE núm. 311, de 28.12). 
quan escaiga, les accions judicials pertinents" (article 10), i declara aplicable "de manera supletòria i acomodada a la naturalesa de l'entitat emissora" el que disposa sobre això la LSA. L'article 301.3 LSA, per la seua part, declara impugnables pels obligacionistes els acords de l'assemblea del sindicat, conforme a allò disposat en la llei en relació a la impugnació d'acords de la junta general ${ }^{798}$.

En virtut d'això, la legitimació activa no ha de suposar especialitats, excepte la substitució dels socis pels obligacionistes. La legitimació passiva recaurà en el comissari del sindicat d'obligacionistes, en la seua qualitat de representant legal del sindicat799, si bé pot reproduir-se ací allò anotat en l'epígraf 1.4 anterior ("Acords de l'assemblea de socis de la secció") per als supòsits en què el comissari siga precisament actor de la impugnació: si ni l'escriptura de l'emissió, ni la assemblea d'obligacionistes mateixa estableixen una altra cosa, el jutge nomenarà, d'entre els obligacionistes que hagueren votat a favor de l'acord, el seu representant.

\footnotetext{
798 Alonso EspinOSA, F. J., Asociación y derechos..., op. cit., pàg. 173 a 179; URfA, MENÉndez, i MuÑoz, La junta ..., pàg. 314 i 315.

Paz Canalejo, N., en PAZ CANalejo, N. i Vicent ChUliá, F., Ley general..., vol. II, pàg. 580, apuntava, respecte a la LGC de 1987, que "quant a l'assemblea d'obligacionistes, els pronunciaments que emanen d'aquesta hauran d'impugnar-se, si escau, mitjançant el procés ordinari corresponent", seguint GIMENO SENDRA, J. V., que en El proceso... , op. cit., pàg. 32 i 33, encara sobre la LSA del 1951 i la LGC del 1974, considerava que els acords de l'assemblea d'obligacionistes no eren impugnables pel "procediment especial", sinó pel "procés ordinari corresponent". Posteriorment, aquest últim autor, en " La reforma..., op. cit., pàg. 15 i 16, considera que "la nova llei, secundant en aquest extrem el criteri sostingut per la legislací cooperativa i per una doctrina minoritària del TS, ha ampliat substancialment l'àmbit d'aplicació d'aquest procediment $i$, així, poden ser impugnats els [...] acords adoptats per l'assemblea d'obligacionistes".

En l'àmbit de les societats anònimes, vegeu ALONSO ESPINOSA, F. J., Asociación y derechos..., op. cit.; BrosetA PONT, M., Manual de derecho mercantil, 10a ed., Tecnos, Madrid, 1994, pàg. 382; DOMÍNGUEZ GARCfA, M. A., "La obligación como título...", op. cit., pàg. 1274, i un desenvolupament de les competències i funcionament de l'assemblea d'obligacionistes, en les pàg. 1314 a 1317; RUBIO, J., Curso..., op. cit., pàg. 443 a 445; i VICENT CHULIA, F., Compendio crítico..., op. cit., tom I, vol. 2n, pàg. 813: "[...] Tanmateix, és difícil traslladar aquella normativa a aquesta matèria. P. e., el concepte $d^{\prime}$ ' «interessos de la societat» ha d'estat substituït pel d' «interess comú dels obligacionistes» (STS esmentada de 3 de març de 1984, R. 1196)". Respecte dels conflictes d'interessos possibles, vegeu supra l'epígraf 1.4 .
}

799 AlONSO EsPINOSA, F. J., Asociación y derechos, op. cit., pàg. 176. En el mateix sentit, RUBIOJ., 
En relació amb l'interès social protegit, s'ha plantejat que ha d'entendre's substituit per $1^{\prime \prime \prime}$ interès comú dels obligacionistes", entenent aquest com "l'organització per a la defensa de les seues posicions actives"

Una altra qüestió serà la possibilitat que els obligacionistes o el comissari del sindicat impugnen els acords dels òrgans de la societat, que serà analitzada en l'epígraf 1.1.1.G, i) del capítol quart.

\subsection{Acords de les juntes especials}

Ja hem vist com, tradicionalment, la coexistència en la cooperativa d'interessos generals comuns i interessos col-lectius de determinats grups de socis s'ha organitzat mitjançant la constitució de seccions; això no obstant, aquesta opció, exercitable per la cooperativa a l'hora de dotar-se de norma estatutària, és voluntària. Però $\mathrm{amb}$ independència de la seua incorporació o no, la Llei garanteix la defensa dels interessos de col-lectius concrets de socis o tercers requerint, bé la seua reunió en juntes especials, bé la seua votació separada dins de l'assemblea general que haja d'adoptar acords que els afecten ${ }^{801}$.

Així, en les cooperatives d'habitatges que desenvolupen més d'una "fase o promoció", tant la LCoop (article 90, 4t paràgraf) com la LCCV (article 81.6) preveuen la necessària regulació estatutària i constitució de juntes especials per a cada promoció. En altres supòsits, en canvi, la Llei es limita a exigir que

Curso..., op. cit., pàg. 444.

${ }^{800}$ ALONSO EsPINOSA, F. J., Asociación y derechos, op. cit., pàg. 178: “[...] en última instància, el que s'ha de verificar és l'adequació de l'acord a l'objecte de l'organització, això és, a la defensa, en sentit ampli, dels drets de crèdit dels obligacionistes que la integren. D'aquesta manera, només els acords que perseguisquen aquesta finalitat hauran de reputar-se conformes a aquest «interès social»".

801

l'assembò no obstant, sense perjudici de la diferència bàsica de règim entre els acords de traslladable docis de la secció i de les juntes especials, alguns aspectes són plenament

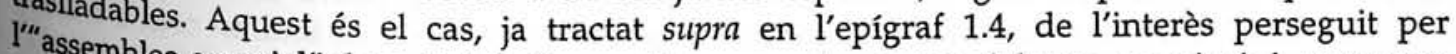
la seumblea especial" davant el de l'assemblea general respecte del que, en principi, se suposa seua identificació amb l'interès social. 
l'acord de l'assemblea general compte amb el vot favorable de la majoria del col-lectiu (de socis o de tercers) afectat; és el cas de l'article 96.6 LCoop, per a l'adopció per la cooperativa d'explotació comunitària de la terra d'acords relatius a obres, millores i servituds als béns cedits a la cooperativa; o el de l'article 107 LCoop, que es refereix expressament a la necessitat de votació separada a l'assemblea general, per a la modificació de drets i obligacions d'algun dels col-lectius de socis de la cooperativa mixta ${ }^{802}$; o el de l'article 33 , 3r paràgraf LCoop, en regular l'elecció de la representació al consell rector dels treballadors per temps indefinit, en les cooperatives que en compten amb més de cinquanta ${ }^{803}$.

Les juntes especials tampoc han de confondre's amb les juntes preparatòries, ja que l'acord majoritari favorable de les especials és requisit imprescindible per a l'adopció vàlida de l'acord de l'assemblea general. L'esmentada figura, juntament amb l'alternativa de la votació separada del col-lectiu de socis

802 BUONOCORE, V., Diritto della cooperazione..., op. cit., pàg. 272, assenyala com, en dret italia, on no es regulava expressament per a les cooperatives la junta especial, ha estat necessari introduir-la a la reforma legislativa de 1992, en crear-se les categories dels socis sovventori i els "accionistes de participacions cooperatives". També es refereix a això PALMA, R., "Il fenómeno cooperativo...", op. cit., pàg. 42.

El mateix succeeix en dret francès, on la creació de les "parts d'interès prioritari sense dret de vot", reservades als tercers $\mathrm{i}$ als associats ha previst, tanmateix, que quan els beneficis econòmics lligats a aquestes parts no són íntegrament desemborsats durant tres exercicis consecutius, els tenidors d'aquestes parts adquireixen un dret de vot limitat. Aquest dret de vot s'exerceix mitjançant la realització d'una assemblea especial, convocada alhora que les assemblees generals ordinàries o extraordinàries, que té com competències: a) Emetre una opinió sobre totes les decisions de l'assemblea general, per majoria de vots presents. Aquesta opinió serà transmesa a la societat i transcrita en l'acta de l'assemblea general; b) Designar un 0 diversos mandataris en les assemblees generals; i c) Aprovar les modificacions de drets relacionades amb les seues parts, per majoria de dos terços dels vots presents o representats (AA. DD., «La coopérative française...», op. cit., pàg. 63 i 65).

803 Més dubtes planteja la norma equivalent de la LCCV, l'article 38.4, en què s'estableix que "els estatuts hauran de regular el procediment per donar una representació estable al consell rector als socis de treball, que tindran com a mínim un conseller. Igualment, els estatuts regularan la representació dels treballadors assalariats de la cooperativa amb contracte per temps indefinit, quan siguen més de 20 durant l'any anterior, cas en què tindran com a mínim un conseller". En efecte, com veurem, la norma no diu qui ha d'elegir aquestes representacions, ni quines persones poden ser elegides representants. 
afectats, ha estat analitzada per la doctrina en relació amb els supòsits expressament delimitats per als quals la LSA recull la fórmula esmentada ${ }^{804}$.

Una de les qüestions que s'ha plantejat ha estat l'opció per un sistema o un altre: junta especial, o votació separada dins de l'assemblea general mateixa. En principi, s'ha de descartar la possibilitat d'elecció en aquells supòsits en què la llei mateixa exigeix la regulació i constitució de junta especial, com és el cas de les cooperatives $d$ 'habitatges amb més d'una fase. D'altra banda, com s'ha indicat, la possibilitat d'optar serà "una mica utòpica" en els supòsits en què els col-lectius afectats no assistisquen regularment $i$ majoritàriament a les assemblees generals ${ }^{805}$; en aquest cas serà necessari procedir a la convocatòria de reunió especial. Però quan puga manifestar-se la preferència per una solució o una altra, sembla que la junta especial ofereix més garanties de respecte a la voluntat dels afectats, si bé suposa costos organitzatius i temporals més elevats ${ }^{806}$.

804 Cabanas Trejo, Ricardo i Calavia Molinero, José Manuel, Praxis mercantil. Sociedades anónimas: fundación y acciones, Praxis, Barcelona, 1990, pàg. 50; DUQUE DOMÍNGUEZ, J. F., Tutela..., pàg. 104 i 105: "la llei ha entès que també els interessos dels accionistes privilegiats se

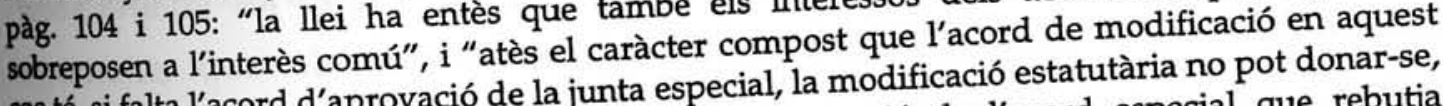
cas té, si falta l'acord d'aprovació de la junta especial, la mocío de l'acord especial que rebution sense que als socis ordinaris siga possible la impugnacio. El nuevo régimen jurídico.... l'adhesió el general"; GARCIA LUENGO, R. i SOTO VAZQÚ, IRfA, Rodrigo, Comentario a lo Le. cit., pàg. 666 a 670; GARRIGUES, J., en GARRIGUES, Joaquí, 1 URA, R, J., op. cit., pàg. 225 i 226 , “L sociedades anónimas, 3a ed., Madrid, 1976, pàg. 248 i 249, nostre dret, ja que se sotmet a sociedades anónimas, 3a ed., Madrid, 1976, pàg.
Junta d'accionistes especials és vertadera junta en el nostre dret, ja que se sotmet a les
prescripcions de la comuna (...). Però no ha de considerar-se independent: l'acord de la comuna prescripcions de la comuna (...). Però no ha de consider co impugnació ha de dirigir-se contra el
és complementat per aquest altre acord, de manera que la impú, encara que porte base de l'especial"; GOMEZ MENDOZA, María, "Juntas especiales:
comú, organización y funcionamiento", en AA. DD., Estudios de derecho mercantil. Homenaje al profesor Justino F. Duque, tom I, Universidad de Valladolid, Valladolid, 1998, pàg. 421 a 429; GOMEZ ORBANEJA, E., «El proceso...", op. cit., pàg. 124; MARINA GARCIA-TUNNÓN, A., "Supuestos específicos de modificación estatutaria: modificaciones perjudiciales a determinadas clases de acciones, restricciones a la libre transmisibilidad de las acciones y cambio de domicilio social", en AA. DD., Derecho de sociedades anónimas, Civitas, Madrid, 1994, tom III, vol. 1, op. cit., pàg. 79 a 146; MENÉNDEZ, A. i BELTRÁN, E., "Las acciones sin voto», en Comentario al régimen legal de las sociedades mercantiles (dirs. R. Uría, A. Menéndez i M. Olivencia), tom IV, Las acciones, Civitas, Madrid, 1992,pàg. 447.

805 Per exemple, en el cas esmentat dels treballadors per temps indefinit que hagen d'elegir la seua representació en el consell rector (article $33,3 \mathrm{r}$ paràgraf LCoop).

806 GOMEZ MENDOZA, M., «Juntas especiales...», op. cit., pàg. 422, esmentant a MiGNOLI, A., Li assemblee speciali, Milà, 1960 , pàg. 317, i BENOIT, La representation de groupes et de minorités 
D'altra banda, no és fàcil articular, en la pràctica, aquesta elecció, que correspondria inicialment al col-lectiu afectat mateix ${ }^{807}$, per la qual cosa s'ha proposat que, a falta de sol-licitud expressa per la seua part, siguen els administradors els qui, en convocar l'assemblea general que haja de decidir sobre l'acord perjudicial, facen constar expressament la votació separada si hi ha quòrum o, si no n'hi ha, la convocatòria de junta especial ${ }^{808}$. I tampoc ha de descartar-se la possibilitat de sol-licitar la convocatòria judicial quan els administradors desatenguen la sol-licitud del col-lectiu afectat.

En tot cas, els dubtes que es plantegen en relació, tant amb la convocatòria, com amb la realització de la junta especial hauran de resoldre's mitjançant la interpretació i l'aplicació d'allò previst, en primer lloc, en la norma concreta de la qual es derive la necessitat de junta especial o votació separada; en segon lloc, $s^{\prime}$ haurà d'atendre allò regulat en els estatuts socials i, si escau, en els reglaments interns; i, finalment, s'hi podria aplicar analògicament la solució prevista en la LSA, això és, seguir les normes de convocatòria, constitució i funcionament de l'assemblea general, en la mesura de les possibilitats i amb les adaptacions necessàries ${ }^{809}$.

d'actionnaires à l'administration des sociétés anonymes, Lausana, 1956, pàg. 97): "En una votací6 separada, és discutible que en la deliberació no puguen intervenir tots els accionistes i el president podria passar ràpidament a votació després d'una intervenció favorable a la modificació estatutària. Tanmateix, quin dubte hi ha que una junta especial suposa certa complexitat, pèrdua de temps $i$ pot resultar més cara (...) la possibilitat a la votació separada d'una manipulació del debat per pressió psicològica dels altres socis, davant una major reflexí́ sobre el vot $\mathrm{i}$ un major contrast d'opinions a les juntes especials. En el mateix sentit, GARCtA LUENGO, R., i SOTO VÁZQUEZ, R., El nuevo régimen jurídico..., op. cit., pàg. 670; i MARINA GARCłATUÑón, Ángel, «Supuestos específicos...», pàg. 112 i 113, si bé manifesta que els problemes del règim legal aplicable a la votació separada poden ser menors, ja que el règim aplicable serł̆ pura i simplement, "el propi de qualsevol reunió d'accionistes".

807 MARINA GARCtA-TUÑón, A., "Supuestos específicos...», op. cit., pàg. 110.

808 GÓMEZ MENDOZA, M., «Juntas especiales...», op. cit., pàg. 422.

809 GÓMEZ MENDOZA, M., "Juntas especiales...", op. cit., pàg. 422, 425 i 426, en una analisí detallada dels problemes que planteja el compliment del que disposa l'article 148.4 LSA ("serch d'aplicació a les juntes especials el que s'ha disposat en aquesta Llei per a la junta generai d'accionistes"), es planteja, entre altres qüestions, la del quòrum de constitució i la majoria decisòria. També considera GÓMEZ MENDOZA admissible la formulació d'una contrapropost 
En relació amb això, l'article 90,4t paràgraf LCoop., en regular la necessitat de juntes especials per a les cooperatives d'habitatges amb més d'una fase o promoció, exigeix que la convocatòria es faça "de la mateixa manera que la de les assemblees". Considerem que aquesta remissió normativa s'hauria d'haver ampliat a tot tipus de cooperatives $i$ a totes les normes relatives a la constitució $i$ el funcionament de les juntes. En tot cas i a falta de norma legal o estatutària expressa, entenem que almenys els quòrums de constitució i el règim de les majories seran els aplicables, en cada cas, a l'assemblea general, però calculats en relació amb els membres del col-lectiu afectat i no del total de socis.

Quant a la possibilitat d'impugnar de manera independent,..separadament, l'acord de la junta especial o el que resulte de la votació separada, la doctrina ha debatut la qüestió en l'àmbit de les societats de capital, a partir de la opinió unànime que és ineficaç la decisió de la reunió general dels socis si no compta amb la ratificació de l'acord preceptiu del col-lectiu de socis afectats.

Alguns autors són partidaris de la impugnabilitat, encara que sense indicar els arguments que els porten a aquesta conclusió810, mentre que uns altres consideren que la impugnació ha de dirigir-se contra l'acord de l'assemblea general ${ }^{111}$. Una tercera postura, qualificada $\mathrm{d}^{\prime \prime}$ intermèdia", manté que, "si bé

per part de la junta especial (citant en contra CABANAS, op. cit., pàg. 50, per entendre que no es poden introduir canvis o variacions en el tenor literal de les modificacions estatutàries), però li atribueix el valor de rebuig a la proposta inicial, de la qual es derivaria la necessitat de tornar a reunir la junta. Per la nostra part, considerem que s'hi podria afegir l'admissió de formulació de contraproposta també en els supòsits de votació separada (l'article 16.2.a LCoop recull expressament el dret dels socis a formular propostes). Pel que fa a la qüestió de la vinculació eventual del soci al sentit del vot emès en la junta especial o en la votació separada, indica que la doctrina admet pacíficament la no-vinculació.

${ }^{810}$ DuQue DomínGUEZ, J. F., Tutela..., pàg. 105 a 107; GIMENO SENDRA, V., La reforma... op. cit., pàg. 15 i 16; GOMEZ ORBANEJA, E., «El proceso...», op. cit., p. 124; i RODRíGUEZ RUIZ DE VILLA, D., Impugnación..., op. cit., pàg. 24.

811 Cabanas Trejo, R. i Calavia Molinero, J. M., Praxis mercantil..., op. cit., pàg. 50; GARRICUES, J., Comentario..., op. cit., pàg. 226, que, com ha quedat indicat, no considera independent l'acord de la junta especial respecte del de la junta general; MARINA GARCtATUÑón, A., "Supuestos específicos...", op. cit., pàg. 113; i MENÉNDEZ, A., i BELTRÁN, E., "Las acciones sin voto», op. cit., pàg. 447: "la impugnació dels acords socials procedirà tant per vicis 
els acords de les juntes especials, almenys en el pla dels principis, tenen substantivitat i independència, i (...), per tant, poden ser impugnats separadament de l'acord de la junta general, això planteja alguns problemes derivats de la legitimació passiva" ${ }^{\prime 812}$.

Per la nostra part, encara que participem de l'opinió de la impugnabilitat separada dels acords de les juntes especials i de les votacions separades, ens costa imaginar supòsits reals en què aquest procediment tinga transcendència pràctica, ja que la invalidesa de l'acord adoptat pel col-lectiu afectat tindrà sempre com a conseqüència la ineficàcia de l'acord de l'assemblea general.

En relació amb la legitimació activa per a la impugnació s’ha apuntat que, quan la de l'assemblea general s'atribueix als socis, la de l'acord de la junta especial ha d'entendre's restringida als integrants del col-lectiu afectat i no als socis "ordinaris", ja que aquests últims "no hi tindrien dret ni interès" ${ }^{\prime 13}$. Dissentim d'aquesta opinió, per les mateixes raons apuntades en relació amb la legitimació activa per a la impugnació dels acords de la secció: una vulneració eventual de la llei, els estatuts o l'interès social per un acord de la junta especial pot perjudicar qualsevol soci, per la qual cosa tots els socis poden tenir interès en la impugnació; tots els socis han de comptar, doncs, amb legitimació, en la mateixa mesura que tindrien si l'acord haguera estat adoptat per l'assemblea general.

de la junta general com per vicis de la votació separada o en la junta especial. En tot cas, el que s'impugna és l'acord social, que té en aquests presumptes naturalesa complexa; amb això es vol significar que no pot estat impugnat separadament l'acord de la classe".

812 Considera GÓMEz MENDOZA, M., «Juntas especiales...", op. cit., pàg. 428, que "la categoria no té personalitat jurídica, i per això en principi seria necessari demandar conjuntament els accionistes de tal categoria i són patents les dificultats pràctiques". Al nostre parer, tanmateix, la legitimació passiva continua tenint-la la representació general de la cooperativa, si bé, com hem vist en epígrafs anteriors, amb aplicació d'allò previst per als supòsits en què la representació legal de l'entitat siga part actora de la impugnació, en què s'efectuarà el nomenament judicial de qui haja d'exercir la legitimació passiva (vegeu infra epígraf 2.1 del capítol quart).

813 GÓMEZ MENDOZA, M., «Juntas especiales...», op. cit., pàg. 428. 
La legitimació activa de les terceres persones membres dels col-lectius afectats presenta més complexitat. Un dels exemples més paradigmàtics és el del nomenament dels representants dels treballadors fixos no socis al consell rector, que s'analitza en l'epígraf 1.7. següent.

1.7 Acords de nomenament de consellers representants de determinats col-lectius

Ja s'ha analitzat supra (epígraf 1.2.5.) la problemàtica que poden plantejar, des de la perspectiva de la seua impugnació, els acords de nomenament de càrrecs socials en general. Tanmateix, sembla més adequat veure ara la casuística d'un tipus concret d'acords de nomenament de càrrecs socials: aquell que s'efectua no ja per l'assemblea (o l'òrgan) en la seua totalitat, sinó per determinats col-lectius als quals la llei o els estatuts reconeixen la possibilitat de tenir una representació específica, en consideració a característiques especials. $\mathrm{La}$ pertinència del seu estudi aquí es deriva de la circumstància essencial que aquests nomenaments requeriran l'actuació independent del col-lectiu afectat, ja siga mitjançant votació separada dins de la sessió de l'òrgan en el seu conjunt, ja siga mitjançant la convocatòria de junta especial.

La legislació cooperativa preveu dos tipus diferents de representació en l'òrgan d'administració: la de determinats col-lectius de socis (la LCCV, estableix, a més, una representació específica per als socis de treball) i la dels treballadors amb contracte per temps indefinit quan la cooperativa hi compte amb un nombre significatiu (article 33, $2 \mathrm{n}$ i 3r paràgrafs LCoop i article $38.4 \mathrm{LCCV}$ ).

En un primer acostament, podria pensar-se que es tracta de supòsits pròxims al de la representació proporcional en l'òrgan d'administració de la societat anònima. La similitud és donada pel reconeixement a un collectiu minoritari del dret a ser representat i a participar en l'activitat de gestió i representació de l'entitat. Tanmateix, s'observen diferències significatives entre ambdós sistemes. 
D'una banda, la legislació cooperativa no atorga una quota proporcional al dret de vot que es tinga, sinó un nombre limitat i estable de representants, siga quina siga la seua influència en les decisions de l'òrgan elector; es tracta més d'obrir una via d'integració del col-lectiu afectat que de reconèixer-li un dret proporcional.

D'altra banda, no sempre queda clar que és el col-lectiu representat mateix qui ha d'elegir, en exclusiva $i$ independentment, els seus representants: com ja hem indicat anteriorment ${ }^{814}$, la LCCV no ho especifica (article 38.4: “...els estatuts socials hauran de regular el procediment per donar una representació estable en el consell rector als socis de treball. Igualment, (...) la representació dels treballadors assalariats de la cooperativa amb contracte per temps indefinit..." $)^{815}$, i una cosa similar succeeix en la LCoop per a la representació de determinats collectius de socis (article 33, 2n paràgraf: "els estatuts podran reservar llocs de vocals o consellers del consell rector per a la seua designació entre col-lectius de socis determinats objectivament $\left.{ }^{\prime \prime}\right)^{816}$. Al nostre parer, el tenor literal de les normes esmentades permetria en aquests casos que els estatuts atribuïren l'elecció a l'assemblea en la seua totalitat.

Ara bé, si els estatuts atribueixen l'elecció directament i exclusiva al col-lectiu d'afectats, s'haurà d'aplicar a aquesta elecció allò que s'ha exposat anteriorment per a les juntes especials o votacions separades, a diferència (també ací) d'allo plantejat per una part important de la doctrina respecte de la representació

814 FAJARDO GARCÍA, I.G. i SENENT VIDAL, M. J., Texto refundido..., op. cit., p. 52.

815 Sí que explicita, tanmateix, l'article $40.3 \mathrm{LCCV}$, que la revocació podrà realitzar-se únicament pels seus representats, sempre que no s'haguera regulat un procediment específic diferent o que la revocació arribe a la totalitat del consell rector.

816 No ocorre el mateix amb la representació dels treballadors fixos a la LCoop (article 33, 3ri 4 t paràgrafs), que s'atribueix a un membre del comitè d'empresa, elegit, bé pels components mateixos del comitè, bé pel collectiu de treballadors fixos. MONTOLfo HERNÁNDEZ, José M., "Consejo rector y dirección en la nueva Ley General de Cooperativas", REVESCO, núms. 5- 57, 1988-89, pàg. 137, ja plantejava aquesta opció en el marc de la LGC, sense deixar d'assenyalar la dificultat de "coordinar l'elecció en assemblea amb la reservada als treballadors, quan molt probablement ni estiguen facultats per assistir a la sessió. Igualment suscita preocupació tot el 
proporcional en el consell d'administració ${ }^{817}$. En efecte, l'elecció de mitjançant la reunió d'un percentatge de vots soc requereix la participació possible de tots aquells que objectivament formen part de la categoria a la qual es reconeix representació, i encara que no es diga expressament en els textos legals, regirà el principi majoritari, ja que l'exigència d'unanimitat significaria la major part de les vegades la impossibilitat pràctica d'obtenir la pretesa representació ${ }^{818}$.

2.Acords, decisions i actes dels òrgans d'administració i gestió

que es refereix a revocació, a disminució del nombre de treballadors, entre altres aspectes".

817 Sobre el sistema de representació proporcional al consell d'administració de l'anònima, GIRÓN TENA, J., Derecho de sociedades anónimas, op. cit., pàg. 343, "aquestes accions agrupades no constitueixen classe, en el sentit de recollir uns drets especials de soci", per la qual cosa es considera necessària la unanimitat de tots els accionistes agrupats, sense que en siga suficient la majoria. Segueixen aquesta interpretació sobre l'exigència d'unanimitat MARTÍNEZ SANZ, Fernando, La representación proporcional de la minoría en el Consejo de administración de la sociedad anónima, Civitas, Madrid, 1992, pàg. 80; i SÁNCHEZ CALERO, F., Administradores..., pàg. 370; en contra, POLO SÁNCHEZ, E., Los administradores..., article 137, pàg. 407: "S'ha d'estimar referent a això que la votació [...] tindrà lloc per majoria, tant per seguir la regla general de l'adopció d'acords a les juntes generals [...], com per aplicació de les regles aplicables a les votacions separades o juntes especials [...] No és, doncs, requisit imprescindible la unanimitat [...] encara que la voluntarietat de l'agrupació és evident que concedeix de fet un dret de veto als seus possibles integrants, als quals no obliga res a agrupar-se sense donar-ne el consentiment previ". AlCALÁ DIAZ, M. A., La impugnación..., op. cit., pàg. 295 a: "l'elecció dels membres del consell d'administració pel sistema de representació proporcional [...] s'efectua [...] per l'agrupació d'accions que representen una porció de capital resultant de dividir el capital social pel nombre de vocals [...] a l'acord d'elecció no és d'aplicació el règim d'impugnació previst en els articles 115 i ss. de la LSA, no sols perquè no es tracta d'un acord de la junta general, sinó perquè tampoc pot qualificar-se com l'acord d'una junta especial, ja que l'elecció correspon a accionistes agrupats per a aquesta finalitat i no per accionistes titulars d'una classe especial d'accions [...] en tot cas, el fet que, llevat d'excepcions autoritzades, la doctrina haja sostingut que no es tracta de juntes especials, fet que explica que no s'hi aplique aspectes essencials de funcionament de la junta general, explica igualment que a l'agrupació d'accions se li negue el caràcter $\mathrm{d}^{\prime}$ òrgan social i no s'aplique el règim d'acords de la junta general".

${ }^{818}$ Aquesta sembla ser també la solució que s'ha de donar en els supòsits que, d'acord amb la modificació introduïda en la LCPV per la Llei 1/2000 de la Presidència del Govern Basc, les cooperatives basques opten pel sistema de representació proporcional en el consell rector que

ara se'ls reconeix a l'article 41.3 . 
Com ressenya la doctrina ${ }^{819}$, durant la vigència de la LSA de 1951 la impugnació dels acords de l'òrgan d'administració va estar absent de regulació, la qual cosa va produir un extens debat doctrinal i una fluctuant interpretació jurisprudencial sobre l'admissibilitat de l'aplicació analògica del procediment especial previst per als acords de la junta general o, en cas contrari, la necessitat de recórrer al procediment ordinari ${ }^{820}$. La compensació posterior d'aquesta llacuna normativa, primer en la LGC de 1987 i després en la LSA de 1989, com veurem, ha solucionat només en part els dubtes doctrinals i jurisprudencials.

Més enllà del que preceptua la norma, alguns autors han discutit l'oportunitat mateixa de la impugnabilitat dels acords de l'òrgan d'administració o, almenys, dels que estan directament relacionats amb la gestió empresarial, en què el tràfic mercantil exigeix agilitat $i$ seguretat ${ }^{821}$, així com la seua confrontació

819 EMBID IRUJO, J. M., «Comentario al art. 70», op. cit., pàg. 739, i «Comentario al artículo 143», en AA. DD., Comentarios a la Ley de sociedades anónimas (Coords. I. Arroyo i J. M. Embid), volum II, Tecnos, Madrid, 2001, pàg. 1526; POLO SÁNCHEZ, E., Los administradores..., op. cit., pàg. 520 i ss.; RODRfGUEZ ARTIGAS, F., i ESTEBAN VELASCO, G., «Los órganos...», op. cit., pàg. 139; SALELLES CLIMENT, J. R., El funcionamiento... op. cit., pàg. 395; VICENT CHULIA, F., en PAZ CANALEjo, N., i VICENT CHULIÅ, F., Ley general... op. cit., pàg. 853.

820 GARCía LUENGO, R., i SOTO VÁZQUEZ, R., El nuevo régimen jurídico..., op. cit., pàg. 535 i 639 , citant jurisprudència en ambdós sentits; SALELLES CLIMENT, J. R., El funcionamiento... op. cit., pàg. 395: "En la doctrina es va postular, d'una banda, la utilització del procediment especial de l'article 70 de la LSA de 1951 [GARRIGUES, J., Comentario..., II, pàg. 152]; d'un altra, la utilització de cursos processals diferents [SÁNCHEZ CALERO, F., Instituciones, pàg. 226], i, finalment, el caràcter no impugnable dels acords del Consell [BÉRGAMO, A., Sociedades anónimas, pàg. 102]. En la jurisprudència, davant el corrent que va admetre l'aplicació analògica del procediment previst per a la impugnació dels acords de la junta [SSTS 30.4.71 (RJA 2405) i 7.1.76 (RJA 23)], va acabar per imposar-se que el règim d'impugnació dels articles 67 a 70 de la LSA de 1951 només era aplicable als acords de la junta general [SSTS de 14.2.68 (RJA 1054), 17.11.72 (RJA 4567), 23.3.74 (RJA 1057), 30.3.78 (RJA 856) i 22.6.79 (RJA 2908)".

Posteriorment, SÁNCHEZ CALERO, F., en Administradores..., op. cit., pàg. 532 a 534, ja sota la vigència del TRLSA de 1989, analitza les diferents fórmules adoptades per la legislació de societats comparada, que segueixen les orientacions que ja apuntava la nostra doctrina: a) no dictar una normativa específica d'impugnació d'acords, sinó sotmetre'ls a les normes generals de la ineficàcia del negoci jurídic, b) aplicar-hi als acords del consell el règim d'impugnació dels acords de la junta general, c) promoure la no-impugnabilitat dels acords del consell, en consideració a l'interès social en una gestió àgil $\mathrm{i}$ amb garanties de seguretat jurídica davant tercers, i d) confiar la declaració de nul-litat dels acords del consell d'administració, no als òrgans judicials, sinó als òrgans mateixos de la societat, en particular a la junta general.

821 ALCALÁ DİAZ, M. A., La impugnación..., op. cit., pàg. 174 i 175; ARANGUREN URRIZA, Francisco José, "La representación de la sociedad anónima», en AA. DD., Las sociedades de capital conforme a la nueva legislación, 2a ed., Trivium, Madrid, 1990, pàg. 555; EMBID IRUJO, J. M. 
possible amb la institució de la responsabilitat dels administradors, com a instruments ambdós de control de la gestió social ${ }^{822}$.

També s'ha qüestionat la correcció del diferent impacte que produeix la impugnabilitat dels acords de l'òrgan d'administració: en les grans societats, en les quals, la major part de les decisions, les prenen cada vegada més els càrrecs tècnics, la impugnació no serà una eina eficaç de control; al contrari, en les petites entitats, on l'òrgan d'administració tendeix a prendre tota classe de decisions, la minoria podria arribar a bloquejar el funcionament empresarial ${ }^{823}$.

Davant de tot això, s'ha justificat la idoneïtat de la mesura en la conveniència de "reforçar el control de la legalitat i de l'adequació a l'interès social sobre les

"Comentario al art. 70", op. cit., pàg. 739 a 744, i «Comentario al artículo 143», pàg. 1526 i 1527; JUSTE MENCIA, J., Los derechos de minoría..., op. cit., pàg. 386 i 387; POLO SÁNCHEZ, E., Los administradores..., op. cit., pàg. 524 i 525; SALELLES CLIMENT, J. R., El funcionamiento..., op. cit., pàg. 397 i 398. SÁNCHEZ CALERO, F., Administradores... op. cit., pàg. 533 i 535 assenyala que "I'aplicació pura i simple del règim de la impugnació dels acords de la Junta general als acords dels administradors" posa de manifest "els problemes que es plantegen per l'aplicació a l'òrgan administratiu, al qual es confia la gestió i la representació de la societat, d'unes normes que estan pensades per a un òrgan deliberant, els acords del qual tenen una eficàcia principalment interna, és a dir, que afecten les relacions intersubjectives que sorgeixen dins de l'organització social". ViCent CHULIÁ, F., en PAZ CANALEjo, N. i ViCENT CHULIÁ, F., Ley general..., vol. II, pàg. 856 i 857: "Sembla que la solució no siga raonable, ja que sotmet a revisió "de mèrit" una matèria com la gestió, en què ha de donar-se un marge de llibertat al CR".

822 EmBID IRUJO, J. M., en "Comentario al art. 70», op. cit., pàg. 740 i 741; en Grupos de sociedades y accionistas minoritarios: la tutela de la minoría en situaciones de dependencia y grupo, Ministerio de Justicia, Madrid, 1987, pàg. 108 a 110; en "Notas sobre la impugnación...», op. cit., pàg. 55 i 56; i en "Impugnació de...", op. cit., pàg. 259. SÁNCHEZ CALERO, F., Administradores... op. cit., pàg. 533 i 534 assenyala que una part de la doctrina italiana entén que "en general, els actes dels administradors no són impugnables, excepte en determinats supòsits previstos expressament per la Llei [...], ja que si els actes dels administradors són contraris a la Llei o als estatuts, en sorgirà una responsabilitat quan es cause un dany, o bé existirà una justa causa per a la revocació dels administradors per la Junta general".

Contràriament, ViCENT CHULIÅ, F., en PAZ CANALEJO, N. i ViCENT CHULIÁ, F., Ley general..., vol. II, pàg. 856 i 857, opina que limitar el control de l'òrgan d'administració a l'acció de responsabilitat probablement no seria suficient per protegir a la Cooperativa. I, com assenyala POLO SÁNCHEZ, E., Los administradores..., op. cit., pàg. 528, seria paradoxal que s'haguera d'esperar a la realització efectiva del dany per exercitar l'acció de responsabilitat i reparar un mal que va poder-se evitar mitjançant l'oportuna impugnació i l'eventual suspensió judicial de l'acord impugnat".

${ }^{823}$ EMBID IRUJO, J. M., "Comentario al art. 70", op. cit., pàg. 740 i 741; POLO SÁNCHEZ, E., Los administradores..., op. cit., pàg. 525; SALELLES CLIMENT, J. R., El funcionamiento..., op. cit., pàg. 397
i 398. 
activitats de l'òrgan de gestió i representació" al si de l'actual societat anònima acumulen els òrgans col-lectius $\mathrm{d}^{\prime}$ administració ${ }^{\prime 825}$. Tanmateix, això també ha estat qüestionat en tipus socials com la SRL, o la cooperativa, on la junta o assemblea general, excepte si hi ha una regulació estatutària diferent, està àmpliament facultada per exercir un control directe de l'activitat de gestió, i pot "donar instruccions a l'òrgan d'administració o sotmetre a autorització l'adopció per l'esmentat òrgan de decisions o acords sobre determinats assumptes de gestió" (articles 44.2 LSRLi

824 JUSTE MENCÍA, J., Los derechos de minoría...,. op. cit., pàg. 386. EMBID IRUJO, J. M., "Comentario al art. 70», op. cit., pàg. 740: "En realitat, darrere del reconeixement de la impugnació d'acords del Consell sembla bategar una (no explícita) voluntat del legislador d'establir un mecanisme efectiu de control sobre la gestió de la societat, davant de la impossibilitat d'aconseguir aquesta finalitat mitjançant la impugnació d'acords de la Junta, que s'orienta, com és sabut, a la defensa de l'interès social i a la protecció de la minoria. Suposada la dissociació entre propietat i gestió, típica de la societat anònima moderna, la impugnació que ens ocupa s'orientaria, així, a disposar d'un instrument de fiscalització sobre el nucli bàsic del poder al si de la societat".

825 URÍA, R., Derecho Mercantil, op. cit., pàg. 340. En la mateixa línia, SALELLES CLIMENT, J. R, El funcionamiento... op. cit., pàg. 395.

En relació amb la necessitat de control de la gestió, conforma un ampli sector de debat i investigació el relacionat amb els Principles of Corporate Governance que es desenvolupa en les últimes dècades, primer als països anglosaxons, i després també a l'Europa continental. En la nostra doctrina constitueix obra bàsica d'anàlisi AA. DD., El gobierno de las sociedades cotizadas, (coord. G. Esteban Velasco), Marcial Pons, Barcelona, 1999. El sector cooperatiu no ha romàs al marge del debat, si bé s'hi planteja amb trets distintius: vegeu VICENT CHULIÁ, F., «Mercado, principios cooperativos...», op. cit.; i RIGIDO, A., "Problemi e proposte di cooperative governance», en Riv. coop., núm. 2, 1999, pàg. 5 a 9; així mateix, l'apartat I del Preàmbul de la LCCM indica, entre els objectius de la norma, "incorporar les recomanacions dels informes internacionals sobre l'anomenat "govern de les societats" fins on ho permet el caràcter autoorganicista de la Cooperativa".

Tanmateix, com assenyala ALCALÁ DIAZ, M. A., La impugnación..., op. cit., pàg. 170, en les propostes relatives a la Corporate Governance "la impugnació d'acords del consell d'administració no s'ha valorat com un instrument eficaç de protecció de la societat i els socis davant actuacions dels administradors contràries a Dret o lesives a l'interès social". Segons l'autora, la raó rauria en el fet que la impugnació d'acords del consell es configura, bàsicament, com un instrument intern de les relacions administrador-consell d'administració, per la qual cosa només en les societats petites o de caràcter familiar podria utilitzar-se com a instrument de protecció. (Una síntesi de les principals propostes de la Corporate Governance en dret comparat pot veure's en ALCALÁ DíAZ, M. A., La impugnación..., op. cit., pàg. 198 i 199, nota 189).

D'altra banda, a les cooperatives, com indica RIGIDO, A., op. cit., pàg. 9, "els instruments de control al servei del soci de la cooperativa són ja avui múltiples i superiors als previstos per a altres tipologies societàries", i hi esmenta el "collegio sindacale» (òrgan, com veurem, en certa mesura equivalent al comitè/comissió de recursos espanyol), així com alguns dels aspectes que integra el dret d'informació del soci, però tampoc esmenta la impugnació dels acords de l'òrgan d'administració com mitjà de control intern. 
$21.1,2 n$ paràgraf $\left.L \operatorname{Coop}^{826}\right)$; per això $s^{\prime}$ ha plantejat que en aquests tipus socials no es requeriria necessàriament el reconeixement legal de la impugnació dels acords del consell ${ }^{827}$.

Això no obstant i sense perjudici de les facultats de control de l'assemblea (prèviament, mitjançant la instrucció o l'autorització, o a posteriori, mitjançant l'acció de responsabilitat), no ha d'oblidar-se que l'òrgan d'administració no és un mer mandatari d'aquesta, sinó un òrgan social amb competència i responsabilitat pròpies davant de la societat i davant de tercers ${ }^{828}$, l'actuació de facultats del qual ha de poder ser revisada per tots aquells que, amb interès legitim, puguen veure's afectats.

Però les crítiques també arriben a aspectes de tècnica jurídica. Així, s'ha posat en relleu la falta de definició de matèries tan essencials com els conceptes d'acords nuls i anul-lables (i, per tant, de les causes d'impugnació) o, si no n'hi ha, la remissió expressa a allò preceptuat per als acords de la junta general ${ }^{829}$; la unificació del termini de caducitat de la impugnació, a la qual s'afegeix la falta

826 La LCCV segueix una orientació més tradicional en matèria de repartiment de competències. Encara que reconeix (article 27.29) que "l'assemblea general podrà debatre i adoptar acords sobre qualsevol altre assumpte d'interès per a la cooperativa que aquesta llei no considere competència exclusiva d'un altre òrgan social", atribueix al consell rector el "govern, la representació i la gestió de la cooperativa amb caràcter exclusiu i excloent", si bé ha d'establir las directrius generals de la gestió de la cooperativa, de conformitat amb la política fixada per l'assemblea general" (article 37.1).

827 EMBID, en «Comentario al art. 70», op. cit., pàg. 740: "La ja esmentada facultat de supervisió que la llei atribueix a la Junta sobre l'òrgan administratiu seria, en aparença, garantia suficient de control preventiu sobre el comportament d'aquest últim, i quedarien les accions de responsabilitat com mecanisme a posteriori."

${ }^{828}$ VICENT CHULIÁ, F., «La asamblea...», op. cit., pàg. 160.

${ }^{829}$ Polo SÁNCHEZ, E., Los administradores..., op. cit., pàg. 521: "L'única remissió explícita a la impugnació dels acords socials de la junta general és la continguda en el paràgraf 2, relativa a la tramitació del procediment d'impugnació". El mateix succeeix en la legislació cooperativa. RODRíguez ARTIGAS, F., i ESTEBAN VELASCO, G., "Los órganos... ", op. cit., pàg. 140: "no s'estableix el criteri de distinció i no es facilita l'aplicació analògica del que s'ha disposat per als acords de la Junta general, ja que, quan en el paràgraf 2 es remet a aquestes normes, en principi sembla que només ho fa a efectes de tramitació i no substantius 
de menció als acords contraris a l'ordre públic ${ }^{830}$; la legitimació indiscriminada a tots els administradors amb independència de la seua posició a l'adopció de l'acord $^{831}$ i, al contrari, la seua restricció per als socis no administradors que veuen convertit en un dret de minoria el que per als acords de l'assemblea és un dret individual, en necessitar assolir un percentatge determinat per poder impugnar $^{832}$. I encara que les successives reformes en la legislació cooperativa han pal-liat en part algunes d'aquestes deficiències, la major part d'aquestes encara són plenament traslladables a l'àmbit cooperatiu.

Una altra qüestió criticada en la legislació de societats de capital és la de la limitació de la impugnació als acords dels òrgans col-legiats d'administració, la transposició del qual o no a l'àmbit cooperatiu tractarem d'analitzar. En efecte, l'article 143.1 LSA es refereix a la impugnació dels "acords nuls i anul.lables del consell d'administració o de qualsevol altre òrgan col-legiat d'administració". Una interpretació estricta d'aquesta norma fa no impugnables les decisions o els acords dels òrgans d'administració unipersonals o pluripersonals no col-legiats ${ }^{833}$, encara que alguns autors han recordat que la possibilitat actual de constituir societats de capital unipersonals obri la possibilitat d'impugnar els "acords" de la junta general, sense que siga necessària la col-legiació de l'òrgan ${ }^{834}$.

${ }^{830}$ Vegeu infra, en l'epígraf 2.1. següent, i en l'epígraf 2.1.2 del capítol segon.

831 La LCoop (article 37.2) ha modificat, tanmateix, en aquest aspecte el criteri anterior de la LGC, i ha passat a l'extrem contrari; com veurem, dels assistents, només els que hi hagueren votat en contra $\mathrm{i}$ ho hagueren fet constar expressament estaran legitimats, i quedaran sense legitimació, per exemple, els qui s'hi hagueren abstingut o hagueren emès vot nul o en blanc.

832 El que AlCALÁ DÍAZ, M. A., La impugnación..., op. cit., pàg. 176, denomina "legitimació taxada" es justificaria, segons aquesta autora, en el reforçament de la seguretat jurídica $i$ de la protecció del tràfic.

833 EMBID IRUJO, J. M., «Notas sobre la impugnación...», op. cit., pàg. 56, i «Comentario al artículo 143", pàg. 1527; JUSTE MENCfA, J., Los derechos de minoría..., op. cit., pàg. 393 i 394; POLO SÁNCHEZ, E., Los administradores, cit., pàg. 523 i 527; SÁNCHEZ CALERO, F., Administradores..., op. cit., pàg. 535 .

834 Vicent Chuliá, F., en Paz CANAlejo, N., i Vicent ChUlí, F., ley general..., op. cit., pàg. 857; DíAZ DE LEZCANO SEVILlANO, N., Los acuerdos del consejo..., op. cit., pàg. 45. 
En l'àmbit cooperatiu la qüestió es complica amb alguns trets propis. S'ha de recordar que la LGC de 1987 regulava expressament la direcció de la cooperativa i reconeixia la impugnabilitat dels seus "actes i decisions" que, a aquest efecte, es consideraven com a acords del consell rector; s'obria amb això la possibilitat de plantejar la impugnació d'òrgans unipersonals o pluripersonals no col-legiats. La LCCV, en canvi, si bé introdueix la possibilitat d'aquestes estructures no col-legiades per a l'òrgan d'administració, ni es refereix expressament a la possibilitat d'impugnar les seues decisions, ni a la de les de la direcció. Finalment, la LCoop suprimeix tota regulació de la direcció, excepció feta de la seua qualificació com a "apoderat principal" de la cooperativa, la qual cosa fa dubtar encara més sobre el caràcter mateix d'òrgan de la figura; tanmateix, incorpora la possibilitat de la forma unipersonal per a l'òrgan d'administració, sense manifestar-se expressament sobre la impugnabilitat de les seues decisions.

Però en la legislació cooperativa vigent no hi ha una limitació expressa de la impugnació als acords dels òrgans col-legiats d'administració (en la línia del que s'estableix a l'article 143.1): regula únicament la impugnació dels acords del consell rector, però preveu la possible existència alternativa d'òrgans unipersonals (articles 32.1, 2n paràgraf LCoop i $37.2 \mathrm{LCCV}$ ) o pluripersonals no col-legiats (37.2 LCCV) als quals, fora d'això, la LCoop els atribueix "les competències i funcions previstes en aquesta Llei per al consell rector", i la LCCV els aplica "el règim previst per al consell rector".

\subsection{Acords del consell rector}

L'exposició de motius de la LGC (VII, 8è paràgraf) ja indicava el que també ha estat assenyalat per molts autors: la innovació important que la Llei introduïa en matèria d'impugnació d'acords socials, en regular la possibilitat de fer-ho en 
relació amb els acords del consell rector i de la dirección ${ }^{835}$. Tanmateix, la innovació no era absoluta, ja que algunes de les anteriors lleis autonòmiques cooperatives incloïen la impugnació dels acords del consell ${ }^{836}$; d'altra banda, ni aquelles primeres normes ni les vigents en l'actualitat ${ }^{837}$ resolen de manera totalment satisfactòria els problemes detectats en la regulació paral-lela de les societats de capital.

Si ens centrem en les dues normes objecte principal de la nostra anàlisi, la LCoop i la LCCV, pel que fa a la regulació de la impugnació dels acords de l'òrgan d'administració, s'observen diferències notables entre el text legal estatal i l'autonòmic valencià; aquestes divergències denoten diferents models, si bé amb influències comunes.

Pel que fa a la LCCV, s'ha optat per copiar de manera literal el text adoptat al seu dia per la LSA, amb una sola excepció: mentre en les societats anònimes

835

un recorregut sobre l'evolució històrica acuerdos del consejo..., op. cit., pàg. 44 (aquest autor fa reconeixement legal per als acords de l'òrgan d'administració dels acords socials $\mathrm{i}$ del seu $\mathrm{M}$., en «Comentario al art. 70», op. cit., pàg. $739 \mathrm{i} 740 \mathrm{i}$ en «Impugnación 57 ); EMBID IRUJO, J. JUSTE MENCfA, J., Los derechos de minoría..., op. cit., pàg. 386 i 387; VICENT CH. op. cit, pàg. 259, CANALEJO, N., i VICENT CHULIÁ, F., Ley general... op. cit., pàg. 853: "La LGC de 1974 només va regular la "revisió" dels acords de AG en l'article 27, ja que malgrat el fet que es refereix als "acords socials" sistemàticament constitueix l'últim precepte dedicat a l'AG i en la regulació del CR no figura cap regulació ni remissió expressa a aquell article. El Reglament de 1978, lògicament, no va cobrir aquesta llacuna"

836 MARÍN LOPEZ, J. J., «Novedades...», op. cit., pàg. 1119, adverteix que en el moment de promulgació de la LGC la impugnació dels acords del consell ja estava contemplada per tres de les quatre lleis autonòmiques llavors en vigor (País Basc, Andalusia i Comunitat Valenciana), $\mathrm{i}$ que en l'anterior LGC de 1974 hi havia la possibilitat d'impugnació "intracooperativa" per a davant de l'assemblea, l'acord de la qual ratificador del Consell sí que era impugnable, fet que produïa una sort d'impugnació judicial "indirecta".

${ }^{837}$ En l'actualitat, l'única Llei de cooperatives que continua sense regular de manera expressa la impugnabilitat dels acords del consell rector és la de Catalunya, en la nova redacció adoptada mitjançant Decret Legislatiu 11/1992, de 10.2. Però si bé l'article 38, genèricament titulat "Impugnació dels acords socials", es refereix, exclusivament, als acords de l'assemblea general, altres articles reconeixen explícitament la impugnabilitat dels acords del consell: article 16.2 [acord de denegació de l'admissió], article 19.3,d) [acords sancionadors del consell], article 20.6 [acord d'expulsió]. D'això ha de deduir-se que, en general, el règim impugnatori de l'assemblea és d'aplicació als acords del consell, si bé determinats acords denegatoris d'informació pel consell als socis es remeten al procediment de jurisdicció voluntària de l'article 2166 de l'anterior LEC. 
només són impugnables els acords del consell d'administració i els "de qualsevol altre òrgan col-legiat", aquesta expressió s'ha suprimit del text cooperatiu valencia ${ }^{838}$. Això significa, bàsicament (deixant per a un comentari posterior aquesta supressió), que la configuració de la impugnació dels acords de l'òrgan d'administració capitalista és essencialment aplicable a la institució prevista en la LCCV.

La legislació estatal, per la seua part, presenta diferències significatives amb el text de la LSA, encara que s'ha produït una evolució radical en l'última regulació feta per la LCoop de la impugnació dels acords del consell rector. En efecte, la LGC, en introduir la norma, ho va fer amb un grau de detall més alt i amb solucions parcialment diferents a les que després es van adoptar per a les societats de capital. La diferència fonamental respecte a la norma equivalent de la LSA era, precisament, l'opció per una regulació pròpia i detallada, sense remissió a la impugnació d'acords de l'assemblea (article 66.1 LGC: “Podran ser impugnats segons les normes $\mathrm{i}$ dins dels terminis establerts en aquest article els acords del consell rector...").

Consegüentment, s'especificava què s'havia d'entendre per acords nuls i anul-lables del consell (repetint gairebé literalment la definició donada per a l'assemblea $\left.{ }^{839}\right)$, i els atribueix diferent legitimació activa: per als anul-lables, els assistents que hagueren fet constar en acta el seu vot en contra, els absents i els illegítimament privats de vot, els interventors i el $5 \%$ dels socis; per als nuls, tots els socis, inclosos els membres del consell que no hi hagueren votat en contra. Entre les similituds amb la LSA, s'establia un termini de caducitat únic per a acords nuls i anul-lables bastant més breu que els de l'assemblea general. I entre els aspectes singulars de la norma, com ja s'ha esmentat, s'equiparaven els

838 Posteriorment, l'article 70 de la LSL també ha reproduït literalment l'article 143 LSA, llevat de la menció a la impugnació de qualsevol altre òrgan col-legiat, que també ha estat suprimida.

${ }^{839}$ ViCent ChULIÁ, F., en PAZ CANALEJO, N. i ViCENT CHULIÁ, F., Ley general..., vol. II, pàg. 856, assenyala tanmateix una omissió important de la norma que es produiia respecte a l'equivalent de l'assemblea general: "en la tercera causa legal d'impugnació [...][la d'acords que lesionen els 
actes i les decisions de la direcció amb els acords del consell rector, als efectes de la impugnació. Com que no es preveien altres estructures de l'òrgan d'administració a banda de la pluripersonal col-legiada, no es feia referència a la possibilitat de la impugnació.

La LCoop ha canviat notablement l'orientació, i s'ha aproximat al model de la $\mathrm{LSA}^{840}$, si bé no tant com la LCCV. S'obvia ara la definició d'acords nuls i anul-lables, i per tant de les causes d'impugnació, sense una remissió expressa a l'efectuada per a l'assemblea general; es manté tanmateix una legitimació diferent, encara que amb alguns canvis respecte a la que estableix la LGC. Respecte als terminis de caducitat incorre el legislador estatal en un greu error: en l'apartat 1 de l'article 37 s'estableixen els de dos mesos o un mes, segons que es tracte $d^{\prime}$ acords nuls o anul-lables; en l'apartat 3, tanmateix, s'esmenta un únic termini d'un mes encara que amb diferents còmputs, segons que l'impugnant siga administrador o no, en la línia del que preceptua l'article 143.1 LSA. En els aspectes procedimentals sí que efectua l'article 37 LCoop remissió a allò que preveu per a l'assemblea.

En tot cas, la diversitat normativa ressenyada i el debat doctrinal mateix (encara obert), en matèria d'impugnació d'acords del consell d'administració/consell rector, aconsellen $\mathrm{d}^{\prime}$ incidir en alguns dels aspectes assenyalats.

En primer lloc, és necessari concretar que l'objecte de la impugnació, legalment especificat, són, precisament, els acords del consell, les decisions adoptades en virtut de la col-legialitat de l'òrgan, això és, "la transformació d'una pluralitat de declaracions individuals en una nova voluntat col-lectiva" ${ }^{\prime 841}$. Una altra qüestió, que serà analitzada més endavant, és la possibilitat d'impugnar els actes $i$ les decisions $d^{\prime}$ òrgans no collegiats, entre els quals es trobaran aquells en

interessos de la cooperativa, l l'article 66 suprimeix els "tercers". No es comprèn bé per què".

840 EMBID IRUJO, J. M., «Comentario al artículo 143», op. cit., pàg. 1529.

841 DíaZ de LeZCANO SEviLlano, N., Los acuerdos del consejo..., op. cit., pàg. 221 i 222. 
què puga delegar el consell. Quan s'opte per la forma col-legiada de l'òrgan d'administració (o quan, en l'àmbit cooperatiu, no hi haja una altra opció possible), la seua declaració de voluntat sorgeix de l'acord resultant de l'aplicació del principi majoritari, segons les declaracions de voluntat individuals manifestades mitjançant els vots.

Així doncs, allò impugnable és l'acord, amb independència que l'origen de la seua impugnabilitat puga situar-se en la invalidesa dels vots ${ }^{842}$. Per tant, queden exclosos d'impugnació els actes que no hagen estat formats mitjançant el procediment, legal i estatutari, de formació de la voluntat de l'òrgan ${ }^{843}$ : actes de membres aillats de $1^{\prime}$ òrgan ${ }^{844}$, del seu president, actes d'execució de l'acord o decisió, etc.

Pel que fa als conceptes d'acord nul i acord anul-lable, la postura majoritària de la doctrina per a les societats de capital és que, malgrat l'absència d'una remissió legal expressa, ha d'entendre's que les causes de nul-litat $i$ anul-labilitat dels acords de l'òrgan d'administració són les mateixes que les especificades per a la junta general, això és, que els acords contraris a la Llei són nuls i els que s'oposen als estatuts o lesionen l'interès social en benefici extrasocial són

842 Això no obstant, SCORDINO, F., La società cooperativa, op. cit., pàg. 342, es refereix a la possibilitat d'impugnar l'acte resultant de "les iniciatives individuals no autoritzades, atribuibles a un administrador", en tant que representen "aspectes anòmals de la gestió"; planteja amb això la possibilitat d'impugnar l'acte invàlid, per la sola raó que ultrapassa les facultats de l'administrador, amb independència de la seua responsabilitat eventual.

843 SÁNCHEZ CALERO, F., Administradores..., p. 538.

844 DiAZ DE LeZCANO SEVILLANO, N., Los acuerdos del consejo..., op. cit., pàg. 222 a 224, citant a GALGANO, F., El negocio jurídico, op. cit., pàg. 238 i ss., i GIRÓN TENA, Derecho de sociedades, op. cit, pàg. 309: "cal distingir entre les persones que formen l'òrgan i l'òrgan en si mateix. L'acord sorgeix com una declaració de voluntat de l'òrgan, ulterior als vots que concorren per a la seua formació. Hi ha, per tant, una voluntat pròpia de la col-lectivitat davant la individual de cada membre, encara que originàriament procedisca d'aquests. [...]. El conseller exerceix les seues facultats al si del Consell d'Administració; fora seu, els consellers no tenen "facultats pròpies de l'òrgan, encara que en casos particulars se li reconeguen possibilitats d'actuació fora de l'àmbit orgànic; tal és el cas, precisament, de la legitimació activa en raó del càrrec. Per a un desenvolupament de les facultats de gestió atribuïdes individualment al membre del consell d'administració, vegeu SALELLES ClimENT, J. R., El funcionamiento... op. cit., pàg. 86 i Capítol Tercer, pàg. 258 i ss. 
anul-lables ${ }^{845}$, si be caldrà tenir en compte la naturalesa mateixa dels acords de l'administració social i les seues normes específiques ${ }^{846}$.

La justificació d'aquesta aplicació analògica cal situar-la en l'excessiva parquedat de l'article 143 LSA, que demanda la seua complementació amb altres normes en els aspectes no regulats, aspectes que no es limiten a la matèria processal. I davant l'alternativa d'aplicar el règim general de nul-litat i anul-labilitat dels negocis jurídics previst en el Codi civil, el principi d'especialitat fa més raonable i segura l'aplicació analògica del règim d'impugnació dels acords de la junta general.

Si traslladem l'argumentació a l'àmbit cooperatiu, ja que en aquest aspecte tant la LCoop com la LCCV obvien la definició del que s'ha d'entendre per acords nuls i anul-lables, s'haurà d'acudir als articles 31.1 i 31.2 LCoop i 36.1 i 36.2 LCCV per determinar que els acords nuls de l'òrgan d'administració són els acords contraris a la Llei, i que els acords anul.lables de l'esmentat òrgan són els que s'oposen als estatuts socials o lesionen, en benefici de socis o tercers, els interessos de la cooperativa.

845 EMBID IRUJO, J. M., "Comentario al artículo 143», op. cit., pàg. 1528; POLO SÁNCHEZ, E., Los administradores..., op. cit., pàg. 529 i 530; RODRíGUEZ ARTIGAS, F., i ESTEBAN VELASCO, G., "Los órganos..., op. cit., pàg. 140; SÁNCHEZ CALERO, F., Administradores..., op. cit., pàg. 535. En contra, ÁvILA NAVARRO, P., La sociedad..,. op. cit., pàg. 550, que estima únicament impugnables els acords del consell d'administració que patisquen defectes formals en la seua adopció. ja que els acords $\mathrm{i}$ les decisions dels òrgans d'administració no col-legiats amb un contingut contrari a la llei o als estatuts o lesiu de l'interès social no són impugnables, "no es comprèn per què han de ser-ho els acords que el consell puga adoptar amb un contingut idèntic".

846 EMBID IRUJO, J. M., "Comentario al art. 70», op. cit., pàg. 742 i 743; JUSTE MENCtA, J., Los derechos de minoría..., op. cit., pàg. 395; SÁNCHEZ CALERO, F., Administradores..., op. cit., pàg. 535. ALCALÁ DÍAZ, M. A., La impugnación..., op. cit., pàg. 212: "si no s'admet la remissió [...] haurien d'aplicar-se les causes de nul-litat i d'anul-labilitat del règim de nul-litat dels actes i negocis jurídics previst en el Codi civil, amb la qual cosa tornaria a manifestar-se la incertesa ja descrita que havia imperat en la doctrina i la jurisprudència anteriorment a l'entrada en vigor de la Llei de 1989 i que el legislador ha volgut evitar amb la previsió legal d'un règim específic d'impugnació d'acords del consell d'administració". Això no obstant, l'autora ressalta que la diferent configuració del règim previst en l'article 143 LSA respecte del que s'estableix en els articles 115 i ss. LSA dóna lloc a un tractament diferent dels acords nuls $\mathrm{i}$ anul-lables: "d'una banda, es preveu un únic règim d'impugnació per als acords nuls $i$ anul-lables $i$, d'un altra, es planteja el dubte sobre el tractament dels acords nuls per contravenció de l'ordre públic". 
Una altra qüestió rellevant és la unificació del termini d'impugnació per a ambdós tipus d'ineficàcia ${ }^{847}$ que incorpora la LCCV. La justificació d'aquesta unificació $\mathrm{i}$ de la major brevetat del termini s'ha situat en la necessitat de més estabilitat $\mathrm{i}$ certesa en els acords de l'òrgan d'administració i gestió, com a garantia del tràfic empresarial ${ }^{848}$. Per la seua part, com ja s'ha fet notar, la LCoop incorre en un greu error ${ }^{849}$ en aquesta matèria: en l'apartat 1 de l'article 37 s'estableixen els terminis de dos mesos o d'un mes, segons si s'han d'impugnar acords nuls o anul-lables; en l'apartat 3 , tanmateix, s'esmenta un únic termini d'un mes, encara que amb diferents còmputs, segons si l'impugnant és administrador o no ${ }^{850}$. Considerem que, probablement, la voluntat legislativa haja estat diferenciar els terminis d'impugnació, en la línia del que preceptua l'apartat 1 ; i que a l'hora d'establir el moment d'inici del còmput, en l'apartat 3, és quan s'ha oblidat que s'havia optat per la diferenciació. Per això, a falta d'una necessària (i urgent) rectificació expressa, s'haurien "de llegir" l'article 37 LCoop en el sentit d'establir terminis diferents d'impugnació per a acords nuls i anul-lables, terminis el còmput dels quals serà diferent segons si els impugnants són consellers o no ${ }^{851}$.

847 Polo SÁNCHEZ, E., Los administradores..., op. cit., pàg. 522 i 523; SÁNCHEZ CALERO, F., Administradores..., op. cit., pàg. 535. JUSTE MENCfA, J., Los derechos de minoría..., op. cit., pàg. 395, planteja una interpretació possible de l'omissió com a renúncia a la definició d'acords nuls i anul-lables en seu d'acords de l'òrgan administratiu; la diferenciació esdevindria intrascendent, ja que es donaria una unificació del procediment d'impugnació. Tanmateix, en l'àmbit cooperatiu la qüestió no és irrellevant, almenys respecte a la llei cooperativa estatal, ja que, com veurem, s'hi estableixen diferents legitimacions i diferents terminis d'impugnació.

848 EMBID IRUJO, J. M., «Comentario al artículo 143», op. cit., pàg. 1533; SALELLES CliMENT, J. R., El funcionamiento... op. cit., pàg. 395 i 400.

${ }^{849}$ Error que el legislador estatal no sembla haver advertit quan ja s'han complert dos anys des de la promulgació de la LCoop que, d'altra banda, sí que ha estat objecte de modificació en altres matèries. Així, l'article 54 de la Llei 55/1999, de mesures fiscals, administratives i de l'ordre social, ha modificat l'article 104 de la LCoop, relatiu a la normativa aplicable a les cooperatives de crèdit.

${ }^{850}$ MORILlas Jarillo, M. J., i Feliú REY, M. I., Curso de cooperativas, op. cit., pàg. 316 i 317: "Resulta incomprensible que la confusió tinga lloc en un mateix article que, d'altra banda, és de dimensions escasses".

${ }^{851}$ MoRILlas Jarillo, M. J. i Feliú REY, M. I., Curso de cooperativas, op. cit., pàg. 316 i 317. 
També s'ha analitzat supra (vegeu l'epígraf 2.1.2. del capítol segon) l'absència d'una referència legal explícita a la caducitat dels acords contraris a l'ordre públic adoptats per l'òrgan d'administració. Ja hem dit que un sector de la doctrina fa una interpretació literal de l'omissió normativa, i els nega la distinció entre acords nuls en general i acords nuls contraris a l'ordre públic, basant-se en una major necessitat de seguretat jurídica en els acords d'aquest $\operatorname{òrgan}^{852}$. Altres autors, en canvi, consideren que la inexistència de mencí expressa no permet de concloure la caducitat dels acords contraris a l'ordre públic; es considera que aquesta referència a la no-caducitat no seria necessària, bé perquè s'atribueix el caràcter de principis generals del dret ${ }^{253}$ als elements integrants del concepte d'ordre públic, bé perquè s'interpreta que la impugnació dels acords nuls per infracció de l'ordre públic s'ha de realitzar mitjançant l'aplicació del règim general de nul-litat dels actes i negocis jurídics, en virtut del qual no s'estableix termini per a l'exercici de les accions $i$ hi està legitimada qualsevol persona titular d'un interès legítim ${ }^{854}$.

Per la nostra part, subscrivim la tesi que manté que el mateix raonament que porta a l'aplicació analògica dels conceptes d'acord nul i anul-lable de la junta/assemblea general a l'òrgan d'administració serveix per estendre aquesta interpretació al concepte d'acord contrari a l'ordre públic ${ }^{855}$. Si com hem vist, el

852 DÍAZ DE LEZCANO SEVILLANO, N., Los acuerdos del consejo..., op. cit., pàg. 253; RODRfGUez ARTIGAS, F., i ESTEBAN VELASCO, G., "Los órganos..., op. cit., pàg. 140: "també se sotmeten al mateix termini de caducitat els contraris a l'ordre públic, el qual condueix a resultats absurds innegables"; SÁNCHEZ CALERO, F., Administradores..., op. cit., pàg. 540.

POLO SÁNCHEZ, E., Los administradores..., op. cit., pàg. 523 i 535: "la unificació del termini de caducitat per als acords nuls i anul·lables sembla excloure, també sense raó aparent que ho justifique, l'excepció de no-caducitat que es formula respecte dels acords nuls de les juntes que per le seua causa o contingut resultaren contraris a l'ordre públic", encara que acaba interpretant que "estem en presència de la mateixa remissió implícita que fa aplicable als acords del consell els conceptes substantius" de la junta, tals com la distinció entre acords nuls i anul-lables.

853 Juste Mencía, J., Los derechos de minoría..., op. cit., pàg. 403; POLO SÁNCHEZ, E., Los administradores..., op. cit., pàg. 535; SÁNCHEZ CALERO, F., Instituciones..., op. cit., tom I, pàg. 350; URIA,R., MENÉNDEZ, A., i MUÑOZ, J. M., La junta ..., pag. 324

854 AlCALÁ DfAZ, M. A., La impugnación..., op. cit., pàg. 221.

855 AlCAlÁ DíAZ, M. A., La impugnación..., op. cit., pàg. 214; POLO SÁNCHEZ, E., Los 
legislador no ha pogut sostraure's a la impossibilitat d'esmena dels acords de la junta/assemblea contraris a l'ordre públic, no sembla la seguretat del tràfic mercantil un argument suficient per permetre que els acords de l'òrgan d'administració puguen vulnerar "principis essencials de l'ordenació que no poden ser desconeguts de cap manera".

També han estat objecte d'atenció per part de la doctrina les diferències en la legitimació per a la impugnació (que s'analitzen en detall infra: vegeu el capítol quart, l'epígraf 1.2), tant pel que fa a la prevista per als acords de l'assemblea general com entre els diferents models adoptats per la LCoop i la LCCV per als acords de l'òrgan d'administració. Recordem que en l'assemblea general s'estableix una distinció clara: davant dels acords nuls estan legitimats tots els socis i els tercers amb interès legítim, però davant dels acords anul-lables es restringeix la legitimació als socis que s'hi hagueren oposat o no hagueren participat en la votació (per absència o per privació il-legítima del vot); en ambdós casos, també compten amb legitimació tots els membres de l'òrgan d'administració i els de l'òrgan de control (la intervenció, en la LCoop; la comissió de control de la gestió, en la LCCV), siguen o no socis i siga quina siga la seua posició en la votació ${ }^{856}$.

En canvi, per a la impugnació dels acords de l'òrgan d'administració, la LCCV, seguint el model de les societats de capital, estableix un únic règim de legitimació davant d'acords nuls i anul-lables: tots els administradors podran impugnar-los, mentre que els socis no administradors necessitaran reunir un $5 \%$ del capital social per poder exercir la impugnació. Contràriament, la LCoop distingeix entre acords nuls $\mathrm{i}$ anul-lables: per a la impugnació dels primers estan legitimats "tots els socis, fins $\mathrm{i}$ tot els membres del consell rector que hagueren

administradores..., op. cit., pàg. 535.

${ }^{856}$ Aquest és, fora d'això, essencialment, el mateix patró que l'establert en l'article 117 LSA per a la legitimació davant els acords de la junta general (amb l'excepció de la inexistència en les anònimes d'òrgan de control intern), en què es legitima tots els administradors tant per a la impugnació d'acords nuls com per a la dels anul-lables, amb independència de quina haguera estat, cas de ser socis, la seua posició en la votació. 
votat a favor de l'acord i els que s'hagueren abstingut"; davant els acords anul-lables sols estaran legitimats "els assistents a la reunió" que hagueren fet constar en acta el seu vot contrari, els privats il-legítimament de vot, els absents, els interventors i el 5\% dels socis. Cap d'ambdues normes (ni la LCCV ni la LCoop), seguint el model capitalista, considera convenient legitimar tercers davant els acords nuls; això no obstant, els seus textos legals permeten considerar legitimats els membres no socis de l'òrgan d'administració i els de la intervenció a la LCoop.

Amb independència d'una anàlisi posterior més detallada, cal apuntar els trets d'una crítica severa a aquestes normes. D'una banda, la unificació del règim de legitimació que la LCCV «hereta» de les societats capitalistes genera algunes injustícies manifestes: mentre que els administradors podran impugnar fins $i$ tot acords anul·lables que hagen ajudat a adoptar ${ }^{857}$, els socis no administradors, a la dificultat d'accedir a informació suficient en el breu termini de caducitat ${ }^{858}$, veuen afegida la de reunir un percentatge determinat que, a més, és respecte del capital social.

En relació amb aquesta conversió en dret de minoria, en l'àmbit de les societats de capital s'ha justificat la fixació d'un percentatge mínim de socis per a l'exercici de la impugnació dels acords de l'òrgan d'administració en la necessitat d'evitar possibles comportaments abusius dels socis minoritaris 0 , almenys, el "control exorbitant sobre el funcionament de l'òrgan administratiu que sembla necessitat d'un cert marge de flexibilitat ${ }^{\prime \prime 55}$. Tanmateix aquests arguments poden ser qüestionats, especialment quan es tracte de la impugnació $d^{\prime}$ acords nuls $i$, molt especialment, quan siguen acords contraris a l'ordre

857 POLO SÁNCHEZ, E., Los administradores..., cit. pàg. 538 i 539.

858 EMBID IRUJO, J. M., «Comentario al artículo 143», op. cit., pàg. 1534.

859 EMBID IRUJO, J. M., «Comentario al art. 70", op. cit., pàg. 740 i 741, i «Comentario al artículo 143», op. cit., pàg. 1527; JUSTE MENCíA, J., Los derechos de minoría..., op. cit., pàg. 386 i 387 , que demanda al legislador, "almenys, més precisió tècnica en la delimitació dels supòsits"; SALELLES CLIMENT, J. R., El funcionamiento..., op. cit., pàg. 27 i ss. 
públic ${ }^{800}$, la remoció dels quals hauria d'estar a l'abast no sols de qualsevol soci sinó també de qualsevol tercer amb interès legítim. D'altra banda, es debat l'adequació de l'establiment d'un percentatge (i quin ha de ser aquest) com a instrument que permeta frenar $l^{\prime \prime \prime}$ intervencionisme" social a l'administració i la gestió, i es dubta, a més, de la legitimitat de la conversió en dret de minoria d'allò que per a la junta/assemblea general es configura com a dret individual.

A més, a l'objecció que un percentatge fix tindrà efectes diversos en entitats de diferents dimensions, tant de capital com de col-lectiu social, s'ha d'afegir que, com és habitual, la qüestió presenta perfils propis en l'àmbit cooperatiu. En les cooperatives el principi general és el d'"una persona un vot", encara que les reformes legislatives successives incorporen, cada vegada més, supòsits de vot plural limitat; l'opció per un dret de minoria, calculat a més sobre el capital i no sobre el total de $\operatorname{socis}^{861}$, és una de nova i dissimulada via d'excepció al principi democràtic d'igualtat de drets dels socis cooperatius: qui, en l'àmbit de la LCCV, més participació tinga en el capital social ${ }^{862}$ o qui, en l'àmbit de la LCoop, tinga vot plural, més possibilitat d'impugnar tindrà.

D'altra banda, la LCoop (article 37.2), en el seu afany diferenciador de la legitimació davant acords nuls i anul-lables (que en aquest aspecte modifica el criteri anterior de la LGC), passa a l'extrem contrari en aquests últims: dels assistents, només els que hi hagueren votat en contra i ho hagueren fet constar en l'acta hi estaran legitimats. Així, es restringeix el règim en relació amb allò

${ }^{860}$ EmBid IRUJO, J. M., «Comentario al art. 70», op. cit., pàg. 743 i 744; POLO SÁNCHEZ, E., Los administradores..., cit. pàg. 539 i 540.

${ }^{861}$ En aquest sentit, la LCoop ha estat almenys més respectuosa amb els principis cooperatius, en fixar la legitimació dels no administradors per a la impugnació d'acords anul.lables en el mateix percentatge, però respecte del total de socis, i tal opció és a més pràctica a l'hora de realitzar el càlcul, tenint en compte la variabilitat del capital social cooperatiu.

862 Recordeu que les aportacions obligatòries al capital de la cooperativa no tenen perquè consistir en la mateixa quantia per a tots els socis (article $50.1 \mathrm{LCCV}$ : "Els estatuts socials fixaran l'aportació obligatòria [...]. Podran preveure que la seua quantia siga [...] proporcional a l'activitat cooperativitzada"...), i que els socis poden subscriure quantitats variables daportacions voluntàries. 
que preveu per a l'assemblea i es queden sense legitimació els que s'hi hagueren abstingut o hagueren emès vot nul o en blanc, i no podran manifestar la seua oposició "mitjançant un document fefaent lliurat en les 48 hores següents".

Finalment, en relació amb la legitimació cal observar que la LCoop, que ha mantingut l'obligació introduïda per la LGC que els administradors han d'impugnar els acords de l'assemblea contraris a la Llei o als estatuts (article 31.4), opta, tanmateix, per suprimir aquesta obligació expressa en relació amb els acords de l'òrgan d'administració. Això no obstant, com ja hem vist, es manté el debat sobre si la impugnació obligatòria d'aquests acords formaria part del deure de diligència dels administradors, malgrat l'absència d'una referència expressa ${ }^{863}$.

Quant als aspectes processals de la impugnació, la remissió a l'aplicació del procediment previst per a la impugnació dels acords de l'assemblea general, que al seu torn remet als articles corresponents de la LSA, és clara i explícita ${ }^{\text {sut }}$. Tanmateix, s'ha de tenir present la possibilitat, única en l'ordenament jurídic espanyol, que alguns acords del consell siguen impugnables mitjançant l'anomenada "via interna d'impugnació judicial diferida" ${ }^{\text {"65 }}$, davant d'altres

863 Epígraf 2 del Capítol Primer. EMBID IRUJO, J. M., "Comentario al art. 70», op. cit., pàg. $740 \mathrm{i}$ 741; SÁNCHEZ CALERO, F., Administradores..., op. cit., pàg. 544.

${ }^{864}$ En relació amb la remissió als articles 115 a 122 LSA que efectua l'article 36.7 de la LCCV, ja hem assenyalat en FAJARDO GARCí, I. G., i SENENT VIDAL, M. J., Texto refundido..., op. cit., pàg. 49, que "s'ha de tenir present que es fa únicament respecte dels aspectes processals de la impugnació ("les accions d'impugnació, en allò no especialment disposat en aquesta Llei ...»). Els articles 115,116 i 117.1 i 2 no són doncs d'aplicació, ja que a més de regular matèries expressament normadas en la Llei de cooperatives de la Comunitat Valenciana no aborden aspectes procedimentals". El legislador estatal, amb millor criteri en aquesta matèria, es remet tan sols als arts. 118 a 121 LSA.

En tot cas, s'ha de tenir en consideració que la Llei 1/2000, de 7 de gener, d'enjudiciament civil n'ha substituït el règim processal de la impugnació d'acords anteriorment previst en els esmentats arts. 118 a 121 LSA. En l'actualitat, es mantenen únicament en vigor els arts. 118 i 122 (que no s'esmenta per la LCoop). La redacció vigent de l'article 118 és la següent: "Per a la impugnació dels acords socials, se seguiran els tràmits del judici ordinari i les disposicions contingudes en la Llei d'enjudiciament civil". 
òrgans de la cooperativa, en concret davant del comitè/comissió de recursos 0 , si no n'hi ha, davant de l'assemblea. Com que aquesta possibilitat sols es preveu en relació amb determinats tipus d'acords del consell, s'analitza en l'epígraf següent, entre els supòsits especials.

Altres aspectes del règim d'impugnació dels acords de l'assemblea amb perfils processals indubtables, si bé es regulen separadament, no ofereixen dubtes respecte de la seua translació a la impugnació d'acords del consell ${ }^{866}$. Es tracta de qüestions com ara la possibilitat de suspendre, deixar sense efecte o substituir l'acord impugnat, així com de l'atorgament del termini pel jutge per eliminar la causa d'impugnació ${ }^{867}$; de l'eficàcia de la sentència estimatòria de la impugnació davant tots els socis, però no respecte dels drets adquirits de bona fe per tercers; i de l'anotació preventiva de la demanda i la cancel-lació, si escau, dels assentaments registrals referits a l'acord impugnat (articles 31.6 LCoop i $36.8 \mathrm{LCCV})$.

\subsection{Supòsits especials}

2.2.1. Acords del consell rector que poden impugnar-se internament

Abans que la legislació societària i de cooperatives reconegueren explícitament la impugnabilitat dels acords del consell, ja es preveia, en la LGC de 1974, la possibilitat de la seua impugnació "intracooperativa", davant de l'assemblea; l'acord de la qual ratificava allò adoptat pel consell sí que era impugnable, i

866 JUSTE MenCía, J., Los derechos de minoría..., op. cit., pàg. 404 a 406; POLO SÁNCHEZ, E., Los administradores..., cit., pp 532, 533 i 541 a 543.

${ }^{867}$ EMBID IRUJO, J. M., «Comentario al artículo 143», op. cit., pàg. 1529 i 1530; POLO SÁNCHEZ, E., Los administradores..., cit. pàg. 533: "... la regularització [...] pot fins i tot "donar més joc» a l'organ administratiu que a la junta general, a causa precisament de les menors formalitats d'aquell en la seua convocatòria i constitució". 
d'aquesta manera es donava una mena d'impugnació judicial "indirecta" Aquesta possibilitat es va incorporar a la legislació cooperativa autonòmica i es va mantenir en la LGC de 1987. En l'actualitat, les dues normes objecte del nostre estudi, LCoop i LCCV, inclouen la denominada "via interna d'impugnació judicial diferida" per a determinats tipus d'acords del consell rector $^{869}$.

Els acords per als quals es preveu expressament la impugnació interna són l'admissió o la inadmissió de la sol-licitud d'ingrés ${ }^{870}$ (articles 13.2 i 13.3 LCoop $^{871}$ i 15.2 LCCV); la denegació d'informació als socis (article 16.4 LCoop ${ }^{\mathrm{m} / 2}$ );

868 MARÍN LÓPEZ, J. J., «Novedades...», op. cit., pàg. 1119.

869 SÁNCHEZ CALERO, F., Administradores..., op. cit., pàg. 534, refereix com el sistema de confiar la declaració de nul-litat dels acords del consell als propis òrgans de la societat ha estat adoptat pel codi de societats mercantils portuguès. En vista del que es preveu en l'article 9 del Código cooperativo portugués, que declara l'aplicació subsidiària del codi de societats comercials (vegeune la traducció anotada de FAJARDO GARCíA, Isabel-Gemma, «Lei 51/1996, de 7 de septiembre. Código cooperativo portugués. Texto legal traducido y anotado", Revista jurídica de economía social y cooperativa, Ciriec-España, octubre 1999, pàg. 457), la via interna d'impugnació és també aplicable a les cooperatives portugueses, davant de la falta de menció en el codi cooperatiu d'un règim específic per a la impugnació dels acords socials. També es refereix al sistema portuguès ALCALÁ DíAZ, M. A., La impugnación..., op. cit., pàg. 175, nota 159. SCORDINO, F., La societa cooperativa, op. cit., pàg. 291, recorda que, en dret italià també s'admet expressament la possibilitat de que els estatuts socials sotmeten a recurs intern davant de l'anomenat col-legi dei probiviri els acords de l'assemblea general. En dret francès, la Llei 72-652, reguladora de les cooperatives de comerciants detallistes, regula, en l'article 11, la possibilitat del soci "exclos" $\mathrm{d}^{\prime \prime \prime}$ apel-lar" la decisió del consell d'administració o del consell de vigilància davant de l'assemblea general.

870 SERRANO Y SOLDEVILLA, A. D., La cooperativa como..., op. cit., pàg. 180 a 192, on critica el risc de falta d'objectivitat dels òrgans cooperatius per garantir prou els interessos de l'aspirant a soci i la dificultat de contradir les al-legacions del consell rector que es fonamenten en causes derivades de l'organització i el funcionament de l'empresa. Aquest autor considera a l'acord denegatori de la sol-licitud d'admissió "sense atendre les limitacions exhaustives que legalment s'estableixen [...] nul de ple de dret", perquè "amb independència absoluta de la naturalesa de la norma infringida (legal o estatutària) és un acord que va en contra de la causa o finalitat mateixa de la societat cooperativa".

871 ALFONSO SÁNCHEZ, R., "Aspectos básicos...», op. cit., pàg. 175, nota 49: "Encara que la LCoop només es refereix a la possibilitat de recórrer l'acord d'admissió, entenem que també ho és l'admissió per silenci. Si no fóra així, la cooperativa i els seus socis quedarien indefensos".

872 La LCCV dedica l'article 21 a regular el dret d'informació del soci, però no sotmet la seua violació al procés intern d'impugnació, pel que, llevat d'especificació estatutària, serà directament impugnable davant de la jurisdicció ordinària. SORIA FERRANDO, J. V., La impugnación..., op. cit., pàg. 201 cita jurisprudència relacionada amb la vulneració del dret 
la imposició de sanció, inclosa la sanció màxima, l'expulsió (articles 18.3, c) LCoop, i $\left.18.2 \mathrm{LCCV}^{873}\right)$; la baixa obligatòria (17.5, 3r LCoop); la qualificació i efectes de la baixa (17.6 LCoop), i la liquidació de les aportacions al capital en cas de baixa (51.2 LCoop). A més, quan hi haja comitè/comissió de recursos (articles 44.1 LCoop i 47.2 i 47.3 LCCV), es preveu expressament la possibilitat d'ampliació estatutària dels supòsits impugnables, i no sembla haver-hi raó que impedisca l'establiment en els estatuts del recurs intern fins $\mathrm{i}$ tot quan no s'adopte el comitè esmentat ${ }^{874}$. Aquesta ampliació estatutària de l'àmbit d'aplicació del recurs intern pot abastar així mateix els acords d'altres òrgans, ja que la LCoop (article 44.1) ho permet per al comitè de recursos, sense més especificació, mentre que la LCCV (article 47.3) permet que la seua actuació s'estenga davant "qualsevol acord del consell rector o de l'assemblea general".

D'altra banda, la terminologia usada per ambdues normes, que utilitzen indistintament els termes impugnació o recurs, ens porta a reflexionar sobre si estem davant d'un vertader procés d'impugnació, sotmès als límits estatuïts per als acords de l'assemblea (únicament acords contraris a la llei o als estatuts, o lesius de l'interès social, legitimació taxada, etc.) o es tracta, més aviat, de l'establiment d'un procediment de revisió de l'acord, no cenyit estrictament a la seua nul-litat o anul-labilitat, sinó obert a un judici d'oportunitat més ampli.

Així, per exemple, per a l'acord d'admissió de soci, la LCoop (article 13.3) parla de la seua impugnació, mentre que per al de denegació (article 13.2) es refereix indistintament al seu recurs o la seua impugnació. La LCCV, que unifica ambdós processos (article 15.2), també els qualifica tant de recurs com

\section{d'informació.}

En matèria de sancions, la LCCV regula únicament, amb caràcter general, l'obligatorietat de 18. ia regulació estatutària, en l'article 10, $k$ ); la sanció màxima aplicable, l'expulsió, en l'article reci i la possibilitat de sotmetre l'exercici del poder disciplinari del consell a una comissió de ecursos (article 47.2). En tot cas, en la pràctica estatutària se sol establir el mateix procediment aprovació i recurs previst per a l'expulsió, per a les altres faltes molt greus. 
voluntat social per excel-lència, puga estar en disposició de "corregir" actuacions del consell $^{882}$. I quant al comitè/comissió de recursos és, si escau, un òrgan la creació del qual és una opció voluntària per part de la cooperativa, que pot decidir dotar-se d'aquest òrgan de revisió i atribuir-li l'àmbit d'actuació que estime convenient, com hem vist. I si és certa la necessitat que l'òrgan d'administració compte amb un ampli marge d'autonomia per a la gestió, no ho és menys que aquesta autonomia ha d'exercir-se de conformitat amb la política general fixada per l'assemblea, que, al seu torn, pot delegar el control de l'esmentada adequació en l'òrgan encarregat dels recursos.

Noteu, a més, que no és casual que els supòsits per als quals es preveu el recurs intern siguen, en general, acords que afecten directament la relació entre el soci individual i la cooperativa: admissió, sanció, expulsió, baixa, liquidació... (i que, per això, estan entre els que més conflictivitat generen en relació amb els acords del consell) ${ }^{883}$. La decisió de l'òrgan d'administració pot ser inqualificable de nul-litat o anul-labilitat i, tanmateix, merèixer la reconsideració per l'assemblea, en consideració al caràcter essencialment solidari, mutualista, de la cooperativa.

882 Recordeu que en l'àmbit cooperatiu la possibilitat de control de l'assemblea sobre l'òrgan d'administració és molt més gran que en el de les societats de capital; en aquest sentit, la LCoop arriba a autoritzar a l'assemblea per "impartir instruccions al consell rector o sotmetre a autorització l'adopció per l'esmentat òrgan de decisions o acords sobre determinats assumptes", llevat de disposició contrària estatutària (article $21.1,2 n$ paràgraf).

883 URf́A, R., MENÉNDEZ, A., i VERGEZ, M., "Sociedades cooperativas», op. cit., pàg. 1286, ja adverteixen que "les peculiaritats del tipus social incideixen sobre la manera com s'inicia i s'extingeix la relació soci-societat i en el contingut mateix de la condició de soci [...]. La Llei regula detingudament tots aquests supòsits d'admissió $i$ sobretot de baixa del soci en un intent clar d'harmonitzar la contraposició possible d'interessos que puguen produir-se entre el soci $\mathrm{i}$ la societat, a través de les atribucions que en aquesta matèria es concedeixen al Consell Rector i els mitjans de defensa que davant les seues decisions es concedeixen al soci afectat, preveient-se, en el seu cas, la impugnació de la decisió del Consell Rector davant del Comitè de Recursos". VERGEZ SÁNCHEZ, M., ja assenyalava, en El derecho de las cooperativas..., op. cit., pàg. 31, que el problema més important que planteja el principi cooperatiu de porta oberta no és el de la seua limitació possible, mitjançant la imposició estatutària de requisits de caràcter objectiu o de terminis per al seu exercici, sinó el de les garanties d'una aplicació correcta, entre les quals es compta l'establiment dels recursos contra possibles decisions arbitràries dels òrgans socials; ${ }^{1}$ GIRÓN TENA, J., Derecho de sociedades, t. I, pàg. 108, nota 20: "el principi de porta oberta no pot portar més que a un règim o tractament jurídic que faça reglada la decisió dels òrgans socials d'admetre o no a qui, estant en les mateixes circumstàncies economicosocials que els socis de la Cooperativa, i que defineix l'objecte d'aquesta, volen entrar-hi, conciliant el seu dret a això, en principi, amb motius d'excepció". 
Una altra qüestió que pot emprendre's en relació amb la via interna d'impugnació de determinats acords socials és el seu caràcter obligatori o potestatiu: el soci pot obviar el recurs intern i acudir directament a la impugnació o a l'arbitratge externs?, o necessàriament ha d'esgotar les possibilitats interiors de resolució? En alguns supòsits, la redacció de la norma legal indica el caràcter precedentment obligatori de la impugnació interna, en esmentar com a objecte de la impugnació jurisdiccional únicament l'acord que resulta del recurs; així succeeix amb els articles 17.6 i 18.3, c) LCoop, i 15.2, 2n i 18.2 LCCV. Tanmateix, en aquests casos el recurs intern es planteja com una mera possibilitat, i és bastant discutible que el no-exercici de l'acció interna haja de tenir com a efecte la pèrdua de l'acció externa. En efecte, si bé en els supòsits esmentats (imposició de sanció, decisió sobre la sol-licitud d'ingrés i expulsió, respectivament) podria estar justificada una limitació de la litigiositat, que a més donaria a la cooperativa la possibilitat de rectificar la seua decisió inicial, una restricció eventual del dret del soci a la impugnació externa sembla requerir, almenys, una explicitació més inequívoca.

En els altres casos, la via interna d'impugnació es planteja com un recurs voluntari, que han d'exercir o no els legitimats, sense esmentar explícitament la possibilitat d'impugnació, successiva o alternativa, davant de la jurisdicció ordinària $^{84}$. Més discutible és encara, al nostre parer, que, tret de previsió legal

${ }^{884}$ Com a excepció, l'article 16.4 LCoop assenyala que, amb independència de la possibilitat de recórrer internament, "...En tot cas, la negativa del consell rector a proporcionar la informació sol.licitada podrà ser impugnada pels sol-licitants d'aquesta pel procediment a què es refereix l'article 31 d'aquesta Llei [impugnació judicial dels acords de l'assemblea], a més, respecte als supòsits (...) podran acudir al procediment previst en l'article 2166 de la LEC". La norma procedeix, pel que sembla, de l'article 25,2 n paràgraf LCPV, que, en lloc de referir-se al procediment d'impugnació dels acords de l'assemblea es remet, més coherentment, al dels acords del consell. També la LCC (article 22.9) remet alguns supòsits de denegació d'informació al procediment de jurisdicció voluntària de l'anterior article 2166 LEC.

Per la seua part, l'article 47.2 LCCV possibilita que els estatuts limiten la via interna de reugnació a una sola instància, en admetre's que determinen que la decisió de la comissió recursos no siga recurrible davant de l'assemblea, i s'obri la via a la impugnació judicial. 
expressa, els estatuts siguen els que puguen restringir el dret d'impugnació externa del soci sotmetent-lo a procediments previs interns ${ }^{885}$.

2.2.2. Acords adoptats amb la concurrència de consellers sotmesos a causes d'incapacitat o prohibició

Ja s'ha exposat amb detall en l'epígraf 1.2.5. el debat doctrinal que es planteja en l'àmbit de les societats de capital en relació amb els acords de nomenament de consellers sotmesos a causes d'incapacitat, inhabilitació, prohibició o incompatibilitat, o que no reunisquen els requisits estatutaris exigits. Com que l'acord de nomenament de membres de l'òrgan d'administració correspon a l'assemblea, allà es reflecteix el debat doctrinal sobre si l'acord de nomenament serà nul o conduirà únicament a la destitució necessària del conseller afectat ${ }^{20 \%}$.

Això no obstant, s'ha de recordar que estan subjectes a règim d'incompatibilitats altres càrrecs socials, entre els quals hi ha alguns el nomenament dels quals correspon a l'òrgan d'administració, com el de director (article 39.3 LCCV) o el de lletrat assessor (article 46 LCCV). En aquests casos, pot considerar-se extensible la interpretació realitzada, en relació amb la qual ja hem manifestat la nostra opinió: l'acord serà nul o anul-lable, segons el caràcter de la norma, legal o estatutària, que establisca la incompatibilitat $i$, per tant, impugnable; i amb independència de l'exercici possible de la impugnació, es podrà produir la destitució immediata del càrrec des que s'advertisca la

885 L'article 47.3 LCCV indica que estatutàriament es podrà establir la impugnació prèvia davant de la comissió de recursos com a requisit inexcusable per a una posterior demanda d'arbitratge o d'impugnació judicial dels acords del consell o de l'assemblea.

886 Vegeu l'epígraf 1.2.5. anterior, "Acords de nomenament de càrrecs socials". Els principals exponents d'ambdues posicions doctrinals són SÁNCHEZ CALERO, F., Administradores, op. cit, pàg. 217 a 219, i POLO SÁNCHEZ, E., Los administradores.., op. cit., pàg. 252 a 254, respectivament En l'àmbit cooperatiu, VICENT CHULIÁ, F., "El derecho de los órganos...», op. cit., pàg. 494. 
concurrència de la causa d'incompatibilitat, ja siga per mandat legal o estatutari exprés, ja siga amb l'objectiu de complir el deure de diligència ${ }^{887}$.

Però una altra qüestió essencial que es deriva del nomenament incorrecte dels administradors per part de l'assemblea és la relativa a la validesa dels acords que puga adoptar l'òrgan d'administració amb la concurrència del vot dels invalidament nomenats, mentre no se'n produïsca la destitucióo ${ }^{888}$. Siga quina siga la postura doctrinal que s'adopte sobre el procediment per a la revocació del nomenament, la defensa de l'eficàcia d'aquests acords i dels actes realitzats per l'administrador en nom de l'entitat és unànime ${ }^{899}$. Si es defensa la nul.litat de l'acord de nomenament, l'eficàcia dels seus efectes es fonamentarà en raó de la protecció de la seguretat jurídica i del tràfic econòmic; si s'exclou la nul-litat del nomenament per mandat legal exprés que, d'acord amb allò previst en l'article 6.3 CC, estableix un efecte diferent, la destitució, els actes realitzats pel nomenat són perfectament vàlids fins que es produïsca aquesta.

Reiterem la nostra opinió: els acords seran nuls o anul-lables segons la norma que convertisca en invàlid el nomenament. Així, el nomenament d'administradors sotmesos a causes d'incompatibilitat legal serà nul, mentre que el dels qui no acomplisquen els requisits establerts estatutàriament serà anul-lable. I l'anul-labilitat implicarà, sense cap mena de dubtes, que els acords adoptats amb la concurrència de l'administrador són vàlids fins a la seua

887 Com a excepció, recordeu que la legislació cooperativa estableix per a la incompatibilitat entre determinats càrrecs de la cooperativa mateixa el deure de l'afectat a optar per un d'aquests dins d'un termini, transcorregut el qual "serà nul.la la segona designació".

${ }^{888}$ No hi ha en dret espanyol una norma equivalent a la prevista a l'article 93 de la Llei francesa de 24 de juliol de 1966, sobre societats comercials, per al consell d'administració de les societats anònimes. Aquest article estableix que la nul.litat del nomenament "no comporta la dels acords en què ha pres part l'administrador irregularment nomenat". Per a un comentari d'aquest supòsit de "nul-litat descartada", veure LEGROS, J.-P., "La nullité des décisions...", op. cit., pàg. 282 i 283.

${ }^{889}$ ALCALÁ DÍAZ, M. A., La impugnación..., op. cit., pàg. 304, adverteix d'una sola excepció a aquesta eficàcia general: els supòsits d'incapacitat, en què el nomenament no pot considerar-se perfeccionat atès que la seua acceptació per l'incapaç és invàlida, i les declaracions de voluntat 
destitució 0 , si aquesta no es produeix anteriorment, fins a la sentència estime l'anul-lació del nomenament.

Un supòsit específic es planteja quan el càrrec nomenat indegudament siga el de qui actua en representació de determinats col-lectius de socis o treballadors de la cooperativa. Ja hem indicat supra (vegeu l'epígraf 1.7) que no queda clar en tots els casos si l'elecció i la revocació corresponen únicament als membres del col-lectiu a representar ${ }^{890}$; encara que aquesta sembla la interpretació més coherent, la redacció legal (articles 33, 2n paràgraf LCoop, i 38.4 LCCV) podria donar peu a una regulació estatutària en què el nomenament i la destitució foren decidits per l'assemblea general, encara que hagueren de recaure en membres del col-lectiu afectat.

2.2.3. Acords de delegació de funcions i de nomenament dels membres de l'òrgan delegat

Com s'ha assenyalat, la facultat de delegar funcions i de nomenar els delegats és una competència ex lege de l'òrgan d'administració ${ }^{891}$. Tanmateix, les facultats que poden delegar-se estan limitades per la LCCV (article 43.2); i la LCoop (article 36.1) permet que els estatuts socials o l'assemblea establisquen restriccions, no sols en el contingut de les competències delegades i en el seu

en què consisteixen els seus vots són nul-les, la qual cosa podria donar lloc a la nul-litat de l'acord adoptat amb la seua participació si el seu vot haguera estat rellevant.

890 Sí que ho és, en la LCoop (article 33, 3 r párr), per al representant dels treballadors amb contracte per temps indefinit, que serà elegit $i$ revocat pel comitè d'empresa 0 , quan $n$ 'hi haja diversos, directament pels treballadors fixos. També s'explicita en l'article $40.3 \mathrm{LCCV}$, que la revocació dels representants de determinats col-lectius podrà realitzar-se únicament pels seus representats, sempre que no $s^{\prime}$ haguera regulat un procediment específic diferent o que la revocació abaste la totalitat del consell rector.

891 Com a excepció, assenyala ESTEBAN VELASCO, G., «Algunas reflexiones...», op. cit., pàg. 561, l'absència de previsió legal expressa en la LSRL, encara que això no siga obstacle perquè tal delegació resulte dels estatuts socials, en virtut de la remissió al règim de delegació de facultats de la SA que s'inclou en l'article 57.1 LSRL. 
exercici, sinó en les modalitats d'òrgan, fins i tot en l'elecció dels seus membres ${ }^{892}$.

Tot això pot donar lloc a una variada casuística d'acords de l'òrgan d'administració que seran nuls si vulneren les limitacions legals respecte de les competències delegables, o anul.lables si la norma vulnerada és estatutària o lesiva dels interessos socials. Quant als supòsits en què les restriccions en el contingut de la delegació o en la competència per al nomenament hagen estat acordades per l'assemblea si no hi ha regulació estatutària, podrien ser reconduits a una vulneració del mandat legal al consell de sotmetre's a la política fixada per l'assemblea (articles 32.1 LCoop i 37.1 LCCV).

2.2.4. Acords adoptats com a òrgan de gestió de les seccions de la cooperativa

Ja hem vist (epígraf 1.4) que s'atribueix autonomia de gestió a les seccions de la cooperativa i que, per tant, es reconeix l'existència d'un òrgan propi, l'assemblea de socis de la secció, la impugnació dels acords de la qual recull explícitament la LCCV (article 7.4), mentre que la LCoop (article 5.3) adopta una redacció més ambigua: l'assemblea general podrà acordar la suspensió dels acords de la "que considere contraris a la llei, als estatuts o a l'interès general".

Però no obstant l'ampli reconeixement explícit de l'autonomia de gestió ${ }^{893}$, tant la Llei estatal (article 5.1) com l'autonòmica valenciana (article 7.7) atribueixen

\footnotetext{
892 ESTEBAN VELASCO, Gaudencio, "Configuración estatutaria del órgano de administración», en AA. DD., Derecho de sociedades anónimas, I, La fundación, Civitas, Madrid, 1991, pàg. 371 i 372: "Els estatuts poden moure's dins d'una sèrie àmplia de possibilitats adaptant el model legal a les necessitats de la societat en qüestió. [...] poden imposar la delegació obligatòria delimitant les respectives competències del Consell $\mathrm{i}$ de l'òrgan delegat. [...] Opcions intermèdies [...] constitueixen aquelles clàusules estatutàries que confien la creació d'òrgans delegats a la Junta general, atribuint també la competència per a la designació de les persones a la Junta [...] pertany al contingut de l'acord de delegació del Consell determinar les facultats delegades (article 149.1), respectant els límits legals sobre les facultats no delegables (article 141 TRLSA), així com establir la composició de l'òrgan o dels òrgans delegats i les modalitats d'actuació".
} 
l'exercici de la representació i gestió de la secció, "en tot cas", al consell rector de la cooperativa, si bé la LCCV preveu la possibilitat (i en alguns casos, l'obligatorietat) que siga designat un director o apoderat de la secció, així com la intervenció, si s'escau, del director de la cooperativa en el gir i el tràfic de la secció $^{894}$. No hi ha, doncs, un òrgan de gestió propi de la secció i diferent del de la cooperativa ${ }^{895}$, opció legislativa l'oportunitat de la qual, tanmateix, havia estat justament qüestionada doctrinalment ${ }^{96}$.

No hi ha dubte que els acords del consell rector adoptats en relació amb la representació i la gestió de la secció són impugnables segons allò establert, en general, per a tots els seus acords (articles 37 LCoop i 41.6. LCCV), ja que les normes reguladores de les seccions no estableixen cap especialitat en la matèriar tanmateix, l'aplicació del règim d'impugnació del consell pot conduir a

d'explotació diferenciats, així com, llevat de disposició estatutària en contra, distribucí́ d'excedents diferenciada. La LCCV (article 7.3) exigeix la tenedoria de comptabilitat independent.

894 Article 7. 2 LCCV: "El consell rector i el director de la cooperativa $i$, en el cas de ser designat, el director o apoderat de la secció, se n'encarregaran del gir i el tràfic". L'article 4 de la Llei de la amb secció de crèdit a la Comunitat Valenciana converteix en obligatòria per a aquestes cooperatives la designació d'apoderat que s'"ocupe de la gestió ordinària de la secció de crèdit" $i$, a partir d'un cert volum de dipòsits, serà obligatòria la designació $d^{\prime \prime \prime}$ un director amb dedicació exclusiva als assumptes de la secció de crèdit".

L'article 43. $5 \mathrm{LCCV}$, per la seua part, estableix que a les cooperatives amb secció de crèdit "serà necessària la designació d'un gestor de dedicació permanent, amb el caràcter de conseller delegat o de director".

895 FAJARDO GARCfA, I-G., La gestión económica..., op. cit., pàg. 207.

896 SANTOS MARTÍNEZ, V., «Las secciones...», op. cit., pàg. 1095 i 1096: "a la nostra manera de veure, atenent el que ens sembla una composició adequada dels interessos en joc, la procedència que siga el consell rector o el director de la cooperativa els qui administren o representen la secció només hauria d'admetre's en determinats supòsits, com els següents: $a$ ) que tots els socis estiguen interessats o participen en la gestió; $b$ ) que, si no és així, aquells socis que formen part de la secció decidisquen encomanar aquestes funcions a aquells òrgans generals de la cooperativa; c) que els socis interessats en la secció estiguen representats enl consell rector per determinats membres d'aquest. [...] "en aquests casos en què l'administració dels interessos de la secció es desenvolupe dins de la trama orgànica general de la cooperativa, pot fàcilment patir o fins i tot arribar a desvirtuar-se $l^{\prime}$ «autonomia de gestión [...]. Certament que aquesta gestió articulada o acoblada amb la gestió general de la cooperativa pot respondre a necessitat pràctiques [...]. però, amb tot, la solució que satisfà més bé els interessos en joc i la configuració legal del supòsit és, sens dubte, que la secció tinga un òrgan propi d'administració $i$ representació, ja siga unipersonal, ja pluripersonal". 
situacions paradoxals, en la línia d'allò que ja s'ha indicat per a la impugnació dels acords de l'assemblea de socis de la secció.

En efecte, hem vist supra com podrien donar-se conflictes entre els interessos defensats legítimament per l'assemblea de socis de la secció i els interessos extrasocials d'altres socis no membres d'aquesta; ens hem de plantejar ara que el conflicte es done entre allò acordat per l'òrgan d'administració general de la cooperativa per a l'administració i gestió de la secció i els interessos dels socis d'aquesta. En aquests casos, desapareix tot vestigi d'autonomia de gestió per part de la secció, ja que els seus socis, llevat que foren membres de l'òrgan d'administració, haurien de reunir el suport d'almenys el $5 \%$ dels socis, segons la LCoop, o del capital social, segons la LCCV, de tota la cooperativa, per poder qüestionar la validesa d'allò acordat.

\subsection{Actes i decisions dels administradors}

Ja ha quedat reflectit anteriorment que els actes individuals dels membres del consell rector no són objecte d'impugnació ${ }^{877}$ i la qüestió que s'analitza ara és la possibilitat d'impugnar els actes i les decisions de l'òrgan de gestió quan adopte formes no col-legiades.

Com ja s'ha avançat, és una qüestió criticada en la legislació de societats de capital la limitació preceptuada per l'article 143.1 LSA, en el sentit de circumscriure la impugnació als acords dels òrgans d'administració col-legiats, la qual cosa faria no impugnables les decisions o els acords dels òrgans d'administració unipersonals o pluripersonals no col-legiats ${ }^{898}$. S'han

\footnotetext{
${ }^{897}$ Epígraf 2.1. d'aquest mateix capítol.
}

898 Polo SÁNCHEZ, E., Los administradores..., op. cit., pàg. 528 i 529; DIAAZ DE LEZCANO SEVILLANO, N., Los acuerdos del consejo..., op. cit., pàg. 57, nota 105: "Així, ÁlVAREZ VALDÉs, [...], manifesta que el nostre legislador es va oblidar de regular la possibilitat d'impugnar els actes o 
argumentat com a raons d'aquesta limitació la necessitat de restringir la impugnació als acords, com a declaració de voluntat col-legiada, per la dificultat que comportaria, d'una banda, discriminar, en el cas dels òrgans unipersonals, entre la decisió i els actes d'execució corresponents ${ }^{899}$, i d'una altra, l'accés al coneixement de l'existència mateixa de la decisiós ${ }^{900}$.

Aquests motius han estat rebatuts ${ }^{901}$ amb diferents arguments: en relació amb la dificultat de diferenciar la decisió pròpiament impugnable dels actes d'execució, es recorda que l'admissió de societats unipersonals no qüestiona la impugnabilitat dels "acords" de la junta general ${ }^{902}$, així com que les modalitats

acords dels administradors únics; DE LA CÁMARA ÁlVAREZ, M., «La administración de la Sociedad Anónima", RJN, 1992, pàg. 68 i 69, hauria de poder plantejar-se la impugnació contra els actes dels altres administradors que, també, poden ser contraris a la Llei; EMBID IRUJO, "Notas sobre la impugnación...", op. cit., pàg. 56 sosté que un dels principals defectes és no haver estès la impugnació a tots els actes $\mathrm{i}$ acords tant d'òrgans unipersonals com pluripersonals no col-legiats d'administració; JUSTE MENCIA, J., Los derechos de minoria..., op. cit., pàg. 393 a 395; RODRíGUEZ ARTIGAS, Fernando, i QUIJANO GONZÁLEZ, Jesús, "Los órganos de la sociedad anónima: junta general y administradores", en AA. DD., El nuevo derecho de las sociedades de capital, (dir. I. Quintana Carlo), Trivium, Saragossa, 1989, op. cit., pàg. 139.

En l'àmbit de la legislació cooperativa, estimen que no són impugnables els actes d'administradors únics i de consellers delegats RODRfGUEZ, M. P., i SUSO, J. M., «Los órganos de la cooperativa", op. cit., pàg. 202, en considerar que "per la seua condició individual, no n'emanen acords"; i GADEA, E., Derecho de las cooperativas..., op. cit., pàg. 191, basant-se en el tenor literal de l'article 49 LCPV.

899 STS de 30.10.1999 (RJA 1999/8170), SAP-Bilbao, de 14.2.2000 (AC 2000/274). ALCALÁ DIAZ, M. A., La impugnación..., op. cit., pàg. 190 i 191.

900 EMBID IRUJO, J. M., "Comentario al artículo 143», op. cit., pàg. 1528; JUSTE MENCfA, J., Los derechos de minoría..., op. cit., pàg. 394, encara apunta dues argumentacions possibles més: una, relacionada amb una hipotètica potencial intenció de legitimar únicament els administradors davant els acords de l'òrgan d'administració, cas en què quedaria sense sentit $1^{\prime \prime \prime}$ autoimpugnació" de l'administrador únic o dels mancomunats, però mantindria els interrogants respecte de la motivació de la impugnabilitat per un administrador solidari respecte de l'actuat per un altre; la segona, la possible intenció del legislador d'evitar impugnacions abusives d'actes de gestió ordinaris i reservar el dret per a les decisions de més transcendència adoptades pel consell d'administració en les societats obertes, cosa que no seria coherent amb la pràctica, que demostra com l'adopció d'una o una altra forma d'administració (en les societats capitalistes) no necessàriament coincideix amb el caràcter tancat 0 obert 0 les dimensions de l'entitat.

901 EMBID IRUJO, J. M., "Comentario al art. 70», pàg. 741; , JUSTE MENCfA, J., Los derechos de minoría..., op. cit., pàg. 394; POLO SÁNCHEZ, E., Los administradores..., op. cit., pàg. 528 i 529.

902 Article 127 LSRL: "En la societat unipersonal de responsabilitat limitada el soci únic exercirà les competències de la junta general, cas en què les seues decisions es consignaran en acta sota 
pluripersonals dels òrgans no col-legiats també adopten acords, si bé no ho fan per majoria, sinó per unanimitat (els mancomunats sempre, però també els solidaris poden fer-ho). En relació amb la dificultat per accedir a la informació sobre les decisions unipersonals, s'ha observat que ocorre el mateix en els acords adoptats pel consell d'administració, sobretot per als socis no administradors, sense que això siga obstacle per a la impugnabilitat ${ }^{93}$.

Les dificultats d'accés al coneixement de la decisió, així com de discriminar entre aquesta $\mathrm{i}$ els actes de la seua execució no són, al nostre parer, un argument de suficient envergadura per negar la impugnació, com a instrument de control

la seua firma o la del seu representant, i podran ser executades i formalitzades pel soci mateix o pels administradors de la societat".

ALONSO UREBA, Alberto, «La sociedad unipersonal», en AA. DD., La reforma del derecho español de sociedades de capital, Civitas, Madrid, 1987, pàg. 260: "la existència d'un únic soci no és obstacle per a la constitució i funcionament dels òrgans socials. La Junta general s'entén com a Junta Universal i no s'hi aplica per tant la normativa sobre convocatòria, ja que val com a acord la decisió de l'únic soci sempre que es documente o es protocolitze de la manera exigida per a l'acord, i haurà de procedir-se també a la seua inscripció en els casos en què això siga necessari. Fora d'això, hauran de respectar-se les disposicions del Dret de societats anònimes [...] relatives a l'organització interna (funcionament, composició i competència dels respectius òrgans socials), sense perjudici de la impossibilitat del joc de determinats preceptes com a conseqüència de la unipersonalitat".

Anteriorment a la LSRL de 1995, DUQUE DOMf́NGUEZ, Justino F., "La Duodécima Directiva del Consejo (89/67/CEEde 21 de diciembre de 1989) sobre la Sociedad de Responsabilidad Limitada de socio único en el horizonte de la empresa individual de responsabilidad limitada", en AA. DD., La reforma del derecho español de sociedades de capital, Civitas, Madrid, 1987; Derecho mercantil de la Comunidad Económica Europea, Civitas, Madrid, 1991, pàg. 288; i RODRf́GUEZ RUIZ DE VILLA, D., Impugnación... op. cit., pp 82 i 83, nota 67: “[...] La DGRN continua exigint que es realitze junta general a fi d'adoptar els acords socials, així com la necessitat de traslladar després als llibres d'actes de la Societat els acords (millor, al nostre parer, seria parlar de decisions preses per l'únic soci)".

ViCent CHULIÁ, F. en PAZ CANALEJO, N. i ViCENT CHULIÁ, F., Ley general..., op. cit., pàg. 857: "El nou article 143 de la LSA només preveu la impugnació d'acords d'òrgans col-legiats. Però en contra d'aquesta opció, i a favor de la LGC, hem de recordar que l'admissió de Societats de Responsabilitat Limitada - i, probablement, Societats anònimes- d'un sol soci, en aplicació de la Directiva CEE de 22 de desembre de 1989, obligarà a reconèixer com a «acords» les decisions individuals d'aquell".

903 JUSTE MENCIA, J., Los derechos de minoría..., op. cit., pàg. 402, que assenyala la importància decisiva a efectes d'impugnació d'acords socials del dret dels accionistes a obtenir la certificació dels acords de la junta general (article $26.2 \mathrm{Cco}$ ), però que no es reconeix per als de l'òrgan d'administració; el mateix autor recull les crítiques doctrinals (POLO SÁNCHEZ, Los administradores..., p. 537; SÁNCHEZ CALERO, Administradores..., pàg. 549) respecte de l'existència d'aquesta llacuna legal que "pot dificultar notablement l'exercici del dret per la minoria, llevat dels casos d'inscripció de l'acord". La legislació cooperativa recull expressament el dret dels socis a obtenir còpia certificada dels acords de l'assemblea general (LCoop, article 16.3, b; LCCV, article 34.4), però només la LCoop preveu alguns supòsits concrets en què el soci podrà 
respecte de les decisions de determinades modalitats d'òrgan d'administració Aquestes dificultats, a més, poden evitar-se (i en alguns casos, ho han de fer mitjançant l'adopció de les mateixes mesures de publicitat que s'estableixen per als acords col-legiats: constància en acta, certificació, inscripció registral, etc. En tot cas, que la formació de la voluntat social en el cas dels òrgans no col-legiats siga d'exteriorització difícil no pot portar a concloure que ha d'actuar-se com si fora inexistent; tractant-se en tot cas d'òrgans socials ${ }^{20}$ adopten decisions que conformen la voluntat social en la mateixa mesura en què l'òrgan pluripersonal col-legiat ho fa mitjançant el procés d'adopció de l'acord. Una qüestió diferent serà que l'exteriorització dels òrgans no col-legiats no es produirà la majoria de les vegades fins que s'inicien els actes i els negocis de la seua execució, per la qual cosa s'hauran de preveure els mitjans adequats per a la seua constatació.

També s'ha argumentat a favor de la no-impugnabilitat "la complexitat que presenta el control dels actes de gestió des del punt de vista de les relacions internes i la conveniència d'evitar un excessiu control extern del funcionament de la societat" ${ }^{\prime 906}$, que propugna en la seua substitució, l'aplicació del règim de responsabilitat. Davant d'això, s'han fet notar els perjudicis que es derivarien de la necessitat d'esperar, per iniciar l'acció de responsabilitat, que es produïra un dany que, en alguns casos, fins i tot podria haver estat evitat mitjançant la impugnació ${ }^{907}$.

accedir a certificació dels acords del consell: quan es tracte d'acords que "afecten el soci
individualment 904 ALONSO UREBA, A., «La sociedad unipersonal», op. cit., pàg. 260 i 261, assenyala com en el dret alemany $i$ el francès s'introdueixen en la legislació positiva particularitats del règim de la societat unipersonal que tendeixen a consagrar garanties complementàries en protecció del

905 GAlgano, F., El negocio jurídico, op. cit., pàg. 403; VICENT CHULIÁ, F., «La asamblea...», op. cit., pàg. 155.

906 SAlelles Climent, J. R., El funcionamiento... op. cit., pàg. 398.

907 POLO SÁNCHEZ, E., Los administradores..., op. cit., pàg. 528 
Però sobretot entenem que no pot fonamentar-se la decisió sobre l'admissió o no de la impugnació en qüestions accessòries, com ara quin és l'origen de l'acte potencialment subjecte, sinó que ha de fer-se sobre la seua "naturalesa intrínseca", suposadament il-legal, antiestatutària o socialment lesiva. El cas contrari porta a la paradoxa de declarar no impugnables decisions que, si foren adoptades per òrgans col-legiats, serien dretament revocables ${ }^{908}$, i obri una via d'elusió del control social sobre l'òrgan d'administració ${ }^{909} \mathrm{amb}$ la sola opció per modalitats no sotmeses a la impugnació ${ }^{910}$.

D'altra banda, en la LGC de 1987, hi ha un antecedent en l'àmbit cooperatiu de reconeixement explícit de la possibilitat d'impugnar actes i decisions d'un

908 Insisteix, a més, POLO SÁNCHEZ, E., Los administradores..., op. cit., pàg. 528 que "És la Llei mateixa la que, en matèria de responsabilitat dels administradors, admet com a origen - no només formal, sinó així mateix material- de la lesió no només els acords adoptats col-legiada $\multimap$ conjuntament-, sinó també els actes lesius realitzats per l'òrgan d'administració [...] . I no deixa de resultar paradoxal que un acte lesiu per a l'interès i el patrimoni social realitzat per un administrador únic, per un administrador solidari o per un conseller delegat no puga impugnar-se, evitant així les seues conseqüències perjudicials per a la societat, i s'haja d'esperar a la realització efectiva del dany per exercitar l'acció de responsabilitat i reparar un mal que va poder evitar-se".

A l'extrem oposat, l'assumpció de la no-impugnabilitat de "la decisió individual, interna i potser secreta, que pren l'administrador únic o solidari, o a l'acord, no subjecte a forma ni a publicitat, al qual poden arribar dos administradors conjunts o mancomunats" porta ÁvILA NAVARRO, P., La sociedad... op. cit., pàg. 550, a afirmar la no-impugnabilitat dels acords del consell per raó del seu contingut: si no són impugnables les decisions individuals o els acords de dos administradors mancomunats, "no es comprèn per què tenen que ser-ho els acords que el consell puga adoptar amb un contingut idèntic". Per això arriba a la conclusió que la impugnació d'acords del consell no es refereix al contingut de l'acord, sinó a la validesa de la seua adopció; és a dir, que només podran impugnar-se si no s'han complert els requisits legals o estatutaris per a la vàlida adopció de l'acord.

909

EMBID IRUJO, J. M., "Comentario al art. 70», op. cit., pàg. 741 i 742; JUSTE MENCtA, J., Los derechos de minoría..., op. cit., pàg. 394 i 395; NEILA NEILA, José M., "Impugnación de acuerdos del consejo de administración (Acerca del art. 143 del Texto Refundido L.S.A.», RDPri, maig
1991, pàg. 421 i 422.

${ }^{910} \mathrm{~S}$

fixació la possibilitat d'opció en la SA i en la SL mitjançant acord de la junta general o la seua 559 i 560 . estùria necessària, vegeu ESTEBAN VELASCO, G., "Algunas reflexiones...», op. cit., pàg. que es . En les cooperatives sembla possible una fórmula estatutària optativa, en la línia del necessiteveu en l'article 185.2 RRM per a les SSLL: la LCCV ni tan sols es refereix a la "els estat de regulació estatutària de l'òrgan no col-legiat d'administració; la LCoop indica que de ser ututs podran establir l'existència d'un administrador únic", però no assenyala que haja principi opció tancada, tal com s'exigeix per a les SA en l'article 124.1 RRM. Però a més, el flexibilitzar l'ta oberta i com a conseqüència, la variabilitat en el nombre de socis, fan necessari un augment opció respecte de l'estructura de l'òrgan administratiu; el contrari significaria que ugment dels socis a més de 10 obligaria a una reforma estatutària. 
òrgan unipersonal de l'entitat: la direccióo ${ }^{11}$. A aquests efectes, es consideraven els seus "actes i decisions" com a acords del consell rector. Certament, la LCCV no ha inclòs la menció a la impugnabilitat de les decisions de la direcció en el seu articulat i la LCoop tendeix a definir la figura com una relació extrasocietària de naturalesa laboral o professional112; però, alhora, en la legislació cooperativa vigent no hi ha una limitació expressa de la impugnació als acords dels òrgans col-legiats d'administració (en la línia del que s'estableix en l'article 143.1 LSA): regula únicament la impugnació dels acords del consell rector, però preveu la possible existència alternativa d'òrgans unipersonals (articles 32.1, 2n paràgraf LCoop i $37.2 \mathrm{LCCV}$ ) o pluripersonals no col-legiats (37.2 LCCV) als quals, fora d'això, la LCoop els atribueix "les competències $\mathrm{i}$ funcions previstes en aquesta Llei per al consell rector", i la LCCV els aplica "el règim previst per al consell rector". Tot això permet de sostenir, al nostre criteri, la impugnabilitat dels actes i de les decisions d'òrgans unipersonals o pluripersonals no col-legiats ${ }^{913}$.

$\mathrm{Si}$, com s'ha plantejat ${ }^{914}$, la impugnabilitat dels acords del consell d'administració s'explica per la presència de dues condicions, que són el caràcter permanent de l'estructura pluripersonal de l'òrgan i la col-legialitat com a principi de funcionament, no sembla que hi haja cap obstacle al

911 Com es veurà més endavant, es discuteix en la doctrina el caràcter d'òrgan de la direcció,i
és la tendència predominant en l'actualitat la que orienta la figura cap la seua consideració més
com relació laboral especial o de prestació de serveis. Tanmateix, en el context de la LGC de
1978 no hi havia dubtes: la direcció es regulava explícitament en diversos articles inclosos en el
capítol VI, titulat "dels òrgans de la societat", que exigia, a més, per a la seua existència en la
cooperativa la seua regulació estatutària.

912 En aquest sentit, EMBID IRUJO, J. M., "Comentario al artículo 143», op. cit., pàg. 1528, estima que la supresió en la LCoop de l'al-lusió anterior a la posibilitat d'impugnar els actes de la direcció ha d'interpretarse com que "només els acords del consell rector podràn ser impugnats judicialmente; els actes de l'administrador únic de la cooperativa, quan n'hi haja (...), quedaran, així com en la societat anònima, lliures d'aquesta posibilitat de control".

913 Tal és la solució adoptada per una de les últimes normes cooperatives autonòmiques, la LCA, que en l'article 63, en regular la figura de l'administrador únic, estableix que el seu règim serà el previst "en els arts. 57 a 62, ambdós inclusivament, d'aquesta Llei per al consell rector". L'article 62 LCA regula la impugnació dels acords del consell rector. 
reconeixement de la impugnabilitat dels acords adoptats per unanimitat pels òrgans pluripersonals "no col-legiats": aquest serà el cas, en la LCCV, dels dos administradors mancomunats o el dels supòsits en què els dos administradors solidaris prenguen les seues decisions de comú acord.

En efecte, si es defineix la col-legialitat com a transformació d'una "pluralitat de declaracions individuals, els vots dels socis individuals, en una nova voluntat unitària"1915, la unanimitat no és sinó el supòsit de col-legialitat més rigorós ${ }^{916}$, i

915 GALGANO, F., El negocio jurídico, op. cit., pàg. 238. Recull el concepte DIAZ DE LEZCANO SEVILLANO, N., Los acuerdos del consejo..., op. cit., pàg. 221 i 222.

916 En contra, encara que sense argumentar-ho, SÁNCHEZ CALERO, F., Administradores..., pàg. 537, definint l'acord com "acte col-legial, que com a tal, és un acte únic format per la fusió de les declaracions dels seus membres, sota el principi majoritari, i sempre que s'hagen produit seguint la normativa prevista per la Llei mateixa", i JUSTE MENCIA, J., Los derechos de minoría..., op. cit., pàg. 393, que, rebatent NEILA NEILA ("Impugnación...”, op. cit., pàg. 419 ), estima que la collegialitat "té a veure amb l'adopció del mètode que li dóna nom, i que generalment tindrà lloc en els òrgans que decideixen per majoria, i no per unanimitat". DIAZ DE LEZCANO SEVILLANO, N., Los acuerdos del consejo..., op. cit., pàg. 226 i 227, nota 680 , intenta diferenciar l'administració "conjunta i no col-legial o mancomunada" de la col-legial, atenent elements dispars: la mancomunada no és col-legial perquè requereix unanimitat, mentre que la col-legial "es basa al seguiment d'un procediment determinat per a la formació de la voluntat del conjunt de membres com voluntat unitària".

Sobre l'admissibilitat de supòsits en què es requerisca la unanimitat per a l'adopció d'acords, és fonamental el desenvolupament d'ASCARELLI, T., "Cooperativa e società. Concettualismo giuridico e magia delle parole», op. cit., pàg. 409 a 413: "El prejudici conceptual es presenta en la confrontació de la possibilitat mateixa en abstracte de poder deliberar vàlidament per unanimitat quan no podria estar adoptat l'acord per majoria. [...] en aquests casos ens trobem davant principis al compliment dels quals el soci pot renunciar, però que la majoria no pot derogar, $\mathrm{i}$ es pot per això dictar-se una disciplina diferent amb un acord unànime de tots els membres de la corporació. [...]. En l'àmbit mateix dels acords majoritaris, el nostre codi distingeix la majoria necessària a l'assemblea ordinària, de la necessària a l'assemblea extraordinària, [...]. I quina és la raó de la distinció?. Sempre una valoració diferent i una acomodació diversa entre els contrastats interessos dels que participen en la col-lectivitat. Quina és llavors la dificultat a admetre la possibilitat d'acords que no poden ser presos ni tan sols amb una majoria qualificada, però que es puguen amb el consens unànime? Probablement aquesta: considerar que estiga inclosa en el "concepte" d'acord la característica de la seua validesa encara que no es done la unanimitat. Amb la qual cosa, tanmateix, s'opera un canvi conceptual. [...] La doctrina combatuda [...] constata que el terme deliberacions és usat en els arts. 2363 i ss. per decisions que poden ser preses fins i tot sense unanimitat; d'això indueix que el "concepte» de deliberació inclou la possibilitat de decisions encara "sense unanimitat» (és el moment no pructiu del conceptualisme); i després dedueix d'aquest "concepte» que, per tant, la decisió prevt ser presa per unanimitat [...] La doctrina contrària es limita a afirmar que el codi no s'haja acords per unanimitat. Però, llavors, el problema és el de veure si de la no-previsió [...] permet (i gumentar una preclusió d'aquestes deliberacions [...] Si es té present que el codi legals (1 sense fixar límits) que el estatut mateix fixe quòrums o majories més elevades que les banda el i que per tant fixa en les majories legals un límit mínim, però no màxim; que d'altra denomin codi reconeix (en una argumentació doctrinal tradicional) que hi ha principis (altres els drets) que la majoria no pot derogar, però a l'aplicació dels quals el soci pot 
en el cas d'un òrgan bipersonal, l'única majoria possible ${ }^{917}$. En realitat, la col-legialitat no es refereix al nombre de vots personals que hagen de concórrer a la formació de la voluntat ${ }^{918}$, sinó a la "manera d'operar", al procés per a l'obtenció de $\mathrm{l}^{\prime}$ acord ${ }^{919}$ : convocatòria de tots els membres de l'òrgan en un

renunciar en el cas concret; que la diferència entre un acord unànime i una dissolució seguida d'una reconstitució no subsisteix en les relacions entre socis i que, en els casos en qüestió, aquella no és rellevant ni tan sols davant tercers (que fins i tot resulten en el primer cas més tutelats) o a l'ordre públic; llavors és lícit concloure que és més coherent amb el sistema legislatiu admetre la possibilitat dels acords per unanimitat, [...] que impedir-la i que la falta de previsió d'aquesta possibilitat en el codi és bastant més explicable pel caràcter relativament marginal dels casos en desenvolupament que amb un rebuig de tal possibilitat".

917 Un exemple d'això es troba en la LCoop mateixa, en l'article 26.6, on, en regular el dret de vot a les cooperatives de segon grau, es reconeix explícitament que si estigueren integrades únicament per dos socis, els acords hauran d'adoptar-se per unanimitat. A favor de la col-legialitat d'un òrgan constituït per dos socis, sempre que s'adopten els acords per
unanimitat, VICENT CHULIÁ, F., "La asamblea...», op. cit., pàg. 151 .

918 Si bé es basa en el principi majoritari per a l'adopció de l'acord, no n'exclou la majoria més radical, la unanimitat: si n'és suficient la majoria que en cada cas s'establisca, la unanimitat no
fa invàlid l'acord.

D'altra banda, en les societats de capital es donen supòsits en què en la junta general, amb la presència d'un sol soci, hi ha majoria suficient per adoptar acords, fet que li porta CARBAjo CASCÓN, F., Los requisitos..., op. cit., pàg. 9, partint del concepte "clàssic» de col-legialitat, a afirmar que en aquests casos "el caràcter col-legiat no és, per tant, dada essencial al concepte de junta general com òrgan, sinó element natural d'aquesta, ja que la junta englobarà normalment una pluralitat d'accionistes": "«la junta general de la societat anònima és, normalment, reunió d'accionistes però no essencialment [...]. La junta és més aviat una reunió de capital amb independència del nombre $d^{\prime}$ accionistes que el representen [...].» En conseqüència, la junta general "existeix com a tal i pot actuar regularment amb l'assistència d'un sol accionista que tinga la majoria de capital exigit per adoptar els acords de què es tracten (Uría/Menéndez/Muñoz Planas)".

919 ASCARELLI, T., "Cooperativa e società. Concettualismo giuridico e magia delle parole», op. cit., pàg. 413, nota 9: "el supòsit identificable com a «acord" es verifica quan diverses persones físiques expressen la seua pròpia voluntat en una determinada i comuna qualitat $i$ la voluntat així expressada està destinada a operar en l'àmbit dels interessos afectats per aquesta comuna qualitat dels subjectes. Entès així l'«acord" pot produir-se qualsevol que siga la "majoria" exigida $i$ així també en el cas límit de l'exigència de la unanimitat. Quina siga, doncs, la majoria demandada dependrà de la normativa que concerneix l'acord concret".; GIRÓN TENA, J., Derecho de sociedades, op. cit., t. I, pàg. 309: "el "acte col-legial». En aquests, allò peculiar és que la unificació es produeix mitjançant la configuració i l'activitat d'un «collegium». El propi d'aquest és que el que aparega com a voluntat unitària del col-legi, sent la dels seus components, s'obtinga mitjançant l'activitat cooperadora de tots ells. D'ací el "procediment»: convocatòria, reunió, deliberació, resolució o votació. A aquest grup solen pertànyer els anomenats "acords", segons la terminologia de la pràctica. Però hi ha acords sense forma col-legial, sense reunió en Junta". ESTEBAN VELASCO, G., "Algunas reflexiones...", op. cit., pàg. 561: "òrgan col-legiat (és a dir, mitjançant procediment formalitzat de convocatòria, reunió, deliberació, votació per majoria i documentació dels acords). En convertir en essencial la "deliberació" (és a dir, possibilitat de comunicació i discussió en un marc procedimentalitzat, que ha d'indicar-se en els estatuts) barra el pas a la possibilitat de l'adopció d'acords per escrit i sense sessió"; DfAZ DE LEZCANO Sevillano, N., Los acuerdos del consejo..., op. cit., pàg. 223, citant abundant doctrina, 
mateix lloc i amb un mateix ordre del dia, informació $\mathrm{i}$ intervenció en els debats, i votació. Davant del mètode col-legial d'adopció d'acords se situen els procediments d'adopció d'acords fora de la reunió del col·lectiu ${ }^{920}$.

Els dubtes més grans es produeixen, doncs, en relació amb les decisions i els actes de l'administrador únic o els de cada un dels administradors solidaris, per als quals alguns autors propugnen la substitució del procediment d'impugnació per l'aplicació del règim jurídic de la representació, ja que al-leguen com a principal fonamentació la dificultat de discernir en aquests casos entre la decisió i la seua execució ${ }^{921}$; segons aquestes tesis, se superaria la dificultat si s'obvia la nul-litat o anul-labilitat d'una decisió unipersonal per atendre els actes de la seua execució, com a vulnerants de la. relació de representació entre

espanyola i comparada: "El mètode col-legial implica una activitat unificadora dels diferents criteris personals que concorren a la reunió; per a això és imprescindible que tots els membres tinguen la possibilitat de participar en l'adopció de l'acord. La voluntat del col-lectiu només pot determinar-se d'acord amb el compliment de les formalitats establertes"; SORIA FERRANDO, J. V., La impugnación..., op. cit., pàg. 38, seguint VASELLI (Deliberazioni nulle $i$ annullabili delle società per azioni, Pàdua, 1948), entén per acte col-legial "l'acte únic format per la fusió de les declaracions dels membres d'un mateix òrgan", sense perjudici de que "en les deliberacions alguns socis poden ser contraris a la voluntat de la majoria".

920 Per al desenvolupament de la teoria de l'acte col-legial, vegeu GALGANO, F., El negocio jurídico, op. cit., epígraf 55 "Els modes de formació de l'acord i la teoria de l'acte col-legial", pàg. 240 a 248. SAlELLES CLIMENT, J. R., El funcionamiento..., op. cit. pàg. 77 i 78: “La col-legialitat com a principi de funcionament del Consell d'administració comporta almenys dos aspectes bàsics. D'una banda, suposa la participació de diversos membres en el procés d'adopció de decisions [...]. D'altra banda, implica el compliment d'un procediment formal que es caracteritza per requerir la convocatòria del Consell [...], l'existència d'un cert quòrum [...], la discussió dels temes que hi han de ser tractats, una majoria determinada per a l'adopció dels acords i una votació que expresse la voluntat dels seus membres [...], així com la tenedoria d'un llibre d'actes en què es faran constar les discussions i els acords del Consell", i en nota 153: "Allò peculiar de l'acte col-legial és que la voluntat es forma mitjançant l'activitat cooperadora dels membres del Consell intervenint-hi una certa organització", citant abundant doctrina espanyola i de dret comparat.

921 DE LA CÁMARA ÁlVAREZ, M., «La administración...», op. cit., pàg. 69; AlCALÁ DíAZ, M. A., La impugnación..., op. cit., pàg. 280, 281 i 379 i ss., si bé el plantejament el fa l'autora per als supòsits de conflicte d'interessos administrador-societat i la porta a plantejar que tant si es tracta d'òrgan unipersonal com de diversos administradors solidaris, l'exercici del poder de representació s'efectua sense un procés previ de formació de la voluntat orgànica", interpretació "també extensible a l'actuació de dos administradors mancomunats", per la qual cosa conclou que "el règim previst en l'article 143 LSA només podrà aplicar-se com a instrument de protecció de la societat en supòsits de conflictes d'interès administrador-societat, en els casos en què siga col-legial l'exercici del poder de representació, és a dir, en els supòsits de delegació a un comitè executiu amb funcionament col-legial. En els altres casos, serà d'aplicació el règim general de representació". 
administrador i persona jurídica ${ }^{922}$. Aquesta interpretació augmentaria la dissociació que el RRM (articles 124.2 i 185.3) estableix entre la titularitat del poder de representació i la del poder de gestió ${ }^{923}$ per a les diferents modalitats dels òrgans d'administració de la SA i la SL.

Tanmateix, això seguiria sense explicar per què en aquests supòsits es descarta la possibilitat d'impugnar les decisions de l'òrgan d'administració en favor d'un procediment menys ajustat a la seua naturalesa jurídica i l'aplicació del qual comportaria, per tant, un nivell més alt d'inseguretat jurídica. Com ja hem assenyalat, que el procés de formació de la voluntat als òrgans unipersonals s'exterioritze en molts casos mitjançant els actes de la seua execució no pot portar únicament a negar-ne l'existència: precisament, l'execució serà la millor prova que l'òrgan ha adoptat una decisió i la base sobre la qual ponderar si aquesta s'ajusta a la llei, als estatuts i a l'interès social.

Siga quina siga, l'estructura de l'òrgan d'administració té atribuïa l'anomenada "representació orgànica""924 de la persona jurídica, i això no

922 SAlELlES CLIMENT, J. R., El funcionamiento... op. cit., pàg. 398, encara que es refereix a kels membres individuals del Consell»: "si es tracta d'actes realitzats pels membres individuals del Consell és difícil distingir-hi entre fase de decisió i fase d'execució. I per això que en aquests casos siga més adequat aplicar el règim previst per a la representació". Tanmateix, com indica GIRÓN TENA, J., Derecho de sociedades, op. cit., tom I, pàg. 304, "els òrgans administratius desenvolupen una activitat interna que no és explicable pel concepte de representació".

923 ESTEBAN VELASCO, G., «Algunas reflexiones...», op. cit., pàg. 563.

924 GALGANO, F., El negocio jurídico, op. cit., capítol XI, secció III, "la representació orgànica", pàg. 403 a 426; DíEZ-PICAZO, Luis, La representación en el derecho privado, Civitas, Madrid, 1979, pàg. 70 a 74; GARRIGUES, J., Curs ..., op. cit., tom I, pàg. 485; RONCERO SÁNCHEZ, Antonio, Le representación del accionista en la Junta General de la Sociedad Anónima, Madrid, McGraw Hill, 1996, pàg. 86 i 87 , que cita també GIRÓN TENA, J, Derecho de sociedades, op. cit., tom I, pàg. 303 i ss., i a POLO, E., Los administradores..., op. cit., pàg. 143 a 145. MENÉNDEZ MENÉNDEZ, Aurelio, "Auxiliares del empresario", RDM, 1959, pàg. 278 i 279, nota 12, explica com que les persones que exerceixen la seua funció administrativa en qualitat d'òrgans d'una societat tenen la representació orgànica, que rep en alguns aspectes un tractament paral.lel al de la representació voluntària que posseeix el factor mercantil, però que es diferencien d'aquest auxiliar de l'empresari en el fet que la seua voluntat, en gran manera autònoma $i$ independent, val com a voluntat de la persona jurídica, i la seua posició en aquesta no és de subordinació sinó que s'identifica amb la del «principal». 
impedeix que l'acord del consell que s'extralimite o abuse ${ }^{925}$ de les seues funcions representatives puga, d'una banda, ser impugnat si pateix de causa de nul-litat o anul-labilitat, i d'una altra, donar lloc a l'acció de responsabilitat, tot això sense perjudici de la normativa específica dels límits de la representació social $^{926}$. Al nostre parer, segueixen sense haver raons consistents per no aplicar el mateix règim als acords $\mathrm{i}$ a les decisions d'altres modalitats d'òrgan $d^{\prime}{ }^{\prime}$ dministració ${ }^{27}$, règim que, recordeu, és més ajustat a la seua naturalesa jurídica i més complet que el de la representació en general ${ }^{928}$.

La nostra opinió en la matèria es decanta, doncs, per la impugnabilitat de les decisions adoptades pels òrgans unipersonals d'administració, i per les dels òrgans pluripersonals quan s'adopten de manera no col-legiada. Les causes de la impugnació es poden donar, tant en els acords collegiats, com en les decisions individuals, per la qual cosa es fa necessari afrontar-les en ambdós casos, i res no justifica que els instruments hagen de ser diferents. Les dificultats a l'hora de discernir entre declaració de voluntat i execució, o la mera prova de la seua existència, no es presenten de manera exclusiva en les formes «no col-legiades" de l'òrgan d'administració, i poden i han de ser evitades

925 Dfez-PICAZO, L., La representación..., op. cit., pàg. 198., qualifica d"“excés de poder el supòsit d'extralimitació dels termes de l'atribució del poder de representació i d'abús de poder la utilització del poder de representació en protecció d'interessos aliens als del poderdant" (ALCALÁ DÍAZ, M. A., La impugnación..., op. cit., pàg. 369).

926 Els arts. 129 LSA i 63 LSRL tenen el seu parangó en els arts. 32.1, 3r. paràgraf LCoop ("les facultats representatives del consell rector s'estenen a tots els actes relacionats amb les activitats que integren l'objecte social de la cooperativa, sense que tinguen efectes davant tercers les limitacions que, pel que fa a aquets, puguen contenir els estatuts") i 37.1, 2n paràgraf LCCV ("la representació s'estendrà a tots els actes compresos a l'objecte social. Qualsevol limitació de les facultats representatives dels administradors serà ineficaç davant tercers").

927

Sense que siga obstacle per a això que, com assenyala ALCALÁ DíAz, M. A., La impugnación...., op. cit., pàg. 366, puga distingir-se entre l'atribució de les competències de representació a l'òrgan i l'exercici del poder de representació pels membres de l'òrgan, cosa que possibilitaria l'aplicació de la normativa general sobre representació per a la solució de conflictes entre aquests últims i la persona jurídica. També es manifesta a favor de l'aplicació a l'actuació dels administradors de les normes relatives al mandat i a la comissió mercantil com a expressió de la relació de representació, LLEBOT MAJó, J. O., Los deberes..., op. cit., pàg. 46.

928 Sobre la manca en el dret espanyol d'obligacions i contractes d'un règim general sobre
representació, i sobre la manera de deduir-lo a partir de les concretes normes existents, vegeu el 
mitjançant l'adopció de les mesures de publicitat legals i estatutàries que es preveuen per a altres modalitats d'òrgan societari, si bé no s'ha d'ocultar la conveniència d'una explicitació eventual, de lege ferenda, de l'obligatorietat també per a les decisions individuals.

A més a més, en l'àmbit cooperatiu, com ja s'ha indicat, les normes legals no sols no impedeixen la impugnació de les decisions no col-legiades de l'organ d'administració, sinó que conviden a una interpretació extensiva de la impugnabilitat dels acords col-legiats: es propugna l'aplicació, en la mesura de le possibilitats, de les normes reguladores del consell rector a les restants modalitats d'òrgan d'administració permeses. La. interpretació restrictiva portaria, a més, a qüestionar què ha de fer-se en els supòsits legalment previstos d'"impugnació interna" davant de l'assemblea o del comitè de recursos quan s'opte per fórmules diferents a la del consel1 ${ }^{929}$.

\subsection{Acords de la comissió executiva i decisions dels consellers delegats}

$\mathrm{Ni}$ la major part de les normes legals cooperatives ni les de societats de capital es manifesten directament $i$ expressament sobre la possibilitat $d$ 'impugnar els acords o les decisions de qui actua en delegació de l'òrgan d'administració de la persona jurídica ${ }^{930}$. Tanmateix, com ja hem avançat, la doctrina entén que la referència de l'article 143 LSA a la impugnabilitat dels acords del consell

desenvolupament d'AlCALÁ DIAZ, M. A., La impugnación..., op. cit., pàg. 366 a 369, i pàg. 372.

929 Veure supra, en l'epígraf 2.2.1., els supòsits d'acords del consell rector per als quals es preveu la impugnació interna, com ara l'admissió o inadmissió de la sol-licitud d'ingrés (arts. 13.2 i .3 LCoop, i 15.2 LCCV); la denegació d'informació als socis (article 16.4 LCoop); la imposició de sanció, inclosa la sanció màxima, l'expulsió (arts. 18.3, c) LCoop, i 18.2 LCCV); la baixa obligatòria (17.5, 3 r LCoop); la qualificació i els efectes de la baixa (17.6 LCoop); i la liquidació de les aportacions al capital en cas de baixa (51.2 LCoop).

930 Les úniques excepcions les constitueixen l'article 49.1 LCPV: "Podran ser impugnats els acords del Consell Rector 0 de la Comissió Executiva en el seu cas "...; la LCG (article 52.1, 3 I paràgraf), que equipara "els acords dels consellers delegats" als adoptats pel consell rector, als efectes de la seua impugnació; i l'article 25.1 RCCred.: "Si l'estatut preveiera l'existència de comissions executives del consell rector [...] els acords d'aquestes seran impugnables partint de 
d'administració o de "qualsevol altre òrgan col-legiat" apunta fonamentalment a la comissió executiva que, quan s'escaiga, es nomene ${ }^{931}$.

En efecte, per a les societats de capital els articles 124 i 185 RRM estableixen un elenc tancat de modalitats d'òrgan administratiu: administrador únic, diversos administradors "que actuen solidàriament", dos administradors "que actuen conjuntament", o un consell d'administració; aquest últim, per la seua banda, pot designar una comissió executiva o un o més consellers delegats. Segons la tesi tradicional anteriorment ressenyada, en la qual la col-legialitat ha de referirse a l'adopció d'acords mitjançant el principi majoritari, però excloent-ne els òrgans que requerisquen unanimitat, l'única altra modalitat possible d'òrgan collegiat d'administració serà la comissió executiva, i per això es conclou que aquest és l'únic altre òrgan d'administració del qual pot predicar-se la impugnabilitat.

Però si hem admès que la col-legialitat és el procediment d'adopció d'acords en què intervenen, ordenadament, una pluralitat de persones, tan col-legiada serà la voluntat de la comissió executiva com la de diversos administradors "que actuen" mitjançant un procediment que els porte a una manifestació de la voluntat única.

En l'àmbit cooperatiu, ja hem vist que no existeix la referència/limitació de la impugnació a les modalitats col-legiades d'òrgan d'administració: els articles 37 LCoop i 41 LCCV només es refereixen a la impugnació dels acords del consell rector, però en algunes cooperatives es permet l'existència alternativa d'òrgans d'administració unipersonals o bipersonals als quals s'atribueixen "les competències i funcions" del consell (article 32.1, 2n paràgraf LCoop) o

les causes i pels subjectes legitimats que assenyala l'article 66 de la Llei 3/1987 [Impugnació dels acords del consell rector]".

931 Polo SÁNCHEZ, E., Los administradores..., op. cit., pàg. 527; SAlELleS CliMENT, J. R., El funcionamiento... op. cit., pàg. 396; SÁNCHEZ CALERO, F., Administradores..., pàg. 536; VICENT CHULIÁ, F., Compendio crítico..., op. cit., I, pàg. 676, i ARANGUREN URRIZA, F. J., «Los órganos de la sociedad anónima», op. cit., pàg. 554. 
expressament el seu règim de funcionament (37.2 LCCV). Això obri la
possibilitat de plantejar l'extensió de la impugnació a altres òrgans de gestió
d'administració d'administració i així ho hem defensat supra, tant per als acords mancomunats, com per a les decisions de les modalitats unipersonals o pluripersonals solidàries de l'òrgan d'administració cooperatiu. Ara es tracta de determinar si els acords o les decisions adoptats per la comissió executiva o el conseller delegat de la cooperativa també poden ser impugnats.

Pel que fa a la naturalesa de la relació jurídica entre el consell i la comissió executiva o el conseller delegat, no sembla haver-hi dubtes: es tracta d'una delegació de facultats que originàriament corresponen al consell, però aquest decideix encomanar-ne a alguns dels seus membres $1^{\prime}$ exercici ${ }^{932}$, sense perjudici de conservar la competència i també la responsabilitat de la gestió duta a terme pels delegats ${ }^{933}$. La naturalesa subordinada ${ }^{934}$ de la relació (nomenament i

932 Noteu, tanmateix, que la LCoop, amb una menció excessivament parca de la delegació, no requereix expressament la qualitat de membre del consell a qui l'exercisca, si bé la inclou en l'article 36, que regula el funcionament del consell, i la denominació mateixa del "conseller" delegat sembla estar indicant la procedència de qui actuarà individualment.

933 La LCCV (article 43) estableix expressament que "en tot cas, el consell rector continua sent competent respecte de les facultats delegades, i responsable davant de la cooperativa, els socis i els tercers, de la gestió duta a terme pels consellers delegats i la comissió executiva"; per a la LCoop, el manteniment de la competència i de la responsabilitat ha de deduir-se de la remissí que l'article 43 LCoop fa al règim de responsabilitat dels administradors de societats anònimes. Sobre la delegació en la LSA, ESTEBAN VELASCO, G., "Configuración estatutaria...», op. cit., pàg. 370: "La delegació altera parcialment el contingut de l'obligació d'administrar dels administradors no delegats (transformant-la realment, en condicions normals, en relació amb l'àmbit delegat, en una obligació de control de l'administració), però continuen sent administradors i responen per la falta de control i/o no-adopció de les mesures convenients per evitar el dany [...]. De la naturalesa de la delegació $i$ del règim de responsabilitat es desprèn que, d'acord la doctrina majoritària, la delegació no priva el Consell de les seues facultats d'administració, sinó que, al contrari: a) conserva competència concurrent amb la de l'organ o dels òrgans delegats; $b$ ) pot substituir-los en el compliment dels actes compresos en les funcions delegades; c) té la facultat de modificar o revocar (abans de la seua conclusió) els actes dels administradors delegats; d) donar instruccions $\mathrm{i} e$ ), llevat que hi haja condicionaments estatutaris en els termes que veurem, revocar els administradors i suprimir la delegació o modificar-ne el contingut. En la mateixa línia, RODRíGUEZ ARTIGAS, Fernando, "La delegación de facultades del consejo de administración de la sociedad anónima. Ejercicio y contenido de la facultad de delegar y estatuto de los titulares de los cargos delegados", RdS, núm. 1, 1993, pàg. 95: "si el Consell en ple és responsable, en els termes dels articles 133 i següents, de l'administració de la societat en el seu conjunt, no pot ser privat de les competències atribuides als delegats com a conseqüència lògica de l'equació responsabilitat/poder". 
revocació ad nutum ${ }^{935}$ ) unida a la inexistència $\mathrm{d}^{\prime \prime \prime}$ una esfera autònoma i diferent de competències exclusives" ha portat algun autor a negar el caràcter d'òrgan del delegat ${ }^{936}$. Si s'accepta aquesta interpretació, podria qüestionar-se la impugnabilitat de les manifestacions de voluntat de qui no actuaria funcions pròpies, sinó les del qui delega, en virtut d'un negoci de mandat.

Per la nostra part, subscrivim la tesi que el concepte d'òrgan social inclou tots els que "tenen el poder de realitzar actes jurídics vinculants" ${ }^{1937}$ per a la persona jurídica, siguen interns o externs, i, des d'aquesta perspectiva, no dubtem de la qualitat orgànica dels delegats. Aquests, a més, no exerciten competències alienes, sinó compartides, 0 "concurrents" ${ }^{\prime 938}$, per mandat legal exprés ${ }^{939}$. S'ha

934 SANCHEZ CALERO, F., Administradores..., P. 450.

935 EMBID IRUJo, José Miguel, «Revocación de un consejero delegado en una sociedad anónima.Comentario a la STS (Sala 1a) de 30 de diciembre de 1992», La Ley, 2.9.1993, pàg. 2: "relació ad nutum entre el consell d'administració i l'administrador delegat, "sotmesa al principi de revocabilitat ad nutum [...] no només en tant que es concep com una facultat exercitable ad nutum [...], sinó així mateix perquè la lliure decisió [...] no és coartada per lexigència de quòrum o majories especials, ni penalitzada sota la forma d'una indemnització a l'administrador separat [...] tal principi s'emmarca en la regla genèrica de l'autonomia privada, segons la qual el despreniment de la gestió dels propis interessos no implica que es perda la competència per organitzar-la com millor convinga".

936 DíaZ De LeZCANO SEVILlanO, N., Los acuerdos del consejo..., op. cit., pàg. 218 i 219: “... no és possible constituir un Consell d'Administració totalment desproveït de facultats de decisió, i recalcar l'obligació que tenen tots els seus membres de respondre solidàriament, tant els consellers que hagueren realitzat competències de gestió, com aquells que realitzen exclusivament competències de control, ja que aquests últims no estarien exclosos de responsabilitat segons l'article 133.1 de la LSA, aleshores no es pot parlar d'òrgans diferents si no hi ha competències diferenciades"; contràriament, a favor de la qualitat de funció orgànica, ESTEBAN VELASCO, G., "Algunas reflexiones...», op. cit., pàg. 558. També distingeix el procediment de delegació del d'apoderament, RODRÍGUEZ ARTIGAS, Fernando, «Notas sobre el régimen jurídico del Director general de la S. A.», en AA. DD., Estudios jurídicos en homenaje a Joaquín Garrigues, Tecnos, Madrid, 1971, pàg. 118, i manté el caràcter orgànic dels delegats en "La delegación...", op. cit., pàg. 95.

937 Git., pàg. 155.
cino, El negocio jurídico, op. cit., pàg. 403; VICENT CHULIÁ, F., «La asamblea...», op.

938

del SCORDINO, F., La società cooperativa, op. cit., pàg. 349: “la delegació no limita la competència sempre d, sinó que crea una competència concurrent cumulativa, en el sentit que el consell pot Tambe deliberar sobre totes les matèries de la seua competència, fins i tot les delegades". VELASCS refereix a les competències concurrents del consell $i$ dels òrgans delegats ESTEBAN linia do, G., "Configuración estatutaria...", op. cit., pàg. 370, que, això no obstant, indica una doctrinal divergent, que considera que es produeix la separació de competències "una 
d'afegir, en definitiva, el reconeixement exprés que efectua l'article 149.3 RRM del caràcter orgànic dels delegats.

La comissió executiva i el conseller delegat són, doncs, òrgans socials perquè en l'exercici de les seues competències realitzen actes jurídics vinculants per a la cooperativa. En la mesura que les seues manifestacions de voluntat tendents a l'actuació de les seues competències (siguen acords, majoritaris o unànimes, 0 decisions individuals) vulneren la llei o els estatuts socials o lesionen els interessos de la cooperativa en benefici extrasocial, ha d'arbitrar-se un procediment per a la seua eliminació possible, i també aquí sembla més ajustat el règim d'impugnació dels acords dels òrgans socials que el d'incompliment d'una relació negocial.

\subsubsection{Acords de la comissió executiva}

Ja hem reiterat l'acceptació majoritària per la doctrina de la impugnabilitat dels acords de la comissió executiva, en virtut de la referència que l'article 143 LSA fa als "òrgans col-legiats" ${ }^{\prime 941}$. Tanmateix, tret d'allò que preveu l'article 25

vegada nomenada la comissió executiva o el conseller delegat", amb la qual cosa "el Consell no podrà immiscir-se en la gestió de l'una o de l'altre ni dur a terme actes, prescindint d'aquells, dels compresos en la delegació. Subsistiria és clar la possibilitat de recuperar aquestes facultats sense més que revocar la delegació. Amb això s'aproximaria la figura del consell d'administració a la de l'anomenat en altres legislacions consell de vigilància encara que tampoc se'n donara una identificació plena i justa » [CÁMARA-LORA-TAMAYO-BOLA, La representació orgànica, 154]".

939 ESTEBAN VELASCO, G., "Configuración estatutaria...», op. cit., pàg. 371; RODRfGUEZ ARTIGAS, Fernando, Consejeros delegados, comisiones ejecutivas y consejos de administración, Montecorvo, Madrid, 1971, pàg. 191. En contra, IGLESIAS PRADA, Juan Luis, Administración y delegación de facultades en la sociedad anónima, Tecnos, Madrid, 1971, pàg. 139 i ss.).

940 Article 149.3 RRM: “L'àmbit del poder de representació dels òrgans delegats serà sempre el que determina l'article 129 de la LSA en relació amb els administradors" 
RCCred. per a les cooperatives de crèdit, no hem trobat cap norma que explicite l'obligatorietat del funcionament col-legial de la comissió ${ }^{942}$.

També s'ha justificat l'admissibilitat de la impugnació, davant de la proposta de rebuig per als acords d'altres comissions, en la seua vocació de permanència en l'exercici de la descentralització administrativa ${ }^{943}$. Aquest és un argument poc solid, ja que, d'una banda, no pot excloure's la possibilitat de crear altres comissions delegades amb una durada indefinida o amb un termini de vigència dilatat, l'activitat de les quals, merament consultiva o assessora, no donaria lloc a "activitat orgànica" en el sentit apuntat, i, de l'altra, com ja s'ha apuntat, el consell compta amb la possibilitat de revocació ad nutum de la delegació, amb la qual cosa la qualitat de permanència es relativitza ${ }^{944}$.

Per la nostra part, reiterem la tesi que justifica la impugnabilitat de les manifestacions de voluntat dels òrgans socials no en aspectes accessoris, sinó en la seua contrarietat a la llei, als estatuts socials o als interessos socials. Els acords o decisions jurídicament rellevants per a l'entitat han de poder ser eliminats quan incorren en les causes de nul-litat $i$ anul-labilitat, amb independència de l'organ del qual provinguen; el cas contrari permetria eludir el control social i optar per estructures orgàniques que incloguen òrgans no sotmesos a la impugnació.

$942 \mathrm{Ni}$ els arts. 143 LSA, 124, 149 i ss. RRM i 57 LSRL, ni els arts. 36 LCoop i 43 LCCV es refereixen al funcionament necessàriament col-legiat de la comissió executiva. Únicament la LCPV, en l'article 49.1 ja esmentat, es refereix als acords de la comissió executiva.

943 SALELLES Climent, J. R., El funcionamiento... op. cit., pàg. 396-398.

944 RODŔ́GUEZ ARTIGAS, F., «La delegación...», op. cit., pàg. 97, explica la «delegació permanents d'alguna facultat del consell com a "figura que es caracteritza no tant per la temporalitat [...], com per les dades de continuïtat, estabilitat $i$ autonomia [...] com assenyala IGLESIAS PRADA ( Administración, pàg. 159), només la permanència entesa així permet que la delegació siga font de relacions orgàniques $i$ tipificadora d'un òrgan delegat". Efectivament, la permanència entesa com a continuïtat, estabilitat $i$ autonomia, forma part dels requisits necessaris per considerar com òrgan social una forma d'organització determinada, però, al nostre parer $i$ com hem reiterat repetidament, la qualitat essencial ha de ser la de produir efectes d'un òrgan rants per a la persona jurídica. En la mesura que això es produïsca, estarem davant voluntat social i s'hauria de preveure la possibilitat d'impugnar les seues manifestacions de oluntat quan vulneren la llei o els estatuts, o lesionen els interessos socials. 


\subsubsection{Decisions dels consellers delegats}

La principal objecció que es planteja respecte a la impugnabilitat de les decisions dels consellers delegats és el caràcter no col-legiat de l'òrgan. Poden repetir-se ací les observacions fetes supra ${ }^{945}$ per a les modalitats d'òrgan d'administració diferents al consell rector.

D'una bana, no hi ha res que impedisca, en l'àmbit de la LCoop (la LCCV només permet la delegació en un conseller delegat o en una comissió executiva), que s'opte per fórmules de delegació en diversos consellers que hagen d'actuar mancomunadament. Per a aquestes fórmules, reiterem la nostra convicció que la unanimitat no és sinó l'expressió més rigorosa del principi de majoria, almenys a l'efecte de considerar l'òrgan com a col-legial. La col-legialitat, com ja s'ha argumentat, es refereix al procés de formació de la voluntat en el qual han de confluir diferents voluntats individuals per formar-ne una d'única $i$ això és el que, d'una manera o d'una altra, haurà de produir-se per reunir, d'altra banda, l'única majoria possible quan siguen dos els consellers delegats mancomunats.

Respecte als supòsits d'un únic conseller delegat o de diversos que actuen solidàriament, també són predicables els arguments apuntats per a les formes unipersonals o pluripersonals solidàries de l'òrgan administratiu. En síntesi, l'argument nuclear és que les causes de la impugnació (contrarietat a la llei o als estatuts o lesió de l'interès de la cooperativa en benefici extrasocial) es poden donar tant en els acords col-legiats com en les decisions individuals, per la qual cosa es fa necessari afrontar-les en ambdós casos, i res no justifica que els instruments hagen de ser diferents. Les dificultats a l'hora de discernir entre declaració de voluntat i execució, o la mera prova de la seua existència (que, 
d'altra banda no es donen en exclusiva en les formes "no col-legiades" dels organs socials) poden $i$ han de ser evitades mitjançant l'adopció de les mesures de publicitat legals $i$ estatutàries que es preveuen per a altres òrgans societaris. A més, a diferència de l'opció seguida en altres aspectes en el sentit d'imitar la regulació de les societats anònimes, en l'àmbit cooperatiu, les normes legals no sols no impedeixen la impugnació de les decisions no col-legiades de l'òrgan d'administració, sinó que conviden a una interpretació extensiva de la impugnabilitat dels acords col-legiats a les restants modalitats d'òrgan d’administració.

25. Actes i decisions de la direcció

Tret d'algunes excepcions notables ${ }^{946}$, l'organització de la direcció com a instància independent de l'òrgan d'administració d'una persona jurídica amb activitat econòmica, no ha estat objecte d'estudi detallat per part de la doctrina juridicomercantil, per la qual cosa, a diferència dels aspectes laborals, els seus contorns societaris no acaben $d^{\prime}$ estar prou delimitats ${ }^{947}$.

D'entrada, la naturalesa contractual de la relació que uneix la direcció amb l'entitat dirigida i de l'apoderament mercantil en el qual es plasma l'atribució

945 Vegeu l'epígraf 2.3. d'aquest mateix capítol.

946 EMBID IRUJO, J. M., «Revocación...», op. cit., pàg. 1 i 2; GARRIGUES, J., Comentario..., op. cit., pàg. 146; MENÉNDEZ MENÉNDEZ, A., "Auxiliares del empresario», op. cit., pàg. 269 a 305; RODRIGUEZ ARTIGAS, F., «Notas sobre...», op. cit., pàg. 113 a 139.

947 A això s'afegeix, com indica RodríGUEZ ARTIGAS, F., «Notas sobre...», op. cit., en pàg. 116, que "el silenci - justificat o no- de la LSA sobre aquest punt dificulta extraordinàriament la tasca de perfilar la figura del Director general i obliga a acudir a altres normes de l'ordenament dins de les quals es puga subsumir aquesta figura a.l'objecte d'integrar el seu règim jurídic. I fins i tot així, aquest recurs no resulta satisfactori més que des d'un punt de vista juridicoformal, ja que la figura del Director general transcendeix la realitat que el legislador ha pretès regular amb altres normes i davant la qual el Director general presenta diferències acusades, no només d'indole quantitativa, sinó fins i tot qualitativa. D'ací la necessitat d'utilitzar amb cura els instruments analògics sense perdre en cap moment de vista els trets que en la realitat viva de les societats anònimes presenten els Directors generals". 
de les seues funcions, ha fet que alguns autors qüestionen el caràcter d'òrgan de la persona jurídica, tant en l'àmbit de les societats capitalistes, com en el de les cooperatives, i això malgrat el fet que, en aquest últim, el Reglament de desenvolupament de la LGC de 1974 establia l'obligatorietat de designació "d'un òrgan de direcció, unipersonal o col-legiat" en determinats tipus de cooperatives $^{948}$; altres opinions, tanmateix, assumeixen la seua naturalesa

948 Article 47.2 del Reglament, aprovat per RD 2710/1978; també l'Exposició de motius de la Llei 52/1974 es refereix a la direcció com a òrgan.

GARRIDO DE PALMA, V. M., «La cooperativa...», op. cit., pàg. 37: "la figura del Director apareix desdibuixada en la Llei: a diferència del projecte de Llei, en la qual aquest era l'òrgan de gestí́ $\mathrm{i}$ representació permanent de la Cooperativa, la figura que plasma la Llei i el Reglament apareix supeditada al Consell Rector; aquell ha d'actuar sempre "sota el control directe d'aquest, i és el Consell Rector [...] l'únic òrgan gestor de l'Empresa Cooperativa, sent , per tant, el director quan hi ha un contractat aliè a la societat; donant lloc la regulació definitiva "a un confusionisme estèril", diga el que vulga l'Exposició de Motius de la Llei"; MONTOLfo HERNÁNDEZ, J. M, "Consejo rector y dirección ...», op. cit., pàg. 129 i 130, comentant el Reglament, indica la seua postura contrària a la seua consideració com a òrgan societari, i el qualifica de servei gerencial contractat, ja siga potestativament, ja siga obligatòriament en els supòsits en que aix́ era imposat per la normativa: "Si es vol és, sens dubte, un servei dotat d'un reconeixement legal especial, possiblement per la seua repercussió en la vida de la Cooperativa, però no ens sembla que passe d'una funció no estructural a l'empara d'un arrendament de servei previsiblement moltes vegades de net caràcter laboral [(22) ... Això no obstant, no pot ocultar-se ni és el nostre propòsit que l'article $47.2 \mathrm{n}$ del Reglament expressament cita "òrgan de caràcter tècrnic, responsable $\mathrm{i}$ de funcionament continu». Ens permetem, això no obstant, posar en dubte la precisió conceptual d'aquella terminologia]. [...] Així mateix, s'ha de tenir en compte que la direcció no podria tenir altres facultats que les pròpies de gestió relatives al gir o el tràfic normal de l'empresa $i$ altres actuacions que la interessaren, sense demèrit de les competències pròpies del Consell rector $\mathrm{i}$ dins sempre de les facultats $\mathrm{i}$ poders [...] que li hagueren estat conferits. No entenem en això una delegació de facultats interorgànica o constitució d'una estructura, a tall d'òrgan, dins d'una persona jurídica, sinó la plasmació d'un contingut obligacional de caràcter contractual". També neguen la qualificació d’òrgan a la direcció en virtut del seu caràcter d'apoderat general, BORJABAD GONZALO, P., Manual ..., op. cit., pàg. 115; CUÑAT EDO, V., "Consideraciones generales...», op. cit., pàg. 141; GADEA, E., Evolución de la legislación..., op. cit., pàg. 112 i 116; MARÍN LÓPEZ, J. J., «Novedades...», op. cit., pàg. 1122; i VICENT CHULIÁ, F., en PAZ CANALEJO, N., i VICENT CHULIÁ, F., Ley general..., op. cit., pàg. 857.

RODRf́GUEZ, M. P., i SUSO, J. M., «Los órganos de la cooperativa», op. cit. , pàg. 174, en relacío amb la figura prevista en el derogat article 42 de la Llei de cooperatives del País Basc del 1982, amb la figura prevista en el derogat article 42 de la Llei de cooperatives del Pais Bare
indiquen que el seu "caràcter orgànic era molt discutible i confús". PANIAGUA ZURER,
reforma de la legislación..., op. cit., pàg. $70 \mathrm{i} 71$, en relació amb el llavors Projecte de la LSCA: "El PLCA la legislación..., op. cit., pag. social? Sota laclareix què és la direcció, és a dir, es tra a la figura de l'òrgan social si atenem la forma de delimitació de les seues competències [...]. El PLSCA es mou en la indecisió [...]. La impressió general és que [...] estem davant d'un apoderat voluntari, normalment de caràcter general. Això no obstant, el Projecte [...] estén als membres de la direcció totes les disposicions comunes al Consell Rector i Interventors [...] aquesta remissió in totum no contribueix a aclarir la configuració jurídica dels membres de la direcció". 
orgànica $^{949}$, almenys en els supòsits en què la designació siga obligatòria ${ }^{950} \mathrm{o}$ la figura estiga regulada en els estatuts socials ${ }^{951}$.

Al nostre parer, la circumstància que no siga la relació soci-societat la que caracteritze el vincle entre direcció i cooperativa no és un argument suficient per descartar la seua qualificació com a òrgan: la legislació cooperativa, com que segueix els passos de la de societats de capital, admet, cada vegada més sovint, que els membres d'òrgans socials poden ser persones no sòcies ${ }^{952} i$, d'altra banda, excepte en els supòsits d'incompatibilitat entre càrrecs, res no

949 MONGE GIL, A. L., "Algunas reflexiones...», op. cit., pàg. 744 i 747, sembla que es decanta per aquesta qualificació, en incloure la direcció entre els òrgans regulats en la LCA, amb caràcter "unipersonal o col-legiat". També implícitament, GARRIDO DE PALMA, V. M., «La cooperativa...", op. cit., pàg. 37; i SUSO VIDAL, José M., "Funcionamiento orgánico de las cooperativas", en Anuario de estudios cooperativos 1987, Instituto de Estudios Cooperativos, Universidad de Deusto, Bilbao, 1987, pàg. 46, 58 i 59 , encara que dubta de la caracterització per la qual opta la norma (en aquest cas, la LCPV de 1982).

950 VICENT CHULIÁ, F., en «Los órganos sociales...», op. cit., pàg. 494, 495, 499 i 500, analitza l'obligatorietat de l'òrgan que s'establia al Reglament d'aplicació de la LGC de 1974. CoZIAN, M., VIANDIER, A., i DEBOISSY, FL., Droit des sociétés, op. cit., pàg. 240 i 241, comentant la figura peculiar del Président-Directeur Général que és "alhora president del consell d'administració $\mathrm{i}$ director general de la societat", assenyalen les dificultats de la seua qualificació jurídica: "Es respon, referint-se a la naturalesa institucional de la SA, que és un òrgan de la societat, fet que testifica que els seus poders depenen de la llei i no d'un mandat conferit pels accionistes; [...]. Si es tracta, per contra, de relacions amb els accionistes, se'l continua qualificant de mandatari social per justificar-ne la revocabilitat i la responsabilitat". També el qualifica d'òrgan JEANTIN, M., Droit des sociétés, op. cit., pàg. 268.

951 STS, Sala 1a, de 20.10.1998, núm. 944/1998, RJA 1998/8229: “Quan el càrrec de directorgerent està previst i regulat en els estatuts socials de la societat anònima respectiva, aquest és considerat com un òrgan d'administració, segons ja va declarar aquesta Sala en S. 30.Abr.1971. D'altra banda, és també doctrina reiterada i uniforme d'aquesta Sala, proclamada en interpretar l'article 75 anterior LSA de 17.07.1951, el precepte del qual té exactament el mateix contingut normatiu que l'article 131 de la Llei vigent, que la junta pot acordar en qualsevol moment la cessació dels administradors, encara que això no s'haguera inclòs en l'ordre del dia de la convocatòria. Atès que el director-gerent estatutari és un òrgan d'administració, segons que hem dit anteriorment, és evident que a l'acord de cessació d'aquest li és aplicable la doctrina d'aquesta sala abans expressada".

952 "menta, R., MENÉNDEZ, A., i VERGEZ, M., «Sociedades cooperativas», op. cit., pàg. 1291: a la societlei de 1987 no excloïa una gestió tècnica i professionalitzada, per qui no pertanyera cooperativat (admetent que es poguera encomanar la direcció personalitzada de l'empresa empresativa a un Director o Gerent les facultats del qual només podrien abastar el tràfic nomenarial ordinari); la Llei actual va més enllà i reconeix que els Estatuts podran admetre el condició dent com a consellers de persones qualificades i experts encara que no tinguen la ndició de socis". 
impedeix que la direcció siga ocupada per una persona sòcia ${ }^{953}$. D'altra banda, hi ha la possibilitat que la direcció siga un òrgan pluripersonal ${ }^{954}$ i fins i tot, com $\mathrm{s}^{\prime}$ ha assenyalat, col-legiat ${ }^{955}$.

Si seguim el fil argumental desenvolupat fins ara, l'element determinant del caràcter d'òrgan hauria de situar-se en l'atribució de competències pròpies, en l'actuació de les quals els titulars del càrrec produïsquen efectes de transcendència jurídica per a l'entitat. En aquesta matèria, la direcció és objecte d'una atribució competencial peculiar: se li encomana la representació de la cooperativa en les tasques de gestió ordinària (articles 32.3 LCoop i 43.4 LCCV). Aquesta funció originàriament és atribuïda a l'òrgan d'administració. D’aquesta circumstància i de la similitud de les seues característiques es podria derivar la qualificació de les facultats de la direcció com a competències delegades; en aquest cas, s'hauria de concloure també que "el consell rector continua sent

953 És, per contra, una realitat molt estesa, per exemple, entre les cooperatives de treball associat de petita i mitjana grandària, que la direcció siga assumida per un dels socis, o que qui accedeix al càrrec en virtut d'una relació inicialment laboral siga aviat convidat a assumir la relació societària, com a prova d'una integració més plena en el projecte empresarial cooperatiu.

954 L'article 9.7 LCCred. Estableix que "la direcció de la cooperativa de crèdit serà exercida per un o més directors generals"; l'article 41.6 LCPV reconeix expressament la possibilitat que el consell rector conferisca apoderaments generals "a un o diversos directors-gerents"; l'article 44.1 LCC es refereix a la possibilitat que l'assemblea instituïsca "una gerència o direcció encarregada de la gestió ordinària", que serà obligatòria en les cooperatives de crèdit i en les que compten amb secció de crèdit; l'article 64 LCA estableix que "els estatuts podran preveure l'establiment d'una direcció integrada per una o diverses persones"; 1'article 39 LFCN, després de regular en l'apartat 1 la possibilitat que el consell rector nomene un director, dedica l'apartat 2 a possibilitar que en les cooperatives de segon o ulterior grau s'establisca "un consell de directors o "gerents que en cap cas" podrà assumir les facultats no delegables d'altres òrgans".

955 L'article $27.12 n$ paràgraf RCCréd. exigeix per a les cooperatives de crèdit que, "quan els directors foren dos o més", els estatuts determinen si la seua actuació ha de ser individual, conjunta o col-legiada. VICENT CHULIÁ, F., «El derecho de los órganos...», op. cit., pàg. 580, en relació amb el Reglament de 1978 assenyalava com el text normatiu mateix "parla de "Direccio" i de "membres de la direcció" i la configura facultativament, no creiem que necessàriament, com a col-legiada", encara que "no diu res [...] respecte al funcionament de la direcció, en el cas de ser col-lectiva". Posteriorment, ja vigent la LGC de 1987, BORJABAD GONZALO, P., Manual ..., op. cit., pàg. 115: "de l'article 60 de la Llei general, així com dels que hi concorden, sembla deduir-se que en l'esperit de la normativa subjau la idea que el director siga una persona física, però és ben cert que no ho preceptua en cap moment, per la qual cosa bé podria, en $110 c$ de Director, organitzar-se una Direcció, pluripersonal, col-legiada", i cita a l'efecte la STS dos 29.11.1990 [RJA 1990/8498]. És de la mateixa opinió DíaZ DE LEZCANO SEVILLANO, N., Lo acuerdos del consejo..., op. cit., pàg. 45, nota 60 . 
competent respecte de les facultats delegades i responsable davant de la cooperativa, els socis i els tercers, de la gestió duta a terme ${ }^{\prime \prime 956}$. Tanmateix, altres trets podrien contradir aquesta interpretació: és el cas dels supòsits en què I'"activació" del càrrec és obligatòria per al consell, per mandat legal o estatutari; o, en la LCCV, 'bicació sistemàtica mateixa, diferenciada de les facultats delegades ${ }^{957}$.

En l'àmbit de les societats de capital s'ha plantejat l'existència de dos procediments diferents per articular la descentralització de funcions de l'òrgan administratiu: la delegació, que donarà lloc a la creació de les figures del conseller delegat i de la comissió executiva, i l'apoderament, que és el que dóna vida a una àmplia gamma de figures que van des de la de la direcció general fins a la del simple apoderat particular ${ }^{958}$. En ambdós procediments es produeix l'atribució a determinades persones $\mathrm{d}^{\prime}$ "una esfera de competència integrada per funcions que en principi corresponen a l'òrgan administratiu en sentit estricte", però mentre que no es qüestiona el caràcter d'òrgan (ni sempre la impugnabilitat dels acords o decisions) de les figures creades mitjançant delegació, la figura de la direcció planteja molts més dubtes, sobretot quan se l'enquadra, amb totes les excepcions i especialitats que es vulga, en el règim

956 Article 43.3 LCCV. En el cas de la LCoop, el manteniment de la competència i de la responsabilitat per part del consell rector es deriva, al nostre parer, del fet que es tracta de facultats pròpies que el consell decideix o no atribuir a altres, així com la seua revocació, per la qual cosa una reclamació eventual sobre el mal ús de tals facultats es dirigirà, en tot cas, al consell.

${ }^{957}$ Encara que la LCCV destina un únic article, el 43, a la delegació de facultats i a la designació de direcció, les regula separadament, i detina els apartats 1,2 i 3 a les facultats delegades, el 4 a la direcció, i el 5 als supòsits de designació obligatòria d'un "gestor de dedicació permanent", amb caràcter bé de conseller delegat, bé de director. Això no obstant, són innegables uns trets comuns a ambdues figures, entre les quals les facultats atribuibles mateixes, relatives en ambdós casos al tràfic empresarial.

958

RODRigueZ ARTIGAS, F., "Notas sobre...", op. cit., pàg. 118; sobre els diferents supòsits d'apoderament mercantil a favor dels anomenats "auxiliars de l'empresari", vegeu MENÉNDEZ MENÉNDEZ, A., "Auxiliares del empresario", op. cit. 
dels "auxiliars de l'empresari", i se la sotmet per tant a una relació subordinació respecte d'aquest ${ }^{959}$.

En tot cas, una anàlisi detallada de la qüestió ultrapassa l'àmbit del nostre estudi, i l'aspecte que ara ens interessa és si les facultats pròpies de la direcció es veurien menyscabades pel fet de ser compartides o controlades pel consell rector, fins al punt de negar a la direcció la qualitat d'òrgan independent. Pel que s'ha dit anteriorment, no sembla ser el cas per a les competències de la comissió executiva o del conseller delegat. El fet que el consell rector mantinga o controle competències atribuïdes a un altre òrgan no impedeix a aquest la seua consideració com a òrgan.

La nostra opinió és que la transcendència de les competències atribuïdes, que inclouen la representació externa de la cooperativa en assumptes de gestió, amb efectes davant de tercers ${ }^{960}$, i l'àmplia disposició sobre els recursos personals ${ }^{961} \mathrm{i}$

959 RODRíGUEZ ARTIGAS, F., "Notas sobre...», op. cit., pàg. 118 i 128: "Tanmateix, a la pràctica aquesta relació de subordinació queda considerablement desdibuixada i, amb aquesta, la funció de control que, en les seues diferents manifestacions correspon a l'òrgan administratiu. No es pot desconèixer referent a això que el director general és, normalment, una persona enterament dedicada a la societat i dotada a més d'amplis coneixements per a l'exercici de la seua funció [...] al contrari, els administradors [...] es reuneixen molt esporàdicament $i$, en general, no tenen els coneixements necessaris per fiscalitzar la tasca d'un Director general. Per això no resulta arriscat afirmar que, excepte en comptades ocasions d'importància excepcional, el Consell es limitarà a ratificar l'actuació del Director general, que a més haurà participat activament, per raó de la seua experiència i dels seus coneixements, en l'elaboració de la política general de la societat $i$ dels plans de gestió, la qual cosa disminueix encara més les distàncies que teòricament poden haver-hi entre ambdós nivells de l'administració".

ALCALÁ DíAZ, M. A., La impugnación..., op. cit., pàg. 200 a 202, també reconeix la progressiva adquisició de poder per part de consellers delegats i directors generals, "no sotmesos a controls interns", i demanda l'articulació d'instruments que en possibiliten el control, si bé l'autora es refereix especialment al reforçament de la responsabilitat interna i externa de tals càrrecs, així com a la introducció d'un sistema d'autoritzacions per part del consell, i descarta la impugnació com a mecanisme de control.

960 Exemple paradigmàtic n'és el dels “poders de representació per al desenvolupament de la gestió" de les promocions a les cooperatives d'habitatge. Els excessos que s'han produit en el sector en el passat han portat una severa limitació d'aquests poders en l'article 1 del RD $2028 / 1995$, que regula les condicions d'accés al finançament qualificat estatal dels habitatges promoguts per cooperatives.

961 Així, per exemple, en la cooperativa de treball associat la direcció pot tenir atribuïdes facultats sancionadores delegades en les faltes relacionades amb la prestació de treball dels socis (article 82 LCoop, aplicable també, al nostre parer, a les cooperatives valencianes per la remissí6 
patrimonials de l'entitat, permeten qualificar com a òrgan la direcció, almenys quan la cooperativa mateixa així ho haja configurat estatutàriament ${ }^{962}$. La seua independència no pot veure's rebutjada per l'atribució del seu nomenament i destitució al consell rector, ja que aquest es veu, al seu torn, sotmès al mateix procés per part de l'assemblea, sense que això servisca de base per qüestionar el seu funcionament autònom; i el manteniment de la responsabilitat del consell pels actes de gestió de la direcció, a més a més de dependre de les circumstàncies de cada cas, tampoc nega la responsabilitat pròpia de la direcció. Una altra qüestió serà la possibilitat d'impugnar o no les seues decisions i els seus actes.

Com ja s'ha indicat reiteradament, la LGC de 1987 regulava expressament la direcció de la cooperativa i reconeixia la impugnabilitat dels seus "actes i decisions" que, a aquests efectes, es consideraven acords del consell rector ${ }^{963}$; en canvi, la LCCV, no va incloure cap menció sobre aquesta qüestió, i la LCoop ha reduït dràsticament la regulació de la figura, ja que la qualifica d'"apoderat principal" de la cooperativa, i elimina les referències possibles a la impugnabilitat de les seues decisions ${ }^{964}$.

que efectua l'article 79.4 LCCV a la "legislació laboral”).

962

S'inclouria aquesta direcció estatutària entre els supòsits que esmenta MENÉNDEZ MENÉNDEZ, A., en "Auxiliares del empresario», op. cit., pàg. 278 i 279, nota 12: "Queden fora del concepte de factor en sentit rigorós les persones que exercisquen la seua funció administrativa en qualitat d'òrgans d'una societat, ja que en aquest cas no som en presència d'un auxiliar de l'empresari, sinó davant d'un òrgan de la societat titular de l'empresa, òrgan necessari per a l'actuació de la persona jurídica, que apareix preordenat per la llei, $i$ la voluntat del qual, en gran manera autònoma $\mathrm{i}$ independent, val com a voluntat de la persona mateixa. El fet de que la representació orgànica atribuïda a aquells òrgans reba en alguns aspectes un tractament paral-lel a la representació voluntària que té el factor no destrueix aquella consideració en virtut de la qual els administradors de les empreses socials s'allunyen de la noció de l'auxiliar i hi ocupen una posició que s'identifica amb la del principal [...] les persones que exerceixen les funcions administratives de la societat en qualitat d'òrgans d'aquesta [...] la seua relació amb la societat és objecte, en el Codi mateix, d'una disciplina diferent i de vegades contrària a l'establerta per a la relació principal-auxiliar".

963

En el mateix sentit, La LCE vigent (article 43.1, 2n paràgraf) estableix explícitament que "els actes $\mathrm{i}$ les decisions adoptats pel gerent, a efectes de la possibilitat de la impugnació a la qual es refereix aquest article, es consideren com a acords adoptats pel consell rector". 
D'altra banda, es repeteixen les posicions derivades de la unipersonalitat eventual del càrrec, ja analitzades en relació amb les diferents formes de l'òrgan d'administració: a diferència d'allò preceptuat per a les societats anònimes, en la legislació cooperativa vigent no hi ha una limitació expressa de la impugnació als acords dels òrgans col-legiats; la criticada dificultat de discernir entre la decisió i l'acte de la seua execució implicaria únicament la impugnació de l'actuació en conjunt, amb la certesa que el resultat seria, si escau, la remocí dels efectes de la decisió nul.la o anul.lable ${ }^{95}$; i el risc de paralització de l'activitat empresarial davant de la impugnació dels actes de gestió es pot i s'ha de veure ponderat, davant la necessitat de defensa del principi de legalitat, de l'interès general de la cooperativa i dels drets dels socis, en la suspensió o no per l'administració judicial de l'execució de l'acord o de l'acte impugnat ${ }^{\text {ss. }}$.

En tot cas, ací es pot reproduir la principal crítica formulada davant la noimpugnabilitat dels actes d'òrgans no col-legiats en la societat anònima, en el sentit que no pot fonamentar-se la impugnació en qüestions accessòries, com quin siga l'origen de l'acte, sinó que ha de fer-se sobre la seua naturalesa il-legal, antiestatutària o socialment lesiva ${ }^{967}$. A més, davant les tesis de noimpugnabilitat de les decisions de la direcció en virtut de la seua unipersonalitat, s'ha de recordar que, si no hi ha director, les seues facultats serien competència del consell $i$, per tant, el resultat del seu exercici impugnable ${ }^{968}$.

director general o gerent $\mathrm{i}$ les atribucions del consell rector en relació amb aquest.

965 ViCent ChUliÁ, F., en PAZ CANAlejo, N., i ViCENT ChUliÁ, F., Ley general..., op. cit., pàg. 857: "El punt és discutible, ja que normalment en els actes del director, per ser individuals, la decisió i l'execució (negoci estipulat amb tercers) no tenen solució de continuïtat, per la qual cosa no té sentit impugnar la primera ailladament. Tan sols serà procedent impugnar la validesa i l'eficàcia davant la cooperativa dels contractes amb els tercers".

966 Vicent Chuliá, F., en Paz CANAlejo, N., i Vicent Chuliá, F., Ley general..., op. cit., pàg. 857. 
També s'ha argumentat la no-necessitat d'impugnar l'actuació de la direcció, ja que els interessos cooperatius estarien prou protegits per les regles pròpies del negoci d'apoderament i per l'acció de responsabilitat ${ }^{969}$. I també ací es poden contraposar les raons adduïdes per a les modalitats unipersonals de l'òrgan d'administració: l'aplicació, si escau, del règim general de resolució dels conflictes derivats de la relació de mandat no aportaria avantatges, sinó tot el contrari, inconvenients (inseguretat, lentitud procedimental...) pel que fa al procediment d'impugnació, especial per als conflictes derivats de la formació incorrecta de la voluntat de la persona jurídica, i per tant més ajustat a la seua naturalesa jurídica i més complet. D'altra banda, s'han indicat reiteradament els perjudicis que es derivarien de la necessitat d'esperar, per iniciar l'acció de responsabilitat, que es produïra un dany que, en alguns casos, fins i tot podria haver-se evitat mitjançant la impugnació ${ }^{970}$.

En la nostra opinió, la impugnabilitat o no de les decisions amb transcendència jurídica de la direcció dependrà de quina haja estat la voluntat de la cooperativa a l'hora d'exercir la seua autonomia organitzativa: si la direcció es configura com a òrgan (i proves d'això podran ser, si s'escau, la seua regulació estatutària i/o la seua designació obligatòria), s'haurà de concloure que les seues decisions són impugnables pel mateix procediment establert per als acords o les decisions de l'òrgan administratiu, de qui rep i amb qui comparteix les seues competències $^{971}$. Si s'opta per configurar el director com un mer apoderat

969

MARÍN LOPEZ, J. J., «Novedades...», op. cit., pàg. 1122 i 1123.

970 PoLOSÁNCHEZ, E., Los administradores..., op. cit., pàg. 528

$971_{1}$

En aquest sentit, l'Informe sobre Promoció de les Cooperatives a la Conferència Internacional del Treball, 89a reunió (OIT), 2001, op. cit., pàg. 93 i 94, alerta sobre l'experiència que mostra que "si no es fa una distinció entre aquests dos òrgans [consell i direcció], i els seus poders respectius no es defineixen clarament, solen sorgir situacions que condueixen a conflictes i que generen ineficàcia". I si bé es reconeix que "des del punt de vista conceptual, el Consell d'Administració és l'òrgan veritablement decisori, mentre que el Director és simplement un empleat [...] en realitat, és molt difícil per als membres del Consell, que són elegits entre les files dels socis, entendre l'entorn empresarial tan complex d'avui en dia i adoptar les decisions més adequades. Per tant, la legislació cooperativa [...] hauria d'incloure 
general, s'haurà d'entendre la seua relació amb la cooperativa directament a les normes reguladores de l'esmentat contracte mercantil ${ }^{9 / 2}$.

\section{Acords d'altres òrgans}

Estructuralment, la cooperativa s'organitza segons dues condicions bàsiques: d'una banda, el segon principi cooperatiu, que reclama la participació dels socis, amb igualtat, en la gestió democràtica; d'una altra, l'assenyalament legal dels òrgans que imprescindiblement ha d'adoptar la cooperativa. Per això, la LCoop, al costat dels òrgans que necessàriament han de funcionar en la cooperativa (assemblea general, consell rector i intervenció), es refereix a la possibilitat de regular estatutàriament l'existència del comitè de recursos, " $\mathrm{i}$ d'altres instàncies de caràcter consultiu o assessor, les funcions de les quals es determinen en els estatuts, que, en cap cas s'han de confondre amb les mateixes dels òrgans socials" (article 19 LCoop). L'article $25 \mathrm{LCCV}$, per la seua part, declara com a òrgans necessaris de la cooperativa a l'assemblea general, el consell rector i els liquidadors, i esmenta explícitament la possibilitat de regular estatutàriament la creació i el funcionament de "comissions delegades de l'assemblea general", entre les quals inclou expressament la comissió de recursos i la comissió de control de la gestión ${ }^{973}$.

normalment disposicions que garantisquen la transparència dels acords de direcció i el procés d'adopció de decisions, i que ajuden a mantenir la naturalesa democràtica de l'adopció de decisions a la cooperativa".

972 En aquest sentit, DUQUE DOMf́NGUEZ, J. F., Tutela ..., op. cit. pàg. 67, nota. (93), cita MINERVINI (Alcune riflessioni sulla teoria degli organi delle persone giuridiche private, RTDPC, 1953, pàg. 942, quan estima que "les persones físiques que actuen per altres de jurídiques poden ser òrgans o no tenir aquesta qualitat, sinó la de representants en sentit estricte. La determinació del caràcter de les que actuen per les persones jurídiques privades ha de realitzar-se «d'acord amb el dret positiu, vegada per vegada, i sense necessitat $d^{\prime}$ acudir - ni en general ni davant del cas concret- a una solució unitària»".

973 Per la seua part, l'article 26 RCCréd. regula la possibilitat de que els estatuts de la cooperativa de crèdit prevegen l'existència d'interventors (sense perjudici que aquestes cooperatives estan, en tot cas, obligades a auditar externament els seus comptes), d'un comitê 
L'estructura orgànica cooperativa inclou, doncs, a més dels òrgans necessaris d'administració, un òrgan de control de la gestió, obligatori a la LCoo intervenció) i potestatiu en la d'altres òrgans (el comitè/la comissió de recursos); i un òrgan de liquir quan la cooperativa haja de dissoldre's. A alguns supòsits en què els estatuts podran crear "“altres instàncies" (LCoop) o comissions delegades de l'assemblea" (LCCV), i també podria plantejar-se la possibilitat que la cooperativa es dote d'altres instruments organitzatius, dins del marc del principi de l'autoorganització, derivat al seu torn del d'autonomia de la voluntat de les persones jurídiques privades. En la mesura que aquests òrgans o instàncies puguen prendre acords o decisions que produïsquen efectes jurídics per a la cooperativa, caldrà analitzar la possibilitat de la seua impugnació.

3.1. Acords i/o decisions dels òrgans de control de la gestió

Amb independència que la cooperativa puga sotmetre els seus comptes a auditoria externa, siga per mandat legal o estatutari, o per acord dels seus òrgans facultats per a aixòำ, tant la LCoop com la LCCV incorporen a

de recursos, i d'" altres òrgans".

974 L'article 39.1 LCoop estableix que "els comptes anuals i l'informe de gestió, abans de ser presentats per a la seua aprovació a l'assemblea general, hauran de ser censurats per l'interventor o interventors, llevat que la cooperativa estiga subjecta a l'auditoria de comptes a què es refereix l'article 62 d'aquesta Llei". Aquest article, en primer lloc, recorda que les cooperatives "estaran obligades a auditar els seus comptes anuals i l'informe de gestió en la forma $i$ en els supòsits previstos en la Llei d'auditoria de comptes $i$ les seues normes de desenvolupament o per qualsevol altra norma legal d'aplicació, així com quan ho establisquen els estatuts o ho acorde l'assemblea general"; a continuació, estableix que "si la cooperativa no està obligada a auditar els seus comptes anuals, el $5 \%$ dels socis podrà sol-licitar del Registre de societats cooperatives que, amb càrrec a la societat, nomene un auditor de comptes perquè efectue la revisió de comptes anuals d'un exercici determinat".

Per la seua part, la LCCV, en l'article 45, sotmet a auditoria externa els comptes anuals i l'informe de gestió de les cooperatives valencianes que resulten obligades per la Llei d'auditoria de comptes $\mathrm{i}$ les seues normes de desenvolupament, a sol-licitud de la minoria de socis que poden demandar convocatòria d'assemblea (en l'actualitat, el $10 \%$ o 50 socis), les que siguen 
l'estructura de la cooperativa un òrgan de control de la gestió, si bé la tipologia és sensiblement diferent.

La LCoop, seguint un model tradicional, regula els interventors (articles 38 i 39) "com a òrgan de fiscalització", la funció bàsica del qual, a més de les que expressament i puntual els encomana la Llei mateixa, és la de la censura dels comptes anuals i de l'informe de gestió ${ }^{975}$, encara que els estatuts poden assignar-los altres funcions "de naturalesa fiscalitzadora"976. Poden ser elegits interventors els socis de la cooperativa que siguen persones físiques $\mathrm{i}$ els representants, legals o voluntaris, dels socis persones jurídiques ${ }^{97}$; però, a més, la LCoop introdueix la possibilitat de designar fins a un terç dels interventors entre "experts independents" com a novetat important en la matèria ${ }^{978}$.

La LCCV estableix una fórmula de control de la gestió diferent. D'una banda, l'informe previ a la censura dels comptes anuals que fa l'assemblea general s'encomana, si escau, a auditors professionals externs $i$ independents, i sols és

obligades per mandat estatutari, o aquelles en que ho acorde la seua assemblea general, "els administradors o la comissió de control de la gestió".

975 Això no obstant, el seu informe sobre els comptes anuals no és obligatori quan la cooperativa estiga subjecta a l'auditoria externa dels comptes, segons l'article 62 LCoop.

976 "fiscalitzar: ... Criticar i portar a judici les accions o obres d'un altre", REAL ACADEMIA ESPAÑOLA DE LA LENGUA, Diccionari de la llengua espanyola, tom I, 21a ed., Espasa Calpe, Madrid, 1992.

977 TATO PLAZA, A., "Os órganos sociais», op. cit., pàg. 99, qüestiona l'eficàcia d'una censura comptable efectuada pels socis mateixos que no tenen perquè comptar amb coneixements necessaris i que, tanmateix, assumeixen amb el càrrec un nivell important de responsabilitat. Reprodueix aquest autor la crítica efectuada en el seu moment pel Consell economic i social davant l'avantprojecte de la LCG: "La figura dels interventors, inspirada en la dels accionistes censors de comptes de la legislació sobre societats anònimes derogada, presenta la mateixa ineficàcia que se'ls atribuïa a aquests censors respecte del compliment d'una tasca efectiva $i$ eficaç de control i de fiscalització de l'actuació dels administradors. La seua desaparició en el modern dret de societats va ser, per això, general, alhora que l'exercici d'aquesta funció de control o bé s'atribuïa a l'actuació d'auditors externs [...] o bé al reconeixement d'un dret d'informació sobre la comptabilitat [...], o bé es desplacen, en part, a la configuració d'un model d'administració dualista integrat per la direcció i el Consell de Vigilància".

978 Encara que no s'acaba d'especificar en l'article 38.3 LCoop, el sentit de la"independència", en l'article 40 següent es fa referència a la possibilitat que "els interventors no socis" perceben retribucions. 
obligatòria l'auditoria en els supòsits expressament previstos en la Llei (article 45). D'altra banda, potestativament, la cooperativa pot dotar-se, si així ho preveuen els estatuts, de l'anomenada comissió de control de la gestió (article 48), les competències de la qual són "examinar la marxa de la cooperativa, les directrius generals i les decisions concretes adoptades pel consell rector, el conseller delegat o la comissió executiva i el director; advertir-los sobre la seua conformitat o no amb la política fixada per l'assemblea general i els criteris d'una bona gestió empresarial, i informar per escrit, en el moment que consideren oportú, a l'assemblea general i, en tot cas, a l'assemblea general ordinària". En el compliment d'aquestes competències, la comissió "podrà demanar i examinar, a tota hora, la documentació i la comptabilitat de la cooperativa", així com acordar la submissió dels comptes anuals i l'informe de gestió a auditoria externa (article $45.1, c)^{979}$.

979 Aquesta estructura del control de la gestió adoptada per la LCCV s'apropa més al model alemany, descrit per PAZ CANALEJO N., en PAZ CANALEJO, N., i VICENT CHULIÁ, F., Ley general..., vol. 3r, op. cit., pàg. 3: "la norma alemanya estableix un cert desglossament o separació en els sistemes de control, ja que, d'una banda, confia la censura dels comptes anuals a unes Associacions de revisió [...] fet que suposa un sistema de fiscalització comptable a càrrec de professionals experts i estranys a la Societat [...]. I, d'altra banda, el control de la gestió és encomanat (com a tasca principal, encara que no exclusiva) a l' «Aufsichtsrat» o Consell de Vigilància. [...] L'«Aufsichtsrat» ha de controlar la gestió de l'empresa realitzada per la Direcció en tots els vessants de l'administració i informar-se sobre la marxa dels negocis de la Cooperativa; en qualsevol moment pot exigir a la direcció un informe sobre els esmentats assumptes, així com examinar [...] els llibres i actes de l'entitat, i examinar el contingut de la caixa i les existències en efectes, valors i mercaderies; $d$ 'altra banda, ha de comprovar el balanç anual, els comptes i la proposta de distribució de pèrdues i guanys i informar sobre tot això l'Assemblea general'. Això no obstant, l'Aufsichtsrat compta a més amb altres competències (entre altres, ha de convocar l'Assemblea general, sempre que això siga d'interès per a la Cooperativa; pot destituir provisionalment, segons el seu propi criteri, els membres de la direcció fins que decidisca l'Assemblea; i pot prendre les mesures necessàries per assumir-ne provisionalment la gestió) que van més enllà del control, per entrar en l'àmbit de la gestió directa i que justifiquen la seua qualificació com a "sistema doble d'administració".

També es refereixen al sistema germànic dualista d'administració de societats en el context cooperatiu MONTOLÍO HERNÁNDEZ, J. M., Legislación cooperativa en la Comunidad europea, op. cit., pàg. 37 i 41 a 44; i MÜNKNER, H., «Ley de cooperativas...», op. cit., pàg. 106 i 107, que adverteix del risc que comporta la possibilitat d'ampliació estatutària de les competències del consell de vigilància en la línia de sotmetre a la seua autorització assumptes de la competència de la direcció, ja que això pot "fer confusa la clara frontera entre les funcions i responsabilitats

d'aquests dos òrgans diferents".

TATO PlAZA, A., "Os órganos sociais", op. cit., pàg. 86, considera que el consell de vigilància basc i la comissió de control de la gestió valenciana són expressions del model dualista
germac.

Per la nostra part, estimem que aquests òrgans col-legiats de control intern guarden més similitud amb un altre model d'òrgan de control intern, l'italià, de caràcter "híbrid", entre el germànic i el monista; és el denominat "collegio sindacale», al qual s'apliquen les disposicions 
Com veurem tot seguit, les diferències en la composició, en les funcions i en el les seues manifestacions de voluntat.

\subsubsection{Acords i/o decisions dels interventors}

La primera qüestió que cal plantejar-se en relació amb la possibilitat d'impugnar les manifestacions de voluntat de la intervenció és, precisament, si es tracta d'un òrgan que funciona col-legiadament o si és possible la seua organització de manera unipersonal o pluripersonal solidària ${ }^{980}$.

La LCoop es refereix a "la intervenció" com a "òrgan" (en singular), però de cap de les referències que el text legal fa a aquesta figura pot deduir-se el seu caràcter col-legiat; més aviat el contrari, s'adverteix que "si hi ha disconformitat" respecte de l'informe definitiu que s'ha de formular davant de l'assemblea sobre els comptes anuals i l'informe de gestió, els "interventors

relatives a els síndics de la societat per accions, i les funcions de la qual són tant col-legials com individuals, però que té menys incidència en la gestió directa. DE CRESCIENZO, E., Legislació sobre cooperatives a Itàlia, en INSTITUT PER A LA PROMOCIÓ I LA FORMACIÓ COOPERATIVES, Legislació sobre cooperatives als estats membres de la CEE., op. cit., pàg. 42: "El "collegio sindacale" és l'organ de control de l'empresa i, per tant, la seua funció està enfocada a controlar el funcionament general de la gestió social i a vigilar el compliment de les lleis i dels estatuts en l'interès dels socis. [...] entre altres funcions, ha de garantir la comptabilitat, la verificació del balanç i del compte de guanys i pèrdues resultants dels llibres i dels documents comptables, així com uns criteris seriosos de valoració del patrimoni social. Està prevista la revisió obligatòria"; EMBID IRUJO, J. M., "Derecho europeo de sociedades anónimas...", op. cit., pàg. 18: "El Codi ha previst l'existència d'un òrgan col-legiat de control (collegio sindacale), designat per la Junta general i encarregat específicament del control de l'actuació dels administradors de la societat"; PAZ CANALEJO, N., en PAZ CANALEJO, N., i VICENT CHULIÁ, F., Ley general..., vol. 3r, pàg. 5, explica a més que els síndics poden arribar a realitzar, excepcionalment, els actes d'administració ordinària quan es produïsca vacança de tots els administradors. Per a l'estudi del collegio sindacale a les cooperatives italianes, veure BASSI, A., Le società cooperative, op. cit., pàg. 261; BONFANTE, G., Imprese cooperative..., op. cit., pàg. 606 a 611; i GENCO, R., "ll volto cooperativo...", op. cit., pàg. 22 i 23, amb propostes de lege ferenda.

Així mateix, el codi cooperatiu portuguès regula el "consell fiscal", amb funcions semblants de control i fiscalització. Vegeu els arts. 60 a 63 CCP (traducció anotada de FAJARDO GARCtA, I. G., op. cit., pàg. 470).

980 BORJABAD GonZALO, P. J., Manual..., op. cit., pàg. 117, 118 i 312, considera $1^{\prime \prime \prime}$ interventor de comptes", en tot cas, un òrgan societari unipersonal, ja que la seua responsabilitat no és 
hauran d'emetre un informe separadament ${ }^{\prime \prime 981}$. D'altra banda, l'apartat 4 de l'article 38 LCoop reconeix la possibilitat que l'òrgan es componga d'un sol interventor titular. Tot això, unit a l'absoluta falta d'altres referències al funcionament de l'òrgan, ens porta a concloure que són possibles ambdues alternatives, això és, organitzar-ho col-legiadament o no, en la seua regulació estatutària necessària ${ }^{982}$. Fora d'això, la resolució de les llacunes i les interpretacions sembla que $s^{\prime}$ ha de reconduir, tant com siga possible, a l'aplicació de les normes reguladores del consell rector, si s'atén les similituds en el seu règim, que han portat el legislador a establir tota una secció, la 5 a del capítol IV, de disposicions comunes a ambdós òrgans.

Així doncs, segons el que es preveu en les clàusules estatutàries corresponents, el funcionament de la intervenció serà col-legial o per separat i, llevat de pacte exprés en contra, els seus acords o les seues decisions podran impugnar-se, segons el règim analitzat per a les diferents modalitats de l'òrgan d’administració.

Podria plantejar-se que la falta de referència legal explícita qüestiona la viabilitat de l'aplicació analògica d'una institució, la impugnació d'acords, que, com s'ha assenyalat reiteradament, introdueix un marge de provisionalitat en el funcionament orgànic. Davant d'això, una vegada més, s'han de fer valer els arguments bàsics reiterats al llarg d'aquest treball: la vulneració de la llei o dels estatuts, o la lesió de l'interès social en benefici extrasocial mitjançant l'adopció d'acords o decisions dels òrgans socials reclamen una resposta normativa, legal 0 estatutària, que en permeta l'eliminació, sense perjudici de l'establiment de

solidària.

981 Això no obstant, entre els antecedents normatius trobem la regulació que del consell de vigilància fa el Reglament de cooperació de 1971 (vegeu el capítol primer), en la qual es configura l'òrgan de control de la gestió i dels comptes (VICENT CHULIÁ, F., "Análisis crítico...», op. cit., pàg. 491) com a òrgan col-legiat, sense perjudici que el membre disconforme puga emetre informe separadament raonadament (article 43.3).

982 En aquest sentit, la LCA estableix que "quan s'hagen designat tres o més interventors i aquest òrgan haguera d'exercir funcions que requerisquen l'adopció d'acords, aquests es prendran per majoria simple dels seus integrants" (article 69). 
límits (subjectes legitimats, terminis de caducitat, procediment davant dels òrgans judicials, etc.) que eviten la inseguretat jurídica i l'esclerotització del funcionament social.

En relació amb el contingut dels acords o les decisions de la intervenció, s'ha de recordar que les funcions d'aquest òrgan són, a més de la censura dels comptes anuals, diverses i de molt variada índole, i poden afectar tant l'interès social com legítims interessos de socis i tercers ${ }^{983}$. Així, a més de les que la cooperativa decidisca assignar-li mitjançant regulació estatutària, la LCoop mateixa li atribueix expressament: $a$ ) requerir el consell rector perquè convoque assemblea general ordinària (o extraordinària, si ho preveuen els estatuts) quan no ho haguera fet dins del termini $i$, quan no siga atès aquest requeriment, instar la convocatòria del jutge competent (article 23.2); b) presentar propostes de punts de l'ordre del dia de qualsevol assemblea no universal, d'inclusió obligada (article 24.2 i 24.3), i c) impugnar, obligatòriament, els acords assemblearis que siguen contraris a la llei o oposats als estatuts; i potestativament, els lesius de l'interès de la cooperativa (article 31.4) i els anul-lables del consell rector (article $37.2)^{984}$.

En tot cas, no cal dubtar que la funció essencial de la intervenció és la censura dels comptes anuals i l'informe de gestió, mitjançant la formulació d'un informe, conjunt o separat. La hipòtesi de la seua impugnació condueix,

983 Paz Canalejo, N., en Paz Canalejo, N., i ViCent ChuliÁ, F., Ley general..., vol. 3r, pàg. 35, en relació amb la LGC anterior, indica com "l'Estatut d'una Cooperativa pot atribuir als Interventors socials funcions de naturalesa fiscalitzadora, sempre que no s'enfronte amb el marc competencial d'altres instàncies, ni traven l'activitat empresarial de l'entitat"; aquest autor classifica les competències de la intervenció en tres àrees possibles, a saber: "A) La censura dels comptes anuals (...); B) Les altres funcions que expressament els encomana la Llei; i C) Altres tasques que poden assignar-los els Estatuts, sempre que no estiguen expressament encomanades a altres òrgans socials, no entorpisquen, ni dificulten l'activitat empresarial de la Cooperativa i siguen de naturalesa fiscalitzadora".

984 Encara que, com veurem més endavant, la legitimació i l'obligació d'impugnar s'estableix per a "els interventors" i no per a "la Intervenció", que és la denominació que amb caràcter genèric utilitza la Llei per referir-se a l'òrgan, res no impedeix que siga aquest qui acorde l'inici de l'acció. La referència individual als interventors corrobora, a més, la possibilitat de que l'òrgan s'organitze de manera no col-legiada. 
consegüentment, a la possibilitat de la suspensió de l'acord o de la decisió impugnats (article 31.5 LCoop en relació amb l'article 120 LSA), en aquest cas, l'esmentat informe de censura, si bé això no impedeix strictu sensu la realització de l'assemblea general a l'aprovació de la qual hagen de sotmetre's els comptes ('article 39.2, in fine sotmet la convocatòria a l'emissió de l'informe o al transcurs del termini per fer-ho); i una eventual sentència estimatòria de la impugnació tindria com a conseqüència, no sols deixar sense efecte l'informe de la intervenció, sinó la nul-litat de l'assemblea que haguera aprovat els comptes. Tanmateix, no serà freqüent la impugnació de l'informe de la intervenció, excepte en els supòsits en què l'informe pretenga substituir l'auditoria externa quan aquesta siga preceptiva (article 39.1 en relació amb el 62.1 i 62.2.LCoop), o quan la falta de diligència manifesta en la seua formulació requerisca, més enllà de l'exigència de responsabilitat, la seua anul-lació.

També s'ha de recordar que la LCoop preveu la possibilitat que el $20 \%$ dels socis sol-licite al jutge de primera instància la designació dels anomenats "interventors de la liquidació" (articles 72 i 74.1), la competència dels quals serà la fiscalització de les operacions de liquidació i, especialment, la censura del balanç final, 1'informe de gestió de la liquidació i el projecte de distribució de l'actiu sobrant ${ }^{955}$. Encara que no s'esmenta en absolut el seu règim de funcionament, sembla que se'ls aplicarà, per analogia, el que s'estableix per a la intervenció ordinària en la LCoop mateixa ${ }^{986} \mathrm{i}$ el que es reculla, si escau, estatutàriament.

\subsubsection{Acords de la comissió de control de la gestió}

985 L'article 72 LCoop es titula "Intervenció de la liquidació" i es refereix a "la designació d'interventor", en singular; però l'article 74.1 atribueix la censura del balanç final, l'informe de gestió de la liquidació i el projecte de distribució de l'actiu sobrant a "els interventors de la liquidació, en el cas d'haver-ne estat nomenats". 
Com ja s'ha indicat, la LCCV estableix un òrgan de control de la gestió de caràcter potestatiu, a elecció de la cooperativa, i amb aquesta finalitat haurà d'incorporar-ne la regulació en els estatuts socials. Es tracta d'una comissió delegada de l'assemblea (article 25 LCCV in fine), els membres de la qual són elegits per aquesta per "examinar la marxa de la cooperativa, les directrius generals i les decisions concretes adoptades pel consell rector, el conseller delegat o la comissió executiva i el director; advertir-los sobre la seua conformitat o no amb la política fixada per l'assemblea general i els criteris d'una bona gestió empresarial, i informar per escrit, en el moment que s'escaiga, l'assemblea general $i$, en tot cas, l'assemblea general ordinària. Amb aquesta finalitat, l'esmentada comissió podrà demanar i examinar, sempre, la documentació i la comptabilitat de la cooperativa" (article 48 LCCV).

A diferència del que es preveu per a la comissió de recursos, la Llei no remet la regulació del seu funcionament a les normes del consell rector, per la qual cosa s'haurà d'atendre estrictament el contingut de les clàusules estatutàries corresponents; sols si no $\mathrm{n}^{\prime} \mathrm{hi}$ ha, entenem que podran aplicar-s'hi analògicament els preceptes relatius a l'òrgan d'administració ${ }^{987}$. En tot cas, la denominació legal mateixa de "comissió", la seua composició plural i les seues funcions semblen indicar que aquest òrgan sí que ha de tenir, llevat d'expressa opció estatutària, un funcionament col-legial. De tot això deduïm que els estatuts socials poden regular la impugnació dels acords de la comissió i que, si no n'hi ha, se'ls pot aplicar el règim d'impugnació establert per als acords de l'òrgan d'administració.

\subsection{Acords del comitè/comissió de recursos}


La impugnabilitat dels acords del comitè (LCoop) o la comissió (LCCV) de recursos s'estableix expressament en la llei estatal (article 44.3$)^{988}$, mentre que en la llei valenciana es dedueix de la remissió que es fa a les normes sobre el consell rector per als aspectes relacionats amb el seu funcionament (article 47.1).

Una diferència essencial es deriva d'ambdues normes: mentre que la LCoop indica que la impugnació es realitzarà com si els acords hagueren estat adoptats per l'assemblea general, la LCCV remet les normes aplicables a la impugnació dels acords del consell rector. Pot reproduir-se, doncs, l'anàlisi realitzada de les característiques, comunes o diferents, d'ambdós processos.

Sens dubte, però, la nota dominant en l'anàlisi de la impugnació dels acords d'aquest òrgan és, precisament, la influència que produeix sobre aquesta la funció que el comitè/comissió acompleix, quan n’hi haja. Com hem anotat supra ${ }^{89}$, el comitè/comissió exerceix de "segona instància interna" davant de la qual s'ha de plantejar la revisió d'acords d'altres òrgans ${ }^{990}$. Es tracta d'evitar, quan siga possible, la impugnació o l'arbitratge externs. La institució ha estat extensament analitzada per la doctrina italiana, ja que la legislació i la pràctica cooperatives compten allà amb un òrgan semblant, de dilatada experiència, el col-legi dei probiviri ${ }^{991}$.

988 També es reconeix expressament en la LCPV (article 55.4, 2n paràgraf), en la LCC (article 49.6), en la LCA (article 75.3), en la LFCN (article 41.2), i en la LCCM (article 47.7).

${ }^{989}$ Vegeu epígraf 2.2.1. d'aquest mateix capítol.

990 La competència "ordinària" del comitè/comissió de recursos és resoldre les reclamacions dels socis davant acords del consell rector relacionats amb el règim disciplinari $o$, en l'àmbit de la LCCV, sobre l'admissió. Però la LCoop (article 44.1) permet que els estatuts amplien els supòsits en què actuarà el comitè de recursos, sense més especificació, mentre que la LCCV (article 47.3) permet d'ampliar la seua actuació davant "qualsevol acord del consell rector o de l'assemblea general",

991 Entre les anàlisis més recents, vegeu BASSI, A., Le società cooperative, op. cit., pàg. 265 a 271; BUONOCORE, V., Diritto della cooperazione, op. cit., pàg. 284 i 285; PALMA, R., «Il fenómeno cooperativo...", op. cit., pàg. 42, que el qualifica $\mathrm{d}^{\prime \prime}$ òrgan molt difós en la praxi societària cooperativa [...] que fa d'instrument de resolució de controvèrsies entre socis i entre socis $i$ societat, que no impedeix, en tot cas, llevat de perfeccionament a una clàusula compromissòria, el recurs a les vies judicials ordinàries"; PAOLUCCI, L. F., Le società cooperative, op. cit., pàg. 40: 
La singularitat, des del punt de vista de la impugnació dels seus acords, rau en el fet que aquests acords formen part d'una espècie de cadena $o$, si es prefereix, escala de revisió dels acords socials. En els supòsits previstos legalment 0 estatutària, els socis podran impugnar els acords del consell rector o d'altres òrgans socials davant del comitè/comissió; de la seua banda, l'acord que aquest òrgan adopte és impugnable davant de la jurisdicció ordinària, com hem vist. Però ha de tenir-se en consideració una excepció notable: mentre que la LCoop permet únicament la revisió externa de l'acord del comitè de recursos, la LCCV estableix una "tercera instància" davant de l'assemblea general.

En efecte, la possible revisió interna d'una àmplia gamma d'acords del consell rector ${ }^{92} s^{\prime}$ ha d'efectuar, segons la LCoop, sempre davant del comitè de recursos, quan n'hi haja; sols quan no s'haja previst aquest òrgan, el recurs es realitzarà davant de l'assemblea general. Així s'especifica en cada cas i es ratifica mitjançant allò previst en l'article 44.3, que defineix els acords del comitè com a

"d'una banda, es persegueix posar a disposició dels socis un instrument menys costós que un arbitratge normal o que un judici davant de l'autoritat judicial per resoldre les controvèrsies internes, d'altra banda, preveure un òrgan estable que, operant com òrgan endosocietari de composició de les controvèrsies socials 0 , exercitant vertaderes i pròpies funcions arbitrals, aconseguisca «lavare $i$ panni» internament, i els sostraga al strepitus fori"; SCORDINO, F., La societa cooperativa, op. cit., pàg. 378 a 383 . Com indica aquest últim autor, es discuteix, sobretot, "si les funcions de tal manera conferides per llei o per disposicions estatutàries serveixen per atribuir al col-legi el caràcter arbitral i a les seues decisions el valor del laude arbitral, encara que siga de fet que servisca com a acte previ a la submissió a l'autoritat judicial ordinària"; hi coincidim en el fet que és "més correcta la solució negativa, que reconeix a l'òrgan en qüestió la mera funció d'oferir-ne al soci una forma de defensa particular, a través de la revisió del procediment per part d'un òrgan diferent del qual ha emanat, que manté normalment "imprejudicat" el recurs a l'autoritat judicial, encara que es proposa evitar-ho". Això no obstant, BASSI, A., Le societḋ cooperative, op. cit., pàg. 266, adverteix que s'haurà d'estar a la redacció concreta de cada clàusula compromissòria; en la mateixa línia, GROSSO, P., I controlli interni..., op. cit., pàg. 69 i 70: “... l'eficàcia del pronunciament dels "probiviri” dependrà, d'una banda, de la previsió estatutària dels poders conferits a aquests, d'una altra, de la naturalesa de la qüestió sotmesa a aquests". SERRANO Y SOLDEVILLA, A. D., La cooperativa como..., op. cit., també ha estudiat la institució en pàg. 180 a 188 , notes 78 i 80.

992 Els acords per als quals es preveu la impugnació interna són l'admissió o inadmissió de la sol-licitud d'ingrés (arts. 13.2 i 13.3 LCoop, i 15.2 LCCV); la denegació d'informació als socis (article 16.4 LCoop); la imposició de sanció, inclosa la sanció màxima, l'expulsió (arts. 18.3, c) LCoop, i 18.2 LCCV); la baixa obligatòria (17.5, 3r LCoop); la qualificació i els efectes de la baixa (17.6 LCoop); i la liquidació de les aportacions al capital en cas de baixa (51.2 LCoop). A més, es (17.6 LCoop); i la liquidació de les aportacions al capital en cas de baixa (51.2 LCoop). A marts. 44.1
preveu expressament la possibilitat d'ampliació estatutària dels supòsits impugnables (arts.
LCoop i 47.2 i .3 LCCV). 
"definitius" i impugnables, "com si hagueren estat adoptats per l'assemblea general", això és, directament davant de la jurisdicció ordinària.

La LCCV, en canvi, estableix com a últim tram intern de la revisió la facultat del soci de recórrer contra la decisió de la comissió davant de l'assemblea, si bé permet l'eliminació estatutària de la "tercera instància" (article 47.2, 2n paràgraf), així com la conversió de la reclamació davant de la comissió en requisit previ a la demanda d'impugnació externa. La singularitat d'aquesta jerarquia impugnadora interna requereix, doncs, atendre sempre la regulació estatutària que la cooperativa sotmesa a la LCCV faça de la comissió.

Com a supòsits concrets que podran impugnar-se hi ha els acords del comitè/comissió en les matèries que no els hagen estat atribuïdes ni legalment ni estatutàriament $\mathrm{o}$ els adoptats amb la concurrència determinant de membres sotmesos a causa d'abstenció ${ }^{993}$ (vegeu STS 12.12.95, RJA 9089/95).

3.3. Acords d'altres comissions delegades de l'assemblea general, del consell rector o d'altres òrgans

Ja hem assenyalat que tant la LCoop com la LCCV inclouen la possibilitat de regular estatutàriament altres òrgans o instàncies potestatius, però la previsió de la llei estatal no presenta elements suficients per proposar la impugnabilitat dels seus acords. En efecte, la referència és a "instàncies de caràcter consultiu o assessor, les funcions del qual (...) en cap cas s'han de confondre amb les mateixes dels òrgans socials" (article 19 LCoop), cosa que indica que aquestes tasques consultives o assessores no tindran una naturalesa jurídicament

993 Els membres del comitè/comissió estan sotmesos a les incompatibilitats, les incapacitats i les prohibicions previstes per als membres de l'òrgan d'administració o de la intervenció (arts. 44.4 LCoop, en relació amb l'article 41; i 47.1 LCCV, en relació amb el 39). La LCoop sotmet a més als membres del comitè a les causes d'abstenció i de recusació aplicables a jutges i magistrats. 
transcendent, ni tan sols internament ${ }^{994}$. Podria pensar-se en la hipòtesi que s'establira estatutàriament la seua intervenció amb caràcter no només necessari, sinó vinculant per als òrgans socials assessorats, però en aquests casos no s'acompliria el mandat legal segons el qual les seues funcions no es poden confondre, ja que llavors l'informe imperatiu de la «instància consultiva» determinaria prèviament l'exercici de la funció de l'òrgan social. Per això, haurà d'estimar-se que l'actuació d'aquestes instàncies, sense efectes jurídics definitius per a la cooperativa, no seria impugnable, per innecessària ${ }^{995}$.

994 Probablement per això, i per aconseguir l'efecte contrari, l'article 76 LSCA es refereix expressament a "altres òrgans socials", el règim d'actuació $i$ les competències del qual hauran d'estar previstos estatutàriament, "sense que en cap cas els siguen atribuïdes les [competències] pròpies dels òrgans necessaris". Tot això indueix a pensar que la Llei autonòmica andalusa sí que permet regular estatutàriament òrgans els acords o les decisions del qual podrien ser impugnables.

995 El caràcter no orgànic d'aquestes "instàncies" s'ha mantingut en les normes estatals de cooperatives successives. Així, VICENT CHULIÁ, F., "Els òrgans socials...», op. cit., pàg. 491, ja esmenta, en relació amb el Reglament de desenvolupament de la LGC de 1974, que "les "Comissions, Comitès, Consells», amb diverses funcions de participació en la vida social de l'entitat [...] hi apareixen concebuts com a "instàncies participatives" (article 4-b), clarament diferenciades dels òrgans socials pròpiament dits".

Posteriorment, la LGC de 1987 preveu, en l'article 61, que "els Estatuts i l'Assemblea general podran crear Comissions, Comitès o Consells amb funcions interpretatives, d'estudi, de propostes, iniciatives i suggeriments, d'investigació, d'enquestes i anàlogues. La denominació completa d'aquestes instàncies participatives $i$ intermèdies no haurà d'induir a confusió amb la dels òrgans de la Cooperativa i en cap cas el seu criteri podrà ser vinculant per a aquests, sense perjudici que el seu informe puga establir-se com a preceptiu". En relació amb tals instàncies, PAZ CANAlejo, N., en PAZ CANAlejo, N., i ViCENT CHULIÁ, F., Ley general... op. cit., pàg. 580 i 581, nega explícitament la impugnabilitat de les seues actuacions: " "Comissions o Comitès de Secció» el criteri dels quals no constituirà un acord, sinó un informe o una proposta no vinculant per als òrgans necessaris. Per tant, de cap manera és vàlid pretendre que davant d'aquestes opinions o criteris suborgànics serà possible accionar a l'empara de l'article 52 de la Llei". BORJABAD GONZALO, P. J., Manual ..., op. cit., pàg. 124, 125 i 314, en el context de la LGC esmentava l'existència d'altres òrgans voluntaris possibles: els interventors d'actes (article 50.2), la comissió instructora o de disciplina (article 37.3.a), la comissió d'informació econòmica (article 36.9), les comissions gestores de seccions i la comissió gestora del fons d'educació i promoció cooperativa, i considerava que "el membre de la Cooperativa, ofès per un acord d'aquests òrgans menors i voluntaris pot recórrer-lo davant de l'Assemblea general, amb la presentació del seu greuge, d'igual manera que si es tractara de la impugnació d'un acord del Consell Rector"; però el caràcter orgànic d'algunes d'aquestes fórmules organitzatives ja era llavors discutible, fonamentalment per la falta de caràcter vinculant de les seues intervencions, $i$ en l'actualitat, el tenor literal de l'article 19 LCoop no hi deixa lloc a dubtes, al nostre parer.

Comentant la Llei estatal vigent, VICENT CHULIÁ, Francisco, «La Ley 27/1999...», op. cit., pàg. 14574: "Els articles 19 a 44 LC regulen els òrgans socials: Assemblea general, Consell Rector, Intervenció (socis interventors, que en el seu cas concorren amb l'actuació dels Auditors de comptes, que no són un òrgan social) i Comitè de Recursos (article 44 LC) i altres instàncies de caràcter consultiu o assessor (que no són òrgans, sinó comitès interns)". 
És la LCCV la que ofereix, al nostre parer, la possibilitat de constituir vertaders òrgans de la cooperativa, dotats de competències pròpies, en l'actuació de les quals els titulars del càrrec produïsquen efectes de transcendència jurídica per a l'entitat. Ja s'ha assenyalat que l'article 25 LCCV esmenta explícitament la possibilitat de regular estatutàriament la creació i el funcionament de "comissions delegades de l'assemblea general", entre les quals s'inclou expressament la comissió de recursos i la comissió de control de la gestió. El caràcter orgànic d'aquestes dues últimes comissions no presenta cap dubte, per la naturalesa mateixa de les funcions atribuïdes legalment $i$ de les atribuibles estatutàriament, i no hi ha res en el contingut de l'esmentat article que impedisca la creació d'altres comissions les funcions de les quals (delegades, no ho oblideu, per l'assemblea entre les seues) puguen ser jurídicament transcendents per a la cooperativa: penseu, per exemple, en la comissió gestora del fons de formació i promoció cooperativa amb què es doten algunes cooperatives, o en el consell social ${ }^{996}$.

En la mesura, doncs, en què els estatuts socials regulen la possibilitat de crear comissions delegades de l'assemblea general i que, bé els estatuts mateixos bé l'acord assembleari de la seua creació, els atribuïsquen funcions que impliquen la producció d'efectes jurídics per a la cooperativa, els seus acords podran ser impugnats. El règim de la seua impugnació serà el que s'adopte, si escau, en els estatuts: recordeu que la LCCV indica que seran els estatuts els que "podran regular" la seua creació i el seu funcionament; però si no hi ha regulació expressa sembla que el procés d'impugnació aplicable serà el previst per als acords de l'assemblea, si s'atén la naturalesa de les funcions delegades atribuïdes a la comissió de què es tracte.

D'altra banda, cal analitzar les possibilitats que la cooperativa adopte altres fórmules organitzatives que tinguen el caràcter de vertaders òrgans socials,

996 Es refereix a la comissió gestora del fons BORJABAD GONZALO, P. J., Manual ..., op. cit., pàg. 125; el consell social es preveu explícitament en els arts. 54 LCPV i 46 LCA, com a òrgan encarregat de matèries relacionades amb la relació de treball. 
dotats de competències que produïsquen efectes jurídics ${ }^{97}$. Això no és possible en l'àmbit de la llei estatal que, com hem vist, es refereix únicament a la possibilitat de constituir instàncies diferents als òrgans socials $\mathrm{i}$ amb funcions merament consultives o assessores. Pel que fa a la LCCV considerem que, si s'atén la falta d'autorització legal expressa, no pot ser suficient l'acord de l'assemblea general, sinó que es requerirà una previsió estatutària explícita. En efecte, si bé és cert que la LCCV (article 27.1, i) permet modificar en general l'estructura de la cooperativa mitjançant acords de l'assemblea, per als supòsits legalment previstos de creació d'òrgans socials potestatius exigeix la regulació estatutària prèvia (comissió de recursos: article 47.1; comissió de control de la gestió: article 48.1). Això és coherent, a més, amb la necessitat de garantir els drets del soci, en particular el dret d'informació, així com el dret-obligació de participar en la gestiós ${ }^{998}$

Caldrà atendre, doncs, el que es dispose en les clàusules dels estatuts que donen forma als òrgans: funcions jurídicament transcendents, composició, funcionament $i$, si escau, règim d'impugnació dels acords o decisions.

997 Pot trobar-se'n un referent en el RCCred., l'article 26 del qual, “Òrgans estatutaris" preveu, en l'apartat 2 la possibilitat de regular estatutàriament la creació i el funcionament d'altres òrgans diferents als previstos en la legislació.

998 En el mateix sentit, per a les societats de capital, ESTEBAN VELASCO, G., «Algunas reflexiones...", op. cit., pàg. 558: "Els estatuts poden preveure un altre o altres òrgans diferents dels contemplats en el model legal. Respectant les disposicions imperatives sobre les respectives competències mínimes dels òrgans previstos per la Llei $i$, en particular, el règim d'actuació a efectes externs, els socis poden determinar lliurement en els estatuts inicials o en els modificats, la composició, designació, règim de funcionament $i$ atribucions dels òrgans facultatius eventuals. La dimensió o altres circumstàncies de la societat en qüestió poden fer aconsellable un Comitè de socis o una comissió de vigilància, amb funcions d'assessorament $\mathrm{i} / \mathrm{o}$ control, rellevants en el pla intern".

En relació amb òrgans delegats de l'òrgan d'administració diferents als previstos legalment, la doctrina i la pràctica en preveuen la constitució possible, si bé les opinions sobre la impugnabilitat dels seus acords o decisions són divergents: QUIJANO GONZÁLEZ, Jesús, «Responsabilidad de los administradores», en AA. DD., El gobierno de las sociedades cotizadas, Marcial Pons, Barcelona, 1999, pàg. 581; i SALELLES CLIMENT, J. R., El funcionamiento... op. cit., pàg. 396 i 397, es refereixen a la no-impugnabilitat dels acords de les comissions o els grups de treball, diferents a la comissió executiva, que es creen al si del consell; GARCtA LUENGO, R, i SOTO VÁzQUEZ, R., El nuevo régimen jurídico..., op. cit., pàg. 641, en canvi, semblen acceptar-ne la impugnació possible. 
El caràcter d'òrgan necessari dels liquidadors queda explicitat en l'article 25 c) de la LCCV, per als supòsits en què la cooperativa es dissolga i entre en liquidació. La LCoop no els esmenta entre els òrgans de la societat quan els enumera en l'article 19, però el seu caràcter orgànic es deriva clarament de les funcions que li són atribuïdes, això és, d'una banda, la realització de les operacions necessàries o convenients per a la liquidació de la cooperativa i, d'una altra, l'administració, la representació i la gestió de la cooperativa durant el procés liquidador ${ }^{999}$.

En relació amb la necessitat de la seua constitució, la LCoop sembla introduir una certa novetat, en indicar, en el segon paràgraf de l'article 71.1, que "si els estatuts no preveuen a qui correspon realitzar les tasques de liquidació, l'assemblea general designarà entre els socis (...) els liquidadors". S'obri així la possibilitat que puga regular-se estatutàriament un altre procés de nomenament (per un altre òrgan, a persones no sòcies...), o que, fins i tot, es fixe per endavant qui, o quins càrrecs, efectuaran les funcions liquidadores, que podrien recaure, per exemple, en membres de l'òrgan d'administració1000. En tot cas, aquestes possibilitats no obsten, al nostre parer, al fet inqüestionable que es constituirà un nou òrgan, amb algunes funcions noves $\mathrm{i}$ amb altres que rebrà de l'òrgan d'administració; aquest, per la seua banda, cessarà en les funcions amb el nomenament dels liquidadors (article 71.3, 2n paràgraf i 71.4 LCoop ${ }^{1001}$ ).

999 En relació amb això, la STS de 13.12 .1999 estableix que quan s'acorda la dissolució d'una cooperativa, si no es nomenen liquidadors, quedarà en les seues funcions el consell rector i la direcció que hi havia en el moment de la dissolució, que no cessaran fins que no es nomenen liquidadors, els quals seran els que assumisquen la representació de la cooperativa i els qui exercitaran les funcions dels òrgans cessats.

1000 CORONADO FERNANDEZ, Francisco, «Capítulo X», op. cit., pàg. 334.

1001 La LCCV no es refereix de manera explícita a la transmissió de funcions i la cessació consegüent de l'òrgan d'administració, com ja hem assenyalat en FAJARDO GARCíA, I.-G., i SENENT VIDAL, M. J., Texto refundido..., op. cit., pàg. 98 i 99, però tot això queda implícit, al nostre 
En relació amb el seu funcionament, en la LCoop s'inclou una única menció (article 71.2), en indicar que, quan en siguen almenys tres, "actuaran de manera col-legiada i adoptaran els acords per majoria". La LCCV és encara més hermètica en aquest aspecte, i sols es dedueix el règim de funcionament que espera dels liquidadors quan assenyala que l'assemblea n'haurà d'elegir-ne tres o cinc entre els seus socis, i quan els assigna l'aplicació d'algunes de les normes previstes per als membres del consell rector (responsabilitat, incompatibilitat i retribució, en tot cas, i elecció i revocació quan, ordinàriament, el nomenament corresponga a l'assemblea); sembla que el nombre senar apunta a un règim col-legiat que possibilite els acords per majoria i evite els empats, i que la similitud parcial de les seues funcions conduïsca a l'aplicació analògica de les normes relatives a l'òrgan d'administració.

En tot cas, la LCoop permet elegir menys de tres liquidadors, i tampoc no sembla haver-hi impediment perquè en l'àmbit de la LCCV es constituïsca un òrgan liquidador no col-legiat, sinó amb actuació solidària dels seus membres. Això no serà obstacle, tanmateix, per a l'aplicació, en allò no previst per cada llei o pels estatuts socials, de la regulació del funcionament de l'òrgan d'administració, col-legiat o no.

Aquesta referència legal tan parca al funcionament de l'òrgan liquidador no inclou, òbviament, cap referència a la impugnabilitat dels acords o les decisions dels liquidadors, que tanmateix es dedueix de la seua qualificació com a òrgan necessari de la cooperativa i de les funcions essencials que se li atribueixen. Tot això condueix a l'aplicació del procediment previst per a la impugnació dels acords del consell rector que, com s'ha vist, també considerem aplicable a les formes no col-legiades de l'òrgan d'administració.

\subsection{Acords i/o decisions de la direcció unitària del grup cooperatiu}


La intercooperació pot adoptar diverses formes d'integració cooperativa, en la mesura que les necessitats $\mathrm{i}$ els interessos de les cooperatives participants ho aconsellen ${ }^{1002}$. Entre aquestes, tenen una tradició arrelada en l'àmbit legislatiu les anomenades cooperatives de segon grau, però també s'han anat incorporant als textos legislatius cooperatius diverses fórmules d'integració de caràcter no necessàriament permanent, com els consorcis $i$ altres contractes, que regulen les relacions entre les cooperatives participants sense la creació d'una persona jurídica independent. En aquestes modalitats la impugnació eventual de les seues declaracions de voluntat o de ciència no presenten especialitats remarcables.

Però la legislació cooperativa preveu, a més, una altra forma jurídica, ja consolidada en l'àmbit de les societats de capital i amb algunes experiències notables en el sector cooperatiu: el grup empresarial. Tant la LCoop (articles $78 \mathrm{i}$ 21.3) com la LCCV (article 93) inclouen entre les seues modalitats d'integració

1002 Sobre la integració cooperativa i les seues diverses formulacions jurídiques s'han publicat molts treballs, en el passat, però també, i sobretot, els últims anys. Hi destaquen, entre altres, els de DUQUE DOMfNGUEZ, Justino F., "Los grupos en el ordenamiento jurídico. Parte I. Grupos de sociedades cooperativas», en AA. DD., Grupos empresariales de la Economía Social en España, Ciriec-España, València, 2000, pàg. 98 a 195; EMBID IRUJO, José Miguel, Concentración de empresas y derecho de cooperativas, Universidad de Murcia, Murcia, 1991; «La integración cooperativa y su tratamiento en la Ley 4/1993, de 24 de junio, de cooperativas de Euskadi», en AA. DD., Estudios de derecho mercantil. Homenaje al profesor Justino F. Duque, tom I, Valladolid, Universidad de Valladolid, 1998, pàg. 223 a 231; EMBID IRUJO, José Miguel, «Los grupos cooperativos», Revista de legislación y jurisprudencia, Ciriec-España, núm. 7, diciembre 1995, pàg. 221 a 231; i "Problemas actuales de la integración cooperativa», RDM, núm. 227, gener-març 1998, pàg. 7 a 36; i el d'AlFONSO SÁNCHEZ, R., La integración cooperativa..., op. cit., i en "Capítulo XI. La integración cooperativa. La cooperativa de segundo grado", en AA. DD., La sociedad cooperativa en la Ley 27/1999, de 16 de julio, de cooperativas, (Coord., F. J. Alonso Espinosa), Editorial Comares, Granada, 2001, pàg. 355 a 386, on classifica les diverses formes d'intercooperació entre la representativa i l'econòmica; en aquesta darrera, segons el grau d'intensitat i la durada dels vincles que s'estableixen, distingueix entre les fòrmules que no alteren la independència econòmica i les que sí que alteren el poder de decisió econòmica. També poden veure's GONZÁLEZ GARCIA, Francisco, "Grupos paritarios de cooperativas de crédito y prácticas restrictivas de la competencia (A propósito del grupo Caja Rural)", DN, febrer 2001, pàg. 1 a 27; i MARTínez CHARTERINA, Alejandro, Análisis de la integración cooperativa, Universidad de Deusto, Bilbao, 1990 
cooperativa el grup cooperatiu, encara que només la llei estatal el dota d'una regulació mínima ${ }^{1003}$.

El grup cooperatiu de la LCoop podrà ser constituït per cooperatives de qualsevol classe que adoptaran una "entitat cap de grup", en la qual delegaran algunes de les seues facultats relatives a la gestió, l'administració i el govern ${ }^{1004}$. En l'exercici d'aquestes facultats, l'entitat cap de grup emetrà instruccions de compliment obligat per a les cooperatives ${ }^{1005}$. La incorporació d'una cooperativa en un grup cooperatiu requerirà un acord de la seua assemblea general, en el qual hauran d'assumir-se els anomenats "compromisos generals" del grup; s'hi establiran, almenys, les facultats l'exercici de les quals s'ha acordat atribuir a l'entitat cap de grup, la durada d'aquest, el procediment per modificar-lo i el de separació de les cooperatives membres ${ }^{1006}$.

1003 L'article 93.1 LCCV es limita a esmentar que "amb independència de les formes d'associació esmentades en l'article anterior [cooperatives de segon grau], les cooperatives podran constituir societats i associacions, consorcis i grups cooperatius, per a la realització de finalitats concretes i determinades, de manera temporal o duradora.". La LCPV, en la reforma més recent, ha incorporat també la regulació del grup cooperatiu a un nou article, el 135bis; MERINO HERNÁNDEZ, Santiago, "Análisis de la reforma de la Ley 4/1993, de 24 de junio de cooperativas de Euskadi (Ley 1/2000, de 29 de junio)", Revista Jurídica de Economía Social y Cooperativa, núm. 11 , noviembre 2000 , pàg. 20 a 22, el comenta, des de la seua postura contrària, i entén que tot el que pot fer-se a través del grup ja podia obtenir-se a través de les altres formes d'integració que sí preveia la Llei 4/1993. Al contrari, VICENT CHULIA, F., "Mercado, principios cooperativos...", op. cit. , pàg. 14, nota 7 , en referir-se a la regulació extremenya del grup cooperatiu la considera $\mathrm{d}^{\prime \prime}$ interès especial".

1004 Article 21.3 LCoop: “La competència de l'assemblea general sobre els actes en què el seu acord és preceptiu en virtut de norma legal o estatutària té caràcter no delegable, llevat d'aquelles competències que puguen estar delegades en el grup cooperatiu regulat en l'article 78 d'aquesta Llei".

1005 Article 78.2. LCoop: "La emissió d'instruccions podrà afectar diferents àmbits de gestió, administració o govern, entre els que podrien incloure's:

a) L'establiment en les cooperatives de base de normes estatutàries i reglamentàries comunes.

b) L'establiment de relacions associatives entre les entitats de base.

c) Compromisos d'aportació periòdica de recursos calculats segons de la respectiva evolució empresarial o compte de resultats..."

1006 Els compromisos generals hauran de formalitzar-se per escrit, ja siga en els estatuts de l'entitat cap de grup, quan aquesta siga cooperativa, o mitjançant un altre document contractual elevat a escriptura pública. Sobre la caracterització jurídica dels compromisos generals pot veure's MARÍN LÓPEZ, J. J., «Notas sobre la Ley 27/1999...», op. cit., pàg. 1802. 
L'existència del grup planteja l'interrogant sobre la possibilitat d'impugnar els seus acords. En primer lloc, caldrà atendre la forma jurídica que adopte la denominada "entitat cap de grup" 1007 . La LCoop admet la possibilitat que es constituïsca com a cooperativa; en aquest cas el règim d'impugnació serà el que es desenvolupa amb caràcter general. Tampoc sembla haver-hi problemes quan l'entitat cap de grup siga una persona jurídica no cooperativa, ja que s'hi aplicarà el procediment corresponent al seu règim jurídic.

Però també poden donar-se fórmules contractuals no personificades: observeu que l'article 78, en l'apartat 4, requereix que els compromisos generals s'incloguen en els estatuts socials únicament quan l'entitat siga una cooperativa; en la resta de casos es refereix a "un altre document contractual". Ja hem vist que en la legislació cooperativa s'admet que les cooperatives participen en altres formes de collaboració econòmica (article 79 LCoop: consorcis, agrupacions, unions, acords intercooperatius; article 93 LCCV: consorcis), per la qual cosa, en aquests casos, per a la impugnació de les seues decisions s'haurà de recórrer al règim general de nul-litat $\mathrm{i}$ anul-labilitat dels negocis jurídics.

Una qüestió bàsica que es planteja en la impugnació dels acords del grup és la possibilitat de l'existència $d^{\prime}$ un conflicte $d^{\prime}$ interessos ${ }^{1008}$ entre l'interès del grup $\mathrm{i}$ $l^{\prime}$ 'interès dels "socis minoritaris" ${ }^{\prime \prime 009}$. En aquest conflicte $d^{\prime}$ 'interessos, la doctrina i la jurisprudència predominants es mostren partidàries d'acceptar la legitimitat dels interessos de grup sempre que no contradiguen els interessos dels seus integrants fins al punt de causar-los perjudici. Davant d'això, s'argumenta que afirmar que l'interès de grup pot ser perseguit mentre no incidisca sobre els interessos de les societats singulars significa, en realitat, afirmar la irrellevància

1007 ALFONSO SÁNCHEZ, R., La integración cooperativa..., op. cit., pàg. 186 a 193.

1008 ALFONSO SÁNCHEZ, R., La integración cooperativa..., op. cit., pàg. 235, nota 213, amb citacions abundants de la doctrina italiana.

1009 JAEGER, P. G., L'interesse sociale rivisitato..., op. cit., pàg. 810/I, indica que, en realitat, en l'àmbit del grup de societats hi ha diversos interessos que poden confrontar-se: el del grup, els de les societats controlades $i$ els dels socis minoritaris d'aquestes últimes. 
de l'interès de grup; per això, una part de la doctrina i de la jurisprudència tendeix a acceptar la prevalença de l'interès del grup davant l'interès social $\mathrm{d}^{\prime}$ un dels seus membres ${ }^{1010}$, i proposa l'establiment eventual de contrapartides al sacrifici dels interessos dels socis, els denominats avantatges compensatoris. Altres autors consideren que si no hi ha un contracte de dominació entre societat dominant i societat dominada, aquella està obligada a respectar els interessos $\mathrm{d}^{\prime}$ aquesta ${ }^{1011}$. Tot això es planteja respecte dels denominats "grups per subordinació" (o verticals), i es considera que als grups per coordinació (o paritaris, o horitzontals) la pròpia naturalesa i caracterització (en aquests no hi ha relació de dependència) faran que sols siguen admissibles les instruccions favorables o, pel cap alt, neutres, per a les societats integrades ${ }^{1012}$.

Efectivament, com tothom sap, en la tipologia dels grups es distingeix entre "grups per subordinació i "grups per coordinació" "1013. En les cooperatives, anteriorment a la LCoop, s'ha mantingut la impossibilitat de crear grups per subordinació pel seu caràcter necessàriament democràtic $\mathrm{i}$ independent ${ }^{1014}$.

1010 Alfaro Aguila-Real, J. , Interés social..., op. cit., pàg. 42 i 43: "Si l'estratègia de grup $s$ 'imposa sobre l'estratègia individual de cada empresa, serà freqüent que la cúspide del grup impose a les societats filials decisions que perjudiquen l'interès d'aquestes. [...] El deure de fidelitat del soci majoritari no li exigeix abstenir-se de prendre aquesta decisió. Només li exigeix compensar a la minoria en la pèrdua del valor de la seua participació com a conseqüència de l'execució de l'estratègia de grup"; COZIAN, M., VIANDIER, A., i DEBOISSY, FL., Droit des sociétés, op. cit., pàg. 170; JAEGER, P. G., L'interesse sociale rivisitato... , op. cit., pàg. 810/I, que assenyala que aquesta última tesi "pressuposa una concepció institucionalista de la societat, quan individualitza altres interessos al costat dels socis". EMBID IRUJO, J. M., "Derecho europeo de sociedades anónimas...", op. cit., pàg. 13 i 14, recull l'acceptació per l'AktG de "la existència d'unions de societats en què una en domina - per la via de la participació en el capital, generalment- una altra o unes altres, i sotmet el seu interès social al del grup en el seu conjunt [...] establint, això sí, mesures de protecció dels socis i creditors de les societats dominades, així com l'obligació de presentar una documentació comptable relativa al grup en conjunt".

1011 Ulmer, P., Principios fundamentales del Derecho alemán..., op. cit., pàg. 161 i 162, en l'àmbit de les SRL alemanyes.

1012 EMBID IRUJO, J. M., Concentración de empresas..., op. cit., pàg. 61; ALFONSO SÁNCHEZ, R, "Capítulo XI", pàg. 354, nota 4.

1013 ALFONSO SÁNCHEZ, R., La integración cooperativa..., op. cit., pàg. 78 a 81.

1014 Com es recordarà, el segon i el quart principis cooperatius, estableixen la gestió democràtica per part dels socis i l'autonomia i independència de les cooperatives. EMBID IRUJO, 
Tanmateix, la regulació prevista en l'article 78 LCoop permet debatre sobre la hipòtesi de grups per subordinació quan l'entitat que encapçala el grup siga, per la seua banda, una cooperativa on s'integren tots els membres del grup ${ }^{1015}$.

J. M., Concentración de empresas..., op. cit., pàg. 48 a 54; ALFONSO SÁNCHEZ, R., La integración cooperativa..., op. cit., pàg. 149 i 150. A favor de l'admissibilitat del contracte de dominació, MASSAGUER FUENTES, José, «La estructura interna de los grupos de sociedades (Aspectos jurídico-societarios)", RDM, 1989, pàg. 315, nota 84 .

1015 Tot i que la postura majoritaria continua considerant que la legislació cooperativa regula la "unicitat de decisió en un grup paritari o per coordinació" (ALFONSO SÁNCHEZ, R., "Capítulo XI", pàg. 375 i 376, així com pàg. 358 a 361) "si el nostre Ordenament admet la submissió d'una societat al control d'una altra, la unitat de decisió $i$ la influència dominant aconseguides gràcies a tècniques societàries, trobant-nos en tals casos davant d'un grup de societats [nota. 269: "Cfr. article 1 RD 1815/1991, article 4 LMV, article $87 \mathrm{LSA}$ ], podria pensar-se que no hi hauria d'haver massa obstacles per admetre que aquesta situació sorgisca, també, de la lliure voluntat de les societats interessades plasmada en un contracte de dominació, de subordinació, d'afiliació, o qualsevol que siga el nom que es vulga donar a aquesta figura contractual. I en tal cas, fins $\mathrm{i}$ tot s'hauria d'admetre que les societats cooperatives puguen valer-se de tal instrument en ordre a instituir-se en societats dominants o caps de grup, ja que aquest estatus poden ja obtenir-lo a través de tècniques societàries. El que no resultaria admissible seria la creació d'un grup per subordinació en què tant societat dominant com societat dominada foren cooperatives, atesa la resistència que manifesta aquesta forma social a ser dominada o dirigida, en consideració al principi cooperatiu d'autonomia de gestió. De manera que, en principi, entre societats cooperatives només resultaran admissibles aquelles tècniques contractuals que comprometen les societats a actuar segons les directrius prèviament concertades i donen lloc a un grup de cooperatives paritari" (ALFONSO SÁNCHEZ, R., La integración cooperativa ..., op. cit., pàg. $150 \mathrm{i}$ 151).

També considera que la nova legislació cooperativa permet la formació de grups de cooperatives per «subordinació» LLOBREGAT HURTADO, M. L., La reforma ..., op. cit., pàg. 167.

VICENT CHULIA, F., "Mercado, principios cooperativos...", op. cit. , pàg. 14, estima que "les cooperatives de segon grau [...] no constitueixen grups de societats per subordinació [...] són grups de societats per coordinació. En conseqüència les relacions de competència [...] han d'estar presidides pel principi de lliure competència, excepte en aquelles matèries que els Estatuts socials $\mathrm{i}$ els acords dels òrgans de la Cooperativa de segon grau hagen establert expressament de competència exclusiva o especialitzada de la cooperativa de primer grau ; si bé en cas de conflicte l'interès de la cooperativa de segon grau ha de prevaler sobre l'interès particular de la cooperativa de primer grau i ha d'inspirar les relacions contractuals entre ambdues".

MORILlAS JARILLO, M. J., "La nueva regulación estatal...», op. cit., pàg. 7, considera, directament, que l'article 78 de la LCoop "opta per un model de grup integrat només per cooperatives de qualsevol classe, $i$ en què es formula el tipus de grup per coordinació; la impossibilitat d'existència d'un grup per dominació, connectada amb el caràcter democràtic de la societat..." .

L'article $157 \mathrm{LCE}$, en regular les cooperatives de segon o ulterior grau, estableix que "els estatuts hauran d'incloure l'enumeració de les facultats essencials que, per ser necessàries per al desenvolupament d'aquell objecte, queden transferides als òrgans de la societat cooperativa; aquestes facultats tindran la mateixa permanència que el propi objecte social i el seu exercici no podrà ser revisat davant dels òrgans de les societats integrades, sense perjudici de la tutela judicial que, en el seu cas procedisca. [...] Els estatuts regularan, a més, les matèries o àrees respecte de les quals les propostes de les entitats associades seran merament indicatives, i no vinculants, per a la societat cooperativa de segon o ulterior grau. En cas de dubte sobre això, es presumeixen transferides a aquesta societat cooperativa totes les facultats directament relacionades amb el seu objecte social, i tenen prioritat els acords i les instruccions d'aquesta 
En tot cas, s'haurà d'establir què ha d'entendre's per "interès del grup" i per "soci minoritari". Sobre aquesta última qüestió ja hem anotat supra ${ }^{1016}$ com de vegades es confon el concepte de minoria amb el de "soci minoritari", que ha d'entendre's, en realitat, com a soci (individualment considerat o juntament amb altres) que en una decisió concreta ha format part del col-lectiu de socis l'opinió dels quals no ha estat acceptada. Pel que fa a l'"interès de grup" s'ha indicat que ha d'identificar-se amb l'interès del conjunt de cooperatives integrades, no amb el de l'entitat cap de grup ${ }^{1017}$.

Per a la defensa dels interessos que poden considerar-se del grup es podrà utilitzar la impugnació dels acords de l'entitat cap de grup. Amb l'excepció dels supòsits en què s'utilitzen formes contractuals no personificades per a la formalització de la direcció unitària, el procediment, com hem apuntat, serà, en general, allò que es preveu per a la persona jurídica la forma del qual s'haja adoptat, però també s'haurà d'atendre el contingut del "contracte de grup" (els denominats "compromisos generals"), els estatuts de l'entitat cap de grup i, si escau, els reglaments de règim intern ${ }^{1018}$.

Una altra qüestió que pot plantejar-se és la necessitat eventual d'ampliar els supòsits de persones legitimades en la impugnació, en línia amb allò proposat en relació amb l'exercici de les accions de responsabilitat ${ }^{1019}$. Així, es podria estudiar la conveniència d'ampliar la legitimació activa en els supòsits $d^{\prime}$ anul-labilitat en favor de tots els socis i dels tercers amb interès legítim (incloent-hi els socis de les cooperatives sòcies).

davant les decisions de cada una de les entitats agrupades".

1016 Capítol primer, epígraf 2.1., en el qual s'analitzen les teories que fonamenten la impugnació en tant que instrument de tutela de "la minoria".

1017 ALFONSO SÁNCHEZ, R., La integración cooperativa..., op. cit., pàg. 236.

1018 ALFONSO SÁNCHEZ, R., La integración cooperativa..., op. cit., pàg. 182 a 184.

1019 Embid Irujo, J. M., Grupos de sociedades..., op. cit., pàg. 137 i ss; AlCALA DiAZ, M. A., La 
En relació amb els supòsits de conflicte entre les cooperatives sòcies $i$ els socis mateixos, al marge de la possibilitat esmentada d'establir compensacions, s'ha proposat la utilització dels mecanismes que disposa el dret de societats, entre els quals es troben la impugnació, tant de l'acord aprovatori d'incorporació al grup, com dels acords de l'òrgan d'administració pels que s'executen les instruccions de l'entitat capçalera del grup ${ }^{1020}$.

4. Possibilitat d'impugnar els informes o dictàmens de professionals externs: auditors, lletrat assessor $\mathrm{o}$ altres perits

En l'àmbit cooperatiu estatal, va ser la Llei general de cooperatives del 1987 la que, seguint les directrius europees en matèria de societats $\mathrm{i}$ el camí ja iniciat per algunes lleis autonòmiques (entre les quals destacava, precisament la LCCV, amb la seua exigència inicial d'auditoria externa per a totes les cooperatives, i la del nomenament d'un lletrat assessor per a les de més volum), va incorporar sense ambages la participació de professionals titulats externs, amb funcions variades ${ }^{1021}$. En alguns casos, l'actuació d'aquests professionals té caràcter merament consultiu o assessor, però en altres les funcions exercides tenen una inequívoca repercussió interna i externa; en aquest sentit, ja hem vist

impugnación..., op. cit., pàg. 202, nota 197.

1020 ALFONSO SÁNCHEZ, R., La integración cooperativa..., op. cit., pàg. 163 i 164.

1021 Això no obstant, el debat doctrinal sobre la conveniència d'aquesta incorporació ve de lluny, tant en l'àmbit cooperatiu com en el capitalista: SANCHEZ CALERO, F., "Los conceptos...", op. cit., pàg. 512 i 513 recull la discussió parlamentària al voltant de la proposta d'inclusió d'una censura de comptes externa en la LGC de 1974, així com una selecció abundant de citacions del debat en la doctrina mercantilista espanyola de l'època al voltant dels arts. 41 del Cco i 108 LSA llavors vigents. VICENT CHULIÁ, F., «La Ley General...», op. cit., pàg. 291, assenyala com aquests professionals contribueixen a crear "un sistema institucional de controls interns i externs (sobre els acords socials, sobre els comptes anuals i l'aplicació de l'excedent), incorporant-los amb les característiques pròpies del seu estatut jurídic i règim de responsabilitat, a fi d'aprofitar al màxim el seu bagatge de coneixements. Així, respecte dels professionals del Dret: notaris, registradors, advocats en exercici (com a lletrats assessors) o simplement llicenciats en dret (com a àrbitres de dret a l'arbitratge cooperatiu institucional); $i$ respecte dels professionals de l'economia i gestió d'empresa: auditors, tècnics en gestió d'empreses (quan la Llei, sobretot, exigeix el nomenament d'un encarregat de la gestió amb caràcter permanent, en les grans cooperatives". 
com la direcció o gerència de la cooperativa, que la majoria de les vegades estarà ocupada per personal professional, pot arribar a ser considerada un òrgan de la cooperativa, almenys, en la mesura que la seua creació i funcionament estiguen previstos estatutàriament o siga obligatòria per mandat legal.

Dues figures més destaquen en el grup de professionals externs que poden col-laborar en el funcionament de la cooperativa: els auditors i el lletrat assessor $^{1022}$, encara que no s'ha d'oblidar que tant la LCoop com la LCCV preveuen altres intervencions, sobretot en l'àmbit del control econòmic ${ }^{1023}$.

Encara que també aquí podria discutir-se, com a qüestió prèvia, si aquests professionals poden considerar-se o no òrgans de la cooperativa ${ }^{1024}$, no sembla

1022 La LCCV regula el lletrat assessor a l'article 46, que configura per si sol la Secció quarta del Capítol IV, titulat "Òrgans socials", del Títol I. En l'àmbit estatal, la LGC de 1987 va incloure la figura en la seua Disposició addicional cinquena, però la LCoop omet qualsevol menció al lletrat assessor, amb la qual cosa es produeix el dubte sobre la seua derogació o vigència tàcites (PAZ CANALEJO, N., "Visión general...», op. cit., pàg. 55, i «Ante la nueva Ley...», pàg. 89)

${ }^{1023} \mathrm{La} \mathrm{LCCV}$ és bastant prolífica en l'exigència d'intervencions externes: l'article 34.4 regula la possibilitat de requerir la presència a l'assemblea d'un notari que alce acta notarial; els arts. 49.6, 2n paràgraf i 67 estableixen l'informe preceptiu d'"experts independents" per a la valoració de l'existència possible del director al capital i del patrimoni cedit, respectivament; es preveu per un professional extern; i l'article 111 de la secció (article 7.2), càrrec que pot ser ocupat aquest serà emès o firmat i i l'article 111.1, b), en regular l'arbitratge de dret estableix que Consell Valencià del Cooperativisme o de la Corts en dret experts en cooperatives, membres del La LCoop també preveu

notarial de l'assembeu la possibilitat de requerir la intervenció d'un notari perquè alce acta notarial de l'assemblea general (article 29.4); conferir apoderaments amb facultats representatives de gestió o direcció diferents a les de l'apoderat principal o gerent (article 32.3); i l'informe d'un o diversos d'experts independents en relació amb la valoració de les aportacions no dineràries (article 45.4).

1024 TATO PLAZA, A., "Os órganos sociais», op. cit., pàg. 102 a 104, inclou l'estudi del lletrat assessor en l'epígraf dedicat als òrgans facultatius i eventuals de la cooperativa.

En relació amb l'auditor, sembla manifestar-se a favor ALFONSO SÁNCHEZ, R., "Aspectos básicos...», op. cit., pàg. 181, quan afirma que "l'auditor es configura com un nou òrgan necessari quan la cooperativa haja de sotmetre's a auditoria"; en contra de la qualificació dels auditors com a òrgans socials, VICENT CHULIÁ, F., "La Ley 27/1999...», op. cit., pàg. 14574; i MONTOLfo HERNÁNDEZ, J. M., Legislación cooperativa en la Comunidad europea, op. cit., pàg. 38, en el context de la legislació cooperativa alemanya, "per inexcusable que siga [...] des del mateix moment constitutiu [...]. Es tractarà en tot cas d'un control/auxili necessari, però sempre aliè, a la cooperativa i a l'esfera de la seua personalitat jurídica". S'ha de recordar que la Llei alemanya de cooperatives exigeix, com a requisit per a la constitució mateixa de la cooperativa, la 
ser aquest l'element rellevant en la consideració d'una impugnació possible de les seues decisions, sinó el caràcter i el règim jurídic de les seues funcions. Segons el que diu la doctrina sobre $\mathrm{l}^{\prime}$ auditoria ${ }^{1025}$, les funcions que realitzen els professionals externs es dirigeixen, no solament a la satisfacció de les necessitats i els interessos de la cooperativa i dels seus socis, sinó també a la salvaguarda $\mathrm{d}^{\prime}$ interessos públics, com ara la seguretat del tràfic empresarial ${ }^{1026}$. En l'acompliment d'aquestes funcions, a més, queden sotmesos a un rigorós règim juridicopúblic: el que regula el seu exercici professional i, molt especialment, la seua responsabilitat civil i penal.

La actuació indeguda dels professionals o la seua falta d'intervenció en els casos en què siga preceptiva té, doncs, el seu propi règim jurídic, que escapa a la

certificació de la seua afiliació a una federació d'auditoria i l'informe d'aquesta sobre la situació economicopatrimonial d'aquella. Sobre el funcionament de les federacions d'auditoria alemanyes i les seues competències, vegeu MÜNKNER, H., "Ley de cooperativas...», op. cit., especialment en pàg. $109 \mathrm{a} 111$.

En l'àmbit de les societats de capital, i amb un criteri més flexible respecte de la possibilitat de configurar estatutàriament òrgans socials, també per a les funcions de control dels comptes socials, ESTEBAN VELASCO, G., "Algunas reflexiones...", op. cit., pàg. 558: "Els estatuts poden preveure un altre o uns altres òrgans diferents dels contemplats en el model legal. [...] Una menció a part mereix, referent a això, el control de comptes. Com és sabut, en el marc de la SA s'ailla la funció del "control comptable", que històricament exerceix la JG mateixa i que després es confia institucionalment a un grup separat d'accionistes (els censors de comptes) i més tard a un grup d'experts professionals $i$ independents (auditors de comptes). És discutible si l'auditoria es pot considerar, encara que debilitat, un "element peculiar de l'organització societària", com es posa de manifest en el mecanisme bàsic de nomenament i revocació dels seus titulars, amb funcions internes, sense perjudici de reconèixer que aquesta funció té rellevància extrasocietària i que els titulars eventuals del càrrec estan sotmesos a un estatut professional específic $i$ vinculats a la societat per una relació d'auditoria peculiar i autònoma. Doncs bé, sense perjudici dels supòsits en què, per la dimensió de la societat, és obligatòria la verificació per auditors de comptes (article 84 LSRL i article 203 LSA) i del dret de la minoria a sol-licitar el nomenament d'un auditor de comptes amb càrrec a la societat (article 86.3), res no impedeix que els socis prevegen en els estatuts l'existència d'un o diversos auditors a nomenar per la JG (article 12.3)".

Es manifesta expresament a favor de la qualificació dels auditors com a órgan, SÁNCHEZ CALERO, Fernando, Principios..., op. cit., pàg. 189.

1025 VICENT CHULIÁ, F., «La Ley General...», op. cit., pàg. 291.

1026 Això queda especialment patent en el sistema alemany d'auditoria cooperativa, que va ser creat explícitament "arran de la necessitat d'una intervenció externa efectiva i el temor a la submissió al control de l'Administració" (MÜNKNER, H., "Ley de cooperativas...», op. cit., pàg. 110). En el mateix sentit, MONTOLf́O HERNÁNDEZ, J. M., Legislación cooperativa en la Comunidad europea, op. cit., pàg. 14: "el convenciment dels cooperativistes va encoratjar que, entre les dues possibilitats (control per part de l'Estat, control per part del moviment cooperatiu mateix), la legislació optara pel segon procediment i establira un precedent importantíssim (afiliació a una federació de revisió) que perdura fins als nostres dies". 
regulació juridicoprivada cooperativa. En conseqüència, considerem que la manera adequada d'afrontar els efectes perjudicials possibles que es puguen derivar de la seua activitat incorrecta o de la seua inactivitat per a la cooperativa no serà la pretensió d'impugnar els acords o decisions en què s'exterioritze l'activitat professional, o la seua inexistència.

D'una banda, tant la cooperativa, com els socis i els tercers amb interès legítim poden actuar l'esmentat règim de responsabilitat del professional; d'una altra, des de la perspectiva del funcionament social de la cooperativa, seran els acords $\mathrm{i}$ les decisions dels òrgans socials que requerisquen la intervenció del professional, els que quedaran afectats de nul-litat o d'anul-labilitat quan aquesta haja estat deficient o, tot i ser necessària, no s'haja produït. L'objecte de la impugnació serà la manifestació de voluntat orgànica que, ja siga per norma legal ${ }^{1027}$ o estatutària, o per acord vàlid de l'òrgan competent, estiga sotmesa a la intervenció professional externa. Consegüentment, el procediment per a la impugnació serà el regulat per a l'òrgan al que corresponga l'acord o la decisió viciades.

Així doncs, un acord ${ }^{1028}$ assembleari d'aprovació de comptes anuals l'auditoria necessària dels quals s'haja realitzat infringint principis bàsics d'actuació professional serà tan impugnable com l'acord adoptat sense la seua realització. I succeirà el mateix en els supòsits en què, en una cooperativa obligada a

1027 En aquest sentit, el legislador extremeny ha considerat oportú (article 47.8 LCE) recordarho: els acords adoptats infringint la regulació legal de l'assessorament jurídic del lletrat assessor seran impugnables "com a actes contraris a la Llei".

1028 GIRÓN TENA, J., Derecho de sociedades, op. cit., t. I, pàg. 312: “L'acord ja adoptat [...] podrà aparèixer com una declaració de voluntat, que serà pressupòsit perquè es produïsquen efectes jurídics posats per la voluntat mateixa, perquè l'ordenament jurídic ho autoritze - negoci jurídic- o com una declaració de ciència o de veritat, o de desig o d'opinió, o de sentiment, en els quals casos la voluntarietat seguirà sent pressupòsit de l'acte, com a acte, però no la dada jurídicament rellevant per a la producció dels efectes. Aquests diferents efectes es donen en el Dret de Societats (acords sobre comptes i balanços, opinions de la Junta imposts als administradors preceptivament per a supòsits determinats, vots de gràcies)". 
designar lletrat assessor per la $\mathrm{LCCV}^{1029}$, un acord del consell rector relatiu a l'alta de socis no porte el dictamen corresponent sobre la seua conformitat a dret, o quan aquest haja estat realitzat indegudament: també podran ser objecte d'impugnació.

En relació amb els acords presos amb la intervenció d'auditors o lletrats sotmesos a causes de prohibició, inhabilitació, incompatibilitat o incapacitat, ja hem vist, en ocasió del tractament de la qüestió en relació amb els administradors, ${ }^{1030}$ que la doctrina considera necessari mantenir la validesa dels acords adoptats amb la participació dels qui han estat nomenats invàlidament, mentre no se'n produïsca la destitució, fonamentalment per raó de la protecció de la seguretat jurídica i del tràfic econòmic.

\section{Acords no impugnables}

Fins ara hem vist els supòsits en què els acords i les decisions de la cooperativa poden ser objecte d'impugnació. Per completar aquest capítol atendrem aquells supòsits en què els acords $\mathrm{i}$ les decisions, que incorren en alguna de les causes d'impugnació, són, tanmateix, no atacables mitjançant aquest procediment.

\subsection{Acords "ferms" per no haver estat impugnats dins de termini}

Com ha quedat reiteradament exposat, una de les modificacions més radicals que ha experimentat la impugnació dels acords socials en les últimes dècades és la que reforma un dels aspectes essencials de la teoria general de la nul-litat dels

1029 Les cooperatives que tinguen una xifra anual de negocis superior a cinc-cents milions de pessetes, per als exercicis successius (article $46 \mathrm{LCCV}$ ). 
negocis jurídics per raó d'una estabilitat societària més gran i del tràfic empresarial. Ens referim al canvi introduït en la distinció clàssica entre nul-litat i anul-labilitat, i considerem que en ambdós casos la ineficàcia pot ser reparada, excepte en els supòsits d'acords que, pel seu contingut o la seua causa, siguen contraris a l'ordre públic.

Així, en l'àmbit de la ineficàcia dels negocis jurídics en general s'estableix que el negoci nul es caracteritza per estar afectat per una nul-litat absoluta o radical, definitiva i no esmenable, que cau fora de l'àmbit de l'autonomia de la voluntat; això deriva, entre altres conseqüències, en la impossibilitat de la seua confirmació o esmena, i en la no-extingibilitat de l'acció de nul-litat per caducitat o per prescripció1031.

En canvi, la reforma del dret de societats i de les cooperatives ha admès tant l'esmena dels acords nuls pel venciment del termini1032, com la convalidació d'aquests mitjançant una nova decisió1033. La conseqüència immediata és que l'acord que pateix de causa de nul-litat, tanmateix, esdevé ferm i no impugnable, si no s'inicia l'acció dins del termini corresponent ${ }^{1034}$.

1030 Vegeu supra epígraf 2.2.2.

1031 DE CASTRO Y BRAVO, Federico, El negocio jurídico, op. cit., pàg. 471 a 481.

1032 TATO PLAZA, A., Sustitución y anulación..., op. cit., pàg. 76 i 77; CABALLOL I ANGELATS, L., "Comentario al artículo 115 ", op. cit., que també indica en pàg. 1108 que "si no pot prosperar una impugnació dirigida contra un acord deixat sense efecte, tampoc hauria de poder fer-ho la que es dirigeix contra un acord mancat d'eficàcia per qualsevol altra causa, per exemple, quan l'acord perd l'eficàcia de manera sobrevinguda".

1033 DE CASTRO MARTíN, José Luis, «La reafirmación de la voluntad social (Delimitación del supuesto de hecho del art. 115.3 LSA)", en AA. DD., Estudios jurídicos en homenaje al profesor Aurelio Menéndez, tom II, Civitas, Madrid, pàg. 1612.

1034 Contràriament, Df́zZ-PICAZo GIMÉNEZ, I., i DE L'OLIVA SANTOS, A., «Especialidades procesales...», op. cit., pàg. 428 a 431 , estimen que la voluntat del legislador no ha estat la d'introduir, amb la caducitat de l'acció, una forma de guariment del vici de nul-litat, pel que aquesta pot estar al-legada per via d'excepció en qualsevol moment. 
I la caducitat de l'acció i la consegüent fermesa de l'acord no impugnat durant el termini tenen altres conseqüències. Així, en l'àmbit de les societats de capital, la jurisprudència reitera la impossibilitat d'impugnar acords merament confirmatoris d'altres d'anteriors que no van ser impugnats ${ }^{1035}$. Per contra, el còmput del termini per a l'acció de nul-litat dels anomenats "acords complexos" (realitzats en el transcurs de diverses sessions de l'assemblea general) haurà de ser el que es derive de l'última assemblea en la qual s'haja «completat» ${ }^{1036}$.

\subsection{L'eliminació o substitució com a causa de no impugnabilitat}

La doctrina coincideix a assenyalar l'article 52.1, 2n paràgraf de la LGC de 1987 com la primera norma que a escala estatal ${ }^{1037}$ va recollir la possibilitat de reparar els acords socials, en establir que "no serà procedent la impugnació d'un acord social quan haja estat deixat sense efecte o substituit vàlidament per un altre". Tenia aquesta norma com a antecedents pròxims la Proposta de cinquena

1035 La STS de 21.2.2000 (RJA 2000/1240) estima que no pot considerar-se lesiu l'acord adoptat per la junta com a conseqüència d'un acord previ del consell, no impugnat per l'administrador demandant. ÁVILA NAVARRO, P., La sociedad ... op. cit., pàg. 424: “ La Llei parteix del principi general de fermesa dels acords no impugnats dins de termini (S. 10.07.85); $i$ aquesta fermesa impedeix la impugnació d'acords simplement confirmatoris d'altres d'anteriors que no van ser impugnats; aquesta doctrina ha estat reiteradament consagrada per la jurisprudència (vegeu, per exemple, S. 02.10.72 i S. 11.11.80)"; SILVETII, C., i CAVALLI, G., Le società per azioni, p. 222.

1036 SIlvetTI, C., i CAVALLI, G., Le società per azioni, p. 223: "la sentència de Cass. 9 novembre 1974, n. 3491, a Giur. Comm., 1975, II, 305 [...] ha examinat el cas del comunament denominat acord complex. Amb aquesta expressió la S.C. ha intentat referir-se a un acord adoptat en tres reunions assembleàries successives en el curs de les quals va ser aprovat $\mathrm{i}$ executat el repartiment d'immobles entre els socis, però mentre en la primera assemblea es va disposar un simple ajornament, l'activitat deliberativa vertadera i pròpia es va desenvolupar en les successives: en la segona el projecte de repartiment va ser aprovat, en la tercera el canvi va ser efectuat mitjançant sorteig de les unitats immobiliàries entre els socis. Un soci va impugnar l'últim acord i, encara que la demanda es limitava a aquest, la S. C. ha considerat que el jutge estava investit de decisió sobre la validesa dels acords adoptats en les tres assemblees, ja que havia de mantenir-se única l'assemblea - fins i tot si s'havia desenvolupat durant diverses fases fraccionades en el temps- i únic l'acord, articulat en diversos actes només formalment diferents entre si, però en realitat concurrents tots a la formació i manifestació d'una única, encara que complexa, voluntat assembleària".

1037 En l'àmbit autonòmic, en el moment de la promulgació de la LGC de 1987, la Llei de cooperatives del País Basc de 1982 (article 37.3) ja recollia una norma en els mateixos termes. 
directiva de la CEE i el Projecte de llei de cooperatives de $1980^{1038}$. Posteriorment, l'article 115.3 LSA, que pren també com a fonament la Proposta modificada de cinquena directiva ${ }^{1039}$, va afegir un segon paràgraf: " $\mathrm{Si}$ és possible eliminar la causa d'impugnació, el jutge atorgarà un termini raonable perquè aquella puga ser reparada". En l'actualitat, tant l'article 31.1, 2n paràgraf LCoop, com l'article 35.3 LCCV incorporen, de manera pràcticament literal ${ }^{1040}$, la redacció adoptada per la LSA, la qual cosa possibilita la translació dels estudis doctrinals elaborats en l'àmbit de les societats de capital ${ }^{1041}$.

1038 DE CASTRO MARTíN, J. L., «La reafirmación...», op. cit. pàg. 1626, on assenyala com, tanmateix, la norma cooperativa estatal va "completar" el text comunitari: mentre que l'article 45 de la Proposta de cinquena directiva evitava únicament l'acció impugnatòria quan l'acord impugnable haguera estat reemplaçat per un altre de conforme amb la llei i els estatuts, la LGC de 1987 també precluïa la impugnació quan l'acord viciat simplement haguera estat deixat "sense efecte". En el mateix sentit, PAZ CANALEJO, N., en PAZ CANALEJO, N., i VICENT CHULIÁ, F., Ley general... op. cit., pàg. 585 i 586; POLO SÁNCHEZ, E., Los administradores..., op. cit., pàg. 532; URtA, MENÉNDEZ, i MUÑOZ, La junta ..., pàg. 309. EMBID IRUJO, J. M., «Notas sobre la impugnación...», op. cit., pàg. 55, i MARTÍNEZ SANZ, F., "La nulidad de la fusión...», op. cit., pàg. 83, assenyalen que la compensació ja es recollia en la Tercera directiva, per als supòsits de nul.litat de la fusió.

1039 DE CASTRO MARTÍN, J. L., "La reafirmación...», op. cit. pàg. 1621; POLO SÁNCHEZ, Los administradores..., op. cit., pàg. 532; RODRíGUEZ ARTIGAS, F., i QUIJANO GONZÁlEZ, J., «Los órganos...», op. cit., pàg. 168; URÍ, MENÉNDEZ, i MUÑOZ, La junta ..., pàg. 309, 327 i 328.

1040 Article 31.1, 2n paràgraf LCoop i article 35.3 LCCV: "No procedirà la impugnació d'un acord social que haja estat deixat sense efecte o substituït vàlidament per un altre. Si fóra possible eliminar la causa d'impugnació, el jutge atorgarà un termini raonable perquè aquella puga ser reparada".

Article 115.3 LSA: "No procedirà la impugnació d'un acord social quan haja estat deixat sense efecte o substituït vàlidament per un altre. Si fóra possible eliminar la causa d'impugnació, el jutge atorgarà un termini raonable perquè aquella puga ser reparada".

1041 Dues monografies s'han ocupat de manera central els últims anys de la matèria: Sustitución y anulación por la sociedad de acuerdos sociales impugnables (contribución al estudio del art. 115.3 LSA), McGraw-Hill, Madrid, 1997, d'Anxo TATO PLAZA; i La subsanación de acuerdos sociales por la junta general de la sociedad anónima, Aranzadi, Elcano (Navarra), 1999, de M. del Mar BUSTILLO SAIZ,. En aquestes i en el treball de José Luis DE CASTRO MARTIN, "La reafirmación de la voluntad social (Delimitación del supuesto de hecho del art. 115.3 LSA)", en AA. DD., Estudios jurídicos en homenaje al profesor Aurelio Menéndez, tom II, Civitas, Madrid, poden trobar-se les diferents interpretacions elaborades per la doctrina en l'àmbit del dret de societats de capital espanyol i comparat, així com extenses relacions bibliogràfiques. 
Sobre la finalitat de la norma, no hi ha dubte que la voluntat del legislador ha estat preservar, fins on siga possible, l'estabilitat dels acords socials ${ }^{1042}, \mathrm{i}$ d'aquesta manera n'evita la impugnació quan la cooperativa, posteriorment, actue per corregir els vicis que els invaliden. Però la preservació de l'estabilitat no ha d'entendre's, amb caràcter general, com a defensa a ultrança del manteniment de la voluntat social, ja que en tots els supòsits no serà així: els acords que es limiten a "deixar sense efecte" els anteriors viciats mitjançant la simple revocació, i els que els substituïsquen per altres de contingut diferent no refermen la voluntat social, sinó que l'adapten en nom de la seguretat jurídica. La finalitat bàsica de la norma és, doncs, eludir o pal-liar en la mesura de les possibilitats els inconvenients d'una intervenció processal1043.

Una observació generalitzada respecte a la redacció donada al precepte pel legislador és la seua falta de precisió juridicotècnica en utilitzar una varietat de termes (deixar sense efecte, substituir, eliminar, reparar) la interpretació dels quals divideix la doctrina ${ }^{1044}$. I no contribueix, precisament, a simplificar $\mathrm{l}^{\prime}$

1042 DE CASTRO MARTÍN, J. L., «La reafirmación...», op. cit., pàg. 1621 i 1624; l'esmentat autor exposa, en relació amb la finalitat de la norma continguda a l'article 45 de la Proposta de cinquena directiva, que no pot ser la que s'expressa en el seu Preàmbul en relació amb els preceptes del capítol cinquè en general, això és, la tutela dels socis minoritaris. L'interès protegit pot deduir-se "de les disposicions similars contingudes en [...] la Tercera directiva, relativa a la fusió [...], i de la Sisena directiva, sobre escissió, les exposicions de motius de les quals afirmen que l'establiment del principi de regularització obeeix a la necessitat de "garantir la seguretat jurídica en les relacions tant entre les societats interessades com entre aquestes $\mathrm{i}$ els tercers, així com entre els accionistes»". En el mateix sentit, DUQUE DOMf́NGUEZ, J. F., "La fusión en el Proyecto...», pàg. 772 a 775; EMBID IRUJO, J. M., «En torno a la nulidad de la fusión...», p. 5610; GARCÍA LUENGO, R., i SOTO VÁZQUEZ, R., El nuevo régimen jurídico..., op. cit., pàg. 544 i 545; i URÍA, R., MENÉNDEZ, A., i MUÑOZ, J. M., La junta ..., p. 309: "i encara que per a això calga sacrificar o subvertir els principis que governen aquesta matèria en les lleis civils".

1043 SAlelles Climent, J. R., El funcionamiento..., op. cit., pàg. 392: “Certament no sempre la impugnació dels acords és la manera més adequada per evitar el perjudici que puga causar-se a la societat com a conseqüència de l'execució d'un acord contrari a la Llei, als estatuts o al seu interès. La correcció de l'activitat de la societat i la tipicitat de l'interès social poden ser tutelats de manera més eficient per vies diferents a les d'un procés judicial, atesa la durada i el cost. Una llei d'economia en porta així a subordinar la iniciativa més greu, la impugnació, a la regularització dels acords viciats". ALCALÁ DíAZ, M. Á., La impugnación..., op. cit., pàg. 461 estima que la finalitat de la norma no és "intensificar l'estabilitat dels acords socials, sinó afavorir els mecanismes interns de negociació entre els socis [...] a fi d'evitar accions judicials d'impugnació".

1044 DE CASTRO MARTíN, J. L., «La reafirmación...», op. cit., pàg. 1587 a 1602; JUSTE MENCÍA, J., 
estudi que la norma comporta, com succeeix amb la impugnació dels acords, la introducció d'especialitats en relació amb la teoria general del negoci jurídic. En efecte, s'ha de tenir present que, d'una banda, s'està plantejant la possibilitat que acords qualificats com a nuls esdevinguen no impugnables, i que, d'una altra, la norma suposa el reconeixement legal explícit de la retroactivitat possible dels efectes esmenables del segon acord respecte al primer.

L'actuació consisteix en l'adopció d'un acord posterior al que es pretén guarir, el contingut del qual pot ser d'índole variada. D'entrada, el text legal esmenta la possibilitat de compensació mitjançant la substitució de l'acord viciat per un altre de vàlid, però també la possibilitat de deixar-lo sense efecte: en la substitució, el segon acord serà diferent del primer, almenys en la mesura que no té els vicis d'aquest; en el segon cas, l'acord posterior es limita a revocar el viciat. Des d'una altra perspectiva, l'acord substitutori pot consistir en la recerca del refermament de la voluntat social, en aquest cas el nou acord pretendrà l'eliminació dels vicis del primer; però la cooperativa també pot canviar la seua voluntat amb la finalitat d'evitar la litigiositat i el marge de provisionalitat que comporta.

En tot cas, com s'ha indicat, la norma jurídica preveu tres supòsits diferents, que són: la substitució d'un acord impugnable per un altre d'adoptat vàlidament, l'anul-lació de l'acord viciat a iniciativa de la cooperativa mateixa, $\mathrm{i}$ la compensació dels vicis una vegada presentada la demanda d'impugnación ${ }^{1045}$. Els dos primers tenen caràcter extraprocessal, dins de l'àmbit de la cooperativa, mentre que el tercer es du a terme ja al si del procés d'impugnació ${ }^{1046}$.

Los derechos de minoría..., op. cit., pàg. 404, nota 65; TATO PLAZA. A., Sustitución y anulación..., op. cit., pàg. 72.

1045 TAto PlaZA. A. , Sustitución y anulación..., op. cit., pàg. XIX i XX.

1046 EMBID IRUJO, J. M., «Notas sobre la impugnación...», op. cit., pàg. 55. 
S'ha plantejat la possibilitat que no totes les causes de la impugnació puguen ser reparades ${ }^{1047}$. La redacció mateixa dels textos legals es fa de manera condicional: "si és possible eliminar la causa d'impugnació", "no procedirà" la impugnació d'un acord quan/que haja estat deixat sense efecte". No creiem, tanmateix, que, com s'ha proposat, els supòsits exclosos hagen de ser tots els acords nuls. Considerem que la referència legal es dirigeix fonamentalment a l'exclusió de la ratificació d'acords que, per la seua causa o el seu contingut, siguen contraris a l'ordre públic ${ }^{1048}$.

1047 GARCía LuENGO, R., i SOTO VÁzQUEZ, R., El nuevo régimen jurídico..., op. cit., pàg. 545, no admeten que la compensació puga aplicar-se als acords "nuls de ple dret"; PAZ CANALEjO, N., en PAZ CANALEJO, N., i VICENT CHULIÁ, F., Ley general... op. cit., pàg. 586, estima que els acords "d'eficàcia convalidadora només seran possibles respecte als acords anul-lables, ja que la nul-litat és no guarible $i$ en conseqüència les resolucions assembleàries nulles no podran ser objecte de convalidació".

TATO PLAZA. A. , Sustitución y anulación..., op. cit., pàg. 71, estima que els supòsits de substitució només són possibles quan la causa d'impugnació raga en l'existència de vicis merament formals, per considerar que "la substitució exigiria l'adopció d'un acord substancialment idèntic $i$, per tant, l'adopció d'un acord igualment viciat i impugnable"; en canvi, considera que la societat "podria anul-lar tant els acords nuls com els anul-lables, i fins i tot també els acords contraris a l'ordre públic". En la mateixa línia, ALCALÁ DíAZ, M. Á., La impugnación..., op. cit., pàg. 458 a 461

1048 ALONSO SOTO, R., "Consideraciones...", op. cit., pàg. 4; ARROYO, Ignacio, "Comentario al art. 56", op. cit., pàg. 614 i 615: "no tots els acords impugnables poden ser objecte de convalidació. Hi ha acords [...] on no és possible eliminar la causa d'impugnació. [...] Segons la doctrina civil, els negocis nuls no són convalidables [...] Aquesta doctrina xoca amb el règim de convalidació instaurat en l'article 115.3 LSA [...] quins acords nuls poden ser objecte de convalidació? Formalment la resposta és clara: els acords nuls sotmesos al termini anual de caducitat. [...] els nuls radical o absolutament que s'identifiquen amb els que, a més de violar la llei, són contraris a l'ordre públic [...] no són convalidables, no prescriuen i poden ser atacats per la via de l'acció o de l'excepció. En tractar-se de caducitat i no de prescripció, la seua existència pot observar-se d'ofici, sense que siga necessari al-legar-ho com a excepció (STS 22 maig 1990, RJA 3.832). Els efectes de la declaració judicial de nul-litat són retroactius, ex tunc [...] Els altres acords contraris a la llei, però que no infringeixen normes d'ordre públic, caduquen pel transcurs d'un any i poden ser objecte de convalidació o substitució. Se'n presumeix la validesa fins que no hi haja una declaració judicial ferma de nul.litat. [...] tots els acords anul-lables [...] poden ser objecte de convalidació o substitució".

DE CASTRO MARTíN, J. L., "La reafirmación...», op. cit., pàg. 1606 a 1618, distingeix, als efectes de l'admissió de compensació, entre els "acords que, per la seua causa o el seu contingut, infringeixen disposicions legals fundades en la protecció d'interessos generals" i aquells altres "que, per la manera com han estat adoptats" infringeixen aquest mateix tipus de normes. Respecte dels primers, si ni la falta d'exercici de l'acció d'impugnació, ni el consentiment exprés o tàcit dels legitimats per exercitar-la produeixen l'efecte de guariment", tampoc pot deduir-se "aquest efecte d'una decisió convalidatòria de la pròpia junta general". En relació amb els segons assenyala que ja durant la vigència de la LSA de 1951 la doctrina sostenia la possibilitat convalidar-los, "en assenyalar que, en el supòsit de nul-litat per conseqüència d'un defecte formal, "no hi ha cap inconvenient en la substitució de l'acord per un altre sobre la mateixa al artículo 143 », op. cit., pàg. 1530 . 
general (articles 31.6 LCoop i 36.8 LCCV) ${ }^{1051}$; però pel que fa als socis s'ha indicat que hauria estat desitjable que la norma s'haguera completat amb la creació d'"una via específica per veure restablert el seu dret" 1052.

Quant als aspectes formals i procedimentals de la compensació o substitució, $s^{\prime}$ han de destacar els derivats de la possibilitat de regularització, tant a instància de la cooperativa mateixa, com per iniciativa del jutge. En aquest últim cas, s'ha observat que la concessió del termini s'estableix amb caràcter obligatori per al jutge $e^{1053}$, però no s'indica quina n'haurà de ser la durada ${ }^{1054}$, per la qual cosa s'interpreta que "el jutge atorgarà un termini raonable" com a lliure discrecionalitat judicial, en consideració a les circumstàncies del $\operatorname{cas}^{1055}$. Pel que fa al termini de què disposa la cooperativa, es discuteix quin ha de ser: mentre que alguns autors consideren que pot tenir lloc fins al moment en què el

cit., pàg. 328.

1051 Paz Canalejo, N., en Paz Canalejo, N., i Vicent ChuliA, F., Ley general... op. cit., pàg. 586.

1052 RODRÍGUEZ ARTIGAS, F., i QUIJANO GONZÁLEZ, J., «Los órganos...», op. cit., pàg. 169, que recull, al seu torn, l'informe que en el seu moment va emetre el Consell general del poder judicial sobre el llavors Projecte de llei de reforma parcial i adaptació de la legislació mercantil a les Directives de la CEE en matèria de societats. En la mateixa línia, GARCÍA LUENGO, R., i SOTC VAZZUEZ, R., El nuevo régimen jurídico..., op. cit., pàg. 545; i PAZ CANALejo, N., en PAZ CANALEjo, N., i VICENT CHULIÁ, F., Ley general... op. cit., pàg. 586.

1053 GOMEZ PORRÚA, J. M., La fusión..., op. cit., pàg. 261; en contra, DíEZ-PICAZO GIMÉNEZ, I., i DE LA OLIVA SANTOS, A., "Especialidades procesales...", op. cit., pàg. 446, 448 i 449, els qui. d'entrada, estimen que, en general, "l'obertura pel jutge, concedint aquell termini, de l'oportunitat de revocació, substitució o compensació suposa [...] un cert prejudici sobre l'existència d'un vici o "causa d'impugnació" en l'acord impugnat"; i més endavant, que "ur deure genuí de donar l'oportunitat de reparar el o els vicis de l'acord impugnat, comportaria en bona lògica $\mathrm{i}$ amb total conseqüència, un deure d'examinar ex officio -com més avia millor- les demandes d'impugnació [...]. Això ens sembla, sens dubte, excessiu".

Per la seua part, DÍAZ DE LEZCANO SEVILLANO, N., Los acuerdos del consejo..., op. cit., pàg. 376 dubta de que el jutge puga decretar la compensació d'ofici, sense que li haja estat sol-licitada, cita abundant doctrina i la STS de 20.10.1998 (RJ 1998/8229).

1054 MARTínEZ SANZ, F., «La nulidad de la fusión...», op. cit., pàg. 83.

1055 ARroYo, Ignacio, "Comentario al art. 56», op. cit., pàg. 616; ÁvILA NAVARRO, P., L sociedad..., op. cit., pàg. 425: "El termini serà de lliure arbitri judicial, i adequat a la naturalesa $\mathrm{d}$ la compensació, des dels casos més fàcils (com seria realitzar una publicació de l'acord omesa als més complicats (com tornar a iniciar un procés de fusió)"; DíEZ-PICAZO GIMÉNEZ, I., i DE L. OLIVA SANTOS, A., «Especialidades procesales...», op. cit., pàg. 450; GÓMEZ PORRÚA, J. M., L fusión..., op. cit., pàg. 261. 
Perquè la compensació siga plenament eficaç, o bé el primer acord no ha produït encara efectes i no en pot produir en el futur, ${ }^{1049}$ o bé el segon acord ha de tenir efectes retroactius. Però això planteja també la protecció necessària dels tercers de bona fe i dels socis mateixos davant dels efectes perjudicials que per als seus interessos i drets adquirits puga tenir la compensación ${ }^{1050}$. En relació amb els tercers, la protecció queda expressament garantida, amb caràcter

Això no obstant, BUSTILLO SAIZ, M. del M., La subsanación..., op. cit., pàg. 390 a 395 , assenyala
que "... l'ordre públic no impedeix revocar l'acord"; i DIAZ DE LEZCANO SEVILLANO, N., Los
acuerdos del consejo..., op. cit., pàg. 374, estima que la compensació intraprocessal dels acords de
l'òrgan col-legiat d'administració es pot donar respecte de tots els impugnables, "fins i tot els
contraris a l'ordre públic".

1049 En aquest cas, el primer acord queda anul-lat pel segon i "no hi ha interès" d'impugnar-lo. Es refereix, entre altres, a la falta d'acció per "defecte d'interès", GOMEZ ORBANEJA, E., «El
proceso...», op. cit., pàg. 127 , nota 1 .

1050 DE CASTRO MARTÍN, J. L., La reafirmació..., op. cit., pàg. 1593 i 1594: "Tant els acords substitutoris com, en general, la resta dels acords revocatoris (acords de supressió) determinen l'aturada dels acords revocats o substituïts. Però ni els uns ni els altres comporten necessàriament o natural la producció d'efectes retroactius. [...] quan, per voluntat expressa de la junta, es tracte d'acords pròpiament revocatoris i no simplement abrogatoris, els efectes retroactius d'aquests estan limitats per la protecció necessària dels interessos d'aquells a qui hagueren ja abastat els efectes del primer acord".

SILVETTI, C., i CAVALLI, G., Le società per azioni..., op. cit., pàg. 241 a 244, recull l'intens debat doctrinal italià, i estima que "el poder de revocació o d'autoanul-lació pot ser exercitat només en tant que l'acord precedent no haja produït els seus efectes i sobre la seua base no s'hagen adquirit drets per socis o per tercers", mentre que "la substitució no pot no tenir eficàcia ex tunc, ja que si un nou acord, encara regulant de manera antitètica les relacions socials, té eficàcia ex nunc, si hi ha un acord contrari que no elimina l'eficàcia de l'acord precedent en el període intermedi és que no val, per tant, per a precloure el pronunciament d'anul-lació de l'acord precedent".

TATO PLAZA, A., Sustitución y anulación..., op. cit., pàg. 75 i 76: "els acords socials poden ser considerats com a negocis jurídics unilaterals. Com a tals, poden ser revocats a través d'un altre negoci jurídic unilateral. L'autor d'aquest últim, fora d'això, ha de ser el mateix que va donar vida al negoci jurídic que es pretén revocar, això és, la societat mateixa. La societat, doncs, té un poder de revocació dels seus propis acords. En altres paraules, de la mateixa manera que l'autonomia privada permet a la societat adoptar els seus propis acords, aquesta mateixa autonomia li atorga després un poder de revocació sobre aquests [...]. Ara bé, com ja sabem, una cosa és tenir un poder de revocació, i una altra de ben diferent és estar legitimat per exercir-lo lícitament respecte a un acord social determinat. [...] d'ordinari, només es té legitimació per al lícit exercici d'un poder de revocació quan s'és també titular de l'esfera jurídica sobre la qual es produiran les conseqüències d'aquella revocació. Així les coses, no ha de resultar-nos estrany que la doctrina afirme - de manera unànime- que la revocació dels acords socials per part de la societat no pot afectar els drets adquirits pels socis o per terceres persones. Així doncs, en absència d'una norma legal específica (o del consentiment dels afectats), la societat només podria procedir a una revocació lícita dels seus propis acords respectant escrupolosament els drets adquirits pels socis o per terceres persones".

Es refereixen als efectes ex tunc dels acords de substitució DÍAZ DE LEZCANO SEVILLANO, N., Los acuerdos del consejo..., op. cit., pàg. 372; URfA, R., MENÉNDEZ, A., i MUNNOZ, J. M., La junta..., op. 
general (articles 31.6 LCoop i 36.8 LCCV) ${ }^{1051}$; però pel que fa als socis s'ha indicat que hauria estat desitjable que la norma s'haguera completat amb la creació d"una via específica per veure restablert el seu dret" 1052.

Quant als aspectes formals i procedimentals de la compensació o substitució, $s^{\prime}$ han de destacar els derivats de la possibilitat de regularització, tant a instància de la cooperativa mateixa, com per iniciativa del jutge. En aquest últim cas, s'ha observat que la concessió del termini s'estableix amb caràcter obligatori per al jutge $e^{1053}$, però no s'indica quina n'haurà de ser la durada ${ }^{1054}$, per la qual cosa s'interpreta que "el jutge atorgarà un termini raonable" com a lliure discrecionalitat judicial, en consideració a les circumstàncies del cas ${ }^{1055}$. Pel que fa al termini de què disposa la cooperativa, es discuteix quin ha de ser: mentre que alguns autors consideren que pot tenir lloc fins al moment en què el

cit., pàg. 328.

1051 Paz Canalejo, N., en PaZ Canalejo, N., i Vicent ChuliÁ, F., Ley general... op. cit., pàg. 586.

1052 RodRíGUEZ ARTIGAS, F., i QUIJANO GONZÁlEZ, J., "Los órganos...», op. cit., pàg. 169, que recull, al seu torn, l'informe que en el seu moment va emetre el Consell general del poder judicial sobre el llavors Projecte de llei de reforma parcial i adaptació de la legislació mercantil a les Directives de la CEE en matèria de societats. En la mateixa línia, GARCÍA LUENGO, R., i SOTO VAZQUEZ, R., El nuevo régimen jurídico..., op. cit., pàg. 545; i PAZ CANALEJO, N., en PAZ CANALEJO, N., i VICENT CHULIÁ, F., Ley general... op. cit., pàg. 586.

1053 GOMEZ PORRÚA, J. M., La fusión..., op. cit., pàg. 261; en contra, DíEZ-PICAZO GIMÉNEZ, I., i DE LA OLIVA SANTOS, A., «Especialidades procesales...», op. cit., pàg. 446, 448 i 449, els qui, d'entrada, estimen que, en general, "l'obertura pel jutge, concedint aquell termini, de l'oportunitat de revocació, substitució o compensació suposa [...] un cert prejudici sobre l'existència d'un vici o "causa d'impugnació" en l'acord impugnat"; i més endavant, que "un deure genuí de donar l'oportunitat de reparar el o els vicis de l'acord impugnat, comportaria, en bona lògica $i$ amb total conseqüència, un deure d'examinar ex officio —com més aviat millor-les demandes d'impugnació [...]. Això ens sembla, sens dubte, excessiu".

Per la seua part, DÍAZ DE LEZCANO SEVILLANO, N., Los acuerdos del consejo..., op. cit., pàg. 376, dubta de que el jutge puga decretar la compensació d'ofici, sense que li haja estat sol.licitada, i cita abundant doctrina i la STS de 20.10.1998 (RJ 1998/8229).

1054 MARTínEZ SANZ, F., «La nulidad de la fusión...», op. cit., pàg. 83.

1055 ARroYo, Ignacio, "Comentario al art. 56», op. cit., pàg. 616; ÁvilA NAVARRO, P., La sociedad..., op. cit., pàg. 425: "El termini serà de lliure arbitri judicial, i adequat a la naturalesa de la compensació, des dels casos més fàcils (com seria realitzar una publicació de l'acord omesa) als més complicats (com tornar a iniciar un procés de fusió)"; DíEZ-PICAZO GIMÉNEZ, I., i DE LA OLIVA SANTOS, A., «Especialidades procesales...», op. cit., pàg. 450; GÓMEZ PORRÚA, J. M., La fusión..., op. cit., pàg. 261. 
tribunal dicte sentència ${ }^{1056}$, uns altres consideren que ha de produir-se abans de la interposició de la demanda1057 o abans de la caducitat de l'acció d'impugnació1058.

En relació amb la possibilitat d'aplicar la norma a acords o decisions d'altres òrgans socials, la major part dels autors que han tractat la qüestió coincideixen a mantenir la seua vigència per als acords de l'òrgan d'administració, malgrat $l^{\prime}$ absència de remissió legal explícita ${ }^{1059}$. L'argument bàsic per a la seua aplicació extensiva és la manifesta voluntat del legislador de tendir a l'estabilitat del funcionament orgànic societari evitant, en la mesura possible, litigis davant dels tribunals de justícia, argument que, al nostre parer, pot servir per a la seua

1056 RodrígueZ ARTIGAS, F., i QUTJANO GonZÁlEZ, J., «Los órganos...», op. cit., pàg. 168.

1057 Díaz DE LEzCANO SEVILlano, N., Los acuerdos del consejo..., op. cit., pàg. 369, cita jurisprudència en la qual es precisa que "els litigis s'hauran de resoldre conforme a la situació existent en el moment de la interposició de la demanda" i que "les vulneracions hagudes no poden validar-se pels acords adoptats en una Junta posterior, quan els primers acords estiguen judicialment impugnats, ja que és sabut que, en relació amb l'objecte del procés, manquen d'eficàcia les innovacions que després d'iniciat el judici introdü̈sca el demandat o un tercer a l'estat dels fets, de les persones o de les coses que hagueren donat origen a la demanda"; en aquesta línia, la STS de 26 gener de 1993 (RJA 1993/504). MARÍN LOPEZ, J. J., «Novedades...», op. cit., pàg. 1124. PAZ CANALEJO, N., en PAZ CANALEjO, N., i ViCENT ChULIA, F., Ley general... op. cit., pàg. 585 i 586: "sembla que els nous acords de l'Assemblea general (revocatoris o substitutoris) han de ser anteriors a la interposició de la demanda; en cas contrari no produirien efecte obstatiu (per la via de l'excepció) sobre el procés iniciat, encara que sí que poden incidir sobre l'abast de la sentència (sempre que s'adopten abans de que aquesta siga dictada). URfA, R., MENÉNDEZ, A., i MUÑOZ, J. M., La junta..., op. cit., pàg. 328, estimen que la revocació pot produir-se encara després de presentada la demanda impugnatòria, però en la mesura que "en la contestació a aquesta sol-licita del Jutge que, en la compareixença prèvia [...] se li concedisca el termini raonable [...] perquè puga reunir-se la junta i prendre la decisió corresponent". En la mateixa línia, SALELLES CLIMENT, J. R., El funcionamiento... op. cit., pàg. 392 i 393.

1058 GARCIA LUENGO, R., i SOTO VÁZQUEZ, R., El nuevo régimen jurídico..., op. cit., pàg. 545.

1059 DíAZ DE LEZCANO SEVILLANO, N., Los acuerdos del consejo..., op. cit., pàg. 369 a 378: “... Aquesta atribució té més incidència en els acords de l'òrgan de gestió que en els acords de la Junta, per tal com, respecte a aquells, és més gran l'interès immediat de la societat a mantenir la seua eficàcia"; EMBID IRUJO, J. M., "Comentario al artículo 143», op. cit., pàg. 1529 i 1530; JUSTE MENCÍA, J., Los derechos de minoría..., op. cit., pàg. 404; POLO SÁNCHEZ, Los administradores..., op. cit., pàg. 532 i 533: "La seua inclusió en el mateix article que estableix quins són els acords nuls i anul-lables- que poden ser objecte d'impugnació, i a què es refereix l'article 143 de la Llei, comporta la mateixa remissió implícita que a aquells. I encara que no fóra així, la seua aplicació analògica estaria fora de tot dubte. D'altra banda, l'admissió de la regularització dels acords socials [...] pot fins i tot «donar més joc» a l'òrgan administratiu que a la junta general, a causa precisament de les menors formalitats d'aquell en la seua convocatòria i constitució". 
aplicació també als acords i les decisions d'altres òrgans socials o altres modalitats de l'òrgan d'administració.

\subsection{L'arbitratge sobre l'objecte de la impugnació}

L'arbitratge ha estat definit com "la resolució d'una qüestió o disceptació entre parts per mitjà d'un tercer. Aquest tercer assumeix el paper de jutge i resol amb el seu judici el problema que prèviament li han sotmès les parts de mutu acord", amb la qual cosa "una o més persones donen solució a un conflicte plantejat per altres que es comprometen prèviament a acceptar la : seua decisió"1060. S'hauria, doncs, de dilucidar si el conflicte que es planteja entre els legitimats per a la impugnació i la cooperativa pot ser resolt mitjançant l'arbitratge.

En l'àmbit de les societats mercantils, tradicionalment, s'ha entès per la major part de la doctrina $\mathrm{i}$ de la jurisprudència que els acords $\mathrm{i}$ les decisions susceptibles d'impugnació dels acords de les societats no podien ser objecte $\mathrm{d}^{\prime}$ arbitratge, ja que es consideraven matèria indisponible per les parts ${ }^{1061}$, encara que hi ha autors que qüestionaven aquesta interpretació. De fet, un indicava que "...no deixa de resultar paradoxal el fet que els mateixos autors que afirmen la no-disponibilitat del dret subjectiu d'impugnació i l'exclusió de l'arbitratge i de la transacció en aquest tipus de litigis anuncien habitualment, alhora, la renúncia o l'assentiment"1062.

1060 RAMOs MÉnDEZ, F.: Derecho procesal civil, 5a ed., José M. Bosch, Barcelona, 1992, pàg. 1213. En la mateixa línia, LORCA NAVARRETE, A., "Algunas observaciones...», op. cit., pàg. 916

1061 Article 1 de la Llei d'arbitratge (36/1988, de 5.12, BOE núm. 293, de 7.12): "Mitjançant l'arbitratge, les persones naturals o jurídiques poden sotmetre, amb conveni previ, a la decisió d'un o diversos àrbitres les qüestions litigioses, sorgides o que puguin sorgir, en matèries de la seua lliure disposició conforme a dret".

1062 GiMENO SENDRA, V., El proceso..., op. cit., pàg. 25. 
Són diversos els arguments que s'han exposat per justificar l'arbitrabilitat dels acords socials. Alguns autors consideren que cal distingir entre les pretensions de nul-litat i les d'anul-labilitat. En les primeres, la impugnació es deriva de la vulneració d'una norma imperativa, en aquest cas "ens trobem davant d'una qüestió indisponible, ja que l'interès de l'Estat en el fet que la persona, individual o collectiva, no transgredisca l'ordenació excedeix l'esfera de l'autonomia de voluntat de les parts". En canvi, en les pretensions d'anul-labilitat "l'acord social ha infringit una norma de caràcter negocial, creada per la voluntat de les parts", com és el cas de les estatutàries, o la lesió a l'interès social; en aquests supòsits, "com que no preval cap qüestió diferent a la de les parts mateixes ni un altre interès que el dels membres que integren la persona jurídica, s'ha de concloure que el dret subjectiu d'impugnació tê caràcter disponible, $\mathrm{i}$ els seus titulars poden fer-ne ús intraprocessalment $\mathrm{o}$ extraprocessal". Altres autors, tanmateix, mantenien l'arbitrabilitat també per als acords nuls ${ }^{1063}$. Finalment, alguns altres autors han indicat que els únics supòsits de "no-disponibilitat" i, per tant, de submissió a arbitratge, són els dels acords que per la seua causa o contingut contravinguen l'ordre públic ${ }^{1064}$.

1063 GIMENO SENDRA, V., El proceso..., op. cit., pàg. 22 a 27. VICENT CHULIÁ, F., en «Análisis crítico...», op. cit., pàg. 519 i 520, estimava que l'únic objecte excluible de l'arbitratge serien els drets personalíssims, que no són objectes de renúncia o transacció, per la qual cosa també els acords nuls podrien ser sotmesos a arbitratge: "La exclusió de l'arbitratge de dret [...] seria poc satisfactòria, ja que sostrauria al Consell matèries com la impugnació dels acords socials per contraris a llei [...]. La naturalesa transaccional de l'acord o pacte estatutari per si mateixa no exclou l'arbitratge de dret"; posteriorment, en Compendio crítico..., op. cit., pàg. 616 a 619, se suma a la posició de GIMENO SENDRA, de rebutjar l'arbitrabilidad dels acords nuls. Ja vigent el TRLSA del 1989, GARCÍA LUENGO, R., i SOTO VÁZQUEZ, R., El nuevo régimen jurídico..., op. cit., pàg. 546, assumeixen la primera postura de VICENT CHULIÁ sobre la possibilitat de sotmetre els acords nuls a arbitratge de dret, partint del fet que "no se sotmet a arbitratge l'aplicació d'una Llei imperativa, com la d'anònimes, sinó un dret potestatiu d'impugnació d'acords socials", i que "la nova Llei, lluny d'establir el caràcter imperatiu del procediment de menor quantia, al qual es remet, pretén, en la mesura de les possibilitats, evitar l'actuació jurisdiccional i, per a això, estableix la possibilitat de que l'acord social siga deixat sense efecte per un altre de vàlid, 0 que si la causa d'impugnació puga ser reparada, hi concedisca el Jutge un termini raonable".

1064 MERINO, S., RODRíguez, M. P., i SAN JOSÉ, F., Manual de arbitraje..., op. cit., pàg. 34 a 37: "el Dret no ofereix una definició del concepte abstracte de disponibilitat. És més, la llibertat de disposar sol considerar-se intrínsecament unida al concepte d'ordre públic (que opera com el seu límit natural) [...] tampoc s'ha definit jurídicament el concepte d'ordre públic [...] a falta d'un criteri unificat, no queda més remei que recórrer a una anàlisi detallada, matèria per matèria [...] solen qualificar-se d'indisponibles els drets subjectius de naturalesa patrimonial, aquells que es qualifiquen d'irrenunciables i els que es fonamenten en normes imperatives 
En tot cas, els últims anys, alguns pronunciaments jurisprudencials i de la Direcció General dels Registres i del Notariat ${ }^{1065}$ ja han admès que, ni l'acció per demanar la nul-litat d'una junta d'accionistes, ni la impugnació d'acords socials, queden excloses de l'arbitratge.

Diversament, en l'àmbit cooperatiu, la recepció de la via arbitral per a la resolució de conflictes en general i d'assumptes relacionats amb la impugnació d'acords socials en particular, ha estat i continua sent més acceptada, tant en el dret espanyol com en el comparat ${ }^{1066}$. En la normativa espanyola va ser el Reglament de 1943 (de desplegament de la LGC de 1974) el que va incloure "l'arbitratge de les qüestions que eleven voluntàriament les cooperatives i unions" entre les funcions del Consell Superior de l'Obra Sindical de Cooperació encara que, des de llavors, l'aplicació possible a les cooperatives tampoc ha estat exempta de polèmica doctrinal ${ }^{1067}$.

considerades d'ordre públic"

1065 STS de 18.4.1998 i resolució de la DGRN de 19.2.1998.

1066 VICENT CHULIA, F., «Análisis crítico...”, op. cit., pàg. 516 i 517: “...El dret cooperatiu s’ha elaborat i ha romàs en gran part al marge de la legislació estatal, amb un predomini de les normes consuetudinàries sobre les legals i de l'arbitratge sobre la jurisprudència dels Tribunals de l'Estat. Aquestes característiques perduren fins i tot després de la intervenció normativa de l'Estat en el moviment cooperatiu. En relació amb l'aspecte contenciós del Dret cooperatiu, la justícia estatal és cara, estricta $i$ allunyada de l'esperit que ha d'animar la resolució de les diferències al si del moviment cooperatiu. I per això l'arbitratge cooperatiu, per voluntat dels cooperadores expressada en els Estatuts mateixos, substitueix en gairebé tots els països el recurs als Tribunals".

1067 Per a l'estudi de l'evolució de l'arbitrabilitat dels conflictes a les cooperatives en el període preconstitucional, vegeu DíEZ ARGAL, W., "Arbitraje cooperativo», en Anuario de estudios cooperativos 1987, Instituto de Estudios Cooperativos, Universidad de Deusto, 1987, pàg. 61 a 80; p. 68; MUÑOZ VIDAL, Antonio B., El arbitraje cooperativo, Caja Rural Provincial de Murcia, Múrcia, 1978; i VICENT CHULIÁ, F., "Análisis crítico...», op. cit., pàg. 516 a 520.

DíEZ ARGAL, W., op. cit., en pàg. 68, estimava, sota la vigència de la LGC de $1987 \mathrm{i}$ de la LCE de 1982, que no pot ser objecte d'arbitratge l'acció d'impugnació d'acords socials: "Sobre aquesta matèria el Tribunal Suprem (Sentències de 15 d'octubre de 1966; 3 de novembre de 1972) ha estat clar i contundent: "El dret d'impugnació constitueix un dels drets individuals del soci, i els motius sostrets es troben a la lliure disposició de les parts, i en tal concepte exclosos de ser matèria d'Arbitratge"". Ja vigent l'actual LCPV de 1993, RODRf́GUEZ, M. P., i SUSO, J. M., en «Los órganos de la cooperativa», op. cit. , pàg. 166, continuen qüestionant-se l'aplicació: "Qüestió diferent és si són d'aplicació a la impugnació d'acords socials les clàusules estatutàries de submissió a un procediment arbitral, ja que de l'articulat de la Llei es dedueix que la qüestió litigiosa ha de recaure sobre matèries de lliure disposició per les parts. L'article 145.2, f) de la 
En l'actualitat, la possibilitat de sotmetre a arbitratge determinats conflictes entre la cooperativa i els seus socis està expressament prevista tant en la LCoop (disposició addicional desena) com en la LCCV (article 111). En la LCoop es preveu, de manera explícita, l'arbitrabilitat de la nul-litat de tota l'assemblea i dels acords impugnables de l'assemblea i del consell rector; la LCCV, amb una formulació més genèrica, es refereix a la resolució "dels conflictes que es plantegen entre entitats cooperatives (...) i els seus socis. Aquesta última definició de l'àmbit objectiu sembla més adequada per considerar extensible l'arbitratge a controvèrsies intracooperatives entre els socis i altres òrgans socials.

En efecte, si, en virtut de la polèmica doctrinal que hi ha en l'àmbit de les societats de capital, s'ha d'agrair l'explicitació que fa la norma estatal respecte de la submissió dels acords impugnables ${ }^{1068}$, és bastant pertorbador que es referisca inicialment a "les discrepàncies o controvèrsies que es poden plantejar en les cooperatives, entre el consell rector o els apoderats, el comitè de recursos i els socis, fins i tot en el període de liquidació", per a després afegir que "pel caràcter negocial i dispositiu dels acords socials, no queden excloses de la possibilitat anterior ni les pretensions de nul-litat de l'assemblea general, ni la impugnació d'acords assemblearis o rectors; però l'àrbitre no podrà pronunciarse sobre aquells extrems que, si escau, estiguen fora del poder de disposició de les parts". Tot això obri diversos interrogants: si la norma es preocupa d'especificar que s'inclouen en l'arbitrabilitat les demandes de nul-litat de

LCPV estableix, entre les funcions del Consell Superior de Cooperatives d'Euskadi la $d^{\prime}$ «intervenir per via d'arbitratge en les qüestions litigioses que se susciten entre les cooperatives, entre aquestes $i$ els seus socis, o al si d'aquestes entre socis, quan ambdues parts ho sol-liciten o estiguen obligades a això d'acord amb els seus Estatuts, Reglament Intern o per clàusula compromissòria. En tot cas, la qüestió litigiosa ha de recaure sobre matèries de lliure disposició per les parts conforme a dret $\mathrm{i}$ afectar primordialment la interpretació $\mathrm{i}$ aplicació de principis, normes, costums i usos de naturalesa cooperativa»".

1068 MORILlAS JARILLO, M. J., «La nueva regulación estatal...», op. cit., pàg. 10: “Com en altres casos, la LC s'anticipa en la regulació d'una matèria controvertida del règim jurídic de les societats en general, $\mathrm{i}$ intervé en la polèmica doctrina $\mathrm{i}$ jurisprudencial oberta, apostant decididament per aquesta via convencional, cosa que és d'aplaudir, des del nostre punt de vista". 
l'assemblea i la impugnació d'acords de l'assemblea o del consell rector, s'han d'entendre exclosos altres supòsits, com la nul-litat de tota la sessió d'altres òrgans, com el d'administració o la impugnació d'acords del comitè de recursos, o d'altres òrgans socials? Entenem que no ha estat aquesta la voluntat del legislador, sinó la de facilitar la resolució extraprocessal dels conflictes intrasocietaris, per la qual cosa la interpretació de la norma ha de ser extensiva.

Ambdues normes es remeten, per a la determinació del procediment arbitral aplicable, a la legislació estatal en la matèria, que en l'actualitat és la Llei $36 / 1988$, de 5 de desembre, d'arbitratge ${ }^{1069}$. A més, perquè puga produir-se l'actuació arbitral prevista en l'article 111 de la LCCV, del Consell Valencià del Cooperativisme, no sols caldrà que les parts en conflicte s'hagen compromès prèviament i expressament a acceptar la resolució arbitral en substitució de la jurisdiccional, sinó que és necessari que es diga també que el Consell Valencià del Cooperativisme (articles 9 i 10 de la LA) realitzarà l'administració de l'arbitratge i la designació dels àrbitres ${ }^{1070}$.

Pel que fa a les modalitats previstes, la LCoop es refereix tant a l'arbitratge de dret ${ }^{1071} \mathrm{com}$ al d'equitat, si bé remet aquest últim als supòsits en què "la disputa afecte principalment els principis cooperatius". Per la seua part, la LCCV admet ambdues modalitats, sense una altra especialitat diferent a la que es derive de la Llei d'arbitratge, $i$ al fet que, mentre que el laude emès en virtut d'arbitratge de dret serà elaborat i firmat per lletrats del Consell Valencià del Cooperativisme 0 de la seua Cort d'Arbitratge, el laude de l'arbitratge d'equitat pot ser emès $i$ firmat per membres no juristes del Consell; a més, la llei valenciana preveu la

${ }^{1069}$ La LCoop es remet directament a Llei 36/1988, de 5 de desembre, d'Arbitratge (BOE núm. 293, de 7 de desembre), mentre que la LCCV es refereix a "la Llei estatal aplicable".

1070 Per al procediment d'arbitratge en l'àmbit de la LCCV, vegeu també l'article 11 del Decret 228/96, de 10 de desembre, del Govern Valencià, pel qual es regula el Consell Valencià del Cooperativisme.

1071 VICENT CHULIÁ, F., "Análisis crítico...», op. cit., pàg. 516 a 520: "l'arbitratge cooperatiu es configura com un arbitratge de Dret privat especial. L'especialitat és determinada per la naturalesa de l'àrbitre i per l'objecte sobre el qual, en principi, ha de versar". 
possibilitat d'una conciliació prèvia a l'exercici d'accions davant dels tribunals, de caràcter voluntari 1072.

En tot cas l'article 11 de la LA ${ }^{1073}$ estableix que "el conveni arbitral obliga les parts a estar i passar per allò estipulat, i impedirà als tribunals conèixer les qüestions litigioses sotmeses a arbitratge al conveni, sempre que la part a qui interesse ho invoque mitjançant declinatòria". Això no obstant, "les parts podran renunciar per conveni a l'arbitratge pactat, de manera que quedarà expedita la via judicial".

L'article 111.2 LCCV fa referència expressament al fet que "la presentació davant del Consell Valencià del Cooperativisme de la reclamació prèvia de conciliació o de la demanda d'arbitratge, interromprà la prescripció i suspendrà la caducitat de les accions, d'acord amb la legislació estatal".

1072 MORILLAS JARILLO, M. J., «La nueva regulación estatal...», op. cit., pàg. 10: "A diferència d'altres preceptes (article 176 de la Llei de Cooperatives d'Andalusia; article 107 de la Llei de Cooperatives de Catalunya; articles 166 a 168 de la Llei de Cooperatives d'Extremadura; $i$ article 111 de la Llei de Cooperatives de València), no es regula [en la LCoop] la mediació ni la conciliació, només l'arbitratge, i no es preveu la participació institucional del Consell de Foment de l'Economia Social ni de cap altre organisme (a diferència del que feia el derogat article 163 de la Llei de 1987)". 


\section{CAPITTOL QUART}

\section{LEGITIMACIÓ PER A LA IMPUGNACIÓ D'ACORDS SOCIALS}

S'ha definit la legitimació, en general, com "el reconeixement que l'ordenament jurídic fa a favor d'una persona, de la possibilitat de realitzar amb eficàcia un acte jurídic; aquesta possibilitat deriva de la relació existent entre el subjecte que actua i els béns o l'interès que afecte el seu acte", ${ }^{1074}$ i s'ha assenyalat que, a més de les persones legitimades directament per la seua qualitat de titulars de la relació jurídica, sobre la qual té efecte l'acte, hi ha persones que poden actuar en virtut d'una legitimació indirecta.

Són els casos de la representació, en què el representant exercita els drets del dominus negotii, tot actuant-hi en el seu nom o pel seu compte, i de la substitució, en què el substitut exercita els drets del substituït, i produeix efectes jurídics en l'esfera jurídica d'aquest, però actuant en el seu nom i interès. ${ }^{1075}$ Així succeeix en el procés d'impugnació d'acords socials, en el qual, com veurem, els subjectes que hi intervenen són diferents i estan sotmesos a diversos condicionants. En el marc cooperatiu, a més, en alguns aspectes, el seu estudi es diversifica, ja que és més gran la varietat d’òrgans socials possibles i, per tant, d'acords i actes impugnables.

1074 Díez PiCAZO, L. i GulLón, A., Instituciones..., vol. I, op. cit, pàg. 294. En la mateixa línia, DUQUe DOMíNGUEZ, J. F., Tutela..., op. cit., pàg. 162, nota 33, tot seguint CARNELUTTI: "una situació de la persona, determinada per la seua relació amb un objecte, en virtut de la qual aquella pot realitzar actes amb efectes jurídics per a l'esfera jurídica de la persona a la qual aquell pertanya".

1075 Díez PICAzo, L. i GULlón, A., Instituciones..., vol. I, op. cit, pàg. 294 i 295; DUQUE DoMínGUEZ, J. F., Tutela..., op. cit pàg. 162, nota 33; TATO PLAZA, A., Substitución y anulación..., op. cit, pàg. 74 i 75. 


\section{Legitimació activa}

Com recorda la STS (Sala 1a), de 8 de maig de 1997, "la legitimació activa ad causam (la legitimació ad processum és tan sols la capacitat processal)" és "la qualitat d'un subjecte consistent a trobar-se en la posició que fonamenta jurídicament el reconeixement d'una pretensió que exercita".

Aquesta qualitat, dirigida a la impugnació d'acords socials, està atribuïda per la legislació cooperativa de manera bastant similar a la que s'estableix per a les societats de capital, sobre les quals s'ha dit que "en matèria de legitimació per a l'exercici judicial de les accions contra els acords impugnables, tant la doctrina com les legislacions s'inspiren en la teoria de l'interès. Tenen interès aquelles persones que puguen sofrir qualsevol dany a causa de l'acord impugnable, i aquest interès legitima la seua actuació i promou el procés". ${ }^{1076}$ Però aquesta afirmació, compartida per la major part de la doctrina, tant espanyola com comparada, s'ha de matisar; com s'ha assenyalat, la finalitat del legislador amb aquesta legitimació activa tan àmplia "no és (...) la protecció immediata de l'interès social, de manera que l'interès del soci [o de tercers] es protegeix indirectament", sinó, contràriament, "aprofitar-se de l'interès que normalment indueix el soci a prendre sobre si la càrrega d'un procés (...), simultàniament, actua[r] la tutela de $l^{\prime}$ interès" ${ }^{\prime \prime \prime r}$ Perquè pot ser diferent $l^{\prime}$ interès que mou cada

1076 URfA, R., MENÉNDEZ, A. i MUÑ̃Z, J. M., La junta..., pàg. 348. També es refereixen a la teoria de l'interès DíEz ARGAL, W., "Impugnación de acuerdos sociales en las sociedades cooperativas", en Anuario de estudios cooperativos 1988, Universitat de Deusto, Bilbao, 1989, pàg. 56; DUQUE DOMf́NGUEZ, J. F., Tutela..., op. cit, pàg. 162; GIMENO SENDRA, J. V., El proceso..., pàg. 70; SORIA FERRANDO, J. V., en SORIA FERRANDO, J. V., La legitimación activa para la impugnación de acuerdos de la junta general de la sociedad anónima, Universitat d'Alacant, València, 1982, pàg. $379 \mathrm{i}$ en La legitimación activa..., pàg. 20, i VICENT CHULIÁ, F., Compendio..., pàg. 613. En relació amb la teoria de l'interès com a fonament de la legitimació, es pot veure la STS (Sala 1a), de 23 d'octubre de 1998 (RJA 1998/8232), en la qual el Tribunal Suprem mostra estranyesa davant la demanda de cassació d'una sentència en la qual es reconeixia la nul-litat d'acords, sol-licitada pel demandant, i considera que "falta l'interès legítim per pretendre una anul-lació de la sentència que li és favorable", per la qual cosa desestima el recurs.

1077 DUQUE, J. F., Tutela..., pàg. 155 a 160. En aquest mateix sentit, VICENT CHULIÅ, F., Compendio..., pàg. 613, qui, en analitzar la legitimació de l'accionista, diu que: "depèn de la idea que es tinga sobre si defensen un interès propi o l'interès del bon funcionament de la societat. $\mathrm{Si}$ com sembla, defensen un interès propi...", i GIMENO SENDRA, V., El proceso..., pàg. 70, que 
subjecte legitimat de la causa, el fonament jurídic que ha portat el legislador a atorgar-li legitimació.

En tot cas, a l'hora d'analitzar la legitimació per a la impugnació, tant la legislació cooperativa, com la mercantil distingeixen, en primer lloc, entre acords de l'assemblea general i acords de l'òrgan d'administració, i ja entre ambdós tipus d'acords es planteja una diferència substancial: mentre que la legitimació en relació amb els acords de l'assemblea es reconeix com un dret individual del soci, en relació amb els acords del consell rector s'atribueix, en alguns casos, únicament a un nombre mínim de socis, i es configura ja no com un dret individual, sinó de minoria.

D'altra banda, la regulació de la legitimació en el marc de cada òrgan social és, normalment, diferent, segons que es tracte d'acords nuls o anul-lables, i de vegades, també, segons el text legal cooperatiu que considerem.

\subsection{Legitimació per a la impugnació d'acords de l'assemblea general}

L'article 31.4 de la LCoop ha corregit alguns errors o omissions que patia la redacció deficient de l'article 52.3 de la LGC, que construïa la legitimació per impugnar acords nuls afegint supòsits concrets als reconeguts per a la legitimació davant l'anul-labilitat. Tot això se substitueix, ara, per una legitimació general davant acords nuls, que s'obri a qualsevol persona amb interès legítim: "Per a la impugnació dels acords nuls estan legitimats: qualsevol soci, els membres del consell rector, els interventors, el comitè de recursos i els tercers que acrediten interès legítim".

afirma que "l'interès que fa valer el soci dins del procés, no difereix gens del seu propi. Com ha posat de relleu FAIRÉN, fins i tot en les pretensions de nul-litat, el soci no actua, en realitat, com a òrgan substitut processal de la societat i en interès d'aquesta, sinó que ho fa en el seu interès". 
La legitimació per a la impugnació d'acords anul-lables incorpora, també, algunes diferències notables entre les quals destaquen aquestes: els assistents poden manifestar, posteriorment a la reunió, la seua oposició a l'acord; es modifica el marc de legitimats en circumscriure'l, d'una banda, als socis, i d'altra, en ampliar-lo als membres del consell rector, als interventors $i$ al comitè de recursos; a més, se suprimeix la referència expressa a la legitimació dels assistents a l'assemblea que hagueren fet constar en l'acta la seua oposició a la celebració d'aquesta. Finalment, entre les novetats que incorpora l'article 31.4, s'ha de ressenyar l'ampliació de l'obligatorietat de la impugnació d'acords contraris a la llei o als estatuts: a la ja atribuïda als membres del consell rector $\mathrm{i}$ als interventors, s'hi afegeix la que ara s'estableix per als liquidadors i, si escau, per al comitè de recursos.

D'altra banda, la Llei de cooperatives de la Comunitat Valenciana estableix la legitimació per a la impugnació dels acords de l'assemblea general, de manera essencialment idèntica a l'establerta en l'article 117 de la Llei de societats anònimes. Així, els apartats 4 i 5 de l'article 36 de la LCCV diuen, literalment, que "l'acció d'impugnació d'acords nuls podrà ser exercitada per tots els socis, pels membres del consell rector, pels administradors, pels membres de la comissió de control de la gestió i per qualsevol tercer amb interès legítim (...). L'acció d'impugnació dels acords anul-lables podrà ser exercitada pels socis assistents que hagen fet constar, en l'acta de l'assemblea general, la seua oposició a l'acord, pels absents i pels que hagueren estat il-legítimament privats del vot, i també, pels membres del consell rector, pels administradors o pels membres de la comissió de control de la gestió... ${ }^{1078}$.

Aqueixa translació és, al nostre entendre, excessivament fidel al text de la LSA; ja que, pel que fa als acords nuls, la legitimació en favor de tots els socis i dels

1078 Article 117 de la LSA: "1. Per a la impugnació dels acords nuls estan legitimats tots els accionistes, els administradors i qualsevol tercer que acredite interès legítim".

2. Per a la impugnació d'acords anul-lables estan legitimats els accionistes assistents a la junta que hagen fet constar en l'acta la seua oposició a l'acord, els absents i els que hagen estat il-legítimament privats del vot $i$, també, els administradors. 
tercers amb interès legítim era suficient. Ha de recordar-se que, en les cooperatives valencianes, els membres de l'òrgan d'administració i els de la comissió de control de la gestió són necessàriament persones sòcies, amb algunes excepcions que es veuran després (com, per exemple, la de la possibilitat d'establir estatutàriament una representació en el consell rector dels treballadors assalariats per temps indefinit), la legitimació de les quals també està assegurada com a tercers amb interès legítim.

En tot cas, podem emprendre, amb caràcter general, l'estudi dels subjectes legitimats, segons la classificació de GIMENO SENDRA, ${ }^{1079}$ que distingeix, en primer $110 \mathrm{c}$, si es tracta de pretensions declaratives de nul-litat o constitutives d'anul-lació. Posteriorment, ja dins de la legitimació per a la impugnació d'acords nuls, analitzarem les diferents categories de legitimats (en el marc cooperatiu, socis, associats, administradors, membres d'òrgans de control i tercers amb interès legítim); mentre que, en relació amb la legitimació per accionar l'anul-labilitat, ens centrarem en els requisits complementaris, és a dir, en la consignació en l'acta de l'oposició a l'acord, en l'absència i en la privació il-legítima d'emetre el vot. ${ }^{1080}$

\subsubsection{Legitimació en pretensions declaratives de nul-litat}

1079 GIMENO SENDRA, J. V., El proceso..., op. cit., pàg. 69 a 94, i en La reforma..., op. cit., pàg. 28 a 37.

1080 Això no obstant, encara que seguim aquesta perspectiva expositiva, no s'ha d'oblidar que també s'han plantejat qüestions que fan referència a la legitimació en funció del contingut dels acords, les quals incorporarem. Així, per exemple, SALELLES CLIMENT, J. R., El funcionamento..., op. cit., pàg. 382 i 383 , recorda que "la possibilitat d'impugnar [els administradors] els acords adoptats per la junta, en matèria de gestió, s'ha negat, per entendre que els perjudicis que es puguen derivar per a la societat es podrien evitar, simplement, si no s'executen", $i$ addueix les raons per les quals discrepa d'aquesta postura doctrinal.

En el marc cooperatiu, Paz Canalejo, en Paz Canalejo, N. i Vicent Chuliá, F., Ley general..., vol. II, pàg. 593, assenyalava, pel que fa a l'LGC, que alguns preceptes dispersos reconeixien expressa legitimació a socis $i$ associats per a supòsits concrets. 
S'ha de constatar, en primer lloc, que no es distingeix especialment la legitimació davant els acords contraris a l'ordre públic. Com s'ha assenyalat, en aquesta matèria no cap distingir entre acords radicals i relativament nuls. Siguen absoluts, contra l'ordre públic, o relatius, només contra la llei, tots estan sotmesos al mateix règim de legitimació ${ }^{1081}$.

Tanmateix, sí que és necessari analitzar els diversos subjectes a qui s'atribueix legitimació, que en el marc cooperatiu poden classificar-se en els grups següents: a) socis, b) associats, c) administradors, d) membres d'òrgans de control i e) tercers amb interès legítim.

\section{A. Legitimació dels socis}

a) La condició de soci

Per a la impugnació dels acords nuls de l'assemblea general, estan legitimats tots els socis. Aquesta afirmació que, a primera vista, pot semblar supèrflua, no ho és tant. D'una banda, com indica la doctrina, fins i tot els socis que hagen votat a favor de l'acord poden demandar la nul-litat, sense que se'ls puga oposar el principi que ningú no pot anar en contra dels seus propis actes; en aquest sentit, s'ha assenyalat que aquest principi només és aplicable quan la conducta de què es tracte siga jurídicament eficaç, no quan constituïsca un acte nul $^{1082}$; així, mentre que "quan es vulnera un interès emparat en una relació

1081 ARROYO, I., "Comentario al art. 56...» op. cit., pàg. 616. En el mateix sentit, ALCALÁ DfAZ, M. A., La impugnación..., pàg. 441.

1082 GARCIAA-MEDALl VillanUEVA, C., "Algunas consideraciones en torno a la junta universal de las sociedades anónimas y a la impugnación de sus acuerdos sociales. Comentario a la STS (Sala 1a) de 17 de febrero de 1992", La Ley, núm. 3227, 29.3.1993, pàg. 3; SORIA FERRANDO, J. V., La legitimación activa..., pàg. 23 i 76: "una de les premisses que han de concórrer, perquè siga aplicable el principi (...) és (...) que la conducta d'un subjecte determinat siga jurídicament eficaç, per la qual cosa quan un negoci jurídic és nul i ha estat realitzat contra una expressa disposició legal, es pot anar contra els actes propis". 
estrictament privada, el soci que ja va emetre el seu vot no hi pot tornar (...) si se segueix l'ordenament jurídic general (...) es permet a qui ja va votar en el seu favor $(. .$.$) intentar la seua rectificació, en nom de l'interès general { }^{\prime \prime}{ }^{1083}$

En tot cas, pel que fa a la qualitat de soci necessària per a la legitimació, es plantegen interrogants en relació $a \mathrm{mb}$ el període en què s'ha de gaudir d'aqueixa condició: en el moment de l'adopció de l'acord?, durant el termini per impugnar?, durant tot el procés?, té legitimació qui adquireix la qualitat de soci posteriorment a l'adopció de l'acord?... Per a les societats mercantils, la doctrina majoritària estima que s'ha d'exigir aqueixa condició en el moment de l'adopció de l'acord, i també, el seu manteniment al llarg del procediment impugnador, però es plantegen dubtes en els casos d'adquisició, intervius o mortis causa, de la condició de soci després de l'adopció de l'acord. ${ }^{1084}$

En aquest sentit, la STS (Sala 1a), de 29 de juny de 1998, núm. 768/1998 (RJA 1998/6379) desestima l'acusació d" "infracció de la doctrina dels actes propis, per haver subscrit un dels demandants l'ampliació de capital acordada pel Consell d'Administració [...], afectat pels mateixos vicis que la demanda atribuïa als acords anteriors; $i$ havia de decaure, no sols perquè la subscripció es duguera a terme ad cautelam, com s'al-lega en la impugnació del recurs, sinó també perquè la nul.litat in radice acordada produeix efecte davant tots $\mathrm{i}$, sens dubte, és suficient que siga sol-licitada per un dels legitimats".

1083 RUBIO, J., Curso..., op. cit., pàg. 258. Sobre aquest tema, pot veure's, també EMBID IRUJO, J. M., «El voto plural...», op. cit., pàg. 693; ARROYO, I., «Comentario al art. 56...», op. cit., pàg. 616; SORIA FERRANDO, J. V., La legitimación activa..., pàg. 23, i RODRÍGUEZ RUIZ DE VILLA, D., Impugnación..., op. cit., pàg. 135.

1084 EMBID IRUJO, J. M., "Notas sobre la impugnación...”, op. cit., pàg. 54: "Respecte a la legimitació dels socis, tant en relació amb acords nuls o anul-lables, entenem que la llei exigeix aqueixa condició per poder impugnar; i també, el seu manteniment al llarg del procés. Per això no ha d'estar considerat accionista qui no posseïsca la titularitat de l'acció en el moment de la realització de la junta, els acords de la qual es pretenen impugnar. Alhora, qui reuneix la condició d'accionista en el moment d'adoptar l'acord, però després la perd, no pot iniciar la impugnació, i si, si escau, deixa de ser accionista una vegada iniciat el procés, no pot continuarlo". GARCíA LUENGO, R. i SOTO VÁZQUEZ, R., El nuevo régimen jurídico..., op. cit., pàg. 551, en citar la STS de 27 de juny de 1988, que alhora recull jurisprudència anterior; GÓMEZ ORBANEJA, E., «El proceso de impugnación...», op. cit., pàg. 127; RUBIO, J., Curso..., op. cit., pàg. 260 i 261 : "Sols per a la transmissió hereditària pot arribar-se a una solució diferent, no sols per la lògica absència d'aqueixos riscos, sinó pel seu caràcter de successió universal", i VICENT CHULIÁ, F., Compendio..., op. cit., pàg. 613.

En el mateix sentit d'exigir el manteniment de la condició de soci, tant per a l'accionista com per al soci cooperatiu, al llarg del procés, fins a la sentència, GIMENO SENDRA, J. V., El proceso..., pàg. 70 i 71.

DUQUE DOMínGUEZ, J. F., Tutela..., op. cit., pàg. 164 a 169, estima també que la transmissió de l'acció condueix naturalment a la pèrdua del poder impugnador del soci alienant; planteja dubtes, inicialment, respecte del fet que l'adquirent, intervivos o mortis causa, posteriorment a 
Creiem que, pel que fa a la impugnació d'acords nuls, la condició de soci s'ha de poder acreditar, en tot cas, per al període que va des del moment en què $s^{\prime}$ adopta l'acord ${ }^{1085}$ fins al d'interposició de l'acció d'impugnació. Posteriorment, no serà necessari el manteniment d'aqueixa qualitat, si hem de ser coherents amb la teoria de l'interès com a causa de la legitimació. El soci que perd aqueixa condició (abans o després d'iniciada l'acció) es converteix en tercer amb interès legítim" i, per tant, legitimat, si bé per una condició diferent, per a la impugnació. ${ }^{1086}$

L'interès que mou el soci a plantejar la impugnació d'un acord (per exemple, d'aprovació de comptes anuals que no permet el retorn cooperatiu, d'admissió de socis nous que modifiquen la composició de la majoria social, d'aprovació

l'adopció de l'acord, adquirisca, amb la titularitat de l'acció, el poder que pertanyia al transmetent, si bé es decideix, finalment, per la seua admissió. Per al soci que exerceix el dret de separació manté, en termes generals, la pèrdua del poder impugnador, "perquè la qualitat de soci [...] és una qualitat de l'acció (legitimatio ad causam), que ha de subsistir, per tant, en el moment d'exercitar judicialment aqueix poder"; no obstant això, "amb relació als acords adoptats anteriorment al que provoca la seua separació, si el soci conserva els drets que són conseqüència de la seua anterior qualitat, podrà impugnar aquells sempre que tinga un interès legítim per a això".

URÍA, Derecho mercantil, op. cit., pàg. 325, es manifesta únicament pel que fa a la necessitat en el moment de la demanda.

En el dret italià queda clara la necessitat de mantenir la qualitat de soci durant tot el procés, ja que l'article 2378.2 del Codice Civile exigeix al soci impugnant el dipòsit d'almenys una acció; dipòsit que es mantindrà durant tot el procés (SILVETTI, C. i CAVALLI, G., Le società per azioni..., op. cit., pàg. 224 i 227). Tanmateix, doctrina i jurisprudència discuteixen sobre l'aplicabilitat de la norma esmentada als socis de les cooperatives; un resum del debat, incloent citacions, pot veure's en PAOLUCCI, L. F., Le società cooperative, pàg. 106.

1085 Com assenyala ARROYO, I., "Comentario al art. 56...», op. cit., pàg. 618, s'ha de prendre en consideració, per a l'establiment de la legitimació, únicament el moment d'adopció de l'acord, i no la totalitat de l'assemblea en què aqueix s'adopta.

1086 Això és així per als acords nuls. Quan es tracte d'acords anul-lables, com veurem, la legitimació a tercers se circumscriurà a determinats supòsits legalment previstos.

SCORDINO, F., La società cooperativa, op. cit., pàg. 292, estima que la nul-litat pot fer-se valer independentment de la possibilitat de provar la condició de soci, sempre que subsistisca l'interès en la declaració de nul-litat. ÁvILA NAVARRO, P., La sociedad limitada... , op. cit., pàg. 426, considera que "ha de negar-se legitimació al soci que deixe de ser-ho abans o durant la impugnació; i en canvi, admetre el que adquireix les seues participacions després d'adoptar-se l'acord; perquè qualssevol que siguen els obstacles conceptuals contra aquest últim, el que és cert és que sempre podrà impugnar els acords nuls com a tercer amb interès legítim". MORILLAS JARILlO, M. J. i FELIÚ REY, M. I., Curso de cooperativas, op. cit., pàg. 258 i 259 recorden als efectes 
$d^{\prime}$ inversions que impliquen un endeutament notable de la cooperativa, etc.) pot subsistir més enllà de la finalització de la seua relació societària. Mantenir en aquests supòsits que, una vegada plantejada la impugnació, s'ha de continuar en qualsevol cas l'associació fins a l'acabament del procediment, implicaria forçar el soci, en casos determinats, a optar entre exercir el seu dret de separació o el d'impugnació $i$, en aquest cas, a suportar acords que, segons el seu parer, implicarien "assumir obligacions o càrregues greument oneroses, no previstes en els estatuts". ${ }^{1087}$

D'altra banda, es discuteix si el soci nou que assumeix aquesta condició amb l'adquisició de la part social de qui posseïa legitimació, adquireix també el dret d'impugnació. Però aquest debat, propi de les societats de capital ${ }^{1088}$, no es pot traslladar, com veurem, sense més ni més, a les cooperatives.

En aquesta matèria, s'ha plantejat en la societat anònima, d'una banda, que "la transmissió del títol valor acció —que incorpora els poders $\mathrm{i}$ els deures que integren la posició jurídica de l'accionista - té com a conseqüència la transmissió de totes i de cada una d'aquelles situacions i, entre aqueixes, la que el soci transmetent té per a impugnar ${ }^{\prime 1099}$, mentre que un altre sector opina que

de la legitimació, que la baixa acordada pel consell rector no és executiva fins que no és ratificada o transcorre el termini per a la seua impugnació.

1087 El dret de separació es regula, amb caràcter general, en l'article 17.4 de la LCoop i en l'article 17.2,b) de la LCCV. També es recullen supòsits específics del dret de separació del soci per a determinades modificacions estatutàries (LCoop, art. 11.3, 2n par. i LCCV, art. 63.4) i en la majoria de les modificacions estructurals de la cooperativa (fusió: LCoop, art. 65, i LCCV, art. 65.2, c); escissió: LCoop, art. 68.5, i LCCV, art. 66.2; transformació: LCoop, art. 69.2, LCCV, art. 68.3). En els supòsits de reactivació (LCoop, arts. 70.5, i LCCV, art. 71.2) i de cessió global de l'actiu i del passiu (LCCV, art. 67), encara que els textos legals no es manifesten expressament, sembla que el dret de separació del soci, reconegut amb caràcter general com hem vist, podrà ser exercit també.

\footnotetext{
1088 ARRoYo, I., «Comentario al art. 56 ...», op. cit., pàg. 618 i 619; DUQUE DOMínGUEZ, J. F., Tutela..., pàg. 164 a 167; GIMENO SENDRA, El proceso..., op. cit., pàg. 70 i 71; MARTINEZ SANZ, F., «La nulidad de la fusión..., op. cit., pàg. 87; RODRfGUEZ RUIZ DE VILLA, D., Impugnación..., op. cit., pàg. 132 i 133; SORIA FERRANDO, J. V., La legitimación activa ..., pàg. $41 \mathrm{a} 50$.
} 
"el dret d'impugnació és un dret personalíssim i, per tant, intransmissible", ja que "els drets personals s'adquireixen, necessàriament, a títol originari"1090

Tot això deixa de tenir sentit en les cooperatives, fonamentalment, per dues raons: d'una banda, en la cooperativa, la qualitat de soci no s'adquireix amb la mera adquisició de participacions socials; d'altra, la participació en el capital cooperatiu no és un títol que, com en les societats de capital, incorpore el conjunt de drets i d'obligacions del soci ${ }^{1091}$ i, amb ells, el dret d'impugnació. Ambdues són conseqüències de la tipologia especial de la cooperativa. ${ }^{102}$

Perquè per ser soci cooperatiu es requereix, essencialment, complir els requisits objectius establerts en els estatuts socials ${ }^{1093}$ i efectuar l'aportació al capital

\begin{abstract}
1090 SORIA FERRANDO, J. V., La legitimación activa..., pàg. 43. GIRÓN TENA, Derecho de sociedades anónimas, op. cit., pàg. 331, també opta per la intransmissibilitat de la legitimació, per entendre que amb la transmissió es renuncia a l'exercici de l'acció.
\end{abstract}

1091 VICENT CHULIÁ, F., en "Análisis crítico...», op. cit., pàg. 456; en «La Ley 27/1999...», op. cit., pàg. 14578: "El capital social de la cooperativa no exerceix les mateixes funcions que en la societat anònima: [...] No es té en compte per determinar la intensitat dels drets dels socis", i també en VICENT CHULIÁ, F., "Mercado, principios cooperativos...», op. cit., pàg. 22. Sobre l'acció com a tècnica jurídica que incorpora la posició de soci i la patrimonialitza, pot veure's ALONSO UREBA, A., «La sociedad unipersonal», op. cit., pàg. 259.

1092 ALFONSO SÁNCHEZ, R., La integración cooperativa..., op. cit., pàg. 141, nota 234: “... L'alta o la baixa d'un soci comporten conseqüències tan importants per a la cooperativa, que el seu control s'encarrega al consell rector. És aquesta una manifestació del caràcter personalista marcat d'aquestes entitats que exigeix considerar si el soci que pretén el seu accés a la cooperativa està en condicions objectives de poder participar en l'activitat cooperativitzada, obligació fonamental del soci i sobre la qual graviten alguns dels seus drets més importants". Això no obstant, la cooperativa "no només es diferencia de les societats anomenades capitalistes, sinó també de les personalistes, ja que encara que hi preval de manera definitiva la consideració dels factors personals davant els capitalistes, no és una societat de persones en el mateix sentit que ho són la societat col-lectiva o comanditària [nota 157: " ... La rellevància personal que el intuitus personae té en aquest tipus de societat i el seu paral.lelisme amb les societats personalistes [...] té el significat especial que s'adverteix mitjançant el principi de porta oberta, i no són rellevants els aspectes personalíssims, i estrictament individuals, ni sobre el contracte ni sobre l'organització social en el seu conjunt (v. sobre això [...] les seues peculiaritats en el règim de [...] poders de la junta general per a la modificació d'estatuts, règim de responsabilitat i l'absència de rellevància en l'estructura social de la fallida del soci cooperatiu...)"] (VERGEZ SÁNCHEZ, M., El derecho de las cooperativas..., op. cit., pàg. 83 i 84).

1093 està cor correlativament limitat pel principi de personalitat, en virtut del qual el vincle social es forma en consideració de la persona dels futurs associats. Així [...] el candidat ha de complir les condicions fixades pels estatuts [...] però aquests no poden instituir requisits d'ordre personal, 
social; però no serà fins que el consell rector comprove el compliment dels requisits esmentats i adopte l'acord corresponent que la persona interessada adquirirà la condició de soci ${ }^{1094}$. I encara que en la legislació cooperativa estan expressament previstos supòsits en els quals la transmissió de participacions acompanya l'adquisició de la condició de soci, no és aquesta transmissió la que converteix la persona interessada en sòcia, sinó el compliment dels requisits estatutaris i l'acord del consell rector ${ }^{1095}$. El soci nou no ho és per l'adquisició de les seues participacions al soci anterior (que podia tenir la facultat d'impugnar), sinó per reunir els requisits legalment i estatutàriament establerts. ${ }^{1096}$

religiós o social".

1094 PALMA, R., "Il fenómeno cooperativo...», op. cit., pàg. 39 i 40. També ALFONSO SÁNCHEZ, R., "Aspectos básicos...», op. cit., pàg. 174: "per ser soci no és suficient sol-licitar formalment l'admissió, sinó que és necessària l'acceptació de la cooperativa. A aquest efecte, els administradors, encarregats de decidir sobre aquest extrem [...], disposen d'un ventall de causes justes per les quals tancar la porta als aspirants. Algunes d'aquestes són motius que deriven exclusivament dels requisits que imposa la llei per ser soci d'acord amb cada tipus de cooperativa [...]; d'altres, s'hauran perfilat en els estatuts socials [...] en consideració de l'interès social mateix".

1095 Tant la LCoop com la LCCV preveuen únicament dos supòsits de transmissibilitat de participacions socials a persones no sòcies: per acte inter vivos, o per successió mortis causa; però en tots els supòsits, la transmissió queda condicionada al fet que els adquirents de les participacions adquirisquen, també, la condició de soci. Així, l'article 50 de la LCoop estableix que les aportacions poden transmetre's: "a) per actes inter vivos, únicament a altres socis de la cooperativa i als qui adquireixen aqueixa qualitat al llarg dels tres mesos següents a la transmissió que, en aquest cas, queda condicionada al compliment del requisit esmentat. [...] b) per successió mortis causa, als causahavents si són socis i així ho sol-liciten, o si no ho són, després de l'admissió prèvia com a tals, feta de conformitat amb el que es disposa en l'article 13 d'aquesta llei, i que haurà de sol-licitar-se en el termini de sis mesos des de la mort...".

D'altra banda, l'article 54.3 de la LCCV reconeix la possibilitat de transmissió inter vivos únicament al soci que perd els requisits per a ser-ho per causa justificada, i únicament en favor de determinats familiars, si són socis o adquireixen aqueixa condició en tres mesos, des de la baixa; i l'apartat 4 del mateix article estableix que "en cas de successió mortis causa, poden adquirir la condició de soci, els hereus que ho sol-liciten i que tinguen dret a l'ingrés ${ }_{\mathbf{L}} \mathrm{d}^{\prime} \mathrm{acord}^{\prime}$ amb els estatuts i amb aquesta llei".

1096 SERRANO Y SOLDEVILLA, A.D., La cooperativa..., op. cit., pàg. 97 i 98: "la societat cooperativa, en ser una entitat en la qual és summament rellevant el caràcter intuitus personae de la seua base personal, obliga que, sobre la dada de la pertinença a la categoria o al grup social de base, s'articule un conjunt de condicions objectives que són requerides com a pressupost possessori, previ per a l'admissió de membres nous [...] en la societat cooperativa. El pressupost previ vàlid i necessari de la pertinença a la categoria d'interessos definida en els estatuts socials, és conditio sine qua non per poder formar part integrant d'aquesta. [...] la funció o la justificació de la restricció legal a la transmissibilitat lliure de la participació social, al si de les cooperatives, no és una altra cosa que el fet d'impedir-hi l'entrada d'aquelles persones que no es troben en possessió de les condicions necessàries per a la seua incorporació social. Es tracta d'evitar l'ingrés social als qui no pertanyen a la categoria o al grup social dels interessos dels quals la 
Però, a més, la participació en el capital cooperatiu no és un valor mobiliari que, com en les societats anònimes, incorpore el conjunt de drets i d'obligacions del soci i que, per això, faça necessari plantejar-se si amb aquests es transmet el dret d'impugnació. Les participacions en el capital social de la cooperativa són, únicament, "el que es rep a canvi de les aportacions", ${ }^{1097}$ els documents (en suport paper $\mathrm{o}$ informàtic) que acrediten les aportacions realitzades al capital social, però no el conjunt de drets ni el seu tipus d'exercici. Com s'ha dit, "la participació del soci cooperatiu en el capital social no representa els seus drets i obligacions com a soci, excepte el dret al cobrament d'interessos i a la responsabilitat pels deutes socials ${ }^{\prime 1098}$, únics drets que es tenen, en proporció al capital aportat ${ }^{1099}$.

societat cooperativa és expressió, i que està determinat pels requisits i per l'objecte social de la

En relació amb el requisit per ser soci de pertinença a la categoria directament interessada en l'objecte social, VICENT CHULIÁ, F., "Análisis crítico...», op. cit., pàg. 460, explica que no és necessari que s'exigisca en la definició legal, ja que "es desprèn necessàriament del règim de la cooperativa; especialment del principi mutualista o de doble qualitat de soci i d'usuari [...] En resum, per ser fundador o soci de la cooperativa s'ha de pertànyer a una categoria determinada de persones directament interessades en la seua activitat, sense perjudici que, de vegades, aquesta categoria incloga grups amplíssims de persones".

1097 VICENT CHULIÁ, F., "Notas en torno...»", pàg. 22; FAJARDO GARCÍA, I. G., La gestión económica de la cooperativa: responsabilidad de los socios, tesi doctoral, València, 1992, pàg. 96. La modificació que es produeix en la concepció de la participació cooperativa pel que fa a l'acció capitalista, és tan radical que, fins $i$ tot, en el context del dret cooperatiu italià (on, com es recordarà, la cooperativa adopta, bàsicament, el règim jurídic de la societat anònima), doctrinalment, han sorgit molts dubtes sobre la naturalesa jurídica de les accions d'una societat cooperativa, atès el caràcter personal de la participació i del fet que el títol de l'acció representa; l'opinió més estesa afirma que es pot parlar, en resum, de mers certificats de quota més que d'accions" (PALMA, R., "Il fenómeno cooperativo...», op. cit., pàg. 36).

1098 FAJARDO GARCíA, I. G., La gestión económica... (tesi doctoral), op. cit., pàg. 102. També VICENT CHULIÁ, F., «Mercado, principios cooperativos...», op. cit., pàg. 23: "El capital social no serveix d'instrument tècnic per a l'organització corporativa: no es té en compte per determinar el quòrum de constitució, les majories en l'assemblea general, la representació proporcional en el consell d'administració, la intensitat dels drets del soci...".

1099 Això no obstant, com veurem en l'epígraf b) següent, "Categories especials de socis", el que s'ha exposat en relació amb la intransmissibilitat de la qualitat de soci o de la legitimació per impugnar, varia radicalment en un supòsit que analitzarem entre les categories especials de socis: el del soci financer de la nova classe de cooperativa, creada per la LCoop, amb la denominació de cooperativa mixta (art. 107). 
I, no obstant això, estimem que qui adquireix la condició de soci posteriorment a l'adopció de l'acord nul està legitimat per a la seua impugnació, sempre que ho faça en el termini de caducitat. Perquè la llei legitima qualsevol soci, sense limitació de cap tipus ${ }^{1100}$, a diferència del que veurem per als acords anul-lables, i perquè l'entitat del vici que invalida l'acord permet que vaja en contra seu qualsevol persona que tinga interès legítim, i és difícil negar que el soci nou tinga l'interès més gran a corregir l'acord que considera nul. Però reiterem que el soci nou no adquireix la legitimació de qui, en aqueix cas, li haguera transmès les participacions socials, sinó com a facultat inclosa en el conjunt de drets i de deures que té en la seua qualitat nova de soci.

D'altra banda, les mateixes raons que ens fan rebutjar, amb caràcter general, la transmissibilitat dels drets de soci i, juntament amb aquests, la legitimació per impugnar, serveixen per fonamentar la inadmissibilitat de la copropietat de les participacions socials cooperatives $i$, amb aquesta, una hipotètica legitimació compartida, exercida per un representant ${ }^{1101}$. En efecte, mentre que l'art. 66 de la LSA regula la copropietat d'accions i estableix la necessitat de designar, en aqueixos casos, una sola persona que exercisca els drets de soci, aquesta previsió legal és innecessària en el marc cooperatiu, on la participació social representa, únicament, l'aportació realitzada per cada soci al capital social, i és inadmissible la seua copropietat.

Hauríem de plantejar-nos, tanmateix, un supòsit que pot aproximar-se al de l'administració de les accions en copropietat: el de l'herència jacent del soci mort. Ja hem vist que la legislació cooperativa (LCoop, article 50, b) i LCCV,

1100 Morillas Jarillo, M. J. i Feliú REY, M. I., Curso de cooperativas, op. cit., pàg. 257; RODRIGUEZ RUIZ DE VILLA, D., Impugnación..., op. cit., pàg. 132 i 133, nota 8, on indica que, en la $\mathrm{SA}$, la legitimació davant acords nuls s'atribueix exclusivament en virtut de la condició d'accionistes, a diferència del que ocorre amb els acords anul-lables, en què la llei exigeix la concurrència d'altres requisits cumulatius, com són els d'absència, de privació il-legítima del vot o de l'oposició; tots aquests relatius al moment d'adopció de l'acord impugnat. Per tant, "si la llei no distingeix", els accionistes posteriors als acords, però que ho són en el moment d'exercitar l'acció, també disposen, segons el seu parer, de legitimació.

1101 Amb la mateixa excepció feta pel que fa al soci capitalista de la cooperativa mixta. 
article 54.4) preveu la possibilitat de transmissió mortis causa de les participacions socials; amb aquesta transmissió, si els hereus encara no són socis, però reuneixen els requisits legals i estatutaris per ser-ho i n'estan interessats, poden accedir a aqueixa condició. ${ }^{1102}$ Però ens referim ara a un moment anterior: aquell en el qual encara no s'ha procedit a l'acceptació de l'herència $i$, per tant, no s'ha pogut exercir el dret d'accés a la cooperativa. En aqueixos casos, sembla que, en defensa dels interessos de l'herència, serà possible la impugnació d'acords que li puguen ser lesius, bé del marmessor o administrador de l'herència, bé dels mateixos hereus ${ }^{1103}$. Però la seua legitimació no serà en qualitat de soci, sinó de tercer amb interès legítim, ja que no s'actua en

1102 La STS (Sala 1a), de 30 de maig de 1997, núm. 464/1997 (RJA 1997/4330) refereix un supòsit en què els estatuts socials d'una SA estableixen que, a la mort d'un soci, no adquiriran la condició de soci ni el cònjuge ni els hereus, sinó únicament el seu contravalor. Podria plantejar-se la qüestió de l'admissibilitat d'una restricció estatutària en el marc cooperatiu, encara que el tenor literal, tant de la LCoop com de la LCCV, no semble deixar un marge ampli
per a la interpretació positiva.

1103 RUBIO, J., Curso..., op. cit., pàg. 261; URfA, R., MENÉNDEZ, A. i MUÑOZ, J. M., La junta..., op. cit., pàg. 349 i 350, referencien jurisprudència del Tribunal Suprem (per a SA) en la qual es reconeix la legitimació al marmessor, comptador $i$ administrador de l'herència, $i$ als hereus de l'accionista mort pocs dies després de realitzada la junta. Aquesta legitimació es justifica "per l'aplicació de l'article 661 del Codi Civil, de la doctrina jurisprudencial que permet, amb herència proindivís, exercitar accions judicials en benefici de la massa i perquè, si no és així, es consagraria una situació d'indefensió, amb una infracció clara de l'article 24 de la Constitució". També es refereixen a la jurisprudència del TS, favorable a la legitimació dels representants de l'herència jacent, SORIA FERRANDO, J. V., La legitimación activa..., pàg. 61, i RODRf́GUEZ RUIZ DE VILLA, D., Impugnación..., op. cit., pàg. 134, 148 i 155, que recorda que aquesta legitimació "ha de suposar, sempre, que el causant mort disposava del dret d'impugnació".

De la seua banda, ROMERO COLOMA, A. M., «En torno a la problemática de la herencia yacente», RCDI, núm. 643, novembre-desembre de 1997, pàg. 2221, recull la STS de 12 de març de 1987, en la qual s'indica que "l'obertura de la successió d'una persona es produeix, justament, en el moment de la seua mort, quan el seu patrimoni es transmuta en herència jacent, que és aquell patrimoni relicte, mentre es manté interinament sense titular i per la qual cosa no té personalitat jurídica, encara que per a determinades finalitats se li atorga, transitòriament, una consideració $i$ un tractament unitaris, i és el seu destí ser adquirida pels hereus voluntaris o legals, i amb
l'admissió que, bé per mitjà de marmessors o d'administradors testamentaris o judicials (s'inclouran els hereus designats), puga ser demandada i estiga habilitada per exceptuar i ara
per recórrer".

En relació amb qui haja d'exercitar l'acció, l'article 902 del CC estableix que "si el testador no ha determinat especialment les facultats dels marmessors, aquests tindran les següents: [...] 4a. Prendre "les precaucions necessàries per a la conservació i la custòdia dels béns, amb intervenció dels hereus", i l'article 911, que diu que quan acabe la marmessoria o el marmessor no haja acceptat el càrrec, "correspondrà als hereus l'execució de la voluntat del testador". Quan l'existència de diversos hereus determine l'aparició de la comunitat hereditària, DíkZ PICAZO, L. i GULLÓN, A., Instituciones..., pàg. 787, indiquen que "els actes d'administració i de gaudi més bo han de regir-se pel que disposa l'article $398^{\prime \prime}$ [per a la comunitat de béns en general]" i és necessari l'acord de la majoria de capital dels cohereus". 
nom del soci mort, sinó en protecció dels interessos legítims dels qui encara no se sap si, finalment, adquiriran la condició de socis ${ }^{1104}$.

b) Categories especials de socis

L'existència en la cooperativa de tipus especials de socis, que en alguns casos veuen limitats o modificats els seus drets, en comparació amb els de la resta de socis, planteja la necessitat de comprovar si els arriba la legitimació.

En el cas dels socis de treball1105, la LCoop assenyala únicament, per a ells, la necessitat d'establir estatutàriament "la participació equitativa i ponderada d'aquests socis en les obligacions $\mathrm{i}$ en els drets de naturalesa social i econòmica". La norma equivalent en la LCCV, l'article 16.1, remet també a la regulació estatutària dels "mòduls d'equivalència que hauran d'assegurar, també equitativament, la participació dels socis de treball en les obligacions i en els drets socials"1106. Segons el nostre parer, les peculiaritats que es reflecteixen estatutàriament, en relació amb els drets dels socis de treball, no hauran d'assolir el dret d'impugnació, que no es veu afectat per la participació especial dels socis de treball en l'activitat social. S'ha de recordar, a més, que es reconeix

1104 MORIllas Jarillo, M. J., i Feliú ReY, M. I., Curso de cooperativas, op. cit., pàg. 259, consideren, tanmateix, que el marmessor o l'administrador de l'herència s'han de considerar com a "socis asistents".

1105 Llobregat HuRTADO, M. L., «Capítulo IV. Posición jurídica del socio (I): clases de socios, adquisición de la condición de socio, derechos y obligaciones y responsabilidad», en AADD, La sociedad cooperativa en la Ley 27/1999, de 16 de julio, de cooperativas, (coord. F.J. Alonso Espinosa), Editorial Comares, Granada, 2001, pàg. 133: "persones físiques que treballen «no en 1'objecte que es cooperativitza" (consum, treball, crèdit, etc.) sinó en els treballs que contribueixen que els socis mutualistes puguen donar satisfacció a l'objecte social de la cooperativa".

1106 ElejabarRieTA GOIENETXE, A., en «De los socios...», op. cit., pàg. 86: "com que la Llei no regula, per ser impossible, la manera en la qual aquests socis de treball poden i han d'exercir els drets socials i complir les obligacions que els corresponen, $[. .$.$] aquestes qüestions han de ser$ regulades i resoltes pels estatuts de cada cooperativa. Per a això, aquests han de tenir en compte els principis cooperatius, han de tendir a equiparar els drets i les obligacions d'ambdós tipus de socis, $\mathrm{i}$ al fet que els drets, en el seu conjunt, no resulten inferiors als dels treballadors per compte d'altri".

Totes les lleis cooperatives autonòmiques regulen, amb variacions lleugeres, la figura del soci de treball. 
a aquest tipus de socis el mateix règim de protecció que l'establert per als soc treballadors de les cooperatives de treball associat, en el qual és peça essenci la possibilitat d'impugnar els acords que afecten la seua prestació de treball1107

Un altre supòsit de soci de característiques especials ha estat introduit per 1 LCPV (art. 26.2), en possibilitar la regulació estatutària de "vincles socials de durada determinada", supòsit que també s'ha incorporat a la LCoop (art. 13.6) El que s'ha anomenat soci temporal no té establert en la llei estatal cap altre límit a la seua participació en la cooperativa que el de la seua aportació obligatòria a capital, que no podrà ser superior al 10\% de l'exigida als socis de caràcter indefinit. La seua qualitat de soci, doncs, sense altres especificitats, serà títol suficient per tenir la legitimació corresponent. ${ }^{1108} \mathrm{La} \mathrm{LCCV}$ no preveu aquesta figura. 1109

1107 LCoop, article 13.4, 2n par. en relació amb els articles 80 a 87; LCCV, article 16.2, en relació pàg. 596, es refereix a la seua legitimació activa indubtable.

1108 resta dels seus drets. establir que el seu dret de vot, i la tampoc sembla que la limitació del vols als dels altres socis i seran regulats en els estatuts. Però d'impugnar, fonamentat en l'intel vot o la temporalitat de l'associació hagen d'influir en el dret Comentaris de la figura poden veurè soci de fer desaparèixer acords que estime invàlids. pàg. 163, i "Capítulo IV...», op. cit., pàg. opina que "haguera estat més positiu ad 132 i 133, on els anomena "socis de temporada", i quals en la cooperativa es limitara als perie socis de durada indeterminada, la prestació dels en què fóra necessària l'activitat [...]. Aquesta mateix, als socis garantir el seu treball indes de les cooperatives sinó que permetria, així PASTOR SEMPERE, C., "Ley foral 12/1996, definidament, encara que limitat temporalment"; i en de octubre de 1996). Principales novedade 2 de julio, de cooperativas de Navarra (BOE de 10 julio», RdS, núm. 8, 1997, pàg. 510 iades con respecto a la anterior Ley foral 12/1989, de 3 de 1/2000 de la Presidència del Govern basc 'article 26.2 de la LCPV ha estat modificat per la Llei el límit màxim de socis d'aquesta cat, que modifica parcialment la Llei 4/1993; s'ha ampliat contractació per compte d'altri (E de mogoria, "amb una reducció paral-lela, si escau, de la ha quedat inalterat. 
La LCoop introdueix una categoria especial nova, la dels socis col-laboradors, hereva de la figura de l'associat de la LGC.1110 Serà l'assemblea general la que "fixarà els criteris de participació ponderada d'aquests en els drets $\mathrm{i}$ en les obligacions socioeconòmiques de la cooperativa". Atribuir exclusivament a l'assemblea la facultat de determinar, en cada moment, quin és el nivell de participació del soci col-laborador, no sembla un sistema que oferisca un nivell adequat de seguretat jurídica. Estimem que, en garantia dels seus interessos, s'hauria d'haver requerit, almenys, una regulació estatutària. En tot cas, caldrà considerar, així doncs, la fixació per l'assemblea de les obligacions i dels drets concrets dels socis collaboradors, per comprovar si s'estima que la seua participació ponderada assoleix la possibilitat d'impugnar els acords socials; a falta de menció estatutària expressa, cal rẹcordar, tanmateix, que-1'article 31.4 de la LCoop legitima els socis en general, sense efectuar cap distinció. ${ }^{1111}$

1110 Llobregat HuRTADO, M. L, "Capítulo IV...», op. cit., pàg. 135, on comenta que aquesta modalitat de soci substitueix l'associat i el soci excedent i en simplifica el règim. Vegeu l'epígraf
B. següent.

LCoop, article 14: "Els estatuts podran preveure l'existència de socis col-laboradors en la cooperativa, persones físiques o jurídiques, que sense poder desenvolupar o participar en l'activitat cooperativitzada, pròpia de l'objecte social de la cooperativa, poden contribuir a la
seua consecució...".

LGC, article 39: "Els estatuts podran preveure l'existència d'associats en la cooperativa. Podran ser associats, tant les persones físiques com les jurídiques, publiques o privades..."; article 40.6: "Els associats, en cap supòsit, tindran dret a retorn, ni podran desenvolupar activitats en la seua exposit. La finalitat de la configuració per la LGC de 1987 dels associats, s'expressa en la seua exposició de motius: "potenciar tot el que afavorisca el desenvolupament de l'activitat empresarial de la cooperativa i estimular l'increment dels recursos financers propis". Sobre el seu règim jurídic, vegeu l'epígraf B. següent, i BORJABAD GONZALO, P. J., en Manual..., pàg. 73 a 80; PAZ CANALEJO, Narciso, "Los socios y los asociados», Documentación social. Revista de estudios sociales y de sociología aplicada, núm. 68, 1987, pàg. 103 a 122, i en PAZ
CANALEJO, N. i VICENT CHULIÁ, F., Ley general..., vol. II, pàg. 243 a 301.

1111 AADD, La sociedad cooperativa en "Capítulo I. La sociedad cooperativa en la Ley 27/1999», en Espinosa), Editorial Comares, Granada 27/1999, de 16 de julio, de cooperativas (coord. F.J. Alonso seccions de crédit, considera que "Haura, 2001, pàg. 16, en el context de les operacions de les aquest terme els usuaris i els "Haurà d'entendre's que quan la Llei diu socis integra en l'associat per la del soci col-laborador, però obligacions, totalment, als estatuts socials i, en tot la regulació dels seus drets i de les seues parts, i fa, no obstant això, limitació exprals en tot allò que no s'hi preveu, a allò pactat entre les contràra no det de vot. LCC els denomina adherits i, d'assistènent, els dota d'un règim legal exprés (art. 25), en el qual es preveu el seu dret ni del comitè l'assemblea amb veu i amb vot limitat; no poden ser membres del consell rector consell. Comentecursos, ni interventors, encara que poden tenir dret a un representant en el "De los socios 
Però, a més, la legislació cooperativa autonòmica recull una gamma variada de tipus especials de socis. Així, la LCCV regula la figura del soci excedent (art. 23), que podrà crear-se, estatutàriament, per mantenir la integració d'aquells socis que, per causa justificada, no puguen continuar participant en l'activitat cooperativitzada. ${ }^{1112}$ Aquest tipus de soci, en la seua regulació per la llei autonòmica valenciana, no té ni el dret a participar en retorns d'exercici i ni el de formar part del consell rector, i té limitat el dret de vot, però se li reconeixen expressament "la resta dels altres drets de soci enunciats en l'article 20".

Podria argumentar-se, pels qui consideren que el d'impugnació és un dret instrumental del de vot, que la limitació d'aquest últim, ponderant-lo pel que fa al total de socis presents i representats, significaria també la limitació del dret a impugnar per als socis excedents; però això no és necessàriament cert, ja que la mateixa LCCV (art. 24) regula, més endavant, el supòsit que als associats se'ls reconega el dret de vot; en aquest cas, els vots que ells emeten no podran superar el $45 \%$ dels vots presents i representats, i, a pesar d'això, "gaudiran dels mateixos drets que el soci quant al seu exercici i a la participació en els òrgans socials, inclòs el dret d'impugnació". En tot cas, compartim l'opinió doctrinal que "no és possible afirmar la instrumentalitat del dret d'impugnació respecte del dret de vot", 1113 ja que, tant la LSA com la legislació cooperativa,

pàg. 161 a 163, i «Capítulo IV...», op. cit., pàg. 135 i 136; MARÍN LÓPEZ, J. J., «Notas sobre la Ley 27/1999...», op. cit., pàg. 1800, i en PANIAGUA ZURERA, M., «La reforma de la legislación...», op. cit., pàg. 62. MONTOLf́o HERNÁNDEZ, J. M., «Leyes de cooperativas...», op. cit., pàg. 239 i 240, els denomina socis no usuaris.

${ }^{1112}$ La LCoop integra aquest supòsit a la figura del soci col-laborador (art. 14, 4t par.) La LCPV (art. 30), la LCC (art. 24) i la LCA (art. 18.3) incorporen, també, la figura del soci excedent, encara que amb trets propis. Així, la LCPV, denomina aquests socis inactius o no usuaris, fa dependre la totalitat dels seus drets (i, per tant, també el d'impugnació) de la regulació estatutària (pot veure's ELEJABARRIETA GOIENETXE, A., "De los socios...», op. cit., pàg. 122 a 124). MONTOLfo HERNÁNDEZ, J. M., "Leyes de cooperativas...», op. cit., pàg. 239 i 240, els denomina exsocis.

Vegeu l'epígraf B. següent.

${ }^{1113}$ SORIA FERRANDO, J. V., La legitimación activa..., pàg. 58. En el mateix sentit, DUQUE DOMíNGUEZ, J. F., Tutela..., op. cit., pàg. 161, que estima que la relació entre ambdós és de complementarietat. En el dret italià, GROsso, P., I controlli interni..., op. cit., pàg. 90 i 91 , cita doctrina $\mathrm{i}$ jurisprudència que estimen que les limitacions d'altres drets, com el de vot, "no pot 
concedeixen legitimació activa per a la impugnació dels acords socials als socis absents, $\mathrm{i}$ això tant als privats legítimament de dret d'assistència com als que no han volgut exercitar aqueix dret. 1114

D'altra banda, l'esmentat article 20 de la LCCV no recull explícitament, entre els drets del soci, el d'impugnar els acords socials, però sí que li atribueix "la resta de drets que s'establisquen expressament o que es desprenguen de les normes imperatives d'aquesta llei o dels estatuts socials". En tot cas, segons la nostra opinió, també en aquest supòsit la legitimació del soci excedent es deriva del qualificatiu de soci que li atribueix la norma, posat ací en relació amb l'article 36. 4 següent, que reconeix la legitimació dels socis, sense distinció.

En el grup de socis especials, s'inclou la figura del soci en situació de prova per a les cooperatives de treball associat ${ }^{1115}$, els drets $\mathrm{i}$ les obligacions del qual són diferents segons la llei aplicable. Així, la LCoop reconeix que "tindran els mateixos drets i les mateixes obligacions que els socis treballadors", amb algunes excepcions expressament previstes, entre les quals no es troba el dret

entendre's ampliada fins a comprimir altres drets connexos a l'estatus de soci", entre els quals s'esmenta el dret a la impugnació dels acords en supòsits de socis morosos, o amb dret de vot limitat, o en situació de conflicte d'interessos.

1114 A la mateixa interpretació s'hauria d'arribar, en el cas d'una fórmula peculiar introduïda per la LCA (art. 84.3) per a les cooperatives d'habitatges: que diverses persones interessades en la consecució com a titulars d'un sol habitatge puguen adquirir la condició simultània de socis, però amb dret a expressar un vot únic. Pot veure's un comentari en GUTIÉRREZ DíEZ, Á., «El Proyecto de Ley..., op. cit., pàg. 99: "El motiu és donar solució a un dels problemes més freqüents que es plantegen en aquest tipus de cooperatives, com és el cas d'aquelles parelles no casades (nuvis per exemple), que volen obtenir el seu habitatge en cotitularitat [...]. L'únic problema que pot plantejar-se és quan no coincideixen en les seues opinions els diferents coparticipants, a l'hora d'expressar el vot únic al qual tenen dret. Encara que el text no diu res, se suposa que, forçosament, hauran de posar-se d'acord o abstenir-se, ja que, altrament, el vot no podria ser vàlid".

1115 La LCoop també reconeix la possibilitat que els estatuts establisquen un període probatori per als socis de treball, de cooperatives diferents a la de treball associat, d'explotació comunitària de la terra o de segon grau (art. 13.4, 5è par.).

La LCG (art. 27) regula la figura dels socis a prova, per a les cooperatives de primer grau, llevat $\mathrm{d}$ 'habitatges, de crèdit i d'assegurances, si els estatuts ho preveuen, amb els mateixos drets $i$ les mateixes obligacions que els altres, tret d'algunes excepcions.

Una altra norma cooperativa autonòmica que preveu un període probatori per a les cooperatives de treball associat és la LCPV (art. 100). 
d'impugnació d'acords (art. 81.3)1116. Al contrari, la LCCV estableix que "els estatuts socials podran fixar un període probatori per als socis (...). Durant aquest període probatori, el soci treballador tindrà els drets de veu i d'informació; i també, de participació en retorns, i li seran imputables, igualment, les pèrdues de l'exercici". Aquesta enumeració tancada sembla excloure el dret d'impugnació com a soci; ara bé, el podrà exercir com a tercer amb interès legítim.

En el camp de les cooperatives d'habitatges, la LCCV (art. 81) esmenta, però no regula, l'existència possible dels anomenats socis expectants. Pel que fa a aquest tipus de soci (també esmentat en l'anterior LGC, article 132), s'ha afirmat que "noméss té dret a ser soci en el seu moment i, per tant, no té legitimació en l'acció de lesivitat"1117, mentre que una altra opinió doctrinal assenyala la possibilitat que, estatutàriament, li siga reconegut el dret d'assistència $i$, fins $i$ tot, de vot; aquesta darrera considera que tindria legitimació per impugnar els corresponents acords ${ }^{1118}$. Estimem que, en el cas de la llei valenciana, com que el qualifica de soci i li atribueix un dret de prioritat en l'adquisició de la condició de soci de ple dret i de l'habitatge o local adjudicats al soci anterior, se li podria reconèixer, estatutàriament, el dret d'impugnació, almenys per als assumptes en els quals puga tenir un interès clar. En cas contrari, la legitimació se li podria atribuir únicament com a tercer $\mathrm{amb}$ interès legítim.

Per contra, la LCoop (art. 92) ha substituït la menció al soci expectant per la del sol-licitant d'admissió com a soci, amb la qual cosa, implícitament, aclareix el seu

1116 Coincidia a atribuir legitimació als socis en període probatori regulats per la LGC (que tenia un contingut molt similar), PAZ CANALEjo, en PAZ CANALEJO, N. i Vicent CHULIÁ, F., Ley general..., vol. II, pàg. 595 i 596, encara que la fonamentava en el seu dret de vot. Aquesta argumentació es veuria ara, almenys en part, invalidada, ja que la regulació actual de la LCoop denega als socis en període probatori el dret de vot "en l'assemblea general", quan l'objecte de la votació "els afecte personalment i directament". De la nostra banda, hem de reiterar tot el que s'ha ressenyat sobre la independència del dret d'impugnació respecte del de vot.

1117 MuÑoz VidAL, A. B., El proceso..., pàg. 45.

1118 Paz Canalejo, N., en Paz Canalejo, N. i Vicent Chuliá, F., Ley general..., pàg. 596. 
règim jurídic: estem davant d'una persona que encara no és sòcia, les expectatives de drets de la qual podran constituir interès suficientment legítim únicament per gaudir, si escau, de la legitimació corresponent com a tercer.

Finalment, la incorporació per la LCoop de la denominada cooperativa mixta (art. $107),{ }^{1119}$ ha fet aparèixer una categoria nova de soci, que s'ha qualificat de soci financer, 1120 "el dret de vot del qual en l'assemblea general es podrà determinar, de manera exclusiva o preferent, en funció del capital aportat en les condicions establertes estatutàriament"; les seues parts socials amb vot se sotmetran a la legislació reguladora del mercat de valors, coherentment amb la possibilitat que estatutàriament s'establisca la seua negociació lliure; i la part d'excedents, positius o negatius, que corresponga al conjunt d'aquests socis, s'hi distribuirà d'acord amb el capital desemborsat.

Quant al règim de drets $\mathrm{i}$ de deures d'aquests socis, l'apartat 3 de l'article 107 de la LCoop estableix que "en el cas de les parts socials amb vot, tant els drets i les obligacions dels seus titulars, com el règim de les aportacions, es regularan pels estatuts $i$, supletòriament, pel que es disposa en la legislació de societats anònimes per a les accions". La remissió a la LSA i al règim de les accions, si bé amb caràcter supletori, és una indicació clara del perfil de soci que es pretén facilitar amb aquesta figura nova. Però, a més, la redacció de la primera part de l'apartat sembla que condueix a interpretar que els drets i les obligacions d'aquest tipus peculiar de socis acompanyen les "parts socials amb vot", siga qui siga el seu titular; i això és així en relació amb el conjunt de drets i d'obligacions del titular, no sols respecte al dret de vot, que expressament se sotmet, exclusivament o preferentment, a un règim capitalista.

1119 PAZ CANALEJO, N., "Visión general...», op. cit., pàg. 53: “[...] Cooperatives mixtes, en les quals, com a comanditàries cooperatives, es podran agrupar dos tipus de socis: els cooperadors [...] i els socis de capital o titulars de parts socials". 
La novetat relativa de la figura en el marc cooperatiu espanyol ${ }^{1121}$ dificulta notablement la projecció de quina serà la tendència en la regulació estatutària de les facultats i dels deures dels socis preferentment capitalistes a la cooperativa mixta, i entre aquests, el d'impugnar els acords socials. Pot ser que la pràctica més habitual siga l'aplicació plena per a aquests del règim de la societat anònima, bé siga per remissió expressa o per silenci estatutari, però estimem que "per a aquest viatge no feien falta aquestes alforges". En efecte, d'una banda, la comoditat relativa d'unir en una sola persona jurídica els dos col-lectius de socis (cooperatius o mutualistes, i preferentment capitalistes) ja podia assolir-se anteriorment, mitjançant la forma jurídica de la societat laboral. D'altra banda, el preu que aquestes cooperatives hauran de pagar per accedir a aquest concepte nou de mutualitat 1122 és, en la nostra opinió, excessiu: s'hi haurà

$1121 \mathrm{El}$ precedent de l'article 107 de la LCoop és l'article 136 de la LCPV que, de manera pràcticament literal en alguns dels seus apartats, s'ha traslladat al text normatiu estatal.

En la legislació italiana també s'admeten els anomenats socis no cooperadors i els socis sovventori, mitjançant l'aplicació del principi jurisprudencial de la preponderància de la finalitat mutualística sobre la finalitat lucrativa (vegeu BASSI, A., Le società cooperative, op. cit., pàg. 174 a 178; BONFANTE, G., Imprese cooperative..., op. cit., pàg. 416 a 427; i PALMA, R., Il fenómeno cooperativo..., op. cit., pàg. 37 a 39), encara que es troba a faltar (GENCO, R., Il volto cooperativo..., op. cit., pàg. 16 i 17), sobretot per al soci sovventor, "una disciplina clara i limitada als vincles no derogables, necessàriament lligats a la forma cooperativa (règim de vot, possibilitat de distribució dels beneficis), que reconega, en canvi, per a la resta d'aspectes, 1'aplicabilitat de la disciplina general comuna a les altres societats".

En el dret francès, una de les modificacions introduïdes en l'Estatut de la cooperació per la Llei 92-643, de 1992, consisteix a oferir a les cooperatives que puguen definir una o diverses categories de socis no cooperadors, i precisar els qui gaudiran d'un règim privilegiat de vot, proporcional al capital detingut; els estatuts han de fixar, tanmateix, la proporció màxima de capital que pot tenir el conjunt dels socis no cooperadors, tinguen o no dret de vot privilegiat, que no podrà superar el $35 \%$ (PIOT, B., "Une réforme en profondeur...», op. cit., pàg. 43). Entre els socis no cooperadors s'ha de distingir els socis no cooperadors amb estatut cooperatiu (els socis anteriorment actius), i els socis no cooperadors a títol no cooperatiu, que inclouen les persones físiques que mai no hagen estat treballadores de la cooperativa, o la qualitat de soci de les quals no s'haja adquirit sinó després de l'expiració del seu contracte de treball, i les persones jurídiques (AADD, «La coopérative française...», op. cit., pàg. 60; FAJARDO GARCAA, I. G., "Ley francesa...», op. cit., pàg. 177. També es refereix a aquests membres inversors no usuaris, SALAZAR LEITE, J., "Sobre o Código cooperativo...», op. cit., pàg. 184.

Un estudi comparatiu de les figures del soci col-laborador basc, l'adherit català i el sovventor italià el realitza LLOBREGAT HURTADO, M. L., en «La reforma...», op. cit., en pàg. 161 a 163.

1122 Llobregat HURTADO, M. L., "Algunas reflexiones...», op. cit., p. 269; PALMA, R., «Il fenómeno cooperativo..., op. cit., pàg. 48 i 49: "Bassi [notes 1 i 2: BASSI, La riforma delle società cooperative, Giuffrè, Milà, 1992, pàg. 29 i 30] seria partidari de parlar d'una mutualitat nova, i d'admetre el declivi del concepte pur per deixar lloc a una expansió progressiva cap a les zones tradicionals de l'ànim de lucre; tindríem, d'alguna manera, els primers gèrmens d'una causa mixta, en la qual no sols es pot configurar una instrumentalitat de la inversió pel que fa al fi 
d'incloure, entre d'altres aspectes, la possibilitat de trencament dels principis cooperatius (porta oberta, estructura i gestió democràtiques, autonomia i independència $\left.{ }^{1123}\right)$, i la incertesa del seu règim fiscal ${ }^{1124}$.

c) La representació del soci

En relació amb la legitimació del soci per impugnar els acords socials nuls, s'ha plantejat en el marc de les societats mercantils la possibilitat que persones diferents als socis posseeixen legitimació per impugnar, en la mesura que siguen titulars del dret de vot (usufructuaris, creditors pignoratius, etc.), o que exercisquen aquest dret en representació del soci ${ }^{1125}$.

cooperatiu; sinó que pot, fins i tot, arribar a valorar la cooperació en la inversió entesa com a objecte material de l'actuació cooperativa".

1123 Això no obstant, en relació amb aquest principi (el quart), PAZ CANALEjo, N., "Principios cooperativos..., op. cit., pàg. 23, assenyala que aquests "financers externs eventuals" no són, d'entrada, rebutjats per l'ACI en la seua formulació última dels principis cooperatius. En efecte, el Congrés de Manchester estableix que les cooperatives, "si aconsegueixen capital de fonts externes, ho fan en termes que asseguren el control democràtic dels seus socis i que mantinguen la seua autonomia cooperativa".

1124 L'èxit escàs que té la implantació d'aquestes fórmules noves de participació en la cooperativa, el denominador comú de les quals és la recerca de fonts de finançament, semblen ratificar que el cost social i pràctic és excessiu. Així, a Itàlia, PALMA, R., "Il fenómeno cooperativo..., op. cit., pàg. 49: "Els quatre anys de vigència de la Piccola Riforma no han patentitzat un increment important dels capitals i de les inversions en el sector cooperatiu. Sobretot, l'institut dels socis sovventori no ha assolit les expectatives".

1125 URí, R., Derecho Mercantil, op. cit., pàg. 324 i 325: "A aquest efecte, han de ser equiparats als accionistes qualssevol altres persones (usufructuaris, creditors pignoratius) que siguen titulars del dret de vot perquè els estatuts els conferisquen aquest dret. (També està legitimat el marmessor del soci mort: sentència de 27 d'octubre de 1972)"; ARROYO, I., "Comentario al art. $56 . . .$, op. cit., pàg. 617: "la dicció legal parla de socis [...] assistents. La jurisprudència del Tribunal Suprem ha tingut ocasió d'ampliar aquest concepte, per incloure els denominats concurrents qualificats. Es tracta d'una sèrie de persones que, sense ser socis ni estar dotats d'un dret estricte d'assistència, concorren a la impugnació, dotats d'un interès legítim, emparats en una situació jurídica reconeguda per la llei. És el cas del cònjuge casat, al qual s'adjudiquen, en la sentència de divorci, participacions socials (STS de 3 maig 1969); del marmessor, comptador partidor i administrador de l'herència (STS de 27 octubre 1972), o dels hereus del soci mort pocs dies després de fer-se la junta, els acords de la qual són objecte d'impugnació, ja que el contrari provocaria indefensió $\mathrm{i}$ infringiria el dret constitucional a la tutela judicial efectiva (STS de 19 desembre 1984). També analitza els supòsits en els quals concorren drets diferents sobre l'acció (usdefruit, penyora, comodat) i el règim de representació del soci i de la copropietat de les accions, DUQUE DOMÍNGUEZ, J. F., en Tutela..., op. cit., pàg. 169 a 180. 
Però, mentre que el primer tipus de supòsits no pot donar-se en el mar cooperatiu, ateses les diferències essencials tant entre les participacions socials cooperatives i les accions ${ }^{1126}$ com en el dret de $\operatorname{vot}^{1127}$, la representació del soc és, per contra, instrument habitual de la participació cooperativa1128. Aixć condueix a qüestionar-se qui té la legitimació per a la impugnació d'acords adoptats amb la participació del representant del soci: el representant?, el soci? ambdós?...

Pel que fa a la representació del soci per a l'exercici dels seus drets, s'ha de fer tanmateix, una excepció prèvia: tant la legislació de les societats de capital con la cooperativa, regulen la institució de la representació del soci i li atribueixer trets específics, però es limiten a posar normes a la representació quant a uns drets determinats del soci; fonamentalment, aquells que el soci pot exercitar er els òrgans socials de què forme part: assistència, veu, proposta, vot, informació etc $^{1129}$.

1126 Vegeu supra, epígraf a) anterior.

1127 SCORDINO, F., La società cooperativa, op. cit., pàg. 288 i 289.

1128 De la normalitat de l'actuació mitjançant representació en la cooperativa, donen exemple les referències múltiples als socis o vots presents o representats. Així, per al còmput de quòrum: de constitució de l'assemblea (LCoop, art. 25.1, i LCCV, art. 31.1), de les majories (LGC, art. 28.2 per a les qualificades, i LCCV, art. 32.4 i 5), i de drets de minoria (per exemple, LGC, art. 25.3, LCCV, art. 32.3).

Això no obstant, com ha recordat VICENT CHULIA («El derecho de los órganos...», op. cit., pàg $520)$, "el dret de vot pot exercitar-se mitjançant representant, però amb limitacions important: amb les quals la legislació cooperativa intenta, una vegada més, fer efectiu el princip democràtic".

1129 RONCERO SÁNCHEZ, A., La representación..., op. cit., pàg. 251 i 252: "El contingut de le posició de soci està formada, al marge d'alguns deures, per un conjunt de drets, entre els qual: s'ha de distingir, juntament amb els drets patrimonials o econòmics, els denominats dret: polítics o administratius que comprenen totes les possibilitats d'actuació que es reconeixen a titular d'aquesta posició per articular la seua participació en la vida de la societat, [...] Aquesta participació de l'accionista en la vida social es porta a terme, de manera molt substancial mitjançant la seua intervenció en la junta general, amb l'exercici de drets determinats (dret: d'assistència, veu, proposta, vot, informació....) o mitjançant l'exercici de drets determinats for de la junta, però en relació amb aquesta (drets de convocatòria, impugnació d'acords...).

L'atenció del legislador, en relació amb la representació de l'accionista, s'adreça, tanmateix, b directament a l'exercici del dret de vot per representant (cas de les ordenacions d'inspiraci germànica - Alemanya, Àustria- i d'altres com Bèlgica) o bé a la participació de l'accionista per representant en la junta general (així, França, Itàlia, Suïssa, Portugal, Espanya...). 
No obstant això, la falta de menció de la possibilitat d'exercitar altres drets i altres facultats per mitjà de representació, no ha de ser interpretada com a privació automàtica de l'aplicació del règim general de la representació. En aquest sentit, s'ha considerat que "en el sector del dret patrimonial o dret de béns, ha de considerar-se com a regla general l'admissibilitat de la representació, en relació amb tot tipus d'actes i negocis. (...) l'exclusió de la representació pel que fa a un acte o negoci particular només es produirà quan existisca un precepte exprés en aquest sentit o quan, d'acord amb uns principis generals, així ho determine la naturalesa de l'acte o negoci i (...) la prohibició de representació tindrà caràcter excepcional en tot cas" ${ }^{\prime 1130}$.

En apropar-nos ja a la regulació cooperativa concreta de la matèria, cal distingir entre els supòsits de representació legal o orgànica i aquells en els quals la representació s'adopta de manera voluntària. Quant als primers (persones jurídiques, menors, incapaços...), com recorda la LCoop, "s'ajustaran a les normes de dret comú o especial que siguen aplicables"1131, i és raonable suposar que, en la majoria dels casos, serà el representant legal qui actuarà el dret d'impugnació, ja que es tracta d'una representació que sol afectar la

Pel que fa a la representació com a exercici de drets del soci en l'assemblea, VICENT CHULIÁ, F., "La asamblea...», op. cit., pàg. 175, l'emmarca en "el principi general del reconeixement del dret de tota persona a fer-se representar per a l'estipulació de negocis jurídics (l'emissió del vot, com a negoci jurídic unilateral del soci o, si es prefereix, declaració de voluntat de negociar, que s'integra en l'acord social)", i recorda la caracterització del vot de GIRÓN TENA (Derecho de sociedades anónimas, op. cit., pàg. 309) com a "manifestació de voluntat de caràcter no receptiu ni constitutiva de negoci jurídic".

1130 RONCERO SÁNCHEZ, A., La representación..., op. cit., pàg. 4 i 5.

1131 LLOBREGAT HURTADO, M. L., «Capítulo IV...», op. cit., pàg. 136, en relació amb les persones jurídiques sòcies; RONCERO SÁNCHEZ, A., La representación..., op. cit., pàg. 95 i 96: "els supòsits de representació legal i orgànica de l'accionista, en tractar-se de casos de representació necessària, queden exclosos del marc d'aplicació del règim legal $\mathrm{i}$ estatutari previst per a la representació voluntària del soci $i$, en conseqüència, es regiran per les seues normes pròpies. [...] En cada cas, el nomenament del representant legal, la determinació de les seues facultats $\mathrm{i}$ el tipus d'exercici del poder de representació, i també, l'extinció d'aquest es regeixen per un conjunt de normes que, en referir-se a matèries d'orde públic, té un marcat caràcter imperatiu o de dret necessari. De la mateixa manera, també per als casos de representació orgànica de les persones jurídiques, existeix un règim jurídic específic pel que fa a nomenament, àmbit del poder de representació i tipus d'exercici d'aquest". 
generalitat dels drets del representat. Això no obstant, com s'ha observat, s'haurà d'estudiar cada cas concret per comprovar que entre les facultats atribuïdes hi siga la de representació processal1132. En relació amb la representació orgànica de la persona jurídica sòcia de la cooperativa, s'ha de tenir present, a més, que té alguns preceptes específics tant en la legislació estatal com en l'autonòmica ${ }^{1133}$.

Més dubtes suscita el supòsit peculiar que apareix amb l'admissió per la LCoop que siguen sòcies d'una cooperativa les comunitats de béns que, com és sabut, no arriben a posseir personalitat jurídica independent. Tanmateix, no hi ha dubte que per a l'exercici de la seua representació en la cooperativa també seran d'aplicació les normes legals (CC, art. 392 a 406) i contractuals que les regulen ${ }^{1134}$.

En la representació voluntària, s'han de tenir en compte, per separat, dos tipus de supòsits: aquells en els quals, mitjançant un negoci jurídic d'apoderament, el soci exerceix el seu dret d'impugnació per mitjà d'un representant, i aquells altres en els quals la representació s'estableix per a l'exercici dels drets actuables en una assemblea general o en un altre òrgan social del qual el soci forma part.

1133 Pel que fa a la representació de la persona jurídica en la LGC, podia plantejar-se algun dubte sobre el caràcter vertader de la seua actuació, en virtut de la redacció que presentava la LGC (art. 56.1: "Només poden ser elegits consellers els socis de la cooperativa que siguen persones físiques [...]. Això no obstant, quan el soci siga persona jurídica, podrà ser elegit conseller el representant legal d'aquesta o la persona física que, pertanyent per qualsevol títol a aquesta, siga designada per a cada elecció. L'elegit actuarà com si fóra conseller en el seu nom $i$ tindrà el càrrec durant tot el període, llevat que perda la condició que tenia en la persona jurídica, i en aquest cas cessarà també com a conseller"). En l'actualitat, ni la LCoop ni la LCCV deixen cap dubte sobre la seua qualitat de representant de la persona jurídica (LCoop, art. $34.2,3$ r par., art. $77.2 \mathrm{i}$ art. 3, i LCCV, art. 39.1, $2 \mathrm{n}$ i $3 \mathrm{r}$ par., i art. $92.4,2 \mathrm{n}$ par.). representant de tots els comuners. 
Respecte al primer tipus de supòsits, no trobem raons que, en aplicació de la teoria general de la representació en el negoci jurídic, justifiquen la seua inadmissibilitat: ni existeix precepte exprés que prohibisca l'exercici del dret d'impugnació mitjançant representant, ni la naturalesa del negoci en determina la denegació. 1135 Tot dependrà, per tant, de si el contingut dels poders concedits per a l'exercici de la representació inclou el de la impugnación ${ }^{1136}$.

Però és la representació del soci en els òrgans socials la que ha plantejat alguns dubtes; en concret, s'ha qüestionat si el poder concedit per a l'exercici de la representació del soci, en una assemblea, legitimaria el representant per a "l'exercici d'altres facultats que, encara que més o menys connectades amb la realització d'una junta, no s'exerciten, en tot cas, al si d'aquesta", entre les quals s'esmenta el dret d'impugnació 1137 .

Sobre això, s'ha d'observar que la representació del soci cooperatiu expressament regulada presenta dos límits, que afecten bàsicament la possibilitat de delegar el dret d'impugnació1138. En primer lloc, la representació

1135 Encara que la facultat d'impugnar els acords socials la inclou la doctrina entre els drets administratius, que "participarien de les notes de(l) [...] tipus de drets [...] de caràcter personal", no sembla que puga atribuir-se-li el caràcter de dret personalíssim.

1136 Admet, expressament, la representació voluntària del soci, mitjançant apoderament, per a l'exercici de l'acció d'impugnació, DUQUE DOMínGUEZ, J. F., Tutela... op. cit., pàg. 174 i 178 a 180 , si bé "serà necessari conferir-li, expressament, aquest poder amb el negoci de procura corresponent".

1137 RONCERO SÁNCHEZ, A., La representación..., op. cit., pàg. 259 i 260, qui estima que "el poder per a la representació de l'accionista en la junta no legitima per a l'exercici del dret d'impugnació d'acords. Això no significa que l'exercici d'aquest dret no puga realitzar-se mitjançant representant; sinó, simplement, que qui ha actuat en la junta com a representant d'un accionista no pot impugnar els acords adoptats en aqueixa sobre la base del poder de representació esmentat, llevat que aquest considere, expressament, aquesta possibilitat". GIRÓN TENA, J., Derecho de sociedades anónimas, op. cit., pàg. 331: "En el supòsit de representació expressa, serà titular el representat si els actes conservatius de l'acció els va realitzar el representant".

1138 SÁNCHEZ ANDRÉS, A., La acción..., op. cit., pàg. 140, recorda que la representació voluntària per apoderat tampoc no és totalment lliure en la SA, ja que l'article 106 de la LSA estableix la possibilitat de "condicionar el mecanisme representatiu" en els estatuts socials.

GENCO, R., «Le operazioni sul capitale..., op. cit., pàg. 26, assenyala que, en el dret italià, també la representació del soci cooperatiu és objecte de limitacions molt fortes: "la delegació, en efecte, 
a la cooperativa s'ha d'efectuar, normalment, per una altra persona que ja tinga la qualitat de sòcia; només en alguns supòsits taxats legalment es permet que el soci siga representat en l'assemblea pels seus familiars més pròxims ${ }^{1139}$.

Però, a més, la representació del soci segueix en la legislació cooperativa la tendència assenyalada per a les societats de capital: es refereix únicament a l'exercici d'aquells drets que es relacionen directament amb la celebració de l'assemblea (assistència, veu, proposta, vot i informació). Així, l'article 27 de la LCoop, expressivament titulat "Vot per representant", assenyala en el seu apartat $1 \mathrm{r}$ que "el soci podrà fer-se representar en les reunions de l'assemblea general..."; dedica l'apartat $2 n$ a la representació legal, i l'apartat $3 \mathrm{r}$ a la delegació de vot. D'altra banda, l'article 33 de la LCCV, titulat "Exercici del dret de vot", mentre que al seu apartat $3 r$ estableix que "cada soci pot fer-se representar per un altre soci...", en l'apartat 4t diu que "els estatuts socials podran preveure que el dret d'assistència $i$ vot siga exercit pel cònjuge, ascendent, descendent o germà del soci, quan els interessos d'aquest en la cooperativa tinguen el caràcter familiar suficient".

pot ser atribuïda, exclusivament, a un altre soci, sempre que estiga previst en els estatuts, i cada soci no pot representar més de cinc socis". En el dret espanyol, la representació del soci cooperativista té uns límits semblants.

1139 La LCoop (art. 27.1) remet a la fixació estatutària del grau de parentiu, mentre que la LCCV (art. 33.4) es refereix expressament al "cònjuge, ascendent, descendent o germà del soci". L'article 21.1, 2n par. del RCC admet l'atribució de representació al "cònjuge, ascendent o descendent del soci amb capacitat plena d'obrar, així com a l'apoderat general".

La STS (Sala 1a), de 14 de març de 1998, núm. 224/1998, RJA 1998/1488 adverteix que no és admissible una interpretació extensiva de la representació familiar en favor de familiars no legitimats per la norma. En aquest sentit, s'ha de remarcar la novetat introduïda per la LCE (art. 126.2) per a les cooperatives agràries, en les quals la representació podrà exercir-la, també, una persona unida al soci per relació d'afectivitat anàloga a la del cònjuge.

Per a la representació en la junta o en l'assemblea general universal, s'ha de tenir present, a més, que la jurisprudència l'admet només "si es va tenir notícia fidedigna de l'ordre del dia, es va poder fer ús del dret d'informació i es van tenir els elements necessaris per donar a l'apoderat les ordres pertinents per a l'emissió del vot" (STS, Sala 1a, de 17 de febrer 1991, RJA 1992/1259, en la qual es fa referència a jurisprudència abundant), i que si l'assemblea "es verifica sense cap convocatòria precedent, sinó que aquesta esdevé $[\ldots]$ in actu, $[\ldots]$ si algun sector del capital social estiguera representat, el representant hauria d'acreditar que està autoritzat per a aquella conformitat ex novo; ja que, altrament, no podria, en nom del representat, consentir en aquella junta universal". (STS Sala 1a, de 23 de desembre de 1997, RJA 1997/9189).

Es refereixen a les limitacions rigoroses del règim de representació en l'assemblea de la cooperativa URÍA, R., MENÉNDEZ, A. i VERGEZ, M., "Sociedades cooperativas...», op. cit., pàg. 1289, i VICENT CHULIÁ, F., «La Ley 27/1999...», op. cit., pàg. 14575. 
Tot això ens porta a concloure que, en el marc cooperatiu, la representació del soci en els òrgans socials només assoleix, en principi, l'exercici dels drets d'assistència, veu, informació, proposta, vot i consignació en l'acta, sense que es produïsca l'extensió a uns altres drets relacionats amb aquests, com el d'impugnació, llevat que el poder de representació mateix assenyale, expressament, aquesta possibilitat. Com ha observat la doctrina, la persona jurídica no té per què veure's obligada a suportar la càrrega d'una impugnació de dos subjectes diferents ${ }^{1140}$, quan, d'altra banda, la representació és una relació juridicoprivada entre el soci i el seu representant.

Pel que fa a la representació del soci, s'ha d'analitzar un supòsit específicament regulat per la legislació cooperativa: el de la realització de l'assemblea mitjançant l'anomenat sistema bifasic ${ }^{1141}$ de juntes preparatòries $\mathrm{i}$ assemblees generals de delegats (art. 30 de la LCoop i art. 35 de la LCCV), cas en què la representació del soci la faça un altre soci, que necessàriament ha de ser, a més, membre també de la mateixa junta preparatòria ${ }^{1142}$. Tant la LCoop com la LCCV assenyalen que "només serà impugnable l'acord adoptat per l'assemblea de delegats; encara que per examinar el seu contingut i la seua validesa es tindran en compte les deliberacions i els acords de les juntes preparatòries", però no atribueixen, en cap cas, el dret d'impugnació al soci representant. Per això, en no ser-ne necessària la intervenció, una vegada realitzada l'assemblea, entenem que també en aquest cas específic de representació la legitimació per a la impugnació recau, exclusivament, en els socis i associats representats.

1140 DuQUe DOMf́NGUEZ, J. F., Tutela..., pàg. 175; SORIA FERRANDO, J. V., La legitimación activa..., pàg. 59.

1141 PaZ CANAlejo, N. i Vicent Chuliá, F., Ley general..., pàg. 596.

1142 La LCCV, a diferència de la LCoop, no ho exigeix expressament, però es dedueix de la funció encomanada a aquest soci: "defensar les diverses posicions manifestades en les juntes preparatòries". 
Finalment, quant a la representació del soci, s'ha de tenir present que, a l'efecte de la seua legitimació per a la impugnació, s'ha de considerar present en la votació i en la reunió, en les quals intervé mitjançant el seu representant ${ }^{143}$.

B. Els associats

La figura de l'associat, ja la recull l'article 1696 del CC dins les normes reguladores de la societat civil. El configura com un soci del soci, en permetre la norma que cada soci puga, independentment, "associar-se un tercer a la seua part $^{\prime \prime}$, tercer que no és membre de la societat ${ }^{1144}$.

La incorporació d'aquesta figura en la legislació cooperativa es va produir en la LGC de 1974 (art. 15) ${ }^{1145}$; en aquesta, quan els estatuts socials ho preveieren, els qui hagueren perdut, per causa justificada, la qualitat de socis o que foren drethavents d'un soci mort, podrien romandre vinculats a la cooperativa mitjançant un règim específic que incloïa, fonamentalment, el manteniment de les aportacions al capital i la seua retribució corresponent, l'abast des seus vots i també del seu dret d'informació. La mateixa ubicació sistemàtica de la figura en la llei, inclosa en el capítol sobre el règim econòmic de la cooperativa $\mathrm{i}$ justament abans de l'article dedicat als ajuts al finançament, indica quina era la

1143 RODRÍGUEZ RUIZ DE VILLA, D., Impugnación..., op. cit., pàg. 149: “considera, amb encert, el Tribunal Suprem que l'accionista representat en la junta no és absent als efectes d'impugnació d'acords [nota 44, vegeu: Sentència de la Sala 1a, del Tribunal Suprem, de 2 de gener de 1990 (RJA 1990, 2)]".

1144 BoRJABAD GonZALO, P. J., Manual..., op. cit., pàg. 74.

1145 Paz Canalejo, en Paz Canalejo, N. i Vicent Chulias, F., Ley general..., pàg. 251 i 252, assenyala com a antecedent la inclusió en la Llei de cooperatives de 1931 de possibilitats de col-laboració financera similars a la de l'associat.

Sobre l'evolució de figures equivalents en el dret comparat i autonòmic, vegeu PAZ CANALEjO, en PAZ CANALejo, N. i Vicent ChULIÁ, F., Ley general..., pàg. 244 a 250, on s'esmenten, entre d'altres, les figures de l'associat no cooperador francès i els títols d'inversió del Código cooperativo portugués. En el dret autonòmic, s'esmenten la inclusió en la primera LCPV i en la primera LCA del soci collaborador i del soci inactiu, el soci excedent de la primera LCC, i de l'associat en la primera LFCN. 
finalitat que atribuïa el legislador a l'associat: fonamentalment, la de "financer dels mitjans de producció i de l'activitat econòmica, i li permet expressar-se i col-laborar en l'adopció d'acords en l'assemblea general, però tot establint una limitació important al seu $\operatorname{vot}^{\prime \prime 146}$. A això s'hauria $\mathrm{d}^{\prime}$ afegir una altra característica: es tractava, en tot cas, de persones físiques que tenien o havien tingut un vincle, directe $o$ indirecte, amb la cooperativa.

La LCCV, en la seua redacció originària de $1985^{1147}$, opta per recollir només una part de les característiques de l'associat, en una figura denominada diversament, el soci excedent. Segons aquesta, "els socis que per causa justificada no puguen continuar participant en l'activitat cooperativitzada, tenen dret a continuar formant part de la cooperativa, sense dret a participar en els retorns d'exercici ni a formar part del consell rector". Se'ls reconeix la possibilitat d'exercir els altres drets de soci enunciats en l'article 20 de la Llei, però el seu dret de vot es limita al $10 \%$ dels vots dels socis presents o representats en l'assemblea general.

La LGC de 1987 va destinar tot un capítol (el V del títol I, articles 39 a 41) a redefinir la figura de l'associat. Podien ser-ho tant les persones físiques com les jurídiques; es regulava, detalladament, el règim econòmic de les seues aportacions: retribució, responsabilitat limitada, transmissibilitat, reembossament, etc., i s'establien límits que garantiren que els associats no pogueren arribar a controlar la cooperativa: límit màxim del volum total de les seues aportacions, límit del total de vots, prohibició de nomenament per a càrrecs socials, etc. En definitiva, es reforçava el caràcter inversor de la figura ${ }^{1148}$, en desaparèixer la limitació anterior que requeria haver perdut, justificadament,

${ }^{1146}$ BORJABAD GonZalo, P. J., Manual..., pàg. 74.

${ }^{1147}$ Llei 11/1985, de 25 d'octubre, de cooperatives de la Comunitat Valenciana (DOGV núm. 300, de 31 d'octubre de 1985)

${ }^{11+k}$ Paz CANAlejo, en PAZ CANAlejo, N. i Vicent ChuliÁ, F., Ley general..., pàg. 257, on arriba a assimilar-la a les accions sense vot de les societats anònimes. 
la qualitat de soci o de ser el seu drethavent, no estar obligat a realitzar noves aportacions, ni tenir dret a desenvolupar cap activitat cooperativitzada ni al retorn d'excedents.

Posteriorment, la Llei 3/1995 de modificació de la LCCV de 1985, tot i mantenir la figura del soci excedent, va afegir un article 23bis que regulava la previsió estatutària possible dels associats, "persones físiques o jurídiques que realitzen aportacions al capital social, de caràcter voluntari". Se'ls excloïa, expressament, de la condició de soci, encara que se'ls atribuïen els mateixos drets i les mateixes obligacions, llevat d'algunes especialitats, com ara: no realitzar operacions cooperativitzades amb la cooperativa; que el seu dret de vot depenguera de la regulació estatutària, que podia ser per cap o proporcional al capital subscrit, i estar, en tot cas, limitats al $45 \%$ dels vots presents i representats en cada votació; poder ser membres del consell rector, sempre que no superaren la tercera part del total, i poder preveure's, estatutàriament, que la retribució de les seues aportacions fóra fins a un $45 \%$ dels excedents anuals, distribuïts entre els associats en proporció al capital desemborsat; en aquest cas també haurà de suportar, en la mateixa proporció, les pèrdues d'exercici, fins al límit de la seua aportació1149.

El Decret legislatiu 1/1998, de 23 de juny, pel qual s'aprova el text refós de la LCCV, actualment vigent, es limita, en aquesta matèria, a canviar la numeració de l'articulat: es manté l'article 23 per a la figura del soci excedent, i es dedica l'article 24 a la de l'associat. Amb això, la llei cooperativa valenciana opta per mantenir dues figures diferents, amb l'objectiu d'obtenir finançament per vies diverses. Pel que fa al soci excedent, fomenta la permanència dels exsocis pel que fa a la seua col-laboració en els objectius cooperatius, a canvi d'una retribució; quant a l'associat, permet la col-laboració dels qui no han tingut vincles amb la cooperativa, però estan interessats a participar-hi, limitadament. 
Finalment, la LCoop de 1999 suprimeix la figura de l'associat, i la substitueix per la del soci col-laborador (LCoop, art. 14), ja esmentada ${ }^{1150}$. El règim jurídic d'aquest tipus nou de soci és, essencialment, igual al de l'associat anterior, definit en la LGC, amb dues excepcions: d'una banda, el text legal actual especifica, novament, que els socis que per causa justificada no realitzen l'activitat cooperativitzada i no sol-liciten la baixa, podran passar a tenir la condició de soci col-laborador; d'altra banda, es tracta d'un soci vertader de la cooperativa, amb totes les conseqüències que això comporta, inclosa la legitimació per a la impugnació d'acords socials.

La LCCV és, doncs, la que manté la figura de l'associat i respecte de la qual, per tant, s'ha d'estudiar la legitimació per a la impugnació ${ }^{1151}$. Els articles 36.4, $36.5 \mathrm{i}$ 41.6, en esmentar les persones legitimades per impugnar els acords nuls i anul-lables de l'assemblea general i del consell rector, ometen qualsevol referència als associats. Això no obstant, l'article 24 de la LCCV, dedicat a regular-ne el règim jurídic, estableix, en l'apartat 1, que "[...] Els associats, que no podran tenir alhora la condició de socis, posseiran els mateixos drets i obligacions que aquests, amb les següents especialitats [...]". Cap dels aspectes que tot seguit es relacionen es refereix a limitacions del dret d'impugnació. I

\section{3bis de $l^{\prime} \mathrm{LCCV}$.}

1150

Vegeu epígraf A. anterior.

En les normes vigents restants del dret cooperatiu autonòmic, ja hem vist que la LCPV preveu, com a figures equivalents, el soci col-laborador (art. 19.2) i el soci inactiu o no usuari (art. 30); la LCC, el soci excedent (art. 24) i l'adherit (art. 25); la LCE, els socis honorífics (art. 26.4) i els associats (art. 29); la LCG, el soci excedent (art. 28) i el soci col-laborador (art. 29), i la LCA, el soci excedent (art. 18.2) i el soci col-laborador (art. 18.3).

La LSCA regula les figures del soci inactiu (art. 33), el soci col-laborador (art. 34) i l'associat (art. 35); la diferència fonamental entre aquestes dues últimes rau en el fet que el soci col-laborador, sense dur a terme l'activitat o les activitats principals de la cooperativa, participa en alguna o algunes de les accessòries, mentre que l'associat no fa activitat cooperativitzada.

La LFCN denomina associats (art. 29) "aquells que cessen com a socis de l'entitat per causa justificada, els drethavents en el cas de mort del soci i aquells a qui els estatuts atorguen aquesta possibilitat pel fet d'haver-se constituït en qualsevol altra situació de naturalesa anàloga", i socis col-laboradors "aquelles cooperatives amb les quals s'haja subscrit l'acord intercooperatiu corresponent".

La LCCM recull les figures del soci inactiu o no usuari (art. 26), de l'associat (art 27) i del "col-laborador" (art. 28); aquest últim correspon a les "persones físiques o jurídiques que, sense poder dur a terme plenament l'activitat cooperativitzada, poden col-laborar en la consecució de 
després, l'apartat 2 indica que "cas que als associats se'ls reconega dret de vot, gaudiran dels mateixos drets que el soci pel que fa al seu exercici i a la seua participació en els òrgans socials, inclòs el dret d'impugnació".

El tenor literal del text legal sembla partir d'una consideració instrumental del dret a impugnar, en relació amb el dret de vot: l'associat gaudirà de dret d'impugnació només si se li reconeix el dret de vot. Ens sembla que aquest cas és un greu error del legislador, ja que es tracta de drets independents; es pot tenir dret d'impugnació encara que s'estiga privat del dret de vot (per exemple, el soci en el conflicte d'interessos), i es pot tenir dret de vot i no dret a impugnar (per exemple, el soci que ha votat a favor de l'acord anul·lable) ${ }^{1152}$.

Més d'acord amb el principi d'equiparació de l'associat amb el soci està el fet de deduir que les puntualitzacions en matèria de drets i d'obligacions dels associats, establertes en l'esmentat apartat 1 de l'article 24 de la LCCV, han $\mathrm{d}^{\prime}$ interpretar-se de manera restrictiva o tancada ${ }^{1153}$, per la qual cosa, com que no s'inclou cap referència a la legitimació per a la impugnació, aquesta se'ls ha de considerar atribuïda.

\section{Els administradors}

Com que tots els socis tenen legitimació per a la impugnació d'acords nuls, el reconeixement de la legitimació activa també als administradors té, segons la nostra opinió, un objectiu bàsic en el marc de les societats de capital: donar accés als administradors no socis a l'acció d'impugnació com a via de compliment eficaç de les seues funcions, "amb la diligència d'un empresari

l'objectiu social".

1152

La LCC regula aquesta figura, amb la denominació d'adherit, en l'article 25. La legitimació dels adherits no presenta cap dubte, perquè l'article esmentat, en establir la possibilitat de l'expulsió, assenyala que la seua tramitació "s'ajustarà al que es disposa per als socis en l'article $20^{\prime \prime}$, que reconeix el dret a impugnar l'expulsió. 
ordenat i d'un representant legal ${ }^{\prime 1154}$. El legislador, per tal d'obtenir la defensa de l'interès social, novament s'aprofita de l'interès particular de l'administrador: el deure de diligència que assumeix en relació amb el compliment de les seues funcions, al qual caldrà afegir el deure de defensar l'interès social ${ }^{1155}$.

En aquest sentit, s'ha indicat que quan l'administrador no posseïsca la qualitat d'accionista, hi concorre una doble legitimació: d'una banda, posseeix un interès personal (diferent al del soci) a eludir una pretensió possible de rescabalament per la societat, partint de la infracció del deure de lleialtat i de diligència que l'obliga a fer el que siga necessari, perquè no puga prosperar l'execució dels acords contraris a la llei, i, d'altra banda, juntament amb aquesta legitimació ordinària, en concorre una altra basada en l'interès que la comunitat social té en defensa de la llei. Segons aquesta, "l'administrador accionista assumeix la defensa de l'interès de la col-lectivitat en la reintegració de l'ordenament jurídic, vulnerat per l'acord nul'1156.

153 En aquest sentit, VICENT CHULIA, F., «La asamblea...», op. cit., pàg. 164.

${ }^{1154}$ GARRIGUES, J. i URíA, R., Comentario..., op. cit., , pàg. 158 i 159: "La llei exigeix, a més, la diligència d'un representant lleial, i al-ludeix així a un deure de fidelitat que imposa a l'administrador la defensa dels interessos de la societat que ell representa, i anteposa aquests interessos als seus propis".

${ }^{1155}$ Vegeu supra, en el capítol primer, l'epígraf 2, "Fonament jurídic de la impugnació dels acords socials".

115

GIMENO Sendra, V., El proceso..., pàg. 72. En canvi, Salelles Climent, J. R., El funcionamiento... op. cit., pàg. 377 a 380 , que també recorda que alguns autors han situat la fonamentació de la legitimació dels administradors en la defensa de $1^{\prime \prime}$ interès dels tercers que poden resultar perjudicats pels acords de la junta", tendeix a estimar que "la justificació de la legitimació dels administradors per impugnar els acords irregulars de la junta no es troba en la tutela d'un interès propi [...] o de tercers", sinó que "el seu fonament ha de buscar-se en la seua condició d'òrgan de la societat que s'atribueix un conjunt de poders i deures per tutelar la tipicitat de l'interès social. [...] Fent valer la nul-litat o anul-labilitat d'un acord pres per la junta general, els membres del consell actuen en interès de la societat $\mathrm{i}$ tutelen la legalitat de la seua actuació". GARCÍA LUENGO, R. i SOTO VÁZQUEZ, R., El Nuevo régimen jurídico..., op. cit., pàg. $552 \mathrm{i}$ 553: "La generalitat de la doctrina no dubta a afirmar que l'administrador, d'una banda, actua en la seua condició d'òrgan social, i assumeix l'interès de la col-lectivitat en l'establiment de l'ordenació, vulnerat per l'acord nul; d'una altra, ha de complir amb la seua obligació de vetllar pels interessos de la societat $\mathrm{i}$ amb l'exercici del seu dret de no executar acords nuls. Des 
En realitat, entenem que ambdós interessos, el particular, adreçat a l'elusió de la responsabilitat personal, i el de defensa de l'interès social, són tan sols conseqüència de l'interès originari de complir amb el seu deure de diligència. El compliment del deure general de diligència inclou, entre d'altres, el deure de realitzar les accions necessàries o convenients per a la defensa més adequada de l'interès social; l'incompliment del deure general de diligència pot generar, entre d'altres efectes, la responsabilitat davant socis i tercers prevista en els articles 133 a 135 de la LSA. En definitiva, el fonament de la legitimació per a la impugnació en favor d'administradors no socis es troba en el seu interès a complir amb el seu deure de diligència, ${ }^{1157}$ interès que resulta, alhora, de caràcter particular, perquè els permet, en aquest cas, exonerar-se d'una responsabilitat eventual, $i$ de caràcter social o general, perquè obri la via perquè la societat corregisca un acord viciat.

En la cooperativa, els administradors han de ser elegits, en principi, entre les persones sòcies ${ }^{1158}$ però tant la LCoop com la LCCV preveuen supòsits en què el nomenament d'administrador pot recaure en una persona no sòcia: d'una banda, l'anomenat conseller laboral, representant dels treballadors no socis, amb contracte per temps indefinit, en les cooperatives que disposen d'un col-lectiu ampli d'aquests (LCoop, art. 33, 3r i 4t par., i LCCV, art. 38.4) ${ }^{1159}$; d'altra banda,

d'aquesta perspectiva, actuen per un interès personal a eludir una possible acció de
responsabilitat". 1157

Sobre el deure de diligència dels administradors, vegeu LLEBOT MAJO, J. O., Los deberes..., op. cit., fonamentalment en pàg. 49 a 85, i, per a les relacions entre l'òrgan d'administració i els seus òrgans delegats, RODRíGUEZ ARTIGAS, F., Consejeros delegados..., op. cit., pàg. 331 a 336, 383 i 384. 115

Article 34.2 de la LCoop: "... Excepte en aquest supòsit $i$ en el previst en l'article anterior, tan sols podran ser elegits consellers els qui tenen la condició de socis de la cooperativa"; art. 32.1, 2n par.: "... els estatuts podran establir l'existència d'un administrador únic, persona física que
tinga la condició de soci...". Article 39.1 de la LCCV: "Els membres del consell rector hauran de ser socis de cooperativa...", i si, alternativament, s'opta per dotar-se d'un administrador únic o de dos administradors, l'article 38.2 de la LCCV estableix que també "seran elegits per l'assemblea general de la cooperativa entre els seus socis...". I si la relació és de representació, qui té el dret
d'impugnació és el representat, en aquest cas la persona jurídica sòcia. en el consell de vigilància, l'òrgan de control del seu sistema dualista d'administració social 
la LCoop permet que els estatuts admeten, en qualsevol cooperativa, el nomenament com a consellers de "persones qualificades $i$ expertes que no tenen la condició de socis, en un nombre inferior a un terç del total" (art. 34.2 i 77.2), mentre que la LCCV només considera aquesta possibilitat en les cooperatives de segon grau $(92.4)^{1160}$.

Sembla, així doncs, que la menció que fan tant la LCoop (art. 31.4) com la LCCV (art. 36.4), en atribuir expressament legitimació als administradors, es destina a aquests consellers no socis; ja que, com hem vist, els administradors socis disposen sempre de legitimació per impugnar els acords nuls.

En tot cas, la legitimació s'atribueix individualment a cada membre de l'òrgan $\mathrm{d}^{\prime}$ administració ${ }^{1161}$. Així es dedueix del tenor literal d'ambdues normes, que parlen dels membres del consell rector (LCoop, art. 31.41162, i LCCV, art. 36.4).

No obstant això, un sector important de la doctrina italiana ha mantingut la necessitat que la impugnació per un dels membres del consell dispose de la deliberació prèvia i l'autorització de l'òrgan ${ }^{1163}$, en base "a la funció de la col-legialitat com a principi de funcionament del consell, a la titularitat

(vegeu en MÜNKNER, H., «Ley de cooperativas...», op. cit., pàg. 106).

1160

Pel que fa a la persona física que exercirà el càrrec quan el soci de la cooperativa siga una persona jurídica, ja hem assenyalat que la LGC pot plantejar algun dubte sobre el caràcter vertader de la seua actuació; però que en l'actualitat, ni la LCoop ni la LCCV presenten cap dubte sobre la qualitat de representant de la persona jurídica (LCoop, art. 34.2, 3r par., art. $77.2 \mathrm{i}$ art. 77.3; LCCV, art. 39.1, 2n i 3 r par., i art. 92.4, 2n par.).

${ }^{1161}$ RuBio, J., Curso..., op. cit., pàg. 262; DÍAZ DE LEZCANO SEVILlaNO, N., Los acuerdos del consejo..., op. cit., pàg. 223 i 224: "El conseller exerceix les seues facultats al si del consell d'administració; fora d'aquest, els consellers no tenen les facultats pròpies de l'òrgan. Però, en casos particulars, s'ha de reconèixer al conseller individual certes possibilitats d'actuació fora del marc orgànic del consell; aquest és el cas de la impugnació dels acords socials, la legitimació activa dels quals té el conseller, amb caràcter personal".

1162 Tot i això, MORILlAS JARILLO, M. J. i FelIú REY, M. I., Curso de cooperativas, op. cit., pàg. 259 i 260 , asenyalen quel'art. 31.4, in fine, a l'hora d'establir l'obligació d'impugnar els acords contraris a la llei o als estatuts es refereix al consell rector, no als seus membres.

1163

Un resum de la doctrina i de la jurisprudència italianes partidàries de la legitimació col-lectiva de l'òrgan d'administració pot veure's en SilveTtI, C. i CAVALLI, G., Le società per 
col-lectiva de les competències d'administració i, finalment, a la necessitat de garantir una tutela més adequada de l'interès de la societat a concloure els negocis ${ }^{\prime 1164}$; això no obstant, aquesta línia doctrinal no ha pogut evitar haver de reconèixer, també, "de manera excepcional, la legitimació individual per a la impugnació dels acords de la junta, relatius a interessos particulars del membre del consell, com aquells pels quals es decideixen la revocació del seu càrrec o la seua remuneració".

En realitat, aquest requisit no sols no té suport en els textos legals, sinó que és rebatible en la seua fonamentació, com argumenta SALELLES CLIMENT: la col-legialitat del consell s'estableix, fonamentalment, en relació amb la presa de decisions, amb la formació de la voluntat de l'òrgan, però no s'estén als "actes d'informació i de control ni a aquelles intervencions realitzades individualment pels membres del consell per tal d'assegurar una correcció més àmplia en la gestió de l'empresa". I és entre aquestes activitats d'informació, de control i d'intervenció, on se situa la impugnació dels acords nuls o anul-lables de la junta, quan l'exerceix, de manera individual, el membre del consell. Però és que, a més, la impugnació dels acords no ha d'interpretar-se, en tot cas, com un perjudici per al desenvolupament de l'activitat social; sinó al contrari, com a garantia d'un funcionament més correcte.

D'altra banda, el temor a una potencial paralització de l'activitat social, sobretot quan se sol-licita la suspensió de l'acord, es contraresta si es té en consideració

azioni..., op. cit., pàg. 204 a 206.

"nis

SALELLES CLIMENT, J. R., El funcionamiento... op. cit., pàg. 387, "En el primer sentit, s'assenyala que en el consell es valoraran, amb més correcció, els avantatges i els desavantatges que comporta la impugnació o l'execució d'un acord determinat de la junta; la decisió d'impugnar col-legiada. En el segon sentit, s'afirma qutat de la facultat d'elecció que justifica una ponderació en línia de principi, al col-legi; així, el me les funcions de l'òrgan d'administració corresponen, impugnar els acords de la junta. Finale del consell no pot considerar-se legitimat per individual dels membres del consell s'evitaent, s'entén que amb l'exclusió de la iniciativa També URf́A sembla decantar-se per aquesien interrupcions perjudicials de l'activitat social". poden exercitar aqueixa acció [impuguesta actitud quan afirma que "la justificació que també està en el fet que actuen en la seua condora d'acords nuls] els administradors no accionistes 325). 
que qui decideix l'adopció d'aquesta mesura és una instància externa a la societat, la judicial, que, amb la seua neutralitat, pot excloure el perjudici que podria ocasionar la iniciativa arbitrària del membre del consell; es garanteix, amb això, l'exercici de l'activitat empresarial davant impugnacions que no tinguen una altra finalitat que no siga obstaculitzar-ne el desenvolupament. Finalment, s'argumenta que "la legitimació del membre del consell fa eficaç una norma que, si no fóra així, en la major part dels casos no seria aplicada. Difícilment, la majoria dels membres del Consell impugnarà un acord adoptat pel grup que controla la societat i al qual, normalment, deuen el seu nomenament ${ }^{\prime 1165}$.

Però que l'acord de l'òrgan col-legiat d'administració no siga necessari perquè algun dels seus membres interpose, a títol individual, l'acció d'impugnació, no és obstacle perquè el consell rector puga adoptar l'acord d'interposar l'acción ${ }^{1166}$. En efecte, encara que el tenor literal de la legitimació expressa es refereix als membres del consell rector (LCoop, art. 31.4., i LCCV, art. 36.4), individualment considerats, la LCoop, en establir, tot seguit, l'obligació que se'ls imposa d'impugnar els acords contraris a la llei o als estatuts, es refereix a l'òrgan en el seu conjunt ("estan obligats a impugnar els acords contraris a la llei o els estatuts, el consell rector..."). Estimem que l'acord d'interposar l'acció

"wo

SALELles Climent, J. R., El funcionamiento... op. cit., pàg. 388 i 389 . En relació amb l'últim aspecte, ja argumentat per RUBIO J., Curso..., op. cit., pàg. 262, assenyala JUSTE MENCIA, J., Los derechos... op. cit., pàg. 387, nota 11, justament, que "la legitimació dels administradors [...] exerceix un paper des del punt de vista de la protecció de les minories, si posem en relació aquest dret amb el de representació proporcional al consell", ja que "permet una intervenció directa d'aquests administradors que no estan lligats a la voluntat del grup de control de la societat". Aquesta afirmació s'acomoda especialment, en el marc cooperatiu, als representants al consell de determinats col-lectius de socis (LCoop, art. 33, 2n i 3r par.: "les cooperatives, si ho preveuen els estatuts, podran reservar càrrecs de vocals o de consellers del consell rector, per a la seua designació d'entre col-lectius de socis, determinats objectivament"; LCCV, art. 38.4, 1r i 3r par., per als socis de treball i "per a grups determinats de socis, definits per la zona de residència o per l'activitat econòmica especial en la qual estiguen interessats" 0 , com hem vist, de treballadors fixos no socis.

1166

ARROYO, I., "Comentario al art. 56...", op. cit., pàg. 618: "S'entén que tant els administradors com a persones físiques, com els administradors com a òrgan_social, estan legitimats". 
d'impugnació serà plenament vàlid, ja que el seu contingut és incardinable en les funcions de govern i de gestió de l'entitat, atribuïdes al consell ${ }^{1167}$.

Una qüestió diferent serà la possibilitat que els administradors deleguen l'exercici de la impugnació. Per tal d'analitzar-la, serà necessari distingir els supòsits de legitimació individual dels casos en què siga l'òrgan col-legiat qui adopte l'acord d'iniciar l'acció d'impugnació.

En relació amb la legitimació individual de l'administrador, com ja hem vist anteriorment per als socis, la legislació cooperativa no preveu un règim general de representació en l'exercici dels drets socials; sí que es regula, exclusivament, la delegació dels drets que els socis poden exercir en l'assemblea, i això, amb limitacions significatives. Per contra, les úniques mencions a la representació del membre del consell es fan en el funcionament de l'òrgan d'administració, bé per prohibir-la expressament, amb caràcter general (LCoop, art. 36.2, i LCCV, art. 41.3), bé per aclarir el caràcter de representació orgànica de la relació entre la persona jurídica sòcia i la física que exercisca el càrrec en el seu lloc (LCoop, art. 34.1, 3r par., i LCCV, art. 39.1, 2n par.). No sembla possible, així doncs, la delegació de la legitimació individual dels administradors ${ }^{1168}$.

Però, com ha quedat assenyalat, res no impedeix que el consell rector acorde la impugnació dels acords nuls; en aquest cas, caldrà acollir-se al règim legal de la representació i de la delegació de facultats de l'òrgan d'administració. En aquest sentit, cal recordar que la representació legal del consell la té, en principi, el president (LCoop, art. 32.2, i LCCV, art. 41.4), però que el consell pot

\footnotetext{
1167

Una altra qüestió serà, més enllà de l'expressament prevista per la LSA en matèria de legitimació passiva (art. 117.3), la que fa referència a l'assumpció de les despeses que es deriven de l'exercici de l'acció. Sembla que, en tractar-se d'un acord vàlidament adoptat per un òrgan de la cooperativa, serà l'entitat mateixa qui haurà de fer-los front. com a persones físiques; com els administradors, com a òrgan social, estan legitimats. [...] El que no sembla possible és que la legitimació puga ser delegable, ja que es tracta d'una facultat personal".
} 
encomanar l'execució dels acords i acordar la delegació de facultats en altres persones, amb la qual cosa seria possible que el consell delegara la facultat impugnadora.

La LCoop (art. 32.3) estableix que el consell "podrà conferir apoderaments, i també, procedir a la seua revocació, a qualsevol persona, les facultats representatives de gestió o de direcció de la qual s'establiran en l'escriptura de poder"; s'ha especificat, així doncs, respecte de la redacció anterior de l'article 54.2 de la LGC, que es tracta de facultats representatives de gestió o de direcció, però no sembla que això impedisca que entre les facultats delegades es puga trobar la d'impugnar acords. L'apoderament pot fer-se, fins i tot, en favor de persones no sòcies.

La LCCV regula la delegació de facultats en l'article 43; la delegació ha de recaure en algun o alguns dels membres del consell, i s'ha de tractar de facultats relatives al tràfic empresarial ordinari; no obstant això, entre les facultats excloses de la possibilitat de delegació no es troba la de la impugnació d'acords. D’altra banda, entenem que la personalitat jurídica de la cooperativa valenciana li ha de permetre realitzar vàlidament el negoci jurídic d'apoderament, amb subjecció al règim juridicoprivat general.

Respecte del moment en què s'ha de posseir la qualitat de membre del consell, considerem que tant ha de poder impugnar qui ja era membre de l'òrgan d'administració en el moment de l'adopció de l'acord, com qui adquirisca aquesta condició posteriorment, dins el termini de caducitat de l'acció; el moment determinant serà, així doncs, el de la interposició de la impugnació. Com s'observarà, això significa una legitimació més àmplia de l'administrador davant el soci no rector ${ }^{1169}$. La fonamentació d'aquesta ampliació rau en el deure

En efecte, com ja hem vist, el soci ha de posseir aquesta qualitat, almenys durant el període que va des de l'adopció de l'acord fins a l'inici de l'acció. I com veurem més endavant, davant els acords anul-lables, els administradors tenen sempre legitimació, mentre que el soci no rector només podrà impugnar si hi concorren determinats requisits legals. 
correlatiu de diligència, que abraça la defensa de l'interès social més enllà dels interessos particulars dels socis. Aquest deure existeix durant tot el seu mandat; consegüentment, ha de poder utilitzar els instruments jurídics de defensa corresponents; entre aquests, la impugnació dels acords invàlids.

Una qüestió diferent serà si la pèrdua de la qualitat d'administrador, després d'haver interposat la impugnació, ha de significar, necessàriament, la decadència de l'acció, a falta de legitimació. Potser l'única resposta possible s'haja de buscar en cada supòsit concret, en aplicació de la teoria de l'interès: en la mesura en què subsistisca un interès legítim per a la pretensió, subsistirà la legitimació ${ }^{1170}$.

Una altra qüestió que es planteja, pel que fa a la legitimació dels administradors per a la impugnació d'acords nuls, i que ja hem analitzat en l'epígraf 2 del capítol primer, és la relacionada amb la seua configuració alhora com a dret $\mathrm{i}$ com a deure ${ }^{1171}$. En aquest sentit, la LCoop, en l'article 31.4 estableix que "estan obligats a impugnar els acords contraris a la Llei o als estatuts el consell rector, els interventors i els liquidadors i, si escau, el comitè de recursos ${ }^{\prime 1172}$. La LCCV es limita a reconèixer la possibilitat que tenen els administradors d'impugnar ${ }^{1173}$,

En aquest sentit sembla pronunciar-se la SJPI-Madrid de 27 de juliol de 1999 (RJA 1999/1685), en la qual s'estima que els qui havien deixat de ser administradors i socis de la societat no disposen de legitimació per impugnar l'acord d'exercici d'accions de responsabilitat en contra d'ells. La sentència considera que, en haver perdut la condició d'administradors $\mathrm{i}$ d'accionistes, l'única legitimació possible és la de tercers amb interès legítim, però no es considera així l'interès dirigit a impedir les conseqüències personals de les accions legals empreses en contra d'ells.

1171

DUQUE DOMÍNGUEZ, J. F., "Introducción a la protección...», op. cit., pàg. 77.

1172

L'article correlatiu 66 de la LGC es refereix a acords socials en general, la qual cosa podria haver servit per afectar l'obligatorietat també als acords d'altres òrgans, especialment als de l'òrgan d'administració, per al qual s'ometia (i es continua ometent) la menció a l'obligatorietat. L'actual text de l'article 31.4 de la LCoop substitueix aquesta expressió per la d'acords contraris a la llei $i$ als estatuts $\mathrm{i}$, en estar ubicat en l'article titulat "Impugnació d'acords de l'assemblea general", sembla que impedeix aquesta generalització. d'impugnació d'acords nuls podrà ser exercitada per [...], els membres del consell rector, els administradors...". 
sense recollir-ne expressament l'obligatorietat, encara que això no impedeix que puga plantejar-se l'existència de l'obligació, com s'ha fet en el marc de les societats anònimes.

Com ja hem exposat, la nostra opinió és que el deure d'impugnar cal considerar-lo per a cada cas $^{1174}$ : serà obligatori impugnar tant en compliment del mandat legal davant acords assemblearis contraris a la Llei o als estatuts en supòsits sotmesos a la LCoop, com perquè el deure de diligència exigible als administradors en el supòsit de fet concret reclama la impugnació, a fi de "fer tot el que siga necessari per evitar el dany". Però sols pot afirmar-se l'existència d'una obligatorietat general d'impugnar per als administradors, quan la impugnació siga el més adequat ${ }^{1175}$. Ni serà, així doncs, imprescindible impugnar en tot cas a fi d'eludir una responsabilitat eventual, ni tampoc la interposició d'una acció d'impugnació, per ella mateixa, exoneraria l'administrador d'aquesta responsabilitat. La fonamentació de l'obligatorietat s'ha de buscar, per tant, en uns altres motius: pensem, una vegada més, en el deure de diligència inherent al càrrec, en virtut del qual es té la legitimació.

D'altra banda, s'han assenyalat opinions respecte de la no-impugnabilitat de determinats tipus d'acords, en funció de la matèria. Així, s'ha expressat l'opinió que els acords adoptats per la junta, en matèria de gestió, serien no impugnables pels administradors, "en entendre que els perjudicis que es pogueren derivar per a la societat es podrien evitar, simplement, si no se'ls executara". Davant d'aquesta interpretació s'ha indicat, tanmateix, que "amb caràcter general, els acords adoptats per la junta, en matèria de gestió, són vinculants per als administradors" i, a més, que "la no-execució d'un acord, en matèria de gestió, pot no ser suficient per evitar els perjudicis que en deriven 
(...), ja que l'acord no impugnat pot esdevenir eficaç amb el transcurs del temps"1176.

També s'ha plantejat la impossibilitat que els administradors puguen impugnar els acords per als quals no s'exigeix una activitat executiva; s'indiquen com a exemples els acords pels quals es nomenen o es revoquen els administradors, o aquells pels quals s'aprova el balanç d'exercici; aquesta no-impugnabilitat s'ha fonamentat, d'una banda, en el fet que "l'acord de la junta no es dirigeix als administradors $i$, per tant, a aquests no els correspon cap deure de comportament", i, d'una altra banda, que, per tant, els administradors no estarien legitimats per "verificar les condicions de validesa dels acords esmentats i, si foren invàlids, impugnar-los". Però aquesta interpretació també ha estat rebutjada, perquè "de l'execució o no d'un acord no se segueix la possibilitat de la seua impugnació. Els administradors han de garantir la legalitat de qualsevol actuació social i la seua concordança amb l'interès social típic, independentment del deure d'executar els acords adoptats per la junta". A més, "s'ha de tenir en compte que l'actuació dels administradors és necessària per exterioritzar l'acord de la junta, i difícilment es pot parlar d'acords de la junta que no requerisquen execució" ${ }^{\prime 117}$.

D. Els membres dels òrgans de control

Com hem vist en l'epígraf 3.1 del capítol tercer ("Acords i/o decisions dels òrgans de control de la gestió"), amb independència que els comptes anuals de les cooperatives puguen estar sotmesos a auditoria externa, tant la LCoop com

1176

SAlelles Climent, J. R., El funcionamiento... op. cit., pàg. 382 i 383; a més, en pàg. 375 i 376 : "Els acords de la junta adoptats de conformitat amb les disposicions de la llei i de l'acte constitutiu, com a manifestació de la voluntat social, són vinculants per als socis i per al consell. Per això, s'afirma el deure dels administradors de procedir-ne a l'execució, en aquelles matèries sobre les quals, legalment o estatutària, la junta siga competent. Convé aplicar el que s'ha dit en relació amb [...] el deure dels administradors de tutelar la tipicitat de l'interès social". 
la LCCV incorporen un òrgan de control de la gestió a l'estructura de la cooperativa, encara que la seua tipologia és sensiblement diferent.

La LCoop, seguint un model tradicional, regula els interventors (art. 38 i 39) com a òrgan de fiscalització, la funció bàsica dels quals, a més de les que expressa i puntualment els encomana la mateixa llei, és la censura dels comptes anuals i de $l^{\prime}$ informe de gestión ${ }^{1178}$, encara que els estatuts poden assignar-los unes altres funcions de naturalesa fiscalitzadora. Poden ser elegits interventors els socis de la cooperativa que siguen persones físiques i els representants, legals o voluntaris, dels socis que siguen persones jurídiques; però, a més, com a novetat important en la matèria, la LCoop introdueix la possibilitat que fins a un terç dels interventors siga designat entre experts independents.

Respecte de la facultat d'impugnar acords socials, l'article 31.4 de la LCoop legitima, expressament, els interventors, tant per a la impugnació d'acords nuls com per a la dels anul-lables, en coherència amb el deure correlatiu que se'ls imposa d'impugnar els acords contraris a la llei o als estatuts ${ }^{1179}$. Potser caldria plantejar-se, de manera similar a com s'ha proposat per a l'òrgan d'administració, si la legitimació recau sobre cada interventor $\mathrm{o}$, contràriament, ha d'adoptar-se un acord previ d'interposició de l'acció pel col-lectiu d'interventors, quan siguen diversos. Però, com ja hem vist, encara que la LCoop s'hi referisca com a òrgan (en singular), de cap de les referències que el text legal fa a aquesta figura pot deduir-se'n el caràcter col-legiat; ans al contrari, s'adverteix que "en cas de disconformitat, els interventors hauran d'emetre un informe, separadament"; a més, es preveu expressament (LCoop, art. 38.4) la possibilitat que la intervenció siga un òrgan unipersonal; tot això,

1178 Això no obstant, el seu informe sobre els comptes anuals no és obligatori quan la cooperativa estiga subjecta a l'auditoria externa dels comptes, segons l'article 62 de la LCoop.

${ }^{1179}$ La regulació que es feia en la LGC únicament es referia, indirectament, a la legitimació dels interventors, en establir la seua obligatorietat d'impugnar els acords contraris a la llei o als estatuts. Amb això es plantejava el dubte de si estaven legitimats per impugnar els acords anul-lables que lesionaven els interessos de la cooperativa, en favor de socis o de tercers. La LCoop corregeix aquest buit $i$ atorga legitimació expressa, en qualsevol cas, als interventors. 
ens fa concloure que hi ha ambdues alternatives. D'altra banda, l'atribució de legitimació de l'article 31.4 no es fa en favor de la intervenció, que és la denominació genèrica que la Llei utilitza per referir-se a l'òrgan de fiscalització, sinó en favor dels seus membres, "els interventors". Per això, estimem que es tracta d'una legitimació individual, a cada membre de l'òrgan.

Finalment, també s'ha d'assenyalar que la legitimació general feta en favor dels interventors permet incloure aquell que, si escau, haja estat designat pel jutge de primera instància com a interventor de la liquidació (art. 72) ${ }^{1180}$.

La LCCV estableix una fórmula diferent de control de la gestió. D'una banda, l'informe previ a la censura dels comptes anuals per l'assemblea general s'encomana a auditors professionals externs $\mathrm{i}$ independents, $\mathrm{i}$ és únicament obligatòria l'auditoria en els supòsits expressament previstos en la Llei (art. 45). D'altra banda, potestativament, la cooperativa pot dotar-se, si així ho preveuen els seus estatuts, de l'anomenada comissió de control de la gestió (art. 48), les competències de la qual són "examinar la marxa de la cooperativa, les directrius generals i les decisions concretes adoptades pel consell rector, pel conseller delegat o per la comissió executiva i el director; advertir-los sobre la seua conformitat o no amb la política fixada per l'assemblea general i els criteris d'una bona gestió empresarial, i informar, per escrit, en el moment que consideren oportú, l'assemblea general i, en tot cas, l'assemblea general ordinària". En el compliment d'aquestes funcions, la comissió "podrà demanar i examinar, en qualsevol moment, la documentació i la comptabilitat de la cooperativa", i també acordar la submissió dels comptes anuals i de l'informe de gestió a l'auditoria externa (art. 45.1, c)).

1180 Es tracta d'una figura prevista per la LCoop, el nomenament de la qual, fet pel jutge, pot ser sol-licitat per una minoria qualificada ( $20 \%$ dels vots socials), a fi que "fiscalitze les operacions de liquidació" i, en concret, censure, abans de l'aprovació per l'assemblea, el balanç final, l'informe de gestió sobre les operacions de liquidació, i el projecte de distribució de l'actiu sobrant, si escau. 
La LCCV atribueix legitimació activa expressa per a la impugnació d'acords nuls de l'assemblea general als membres de la comissió de control de la gestió (art. 36.4), la qual cosa resulta coherent amb les funcions legalment atribuïdes; però, a diferència del que succeeix amb els membres de l'òrgan d'administració o amb el de control de la llei estatal, no s'estableix per a la comissió l'obligació d'impugnar.

També, en relació amb els membres de la comissió de control de la gestió, podria plantejar-se el dubte sobre si la legitimació és individual, a cada membre, o col-lectiva, a l'òrgan en el seu conjunt. Però el text legal és prou explícit: l'article 36.4 de la LCCV es refereix a la legitimació dels membres de la comissió. Per això, sense perjudici que, tenint en compte les funcions d'aquest òrgan de control, moltes vegades serà al seu si on sorgirà la iniciativa, estimem que l'acció s'atribueix als seus membres a títol individual.

En tot cas, potser la LCCV es podia haver estalviat aquesta legitimació expressa, ja que els membres de la comissió de control de la gestió han de ser necessàriament socis de la cooperativa ${ }^{1181} \mathrm{i}$ aquests tenen tots legitimació per a la impugnació d'acords nuls ${ }^{1182}$.

1181 El supòsit de la representació del soci persona jurídica no es preveu en la comissió de control de la gestió, a diferència del que es preveu per als interventors en la LCoop. Aquesta omissió de la LCCV es fa més patent si considerem que, per contra, en regular la comissió de recursos, sí que està prevista l'aplicació de les normes del consell rector en matèria d'elecció dels seus membres (art. 47.1). Això ens fa concloure que si la LCCV no ha previst la possibilitat que siguen membres de la comissió de control de la gestió els representants (voluntaris o legals) de les persones jurídiques sòcies, s'ha de tractar d'una omissió voluntària.

1182 L'única explicació que trobem a la legitimació expressa dels membres de la comissió de control de la gestió per a la impugnació d'acords nuls, seria estrictament aclaridora. La llei reconeix legitimació als membres de la comissió per a la impugnació d'acords anul-lables, especificació plenament justificada, en aquest cas, ja que no tots els socis en gaudeixen. Podria ser que el legislador haguera volgut evitar que l'absència de menció fera dubtar de l'existència de legitimació en els supòsits d'acords nuls.

$\mathrm{D}$ 'altres lleis autonòmiques reconeixen també legitimació, contra els acords nuls, als membres de l'òrgan de control. Així, l'article 39.4 de la LCPV estableix que "l'acció d'impugnació d'acords nuls podrà ser exercitada per [...] els membres de la comissió de vigilància", i l'article 38.3 de la LCC diu que "els [...] interventors tenen l'obligació d'exercir les accions d'impugnació contra els acords socials que siguen contraris a la llei". 
E. El comitè de recursos

La LCoop incorpora, com a novetat en matèria de legitimació per a la impugnació, la del comitè de recursos, que presenta perfils poc definits. La primera qüestió que es planteja és la de la seua justificació. Els membres del comitè han de ser, en principi, socis, amb la qual cosa tenen tots ells, individualment, legitimació per a la impugnació d'acords nuls. Potser s'ha tractat, precisament, de reconèixer que l'òrgan, en el seu conjunt, té legitimació, a fi de dotar-lo, expressament, d'un instrument d'intervenció directa.

En efecte, recordeu que el comitè de recursos, excepte en aquest cas que ara analitzem, limita la seua actuació a la tramitació i a la resolució de recursos que li interposen els socis; no té, d'ordinari, competència per actuar per iniciativa pròpia, sinó només a instància de part. Pot ser que amb la legitimació atribuïda ara, es vulga proveir el comitè de recursos de l'instrument per intentar la supressió d'acords, respecte dels quals no se li hagen plantejat recursos, però que, segons la seua opinió, hagen de ser anul·lats.

En tot cas, no hi ha dubte que, contràriament als supòsits anteriors, la legitimació recau, directament i expressament, sobre l'òrgan, que sí que funciona col-legialment ${ }^{1183}$, i no sobre cada un dels seus membres ${ }^{1184}$. I es tracta, a més, d'una obligació (LCoop, art. 31.4: “... Estan obligats a impugnar els acords contraris a la llei (...), en el seu cas, el comitè de recursos").

1183 Encara que l'article 44.2 remet als estatuts per a la fixació del funcionament del comitè, no es pot dubtar del seu caràcter col-legiat, ja que l'apartat 3r següent estableix que "els acords del comitè de recursos seran immediatament executius...", i l'apartat 4t diu que "els seus acords, quan recaiguen sobre matèria disciplinària, s'adoptaran mitjançant votació secreta i sense vot de qualitat"; també són d'aplicació les disposicions comunes al consell rector i als interventors, entre les quals es troba la relativa al conflicte d'interessos amb la cooperativa.

1184 Morillas Jarillo, M. J., i Feliú ReY, M. I., Curso de cooperativas, op. cit., pàg. 261. 
La LCCV, en canvi, no preveu la legitimació expressa del seu òrgan equivalent, la comissió de recursos (art. 47).

\section{F. Els liquidadors}

La LCoop també innova en legitimar els liquidadors per a la impugnació d'acords nuls. Es tracta, també, d'una facultat i d'una obligació alhora. Però, a diferència del que succeeix amb la que s'atribueix al comitè de recursos, la fonamentació jurídica de la legitimació als liquidadors sembla més clara, ja que, en l'exercici de la seua funció, els liquidadors són els continuadors del consell rector en la representació i en la gestió de la societat ${ }^{1185}$; es pretén, així doncs; garantir amb aquesta atribució de legitimació que l'òrgan d'administració de la liquidació puga (i necessite) intentar la desaparició d'aquells acords assemblearis que considere nuls.

La legitimació s'atribueix als liquidadors, la qual cosa fa pensar, en principi, que ho és a títol individual; això no obstant, s'ha de considerar que "quan els liquidadors siguen tres o més, actuaran col-legialment $i$ adoptaran els acords per majoria" (LCoop, art. 71.2). Estimem que, per analogia amb la legitimació reconeguda als membres de l'òrgan d'administració ordinari, es tracta d'una facultat susceptible d'exercici individual, sense perjudici que l'òrgan col-legiat, en execució de les seues funcions, puga, també, acordar l'inici de l'acció.

1185 LCoop, art. 73: “Correspon als liquidadors: [...] 6. Tenir la representació de la cooperativa en judici i fora d'aquest, per al compliment de les funcions que tenen encomanades". Art. 71.3, 2n par.: "Fins al nomenament dels liquidadors, el consell rector continuarà en les funcions gestores i representatives de la societat". Art. 71.5: "Durant el període de liquidació, es mantindran les convocatòries i reunions d'assemblees generals, que convocaran els liquidadors, els quals les presidiran i donaran compte de la marxa de la liquidació". 
D'altra banda, s'ha de tenir present que la LCoop preveu la possibilitat que el nomenament dels liquidadors recaiga en persones no sòcies, ${ }^{1186}$ cosa que sembla bastant adequada al caràcter notablement tècnic de la seua gestió.

La LCCV tampoc no preveu la legitimació expressa dels liquidadors, encara que aquesta no serà necessària en els supòsits d'acords nuls, quan els liquidadors siguen socis o acrediten el seu interès legítim ${ }^{1187}$.

\section{G. Qualsevol tercer amb interès legítim}

El Reial Decret legislatiu 1564/1989, pel qual es va aprovar el text refós de la Llei de societats anònimes, reconeix, legalment, un fet que la doctrina ja reclamava, i la manca d'admissió expressa de la qual la jurisprudència del Tribunal Suprem havia hagut de salvar: el reconeixement de la legitimació activa per a la impugnació d'acords nuls de "qualsevol tercer que acredite interès legítim ${ }^{\prime 1188}$.

1186 D'una banda, l'article 71.1 de la LCoop indica que "si els estatuts no hagueren previst a qui correspon realitzar les tasques de liquidació, l'assemblea general designarà, entre els socis [...], els liquidadors". Això significa que són, en primer lloc, els estatuts els que podran establir el nomenament directe de liquidadors, sense que s'haja de suposar necessàriament que aquest nomenament també haja de circumscriure's al col-lectiu dels socis. D'altra banda, l'article 71.3 estableix que "transcorreguts dos mesos des de la dissolució sense que s'haguera efectuat el nomenament de liquidadors, el consell rector o qualsevol soci podrà sol-licitar, del jutge de primera instància, la seua designació, que podrà recaure en persones que no siguen sòcies...".

1187 Article 71.3 de la LCCV: "La liquidació estarà al càrrec dels socis liquidadors, que en nombre de tres o de cinc haurà d'elegir l'assemblea general, en el mateix acord de dissolució o en el termini d'un mes des de l'entrada en liquidació. En cas contrari, els liquidadors socis o no, seran designats pel Consell Valencià del Cooperativisme...".

1188 URÍA, R., MENÉNDEZ, A. i MUÑoz, J. M., La junta..., op. cit., pàg. 358 i 359, recorden que la legitimació de tercers ja va ser proposada per l'avantprojecte de la LSA de 1951, però aquella proposició no va ser atesa fins a la reforma de 1989. Mentrestant, "aquest buit obligava la doctrina a recórrer, per encegar-la, als principis comuns i a la jurisprudència del Tribunal Suprem, que, en referir-se a l'acció de nul-litat dels contractes, ha declarat reiteradament que poden exercitar-la, també, els tercers a qui perjudique l'obligació". 
La LGC de 1987, tot i ser anterior la seua promulgació, no recollia expressament, amb caràcter general ${ }^{1189}$, la legitimació de terceres persones $\mathrm{amb}$ interès legítim; mentre que la LCCV sí que la va incorporar (art. 36.4: "L'acció d'impugnació d'acords nuls podrà ser exercitada per (...) qualsevol tercer amb interès legítim"). La LCoop salva l'omissió de la llei estatal anterior en incloure, entre els supòsits legitimats per impugnar els acords nuls de l'assemblea general, "els tercers que acrediten interès legítim".

La primera qüestió que pot plantejar-se en aquesta matèria és, precisament, què s'ha d'entendre per "interès legítim". Sembla que hi ha consens tant en la doctrina com en la jurisprudència per estimar que "té interès qualsevol persona que puga sofrir algun mal o perjudici a conseqüència de. l'acord impugnable ${ }^{\prime 1190}$.

1189 Sí que recollia, tanmateix, els supòsits de legitimació per a la impugnació dels qui ja no posseeixen la qualitat de socis: l'expulsat (LGC, art. 38.4), el declarat en situació de baixa obligatòria (LGC, art. 33.2) i el que, després de donar-se de baixa voluntàriament, estiga disconforme amb la qualificació $\mathrm{i} / \mathrm{o}$ amb els efectes que l'assemblea li assigne (LGC, art. 32.4). Partint d'aquests, s'han dictat sentències com la STS (Sala 1a), de 16 de març de 1998, núm. 229/1998 (RJA 1998/1568), en la qual s'estima la demanda interposada pel ja exsoci, "en el sentit següent: 1r Declarar que les baixes voluntàries dels socis Sr. Lucas S. G. R. i Sr. Alfonso T. B. en la Cooperativa Agrària La Valdepeñera es van produir el 27 i el 25 de setembre de 1991, respectivament. $2 n$ Declarar la nul.litat dels acords de l'Assemblea general de l'esmentada cooperativa, de data 22 abril de 1992 (els dos), que van ratificar sengles acords del Consell, de data 27 de setembre de 1991 [...]. 3r Declarar la nul.litat total dels dos acords del Consell rector de l'esmentada cooperativa, de data (tots dos) 18 de febrer de $1992 . . . "$.

1190 ALONSO SOTO, R., «Consideraciones...», op. cit., pàg. 4; GIMENO SENDRA, J. V., El proceso..., op. cit., pàg. 74: "que tinguen un interès directe [...] $\mathrm{o}$, dit amb unes altres paraules, aquelles terceres persones que puguen veure's afectades pels efectes ulteriors de la cosa jutjada" (també en La reforma..., op. cit., pàg. 30); HANNOUN, C., "L'action en nullité...», op. cit., pàg. 231 a 234, on també planteja supòsits en els quals "la irregularitat només siga invocada per aprofitar la supressió de l'acte", i que la jurisprudència francesa tendeix a rebutjar; SERRANO Y Soldevilla, A. D., La cooperativa como..., op. cit., pàg. 215 i 216, on es refereix a la necessitat d'interès suficient i a la jurisprudència del Tribunal Suprem en matèria de nul-litat contractual, on es reconeix acció als tercers a qui perjudique l'obligació. En el dret italià, SILVETTI, C. i CAVALLI, G., Le società per azioni..., op. cit., pàg. 198: "qui actua en judici ha de provar la subsistència d'un interès propi, quan actue, mitjançant la demostració de la necessitat de recórrer al jutge per evitar una lesió actual al dret mateix i el consegüent dany a la mateixa esfera jurídica". A més, "és necessari demostrar un interès concret a actuar, i no és suficient al-legar l'interès abstracte en l'observació de la llei, sinó aquell connex a un perjudici relacionat amb l'objecte de l'acord impugnat"; aquests autors esmenten, per a la distinció entre legitimació i interès i sobre la necessitat del segon juntament amb la primera, CARNELUTTI, Legittimazione $e$ interesse a 
A fi de fer una certa aproximació al concepte, s'han assenyalat diversos trets característics del concepte d'interès legítim. Així, s'ha dit que "l'interès legítim no ha de ser necessàriament directe", i que "tampoc cal que els efectes d'allò que es jutja recaiguen sobre l'esfera patrimonial; és suficient que afecte drets personals o socials"1191 , és a dir, que "cause un perjudici d'ordre jurídic"1192. I en un marc jurídic diferent, l'exposició de motius de la Llei 29/1998, de 13 de juliol, reguladora de la jurisdicció contenciosa administrativa, en el seu apartat IV, "Les parts", indica que l'interès legítim és un "concepte comprensiu dels drets subjectius però més ampli" ${ }^{\prime 193}$.

impugnare una deliberazione dell'assemblea degli azionisti , a Riv. dir. proc., 1960, pàg. 510.

1191 interessos siguen de caràcter ecoforma..., pàg. 30 . En relació amb la no-necessitat que els dels comptes anuals, SILVETTI, C. i CAVA, en el marc dels supòsits d'impugnació de l'aprovació les crítiques d'una part de la doctrina, G., Le società per azioni..., op. cit., pàg. 201, recullen consideració absorbent que, subordinant la de la jurisprudència italianes, respecte de "la al perjudici econòmic de qui actua en judici, es deó per a l'acció de nul-litat (o anul-labilitat) exactament informat sobre la gestió social", i citen jurio tenir compte del dret del soci a ser l'interès a la impugnació de l'acord d'aprovació citen jurisprudència que manté que "integra situació efectiva patrimonial i econòmica de lació del balanç, el del soci a la representació de la a l'acció, encara que l'acolliment eventual d'a societat [...] i precisa [...] que subsisteix l'interès $i$, per les mateixes raons, "s'exclou l'interès desta evidencie una pèrdua més gran d'exercici" operacions il-lícites dels administradors soci haja obtingut, en l'assemblea, expls ha estat fidelment representat en balanç", o "quan el del balanç".

1192 adquirit, amenaçant-lo d'ineficà nullité....", op. cit., pàg. 234, nota 42: "Atemptat a un dret un acte font d'obligacions des de la perspectiva d'un tercer dels creditors) o incidència sobre naixement d'un dret, en profit d'aquest últim"; "L'atemptat a una prerrogativa de finalitat políticaro, a la pàgina 237, nota 62, adverteix: vot, és, sens dubte, font d'interès per actuar; però la utilitza el dret d'informació o el dret de l'acció de nul-litat amb la perspectiva d'extreure un utilització amb finalitats estratègiques de legitimitat del qual [...] pot prestar-se a discussió profit no jurídic, constitueix un interès, la l'anul-lació".

\section{3}

GARCÍA LUENGO, R. i SOTO VÁZQUEZ, R., El nuevo régimen jurídico..., op. cit., pàg. 553: "el nostre legislador utilitza l'expressió interès legítim, categoria procedent del procés administratiu, atemptatori a algun dret integrés àmplia que l'interès directe. Aquest és el derivat d'un acte, Aquell pot qualificar-se com a tel patrimoni jurídic de l'accionista (STS de 30 d'abril 1988). protecció de l'interès general i not interès tutelat pel dret indirectament, amb ocasió de la de intereses..., op. cit., pàg. 53 i 54: "Sigurat com a dret subjectiu"; SÁNCHEZ RUIZ, M., Conflictos legítim consisteix en «una situació subjectiva materix un sector de la doctrina civilista, l'interès consisteix en la conservació o en la laspiració d'un subjecte a un resultat favorable, que inactiva», ja que no és susceptible modificació al seu favor d'una realitat jurídica) però comportament d'un subjecte diferent d'exercici, sinó que la seua satisfacció depèn del 
En tot cas, sembla que l'existència d'interès legítim en els tercers és un "extrem que només podrà valorar-se per meres aparences en el moment d'iniciar-se el procés $^{\prime \prime 1194}$.

D'altra banda, una certa diferència s'observa entre el text de la LCoop i el de la LCCV: la norma cooperativa valenciana no exigeix, expressament, que el tercer acredite el seu interès legítim. Podria, doncs, interpretar-se que mentre que en l'àmbit de les cooperatives sotmeses a la LCoop serà requisit per iniciar l'acció l'acreditació de la legitimitat del seu interès ${ }^{1195}$, en el de les cooperatives valencianes, per a alguns supòsits, podria presumir-se l'existència d'aquest interès.

En aquest sentit, s'ha de recordar que dels mateixos textos legals es pot deduir, clarament, l'interès que determinats tercers poden tenir en la impugnació d'acords que els afecten. En tot cas, i com a supòsits específics de tercers possiblement legitimats, vegem quins són.

necessàriament, en una relació jurídica. [...] s'assembla al concepte de dret subjectiu, ja que aquest també denota una situació d'avantatge reconegut a un subjecte, i susceptible de tutela per l'ordenament. No obstant això, se'n distingeix per no tenir un contingut específic d'activitat, de la possibilitat d'actuació del seu titular, per la qual cosa permet a aquest sols la conservació o la modificació d'una realitat jurídica, però no la seua creació. La inactivitat [...] no ha de portar a la confusió amb la noció d'expectativa. El valor jurídic de l'expectativa es redueix a produir una vinculació jurídica provisional [...]. L'interès legítim, al contrari, no és una situació transitòria, sinó definitiva".

1194 URtA, R., MENÉNDEZ, A. i MUÑOZ, J. M., La junta..., op. cit., pàg. 358, que també citen FAIRÉN [El proceso ..., op. cit.]; SERRANO Y SOLDEVILLA, A. D., La cooperativa como..., op. cit., pàg. 216 i 217; HANNOUN, C., "L'action en nullité...», op. cit., pàg. 253: "el control de l'interès legítim afecta l'abast concret del vici i amplia els poders d'apreciació del jutge. Solament l'examen dels objectius de la llei seria, doncs, insuficient; cal també tenir en compte el medi (context en el qual és invocada la nul.litat) [...], per determinar els titulars efectius del dret de crítica". MORILLAS JARILLO, M. J. i FELIÚ REY, M. I., Curso de cooperativas, op. cit., pàg. 262, estimen que també caldrà tenir en compte la classe concreta de cooperativa de què es tracte, i en posen un exemple: si és una cooperativa d'usuaris i consumidors, podran tenir consideració de tercers amb interès legítim les associacions de consumidors.

1195 HANNOUN, C., "L'action en nullité...», op. cit., pàg. 240 i 241: “Sota la capa d'aquesta condició d'ordre processal, interfereix, en realitat, una exigència pròpia: la d'una limitació del dret a actuar [...] l'interès legítim [...] podria donar qualitat per actuar. I aquest seria el cas quan la irregularitat afecte la situació jurídica del tercer i quan la valoració d'interessos atribuïda a l'apreciació del jutge resulte en profit del demandant". 
a) Els exsocis, l'administrador de l'herència jacent

En la LCoop es recullen expressament tres supòsits d'exsocis legitimats per impugnar acords determinats de l'assemblea general o, si escau, del comitè de recursos: 1'expulsat (art. 18.5, en relació amb l'art. 18.3, c), in fine), el declarat en situació de baixa obligatòria (art. 17.5 i 6, en relació amb l'art. 18.3, c), in fine), i el que després de donar-se de baixa voluntàriament o per causa justificada, estiga disconforme amb la qualificació i/o efectes que l'assemblea li assigne (art. 17.6, en relació amb l'art. 18.3, c), in fine). D'altra banda, la LCCV també expressa la legitimació del soci expulsat (art. 18.2). Són supòsits, aquests, per als quals la llei reconeix l'existència d'un interès legítim digne de tutela. No sembla, així doncs, que es puga demanar una altra acreditació que la de trobarse en les situacions descrites en les normes esmentades.

D'altra banda, un supòsit que presenta característiques similars al de qui ha deixat de ser soci, però que, no obstant això, no es troba reflectit en els textos legals, és el de l'herència jacent del soci mort. En aquests casos, estimem que, mentre que no es produïsca l'adjudicació de les participacions entre els hereus, la impugnació d'acords que puguen ser lesius als interessos derivats de la titularitat de les participacions, correspondrà al marmessor o a l'administrador de l'herència $o$, si no n'hi ha, als hereus mateixos. Però la seua legitimació, com ja s'ha indicat, no serà en qualitat de soci, sinó de "tercer amb interès legítim ${ }^{\prime 1196}$.

b) Els socis i els associats de les cooperatives sòcies i els socis d'altres persones jurídiques sòcies

La LCoop reconeix, amb caràcter general (art. 12.1), que pot ser sòcia de les cooperatives de primer grau qualsevol persona jurídica, "en funció de l'activitat cooperativitzada". Aquesta condició significa que, en determinades cooperatives, la naturalesa mateix de l'activitat cooperativitzada serà 
determinant per a la prohibició o la limitació de l'ingrés com a sòcies de tots o d'alguns tipus de persones jurídiques. És el cas de les cooperatives de treball associat (art. 80), els socis de les quals poden ser únicament persones físiques, ja que han d'aportar a la cooperativa el seu treball personal i directe; els de les cooperatives de consumidors i usuaris (art. 88), i els de les cooperatives d'habitatges (art. 89.1), que admeten només determinats tipus de persones jurídiques, en qualitat de sòcies. Pel que fa a les cooperatives de segon grau de la LCoop, poden ser sòcies totes les persones jurídiques, fins a un màxim del $45 \%$ del total de socis.

La LCCV, d'altra banda, reconeix, amb caràcter general, la possibilitat que les persones jurídiques de qualsevol tipus siguen sòcies de la cooperativa de primer grau, quan la seua finalitat i el seu objecte social "no siga contrari als principis cooperatius, ni a l'objecte social de la cooperativa" (art. 14.1). Per això, en les cooperatives de treball associat (art. 79.1, 84.2a, 87.2a, 88.2a), sols podran ser sòcies les persones físiques. En les cooperatives de segon grau, pot ser sòcia qualsevol persona jurídica (art. 14 i 92.1 ).

I ja que poden ser sòcies de les cooperatives d'altres persones jurídiques, no hi ha dubte que els socis ${ }^{1197} \mathrm{i}$, si escau, els associats d'aquestes últimes, tindran en molts casos un interès legítim en la impugnació dels seus acords ${ }^{1198}$.

1196 Vegeu supra epígraf 1.1. A, a).

1197 VICENT CHULIA, F. en "La asamblea...», op. cit., pàg. 150, i en VICENT CHULIÁ, F. «Nota breve sobre la breve ley de cooperativas de crédito", La Ley, 1989-3, pàg. 171, per referir-se a aquests socis de les persones sòcies, recull la denominació expressiva de socis indirectes encunyada per MuÑOz VIDAL, A. B., en El socio indirecto en las Cajas Rurales, Caja Rural Provincial de Múrcia, 1973, pàg. 119 a 121. PAZ CANALEJO, N. , «Las cooperativas de segundo y ulterior grado", RDPri, juliol-agost, 1977, pàg. 518, es refereix a l'usuari no soci, que, malgrat no ser soci de la cooperativa de segon grau, pot accedir als seus serveis i a les seues operacions. ALFONSO SÁNCHEZ, R., La integración cooperativa..., op. cit., pàg. 332 , nota 11 , assenyala que aquesta figura es recull tant en la LCoop (art. 79.3), com en diverses lleis autonòmiques. En relació amb aquesta, SANTOS DOMfNGUEZ, M. Á., "Notas sobre la Ley 2/1998...», op. cit., pàg. 111, assenyala que l'article 22.3 amplia l'abast de certes obligacions dels socis als qui no ho són ("persones físiques que siguen socis de les societats cooperatives integrades en aquelles").

1198 HANNOUN, C., "L'action en nullité...», op. cit., pàg. 239, recull la tendència doctrinal i jurisprudencial a admetre que "al si d'un grup [...] un soci d'una filial puga estar considerat 
c) Els treballadors

A més dels consellers laborals que, com hem vist, estan expressament legitimats, sembla obvi que la resta dels treballadors de la cooperativa té interès directe en la marxa de la cooperativa, fins i tot pel que fa als acords que no els afecten directament en els seus drets, per la qual cosa entren dins de la categoria de tercers amb interès legítim ${ }^{199}$.

D'altra banda, un supòsit que pot assimilar-se al dels treballadors per compte d'altri, és el del soci en període de prova en les cooperatives de treball associat de la llei valenciana. La LCCV estableix que "els estatuts socials podran fixar un període de prova per als socis (...). Durant aquest període de prova, el soci treballador tindrà els drets de veu i d'informació, i els de participació en retorns, i li seran imputables, igualment, les pèrdues de l'exercici"; aquesta enumeració tancada sembla excloure el dret d'impugnació en qualitat de soci; per la qual cosa el seu exercici haurà de basar-se en la seua qualitat de "tercer" amb interès legítim ${ }^{1200}$.

d) La direcció i d'altres càrrecs similars

com a persona interessada en l'anul-lació d'una deliberació de la societat mare, sense necessitat de mantenir la qualitat de soci d'aquesta última".

1199 Sobre la legitimació activa dels treballadors en el procés de fusió, vegeu MARTínEZ SANZ, F., «La nulidad de la fusión...», op. cit., pàg. 86 i 87.

1200 Com ja hem vist, la LCoop (art. 81.3) reconeix que els socis en període de prova de les CTA tenen "els mateixos drets $\mathrm{i}$ les mateixes obligacions que els socis treballadors", amb algunes particularitats expressament previstes, entre les quals no es troba el dret d'impugnació d'acords, per la qual cosa podem concloure que sí que estan legitimats com a socis. 
En l'àmbit de les societats de capital, s'ha assenyalat que el director general, el gerent o d'altres càrrecs similars ${ }^{1201}$ i l'apoderat poden exercitar l'acció de nul-litat en el concepte de tercer que acredite interès legítim ${ }^{1202}$. Ja en relació amb la LGC anterior, algun autor considera que "quant a la validesa d'una posició actora eventual del director d'una cooperativa, que no siga soci (...), com a assistent a l'assemblea amb dret a veu (art. 46.6), una interpretació àmplia (però no incontestable) de l'article 52.3, primer paràgraf, portaria a reconèixer-li legitimació quan haguera fet constar la seua oposició a la realització $\mathrm{d}^{\prime}$ aquella"1203.

Nosaltres estimem que, efectivament, en la mesura en què el director, o qualsevol altre càrrec similar, o l'apoderat, hagueren assistit a l'assemblea, la LGC els legitimava per a la impugnació d'acords nuls, sense que fóra necessari que hagueren fet constar la seua oposició, si el que es tractava d'impugnar eren acords nuls. En tot cas, amb la introducció en la LCoop de la legitimació en favor de terceres persones, queda fora de dubte que l'apoderat de qualsevol tipus, i molt especialment l'apoderat principal (el factor de la terminologia mercantil tradicional; el "gerent, director general o càrrec equivalent", segons la terminologia de la LCoop, art. 32.3), entraran en molts casos en aquesta categoria. I el mateix podem dir pel que fa al director $\mathrm{o}$ a qualsevol altre càrrec similar en les cooperatives regulades per la LCCV. Aquests subjectes tenen un interès legítim i directe en el bon funcionament societari, en virtut, justament, del compliment correcte de les seues funcions, per la qual cosa s'inclouen entre els tercers legitimats ${ }^{1204}$.

1201 Cal recordar que el gestor de dedicació permanent previst en l'article 43.5 de la LCCV ho serà amb caràcter de conseller delegat o de director.

1202 Ávila NAVARRO, P., La sociedad..., op. cit., pàg. 427.

1203 Paz Canalejo, N., en PAZ CANALejo, N. i ViCent Chuliá, F., Ley general..., pàg. 595.

1204 RODRígUEZ RUIZ DE VILLA, D., Impugnación..., op. cit., pàg. 140, considera que "els directors, gerents, tècnics i d'altres persones que tinguen interès en la bona marxa dels assumptes socials" efectivament estan interessats, com a tercers amb interès legítim, encara que és millor considerar-los dins el grup dels treballadors de l'entitat, encara que mantinguen amb 
Però també s'ha assenyalat l'existència d'altres subjectes amb funcions relacionades amb la gestió de la cooperativa, i que, per tant, poden considerarse tercers amb interès legítim per impugnar: els administradors de les societats $\operatorname{controlades}^{1205}$, i els interventors temporals de la cooperativa. No obstant això, sobre aquests últims s'han de fer dues excepcions importants: d'una banda, la LCoop ha suprimit la intervenció temporal de la cooperativa, anteriorment regulada per la LGC (art. 152.1,b)) com a mesura de control administratiu, en cas de risc greu per als interessos de socis o de tercers, i, consegüentment, també ha desaparegut la figura de l'interventor temporal en l'àmbit cooperatiu estatal.

D'altra banda, la LCCV (art. 109,a) sí que preveu la nul-litat dels acords adoptats pels òrgans de la cooperativa que no compten amb l'autorització dels interventors temporals, però no és menys cert que no atribueix a aquests legitimació expressa per a la seua impugnació, almenys en funció del seu càrrec. Per això no hi ha una altra solució que reconduir la seua legitimació possible a la qualitat de tercers amb interès legítim.

e) Els creditors, els obligacionistes, el comissari del sindicat d'obligacionistes

l'empresa relacions de personal d'alta direcció. De la nostra banda, considerem que si, efectivament, la relació que els lliga a la cooperativa és en la major part dels casos (almenys per al director o per al gerent) de personal laboral d'alta direcció, també poden presentar-se contractes de prestació de serveis $i$, en tot cas, l'apoderament de què seran titulars, en la majoria dels casos, i la responsabilitat especial que, en relació amb l'entitat, adquireixen, justifiquen un tractament especial.

1205 SAlelles Climent, J. R., El funcionamiento..., op. cit., pàg. 394: “com qualsevol tercer interessat, els administradors de les societats controlades poden impugnar els acords nuls adoptats per la societat dominant. En canvi, quan es tracta d'acords anul-lables, la rellevància del vici només pot ser admesa a partir de la iniciativa del subjecte al qual s'atribueix l'acte; en aquest cas, als administradors o als socis de la societat dominant, ja que la violació efectiva del seu interès no pot ser valorada per un tercer. Si els membres dels consells de les societats del grup consideren que aquests acords poden causar un dany a la societat mateix, no poden impugnar-los. Per això, i per evitar el perjudici que es puga ocasionar a les societats que 
Els creditors socials són els tercers amb interès legítim per excel-lència, un dels col-lectius que més habitualment estaran interessats en la impugnació dels acords que lesionen els seus interessos. Per aquest motiu, la jurisprudència ha recordat que "l'expressió tercer s'ha de prendre en sentit ampli, com tota persona, física o jurídica, aliena a la condició de soci, sense que es puga exigir la condició de creditor social" ${ }^{1206}$

En relació amb els creditors, la LCoop preveu un supòsit específic en el qual el creditor podrà impugnar acords que el perjudiquen: quan l'assemblea aprove el balanç final i el projecte de distribució de l'actiu sobrant en el procés liquidador de la cooperativa, i no hagen estat satisfets o consignats els crèdits del creditor $(\text { art. 74.2) })^{1207}$.

Però la Llei permet l'existència d'uns tercers creditors: les persones no sòcies, titulars de qualsevol modalitat de finançament voluntari que la cooperativa haja adoptat. En efecte, la LCoop preveu, en el seu article 54, que les cooperatives que hi estiguen sotmeses podran emetre obligacions, títols participatius $\mathrm{i}$ emissions en sèrie de qualsevol modalitat jurídica de finançament voluntari, i contractar comptes en participació. D’altra banda, la LCCV (art. 56.3 i 56.4) accepta la possibilitat d'admetre obligacions i títols participatius. Tots els seus titulars poden trobar-se en la situació de ser considerats tercers amb interès legítim.

administren, no hauran d'executar-los. Si el consell acordara executar aquestes decisions, qualsevol dels membres podrà i haurà d'impugnar l'acord adoptat".

1206 ARROYO, I., «Comentario al art. 56...», op. cit., pàg. 613.

1207 Encara que la Llei no ho especifica, aquesta legitimació ho és respecte d'acords nuls, ja que l'aprovació del balanç i la de la proposta de distribució de l'actiu que no preveja el pagament o la consignació de deutes socials vulnera el que preveuen els articles $73.5 \mathrm{i} 75.1$. D'altra banda, encara que el tenor literal de l'article 72.2 es refereix a la impugnació directa del balanç i del projecte de distribució, sembla que allò correcte és que s'impugne l'acord de l'assemblea que fixa i que dóna validesa al contingut dels documents aprovats. 
Respecte als obligacionistes, no hi ha dubte que la seua relació amb la cooperativa és la de creditors ${ }^{1208}$ (LSA, art. 282.1 ${ }^{1209}$ : "La societat podrà emetre sèries numerades d'obligacions o d'altres valors que reconeguen o que creen un deute...") i, en aquest sentit, gaudiran de legitimació per a la impugnació ${ }^{1210}$. I el mateix tractament de tercers legitimats hauran de rebre els titulars d'altres modalitats de finançament, que també siguen creditors socials.

Quant al comissari del sindicat d'obligacionistes d'una cooperativa que haja emès obligacions, la seua funció és la de representant de tercers no socis, en la defensa dels interessos dels quals, així com en el compliment de les seues funcions, pot trobar-se, clarament, legítimament interessat ẹn la impugnació dels acords socials ${ }^{1211}$.

\section{8} les facultats i les accion. J., Asociación y..., op. cit., pàg. 193: "l'obligacionista, com a creditor, té vegeu pàg. $222 \mathrm{a} 224$.

PAZ CANALEjO, N. i VICENT CHULIÁ, F., Ley general..., pàg. 594: "encara que s'ha considerat que els obligacionistes estan legitimats com a membres de la cooperativa (expressió que figurava en l'article 2 de la llei de 1974) [així, MUÑNOZ VIDAL, en El proceso..., cit., pàg. 46], considere més fundada l'opinió que estima que, en ser creditors de la societat, tenen l'estatus de tercer, pel que fa a la impugnació dels acords socials [GIMENO SENDRA, El proceso de impugnación..., cit., pàg. 76.]. En canvi, pel que fa a la posició del comissari del sindicat d'obligacionistes, crec que, en l'actualitat, podria sostenir-se la seua legitimació amb certes condicions...". Estimem que s'han davant de tercers possiblement lupòsits (encara que en els dos casos, com veurem, ens trobem Respecte a la citació de MUÑOZ Vimats) atenent a la seua relació diferent amb la cooperativa. en la cooperativa, no és ni soci ni limiten la legitimació als socis o associat, però, dins l'acció de lesivitat, ni la llei ni el reglament dret als membres". D., Impugnación..., op. cit., pàg. 138.

1209 en virtut del que preveuen els articlese la LSA (art. 282-310), és aplicable a les cooperatives, l'assemblea general, podran emetre obles 54.1 de la LCoop ("Les cooperatives, per acord de la legislació aplicable") i 56.3 de la LCCV ["L'a el règim de les quals s'ajustarà al que disposa sempre de caràcter no convertible en pV [“L'assemblea general [...] podrà emetre obligacions, com a conseqüència, alhora, de l'articticipacions socials, d'acord amb la legislació vigent"], d'obligacions per societats que no harticle 12 de la Llei 211/1964, de regulació de l'emissió persones jurídiques. Vegeu supra l'epígen adoptat la forma d'anònimes, associacions o d'altres

DOMfNGUEZ GARCíA, M. A., "La obligación como título...», op. cit., pàg. 1269.

1211 Alonso EsPinOSA, F. J., Asociación y..., op. cit., pàg. 338: “En el nostre dret està fora de dubte que la legitimació processal per a l'exercici d'accions col-lectives correspon al comissari,
segons disposa l'article 118 de la LSA". 
En efecte, en virtut de l'aplicació de la regulació establerta en la LSA per a aquesta figura, el comissari, també en les cooperatives, "a més de les facultats que li hagen estat conferides en l'escriptura d'emissió i les que li atribuïsca l'assemblea general d'obligacionistes, tindrà la representació legal del sindicat $\mathrm{i}$ podrà exercitar les accions que a aquest corresponen" (art. 303.1), entre les quals es troben les necessàries per a "la millor defensa dels interessos legítims dels obligacionistes" (art. 300). A més de l'exercici d'aquesta representació, el comissari serà " 1 'òrgan de relació entre la societat i el sindicat i, en aquest sentit, podrà assistir, amb veu i sense vot, a les deliberacions de la junta general de la societat emissora" (art. 301.2); i "en general, tutelarà els interessos comuns dels obligacionistes" (art. 303.3). Finalment, els articles 304 i 305 li reconeixen altres facultats en defensa dels interessos del sindicat per a supòsits concrets, en els quals pot arribar, per exemple, a "assistir, amb veu i sense vot, a les reunions del Consell d'administració, a proposar al Consell la suspensió de qualsevol dels administradors i a convocar la junta general d'accionistes, si aquells no ho feren, quan estime que han de ser substituïts".

En relació amb l'exercici de les accions en defensa dels drets dels obligacionistes en general (i, per tant, d'aplicació a l'acció d'impugnació d'acords), s'ha plantejat la possibilitat $d^{\prime}$ interessos coexistents a iniciar una acció col-lectiva (la duta a terme, en principi, pel comissari) i una acció individual, en virtut del dret que assisteix a cada obligacionista. Sobre això, es conclou que "l'acció col·lectiva procedeix quan la totalitat o part dels obligacionistes estan afectats per una situació susceptible de generalitzar-se a la totalitat d'obligacionistes. (...) L'exercici de l'acció col-lectiva exclou l'exercici d'accions individuals sobre el mateix objecte", i "si l'AO [associació d'obligacionistes] decideix no interposar l'acció col-lectiva, automàticament queda expedita la via de les accions individuals". ${ }^{1212}$ 
f) Les entitats associatives a les quals pertanya la cooperativa

A més de constituir cooperatives de segon grau, les cooperatives poden participar en d'altres fórmules associatives, ja siga amb la finalitat de defensar i de promoure els seus interessos, en general, ja siga amb la de facilitar la seua activitat econòmica, en particular.

Així, el títol III, "De l'associacionisme cooperatiu" (art. 117-120) de la LCoop, regula la participació de les cooperatives en unions, federacions i confederacions, mentre que la LCCV ho fa en els seus articles 9 a 97; ambdues normes regulen també la possibilitat que la cooperativa contraga vincles societaris o que forme consorcis, de manera temporal o indefinida, per a la realització millor del seu objecte social (LCoop, art. 79, i LCCV, art. 93), i la LCoop ha introduït la figura del grup cooperatiu (art. 78).

Creiem que en aquests casos no és absurd suposar que poden produir-se supòsits en els quals les mateixes entitats, de les quals forma part la cooperativa, o els seus socis, puguen tenir un interès legítim a impugnar els seus acords (pensem, per exemple, en una unió temporal en la qual participe la cooperativa, que pot veure's radicalment afectada per un acord de l'assemblea general que implique una modificació estructural).

Pel que fa al denominat grup cooperatiu de la LCoop, s'ha de tenir en compte que aquesta unitat de decisió, formada per diverses cooperatives de qualsevol tipus i una entitat cap del grup, pot afectar àmbits diferents, entre els quals, per indicació legal expressa, poden incloure's "l'establiment, en les cooperatives de base, de normes estatutàries i reglamentàries comunes", i "l'establiment de relacions associatives entre les entitats de base". Més enllà de la legitimació immediata que, com a tercers, poden tenir les cooperatives de base o l'entitat cap de grup, en relació amb els acords adoptats per una de les integrants del grup, sembla que la possibilitat d'establir normes estatutàries i relacions 
associatives comunes obri la porta a un possible reconeixement explícit, estatutari o no, d'una legitimació més àmplia.

\subsubsection{Legitimació en pretensions constitutives d'anul·labilitat}

L'article 31.4 de la LCoop circumscriu, en principi, la legitimació per a la impugnació d'acords anul-lables, als socis assistents a l'assemblea que hagueren fet constar, en l'acta o mitjançant document fefaent lliurat dins de les 48 hores següents, la seua oposició a l'acord, encara que la votació haguera estat secreta; els il.legítimament privats del dret de vot, els absents, i els membres del consell rector i els interventors ${ }^{\prime 1213}$. Sorprenentment, en el paràgraf immediatament següent, estableix que "estan obligats a impugnar els acords contraris a la llei o els estatuts, el consell rector, els interventors i els liquidadors $i$, si escau, el comitè de recursos". En efecte, crida l'atenció que s'obligue a la impugnació d'acords contraris als estatuts els liquidadors i el comitè de recursos quan, prèviament, no se'ls ha reconegut legitimació; ja que, si bé és cert que seran, en tot cas, socis, no necessàriament han d'estar entre els que hagueren fet constar la seua oposició a l'acord. S'haurà d'entendre que l'obligació porta implícit el reconeixement de la seua legitimació, si bé, en aquest cas, ignorem per què es repeteix la seua expressió per als membres del consell i per als interventors...

La LCCV considera legitimats "els socis assistents que hagueren fet constar en l'acta de l'assemblea general la seua oposició a l'acord, els absents i els que hagueren estat il-legítimament privats del vot, així com els membres del consell rector, els administradors o els membres de la comissió de control de la gestió".

1213 Aquesta norma presenta algunes diferències notables, que analitzarem, respecte al text de l'article 52.3 de la LGC, que reconeixia legitimació davant els acords anul-lables als "assistents a l'assemblea que hagueren fet constar en l'acta la seua oposició a la realització o el seu vot contra l'acord adoptat, els socis $i$ associats absents i els que hagen estat il-legítimament privats d'emetre el seu vot". 
Abans d'entrar en l'anàlisi de cada un dels supòsits de legitimació i de les seues condicions, es planteja una qüestió prèvia: per què es redueix l'àmbit de la legitimació activa per als acords anul-lables, en relació amb la prevista per als acords nuls, si tenen, essencialment, la mateixa fonamentació jurídica? ${ }^{1214}$.

SORIA FERRANDO, buscant les raons que aconsellen la denegació de legitimació activa al soci que vota a favor de l'acord, arriba, en principi, a la conclusió que potser puguen trobar-se en la doctrina dels actes propis que, per contra, no seria aplicable per a la legitimació, davant els acords nuls, per les raons apuntades supra ${ }^{1215}$.

Tanmateix, adverteix que no deixa de ser problemàtica l'aplicació de la doctrina dels actes propis, ja que "s'ha arribat a afirmar que l'exercici del dret d'impugnació no persegueix invalidar el vot propi o el dels restants accionistes que van votar a favor de l'acord, sinó desposseir del caràcter d'expressió vàlida de voluntat social l'acord d'una junta general, considerat en si i per si mateix, independentment de les persones que la formen", ja que "el soci (...) que va votar a favor de la deliberació, de cap manera es vincula, sinó que, actuant com un element de l'òrgan de la societat, concorre, únicament, a la formació de la voluntat social; no hi ha, així doncs, cap raó per impedir-li l'exercici de l'acció... ${ }^{\text {1216. }}$. Per això, prefereix fonamentar la denegació de legitimació per a la

1214 SORIA FERRANDO, J. V., en La impugnació..., op. cit., pàg. 389, i en La legitimació activa..., pàg. 28 , en un context diferent (el de la Llei de societats anònimes de 1951, que establia una doble via procedimental, la declarativa ordinària i l'especial del seu article 70 , en la qual es restringia la legitimació davant la reconeguda per a la nul-litat i anul-labilitat dels actes i negocis jurídics en general), ja es preguntava: "si el procés impugnador especial és instrument essencial per a la tutela de la minoria, quin sentit té restringir la legitimació activa per a la impugnació d'acords socials pel procés especial de l'article 70?". I és que, com SORIA mateix recorda, en l'Exposició de motius de la Llei de societats anònimes de 1951 s'afirmava explícitament que la impugnació dels acords de les juntes generals és considerada pel legislador un "mitjà de garantir els drets de les minories".

1215 Vegeu epígraf 1.1.1. A. a).

1216 SORIA FERRANDO, J. V., La legitimación activa..., op. cit., pàg. 77. En contra, GIMENO SENDRA, El proceso..., op. cit., pàg. 83 i 84 , estima que hi ha vulneració de la doctrina dels actes propis, ja que l'acord social no s'hauria adoptat sense la suma de les voluntats individuals dels accionistes 
impugnació d'acords anul-lables dels socis que votaren a favor en la teoria de l'interès: "el soci que assent veu prevaler la seua opinió en els acords socials adoptats $i$, per tant, no té l'interès que el dret d'impugnació tendeix a tutelar" ${ }^{\prime 217}$.

Això no obstant, la teoria de l'interès entra en contradicció amb els supòsits en què, posteriorment a l'emissió del seu vot positiu, el soci arribe a la conclusió del seu error i que els seus interessos queden millor tutelats mitjançant la impugnació de l'acord $^{1218}$. Per això, considerem més encertada l'opinió $\mathrm{d}^{\prime} \mathrm{ARROYO}{ }^{1219}$, qui estima que "es retalla la legitimació activa, amb bon criteri, ja que no està en joc el compliment de la llei, sinó la voluntat dels contractants manifestada en els estatuts socials o en l'interès dels socis". L'autonomia de la voluntat, lligada a la protecció de la seguretat jurídica, serien raons suficients per comprometre el soci a assumir el sentit dels seus actes.

favorables, que els vinculen. En el mateix sentit, RODRíGUEZ RUIZ DE VILLA, D., Impugnación..., op. cit., pàg. 168 , nota 86 .

1217 SORIA FERRANDO, J. V., La legitimación activa..., pàg. 88, seguint PAVONE LA ROSA [Diritto di voto $i$ diritto di anullamento delle deliberazione assembleari, Riv. Dir. $i$ Proc. Civ., 1953, pàg. 912 i ss.] en la consideració que el dret d'impugnació és un "dret-mitjà" concedit al soci amb la finalitat de tutelar el seu interès al fet que els acords socials tinguen un contingut determinat: "...la denegació de legitimació al soci que assent troba fonament en la falta d'aquell interès específic que tutela el poder d'impugnació".

1218 DUQUE DOMÍNGUEZ, J. F., en citar la doctrina alemanya i la italiana, refereix el supòsit equivalent, respecte d'acords nuls: "el soci que s'ha manifestat, mitjançant el seu vot, conforme amb l'estimació que de l'interès social ha realitzat la junta general, quan, després de votar, s'adone de la il-legalitat d'aquest, pot impugnar l'acord quan, simultàniament, proposa també la impugnació del vot, qüestió que, tant en l'aspecte material com en el processal, es regula d'acord amb les normes del dret comú, ja que no es preveu res específic en la LSA"; això no obstant, adverteix en nota al peu que "les qüestions processals obertes amb aquesta possibilitat són greus", i finalment, es pregunta: "la interposició de la impugnació del vot, quins efectes produeix sobre el procés especial d'impugnació d'acords socials?".

En l'actualitat, la legitimació del soci que va votar a favor de l'acord nul està fora de tot dubte. Per contra, mantenir la possibilitat de legitimació del soci que va votar a favor d'un acord anul-lable sobre la base de la impugnació del seu vot, és inviable.

1219 ARROYO, I., "Comentario al art. 56...» op. cit., pàg. 617. En un sentit similar, RODRíGUEZ RUIZ DE VILLA, D., Impugnación... , op. cit., pàg. 130, que cita FERRÁNDIZ, J. R. i GIMENO-BAYÓN, R., [Praxis mercantil, op. cit., pàg. 355] arriba a la conclusió que "en els casos de nul-litat entren en joc interessos públics, la qual cosa implica una legitimació per a la seua impugnació oberta a 
A. Legitimació dels socis assistents que hagueren fet constar en l'acta la seua oposició, els absents i els il-legítimament privats de vot

El primer collectiu de persones legitimades per a la impugnació d'acords anul-lables és el dels socis, encara que "a més de la qualitat de soci (...) és necessària la concurrència d'altres qualitats complementàries que evidencien $l^{\prime}$ interès concret per impugnar un acord determinat ${ }^{\prime \prime 220}$. Però abans d'emprendre l'anàlisi d'aquests complements cal fer algunes observacions sobre la qualitat de soci com a requisit de la legitimació.

a) La qualitat de soci

A diferència de la redacció anterior de la LGC (art. 52.3), tant la LCoop (art. 31.4) com la LCCV (art. 36.5) es refereixen, expressament, als socis assistents... a l'hora de referir-se al primer grup de persones legitimades per a la impugnació d'acords anul-lables. Això planteja la qüestió de si poden considerar-se també legitimats els no socis assistents a l'assemblea, qüestió que assoleix gran transcendència respecte dels acords anul-lables, ja que per a ells no es preveu una legitimació general dels tercers.

En aquest sentit, l'article 20 de la LCoop indica, únicament, que l'assemblea general és la reunió dels socis de la cooperativa, en haver-se suprimit la menció anterior de la LGC (art. 46.6) a la possibilitat d'assistència a l'assemblea, "amb veu i sense vot, si els convoca el consell rector", de persones no sòcies, la presència de les quals es considerara " $\mathrm{d}$ 'interès per al bon funcionament de la cooperativa". Una autorització tan àmplia permetia, sota la LGC, incloure entre els assistents legitimats per a la impugnació un grup ampli de persones no sòcies: els associats, els membres del consell rector no socis, els membres de la

qualsevol persona, mentre que en l'anul-labilitat s'afecta els interessos particulars, per la qual cosa, només els participants en el negoci jurídic anul-lable estaran legitimats per impugnar-lo".

1220 DuQue Domf́nguez, J. F., Tutela..., op. cit., pàg. 180; GIMENO SENDRA, V., La reforma..., pàg. 32, també parla dels "requisits complementaris" del soci que pretenga impugnar acords anul-lables. 
direcció i d'altres càrrecs de gestió i, si escau, el comissari del sindicat d'obligacionistes i els interventors temporals de la cooperativa (art. 152.1 b)), sempre que hagueren assistit a l'assemblea en què s'adoptà l'acord ${ }^{1221}$.

Ara bé, ni l'especificació actual que els assistents legitimats han de ser socis (art. 31.4 de la LCoop), ni l'omissió de tota menció a la possibilitat d'assistència a l'assemblea de persones no sòcies, semblen ser l'origen de la limitació actual del col-lectiu de legitimats, almenys en la major part dels casos. Perquè, com ja hem vist, els associats i els interventors temporals han desaparegut de la norma cooperativa estatal nova, mentre que els membres del consell rector (socis o no) i els interventors tenen legitimació expressa i diferent a la dels socis sense càrrec, com veurem més endavant.

Són els supòsits dels membres de la direcció i del comissari del sindicat d'obligacionistes els que plantegen més dubtes, perquè, en alguns casos, poden assistir a l'assemblea general encara que no tinguen la condició de socis.

En relació amb la direcció de la cooperativa, encara que la LCoop haja suprimit tota menció a la possibilitat que s'autoritze l'assistència a l'assemblea de persones no sòcies, d'altres omissions de l'esmentat text legal semblen afavorirne la participació en la reunió, encara que només siga per tal de presentar la informació necessària per al desenvolupament de l'ordre del dia, o per retre comptes de la seua actuació.

En efecte, la LGC establia una reserva de facultats que el consell rector no podia delegar en el director, entre les quals es trobaven la fixació de les directrius generals de la gestió de la cooperativa, "amb subjecció a la política general establerta en l'assemblea general, i la presentació a l'assemblea general de la rendició de comptes, la proposta d'imputació i d'assignació de resultats i la memòria explicativa de la gestió de l'exercici econòmic". Amb la promulgació 
de la LCoop, el consell rector pot conferir apoderaments a qualsevol persona, "les facultats representatives de gestió o de direcció de la qual s'establiran en l'escriptura de poder" (art. 32.3), sense que s'indique cap tipus de limitació quant al contingut de les facultats que poden ser delegades. Això significa que, a partir d'ara, en molts casos, podran ser els membres de la direcció els qui presenten directament a l'assemblea les seues directrius generals de gestió, i també els qui reten comptes sobre els resultats de l'exercici econòmic anterior $i$ proposen la seua assignació ${ }^{122}$.

Quant al comissari del sindicat d'obligacionistes d'una cooperativa que haja emès obligacions, com ja hem vist, la seua legislació aplicable és, en l'actualitat, el Text refós de la llei de societats anònimes (art. 295-305) ${ }^{1223}$. En virtut de la seua aplicació, el comissari, "a més de les facultats que li hagen estat conferides en l'escriptura d'emissió i les que li atribuïsca l'assemblea general d'obligacionistes, tindrà la representació legal del sindicat i podrà exercitar les accions que a aquest corresponen" (art. 303.1) ${ }^{1224}$.

1222 No obstant això, una interpretació estricta de l'article 20 de la LCoop podria portar a la impugnació de l'assemblea en la qual fóra present el no soci, com indica SUSO VIDAL, J. M., «Funcionamiento orgánico...», op. cit., pàg. 51.

1223 Article 54 de la LCoop: "1. Les cooperatives, per acord de l'assemblea general, podran emetre obligacions el règim de les quals s'ajustarà al que es dispose en la legislació aplicable...". Article 56.3 de la LCCV: "L'assemblea general pot acordar qualsevol modalitat de finançament voluntari de la cooperativa pels seus socis i associats, que en cap cas integraran el capital social. Igualment, podrà emetre obligacions, sempre de caràcter no convertible en participacions socials, d'acord amb la legislació vigent".

La legislació aplicable vigent és la Llei 211/1964 de regulació de l'emissió d'obligacions per societats que no hagen adoptat la forma d'anònimes, associacions o altres persones jurídiques que, alhora (art. 12), reexpedeix al capítol X, "de les obligacions", de la LSA (articles 282-310) Vegeu els epígrafs 1.1.1.G. i) d'aquest mateix capítol i l'1.5 del capítol tercer.

1224 Ja hem vist, en incloure el comissari del sindicat d'obligacionistes entre els tercers legitimats per impugnar acords nuls, l'amplitud de facultats amb què aquell pot actuar. Així, entre les accions que el comissari pot exercir en el compliment de les seues funcions, es troben les que siguen necessàries per a "la defensa més adequada dels interessos legítims dels obligacionistes" (art. 300). A més, el comissari serà "l'òrgan de relació entre la societat i el sindicat $i$, com a tal, podrà assistir, amb veu i sense vot, a les deliberacions de la junta general de la societat emissora" (art. 301.2), i "en general, tutelarà els interessos comuns dels obligacionistes" (art. 303.3). Finalment, els articles 304 i 305 li reconeixen altres facultats en defensa dels interessos del sindicat per a supòsits concrets, en els quals pot arribar, per exemple, a assistir, amb veu i sense vot, a les reunions del consell d'administració, "proposar al 
No obstant això, entenem que pel que fa a la impugnació d'acords anul·lables, ni la mera assistència a l'assemblea en la qual s'haja adoptat l'acord, ni l'exercici de la representació de tercers no socis, constitueixen motiu suficient de legitimació. Quant a l'assistència, ja hem vist que la LCoop, que podia haver mantingut l'al-lusió àmplia de la LGC (art. 52.3) als assistents, ha especificat que els legitimats són els socis assistents (art. 31.4); es limita, amb això, l'atribució de la facultat d'impugnar els acords anul-lables a l'àmbit del colllectiu de socis, i només amb caràcter excepcional, se'l pot entendre ampliat. I com ja hem indicat, el fet que la llei atribuïsca, a determinats subjectes o col-lectius, un dret (ara, el d'assistència a l'assemblea; en d'altres casos, per exemple, el de: vot), no significa, necessàriament, que la facultat d'impugnació haja d'acompanyar-lo, ja que no estem davant $d^{\prime}$ un dret instrumental ${ }^{1225}$.

Quant a l'exercici de la representació dels obligacionistes pel comissari del seu sindicat, $\mathrm{s}^{\prime}$ ha de considerar que si bé la LSA atribueix al comissari unes facultats que, en alguns casos, efectivament, presenten un caràcter extraordinari, no per això deixen de tenir el seu origen en una relació de representació en la qual els representats, els obligacionistes, són tercers no socis, col-lectiu que no disposa de la legitimació per a la impugnació d'acords merament anul-lables. I el representant no pot exercir una facultat que no posseeix el representat; no,

consell la suspensió de qualsevol dels administradors i convocar la junta general d'accionistes, si aquells no ho feren, quan crega que han de ser substituits".

1225 RUBiO, J., Curso..., op. cit., pàg. 259: “Sol assenyalar-se que el dret d'impugnació es preveu en connexió íntima amb el dret de vot com a complement d'aquest en la seua funció d'integrar la voluntat social. Però ha de tenir-se en compte que, si bé ambdós drets formen part dels mateixos poders - els de caràcter polític o administratiu, el nucli fonamental dels quals el constitueix el de vot-, poden, en casos excepcionals, seguir una destinació diferent. Qui per precepte estatutari [...] no pot assistir a la junta ni exercitar-hi el dret de vot, conserva, tanmateix, acció per a la defensa irrenunciable de la seua posició d'accionista. En sentit ampli, pot equiparar-se [...] als accionistes absents. També, per això, assisteix el dret d'impugnació aquells socis la condició dels quals roman intacta, encara que eventualment es troben privats de l'exercici ple del dret de vot". Sobre els supòsits de conflicte d'interessos, que només generen deure d'abstenció en l'exercici del vot, no respecte de l'exercici d'altres drets socials, com ara el d'impugnació, vegeu infra, nota 192. 
almenys, sense un altre títol que la sustente ${ }^{1226}$.

Finalment, alguns exsocis gaudien, en la LGC, de legitimació legal expressa per a la impugnació, tant d'acords nuls com d'anul-lables: el soci expulsat, el declarat en situació de baixa obligatòria i el disconforme amb la qualificació i/o efectes de la baixa ${ }^{1227}$; la LCoop ha mantingut els tres supòsits ${ }^{1228}$. Aquestes legitimacions expresses de persones que han perdut la condició de soci no fan sinó reforçar la interpretació del fet que la LCoop reafirma la circumscripció de la legitimació davant acords anul.lables pel que fa a les persones sòcies que reunisquen, a més, els requisits legals previstos.

D'altra banda, la LCCV també legitima, explícitament, el conseller laboral (art. 36.5 en relació amb l'art. 38.4) i el soci expulsat (art. 18.2), i regula les figures dels interventors temporals i dels administradors provisionals (art. 109, a) i b)), la del comissari del sindicat d'obligacionistes (art. 56.3 en relació amb els art. 282-310 de la LSA), i la de director, no necessàriament soci (art. 43.4); persones que poden ser convidades (art. 31.4) o tenir dret a assistir a l'assemblea.

En relació amb el conseller laboral, s'ha de remetre el seu estudi a la legitimació que, per a tots els membres de l'òrgan d'administració, es preveu explícitament, i que adquireix característiques específiques; la legitimació expressa del soci

1226

l'apoderat queda facultat en els mateixentación..., op. cit., pàg. 259: "no hi ha dubte que DíEZ PICAZO, L. i GULLÓN, A., Instituciones en els quals ho estiga l'accionista-poderdant"; determinades són exigides per la llei per a la, vol. I, pàg. 357: "Quan unes qualitats personals ha estat realitzat per representació, podem validesa o eficàcia del negoci jurídic, si el negoci qüestió no ofereix massa dificultats quan discutir en quina persona han de concórrer. La negoci o requisits de la situació que el negocixes qüestions no són més que pressupòssit del persona del representat i no en la del crea. La qualitat en qüestió ha de concórrer en la mpugnación..., op. cit., pàg. 147: "ningú nol representant"; RODRígUEZ RUIZ DE VILLA, D., tular, cosa que és manifestació del clàssic pot atorgar la representació de drets dels quals no és

227 Articles 38.4, 33.2 i 32.4, respectivament, de la LGC

228

El del soci expulsat, article 18.5, en relació amb el 18.3, c), in fine; el del declarat en situació eaixa obligatòria, en l'article 17.5 i 17.6, en relació amb el 18.3, c), in fine; i el de qui, en haverdonat de baixa voluntàriament o per causa justificada, estiga disconforme amb la qualificació 
expulsat no mereix ací un comentari especial. Respecte de la figura de l'interventor temporal, ja hem vist, pel que fa a la seua legitimació possible davant els acords nuls, que, en tot cas, hauria de ser reconduïda a la dels tercers amb interès legítim, que no gaudeixen de legitimació per impugnar acords anul-lables. El mateix ocorre, com ja hem exposat, amb el comissari del sindicat d'obligacionistes. I quant a la direcció o a l'administració temporal de l'article 109 , b) de la LCCV, també s'han exposat les raons que ens porten a concloure que la mera assistència a l'assemblea general no seria títol suficient de legitimació davant acords anul-lables.

El fonament jurídic de la reducció sensible de l'àmbit de la legitimació davant els acords anul-lables s'ha de situar, segons el nostre parer, una vegada més, en la teoria de l'interès, ara en relació amb el principi d'autoregulació, que duria a la conclusió que les persones no sòcies no estarien legitimades, excepte en els supòsits expressament previstos (conseller laboral i soci expulsat), davant uns acords que vulneren, únicament, el pacte estatutari intern o els interessos derivats del contracte social.

Pel que fa a uns altres temes relacionats amb la qualitat de soci, alguns dubtes que es plantejaven per a la legitimació davant acords nuls podrien traslladar-se als supòsits d'acords anul-lables, i presentar, en alguns casos, solucions diverses. Així, en relació amb el període en què és necessari mantenir la qualitat de soci per a l'anul-labilitat, considerem que qui pretenga impugnar ha de ser soci des del moment de l'adopció de l'acord fins a, almenys, el de la interposició de l'acció. I això perquè, d'una banda, els requisits que es demanen al soci que vol impugnar un acord anul-lable (assistència a l'assemblea i oposició en l'acta, o absència, o privació il-legítima del vot) impliquen que ja en el moment d'adoptar l'acord posseïa aqueixa qualitat, i d'una altra, que els tercers no estan legitimats, amb caràcter general, davant acords anul-lables, amb la qual cosa s'ha de poder acreditar la condició de soci en iniciar el procediment judicial. 
Si qui era soci en el moment de l'adopció de l'acord anul-lable i reunia els requisits exigits per a la impugnació, perd posteriorment la condició de soci, pot donar lloc a diferents supòsits relacionats amb una legitimació possible per a la impugnació. En primer lloc, cal distingir si la pèrdua de la condició de soci s'ha produit abans o després d'interposar l'acció d'impugnació. Si encara no s'havia exercitat el dret, també poden produir-se supòsits diferents: si la pèrdua de la condició de soci es produeix per mort, ja hem vist en relació amb els acords nuls que la doctrina i la jurisprudència coincideixen a reconèixer legitimació tant a l'administrador de l'herència jacent com, si no n'hi ha, als hereus, per exercir l'acció a la qual el causant tenia dret; si l'acabament de la relació societària es produeix per qualsevol altra causa, l'exsoci passa a ser tercer que, com hem assenyalat reiteradament, no gaudeix de legitimació davant els acords anul-lables, llevat dels supòsits previstos expressament per la llei ${ }^{1229}$.

Els dubtes es plantegen quan el soci deixa de ser-ho després d'haver interposat l'acció d'impugnació. D'una banda, no podem entendre en l'àmbit d'acords anul-lables que la legitimació en qualitat de soci s'ha transformat en legitimació

1229 Vegeu supra, la referència als supòsits del soci expulsat (art. 18.5, en relació amb el 18.3, c), in fine de la LCoop; art. 18.2 LCCV), el del declarat en situació de baixa obligatòria (art. 17.5 i 17.6, en relació amb el 18.3, c), in fine de la LCoop) i el de qui en haver-se donat de baixa voluntàriament o per causa justificada estiga disconforme amb la qualificació i/o efectes que
l'assemblea li assigne (art. 17.6, en relació amb el 18.3, c), in fine, de la LCoop).

${ }^{153}$ GÓMEZ ORBANEJA, E., "El proceso...», op. cit., pàg. 127: "La qualitat d'accionista, per estar legitimat per a l'acció, ha de tenir-se tant en el moment de la junta com en el de la demanda, $i$ ha de durar fins a la conclusió del plet per a sentència. En perdre's durant la substanciació del procés, la decisió ha de desestimar la demanda, a falta d'acció"; RUBIO, J., Curso..., op. cit., pàg. 260 , en estimar que amb la condició de soci perd l'interès emparat, considera que no pot iniciar-se o, si escau, continuar el procediment. En la mateixa línia, RODRf́GUEZ RUIZ DE VILLA, D., Impugnación..., op. cit., pàg. 156, que al.ludeix també a altres opinions doctrinals (RUBIO, op. cit.; GÓMEZ ORBANEJA, op. cit.; BERGOS TEJERO, J. J., "Juicio especial de impugnación de acuerdos sociales", en Nueva enciclopedia jurídica, tom XIV, ed. Francisco Seix, Barcelona, 1978, on cita la STS de 17 de març de 1967 (RJA 1967/1524), "en la qual es va estimar la legitimació d'impugnant, a causa que aquest havia acreditat la seua condició d'accionista en el moment de l'adopció de l'acord; la Sala considera que si es volia acreditar que aquest havia perdut la seua condició entre aquell moment i el de presentació de la demanda, l'onus probandi requeia sobre la representació de la societat demandada, que hauria d'acreditar el fet impeditiu de la demanda". 
del tercer amb interès, però tampoc no podem afirmar, rotundament i en tot cas, que qui ha deixat de ser soci ha perdut l'interès legítim que sostenia la seua legitimació com a soci: ni ha d'haver desaparegut, necessàriament, l'interès individual que el movia a fer la impugnació (pensem, per exemple, en acords que perjudiquen els interessos econòmics de determinats socis), ni tampoc la defensa de l'interès social que fonamenta la legitimació deixa d'estar necessitada de consideració. Tanmateix, la doctrina, pel que fa a les societats anònimes, reitera la necessitat de mantenir la qualitat de soci fins a la conclusió del procediment ${ }^{1230}$.

D'altra banda, i segons el que s'ha exposat, tampoc pot admetre's la legitimació per a l'anul-labilitat de qui adquireix la condició de soci posteriorment a l'adopció de l'acord, ja que la llei exigeix que el soci complisca, a més, algunes condicions (assistent que haguera fet constar l'oposició, absent o il-legítimament privat del vot) que en cap cas podrà acreditar el soci nou.

Finalment, pel que fa a la legitimació de les categories especials de socis i a l'exercici del seu dret d'impugnació mitjançant representació, ens remetem a allò que s'exposa en la legitimació per a la impugnació d'acords nuls.

b) Els assistents que hagueren fet constar en l'acta la seua oposició

El Tribunal Suprem, encara que amb algunes vacil-lacions, exigeix amb rigor un requisit formal de legitimació consistent en el fet que el soci assistent a l'assemblea que pretenga impugnar l'acord anul-lable, faça constar la seua oposició en l'acta de la sessió, amb el compliment d'una sèrie d'aspectes de temps i de forma que després veurem. Aquesta trajectòria jurisprudencial ha estat criticada per la doctrina per ser excessivament rigorosa, respecte de socis que, moltes vegades, no coneixeran aquestes exigències, almenys en l'àmbit 
cooperatiu $^{1231}$.

A la recerca de raons que justifiquen aquest requisit formal per a l'atribució de legitimació, alguns autors opinen que l'exigència que es formule oposició i que es faça constar en l'acta aporta l'avantatge pràctic de fer saber als òrgans executius de la societat, que l'accionista es proposa impugnar; es tractaria, doncs, amb aquest requisit, de donar seguretat als acords socials: si els socis no s'han oposat, la societat ja no ha de témer accions d'impugnació per anul-labilitat ${ }^{1232}$. Aquest corrent doctrinal pot veure's reflectit en alguna sentència, com ara la de l'AP de Valladolid (Sala 3a), de 20 de setembre de 1997, en la qual s'afirma que "aquesta exigència està imposada per la llei per raons de seguretat jurídica i perquè la societat sempre sàpia si els acords que ha pres són ferms o, al contrari, seran impugnats, i per quina causa".

Davant aquesta opinió, uns altres autors argumenten que l'aplicació de la llei permet, per si mateixa, evitar la situació d'inseguretat o d'incertesa, en establir, d'una banda, que la sentència que, en aqueix cas, estime la impugnació, no afectarà els drets de tercers de bona fe, i d'una altra, que pot sol-licitar-se ja en la

1231 EMBID IRUJO, J. M., «Notas sobre la impugnación...» op. cit., pàg. 54: “es tracta d'un requisit que, en vista del rigor amb què s'exigeix pels nostres tribunals, no ha deixat de suscitar objeccions en la doctrina, ja que en realitat el precepte esmentat només requereix la

1232 Ávila Navarro, P., La sociedad..., op. cit., pàg. 429; García LuenGO, G. R. i Soto VÁZQUEZ, R., El nuevo régimen jurídico..., op. cit., pàg. 555; GOMEZ ORBANEJA, E., "El proceso...», op. cit., pàg. 127, si bé aquest autor adverteix que el requisit legitimador "es correspon "tampont [...] amb una legitimació estesa als accionistes que no hagen concorregut" i que mòbil de l'acord [ la naturalesa de la tercera causa d'impugnació, ja que siga el que siga el realitat, sembla que aquicilment podrà saber-se durant el transcurs de la junta general". En que sobre la marxa l'acci requisit pot generar més inseguretat, ja que "de vegades, serà difícil acord vulnera o no els estatuta mateix tinga els coneixements suficients com per saber si un difícil, lesiona els interessos socials en benefici pràctica és anunciar l'oposició a l'acord, després de la solució més clara que s'adopta en la demandarà o no. Això pot ser, en certa després de votar en contra i, després, pensar-se si es elements d'incertesa indesitjables, però és l'única seua acció d'impugnació, per causes d'anul. Impugnación..., op. cit., pàg. 158. 
mateixa demanda la suspensió de l'acord impugnat ${ }^{1233}$.

DUQUE ${ }^{1234}$ estima que "la ratio de la norma és evitar dificultats probatòries amb les quals el soci podria topar si volguera acudir als mitjans de prova ordinaris", i afegeix que "una altra explicació de la ratio de l'exigència, «fer saber als òrgans executius de la societat que l'accionista es proposa impugnar», és incongruent amb l'extensió de la legitimació per impugnar els accionistes que, encara que foren degudament convocats, no van assistir a la junta. Aquesta dificultat desapareix si considerem que el legislador va pensar que la prova de la noconcurrència a la formació de la voluntat social, en el cas de l'absent, no presentaria les dificultats que, possiblement, sorgirien per a la prova de la voluntat de l'assistent que vota en contra".

Altres autors s'han sumat a l'opinió de DUQUE, i han afegit alguns arguments que la corroboren. Així, s'indica que "quan la votació és secreta, resulta difícil conèixer si efectivament qui hi assisteix $i$ vota ho fa a favor o en contra, o diposita un vot en blanc"1235, i que "aquesta finalitat probatòria adquireix més sentit si es té en compte l'absència, en el nostre dret, d'una norma que establisca les dades de constància obligatòria en l'acta de la junta general ${ }^{\prime 2236}$.

Això no obstant, el debat ressenyat es desenvolupa per a les societats de capital, per la qual cosa convé efectuar-ne la translació, i adaptar-lo a les característiques de les cooperatives. Amb aquest objectiu, s'han de fer dues excepcions. D'una banda, la LCoop, tenint en compte la contradicció eventual de la constància en l'acta amb el desenvolupament secret de la votació, preveu

1233 SORIA FERRANDO, J. V., La legitimación activa..., pàg. 73 i 74.

1234 DUQue DOMÍNGUEZ, J. F., Tutela..., op. cit., pàg. 181 i 182.

1235 ARROYO, I., «Comentario al art. 56...» op. cit., pàg. 617; també critica les dificultats que aquest requisit planteja per als supòsits de votació secreta, SORIA FERRANDO, J. V., La legitimación activa..., pàg. 85 . 
la possibilitat alternativa que la manifestació es faça bé en l'acta de la sessió, bé "mitjançant document fefaent, lliurat dins de les 48 hores següents", i adverteix, expressament, que pot efectuar-se la manifestació de l'oposició "encara que la votació haguera estat secreta" (art. 31.4). La segona qüestió que cal tenir en compte és que tant la LCoop (art. 29) com la LCCV (art. 34) sí que especifiquen el contingut bàsic de l'acta de l'assemblea i hi inclouen la necessitat d'expressar les intervencions que s'haja sol-licitat que consten en l'acta i els resultats de la votació, encara que, efectivament, no exigeixen que es faça constar el sentit del vot de cada soci. Sembla, doncs, que també per a les cooperatives l'exigència al soci del fet que faça constar en l'acta la seua oposició, pot col-laborar a provar que va assistir ${ }^{1237}$ i no va votar a favor.

En tot cas, aquest requisit de fer constar en l'acta l'oposició ha estat durament criticat per la doctrina, ${ }^{1238}$ i s'ha estimat que l'actitud jurisprudencial, de rigor en l'exigència del seu compliment, no és encertada i constitueix una vertadera restricció al dret a la tutela judicial (art. 24 de la Constitució), la qual cosa no té cap justificació racional ${ }^{1239}$. S’ha assenyalat, a més, que col-loca els socis amb dret de vot en una situació especialment costosa i desfavorable pel que fa als que

1236

SORIA FERRANDO, J. V., La legitimación activa..., pàg. 74. En la mateixa línia, GARCÍA LUENGO, R. i SOTO VAZQUEZ, R., El nuevo régimen jurídico..., op. cit., pàg. 555.

1237 La prova de l'assist

inclusió del soci la llista d'assisé pot obtenir-se mitjançant la certificació del secretari de la art. 29, i LCCV, art. 34.1).

Vegeu, per tots, URÍA, R., MENÉNDEZ, A. i MUÑOZ, J. M., La junta..., op. cit., pàg. 351 i 352.

(RJA 1997/6016 aquesta interpretació, la STS (Sala 1a), de 14 de juliol de 1997, núm. 678/1997 en compte el rigor fro que, davant l'al-legació de la part recurrent que "encara que es tinga d'oblidar la tutela dels dista de la Llei de societats anònimes en aquest extrem, no s'ha estrictament formals, segon aquesta, per principi, no pot veure's desemparada per qüestions principi de tutela judicial efectivactrina reiterada del Tribunal Constitucional", i que "el interpretació restrictiva dels defectesticle 24 de la Constitució Espanyola obliga a una pronunciament de fons"; estima, tanes formals no substancials, que impedisquen un tanmateix, que "l'observança del requisit referent a «fer considerem la transcendència, no po l'acord" [...] és exigit de manera imperativa $i$, si en l'omissió a la dels supòsits previstos en la jut relegat a una simple formalitat ni equiparar-ne decantar per criteris contraris a un rigor formalistaencia del Tribunal Constitucional, que es va proclama l'article 24 de la Constitució". 
n'estan privats, perquè aquests estarien legitimats sempre: si no van assistir, per absents, i, si van assistir, pel sol fet de ser presents, mentre que els primers no en tindrien prou amb el fet haver-se oposat, votant contra l'acord. Així mateix, s'adverteix que presenta inconvenients veritables per a la seua realització efectiva en les entitats amb un col-lectiu de socis important ${ }^{1240}$.

\section{a') Moment de la constància de l'oposició}

Llevat d'alguna excepció, la jurisprudència del Tribunal Suprem ha reiterat la necessitat que la manifestació de l'oposició a l'acord que es pretén anul-lable es faça una vegada adoptat aquest, i no en cap moment anterior, abans o durant la reunió. Així, s'argumenta que "els dissidents no poden manifestar la seua voluntat d'oposar-se fins que es verifique el recompte de vots obtinguts i es proclame el resultat, ja que fins aqueix moment no hi ha acord al qual oposar$\mathrm{Se}^{\prime 1241}$.

1241 STS de 13 de juliol de 1992, citada per ÁvIlA NAVARRO, P., La sociedad..., op. cit., pàg. 428 : "sembla que no ens podem oposar a un acord que no ha estat adoptat encara, i així, mentre que algunes sentències (sentència de 10 de setembre de 1986, sentència de 20 de desembre de 1986, sentència de 22 de desembre de 1986, sentència de 15 de juny de 1987, sentència de 30 de novembre de 1987, sentència de 15 d'abril de 1988 i sentència de 22 de juny de 1988) no donen el valor d'oposició a la manifestació davant notari que el soci s'oposa, per endavant, als acords que s'adoptaran, alguna altra (sentència d'11 de novembre de 1988) admet l'oposició prèvia davant notari, sobre els acords que s'adoptaran en favor dels punts continguts en l'ordre del dia". També SORIA FERRANDO, J. V., La legitimación activa..., pàg. 84 , que cita la sentència de 30 de gener de 1976, en la qual s'adverteix que l'acord no existeix: "mentre no es verifique el recompte dels vots obtinguts, i siga proclamat el resultat de la votació, [...] els dissidents han de manifestar, posteriorment a aquests moments, en els quals l'acord es perfecciona o adquireix consistència jurídica, la seua voluntat d'oposar-s'hi". RODRfGUEZ RUIZ DE VILLA, D., Impugnación..., op. cit., pàg. 159, cita la STS de 13 de novembre de 1989 (RJA 1989/7874), en la qual s'afirma que l'acord "naix en el moment en què, acabada la votació sobre un extrem sotmès a resolució, el còmput de vots emesos dóna un resultat favorable al que, fins a aquest moment, era una proposta, i és aleshores que queda adoptat l'acord i que cal que el soci que s'hi opose faça constar la seua oposició". En contra d'aquesta interpretació, URíA, R., MENÉNDEZ, A. i MuÑoz, J. M., La junta..., op. cit., pàg. 352: "No pot compartir-se, en efecte, l'argument, estrictament formalista, que l'oposició només pot produir-se després que l'acord ha estat pres, perquè l'oposició naix, i només pot nàixer, del vot en contra, de l'oposició al fet que es prenga l'acord. Per la qual cosa, no té més sentit exigir que qui s'ha oposat a l'adopció de l'acord, de l'única manera que cap oposar-se, votant en contra, haja de tornar a reiterar la seua disconformitat amb la decisió dels altres. Aquest requisit addicional no l'exigeix la llei. La llei 
No hi ha cap dubte de la congruència d'aquesta interpretació jurisprudencial: fins al moment de la votació els termes de l'acord poden variar, i poden, fins i tot, desaparèixer els motius possibles d'impugnació, i durant la votació ja no és possible fer cap altra manifestació diferent a la relativa al sentit del vot. En relació amb això, s'ha de recordar que la LGC requeria que els assistents hagueren fet constar (...) el seu vot contra l'acord adoptat, amb la qual cosa semblava corroborar la necessitat que l'acord ja s'haguera perfeccionat. La LCoop ha suprimit aquesta menció; tanmateix, la inclusió de la possibilitat de manifestar l'oposició fins a 48 hores després de celebrada l'assemblea, així com la mateixa redacció del text ("... que hagueren fet constar (...) la seua oposició a l'acord, encara que la votació haguera estat secreta) semblen indicar que, efectivament, el legislador pensava en una oposició posterior al moment de la votació.

No obstant això, aquesta exigència pareix ignorar el dret del soci a delegar el seu vot i l'obligatorietat que recau sobre l'òrgan d'administració d'expressar amb claredat i amb precisió els assumptes que componen l'ordre del dia, institucions previstes per garantir, entre altres qüestions, que el soci puga formar-se una opinió prèvia $i$, en conseqüència, decidir si assisteix o no a la reunió i si delega o no el seu vot; pot, fins i tot, efectuar mandats concrets de $\operatorname{vot}^{1242}$. El soci que, en vista de l'ordre del dia, decidisca delegar el seu vot, haurà

només demana que conste en l'acta l'oposició i si aquesta oposició és demostrada amb el vot contrari, no es pot anar més enllà del que el bon sentit i el tenor mateix de la norma demana".

En tot cas, la jurisprudència més recent reitera la necessitat que "l'oposició ha de recaure sobre l'acord, no sobre la proposta o sobre l'aprovació de l'assumpte fixat en els punts de l'ordre del dia", com assenyala la STS (Sala 1a) de 14 de juliol de 1997, núm. 678/1997 (RJA 1997/ 6016 i 5470), davant la pretensió del recurrent que es reconeguera la consignació en l'acta de la seua dissidència, pel fet que "la votació va ser nominativa, i els accionistes que van votar a favor, representaven el $71,7 \%$ del capital social, mentre que els que, posteriorment, van votar en contra, quan l'acord ja estava aprovat, entre els quals es trobava la recurrent, representaven el $21,24 \%$ del capital social".

1242 STS (Sala 1a) de 17 de maig de 1995, núm. 451/1995 (RJA 1995/3924): "l'anunci de la junta ha d'expressar tots els assumptes que s'hi han de tractar i ha de ser bastant informatiu com per consentir als socis la intervenció en les discussions i en les votacions, amb una preparació suficient $i$ que no siguen sorpresos amb deliberacions sobre punts que no hi havia motiu per pensar que es tractarien". També cita jurisprudència abundant relativa a la necessitat de 
de valorar, a més, si resulta convenient als seus interessos instruir el seu representant perquè, eventualment, formule, en el seu nom, l'oposició corresponent, ja que el soci representat és, al cap i a la fi, un soci assistent ${ }^{1243}$. Això no obstant, més enllà de l'opinió que considera que la relació jurídica subjacent entre representat i representant implica que aquest té la mateixa facultat que aquell per fer constar en l'acta l'oposició, sense necessitat $\mathrm{d}^{\prime}$ apoderament exprés ${ }^{1244}$, no hi ha cap dubte que la possibilitat introduïda per la LCoop (art. 31.4) de fer constar l'oposició després de la realització de l'assemblea, facilita al soci representat que siga ell mateix qui ho faça ${ }^{1245}$.

Com a excepció a la necessitat de manifestar l'oposició posteriorment a l'adopció de l'acord, es troben els supòsits en els quals l'anul-labilitat puga provenir no ja del contingut dels acords, sinó de la irregularitat en la realització mateix de l'assemblea. En aquests casos, la jurisprudència del Tribunal Suprem exigeix, en l'àmbit de les societats de capital, que l'oposició es manifeste a l'inici de la sessió ${ }^{1246}$, encara que les seues normes reguladores no recullen, de manera

claredat i de detall en l'ordre del dia SORIA FERRANDO, J. V., La impugnación...., op. cit., pàg. 176 a 182.

1243 A aquest efecte, en els còmputs basats en el nombre d'assistents o de votants, es fa referència als "presents o representats". Així, per al còmput de quòrums de constitució de l'assemblea (LCoop, art. 25.1; LCCV, art. 31.1), de les majories (LCoop, art. 28.2, per a les qualificades; LCCV, art. 32.4 i 5), i de drets de minoria (p. ex., LCoop, art. 25.3; LCCV, art. 32.3).

1244 RONCERO SÁNCHEZ, A., La representación..., op. cit., pàg. 259: "no hi ha dubte que l'apoderat està facultat en els mateixos termes en què ho estiga l'accionista-poderdant, tant per formular propostes d'acord, com per fer constar en l'acta l'oposició a un acord".

1245 MORILlas JARILlo, M. J. i Feliú REY, M. I., Curso de cooperativas, op. cit., pàg. 257 i 258 , consideren que el còmput de les 48 hores ha de fer-se a partir del moment en què s'alça la sessió.

1246 EMBID IRUJO, J. M., "Notas sobre la impugnación...», op. cit., pàg. 52: "Pot continuar considerant-se vàlida, per això, la distinció entre aquells acords la invalidesa dels quals siga resultat de vicis del procés mateix de la seua adopció per la junta i aquells altres nuls o anul-lables per raó del seu contingut. L'amplitud del primer enunciat ha permès parlar als tribunals, de vegades, de la incidència del vici de l'acord en la validesa de la junta. Per evitar la invalidesa de totes les actuacions que s'hi ha fet, a causa d'aquest criteri, els tribunals mateixos han exigit a l'accionista que impugna que advertisca els defectes de convocatòria, de constitució o de quòrum, entre altres extrems, al començament de la junta".

En el mateix sentit, SORIA FERRANDO, J. V., La legitimación activa..., pàg. 81 a 83: qui manifesta el seu acord amb "la conveniència que, quan es vulneren preceptes que tutelen la convocatòria regular $i$ 
expressa, aquesta exigència.

En l'àmbit cooperatiu, la LGC sí que expressava la necessitat de manifestar l'oposició a la realització de l'assemblea, encara que només per als acords de l'assemblea i sense indicar que s'haguera de formular, necessàriament, al seu inici ${ }^{1247}$. La LCoop, tanmateix, ha suprimit aquesta menció, i la LCCV tampoc indica la necessitat d'oposar-se a la realització de l'assemblea. En tot cas, encara sense referència expressa, el que és cert és que sembla que el deure de fidelitat del soci l'ha de portar a advertir l'assemblea dels vicis invalidants possibles, amb la finalitat de fer tots els possibles per tal d'evitar-losho ${ }^{1248}$.

Els supòsits en els quals la constància de l'oposició s'ha de fer amb anticipació

la constitució de la junta general, l'accionista dissident faça constar en l'acta la seua oposició a l'inici de la sessió, amb la finalitat d'evitar la realització d'una junta ineficaç des del seu començament". Aquest autor cita, també, algunes sentències (pàg. 80 i 81): "el Tribunal Suprem ha entès que complia amb aquest requisit l'accionista que va expressar, en ser oberta la sessió, que la junta que es realitzava no es podia verificar, perquè s'havia infringit, en els anuncis de la convocatòria, [...] la Llei de societats anònimes i, a més, va fer l'advertiment que si s'insistia en la seua realització, els acords serien impugnats per ell [sentència de 13 d'octubre de 1961][...]". Entre la jurisprudència menor mereix destacar-se la sentència de 5 d'octubre de 1967 de l'Audiència Territorial d'Oviedo, que va manifestar que l'impugnant havia complert aquest requisit, ja que s'havia reservat el dret a impugnar la totalitat dels acords i, sobretot, per l'afirmació explícita i terminant feta per aquell, com a qüestió prèvia, que la Junta no havia estat legalment convocada per no haver estat decidida la seua realització pel consell d'administració de la societat, "la qual cosa, inequívocament, revela la seua actitud disconforme".

També podeu veure CARBAJO CASCÓN, F., Los requisitos..., op. cit., pàg. 40; GARCÍA LUENGO, R. i SOTO VÁZQUEZ, R., El nuevo régimen jurídico..., op. cit., pàg. 551, i RODRígUEZ RUIZ DE VILLA, D., Impugnación..., op. cit., pàg. 163 i 173, on tots citen jurisprudència.

1247 "Estan legitimats per a l'exercici de les accions d'impugnació dels acords nuls o anul-lables els assistents a l'assemblea que hagueren fet constar en l'acta l'oposició a la seua realització..." (LGC, art. 52.3); als acords del consell, tanmateix, no feia cap referència.

En relació amb això, la STS (Sala 1a) de 3 de maig de 1994, núm. 416/1994 (RJA 1994/3559) declara plenament aplicables les sentències del TS de la mateixa sala, de 13 d'octubre de 1961 (RJA 1961/3297), de 23 de novembre de 1970 (RJA 1970/4885) i de 30 d'abril de 1988 (RJA 1961/3329); aquesta última explicita la tesi jurisprudencial que "si s'adverteix, al principi de la sessió, que la reunió que es realitzava no es podia verificar per les causes esmentades, i s'absté després en les votacions, és clar que, amb l'admonició formulada que si s'insisteix en la realització, impugnaria els acords, aquests eren afectats pel vici de nul-litat anunciat, sense que fóra necessari que sobre ells, ni totalment ni particularment en cada un, es fera constar la protesta per qui feia ja saber el defecte en el qual s'havia incorregut". Tanmateix, la STS esmentada de 3 de maig de 1994, RJA 3559, en sintetitzar perfectament la interpretació jurisprudencial que ara s'analitza, incorre, al nostre entendre, en error, en aplicar-la a un supòsit no ja d'acord anul-lable, sinó d'acord nul, com la sentència mateixa el qualifica, per vulneració de norma imperativa relativa als requisits de la convocatòria. 
són aquells en els quals els vicis són de caràcter formal, no relatius al contingut de l'assumpte debatut; allò anul-lable en aquests casos no és l'assumpte que es decideix, sinó la manera com es decideix. Però, pel que fa al moment idoni per manifestar l'oposició, entenem que cal distingir els vicis que puguen invalidar la totalitat dels acords de l'assemblea (aquells que afecten la convocatòria ${ }^{1249}$, quòrum i constitució), d'aquells altres que només afecten determinats acords (així, per exemple, la participació en la votació de socis que no poden intervenir, com el soci en conflicte d'interès per mandat estatutari) ${ }^{1250}$. En aquests últims casos estimem que l'anticipació a l'oposició no ha de situar-se, exclusivament, al començament de la sessió, ja que el vici no invalida la totalitat dels acords, $\mathrm{i}$ en alguns supòsits només adquirirà sentit l'advertiment respecte als assumptes que puguen ser afectats ${ }^{1251}$.

\section{$b^{\prime}$ ) Forma de la constància de l'oposició}

1249 STS (Sala $1^{\text {å }}$ ) de 17 de maig de 1995, núm. 451/1995 (RJA 1995/3924): “els vicis de convocatòria hauran de ser denunciats en obrir-se la sessió de la junta (sentències, entre altres, de 29 de setembre de 1971 [RJA 1971/3676], de 12 de maig de 1976 [RJA 1976/2040] i de 4 maig de 1978 [RJA 1978/1639])".

1250 Article 26.8 de la LCoop: "Els estatuts establiran els supòsits en els quals el soci haja d'abstenir-se de votar, per trobar-se en conflicte d'interessos; s'inclourà, en tot cas, aquells previstos en la Llei de societats de responsabilitat limitada"; això no obstant, s'ha de tenir en compte que la referència a la inclusió necessària en els estatuts dels supòsits de conflicte d'interessos de la LSRL converteix els acords resultants de la vulneració d'aquests supòsits LSRL en nuls, no en anul-lables. És el cas, també, del supòsit previst tant en l'article 42.1 de la LCoop com en l'article 44.1 de la LCCV, de conflicte d'interessos entre la cooperativa i els membres del consell, de la intervenció (LCoop) o de la direcció (LCCV), o els seus parents pròxims, ja que la vulneració d'un text legal és motiu de nul-litat.

En tot cas, això no ha de confondre's amb el supòsit de l'article 42.2 de la LCoop, que preveu que els actes, contractes i operacions realitzats entre la cooperativa i qualsevol conseller o interventor, o parents pròxims, sense l'autorització de l'assemblea, també "seran anul-lables", però ací per mandat legal exprés; l'apartat 2 de l'article 42 de la LCoop no es refereix a un acord en el qual haja intervingut un soci en conflicte d'interessos, sinó a un acte o a un negoci jurídic que s'ha realitzat sense l'autorització corresponent de l'assemblea: allò que és anul-lable és l'acte o el negoci jurídics, no un acord inexistent.

Vegeu supra epígraf 2.2.1 del capítol II.

1251 RODRíGUeZ RUIZ DE VILLA, D., Impugnación..., op. cit., pàg. 164: “En tot cas, és evident que no serà necessària la formulació de l'oposició al principi de la junta quan s'impugnen acords 
Pel que fa a la forma que haja d'adoptar la constància de l'oposició, la jurisprudència majoritària afirma que no és suficient que s'haja votat contra l'acord. Així, "la votació en contra no equival a la declaració formal i expressa d'impugnar l'acord, que ha de constar en l'acta de la junta. Una vegada consumat l'acord, que no es produeix sinó després de la votació, s'ha de manifestar la voluntat inequívoca d'impugnar ${ }^{\prime \prime 252}$. És per això que tampoc es considera suficient l'abandonament de la reunión ${ }^{1253} \mathrm{ni}$ la sol-licitud expressa que es faça constar en l'acta el vot negatiu davant l'acord, sense "expressió clara de

independents [nota 78: vegeu la sentència de la Sala 1a del Tribunal Suprem de 28 de gener de
1984 (RJA 1984, 390)].

1252 30 d'abril de 1988; de 22 de juny de 1989 , op. cit., pàg. 617 i 618, cita les sentències del TS de seleccionat en URÍA, MENÉNDEZ i MUÑ 1 de 2 de gener de 1990, i el "repertori abundant del Tribunal Suprem perquè posa inclou una referència notable de en perill el principi de la tutela judicial efectiva". També hi op. cit., i cita, literalment, entre sentències del TS RODRfGUEZ RUIZ DE VILLA, D., Impugnación.... cert que la llei no exigeix cap fórmes, la de 13 de novembre de 1989 (RJA 1989/7874): "si bé és sí que ha de constar de manera prou clara inada per expressar la disconformitat amb l'acord, simple expressió de l'aprovació de l'acta, amb es pot reputar bastant amb aquest objectiu la expressió del motiu que els porta a oposar-se at en contra del recurrent o recurrents, sense interpreta amb rigor aquest requisit, exigite a l'aprovació esmentada [...]. La jurisprudència normal de les persones socials puga quedar pel legislador per impedir que el funcionament l'expressió de la voluntat d'impugnar, que a la mercè injustificada de les accions pel que fa a perfecciona l'acord i en tenen coneixement de constar clarament des del moment en què es seguretat social i dels acords mateix [... els accionistes assistents a la junta, en benefici de la requereix no sols la constància de l'opo. La viabilitat de la impugnació dels acords socials desacord amb la voluntat majoritària, sinó l'ó, en el sentit de salvar el seu vot qui estiga en es formalitzarà oposició". En el mateix sentit Ávició expressa i formal a aquest, indicativa que 428 , on cita les sentències del TS de 4 de novit, ÁVILA NAVARRO, P., La sociedad..., op. cit., pàg. 4 de novembre de 1980,13 de novembre de 1989 i 30 de Mús recentment, la STS, Sala 1a, núm. 678/1997, RJA 1997/6061 ha sintetitzat la doctrina manera tan inequívoca, que "la declaració de voluntat d'oposar-se ha de ser manifestada de de l'acord, ja que, com és lògic, només quan el rubstituïda pel fet de la votació prèvia en contra que el soci dissident formule la seua oposició".

1253

Ávila NAvarro, P., La sociedad... l'abandonament de la junta (vegeu les sente, op. cit., pàg. 428: "Tampoc no és suficient amb respecte de si l'abandonament de la reunió hies de 3 de març de 1989 i d'11 de maig de 1989)", d'oposició a l'acord que es pretén adoptar ha de considerar-se com a manifestació implícita absentència ARROYO, I., "Comentario al art. 56...» op. cit., pàg. 618: "cas de la negativa a explicar el vot a 1989)"
(Iicitud del president, de qui s'absenta arribat el moment de la votació (STS de 3 març de 
la voluntat d'impugnar-1o ${ }^{\prime 1254}$. En aquesta línia jurisprudencial, alguna sentència més rigorosa ha arribat a exigir que s'expressen els motius que porten a oposar-se a l'aprovacióo ${ }^{1255}$.

Però no sols la doctrina ha criticat reiteradament el rigor excessiu d'aquesta interpretació doctrinal, sinó que poden trobar-se sentències del Tribunal Suprem en les quals el criteri és més permissiu i menys formal ${ }^{1256}$. En tot cas, l'alt tribunal ha manifestat que l'oposició no ha de subjectar-se, necessàriament, a determinades fórmules sacramentals ${ }^{1257}$.

1254 URÍA, R., MENÉNDEZ, A. i MUÑoz, J. M., La junta..., op. cit., pàg. 351. En la mateixa línia, GARCÍA LUENGO, R. i SOTO VÁZQUEZ, R., El Nuevo régimen jurídico..., op. cit., pàg. 556 i 557, citen la STS de 13 de novembre de 1989. Podeu veure també les sentències del TS de 29 de novembre de 1985 i de 22 de desembre de 1986.

1255 Podeu veure la sentència de l'AP de Valladolid (Sala 3a), de 20 de setembre de 1997, que cita les sentències del TS de 30 de novembre de 1970, de 27 d'abril de 1973 i de 19 de gener de 1974. MUÑOZ VIDAL, A. B., El proceso..., op. cit., pàg. 41, també es refereix a la STS de 19 de gener de 1974.

1256 ARROYO, I., "Comentario al art. 56...», op. cit., pàg. 617 i 618: "no falten casos d'una permissivitat més gran que declaren vàlida l'oposició en un requeriment notarial previ a la realització de l'assemblea (STS d'11 de novembre de 1978) i aquell anterior en el qual va considerar suficient la constància del nom del dissident, sense que s'acreditara la manera de manifestar l'oposició (sentència del TS de 31 de gener de 1972)".

SORIA FERRANDO, J. V., La legitimación activa..., pàg. 78 a 81: "en algunes ocasions el Tribunal Suprem ha concedit la legitimació activa al soci que simplement va votar en contra de l'acord impugnat. Així, la sentència de 28 de setembre de 1970 [...]. En termes semblants es pronuncien les sentències de 14 de febrer de 1967 de l'Audiència Territorial de València i de 16 de març de 1972 de l'Audiència Territorial de Barcelona [...]. També ha estimat [el TS], en la sentència de 10 de maig de 1967, que l'impugnant va complir aquest requisit amb la presentació d'un escrit "el duplicat del qual va firmar el secretari de l'entitat $i$ al qual es refereix l'acta de la junta, en consignar-se que presenta un escrit del qual se li lliura còpia i on, entre altres coses, impugna el tancament del balanç [CLJC, 1967, sentència núm. 328]. [...] Entre la jurisprudència menor mereix assenyalar-se que per a [...] l'Audiència Territorial de Barcelona, en la sentència de 23 de febrer de 1965, està legitimat l'accionista que va votar en contra, però no va fer constar en l'acta la seua oposició, ja que "... partint d'un criteri ampli de la interpretació del precepte i considerant la finalitat d'aquest, [...] l'exigència poguera referir-se a l'oposició respecte a la matèria que és objecte de l'acord, i no a aquest en sentit formal, i que fóra acceptable, que en qualsevol forma en la qual es manifeste l'oposició de l'accionista, ja siga mitjançant l'emissió del vot en contra [...], mentre apareguera clarament la persona que el va emetre, $[. .$.$] ja era suficient$ per a la impugnació [...]".

1257 STS, Sala 1a, de 18 de setembre de 1998, núm. 825/1998 (RJA 1998/6545): “No és suficient votar en contra d'aquest, ni perdre una votació. Ha de constar en l'acta l'oposició a l'acord, si bé no cal que conste literalment, com si fóra una fórmula sacramental, sinó que és suficient que conste $i$ així ha succeït en aquest cas, en què la sentència d'instància diu literalment que «sí que consta en l'acta la voluntat explícita i clara d'oposar-se a l'acord", la qual cosa es dedueix 
Una altra doctrina i jurisprudència va més enllà en la simplificació del requisit, i estiman que la constància de l'oposició no exigeix ni la manifestació d'una declaració especial, qualificada mitjançant la incorporació al vot contrari del motiu d'aquest o de la causa d'oposició, ni l'anunci de la intenció d'interposar, posteriorment, demanda d'impugnació: “Si l'oposició ha estat ja reflectida, espontàniament, pels redactors de l'acta, el pressupòsit legal al qual es condiciona l'exercici del poder d'impugnació ha estat acomplert, ja que (...) la ratio de la norma és evitar dificultats probatòries amb què el soci podria toparse si volguera acudir als mitjans de prova ordinaris"1258.

D'altra banda, la legislació cooperativa no preveu procediments que garantisquen el compliment de l'obligatorietat del secretari de fer constar en l'acta les intervencions dels socis ${ }^{1259}$. Davant l'eventualitat que l'expressió

correctament de l'acta de la junta general [...] ja que l'espòs de la demandant, [...] actuant en nom d'aquesta, després de perdre la votació, fa una sèrie de manifestacions que indiquen D'altres sentències en les quals el Tribunal Suprem manifesta la indiferència de la forma de l'oposició són les de 12 de juliol de 1983 (RJA 1983/4212), de 25 de novembre de 1985 (RJA 1985/5987), de 29 de novembre de 1985 (RJA 1985/5913), de 19 de setembre de 1986 (RJA 1986/4715), i de 15 d'abril de 1988 (RJA 1988/3149).

Ávila NAVARRO, P., La sociedad..., op. cit., pàg. 428 i 429, “segons la sentència de 7 d'octubre de 1991 , pot ser equivalent a l'oposició la reserva d'accions impugnadores d'un acord social
determinat...".

1258 DuQue DomíngueZ, J. F., Tutela..., op. cit., pàg. 181. MUÑOZ VIDAL, A. B., El proceso..., op. cit., pàg. 41, cita les sentències del TS de 31 de gener de 1972 i de 20 de febrer de 1968. En el mateix sentit, SORIA FERRANDO, J. V., La legitimación activa..., pàg. 81: "sembla innecessari $\mathrm{i}$ mancat de sentit exigir a l'accionista dissident que inste que conste en l'acta la seua oposició a l'acord, quan la seua dissidència ja apareix reflectida en l'acta"; en les pàg. 79 i 80 cita també la sentència del Tribunal Suprem de 31 de gener de 1972, que considera que "...quan en l'acta consta el nom de dissident o dissidents, cada un d'ells ha d'estimar-se, ja que la llei no especifica cap forma concreta de manifestar-se l'oposició, que ha complert amb aquest requisit
previ a l'exercici de l'acció".

1259

Es preveu únicament, entre els continguts de l'acta de la sessió, la incorporació de les intervencions que els interessats hagen sol-licitat que consten (LCoop., art. 29.1, i LCCV, art. 34.1), però no es preveu cap procediment per garantir-ne el compliment, ni per demanar la correcció de l'acta on s'incomplisca, totalment o parcialment, la constància reclamada. Només es regula, com a mesura preventiva, i sempre que s'actue amb l'antelació necessària, i que es tinga, almenys, el suport d'una minoria rellevant (del 10\%, segons la LCoop; del 5\%, segons la LCCV), la possibilitat de sol-licitar la presència d'un notari perquè siga ell qui alce acta; en un altre cas, ROJO FERNÁNDEZ-Río, Á., "El derecho...», op. cit., pàg. 1138, arriba a aconsellar als socis que ponderen l'alternativa de no acudir a la junta, a fi de legitimar-se com a absents. 
d'oposició a l'acord no siga recollida, o que no ho siga amb la suficient fidelitat, seria desitjable, de lege ferenda, la incorporació de normes com la prevista en l'article 97.1,7è, del $\mathrm{RRM}^{1260}$, o en l'article 27.2 de la LRJAPPAC ${ }^{1261}$, que permeten al soci fer constar en l'acta la seua oposició i, fins i tot, presentar per escrit la redacció que proposa per a la constància de la seua intervenció. En tot cas, a falta d'aquestes previsions normatives, donem suport a l'opinió que "ha d'entendre's legitimat per impugnar el soci que vota en contra, però la presidència o la secretaria de la junta li neguen el dret a mostrar en l'acta la seua oposició" ${ }^{1262}$.

\section{c') Oposició o vot negatiu?}

La doctrina ha debatut, en l'àmbit de les societats de capital, quina és la dissidència exigida i, en especial, si l'accionista que es va oposar en l'acta i que es va abstenir de votar, o va votar en blanc, o va emetre un vot nul, pot considerar-se inclòs en el concepte d'accionista dissident o si, al contrari, pertany al grup d'accionistes que van acceptar l'acord adoptat.

SORIA FERRANDO, que dedica un espai ampli a l'anàlisi d'aquesta qüestió,

L'absència de previsió normativa en aquesta matèria és pregona; anteriorment, el reglament de desenvolupament de la LGC de 1974 (art. 54.2) sí que recollia el dret del soci a manifestar, en l'assemblea, la seua oposició "a l'efecte de poder impugnar l'acord", si bé, com assenyalava VICENT CHULIÁ ("El derecho de los órganos...», op. cit., pàg. 525 i 526), això s'"hauria d'haver completat amb el reconeixement del dret que l'oposició conste o s'incorpore a l'acta de la sessió".

1260 Article 97.1, 7è, 2n par. del RRM: “... sempre que ho sol-licite qui haja votat en contra, es farà constar l'oposició als acords adoptats".

1261 Article 27.2 de la LRJAPPAC: "En l'acta figurarà, per sol-licitud dels respectius membres de l'òrgan, el vot contrari a l'acord adoptat, la seua abstenció i els motius que la justifiquen o el sentit del seu vot favorable. Així mateix, qualsevol membre té dret a sol-licitar la transcripció íntegra de la seua intervenció o proposta, sempre que aporte en l'acte, o en el termini que assenyale el president, el text que es corresponga fidelment amb la seua intervenció; es fa així constar en l'acta o s'hi uneix una còpia".

1262 Ávila NAVARRO, P., La sociedad... , op. cit., pàg. 428. Qüestió diferent serà la relativa als mitjans de prova, tant del sentit del vot com de la negativa a la demanda de constància de l'oposició. 
recorda que la inclusió en la Llei de societats anònimes de 1951 del que qualific: com "requisit legitimador poc afortunat", té el seu origen en les modificacion que el Ministeri de Justícia va introduir en l'avantprojecte elaborat per l'Institu d'Estudis Polítics. Així, l'article 70, paràgraf $1 \mathrm{r}$ d'aquell avantprojecte establia que: "Només estan legitimats... els accionistes absents, els concurrents a la junta que no hagueren votat a favor de l'acord impugnat i els que hagen estat il-legítimament privats d'emetre el seu vot". ${ }^{120}$

No va ser aquesta la redacció definitivament adoptada per a aquell article, ni ho és en l'actualitat la de l'article equivalent, l'article 117.2 de la LSA, que estableix que "per a la impugnació d'acords anul-lables estan legitimats els accionistes assistents a la junta que hagueren fet constar en l'acta la seua oposició a l'acord". Tant la LCoop (art. 31.4) com la LCCV (art. 36.5) adopten la mateixa expressió i que diu que el que el soci assistent ha de fer constar és "la seua oposició a l'acord".

Però, com veurem tot seguit, aquesta expressió no queda exempta de diferents lectures. Es tracta d'esbrinar si l'oposició a l'acord és únicament la manifestació expressament oposada a la proposta sotmesa a votació, això és, el vot negatiu, o si l'abstenció, el vot nul o el vot en blanc poden obstaculitzar també la reunió de voluntats necessària per a l'adopció de l'acord. S'ha de determinar si la llei exigeix per a la legitimació que el soci haja votat en sentit negatiu, o si permet altres formes de dissidència. És en les societats de capital i respecte a l'abstenció, on s'ha centrat el debat que a continuació resumim, a fi d'intentar, posteriorment, l'adaptació d'aquestes propostes a les cooperatives.

Les diverses opinions doctrinals en la matèria s'han agrupat ${ }^{12 s}$ en dues posicions 
bàsiques: la negativa i la positiva. L'actitud negativa, ${ }^{12 / 5}$ sosté que el soci que és present en la junta general i s'absté de votar, no està legitimat, en base, fonamentalment, a tres arguments: d'una banda, es considera que l'abstenció conté, implícitament, una renúncia al poder d'impugnació; a més, s'estima que la literalitat del precepte legal seria "un obstacle per a l'admissió del poder impugnador en qui no haja votat en contra"1266; finalment, es considera que el significat de l'abstenció, la intenció de l'abstinent, està d'acord amb el resultat que en la votació es produïsca i, en últim extrem, de renúncia a accions d'impugnació posteriors. ${ }^{12 \pi}$

Tanmateix, davant aquests arguments s'ha assenyalat que el soci que s'absté no pot estar, alhora, renunciant a l'exercici del dret d'impugnació, perquè en el moment de produir-se l'abstenció encara no ha nascut el dret d'impugnació, ja que el seu objecte, l'acord, encara no ha estat adoptat;1268 que de cap precepte

1265 GARRIGUES, J. i URÍA, R., Comentario..., op. cit., I, pàg. 772; també en URÍA, R., MENÉNDEZ, A. i MUNNOZ, J. M., La junta..., pàg. 350: "Per estar legitimat, no és suficient que l'assistent a la junta s'haja abstingut de votar l'acord. [...] La llei vol que vote en contra i que faça constar la seua oposició, per descartar la possibilitat que qui haja assistit a la junta i no s'haja oposat a l'acord de la majoria, puga impugnar-lo després judicialment". En el mateix sentit, GIMENO SENDRA, V., El proceso..., pàg. $85 \mathrm{i} 86$ : "la llei vol, en definitiva, que l'accionista s'opose a l'adopció de l'acord, i el mitjà arbitrat per la LSA a l'efecte és el de l'emissió del vot en contra, de manera que qui així no ho manifesta, i renuncia a l'emissió de la seua declaració de voluntat per a l'adopció de l'acord, també renuncia al seu dret subjectiu d'impugnació, atés que el dret esmentat presenta caràcter complementari o subsidiari del de vot. Una argumentació similar pot formular-se per als supòsits dels vots en blanc o nuls" i RUBIO, J., Curso..., op. cit., pàg. 257 i 258: "Entès sempre el terme dissident en el sentit restrictiu que es desprèn de l'article 69 de la Llei: els que hagueren fet constar en l'acta la seua oposició, no així qui s'absté".

Es manifesta en contra de la legitimació del soci que s'absté, ÁVILA, op. cit., pàg. 428-429.

1266 MORILlAS JARILLO, M. J. i FELIÚ REY, M. I., Curso de cooperativas, op. cit., pàg. 258, addueixen una interpretació sistemàtica per a l'exigència de l'exercici efectiu del dret de vot: “En cas contrari quedaria sense contingut la legitimació dels socis "privats il-legítimament del dret de vot»", encara que manifesten "el valor innegable de l'abstenció" i que aquesta privació de legitimació "no pareix congruent amb el dret constitucional a la defensa jurídica de l'article 24 CE".

1267 DUQUE DOMíNGUEZ, J. F., Tutela..., op. cit., pàg. 190, reflectint els arguments dels autors d'aquest corrent negatiu: "el soci que, per no haver usat la diligència normal per valorar les propostes de l'ordre del dia i per adoptar-hi una actitud en conseqüència, no haja votat [...] ha contribuït, amb el seu desinterès, a fer que la proposta triomfe, "d'on és lògic deduir que, actuant així, haja renunciat també a discutir ulteriorment l'acord"”. 
de la Llei de societats anònimes es desprèn, clarament, la necessitat de votar en contra de l'acord, per conservar l'acció d'impugnació, 1269 i que, en definitiva, donar a l'abstenció el significat de conformitat tàcita amb el resultat de la votació, seria com aplicar la regla que qui calla, atorga, regla que, com assenyala Palá Berdejo, "pressuposa una sola proposta concreta i, quan se sotmet a votació individual un acord, es formulen, en realitat, dues propostes diferents $o$, més aviat, una disjuntiva, ja que es demana a cada soci que vote a favor o en contra".

Quant a la posició doctrinal afirmativa, ${ }^{1270}$ pot resumir-se en l'admissió de legitimació per a «tots els que han assistit a la junta i no han votat a favor de l'acord adoptat»; així, el dret d'impugnació "està subordinat, no tant a la manifestació de voluntat contrària a la deliberació; sinó, sobretot, a la circumstància negativa que l'accionista no haja concorregut, amb la seua pròpia voluntat, a formar l'acord". El fonament de la legitimació s'hi trobaria, també, en la teoria de l'interès: el comportament de qui s'absté no implica, necessàriament, una manca d'interès per accionar, per la qual cosa no es pot negar al soci que s'absté el dret d'impugnació; així succeeix, per exemple, amb

1269 GARCtA LUENGO, R. i SOTO VÁZQUEZ, R., El nuevo régimen jurídico..., op. cit., pàg. 557 i 558 : "la Llei no parla d'emissió de vot contrari a l'adopció de l'acord, STS de 30 de gener de 1970; fins i tot, l'emissió del vot contrari no és suficient a efectes de legitimació, STS de 30 de gener de $1976 ;[. .$.$] hi ha casos en què en l'acta de la junta es fa constar que l'acord es va prendre per$ majoria, sense especificar el sentit en el qual va votar cada assistent, STS de 31 de gener de

1270 POLO SÁNCHEZ («Reflexiones sobre el régimen de quorums y mayorías en los órganos colegiados de la sociedad anónima», RDM, 1973. pàg. 250), per a qui el soci que s'absté és un dissident més, com el que vota en contra, encara que es diferencien en el fet que aquest manifesta la seua oposició concreta a una proposta determinada, i qui s'absté dissent "no solament d'aquesta proposta, sinó també de la contrària [...] El soci que s'absté és sempre per definició un dissident, i com a tal [...], se li concedeixen els drets d'impugnació d'acords i de separació de la societat, drets que, així mateix, es concedeixen als accionistes que voten en contra, no tant per votar en contra (dissidència específica) com per ser també genèricament dissidents, és a dir, per no votar a favor de l'acord". També ARROYO, I., "Comentario al art. 56», op. cit., pàg. 617, entén dotats de legitimació "els accionistes que, assistint, es van abstenir però van fer constar en l'acta la seua oposició. La hipòtesi no és acadèmica, sinó que es produeix en la realitat quan el soci no vol influir amb el seu vot en la decisió; l'abstenció és una posició legítima i, tanmateix, una vegada aprovat l'acord, vol mantenir la legitimació per impugnar-lo, en fer constar en l'acta la seua oposició".

A Itàlia, la major part de la jurisprudència i de la doctrina acullen la tesi; pot veure's un resum 
el soci que s'absté per trobar-se en conflicte d'interessos; ${ }^{1271}$ però el mateix pot dir-se dels supòsits en què el soci no s'absté, sinó que vota en blanc o mitjançant un vot nul.

Una tercera opinió1272 distingeix entre el soci que s'absté i que tenia coneixement dels vicis de l'acord $\mathrm{i}$ aquell que els desconeixia en el moment d'abstenir-se. Segons aquesta distinció, el soci que es va abstenir, si no tenia coneixement en el moment de la votació del vici que determinava l'anul-labilitat de l'acord, podrà impugnar-lo, ja que no s'interpreta l'abstenció com a acceptació incondicional de l'acord, qualsevol que siga el seu contingut, sinó que "la seua voluntat d'adhesió al que decidisca la majoria ha d'entendre's, sempre que aquesta s'aconseguisca legalment". ${ }^{1273}$ En canvi, el soci que té coneixement del vici i no fa constar la seua oposició a l'acord, no ha de poder impugnar l'acord adoptat basant-se precisament "en el vici que li era conegut; ja que, si coneixent-lo no es va oposar a la seua adopció, demostra, amb la seua actuació, que no vol valer-se de la causa d'impugnabilitat, i s'entén, per tant, que amb la seua activitat va renunciar a l'acció esmentada". ${ }^{1274}$

Nosaltres compartim l'opinió que estima que ha de rebutjar-se la solució que es fonamente en la interpretació de la voluntat i de les causes que provoquen

dels seus arguments en SILVETTI, C. i CAVALLI, G., Le società per azioni, pàg. 211 i 212.

1271 BOQUERA MATARREDONA, J., «La regulación del conflicto...», op. cit., pàg. 1036-1038; COSTAS COMESAÑA, J., El deber..., op. cit., pàg. 271-275; DUQUE DOMÍNGUEZ, J. F., Tutela..., op. cit., pàg. 135; EMBID IRUJO, J. M., "Comentario al art. 52», op. cit., pàg. 566: “el soci en qüestió reté tots els drets que, al marge del vot, li corresponen en relació amb el funcionament i el desenvolupament de la junta general. [...] com el d'impugnar els acords socials"; GALÁN CORONA, E., «La junta general», op. cit., pàg. 517; HERNÁNDEZ SAINZ, E., «El deber de abstención", op. cit., pàg. 121; SALELLES CLIMENT, J. R., El funcionamiento..., op. cit., pàg. 191; SÁNCHEZ-CALERO GUILARTE, J., «El conflicto de intereses...», op. cit., pàg. 697; SILVETTI, C. i CAVALLI, G., Le società per azioni, pàg. 216.

1272 DUQUE, Tutela..., op. cit., pàg. 191-194.

1273 SORIA FERRANDO, J. V., La legitimación activa..., pàg. 89.

1274 DuQue, Tutela..., op. cit., pàg. 193, nota 176, però adverteix que "es tractaria d'una renúncia preventiva, per la qual cosa és necessari que, després de l'acord, tinga lloc la renúncia, bé de manera expressa, bé per actes concloents". 
l'abstenció del soci, ja que aquestes poden ser molt diverses i, alhora, dependre de múltiples circumstàncies. ${ }^{1275}$ En efecte, atribuir una intenció determinada, en tot cas, al soci que s'absté (que la seua abstenció implica la renúncia a l'acció d'impugnació, o la conformitat amb qualsevol resultat de la votació), és totalment arbitrari, com ja s'ha indicat, i provar quina ha estat la intenció vertadera en cada cas és una tasca molt difícil, si no impossible. Potser la solució puga estar en el sentit indicat de considerar el fenomen de l'abstenció des d'un punt de vista dinàmic i no en el seu aspecte estàtic; així, "si s'examina el comportament de qui s'absté en la dinàmica del procés deliberatiu, aleshores és quan la conducta de qui s'absté adquireix valor i significació, i el problema de la legitimació pot estat resolt".1276 Amb aquest objectiu, s'ha d'establir, amb caràcter previ, si la majoria es computa sobre el nombre de presents i representats o només sobre els vots emesos. Si la majoria s'obté sobre el total de presents i representats, pot afirmar-se que el soci present en la junta reforça amb la seua abstenció la posició dels socis contraris a l'adopció de l'acord. ${ }^{1277} \mathrm{Si}$ s'admet que la majoria ha de computar-se tenint en compte només els votants, l'abstenció opera en sentit invers i contribueix a l'adopció de l'acord, en reduir la majoria exigida per a la seua adopció. ${ }^{1278} \mathrm{Si}$ el còmput és sobre el total de presents, el soci que s'absté és un soci dissident; si s'aplica el segon sistema, qui s'absté s'equipara als qui assenteixen.

1275 POLO SÁNCHEZ, E., «Reflexiones sobre el régimen...”, op. cit., pàg. 251 i 252.

1276 SORIA FERRANDO, J. V., La legitimación activa..., pàg. 91 i 92.

1277 En aqueix sentit, VICENT CHULIÁ, F., en «El derecho de los órganos...», pàg. 514-516, refereix que la jurisprudència i la doctrina majoritària han interpretat, pel que fa a la LSA, que s'exigeix la majoria del capital present o representat $i$, per tant, "las abstencions, vots en blanc i vots nuls augmentaran, en el comput, els vots efectivament contraris a l'acord". També es mostra partidari del "còmput sobre els vots (potencials) de les accions concurrents en la junta" POLOSÁNCHEZ, E., «Reflexiones sobre el régimen...», op. cit., pàg. 239.

1278 POLO SÁNCHEZ, E., "Reflexiones sobre el régimen...», op. cit., pàg. 238 i 239, que, tanmateix, estima que "això és així només quan les abstencions no passen de ser posició minoritària [...] pot produir-se el supòsit que hi haja més abstencions que vots reben qualsevol de les propostes, pel que cap d'aquestes tindrà ni tan sols aquesta majoria relativa necessària per a l'adopció d'acords, sota el risc de no comptabilitzar les abstencions i de considerar-les com 
L'article 28.1 de la LCoop estableix que "excepte en els supòsits previstos en aquesta Llei, l'assemblea general adoptarà els acords per més de la meitat dels vots vàlidament expressats, i no seran computables, a aquest efecte, ni els vots en blanc ni les abstencions", i l'article 34.1 considera elegits com a consellers els candidats que obtinguen "el nombre més gran de vots"; en canvi, l'article 28.2 de la LCoop requereix que el còmput de la majoria, reforçada de dos terços, s'efectue sobre el total dels vots presents i representats. Així, quan l'acord haja d'adoptar-se per majoria reforçada de dos terços, l'abstenció del soci significarà la seua dissidència efectiva, perquè obstaculitzarà l'obtenció del nombre de vots requerit. Però quan no se'n requerisca una majoria qualificada, aquesta Llei demana, únicament, un nombre més elevat de vots positius davant els negatius i descarta d'entre aquests últims, expressament, les abstencions, que no juguen un paper dissident, ja que no dificulten l'obtenció de la majoria. ${ }^{1279}$

Pel que fa a la LCCV, el seu article 32.4 indica que "els acords quedaran adoptats quan voten a favor de la proposta més de la meitat dels socis presents $\mathrm{i}$ representats en l'assemblea, llevat que aquesta llei o els estatuts socials establisquen majories reforçades, que no podran ultrapassar els dos terços dels socis presents i representats. Queden exceptuats d'aquest precepte els casos d'elecció de càrrecs, on podrà resultar elegit el candidat que obtinga majoria relativa o una quantitat més elevada de vots". Llevat d'aquest últim supòsit, així doncs, l'abstenció hi juga un paper de vot dissident.

Quant al sentit del vot en blanc i del vot nul, pocs autors s'han interessat per la seua anàlisi. ${ }^{1280}$ Nosaltres entenem que, pel que fa a l'atribució de legitimació

a absències".

1279 ALONSO ESPINOSA, F. J., "Capítulo VII», op. cit., p. 246. L'apartat 3 de l'article 28 de la LCoop recull la possibilitat que estatutàriament s'exigisquen majories superiors, sense que, en cap cas, excedisquen les quatre cinquenes parts dels vots vàlidament emesos. Així doncs, caldrà considerar la redacció concreta de les clàusules estatutàries eventuals; però si aquestes reproduïren, parcialment, el text legal, estaríem davant d'un altre supòsit d'abstenció equivalent al vot afirmatiu.

1280 POLO SÁNCHEZ, E., "Reflexiones sobre el régimen...», op. cit., pàg. 256-262: "fins i tot computant-se en la totalitat a efectes del quòrum, els vots nuls no tenen substantivitat i no 
per a la impugnació, els és aplicable la solució adoptada per a l'abstenció: si el còmput de la majoria requereix un nombre determinat de vots positius, el vot en blanc i el nul seran vots dissidents, que obstaculitzaran l'adopció de l'acord; si la majoria computa únicament la diferència entre vots positius i negatius, els vots en blanc i els nuls faciliten l'obtenció de l'acord, en minvar el nombre de vots positius necessaris. En relació amb això, recordeu que, com hem vist, la LCoop (art. 28.1) considera no computables per a la majoria els vots en blanc.

Per tot això, s'haurà de concloure que el soci que, en haver-se abstingut o haver emès vot nul o en blanc, pretenga impugnar l'acord resultant, podrà fer-ho únicament si la majoria corresponent requeria un nombre determinat de vots (presents o representats, o del total de socis), i sempre que haja fet constar la seua oposició.

\section{Pel que fa als supòsits de vot nul, s'ha de tenir en compte, a més, que llevat que haja quedat constància expressa de la nul-litat del vot del soci, haurà de}

poden comptabilitzar-se a efectes de la formació de la voluntat social ni, fins i tot, entre les abstencions. La diferència, segons el meu parer, amb l'abstenció rau en el fet que, efectivament, un vot nul és com si no s'haguera emès, però no a raó d'un acte voluntari de decisió com les formalitats requerits per - la decisió de no votar-, sinó per raó de no complir els requisits i votar; sinó, fins i tot, una declaració de del vot, de manera que no sols existeix la voluntat de se aquesta declaració de voluntat, per estar fat. El que succeeix és que en no poder interpretarun resultat semblant al de no haver formulat formulada defectuosament, s'anul-la i s'aconsegueix segons la meva opinió- que qui s'absté mania declaració, però amb la diferència -essencial vot nul manifesta la seua voluntat de declaració"; "qui vota en blanc, no sols ancriorment s'anul.le la seua sinó que també, materialment, la seua acitupta una actitud formal diferent de la de qui s'absté, votació, ja que la voluntat d'aquest votantud és diferent: el vot en blanc no és una oposició a la mínim, una adhesió a la votació. Si existeix la de votar: el que vota en blanc manifesta, com a concret és perquè la declaració s'emet enteix voluntat de votar i la declaració no té contingut mateixa manera que poden subscriu en blanc perquè siga posteriorment emplenada, de la FERRANDO, J. V., La legitimación activa a l'adopció vàlida d'acords és la relativa (màg. 97-99: "com en el nostre dret la majoria exigida per presents i representats [...], el soci que (més de la meitat), computada sobre el nombre de vots d'aqueix vot té en l'adopció de l'acomet un vot nul, per la influència pràctica que l'emissió afirme que "el soci que vota en blacord, és un dissident", i la mateixa argumentació fa que GARCIA LUENGO, R. i SOTO VÁzOUEZ ha d'incloure's dins del grup dels dissidents".

supòsit de vot nul [...] no podrà con, R., El nuevo régimen jurídico..., op. cit., pàg. 558: "per al emès el seu vot $i$ existeix un considerar-se que ha votat a favor de l'acord - l'accionista ha Tanmateix, resulta més dubtós que l'a en no haver manifestat la seua voluntat vertadera". oposició a qualsevol acord, sinó la seua adhesió a tots. 
sol-licitar-se judicialment la seua invalidació. ${ }^{1281}$

$d^{\prime}$ ) Supòsits especials de socis assistents

En la realització de l'assemblea mitjançant delegats elegits en juntes preparatòries (supòsit comentat en l'epígraf 1.3 del capítol tercer), compartim l'opinió doctrinal que estima que s'ha d'entendre que l'expressió assistents cobreix tant els delegats $i$ els titulars de càrrecs que concorren a l'assemblea de segon grau, com els socis i els associats que només assisteixen a les juntes preparatòries corresponents (perquè la llei els veda l'accés a l'assemblea), i en les actes de les quals poden fer constar la seua oposició, prèvia i condicionada al supòsit que l'assemblea de delegats arribe a adoptar l'acord del qual discrepen. ${ }^{1282}$ Això es fonamenta en la naturalesa de representació voluntària de la relació entre el soci que només assisteix a la junta preparatòria i el soci en qui delega els seus drets d'assistència, veu i vot: el soci de base assisteix a l'assemblea de delegats mitjançant la representació que, en el seu nom, exerceix el delegat elegit per ell.

Cal plantejar-se, no obstant això, si, alternativament, podria considerar-se el soci que no pot assistir a l'assemblea de delegats com un supòsit de soci absent, com ocorre amb els accionistes que no reuneixen el nombre mínim d'accions que s'exigeix en els estatuts de la societat anònima per assistir i votar, ja que

1281 AlborCh BATALLER, C., El derecho..., op. cit., pàg. 158 i 159: “la concurrència d'un vici en l'emissió del vot produeix, sempre que s'hagen reunit els requisits necessaris, la nul-litat o anul-labilitat d'aquest, i això té rellevància jurídica, encara que el vot o vots viciats no hagen estat decisius per a l'adopció de l'acord, ja que pot ser necessària o convenient per a l'accionista la impugnació del vot, perquè si aquest s'haguera pronunciat a favor de l'acord, podria retirar el seu consentiment, i manifestaria l'existència d'un vici, i exercitaria una sèrie de drets, com el de separació, per a l'exercici del qual la llei legitima, exclusivament, aquells socis que no hagen votat a favor de l'acord adoptat". RODRíGUEZ RUIZ DE VILLA, D., Impugnación..., op. cit., pàg. 169 , indica, en relació amb els vots nuls, que "el termini de caducitat breu farà impossible que es declare judicialment la nul-litat esmentada dins del termini citat dels 40 dies"; tanmateix, entenem que res no impedeix que es diluciden ambdues qüestions en un mateix procés; això és, la nul-litat (o anul-labilitat) del vot, que podria condicionar la legitimació per impugnar, i l'anul-labilitat de l'acord adoptat, amb la concurrència del vot que es pretén nul (o anul.lable). 
ambdós supòsits tenen en comú el fet que el soci es veu legítimament privat dels drets d'assistència i de vot. Tanmateix, el soci cooperativista sí que intervé, encara que siga de manera mediata, en la formació de la voluntat de la cooperativa: assisteix a la junta preparatòria, en la qual participa en el debat dels punts de l'ordre del dia, elegeix el seu representant (i, segons la LCCV, pot donar-li instruccions específiques de vot,) i, sobretot (des del punt de vista del dret d'impugnació), pot fer constar en l'acta la seua oposició expressa als acords que l'assemblea de delegats puga, eventualment, adoptar; no sembla, doncs, que puga aplicar-se-li el qualificatiu d'absent.

Pel que fa al supòsit de vot divergent que pot plantejar-se en les societats de capital, quan un mateix soci utilitze la pluralitat de vots que per la seua participació en el capital li corresponguen per tal de votar opcions diferents en relació amb un mateix assumpte, ${ }^{1283}$ sembla més difícil el seu plantejament en les cooperatives que en les societats de capital. S'ha de recordar que, precisament, en les cooperatives regeix el principi de funcionament democràtic que atribueix igualtat de drets als socis, en general, i un vot a cada soci, en particular. Així doncs, només en els casos en què es permeta el vot plural o en què es vote en representació, podrà plantejar-se la qüestió de si qui ha votat a favor de l'acord, amb una part dels vots, podrà, tanmateix, manifestar la seua

\section{Paz CANalejo, N., en Paz Canalejo, N. i Vicent Chulí, F., Ley general..., pàg. 596.}

1283 Un resum sumari de les actituds a favor i en contra de la seua admissió en el dret de societats de capital pot veure's en VICENT CHULIA, F., "La asamblea...», op. cit., pàg. 457. Més recentment, en BADIA, E., "Ejercicio divergente o contrario del derecho de voto en las sociedades anónimas y en las limitadas», La Ley, núm. 4716, 20.1.1999, pàg. 1-4. També es refereixen a l'accionista divergent DUQUE DOMÍNGUEZ, J. F., Tutela..., op. cit., pàg. 183 i 184, que assimila al supòsit de vot divergent el de qui vota a favor i després adquireix "alguna acció que conserva el dret a impugnar", i SORIA FERRANDO, J., La legitimación activa..., op. cit., pàg. $99 \mathrm{i}$ 100, que admet la legitimació del divergent, però computant a aquests efectes únicament les accions amb les quals va votar en contra. En contra, RODRf́GUEZ RUIZ DE VILLA, D., Impugnación..., op. cit., pàg. 170: "potser podria denegar-se la legitimació esmentada en base a l'aplicació de l'article 6.4 del CC (frau de llei), perquè, en votar a favor i en contra i manifestar la seua oposició, segueix una conducta que, segons que pensem, persegueix una finalitat diferent a la que es pretén en l'article 117.2 del TR, com és la de la constància clara i diàfana de la voluntat d'impugnar un acord que, en certa mesura, es veu desvirtuada pel vot favorable amb part de les seues accions". 
oposició i impugnar l'acord esmentat. ${ }^{1284}$

Plantejada la qüestió en aquests termes, l'admissió de la impugnació sembla completament contrària a la bona fe, almenys en els supòsits en què el soci persona física emeta més d'un vot, ja siga per tenir vot plural, ja siga per exercir la representació d'altres. No obstant això, unes altres circumstàncies poden fer admissible la legitimació: són els casos en què el soci que vota "porta un mandat imperatiu ${ }^{1285^{\prime \prime}}$; o quan, en representació de la persona jurídica sòcia, amb vot plural, assistisquen a l'assemblea diferents persones, amb llibertat de vot $\mathrm{o}$, fins i tot, amb instruccions de vot diferents; ${ }^{1286}$ o quan la representació de les persones jurídiques sòcies d'una cooperativa de segon grau estiga formada per diverses persones (art. 77.3 de la LCoop i art. 92.2 de la LCCV).

c) Els absents

1284 En aquest sentit, VICENT CHULIÁ, F., en «El derecho de los órganos...», op. cit., pàg. 519, i en "La asamblea...", op. cit., pàg. 457 i 458, interpretava que la prohibició de concedir als socis vots fraccionats establerta en la LGC de 1974 i en el seu Reglament, de 1978, havia d'entendre's com la prohibició que "puguen, en cas d'exercitar vots diferents, per ells o per representació, fer-ho utilitzant cada un d'ells en un sentit divergent". Aquesta prohibició no va ser recollida en la LGC de 1987, però sembla haver-se reincorporat en la LCoop, que en el seu article 26, apartats 3 i 5 , autoritza, en les cooperatives amb modalitats diferents de socis i en les d'explotació comunitària de la terra, el vot fraccionat, en la mesura que això siga necessari per mantenir les proporcions que s'hagen establert per als tipus diferents de socis, o en funció de la valoració dels béns cedits a la cooperativa.

1285 VICENT CHULIÁ, F., La asamblea... op. cit., pàg. 458: “En aquest cas, més que representant és un simple nunci, un portador de l'emissió de vot a distància pel titular vertader".

1286 VICENT CHULIÁ, F., en Compendio crítico..., op. cit., pàg. 516 i 517, considera que en la SA existeix, com a principi configurador, el d'unitat de vot de cada accionista, quan aquest siga una persona física, però admet que "la disgregació de vots d'un mateix accionista és possible si es tracta d'una persona jurídica, privada o pública, que sol enviar alguns delegats o representants perquè davant de les qüestions que se susciten en la Junta puguen representar les diferents opinions del col-lectiu que engloben aquelles persones jurídiques" $\mathrm{i}$ "en el cas de representant en la junta de diferents accionistes, si entén que defensa així més bé l'interès de cada un dels seus representats o ha de seguir les seues instruccions".

La LCCV possibilita que, per a la representació de la persona jurídica en el consell rector, els estatuts regulen la intervenció de "fins a tres representants en aquell òrgan, que actuaran amb caràcter solidari sense perjudici de la responsabilitat de la persona que representen". Res impedeix, al nostre entendre, que els estatuts reconeguen la possibilitat de representació voluntària múltiple, també per a l'assemblea general, almenys en relació amb les persones jurídiques sòcies, que poden estar interessades en el fet que la seua representació reflectisca les diferents opinions del seu collectiu de socis. 
Encara que, tant la LCoop (art. 31.4), com la LCCV (art. 36.4), quan atribueixen legitimació per a la impugnació dels acords de l'assemblea general, es refereixen als socis (...) absents, ja hem vist que les persones legitimades per a la impugnació d'acords anul-lables poden ser també algunes no sòcies, ${ }^{1287}$ per la qual cosa també aquestes entraran en el concepte de persones absents que tenen legitimació.

D'altra banda, com s'ha indicat, la llei no exigeix als absents cap altra condició per entendre'ls legitimats. ${ }^{1288}$ No són, per tant, rellevants les causes o motius, justificats o no, de l'absència. ${ }^{1289}$ Perquè "l'assistència és un dret del soci, no una càrrega ni una obligació, i l'exercici, positiu o negatiu, d'un dret, no pot condicionar uns altres drets independents com, en aquest cas, el dret d'impugnació". 1290 En aquesta línia, també s'ha referit un supòsit concret que reflecteix la incondicionalitat del dret, en aclarir el Tribunal Suprem (sentència de 3 de febrer de 1966) que els socis absents no estan obligats a la denúncia anticipada dels vicis produïts en la convocatòria de la junta general.1291

En l'àmbit cooperatiu, la LCoop ha suprimit l'obligació anterior d'assistència a les reunions dels òrgans socials dels quals el soci forma part (art. 34.2,a) de la LGC), que sí que es manté en la LCCV (art. 22, b)). Malgrat això, entenem que aquesta última obligatorietat no és obstacle per a la legitimació dels absents, ja

\section{Vegeu supra epígraf 1.1.1., i infra epígrafs 1.1.2.B., C. i D.}

1288 ARROYO, I., «Comentario al art. 56»op. cit., pàg. 618; ÁVILA NAVARRO, P., La sociedad... , op. cit., pàg. 429; SCORDINO, F., La società cooperativa, op. cit., pàg. 287, nota 218.

1289 DuQue Domínguez, J. F., Tutela..., op. cit., pàg. 194 i 195; GARCf́A Luengo, R. i SOTO VÁZQUEZ, R., El nuevo régimen jurídico..., op. cit., pàg. 559 i 560, on inclou en el concepte d'absents els supòsits de privació legítima del dret de vot; GIMENO SENDRA, J. V., El proceso..., op. cit., pàg. 86 i 87: "accionista absent ho és tant el qui gaudint del dret d'assistència no l'exercita, com qui no tenint aquest dret, per una disposició estatutària, es troba impedit d'assistir a la junta". 
que es tracta d'aspectes diferents del règim jurídic del soci. ${ }^{1292}$ L'assistència a les reunions i la impugnació d'acords per absents són drets del soci. D'altra banda, en els supòsits en què l'absència estiga motivada per una causa que supose l'incompliment de l'obligació d'assistència, el soci podrà ser, si escau, sancionat mitjançant l'expedient corresponent $i$, en alguns supòsits, el desenvolupament de l'expedient podrà suposar, fins i tot, la suspensió del dret d'impugnació;1293 però tot això succeiria, si escau, en paral-lel i sense detriment del dret originari del soci a impugnar, mentre no s'establira, tot seguint el procediment corresponent, aquesta suspensió.

En tot cas, un sector doctrinal important ha criticat obertament aquesta causa de legitimació. Mentre que al soci present, se li exigeix que expresse en l'acta la seua oposició, als no assistents se'ls concedeix l'acció sense restriccions, ${ }^{1294}$ la qual cosa suposa un tractament discriminatori respecte dels assistents a la junta. S'estima que el soci que no assisteix a la junta, tret del supòsit que no posseïsca una quantitat mínima d'accions, mostra, amb la seua no-assistència, un desinterès pel desenvolupament de la vida social que no hauria de ser recompensat: per romandre totalment inactiu, està legitimat, mentre que l'assistent (llevat del supòsit de privació il-legítima del dret de vot), si desitja conservar l'acció, haurà de manifestar la seua oposició en l'acta. A més, s’ha

1291 SORIA FERRANDO, J. V., La legitimación activa..., pàg. 70.

1292 No semblava opinar el mateix GIMENO SENDRA, J. V., en El proceso..., op. cit., pàg. 86, qui, en relació amb la LSA de 1951 i la LGC de 1974 es mostrava especialment crític, en dir que "ni la LSA ni la LGC distingeixen, almenys, entre el soci que no acudeix a la celebració de la junta per causa justificada, i el soci absent per desídia o per desinterès. La discriminació esmentada entre el soci assistent i l'absent no només resulta en si mateixa censurable, sinó que revesteix una disfuncionalitat especial en la legislació cooperativa, on la concessió de la legitimació a l'accionista [sic] absent sense motiu justificat no s'entén, si es pensa que l'assistència a les assemblees té caràcter d'obligació".

1293 L'article 18.2 de la LCCV estableix que "contra l'acord d'expulsió podrà recórrer el soci afectat [...]. En cas de socis de treball i de socis de cooperatives de treball associat, l'acord del consell rector podrà decidir la suspensió en els drets del soci, fins que decidisca l'assemblea general".

1294 GIRÓN TENA, J., Derecho de sociedades anónimas, op. cit., pàg. 331; GÓMEZ ORBANEJA, E., «El proceso...", op. cit., pàg. 127, nota 1 . 
indicat que amb la seua no-assistència rebaixa el quòrum $i$, per tant, la majoria necessària per a l'adopció de l'acord, per la qual cosa facilita, amb la seua absència, l'adopció dels acords. Per tot això, s'estima criticable l'atribució de legitimació activa als socis que "tenint el dret d'assistència, no l'exerciten per desídia o per desinterès". ${ }^{1295}$

Nosaltres, encara que participant de l'opinió que, possiblement, serà excessiu concedir la legitimació a qui s'absenta per desinterès, estimem que els arguments exposats pateixen de dos punts febles: d'una banda, es parteix del supòsit que la consignació en l'acta exigida al present dissident es fa "com a mesura de precaució", 1296 en favor de la societat, i és més probable que, com ha quedat exposat, el sentit de la norma siga actuar com a prova de l'assistència i de la dissidència; d'altra banda, s'afirma que, llevat dels supòsits de privació legítima del dret d'assistència, l'absent sempre "mostra desinterès sobre el desenvolupament de la vida social", afirmació, segons la nostra opinió, excessiva, perquè les causes que poden conduir a la no-assistència poden ser molt diverses, i poden estar, en molts casos, plenament justificades. I justament perquè la prova i la valoració de la justificació de la causa de no-assistència poden fer excessivament complexa l'atribució de legitimació, sembla menys incorrecte concedir-la a qui és possible que no la meresca, que dificultar el procés de la impugnació, sotmès al control judicial i que, en definitiva, s'estableix en garantia de l'interès social mateix.

D'altra banda, la doctrina ha plantejat alguns supòsits que no poden considerarse casos d'absència, o que susciten dubtes sobre la seua qualificació. Així, es recorda que no són absents els que estiguen correctament representats. ${ }^{1297}$ Tampoc no poden reconduir-se a la legitimació per absència els supòsits dels

1295 SORIA FERRANDO, J. V., La legitimación activa..., pàg. 71 i 72.

1296 GIRÓN TENA, J., Derecho de sociedades anónimas, op. cit., pàg. 331. 
qui adquireixen la condició de soci després de l'acord, justament perquè quan aquest s'adopta encara no són socis. ${ }^{1298}$

Els casos de mort del soci amb dret a impugnar els acords anul-lables plantegen més dubtes. Ja hem vist que, davant els acords nuls, l'administrador de $l^{\prime}$ herència jacent pot actuar en qualitat de tercer amb interès legítim, a fi de complir amb el seu deure de conservar els béns de l'herència en les condicions més favorables possibles; però davant els acords anul·lables, no estan legitimats els tercers. Pel que fa als hereus, ni tan sols en els supòsits en els quals accedisquen a la condició de soci dins del termini per exercitar l'acció podrien plantejar-la, ja que no eren socis en el moment de l'adopció de l'acord.

Finalment, la doctrina debat quin ha de ser el moment que s'ha de prendre en consideració per estimar que el soci és absent pel que fa a la seua legitimació per impugnar, en aquells supòsits en els quals la seua assistència a l'assemblea és parcial (incorporació del soci posteriorment a la constitució, o abandonament, definitiu o temporal, de l'assemblea, posteriorment a l'inici de la sessió). La nostra opinió és que, com a norma general, caldrà qualificar el soci d'absent en els acords aprovats sense la seua presència o sense la delegació de vot;:1299 mentre que, per a aquells amb la presència o la representació dels quals

1298 URíA, R., Derecho mercantil, op. cit., pàg. 325: “El Tribunal Suprem ha declarat que el concepte d'accionista absent només pot comprendre qui tinga la condició d'accionista en el moment de la realització de la junta, però no qui haja adquirit les accions posteriorment a aquesta (vegeu les sentències de 7 de febrer de 1959 i de 24 d'octubre de 1967)". En la mateixa línia, GARCIA LUENGO, R. i SOTO VÁZQUEZ, R., El nuevo régimen jurídico..., op. cit. pàg. 559 i 560; i ÁvILA NAVARRO, P., La sociedad..., op. cit., pàg. 427: “Per a la impugnació pels socis és necessari que tingueren aquesta qualitat en el moment de l'adopció de l'acord: com assenyalen les sentències de 2 de juliol de 1975 i de 24 d'octubre de 1967, no tenen legitimació els socis que hagen entrat en la societat posteriorment a la celebració de la junta". Aquest autor apunta, tanmateix, que sí que gaudeixen de legitimació els qui adquirisquen la condició de soci a títol hereditari, "subrogant-se en la posició jurídica del seu causant (en aquest sentit, la sentència de 19 de desembre de 1984 considera legitimats els hereus del soci mort després de la junta i que presenten la demanda abans de transcorregut el termini)".

En relació amb la no-legitimació de qui encara no és soci en el moment de l'acord, vegeu supra el que s'indica en l'epígraf 1.1.1.A.a), per a la legitimació d'impugnació davant acords nuls. 
s'ha comptat, la legitimació dependrà del sentit de la seua participació en la votació i de la constància, si escau, de la seua oposició.

Això no obstant, s'haurà d'atendre els supòsits en els quals el soci que s'absenta, consta en la llista d'assistents ${ }^{1300}$ i compta, en aquest sentit, en votacions per a l'adopció d'acords, la majoria a obtenir dels quals s'ha de calcular considerant, precisament, el total de presents i de representats. Si el soci, absent en aquell moment, ha estat computat com a present, i no està tampoc representat en la votació, la seua absència tindrà els efectes d'una abstenció que dificulta l'adopció de l'acord; ja que, participant en el càlcul de la majoria necessària, el seu vot no concorre en l'adopció de la proposta. ${ }^{1301}$ Però també s'ha de tenir present que poden produir-se situacions diferents: que se sol-licite un recompte del quòrum per a cada votació i, per tant, el soci ja no computaria com a present; que la majoria necessària només ho siga pel que fa als vots vàlidament emesos; que el soci haja delegat el seu vot abans d'absentarse, etc.

Tampoc no cal generalitzar l'atribució d'una voluntat dissident en la retirada del soci. Com ja s'ha indicat, atribuir una intenció determinada al soci resulta no només de demostració difícil, sinó excessivament simplificador: el soci pot absentar-se, per exemple, per desconèixer la transcendència possible de debats ulteriors. En aquest sentit, entenem que la intenció dissident del soci que s'absenta només serà rellevant quan haja estat expressament manifestada abans de la seua absència, i tan sols respecte a aquells acords l'adopció dels quals

V., El proceso..., op. cit., pàg. 87 i 88, i SORIA FERRANDO, J. V., La legitimación activa..., op. cit., pàg. 69 i 70; aquests dos últims citen la STS d'11 de juny de 1982, RJA 3415.

1300 Com indica ARROYO, I., "Comentario al art. 56", op. cit., pàg. 617, si el soci consta en la llista d'assistents a la sessió haurà de provar que era absent durant el moment de l'adopció de l'acord. 
considera formalment invàlida. ${ }^{1302}$ En d'altres casos, el seu abandonament de la reunió entra, segons la nostra opinió, en els supòsits d'absència, per als quals la llei no exigeix l'oposició expressa a l'acord.

d) Els il-legítimament privats d'emetre el seu vot

Pel que fa a aquest supòsit de legitimació cal subscriure, amb caràcter general, l'advertiment que "no deixa de ser absurd que la Llei de societats anònimes reclame, com a requisit per a la impugnació d'un acord anul-lable, que l'accionista impugnant "haja estat privat il-legítimament d'emetre el seu vot", ja que el compliment del supòsit [de] fet (privar il-legítimament del dret de vot) provoca la nul-litat, bé de la junta general, quan al seu començament es denegue a un accionista l'exercici dels drets d'assistència i vot, o bé, la de l'acord, quan en el moment de realitzar una junta, els socis, majoritàriament, decidisquen impedir a un determinat accionista emetre el seu vot a favor o en contra d'una proposta determinada".$^{1300}$ En aqueix sentit, la STS (Sala 1a) de 30 de setembre de 1997, núm. 829/1997 (RJA 1997/6461) és absolutament explícita: “sent la junta general l'òrgan sobirà de l'organització de la societat anònima, es veu tanmateix limitada pels drets dels accionistes, ja que només el respecte als drets del soci i l'exercici d'aquests d'acord amb la llei, pot legitimar la majoria societària; la vulneració del dret d'assistència, en aquest cas, o de qualsevol altre

1302 Vegeu supra, respecte del moment en el qual els assistents han de fer constar la seua oposició a l'acord.

1303 SORIA FERRANDO, J. V., La legitimación activa..., op. cit., pàg. 26. En realitat, la majoria de les vegades serà el president de l'assemblea qui, en funció del seu càrrec, decidirà denegar la participació del soci en la votació, per la qual cosa, com ha assenyalat RECALDE CASTELLS, Limitación estatutaria..., op. cit., pàg. 130 , nota 239 , una acció eventual d'indemnització podria dirigir-se en contra d'ell ("almenys en el supòsit en què aquest haguera obrat de manera fraudulenta en aplicar la limitació del vot"), exclusivament o en litisconsorci passiu amb la cooperativa. Aquest mateix autor, en l'op. cit., pàg. 131 recull la proposta d'un sector doctrinal sobre la nul-litat d'un supòsit similar: quan s'aplica al soci una limitació en el seu dret de vot il-legítimament, "i se li atribueixen menys vots dels que en realitat li correspondrien". 
que reconega la llei a l'accionista, fan nuls els acords adoptats". 1304

Curiosament, no sols hem trobat pocs autors que coincidisquen en l'apreciació, 'ars sinó que l'esmentada causa de legitimació per a l'anul-labilitat es recull, reiteradament, en totes les normes reguladores de la impugnació, tant per a les societats de capital com per a les cooperatives. ${ }^{136}$

Això no obstant, és cert que poden presentar-se alguns supòsits en les societats de capital, en els quals la privació al soci del seu dret legítim de vot es produïsca per l'aplicació incorrecta d'una clàusula estatutària, com ara les que introdueixen limitacions del vot (art. 105 de la LSA, art. 53.4 de la LSRL, art. 122 i 184 de la RRM). Estaríem, aleshores, davant d'una vertadera privació il.legítima del dret de vot del soci, que produiria un acord merament anul.lable, ja que la norma vulnerada no seria de rang legal, sinó estatutari. ${ }^{13 m}$ Però aquest supòsit podria aplicar-se en l'àmbit cooperatiu, únicament en les cooperatives que tinguen previst en els seus estatuts un règim de vot plural o causes extralegals

${ }^{1304}$ En el mateix sentit, la SAP d'Osca, de 28 de juliol de 1999 (AC 1999/1585).

1305 RodRígUeZ RUIZ DE VILLA, D., Impugnación..., op. cit., pàg. 174 i VICENT CHULIÁ, F., «La "encara que la Llei no, pàg. 206. GIMENO SENDRA, V., El proceso..., op. cit., pàg. 88 estima que el president de la junta o de l'assemblea general impedisca al soci exercitar el seu dret al vot [nota 179: VELASCO ALONSO: La Ley de sociedades anónimas, cit., pàg. 327 [...]], i no que l'òrgan deliberant decidisca privar del dret de vot un soci o un grup de socis; ja que, en aquest últim cas, l'acord social seria nul de ple dret". Estimem que també quan es tracte d'una privació del vot decidida unilateralment pel president (en l'exercici de les seues funcions de moderació de l'òrgan, no ho oblidem) el resultat serà un acord nul, per violació de la norma legal imperativa
que atribueix al soci el seu dret de vot.

1306 LSA, art. 117.2; LCoop, art. 31.4; LCCV, art. 36.5; LCPV, art. 39.5; LCC, art. 38.3; LSCA, art. 56.3; LFCN, art. 36.2; LSCE, art. 35.5; LCG, art. 40.4; LCA, art. 36.2, i LCCM, art. 38.5. RODRífUEZ RUIZ DE VILLA, D., Impugnación..., op. cit., pàg. 174: "entenem que ens trobem davant d'una contradicció del legislador, derivada d'una regulació legislativa sedimentària en la qual, de vegades, queden estrats d'una legislació anterior que perd sentit amb la reforma subsegüent, sense que s'advertisca la necessitat d'eliminació".

1307 RECALDE CASTELls, Limitación estatutaria..., op. cit., pàg. 132: "en haver-se aplicat il-lícitament la limitació a un accionista determinat, en atribuir-li menys vots dels que en realitat li corresponien, aquest estaria legitimat per exercitar l'acció d'impugnació encara que no haguera fet constar en l'acta la seua oposició a l'acord o haguera votat parcialment [...]. Es 
de conflicte d'interessos, en les cooperatives de segon grau i en les cooperatives mixtes.

e) Supòsits especials

La LGC reconeixia, en alguns dels seus preceptes, una expressa legitimació impugnadora a socis i associats per a supòsits concrets ${ }^{\text {13x }}$ que, en alguns casos, podien ser d'anul-labilitat. ${ }^{139}$ D'aquests supòsits de legitimació específica, la LCoop manté únicament el de l'article 74.2, en legitimar per a la impugnació dels acords d'aprovació del balanç final de la liquidació i del projecte de distribució de l'actiu de la cooperativa, qualsevol soci "que se senta ofès". En aquest cas, està clarament ampliada la legitimació, ja que, en aquells supòsits en què el greuge siga causa d'anul-labilitat, podrà impugnar l'acord qualsevol soci, sense que siga necessari trobar-se en alguna de les circumstàncies previstes en l'article 31.4; una altra interpretació deixaria sense sentit l'especificació de l'article 74.2.

tractaria d'un cas perfectament relacionat amb el penúltim dels supòsits previstos en l'article 117.2 de la Llei de societats anònimes: haver estat il.legitimament privat del vot".

1308 PAZ CANALEJO, N. i ViCENT CHULIÁ, F., Ley general..., pàg. 593.

1309 Així, el que es recull en l'article 69.6, d'aprovació dels comptes de l'exercici sense l'informe d'auditoria externa, quan aquesta s'exigia, no per una norma legal, sinó estatutària; la remissió a l'aplicació dels "cursos processals previstos" per a la impugnació d'acords en general, convertien el supòsit en un acord anul-lable, per vulneració d'una norma estatutària. En l'actualitat, la LCoop (art. 62) omet tota referència a la impugnabilitat dels acords d'aprovació dels comptes anuals i de l'informe de gestió que, estant sotmesos a revisió externa per aplicació de la Llei d'auditoria de comptes o perquè ho sol-licite un $5 \%$ dels socis, no incorporen l'informe d'auditoria corresponent; tanmateix, no hi ha cap dubte que, en aquests casos, els acords esmentats són impugnables, però de nul-litat, ja que vulneren preceptes legals.

La LCoop no es refereix, en l'article 62, a la possibilitat que l'auditoria siga imposada estatutàriament, i l'article 39.1 estableix que "els comptes anuals i l'informe de gestió, abans de ser presentats per a la seua aprovació a l'assemblea general, hauran de ser censurats per l'interventor o pels interventors, llevat que la cooperativa estiga subjecta a l'auditoria de comptes als quals es refereix l'article 62 d'aquesta Llei". Sembla, doncs, que, llevat dels supòsits explicitats en l'article 62 (obligació per la LAC, o petició del $5 \%$ dels socis), l'informe haurà de ser realitzat pels interventors, sense que siga possible cap auditoria per manament estatutari $i$, per tant, la seua absència no serà ara, en cap cas, motiu d'anul-labilitat. 
Tant la LCoop (art. 31.4) com la LCCV (art. 36.4) legitimen, expressament, els administradors per impugnar els acords anul-lables. ${ }^{1310}$ En relació amb això, ja hem recollit les indicacions doctrinals pel que fa al fet que, contràriament al que s'exigeix als socis no administradors, la llei no requereix l'absència o la dissidència de l'administrador (ni, per tant, la consignació de la seua oposició en l'acta) per atorgar-li legitimació per a la impugnació d'acords anul-lables, la qual cosa crea la possibilitat que l'administrador que haja contribuït a la producció de l'acord puga instar-ne l'anul-lació. 1311

La justificació d'aquesta legitimació més àmplia s'ha situat, per a alguns autors, en la línia d'oferir a l'administrador (fins i tot al que va votar a favor de l'acord anul-lable) una via d'exoneració de responsabilitat, ${ }^{1312}$ mentre que altres la

1310 La LGC no legitimava, expressament, els membres del consell per a l'anul-labilitat (art. 52.3 , 1r par.), però sí que establia l'obligatorietat d'impugnar els acords que s'oposaren als estatuts (art. 52.3, 3r par.). Es plantejava, amb això, el dubte de si la legitimació implícita s'havia d'estendre a tot tipus d'acords anul-lables, o si l'omissió de l'obligatorietat d'impugnació per als acords lesius de l'interès social indicava voluntat de no reconèixer legitimació, davant seu, els consellers. Ja en aquell moment, consideràvem més acceptable la primera opció, ja que si la falta de legitimació expressa davant acords antiestatutaris no suposava la seua no-impugnabilitat, tampoc era necessari deduir-la per als acords lesius del fet de la seua no- obligatorietat: que no siga obligatori per als administradors impugnar els acords que lesionen interessos socials, en benefici de socis o de tercers, no havia de significar, necessàriament, la seua prohibició. Amb el reconeixement exprés i general de la LCoop de legitimació als administradors per a la impugnació d'acords anul-lables, desapareixen, afortunadament, els dubtes.

1311 Els administradors estan legitimats sempre per a la impugnació, tant dels acords nuls com dels anul-lables de l'assemblea general (LCoop, art. 31.4, i LCCV, art. 36.4 i 5), amb independència de quina haja estat la seua posició en l'adopció de l'acord; respecte dels acords del consell rector, la LCCV manté la seua legitimació en tot cas (art. 41.6), mentre que la LCoop (art. 37.2) en els supòsits d'acords anul-lables la restringeix. Vegeu infra l'epígraf 1.1.1.A., sobre la legitimació que atorga la LCCV a tots els administradors davant els acords, tant nuls com anul-lables, de l'òrgan d'administració.

1312 EMBID IRUJO, J. M., «Notas sobre la impugnación...», op. cit., pàg. 56; SÁNCHEZ CALERO, Administradores..., op. cit., pàg. 544: "La justificació de no exigir aquests requisits complementaris pot trobar-se en la pretensió que té la llei de [no?] impedir que els administradors s'oposen als acords lesius per a la societat, no solament en el moment de la seua adopció, sinó també en el de la seua execució (xfr. art. 133.2)". 
fonamenten en el deure de l'administrador de defensar l'interès social. ${ }^{1313}$ En relació amb la primera opinió doctrinal, s'ha de recordar el que ja s'ha desenvolupat: la impugnació de l'acord que es considera invàlid no exonera, per si sola, d'una eventual responsabilitat per la participació en la seua adopció. ${ }^{134}$ Pel que fa a la segona, reiterem la nostra opinió que el fonament de la legitimació per a la impugnació, en favor d'administradors no socis, es troba, en realitat, en el seu interès a complir amb el seu deure de diligència; aquest interès resulta, alhora, de caràcter particular, ja que els permet, si escau, exonerar-se d'una responsabilitat eventual, i de caràcter social o general, perquè obri la via perquè la societat corregisca un acord viciat.

Si traslladem la qüestió a l'àmbit cooperatiu i als supòsits d'acords anul-lables, també s'ha de mantenir la fonamentació d'una legitimaciómés àmplia en favor dels administradors en el seu deure de diligència, que inclou, entre altres aspectes, la vigilància de la "subjecció a la llei i als estatuts" de tots els acords que adopten els òrgans de la cooperativa, ${ }^{1315}$ i la defensa de l'interès social, més

1313 AlCALÁ DíAZ, M. A., La impugnación..., op. cit., pàg. 190; ÁvILA NAVARRO, P., La sociedad..., op. cit., pàg. 429 i 430: “Observeu que no és necessari que l'administrador s'haja oposat a l'acord [...], perquè el seu deure com a administrador ha d'estar per sobre dels seus interessos particulars de soci"; DíAZ DE LEZCANO SEVILLANO, N., Los acuerdos del consejo..., op. cit., pàg. 200 , que estima que la legitimació es confereix als administradors "per vetllar pel funcionament legal d'aquest òrgan" i que "considerant les seues funcions especials de tutela de la legalitat en el funcionament $d^{\prime}$ aquest òrgan, derivades del deure de fidelitat que li imposa l'article 127 de la LSA, poden, fins i tot, impugnar sense ser part de l'òrgan emissor de l'acord, com en el cas del conseller no membre de la comissió executiva que impugna un acord d'aquesta"; RUBIO, J., Curso..., op. cit., pàg. 261: “Quan els administradors impugnen, davant la majoria o davant la mateixa unanimitat de socis, un acord il-legal, defensen els interessos permanents i objectius de la societat sacrificats als ocasionals i subjectius dels socis, considerats individualment, en grup majoritari o, fins i tot, unànime"; SALELLES CLIMENT, J. R., El funcionamiento... op. cit., pàg. 401 i 402: "els termes amplis en què es concep la legitimació dels administradors per impugnar els acords del consell són coherents amb la funció de tutela de l'interès social que en la llei se'ls encomana. Així, als administradors correspon la salvaguarda de l'interès típic de la societat i la garantia de la correcció de l'activitat realitzada mitjançant els acords que adopten els seus òrgans. Que els membres del consell no defensen en la seua actuació un interès propi, fa que no tinga transcendència la posició que adopten en relació amb l'acord que s'impugna".

1314 Vegeu supra, epígraf 1.1.1.C, d'aquest mateix capítol, i l'epígraf 2. "Fonament jurídic de la impugnació dels acords socials del capítol I", in fine.

1315 PAZ CANAlejo, N. i ViCENT ChUliÁ, F., Ley general... op. cit., pàg. 574: "la legitimació, també innovadora, que es reconeix [...] als membres del consell rector, concorda amb la pauta de subjecció a la llei $i$ als estatuts... que, per a aquest òrgan, marca l'article 53 , núm. 1". En 
enllà dels interessos concrets dels socis. És, justament, l'existència d'un interès social cooperatiu diferent a la suma d'interessos particulars dels socis la que, al nostre entendre, permet als administradors cooperatius, sense cap problema, impugnar, fins i tot, aquells acords anul-lables que hagen estat adoptats per unanimitat. ${ }^{136}$

Cal reproduir-hi tot el que s'ha argumentat per a la legitimació dels administradors davant acords nuls, en relació amb el caràcter individual de la legitimació, que no impedeix, no obstant això, la possibilitat que l'òrgan col-legiat adopte l'acord d'iniciar l'acció d'impugnació.

Quant a la necessitat del manteniment de la qualitat d'administrador, estimem que, davant acords anul-lables, ha d'exigir-se durant tot el període que s'estén des de l'adopció de l'acord que es pretén impugnar ${ }^{\text {1nz }}$ fins a la publicació de la sentència. Perquè si es perd la condició d'administrador i la de soci, com a tercer, ja no es té legitimació davant els acords anul-lables, i, si el que s'ha deixat és, únicament, el càrrec social, el règim de la legitimació serà el més restrictiu reconegut al soci no administrador.

\section{Legitimació dels membres de l'òrgan de control de la gestió}

Com ja s'ha assenyalat per a la legitimació davant acords nuls, la llei estatal i la

l'actualitat, la LCoop (art. 32.1) manté com a funcions del consell "l'alta gestió, la supervisió
dels directius i la representació de la societat cooperativa, amb subjecció a la llei, als estatuts i a
la política general fixada per l'assemblea general”. 1316 SALELLES CLIMENT, J. R., El funcionamiento... op. cit., pàg. 381 i 382 , descriu el debat que
per a les societats de capital es planteja respecte de la possibilitat d'impugnació, pels
administradors, dels acords que $d$ 'interès social no estat adoptats per unanimitat. Sobre el concepte 1317 La STS (Sala 1a) de 14 de juliol de 1997, núm. 678/1997 (RJA 1997/6016 i 5470) denega legitimació en qualitat d'administradora a la recurrent, que havia estat nomenada administradora en la mateixa junta general en què s'adoptà l'acord que es pretenia impugnar, però en un punt posterior de l'ordre del dia; restà per a un moment posterior no solament la 
valenciana estableixen diferents models d'òrgan de control de la gestió: mentre que la LCoop manté la figura tradicional del soci interventor, si bé admet expressament la possibilitat que alternativament es realitze un control auditor extern, la LCCV, contràriament, preveu que només les cooperatives que reunisquen els requisits legals estaran obligades a auditar externament els seus comptes; però permet tant l'auditoria voluntària com la creació d'un òrgan de control de la gestió, format per socis. Així doncs, l'anàlisi de la legitimació dels membres de l'òrgan de control ha de fer-se separadament.

Pel que respecta a l'àmbit estatal, la regulació que es produïa amb la LGC únicament feia referència a la legitimació dels interventors, en assenyalar la seua obligatorietat $d$ 'impugnar els acords contraris a la llei o als estatuts, amb la qual cosa es plantejava el mateix dubte que per als administradors, és a dir, si estaven legitimats per impugnar els acords anul-lables que lesionaren els interessos de la cooperativa en favor de socis o de tercers. La LCoop ha corregit aquest buit, en atorgar legitimació expressa i, en tot cas, als interventors.

Pel que fa a les cooperatives sotmeses a la LCCV, l'article 36.5 també estableix, expressament, la legitimació dels membres de la comissió de control davant els acords anul·lables, i això en tot cas, sense necessitat d'oposició a l'acord. ${ }^{1318}$

A més a més, hi són reproduibles els aspectes ressenyats supra, ${ }^{139}$ pel que fa a la legitimació dels membres de l'òrgan de control davant acords nuls.

D. Legitimació del comitè de recursos i dels liquidadors

designació de la persona física representant, sinó també l'acceptació expressa del càrrec i la declaració de no-incompatibilitat.

1318 També, davant acords anul-lables, d'altres lleis autonòmiques reconeixen legitimació als membres de l'òrgan de control (LCPV, art. 39.5, en tot cas; LCC, art. 38.3, estableix únicament l'obligació d'impugnació davant acords socials que s'oposen als estatuts). 
Ja hem vist, en relació amb els acords nuls, que la LCoop ha introduït dues noves legitimacions per a la impugnació, en favor del comitè de recursos i dels liquidadors. Això no obstant, aquestes legitimacions només es fan explícites pel que fa a la impugnació d'acords nuls, mentre que s'ometen en la relació de subjectes legitimats per impugnar acords anul-lables. I no obstant això, tot seguit, en la relació d'obligats a impugnar els acords contraris a la llei o als estatuts, sí que s'inclou "els liquidadors i, si escau, el comitè de recursos". Així doncs, es planteja, novament, una qüestió que la LGC ja suscitava en relació amb la legitimació dels administradors i que es podria haver evitat amb unaredacció més acurada del text legal: tot estimant l'obligació com a legitimació implícita davant els acords anul-lables contraris als estatuts, cal estendre la legitimació als acords anul-lables lesius de l'interès social?, o l'omissió de l'obligatorietat de la seua impugnació, sens dubte, voluntària, indica també voluntat de no reconèixer legitimació davant aquests al comitè de recursos i als liquidadors?

La resposta a aquests interrogants no és fàcil, ja que cal adoptar una posició determinada; considerem més acceptable la primera opció ${ }^{1320}$, ja que si la falta de legitimació expressa davant acords antiestatutaris no en suposa la noimpugnabilitat, tampoc no s'ha de deduir, necessàriament, per als acords lesius del fet de la seua no-obligatorietat: que no siga obligatori per al comitè de recursos o per als liquidadors impugnar els acords que lesionen interessos socials en benefici de socis o de tercers no ha de significar, sempre, la seua prohibició. En relació amb els liquidadors s'ha d'afegir, com a argument favorable a la seua legitimació, que les seues funcions són, almenys parcialment, anàlogues a les desenvolupades pel consell rector, els membres de les quals sí que tenen, ara, legitimació expressa davant els acords anul-lables. 
D'altra banda, tampoc per al comitè de recursos o per als liquidadors serà exigible cap requisit addicional per exercir la seua legitimació (ni dissidència, ni constància en l'acta, o absència), la qual cosa reprodueix per a ells la hipòtesi que qui ha contribuït a la producció de l'acord puga instar-ne l'anul-lació. Entenem que, també pel que fa a aquesta legitimació més àmplia (davant la reconeguda als socis que no tenen càrrecs), la justificació s'ha de situar en el deure de diligència i de defensa de l'interès social que adquireixen amb l'acceptació del càrrec. ${ }^{121}$

Quant a les característiques concretes de la legitimació al comitè de recursos, ja $s^{\prime}$ ha assenyalat també que es tracta d'una atribució a l'òrgan en el seù conjunt, a fi de dotar-lo, expressament, d'un instrument d'intervenció directa, per intentar la supressió d'acords que, al seu entendre, hagen de ser anul.lats.

I per a la legitimació concreta als liquidadors s'ha de recordar, d'una banda, que, en principi, és de caràcter individual, però que quan els liquidadors siguen tres o més, han d'actuar en forma col-legiada, i han d'adoptar els acords per majoria, per la qual cosa estimem que l'òrgan, en execució de les seues funcions, podrà acordar, també, l'inici de l'acció; d'altra banda, que hi ha la possibilitat que els liquidadors siguen persones no sòcies.

La LCCV no preveu la legitimació dels seus òrgans equivalents, la comissió de recursos i els liquidadors.

supòsits d'acords contraris als estatuts.

1321 Ja hem vist com la legitimació àmplia atribuïda als administradors de les societats de capital és fonamentada per alguns autors en la línia d'oferir a l'administrador una via d'exoneració de responsabilitat, mentre que d'altres la fonamenten en el deure de l'administrador de defensar l'interès social. Traslladant el debat a l'àmbit cooperatiu i a dues figures diferents, com són el comitè de recursos i els liquidadors, $s$ 'ha de recordar que mentre que la LCoop sí que preveu l'exercici de l'acció de responsabilitat davant el comitè de recursos, paradoxalment, no es refereix a això en relació amb els liquidadors; d'altra banda, i en tot cas, ja hem vist (epígraf 2 del capítol primer) que en les cooperatives la impugnació de l'acord que es 


\subsection{Legitimació per a la impugnació d'acords de l'òrgan d'administració}

L'exposició de motius de la LGC, VII, 8è par., qualificava d'“innovació important en ordre a facilitar i a incrementar els mitjans de control a disposició dels socis, la incorporació de la possibilitat d'impugnació dels acords del consell rector". També URÍA ${ }^{132}$, en comentar-ne la introducció posterior en la LSA, estimava que amb això s'ampliaven les possibilitats de defensa dels socis "davant del creixent poder que en l'interior de l'actual societat anònima acumulen els òrgans col-lectius d'administració".

No obstant això, més enllà de l'indubtable valor del reconeixement legal expressat, no sembla, com veurem, que la regulació específica de la impugnació dels acords de l'òrgan d'administració millore, necessàriament, la que s'atribueix davant els acords impugnables de l'assemblea general. Però vegem quina és la regulació cooperativa positiva, també en aquesta matèria divergent.

\subsubsection{LCoop}

La LCoop, continuant el criteri ja introduït per la LGC, i, a diferència, de l'opció escollida per la LSA i la LCCV, adopta el model de la legitimació diferenciada davant els acords nuls $\mathrm{i}$ anul-lables, com hem vist que ocorre amb l'assemblea1323.
A. Per impugnar acords anul-lables

La legitimació per impugnar els acords anul-lables del consell s'atribueix, en la LCoop, a tres col-lectius: els membres del consell, els interventors i el $5 \%$ dels socis.

\footnotetext{
considera invàlid no exonera, per ella mateixa, d'una responsabilitat eventual per la participació
en la seua adopció.
} 1322 URtA, R., Derecho mercantil, pàg. 344 i 345. 
En relació amb la legitimació dels membres del consell, no hi ha cap dubte que la LCoop es refereix, fonamentalment, a aquests quan legitima "els assistents a la reunió del consell que hagueren fet constar en l'acta el seu vot contra l'acord adoptat, els absents i els que hagen estat il-legítimament privats d'emetre el seu vot", però s'ha de recordar que no tots els membres del consell han de ser necessàriament socis: la LCoop permet l'existència de consellers laborals (art. 33, $3 \mathrm{r}$ i 4t par.), consellers experts no socis (art. $34.2 \mathrm{i}$ art. 77.2) o, en cooperatives de segon grau, socis de cooperatives sòcies (art. 77.2); també, com veurem, poden assistir a les reunions del consell persones que no són membres.

Si delimitem ja les característiques de la legitimació dels "assistents a la reunió del consell que hagueren fet constar en l'acta el seu vot contra l'acord adoptat", $i$ tot seguint, en bona mesura, el que s'ha argumentat per a la legitimació davant acords de l'assemblea general, podem destacar diverses conclusions. En primer lloc, s'ha de tenir present que, si bé no es permet, amb caràcter general, la representació dels consellers (art. 36.2 de la LCoop), els assistents poden ser en alguna ocasió persones que no exerceixen el càrrec d'administrador. Així, per exemple, encara que no es preveu, expressament, en el text legal, res no impedeix que els estatuts, l'assemblea general o els membres del consell autoritzen l'assistència a les reunions de no consellers, ${ }^{1324}$ com per exemple, el director o d'altres càrrecs de gestió, o el comissari del sindicat d'obligacionistes, ${ }^{135}$ si escau. Això no obstant, entenem que perquè puguen considerar-se legitimats, s'ha de tractar de persones l'assistència de les quals tinga una estabilitat determinada, siga perquè es tracta un dret reconegut,

1323 EMBID IRUJO, J. M., «Comentario al artículo 143», op. cit., pàg. 1530 i 1531.

1324 Article 36.1 de la LCoop: "Els estatuts o, si no n'hi ha, l'assemblea general, regularan el funcionament intern del consell rector".

1325 Com ja s'ha vist supra, el comissari del sindicat d'obligacionistes tindrà les facultats que li atorga la LSA (art. 282-310, en virtut de la remissió expressa de la legislació cooperativa), i també, les que li atribueixen l'escriptura d'emissió o l'assemblea general d'obligacionistes. Entre 
legalment o estatutàriament, ja perquè l'autorització de l'òrgan corresponent va més enllà de la singular per a una reunió concreta.

Quant al sentit de l'oposició, per als acords anul-lables del consell, s'estableix la legitimació únicament en favor dels qui hagen votat en contra. ${ }^{1326}$ En relació amb el significat que haja d'atribuir-se a l'expressió vot en contra, ens remetem al que $s$ 'ha desenvolupat per als acords de l'assemblea general: si en virtut del còmput de la majoria exigida, l'abstenció, el vot nul o el vot en blanc suposen un obstacle en l'adopció de l'acord, pot interpretar-se que aquestes actuacions tenen un efecte essencialment idèntic al vot expressament negatiu. ${ }^{132}$

Els membres del consell absents estan tots legitimats, al marge de les causes, justificades o no, de l'absència. ${ }^{132}$ En els supòsits en què el membre del consell haja assistit parcialment a la reunió, caldrà considerar-lo absent sols en relació $\mathrm{amb}$ els aprovats sense la seua presència. les facultats atribuïdes legalment, l'article 304.1 preveu un supòsit concret, en què el comissari
podrà assistir, amb veu i sense vot, a les reunions de l'òrgan d'administració.

1326 dels acords anul.lables, els assistents a legitimats, per a l'exercici de les accions d'impugnació el seu vot contra l'acord adopta". general..., pàg. 857, en relació amb la LGC.

1327 Vegeu supra, epígraf 1.2.1.A.a) c'): "si la majoria es computa sobre el nombre de presents i de representats, l'abstenció, el vot nul o el vot en blanc reforcen la posició dels socis contraris a l'adopció de l'acord; si la majoria ho és tan sols en relació amb els vots vàlidament emesos, necessària per a l'aprovació". Tanmateix, una ombra de dubte s'introdueix en la redacció de l'article 37.2 de la LCoop, que reconeix legitimació davant acords nuls del consell a "tots els socis, fins i tot als membres del consell rector que hagueren votat a favor de l'acord $i$ els que s'hagueren abstingut. Així mateix, assistents a la reunió a l'exercici de les accions d'impugnació dels acords anul-lables, els Fa la impressió que, ensell que hagueren fet constar, en l'acta, el seu vot contra l'acord...". col-lectiu diferent a aquells que hagueren vols consellers que s'abstenen formarien part d'un $d^{\prime}$ una construcció deficient del hagueren votat en contra. En realitat, estimem que es tracta legitimats els consellers que van vo s'ha d'entendre que davant els acords anul-lables estan en contra; l'adverbi de ma van votar a favor i els que s'abstingueren, $i$ també els que van votar desafortunada. responsabilitat, si se'n dedueix una falta de diligència dolosa, abusiva o negligent; però no suposa la privació de legitimació per a la impugnació d'acords adoptats sense la seua presència. 
Pel que fa als que "hagen estat il-legítimament privats d'emetre el seu vot", ja hem referit el nostre estupor: si s'adopta un acord que prive, il-legítimament, el titular, del seu dret de vot, aquest acord és nul, no anul-lable, i davant els acords nuls del consell, com veurem, estan legitimats tots els socis.

La qüestió relativa al moment en què s'ha de posseir la qualitat de membre del consell per a la impugnació dels seus acords, ha suscitat una certa divergència doctrinal per a les societats de capital. ${ }^{139}$ Nosaltres, com ja hem manifestat en relació amb la impugnació pels administradors dels acords assemblearis, considerem que el deure de diligència que hi recau i que fonamenta la seua legitimació, justifica també la legitimació, tant de qui ja era membre de l’òrgan d'administració en el moment de l'adopció de l'acord, com de qui adquirisca la condició posteriorment.

També estan legitimats, sempre, els interventors, en coherència amb la seua funció d'òrgan de fiscalització de la cooperativa (art. 38). ${ }^{1300}$

D'altra banda, cal assenyalar que per als acords del consell desapareix l'obligació d'impugnar, tant per als administradors com per als interventors,

1329 Pel que fa a les societats de capital, s'han indicat opinions diferents en relació amb la legitimació dels administradors, per a la impugnació d'acords del consell mateix; així, SALELLES CLIMENT, J. R., El funcionamento... op. cit., pàg. 400 i 401: "el membre del consell, per impugnar l'acord, ha de tenir aqueixa condició no en el moment de l'adopció de l'acord, sinó en el d'exercici de l'acció [...]. Aqueix poder es configura com un deure quan la impugnació siga la solució més adequada per tutelar l'interès social típic $i$, per això, és irrellevant el moment en el qual va ser adoptat l'acord del consell"; SÁNCHEZ CALERO, F., Administradores, op. cit., pàg. 543, per contra, opina que "l'administrador o el conseller, per estar legitimats per a l'exercici de l'acció, han de tenir aqueixa condició no en el moment en el qual fan l'exercici, sinó en el de l'adopció de l'acord que impugnen. És a dir, que no tindrà aquesta legitimació l'administrador que va deixar de ser-ho abans de l'adopció de l'acord, o el que ha estat designat posteriorment a aquest"; d'altra banda, EMBID IRUJO, J. M., "Comentario al art. 70», op. cit., pàg. 743, estima que "en tot cas, aqueixos administradors, per poder impugnar l'acord, hauran de tenir aqueixa condició, no sols en el moment de la impugnació, sinó, sobretot, quan s'haja adoptat l'acord" (també en «Comentario al artículo 143», op. cit., pàg. 1531).

1330 EMBID IRUJO, J. M., «Comentario al artículo 143», op. cit., pàg. 1530. Per a d'altres qüestions relatives a la legitimació dels interventors, vegeu el que s'ha argumentat supra per a la impugnació dels acords nuls de l'assemblea (epígraf 1.1.1.D). 
obligació que, com es recordarà, la LCoop sí que estableix en relació amb els acords assemblearis contraris a la llei o als estatuts.

\section{Quant a la legitimació reconeguda al 5\% dels socis, constitueix una} transformació radical del seu dret: mentre que la legitimació dels socis davant dels acords anul-lables de l'assemblea, encara que sotmesa al compliment de determinades circumstàncies és un dret individual, respecte dels acords del consell s'ha considerat convenient configurar-lo com un dret de minoria. La doctrina ha justificat aquesta reducció de les possibilitats d'exercici del dret "en la tutela per la llei de l'actuació de l'òrgan administratiu", que no ha de veure's alterada per processos d'impugnació plantejats per socis que no arriben a tenir una certa entitat. Amb això, sols si almenys un $5 \%$ dels socis considera que s'ha d'iniciar l'acció, podrà impugnar-se l'acord que s'estima anul·lable. ${ }^{132}$

\footnotetext{
1331

Vicent ChuliÁ, en Paz Canalejo, N. i Vicent Chuliá, F., Ley general..., pàg. 857, en relació amb la LGC: "L'article 66 suprimeix el deure d'impugnació dels acords del CR que els membres d'aquest $\mathrm{i}$ els interventors suporten en relació amb els acords de l'AG contraris a la

L'article 52 de la LGC, titulat Impugnación de acuerdos de la asamblea general, es referia, tanmateix, a "acords socials" en general, a l'hora d'establir l'obligació d'impugnar que feia recaure sobre membres del consell rector $\mathrm{i}$ interventors, cosa que podria haver servit per justificar una interpretació eventual d'obligatorietat també per als acords d'altres òrgans, especialment en els de l'òrgan d'administració. Però el text actual de l'article 31.4 de la LCoop substitueix aqueixa "expressió per la d'"acords contraris a la llei i als estatuts" i, ubicat en l'article titulat "Impugnació d'acords de l'assemblea general", sembla que impedeix la interpretació
generalitzadora.
}

1332

acords de la junta, J. M., "Notas sobre la impugnación...", op. cit., pàg. 56: "A diferència dels minoria". Amb això, el legislador un dret individual de l'accionista, sinó un dret autèntic de grups estables i rellevants '́ fa a la legitimació activa dels socis per , en "Comentario al art. 70», op. cit., pàg. 744: "pel que possible [...] proposar cap interpro per impugnar els acords [...] anul-lables [...] No sembla (endisca a atribuir al soci legitimació individual"; SÁNCHEZ CALERO, F. d'impugnació dels à considera que el dret [...], això no nersonal d'administracióo jaceix en relació a la impugnació dels acords de l'òrgan col-legiat configura com jue la llei nega al soci, com a tal, el dret a impugnar aqueixos acords $\mathrm{i}$ el criticada l'actuació la la latela de la le dels seus acords, per uninistratiu, que no ha de veure's alterada per processos d'impugnació 
D’altra banda, com ja hem indicat supra (epígraf 2.1 del capítol primer), que l'atribució de legitimació al 5\% dels socis no administradors puga qualificar-se, en un sentit ampli, com a dret de la minoria, no significa que la seua finalitat directa siga la tutela dels interessos de la minoria..$^{130}$ En realitat, quan es qualifica la impugnació com a mitjà de tutela de la minoria s'incorre en una certa confusió terminològica. ${ }^{134}$ Estrictament parlant, són únicament mitjans de tutela de la minoria aquells en què aquesta (definida normativament mitjançant la fixació de la seua composició mínima: normalment amb un percentatge sobre el total dels socis o sobre el capital social) ${ }^{1355}$ no necessita acudir a una instància externa a la societat (jurisdiccional o administrativa), ni invocar cap transgressió de la llei, dels estatuts o de l'interès social. En aquest sentit, "a falta d'un criteri de raó, la llei atén un criteri de quantitat"; quan el grup minoritari representa un percentatge important del capital social, la llei, sense motiu, deroga el principi de submissió a la majoria" ${ }^{1336}$ Així doncs, en la legitimació dels socis no administradors per a la impugnació d'acords de l'òrgan d'administració, no pot parlar-se estrictament d'instrument de tutela de la minoria, ja que aquesta

social". En el mateix sentit, GARCÍA LUENGO, R. i SOTO VAZQUEZ, R., El nuevo régimen jurídico..., op. cit., pàg. 642 .

1333 DíAZ DE LEZCANO SEVILlANO, N., Los acuerdos del consejo..., op. cit., pàg. 195 i ss., on ressalta que "si el legislador haguera pretès garantir un curs idoni per a la protecció d'interessos particulars, de minories o generals, no haguera privat ni el tercer ni el soci individual de legitimació, ja que aquest últim no en té, ni tan sols quan resulte perjudicat per l'acord".

1334 GIRÓN TENA, J., Derecho de sociedades anónimas, op. cit., pàg. 188. Sobre la "pluralitat de significats en una diversitat de contextos" amb els quals sol utilitzar-se el concepte de minoria, vegeu JUSTE MENCfA, J., Los derechos de minoria..., op. cit., pàg. 46-49; RUBIO, J., Curso..., op. cit., pàg. 180; i SÁNCHEZ RUIZ, M., Conflictos de intereses..., op. cit., pàg. 115-142.

1335 El principi d'un vot per persona imposa en la cooperativa que els computs de majories i de minories s'establisquen, com a norma general, sobre el total de socis i no del capital social, com ocorre en les societats capitalistes. Com a excepció, l'article 41.6 de la LCCV estableix que la legitimació dels socis per a la impugnació dels acords del consell rector requerirà que representen, almenys, un $5 \%$ del capital social (vegeu infra).

1336 GARRIGUES, J., «La protección de las minorías...», op. cit., pàg. 98 i 99; POLO SÁNCHEZ, E., "Abuso o tiranía...", op. cit., pàg. 2285. SÁNCHEZ RUIZ, M., Conflictos de intereses..., op. cit., pàg. 140 i 141, tampoc no considera suficient aquesta concepció de la tutela de la minoria, ja que, segons el seu parer, "no esgota totes les hipòtesis de conflicte majoria-minoria [...], únicament resulten protegits aquells interessos específics del soci i de la minoria que han assolit el rang de dret subjectiu $\mathrm{i}$ que han estat reconeguts com a tals en el règim jurídic de les societats de 
necessitarà recórrer a un àmbit extern, judicial, perquè es determine si l'acord vulnera la llei, els estatuts socials o l'interès social.

\section{En tot cas, el reconeixement d'aquesta legitimació als socis davant els acords} anul-lables de l'òrgan de gestió, ha rebut crítiques de diversa índole. Així, per exemple, la d'establir un únic percentatge amb independència de la mesura de l'entitat, ${ }^{1397}$ la dificultat dels socis no administradors per obtenir informació suficient i puntual que els permeta d'exercir el dret, ${ }^{130}$ o la de crear la possibilitat que un reduït grup de socis impugne tot tipus d'acords, inclosos els de "mera

capital"; en la seua opinió, la tutela de la minoria hauria d'incloure els supòsits d'abús de la
majoria en dany de la minoria o d'abús de la regla de la majoria.

1337 congruent per ser de capital, la mesura que es pren en consideració és la del capital, criteri F., Administradores..., op. cit., pàg. 545: "pot estima, alhora, el dret de vot. Així, SÁNCHEZ CALERO, del capital social per a tota classe de "pot estimar-se fundada la crítica a la llei d'exigir el $5 \%$ en aqueix cas, resulta molt dificile societats, fins $i$ tot d'aquelles de capital molt elevat; ja que, crítica [...] ha d'estendre's dificil la possibilitat pràctica d'efectuar la impugnació [...] Aquesta caràcter general, exigeix ul sistema seguit per la llei per a la tutela de la minoria, ja que, amb no un percentatge que varie SEVILLANO, N., Los acuerdos del cons aquesta quantia". En el mateix sentit, DíAz DE LEZCANO minorías...», op. cit., pàg. 114-116. JJ..., op. cit., pàg. 199; GARRIGUES, J., «La protección de las "Quant a l'oportunitat d'assenyalar un MENCFA, J., Los derechos de minoria..., op. cit., pàg. 391: crítiques que afavorisquen que s'eleve, percentatge fix del $5 \%$, poden fer-se consideracions imprevisió del legislador a l'hora deve, o que es reduïsca la quota. El problema rau en la nou, les reflexions sobre la dificultat regular una institució tan delicada. [...] Cal recordar, de l'oportunitat d'establir quotes decltat d'assolir el $5 \%$ en les societats obertes. [...] S'ha defensat Per a les cooperatives, la crítica podrixts, desaprofitada en l'última reforma". referència a uns altres paràmetres, per exemple, el del no-observança de la grandària, però en

\section{8} poden trobar els existeix cap mecanisme legal que obligue a la seuat dels acords adoptats pel consell, ja que no pot posar a prova la bondat de l'instrument de control difusió. En la nostra opinió, aquest extrem suficient per salvar aquest dèficit informatiu, el dret a establert en favor dels socis. No sembla a més, l'article $26.2 \mathrm{n}$ del Codi de comerç sembla liet a obtenir certificacions dels acords socials; no obstant això, no seria un obstacle insalvablimitar-lo als acords de la junta -la qual cosa, exactitud, les dates de reunió del consell, amble; en moltes societats és difícil saber, amb terminis tan breus existents per a la impugnació consegüent possibilitat que transcorren els SÁNCHEZ, E. Los administradores..., op. cit., pàg. 537 i 538 .

En l'àmbit cooperatiu estatal, si bé és cert que sí que existeix una regulació detallada del dret d'informació del soci (art. 16.3 de la LCoop), aquesta s'orienta, fonamentalment, al coneixement L'única referència expressa aserativa i dels assumptes que es tractaran en l'assemblea general. reconeix el dret del soci a "rebre, si lal consell és la continguda en l'article 16.3, c) que acords del consell que afecten el soci, individita, del consell rector, una còpia certificada dels que se li aclarisca, en un termini no superior a un particularment $i$, en tot cas, que se li mostre $i$ relació amb la cooperativa". 
gestió." ${ }^{\prime 139}$ La varietat de perspectives en la crítica, ha portat a plantejar, tant la possibilitat d'augmentar com la de disminuir estatutàriament aquest percentatge, o la de condicionar l'exercici del dret que atribueix, encara que sembla que ha de concloure's que cap d'aqueixes opcions és possible. ${ }^{132}$

També s'han plantejat dubtes pel que fa al període que s'ha de prendre en consideració per a l'acreditació de la minoria, és a dir, si aqueixa minoria ha de produir-se només en el moment de la iniciació del procediment o bé al llarg de tot el procés, "des de la demanda fins a arribar a la sentència, de manera que si

1339 EMBID IRUJO, J. M., "Comentario al art. 70», op. cit., pàg. 744: “el criteri legislatiu ha estat vist de manera desfavorable, ja que posa a l'abast de la minoria reconeguda en la llei el control de tot tipus d'acords, fins i tot els de mera gestió, el vici possible dels quals no justifica, segurament, el remei legislatiu, [...] En vista de les tendències actuals en matèria d'administració social [...], no sembla discutible reconèixer a uns administradors cada vegada més professionalitzats un marge d'actuació que, sense estar exempt de límits i de controls, permeta desenvolupar, en un mercat competitiu, els objectius de l'empresa social. En el mateix sentit de denunciar abusos possibles de la minoria, sobretot en assumptes de mera gestió, JUSTE MENCÍA, J., Los derechos de minoría..., op. cit., pàg. 391 i 392.

1340 JUSTE MENCfA, J., Los derechos de minoría..., op. cit., pàg. 392 i 393: “Quant a la possibilitat de reduir el percentatge als estatuts [...], el caràcter esmentat de norma processal que acompanya l'exercici pot fer dubtar sobre la possibilitat [núm. 23: en aquest sentit, ARANGUREN URRIZA, "Los órganos...», op. cit., pàg. 555] [...] s'ha d'entendre il-lícit l'augment del quòrum i l'establiment de règims estatutaris que agreugen les condicions d'exercici. No s'ha d'oblidar el caràcter de dret no derogable que cal atribuir a aquestes figures, pel fet de derivar de la posició de soci en la societat. [núm. 24: en contra, ARANGUREN URRIZA, «Los órganos...», op. cit., pàg. 555 i 556. Per a aquest autor, conscient dels riscos greus d'obstruccionisme plantejats, els estatuts poden permetre que la junta general impose sancions, en cas d'exercici extemporani o de mala fe. Aquesta solució sembla, tanmateix, contrària a la intenció del legislador, que és la de permetre la valoració dels acords del consell d'administració per un o per diversos socis, al marge de qualsevol competència de la junta. S'ha de pensar, a més, que entre la majoria de la junta $\mathrm{i}$ dels administradors, hi haurà ordinàriament una comunitat d'interessos, raó per la qual s'autoritza l'actuació de la minoria. Per idèntics motius, la proposta d'aquest autor, en ordre a condicionar l'exercici efectiu de l'acció a l'aprovació o ratificació de la junta, presenta problemes de licitud. Certament, la llei dissenya la impugnació per anul-labilitat com un dret disponible, en la mesura que el no-exercici equival a la renúncia. Però sembla haver-hi una diferència de grau entre el no-exercici davant d'un acord concret $i$ el condicionament de qualsevol exercici amb la clàusula estatutària-, respecte de tots: el segon equival a expropiar un dret de font legal als socis. Un sistema en el qual la junta apareix com a òrgan de decisió en la matèria és el portuguès; vegeu els articles 411 i 412 (op. cit.)].

En relació amb un altre dret de minoria, l'atribuït al 5\% del capital social per tal de sol-licitar la convocatòria de junta general (en SA, art. 100.2 i 100.3), CARBAJO CASCÓN, F., Los requisitos..., op. cit., pàg. 16 i 23, estima que el percentatge "té caràcter mínim, és a dir, que els estatuts podran reduir aquest percentatge legal; però, en cap cas, serà vàlida una clàusula que n'exigisca un de superior per sol-licitar la convocatòria de la junta, «ja que aquest és un dret de la minoria i no pot ser ni suprimit ni limitat» (De la Cámara) [...] Si hi ha una clàusula estatutària que rebaixe el percentatge legalment exigit, es farà extensiva a la sol-licitud de convocatòria judicial 
la minoria es desfà $(\ldots)$ haurà d'estimar-se que perd la seua legitimació", encara que finalment la doctrina semble decantar-se per la necessitat de mantenir el percentatge durant tot el procés. ${ }^{\text {131 }}$

\section{B. Per impugnar acords nuls}

Davant els acords nuls del consell rector, la LCoop concedeix acció d'impugnació a "tots els socis; fins i tot, als membres del consell que hagen votat a favor i els que s'hagen abstingut". L'ampliació de la legitimació és plenament coherent amb la gravetat del vici, però planteja diverses qüestions.

En primer lloc, s'observa que la LCoop, a diferència del que s'estableix per als acords de l'assemblea, no atribueix una legitimació general als tercers amb interès legítim davant els acords nuls del consell1342. Sembla, doncs, que els tercers, l'interès dels quals es veja afectat per acords del consell, hauran de recórrer a altres vies de defensa (acció de responsabilitat, impugnació de l'acord

de l'article 101.2 de la LSA".

1341 SÁNCHEZ CALERO, F., Administradores.., op. cit., pàg. 545, es basa en els arguments de GIMENO SENDRA, V., El proceso, pàg. 70 i 71, i de GÓMEZ ORBANEJA, E., Derecho procesal civil II, Madrid, 1976, pàg. 148, per a la legitimació del soci davant els acords nuls.

JUSTE MENCf́, J., Los derechos de minoría..., op. cit., pàg. 390 i 391 : “Quant al moment en el qual $s$ 'ha de reunir el percentatge requerit, aquest ha de constar a l'hora de presentar la demanda, encara que la participació s'haja adquirit posteriorment a la realització de l'acord [...]. La titularitat del nombre suficient d'accions ha de mantenir-se al llarg del procés, en la mesura que aquest requisit ho és de la legitimació dels socis davant el jutge. D'aquesta manera, l'alienació posterior de totes o de part de les accions - sempre que se'n derive una participació menor al 5\%-comporta la impossibilitat de portar a terme la impugnació. [núm. 18: ... cas de suspensió de l'acord de la junta impugnat, existeix una posició doctrinal que identifica el $5 \%$ amb el que es puga calcular en el moment d'assistir a l'assemblea els acords de la qual s'impugnen. Tanmateix, en aquest cas, no hi ha relació entre els titulars de la quota i l'acord impugnat -els accionistes no prenen part, lògicament, en l'acord del consell- [...] ja que la llei no estableix la necessitat de reunir la quota, exclusivament, en el moment de presentar la demanda, la conclusió sembla ser la que s'assenyala]". 
de ratificació per l'assemblea, si escau...), ${ }^{133}$ excepte en els supòsits expressament previstos en la norma legal: el de l'art. 13.2, en atorgar legitimació a qui el consell li denega la seua sol-licitud d'admissió, el del soci expulsat (art. 18.5, en relació amb l'art. 18.3, c), in fine), el del declarat en situació de baixa obligatòria (art. 17.5 i 6 , en relació amb l'art. 18.3, c), in fine), i el que, en haver causat baixa voluntària o per causa justificada, estiga disconforme amb la qualificació i/o els efectes que l'assemblea li assigne (art. 17.6, en relació amb $1^{\prime}$ art. $\left.18.3, c\right)$, in fine. ${ }^{13+4}$

D'altra banda, com ja s'ha indicat, per als acords contraris als estatuts no es considera obligació dels membres dels òrgans d'administració o de control la impugnació dels acords nuls del consell. Considerem que es tracta d'una omissió que adquireix la màxima gravetat precisament ací, tant per la radicalitat del vici com per tractar-se, justament, d'acords del consell, davant els quals els socis que no ocupen càrrecs estan especialment indefensos.

\subsubsection{LCCV}

L'article 41.6 LCCV, la redacció actual del qual prové de la reforma introduïda per la Llei 8/1995, incorpora, pràcticament literal, el model establert per la LSA en l'article 143, per a la impugnació d'acords de l'òrgan d'administració. Això significa, en primer lloc, que, a diferència del que es preveu en els acords de l'assemblea general, o del règim analitzat de la LCoop, s'estableix un sistema

1343 En aquest sentit, cal recordar alguns supòsits de tercers, l'interès legítim dels quals, almenys en alguns casos, no ofereix dubtes: treballadors, socis $i$ associats de persones jurídiques sòcies, directors i d'altres càrrecs de gestió, creditors, etc.

${ }^{1344}$ Però s'ha de tenir en compte que en els casos de l'expulsat i del declarat en situació de baixa obligatòria, el recurs inicial davant l'acord del consell l'interposa qui encara és soci, ja que els acords de baixa obligatòria i d'expulsió són únicament executius "des del moment que siga notificada la ratificació del comitè de recursos o, si no n'hi ha, de l'assemblea general, o haja transcorregut el termini per recórrer davant d'aquests"; és a partir d'aqueix moment que el recurrent es converteix en tercer no soci; per la qual cosa, només la impugnació de l'acord de l'assemblea general o, si escau, del comitè de recursos, ho serà en qualitat de tercer. 
unitari d'impugnació davant acords nuls i anul-lables. Així doncs, la legitimació (que, juntament amb el termini de caducitat, són les úniques especificitats que es regulen) ${ }^{\text {1.35 }}$ serà única, amb independència del vici que afecte l'acord.

\section{A. Tots els administradors}

La LCCV atribueix legitimació davant els acords invàlids a tots i a cadascun dels administradors de la cooperativa (art. 41.6). Consegüentment, això abasta, si escau, tant consellers no socis com l'administrador únic o els dos administradors de què s'haja dotat, alternativament, la cooperativa (art. 37.2).

D'altra banda, com s'ha assenyalat per als acords de l'assemblea, la legitimació és individual, i si bé la llei no ho impedeix, és difícil imaginar per al consell supòsits en què l'òrgan mateix decidisca la impugnació dels seus acords abans que procedir-ne a l'esmena o la substitució, i el mateix s'ha de dir pel que fa a supòsits hipotètics en què l'administrador únic poguera plantejar la impugnació de les seues pròpies decisions, o dels dos administradors conjuntament. $^{1346}$

En tot cas, la conseqüència principal del règim unitari d'impugnació és que, com s'ha assenyalat repetidament, 1347 fins $\mathrm{i}$ tot els administradors que hagen votat a favor d'un acord anul-lable podran instar-ne la impugnació. Aquesta ampliació de la legitimació dels administradors ha estat criticada per una part

1345 L'article 41.6 (de manera idèntica a com ho fa l'article 143 de la LSA) es limita a declarar, expressament, la impugnabilitat dels acords del consell, a establir un termini únic de caducitat $\mathrm{i}$ una legitimació única per a acords nuls i anul-lables, i a remetre expressament, quant al procediment d'impugnació, al que es preveu per a l'assemblea general, i implícitament per a la determinació de què s'ha d'entendre per acords nuls i per acords anul-lables.

1346 Qüestió diferent, i més probable, serà que l'administrador únic o els dos administradors vulguen impugnar acords o decisions dels qui els han precedit en els seus càrrecs.

1347 Vegeu supra, en el capítol primer, la introducció a l'epígraf 2., in fine, en relació amb el concepte d'interès social en la cooperativa i la seua defensa, mitjançant l'atribució de legitimació als administradors; també, en aquest mateix capítol IV, els epígrafs 1.1.1.C i 1.1.2.B. 
de la doctrina; ${ }^{13+\alpha}$ mentre que altres autors, com ja hem indicat, la justifiquen, bé com a via d'exoneració de responsabilitat, bé com a conseqüència del deure de tutela de l'interès social pels administradors. Reiterem que no s'ha d'entendre la impugnació d'acords socials, per si mateixa, com a forma d'exclusió de responsabilitat, mentre que, per contra, pesa sobre els administradors una responsabilitat explícita de prendre "les iniciatives que corresponguen" perquè s'hi apliquen la llei i els estatuts (art. 37.1 de la LCCV). Així doncs, la legitimació als administradors no constitueix, per si mateixa, un instrument per evitar la reclamació de la seua responsabilitat; però sí, per al compliment del seu deure de diligència, sense perjudici que s'hi observe una certa incoherència: estarà legitimat per impugnar un acord anul-lable l'administrador que haja votat a favor de la seua adopció.

Finalment, la LCCV tampoc considera necessari fer de la impugnació, davant d'acords nuls o contraris als estatuts, una obligació d'administradors i de membres de la comissió de control.

B. Els socis que representen un $5 \%$ del capital

Ja hem vist, en relació amb la impugnació d'acords del consell en la LCoop, el debat doctrinal que es planteja al voltant de la transformació en un dret de minoria del que, davant els acords de l'assemblea, és un dret individual del soci. ${ }^{139}$ Sense perjudici de considerar reproduïdes les observacions que se'n facen, la legitimació establerta en la LCCV presenta característiques específiques que convé analitzar.

En primer lloc, considerem obertament criticable que s'establisca com a criteri

1348 De la CÁmara Álvarez, M., "La administración de la Sociedad Anónima», RJN, 1992, pàg. 69; GARCiA LUENGO, R., i SOTO VAZQUEZ, R., El nuevo régimen jurídico..., op. cit., pàg. 643; POLOSÁNCHEZ, E., Los administradores..., op. cit., pàg. 523. 
de còmput de la minoria necessària per impugnar, el manteniment pels socis d'un percentatge de capital social determinat. És probable que aqueixa opció legislativa siga conseqüència d'un mimetisme excessiu, pel que fa a la regulació establerta per la LSA en l'article 143; però, el que és cert, és que l'article 41.6 de la LCCV exigeix que la minoria de socis que pretenga impugnar els acords del consell posseïsca la titularitat, almenys, d'un $5 \%$ del capital social. Si es té en compte que les aportacions dels socis al capital social no han de ser, necessàriament de la mateixa quantia, ${ }^{1350}$ pot concloure's que per als socis amb una aportació més gran serà més fàcil accedir a la impugnació, amb la qual cosa es produeix una vulneració del principi cooperatiu de gestió democràtica, que inclou el reconeixement de la igualtat de drets dels socis; ${ }^{1351}$ a més a més, s'introdueix una certa dificultat per calcular-lo i acreditar-lo: recordeu que el capital social en la cooperativa és essencialment variable.

\section{D'altra banda, la doctrina ha criticat un dels efectes del sistema unitari} d'impugnació: també per als acords radicalment nuls (inclosos els contraris a l'ordre públic) es requereix la reunió d'una determinada minoria ${ }^{135}$ que, a més i

1350 Article 46 de la 1 LCoop: "Els estatuts fixaran l'aportació obligatòria mínima al capital social per ser soci, que podrà ser diferent per a les distintes classes de socis o per a cada soci, en proporció amb el compromís o amb l'ús potencial que cadascun d'ells assumisca de l'activitat cooperativitzada"; article 50.1, de la LCCV: "Els estatuts socials fixaran l'aportació obligatòria per als socis de la cooperativa. Podran preveure que la seua quantia siga igual per a tots, o proporcional a l'activitat cooperativitzada desenvolupada o compromesa per cada soci". A més, tant l'article 47 de la LCoop com el 51 de la LCCV preveuen la possibilitat que la cooperativa acorde admetre que els socis facen aportacions voluntàries al capital social. Tot això, possibilita que la quantia total de les aportacions al capital de cada soci siga diferent de les dels altres.

1351 Com hem vist en l'epígraf 3.2.4. del capítol primer, els principis cooperatius són legalment aplicables a les cooperatives valencianes en virtut del que es preveu en l'article $3 i$ en la seua disposició addicional 2a. Amb l'exigència del manteniment d'un $5 \%$ de capital podrà produirse, freqüentment, que un nombre reduït de socis o, fins i tot, només un d'ells, puga impugnar, mentre que d'altres només podran accedir a l'exercici si reuneixen un nombre elevat de voluntats.

1352 EMBID IRUJO, J. M., "Comentario al art. 70», op. cit., pàg. 743 i 744: "En síntesi, aquestes crítiques indiquen la falta de fonament que suposa privar el soci, individualment considerat, de la possibilitat d'impugnar els acords nuls, sobretot quan aquesta nul-litat és el resultat d'una contradicció greu amb l'ordenació (com és el cas dels acords contraris, per la seua causa o contingut, en l'ordre públic...)"; també en EMBID IRUjO, J. M., "Comentario al artículo 143», op. cit., pàg. 1531 a 1533; JUSTE MENCÍA, J. Los derechos de minoría..., op. cit., pàg. 391, 392 i 396; POLO SÁNCHEZ, E., Los administradores..., op. cit., pàg. 523, 539 i 540. 
pel que sembla, haurà de mantenir-se durant tot el procediment. Creiem, com POLO SÁNCHEZ, que "negar, a l'accionista, aquest dret individual a exercitar l'acció d'impugnació d'un acord nul per contrari a la llei, i transformar-lo en dret corporatiu o de minoria, i condicionar-ne la legitimació a la possessió d'un percentatge del capital social determinat" no sols "no és ajustat a dret, sinó que és més perillós per a la societat que el risc de suportar impugnacions intranscendents i infundades". ${ }^{1350}$

Tampoc no es refereix la possibilitat d'impugnació pels associats, encara que això queda suplit, amb caràcter general, amb l'explicitació que fa la norma específica, l'article 24, quan, en l'apartat 2, diu que "en el supòsit que es reconega dret de vot als associats, gaudiran dels mateixos drets que el soci quant al seu exercici i participació en els òrgans socials, inclosos el dret d'impugnació". Això suposa, a més, al nostre entendre, que, almenys quan se'ls haja reconegut estatutàriament dret de vot, podran participar en el còmput de la minoria del $5 \%$ del capital necessari per a la impugnació dels acords del consell.

Finalment, la legitimació unitària també omet la inclusió de tercers amb interès legítim.

\subsection{Altres supòsits de legitimació activa}

1353 POLO SÁNCHEZ, E., Los administradores..., op. cit., pàg. 540.

1354 EMBID IRUJO, J. M., "Comentario al art. 70», op. cit., pàg. 744, comentant l'article equivalent de la LSRL: "la regulació continguda en l'article 70 de la LSRL serviria per privar de legitimació davant els acords nuls els tercers que acrediten interès legítim, segons expressa l'article $117 \mathrm{de}$ la LSA [...]". En el mateix sentit, per als acords dels òrgans collegiats d'administració de la LSA, GARCía LUENGO, R. i SOTO VÁzQUEZ, R., El nuevo régimen jurídico..., op. cit., pàg. 644, encara que opinen que "aquest buit legal pot ser satisfet en seguir els postulats doctrinals creats sota la vigència de la LSA, de 1951, per tal de legitimar els tercers per impugnar els acords de la junta. Aquests postulats es basen en els principis comuns i en la jurisprudència del TS, relativa a l'acció de nul-litat dels contractes, que ha confirmat, reiteradament, la legitimació dels tercers a qui perjudique l'obligació". 
1.3.1. Legitimació activa per impugnar acords o decisions d'altres òrgans socials

Fins ara, hem analitzat la legitimació activa davant els acords de l'assemblea general i del consell d'administració, únics òrgans respecte dels quals la legislació cooperativa estableix una atribució explícita. La resta d'òrgans socials, com ja hem vist (fonamentalment, en el capítol tercer), la majoria de les vegades ni tan sols disposen d'un reconeixement exprés de la impugnabilitat dels seus acords o les seues decisions, i encara menys, indicació de les persones que podran, si escau, exercir l'acció corresponent. Com a excepció, la regulació que fa la LCoop (art. 44) del comitè de recursos preveu que els seus acords podran ser impugnats " $\mathrm{d}$ 'acord amb el que s'estableix en aquesta llei, com si hagueren estat adoptats per l'assemblea general", la qual cosa inclou el corresponent règim legitimador. La LCCV és més genèrica en la seua remissió, en establir, en la regulació de la comissió de recursos, que "s'aplicaran les normes d'aquesta llei sobre el consell rector a (...) funcionament de la comissió de recursos" (art. $47.1,2 n$ par.).

Per a la resta d'òrgans socials, s'ha d'assenyalar, únicament, a falta de previsió estatutària, l'aplicació de les regles que, per analogia, resulten més pròximes. Així, en relació amb les formes no col-legiades de l'òrgan d'administració i amb els seus òrgans delegats, sembla que s'haurà d'entendre aplicable la legitimació desenvolupada per al consell rector. I el mateix succeeix amb els interventors, per als quals, com hem vist, ${ }^{1355}$ la resolució de les llacunes i les interpretacions s'ha de reconduir, en tot el que siga possible, a l'aplicació de les normes reguladores del consell rector, ateses les similituds en el seu règim que han conduït el legislador a establir tota una secció de disposicions comunes a ambdós òrgans, la 5a del capítol IV de la LCoop.

Més difícil resulta respondre a la qüestió pel que fa a la comissió de control de la gestió regulada per la LCCV. Ja hem indicat com, a diferència del que es 
preveu per a la comissió de recursos, la llei valenciana no remet la regulació del funcionament del seu òrgan potestatiu de control a les normes del consell rector, per la qual cosa s'haurà d'atendre, estrictament, el contingut de les clàusules estatutàries corresponents; sols, si no n'hi haguera, entenem que podran aplicar-s'hi, analògicament, els preceptes relatius a l'òrgan d'administració. ${ }^{1356}$

En relació amb les decisions de la direcció, ja hem reiterat que la LGC del 1987 les considerava, pel que fa a la seua impugnació, com a acords del consell rector, i també, ho fa en l'actualitat la LCE (art. 43.1, 2n par.). D'altra banda, a la direcció se li atribueixen competències originàriament atribuïdes a l'òrgan d'administració, cosa que ens ha fet concloure que si la direcció es configura com a òrgan (i en podran ser proves, si escau, la seua regulació estatutària i/o la seua designació obligatòria), les seues decisions podran impugnar-se pel mateix procediment establert per als acords o les decisions de l'òrgan administratiu, de qui rep i amb qui comparteix les competències.

També per als liquidadors hem conclòs ${ }^{1357}$ l'aplicabilitat supletòria, amb les adaptacions que corresponguen i, a falta d'una altra previsió estatutària, del règim de funcionament del consell rector, per raó de les funcions que se'ls atribueixen.

Finalment, hem comprovat que la LCoop (art. 19) no permet la constitució d'altres instàncies que puguen qualificar-se d'òrgans, mentre que la LCCV sí que recull, expressament, la facultat de creació estatutària de comissions delegades de l'assemblea general. A més, ja hem exposat la nostra opinió sobre la possibilitat que, en el marc de la LCCV, puguen crear-se altres òrgans socials. Respecte de les comissions delegades de l'assemblea (diferents a la de recursos i a la de control de la gestió), el règim de la seua impugnació serà el que s'adopte, 
en aqueix cas, en els estatuts, però a falta de regulació expressa, sembla que el procés d'impugnació aplicable serà el previst per als acords de l'assemblea, atesa la naturalesa de les funcions delegades atribuïdes a la comissió de què es tracte. Quant a la possibilitat de creació d'altres òrgans no previstos legalment, estimem que, atesa la falta d'autorització legal expressa, no pot ser suficient l'acord de l'assemblea general, sinó que es requerirà una previsió estatutària explícita; 1358 caldrà fer el que es dispose en les clàusules dels estatuts que donen forma a aqueixos òrgans.

Des d'una altra perspectiva, i com hem indicat anteriorment, tant la LCoop com la LCCV reconeixen, al llarg dels seus articles, supòsits concrets de legitimació activa, encara que es tracta, de vegades, de simples enunciats de la possibilitat d'impugnar. En alguns casos, com veurem, el procediment corresponent ni tan sols es denomina impugnació, sinó recurs, encara que no hi ha cap dubte que ens trobem davant de reconeixements explícits de la facultat dels legitimats per intentar fer desaparèixer acords dels òrgans socials, fonamentalment de l'òrgan d'administració.

Es tracta de supòsits d'índole molt variada que, això no obstant, tenen en comú no distingir entre la possible nul-litat o anul-labilitat dels acords i de les actuacions, davant els quals es concedeix legitimació.

1.3.2. Legitimació per a la impugnació de l'acord sobre l’admissió de nous socis

Tant la LCoop com la LCCV estableixen, dins del procés d'admissió de nous

1357 Epígraf 3.4 del capítol tercer.

1358 Aqueixa estimació es deriva del fet que si bé és cert que la LCCV (art. 27.1, e) permet modificar, en general, l'estructura de la cooperativa mitjançant acords de l'assemblea, quan regula els supòsits, que sí que estan legalment previstos, de creació d'òrgans socials potestatius, n'exigeix la regulació estatutària prèvia (comissió de recursos: article 47.1; comissió de control de la gestió: article 48.1). Això és, a més, coherent amb la necessitat de garantir els drets del soci, en particular el seu dret d'informació, i també, el seu dret-obligació de participar en la gestió. 
socis, la possibilitat d'impugnar l'acord que adopte el consell rector en primera instància. Tanmateix, com veurem, aqueix procediment específic d'impugnació planteja més d'un interrogant. ${ }^{1.39}$ Vegem, tot seguit, els diferents supòsits de legitimació activa específica que es poden produir.

\section{A. En la LCoop}

En la Llei estatal (art. 13), s'estableix una distinció bàsica, segons que l'acord siga denegatori o d'admissió. En el primer supòsit, es reconeix únicament legitimació activa al sol-licitant de la condició de soci, per a la seua impugnació davant del comitè de recursos o de l'assemblea general; per contra, davant l'acord d'admissió s'atribueix legitimació al "nombre de socis i en la forma que estatutàriament es determine". ${ }^{\prime 30} \mathrm{D}^{\prime}$ aqueixa regulació, cal destacar alguns aspectes, que desenvolupem tot seguit.

En primer lloc, s'observa que sols s'atribueix legitimació per impugnar la inadmissió, a la persona sol-licitant; es tracta, com ja hem destacat, d'un supòsit de "tercera persona amb interès legítim", a la qual és reconeix, expressament, dret per impugnar un acord de la cooperativa, i tot això, sense discriminar segons les causes d'impugnació: el sol-licitant sempre podrà recórrer davant la denegació, siga nul-la o anul-lable. Entenem que aquest tipus de legitimació se sosté sobre el principi cooperatiu de porta oberta: ${ }^{1361}$ si qui reuneix els requisits

1359 Així, per exemple, sembla que, encara que no ho expresse el text normatiu, la impugnació haurà de fonamentar-se sobre la base, bé de la seua oposició a la llei o als estatuts, bé de la seua lesivitat a l'interès social, ja que són aquestes les úniques causes legals que poden prevaler sobre la voluntat majoritària dels òrgans socials en l'exercici de les seues competències.

1360 La LGC (art. 31.3) establia, únicament com una opció estatutària, la possibilitat de reconèixer legitimació davant l'admissió de nous socis; en canvi, el tenor literal de la LCoop (art. 13.3) sembla que es decanta per reconèixer tal possibilitat com un dret que, en tot cas, haurà de concretar-se estatutàriament.

1361 El primer principi cooperatiu, el d'adhesió voluntària i oberta, més conegut com de porta oberta, ha estat explicat per la Declaració de l'ACI de Manchester, de 1995, amb el següent text: "Les cooperatives són organitzacions voluntàries, obertes a totes les persones capaces d'utilitzar els seus serveis i disposades a acceptar les responsabilitats de ser soci, sense discriminació sexual, social, racial, política o religiosa". 
objectius necessaris té dret a ingressar com a soci, s'ha de garantir la defensa adequada d'aqueix dret.

En canvi, davant la inadmissió, no tenen legitimació els qui ja siguen socis, inclosos aquells que pogueren tenir interès en l'ingrés del sol-licitant. No obstant això, que els socis no tinguen opció a la impugnació mitjançant el procediment descrit en l'article 13 de la LCoop, no impedeix la possibilitat de recórrer l'acord per la via de l'article 37 de la LCoop (impugnació d'acords del consell rector), sempre que es reunisquen els requisits que s'hi hagen establert. Tot això, sempre que no haguera estat ampliada estatutàriament la legitimació activa, opció que estimem possible, sobretot vista la solució legal adoptada pel que fa als acords d'admissió.

En efecte, per a la impugnabilitat interna específica de l'acord d'admissió de socis, la LCoop només esmenta la qüestió de la legitimació quan remet al text estatutari la fixació del nombre mínim de socis que es consideraran legitimats. No hi ha dubte, doncs, que els estatuts podrien reconèixer la possibilitat de recórrer a un sol soci, ni que els recurrents podran fer-ho tant contra l'admissió en si mateixa, en rebutjar-la, com pel que fa a les circumstàncies en què s'ha de produir l'ingrés, és a dir, en acceptar el reconeixement de la qualitat de soci al sol-licitant, però en manifestar disconformitat amb les condicions establertes perquè es produïsca: aportació a capital i/o quota d'ingrés a realitzar, drets i obligacions que se li atribuïsquen, etc.

Per contra, sembla que el tenor literal de la llei impedeix la iniciació de la impugnació pel sol-licitant admès, en relació amb les condicions de l'admissió, ja que "l'acord d'admissió podrà ser impugnat pel nombre de socis (...) que, estatutàriament, es determine", mentre que l'adquisició de la condició de soci pel sol-licitant "quedarà en suspens fins que haja transcorregut el termini per recórrer l'admissió o, si aquesta fóra recorreguda, fins que resolga el comitè de recursos o, si escau, l'assemblea general". Si el sol-licitant encara no és soci, no sembla possible que puga recórrer les condicions que se li imposen per a 
l'ingrés.

En tot cas, la llei reitera la preceptivitat de l'audiència de l'interessat abans de resoldre la impugnació interna de l'acord. D'això es derivaran, al nostre entendre, dues qüestions relacionades amb la legitimació: d'una banda, en el supòsit esmentat de la no-possibilitat de recórrer de les condicions de l'admissió pel sol-licitant admès, si aqueix acord és impugnat pels qui ja eren socis, el procediment permetrà, paradoxalment, que el sol-licitant puga efectuar al-legacions en relació amb aqueixes condicions d'ingrés; al-legacions que, en altre cas, quedarien limitades a la utilització de la via jurisdiccional. D'altra, en els supòsits d'inadmissió, i encara que entenem que no sembla ser aquesta la intenció del legislador, es podria considerar que també és interessat el soci que demostre un interès legítim pel que fa a la denegació d'admissió, per la qual cosa podria sol-licitar ser escoltat abans que el comitè de recursos o l'assemblea resolguen la impugnació.

\section{B. En la LCCV}

La LCCV (art. 15.2) estableix, a diferència del que acabem de veure per a la LCoop, una legitimació unitària, tant en favor del sol-licitant com de "qualsevol dels socis anteriors", davant la decisió del consell sobre l'admissió, siga aquesta denegatòria o d'acceptació. La de la llei autonòmica sembla una opció més correcta, tant per la possibilitat que qualsevol interessat puga intentar la defensa dels seus interessos, com per la major senzillesa de la norma i de la seua aplicació.

1.3.3. Legitimació per impugnar els acords sobre la qualificació i els efectes de la baixa, els d'expulsió o els que imposen altres sancions disciplinàries

L'article 17.6 de la LCoop estableix que "el soci disconforme amb l'acord motivat del consell rector sobre la qualificació i els efectes de la seua baixa, 
podrà impugnar-lo en els termes previstos en l'apartat $c$ ) del punt 3 de l'article 18 d'aquesta Llei". Aquest article 18 regula les "normes de disciplina social", i en l'apartat $c$ ) del punt 3, es reconeix que "l'acord de sanció pot estar impugnat en el termini d'un mes, des de la seua notificació, davant del comitè de recursos (...) o si no n'hi ha, davant de l'assemblea general. (...) En el supòsit que la impugnació no siga admesa o es desestimara, es podrà recórrer (...) davant del jutge de primera instància, per la via processal prevista en l'article 31 d'aquesta Llei".

Així doncs, aquest procediment específic, comú als supòsits de disconformitat amb la qualificació i els efectes de la baixa i als acords de sanció (inclosa la màxima, d'expulsió), presenta un règim de legitimació diferent. Per a la discrepància amb les característiques de la baixa, es legitima únicament el soci que la causa; mentre que davant la imposició de sanció, el text legal estableix una legitimació impersonal: "l'acord de sanció pot estar impugnat" i "podrà recórrer-se", cosa per la qual res no impedeix el seu exercici per qualsevol interessat.

En relació amb aquests supòsits, la LCCV només preveu, expressament, la impugnació específica de l'acord d'expulsió del consell rector (art. 18.2), i únicament en favor del soci afectat, davant de l'assemblea general o, si escau, davant de la comissió de recursos. Posteriorment, l'acord definitiu de l'assemblea o, si escau, de la comissió de recursos pot estat sotmès a arbitratge, o ser impugnat en via jurisdiccional" pel soci expulsat.

Pel que fa a la impugnació de la qualificació i dels efectes de la baixa i a la resta de les sancions que puguen ser acordades pel consell, atesa la falta de menció expressa en la LCCV, entenem que poden impugnar-se pel procediment general d'impugnació d'acords del consell rector (art. 41.6), si és que els estatuts no preveuen una altra cosa. En aquest sentit, no és tan infreqüent trobar, en els estatuts socials de les cooperatives, un règim unitari d'impugnació davant tots els acords del consell que suposen la imposició de faltes molt greus; amb això, 
el procediment específic de la impugnació de l'expulsió, es generalitza.

1.3.4. Legitimació per impugnar la denegació d'informació sol-licitada al consell rector (art. 16.3 i 16.4 de la LCoop)

Es tracta d'un supòsit únicament previst per la llei estatal, davant la denegació possible d'informació del consell rector. La LCCV no preveu un procediment específic davant la denegació de l'òrgan d'administració de la informació a què el soci té de dret, segons l'article 21 de la LCCV; per això, en aqueixos casos, s'aplicarà el procediment general previst per a la impugnació de l'acord o de la decisió denegatoris.

Els apartats 3 i 4 de l'article 16 de la LCoop estableixen, d'una banda, la informació que com a mínim tindrà dret a rebre el soci; d'una altra, indiquen els supòsits en què el consell podrà denegar aqueixa informació, i finalment, els casos en què la denegació del consell haurà de cedir davant d'un acord en contra, bé de l'assemblea, bé del comitè de recursos. Però, a més, en el segon paràgraf de l'article 16.4 de la LCoop es disposa que "en tot cas, la negativa del consell rector a proporcionar la informació sol-licitada podrà ser impugnada pels seus sol-licitants pel procediment al qual es refereix l'article 31 d'aquesta Llei", és a dir, el que fa referència a la impugnació dels acords de l'assemblea general. I, "a més, pel que fa als supòsits de les lletres $a$ ), b) i c) (132 $^{132}$ d'apartat 3 d'aquest article, podran acudir al procediment previst en l'article 2.166 de la Llei d'enjudiciament civil".

1362 Article 16.3: “ ...a) Rebre còpia dels estatuts socials i, si existira, del reglament de règim intern $\mathrm{i}$ de les seues modificacions, amb menció expressa al moment d'entrada en vigor d'aquestes.

b) Lliure accés als llibres de registre de socis de la cooperativa, i al llibre d'actes de l'assemblea general i, si ho sol-licita, el consell rector haurà de proporcionar-li còpia certificada dels acords adoptats en les assemblees generals.

c) Rebre, si ho sol-licita, del consell rector, còpia certificada dels acords del consell que afecten el soci, individualment o particularment $i$, en tot cas, que se li mostre $i$ aclarisca, en un termini no superior a un mes, l'estat de la seua situació econòmica en relació amb la cooperativa...". 
De tot això, cal destacar-hi els aspectes següents: que són únicament els sol-licitants de la informació els que tenen la legitimació específica per impugnar, en tot cas, la denegació d'informació del consell; que la impugnació es farà per la via directament jurisdiccional, que és l'única que hi ha mitjançant l'aplicació de l'article 31; i que davant la denegació de la informació més elemental [la prevista en els apartats $a$ ), b) i $c$ )] es preveu alternativament o, acumulativa, la possibilitat de recórrer al que es preveu en l'article 2166 de la LEC. $^{13 \times 3}$ En aquest últim aspecte, en virtut de l'entrada en vigor de la LEC de 2000, la remissió ha d'entendre's feta en els articles 326-329 d'aquesta última. ${ }^{1364}$

\subsubsection{Legitimació per impugnar el balanç final i el projecte de distribució de l'actiu sobrant de la liquidació de la cooperativa (article 74.2 LCoop)}

Diferents preceptes de l'anterior LGC reconeixien una legitimació expressa a socis i associats per a la impugnació de supòsits concrets relacionats amb l'aprovació dels comptes: així, l'article 68.6 recordava la possibilitat que qualsevol soci o associat demanarà la nul-litat de l'acord d'aprovació de comptes anuals per l'assemblea, sense el previ informe dels interventors; l'art. 69.6 establia la possibilitat d'impugnar-lo quan la cooperativa, obligada a auditar els seus comptes, no comptara amb l'informe previ d'auditoria; finalment, l'article 113.3 recollia la possibilitat que els acords d'aprovació del balanç final de la liquidació i del projecte de distribució de l'actiu foren impugnats "pel soci o l'associat que se sentira ofès, o pels creditors els crèdits

1363 Article 2166 de la LEC: "Tot soci que vulga fer servir el dret que li concedeixen els articles [...] del Codi, o dels d'igual índole que resulten del contracte o dels reglaments socials, si no ho consentira l'administrador, podrà acudir per escrit al jutge, i aquest ordenarà que immediatament li siguen mostrats els llibres i documents de la societat que vulga examinar. $\mathrm{Si}$ el soci administrador s'oposara de qualsevol manera a mostrar-ho, el jutge acordarà les providències necessàries per compel-lir-lo fins a aconseguir-ho". 
dels quals no hagueren estat satisfets o consignats. ${ }^{13.5}$ D'aquests preceptes, $\mathrm{l}^{\prime}$ únic realment necessari era l'últim, ja que suposava una ampliació real de la legitimació davant el règim general establert en l'anterior article 52 de la LGC. ${ }^{\text {Ijok }}$

I, amb bon criteri, el legislador de la nova LCoop ha mantingut únicament com a supòsit específic d'impugnació dels comptes de la cooperativa, el que es preveu en l'anterior article 113.3 de la LGC, que ara recull, modificat parcialment, a l'article 74.2 de la LCoop. En tot cas, "qualsevol soci que se senta ofès" o "els creditors, els crèdits dels quals no hagueren estat satisfets o garantits" estan legitimats per impugnar el balanç final i el projecte de distribució de l'actiu sobrant de la liquidació de la cooperativa.

Respecte d'aquesta legitimació, cal distingir els dos supòsits que la norma recull. Pel que fa a la legitimació de "qualsevol soci que se senta ofès", s'observa clarament una ampliació, en relació amb la legitimació general: quan la causa del greuge siga un acord anul-lable, respecte del qual no tots els socis tenen acció, segons el procediment general.

En canvi, l'aprovació del balanç final i del projecte de distribució de l'actiu que no incloguen el pagament de tots els deutes socials, o la seua consignació o el

1365 Paz Canalejo, N., en Paz Canalejo, N. i Vicent Chuliá, F., Ley general..., pàg. 593.

1366 En efecte, "l'aprovació dels comptes anuals per l'assemblea general sense l'informe previ dels interventors" (art. 68.6 de la LGC) donava origen a un acord nul, impugnable per qualsevol soci o associat, segons es preveu en l'article 52 de la LGC, sense necessitat de repetir-ho en l'article 68.6 que, a més podia donar lloc a una certa confusió, ja que no advertia que aqueixa impugnabilitat tan sols s'establia per als supòsits en els quals l'informe dels interventors fóra preceptiu. En aquest sentit, la STS (Sala 1a), de 9 juliol de 1998, núm. 680/1998 (RJA 1998/5780) en relació amb l'obligació anterior de les societats anònimes de dotar-se de socis censors de comptes, resol, sense necessitat de norma expressa, que "l'actuació dels accionistes censors de comptes està sotmesa a normes de dret necessari perquè es tracta d'un òrgan imprescindible per a la fiscalització i censura de la gestió social [...]. Aquesta necessitat d'actuació fa que ineludiblement haja de determinar-se la nul-litat dels acords adoptats per la junta general d'accionistes esmentada, tant en la primera com en la segona convocatòria, des del moment mateix que no s'ha pogut donar la informació precisa i certa".

Pel que fa a l'article 69.6 de la LGC, tampoc no aportava res nou, ja que remetia la impugnació de l'aprovació dels comptes anuals sense el preceptiu informe d'auditoria externa "als cursos processals previstos en $l^{\prime}$ article $52 . . . "$, sense introduir cap especialitat en matèria de legitimació. 
seu assegurament, constituirà clarament un acord nul (arts. 73.5 i 75.1 de la LCoop), per la qual cosa la legitimació dels creditors afectats ja queda plenament garantida per la via de l'article 31.3, en reconèixer-la als "tercers que acrediten interès legítim". En aquest aspecte, així doncs, la menció de l'article 74.2 als creditors era innecessària.

La LCCV, al nostre entendre amb més bon criteri, no esmenta cap supòsit específic d'impugnació dels comptes de la cooperativa, ni en relació amb l'absència dels informes d'auditoria quan siguen preceptius, ni en relació amb el balanç final i el projecte de distribució de l'actiu resultant de la liquidació. En efecte, entenem que estan prou garantits els interessos dels afectats possibles, mitjançant el procediment general d'impugnació; la introducció de supòsits específics no aportaria avantatges notables que justificaren el cost que, en seguretat jurídica i agilitat, sempre suposa l'establiment de casos especials.

\subsubsection{La impugnació d'acords presos per determinats col-lectius de socis}

Ja hem vist en els epígrafs 1.4. ("Acords de l'assemblea de socis de la secció") i 1.6. ("Acords de les juntes especials") del capítol tercer que ena la cooperativa poden presentar-se diferents supòsits en què una part dels socis hagen de prendre decisions amb transcendència jurídica, de manera independent a l'assemblea general.

En el supòsit dels socis agrupats en seccions, ja s'ha referit l'absència de menció en la LCoop a la impugnabilitat dels acords de l'assemblea de socis de la secció, encara que la redacció de la facultat de la seua suspensió per l'assemblea general sembla estar pensada com a pas previ a una impugnació eventual de l'acord que es vol suspendre. Es produeix, en aquests casos el dubte sobre si, en general, la impugnació ha de seguir les normes previstes per a la dels acords de l'assemblea general, amb les adaptacions necessàries, o es considera preferible optar per un règim propi, que tinguera en compte les seues circumstàncies 
especials, en aspectes com ara la legitimació.

Aquestes circumstàncies especials que demanarien una legitimació específica, són les apuntades en relació amb la normativa prevista en la LCCV. La Llei valenciana demanda l'aplicació en la impugnació dels acords de l'assemblea de socis de la secció, del que es preveu en l'article 36 per a l'assemblea general. Però la translació de les pautes de legitimació contingudes en els apartats 4 i 5 d'aquest article, planteja alguns interrogants.

Quan era vigent la Llei de cooperatives de 1974 es va qüestionar la legitimació dels socis no adscrits, i estimava algun autor que se'ls havia de considerar com a tercers, a l'efecte de la impugnació dels acords de la secció, ${ }^{1367}$ amb la qual cosa es produiria la seua deslegitimació per a la impugnació dels acords anul-lables, opció que ens sembla incorrecta. En efecte, si bé és cert que els socis de la secció són els qui han de decidir el que corresponga més bé a la defensa dels seus interessos, no ho és menys que això ha de ser amb un respecte total a la llei, als estatuts socials i a l'interès general de la cooperativa, i que una vulneració eventual d'aquestes causes ha de legitimar tots els socis per a la seua impugnació, ja que tots es veurien perjudicats per la lesió.

Tanmateix, no sembla haver-hi dubtes que l'aplicació de l'article 36.5 de la LCCV als acords anul-lables de l'assemblea de la secció, tindrà efectes similars als ara criticats, ja que legitima únicament els assistents que hagueren fet constar la seua oposició, els absents i els il-legítimament privats de vot, els

1367 MUÑOZ VIDAL, A. B., "El proceso...», op. cit., pàg. 35: "l'acord nul o lesiu pot afectar els altres socis de la cooperativa no integrats en la secció. En aquest cas, s'ha d'ampliar la interpretació i entendre que els socis esmentats, no de la secció, però sí de la cooperativa, poden, igualment, estar legitimats de manera activa per interposar la demanda corresponent. Però només en el cas que exercite l'acció de nul-litat; ja que, com veurem, també correspon, fins i tot, als tercers. Si el perjudici es produeix per infracció dels estatuts, entenent per aquests també el reglament propi de la secció, o per infracció de normes, el camí queda expedit. Però si no és així, encara que l'acord siga lesiu, el soci no membre de la secció no podrà accionar; ja que, com a molt, podria, en el seu moment, haver-se oposat a la constitució de la secció, que ha d'estar legalment prevista en els estatuts generals de l'entitat". (Recordeu que l'article 27.1 de la Llei de cooperatives, del 1974, considerava nuls tant els acords contraris a la llei com els contraris als estatuts socials.) 
membres del consell rector, els administradors i els membres de la comissió de control de la gestió. I no sembla que es puguen equiparar, a l'efecte de legitimació, els socis no adscrits amb els socis de la secció que són absents, ja que aquells no són membres de l'assemblea de la secció.

Pel que fa a aquells supòsits en què la Llei requereix que col-lectius de socis o de tercers concrets aproven majoritàriament, mitjançant la seua reunió en juntes especials, o amb la seua votació separada dins de l'assemblea general, els acords que els afecten especialment (epígraf 1.6 del capítol tercer), també hem recollit l'opinió doctrinal que estima que la legitimació activa per a la impugnació de l'acord de la junta especial ha d'entendre's restringida als integrants del col-lectiu afectat i no als socis "ordinaris", ja que aquests últims "no tindrien dret ni interès". ${ }^{1368}$ Dissentim d'aquesta opinió, per les mateixes raons apuntades en relació amb la legitimació activa per a la impugnació dels acords de la secció: una vulneració eventual de la llei, dels estatuts o l'interès social per un acord de la junta especial, pot perjudicar qualsevol soci, per la qual cosa tots els socis poden tenir interès en la seua impugnació. Tots els socis han de comptar, així doncs, amb legitimació, de la mateixa manera que la tindrien si l'acord haguera estat adoptat per l'assemblea general.

\subsubsection{La legitimació de la CNMV i del Banc d'Espanya davant determinats acords}

En l'àmbit de les societats de capital s'ha assenyalat l'atribució de legitimació, d'una banda, a la Comissió nacional del mercat de valors, per a la impugnació dels acords adoptats amb accions que representen una participació significativa en el capital, adquirides sense l'oferta pública preceptiva (art. 60.3 de la Llei del mercat de valors), ${ }^{1369}$ i d'altra, al Banc d'Espanya, per impugnar els acords volum determinat d'accions admeses a negociació en una borsa de valors o d'altres valors que, 
socials de les societats anònimes de crèdit (Disp. Ad. 2a de la Llei sobre disciplina i d'intervenció de les entitats de crèdit). ${ }^{1370}$

Fins a la promulgació de la LCoop, aquests preceptes no eren d'aplicació en les cooperatives, ${ }^{1371}$ ja que afecten "accions admeses a negociació en una borsa de valors o en altres valors que, directament o indirectament, puguen donar dret a la seua subscripció o adquisició i, d'aquesta manera, arribar a assolir una participació significativa en el capital d'una societat". Tanmateix, amb la introducció en la llei estatal de la figura de les cooperatives mixtes (art. 107), es crea la possibilitat de la seua aplicació.

En efecte, aquestes cooperatives són "aquelles en què hi ha socis que el seu dret de vot a l'assemblea general, es podrà determinar, de manera exclusiva $o$ preferent, segons el capital aportat (...), que estarà representat per títols o per anotacions en compte i que es denominaran parts socials amb vot, sotmeses a la legislació reguladora del mercat de valors". També s'estableix que "en el cas de les parts socials amb vot, tant els drets i obligacions dels seus titulars, com el règim de les aportacions, seran regulats pels estatuts $i$, supletòriament, pel que es disposa en la legislació de societats anònimes per a les accions". Finalment,

directament o indirectament, puguen donar dret a la seua subscripció o adquisició i, d'aquesta manera, arribar a una participació significativa en el capital d'una societat, no podrà fer-ho sense promoure una oferta pública d'adquisició, dirigida a tots els seus titulars [...].

"Qui adquirisca el volum d'accions i assolisca la participació significativa a la qual es refereix el paràgraf primer, sense la oferta pública d'adquisició preceptiva, no podrà exercir els drets polítics derivats de les accions així adquirides, sense perjudici de les sancions previstes en el títol VIII d'aquesta Llei. Els acords adoptats amb la seua participació seran nuls. La Comissió Nacional del Mercat de Valors estarà legitimada per a l'exercici de les accions d'impugnació corresponents".

El RD 1197/1991, de 26 de juliol, pel qual es desenvolupa el règim de les ofertes públiques d'adquisició de valors, en l'article 40, reitera la legitimació de la CNMV, "sense perjudici de la legitimació que puga correspondre a unes altres persones" i estableix que quan la Comissió exercite l'acció d'impugnació no li seran d'aplicació els terminis que, per a administradors i accionistes, estableix l'article 143 de TRLSA.

1370 JUSTE MENCIAA, J., Los derechos de minoria..., op. cit., pàg. 388-390, especialment l'extensa nota 14; SAlELlES CLIMENT, J. R., El funcionamiento..., op. cit., pàg. 379: "Les exigències de tipicitat i de correcció [...] justifiquen la intervenció del Banc d’Espanya i de la CNMV per tutelar l'interès públic" URÍA, R., MENÉNDEZ, A. i MUÑOZ, J. M., La junta..., pàg. 358 i 359. 
s'indica que les parts socials amb vot, "si els estatuts ho preveuen, podran ser lliurement negociables en mercat". Amb independència dels interrogants, de la més variada índole, que planteja aquest nou tipus de cooperativa en general, i les repercussions de la creació i del funcionament de les parts socials amb vot, sembla que s'obre la possibilitat que, en algun supòsit, puguen intervenir la CNMV o el Banc d'Espanya, en qualitat de legitimats per a la impugnació de determinats acords cooperatius.

De la tota l'exposició casuística efectuada fins ara en els diferents epígrafs anteriors, es dedueix, amb claredat, que la llei autonòmica valenciana és més renitent que l'estatal a l'establiment de supòsits específics de legitimació per a la impugnació. És al nostre entendre, un criteri encertat, ja que és més senzill i més concorde amb el principi de seguretat jurídica, sotmetre la impugnació dels acords socials a un règim general unitari i només excepcionalment $i$, de manera justificada, reconèixer algun supòsit excepcional. És el cas, sens dubte, de la legitimació a qui encara no és soci, o a qui ha deixat de ser-ho, però que pot estar interessat a impugnar acords anul.lables.

En canvi, la resta dels supòsits recollits per la LCoop, encara que es refereixen a moments crucials en la defensa dels interessos dels socis, o no aporten un augment notable de les garanties individuals respecte de les que ja es reconeixen en el procediment impugnador general, o bé atribueixen legitimació només a determinats socis que no sempre han de ser, tanmateix, els únics afectats pels acords a impugnar.

\section{Legitimació passiva}

S'ha definit la legitimació passiva, en general, com la idoneïtat per suportar l'exercici d'un dret subjectiu, tot responent a la qüestió: davant qui ha de ser 
exercitat el dret? $?^{1372}$ En la legislació cooperativa no hi ha un precepte equivalent al de l'article 117.3 de la LSA, en el qual es declara que "les accions d'impugnació hauran de dirigir-se contra la societat". I encara que poguera semblar innecessari, no ho és tant, en vista d'alguna de sentencia pintoresca del Tribunal Suprem en la qual s'atribueix personalitat jurídica independent al consell rector d'una cooperativa. ${ }^{1373}$

En tot cas, encara que sense un pronunciament exprés ni en la LCoop ni en la LCCV, no hi ha cap dubte que la legitimació passiva correspon a la cooperativa, ja que són els seus acords els que es pretenen deixar sense efecte. És la cooperativa, i en el seu nom els seus representants legals o voluntaris, els qui hauran de defensar la correcció de la seua voluntat manifestada pels seus òrgans socials. Així doncs, si la cooperativa no ha designat expressament uns altres representants específics per actuar en el seu nom en l'acció d'impugnació, és el consell rector (o, alternativament, el/els administrador/s) l'òrgan social que té la representació de la cooperativa i, en el seu nom, si no es preveu cap altra cosa, actuarà el president del consell. ${ }^{1374}$ Això no obstant, quan la

l'article 136 de la LCPV.

1372 DíEz PicAZo, L. i Gullón, A., Instituciones..., op. cit., pàg. 294.

1373 Es tracta de la STS (Sala 1a), de 25 de juny de 1991. En el seu comentari, EMBID IRUJo, José Miguel, «Impugnación de acuerdos del consejo rector y responsabilidad de los administradores en una sociedad cooperativa. Comentario a la STS (Sala $1^{\mathrm{a}}$ ) de 25 de junio de 1991", La Ley, 1992-III, pàg. 261, adverteix que "És notori que, tant pel que fa a les cooperatives com a l'àmbit de les societats de capital, la legitimació passiva en els processos d'impugnació d'acords, ja siguen de l'assemblea o de l'òrgan d'administració, correspon, indefugiblement, a la societat mateix (vegeu, amb caràcter general, el que disposa l'article 117.3 de la Llei de societats anònimes). En conseqüència, no s'ha d'obtenir cap pronunciament judicial sobre la validesa o la nul.litat d'un acord social, si no es demanda directament l'entitat l'òrgan de la qual ha adoptat l'acord"; d'altra banda, VICENT CHULIÁ, F., "Comentario a la STS (S. 1ª) de 25.6.91», RGD, núm. 564, 1991, pàg. 7853 i 7854: "la legitimació passiva de la cooperativa, en aquest judici, estava fora de dubte, ja que la demanda de nul.litat de l'acord del consell rector havia de ser presentada contra la cooperativa i no contra el consell rector (que no té la "personalitat jurídica" amb què l'adorna aquesta sentència tan pintoresca)".

1374 Article 32.2 de la LCoop: "El president del consell rector i, si escau, el vicepresident, que ho serà també de la cooperativa, en tindran la representació legal, dins de l'àmbit de facultats que els atribuïsquen els estatuts $i$ les concretes que, per a la seua execució, resulten dels acords de l'assemblea general o del consell rector". La LCCV, d'altra banda, sembla exigir, també per a l'actuació del president, la capacitació expressa en cada cas, en requerir el seu article 41.4 que 
cooperativa entre en liquidació, seran els liquidadors els qui actuaran la legitimació passiva en representació de la cooperativa. ${ }^{1375}$

Més difícil de determinar és la legitimació passiva en les cooperatives en constitució, $^{1376}$ encara que la hipòtesi de la impugnació dels acords durant el període que va des de l'atorgament de l'escriptura fins a la seua inscripció registral $^{137}$ sembla poc probable. ${ }^{1378}$ Tant la LCoop com la LCCV inclouen una

"l'execució dels acords, quan no es prenga decisió en contra, serà competència del president, en
nom del consell rector, i s'exhibirà la certificació de l'acord corresponent". 1375 ni les facultats representatives dessent, ni el cessament del consell rector durant la liquidació, que no hi haja una altra solució que no siga l'aplicació supletòria, tant de la LCoop com de la LSA, ja que ambdues atribueixen la representació de l'entitat als liquidadors.

Article 73.6 de la LCoop: "Correspon als liquidadors [...] 6. Tenir la representació de la cooperativa en judici i fora d'ell, per al compliment de les funcions que té encomanades". Article 71.3, 2n par. de la LCoop: "Fins al nomenament dels liquidadors, el consell rector continuarà en les funcions gestores i representatives de la societat".

També pot veure's la STS (Sala 1a) de 14 de març de 1998, núm. 224/1998, (RJA 1998/1488), en la qual intervé, en representació de la societat els acords de la qual s'impugnen, un vocal de la comissió liquidadora en qui s'havien delegat "la totalitat de les facultats de la comissió".

1376 SANTOS DomíngueZ, M. À., «Notas sobre la Ley 2/1998...», op. cit., pàg. 109 i 110: “el legislador extremeny ha optat per no establir un règim per a la societat cooperativa irregular, a diferència del que succeeix en altres lleis autonòmiques. Aquesta solució sembla la més conforme al dret de cooperatives i a l'ordre constitucional de repartiment de competències. Quant al primer: no és necessari que es verifique la voluntat de no inscriure la societat cooperativa o que transcorrega un termini determinat sense que s'haja sol-licitat la inscripció $[\ldots .$.$] en qualsevol moment el soci pot separar-se de la cooperativa, amb el reemborsament$ corresponent i sense necessitat que es dissolga la societat cooperativa en constitució [...]. I quant al segon: comunament, en el règim de la societat irregular [...] es preveu l'aplicació de les normes de la societat col-lectiva o, si escau, de la societat civil; però, tenint en compte que les legislacions mercantil i civil són competència exclusiva de l'estat, les comunitats autònomes no poden estendre l'àmbit de l'aplicació de les societats col-lectives o de les societats civils. L'absència de regulació expressa en la llei extremenya no significa inexistència de règim jurídic per al supòsit de fet en què consisteix la societat cooperativa irregular: o s'aplica l'article 10 de la llei, relatiu a la societat cooperativa en constitució, el règim de la qual no té límits temporals $[\ldots]$, o si els actes i els contractes no són els previstos [...] ens trobarem o davant d'una societat col-lectiva irregular o davant d'una comunitat de béns, per aplicació directa del dret de l'estat".

1377 Abans de l'atorgament d'escriptura, no sembla que hi haja suport documental de cap decisió del grup promotor que puga ser susceptible d'impugnació; després de la seua inscripció, la cooperativa disposa, ja, de representants legals $i$, tret d'un acord en sentit contrari, assumeix les actuacions anteriors dels qui hagueren actuat en el seu nom.

1378 Tanmateix, una impugnació eventual podria tenir una transcendència extraordinària: per exemple, en el contingut de l'escriptura de constitució (estatuts socials, aportacions al capital, nomenament de càrrecs, apoderaments, etc.), o en decisions relatives a adquisicions patrimonials. 
regulació expressa de la cooperativa en període de constitució, però que, com és previsible, no es refereix al supòsit d'impugnació; sembla que en aquests casos, la legitimació passiva de la cooperativa podria correspondre a les persones designades per a la realització de les gestions de constitució. ${ }^{1379}$

La LSA (art. 246) recull un supòsit específic de legitimació passiva, davant la impugnació d'una fusió ja inscrita; en aquest cas, l'acció "haurà de dirigir-se contra la societat absorbent o contra la nova societat resultant de la fusió", "ja que, en molts casos, els acords impugnats correspondran a societats que, en el moment d'interposar l'acció de nul-litat, estan extingides en virtut de la fusió" ${ }^{1380}$ En canvi, en els supòsits d'escissió, es manté l'existència d'“una situació de litisconsorci passiu necessari; pel que fa a l'escissió total, seran les societats beneficiàries les úniques legitimades, i s'hi afegirà la societat escindida, quan ens trobem en presència d'una escissió parcial" ${ }^{1381}$ En qualsevol cas, per a la seua translació a l'àmbit cooperatiu, s'ha de recordar que en l'àmbit cooperatiu no hi ha un procediment específic per a la nul-litat de la fusió ja inscrita, per la qual cosa, la legitimació passiva de la cooperativa absorbent o de nova creació es produirà, per analogia amb el que es preveu per a les societats anònimes, per la inexistència possible de la cooperativa integrada en el procés de fusió.

Com a conseqüència de l'atribució de legitimació passiva, la legitimació activa no pot correspondre mai a la cooperativa. Qüestió diferent serà, com veurem a continuació, la de l'atribució de la legitimació passiva en els supòsits en els quals els qui tinguen la representació de la cooperativa siguen, justament, els qui interposen l'acció d'impugnació.

1379 LORCA NAVARRETE, A., «Algunas observaciones...», op. cit., pàg. 903.

1380 MARTÍNEZ SANZ, F., «La nulidad de la fusión...», op. cit., pàg. 86. En el mateix sentit, EMBID IRUJO, J. M., «En torno a la nulidad de la fusión...», op. cit., pàg. 5612, i GÓMEZ PORRÚA, J. M., La fusión de sociedades anónimas..., op. cit., pàg. 259. 


\subsection{Supòsits en què els representants de la cooperativa són part impugnant}

Si la legislació cooperativa no ha previst la legitimació passiva, en general, ${ }^{1382}$ no es pot tampoc esperar que ni la LCoop ni la LCCV prevegen el supòsit concret del segon paràgraf de l'article 117.3 de la LSA, és a dir, que "quan l'actor tinguera la representació exclusiva de la societat i la junta no tinguera designat ningú amb aquesta finalitat, el jutge nomenarà la persona que ha de representar-la en el procés, entre els accionistes que hagen votat a favor de l'acord impugnat". No obstant això, estimem que és possible l'aplicació $\mathrm{d}^{\prime}$ aquesta norma, ${ }^{1383}$ en virtut de les regles generals de l'analogia. ${ }^{1384}$

Això no obstant, s'ha d'advertir que el nomenament judicial només procedirà quan qui impugna és representant exclusiu i no s'haja designat un altre representant per a l'exercici de la legitimació passiva. ${ }^{1385}$ En relació, justament, amb el supòsit que l'assemblea haja nomenat, a l'efecte, el seu representant, s'ha

\footnotetext{
1382 Com a excepció, l'article 52 de la LCE legitima la comissió de vigilància per actuar en representació de la cooperativa en els casos d'impugnació d'acords de l'òrgan d'administració, órganos de la cooperativa", op. cit. , pàg. 165, proposen la seua extensió, per analogia, als "dirigisquen l'acció d'impugnació contra la societat".
}

1383 (article 54.3. 5 del Reglament d' expressament, que "quan l'actor designarà la persona que ha de repro la representació exclusiva de la societat, el jutge favor de l'acord impugnat, tenint en compt-la en aquest judici entre els socis que han votat a aquests socis". Ignorem quina era la intente lecció eventual que entre ells hagueren realitzat tant en la LGC de 1987 com en la recentó degislador en suprimir tota menció a la qüestió, d'aplicar al buit normatiu, i és l'aplicació analògica 1999. No obstant això, alguna solució s'ha

1384 S'ha de recórrer a l'aplicació analògica, ja que la remissió a les normes de la LSA que en matèria d'impugnació efectuen l'article 31.5 de la LCoop i l'article 36.7 de la LCCV es refereix únicament a les normes processals ("les accions d'impugnació"...), mentre que per a la legitimació el legislador ha considerat més adequat regular-la específicament en la norma 
assenyalat que "quan l'article 117.3 del TR es refereix a la persona que podrà designar la junta per representar la societat en judici, no es qualifica, de cap manera específica, aquesta persona, amb l'exigència que reunisca algun requisit concret, per la qual cosa, cal entendre que pot tractar-se tant d'un accionista (en aquest cas raons de mera lògica aconsellen que haja votat a favor de l'acord...) (...), com d'un administrador que no haja impugnat l'acord o, fins i tot, d'un tercer aliè a la societat" ${ }^{1386}$

\subsection{Supòsits en què puga admetre's com a part coadjuvant persones interessades}

Tampoc s'esmenta en la legislació cooperativa la possibilitat que socis o terceres persones interessades puguen intervenir en el procés d'impugnació com a part coadjuvant, per defensar la validesa dels acords sotmesos a impugnació. Ni la LCoop ni la LCCV incorporen un precepte de contingut similar al de l'article 117.4 ("els accionistes que hagen votat a favor de l'acord impugnat podran intervenir a costa seua en el procés, per mantenir la seua validesa"), referit als acords de la junta general. I més dubtes es plantegen, encara, sobre la possibilitat de la seua aplicació en la impugnació dels acords de l'òrgan d'administració. ${ }^{1387}$

1386RodRíGUEZ RUIZ DE VILLA, D., Impugnación..., op. cit., pàg. 179, que també destaca la interpretació alternativa, en el sentit d'aplicar analògicament el requisit de la condició d'accionista que s'exigeix per al representant de la societat demandada designat pel jutge. Però considera més correcta la primera, ja que el legislador no ha estimat necessari especificar-ho.

1387 JUSTE MENCÍA, J., Los derechos de minoría..., op. cit., pàg. 404 i 405, en relació amb les societats de capital; SALELlES CLIMENT, J. R., El funcionamiento..., op. cit., pàg. 402: "no sembla que els accionistes puguen intervenir en el procediment d'impugnació dels acords del consell: si no han participat en la seua adopció, no té sentit que participen per mantenir la seua validesa. Per això, sí que sembla admissible la participació, a costa seua, dels membres del consell que hagueren votat a favor de l'acord. En aquest cas, tanmateix, no tindran la condició de part, sinó la de simple intervinent". SÁNCHEZ CALERO, F., Administradores..., op. cit., pàg. 546, admet la possibilitat d'intervenció, a la seua costa, dels administradors que hagen votat a favor de l'acord, i nega la possibilitat als socis no administradors, ja que els faltarà en el seu cas el requisit d'haver votat a favor. També es manifesten a favor de la validesa de la intervenció dels administradors GARCÍA LUENGO, R. i SOTO VÁZQUEZ, R., El nuevo régimen jurídico..., op. cit., pàg. 645. 
Potser seria acceptable interpretar que és possible una aplicació analògica de l'article 117.4 de la LSA en el seu sentit més estricte, és a dir, que comptarien amb legitimació els qui acrediten que han votat a favor de l'acord impugnat $i$ que intervinguen a costa seua. La seua intervenció, l'admissibilitat de la qual se sustentaria en l'eficàcia que davant tots els socis tindrà la sentència que resolga la impugnació, seria, no en qualitat de legitimats independents, sinó com a coadjuvants. ${ }^{1388} \mathrm{Si}$ s'acceptara l'esmentada intervenció, caldria ampliar-la a la dels altres subjectes que compten amb legitimació activa: administradors, membres de l'òrgan de control de la gestió i, en l'àmbit de la LCoop, també al comitè de recursos i als liquidadors.

Però això no permetria la intervenció com a part en el procés a dos tercers que, tanmateix, no sols disposaran, molt probablement, d'interessos dignes de defensa, sinó que poden ser cridats a intervenir-hi, encara que només siga en qualitat de testimonis. Es tracta, d'una banda, del sol-licitant d'ingrés com a soci que veu com és impugnat l'acord de la seua admissió segons la LCoop i, d'altra, del tercer a qui s'atribueix un benefici en lesió d'interessos de la cooperativa.

Pel que respecta al primer supòsit, ja hem vist que, mentre que la LCCV reconeix legitimació, tant al sol-licitant com als socis anteriors, per impugnar l'acord sobre l'admissió, siga d'acceptació o de denegació, la LCoop (art. 13.2 i 13.3) estableix una discriminació, segons el signe de l'acord: si és denegatori de

1388 Sobre la caracterització de l'anomenat intervinent i el debat doctrinal sobre aquest tema, vegeu GARCÍA LUENGO, R. i SOTO VÁZQUEZ, R., El nuevo régimen jurídico..., op. cit. pàg. 561 i 562 ; i GIMENO SENDRA, J. V., El proceso..., op. cit., pàg. 91-94. GOMEZ ORBANEJA, E., «El proceso de impugnación...", op. cit., pàg. 129: "L'intervinent és un coadjuvant, però de caràcter litisconsorcial, ja que la sentència el comprèn. La seua activitat processal és independent de la de la societat coadjuvada; així, en especial, podrà recórrer contra la sentència encara que la Societat no ho faça"; DíEz ARGAL, W., "Impugnación de acuerdos...», op. cit., pàg. 58 i 59 , i manera, d'intervenció adhesiva suba per azioni..., op. cit., pàg. 231 i 232: "es tracta, de tota relació substancial que és objecte derdinada, ja que el soci no dedueix, en judici, la mateixa societat". Aquests mateixos autors reculrovèrsia, sinó que es limita a sostenir les raons de la legitimació independent dels socis, fins i també, una línia jurisprudencial que manté la d'anul-lació de primera instància, per impugnar quan la societat haja acceptat la sentència 
l'admissió, es reconeix únicament legitimació activa al sol-licitant de la condició de soci; per contra, davant l'acord d'admissió s'atribueix legitimació al "nombre de socis i en la forma que estatutàriament es determine", amb la qual cosa es nega la legitimació al sol-licitant, que manté en suspens la seua admissió fins que es resolga el recurs intern pel comitè de recursos o per l'assemblea general. Posteriorment, si es ratifica l'admissió el sol-licitant s'haurà convertit en soci i tindrà la legitimació corresponent a aquesta categoria per a la impugnació jurisdiccional; i si l'acord executiu és de denegació, tindrà la legitimació pròpia del sol-licitant davant la inadmissió, és a dir, la de tercer amb interès legítim. La qüestió paradoxal es planteja quan, tot i ser admesa en primera instància, pel consell, la sol-licitud d'ingrés, un grup de socis anteriors impugna l'admissió: el sol-licitant no té legitimació, ni activa ni passiva. La llei reconeix, únicament, que serà preceptiva l'audiència de l'interessat abans de resoldre la impugnació interna.

D'altra banda, com ja hem indicat, caldria plantejar-se si en la impugnació $\mathrm{d}$ 'acords que lesionen els interessos de la cooperativa en benefici de terceres persones, aquestes podrien intervenir en el procés com a legitimats passius. Penseu que els tercers poden estar legítimament interessats a demostrar que l'acord no lesiona interessos cooperatius, o que no els beneficia, i també que, d'altra banda i independentment, una anul-lació eventual podria perjudicarlos. $^{1389}$

Finalment, s'ha plantejat un altre supòsit de part coadjuvant: el de la

13891389 La jurisprudència menor italiana i alguns autors s'han plantejat un cas concret, en el qual es pretenia anul-lar un acord de nomenament de càrrecs socials (que no necessàriament han de ser socis), i han estimat que les persones elegides, si bé no podrien considerar-se absolutament indiferents a l'objecte de la contesa, certament tampoc legitimades passivament. S'argumenta que l'acte jurídic impugnat és refereix, només, a la persona jurídica, ja que l'acord constitueix un acte unilateral, creat pel col-legi dels socis i expressió, tan sols, de la voluntat de l'ens; com també, que els nomenats no tenen drets que puguen fer valer, derivats de la seua elecció, que només serà efectiva en un moment posterior al que es discuteix. Tanmateix, se'ls reconeix un interès del fet que la impugnació no siga acollida i, en relació amb aqueixa posició, se'ls permet intervenir ad adiuvandum en el procés (SILveTtI, C. i CAVALLI, G., Le società per azioni..., op. cit., pàg. 228 i 229, on es comenta la sentència del Tribunal de Perusa, de 28 de febrer de 1950, Guerini-Consorzio Agrario, en Fòrum it., 1951, I, 1447). 
intervenció d'un soci en favor d'un altre que haja impugnat un acord, fins i tot amb la reclamació de la possibilitat que puga al-legar motius d'anul-lació diferents als proposats per l'actor, en una intervenció que es qualifica com a litisconsorcial o adhesiva autònoma. ${ }^{1390}$

SilvetTI, C. i CAVAlLI, G., Le società per azioni..., op. cit., pàg. 232: “l'intervinent no es presenta com a titular d'una relació de dret substancial amb l'actor, per la qual tindria interès a vida a la impugnació; l'intervinent tedueix en judici la mateixa relació bàsica que ha donat paral-lela i confluent amb la de l'actor". 


\section{CONCLUSIONS}

PRIMERA. Encara que les normes legals que regulen la impugnació dels acords a la cooperativa són gairebé exclusivament una translació literal dels textos normatius de les societats de capital (fonamentalment, de la LSA), i sense perjudici que aquesta siga la intenció indissimulada del legislador, la identitat cooperativa especial impregna la institució i la dota de trets específics.

D'una banda, la mutualitat que caracteritza la fórmula cooperativa, amb l'obligatorietat consegüent per als socis de participar en l'activitat cooperativitzada, sumada al principi cooperatiu de gestió democràtica, es tradueixen estructuralment en una multiplicitat d'òrgans socials que no es produeix en altres fórmules juridicosocietàries, i en la necessitat de preveure els instruments que en garantisquen la participació o representació igualitària en els esmentats òrgans. Al seu torn, aquesta efervescència participativa comporta un risc més alt de conflictivitat interna, cosa per la qual adquireixen més transcendència els procediments de resolució dels conflictes. En aquest sentit, no és casual que a la cooperativa, juntament amb el procediment ordinari (la impugnació) se'n prevegen uns altres d'alternatius, com l'arbitratge, o previs, com el procediment de revisió interna davant dels òrgans socials.

D'una altra banda, la proliferació de normes cooperatives al llarg de tot el procés de reconversió de l'Estat espanyol en un sistema democràtic origina un problema competencial que no es dóna en relació amb altres persones jurídiques. Hi ha en l'actualitat deu lleis reguladores de l'estructura cooperativa vigents als diferents territoris de l'Estat $i$, encara que no aporten grans diferències en el contingut són, majoritàriament, d'aplicació exclusiva i, per tant, excloent. Això fa inevitable de tenir en compte les divergències més significatives que es donen entre aquestes. 
SEGONA. Davant de l'escassetat d'aportacions doctrinals en l'àmbit cooperatiu i atès l'indubtable origen tecnicojurídic de la institució, l'elaboració de la fonamentació jurídica de la impugnació d'acords socials en la cooperativa fa aconsellable recórrer (com, en general, succeeix en l'estudi dels òrgans socials) als treballs desenvolupats per a les societats mercantils, i intentar aplicar-los, amb les modificacions necessàries, a les característiques especials del model cooperatiu.

En aquest sentit, pot afirmar-se, tant per a les cooperatives com per a les societats mercantils, que la institució de la impugnació dels acords socials, encara que deutora de la teoria general sobre la ineficàcia dels negocis jurídics, ha esdevingut un sistema d'invalidesa diferent, per raó de l'especialitat de l'objecte sobre el qual recauen: les declaracions de voluntat o de ciència dels òrgans de les persones jurídiques.

Els principals trets diferenciadors del règim d'ineficàcia dels acords socials són la consideració de l'anul-labilitat com a regla general, evitant tant com es puga els casos de nul-litat, i l'establiment d'un termini de caducitat també per als acords nuls. Es tracta amb això de preservar l'estabilitat societària i la seguretat del tràfic empresarial. Tanmateix, introdueix la necessitat d'exceptuar de caducitat la impugnació d'aquells acords que siguen contraris a l'ordre públic.

TERCERA. Configurada així la impugnació, com un instrument processal per eliminar acords $\mathrm{i}$ altres actes i negocis jurídics d'autoorganització de la persona jurídica, es desvetla el seu caràcter de límit, de mesura de control contra l'exercici abusiu de l'autonomia privada. Quan la cooperativa excedisca els límits del seu dret d'autoorganització i prenga decisions que vulneren la llei, els estatuts o l'interès social de la persona jurídica, aqueixes decisions podran ser impugnades. 
Tot això posa de relleu la importància d'analitzar què s'ha d'entendre per interès social. Però el debat tradicional que s'ha desenvolupat en l'àmbit de les societats mercantils, no és reproduible en l'àmbit cooperatiu, almenys en els termes exposats per les postures més clàssiques, institucionalistes i contractualistes. En efecte, si es traslladen aquestes posicions al concepte d'interès cooperatiu, haurien de desestimar-se, de partida, almenys les teories contractualistes més radicals. L'afirmació que efectuem se sosté en la constatació que la finalitat social de la cooperativa no és l'ànim de lucre propi de les societats, entès aquest com la intenció d'obtenir un benefici repartible entre els socis, sinó l'atenció a una doble finalitat: la satisfacció de necessitats i d'interessos comuns dels qui en cada moment en siguen socis, mitjançant l'ajuda mútua, i la creació d'un patrimoni comú irrepartible que garantisca el manteniment de l'entitat.

En efecte, és lloc comú de la doctrina juridicocooperativa que la finalitat de la cooperativa és satisfer els interessos i les necessitats de tota una categoria social, entre la qual, els socis només són els beneficiaris actuals de l'activitat cooperativitzada. Sobre aquesta finalitat es construeix, precisament, el principi cooperatiu de porta oberta, que garanteix que qualsevol persona que complisca els requisits objectius que defineixen la pertinença a la categoria, tinga accés a la cooperativa.

En la cooperativa queda clar, fins i tot materialment, que l'interès social és alguna cosa més que la suma dels interessos particulars dels socis, en la mesura que una part important dels excedents econòmics i dels beneficis es converteix en patrimoni comú, irrepartible, tant en cas de baixa del soci, com en la liquidació de la cooperativa. Aquest patrimoni pretén garantir l'atenció a tots els membres de la categoria que en cada moment constituïsquen el col-lectiu social, i materialitza la inclusió en el concepte d'interès social cooperatiu no sols dels interessos dels socis actuals, sinó també dels de qui poden arribar a ser-ho, 
així com dels treballadors, i de l'entorn social en què la cooperativa es desenvolupa.

Paradigma de tot això és el funcionament dels fons obligatoris a la cooperativa, amb caràcter essencialment irrepartible, i particularment l'obligatorietat per a la cooperativa de constituir, en tot cas, un fons econòmic de reserva destinat a la formació i la promoció cooperativa. Aquest fons, irrepartible entre els socis fins i tot en el moment de la dissolució de la cooperativa, ha de ser aplicat en cada exercici a la realització d'activitats relacionades amb la formació dels socis i els treballadors de la cooperativa en els principis i les tècniques cooperatives, econòmiques i professionals, la promoció de les relacions intercooperatives, la difusió del cooperativisme i la promoció cultural, professional i social de l'entorn local o de la comunitat en general. A més, les quantitats del fons que no hagen estat aplicades en un exercici, han de materialitzar-se en l'exercici següent en béns de liquiditat fàcil, afectes al compliment de les finalitats del fons. Es tracta de garantir així el compliment dels principis cooperatius $i, a m b$ això, d'una finalitat social que va més enllà de la satisfacció dels interessos particulars dels socis actuals.

Així doncs, amb la constitució de la cooperativa es pretén no sols adoptar la forma jurídica més adequada per al desenvolupament de l'objecte social, sinó que l'estructura creada en garantisca la disponibilitat per a tota la categoria social, a la satisfacció dels interessos de la qual es dirigeix; que la realització de l'objecte social es desenvolupe, bàsicament, mitjançant la necessària participació directa dels socis; i que els efectes econòmics positius revertisquen no sols en els socis, sinó en l'entorn en què la cooperativa es desenvolupa. La finalitat mutualista fa que en la noció d'interès social cooperatiu hagen $d$ 'incloure's, sens dubte, al costat de la satisfacció de les necessitats dels socis, la consolidació progressiva d'un patrimoni comú i irrepartible que romanga davant la variabilitat consubstancial del col-lectiu de socis cooperatius. En la cooperativa hi ha, doncs, interessos socials diversos a la suma d'interessos individuals dels socis en la satisfacció de les seues necessitats mitjançant l'ajuda mútua. 
QUARTA. En qualsevol cas, de l'estudi de les posicions doctrinals més recents al voltant de l'interès social, podem concloure que, tant en l'àmbit mercantil com en el cooperatiu, amb la impugnació, el legislador intenta tutelar diversos interessos que considera mereixedors de protecció. Entre aquests, és bàsic el respecte al principi de legalitat, com a límit al d'autonomia privada de la voluntat: els acords socials mitjançant els quals la persona jurídica s'autoorganitza en la seua esfera de lliure determinació no poden contradir l'ordenament jurídic vigent. Si això es produeix, la impugnació facilitarà el procediment per al restabliment de la legalitat. La defensa de l'ordenació constitucional és la que fonamenta la impugnació dels acords que vulneren la legalitat vigent $\mathrm{i}$ els interessos públics.

D'altra banda, també es tutela allò que tradicionalment s'ha denominat "interès social", encara que considerem que no es tractaria d'un interès únic, sinó que els diversos interessos que conflueixen en el contracte social poden ser considerats socials. Ja hem vist com l'interès que porta el soci a ingressar en la cooperativa no és un ànim de lucre directe, sinó la satisfacció de necessitats mitjançant l'ajuda mútua. Però també s'han de considerar altres interessos socials: l'interès en la realització de l'objecte social de manera mutualista, i l'interès en el manteniment de la cooperativa mitjançant la creació d'un patrimoni comú.

Finalment, es protegeixen interessos legítims de terceres persones: treballadors, creditors, consumidors i usuaris, inversors... El fonament de la seua protecció es pot reconduir tant a la defensa d'interessos generals presents en l'ordenament jurídic, com a la de l'interès social. D'una banda, s'observa la tendència legislativa general a la restricció de l'autonomia contractual en favor de la protecció necessària dels qui quedarien, en cas contrari, en situació d'indefensió; d'una altra, la garantia de la seguretat jurídica en general i la del tràfic empresarial en particular, ja no pot entendre's protegida exclusivament mitjançant una defensa a ultrança del principi de manteniment de les decisions 
socials, sinó amb l'establiment de procediments de revisió àgils, segurs i transparents.

CINQUENA. En relació amb la legislació cooperativa actualment aplicable a l'Estat espanyol, i vistos els textos vigents actualment, poden extraure's dues conclusions bàsiques. La primera, reiterada per la doctrina, que veritablement, no hi ha una raó objectiva que justifique la multiplicitat de regulacions amb vocació de bastir un règim juridicocooperatiu complet. Es fa cada vegada més patent la conveniència d'adoptar un nou model de distribució competencial, en el qual una llei estatal harmonitzadora regule els aspectes bàsics del funcionament i de l'estructura cooperativa (entre els quals, els relatius a l'estructura orgànica bàsica i al procediment d'impugnació de declaracions orgàniques de voluntat) $i$ les comunitats autònomes mantinguen la capacitat de desenvolupament.

La segona conclusió és que la legislació cooperativa actual es debat entre dues tendències: d'una banda, la fidelitat als principis cooperatius i a la formació d'un patrimoni cooperatiu col-lectiu o irrepartible; i d'una altra, la "relaxació" d'aquests objectius, a fi de donar resposta a les exigències de competitivitat de l'activitat empresarial. No és fàcil de resoldre la tensió entre ambdues tendències: si bé és previsible que l'evolució legislativa vaja aprofundint en la uniformització de la cooperativa en els paràmetres de les formes empresarials col-lectives per excel-lència, les societats de capital, la relaxació dels principis cooperatius comporta la desaparició progressiva dels motius que justifiquen l'existència mateixa de la forma empresarial cooperativa. Per això, amb independència del criteri d'oportunitat que es mantinga, la doctrina continua posant èmfasi en el caràcter de principis configuradors que es pot atribuir als principis cooperatius, cosa que ha portat fins i tot a proposar-los com a regles $\mathrm{d}$ 'harmonització legislativa, tant a escala estatal com internacional. 
SISENA. En relació amb els principis cooperatius i el seu paper en el marc normatiu de les cooperatives, el seu origen històric prelegislatiu així com el seu caràcter marcadament ètic, i la denominació mateixa de principis, poden portar a pensar, en una primera aproximació, que es tracta de normes metajurídiques o, almenys, de principis generals del dret, informadors només de manera implícita del concepte de cooperativa i dels seus trets normatius. Això no és així, almenys en les normes cooperatives de l'Estat espanyol, totes les quals assumeixen, de manera explícita, encara que amb diferents fórmules, que l'estructura i el funcionament de les cooperatives que regulen han d'ajustar-se als principis cooperatius. Són, doncs, vertaderes normes jurídiques, i ho són $\mathrm{amb}$ rang legislatiu, no en qualitat de principis generals del dret.

Però a més, el seu caràcter definitori del model cooperatiu converteix els principis cooperatius en l'equivalent dels anomenats principis configuradors dels tipus societaris capitalistes. Així, en l'àmbit de les societats mercantils s'ha proposat, en tractar el concepte d'ordre públic com a límit a la caducitat de la impugnació dels acords nuls, que els acords contraris als principis configuradors són contraris a l'ordre públic i, per tant, nuls amb una nul-litat indefinida, no caducable. Per la seua part, en l'àmbit cooperatiu s'assigna als principis cooperatius la funció de bases essencials de la cooperativa. Des d'aquesta perspectiva, és gairebé obvi establir l'equivalència: els acords de la cooperativa que siguen contraris als principis cooperatius no sols seran nuls per ser contraris a la norma legal que els converteix en jurídicament obligatoris, sinó que la nul.litat podrà ser actuada sempre, ja que la vulneració es considera contrària a l'uordre públic cooperatiu», als elements essencials de la cooperativa.

SETENA. Quan s'aborda el marc normatiu de les cooperatives ha d'atendre's també la capacitat autocompositiva de les persones jurídiques, que es manifesta fonamentalment en els estatuts socials, en els reglaments de règim intern i en els acords dels òrgans socials amb competències per decidir sobre 
l'organització. L'interrogant bàsic que es produeix és l'abast d'aquesta autonomia: fins on pot arribar la voluntat de la persona jurídica en la configuració del procés d'impugnació?

Com s'ha dit, el paper de l'autonomia privada en la determinació del règim de la persona jurídica, en general, pot considerar-se des d'una doble perspectiva: l'estructural i la tecnicolegislativa. En el primer sentit, ja hem conclòs que els elements configuradors del tipus social de què es tracte actuen com a límit a la llibertat d'individualització de l'entitat particular; en el cas que ens ocupa, són els principis cooperatius els que hauran de ser respectats, en tot cas, per les normes juridicoprivades amb què es dote la cooperativa. El segon aspecte atén l'abundància o la mancança de normes legals dispositives i imperatives que regulen la matèria. Com més normes obligatòries o prohibitives continguen els textos legals aplicables, el marge a l'autoregulació serà més menut; contràriament, si la norma legal conté fonamentalment normes dispositives (derogables o que ofereixen alternatives, o un contingut mínim ampliable), la flexibilitat del tipus serà més gran.

Posats així els termes de la qüestió, poden observar-se tendències contradictòries en el marc de l'autoregulació cooperativa. Al nostre entendre, es pot afirmar que els principis cooperatius atribueixen, en principi, un grau de rigidesa més alt al tipus cooperatiu, ja que inclouen trets metajurídics: l'entitat que pretenga ser qualificada com a cooperativa, no sols ha d'establir mecanismes que permeten l'adhesió voluntària i oberta dels qui vulguen ser-ne socis o deixar de ser-ho, així com la seua participació democràtica en la gestió i en l'activitat econòmica dels socis, sinó que ha de garantir l'autonomia i la independència de la cooperativa, ha de procurar l'educació, la formació i la informació dels seus socis i treballadors, i ha de tendir cap a la intercooperació entre cooperatives i el desenvolupament sostenible de la seua comunitat. Tanmateix, com manifesta la doctrina, en les últimes dècades s'està produint una clara tendència cap a la «hibridació» de la cooperativa, mitjançant $l^{\prime}$ «atenuació» del rigor en l'exigència del compliment dels principis cooperatius. 
La necessitat constatada per les cooperatives d'adaptar-se a un mercat competitiu les porta a demandar canvis legislatius en aquest sentit i a adoptar fórmules organitzatives cada vegada més pròximes a les de les societats de capital.

Quant a l'aspecte relacionat amb el grau de flexibilitat del marc legal, el punt de partida no és gens encoratjador: en l'elenc de normes legals cooperatives de l'Estat espanyol s'observa una resistència general a abandonar el tradicional i marcat caràcter reglamentista. Tanmateix, en els textos legals aprovats en el procés de reforma de la dècada dels noranta s'apunta una tendència cap a la simplificació i la confiança en els mecanismes d'autocomposició societària, tant per la influència del dret de societats mercantils, al qual expressament s'aproximen, com per les demandes de flexibilitat legal efectuades pel moviment cooperatiu mateix. En aquest sentit, la LCoop és una de les normes que recullen més bé aquest esperit desregulador, expressant amb més amplitud l'admissibilitat d'autoorganització, remetent aspectes importants al desenvolupament estatutari i renunciant a normar-ne d'altres o simplificant els seus requisits imperatius.

VUITENA. De manera general s'admet que l'objecte de la impugnació en l'àmbit de les persones jurídiques són els acords dels seus òrgans, en tant que específics negocis jurídics unilaterals formats mitjançant els procediments adients. Però tot això requereix diverses matisacions.

Entenem que han de poder ser impugnades les diverses declaracions de voluntat o de ciència que la persona jurídica emeta amb la finalitat de produir efectes jurídics en el seu àmbit de disposició. Si la finalitat amb què l'ordenament jurídic institueix la impugnació és la d'actuar com a mitjà de control de la capacitat autonormativa de la persona jurídica, no han de suposar un entrebanc a aquest control les diverses modalitats de formació de la voluntat que puguen adoptar els diferents òrgans facultats. Això vol dir que també les 
decisions que hagen de ser adoptades per unanimitat per òrgans pluripersonals no col-legiats, o les dels òrgans unipersonals, han de poder ser sotmeses a impugnació.

Per contra, estimem que, en general, no pot parlar-se d'altres objectes de la impugnació que no siguen els acords i altres declaracions de voluntat o coneixement de la persona jurídica. Quan s'impugna la realització de tota una sessió d'un òrgan social, com ara, de l'assemblea general, en realitat s'està demanant l'anul-lació de tots els acords que aquesta ha adoptat. Quan s'impugna el balanç de l'entitat, o altres documents amb rellevància jurídica, s'impugna en realitat l'acord que li ha donat validesa jurídica. Només hem trobat en la legislació cooperativa una excepció a aquesta darrera afirmació: la impugnació del balanç final de la liquidació de la cooperativa i del projecte de distribució de l'actiu sobrant. En aquest cas, la Llei estatal estableix un procediment especial perquè els "socis que se senten ofesos i [els] creditors els crèdits dels quals no hagueren estat satisfets o garantits" puguen contradir-los, amb independència de la possibilitat d'impugnar, o no, l'acord de la seua aprovació.

NOVENA. Si atenem la causa d'invalidesa de l'acord, l'ordenament jurídic distingeix entre acords contraris a la Llei, acords que s'oposen als estatuts i acords que lesionen els interessos de la cooperativa en benefici de socis o tercers. Aquesta classificació dels diferents acords sotmesos a control ha estat àmpliament estudiada per la doctrina en seu de societats mercantils, i no sol presentar perfils específics en la cooperativa, a excepció dels supòsits de conflicte d'interessos.

L'ordenament jurídic estableix, essencialment, dues vies per a la superació de les situacions en què, amb caràcter general, puga plantejar-se un conflicte $\mathrm{d}$ 'interessos entre el soci i la persona jurídica de la qual forma part. D'una banda, quan la majoria de socis adopta un acord que lesiona l'interès social en 
benefici propi o de tercers, la llei sanciona aquesta infracció del deure de fidelitat amb l'anul-labilitat de l'acord. Però també preveu la possibilitat de prevenir i, per tant, d'evitar l'incompliment, prohibint al soci en situació de conflicte l'exercici del seu dret de vot. Són aquests últims casos els que són denominats correntment situacions de "conflicte d'interessos" per l'ordenament jurídic i per la doctrina.

La legislació cooperativa es va avançar en la regulació dels conflictes d'interessos, siga en relació amb els socis i els associats en general, siga en els supòsits que afecten els membres del consell rector, de la direcció o de la direcció ??????????2????2???2. El principal problema no ha estat, doncs (com succeïa en l'àmbit mercantil fins a la promulgació de la LSRL vigent), el de la validesa eventual d'una clàusula estatutària que establira el deure d'abstenció del soci, ja que això és exigit expressament i amb caràcter imperatiu per la norma legal, sinó els supòsits que poden estar regulats estatutàriament com a conflicte. Sembla que l'element determinant ha de ser que els interessos contraposats (socials $\mathrm{i}$ extrasocials) siguen efectivament antitètics $\mathrm{i}$ impossibles de conciliar, la qual cosa ha portat la doctrina a admetre la participació del soci, per exemple, en la votació en què se'l propose per a un càrrec social, o de l'administrador en l'aprovació de la gestió i del balanç social, o en l'exercici de l'acció de responsabilitat que l'afecte, quan es considera que en aquests casos els interessos coexistents són compatibles.

En tot cas, la validesa de l'acord pres amb la participació de persones afectades pel conflicte d'interessos dependrà de l'anomenada "prova de resistència»: la nul-litat o l'anul-labilitat del vot d'un soci afectarà únicament la validesa de l'acord a què haja concorregut si aquell fóra necessari per a la seua adopció, en virtut del joc de les majories i dels quòrums de l'òrgan i de la matèria corresponents. Pel que fa a la sanció corresponent a l'acord viciat, al nostre parer, s'haurà d'atendre, no el vici que invalida el vot, sinó la naturalesa de la norma que establia el deure d'abstenció i que ha estat vulnerada amb el vot: si el conflicte d'interessos es recull en una norma legal imperativa, l'acord que la 
incompleix serà nul; si el conflicte és dels concretats estatutàriament, en ampliació dels exigits legalment, l'acord haurà de considerar-se anul-lable.

DESENA. La doctrina s'ha plantejat reiteradament l'admissibilitat o no de la impugnació de l'acord adoptat mitjançant abús de dret per part de la majoria social, proposant-ne en alguns casos la impugnació en tant que supòsit específic d'acord lesiu de l'interès social. Tanmateix, s'ha de recordar que, perquè es done aquest concret tipus d'acord impugnable, l'exercici abusiu del propi dret no sols ha de lesionar l'interès social, sinó que ha de produir un benefici aliè, lligats ambdós per una relació causal.

L'abús de dret és, al nostre entendre, una institució més àmplia, en la qual poden enquadrar-se, entre altres, els supòsits d'exercici abusiu del seu dret per la majoria social que produiran perjudici a la cooperativa $i$ benefici a altres persones. Però també se n'inclouen d'altres, en els quals l'abús de dret per la majoria no té per objecte beneficiar a ningú: la finalitat pot ser, exclusivament, el perjudici a determinats socis o tercers o a la cooperativa mateixa, o no haverhi una finalitat, com és el cas dels anomenats «acords irracionals».

En la nostra opinió, a l'efecte d'evitar les conseqüències perjudicials de l'abús de dret han de distingir-se ambdues modalitats. L'abús realitzat amb perjudici social i en benefici extrasocial serà plenament anul-lable quan s'exercisca mitjançant l'adopció d'un acord per la majoria. En canvi, l'arbitrarietat en l'exercici del propi dret quan no es donen els elements de l'acord impugnable per lesiu a l'interès social (acord que lesiona interessos de la cooperativa i que produeix beneficis extrasocials), només podrà donar lloc a la reclamació de «la indemnització corresponent i l'adopció de les mesures judicials o administratives que impedisquen la persistència en l'abús» en la mesura que es donen les circumstàncies previstes en 1'article 7.2 del Codi civil. 
ONZENA. Si el que es pren en consideració és la naturalesa de la causa d'invalidesa, parlarem d'acords nuls i d'acords anul-lables. En relació amb aquesta classificació, les qüestions amb més transcendència que es plantegen són les que deriven dels principis que ara regeixen la ineficàcia dels acords socials. En efecte, l'anul-labilitat com a regla general i la caducitat també de la impugnació dels acords nuls fan que prenguen relleu especial, d'una banda, la possibilitat de deixar sense efecte o de substituir els acords invàlids; i d'una altra, el concepte d'acord contrari a l'ordre públic.

Pareix que no hi ha dubte que, amb l'admissió de l'esmena, la voluntat del legislador ha estat preservar, fins on siga possible, l'estabilitat dels acords socials, i d'aquesta manera evitar-ne la impugnació quan la cooperativa, posteriorment, actue per corregir els vicis que els invaliden. Però la preservació de l'estabilitat no ha d'entendre's, amb caràcter general, com a defensa a ultrança del manteniment de la voluntat social, ja que en tots els supòsits no serà així: els acords que es limiten a "deixar sense efecte" els anteriors viciats mitjançant la simple revocació, i els que els substituïsquen per altres de contingut diferent no refermen la voluntat social, sinó que l'adapten en nom de la seguretat jurídica. La finalitat bàsica de la norma és, doncs, eludir o pal-liar en la mesura de les possibilitats els inconvenients d'una intervenció processal.

S'ha plantejat, però, la possibilitat que no totes les causes de la impugnació puguen ser reparades, ja que la redacció mateixa dels textos legals es fa de manera condicional: «si és possible eliminar la causa d'impugnació», «no procedirà la impugnació d'un acord quan/que haja estat deixat sense efecte». No creiem, tanmateix, que, com s'ha proposat, els supòsits exclosos hagen de ser tots els acords nuls. Considerem que la referència legal es dirigeix fonamentalment a l'exclusió de la ratificació d'acords que, per la seua causa o el seu contingut, siguen contraris a l'ordre públic. 
DOTZENA. En l'aproximació al concepte d'«acords contraris a l'ordre públic», la doctrina ha ressaltat tres aspectes: la necessitat que la contrarietat a l'ordre públic implique la vulneració d'una norma de caràcter imperatiu; la limitació als supòsits en què la vulneració de l'ordre públic es produïsca en virtut de la causa o el contingut de l'acord, i finalment el significat que s'haja de donar a l'expressió ordre públic. És aquest darrer aspecte el que, sens dubte, més inseguretat suscita, per la dificultat de concretar-lo. Si, com sembla, la pretensió legislativa ha estat conciliar la seguretat jurídica i del tràfic mercantil amb el respecte als "principis essencials de l'ordenament que no poden ser desconeguts de cap manera", s'haurà d'intentar concretar quins d'aquests principis poden veure's afectats per la causa o pel contingut d'un acord social.

En aquest sentit, s'ha fet notar que podrem trobar-nos tant amb normes d'ordre públic corporatiu com extracorporatiu. Les primeres s'identifiquen amb els anomenats "principis configuradors" del tipus societari que es tracte; per a la integració de les segones s'han proposat "els postulats bàsics de l'ordre públic econòmic", les normes imperatives de sectors del dret diferents al societari (dret laboral, fiscal, penal, etc.) $\mathrm{i}$ «el respecte a la moral $\mathrm{i}$ als bons costums».

Com s'ha indicat, la noció de principis configuradors s'ha elaborat fonamentalment al voltant de la societat anònima, però, en traslladar el concepte al tipus cooperatiu, s'ha fet identificant-los amb els principis cooperatius establerts per l'Aliança Cooperativa Internacional, que han estat incorporats a tots els textos legals cooperatius de l'Estat espanyol.

En relació a la menció a l'ordre públic econòmic com a integrant del concepte d'ordre públic extrasocietari, sembla que ha d'entendre's conformada pels principis generals ofonamentals del tràfic mercantil, com ara les normes imperatives i prohibitives sobre competència o sobre regulació del mercat.

Finalment, també s'ha proposat la inclusió entre els principis generals extracorporatius que conformarien el concepte d'ordre públic, el respecte a la 
moral $\mathrm{i}$ als bons costums, com a límits a l'autonomia contractual, «en defensa de valors de naturalesa col-lectiva que afecten la convivència dels ciutadans i l'organització social». Per a concretar-los, s'apunta cap a les regles que connecten l'ordenament jurídic amb els valors ètics predominants en una societat en un moment històric determinat. En aquest sentit, es pot destacar alguna nova proposta doctrinal que propugna la inclusió, per aquesta via, en la conformació del contingut de l'ordre públic, tant de l'anomenada "globalització de l'economia» com l'exigència del respecte al pluralisme cultural i ideològic; així, s'entén que «la globalització afavoreix la reducció de la influència de l’ordre públic particular» i que el pluralisme «té com a conseqüència la reducció progressiva dels continguts exclusius del grup majoritari o dominant en la conformació de l'ordre públic general, per passar a quedar constituït per aquells continguts que el converteixen en una garantia global de l'exercici de llibertat col-lectiva i individual que està implícita en l'accepció de la pluralitat».

En tot cas, sembla clar que el concepte d'ordre públic no gaudeix d'un contingut unívoc d'acceptació general, a més a més de caracteritzar-se per la variabilitat a través del temps, raó per la qual resultaria infructuós intentar-ne una elaboració completa; s'haurà d'atendre cada cas concret per intentar determinar si som davant d'un acord que contravinga l'ordre públic.

TRETZENA. Un dels aspectes de la impugnació d'acords socials on pot observar-se clarament la diferència estructural i teleològica entre cooperatives $\mathrm{i}$ societats de capital és el relacionat amb l'origen dels acords. En la cooperativa la participació del soci no és només un dret, sinó també una obligació, i el seu vessant polític es realitza segons el principi democràtic d'una persona, un vot; a més, és possible la intervenció de persones no sòcies en les decisions socials, en la gestió i, fins i tot, en el control de la gestió. La necessitat de donar curs a la proliferació de les diverses ocasions i modalitats de participació fa que es multipliquen els òrgans socials. D'altra banda, el fet que la participació s'articule normalment segons el principi igualitari d'"una persona, un vot" 
influeix en l'estructura dels òrgans en què es materialitza, que adopta més sovint la forma pluripersonal col-legiada, i que, més habitualment que en les societats de capital, estableix representacions de determinats col-lectius, amb la finalitat de garantir-ne la participació. Tot açò fa necessari analitzar quan i de quina manera els acords i les decisions d'aquesta multiplicitat d'òrgans poden ser objecte d'oposició.

Al nostre parer, pot plantejar-se la possibilitat d'impugnar els acords o les decisions de la major part dels seus òrgans col-legiats (assemblea general, altres assemblees i juntes, consell rector, comitè de recursos...) i d'alguns que són o poden ser unipersonals (òrgan d'administració unipersonal o pluripersonal solidari, direcció...); a més, per a alguns supòsits concrets d'acords impugnables (alta, sanció, baixa o expulsió de socis, denegació d'informació...) la llei estableix la possibilitat de la impugnació interna, prèvia a la judicial, davant d'òrgans diferents al que va formular l'acord.

CATORZENA. La impugnació dels acords socials es va establir inicialment com a instrument de control del funcionament correcte de l'assemblea general, per això no és estrany que la seua regulació siga la més detallada i que funcione com a règim supletori per a la impugnació dels acords d'altres òrgans socials, ja siga per mandat explícit, ja siga per aplicació analògica.

Així, a més de l'aplicació supletòria a la impugnació de les decisions de l’òrgan d'administració i del comitè de recursos de la LCoop, el règim de la impugnació dels acords de l'assemblea serveix per conformar la parca o inexistent regulació de la impugnació dels acords d'altres assemblees o juntes que es poden donar en la cooperativa. Són els supòsits de la impugnació dels acords de l'assemblea de delegats, de l'assemblea de socis de la secció, de les juntes especials o votacions separades, i de les assemblees d'obligacionistes. Entre aquests casos destaca, per la seua rellevància pràctica, el de l'assemblea de socis de la secció. 
QUINZENA. La LCoop no es refereix obertament a la impugnabilitat dels acords de l'assemblea de socis de la secció, encara que la redacció de la facultat de la seua suspensió que fa l'assemblea general sembla estar pensada com a pas previ a una impugnació eventual de l'acord que s'ha de suspendre. És aconsellable, de lege ferenda, l'esmena d'aquesta llacuna legislativa que tinguera en compte aspectes que demanen una regulació específica, com ara la legitimació; mentrestant, una regulació estatutària eventual de la impugnació dels acords de l'assemblea de socis de la secció en les cooperatives sotmeses a la LCoop es converteix en altament aconsellable.

La LCCV sí que reconeix explícitament la impugnació dels acords de l'assemblea de socis de la secció, amb remissió expressa a allò que es preveu per a la impugnació dels acords de l'assemblea general, la qual cosa tampoc evita l'aparició d'interrogants, entre els quals el relatiu a l'interès protegit. En efecte, $s^{\prime}$ ha de tenir en consideració que els interessos dels socis de la secció poden ser diferents, i fins $\mathrm{i}$ tot contradictoris amb els de la cooperativa en conjunt, o amb els dels socis no adscrits a la secció, la qual cosa afecta, almenys, dos aspectes essencials: l'interès eventualment lesionat amb l'acord com a causa de la impugnació, i la legitimació, activa i passiva, per a la impugnació.

En relació amb l'interès que puga resultar lesionat per l'acord, no hi ha dubte que l'acord de la secció que lesione l'interès general de la cooperativa en benefici extrasocial (siga a favor dels socis de la secció, siga a favor de tercers) és dretament impugnable; tampoc obri interrogants especials la legitimitat segons la qual els socis adscrits a la secció actuen en defensa dels seus interessos mitjançant l'adopció d'acords que no lesionen interessos de la cooperativa en conjunt. El conflicte podria plantejar-se, tanmateix, quan l'assemblea de socis de la secció adoptara un acord, en benefici dels seus socis adscrits i sense lesió de l'interès social, però que perjudicara els interessos d'altres socis de la cooperativa. 
Ja ha quedat ressenyat que la legislació espanyola no preveu la impugnació dels acords que lesionen interessos legítims, però extrasocials dels socis. Però també s'han de tenir ara en consideració altres aspectes derivats de la estructura cooperativa peculiar i de les seues seccions: l'assemblea de socis de la secció, la composició de la qual pot ser minoritària respecte al total col-lectiu de socis de la cooperativa, podria adoptar acords que, tot i no patir de cap de les causes d'impugnació assenyalades en la LCCV, podrien ser perjudicials per als interessos d'altres socis (que poden ser fins i tot la majoria), però no atacables per l'assemblea general. No hi trobem una solució senzilla: permetre que l'assemblea de la secció adopte acords perjudicials als socis no adscrits pot generar conflictes interns greus $i$, fins i tot, produir-se la paradoxa que l'estructura cooperativa done cobertura a la defensa dels interessos minoritaris davant els de la majoria; regular la segona instància davant l'assemblea general obri la via del control d'oportunitat de les decisions de la secció, amb greu limitació de la seua pretesa autonomia de gestió. Per això, potser caldrà defensar la impugnabilitat d'aquells acords adoptats exclusivament en satisfacció d'interessos extrasocials quan no es perseguisca simultàniament l'interès comú.

Tampoc és menys conflictiva la qüestió de la legitimació per a la impugnació dels acords de l'assemblea de la secció. Algun autor ha proposat que els socis no adscrits se'ls havia de considerar com a tercers a l'efecte de la impugnació dels acords de la secció; amb això es produiria la seua deslegitimació per a la impugnació dels acords anul-lables, opció que ens sembla incorrecta. En efecte, si bé és cert que els socis de la secció són els qui han de decidir el que millor corresponga a la defensa dels seus interessos, no ho és menys que haja de ser amb respecte total a la llei, als estatuts socials i a l'interès general de la cooperativa, i que una vulneració eventual d'aquestes causes ha de legitimar tots els socis per a la seua impugnació, ja que tots es veurien perjudicats per la lesió. 
La LCCV demanda l'aplicació a aquesta impugnació de les pautes de legitimació de l'assemblea general; tanmateix, la translació d'aquestes normes a l'àmbit de la secció tindria efectes similars als criticats, ja que legitima únicament els assistents que hi hagueren fet constar la seua oposició, els absents i els il-legítimament privats de vot, els membres del consell rector, els administradors i els membres de la comissió de control de la gestió. I no escau equiparar, a l'efecte de la legitimació, els socis no adscrits amb els socis de la secció absents, ja que aquells no són membres de l'assemblea de la secció.

Quant a la legitimació passiva, la falta de personalitat jurídica independent de la secció condueix inevitablement a l'exercici de la defensa de l'acord de la secció per la representació general de la cooperativa, això és, l'òrgan d'administració. Tanmateix, en aquests casos pot donar-se amb més freqüència que en la impugnació dels acords de l'assemblea general que siguen els administradors de la cooperativa els que actuen la legitimació activa. En aquests supòsits, s'hi ha d'aplicar analògicament la solució adoptada per la LSA, això és, que "quan l'actor tinguera la representació exclusiva de la societat i la junta no tinguera designat ningú a aquest efecte, el jutge nomenarà la persona que ha de representar-la en el procés, entre els accionistes que han votat a favor de l'acord impugnat".

En tot cas, ja que el mandat legal cooperatiu mateix exigeix la regulació estatutària de les seccions, és molt convenient aprofitar aquest desenvolupament per concretar-ne i detallar-ne l'estructura i el funcionament orgànic en general, i el règim d'impugnació dels acords de la seua assemblea en particular. La pràctica i la doctrina també aconsellen dotar de reglament propi les seccions que compten amb un volum d'activitat suficient, cosa que en alguns casos és obligatori, en virtut de normatives sectorials; tanmateix, encara que els reglaments de les seccions són instruments útils per a la seua organització, s'ha de recordar que la seua vulneració no dóna lloc, en principi, a la impugnació de l'acord corresponent. 
SETZENA. La impugnació de les declaracions de voluntat dels òrgans d'administració i gestió de la cooperativa planteja nombrosos i diversos aspectes, entre els quals té, al nostre parer, una importància especial la qüestió relativa a la possibilitat d'impugnar decisions d'òrgans no col-legiats. En efecte, cal recordar que, tot i que la forma que tradicionalment adopta l'òrgan bàsic d'administració a la cooperativa és la pluripersonal col-legiada, no és, a hores d'ara, l'única possible.

Així, ja hem vist com s'ha incorporat la possibilitat de substituir en algunes cooperatives el consell rector per un administrador únic, o, en l'àmbit de la LCCV per dos administradors mancomunats o solidaris. A més a més, es reconeix la possibilitat que el consell rector delegue part de les seues facultats, bé en una comissió executiva, bé en un conseller delegat. Finalment, tot i que es qüestiona cada vegada més el seu caràcter orgànic, la direcció compta amb antecedents de reconeixement exprés de la impugnabilitat de les seues decisions.

Com a motius que justificarien la restricció de la impugnació als acords, com a declaració de voluntat col-legiada, s'han indicat les dificultats que comportaria, d'una banda, discriminar, en el cas dels òrgans unipersonals, entre la decisió i els actes d'execució corresponent, i, d'una altra, l'accés al coneixement de l'existència mateixa de la decisió. Aquests motius han estat rebatuts amb diferents arguments: en relació amb la dificultat de diferenciar la decisió pròpiament impugnable dels actes d'execució, es recorda que l'admissió de societats unipersonals no qüestiona la impugnabilitat dels acords de la junta general. En relació amb la dificultat per accedir a la informació sobre les decisions unipersonals, s'ha observat que ocorre el mateix en els acords adoptats pel consell d'administració, sobretot per als socis no administradors, sense que això siga obstacle per a la impugnabilitat. 
Les dificultats d'accés al coneixement de la decisió, així com de discriminar entre aquesta i els actes de la seua execució no són, al nostre parer, un argument de suficient envergadura per negar la impugnació, com a instrument de control respecte de les decisions de determinades modalitats d'òrgan d'administració. Aquestes dificultats, a més, poden evitar-se (i en alguns casos, ho han de fer) mitjançant l'adopció de les mateixes mesures de publicitat que s'estableixen per als acords col-legiats: constància en acta, certificació, inscripció registral, etc. En tot cas, que la formació de la voluntat social en el cas dels òrgans no col-legiats siga d'exteriorització difícil no pot portar a concloure que ha d'actuar-se com si fóra inexistent; tractant-se en tot cas d'òrgans socials, adopten decisions que conformen la voluntat social en la mateixa mesura que l'òrgan pluripersonal col-legiat ho fa mitjançant el procés d'adopció de l'acord. Una qüestió diferent és que l'exteriorització dels òrgans no col-legiats no es produirà, la majoria de les vegades, fins que s'inicien els actes i els negocis de la seua execució, per la qual cosa s'hauran de preveure els mitjans adequats per a la seua constatació.

També s'ha argumentat a favor de la no-impugnabilitat "la complexitat que presenta el control dels actes de gestió des del punt de vista de les relacions internes i.la conveniència d'evitar un control extern excessiu del funcionament de la societat", i es propugna en la seua substitució l'aplicació del règim de responsabilitat. Davant d'això, s'han fet notar els perjudicis que es derivarien de la necessitat d'esperar, per iniciar l'acció de responsabilitat, que es produïra un dany que, en alguns casos, fins i tot podria haver estat evitat mitjançant la impugnació.

Però sobretot entenem que no pot fonamentar-se la decisió sobre l'admissió o no de la impugnació en qüestions accessòries, com ara quin és l'origen de l'acte potencialment subjecte, sinó que ha de fer-se sobre la seua naturalesa, suposadament il·legal, antiestatutària o socialment lesiva. El cas contrari porta a la paradoxa de declarar no impugnables decisions que, si foren adoptades per òrgans col-legiats, serien dretament revocables, i obre una via d'elusió del 
control social sobre l'òrgan d'administració amb la sola opció per modalitats no sotmeses a la impugnació.

La nostra opinió en la matèria es decanta, doncs, per la impugnabilitat de les decisions adoptades pels òrgans unipersonals d'administració, i per les dels òrgans pluripersonals quan s'adopten de manera no col-legiada. Les causes de la impugnació es poden donar, tant en els acords col-legiats, com en les decisions individuals, per la qual cosa cal afrontar-les en ambdós casos, i res no justifica que els instruments hagen de ser diferents. Les dificultats a l'hora de discernir entre declaració de voluntat i execució, o la mera prova de la seua existència, no es presenten de forma exclusiva en les formes «no col-legiades» de l'òrgan d'administració, i poden i han de ser evitades mitjançant l'adopció de les mesures de publicitat legals $i$ estatutàries que es preveuen per a altres modalitats d'òrgan societari, si bé no s'ha d'ocultar la conveniència d'una explicitació eventual, de lege ferenda, de l'obligatorietat també per a les decisions individuals.

A més a més, en l'àmbit cooperatiu, com ja s'ha indicat, les normes legals no sols no impedeixen la impugnació de les decisions no col-legiades de l'òrgan d'administració, sinó que conviden a una interpretació extensiva de la impugnabilitat dels acords col-legiats: es propugna l'aplicació, en la mesura de les possibilitats, de les normes reguladores del consell rector a la resta de les modalitats d'òrgan d'administració permeses. La interpretació restrictiva portaria, a més, a qüestionar què ha de fer-se en els supòsits legalment previstos d'"impugnació interna" davant de l'assemblea o del comitè de recursos quan s'opte per fórmules diferents a la del consell.

DISSETENA. La LCoop incorre en un greu error a l'hora d'establir els terminis per a la caducitat de la impugnació dels acords del consell rector. En l'apartat 1 de l'article 37 s'estableixen els terminis de dos mesos o d'un mes, segons si s'han d'impugnar acords nuls o anul-lables; en l'apartat 3, tanmateix, s'esmenta 
un únic termini d'un mes, encara que amb diferents còmputs, segons si l'impugnant és administrador o no.

Considerem que, probablement, la voluntat legislativa haja estat diferenciar els terminis d'impugnació, en la línia del que preceptua l'apartat 1, i que a l'hora d'establir el moment d'inici del còmput, en l'apartat 3, és quan s'ha oblidat que s'havia optat per la diferenciació. Per això, a falta d'una necessària (i urgent) rectificació expressa, s'hauria de "llegir" l'article 37 de la LCoop en el sentit d'establir terminis diferents d'impugnació per a acords nuls i anul·lables, terminis el còmput dels quals serà diferent segons si els impugnants són consellers o no.

DIVUITENA. Al nostre parer, el recurs intern que la legislació cooperativa preveu davant determinats acords del consell rector (o de l'assemblea, o d'altres òrgans) és un procés d'impugnació, perquè s'estableix com a via de destrucció potencial dels efectes de determinats acords, però amb un marge més ampli per a la seua autoregulació estatutària i per a l'autocomposició social. En aquest sentit, res no sembla impedir, per aquesta via, la impugnació d'acords que, si no són contraris a norma legal o estatutària, ni lesius de l'interès social en benefici extrasocial, són considerats inadequats pels afectats.

Per la mateixa raó que es considera que els tribunals no han d'entrar en judicis sobre l'oportunitat dels acords socials, sembla correcte pensar que, almenys l'assemblea general, com a òrgan de formació de la voluntat social per excel-lència, puga estar en disposició de "corregir" actuacions del consell.

Quant al comitè/comissió de recursos, poden ser creats voluntàriament, si escau, per la cooperativa, la qual pot decidir dotar-se d'aquest òrgan de revisió i atribuir-li l'àmbit d'actuació que considere convenient. I si és certa la necessitat que l'òrgan d'administració compte amb un ampli marge d'autonomia per a la gestió, no ho és menys que aquesta autonomia ha d'exercir-se de conformitat 
amb la política general fixada per l'assemblea, que, al seu torn, pot delegar el control d'aquesta adequació en l'òrgan encarregat dels recursos.

Noteu, a més, que no és casual que els supòsits per als quals es preveu el recurs intern siguen, en general, acords que afecten directament la relació entre el soci individual i la cooperativa: admissió, sanció, expulsió, baixa, liquidació... (i que, per això, estan entre els que més conflictivitat generen en relació amb els acords del consell). La decisió de l'òrgan d'administració pot ser inqualificable de nul-litat o anul-labilitat i, tanmateix, merèixer la reconsideració per l'assemblea, en consideració al caràcter essencialment solidari, mutualista, de la cooperativa.

DINOVENA. L'existència del grup planteja l'interrogant sobre la possibilitat d'impugnar els seus acords. En primer lloc, caldrà atendre la forma jurídica que adopte la denominada "entitat cap de grup". La LCoop admet la possibilitat que es constituïsca com a cooperativa; en aquest cas el règim d'impugnació serà el que es desenvolupa amb caràcter general. Tampoc sembla haver-hi problemes si l'entitat cap de grup és una persona jurídica no cooperativa, ja que $s^{\prime}$ hi aplicarà el procediment corresponent al seu règim jurídic. Però també poden donar-se fórmules contractuals no personificades, ja que s'admet que les cooperatives participen en altres formes de col-laboració econòmica, com ara consorcis, agrupacions, unions i acords intercooperatius, per la qual cosa, en aquests casos, per a la impugnació de les seues decisions, s'haurà de recórrer al règim general de nul-litat i d'anul-labilitat dels negocis jurídics.

Una qüestió important que planteja la impugnació dels acords del grup és la possibilitat de l'existència d'un conflicte d'interessos entre l'interès del grup i l'interès dels "socis minoritaris". En les cooperatives, anteriorment a la LCoop, s'ha mantingut la impossibilitat de crear grups per subordinació pel seu caràcter necessàriament democràtic $i$ independent, $i$ es descartava que en els grups per coordinació poguera imposar-se als socis acords contraris al seu interès social. Tanmateix, la regulació prevista en l'article 78 de la LCoop 
permet mantenir la hipòtesi de grups per subordinació quan l'entitat que encapçala el grup siga, de la seua banda, una cooperativa on s'integren tots els membres del grup.

Per a la defensa dels interessos que poden considerar-se del grup es podrà utilitzar la impugnació dels acords de l'entitat cap de grup. Amb l'excepció dels supòsits en què s'utilitzen formes contractuals no personificades per a la formalització de la direcció unitària, el procediment, com hem apuntat, serà, en general, allò que es preveu per a la persona jurídica la forma del qual s'haja adoptat, però també s'haurà d'atendre el contingut del "contracte de grup" (els denominats "compromisos generals"), els estatuts de l'entitat cap de grup i, si escau, els reglaments de règim intern.

Una altra qüestió que pot plantejar-se és la necessitat eventual d'ampliar els supòsits de persones legitimades en la impugnació. Així, es podria estudiar la conveniència d'ampliar la legitimació activa en els supòsits d'anul-labilitat, en favor de tots els socis i dels tercers amb interès legítim (incloent-hi els socis de les cooperatives sòcies).

I en relació amb els supòsits de conflicte entre les cooperatives sòcies i els seus socis, al marge de la possibilitat d'establir compensacions, s'hi podrà utilitzar la impugnació, tant de l'acord aprovatori d'incorporació al grup, com dels acords de l'òrgan d'administració pels quals s'executen les instruccions de l'entitat capçalera del grup.

VINTENA. La legitimació activa i passiva per a la impugnació dels acords està atribuïda per la legislació cooperativa, de manera bastant similar a la que s'estableix per a les societats de capital, sobre les quals s'ha dit que s'inspiren en la teoria de l'interès: "tenen interès aquelles persones que puguen sofrir qualsevol dany a causa de l'acord impugnable, i aquest interès legitima la seua actuació i promou el procés". 
amb la política general fixada per l'assemblea, que, al seu torn, pot delegar el control d'aquesta adequació en l'òrgan encarregat dels recursos.

Noteu, a més, que no és casual que els supòsits per als quals es preveu el recurs intern siguen, en general, acords que afecten directament la relació entre el soci individual i la cooperativa: admissió, sanció, expulsió, baixa, liquidació... (i que, per això, estan entre els que més conflictivitat generen en relació amb els acords del consell). La decisió de l'òrgan d'administració pot ser inqualificable de nul-litat o anul-labilitat $i$, tanmateix, merèixer la reconsideració per l'assemblea, en consideració al caràcter essencialment solidari, mutualista, de la cooperativa.

DINOVENA. L'existència del grup planteja l'interrogant sobre la possibilitat d'impugnar els seus acords. En primer lloc, caldrà atendre la forma jurídica que adopte la denominada "entitat cap de grup". La LCoop admet la possibilitat que es constituïsca com a cooperativa; en aquest cas el règim d'impugnació serà el que es desenvolupa amb caràcter general. Tampoc sembla haver-hi problemes si l'entitat cap de grup és una persona jurídica no cooperativa, ja que $\mathrm{s}^{\prime}$ hi aplicarà el procediment corresponent al seu règim jurídic. Però també poden donar-se fórmules contractuals no personificades, ja que s'admet que les cooperatives participen en altres formes de col-laboració econòmica, com ara consorcis, agrupacions, unions i acords intercooperatius, per la qual cosa, en aquests casos, per a la impugnació de les seues decisions, s'haurà de recórrer al règim general de nul-litat i d'anul-labilitat dels negocis jurídics.

Una qüestió important que planteja la impugnació dels acords del grup és la possibilitat de l'existència d'un conflicte $d$ 'interessos entre l'interès del grup i l'interès dels "socis minoritaris". En les cooperatives, anteriorment a la LCoop, s'ha mantingut la impossibilitat de crear grups per subordinació pel seu caràcter necessàriament democràtic i independent, i es descartava que en els grups per coordinació poguera imposar-se als socis acords contraris al seu interès social. Tanmateix, la regulació prevista en l'article 78 de la LCoop 
permet mantenir la hipòtesi de grups per subordinació quan l'entitat que encapçala el grup siga, de la seua banda, una cooperativa on s'integren tots els membres del grup.

Per a la defensa dels interessos que poden considerar-se del grup es podrà utilitzar la impugnació dels acords de l'entitat cap de grup. Amb l'excepció dels supòsits en què s'utilitzen formes contractuals no personificades per a la formalització de la direcció unitària, el procediment, com hem apuntat, serà, en general, allò que es preveu per a la persona jurídica la forma del qual s'haja adoptat, però també s'haurà d'atendre el contingut del "contracte de grup" (els denominats "compromisos generals"), els estatuts de l'entitat cap de grup i, si escau, els reglaments de règim intern.

Una altra qüestió que pot plantejar-se és la necessitat eventual d'ampliar els supòsits de persones legitimades en la impugnació. Així, es podria estudiar la conveniència d'ampliar la legitimació activa en els supòsits d'anul.labilitat, en favor de tots els socis i dels tercers amb interès legítim (incloent-hi els socis de les cooperatives sòcies).

I en relació amb els supòsits de conflicte entre les cooperatives sòcies i els seus socis, al marge de la possibilitat d'establir compensacions, s'hi podrà utilitzar la impugnació, tant de l'acord aprovatori d'incorporació al grup, com dels acords de l'òrgan d'administració pels quals s'executen les instruccions de l'entitat capçalera del grup.

VINTENA. La legitimació activa i passiva per a la impugnació dels acords està atribuïda per la legislació cooperativa, de manera bastant similar a la que s'estableix per a les societats de capital, sobre les quals s'ha dit que s'inspiren en la teoria de l'interès: "tenen interès aquelles persones que puguen sofrir qualsevol dany a causa de l'acord impugnable, i aquest interès legitima la seua actuació i promou el procés". 
En tot cas, entre l'àmplia i variada casuística que planteja la legitimació per a la impugnació en la multiplicitat d'òrgans de la cooperativa, dues qüestions destaquen sobre la resta: la primera, la reducció que pateix l'àmbit de la legitimació enfront dels acords anul-lables respecte de la més àmplia atorgada enfront d'acords nuls; la segona, la conversió, en alguns supòsits, del dret/poder d'impugnació en un "dret de minoria", en reconèixer la legitimació individual només a un determinat percentatge de socis.

VINT-I-UNENA. Respecte de la reducció de l'àmbit de la legitimació activa per als acords anul-lables, en relació amb la prevista per als acords nuls, s'hi han apuntat diverses tesis.

D'una banda, buscant les raons que hi aconsellen la denegació de legitimació activa al soci que vota a favor de l'acord, s'ha arribat a la conclusió que potser puguen trobar-se en la doctrina dels actes propis que, per contra, no seria aplicable per a la legitimació davant els acords nuls. En efecte, una de les premisses que han de concórrer, perquè siga aplicable aquest principi, és "que la conducta d'un subjecte determinat siga jurídicament eficaç, per la qual cosa, quan un negoci jurídic és nul i ha estat realitzat contra una disposició legal expressa, es pot anar contra els propis actes".

Però també s'ha qüestionat l'aplicació de la doctrina dels actes propis, ja que l'exercici del dret d'impugnació no persegueix invalidar el vot propi o el de la resta del accionistes que van votar a favor de l'acord, sinó desposseir del caràcter d'expressió vàlida de voluntat social l'acord d'una junta general. Per això, algun autor prefereix fonamentar la denegació de legitimació per a la impugnació d'acords anul-lables dels socis que votaren a favor en la teoria de l'interès: "el soci que assent veu prevaler la seua opinió en els acords socials adoptats $i$, per tant, no té l'interès que el dret d'impugnació tendeix a tutelar". 
Això no obstant, la teoria de l'interès entra en contradicció amb els supòsits en què, posteriorment a l'emissió del seu vot positiu, el soci arribe a la conclusió del seu error i que els seus interessos queden més ben tutelats mitjançant la impugnació de l'acord. Per això, considerem més encertada l'opinió que considera que es retalla la legitimació activa, perquè no està en joc el compliment de la llei, sinó la voluntat dels contractants manifestada en els estatuts socials o en l'interès dels socis. L'autonomia de la voluntat, lligada a la protecció de la seguretat jurídica, seran raons suficients per comprometre el soci a assumir el sentit dels seus actes.

VINT-I-DOSENA. La legitimació dels socis no administradors davant alguns acords del consell rector pateix una transformació radical: mentre que la legitimació davant dels acords anul-lables de l'assemblea, encara que sotmesa al compliment de determinades circumstàncies és un dret individual, respecte dels acords del consell s'ha considerat convenient configurar-lo com un "dret de minoria". La doctrina ha justificat aquesta reducció de les possibilitats d'exercici del dret "en la tutela per la llei de l'actuació de l'òrgan administratiu", que no ha de veure's alterada per processos d'impugnació plantejats per socis que no arriben a tenir una certa entitat. Amb això, sols si almenys un $5 \%$ dels socis considera que s'ha d'iniciar l'acció, podrà impugnarse l'acord.

Com ja hem indicat, que aquesta atribució de legitimació puga qualificar-se, en un sentit ampli, com a dret de la minoria, no significa que la seua finalitat directa siga la tutela dels interessos de la minoria. En realitat, quan es qualifica la impugnació com a mitjà de tutela de la minoria s'incorre en una certa confusió terminològica; estrictament parlant, són únicament mitjans de tutela de la minoria aquells en què aquesta (definida normativament mitjançant la fixació de la seua composició mínima: normalment amb un percentatge sobre el total de socis o sobre el capital social) no necessita acudir a una instància externa a la societat (jurisdiccional o administrativa), ni invocar cap transgressió de la llei, 
dels estatuts o de l'interès social. En aquest sentit, "a falta d'un criteri de raó, la llei atén un criteri de quantitat"; quan el grup minoritari representa un percentatge important del capital social, la llei, sense motiu, deroga el principi de submissió a la majoria". Així doncs, en la legitimació dels socis no administradors per a la impugnació d'acords de l'òrgan d'administració, no pot parlar-se estrictament d'instrument de tutela de la minoria, ja que aquesta necessitarà recórrer a un àmbit extern, judicial, perquè es determine si l'acord vulnera la llei, els estatuts socials o l'interès social.

En tot cas, aquesta reducció de la legitimació dels socis ha rebut crítiques de diversa índole. Així, per exemple, la d'establir un únic percentatge amb independència de la mesura de l'entitat, la dificultat dels socis no administradors per obtenir informació suficient i puntual que els permeta d'exercir el dret, o la de crear la possibilitat que un grup reduït de socis impugne tota mena d'acords, inclosos els de "mera gestió". La varietat de perspectives en la crítica ha portat a plantejar, tant la possibilitat d'augmentar com la de disminuir estatutàriament aquest percentatge, o la de condicionar l'exercici del dret que atribueix, encara que sembla que ha de concloure's que cap d'aqueixes opcions no és possible.

A més a més, la formulació d'aquesta legitimació en la LCCV presenta característiques específiques que convé analitzar. En primer lloc, considerem obertament criticable que s'establisca com a criteri de còmput de la minoria necessària per impugnar el manteniment pels socis d'un percentatge determinat de capital social. És probable que aqueixa opció legislativa siga conseqüència d'un mimetisme excessiu, pel que fa a la regulació establerta per la LSA en l'article 143; però, el que és cert és que l'article 41.6 de la LCCV exigeix que la minoria de socis que pretenga impugnar els acords del consell tinga la titularitat, almenys, d'un $5 \%$ del capital social. Si es té en compte que les aportacions dels socis al capital social no han de ser, necessàriament, de la mateixa quantia, pot concloure's que, per als socis amb una aportació més elevada, serà més fàcil accedir a la impugnació, amb la qual cosa es produeix 
una vulneració del principi cooperatiu de gestió democràtica, que inclou el reconeixement de la igualtat de drets dels socis. A més a més, s'introdueix una certa dificultat per a calcular-lo i acreditar-lo; i cal recordar que el capital social en la cooperativa és essencialment variable.

D'altra banda, es produeix ací un dels efectes més greus del sistema unitari d'impugnació que recull la LCCV en matèria d'impugnació d'acords del consell rector: també per als acords radicalment nuls (inclosos els contraris a l'ordre públic) es requereix la reunió d'una minoria determinada. Creiem, com Polo Sánchez, que "negar a l'accionista aquest dret individual a exercitar l'acció d'impugnació d'un acord nul per contrari a la llei, i transformar-lo en dret corporatiu o de minoria, i condicionar-ne la legitimació a la possessió d'un percentatge determinat del capital social", no sols no és ajustat a dret, sinó que és més perillós per a la societat que el risc de suportar impugnacions intranscendents i infundades.

VINT-I-TRESENA. La legislació cooperativa sols desplega la legitimació activa davant els acords de l'assemblea general i del consell d'administració. La resta d'òrgans socials, la majoria de les vegades ni tan sols disposen d'un reconeixement exprés de la impugnabilitat dels seus acords o les seues decisions, i encara menys, de la indicació de les persones que podran, si escau, exercir l'acció corresponent. Com a excepció, la regulació que fa la LCoop del comitè de recursos preveu que els seus acords podran ser impugnats " $\mathrm{d}$ 'acord amb el que s'estableix en aquesta Llei, com si hagueren estat adoptats per l'assemblea general"; la LCCV és més genèrica en la seua remissió, en establir, en la regulació de la comissió de recursos, que en el seu funcionament "s'aplicaran les normes d'aquesta llei sobre el consell rector".

Per a la resta d'òrgans socials, entenem que, a falta de previsió estatutària, s'hi han d'aplicar les regles que, per analogia, resulten més pròximes. Així, en relació amb les formes no col-legiades de l'òrgan d'administració i amb els seus 
òrgans delegats, s'haurà d'entendre aplicable la legitimació desenvolupada per al consell rector. I el mateix succeeix amb els interventors, per als quals, com hem vist, la resolució de les llacunes i les interpretacions s'ha de reconduir, en tot el que siga possible, a l'aplicació de les normes reguladores del consell rector, ateses les similituds en el seu règim.

Més difícil resulta respondre a la qüestió pel que fa a la comissió de control de la gestió regulada per la LCCV. Ja hem indicat com, a diferència del que es preveu per a la comissió de recursos, la llei valenciana no remet la regulació del funcionament del seu òrgan potestatiu de control a les normes del consell rector, per la qual cosa s'haurà d'atendre, estrictament, el contingut de les clàusules estatutàries corresponents; sols, si no n'hi haguera, entenem que podran aplicar-s'hi, analògicament, els preceptes relatius a l'òrgan d'administració.

En relació amb la direcció, com que se li atribueixen competències originàriament atribuïdes a l'òrgan d'administració, entenem que si es configura com a òrgan (i proves d'això podran ser, si escau, la seua regulació estatutària i/o la seua designació obligatòria), les seues decisions podran impugnar-se pel mateix procediment establert per als acords o les decisions de l'òrgan administratiu, de qui rep i amb qui comparteix les competències. També per als liquidadors hem conclòs l'aplicabilitat supletòria, amb les adaptacions que corresponguen i, a falta d'una altra previsió estatutària, del règim de funcionament del consell rector, per raó de les funcions que se'ls atribueixen.

Finalment, respecte de les comissions delegades de l'assemblea, diferents a la de recursos i a la de control de la gestió, que preveu la LCCV, el règim de la seua impugnació serà el que s'adopte, en aqueix cas, en els estatuts, però a falta de regulació expressa, sembla que el procés d'impugnació aplicable serà el previst per als acords de l'assemblea, atesa la naturalesa de les funcions delegades atribuïdes. Quant a la possibilitat de creació d'altres òrgans no previstos legalment, considerem que, atesa la falta d'autorització legal expressa, no pot 
ser suficient l'acord de l'assemblea general, sinó que es requerirà una previsió estatutària explícita; caldrà fer el que es dispose en les clàusules dels estatuts que donen forma a aqueixos òrgans.

VINT-I-QUATRENA. Encara que ni la LCoop ni la LCCV es pronuncien de manera explícita, no hi ha cap dubte que la legitimació passiva correspon a la cooperativa, ja que són els seus acords els que es pretenen deixar sense efecte. És la cooperativa, i en el seu nom els seus representants legals o voluntaris, els qui hauran de defensar la correcció de la seua voluntat manifestada pels seus òrgans socials. Així doncs, si la cooperativa no ha designat expressament uns altres representants específics per actuar en el seu nom en l'acció d'impugnació, és el consell rector (o, alternativament, el/els administrador/s) l’òrgan social que té la representació de la cooperativa i, en el seu nom, si no es preveu cap altra cosa, actuarà el president del consell. Això no obstant, quan la cooperativa entre en liquidació, seran els liquidadors els qui actuaran la legitimació passiva en representació de la cooperativa.

Més difícil de determinar és la legitimació passiva en les cooperatives en constitució, encara que la hipòtesi de la impugnació dels acords durant el període que va des de l'atorgament de l'escriptura fins a la seua inscripció registral sembla poc probable. Tant la LCoop com la LCCV inclouen una regulació expressa de la cooperativa en període de constitució, però que, com és previsible, no es refereix al supòsit d'impugnació; sembla que en aquests casos, la legitimació passiva de la cooperativa podria correspondre a les persones designades per a la realització de les gestions de constitució.

Com a conseqüència de l'atribució de legitimació passiva, la legitimació activa no pot correspondre mai a la cooperativa. Però si la legislació cooperativa no ha previst la legitimació passiva en general, no es pot tampoc esperar que ni la LCoop ni la LCCV prevegen el supòsit concret que es recull en el segon paràgraf de l'article 117.3 de la LSA, és a dir, que "quan l'actor tinga la 
representació exclusiva de la societat i la junta no tinga designat ningú amb aquesta finalitat, el jutge nomenarà la persona que ha de representar-la en el procés, entre els accionistes que hagen votat a favor de l'acord impugnat". No obstant això, estimem que és possible l'aplicació d'aquesta norma, en virtut de les regles generals de l'analogia.

VINT-I-CINQUENA. Tampoc s'esmenta en la legislació cooperativa la possibilitat que socis o terceres persones interessades puguen intervenir en el procés d'impugnació com a part coadjuvant, per defensar la validesa dels acords sotmesos a impugnació. Ni la LCoop ni la LCCV incorporen un precepte de contingut similar al de l'article 117.4 ("els accionistes que hagen votat a favor de l'acord impugnat podran intervenir a costa seua en el procés, per mantenir la seua validesa"), referit als acords de la junta general. I més dubtes es plantegen, encara, sobre la possibilitat de la seua aplicació en la impugnació dels acords de l’òrgan d'administració.

Potser seria acceptable interpretar que és possible una aplicació analògica de l'article 117.4 de la LSA en el seu sentit més estricte, és a dir, que comptarien amb legitimació els qui acrediten que han votat a favor de l'acord impugnat $i$ que hi intervinguen a costa seua. La seua intervenció, l'admissibilitat de la qual se sostindria en l'eficàcia que davant de tots els socis tindrà la sentència que resolga la impugnació, seria, no en qualitat de legitimats independents, sinó com a coadjuvants. Si s'acceptara aquesta intervenció, caldria ampliar-la a la dels altres subjectes que compten amb legitimació activa: administradors, membres de l'òrgan de control de la gestió i, en l'àmbit de la LCoop, també al comitè de recursos i als liquidadors.

Però això no permetria la intervenció com a part en el procés a dos tercers que, tanmateix, no sols disposaran, molt probablement, d'interessos dignes de defensa, sinó que poden ser cridats a intervenir, encara que només siga en qualitat de testimonis. Es tracta, d'una banda, del sol-licitant d'ingrés com a soci 
que veu com és impugnat l'acord de la seua admissió, segons la LCoop i, d'altra, del tercer a qui s'atribueix un benefici en lesió d'interessos de la cooperativa. 


\section{BIBLIOGRAFIA}

- AA. DD. (Nordine Aïci, Claire Autran, Iannis Ait-Ali, Arnaud Dupin, Olivier Dartois, Michel Palos Pinto), "La coopérative française. Le statut général de la coopération: Statut 10 septembre 1947 modifiée par la Loi du 13 juillet 1992», Boletín de la Asociación Internacional de Derecho
Cooperativo, núm. 29, 1997, pàgs. 51-112. - AA. DD., Manual de derecho cooperativo. Adaptado a la Ley 3/1987 de 2 de abril, General de
Cooperativas, (dir., B. Pendás Díaz), Editorial Praxis, Barcelona, 1987.

- Alborch Bataller, Carmen, El derecho de voto del accionista (supuestos especiales), Tecnos,
Madrid, 1977. - AlCALÁ Df́AZ, M. Ángeles, "El conflicto de interés socio-sociedad en las sociedades de
capital», RdS, núm. 9, 1997, pàgs. 89-141.

Madrid, 1998.

La impugnación de acuerdos del consejo de administración de sociedades anónimas, Civitas,

- Alfaro Aguila-Real, Jesús, "Conflictos intrasocietarios (Los justos motivos como causa legal no escrita de exclusión y separación de un socio en la sociedad de responsabilidad limitada)", Civitas, Madrid, 1995.

Interés social y derecho de subscripción preferente (Una aproximación económica),

- ALFONSO SÁNCHEZ, Rosalía, "Ámbito subjetivo de la transformación en la legislación cooperativa (algunos aspectos críticos)», RdS, núm. 8, 1997, pàg. 178 a 193.

27/1999, de 16 de julio)", CDC, núm. 31, abril, 2000, pàg. 161 a 199.

- "Capítulo XI. La integración cooperativa. La cooperativa de segundo grado", en AA. DD., La sociedad cooperativa en la Ley 27/1999, de 16 de julio, de cooperativas, (coord., F. J.
Alonso Espinosa), Editorial Comares, Granada, 2001, pàg. 355 a 386. en las comunidades autónomas sin ley reguladora», La Ley, núm. 4750, 9.3.1999, pàg. 1 a 6 .

Tirant lo Blanch, València, 2000.

- ALLEGRI, V., Contributo allo studio della responsabilità civile degli amministratori, Milano, 1979.

- AlONSO EsPINOSA, Francisco José, "Capítulo VII. Órgano de administración", en AA. DD., La Editorial Comares, Granada, 2001, pàg. 229 a 248.

Barcelona, 1988.

social en la supresión o limita "Algunas consideraciones sobre el juego de la cláusula del interés mercantil de la Comunidad Econón del derecho de suscripción preferente», en AA. DD., Derecho Madrid, 1991, pàg. 30 a 61. 
1995.

La exclusión del derecho de suscripción preferente en las sociedades anónimas, Madrid,

- AlONSO PÉREZ, Matilde, «El cooperativismo valenciano: desde sus inicios hasta la Ley de 1974», CIRIEC-España, núm. 11, octubre, 1991, pàg. 53 a 68.

- AlONSO SOTO, Ricardo, "Consideraciones sobre el ejercicio de la acción social de responsabilidad de los administradores de la sociedad anónima", La Ley, núm. 5090, 5.7.2000, pàg. 1 a 4.

- ALONSO UREBA, Alberto, «La sociedad unipersonal», en AA. DD., La reforma del derecho español de sociedades de capital, Civitas, Madrid, 1987.

- Álvarez Rubio, Amparo, Història del cooperativisme al País Valencià, Editorial Lavinia, Barcelona, 1968.

- AÑoveros TRIAS DE BES, X., «Validez de la junta general de la sociedad anónima con convocatoria irregular y falta de quorum. Comentario de la Sentencia del Tribunal Supremo de 7 de abril de 1987», RJC, 1988, núm. 4, pàg. 1040 a 1041.

- ARANGUREN URRIZA, Francisco José, "La representación de la sociedad anónima», en AA. DD., Las sociedades de capital conforme a la nueva legislación, 2a ed., Trivium, Madrid, 1990, pàg. 555 i ss.

- - "Los órganos de la sociedad anónima», en AA. DD., Las sociedades de capital conforme a la nueva legislación, 2a ed., Trivium, Madrid, 1990, pàg. 433 a 534.

- --_Los órganos de la sociedad limitada», en AA. DD., La sociedad de responsabilidad limitada, tom I, Madrid, Trivium, 1996, pàg. 967 a 1405.

- ARANZAdi Tellería, Dionisio, "Orígenes históricos y asentamientos ideológicos del asociacionismo socioeconómico", en AA. DD., Congreso de cooperativismo, Departamento de publicaciones de la Universidad de Deusto, Bilbao, 1988, pàg. 23 a 47.

- ARroyo, Ignacio, "Comentario al art. 56", en AA. DD., Comentarios a la Ley de sociedades de responsabilidad limitada, (coords. I. Arroyo i J. M. Embid), Tecnos, Madrid, 1997, pàg. 604 a 624.

1995, pàg. 11 a 18.

- AsCARELl, Tullio, "Cooperativa e società. Concettualismo giuridico e magia delle parole», Riv. soc., 1957, pàg. 397 a 438.

dei vizi delle deliberazioni assambleare», en Riv. soc., 1956, pàg. 93 a 118.

- Ávila NAvarro, Pedro, La sociedad limitada, tom I, Barcelona, Bosch, 1996, pàg. 421 a 551.

- Bacigalupo, Los delitos societarios en el nuevo Código penal, Curso de Derecho penal económico (Madrid-Barcelona, 1998), pàg. 129 i ss.

- BADÍA, Enrique, «Ejercicio divergente o contrario del derecho de voto en las sociedades anónimas y en las limitadas», La Ley, núm. 4716, 20.1.1999, pàg. 1 a 4.

- BASSI, Amedeo, Delle imprese cooperative e delle mutue assicuratrici, art. 2511-2548, en Codice civile. Commentario (dir. P. Schlesinger), Giuffré, Milà, 1995. 
- - El derecho cooperativo en Italia, Cuadernos de trabajo núm. 9, Ciriec-España, València, [1991?].

- --- La riforma delle società cooperative, Giuffré, Milà, 1992.

- Le società cooperative, UTET, Torí, 1995.

- BerCovitz, Alberto, "Los acuerdos impugnables en la Sociedad Anónima», en AA.DD., Estudios de derecho mercantil en homenaje al profesor Manuel Broseta Pont, Tirant lo Blanch, València, 1995, pàg. 374 a 396.

- BONFANTE, Guido, Cooperativism and large cooperatives, Boletín de la Asociación internacional de Derecho Cooperativo, núm. 23/24, maig-agost i setembre-desembre 1995, pàg. 65 a 71.

- - --- Imprese cooperative, en AA. DD., Commentario del Codice Civile Scialoja-Branca, a cura di Francesco Galgano, Libro quinto: Lavoro art. 2511-2545, Zanichelli Editore, Bolonya, 1999.

- Boquera matarredona, Josefina, «La regulación del conflicto de intereses en la ley de sociedades de responsabilidad limitada», RDM, 1995, núm. 217, juliol-setembre, pàg. 1007-1047.

- BorJabad GonZalo, Primitiu J., "Capítulo I. La sociedad cooperativa en la Ley 27/1999», en AA. DD., La sociedad cooperativa en la Ley 27/1999, de 16 de julio, de cooperativas, (coord., F. J. Alonso Espinosa), Editorial Comares, Granada, 2001, pàg. 1 a 40.

1993.

- BOTTERI, Tullio, «La normativa delle cooperative nella legislazione della Repubblica Federale Tedesca», Riv. coop., abril-juny 1980, pàg. 87 a 102.

- Broseta Pont, Manuel, Manual de derecho mercantil, 10a ed., Tecnos, Madrid, 1994.

- BUONOCORE, Vincenzo, Diritto della cooperazione, Il Mulino, Bolonya, 1997.

- Bustillo SAIZ, M. del Mar, La subsanación de acuerdos sociales por la junta general de la sociedad anónima, Aranzadi, Elcano, 1999.

- CABAllol i ANGElATS, Lluís, "Comentario al artículo 115», en AA. DD., Comentarios a la Ley de sociedades anónimas (coords. I. Arroyo i J. M. Embid), volum II, Tecnos, Madrid, 2001, pàg. 1105 a 1128.

- --, «Comentario al artículo 122», en AA. DD., Comentarios a la Ley de sociedades anónimas (coords. I. Arroyo i J. M. Embid), volum II, Tecnos, Madrid, 2001, pàg. 1271 a 1281.

- CABANAS TREjo, Ricardo, "Comentario al artículo 56 LSRL», en AA. DD., La sociedad de responsabilidad limitada, tom I, Colegios Notariales de España, Madrid, 1995, pàg. 315 i 316.

- - - i CAlavia Molinero, José Manuel, Praxis mercantil. Sociedades anónimas: fundación y acciones, Praxis, Barcelona, 1990.

- CABAnIllas SÁNCHez, Antonio, "Comentario al artículo 6.2», en AA. DD., Comentarios al Código Civil y Compilaciones forales (dirs. M. Albaladejo i S. Díaz Alabart), tom I, volum 1r, 2a ed., Edersa, Madrid, 1992.

- Campobasso, G. F., Diritto Commerciale, 2, Diritto delle società, 2a ed., UTET, Torí, 1992.

- CAPO, G., Piccole società cooperative e grandi illusioni: riflettendo sull'art. 21, l. 7 agosto 1997, n. 266, Gitur. contm., núm. 25.3, maig-juny 1998, pàg. 444/I a 470/I. 
- CARBajo CASCÓN, Fernando, Los requisitos de convocatoria de junta general de la sociedad anónima, Tecnos, Madrid, 1996.

- CARELlo, L. A., «El empresarialismo cooperativo, el cambio de los principios», en AA. DD., Congreso de cooperativismo, Universidad de Deusto, Bilbao, 1988, pàg. 183 a 203.

- CASTÁN TOBEÑAS, José, Derecho civil español, comín y foral, Reus S. A., Madrid, 1986, 12a ed. (rev. J. L. De los Mozos), tom I, volum 1.

- CHARLESWORTH \& MORSE, Company Law, 16a ed., Sweet \& Maxwell, Londres, 1999.

- ChOMEl, André i VIENNEY, Claude, «Déclaration de l'ACI: la continuité au risque de l'irrealité», RECMA, núm. 260, 2n trim. 1996, pàg. 64 a 71.

- CORONADO FERNÁNDEZ, Francisco, "Capítulo X. Disolución, liquidación y extinción», en AA. DD., La sociedad cooperativa en la Ley 27/1999, de 16 de julio, de cooperativas, (coord., F. J. Alonso Espinosa), Editorial Comares, Granada, 2001, pàg. 309 a 354.

- COStas COMESAÑA, Julio, El deber de abstención del socio en las votaciones, Tirant lo Blanch, València, 1999.

- Cozian, M., Viandier, A., i Deboissy, F., Droit des sociétés, 12a ed., Litec, París, 1999.

- Cracogna, Dante, «Reflexiones sobre los valores y los principios cooperativos en la Alianza Cooperativa Internacional», en Anuario de estudios cooperativos 1991, Instituto de Estudios Cooperativos, Universidad de Deusto, Bilbao, 1991, pàg. 97 a 109.

- CUÑAT EDO, Vicente, «Consideraciones generales sobre la reforma del régimen de los órganos sociales de la Ley de cooperativas de la Comunidad Valenciana", Revista Jurídica de Economía Social y Cooperativa, CIRIEC-España, núm. 9, pàg. 134 a 148.

- DABÓRMIDA, Renato, «Derecho cooperativo europeo y ordenamiento comunitario: ¿Hacia la armonización o la uniformación de las legislaciones en el seno de la C.E.E.?», Revista CIRIECEspaña, núm. 7, juny-setembre 1989, pàg. 6 a 67.

- - _-_EEC LAW, Cooperatives and co-operative principles», Boletín de la Asociación internacional de Derecho Cooperativo, núm. 23/24, maig-agost i setembre-desembre 1995, pàg. 105 a 111.

- -_._-_._- «voluzione dei principi e dei diritto cooperativo: dall'utopia ad imprenditoria del futuro", en Anuario de estudios cooperativos 1988, Instituto de Estudios Cooperativos, Universidad de Deusto, Bilbao, 1988, pàg. 87 a 110.

- _-_._-, «ecientes reformas en el derecho cooperativo italiano», (trad., G. Fajardo), Revista de legislación y jurisprudencia, Revista CIRIEC-España, núm. 4, pàg. 162 a 170.

- DAMIÁN MORENO, Juan, «Aspectos generales en torno al proceso de impugnación de acuerdos sociales de las sociedades anónimas», RDPro, núm. 1, 2000, pàg. 49 a 76.

- De CASTRo MARTín, José Luis, "La reafirmación de la voluntad social (Delimitación del supuesto de hecho del art. 115.3 LSA)", en AA. DD., Estudios jurídicos en homenaje al profesor Aurrelio Menéndez, tom II, Civitas, Madrid, pàg. 1587 a 1627.

- De Castro y Bravo, Federico, El negocio jurídico, Civitas, Madrid, 1985.

- DE FOURnY, J., "De la cooperation a l'economie sociale», en AA. DD., Congreso de cooperativismo, Universidad de Deusto, Bilbao, 1988, pàg. 71 a 88 
- De la Cámara Álvarez, M., "La administración de la Sociedad Anónima», RJN, 1992, pàg. 51 a 153.

- De la Vega García, Fernando L., "Aspectos mercantiles de la nueva Ley de enjuiciamiento civil», La Ley, núm. 5103, 24.7.2000, pàg. 1 a 10.

- Del ArCo Álvarez, José Luis, "Alianza Cooperativa Internacional», en AA. DD., Congreso de cooperativismo, Universidad de Deusto, Bilbao, 1988, pàg. 205 a 230.

- Delgado Echeverría, J., Comentarios al Código civil y compilaciones forales, tom XVII, volum 2, Madrid, 1992, pàg. 306 a 310.

- Díaz De lezcano Sevillano, Nicolás, Los acuerdos del consejo de administración. Especial referencia a su régimen de impugnación, J. M. Bosch Editor, Barcelona, 1999.

- DíEZ ARGal, Wenceslao, "Arbitraje cooperativo", en Anuario de estudios cooperativos 1987, Instituto de Estudios Cooperativos, Universidad de Deusto, 1987, pàg. 61 a 80.

- - -----, «Impugnación de acuerdos sociales en las sociedades cooperativas», en Anuario de estudios cooperativos 1988, Universidad de Deusto, Bilbao, 1989, pàg. 51 a 71.

- Díez-PICAZo GIMÉNEZ, Ignacio, i DE LA OlIVA SANTOS, Andrés, «Los procedimientos judiciales en la nueva legislación societaria», La Ley, 1990 - 1, pàg. 1049 a 1065.

- - núm. 3, pàg. 421 a 452.

- DíEZ-PICAzo, Luis, «La autonomía privada y el derecho necesario en la Ley de Arrendamientos Urbanos", $A D C, 1956$, II, pàg. 1149 a 1181.

- -...... La representación en el derecho privado, Civitas, Madrid, 1979.

- ----at i GULLÓN, Antonio, Instituciones de derecho civil, 2 vol., Tecnos, Madrid, 1995.

- Dívar, Javier, "El derecho comparado cooperativo en Europa», Anuario de estudios cooperativos 1988, Instituto de Estudios Cooperativos, Universidad de Deusto, Bilbao, 1988, pàg. 111 a 120.

- DOLDE, Tobías, "The organs of the German registrated co-operative society and their functions", Boletín de la Asociación internacional de Derecho cooperativo, núm. 29, 1995, pàg. 281 a 303.

- Domínguez GarcíA, Manuel Antonio, "La obligación como título. El sindicato de obligacionistas", en AA. DD., Derecho de sociedades anónimas, III, Modificación de estatutos, aumento y reducción del capital, obligaciones, volum 2, Civitas, Madrid, 1994, pàg. 1209 a 1331.

- DRAPERI, Jean-François, "L'ACI a cent ans: regard sur une histoire mémorable», RECMA, núm. 258, 3r. trim. 1995, pàg. 73 a 82; i 259, 1r. trim. 1996, pàg. 75 a 86.

- DuQUe DOMínGUEZ, Justino F., «Introducción a la protección de los derechos del accionista frente a los acuerdos de la mayoría", $R d S$, núm. 1, 1993; i en AA. DD., Derecho de sociedades anónimas, II, Capital y acciones, Volum 1, Civitas, Madrid, 1994, pàg. 29 a 84.

- - "La baja obligatoria del socio», REVESCO, núm. 56 - 57, 1988-89, pàg. 13-48.

- ------, «La Duodécima Directiva del Consejo (89/67/CEEde 21 de diciembre de 1989) sobre la Sociedad de Responsabilidad Limitada de socio único en el horizonte de la empresa individual de responsabilidad limitada", en AA. DD., La reforma del derecho español de sociedades 
de capital, Civitas, Madrid, 1987; Derecho mercantil de la Comunidad Económica Europea, Civitas, Madrid, 1991, pàg. 241 a 289.

- --_-_---, «La fusión en el Proyecto de reforma del Derecho de las Sociedades de Capital y su comparación con el Derecho comunitario de la Tercera Directiva», RDBB, núm. 32, octubredesembre 1988, pàg. 725 a 781.

- --.---.-.- «La libre adhesión y el principio de puerta abierta en las sociedades cooperativas", en AA. DD., Primeros encuentros cooperativos de la Universidad del País Vasco, Departamento de Trabajo, Sanidad y Seguridad Social. Administración de la Comunidad Autónoma Vasca, Bilbao, 1986, 183 a 222.

$\bullet$ 1962, pàg. 7 a 45 i 315 a 363.

- _-_-_ «Los grupos en el ordenamiento jurídico. Parte I. Grupos de sociedades cooperativas", en AA. DD., Grupos empresariales de la Economía Social en España, Ciriec-España, València, 2000, pàg. 98 a 195.

- - - "Principios cooperativos y experiencia cooperativa», en AA. DD., Congreso de cooperativismo, Instituto de Estudios Cooperativos, Universidad de Deusto/Gobierno Vasco, Bilbao, 1988, pàg. 89 a 118.

-

Tutela de la minoría. Impugnación de acuerdos lesivos (art. 67 L.S.A.), tesi doctoral, Universidad de Valladolid, Valladolid, 1957.

- Elejabarrieta GoIenETXE, Alejandro, Capítulo IV, «De los socios», en AA. DD., Glosa a la Ley de cooperativas de Euskadi, (dir. N. Paz Canalejo), Consejo Superior de Cooperativas de Euskadi, Vitòria, 1999, pàg. 65 a 124.

- EMBID IRUjo, José Miguel, "Comentario al art. 52», en AA. DD., Comentarios a la Ley de sociedades de responsabilidad limitada, (coords. I. Arroyo i J. M. Embid), Tecnos, Madrid, 1997, pàg. 561 a 571.

- - "Comentario al art. 70», en AA. DD., Comentarios a la Ley de sociedades de responsabilidad limitada, (coords. I. Arroyo i J. M. Embid), Tecnos, Madrid, 1997, pàg. 738 a 746.

anónimas (coords. I. Arroyo i J. M. Embid), volum II, Tecnos, Madrid, 2001, pàg. 1525 a 1535.

- _-_- «Derecho europeo de sociedades anónimas. Estudio preliminar y traducción de las normas sobre la sociedad anónima de la República Federal de Alemania, Francia e Italia», en Documentación Jurídica, núm. 55, tom XIV, juliol-setembre 1987.

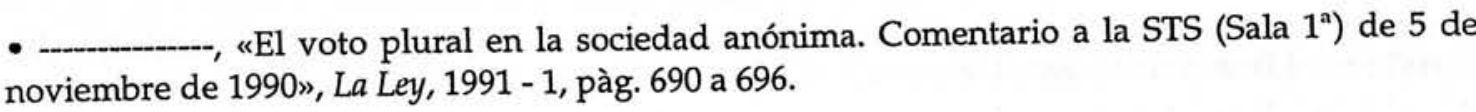

- _- En torno a la nulidad de la fusión y de la escisión en la nueva Ley de Sociedades Anónimas», RGD, núm. 550-551, juliol-agost 1990, pàg. 5605 a 5618.

(fusión, escisión y otros procedimientos similares)», $C D C$ núm 9 , setembre 1991, pàg.

- - - En torno a las modificaciones estructurales de las sociedades mercantiles (fusión, escisión y otros procedimientos similares)", CDC, núm. 9, setembre 1991, pàg. 13 a 37. 
- ------- «Impugnación de acuerdos del consejo rector y responsabilidad de los administradores en una sociedad cooperativa. Comentario a la STS (Sala $1^{\text {}}$ ) de 25 de junio de 1991", La Ley, 1992 - III, pp 257 a 261.

- ------, «La integración cooperativa y su tratamiento en la Ley 4/1993, de 24 de junio, de cooperativas de Euskadi», en AA.DD., Estudios de derecho mercantil. Homenaje al profesor Justino F. Duque, tom I, Universidad de Valladolid, Valladolid, 1998, pàg. 223 a 231.

- ----, «Los grupos cooperativos», Revista de legislación y jurisprudencia, Ciriec-España, núm. 7, desembre 1995, pàg. 221 a 231.

- - administradores en la nueva ley de sociedades anónimas", en Anales de Derecho, Universidad de Murcia, núm. 10, 1987-1990, pàg. 155 a 174.

- - - «Notas sobre la impugnación de acuerdos sociales en la Ley española de Sociedades Anónimas», Noticias de la Unión Europea - CISS, núm. 121, 1995, pàg. 49 a 57.

- - - "Problemas actuales de la integración cooperativa», $R D M$, núm. 227, gener-març 1998, pàg. 7 a 36.

- - «Revocación de un consejero delegado en una sociedad anónima.Comentario a la STS (Sala $1^{\text {n}}$ ) de 30 de diciembre de 1992", La Ley, 2.9.1993, pàg. 1 a 3.

1991.

, Concentración de empresas y derecho de cooperativas, Universidad de Murcia, Múrcia,

-

Grupos de sociedades y accionistas minoritarios: la tutela de la minoría en situaciones de dependencia y grupo, Ministerio de Justicia, Madrid, 1987.

español de sociedades de capital», RdS, núm. 7, 1996, pàg. 11 a 30.

- ESPAGNE, François, "Les coopératives à but social et le multisociétariat», RECMA, núm. 274, pàg. 69 a 85 .

- Esteban Velasco, Gaudencio, "Algunas reflexiones sobre la estructura orgánica de la sociedad de responsabilidad limitada en la nueva Ley", en AA. DD., Derecho de sociedades de responsabilidad limitada. Estudio sistemático de la Ley 2/1995, Tomo II, McGraw Hill, Madrid, 1996, pàg. $549 \mathrm{a} 585$.

- ---.-, "Configuración estatutaria del órgano de administración», en AA. DD., Derecho de sociedades anónimas, I, La fundación, Civitas, Madrid, 1991, pàg. 345 a 377.

- ---, «La estructura de las sociedades anónimas en el Derecho comunitario (El Proyecto modificado de Quinta Directiva)", CDC, núm. 5, juny, 1989, pàg. 231 a 358.

El poder de decisión en las sociedades anónimas, Civitas, Madrid, 1982.

- FAIRÉn GUILlÉN, Víctor, El proceso en la Ley de sociedades anónimas (estudio sobre los artículos 67 a 70), Bosch, Barcelona, 1954.

- Fajardo García, Isabel-Gemma, «El derecho cooperativo en España: incidencia de la Constitución de 1978", Revista CIRIEC-España, núm. 11, octubre 1991, pàg. 11 a 35.

- --.---.-.- "La reforma de la legislación cooperativa estatal», Revista jurídica de economía social y cooperativa, Ciriec-España, núm. 10, octubre 1999, pàg. 45 a 76. 
- - _Lei 51/1996, de 7 de septiembre. Código cooperativo portugués. Texto legal traducido y anotado", Revista jurídica de economía social y cooperativa, Ciriec-España, octubre 1999, pàg. $455 \mathrm{a} 477$.

- _-_-_-_- «Ley francesa $n^{\circ} 92$ de 13 de julio 1992 relativa a la modernización de las empresas cooperativas", Revista de legislación y jurisprudencia, CIRIEC-España, núm. 4, pàg. 171 a 180.

La gestión económica de la cooperativa: responsabilidad de los socios, tesi doctoral, València, 1992.

La gestión económica de la cooperativa: responsabilidad de los socios, Tecnos i Confederación de cooperativas de la Comunidad Valenciana, Madrid, 1997.

i SENENT VIDAL, M. José, Texto refundido de la Ley de cooperativas de la Comunidad Valenciana. Edición comentada, Confederación de Cooperativas de la Comunidad Valenciana, València, 1999.

- Faraldo Cabana, Patricia, Los delitos societarios. Aspectos dogmáticos y jurisprudenciales, Tirant lo Blanch, València, 2000.

- FERNÁNDEZ DE LA GÁNDARA, Luis, «La sociedad de responsabilidad limitada: acto final», RdS, núm. 5, 1995, pàg. 11 a 31 .

Luis, La atipicidad en derecho de sociedades, Pórtico, Saragossa, 1977.

- Ferrándiz, J. R., i GIMeno-Bayón, R., Praxis mercantil. Sociedades mercantiles. Sociedades anónimas: junta general y administradores, volum II.

- FERRI, G., recensión a la monografía de JAEGER (L'interesse sociale, Milà, 1963), en Riv. dir. comm., 1965, I, pàg. 244 i 245.

- FLORES DOÑA, M. de la Sierra, «La suspensión del ejercicio de los derechos correspondientes a las acciones, sobre las que se debe informar a la sociedad", en AA. DD., Estudios jurídicos en homenaje al profesor Aurelio Menéndez (coord. J. L. Iglesias Prada), Civitas, Madrid, 1996, tom II, pàg. 1751 a 1767.

- GADEA, Enrique, Derecho de las cooperativas. Análisis de la Ley 4/1993, de 24 de junio, de cooperativas del País Vasco, Universidad de Deusto, Bilbao, 1999.

- - Evolución de la legislación cooperativa en España, Consejo Superior de Cooperativas de Euskadi, Vitória, 1999.

- GALÁN CORONA, Eduardo, «La Junta general», en AA.DD., La reforma de la sociedad de responsabilidad limitada, (coords. R. Bonardell Lenzano, J. Mejías Gómez, U. Nieto Carol), Civitas, Madrid, 1994, pàg. 494 a 522.

- GAlgano, Francesco La società per azioni. Le altre società di capitale. Le cooperative. 3a ed., Zanichelli, Bolonya, 1978.

- _-____ Diritto commerciale. Le società, ed. 1997/1998, Zanichelli, Bolonya, 1997.

- - El negocio jurídico, (traducció de F. Blasco i L. Prats), Tirant lo Blanch, València, 1992.

- García de ENTERría, Javier, Los delitos societarios. Un enfoque mercantil, Civitas, Madrid, 1996. 
- García Luengo, Ramón i Soto VÁzQuez, Rodolfo, El nuevo régimen jurídico de la sociedad anónima. Comentarios y jurisprudencia, Editorial Comares, Granada, 1991.

- García-Medall Villanueva, Carmen, "Algunas consideraciones en torno a la junta universal de las sociedades anónimas y a la impugnación de sus acuerdos sociales. Comentario a la STS $\left(\right.$ Sala $\left.1^{\circledR}\right)$ de 17 de febrero de 1992", La Ley, núm. 3227, 29.3.1993, pàg. 1 a 3.

- GARRIDO DE PALMA, Víctor M., «Autonomía de la voluntad y principios configuradores. Su problemática en las sociedades anónimas y de responsabilidad limitada ", en AA. DD., Estudios jurídicos en homenaje al profesor Aurelio Menéndez (coord. J. L. Iglesias Prada), Madrid, Civitas, 1996, tom II, pàg. 1869 a 1881. - 111 , gener-març 1981, pàg. 7 a 41.
.

- GARrigues, J., Curso de derecho mercantil, tom I, 7a ed. revisada amb la col-laboració d'A. BERCOVITZ, Imprenta Aguirre, Madrid, 1982.

Tecnos, Madrid, 1978. -1
volum I, 1946, pàg. 415 a 430 .

- i URÍA, Rodrigo, Comentario a la Ley de sociedades anónimas, 3a ed., Madrid, 1976.

- GENCO, Roberto, «Il volto cooperativo della democrazia societaria», Riv. coop., 1999, núm. 2, pàg. 15 a 23. Riv. coop., 2000, núm. 1-2, pàg. 23 a 45.

- Gete-Alonso y CALERA, M. del C., "Comentario al art. 7», en AA. DD., Comentarios al Código Civil y Compilaciones forales (dirs. M. Albaladejo i S. Díaz Alabart), tom I, volum 1r, 2a ed.,
EDERSA, 1992 .

- GIMENO SENDRA, Vicente, El proceso de impugnación de acuerdos de las sociedades anónimas y cooperativas, 2a ed., Civitas, Madrid, 1985.

- --. La reforma procesal mercantil. Los nuevos procesos de impugnación de acuerdos y de la propiedad industrial (Estudios sobre la L.S.A. 19/1989 y las Leyes 11/1989 y 32/1988), Tirant lo Blanch,
València, 1990.

- GIRÓN TENA, José, Derecho de sociedades anónimas, Valladolid, 1952.

, José, Derecho de sociedades, I, Madrid, 1976.

- GÓMEZ MENDOZA, María, "Juntas especiales: organización y funcionamiento», en AA. DD., Estudios de derecho mercantil. Homenaje al profesor Justino F. Duque, tom I, Universidad de Valladolid, Valladolid, 1998, pàg. 421 a 429.

- GÓMEZ ORBANEja, Emilio, "El proceso de impugnación de la Ley de sociedades anónimas», RDPri, 1955, pàg. 123 a 129.

- GÓmez PORRÚA, Juan Manuel, La fusión de sociedades anónimas en el derecho español y comunitario, La Ley, Madrid, 1991. 
- GONDRA ROMERO, José M., «Significado y función del principio de «imagen fiel» («true and fair view») en el sistema del nuevo Derecho de balances», en AA. DD., Derecho mercantil de la CEE, Civitas, Madrid, 1991, pàg. 553 a 599.

- GonZÁlez GARCíA, Francisco, "Grupos paritarios de cooperativas de crédito y prácticas restrictivas de la competencia (A propósito del grupo Caja Rural)", DN, febrer 2001, pàg. 1 a 27.

- Gouveia e CÁssio, M., "Legislació sobre cooperatives a Portugal», en INSTITUT PER A LA PROMOCIÓ I LA FORMACIÓ COOPERATIVES, Legislació sobre cooperatives als Estats membres de la C.E.E, pàg. 50 a 54 i 113 a 116.

- GRAZIANI, Alessandro, "Società cooperativa e scopo mutualistico», Riv. dir. com., 1950, pàg. 276 a 286.

- Grosso, Patrizia, I controlli interni nelle società cooperative, QGC, núm. 117, Giuffré, Milà, 1990.

- GutiÉrrez DíEZ, Ángel, «El Proyecto de Ley de Cooperativas de Aragón», Revista CIRIECEspaña, núm. 29, agost 1998, pàg. 79 a 102.

- HANNOUN; Charley, «L'action en nullité et le droit des sociétés (Réflexions sur les sources procédurales du droit de critique et leurs fonctions)", RTDCDE núm. 2 abril-juny 1993, pàg. 227-253.

- HERNÁNDEZ SAINZ, Esther, «El deber de abstención en el voto como solución legal ante determinados supuestos de conflicto de intereses en la sociedad de responsabilidad limitada", RdS, núm. 6, 1996, pàg. 105 a 128.

- Hollington, Robin, Minority shareholders'rights, 3a ed., Sweet \& Maxwell, Londres, 1999.

- IGLESIAS PRADA, Juan Luis, Administración y delegación de facultades en la sociedad anónima, Tecnos, Madrid, 1971.

- JAEGER, Pier Giusto, "L'interesse sociale rivisitato (quarant'anni dopo)", Giur. comm., núm. $27 / 6$, novembre-desembre 2000, pàg. 795/I a 812/I.

- - -._._._. «'interesse sociale rivisitato (quarant'anni dopo)», Giur. comm., núm. 27/6, novembre-desembre 2000, pàg. 795/I a 812/I.

- _._._. L'interesse sociale, Milà, 1964.

- JEANTIN, Michel, Droit des sociétés, 2a ed., Montchrestien, París, 1992.

- JIMÉNEZ DE PARGA, Rafael, La impugnación de los acuerdos sociales en la ley reguladora de las sociedades anónimas, en AA. DD., Estudios jurídicos sobre la sociedad anónima, Madrid, Civitas, 1995, pàg. 319 a 355.; tb. en AA. DD., Estudios de derecho mercantil en homenaje al profesor Manuel Broseta Pont, tom II, Tirant lo Blanch, València, 1995, pàg. 1801 a 1833.

- JUSTE MENCÍA, Javier, Los derechos de minoría en la sociedad anónima, Aranzadi, Pamplona, 1995.

- KELLNER, Herbert, «La specifité et la realité socio-économique du secteur cooperatif dans la Communauté Éuropéene», Congreso de cooperativismo, Universidad de Deusto, Bilbao, 1988, pàg. $301 \mathrm{a} 311$.

- Lacruz Berdejo, José Luis, Derecho Civil. Parte General, vol I. Introducción, Librería Bosch, Barcelona, 1988. 
- LARGO GIL, Rita, "La exclusión del derecho de suscripción preferente», en AA. DD., Derecho de sociedades anónimas, t. III, volum 1, Civitas, Madrid, 1994, pàg. 603 a 700.

- Lassaleta García, Pedro, "Impugnación de acuerdos del consejo rector en las sociedades cooperativas", RDPri, abril, 1994, pàg. 333 a 349.

- Legros, Jean-Pierre, "La nullité des décisions de sociétés», Rev. des soc., 1991, pàg. 275 a 329.

- LEÓN SANZ, Francisco José, «Fusión, transformación y otras modificaciones estructurales de sociedades cooperativas. Distribución de competencias entre el Estado y las Comunidades Autónomas", RdS, núm. 9, 1997, pàg. 25 a 59.

- ----, "Modificaciones estructurales de sociedades cooperativas. Distribución de competencias entre el Estado y las Comunidades Autónomas", en AA. DD., Estudios de derecho mercantil. Homenaje al profesor Justino F. Duque, tom I, Universidad de Valladolid, Valladolid, 1998, pàg. 465 a 488.

- LÉVESQUE, Benoît, i CÔTÉ, Daniel, "La renovación de las legislaciones nacionales de la cooperación en el momento de la mundialización: la búsqueda de una metodología», en AA. DD., Cooperativas, mercado, principios cooperativos (dirs. J. L. Monzón, i A. Zevi), Ciriec-España, València, 1994, pp 9 a 24.

- Llebot MAJó, José Oriol, Los deberes de los administradores de la sociedad anónima, Civitas, Madrid, 1996.

- LlOBREgat HURTADO, M. Luisa, "Algunas reflexiones en torno a la nueva Ley de cooperativas valenciana", en Legislación y jurisprudencia, Revista CIRIEC-España, núm. 6, octubre, 1995, pàg.
265 a 269.

- - -Capítulo IV. Posición jurídica del socio (I): clases de socios, adquisición de la condición de socio, derechos y obligaciones y responsabilidad", en AA. DD., La sociedad cooperativa en la Ley 27/1999, de 16 de julio, de cooperativas, (coord., F. J. Alonso Espinosa), Editorial Comares, Granada, 2001, pàg. 129 a 144.

- - - "La reforma de la legislación cooperativa», RdS, 1994, núm. 2, pàg. 146 a 167.

- Mutualidad y empresas cooperativas, José M. Bosch editor, S.A., Barcelona, 1990.

- LLUIS Y NAVAS, Jaime, «La evolución de las directrices fundamentales de la legislación cooperativa española (1931-1975)», en Estudios Cooperativos, núm. 36-37-38, maig 1975/abril 1976, pàg. 3 a 39.

- LOJENDIO OsBORNE, Ignacio, «La junta general de accionistas», en AA. DD., Derecho mercantil, (coord. G. J. Jiménez Sánchez), 4a ed., Ariel, 1997, pàg. 282 a 298.

- LORCA NAVARRETE, Antonio, "Algunas observaciones procesales sobre la Ley de cooperativas de la comunidad autónoma de Euskadi», RDPri, octubre, 1983, pàg. 899 a 916.

- MARín LÓPEZ, Juan José, «Notas sobre la Ley 27/1999, de 16 de julio, de cooperativas», Diario La Ley, núm. 4930, 18.11.1999, D-284, pàg. 1797 a 1803.

impugnación «Novedades de la Ley general de cooperativas de 2 de abril de 1987 en materia de impugnación de acuerdos sociales», La Ley, 1988 - 2, pàg. 1114 a 1135.

- MARINA GARCíA-TUÑóN, Ángel, «Supuestos específicos de modificación estatutaria: modificaciones perjudiciales a determinadas clases de acciones, restricciones a la libre 
transmisibilidad de las acciones y cambio de domicilio social", en AA. DD., Derecho de sociedades anónimas, Civitas, Madrid, 1994, tom III, volum 1, pàg. 90 a 115.

- Martí Lacalle, Rocío, «El derecho de información del accionista en materia de contabilidad social: contenido y límites (Comentario a la STS de 15 de diciembre de 1998 [Civil]. R.A. 9636/1998)", RDM, núm. 232, abril-juny 1999, pàg. 843 a 855.

- MARTINEZ ChARTERINA, Alejandro, "Los valores y principios cooperativos», REVESCO, núm. 61,1995 , pàg. 35 a 45.

, Análisis de la integración cooperativa, Universidad de Deusto, Bilbao, 1990.

- Martínez MachuCA, Pablo, La protección de los socios externos en los grupos de sociedades, Publicaciones del Real Colegio de España, Bolonya, 1999.

- MARTínez SANZ, Fernando, "La nulidad de la fusión en la Ley de sociedades anónimas», RDM, núm. 195, gener-març 1990, pàg. 65 a 93.

- ---.-----, La representación proporcional de la minoría en el Consejo de administración de la sociedad anónima, Civitas, Madrid, 1992.

- MASSAGUER FUENTES, José, «La autonomía privada y la configuración del régimen jurídico de la sociedad de responsabilidad limitada», RGD, núm. 603, 1994, pàg. 12959 a 12979.

- - _La estructura interna de los grupos de sociedades (Aspectos jurídicosocietarios)", RDM, 1989, pàg. 281 a 325.

- MATA MARTíN, Ricardo M., «Delitos societarios: administración desleal y demás figuras delictivas", en AA. DD., Empresa y derecho penal (I), Consejo General del Poder Judicial, Madrid, 1999, pàg. 337 a 407.

- MENÉNDEZ MENÉNDEZ, Aurelio, «Auxiliares del empresario», RDM, 1959, pàg. 269 a 305.

- MENÉNDEZ, A. i BELTRÁN, E., "Las acciones sin voto", en Comentario al régimen legal de las sociedades mercantiles (dirs. R. Uría, A. Menéndez, i M. Olivencia), tom IV, Las acciones, Civitas, Madrid, 1992.

- MERINO HeRnÁNDEZ, Santiago, «Análisis de la reforma de la Ley 4/1993, de 24 de junio de cooperativas de Euskadi (Ley $1 / 2000$, de 29 de junio)", Revista Jurídica de Economía Social y Cooperativa, núm. 11, noviembre 2000, pàg. 9 a 23.

- - Rodríguez Álvarez, M. Pilar, i SAN JosÉ MARTínez, Fernando, Manual de arbitraje cooperativo vasco, Consejo Superior de Cooperativas de Euskadi, Vitòria, 2001.

- MESTRE, Jacques, «Sur l’originalité du droit coopératif», RECMA, núm. 261, 3r. trim. 1996, pàg. 81 a 88.

- MINERVINI, G., «Sulla legittimazione degli amministratori a l'impugnativa delle deliberazioni assembleari di società perazioni», Riv. dir. comm., I, 1955, pàg. 207 i ss.

- MONGE GIL, Ángel Luis, "Algunas reflexiones a propósito y sobre la Ley de Cooperativas de Aragón", RDM, núm. 232, abril-juny 1999, pàg. 723 a 754.

- MONTOlío HeRnÁNDEZ, José M., «Consejo rector y dirección en la nueva Ley General de Cooperativas», REVESCO, núm. 56 - 57, 1988-89, pàg. 123 a 150.

«Leyes de cooperativas de las comunidades autónomas: determinación de un modelo", REVESCO, núm. 66, 1998, pàg. 235 a 248. 
la Economía Social, Madrid, 1993.

- Morillas Jarillo, M. José, «La nueva regulación estatal de las sociedades cooperativas», DN, núm. 111, desembre 1999, pàg. 1 a 13.

i FELIÚ REY, Manuel Ignacio, Curso de cooperativas, Tecnos, Madrid, 2000. - MOSCONI, Romano, La piccola società cooperativa. Costitucione. Adempimenti contabili e fiscali.
Statuto, Pirola Società, Milà, 1995.

- MÜNKNER, Hans-H, «La réforme allemande de 1973 et la question des sociétaires non coopérateurs», RECMA, núm. 44-45, 4t trim. 1992/1r trim. 1993.

núm 9, pàg. 149 a 164 .

de l'Allemagne, "Panorama d'une économie sociale qui ne se reconnaît pas comme telle: le cas de l'Allemagne", RECMA, núm. 44-45, 4t trim. 1992/1r trim. 1993, pàg. 101 a 135.

Federal de Alemania, Ley cooperativa de 1973 y evolución de la legislación cooperativa en la República Marburg/Lahn, 1976.

Boletin de la "-Co-operative principles and the national co-operative legislation in Germany", Boletín de la Asociación Internacional de Derecho Cooperativo, 1995, núm. 23-24, pàg. 27 i ss.

núm. 7, juny-seter eLey de cooperativas en la República Federal Alemana», Revista CIRIEC-España,

- MuÑoz Vidal, Antonio B., El arbitraje cooperativo, Caja Rural Provincial de Murcia, Múrcia, 1978.

del Reglamento El proceso de impugnación de acuerdos sociales en las cooperativas: comentarios al art. 54 cooperativas, separata de REVESCO, núm. 46, 1978.

El socio indirecto en las Cajas Rurales, Caja Rural Provincial de Murcia, 1973.

- NAMORADO, Rui, Introdução ao direito cooperativo, Livraria Almedina, Coïmbra, 2000.

- NeIla NeIla, José M., «Impugnación de acuerdos del consejo de administración (Acerca del art. 143 del Texto Refundido L.S.A.», RDPri, mayo 1991, pàg. 418 a 422.

- Oficina Internacional del Trabajo, Conferencia internacional del trabajo, 89a reunión, 2001. Informe V. Promoción de las cooperativas, Ginebra, 2001.

- PALÁ BERDEJO, Francisco, «El cómputo de la mayoría en la junta general de accionistas», RDM, núm. 95, 1965, pàg. 41 a 76.

- PAlma, Rocco, "Il fenómeno cooperativo nella legislazione italiana», Boletín de la Asociación Internacional de Derecho Cooperativo, núm. 29, 1997, pàg. 23 a 50.

- PANiagua Zurera, Manuel, "La reforma de la legislación cooperativa andaluza», Revista CIRIEC-España, núm. 29, agosto 1998, pàg. 49 a 77. 
- PAOLUCCI, Luigi Filippo, Le società cooperative, Giuffrè Editore, Milà, 1999.

- PAStor Sempere, Carmen, "La nueva "piccola cooperativa" del derecho italiano: una manifestación de la tendencia a la simplificación del derecho de sociedades", RdS, núm. 8, 1997, pàg. 496 a 505.

- - -..-- «Ley foral 12/1996, de 2 de julio, de cooperativas de Navarra (BOE de 10 de octubre de 1996). Principales novedades con respecto a la anterior Ley foral 12/1989, de 3 de julio», RdS, núm. 8, 1997, pàg. 506 a 514.

- PATERnOtTre SuÁrez, Aquiles, Las actas de las juntas de accionistas, Civitas, Madrid, 1994.

- PAZ CANAlEjo, Narciso, "Ante la nueva Ley estatal de cooperativas: algunos puntos críticos», Anuario de estudios cooperativos 1998, Instituto de Estudios Cooperativos, Universidad de Deusto, Bilbao, 1999, pàg. 79 a 102.

- - _-_Las cooperativas de segundo y ulterior grado», RDPri, juliol-agost, 1977, pàg.

495 a 522.

- - _-_._os socios y los asociados», Documentación social. Revista de estudios sociales y de sociología aplicada, núm. 68, 1987, pàg. 103 a 121.

- - _-_ Principios cooperativos y prácticas societarias de la cooperación», REVESCO, núm. 61, 1995, pàg. 15 a 33.

- _._._._. «Visión general de la legislación cooperativa estatal: situación actual y perspectiva de reforma", REVESCO, núm. 66, 1998, pàg. 31 a 57.

- _._._..., El nuevo derecho cooperativo español, Madrid, 1979.

- - - i VICENT CHULIÁ, F., Ley general de cooperativas, en Comentarios al Código de comercio y legislación mercantil especial, tom XX, Edersa, Madrid, volum I: 1989, volum II: 1990, volum III:1994.

- PEMÁN MELERO, M., en AA. DD., Comunidades de bienes, cooperativas y otras formas de empresa, 3 vol., Consejo General del Notariado, Madrid, 1996.

- Pereira de Almeida, Antonio, Sociedades comerciais, Coimbra Editora, Coïmbra, 1997.

- PÉREZ BARÓ, Albert, Recull Cooperatiu (Miscel.lània Cooperativista) 1936/1981, Fundació Roca Galès, Barcelona, 1981.

- PÉREZ CARrILlo, Elena, «El deber de diligencia de los administradores de sociedades», RdS, núm. 14, 2000, pàg. 275 a 323.

- PÉREZ DAUdí, Vicente., "Comentario al artículo 117», en AA. DD., Comentarios a la Ley de sociedades anónimas (coords. I. Arroyo i J. M. Embid), volum II, Tecnos, Madrid, 2001, pàg. 1135 a 1174.

- - -...-. V., CACHÓN CADENAS, M., i FRANCO ARIAS, J., "Comentario al artículo 118», en AA. DD., Comentarios a la Ley de sociedades anónimas (coords. I. Arroyo i J. M. Embid), volum II, Tecnos, Madrid, 2001, pàg. 1174 a 1269.

- PIOT, Bernard, «Les principes coopératifs et la réforme de la legislation cooperative française», Boletín de la Asociación internacional de Derecho Cooperativo, núm. 23/24, maig-agost i setembredesembre, 1995, pàg. 15 a 26. 
«Une réforme en profondeur de la loi du 10 septembre 1947», RECMA, núm. 4445 , enero 1992 , pàg. 36 a 53.

- POlo DíEZ, Antonio, "Misión y sentido de la nueva Ley de cooperación», RDPri, núm. 302 i 303, abril i maig 1942, pàg. 213 a 235 i 273 a 301.

- POlO SÁNCHEZ, Eduardo, "Abuso o tiranía. Reflexiones sobre la dialéctica entre mayoría y minoría en la sociedad anónima», en AA. DD., Estudios jurídicos en homenaje al profesor Aurelio Menéndez (Coord. Juan Luis Iglesias Prada), Civitas, Madrid, 1996, tomo II, pàg. 2269 a 2293.

- _-_._-_ «eflexiones sobre el régimen de quorums y mayorías en los órganos colegiados de la sociedad anónima", RDM, 1973, pàg. 199 a 284.

Los administradores y el consejo de administración de la S.A., en Comentario al régimen legal de las sociedades mercantiles (dirs. R. Uría, A. Menéndez, i M. Olivencia), tom VI, Civitas, Madrid, 1992.

- QUIJANO GONZÁLEZ, Jesús, «Responsabilidad de los administradores», en AA. DD., El gobierno de las sociedades cotizadas, Marcial Pons, Barcelona, 1999, pàg. 537 a 594.

La responsabilidad civil de los administradores de la sociedad anónima, Valladolid, 1985.

- RAmos MéndeZ, F.: Derecho procesal civil, 5a ed., José M. Bosch, Barcelona, 1992.

- ReCAlde CASTells, Andrés, "Deberes de fidelidad y exclusión del socio incumplidor en la sociedad civil. Comentario a la STS (Sala 1a) de 6 de marzo de 1992», La Ley, 1993 - 1, pàg. 304 i ss.

1996.

- ReVENTÓs CARNER, Joan, El movimiento cooperativo en España, Ariel, Barcelona, 1960.

- Reverte Navarro, Antonio, Comentarios al Código Civil y Compilaciones forales, Madrid, 1993, tom XVII, volum $1 \mathrm{~A}$, article 1255.

- Rigido, A., «Problemi e proposte di cooperative governance», en Riv. coop., núm. 2, 1999, pàg. 5 a 9.

- RIPERT, G., i ROBLOT, R., Traité de droit commercial, tom 1, 16a ed. (M. Germain), L.G.D.J., 1996.

- RoDRÍGUEZ ARTIGAS, Fernando, «La delegación de facultades del consejo de administración de la sociedad anónima. Ejercicio y contenido de la facultad de delegar y estatuto de los titulares de los cargos delegados", RdS, núm. 1, 1993, pàg. 91 a 114.

- _._____-_La junta general de socios», en AA. DD., Derecho de sociedades de responsabilidad limitada. Estudio sistemático de la Ley 2/1995, tom II, McGraw Hill, Madrid, 1996, pàg. 587 a 642.

- - -_-_._.-. "Notas sobre el régimen jurídico del Director general de la S. A.», en AA. DD., Estudios jurídicos en homenaje a Joaquin Garrigues, Tecnos, Madrid, 1971, pàg. 115 a 139.

- - Consejeros delegados, comisiones ejecutivas y consejos de administración, Montecorvo, Madrid, 1971.

- - i ESTEBAN Velasco, Gaudencio, "Los órganos de la sociedad anónima», en AA. DD., El nuevo régimen jurídico de la sociedad anónima, Centro de estudios judiciales, Ministerio de Justicia, Centro de Publicaciones, Madrid, 1991, pàg. 95 a 140. 
i QUIJANO GONZÁLEZ, Jesús, «Los órganos de la sociedad anónima: junta general y administradores", en AA. DD., El nuevo derecho de las sociedades de capital, (dir. I. Quintana Carlo), Trivium, Saragossa, 1989, pàg. 121 a 258.

- Rodríguez RUIZ DE VILlA, Daniel, Impugnación de acuerdos de las juntas de accionistas. Legislación, doctrina y jurisprudencia según el nuevo texto refundido de la Ley de sociedades anónimas, Aranzadi, Pamplona, 1992.

- Rodríguez, M. P., i SUSO, J. M., "Capítulo V. Los órganos de la cooperativa», en AA. DD., Glosa a la Ley de cooperativas de Euskadi, (dir. N. Paz Canalejo), Consejo Superior de Cooperativas de Euskadi, Vitòria, 1999, pàg. 125 a 203.

- ROJO FERNÁNDEZ-Rfo, Ángel, «El derecho a obtener la certificación de acuerdos sociales», La Ley, 1984 - 2, pàg. 1131 a 1143.

- ROMERo Coloma, Aurelia M., «En torno a la problemática de la herencia yacente», RCDI, núm. 643, novembre-desembre 1997, pàg. 2217 a 2225

- RONCERO SÁNCHEZ, Antonio, La representación del accionista en la Junta General de la Sociedad Anónima, McGraw Hill, Madrid, 1996.

- Rubio, Jesús, Curso de derecho de sociedades anónimas, 3a ed., Editorial de Derecho Financiero, Madrid, 1974.

- RuedA MARTÍNEZ, José-Alejo, "Comentario al art. 54», en AA. DD., Comentarios a la Ley de sociedades de responsabilidad limitada, (coords., I. Arroyo i J. M. Embid), Tecnos, Madrid, 1997, pàg. $582 \mathrm{a} 595$.

- SAINTOURENS, Bernard, "La nullité d'une délibération du conseil d'administration d'une coopérative agricole pour violation de dispositions impératives relatives à la composition du conseil", Rev. des soc., núm. 3, juliol-setembre 2000, pàg. 542 a 546.

1996, pàg. 1 a 15.

"Sociétés coopératives et sociétés de droit commun", Rev. des soc., gener-març,

- SAlAZAR Leite, João, "Sobre o Código cooperativo e da necessidade da sua revisão", Anuario de estudios cooperativos 1992, Instituto de Estudios Cooperativos, Universidad de Deusto, Bilbao, 1993.

- SAlelles CLIMENT, José Ramón, El funcionamiento del consejo de administración, Civitas, Madrid, 1995.

- SAlinas RAMOS, Francisco, «El primer marco jurídico del cooperativismo agrario (Ley de sindicatos agrícolas de 1906)", en Estudios cooperativos, núm. 39 (maig-agost) i 40 (setembredesembre), 1976, pàg. 41 a 73 i 49 a 75.

- SAlvador CODERCh, P. (coord.), VON MŸNCH, I., i FerRer I RiBA, J., Asociaciones, derechos fundamentales y autonomía privada, Civitas, Madrid, 1997.

- SÁNCHez Álvarez, Manuel M., «Aspectos societarios de la nueva Ley de enjuiciamiento civil: la impugnación de acuerdos sociales, en particular", RdS, núm. 15, pàg. 383 a 387.

- SÁNCHEZ ANDRÉS, A., Las acciones, en Comentario al régimen legal de las sociedades mercantiles, (dirs. R. Uría, A. Menéndez i M. Olivencia), tom IV, volum 1r, Civitas, Madrid, 1994. 
- SÁnchez CAlero, Fernando, "Los conceptos de sociedad y de empresa en la Ley de cooperativas", en AA. DD., Libro-homenaje a Ramon M. Roca Sastre, t. III, Madrid, 1976, pàg. 493 a 524.

Administradores. Artículos 123 a 143, en Comentarios a la Ley de Sociedades Anónimas, (Dir. F. Sanchez Calero), t. IV, EDERSA, Madrid, 1994.

, Instituciones de derecho mercantil, tom I, 24a ed., McGraw Hill, Madrid, 2001.

, Principios de derecho mercantil, McGraw Hill, Madrid, 2000.

i OlivenCIA RUIZ, M., "Relaciones del régimen jurídico de las sociedades mercantiles y de las sociedades cooperativas", en El cooperativismo en la coyuntura española actual, Anales de Moral Social y Económica, Madrid, 1964, pàg. 135 a 176.

- SÁNCHEZ RUIZ, Mercedes, "Capítulo VI. Asamblea general», en AA. DD., La sociedad cooperativa en la Ley 27/1999, de 16 de julio, de cooperativas, (coord., F. J. Alonso Espinosa), Editorial Comares, Granada, 2001, pàg. 197 a 228.

- - Conflictos de intereses entre socios en sociedades de capital. Artículo 52 de la Ley 2/1995, de 23 de marzo, RdS Monografías, núm. 15, Aranzadi, Elcano (Navarra), 2000.

- SÁNCHEZ-CALERO GUILARTE, Juan, "El conflicto de intereses en la sociedad limitada", en AA. DD., Derecho de sociedades de responsabilidad limitada. Estudio sistemático de la Ley 2/1995, tom I, McGraw Hill, Madrid, 1996, pàg. 677 a 701.

- --_-_-_ «Principio mayoritario y conflicto de intereses en la Ley de sociedades de responsabilidad limitada de 1995», en AA. DD., Jornadas de Derecho de sociedades (Málaga 14, 15 y 16 de Mayo de 1997), (coords. A. Aurioles Martín i J. C. Martín Romero), Ilustre Colegio Notarial de Granada, Granada, 1998, pàg. 7 a 30.

- SANTOS Domínguez, Miguel Ángel, "Notas sobre la Ley 2/1998, de 26 de marzo, de Sociedades Cooperativas de Extremadura», Revista CIRIEC-España, núm. 29, agosto 1998, pàg. 103 a 126.

- SANTOS MARTíneZ, Vicente, «Las secciones de las cooperativas en el derecho español», en AA. DD., Estudios de derecho mercantil en homenaje al profesor Antonio Polo, Madrid, 1981, pàg. 1071 a 1139.

- SANZ PARAíso, Luis Fernando, «Efectos de la nulidad del acuerdo de aprobación de las cuentas anuales sobre otros acuerdos sociales (SAP Burgos 3 diciembre 1997)", RdS, núm 12, 1999, pàg. 326 a 335.

- SARAle, M., «Un nuovo tipo di società mutualistica: la piccola società cooperativa», Giur. comm., núm. 25.5, setembre-octubre 1998, pàg. 735/I a 763/I.

- SCHRIEVER, Olav, «Membership in a registered cooperative society and the of this resulting legal relationship between the registered cooperative society and its members", Boletin de la Asociación internacional de Derecho cooperativo, núm. 29, 1995, pàg. 237 a 254.

- SCHUJMAN, L., "La línea ortodoxa cooperativa, el cooperativismo tradicional», en AA. DD., Congreso de cooperativismo, Universidad de Deusto, Bilbao, 1988, pàg. 163 a 182

- SCORDINO, F., La società cooperativa, Casa editrice Dott. Eugenio Jovene, Nàpols, 1970.

- SCORZA, «Gli amministratori di società per azioni di fronte alle delibere invalide dell'assemblea", Riv. soc., 1963, p. 510 i ss. 
- SERRA, A., "Note in tema di piccola società cooperativa", en AA. DD., Scritti in onore di ANTONIO PAVONE LA ROSA, volum primer, tom III, Giuffrè Editore, Milà, 1999, pàg. 1281 a 1297.

- Serrano y Soldevilla, Alfonso Diego, La cooperativa como sociedad abierta, Ministerio de Trabajo y Seguridad Social. Col-lecció "Tesis doctorales", Sevilla, 1982.

- SIlvetTI, Cesare, i CAVALLI, Gino, Le società per azioni, tom 2n, Gli organi e il controllo giudiziario, 2a ed., UTET, Torí, 1983.

- SNAITH, Ian, «U. K. co-operative legislation in the 1980's: a decade of Neglect», Yearbook of coooperative entreprise 1988, pàg. 157 a 169.

- Soria FERRANDO, José Vicente, "Consideraciones sobre la eficacia de los acuerdos sociales declarados nulos (art. 67, párrafo 2 ${ }^{\circ}$ de la Ley de sociedades anónimas)", RDM, 1982, núm. 165166 , pàg. 537 a 554.

La impugnación de los acuerdos sociales en la Ley de sociedades anónimas, tesi doctoral inèdita, València, 1978.

- -_-_e legitimación activa para la impugnación de acuerdos de la junta general de la sociedad anónima, Universidad de Alicante, València, 1982.

- Suso VIDAL, José M., "Algunas notas sobre la armonización del derecho de sociedades cooperativas en la Comunidad Económica Europea", Congreso de cooperativismo, Universidad de Deusto, Bilbao, 1988, pàg. 319 a 324.

- -._-_._.-. «Funcionamiento orgánico de las cooperativas», en Anuario de estudios cooperativos 1987, Instituto de Estudios Cooperativos, Universidad de Deusto, Bilbao, 1987, pàg. 43 a 60.

- TAto PlAZA, Anxo, "Os órganos sociais», en Estudios sobre a Lei de cooperativas de Galicia, (dir. D. Bello Janeiro), Escola Galega de Administración Pública, Santiago de Compostel-la, 1999, pàg. 69 a 104.

estudio del art. 115.3 LSA), McGraw-Hill, Madrid, 1997.

- TRICOT, Daniel, «Abus de droits dans les sociétés. Abus de majorité et abus de minorité», RTDCDE, núm. 4 oct.-dec. 1994, pàg. 617 a 627.

- TRIMARCHI, P., «Titolarità del diritto di impugnare le deliberazioni annullabili», Riv. soc., 1957, pàg. $68 \mathrm{i}$ ss.

- TRUjILlo DíEZ, Iván Jesús, «El valor jurídico de los principios cooperativos. A propósito de la Ley 27/1999, de 16 de julio, de cooperativas", RCDI, núm. 658, marzo-abril, 2000, pàg. 1329 a 1360.

- TURNER, J., «La regulació legal de les cooperatives al Regne Unit», en INSTITUT PER A LA PROMOCIÓ I LA FORMACIÓ COOPERATIVES, Legislació sobre cooperatives als Estats membres de la C.E.E, pp 13 a 17 i 83 a 86.

- TUSQUETS TRIAS DE BES, F., «La profesionalización de los cargos directivos en la nueva Ley de Cooperativas", RGD, núm. 664-665, 2000, pàg. 49 a 60.

- UCELAY URECH, Inés, «El abuso del derecho por socios de cooperativas», La Ley, 1997 (2.9.97), D-228, pàg. 1349 a 1359. 

- Ulmer, Peter, Principios fundamentales del Derecho alemán de sociedades de responsabilidad
limitada, Civitas, Madrid, 1998.

- Uría Gonzalez, Rodrigo, Derecho mercantil, 27a ed., Madrid, Marcial Pons, 2000.

- ---, MENÉNDEZ, A., i MUÑOz, J. M., La junta general de accionistas (arts. 93 a 122 de la Ley A. Menéndez i M. Olivencia), tom V, Civitas, Madrid, 1992. A. Menéndez i M. Olivencia), tom V, Civitas, Madrid, 1992. derecho mercantil (Dirs. R. Uría i A. Menéndez), tom I, Civitas, Madrid, 1999, Cap. 53, pàg. 1279 a
1302.

- VÁZQUEZ AlberT, Daniel, «El conflicto entre mayoría y minoría en la exclusión del derecho de suscripción preferente», CDC, núm. 26, setembre 1998, pàg. 159 a 202. - VENTOSA I RoIG, Joan, Antologia cooperativista, (a cura de Jacint Dunyó i Clarà), Fundació Roca
i Galès, Barcelona, 1980.

- Vergez SÁNCHEZ, Mercedes, El derecho de las cooperativas y su reforma, Madrid, Civitas, 1973.

- Verrucoli, Piero, La società cooperativa, Milà, 1958.

- VICENT CHULIÁ, Francisco, "Análisis crítico del nuevo Reglamento de cooperación», RDM, 1972, núm. 125-126, juliol-desembre, pàg. 429 a 537.

- - "Comentario a la STS (S. 1ª) de 25.6.91», RGD, núm. 564, 1991, pàg. 7852 a 7855.

- "Consideraciones sobre la futura ley valenciana de cooperativas. La sentencia del Tribunal constitucional sobre la Ley de cooperativas vascas (I)», Revista UTECO, núm. 7,
octubre 1983, pàg. 17 a 19. 869 i ss.; i en "El accidentado desarrollo de nuestra legislación cooperativa», RJC, 1979 (4), pàg. 1209 a 1255.

- «El derecho de los órganos sociales desde la perspectiva de la legislación cooperativa", RDM, núm. 153-154, juliol-desembre, 1979, pàg. 483 a 590.

- -..-, "La asamblea general de la cooperativa», RJC, núm. 2, 1978, pàg. 417 a 495.

- --.-, "La legislación cooperativa como desafío para el jurista», en AA. DD., Primeros encuentros cooperativos de la Universidad del País Vasco, Departamento de Trabajo, Sanidad y Seguridad Social. Administración de la Comunidad autónoma vasca, Bilbao, 1986, pàg. 35 a 59 . pàg. $14561 \mathrm{a} 14583$.

"La Ley 27/1999 de 16 de julio de Cooperativas Estatal», RGD, núm. 663, 1999,
4583 .

autonómicas", REVESCO, núm 54-55, 1986-87, pàg. 285 a 305.

- - "La Llei de cooperatives catalana cinc anys ençà», RJC, 1988 (3), pàg. 575 a 591.

, «Las empresas mutualisticas y el Derecho mercantil en el ordenamiento español»,

RCDI, núm. 512, 1976, gener-febrer, pàg. 69 a 132. 
- "Mercado, principios cooperativos y reforma de la legislación cooperativa (estudio introductorio y de síntesis)", Revista Ciriec-España, núm. 29, agost 1998, pàg. 7 a 33.

169 a 174 . "Nota breve sobre la breve ley de cooperativas de crédito», La Ley, 1989 - 3, pàg. "Notas en torno a la Ley General de Cooperativas de 2 de abril de 1987», La Ley, 1987 - 3, pàg. 938 a 949.

- - "Situación actual de las cooperativas en el marco constitucional español: legalidad autonómica, estatal y fiscal», Revista Ciriec-España, núm. extraordinari, pàg. 27 a 47.

- Compendio crítico de derecho mercantil, toms I, vol. 1r i 2n, i II, 3a ed, Barcelona, J. M. Bosch editor, 1990 i 1991.

- - Introducción al derecho mercantil, Tirant lo Blanch, 12a ed., València, 1999.

- Villa VeGa, Enrique, "Comentario a la sentencia de 25 de mayo de 1984», CCJC, núm. 5, abril-agost 1984, pàg. 1703 a 1705.

- VON SPIES, F., «La legislació sobre cooperatives a Alemanya», en INSTITUT PER A LA PROMOCIÓ I LA FORMACIÓ COOPERATIVES, Legislació sobre cooperatives als Estats membres de la C.E.E, Generalitat de Catalunya, Departament de Treball, Barcelona, 1987, pàg. 9 a 12 i 79 a 82.

- ZANARONE, Giuseppe, "L'invalidità delle deliberazioni assembleari», en Tratato delle società per azioni, volum 3**, (dirs. G. E., Colombo i G. B. Portale), UTET, Torí, 1993, pàg. 187 a 498. 


\section{ÍNDEX SISTEMÀTIC}

ÍNDEX D'ABREVIACIONS

CAPÍTOL PRIMER.

LA IMPUGNACIÓ DELS ACORDS SOCIALS A LA COOPERATIVA

Introducció

1. Concepte i naturalesa jurídica de la impugnació dels acords socials .6

1.1 La impugnació com a eina d'invalidació de negocis jurídics .8

1.2 La impugnació $\mathrm{i}$ la capacitat autonormativa de la persona jurídica ...................................................13

2. Fonament jurídic de la impugnació dels acords socials .................................................................................17

2.1 La impugnació i el concepte d'interès social.............................................................................................19

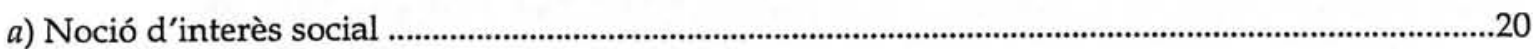

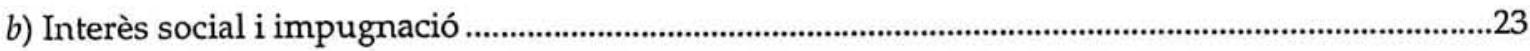

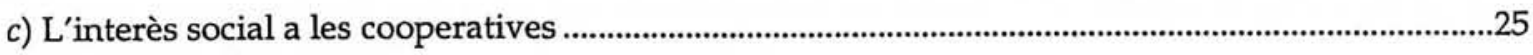

d) L'interès social com a conjunt d'interessos derivats del contracte social.......................................31

e) Defensa de l'interès social i obligació d'impugnar................................................................................38

2.2 La impugnació com a instrument de tutela de la minoria .....................................................................43

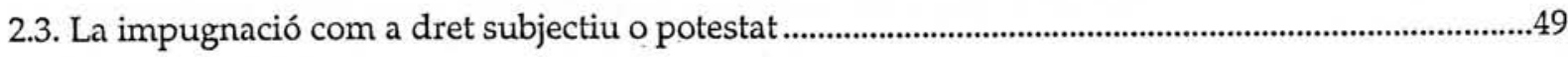

2.4 La impugnació com a instrument de tutela d'interessos generals ........................................................55

3. Normes reguladores de la impugnació d'acords de la cooperativa ...........................................................61

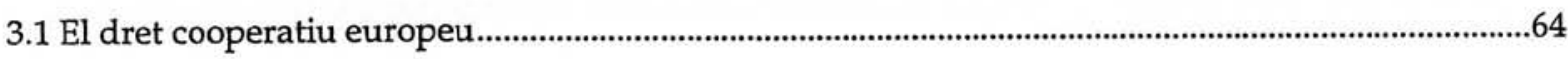

3.2. Legislació cooperativa de l'Estat espanyol ...............................................................................................93

3.2.1 Evolució històrica. L'estat de les autonomies i les cooperatives Conflicte de competències ............................................................................................................................94

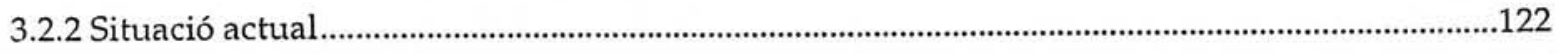

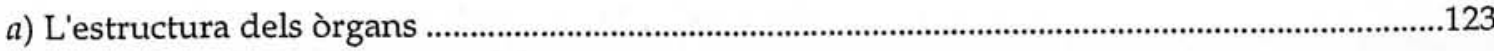

b) La regulació de la impugnació dels acords...................................................................................131

3.3 Els principis cooperatius 
3.4 Normes derivades de l'autonomia de la voluntat

3.4.1 Els estatuts socials: contingut obligatori i possibilitats d'autoregulació.

El procediment intern d'impugnació.

3.4.2 Altres normes: el reglament de règim intern; altres reglaments; els acords vàlidament adoptats pels òrgans competents.

CAPÍTOL SEGON.

L'OBJECTE DE LA IMPUGNACIÓ (I): SEGONS LA CAUSA DE LA INVALIDESA

ISEGONS LA NATURALESA DE LA CAUSA D'INVALIDESA

Introducció

1. L'objecte de la impugnació segons la causa d'invalidesa

1.1 Açords contraris a la Llei

1.2 Acords que s'oposen als Estatuts

1.3 Acords que lesionen els interessos de la cooperativa en benefici d'un o diversos socis, associats o tercers

2. L'objecte de la impugnació segons la naturalesa de la causa d'invalidesa

2.1 Acords nuls.

2.1.1 Supòsits de conflicte d'interessos

2.1.2 Acords contraris a l'ordre públic

2.2 Acords anul-lables

\section{CAPÍTOL TERCER.}

L'OBJECTE DE LA IMPUGNACIÓ (II):SEGONS L'ÒRGAN DEL QUE EMANEN.

ACORDS NO IMPUGNABLES

Introducció

1. Acords de l'assemblea general i d'altres assemblees de la cooperativa

1.1. Acords de l'assemblea general

1.2 Supòsits específics

1.2.1. Acords de l'assemblea en matèries atribuïdes a l'òrgan d'administració

1.2.2 Acords d'aprovació de comptes

A. Aprovació dels comptes anuals i de l'informe de gestió 
B. Aprovació del balanç en cas de modificació estructural

C. Impugnació del balanç final i del projecte de distribució de l'actiu sobrant .251

1.2.3. Impugnació de la realització de l'assemblea i, per tant, de tots els seus acords.

1.2.4 Impugnació d'acords en virtut de l'actuació de la presidència o de la secretaria de la sessió.

1.2.5 Acords de nomenament de càrrecs socials

1.3. Acords de l'assemblea de delegats i de les juntes preparatòries

1.4 Acords de l'assemblea de socis de la secció

1.5. Acords de l'assemblea d'obligacionistes.

1.6. Acords de les juntes especials

1.7 Acords de nomenament de consellers representants de determinats col-lectius.

2. Acords, decisions i actes dels òrgans d'administració i gestió 301

2.1. Acords del consell rector 307

2.2. Supòsits especials.

2.2.1. Acords del consell rector que poden impugnar-se internament

2.2.2. Acords adoptats amb la concurrència de consellers incursos en causes d'incapacitat o prohibició

2.2.3. Acords de delegació de funcions i de nomenament dels membres de l'òrgan delegat 328

2.2.4. Acords adoptats com a òrgan de gestió de les seccions de la cooperativa

2.3 Actes i decisions dels administradors

2.4. Acords de la comissió executiva i decissions dels consellers delegats

2.4.1. Acords de la comissió executiva

2.4.2. Decisions dels consellers delegats

2.5. Actes i decisions de la direcció

3. Acords d'altres òrgans

3.1. Acords i/o decisions dels òrgans de control de la gestió

3.1.1. Acords $\mathrm{i} / \mathrm{o}$ decisions dels interventors

3.1.2. Acords de la comissió de control de la gestió 
3.3. Acords d'altres comissions delegades de l'assemblea general, del consell rector o d'altres òrgans

3.4. Acords i/o decisions dels liquidadors.

3.5. Acords $\mathrm{i} / \mathrm{o}$ decisions de la direcció unitària del grup cooperatiu

4. Possibilitat d'impugnar els informes o dictàmens de professionals externs: auditors, lletrat assessor, $\mathrm{o}$ altres perits

5. Acords no impugnables

5.1. Acords "ferms" per no haver estat impugnats dins de termini

5.2 L'eliminació o substitució com a causa de no impugnabilitat.

5.3. L'arbitratge sobre l'objecte de la impugnació

\section{CAPITTOL QUART.}

LEGITIMACIÓ PER A LA IMPUGNACIÓ D'ACORDS SOCIALS

1. Legitimació activa

1.1. Legitimació per a la impugnació d'acords de l'assemblea general

1.1.1 Legitimació en pretensions declaratives de nul-litat

A. Legitimació dels socis

a) La condició de soci

b) Categories especials de socis

c) La representació del soci.

B. Els associats.

C. Els administradors

D. Els membres dels òrgans de control

E. El comitè de recursos.

F. Els liquidadors

G. Qualsevol tercer amb interès legítim

a) Els exsocis, l'administrador de l'herència jacent.

b) Els socis i els associats de les cooperatives sòcies i els socis d'altres persones jurídiques sòcies

c) Els treballadors 


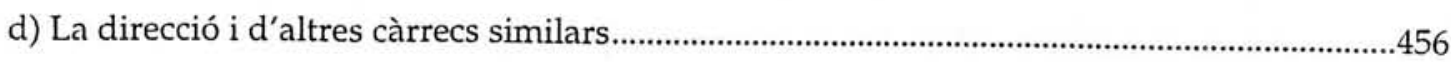

e) Els creditors, els obligacionistes, el comissari del sindicat d'obligacionistes .......................458

f) Les entitats associatives a les quals pertanya la cooperativa .................................................462

1.1.2. Legitimació en pretensions constitutives d'anul-labilitat

A. Legitimació dels socis assistents que hagueren fet constar en l'acta la seua oposició, els absents i els il-legítimament privats de vot.

a) La qualitat de soci

b) Els assistents que hagueren fet constar en l'acta la seua oposició

a') Moment de la constància de l'oposició

b') Forma de la constància de l'oposició

c) Oposició o vot negatiu?

d') Supòsits especials de socis assistents

c) Els absents.

d) Els il-legítimament privats d'emetre el seu vot .501

e) Supòsits especials . .503

B. Legitimació dels membres del consell rector o administradors ..................................................504

C. Legitimació dels membres de l'òrgan de control de la gestió ......................................................506

D. Legitimació del comitè de recursos i dels liquidadors ................................................................507

1.2. Legitimació per a la impugnació d'acords de l'òrgan d'administració..................................................510

1.2.1. Lcoop

A. Per impugnar acords anul-lables.

B. Per impugnar acords nuls

1.2.2. LCCV

A. Tots els administradors

B. Els socis que representen un $5 \%$ del capital

1.3. Altres supòsits de legitimació activa.

1.3.1. Legitimació activa per impugnar acords o decisions d'altres òrgans socials

1.3.2. Legitimació per a la impugnació de l'acord sobre l'admissió de nous socis

A. En la Lcoop 
1.3.3. Legitimació per impugnar els acords sobre la qualificació i els efectes de la baixa, els d'expulsió o els que imposen altres sancions disciplinàries

1.3.4. Legitimació per impugnar la denegació d'informació sol-licitada al consell rector (art. 16.3 i 16.4 de la Lcoop)

1.3.5. Legitimació per impugnar el balanç final i el projecte de distribució de l'actiu sobrant de la liquidació de la cooperativa (article 74.2 Lcoop)

1.3.6. La impugnació d'acords presos per determinats col-lectius de socis .534

1.3.7. La legitimació de la CNMV i del Banc d'Espanya davant determinats acords .536

2. Legitimació passiva .538

2.1. Supòsits en què els representants de la cooperativa són part impugnant .542

2.2 Supòsits en què puga admetre's com a part coadjuvant persones interessades .543

CONCLUSIONS 